БЕЛЕНИЧЕВ И. Ф., ЧЕРНИЙ В. И., НАГОРНАЯ Е. А., ПАВЛОВ С. В., ЧЕРНИЙ Т. В., ГОРЧАКОВА Н. А., БУХТИЯРОВА Н. В., АНДРОНОВА И. А., КУЧЕРЕНКО Л. И.

\title{
НЕЙРОПРОТЕКЦИЯ И НЕЙРОПЛАСТИЧНОСТЬ
}

МОНОГРАФИЯ

КИЕВ 2014 


\author{
Авторы: \\ Беленичев И. Ф., Черний В. И., Нагорная Е. А., Павлов С. В., \\ Черний Т. В., Горчакова Н. А., Бухтиярова Н. В., \\ Андронова И. А., Кучеренко Л. И.
}

\title{
Рецензенты:
}

Громов Леонид Александрович, д.мед.н., профессор, Заслуженный деятель науки и техники Украины, заведующий отделом нейрофармакологии Института фармакологии и токсикологии АМН Украины

Толстикова Татьяна Генриховна, д.биол.н, профессор, заведующая лабораторией фрармакологических исследований Новосибирского института органической химии им. Н. Н. Ворожцова СО РАН

Беленичев И. Ф и др.

Нейропротекция и нейропластичность. Монография. - К.: ООО «Полиграф плюс», 2014. - 512 с.: ил.

\section{ISBN}

В монографии представлена современная концепция молекулярнобиохимических механизмов гибели нейронов в условиях острой церебральной ишемии. Показана роль глутамат-кальциевого каскада (изменения метаболизма глутамата и кальция, оксидативный стресс, гиперпродукция NO*), митохондриальной дисфункции, дискоординации тиол-дисульфидной системы, которые индуцируют отдаленные последствия ишемии - реакцию генома с включением генетически запрограммированных молекулярных механизмов, дисфункцию астроцитарного и микроглиального пулов, развитие иммунных изменений и инициацию нейроапоптоза. Представлены данные о значении молекулярных фракторов эндогенной нейропротекции. Выделены два основных направления терапии мозгового инсульта первичная нейропротекция, направленная на прерывание быстрых механизмов некротической смерти клеток и вторичная нейропротекция, цель которой - уменьшение выраженности отдаленных последствий ишемии (блокада провоспалительных цитокинов, молекул клеточной адгезии, торможение оксидативного стресса, нормализация нейрометаболических процессов, ингибирование апоптоза). Приведены фармакологические характеристики современных нейропротекторов. Книга представляет интерес для клиницистов - невропатологов, нейрохирургов, нейрореаниматологов, терапевтов, а также для фрармакологов, нейрофизиологов и биохимиков. 
СОВРЕМЕННЫЕ АСПЕКТЫ РАЗВИТИЯ НЕЙРОНАУК . . . . . . . . . . . . . 5

ГЛАВА 1. КЛЕТОЧНО-МОЛЕКУЛЯРНО-БИОХИМИЧЕСКИЕ МЕХАНИЗМЫ НЕЙРОДЕСТРУКТИВНОГО КАСКАДА ПОСТИШЕМИЧЕСКОГО ПОВРЕЖДЕНИЯ ГОЛОВНОГО МОЗГА . . . . . . . . . . . . 7

1.1. Нарушения кислородного режима тканей головного мозга при остром нарушении мозгового кровообращения . . . . . . . 7

1.2. Нарушения энергетического метаболизма головного мозга в условиях ишемии и фрормирование митохондриальной

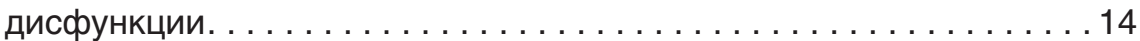

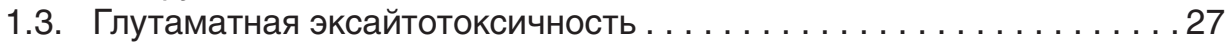

1.4. Нарушения в системе оксида азота и инициирование нитрозирующего стресса в условиях церебральной ишемии . . . . 37

1.5. Роль оксидативного стресса в реализации механизмов нейродеструкции ...................... 43

1.6. Роль воспаления и цитокиновые механизмы нейродеструкции . . . 79

1.7. Нейроапоптоз ........................... 83

ГЛАВА 2. МОЛЕКУЛЯРНО-БИОХИМИЧЕСКИЕ МЕХАНИЗМЫ ЭНДОГЕННОЙ НЕЙРОПРОТЕКЦИИ И НЕЙРОПЛАСТИЧНОСТИ . . . . . . . . . . . . . . . . . . . . .95

2.1. Роль генов раннего реагирования c-fos в процесcax выживания/гибели нейронов. . . . . . . . . . . . . . 95

2.2. Участие белков теплового шока (HSP 70) в механизмах эндогенной нейропротекции . . . . . . . . . . . . . . 101

2.3. Белки bcl-2 в регуляции нейроапоптоза. . . . . . . . . . . . . . 115

2.4. Участие нейротрофических факторов в механизмах

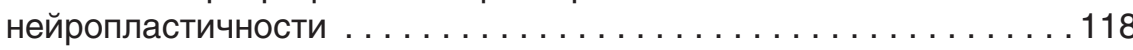

2.5. Роль эстрогенов в реализации эндогенной нейропротекции. Тамоксифрен . . . . . . . . . . . . . . . . . . . 128

2.6. Тиол-дисульфридная система. . . . . . . . . . . . . . . . . . . 150

ГЛАВА З. СОВРЕМЕННАЯ СТРАТЕГИЯ НЕЙРОПРОТЕКЦИИ. СРЕДСТВА ПЕРВИЧНОЙ НЕЙРОПРОТЕКЦИИ . . . . . . . . 160

3.1. Антагонисты NMDA- и AMPA-рецепторов. Препараты магния. Глицин . . . . . . . . . . . . . . . . 160

3.2. Ангиолин - новый первичный нейропротектор с выраженным влиянием на эндотелий сосудов и метаболизм . . . . . . . . 171

3.3. Блокаторы нейрональных кальциевых каналов Нимотоп, Исрадипин, Дародипин . . . . . . . . . . . . . . 191

3.4. Селективные модуляторы эстрогеновых рецепторов. . . . . . . . . 196 
ГЛАВА 4. СРЕДСТВА ВТОРИЧНОЙ НЕЙРОПРОТЕКЦИИ НЕЙРОМЕТАБОЛИЧЕСКИЕ ЦЕРЕБРОПРОТЕКТОРЫ, АНТИОКСИДАНТЫ, НЕЙРОТРОФИЧЕСКИЕ ЦЕРЕБРОПРОТЕКТОРЫ.

4.1. Тиоцетам - родоначальник семейства комбинированных нейрометаболических церебропротекторов . . . . . . . . . . . . 207

4.2. Цитиколин . . . . . . . . . . . . . . . . . . . . . . . . . . 237

4.3. Фенотропил. . ............................249

4.4. Нейротрофические церебропротекторы - Кортексин, Цереброкурин и Церебролизин. Митотропные механизмы нейропротекции .......................... 260

4.5. Роль и место антиоксидантов во вторичной нейропротекции . . . . 342

ГЛАВА 5. ОСНОВНЫЕ СТРАТЕГИИ НЕЙРОПРОТЕКЦИИ ПРИ ОСТРОЙ ЦЕРЕБРАЛЬНОЙ НЕДОСТАТОЧНОСТИ, ОБУСЛОВЛЕННОЙ ТЯЖЕЛОЙ ЧЕРЕПНО-МОЗГОВОЙ ТРАВМОЙ И МОЗГОВЫМ ИНСУЛЬТОМ. . . . . . . . . . . . . . . . . 352

5.1. Характеристика основных нейропротекторов, применяемых для лечения тяжелой черепно-мозговой травмы и мозгового

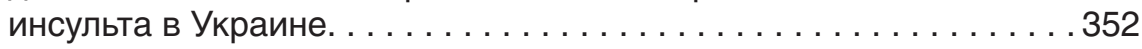

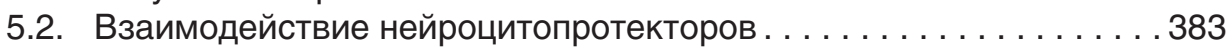

5.3. Стратегии нейропротекции при тяжелой черепно-

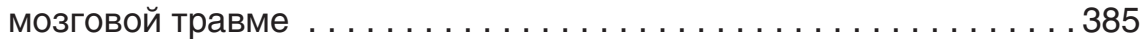

5.4. Современные подходы к диагностике и лечению ишемического инсульта. . . . . . . . . . . . . . . . . 390

5.5. Эволюция стратегии нейропротекции . . . . . . . . . . . . . 399

5.6. Концепция патогенетической нейропротекции пораженного мозга . . . . . . . . . . . . . . . . . .406

СПИСОК ЛИТЕРАТУРЫ. . . . . . . . . . . . . . . . . . . . . . 475 


\section{COBPEMEHНЫE АСПЕКТЫ РАЗВИТИЯ НЕЙРОНАУК}

$\mathrm{H}$ есмотря на определенные успехи в диагностике и лечении сосудистых заболеваний головного мозга, среди которых классифицируется ишемический инсульт, актуальность данной проблемы не снижается. Ее значимость определяется широкой распространенностью, высокой частотой инвалидизации и смертности. По данным ВОЗ, в экономически развитых странах летальность от инсульта занимает 2-3 место в структуре общей смертности и лидирует среди всех причин инвалидизации. В странах СНГ показатели инвалидизации и смертности остаются одними из самых высоких в мире [1-3]. Изучение молекулярнобиохимических механизмов гибели нейрона при ишемическом инсульте и разработка подходов к рациональной нейропротекции являются актуальными задачами современной нейрофармакологии, нейрореанимации и неврологии.

Согласно современным представлениям нейродеструкция ишемического генеза сопровождается развитием сложных патобиохимических и молекулярных каскадов в нейроне - нарушением энергетического метаболизма, развитием трансмиттерного аутокоидоза, формированием стойкой митохондриальной дисфункции, сопровождающейся гиперпродукцией активных фрорм кислорода и NO, экспрессией проапоптотических белков и гибелью клетки по типу апоптоза или некроза. Запуск программы нейроапоптоза может осуществляться цитокинами, гормонами, дериватами NO, окисленными тиолами, продуктами окислительной модификации белков и нуклеиновых кислот [1-7]. При действии подобных факторов на клетку в ней запускается множество сигнальных путей, ведущих к нейтрализации последствий их отрицательного воздействия или, в случае непоправимого ущерба, к элиминации клетки. Накоплено большое количество данных о нейродеструктивных/нейропротективных функциях NO и других активных молекул. Интенсивно изучаются механизмы эндогенной нейропротекции, заключающиеся в активации генов, кодирующих фракторы транскрипции (c-fos и c-jun) в первые несколько минут от начала инсульта и запускающих вторую волну экспрессии генов белков теплового шока (HSP 70 и HSP 72), а также фрактора, индуцируемого гипоксией (HIF-1), концентрация которых нарастает в течение первых 1-2 часов заболевания с последующей депрессией на 1-2-й день после инсульта. К молекулярным факторам эндогенной нейропротекции относят нейротрофический 
фрактор мозга (BDNF) и цилиарный нейротрофический фрактор (CNTF), активированные через рецептор TNF- $\alpha-$ R2 (p75), а также сосудистый эндотелиальный фрактор роста (VEGF), отвечающий за сосудистое ремоделирование.

В настоящее время концепция поэтапной нейропротекции включает в себя два основных направления. Первичная нейропротекция направлена на прерывание быстрых механизмов некротической гибели нейронов - устранение эксайтотоксичности за счет снижения активности эрготропных систем мозга - NMDA-, AMPAтрансмиттерных и торможение кальциевых трансмембранных токов. Вторичная нейропротекция направлена на торможение отсроченных механизмов гибели нейронов и уменьшение выраженности отдаленных последствий ишемии - ограничение активности iNOS и томожение нитрозирующего и оксидативного стресса, блокаду провоспалительных цитокинов, активацию компенсаторных митохондриально-цитозольных шунтов энергии и защиту митохондрий, модуляцию экспрессии белков (HSP 70, HIF-1) и прерывание каскадных реакций нейроапоптоза [8-15]. Исходя из самой сути нейропротекции - лечебного процесса, способствующего не только сохранению «жизни» пострадавших нейронов, но и восстановлению их функционирования, - поиск, создание и клиническая апробация новых лекарственных средств является важным направлением неврологии и нейрофрармакологии. В настоящей монографии на основании собственных экспериментально-клинических исследований и обзора научной литературы представлен анализ молекулярно-биохимических механизмов ишемической нейродеструкции и эффективности препаратов с нейропротективным действием при ишемическом инсульте. Представленная монография будет полезна в повседневном научном и лечебном процессе неврологам, нейрореаниматорам, неонатологам, нейрохирургам, нейрофрармакологам и нейрофизиологам, а также врачам-интернам и студентам.

Авторы 


\section{ГЛАВА 1}

\section{КЛЕТОЧНО-МОЛЕКУЛЯРНО-БИОХИМИЧЕСКИЕ МЕХАНИЗМЫ НЕЙРОДЕСТРУКТИВНОГО КАСКАДА ПОСТИШЕМИЧЕСКОГО ПОВРЕЖДЕНИЯ ГОЛОВНОГО МОЗГА}

\section{1. НАРУШЕНИЯ КИСЛОРОДНОГО РЕЖИМА ТКАНЕЙ ГОЛОВНОГО МОЗГА ПРИ ОСТРОМ НАРУШЕНИИ МОЗГОВОГО КРОВООБРАЩЕНИЯ}

В последние годы XX столетия произошла эволюция представлений о механизме повреждения ткани мозга при остро возникающей ишемии, что радикально изменило взгляды на лечение острого нарушения мозгового кровообращения (ОНМК) [1, 3, 12]. Длительное время считалось, что основным повреждающим фактором при церебральной ишемии любого генеза является недостаточное снабжение мозговой ткани энергетическими субстратами кислородом и глюкозой. Однако данные, полученные в 70-е годы прошлого столетия, показали, что ишемия (аноксия-гипоксия) выступает только в роли пускового повреждающего фактора [15]. Современная концепция патогенеза острой ишемии мозга рассматривает изменения его функции, связанные с редукцией мозгового кровотока, реперфузией и формированием зоны «ишемической полутени» [6-8].

В середине 80-х годов была открыта $\mathrm{Ca}^{2+}$-индуцированная эксайтотоксичность и разработана теория эксайтотоксической смерти нейронов [207, 222, 259]. Было установлено, что снижение энергетического потенциала нервной ткани является триггерным механизмом, обуславливающим постаноксические нарушения метаболизма, ионного гомеостаза и активацию трех основных механизмов аноксического повреждения клеток мозга: свободнорадикального, кальцийзависимого и фосфолипазного [17, 23].

Анализ динамики патогенетических механизмов, запускаемых острой ишемией мозга, установил их четкую временную последовательность. В течение первых 3-х часов с момента ОНМК максимально представлен энергетический дефицит в ишемизированной ткани; через 3-6 часов развивается глутаматная эксайтотоксичность, нарушение кальциевого гомеостаза и лактат-ацидоз, которые угасают к концу первых суток. Отдаленные последствия ишемии, такие как оксидантный стресс и локальное воспаление, начинают проявляться через 2-3 часа, достигают максимума через 12-36 часов, а на 2-3 сутки начинается апоптоз. Эти процессы сохраняются длительно, в течение нескольких месяцев, способствуя в постинсультном периоде прогрессированию процессов атерогенеза и диффузного повреждения ткани головного мозга, в т. ч. энцефалопатии [3-17].

Установлено, что степень повреждающего действия ишемии определяется прежде всего глубиной и длительностью снижения мозгового кровотока. Было сформулировано положение о критическом пороге мозгового кровотока, когда прекращается метаболизм [17]. Область мозга с наиболее выраженной 
олигемией (менее 10-15 мл/100 г/мин) в течение 6-8 минут становится необратимо поврежденной. Это - сердцевина, или ядерная зона ишемии [18-22]. На протяжении нескольких часов центральный точечный инфаркт окружен ишемизированной, но живой тканью - зоной ишемической полутени, или пенумбры, в которой сохранен энергетический метаболизм на уровне поддержания функции клетки и развиваются лишь функциональные, но не структурные, изменения. Область ишемической полутени может быть трансформирована в здоровую ткань мозга и является главной мишенью терапии инсульта в первые часы и дни заболевания [1-3, 19-24].

Происходящие при ишемии патологические изменения называют ишемическим каскадом [25-33], сущность которого сводится к следующему: снижение доставки $\mathrm{O}_{2}$ и глюкозы вызывает немедленное расщепление аденозинтрифосфата (АТФ) для покрытия потребностей клеток в энергии (длится 2-4 минуты после полной ишемии). Далее используется фосфокреатинин, уровень которого в мозге в 3 раза выше, чем АТФ, для процессов ресинтеза АТФ из аденозиндифосфатов (АДФ). Развивается снижение внутриклеточного $\mathrm{pH}$ и переход на анаэробный гликолиз, что ведет к повышению содержания молочной кислоты, превращению с помощью лактата трехвалентного железа в двухвалентное. Именно это способствует образованию свободных радикалов и окислению липидов клеточных мембран [3, 17].

Сегодня достаточно исследована роль сосудистого эндотелия в патогенезе церебральной ишемии. Развитие отека мозга и постаноксических повреждений ГЭБ в значительной степени инициировано биологически активными веществами самой сосудистой стенки. Ишемизированные эндотелиальные клетки экспрессируют и выделяют биологически активные воспалительные цитокины и хемокины, адгезивные молекулы и лейкоцитарные хемоаттрактанты в зоне ГЭБ, стимулируют мобилизацию клеток крови и их инфильтрацию в мозг. Поврежденные мембраны клеток, а точнее - арахидоновая кислота в месте деструкции нейроцитов, сдвигает $\mathrm{pH}$ среды в кислую сторону [34-42]. Универсальные фагоциты - нейтрофилы - обладают свойством неспецифического хемотаксиса в сторону кислой $\mathrm{pH}$, т. е. к месту повреждения. Присутствие в очаге повреждения базофилов усугубляет ситуацию, увеличивая проницаемость ГЭБ путем выделения гистамина и гепарина при дегрануляции [3].

Цепь воспалительных реакций продолжается в течение нескольких дней даже после восстановления перфузии тканей [3]. Механизм лейкоцитарной миграции, дисфункции ГЭБ и усиление воспалительного процесса усугубляется тем, что нейроны, астроциты и эндотелиальные клетки продуцируют протеиназы, которые также неспецифически повреждают ГЭБ [6, 7]. А проникшие в мозговую ткань нейтрофилы производят еще больше провоспалительных цитокинов $[4,7,38]$, в том числе достаточно агрессивный фермент циклооксигеназу-2 (ЦОГ-2), который считается одним из ключевых ферментов, отвечающих за воспалительную реакцию в ЦНС. Индукция ЦОГ-2 может происходить не только в нейронах, но и в макрофагах, астроцитах, эндотелиальных клетках, что также приводит к повреждению ГЭБ [6-44]. 
Таким образом, отек головного мозга возникает уже через несколько минут после развития локальной ишемии вследствие повреждения клеточных мембран и накопления воды в клетках (цитотоксический отек), а также повреждения ГЭБ и попадания плазмы во внеклеточное пространство мозга (вазогенный отек). Выраженность отека мозга находится в прямой зависимости от размеров инфаркта мозга [4], а также от степени тяжести и длительности снижения церебральной гемодинамики. Рядом исследований было выявлено, что при снижении мозгового кровотока до 50-55 мл/100 г ткани в минуту (при норме 75-80 мл/100 г ткани в минуту) наблюдается снижение синтеза белка, рассредоточение рибосом, селективная экспрессия генов - так называемый I критический уровень. При снижении кровотока до 35 мл/100 г/мин наблюдается активация анаэробного гликолиза, развитие лактат-ацидоза и отека тканей мозга - так называемый II критический уровень [4-7].

Дальнейшее снижение мозгового кровотока до 20 мл/100 г/мин и ниже приводит к развитию сложного каскада патобиохимических реакций в нейронах: дискоординации в цикле Кребса, нарушению работы дыхательной цепи митохондрий, возникновению энергодефицита, выбросу возбуждающих продукцию АФК аминоацидергических нейротрансмиттеров, развитию деполяризации мембран - так называемый III критический уровень, когда ишемические повреждения становятся необратимыми (рис. 1.1).

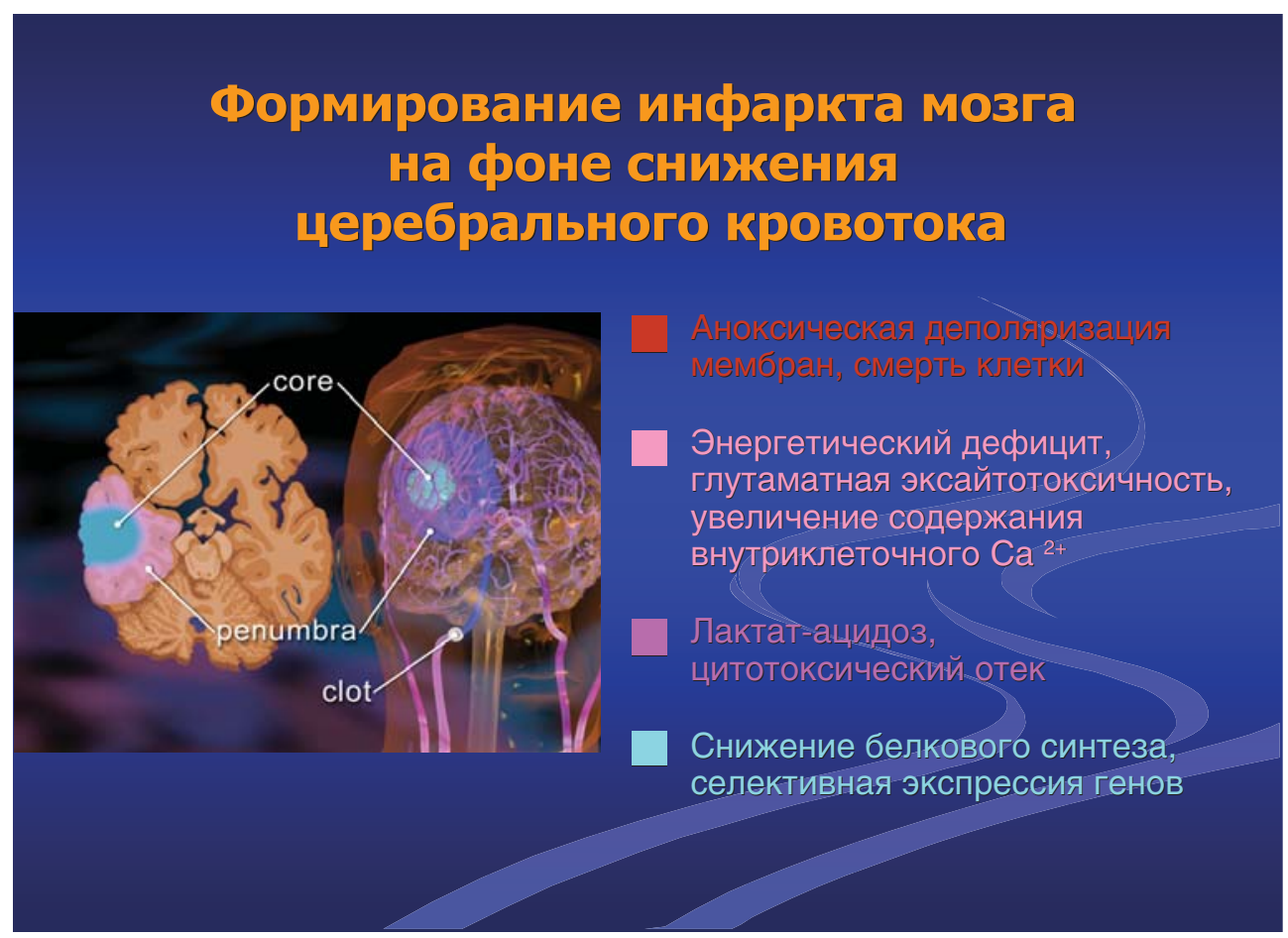

Рис. 1.1. Формирование инфаркта мозга 
Таким образом, при снижении кровотока ниже 20 мл/100 г/мин в мозге происходит формирование очагового некроза на фоне ишемии, в основе которого лежат реакции глутамат-кальциевого каскада, разворачивающиеся в первые минуты и часы после сосудистого инцидента. В развитии глутамат-кальциевого каскада выделяют три основных этапа: индукция (запуск), амплификация (усиление повреждающего потенциала) и экспрессия (конечные реакции каскада, непосредственно приводящие к гибели клетки) (рис. 1.2) [4, 7].

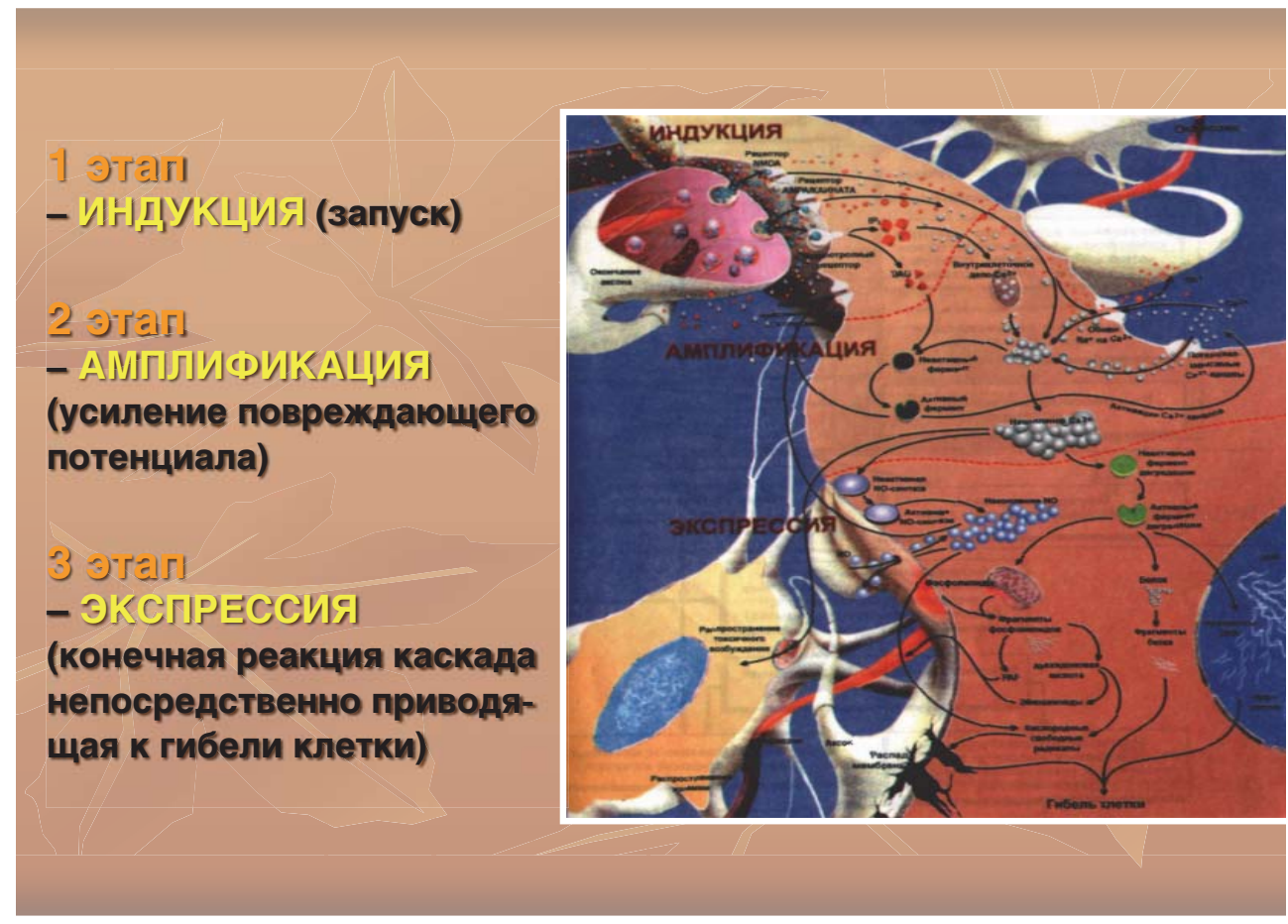

Рис. 1.2. Этапы глутамат-кальциевого каскада

Первый этап - индукиия. Патобиохимические реакции этого этапа запускаются нарушениями энергетического метаболизма. Так, одной из первых реакций ткани мозга на ишемию является активация анаэробного гликолиза и усиление образования лактата и ионов $\mathrm{H}^{+}$, что обуславливает формирование метаболического ацидоза. Значительное нарастание лактата в первые минуты после развития ишемии мозга вызывает снижение рН до 6,4-6,7. Показано, что лактат-ацидоз играет важную роль в формировании инфаркта мозга. В целом ацидоз угнетает метаболические реакции и ионный транспорт. Также ацидоз может усиливать образование АФК в реакциях Фентона и Габера-Вейсса. В дальнейшем наблюдается ингибирование NAD/NADHзависимого пути окисления, увеличение уровня восстановленных форм пиридиннуклеотидов и флавинов, и как следствие - потеря клеткой способности к окислению энергетических субстратов, т. е. формируется «субстратный 
голод». Нарастание кислородной недостаточности приводит к подавлению или полной инактивации электротранспортной функции дыхательной цепи в области цитохромов B-C, что отражает прекращение дыхания и окислительного фосфорилирования. Именно в этот период уровень энергетического дефицита становится достаточным для запуска основных механизмов, приводящих к нарушению и гибели клетки. Снижение уровня АТФ и АДФ, и как следствие - стремительное повышение уровня АМФ, сопровождается активацией протеинкиназной системы и является дополнительным механизмом разрушения мембран нейрона [16, 41, 43-48]. Снижение содержания АТФ, повышение уровня неорганического фосфора, формирование лактат-ацидоза приводят к обесточиванию $\mathrm{Na}^{+} / \mathrm{K}^{+}$-АТФ-азной ферментной системы, которая управляет энергозависимым ионным транспортом. Нарушение активного ионного транспорта обусловливает пассивный отток $\mathrm{K}^{+}$из клетки, приток $\mathrm{Ca}^{2+}$ и приводит к деполяризации мембран нейрона. В связи с энергодефицитом и лактат-ацидозом нарушается секвестрация $\mathrm{Ca}^{2+}$ в митохондриях и эндоплазматическом ретикулуме, а также усиливается высвобождение $\mathrm{Ca}^{2+}$ из органелл. Внутриклеточное накопление $\mathrm{Ca}^{2+}$ при мозговой ишемии усиливает угнетение окислительного фосфорилирования и катаболизм. Таким образом, уже на стадии патобиохимических реакций, вызванных энергодефицитом, начинается процесс накопления $\mathrm{Ca}^{2+}$ и запускаются ключевые механизмы гибели нейрона при ишемии [47-48].

Другим, более важным, путём поступления $\mathrm{Ca}^{2+}$ в клетку являются агонист-зависимые $\mathrm{Ca}^{2+}$-каналы, регулируемые рецепторами, которые активируются аминоацидергическими нейротрансмиттерами - глутаматом и аспартатом. В 80-е годы ХХ столетия была сформулирована теория эксайтотоксичности, заключающаяся в том, что из окончаний ишемизированных нейронов в межклеточное пространство высвобождается избыточное цитотоксическое количество глутамата и аспартата, которое запускает в действие каскад патобиохимических процессов, приводящих к гибели нейрона. Основное влияние на экстрацеллюлярные уровни аспартата и глутамата, а следовательно - на выраженность эксайтотоксичности, оказывает степень энергодефицита. Усиление выброса глутамата развивается при повышении уровня $\mathrm{K}^{+}$ в экстрацеллюлярном пространстве, а повышение во внеклеточной среде $\mathrm{Na}^{+}$ изменяет $\mathrm{Na}^{+}$-зависимый отток глутамата из синаптической щели $[4,48]$.

Таким образом, в условиях снижения мозгового кровотока ниже 20 мл/100 г/мин на фоне развития энергодефицита нарушается высокоселективная система транспорта глутамата и аспартата из синаптической щели в астроглию и меняется система путей преобразования медиаторов. Эти изменения приводят к тому, что абсолютная концентрация и время пребывания глутамата и аспартата в синаптической щели превышают допустимые пределы и процесс деполяризации мембран нейронов приобретает необратимый характер. Так, у больных с каротидным ишемическим инсультом в первые 6 часов заболевания концентрация глутамата в цереброспинальной жидкости в 18 раз превышала контрольные значения. Установлено, что динамика концентраций нейротрансмиттерных аминокислот зависит от тяжести ишемии 
мозга и имеет прогностическое значение. Накопление в синаптической щели высоких концентраций возбуждающих нейротрансмиттерных аминокислот обусловливает перевозбуждение глутаматных рецепторов [38, 42]. Наибольшее значение в процессе развития ишемической патологии мозга играет активность ионотропных глутаматных рецепторов: N-метил-D-аспартат (NMDA), $\alpha$-амино-3-гидрокси-5-метил-4-изоксазол-пропионовой кислоты (AMPA), каиновой кислоты (К) и $\alpha$-2-амино-4-фосфорномасляной кислоты $\left(\mathrm{L}-\mathrm{AP}_{4}\right) . \mathrm{B}$ настоящее время наиболее изучены NMDA-рецепторы. Перевозбуждение NMDA-рецепторов приводит к «шоковому» открытию $\mathrm{Ca}^{2+}$-каналов и мощному притоку $\mathrm{Ca}^{2+}$ в нейроны с внезапным увеличением его концентрации. NMDA-рецептор представляет собой сложное надмолекулярное образование, имеющее несколько сайтов регуляции: сайт специфического связывания медиатора (глутаматный сайт), сайт специфического связывания коагониста (глициновый сайт), а также сайты, расположенные на мембране (полиаминовый сайт) и в ионном канале, сопряженном с рецептором (фенциклидиновый сайт). Исследованиями, проведенными в Институте мозга РАН, было установлено, что в сыворотке крови больных с острым ишемическим инсультом титр аутоантител к фенциклидин-связывающему белку NMDA-рецепторов в 5 раз превышал норму уже через 3 часа от начала заболевания. Степень повышения титра аутоантител к глутаматным NMDA-рецепторам коррелировала с тяжестью инсульта $[4,42]$. Развитие эксайтотоксичности глутамата в условиях ишемии может происходить и при активации АМРА и каинатных рецепторов. Так, активация AMPA и каинатных рецепторов в ишемизированном мозге усиливает входящий ток $\mathrm{Na}^{+}$(через АMPА и потенциалзависимые натриевые каналы), а также ионов $\mathrm{Cl}^{-}$и $\mathrm{H}_{2} \mathrm{O}$ и вызывает «осмотическое набухание» клеток и снятие магниевого блока NMDA-рецепторов, в результате чего происходит кратковременная деполяризация постсинаптической мембраны и усиление притока $\mathrm{Ca}^{2+}$ в клетку через агонист-зависимые (NMDA-рецепторы) каналы [47-51]. Удельный вес AMPA/каинатной эксайтотоксичности может увеличиваться за счёт повышения внеклеточного лактат-ацидоза. Рядом работ показано, что NMDA и AMPA-эксайтотоксичность является преобладающим механизмом, запускающим каскад дальнейших патобиохимических реакций, приводящих к гибели клеток мозга. Таким образом, первый этап глутамат-кальциевого каскада характеризуется нарушением энергетического метаболизма (активацией гликолиза, дискоординацией в цикле Кребса, торможением дыхания в митохондриальной цепи, дефицитом АТФ), усилением выброса возбуждающих аминоацидергических нейротрансмиттеров, развитием глутаматной эксайтотоксичности и «шоковым» притоком $\mathrm{Ca}^{2+}$ в нейроны [6-12].

Второй этап - алплификация характеризуется внутриклеточным накоплением ионов $\mathrm{Ca}^{2+}$, распространяющейся глутаматной эксайтотоксичностью. Значимость механизмов кальций-опосредованной эксайтотоксичности в развитии острой церебральной ишемии и формировании инфаркта мозга подтверждена серией работ. Так, нарастание внутриклеточного уровня $\mathrm{Ca}^{2+}$ в сочетании с повышением диацилглицерола меняет активность ферментов, 
модифицирующих мембранные белки, и особенно - глутаматные рецепторы, увеличивая тем самым чувствительность нейронов к возбуждающим сигналам глутамата. В результате этого повышенная возбудимость может способствовать дальнейшему накоплению $\mathrm{Ca}^{2+}$ и усилению выделения глутамата, причем одна массивно деполяризованная клетка индуцирует количество глутамата необходимое для возбуждения соседних нейронов. Таким образом, происходит повреждение соседних нейронов, индуцирование дальнейшего выброса нейротрансмиттера и развитие механизма распространения глутаматной эксайтотоксичности $[4,7,49]$. Альтернативной причиной повышения концентрации внеклеточного глутамата в соседних с ишемизированными клетками нейронах является «распространяющаяся депрессия» - феномен, при котором развивается переходящее нарушение ионного градиента мембран клеток мозга, имеющее форму волны, движущейся по тканям мозга. Для распространяющейся депрессии характерны повышение уровня $\mathrm{Ca}^{2+}$, $\mathrm{Na}^{+}, \mathrm{Cl}^{-}$и $\mathrm{H}_{2} \mathrm{O}$ внутри нейрона, a $\mathrm{K}^{+}$- снаружи. Имеются данные об участии распространяющейся депрессии в ухудшении митохондриального дыхания, усилении лактат-ацидоза и в расширении инфарктной зоны при фокальной ишемии. Кроме того, ионы $\mathrm{Ca}^{2+}$ усиливают образование арахидоновой кислоты под действием фосфолипазы А, образование ксантиноксидазы из ксантиндегидрогеназы.

В последние годы появились данные о том, что наряду с $\mathrm{Ca}^{2+}$ в механизмах ишемического повреждения мозга принимают участие ионы $\mathrm{Zn}^{2+}$, в связи с чем возникло понятие $\mathrm{Zn}^{2+}$-опосредованной эксайтотоксичности. Причем $\mathrm{Zn}^{2+}$-опосредованная гибель нейронов наиболее часта при глобальной ишемии. Механизм $\mathrm{Zn}^{2+}$-опосредованной эксайтотоксичности заключается в том, что $\mathrm{Zn}^{2+}$ воздействует на ряд рецепторов и каналов подобно глутамату, особенно в отношении $\mathrm{CA}_{3}$-нейронов. Кроме того, избыток $\mathrm{Zn}^{2+}$ в нейронах усиливает их деполяризацию, снижает АТФ и, усиливая явления энергодефицита, инициирует процессы апоптоза. Также $\mathrm{Ca}^{2+}$ участвует в ферментативном распаде фосфолипидов наружной мембраны нейрона. Так, уже через 30 минут ишемии разрушается 16 \% мембранного фосфотидилэтаноламина и высвобождается $37 \%$ арахидоновой кислоты, метаболизм которой сопряжен с образованием простагландинов, тромбоксанов, гидрокси- и гидропероксижирных кислот, лейкотриенов и липоперекисей. Описана роль избытка $\mathrm{Ca}^{2+}$ в подавлении активности каталазы в ишемизированном мозге [13-15].

третий этап - экспрессия. На этом этапе происходит развитие оксидативного стресса и накопление низкомолекулярных цитотоксических продуктов. Развитие оксидативного стресса в условиях ишемии головного мозга протекает в несколько стадий и наиболее важной является продукция АФК. В настоящее время выделяют десять видов АФК, имеющих разную реакционную способность, характеризующихся различным временем жизни и выполняемыми функциями [16]. 


\section{2. НАРУШЕНИЯ ЭНЕРГЕТИЧЕСКОГО МЕТАБОЛИЗМА ГОЛОВНОГО МОЗГА В УСЛОВИЯХ ИШЕМИИ И ФОРМИРОВАНИЕ МИТОХОНДРИАЛЬНОЙ ДИСФУНКЦИИ}

Первый этап гипоксических нарушений нервной ткани характеризуется сосудистыми и гематологическими изменениями, которые вызывают начальное снижение и последующие изменения локального мозгового кровотока, - так называемая циркуляторная гипоксия. Второй - вызывающий изменения химических процессов в клетке в результате ишемии и ведущий к некрозу нейронов, глии и других клеток мозга, - так называемая биоэнергетическая гипоксия. Среди известных молекулярных и клеточных изменений, вызываемых кислородным голоданием, основное место занимают нарушения тканевого дыхания, биологического окисления субстратов и процесса энергообразования, который происходит в митохондриях, где находятся ферменты и субстраты цикла Кребса и дыхательной цепи. Вследствие кислородного голодания изменяется возбудимость и проницаемость клеточных мембран и ультраструктуры митохондрий, нарушается ионное равновесие электролитов, ионы калия и ферменты в значительном количестве поступают в межклеточную жидкость, митохондрии клеток ЦНС набухают и разрушаются $[6,7,13,54,55]$. При снижении мозгового кровотока существуют критические пороги ишемии:

1) подавление электрической активности нейронов;

2) нарушение целостности клетки.

Клетки, находящиеся между этими двумя порогами, образуют «ишемическую полутень», или пенумбру, они могут уже не функционировать, но все еще оставаться живыми $[4,52,53]$.

Для корректного фармакологического вмешательства в патологический процесс при ишемии оценка степени митохондриальных нарушений имеет существенное значение. Это важно как для формирования представлений о сути и степени происходящих на тканевом уровне процессов, так и для разработки плана терапевтической коррекции возникшего патологического состояния. Степень выраженности метаболических нарушений в головном мозге связана со степенью зависимости его тканевых элементов от эффективности аэробного окисления [54].

Развитие энергетического дефицита и лактат-ацидоза запускает патобиохимические реакции, которые протекают во всех основных клеточных пулах ЦНС и вызывают:

а) нейрональную дисфункцию;

б) астроцитоз;

в) микроглиальную активацию;

г) дисфункцию трофических факторов.

Исходом данных изменений является формирование инфаркта мозга, происходящее по двум основным механизмам: некротической смерти нейрона и апоптоза. 
В основе этиопатогенеза церебральной ишемии также лежат вышеперечисленные причины гипоксии, однако более тяжелое течение последнего обусловлено следующими ключевыми моментами:

1) сдавлением мозговой ткани излившейся кровью (нервная ткань в этом месте гибнет);

2) выраженностью факторов компрессии и отека мозга (усугубление гипоксии, возникновение гипоксии застойного характера в результате сдавливания мозговых сосудов);

3) компенсаторным повышением внутричерепного давления за счет активации излившейся кровью интражелудочковых хориоидальных сплетений, вырабатывающих ликвор;

4) выраженностью фактора интоксикации продуктами распада вследствие диапедеза крови, ее компонентов (активация перекисного окисления липидов продуктами распада);

4) большей выраженностью вторичной ишемии и гипоксии;

5) влиянием вазоконстрикторных веществ излившейся крови [52, 56-58].

Возрастающий метаболический ацидоз и гипергликемия препятствуют восстановлению митохондриальных функций. Снижение $\mathrm{pH}$ внутри- и внеклеточной среды оказывает непосредственное цитотоксическое действие, вызывая «разрыхление» клеточных мембран, изменяя их физико-химические свойства, способствуя повышенной проницаемости нейронов и эндотелия сосудов. Существует предположение, что одним из наиболее важных механизмов повреждающего действия ацидоза является морфофункциональное разобщение нейронально-глиальных связей [58].

Ионам $\mathrm{Ca}^{2+}$ принадлежит центральная роль в регуляции многих клеточных функций. Изменение концентрации внутриклеточного свободного $\mathrm{Ca}^{2+}$ является сигналом для активации или ингибирования ферментов, которые, в свою очередь, регулируют метаболизм, сократительную и секреторную активность, адгезию и клеточный рост. Источники $\mathrm{Ca}^{2+}$ могут быть внутри- и внеклеточными. При повышении концентрации $\mathrm{Ca}^{2+}$ в клетке в ответ на поступающие сигналы специфическая протеинкиназа катализирует фосфорилирование множества внутриклеточных ферментов-мишеней, регулируя тем самым их активность. Показано, что в состав киназы фосфорилазы b, активируемой ионами $\mathrm{Ca}^{2+}$, как и NO-синтазы, входит кальмодулин в качестве субъединицы. При повышении концентрации кальция связывание $\mathrm{Ca}^{2+}$ с кальмодулином сопровождается конформационными его изменениями, и в этой $\mathrm{Ca}^{2+}$-связанной форме кальмодулин модулирует активность множества внутриклеточных белков. В результате меняется не только активность, но и регуляторные и каталитические свойства многих ферментных систем клетки: ионных каналов, внутриклеточных структурных элементов и генетического аппарата $[4,42,58]$.

Основными биохимическими процессами, происходящими в митохондриях и имеющими отношение к энергообмену, являются: цикл трикарбоновых кислот (цикл Кребса), окисление жирных кислот, карнитиновый цикл, транспорт электронов в дыхательной цепи и окислительное фосфорилирование [6, 7]. 
Снижение перфузии ткани мозга, за счет вторичного вазоспазма сосудов и сдавливания излившейся кровью, сопровождается уменьшенной доставкой кислорода из кровеносного русла к клеткам, где он участвует в реакциях аэробного образования энергии, так как является субстратом терминального фермента митохондриальной дыхательной цепи - цитохромоксидазы. Развивающееся вслед за этим гипоксическое состояние представляет собой сложный фазный процесс, в основе которого лежат последовательные изменения свойств митохондриальных ферментных комплексов.

Работами Л. Д. Лукьяновой с соавторами установлены последовательные этапы развития гипоксических изменений в ткани мозга [6, 7].

Первая (колпенсаторная) стадия процесса связана с инактивацией никотинамидадениннуклеотид (НАД/НАДН)-зависимого пути окисления и активацией компенсаторных метаболических потоков, позволяющих сохранить энергосинтезирующую функцию цитохромного участка и способность к окислительному фосфорилированию. Особую роль в компенсаторных процессах играет сукцинатоксидазный путь окисления, о котором речь пойдет позже [6-11]. Изменения функции дыхательной цепи начинаются на субстратном ее участке, в области митохондриального ферментного комплекса-I. Наиболее ранним ответом на гипоксическое воздействие является усиление интенсивности НАДН-зависимого пути окисления и его вклада в общее дыхание, чему соответствует увеличение максимальной активности ротенончувствительной НАДН-цитохром-С-оксидоредуктазы. Связанное с этим усиление потока электронов от НАД-зависимых субстратов может быть причиной увеличения на раннем этапе гипоксии степени восстановленности цитохромоксидазы, которая корелирует также с повышением содержания АТФ и усилением функциональной активности нейронов [4, 10, 42, 64-68].

Нарастание гипоксического состояния приводит вслед за активацией к подавлению функционирования митохондриального ферментного комплекса-I: снижаются интенсивность окисления НАД-зависимых субстратов и связанного с ним окислительного фосфорилирования, чувствительность дыхания к специфическим ингибиторам НАД-зависимого участка дыхательной цепи. Восстанавливаются дыхательные переносчики митохондриального ферментного комплекса-I (пиридиннуклеотиды и флавины), что отражает нарушение переноса восстановительных эквивалентов через этот участок. Следствием перечисленных изменений является потеря клеткой способности к окислению ряда энергетических субстратов даже при наличии их в среде. Таким образом, уже на ранней стадии гипоксии формируется «субстратный голод», особенно характерный для ишемических процессов [69].

Дальнейшее усиление кислородной недостаточности сопровождается присоединением к нарушениям, характерным для первой стадии гипоксии, подавления электронтранспортной цепи в области цитохромов В-С, что составляет суть второй (неколпенсируелой) стадии. Несмотря на то, что возможность образования АТФ за счет функционирования митохондриального комплекса-IV еще сохраняется, активность цитохромоксидазы снижается, что приводит к прекращению (или резкому подавлению) поступления электронов 
от субстратного участка дыхательной цепи (как НАД-зависимого, так и сукцинатоксидазного) $[10,56]$. Вследствие этого отмечается уменьшение содержания АТФ и появляется линейная зависимость дыхания и концентрации АТФ от парциального давления кислорода.

Полная инактивация цитохромоксидазы наблюдается в условиях, близких к аноксическим, и отражает прекращение дыхания и окислительного фосфорилирования. Это третья - терлинальная - стадия гипоксии.

Стадии гипоксии коррелируют с фазными изменениями содержания АТФ и ведущих энергозависимых процессов в клетках. Только на последних этапах кислородного голодания уровень энергетического дефицита становится достаточным для запуска основных механизмов, приводящих к нарушению жизнедеятельности и гибели клетки. Стремительное увеличение концентрации аденозинмонофосфата (АМФ) сопровождается активацией протеинкиназной системы, что является дополнительным механизмом разрушения клеточных мембран.

Гликолиз не предотвращает снижения уровня АТФ на поздних стадиях кислородного голодания [10,68]. Однако существует большое число экспериментальных данных, указывающих на то, что увеличение утилизации глюкозы астроцитами, вследствие глутамат-индуцированной активации $\mathrm{Na}^{+} / \mathrm{K}^{+}$АТФ-азы, приводит к ее метаболизации по гликолитическому пути до лактата, который, высвобождаясь, трансформируется нейронами в пируват и используется как адекватный энергетический субстрат [4-10].

Считают, что пентозофосфатный путь и гликолиз, протекающие в цитозоле, взаимосвязаны и способны переключаться друг на друга в зависимости от соотношения концентраций промежуточных продуктов, образовавшихся в клетке. Гликолиз - это совокупность реакций превращения глюкозы в лактат. У аэробных организмов гликолиз служит как бы прелюдией к циклу трикарбоновых кислот (циклу Кребса). Десять реакций гликолиза протекают в цитозоле. Гликолитический путь играет двоякую роль: приводит к генерированию АТФ в результате распада глюкозы, и он же поставляет строительные блоки для синтеза клеточных компонентов. Реакции гликолитического пути в физиологических условиях легкообратимы, кроме реакций, катализируемых гексокиназой, фосфофруктокиназой и пируваткиназой. Фосфофруктокиназа - наиболее важный регуляторный элемент (фермент) в процессе гликолиза - ингибируется высокими концентрациями АТФ и цитрата и активируется АMФ [64-67].

Особенности энергетических изменений в ткани мозга зависят и от локализации ишемического процесса. В большинстве областей мозга реперфузия сопровождается полным или частичным возвращением энергетического метаболизма к нормальным показателям: увеличиваются концентрации АТФ и креатинфосфата, снижается уровень лактата. В то же время в селективно чувствительных к ишемии нейронах $\left(\mathrm{CA}_{1}\right.$ зона гиппокампа, дорсолатеральный отдел стриатума) изменения энергетического метаболизма имеют двухфазный характер: вслед за кратковременной нормализацией отмечается его вторичное торможение [69-73]. Развитие постишемической гипоксии приводит к значи- 
тельному нарушению функций митохондрий, уменьшению производства никотинамиддинуклеотидфосфата (НАДФ) в синаптосомах, что оказывает дополнительное воздействие на процессы необратимого повреждения ткани мозга [73]. Скорость развития аноксической деполяризации мембран нейронов зависит от глубины и длительности ишемии и ведет к некротической смерти клетки. Вероятно, энергетический дефицит является главенствующим механизмом гибели нейронов в области центрального инфаркта («ядерной» зоне ишемии). В зоне пенумбры более «мягкая» ишемия инициирует развитие комплекса биохимических преобразований, поддерживаемых реакцией генома и молекулярными последствиями ишемического процесса: «включением» генов раннего реагирования с вторичной экспрессией генов, кодирующих цитокины, молекулы адгезии, другие провоспалительные и трофические факторы, а также гены апоптоза [73-77].

Снижение скорости окислительного фосфорилирования на начальных этапах гипоксии приводит к снижению синтеза белков и экспрессии генов, уменьшению коэффициента АТФ/ADФ+AMФ. При дальнейшем снижении мозгового кровотока активируется фермент фосфофруктокиназа, усиливается анаэробный гликолиз, а потом отмечается окончательный переход на анаэробное дыхание, что адаптирует клетку к гипоксии, однако запасы гликогена истощаются. Это, в свою очередь, влечет за собой накопление недоокисленного лактата, снижение пирувата с развитием лактат-ацидоза - вплоть до развития отека мозга. Наблюдается также увеличение активности лактатдегидрогеназы и уменьшение активности сукцинатдегидрогеназы, поставляющей электроны в дыхательную цепь митохондрий, что указывает на нарушение процессов энергообразования в ишемизированном мозге. В таких условиях аэробное расщепление глюкозы не происходит, что приводит к тяжелому энергодефициту $[10,77,78]$.

В дальнейшем наблюдается дестабилизация клеточных мембран, нарушение работы ионных каналов, повреждение калий-натриевого насоса, калий (возбуждающий нейротрансмиттер) выходит из клетки, что делает ее менее возбудимой, а натрий избыточно поступает в клетку, за натрием по осмотическому градиенту в клетку поступает и накапливается излишнее количество воды, покидающей интерстиций, что приводит к гипергидратации клеток, мутному набуханию, а затем баллонной дистрофии. Важнейшая роль в этом процессе принадлежит глутаматным рецепторам [78].

Для лучшего понимания механизмов нарушения энергетического метаболизма остановимся более подробно на локализации ключевых ферментов, участвующих в нем. Ферменты цикла трикарбоновых кислот (ЦТК) локализованы в митохондриальном матриксе, где они находятся либо в свободном состоянии, либо на внутренней поверхности внутренней митохондриальной мембраны; в последнем случае облегчается перенос восстановительных эквивалентов на ферменты дыхательной цепи, локализованные во внутренней митохондриальной мембране [79-83]. В матриксе митохондрий находятся также ферменты b-окисления жирных кислот, в связи с чем возникает необходимость в механизмах транспорта метаболитов и нуклеотидов через внутреннюю мембрану. Сукцинатдегидро- 
геназа локализована на внутренней поверхности внутренней митохондриальной мембраны, где она передает восстановительные эквиваленты дыхательной цепи на уровне убихинона (минуя первую окислительно-восстановительную петлю). Глицерол-3-фосфатдегидрогеназа находится на наружной поверхности внутренней мембраны, где она участвует в функционировании глицерофосфатного челночного механизма [84-85]. Хотя ЦТК составляет часть аэробного метаболизма, ни в одной из реакций этого цикла, приводящих к образованию НАДН и ФАДН, молекулярный кислород не принимает прямого участия; это происходит только в завершающей серии катаболических реакций, протекающих на внутренней мембране. Митохондриальная дыхательная цепь, находящаяся во внутренней мембране, способна перемещать протоны; при прохождении электронов по дыхательной цепи происходит «откачивание» $\mathrm{H}^{+}$из матрикса. Митохондриальный АТФ-синтетазный комплекс тоже перемещает протоны через внутреннюю мембрану. Поскольку этот процесс обратим, фермент может не только использовать энергию гидролиза АТФ для переноса $\mathrm{H}^{+}$через мембрану, но при достаточно большом протонном градиенте протоны начинают «течь» через АТФ-синтетазу в обратном направлении, что сопровождается синтезом АТФ. Внутренняя митохондриальная мембрана содержит ряд белков-переносчиков, осуществляющих транспорт необходимых метаболитов и неорганических ионов [6, 83-88].

Окислительное фосфорилирование возможно благодаря тесной ассоциации переносчиков электронов с белковыми молекулами. Белки направляют электроны по дыхательной цепи так, что они последовательно переходят от одного ферментного комплекса к другому, не «перескакивая» через промежуточные звенья. Внутренняя мембрана митохондрий отличается необычно высоким содержанием белка - в ней по весу примерно 70 \% белка и 30 \% фосфолипидов.

Основными комплексами дыхательной цепи являются:

I. НАДН-убихинон-оксидоредуктаза. Принимает электроны и протоны от НАДН Н+; протоны выбрасываются в межмембранное пространство, электроны передаются на КоQ.

II. Сукцинат-убихинон-оксидоредуктаза. Принимает электроны и протоны от субстратов в матриксе и передает их на убихинон. Убихинон - липофильная молекула, хинон, легко перемещается по мембране, принимает электроны и протоны от I и II комплексов дыхательной цепи и передает электроны на III комплекс. Цитохромы, входящие в состав дыхательной цепи, представляют собой железосодержащие белки, простетическая группа которых представлена гемом. Цитохромы могут переносить только электроны за счет атома железа с переменной валентностью, входящего в состав гема:

$$
\mathrm{Fe}^{3+}+\overline{\mathrm{e}} \leftrightarrow \mathrm{Fe}^{2+}
$$

III. Убихинон-цитохром-С-оксидоредуктаза. Переносит электроны с убихинона на цитохром С. Одновременно за счет энергии, выделившейся при переносе, из матрикса переносятся протоны в межмембранное пространство.

IV. Цитохром-С-оксидаза. Переносит электроны с цитохрома C непосредственно на кислород. Цитохромы А-А , помимо атомов железа, содержат атомы меди, поэтому комплекс одновременно осуществляет полное 
(4-электронное) восстановление молекулы кислорода. Энергия переноса электронов используется на перекачивание в межмембранное пространство протонов [6-10].

Два компонента, переносящие электроны между тремя главными ферментными комплексами дыхательной цепи, - убихинон и цитохром C - быстро перемещаются путем диффузии в плоскости мембран.

Столкновения между этими подвижными переносчиками и ферментными комплексами вполне позволяют объяснить наблюдаемую скорость переноса электронов (каждый комплекс отдает и принимает один электрон каждые 5-10 миллисекунд). Поэтому нет необходимости предполагать структурную упорядоченность цепи белков-переносчиков в липидном бислое. В самом деле, ферментные комплексы, видимо, существуют в мембране как независимые компоненты и упорядоченный перенос электронов обеспечивается только специфичностью функциональных взаимодействий между компонентами цепи [11].

Сохранение барьерной функции митохондриальных мембран - тоже немаловажный фактор эффективной энергопродукции. Ионные каналы являются интегральными белками мембран, которые образуют поры, позволяющие проходить специфическим ионам с помощью пассивной диффузии. Большинство, если не все, ионные каналы подвергаются конформационным изменениям из закрытого в открытое состояние и, будучи однажды открытыми, каналы позволяют проходить тысячам ионов. Открытие и закрытие каналов может контролироваться разными способами, включая электрическое напряжение, связывание лигандов, таких как внутриклеточные $\mathrm{Ca}^{2+}$ или внеклеточные нейротрансмиттеры, и посттранскрипционные модификации, такие как фосфорилирование. Нарушение проницаемости митохондриальных мембран, вследствие открытия пор, сводит на нет синтез макроэргов [80-83].

На сегодняшний день не вызывает сомнений высокая значимость митохондрий в жизнедеятельности эукариотических клеток. Доминирующая роль этих органелл в продукции АТФ, реализации процессов программированной гибели клетки, участие в генерации активных форм кислорода и депонировании ионов кальция предопределяет участие нарушений митохондриальных функций в развитии многих патологических процессов. В настоящее время известно, что основными проявлениями митохондриальной дисфункции являются снижение уровня АТФ в клетке, активизация механизмов гибели клетки и продукция митохондриями АФК. Известно, что в процессе функционирования дыхательной цепи митохондрий происходит образование незначительных количеств супероксидного радикала $\left(\mathrm{O}^{-2}\right)$, являющегося побочным продуктом дыхательных комплексов. В функционально полноценных митохондриях действие митохондриальной антиоксидантной системы, включающей глутатион, тиоредоксин-2, глутатион-пероксидазу, фосфолипид-гидропероксидглутатион-пероксидазу и Mn-супероксиддисмутазу, предотвращает повреждение митохондриальных структур активными формами кислорода [2]. При нарушении переноса электронов между компонентами дыхательной цепи генерация митохондриями О•-2 существенно усиливается. Недостаточность функций митохондриальной антиоксидантной системы в этом случае способствует раз- 
витию окислительного стресса, активизации самоподдерживающихся процессов перекисного окисления липидов, окислительным повреждениям белков и нуклеиновых кислот. В конечном итоге эти события приводят к снижению функций клетки, накоплению мутаций в митохондриальной и ядерной ДНК. В свою очередь, повреждение митохондриальных генов способствует нарушению процесса переноса электронов в дыхательной цепи, результатом чего является дополнительное усиление продукции свободных радикалов в митохондриях [14, 84-87].

В точных биохимических исследованиях было установлено, что нарушение кислородного режима тканей, гиперпродукция эксайтотоксичных аминокислот, снижение нормальной аккумуляции $\mathrm{Ca}^{2+}$ митохондриями, повреждение мембраны митохондрий АФК усиливает открытие пор и высвобождение апоптогенных белков из поврежденных митохондрий [77-80]. В этом контексте существенна роль одного из нейротрофических факторов - фактора некроза опухоли (TNF- $\alpha$ ), с которым связаны открытие пор в митохондриях, последующее нарушение их мембран и развитие митоптоза. Митохондриальная пора представляет собой канал, проходящий через обе митохондриальные мембраны и состоящий из трех белков: транслокатора адениновых нуклеотидов, потенциалзависимого анионного канала (порина) и бензодиазепинового рецептора. Когда этот комплекс связывается с $\mathrm{Ca}^{2+}$, через мембранную пору могут проходить вещества с небольшой молекулярной массой. Это приводит к падению мембранного потенциала и набуханию матрикса, целостность внешней мембраны неизбежно нарушается, и из межмембранного пространства в цитоплазму выходят белки апоптоза. Их несколько: фактор, индуцирующий апоптоз (APOptosis-inducing factor - AIF), вторичный митохондриальный активатор каспаз (second mitochondria-derived activator of caspases - Smac) и некоторые прокаспазы. Индуцирующий фактор направляется прямо в ядро, где вызывает деградацию ДНК. Наряду со специфически апоптозными белками, из митохондрии через открытую пору выходит цитохром С, который в норме служит конечным звеном электронтранспортной цепи. В цитоплазме этот белок связывается с белком Apaf-1 (APOptotic protease activating factor-1 - активирующий протеазу фактор-1) и формирует апоптосомный комплекс. Он с помощью Smac и еще одного фактора (Omi/HtrA2) активирует прокаспазу-9, и, став каспазой-9, превращает два других профермента в каспазы-3 и -7; а они уже расщепляют структурные белки, приводя к появлению биохимических и морфологических признаков апоптоза [81-84].

В числе биохимических признаков можно назвать, в частности, переход фосфатидилсерина в наружный мембранный слой и фрагментацию ДНК под действием АФК и NO. В этой мембране фосфатидилсерин обычно присутствует только во внутреннем липидном слое. Такое асимметричное распределение данного фосфолипида обусловлено действием особой транспортной АТРазы, переносящей фосфатидилсерин из внешнего липидного слоя плазматической мембраны во внутренний. Эта АТРаза либо инактивируется окисленной формой фосфатидилсерина, либо просто не узнает окисленный фосфолипид. Вот почему окисление фосфатидилсерина посредством АФК ведет к его появлению 
во внешнем слое плазматической мембраны. По-видимому, существует специальный рецептор, обнаруживающий фосфатидилсерин в наружном липидном слое. Предполагается, что этот рецептор, связав фосфатидилсерин, посылает внутрь клетки сигнал апоптоза [85].

Фосфатидилсерин играет ключевую роль в так называемом принудительном апоптозе, вызываемом определенным типом лейкоцитов. Клетка с фосфатидилсерином во внешнем слое клеточной мембраны узнается этими лейкоцитами, которые посылают ее в апоптоз. Один из апоптогенных механизмов, используемых лейкоцитами, состоит в том, что лейкоциты начинают выделять в межклеточное пространство вблизи клетки-мишени белки перфорин и гранзимы. Перфорин проделывает отверстия во внешней мембране клетки-мишени. Гранзимы входят в клетку и запускают в ней апоптоз.

Иной способ, используемый лейкоцитом для принуждения клеткимишени войти в апоптоз, состоит в ее бомбардировке супероксидом, образующимся снаружи лейкоцита посредством специальной трансмембранной дыхательной цепи плазматической мембраны. Эта цепь окисляет внутриклеточный NADPH, с которого электроны переносятся на флавин и далее - на особый цитохром В, способный окисляться кислородом с выделением супероксида снаружи лейкоцита. Супероксид и другие образующиеся из него АФК окисляют фосфатидилсерин плазматической мембраны клетки-мишени, тем самым усиливая апоптозный сигнал, посылаемый клетке этим фосфолипидом [86-87].

Кроме того, лейкоциты включают фактор некроза опухолей (tumor necrosis factor, TNF). TNF связывается с рецептором на внешней стороне плазматической мембраны клетки-мишени, что активирует сразу несколько параллельных путей запуска апоптоза. В одном из них происходит образование активной каспазы-8 из прокаспазы-8. Каспаза-8 - протеаза, расщепляющая цитозольный белок Bid с образованием его активной формы, tBid (truncated Bid). tBid меняет конформацию другого белка, Вах, вызывая образование проницаемого для белков канала во внешней мембране митохондрий, что приводит к их выходу из межмембранного пространства в цитозоль.

Разнообразие путей АФК-зависимого апоптоза иллюстрирует рис. 1.3. Истинная картина, по всей вероятности, еще более сложна, так как помимо TNF есть и другие внеклеточные индукторы апоптоза (цитокины), действующие каждый через свой собственный рецептор. Кроме того, существуют антиапоптозные системы, противостоящие проапоптозным системам. Среди них белки типа bcl-2, тормозящие проапоптотическую активность Вах; уже упоминавшиеся ингибиторы каспаз (IAP); белок NFkB (nuclear factor kB), индуцируемый посредством TNF. NFkB включает группу генов, среди которых есть те, которые кодируют супероксиддисмутазу и другие антиоксидантные и антиапоптозные белки [88].

Указанные сложности отражают то очевидное обстоятельство, что для клетки решение покончить с собой является крайней мерой, когда исчерпаны все другие возможности предотвращения ее ошибочных действий. 


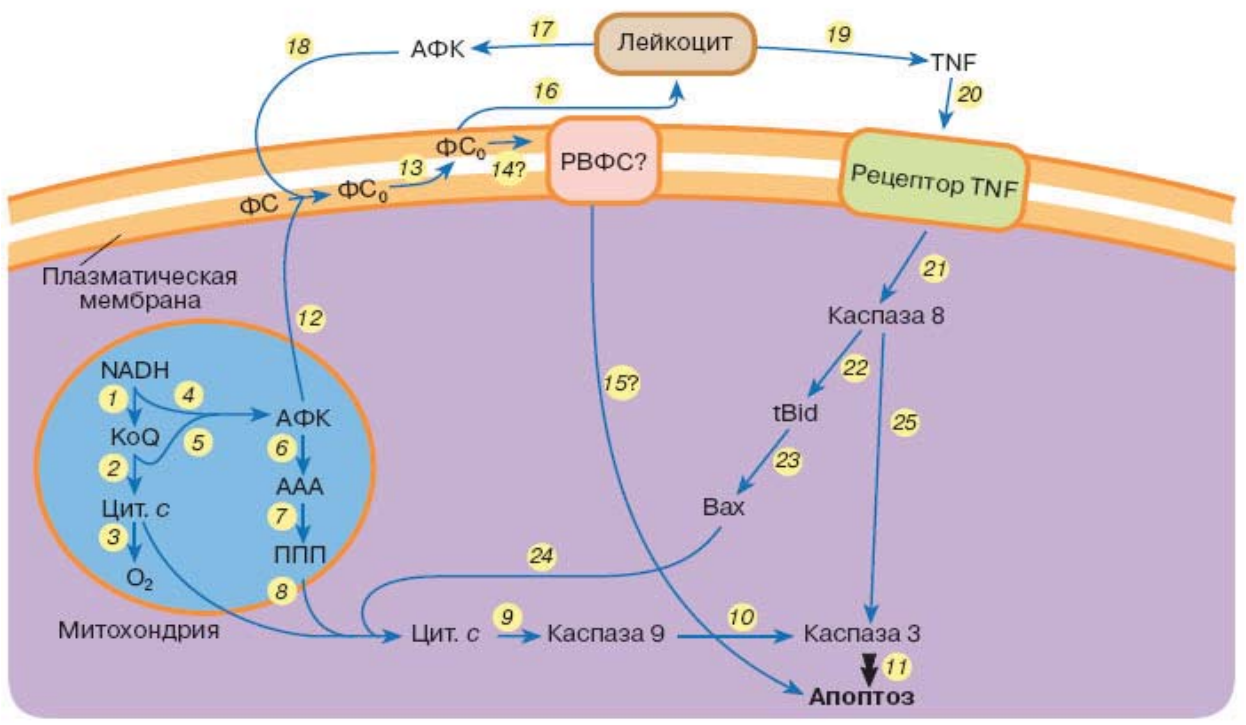

Рис. 1.3. Некоторые пути передачи апоптозных сигналов (по В. П. Скулачеву):

1-3 - митохондриальная дыхательная цепь; 4, 5 - образование АФК дыхательной цепью; 6,7 - превращение ATP/ADP-антипортера (AAA) в пору (ППП) во внутренней митохондриальной мембране под действием АФК; 8 - выход цитохрома C, AIF и других проапоптозных белков (не показаны) из-за разрыва внешней мембраны митохондрий, произошедшего вследствие открытия ППП; 9-10 - активация каспазы-9 и далее каспазы-3 вследствие выхода цитохрома C; 11 - апоптоз под действием каспазы-3; 12 - окисление фосфатидилсерина (ФС) внутреннего фосфолипидного слоя плазматической мембраны клетки активными формами кислорода, продуцируемыми митохондриями; 13 - появление ФС и окисленного ФС $\left(\Phi_{0}\right)$ во внешнем фосфолипидном слое плазматической мембраны; 14 - связывание $\Phi_{0}$ или ФС с рецептором внешнего фосфатидилсерина (РВФС), отслеживающим их появление во внешнем фосфолипидном слое; 15 - индукция апоптоза, включаемая комплексом РВФС-ФС; 16 - стимуляция проапоптозной активности лейкоцитов, отслеживающих появление ФС снаружи клеткимишени. Эта стимуляция состоит в: а) продукции АФК дыхательной цепью плазматической мембраны лейкоцита (17), что приводит к дальнейшему окислению ФС в клетке-мишени (18); и б) выделении TNF (19), активирующего соответствующий рецептор клетки-мишени (20); 2124 - цепь событий, ведущих к выходу митохондриальных белков без участия АФК; 25 - прямая активация каспазы-3 посредством каспазы-8.

Из морфологических признаков наиболее характерны «отшелушивание» клетки от матрикса, сморщивание мембраны, сжатие ядра и формирование пузырьков с клеточным содержимым - апоптозных телец. Выходу цитохрома $\mathrm{C}$ в цитоплазму способствуют снижение $\mathrm{pH}$ при развитии лактат-ацидоза, усиление окислительной модификации митохондриальных белков и липидов. Последнюю реакцию как раз и вызывают АФК, которые неизбежно образуются в результате паразитарных энергетических реакций. Цитохром С может высвобождаться в ответ на повышение концентрации ионов $\mathrm{Ca}^{2+}$, которое вызывает открывание поры, а также контролироваться белками семейства bcl-2. Именно они регулируют апоптоз на уровне митохондрий. В запуске апоптоза, 
вызванного повреждениями ДНК, активацией онкогенов и гипоксией, принимает участие белок-53 (р53), взаимодействуя с Вах, стимулируя «рецепторы смерти" и апоптозные гены. р53 активирует модулятор суицида PUMA (p53 upregulated modulator of APOptosis), который затем связывает bcl-2 и выводит из строя этот препятствующий апоптозу белок. Тем самым выход цитохрома $\mathrm{C}$ из митохондрий уже ничем не сдерживается. Некоторые белки, связывающие ионы кальция, например ALG-2, кодируемый одноименным геном (APOptosislinked gene-2), тоже принимают участие в развитии нейроапоптоза. Так, взаимодействием ALG-2 и белка Alix (ALG-interacting protein X, известный и как AIP1) осуществляется регуляция нейроапоптоза [89-93].

Приняв во внимание изложенное выше, можно представить себе следующий сценарий событий, призванных защитить организм от АФК, генерируемых митохондриями: образовавшись в митохондриях, АФК вызывают открытие ППП и как следствие - выход цитохрома С в цитозоль, что немедленно включает дополнительные антиоксидантные механизмы, а затем митоптоз. Если в митоптоз уходит лишь небольшая часть внутриклеточной популяции митохондрий, концентрации цитохрома $\mathrm{C}$ и других митохондриальных проапоптотических белков в цитозоле не достигают значений, необходимых, чтобы активировать апоптоз. Если же все больше и больше митохондрий становятся суперпродуцентами АФК и «открывают кингстоны», эти концентрации возрастают, и начинается апоптоз клетки, содержащей много дефектных митохондрий. В результате происходит очистка ткани от клеток, митохондрии которых образуют слишком много АФК [94].

Дополнительным фактором повреждения митохондрий является «ответ на нарушение нативной структуры белков» (unfolded protein response - UPR), активизирующийся в условиях гипоксии. В настоящее время показано, что эндоплазматический ретикулум (ЭР), находящийся в состоянии стресса, опосредованного UPR, может способствовать развитию дегенеративных изменений в митохондриях за счет высвобождения в цитоплазму из ЭР ионов кальция и ассоциированного с мембраной ЭР белка Ire1 [15]. На сегодняшний день известно, что нарушение функций митохондрий возможно посредством инактивации транскрипционного фактора, индуцируемого гипоксией HIF-1. Исследованиями последних лет установлено, что адаптация к гипоксии на клеточном и субклеточном уровнях тесно связана с транскрипционной экспрессией индуцируемых гипоксией генов позднего действия, которые участвуют в регуляции множественных клеточных и системных функций и необходимы для формирования адаптивных признаков. Известно, что при низких концентрациях кислорода этот процесс контролируется, прежде всего, специфическим транскрипционным фактором, индуцируемым при гипоксии во всех тканях (HIF-1 - hypoxia inducible factor). Этот фактор, открытый в начале 90-х годов, функционирует как главный регулятор кислородного гомеостаза и является механизмом, с помощью которого организм, отвечая на тканевую гипоксию, контролирует экспрессию белков, ответственных за механизм доставки кислорода в клетку, т. е. регулирует адаптивные ответы клетки на изменения оксигенации тканей [68]. 
Таким образом, можно говорить о митохондриальной дисфункции как новом патобиохимическом механизме нейродегенеративных расстройств широкого спектра. В настоящий момент выделяют два вида митохондриальной дисфункции - первичную как следствие врожденного генетического дефекта и вторичную, возникающую под действием различных факторов: гипоксии, ишемии, оксидативного и нитрозирующего стресса, экспрессии провоспалительных цитокинов. В современной медицине все более значимое положение занимает учение о полисистемных нарушениях клеточного энергообмена, т. н. митохондриальной патологии или митохондриальной дисфункции.

Митохондриальные дисфункции - разнородная группа патологий, вызванных генетическими, биохимическими и структурно-функциональными дефектами митохондрий с нарушением клеточно-тканевого дыхания. Классификация митохондриальных дисфункций имеет свою историю. Одной из первых была схема, основанная на биохимических дефектах метаболизма. Недостаточно глубокой оказалась и систематизация по клиническим синдромам, среди которых ранее выделяли:

1) синдромы установленной митохондриальной природы;

2) синдромы предположительно митохондриальной природы;

3) синдромы - следствия митохондриальной патологии.

Первое упоминание о болезни, связанной с дефектом митохондрий, относится к 1962 г.: R. Luft и соавт. описали случай заболевания, при котором имело место нарушение сопряжения дыхания и фосфорилирования в митохондриях скелетных мышц у пациента с нетиреоидным гиперметаболизмом. В последующие годы были описаны клинические, биохимические и морфологические аспекты митохондриальных энцефаломиопатий. Для развития этого направления большую пользу принесло использование модифицированной окраски по Гомори, с помощью которой удавалось выявлять в скелетных мышцах волокна с измененными митохондриями - так называемые ragged-red волокна (RRF) [95-98].

Позднее, с открытием митохондриального генома и мутаций мДНК или яДНК, удалось применить генетический принцип классификации первичной, врожденной митохондриальной дисфункции - сначала в упрощенном виде, затем в усложненном. Ключевая область митохондриальной патологии - наследственные синдромы, в основе которых лежат мутации генов, ответственных за митохондриальные белки (синдромы Кернса-Сейра, MELAS, MERRF, Пирсона, Барта и др.). Митохондриальные дисфункции проявляются широким рядом клинических симптомов. Эти мутации способны вовлекать тРНК, рРНК или структурные гены и могут выражаться биохимически как дефекты всей электронтранспортной цепи или как дефекты отдельных энзимов [97-101].

На протяжении 90-х годов XX столетия идентификация множества митохондриальных дефектов, обуславливающих клинически совершенно разные расстройства, ставила в тупик клиницистов в отношении диагностики гетерогенных и сложных синдромов, характеризующихся следующими признаками [101-113]: 
- Скелетные мышцы: низкая толерантность к физической нагрузке, гипотония, проксимальная миопатия, включающая фациальные и фарингеальные мышцы, офтальмопарез, птоз.

- Сердце: нарушение сердечного ритма, гипертрофическая миокардиопатия.

- ЦНС: атрофия зрительного нерва, пигментная ретинопатия, миоклонус, деменция, инсультоподобные эпизоды, расстройства психики.

- Периферическая нервная система: аксональная нейропатия, нарушение двигательной активности гастроинтестинального тракта.

- Эндокринная система: диабет, гипопаратиреоидизм, нарушение экзокринной функции поджелудочной железы, низкий рост.

Поскольку первичные митохондриальные дисфункции проявляются у человека целым рядом различных симптомов, клиницисты попробовали объединить некоторые группы наиболее часто встречающихся комбинаций симптомов в синдромы [114-116].

MELAS - Mitochondrial Myopathy, Encephalopathy, Lactic Acidosis and Stroke-like episodes (митохондриальная миопатия, энцефалопатия, лактатный ацидоз, инсультоподобные эпизоды).

CPEO/PEO - External Ophtalmoplegia, Ophtalmoplegia plus syndrome (офтальмоплегия, связанная с поражением глазодвигательных мышц, офтальмоплегия плюс синдром).

KSS - Kearns-Sayre Syndrome - retinopathy, proximal muscle weakness, cardiac arrythmia and ataxia (ретинопатия, слабость проксимальных мышц, аритмия, атаксия).

MERRF - Myoclonic Epilepsy associated with Ragged Red Fibres (миоклоническая эпилепсия с обнаружением RRF).

LHON - Leber Hereditary Optic Neuropathy (врожденная нейропатия глазного нерва).

Leig syndrome - infantile subacute necrotizing encephalopathy (инфантильная подострая некротизирующая энцефалопатия).

NAPR - Neuropathy, Ataxia and Pigmentary Retinopathy (нейропатия, атаксия и пигментная ретинопатия.

Однако, класс состояний, характеризующихся митохондриальной дисфункцией, отнюдь не ограничивается этими «первичными» митохондриальными дисфункциями. Громадное количество болезней включает в себя нарушения клеточного энергообмена - вторичные митохондриальные дисфункции в качестве важных звеньев патогенеза. Среди них: интрацеребральная геморрагия, эпилептогенные судороги, локальное термическое повреждение мозга, нейродегенеративные расстройства, транзиторная церебральная ишемия, синдром хронического утомления, мигрени, кардиомиопатии, алкогольные энцефалопатии, сенильная деменция, нейроинфекции, кардиомиопатии, гликогенозы, болезни соединительной ткани, диабет, рахит, тубулопатии, панцитопения, гипопаратиреоз, печеночная недостаточность и многие другие (рис. 1.4). Особое значение изучение указанных нарушений имеет для практической медицины в связи с наличием достаточно эффективных возможностей терапевтической 
коррекции. Однако при этом следует принять во внимание, что спектр патологических нарушений клеточного энергообмена чрезвычайно велик (повреждения различных звеньев цикла Кребса, дыхательной цепи, бета-окисления и др.) [114-116].

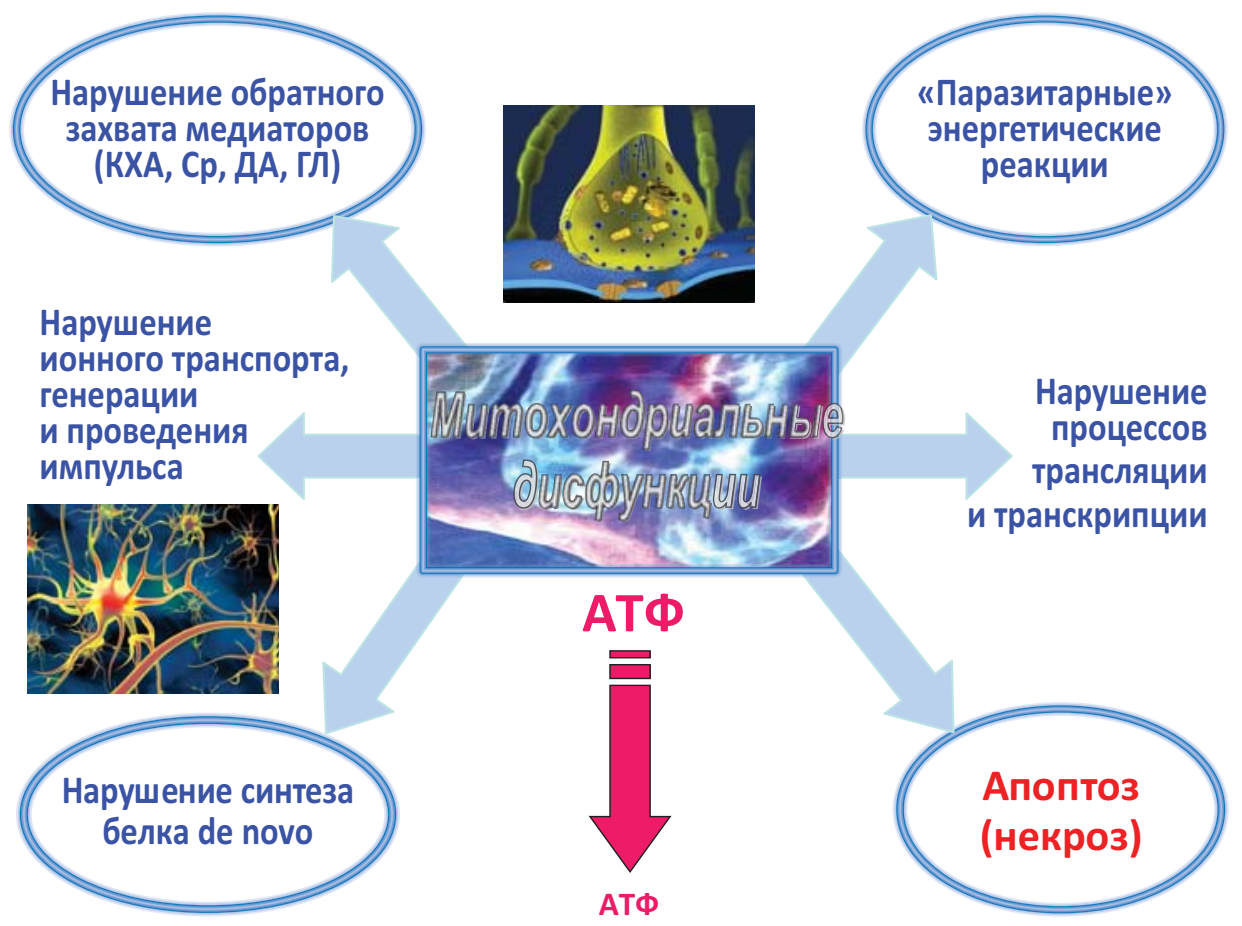

Puc. 1.4. Роль митохондриальных дисфункций в нейродеструктивных процессах в условиях церебральной патологии

В итоге теперь митохондриальная патология подразделяется с учетом таких обстоятельств, как дефекты мДНК, дефекты яДНК, межгеномные дефекты, виды мутаций, их локус и характер, тип наследования или нозологическая единица. Разработка классификаций продолжается.

\section{3. ГЛУТАМАТНАЯ ЭКСАЙТОТОКСИЧНОСТЬ}

Головному мозгу, в силу особенностей функционирования, свойственна высокоразвитая и тонко дифференцированная сосудистая сетка. Система внутричерепных и внутримозговых сосудов, обеспечивающая постоянство и функциональную динамичность микроциркуляции мозга, находится в зависимости не только от состояния общего кровообращения организма, но и от общих нейрогуморальных влияний и уровня состояния внутримозгового обмена веществ. Ухудшение кровообращения может развиваться как в результате изменения тонуса сосудов, так и затруднения кровотока вследствие их ограниченного 
сужения, вызванного атеросклерозом. Нарушение тонуса мозговых сосудов может проявляться в виде спазмов артерий, что приводит к недостаточному кровоснабжению и развитию гипоксии мозга, или снижения тонуса внутричерепных вен, что сопровождается застоем крови и приводит к сжатию мозга. Возможно постадийное протекание процесса, когда сначала возникает спазм, а потом - расширение артериальных и венозных сосудов. Изменения в сосудах мозга, связанные с тонусом и их ограниченным сужением, могут привести к разным формам нарушения мозгового кровообращения, как ишемического, так и геморрагического характера [7].

Степень повреждающего действия церебральной ишемии в первую очередь определяется тяжестью и длительностью снижения мозгового кровообращения. При снижении уровня кровотока до 70-80 \% возникает первичная реакция в виде торможения биосинтеза белка и селективная экспрессия генов. В результате дальнейшего снижения кровотока происходит увеличение концентрации лактата, развитие лактат-ацидоза, отек тканей мозга.

Возрастающая ишемия приводит к развитию ряда патобиохимических реакций в нейронах - возникновению энергодефицита за счет снижения синтеза АТФ, дискоординаций в цикле Кребса, нарушений работы дыхательной цепи митохондрий, что сопровождается развитием аноксической деполяризации мембран и является критерием необратимости ишемических поражений.

Часть мозга, повреждаемая на протяжении 6-8 минут с момента развития острого нарушения мозгового кровообращения, с наиболее выраженным снижением кровотока (менее 10 мл/100 г в минуту), - ядерная зона ишемии, обычно окружена ишемизированной, но живой тканью - зоной пенумбры [117-118].

Таким образом, при максимальном снижении кровотока в мозге на фоне ишемии происходит формирование некрозов, в основе которых протекают реакции глутамат-кальциевого каскада. В развитии глутамат-кальциевого каскада выделяют три основных этапа: индукция, амплификация, экспрессия.

Патобиохимические реакции на этапе индукции начинаются в результате нарушения энергетического метаболизма. При снижении содержания АТФ в ишемизированной зоне и компенсаторной активации анаэробного гликолиза в ответ на гипоксию развивается метаболический ацидоз. Тканевой ацидоз играет довольно важную роль при переходе от селективного нейронального некроза до инфаркта мозга. Снижение $\mathrm{pH}$ внешне- и внутриклеточной среды приводит к «разрыхлению» клеточных мембран, изменению их физикохимических свойств, повышению проницаемости нейрональных клеток и эндотелия сосудов [4 ,7, 10, 24, 27].

Нарастание кислородной недостаточности приводит к частичной или полной инактивации электроннотранспортной функции цитохромов В-С [27], что является причиной приостановки дыхания, и как следствие - окислительного фосфорилирования. Именно в этот период уровень энергетического дефицита становится достаточным для запуска основных механизмов, приводящих к нарушению и смерти клетки [4].

Энергодефицит приводит к обесточиванию $\mathrm{Na}^{+} / \mathrm{K}^{+}$-АТФ-азной ферментной системы, которая руководит энергозависимым ионным транспортом. 
Нарушение активного ионного транспорта обуславливает отток ионов $\mathrm{K}^{+}$из клетки, увеличение содержания ионов $\mathrm{Ca}^{2+}$, что приводит к деполяризации клеточных мембран. Внутриклеточное накопление ионов $\mathrm{Ca}^{2+}$ при церебральной ишемии создает перегрузку митохондрий, индуцирует открытие циклоспорин-Азависимой митохондриальной поры, а в дальнейшем - усиление паразитарных реакций, образование избытка АФК и экспрессию проапоптотических факторов $[4,10,11]$. Митохондриальная пора представляет собой канал, проходящий через обе митохондриальные мембраны и состоящий из трех белков: транслокатора адениловых нуклеотидов, потенциалзависимого анионного канала (порина) и бензодиазепинового рецептора [11]. Когда этот комплекс связывается с $\mathrm{Ca}^{2+}$, через мембранную пору могут проходить вещества с небольшой молекулярной массой, что приводит к падению мембранного потенциала и набуханию матрикса, целостность внешней мембраны неизбежно нарушается, и из межмембранного пространства в цитоплазму выходят белки апоптоза - фактор, индуцирующий апоптоз (Apoptosis-inducing factor - AIF), вторичный митохондриальный активатор каспаз (second mitochondria-derived activator of caspases - Smac) и некоторые прокаспазы [118-120]. Индуцирующий фактор направляется прямо в ядро, где вызывает деградацию ДНК [120].

Наряду со специфическими апоптозными белками, из митохондрии через открытую пору выходит цитохром C, который в норме служит конечным звеном электронтранспортной цепи. В цитоплазме этот белок связывается с белком Apaf-1 (Apoptotic protease activating factor-1 - активирующий протеазу фактор-1) и формирует апоптосомный комплекс. Он с помощью Smac и еще одного фактора (Omi/HtrA2) активирует прокаспазу-9, а та, став каспазой-9, превращает два других профермента в каспазы-3 и -7, которые уже расщепляют структурные белки, приводя к появлению биохимических и морфологических признаков апоптоза [118-123].

В конце XX столетия была сформулирована теория эксайтотоксичности, которая подтвердила исключительную роль аминоспецифических трансмиттеров в патогенезе ишемического инсульта. Глутамат-кальциевый каскад активируется избыточным высвобождением возбуждающих нейротрансмиттеров глутамата и аспартата из окончаний ишемизированных нейронов в межклеточное пространство [4].

Накопление больших концентраций возбуждающих нейро-трансмиттерных аминокислот обуславливает перевозбуждение глутаматных рецепторов. Особого внимания в процессе развития ишемии головного мозга заслуживает активность ионотропных глутаматных рецепторов: N-метил-D-аспартата (NMDA), 2-амино-3-гидрокси-4-изоксазол-5-метилпропановой кислоты (AMPA), каиновой кислоты и 2-амино-4-фосфатнобутановой кислоты (L-AP $\mathrm{A}_{4}$, из которых наиболее детально изучены NMDA-рецепторы. NMDA-рецептор является сложным надмолекулярным образованием, которое включает в себя несколько сайтов регуляции: сайт специфического связывания коантагониста медиатора (L-глутаминовой кислоты), сайт специфического связывания коантагониста (глицина) и аллостерические модуляторные сайты, размещенные как на мембране, так и в ионном канале, сопряженном с рецептором (сайт 
связывания двухвалентных катионов) - и «фенциклидиновый сайт» - участок связывания неконкурентных антагонистов. Перевозбуждение NMDAрецепторов приводит к избыточному поступлению $\mathrm{Ca}^{2+}$-ионов к нейронам и внезапному увеличению его концентрации $[4,41,42]$. Развитие эксайтотоксичности глутамата в условиях ишемии может происходить также при активации AMPA- и каинатных рецепторов, что усиливает проницаемость для одновалентных ионов и развитие кратковременной деполяризации постсинаптической мембраны, способствующей усилению притока ионов $\mathrm{Ca}^{2+}[4,41,42]$. Таким образом, первый этап глутамат-кальциевого каскада характеризуется нарушением энергетического метаболизма (дефицитом АТФ, торможением дыхания в митохондриальной цепи, дискоординацией в цикле Кребса, активацией гликолиза), усиленным выбросом аминоспецифических нейротрансмиттеров, развитием глутаматной эксайтотоксичности и шоковым поступлением ионов $\mathrm{Ca}^{2+}$ в нейроны.

На этапе амплификации продолжается увеличение концентрации внутриклеточных ионов $\mathrm{Ca}^{2+}$ и распространяется глутаматная эксайтотоксичность [4]. Увеличение концентрации внутриклеточных ионов $\mathrm{Ca}^{2+}$ обусловлено тем, что инозитол-1,4,5-трифосфат индуцирует их высвобождение из внутриклеточных депо. Кроме того, дополнительные ионы $\mathrm{Ca}^{2+}$ поступают в клетки извне через потенциалзависимые кальциевые каналы, которые реагируют на изменение трансмембранного распределения зарядов, а также при помощи мембранных молекул-переносчиков, которые обменивают ионы $\mathrm{Na}^{+}$на ионы $\mathrm{Ca}^{2+}$.

Увеличение концентрации внутриклеточных ионов $\mathrm{Ca}^{2+}$ изменяет активность ферментов, модифицирующих клеточные мембраны, в том числе глутаматные рецепторы. В результате увеличивается чувствительность нейронов к возбуждающим сигналам. Повышенная возбуждаемость способствует дальнейшему накоплению ионов $\mathrm{Ca}^{2+}$ и усиленному выделению глутамата из нервных окончаний [4].

По некоторым экспериментальным данным, в частях мозга с плотно размещенными нейронами, которые содержат NMDA-рецепторы, одна массивно деполяризированная клетка индуцирует высвобождение глутамата в таком количестве, что это благоприятствует возбуждению соседних нейронов.

Таким образом, происходит повреждение соседних нейронов, индуцирование дальнейшего выброса нейротрансмиттера и развитие механизма распространяющейся глутаматной эксайтотоксичности [4].

В зоне пенумбры не отмечается длительное увеличение глутамата, что свидетельствует о том, что эксайтотоксические процессы в ней не связаны с повышением синтеза возбуждающих аминокислот. Повышенное количество глутамата может поступать к зоне пенумбры из ядерной зоны ишемии и повреждать окружающие нейроны, индуцируя дальнейший выброс нейротрансмиттера. Третий этап - экспрессия. Этот этап характеризуется развитием оксидативного стресса и накоплением низкомолекулярных цитотоксических продуктов. Развитие оксидативного стресса в условиях ишемии головного мозга протекает в несколько стадий, и наиболее важной является продукция АФК [4, 41, $42,49-55]$. Первичным источником АФК оказываются митохондрии, которые 
играют ключевую роль в энергетическом обеспечении клетки. Ныне существует обобщенное клиническое понятие «митохондриальная дисфункция»: повреждение мембран митохондрий и открытие митохондриальной поры ведет к образованию в «паразитарных» биоэнергетических реакциях супероксидных радикалов, которые, реагируя с NO^, образуют пероксинитриты [50, 52, 55]. Кроме того, активация NMDA-рецепторов на постсинаптической мембране глутаматергического синапса приводит к увеличению внутриклеточного $\mathrm{Ca}^{2+}$ и продукции АФК (супероксидрадикала, гидроксилрадикала, NO-радикала). В этих нейронах происходит активация $\mathrm{Ca}^{2+}$-зависимой нейрональной NO-синтазы, что приводит, во-первых, к гиперпродукции NO-синтазы, а во-вторых, в условиях дефицита субстрата NO-синтазы - L-аргинина - к образованию супероксидрадикала и гидроксилрадикала. При взаимодействии супероксидрадикала и NO^ образуется более агрессивная молекула - пероксинитрит $\left(\mathrm{ONOO}^{-}\right)$, которая вызывает повреждение макромолекул. Более существенная роль в образовании $\mathrm{NO}^{\bullet}$ и $\mathrm{ONOO}^{-}$в условиях нейродеструкции принадлежит индуцибельной NO-синтазе, которая менее зависима от $\mathrm{Ca}^{2+}$, экспрессируется в глиальных клетках под действием различных цитокинов (IL-1 $\beta$, TNF- $\alpha, \mathrm{HIF}-1$ ) и регулируется факторами транскрипции (NF-Kappa B, JNK) [49, 51]. Не менее важным источником образования АФК при ишемии мозга является реакция окисления гипоксантина и ксантина в мочевую кислоту, катализируемая ксантиндегидрогеназой, которая превращается в ксантиноксидазу и генерирует супероксидрадикал. В протеолитическом образовании ксантиноксидазы из ксантиндегидрогеназы активное участие принимает $\mathrm{Ca}^{2+}$, повышение уровня которого происходит при активации NMDA-рецепторов.

Maragos W. F., применяя радиолигандный анализ, показал, что наибольшая плотность NMDA-рецепторов, прежде всего в гиппокампе, коре больших полушарий, миндалине и стриатуме [90]. Беспалов А. Ю. отмечает, что именно эти структуры прежде всего ответственны за память и обучение в традиционном понимании и ассоциированы с сенсорной функцией, осуществление которой требует повышенного ресурса синаптической пластичности [85]. Представляет также интерес то, что указанные структуры обладают низким порогом эпилептизации и высокой степенью возбудимости [94].

Во всех слоях гиппокампа выявлен высокий уровень NMDA-рецепторов, за исключением тел нейронов пирамидного и гранулярного слоев, а также терминальной зоны мшистых волокон гиппокампа. Среди кортикальных областей ассоциативные зоны коры часто имеют большую плотность рецепторов, чем проекционные зоны. Фронтальная, инсулярная, пириформная, периринальная и передняя поясная кора также содержат большое количество рецепторов, в отличие от височной, затылочной, париетальной и задней поясной коры. Гранулярные корковые области имеют выраженную ламинарность распределения NMDA-рецепторов. Так, во внешних слоях I-III и в V слое париетальной коры показана большая плотность рецепторов, чем в других корковых слоях.

Изначально ионотропные рецепторы глутамата были разделены на три семейства по различиям в фармакологических свойствах и структуре. 
По-видимому, это тетра- или пентамеры со специфичными для каждого подтипа субъединицами. Композиция субъединиц определяет биофизические и фармакологические свойства рецепторов. $К$ примеру, присутствие в АМРАрецепторе субъединицы GluR2 (GluRB) меняет его свойства таким образом, что в открытом состоянии он становится непроницаем для ионов кальция. Te же рецепторы, которые состоят только из GluR1 и GluR3 демонстрируют хорошую проницаемость для кальция. AMPA-рецепторы обладают меньшим сродством к глутамату, чем NMDA-рецепторы, но они обладают быстрой кинетикой и формируют быстрый компонент возбуждающего постсинаптического потенциала. Ведутся исследования по определению структуры сайтов связывания агонистов [82].

Изучение действия на NMDA-рецепторы различных классов соединений показало, что постсинаптический NMDA-рецептор представляет собой сложное надмолекулярное образование, включающее в себя несколько сайтов регуляции: сайт специфического связывания медиатора (L-глутаминовой кислоты), сайт специфического связывания коагониста (глицина) и аллостерические модуляторные сайты, расположенные как на мембране (полиаминовый), так и в ионном канале, сопряженном с рецептором (сайты связывания двухвалентных катионов и фенциклидиновый сайт - участок связывания неконкурентных антагонистов). К особенностям всего NMDA-рецепторно-ионоформного комплекса относятся:

- хемо- и потенциал-чувствительность одновременно;

- медленная динамика и определенная частотная характеристика запуска;

- длительность эффекта;

- потенциал-чувствительное «окно» (-30 ... -20 мВ);

- способность к временной суммации и усилению вызванного потенциала [95].

К истинным агонистам и конкурентным антагонистам NMDA-рецепторов относятся соединения, способные избирательно взаимодействовать непосредственно с глутамат-связывающим сайтом рецептора, участком узнавания медиатора. В отличие от них, неконкурентные антагонисты модулируют активность NMDA-рецепторно-ионоформного комплекса, связываясь с другими молекулярными структурами в рецепторе, а коагонист глицин имеет свой специфический узнающий сайт [96].

Важной особенностью NMDA-рецепторов, отличающей их от других типов рецепторов ВАК, являются потенциалзависимые свойства их ионного канала [97]. При обычном потенциале покоя мембраны NMDA-активируемые входящие токи практически не регистрируются. Однако, при повышении потенциала до $-30 \mathrm{mB}$ они значительно возрастают и достигают максимума при мембранном потенциале от -30 до $-20 \mathrm{mB}$, снижаясь при дальнейшей деполяризации. B NMDA-рецепторном канале в каждый момент времени один катион занимает место в области около поры канала. Ионный канал, сопряженный c NMDA-рецептором, отличается от трансмембранных каналов других рецепторов в центральной и периферической нервных системах [98]. 
Из эндогенных соединений агонистами NMDA-рецепторов являются L-глутаминовая кислота и хинолиновая кислота - один из продуктов триптофана. $K$ агонистам NMDA-рецепторов относится также природная иботеновая кислота. Для всех агонистов NMDA-рецепторов характерны следующие структурные особенности: короткая цепочка, соединяющая терминальные кислотные функции; предпочтительность замещения атома азота аминогруппы; D-конфигурация хирального центра [96].

Наиболее известными конкурентными антагонистами NMDA-рецепторов являются D-2-амино-5-фосфоновалериановая, D-2-амино-7-фосфоногептановая и $\beta$-D-аспартиламинометил-фосфоновая кислоты. Эти соединения конкурентно ингибируют связывание лигандов NMDA-рецепторов с мембранами мозга и устраняют NMDA-индуцированную деполяризацию спинальных мотонейронов, но не влияют на возбуждение нейронов, вызванное каинатом, квисквалатом или AMPA. Основные закономерности связи химической структуры с биологической активностью в ряду антагонистов NMDA-рецепторов сводятся к следующему: относительно длинная цепочка, соединяющая терминальные кислотные функции (четыре - шесть атомов); предпочтительность замещения атома азота аминогруппы; D-конфигурация хирального центра [95].

Отличительной особенностью NMDA-рецепторов является то, что они блокируются ионами магния по потенциалзависимому механизму. Этот механизм работает при физиологических условиях, но ослабляется при снижении потенциала покоя. Другая специфическая черта NMDA-рецепторов заключается в том, что для активации им требуется глицин в качестве коагониста глутамату. Каждая субъединица несет по два сайта связывания глицина и глутамата [95].

Функции ионотропных рецепторов не ограничиваются только открытием канала. Эти функции связаны со способностью внутриклеточной карбоксильной терминали взаимодействовать с широким кругом внутриклеточных белков, которые вовлечены в структурно-функциональную организацию постсинаптического аппарата и внутриклеточную передачу сигналов [99]. Например, АМРА-рецепторы активируют тирозинкиназу, которая запускает каскад митоген-активированной протеинкиназы [88]. Нейротоксичность глутамата может реализовываться через все подтипы ионотропных рецепторов и метаботропные рецепторы. Вклад каждого из этих подтипов в нейротоксичность глутамата зависит от рассматриваемой группы нейронов и множества других обстоятельств [84]. Гибель нейронов, связанная с эпилептическим статусом, в основном, зависит от гиперактивации NMDA-рецепторов. Острая нейродегенеративная патология, развивающаяся после ишемии мозга (общей или фокальной), опосредуется как NMDA- так и AMPA-рецепторами [100].

Дополнительным результатом активации NMDA-рецепторов является внутриклеточная продукция активных форм кислорода, прежде всего супероксид-аниона и гидроксид-радикала [101]. При дефиците аргинина, субстрата нитроксидсинтазы, также может образовываться супероксид-анион. Как отмечает Snyder S. H., в условиях избыточного образования различных радикалов возможно взаимодействие вторичного мессенджера - оксида азота 
и супероксида с образованием пероксинитрита, обладающего исключительно высоким окислительным потенциалом [102-105].

Johnson и Ascher впервые сообщили о способности глицина в субмикромолярных концентрациях усиливать NMDA-вызванные ответы нейронов в культуре тканей $[95,106]$. Поначалу было отмечено, что величина NMDAиндуцированных токов в нейронах уменьшалась в двух случаях: при удалении изолированных нервных клеток от материнской колонии и при увеличении скорости перфузии культуры. Было высказано предположение о том, что культуральная ткань выделяет неизвестное вещество, потенцирующее NMDAответы. Позже установили, что этим веществом является простейшая аминокислота - глицин. Этот эффект глицина проявляется в низких концентрациях, которые примерно в десять раз меньше, чем требуется для активации тормозного, стрихнин-чувствительного, рецептора $[4,89]$.

Klecker удалось получить четкие доказательства того, что активация глициновых сайтов является абсолютно необходимым условием для нормального функционирования NMDA-рецепторно-ионоформного комплекса, и аргументировать гипотезу о глицине как о коагонисте NMDA-рецепторов. Для открытия ионного канала требуется связывание соответствующих агонистов как с глутамат-, так и с глицин-узнающими сайтами NMDA-рецепторов.

Глицин и его аналоги могут усиливать нейропередачу, опосредованную NMDA-рецепторами, в мозговой ткани in vivo. Было установлено, что D-серин усиливал возбуждение нейронов, индуцированное микроионофоретически подведением NMDA, в таламусе или в красном ядре $[4,15,26]$. Глицин также потенцировал NMDA-вызванное выделение цГМФ из клеток мозжечка крыс. Однако в других опытах in vivo и на срезах взрослой ткани не удалось показать потенцирующий эффект самого глицина на NMDA-индуцированные ответы. Эти результаты указывают на то, что в нормальных условиях концентрация глицина вполне достаточна для полной активации глицинового сайта. Однако, вполне возможна и другая ситуация: NMDA вызывает выброс глицина из нейронов или глии до уровня, насыщающего глициновый сайт $[26,95]$.

Глутамат- и глицин-узнающие сайты NMDA-рецепторно-канального комплекса аллостерически влияют друг на друга, при этом изменяется внутренняя активность агониста, а не его аффинность. Частичный агонист, занимая один из узнающих сайтов, вызывает такие конформационные изменения всего рецепторного комплекса, которые приводят к увеличению скорости образования комплекса второго коагониста с рецептором [4, 26].

К антагонистам глицинового сайта относится, в первую очередь, 3 -амино1-гидрокси-2-пирролидон. Однако, блокада NMDA-индуцированных ответов под его действием зависит от наличия в среде глицина. То есть, он является конкурентным антагонистом глициновых сайтов NMDA-рецепторно-ионоформного комплекса. Работы по разделению 3-амино-1-гидрокси-2-пирролидона на стереоизомеры показали, что в действительности это соединение является частичным агонистом [109].

Среди антагонистов глициновых сайтов можно выделить несколько групп гетероциклических, полициклических и алифатических соединений. 
Достаточно сильными антагонистами этого сайта являются также циклолейцин и 1 -аминоциклобутанкарбоновая кислота, причем эти соединения ингибируют связывание глицина только с NMDA-рецепторно-ионоформным комплекcoм, но не со стрихнин-чувствительными глициновыми рецепторами [110].

Monaghan высказал предположение, что NMDA-рецепторы существуют в двух конформационных состояниях — агонист-предпочитающее и антагонистпредпочитающее [111]. Роль глицина как коагониста заключается в том, что он превращает антагонист-предпочитающую конформацию рецептора в агонистпредпочитающую. Кроме глицина, равновесие в сторону увеличения доли глицин-предпочитающей конформации, сдвигает кинуреновая кислота [112].

Таким образом, участие глицина в функционировании NMDA-рецепторного комплекса в нейронах ЦНС является необходимым условием активации этого комплекса, то есть он играет роль коагониста. Поэтому глицинсвязывающий сайт является структурой NMDA-рецепторно-ионоформного комплекса, через которую возможна его регуляция. Также необходимо отметить, что, в связи с трудностями внедрения в клинику конкурентных агонистов глутамат-связывающего сайта, соединения, влияющие на глициновый сайт, начинают привлекать особое внимание.

Важную роль в регулировании функций NMDA-рецепторно-ионоформного комплекса играют двухвалентные катионы. Среди антагонистов NMDA-рецепторов своей безопасностью и длительной историей клинического применения выделяется сульфат магния [113-116]. В последнее время обнаружен ряд уникальных свойств этого препарата. Установлено, что ионы $\mathrm{Mg}^{2+}$ блокируют NMDA-ассоциированные каналы потенциалзависимым способом [117]. В экспериментах было выявлено значительное уменьшение зоны ишемии при использовании сульфата магния; у больных с ишемическим инсультом применение этого препарата в первые часы заболевания улучшало клинический исход [118].

Ионы $\mathrm{Mg}^{2+}$ участвуют во многих обменных процессах в ЦНС. К примеру, в синтезе всех нейропептидов в головном мозге [119]. Магний входит в состав металлопротеинов, ферментов, в том числе глутатионсинтетазы, превращающей глутамат в глутамин [120]. Кроме того, выявлено антидегенеративное действие вальпроата магния на культуру церебральных нейронов. Магний расценивают как ион с нейроседативными свойствами вследствие его способности блокировать проведение нервного импульса [121].

Таким образом, приведенные данные свидетельствуют, что ионы $\mathrm{Mg}^{2+}$ можно отнести к наиболее безопасным нейропротекторам.

В клинической практике сульфат магния издавна применяли для снижения повышенного артериального давления и при внутричерепной гипертензии [122]. Потенциалзависимые свойства канала, ассоциированного с NMDAрецепторным комплексом, определяются в первую очередь ионами магния. Эта идея была высказана при обнаружении ингибирующего действия $\mathrm{Mg}^{2+}$ на деполяризацию нейронов спинного мозга, вызываемую агонистами NMDAрецепторов [123]. В дальнейшем был установлен неконкурентный и потенциалзависимый характер торможения ионами магния синаптического возбужде- 
ния. Ионы $\mathrm{Mg}^{2+}$ могут вызывать потенциал-зависимую блокаду канала, находясь не только с наружной, но и с внутренней стороны клеточной мембраны. При этом внутриклеточный магний уменьшает величину выходного тока при положительных потенциалах [124]. Этот феномен имеет место при концентрации ионов $\mathrm{Mg}^{2+}$ в среде около $1 \mathrm{mM}$, что соответствует их физиологической концентрации во внеклеточной среде. В этих условиях высокочастотная стимуляция пресинаптического входа может «пробить» магниевый блок NMDA-канала и вызвать деполяризацию пресинаптической мембраны. Торможение синаптической передачи через NMDA-рецепторы ионами $\mathrm{Mg}^{2+}$ можно зафиксировать не только на электрофизиологических моделях, но и при изучении биохимических сдвигов, происходящих в нейронах при деполяризации мембраны. В исследованиях на культуре нервной ткани установлено, что $\mathrm{Mg}^{2+}$ устраняет индуцированные агонистами NMDA-типа изменения концентрации внутриклеточных посредников проведения нервного импульса: тормозит вход ионов кальция, образование цГМФ и выделение арахидоновой кислоты [125-126].

Ингибирующее действие ионов магния на процессы синаптического возбуждения избирательно проявляется при активации ВАК только NMDA-типа. В канале NMDA-рецептора существует участок специфического связывания этих ионов, который чувствителен к изменению трансмембранного потенциала, причем сродство этого участка $\mathrm{Mg}^{2+}$ повышается при гиперполяризации. Важную роль ионов магния подчеркивают не только электрофизиологические и биохимические данные, но и результаты радиолигандного анализа. Хотя ионы магния не влияют на специфическое связывание глутаминовой кислоты, они способны модулировать связывание агонистов других специфических сайтов, входящих в состав NMDA-рецепторов - фенциклидиновых и глициновых. Тормозной эффект ионов магния объясняется их связыванием со специфическим сайтом, расположенным в канале, в результате чего и блокируется синаптическая передача, а стимулирующее действие в малых концентрациях - взаимодействием с дополнительными сайтами связывания. Добавление глутамата усиливает модулирующее действие $\mathrm{Mg}^{2+}$ на связывание лигандов фенциклидинового сайта и глицина [127].

Таким образом, ионы магния, связываясь со специфическими сайтами в канале NMDA-рецептора, способны не только модулировать проводимость канала, но и вызывать конформационные изменения всего NMDA-рецепторноионоформного комплекса. На уровне синапса суммарный ответ при стимуляции NMDA-ергического синапса зависит не только от количества медиатора, выделившегося из пресинаптической мембраны, но и от величины исходного потенциала постсинаптической мембраны, который, в свою очередь, определяется ионами магния [128].

Мультицентровое исследование при ОНМК показало безопасность препаратов магния и отсутствие значимых побочных эффектов, снижение 30 дневной летальности на $10 \%$ и ранней летальности (в первую неделю) на $5,7 \%$ по сравнению с контролем.

Комбинированный препарат магния лактата и пиридоксина гидрохлорида Магне-В6 - природный антагонист кальция. Контролирует нормальное 
функционирование клетки на всех уровнях субклеточных структур. Первая реакция клетки на ишемию - это потеря ионов магния и перегрузка кальцием. Ионы магния уменьшают возбудимость нейронов, уменьшают их перегрузку кальцием, нормализуют многие ферментативные реакции, активируют окислительно-восстановительные процессы [129].

Фенциклидин и подобные ему соединения селективно блокируют постсинаптические NMDA-рецепторы. Указанные соединения не ингибируют специфическое связывание агонистов NMDA-рецепторов, следовательно эти соединения являются неконкурентными антагонистами. Они действуют на NMDA-рецепторно-ионоформный комплекс только в присутствии агониста. Отсюда следует, что механизм их действия заключается в блокаде открытого ионного канала. Потенцирующее действие глутамата на связывание фенциклидина и его аналогов увеличивалось и в присутствии глицина, аллостерического регулятора NMDA-рецепторов. Вначале считали, что место связывания фенциклидин-подобных неконкурентных антагонистов NMDA-рецепторов расположено в ионном канале рядом с участком, специфически связывающим двухвалентные катионы, затем было показано, что эти сайты частично перекрываются.

\section{4. НАРУШЕНИЯ В СИСТЕМЕ ОКСИДА АЗОТА И ИНИЦИИРОВАНИЕ НИТРОЗИРУЮЩЕГО СТРЕССА В УСЛОВИЯХ ЦЕРЕБРАЛЬНОЙ ИШЕМИИ}

Оксид азота (NO) является уникальной молекулой, обладающей, несмотря на крайнюю простоту строения, большим набором функций в организме, что послужило причиной его детального изучения в последнее десятилетие. NO функционирует как ключевой элемент в сердечно-сосудистой системе, обеспечивая расширение сосудов и регуляцию артериального давления, он участвует в передаче сигналов в центральной и периферической нервной системе. Большинство этих эффектов оксида азота связано с активацией растворимой гуанилатциклазы и образованием циклического GMP. NO также чрезвычайно важен для системы неспецифического иммунитета. На мышиных макрофагах, а затем и на различных других макрофагах, было показано, что NO необходим для обеспечения их цитотоксического действия на опухолевые клетки и клетки, пораженные вирусом [19, 20, 22, 127, 128]. Механизм действия оксида азота в этом случае не связан с активацией гуанилатциклазы и обусловлен, в основном, эффектами самого NO. В связис этим следует указать на свободнорадикальную природу молекулы оксида азота (наличие неспаренного электрона у атома азота), что делает его весьма реакционно-способным соединением. Среднее время жизни NO in vivo составляет 5-30 секунд, он достаточно быстро взаимодействует со своими мишенями (в основном - тиолами и переходными металлами) или окисляется до неактивных нитрата и нитрита, например, цитохром-С-оксидазой, или образует так называемые активные формы азота. Таким образом, действие NO носит прямой или косвенный характер. Прямое действие обусловлено реакциями самого NO с мишенями, например, стимуля- 
ция гуанилатциклазы, образование нитрозильных комплексов с металлами (часто в результате этого ферменты, содержащие ионы этих металлов, инактивируются) и др. Непрямые эффекты NO определяются как химические реакции, опосредованные активными формами оксида азота, которые образуются при взаимодействии с супероксидом $\left(\mathrm{O}^{2-}\right)$ или кислородом $\left(\mathrm{O}_{2}\right)$. В результате действия активных форм NO развивается либо нитрозилирующий стресс (образование нитрозаминов, S-нитрозотиолов, дезаминирование оснований ДНК), либо окислительный стресс. Благодаря высокой липофильности NO столь эффективно проникает через мембраны, что способен распространяться от источника на расстояния, в несколько раз превышающие размеры клетки, и поражать там свои мишени $[129,130]$.

Изучение вопроса происхождения эндогенного NO показало, что для его продукции активными макрофагами необходим L-аргинин. B дальнейшем было выяснено, что выработка обеспечивается семейством NO-синтаз (NOS), которые в процессе работы образуют из L-аргинина NO и L-цитруллин, одновременно окисляя NADPH и восстанавливая кислород до воды (Горрен А. К. Ф. и Майер Б., 1998). Оказалось, что NOS присутствуют в клетках практически всех типов тканей и по типу экспрессии их разделяют на конститутивно присутствующие в клетках cNOS и индуцибельные iNOS. Группа cNOS обычно делится на нейрональную ncNOS (NOS1) и эндотелиальную ecNOS (NOS3) по месту их основной локализации, хотя они находятся и в других клетках. iNOS accoциирована в основном с макрофагами и участвует в работе иммунной системы, накапливаясь в этих клетках после активации их цитокинами (IFN-g, IL-1b, TNF- $\alpha$ ) и другими агентами (ЛПC). В печени при стимуляции также экспрессируется эта изоформа, что связано с барьерной функцией органа. Комплексное изучение NOS показало, что они являются одними из наиболее сложно устроенных и регулируемых ферментов, имеющих необычно высокое количество кофакторов [19, 24, 109, 131].

NO-синтазы существуют в клетке в виде димера и активны только в таком состоянии. В составе каждой субъединицы димера различают редуктазный, кальмодулинсвязывающий и оксигеназный домены. Редуктазный домен содержит флавины FAD и FMN: FAD является первичным акцептором электронов от NADPH, a FMN переносит электроны от FAD на гем оксигеназного домена. Оксигеназный домен содержит участки связывания гема, аргинина (L-Arg) и тетрагидробиоптерина (BH4). Считается, что кальмодулин-Сa ${ }^{2+}$ придает ферменту конформационное состояние, необходимое для внутреннего переноса электронов (Горрен А. К. Ф. и Майер Б., 1998). Именно различия в прочности связывания кальмодулина с димером NOS обуславливают каталитические различия изоформ: активность nNOS и eNOS сильно зависит от концентрации $\mathrm{Ca}^{2+}$, в то время как c iNOS кальмодулин связан столь прочно, что она не нуждается в добавлении $\mathrm{Ca}^{2+}$. Хотя удельные активности всех изоформ NOS одинаковы, при работе в организме оказывается, что cNOS синтезирует небольшие концентрации NO в течение короткого времени, a iNOS синтезирует значительно большие концентрации NO в течение длительных периодов (до нескольких дней). Таким образом, экспрессия и активность той или иной изоформы может обу- 
славливать способность NO выступать в качестве физиологического регулятора или же токсического агента [128].

В настоящее время изоформы NOS делятся на конституционные формы (нейрональная — nNOS; и эндотелиальная — eNOS) и индуцибельную (iNOS).

Изучение NO-опосредованной цитотоксичности макрофагов, проводимое in vitro, отчетливо показало, что добавление в среду ингибиторов NOS, таких как аналог субстрата NG-монометил-L-аргинин (L-NMMA), подавляет цитотоксический эффект макрофагов на опухолевые клетки. Это свидетельствует в пользу доминирующей роли NO в опосредовании воздействия макрофагов на клеткимишени, хотя следует помнить и об известном явлении дыхательной вспышки, играющей существенную роль в уничтожении патогенов фагоцитами. В частности, появились данные, усложняющие схему макрофагальной цитотоксичности, обусловленной оксидом азота. Выяснено, что раневые макрофаги, способные к выработке NO, не являются цитотоксичными для NO-чувствительных клеток линии P815. Таким образом, встает вопрос о необходимости и достаточности NO для проявления цитотоксичности макрофагов [4, 29, 128, 132$]$.

Следует упомянуть также о том, что производство NO вызывает значительные отрицательные эффекты и в продуцирующих его макрофагах. Показано, что фагоцитоз и выработка активных форм кислорода сильно подавляются у крысиных или перитонеальных макрофагов, культивируемых в условиях, позволяющих производить NO. Макрофаги, экспрессирующие iNOS или обработанные оксидом азота, имеют конденсированное ядро и цитоплазму. Таким образом, выделение NO активированными макрофагами ведет к их функциональной супрессии, и в конце концов - к апоптозу. Эти явления явно связаны с NO, поскольку предупреждаются добавлением ингибиторов NOS.

Сейчас идет активное изучение мишеней оксида азота и выяснение вопроса, является ли NO per se достаточно цитотоксичным, или же более активны его производные. Как было описано выше, NO в нейроцитах в условиях церебральной патологии образует активные интермедиаты, такие как нитрозоний $\left(\mathrm{NO}^{+}\right)$, нитроксил $\left(\mathrm{NO}^{-}\right)$и пероксинитрит $\left(\mathrm{ONOO}^{-}\right)$. В этой связи некоторые исследователи считают, что большинство цитотоксических эффектов NO принадлежит на самом деле $\mathrm{ONOO}^{-}$, который образуется в реакции с супероксидом $\left(\mathrm{O}^{2-}\right)$. Действительно, пероксинитрит значительно более активен, он интенсивно нитрозилирует белки и может являться источником очень токсичного гидроксил-радикала·ОН в реакции:

\section{$\mathrm{NO}+\mathrm{O}^{2-} \mathrm{a} \mathrm{ONOO}^{-}+\mathrm{H}+\mathrm{a} \mathrm{ONOOH}$ a $\mathrm{ONO}+\mathrm{OH}$}

ОН вызывает перекисное окисление липидов и другие явления, входящие в понятие «окислительный стресс» .

Другая проблема, возникающая при исследовании механизмов цитотоксичности азота, связана с используемыми для его генерации NO-донорами, описанными выше. Дело в том, что S-нитрозотиолы (в основном - GSNO и SNAP), используемые во многих исследованиях, способны участвовать в реакциях транснитрозилирования, то есть передавать $\mathrm{NO}^{+}$-группу тиолам (глутатиону

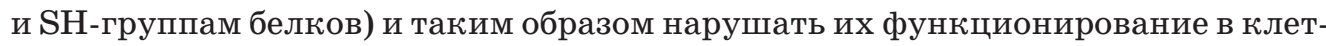


ке. При этом непонятно, относить ли такие реакции к эффектам собственно NO [133].

Показано, что в первую очередь NO (макрофагальный или экзогенный) ингибирует окислительное фосфорилирование в митохондриях нейроцитов. Это происходит, так как NO обратимо связывается с цитохромоксидазой ЭТЦ митохондрии. С другой стороны, подавление электронного транспорта в митохондрии приводит к генерации супероксида и образованию пероксинитрита. $\mathrm{ONOO}^{-}$, который подавляет ферменты дыхательной цепи уже необратимо, нитрозилируя их и отнимая железо. Подавление митохондриального дыхания приводит к падению Dу, что может привести к развитию митохондриальной дисфункции и инициировать апоптотический процесс [134].

Имеются данные и о прямой активации открытия гигантской поры оксидом азота, приводящей к выходу цитохрома $\mathrm{C}$ и запуску каспазного каскада, о чем было описано выше.

NO и его производные могут вызывать перекисное окисление фосфолипидов и окисление тиольных групп белков митохондриальной мембраны, что также приводит к высвобождению в цитозоль апоптогенных факторов.

Нитрозилирование белков по остаткам тирозина (Reiter C. D. et al., 2000), осуществляемое $\mathrm{ONOO}^{-}$, может иметь серьезные функциональные последствия, так как оно подавляет фосфорилирование Tyr, то есть нарушает некоторые пути передачи сигнала в нервной клетке. Недавно сообщалось, что пероксинитрит может нитрозилировать и цитохром С в митохондриях, что приводит к изменению его функций, в частности он становится неспособным поддерживать перенос электронов в дыхательной цепи и не восстанавливается аскорбатом. Поскольку одновременно происходит выход цитохрома С (в том числе и нитрозилированного) в цитоплазму, то можно предполагать участие такого нитрозилирования и в каких-то сигнальных процессах. В этом отношении сейчас появляются гипотезы о том, что селективное нитрозилирование некоторых белков может являться регуляторным процессом, в чем-то похожим на фосфорилирование [29, 30,37].

Спектр активности пероксинитрита включает также нитрозилирование гуанина и разрывы цепочек ДНК, что может приводить к мутациям или запуску процессов апоптоза. В отношении повреждений генома известен еще один эффект NO: продукты его реакции с $\mathrm{O}_{2}$ ингибируют ферменты, ответственные за репарацию ДНК. В зависимости от источника (разные доноры NO) показано действие NO на алкилтрансферазу, формамидопиримидин-ДНК-гликозилазу и лигазу. Известно также, что NO может активировать PARP- и ADPрибозилирование, возможно вследствие разрывов ДНК, но это скорее приводит к некрозу из-за истощения пула NAD и ATP [126].

В связи с действием $\mathrm{NO}$ и его производных на ДНК интересны данные о его влиянии на экспрессию 553 . Белок р 53, подавляющий рост опухолей, поддерживает целостность генома и может вызывать остановку клеточного цикла или нейроапоптоз. Известно, что p53 может индуцировать экспрессию Bax, Fas, p53AIP (apoptosis inducing protein) и других апоптогенных белков, а также сам 
перемещается в митохондрию при апоптозе, что может быть одной из причин выработки АФК и падения Dу. В норме концентрация р53 в клетке очень мала и он быстро деградирует. Повреждение ДНК ведет к накоплению р53. В экспериментах на макрофагах и клетках инсулиномы RINm5F выявлено накопление p53 при гибели клеток, вызванной NO [138]. Выяснилось, что L-NMMA (ингибитор NOS) подавляет накопление p53, вызванное действием цитокинов или LPS, что указывает на активную роль NO. По некоторым данным этот эффект NO связан с его способностью подавлять функционирование протеосомы. Однако, эксперименты выявили также функционирование р53-независимых путей при NO-индуцированном апоптозе. В других работах обнаружено существование в разнообразных клетках человека отрицательной обратной связи между соотношением NO и p53: повреждение ДНК, вызванное накоплением NO, активирует экспрессию p53, а он репрессирует ген iNOS человека. NO также подавляет экспрессию iNOS путем ослабления активности NFkB в гепатоцитах. Этими путями достигается жесткая регуляция синтеза NO, что предупреждает его повреждающее действие на ткань [139].

Поскольку участие митохондрии и оксида азота в апоптозе уже подробно рассматривалось в данной работе, то не лишним будет описать их совместное участие в его регуляции. В экспериментах по трансфекции макрофагов линии RAW264.7 человеческим bcl-2 трансфицированные клетки были защищены от гибели, вызванной активацией iNOS. Сделано заключение, что bcl-2 работает посредством снижения до нуля NO-индуцированного повышения экспрессии белка Вах. В других опытах клетки опухолевой линии Р815, трансфицированные bcl-2, были устойчивы к действию NO-донора SNAP (S-нитрозо-Nацетилпеницилламин) и к NO-ассоциированной цитотоксичности активированных мышиных макрофагов. Клетки L929 были защищены сверхэкспрессией bcl-2 от апоптоза, вызванного активацией iNOS. Множество других примеров взаимодействия NO c bcl-2 приведено в обзоре Брюне [109, 125, 126, 140-141].

Взаимодействие NO с членами суперсемейства bcl-2 выражается также в том, что при действии оксида азота на клетку сильно понижается уровень внутриклеточного bcl-2 белка, возможно, через каспаз-индуцированное расщепление или р53-зависимое подавление его экспрессии, хотя есть и противоположные свидетельства. Проапоптотический эффект оксида азота выражается также в индуцируемом им повышении экспрессии Вах [142].

В дополнение к описанным выше функциям митохондрий следует упомянуть последние исследования в этой области, показывающие, что митохондрия имеет отношение не только к восприятию апоптотического сигнала от NO, но и к производству самого NO. Действительно, в последних работах показано наличие конститутивной формы NOS в митохондриях. В первую очередь производство NO было обнаружено в митохондриях печени крыс. Были проведены работы по очистке митохондриальной NOS и изучению ее ферментативных характеристик. Было показано, что эта изоформа NOS локализована в митохондриальной мембране, судя по всему - во внутренней. Оказалось, что mtNOS очень схожа с макрофагальной iNOS, но экспрессируется конститутивно. Пока не ясно, считать ли mLNOS отдельной изоформой, или это iNOS, содержащая 
посттрансляционные модификации, которые ведут к иной субклеточной локализации. Показана независимость этой NO-синтазы от добавления кальмодулина и кальция, что говорит о ее прочной связи кальмодулином [142].

Очищенная mtNOS при субоптимальных концентрациях L-Arg способна продуцировать $\mathrm{O}^{2-}$, однако с не слишком значительной скоростью. Это коррелирует с наблюдаемой гомологией C-концевого домена NOS к NADPH: цитохром P450-оксидоредуктазе, которая тоже обладает NADPH-оксидазной активностью и вырабатывает $\mathrm{O}^{2-}$, но в 10 раз быстрее, чем mtNOS $[143,144]$.

Открытие такой NOS в митохондрии ставит ряд вопросов и указывает новые возможные пути исследований. Во-первых, как образующийся митохондриальный NO влияет на апоптоз? Известно, что немитохондриальный NO действует, в том числе и непосредственно на митохондрии, вызывая ряд явлений, приводящих к апоптозу. Таким образом, хотя это не доказано, логично предположить участие этой mtNOS в регуляции апоптоза. Тем более, что кроме NO она вырабатывает $\mathrm{O}^{2-}$, то есть может иметь отношение к производству активных форм кислорода, а значит - к различным биологическим повреждениям.

В отношении нейроапоптоза интересные данные были получены при изучении выхода цитохрома С из митохондрий после стимуляции mtNOS. Повышение уровня $\mathrm{Ca}^{2+}$ в цитозоли - хорошо известный индуктор апоптоза, но только недавно выяснено, что при этом значительную роль играет mtNOS. Показано, что для такого типа апоптоза необходимо поглощение $\mathrm{Ca}^{2+}$ митохондриями, при этом происходит активация mtNOS, и начинается выход цитохрома С в цитозоль. Одновременно происходит усиление перекисного окисления липидов (LPO). Выход цитохрома C, также как LPO предотвращается ингибиторами NOS (L-NMMA), поглотителем пероксинитрита (урат) и экспрессией bcl-2. В результате сделан вывод, что при $\mathrm{Ca}^{2+}$-индуцированной активации mtNOS, в митохондрии формируется пероксинитрит, что вызывает LPO и выход цитохрома $\mathrm{C}$ и в конечном счете приводит к картине типичного апоптоза. Дальнейшая проработка этих явлений, несомненно, внесет вклад в понимание роли митохондрий и NO в самых разных путях клеточной смерти. Например, недавно было показано (Brookes P. S. et al., 2000), что ингибирование митохондриальной NOS приводит к накоплению внутримитохондриального $\mathrm{Ca}^{2+}$, то есть NO, вырабатываемый mtNOS, препятствует накоплению $\mathrm{Ca}^{2+}$. Поскольку именно повышение концентрации $\mathrm{Ca}^{2+}$ в матриксе ответственно за изменение проницаемости митохондриальной мембраны, то делается вывод (противоположный описанному выше!), что митохондриальный NO замедляет открытие гигантской поры и выход цитохрома С.

Второй вопрос: как регулируется продукция NO в митохондриях? Исследования показывают, что регуляция синтеза NO может происходить за счет субстратов mtNOS (L-Arg, NADPH) и ее кофакторов (FMN, FAD, BH4), как это показано для других изоформ, но в остальном этот вопрос остается открытым. Наконец, в-третьих, этот эндогенный митохондриальный NO может быть очень важен для регуляции деятельности самой митохондрии, так как известен его ингибирующий эффект на цитохромоксидазу (KIV), комплексы I и II электронтранспортной цепи. Его реакция с кислородом может регули- 
ровать митохондриальное дыхание, изменяя доступность $\mathrm{O}_{2}$ для акцептирования электронов и, следовательно, влиять на энергообеспечение клетки. Впрочем, и этот аспект биологии митохондриального NO требует дальнейшего изучения [142, 145-147].

\section{5. РОЛЬ ОКСИДАТИВНОГО СТРЕССА В РЕАЛИЗАЦИИ МЕХАНИЗМОВ НЕЙРОДЕСТРУКЦИИ}

Исследованиями последних лет установлено, что в патогенезе большинства заболеваний, определяющих большой процент смертности и инвалидизации населения (мозговые инсульты, инфаркт миокарда, онкологические заболевания, гипертоническая болезнь и прочие) важную роль играет оксидативный стресс, включающий свободнорадикальное и перекисное окисление, которые приводят к повреждению мембран и гибели клеток. Свободнорадикальные и перекисные окисления как процесс проявляются в метаболизме клетки, как в норме, так и при патологии. Свободнорадикальные и перекисные реакции являются неотъемлемым звеном таких важных биологических процессов, как транспорт электронов в дыхательной цепи, синтез простагландинов и лейкотриенов, пролиферации и дифференциации клеток, метаболизм и синтез катехоламинов, фагоцитоз, метаболизм некоторых ксенобиотиков. Ишемические изменения в органах и тканях сопровождаются гиперактивацией свободнорадикальных процессов и нарушением функционально-структурной целостности биомембран. Оксидативный стресс можно условно разделить на три этапа: инициация активных форм кислорода - свободнорадикальное окисление (CPO); образование свободных радикалов; образование перекисей и гидроперекисей липидов - перекисное окисление липидов.

Важнейшую роль в развитии оксидативного стресса играет первый этап - инициальный, так как он непосредственно связан с нарушением метаболизма при патологических состояниях и наиболее полно поддается фармакокоррекции.

Исходя из вышеизложенного, необходимо более детально остановиться на свободнорадикальных реакциях (CPP), которые оказывают содействие образованию активных форм кислорода (инициальный этап). СРР могут быть как ферментативной, так и неферментативной природы. К первым относятся реакции дыхательной цепи, синтеза простагландинов, цитохрома, фагоцитоза, усиление метаболизма адениловых нуклеотидов и т. д. Ко вторым - катализируемые ионами меди и цинка процессы окисления органических соединений, реакции, индуцированные разными токсичными факторами, ионизацией и т. д. Важнейшей особенностью СРР является цепной характер и обязательное участие свободных радикалов в их реализации.

Свободный радикал - это молекула или ее часть, которая имеет неспаренный электрон на молекулярной или внешней атомной орбитали. Наличие такого электрона наделяет систему высокой реакционной способностью в химических преобразованиях и в связи с этим - возможностью повреждения биологически важных молекул. 
Инициальным звеном оксидативного стресса при повреждении клетки является, как правило, образование в процессе оксигеназных реакций так называемых активных форм кислорода (АФК). Исследования, проведенные в 60-80-х гг. XX ст. показали, что в патогенезе наиболее распространенных заболеваний человека (патология сердечно-сосудистой, эндокринной системы, дыхания, злокачественные образования) имеется четко выраженная свободнорадикальная фаза. При этом была также установлена ведущая роль активных форм кислорода (АФК) в качестве инициаторов реакций свободнорадикального окисления, которые вызывают окислительную модификацию липидов, белков, нуклеиновых кислот, что в ходе развития патологического процесса может приводить к гибели клетки по апоптотическому или некротическому механизму. Кроме того, было обосновано представление об общебиологической роли АФК, определенное количество которых образуется нейрохимическими и биоэнергетическими системами клетки в нормальных условиях, играя существенную роль в различных сторонах ее жизнедеятельности. Эта роль не ограничивается, как представлялось ранее, бактерицидной функцией супероксид-аниона, генерируемого НАДФ-оксидазой, и гипохлорит-аниона, продуцируемого миело- $\mathrm{H}_{2} \mathrm{O}_{2}$-пероксидазой. В последние годы, особенно после открытия роли оксида азота (NO) в регуляции физиологических функций, появились экспериментальные данные об участии АФК в экспрессии генов, синтезе белка, регуляции клеточного метаболизма и локальной гемодинамики. Однако, в связи с многообразием видов АФК, путей их образования и механизмов реализации физиологических эффектов, не существует общепринятой точки зрения относительно роли этих биологически активных молекул в жизнедеятельности клетки.

Пути и механизмы образования АФК в биологических системах в норме. Особенности строения молекулы кислорода (бирадикальная природа, наличие на внешней орбитали двух неспаренных электронов с параллельно расположенными спинами) в ходе его взаимодействия с окисляемыми соединениями приводят к образованию короткоживущих комплексов - АФК, наиболее изученными из которых являются супероксидный анион-радикал, гидроксид и синглетный кислород. В настоящее время выделяют 10 основных видов АФК с разной реакционной способностью, характеризующихся различным временем жизни и выполняемыми физиологическими функциями (таблица 1.1); при этом образование одних форм АФК биохимически сопряжено с образованием других. Образующиеся под контролем антиоксидантных систем АФК могут инициировать образование вторичных мессенджеров (NF-кB - Nuclear Factor kappa B, AP-1 - Activator Protein 1, JNK - Jun NTerminal Kinase), которые регулируют многие ключевые стороны функциональной активности клетки. $\kappa$ настоящему времени достаточно четко описаны пути образования АФК при различных патологических состояниях, ведущих к активации свободнорадикального окисления. Эти реакции характеризуются как процессы нерегулируемого образования АФК. В физиологических условиях АФК образуются преимущественно в следующих системах: 
- в дыхательной цепи митохондрий в небольшом количестве (до 100 пмоль) вследствие "утечки» 5-10 \% электронов с физиологических акцепторов на молекулярный кислород (в этом случае генерируется в основном супероксид $\mathrm{O}^{2}$, скорость образования которого находится в прямой зависимости от степени сопряженности дыхательной цепи); ферментативные комплексы дыхательной цепи митохондрий, которые генерируют $\mathrm{O}^{2} \cdot(\mathrm{HАДФ-зависимая}$ дегидрогеназа, НАД-зависимая убихинонредуктаза), могут активироваться при физических нагрузках (мышечное сокращение), энергозависимых процессах в почках, трансмембранных процессах и др.; полагают, что $\mathrm{O}^{2}$ является родоначальником всех других форм АФК in vivo;

- в процессе активации НАД(Ф)Н-оксидазы; экспрессия этого фермента характерна для фагоцитирующих клеток крови (нейтрофилы, эозинофилы, макрофаги), эндотелиальных клеток, хондроцитов и астроцитов; НАД(Ф) Н-оксидаза катализирует одноэлектронное восстановление $\mathrm{O}_{2}$, принимая восстановительный эквивалент от НАДН или НАДФН; активация НАД(Ф) Н-оксидазы происходит под действием цитокинов (INF- $\gamma$, TNF- $\alpha$, IL- $1 \beta$, некоторые ростовые факторы) и сопровождается образованием $\mathrm{O}^{2 \bullet}$ и $_{2} \mathrm{O}_{2}$ [1];

- при синтезе простагландинов как по циклооксигеназному пути - в процессе превращения PgG2 в PgH2 (пероксидазная функция PgH-синтазы), так и по липоксигеназному пути - в процессе превращения гидроперекиси арахидоновой кислоты в оксикислоту; этот процесс контролируется рядом пептидных гормонов (ангиотензин), цитокинов (TNF- $\alpha$ ) и ростовых факторов;

- в системе миелопероксидаза- $\mathrm{H}_{2} \mathrm{O}_{2}$-галогены $\left(\mathrm{Cl}^{-}, \mathrm{Br}^{-}, \mathrm{I}^{-}\right)$, которая запускается вследствие активации фагоцитоза и приводит к образованию $\mathrm{O}^{2 \bullet}, \mathrm{OCl}^{-}$ и $\mathrm{HO}^{\circ}$;

- при спонтанном или катализируемом МАО окислении дофамина и адреналина (при спонтанном окислении образуется $\mathrm{O}^{2 \bullet}$, а при катализируемом $\left.\mathrm{MAO}-\mathrm{H}_{2} \mathrm{O}_{2}\right)$

В настоящее время выделяют десять видов АФК, имеющих разную реакционную способность, характеризующихся различным временем жизни и выполняемыми функциями.

таблица 1

\section{Основные виды АФК}

\begin{tabular}{|c|c|c|c|}
\hline Вид АФК & $\begin{array}{l}\text { Химический } \\
\text { символ }\end{array}$ & $\begin{array}{c}\text { Время полу- } \\
\text { жизни, с } \\
\text { при }{\text { t’ } 37^{\circ} \mathrm{C}}^{-}\end{array}$ & Свойства \\
\hline $\begin{array}{l}\text { Супероксид- } \\
\text { радикал }\end{array}$ & $0^{2-}$ & $10^{-6}$ & $\begin{array}{l}\text { Хороший восстановитель, умеренный окис- } \\
\text { литель. Обладает свойствами мессенджера } \\
\text { при возбуждении NMDA- и AMPA-рецепторов. } \\
\text { Окисляет - SH и NH2-группы макромолекул. } \\
\text { Вазоконстриктор }\end{array}$ \\
\hline
\end{tabular}




\begin{tabular}{|c|c|c|c|}
\hline $\begin{array}{l}\text { Гидроксил - } \\
\text { радикал }\end{array}$ & $\mathrm{OH}^{\cdot}$ & $10^{-9}$ & $\begin{array}{l}\text { Мощный окислитель. Активен в реакциях ак- } \\
\text { цепции, донирования и переноса электронов. } \\
\text { Участвует в окислительной модификации белка } \\
\text { и нуклеиновых кислот, простагландинов }\end{array}$ \\
\hline $\begin{array}{l}\text { Перекись } \\
\text { водорода }\end{array}$ & $\mathrm{H}_{2} \mathrm{O}_{2}$ & $10-100$ & $\begin{array}{l}\text { Оксидант. Обладает высокой диффузной спо- } \\
\text { собностью. Активирует факторы транскрипции } \\
\text { NF-Карра B, APO-1, регулирует синтез COX-1 } \\
\text { и iNOS }\end{array}$ \\
\hline $\begin{array}{l}\text { Синглетный } \\
\text { кислород }\end{array}$ & $0^{2 \cdot}$ & $10^{-6}$ & Мощный окислитель \\
\hline $\begin{array}{l}\text { Молекулярный } \\
\text { кислород }\end{array}$ & $\mathrm{O}_{2}$ & $>10^{-2}$ & Умеренный окислитель \\
\hline $\begin{array}{l}\text { Пероксильный } \\
\text { радикал }\end{array}$ & R00 & $10^{-2}$ & $\begin{array}{l}\text { Характеризуется более низкой, чем у ОН, окис- } \\
\text { лительной способностью, но более высокой } \\
\text { диффузией }\end{array}$ \\
\hline $\begin{array}{l}\text { Алкоксильный } \\
\text { радикал }\end{array}$ & RO & $10^{-6}$ & $\begin{array}{l}\text { Активен при взаимодействии с липидами, при- } \\
\text { водит к их окислительной модификации }\end{array}$ \\
\hline $\begin{array}{l}\text { Монооксид } \\
\text { азота }\end{array}$ & NO ${ }^{\circ}$ & $10^{-3}$ & $\begin{array}{l}\text { Умеренный окислитель, хорошо диффундирует. } \\
\text { Обладает свойствами мессенджера. Участвует } \\
\text { в экспрессии генов }\end{array}$ \\
\hline Пероксинитрит & ONOO: & $10^{-7}$ & $\begin{array}{l}\text { Мощный окислитель. Участвует в реакции } \\
\text { нитрования тирозина, окислении SН + групп } \\
\text { и металлопротеинов, разрыве цепей ДНК, акти- } \\
\text { вирует поли(АДФ-ректоза)полимеразу, иниции- } \\
\text { рует апоптоз }\end{array}$ \\
\hline Гипохлорит & $\mathrm{OCl}^{-}$ & $10^{-6}$ & $\begin{array}{l}\text { Мощный окислитель. Характеризуется более } \\
\text { высокой, чем у ONOO-, диффузной способ- } \\
\text { ностью, участвует в окислении сульфоновых } \\
\text { и дисульфоновых групп белков и ДНК, хлориро- } \\
\text { вании тирозина }\end{array}$ \\
\hline
\end{tabular}

- при «мягкой» (позитивный процесс, улучшение памяти, обучение) и при повышенной (тревога, стресс, беспокойство - «электрический шторм») активации глутаматных рецепторов, где АФК играют роль эндогенных регуляторов активности этих рецепторов;

- активация NMDA-подтипа глутаматных рецепторов на постсинаптической мембране приводит к открытию каналов, проницаемых для $\mathrm{Ca}^{2+}$ (входящий ток) и $\mathbf{K}^{+}$(выходящий ток); следствием активации этих рецепторов является внутриклеточная продукция $\mathrm{A} \Phi К\left(\mathrm{O}^{2 *}\right.$ и $\left.\mathrm{HO}^{*}\right)$, а результатом активации $\mathrm{Ca}^{2+}$-зависимой $\mathrm{NO}$-синтазы - $\mathrm{NO}$;

- при активации AMPA/каинатных рецепторов, в основе чего лежат как $\mathrm{Ca}^{2+}$ зависимые, так и митохондриальные механизмы;

- во время синтезаNO', образуемого из гуанидинового атомаазота и L-аргинина синтазой оксида азота (NOS), которая присоединяет молекулярный кислород к терминальному атому азота в гуанидиновой группе L-аргинина (NOS образует также конечный неактивный продукт - L-цитруллин). 
Биохимические и молекулярно-генетические функции АФК в клетке. Как следует из вышеизложенного, небольшие (физиологические) количества АФК постоянно образуются в процессе нормального физиологического функционирования биоэнергетических и нейро-химических систем животных клеток. При этом АФК выполняют функции вторичных мессенджеров и могут обеспечивать адаптацию клетки к изменяющимся условиям функционирования. Сигнальная функция АФК четко проявляется в поддержании вазоконстрикторновазодилатационного баланса, обусловливающего гетерогенность органного кровотока. Так, NO^ участвует в регулировании процессов вазодилатации посредством регуляции концентрации цАМФ в клетках эндотелия. $\mathrm{O}^{2 \bullet}$ участвует в регуляции процесса вазоконстрикции, не оказывая прямого действия на гладкомышечные клетки сосудов, но инактивируя $\mathrm{NO}^{*}, \mathrm{H}_{2} \mathrm{O}_{2}$ и $\mathrm{HO} \mathrm{O}^{*}$, которые, напротив, индуцируют вазодилатацию. Предполагается, что $\mathrm{NO}^{\circ}, \mathrm{H}_{2} \mathrm{O}_{2}$ и $\mathrm{HO}^{\bullet}$ могут оказывать прямое влияние на миоциты, активируя гуанилилциклазу, или стимулировать высвобождение из эндотелия непростаноидного релаксирующего фактора. Кроме того, $\mathrm{O}^{2 \bullet}$ способен активировать синтез $i \mathrm{NOS}$ посредством активации синтеза цитокинов, повышая тем самым уровень NO. Достаточно детально изучена сигнальная роль АФК при взаимодействии различных подтипов глутаматных рецепторов. Так, показано, что АФК, образованные в результате активации NMDA-рецепторов, окисляют SH-группы в фенциклидиновом и глутаминовом сайтах этих рецепторов и приводят к подавлению их функции. Данный механизм, являющийся примером обратной связи в контроле рецепторных структур, стал основой для формирования представлений o redox-регуляции ионотропных рецепторов. Согласно redox-гипотезе, баланс между прооксидантами и оксидантами в нервной клетке может управлять процессами долговременной памяти и обучения. Так, АФК $\left(\mathrm{O}^{2 \bullet}\right.$ и $\left.\mathrm{NO}^{*}\right)$, генерируемые в результате активации NMDA-рецепторов, модулируют активность метаботропных рецепторов, что препятствует росту АФК и свидетельствует о способности АФК регулировать физиологическое взаимодействие ионотропных и метаботропных глутаминовых рецепторов. Полагают, что такое взаимодействие, изменяя способность связывания лигандов в синаптических структурах, образование вторичных мессенджеров и активность ключевых регуляторных ферментов в нейронах, лежит в основе синаптической пластичности головного мозга.

АФК способны также регулировать активный трансмембранный ионный транспорт за счет модуляции мембранных ферментов и белков, входящих в структуру ионных каналов. Так, обратимое окисление $\mathrm{SH}-г$ руппы $\mathrm{Na}^{+} /$ $\mathrm{K}^{+}$-зависимой-АТФазы под действием АФК приводит к снижению ее сродства к субстрату и, соответственно, каталитической активности фермента. Ингибирующим действием в отношении $\mathrm{Na}^{+} / \mathrm{K}^{+}$-зависимой АТФазы обладают и образующиеся внутриклеточно комплексы NO с низкомолекулярными тиолами, содержащие $\mathrm{Fe}^{2+}$. Сам $\mathrm{NO}$ ' обладает активирующим действием. АФК влияют на процессы ионного транспорта также путем химической модификации белковых компонентов ионных каналов, в основе чего лежит способность АФК окислять $\mathrm{SH}-$ и $\mathrm{NH}_{2}$-группы соответствующих белковых структур. Показано, что $\mathrm{O}^{2 \cdot}$ может активировать $\mathrm{Cl}^{-}$и $\mathrm{K}^{+}$-каналы, что приводит к изменению элек- 
трической активности нейронов и способности обратного захвата медиаторов. В условиях дозируемого (контролируемого физиологическими антиоксидантными системами) повышения уровня АФК происходит также экспрессия redoxчувствительных генов, ответственных за синтез ряда белков, необходимых для нормального функционирования клетки, защиты от токсических эффектов окислительного стресса. Судя по всему, это происходит на уровне транскрипции генов, среди которых гены глутатионпероксидазы, хинонредуктазы, каталазы, супероксиддисмутазы, гемоксигеназы 1 , ферритина, глутатионредуктазы, тиоредоксина, тиоредоксинредуктазы и металлотионеина. Помимо перечисленных, АФК активируют экспрессию генов, действие которых не направлено непосредственно на усиление устойчивости клеток к окислительному стрессу, и которые функционально можно объединить как отвечающие за межклеточные взаимодействия. Промоторные области индуцируемых под действием АФК генов содержат участки связывания факторов транскрипции AP-1, ATF/CREB, Ets, C/EBP и NF-кB. Активирующее действие АФК на факторы транскрипции опосредовано сложными редокс-чувствительными сигнальными системами.

МАР-киназа как регуляторная система реализации действия АФК. Основная регуляторная система, которая контролирует экспрессию генов в ответ на действие АФК, представлена в клетке MAP-киназами (Mitogen Activated Protein kinases). АФК способны активировать MAP-киназный каскад, регулируя активность глобальных транскрипционных факторов NFкB, AP-1 и ATF-2 (Activating Transcription Factor). Избыток АФК (NO', НО') способен ограничивать активность МАР-киназ. Активация МАР-киназ под действием АФК начинается с активации редоксзависимой киназы ASK-1 (Apoptosis Signal Regulating Kinase-1). Эта киназа, входящая в группу MAP3К, контролирует каскады MAP-киназ - p38 и JNK. Активность ASK-1 зависит от тиоредоксина - низкомолекулярного многофункционального тиолсодержащего белкового фактора. В зависимости от состояния SH-группы, тиоредоксин находится либо в окисленном, либо в восстановленном состоянии. В восстановленной форме тиоредоксин связывается с ASK-1, тем самым ингибирует его, препятствуя контакту между ASK-1 и активирующим фактором TRAF-2 (TNF Receptor Associated Factor 2). При дозированном повышении уровня АФК $\left(\mathrm{O}, \mathrm{H}_{2} \mathrm{O}_{2}\right) \mathrm{SH}$-группа тиоредоксина превращается в S-Sгруппу, он переходит в окисленную форму и диссоциируется из комплекса c ASK-1 (при этом наблюдается активация последней). Этот процесс обратимый, и под действием глутатиона, метионина или цистеина тиоредоксин восстанавливается. Таким образом, тиоредоксин довольно чувствителен к изменению равновесия АФК/антиоксиданты, что позволяет рассматривать этот белок в качестве внутриклеточного буфера АФК. Активная киназа ASK-1 посредством активации киназ МКК4, МКК6 активирует JNK и p38, соответственно. Каскад JNK наиболее чувствителен к АФК, действие которых вызывает продолжительную (несколько часов) активацию этого фермента. Фактор транскрипции JNK вызывает активацию ДНК-связывающих белков сJun, c-Fos и AP-1. Связывание этих белков с палиндромными последовательностями ДНК вызывает индукцию апоптоза, активацию синтеза ферментов и фак- 
торов пролиферации. Кроме того, активная форма киназы ASK1 активирует 1КВ-киназу, которая фосфорилирует 1-КВ (ингибитор NF-kappa B), в результате чего происходит активация фактора транскрипции NF-kappa B, который усиливает синтез ферментов, участвующих в защите клеток в условиях оксидативного стресса. Кроме АФК-зависимой ASK-1 в активации NF-kappa B принимают участие еще 6 киназ (NIK, IRAK, MEKK, PKR, PUCe и PUCq), которые активируются свободными жирными кислотами, липополисахаридами, интерлейкинами, TNF- $\alpha$, HIF-1. Подобная редоксзависимая активация факторов транскрипции дает пример многоуровневого регуляторного действия АФК на жизнедеятельность клетки.

Образование АФК при нейродеструктивных заболеваниях. Активация АФК при нейродеструктивных заболеваниях может быть вызвана следующими факторами:

- дискоординацией электронтранспортных цепей митохондрий и микросом;

- снижением концентрации кислорода в тканях организма (гипоксия) и накоплением восстановленных форм пиридиннуклеотидов;

- накоплением катехоламинов, их предшественников и продуктов метаболизма;

- усилением метаболизма адениловых нуклеотидов и активацией ксантиноксидазы;

- дисбалансом микроэлементов, в особенности - d-элементов;

- усилением метаболизма арахидоновой кислоты;

- активацией системы миелопероксидаза- $\mathrm{H}_{2} \mathrm{O}_{2}$-галогены $\left(\mathrm{Cl}^{-}, \mathrm{Br}^{-}, \mathrm{I}^{-}\right)$ в фагоцитах;

- гиперактивацией индуцибельной формы синтазы оксида азота (iNOS), в особенности при дефиците L-аргинина и нейрональной формы синтазы оксида азота (nNOS);

- гиперактивность глутамат- и аспартатергических систем ЦНС (нейрометаболический аутокоидоз) при чрезмерной и экстрамаксимальной активации нейронов в условиях острой ишемии. Происходит подавление деятельности нейронов, гибель дендритов и нейрона.

- снижением активности антиоксидантных ферментных систем и уровня эндогенных антиоксидантов.

В дыхательной цепи митохондрий активные формы кислорода образуются в небольшом количестве в физиологических условиях вследствие "утечки" 5-10\% электронов, которые транспортируются по цепи. $\mathrm{O}^{2}$ принимает участие в процессе соединения дыхания с окислительным фосфорилированием и лежит в основе окислительных процессов в митохондриях. Скорость образования $\mathrm{O}^{2}$ в митохондриях находится в прямой зависимости от степени сопряженности дыхательной цепи и резко повышается при ее блокаде.

В электронтранспортной цепи микросом образование активных форм кислорода происходит большей частью вследствие действия цитохрома $\mathrm{P} 450$, который образует с гидрофобным субстратом ряд фермент-субстратных комплексов. Распад этих комплексов обеспечивает окисление $\mathrm{O}^{2 \bullet-}$-субстрата, вос- 
становление фермента (цитохром $\mathrm{P} 450 \cdot \mathrm{Fe}^{3+}$ ) и может сопровождаться высвобождением $\mathrm{O}^{2}$ с с дальнейшим его восстановлением до $\mathrm{H}_{2} \mathrm{O}_{2}$ и $\mathrm{OH}$ -

Снижение концентрации кислорода в тканях организма (гипоксия) сопровождается накоплением большого количества восстановленных форм разных соединений, в том числе коферментов - НАДН, НАДФН, ФАДН, убихинонов. В условиях $\mathrm{O}_{2}$-дефицита это приводит к одноэлектронному восстановлению кислорода до $\mathrm{O}^{2 \bullet}$. Данный процесс происходит на конечном участке электронной дыхательной цепи.

Выявлено также, что радикалобразующие системы митохондрий $\mathrm{pH}$ зависимы и активизируются при ацидозе, а активность одного из ферментов НАДН-оксидазы митохондрий, образующей активные формы кислорода, возрастает в поврежденных гипоксией тканях. В условиях ишемии резко возрастает образование АФК в митохондриях при разобщении дыхательной цепи и окислительного фосфорилирования. Причем скорость образования АФК находится в прямой зависимости от степени блокирования дыхательной цепи. Данный процесс приводит к восстановлению переносчиков на предшествующих блокаде участках, особенно ротенон- и актиномицин- зависимых, которые способствуют усилению блокады, «утечке» электронов и, в конечном итоге, гиперпродукции АФК. Ферментативные комплексы дыхательной цепи митохондрий, генерирующие АФК (НАДН-зависимая дегидрогеназа, НАД-зависимая убихинонредуктаза), активируются в ответ на снижение мозгового кровотока ниже 20 мл/100 г/мин. В условиях $\mathrm{O}_{2}$-дефицита в тканях мозга резко повышается уровень восстановленных форм коферментов - НАДН, НАДФН, убихинонов, что приводит к одноэлектронному восстановлению $\mathrm{O}_{2}$ до $\mathrm{O}^{2} \bullet$. Существуют убедительные доказательства того, что центральная роль в продукции АФК принадлежит митохондриям, изменению проницаемости их мембран в результате формирования специфического комплекса митохондриальных пор и инициированию митоптоза. Первичным источником АФК оказываются митохондрии, которые играют ключевую роль в энергетическом обеспечении клетки. АФК, особенно супероксид, образуются в условиях ишемии и гипоксии в так называемых паразитарных реакциях, в начальном участке дыхательной цепи митохондрий.

Первый путь инициации СРО катехоламинами возможен в органахмишенях, одним из которых является мозг. Второй путь может реализовываться за счет образования активных форм кислорода (в частности, $\mathrm{O}^{2 \bullet}$ ) как при биосинтезе адреналина (переход тирамина в октопамин), так и при окислении адреналина в адренохром (переход адреналина в семихинон, а семихинона в хинон).

Кроме того, стимуляция катехолзависимых нейронов ведет к накоплению аналогов катехоламинов (6-гидроксидопамина и 6-аминодопамина), которые при аутоокислении также генерируют $\mathrm{O}^{2 \cdot}, \mathrm{O}_{2}{ }^{2-}$ и $\mathrm{OH}^{-}$. При этом важное значение имеет содержание норадреналина, который, возможно, играет роль ингибитора активных форм кислорода. Участие катехоламинов в продукции АФК может также реализовываться через интенсификацию глюкозомонофосфатного шунта в нейтрофилах. При метаболизме адениловых нуклеотидов $(\mathrm{AT \Phi} \rightarrow$ АДФ $\rightarrow$ АМФ $\rightarrow$ аденин $\rightarrow$ аденозин $\rightarrow$ гипоксантин $\rightarrow$ ксантин $\rightarrow$ моче- 
вая кислота), на последнем его этапе, активируется ксантиноксидаза, которая также генерирует активные формы кислорода.

Окисление гипоксантина в мочевую кислоту с помощью ксантиндегидрогеназы происходит в присутствии НАДН, а с помощью ксантиноксидазы - без НАД, и этот процесс приводит к образованию $\mathrm{O}^{2} \cdot$. При наличии в среде данной реакции металлов переменной валентности происходит образование $\mathrm{O}^{2 *}, \mathrm{OH}^{*}$ и усиливается индукция процессов оксидативного стресса.

АФК также образуются на всех этапах глутамат-кальциевого каскада, но большинство исследователей ведущую роль в индукции АФК при ишемии мозга отводят глутамат- и аспартатергическим системам. Так, активация NMDA-рецепторов на постсинаптической мембране глутаматергического синапса приводит к повышению уровня внутриклеточного $\mathrm{Ca}^{++}$и продукции АФК (супероксид-радикала, гидроксил-радикала, NO-радикала). Другим, не менее важным, источником образования АФК при ишемии мозга, является реакция окисления гипоксантина и ксантина в мочевую кислоту, катализируемая ксантиндегидрогеназой, которая превращается в ксантиноксидазу и генерирует супероксид-радикал. В протеолитическом образовании ксантиноксидазы из ксантиндегидрогеназы активное участие принимает $\mathrm{Ca}^{++}$, повышение уровня которого происходит при активации NMDA-рецепторов. Кроме того, ксантиноксидаза превращается из ксантиндегидрогеназы при окислении SH-групп в молекуле последней под действием таких АФК, как $\mathrm{ONOO}^{-}$и супероксидрадикал. Этот способ модификации ксантиндегидрогеназы наблюдается в более поздние сроки ишемии мозга. Подобный механизм образования АФК описан при гипоксии, модельном ОНМК и черепно-мозговой травме. Усиление продукции АФК в ксантиноксидазной реакции может происходить в условиях формирования энергодефицита и деградации адениловых нуклеотидов. При наличии в среде металлов переменной валентности, таких как железо или цинк, в этой реакции образуется более реакционная молекула - гидроксил-радикал.

Многочисленными работами показана прооксидантная роль металлов переменной валентности $\left(\mathrm{Fe}^{2+}, \mathrm{Cu}^{2+}, \mathrm{Mn}^{2+}, \mathrm{Co}^{2+}, \mathrm{Cr}^{2+}\right.$ и др.) как в химических, так и биологических модельных системах. Инициирующая роль металлов в образовании свободных форм кислорода и разветвлении цепей свободнорадикального окисления, а также преобразование некоторых из них из прооксидантов в антиоксиданты и наоборот $\left(\mathrm{Cu}^{2+}, \mathrm{Co}^{2+}\right)$, зависит от связывания металла, изменения его концентрации, отсутствия достаточного количества восстановителей в биологических системах. Наиболее важная роль в инициировании оксидативного стресса и образовании АФК, принадлежит $\mathrm{Fe}^{2+}$, а вернее окислительно-восстановительной паре $\mathrm{Fe}^{2+} / \mathrm{Fe}^{3+}$. Присутствие $\mathrm{Fe}^{2+}$ обязательно во всех системах образования $\mathrm{O}_{2} \div$ из кислорода (микросомы, митохондрии, ксантин-ксантиноксидаза, метаболизм катехоламинов) и в особенности - при образовании $\mathrm{OH}^{\bullet}$ в реакциях Фентона и Габера-Вейсса.

$$
\begin{gathered}
\mathrm{H}_{2} \mathrm{O}_{2}+\mathrm{Fe}^{2+} \rightarrow \mathrm{OH}^{-}+\mathrm{Fe}^{3+}+\mathrm{OH}^{\bullet} \text { (реакция Фентона) } \\
\mathrm{H}_{2} \mathrm{O}_{2}+\mathrm{O}_{2}^{-}+\mathrm{Fe}^{2+} \leftrightarrow \mathrm{OH}^{-}+\mathrm{O}_{2}+\mathrm{OH}^{\bullet}+\mathrm{Fe}^{3+} \text { (реакция Хабера-Вейсса) }
\end{gathered}
$$


Кроме того, железо (II) инициирует образование $\mathrm{O}^{2 \bullet}$ из миелопероксидазы:

$$
\mathrm{Fe}^{2+}+\mathrm{O}_{2} \rightarrow \mathrm{Fe}^{3+}+\mathrm{O}^{2 \cdot}
$$

Необходимо отметить, что свободное закисное железо (цитоплазматический пул) лидирует на инициальных этапах СРО при образовании активных форм кислорода в реакциях Фентона и Габера-Вейсса.

В условиях ишемии органов и тканей наблюдается увеличение цитозольной фракции $\mathrm{Fe}^{2+}$ уже через 60 минут, причем в ранний срок ишемии повышение железа происходит за счет его декомпартментализации, а в более поздние сроки - вследствие выхода его из ферритина, что может обуславливать повторный всплеск свободнорадикальных реакций. Кроме железа, участие в образовании АФК в ишемизированном мозге, особенно в нейронах $\mathrm{CA}_{3}$ играет $\mathrm{Zn}^{2+}$, а в некоторых случаях и одновалентная медь $\left(\mathrm{Cu}^{+}\right)$.

Синтез простагландинов из арахидоновой кислоты происходит по циклооксигеназному и липоксигеназному путям. Данный биосинтез на начальных этапах сопровождается образованием активных форм кислорода:

- в циклооксигеназном пути метаболизма арахидоновой кислоты в процессе преобразования $\mathrm{Pg}_{2}$ в $\mathrm{PgH}_{2}$ (пероксидазная функция $\mathrm{PgH}$ синтетазы);

- в липоксигеназном пути метаболизма арахидоновой кислоты - в процессе преобразования гидроперекиси арахидоновой кислоты в оксикислоту (пероксидазная функция глутатионпероксидазы (ГПР)).

Благодаря неспецифичности PgН-синтетазы, она способна метаболизировать не только эндоперекиси, но и гидроперекиси арахидоновой кислоты и других кислот.

Таким образом, на начальных этапах синтеза простагландинов из арахидоновой кислоты образуются активные формы кислорода, которые могут инициировать запуск реакций оксидативного стресса в тканях.

Функциональная активность фагоцитирующих клеток (нейтрофилы, моноциты и макрофаги) в значительной мере обусловлена способностью генерировать активные формы кислорода. Это наиболее четко проявляется в их бактерицидной функции.

Источником генерации активных форм кислорода в фагоцитах является система миелопероксидаза- $\mathrm{H}_{2} \mathrm{O}_{2}$-галогены $\left(\mathrm{Cl}^{-}, \mathrm{Br}^{-}, \mathrm{I}^{-}\right)$или тиоцианаты. Эта система запускается вследствие активации фагоцитов и приводит к образованию наиболее активных форм кислорода $\left(\mathrm{O}^{2 \cdot}, \mathrm{OCl}^{-}, \mathrm{OBr}^{-}, \mathrm{OI}^{-}\right)$. Миграция фагоцитов в область ишемического повреждения приводит к концентрации в ней миелопероксидазы, которая, при наличии своего субстрата гидропероксида, способна быстро вырабатывать гипохлорит-анион. В этих условиях (так называемый «окислительный взрыв») в нейтрофилах до $90 \%$ потребляемого $\mathrm{O}_{2}$ восстанавливается до $\mathrm{O}^{2}$.

Усиление образования АФК в ишемизированном органе происходит при снижении функциональной активности антиоксидантной системы нейрона. 
В ряде работ показано, что повреждению АО ферментов, в особенности СОД, при ишемии оказывает содействие ряд факторов [16, 31, 43, 111, 134, 146, 175]:

- снижение уровня макроэргических фосфатов;

- резкое повышение концентрации активных форм кислорода, в особенности - ОН:;

- метаболический ацидоз, развивающийся в ишемизированных тканях.

Причина резкого снижения активности АО ферментов при ишемии до конца не выяснена, вероятнее всего, это связано с их (в особенности СОД) высокой чувствительностью к активным формам кислорода или липидным перекисям.

Кроме АО ферментов, в организме важное значение имеют эндогенные антиоксиданты и антиоксидантные соединения (токоферолы, аскорбиновая кислота, тио- и селенсодержащие соединения).

Активность протекания реакций оксидативного стресса и инициирование АФК зависит от абсолютного или относительного содержания в тканях эндогенных антиоксидантов, вследствие чего повышение или снижение их количества может влиять на интенсивность оксидативного стресса.

В условиях оксидативного стресса АФК атакуют макромолекулы клеточной мембраны нейрона, что приводит к их окислительной модификации и деструкции. Мембраны клеток, в частности нейронов, характеризуются высоким содержанием арахидоновой, декозогексаеновой и других жирных полиненасыщенных кислот, легко окисляемых под действием АФК, особенно супероксидрадикала и гидроксил-радикала. Окисление жирных кислот мембран носит цепной характер и идет по свободнорадикальному механизму с промежуточным образованием нестабильных алоксильных и пероксильных радикалов и, в конечном итоге, с образованием стабильных продуктов: п-алкеналей, 2 -алкеналей, 2,4-алкандиенов, алкантриенов, $\alpha$-гидроксиалкеналей, гидропероксиалкенов и малонового диальдегида. Многочисленными работами на примере экспериментальных моделей ишемии мозга показано, что уже минимум через 15 мин ишемии в тканях мозга достоверно наблюдается рост алкандиенов, триенов и малонового диальдегида. Пероксидные продукты окисления мембранных липидов нарушают регулярную упаковку мембранного бислоя и вызывают образование в мембране дефектных зон. Алкенали и гидроксиалкенали, особенно продукт окисления $\omega-6$ ПНЖКК - 4-гидрокси-2,3-трансноненаль, образуют аддукты с фосфолипидами, белками, нуклеиновыми кислотами, приводя к их повреждению.

Малоновый диальдегид, взаимодействуя с белками и нуклеиновыми кислотами, кроме того, вызывает образование межмолекулярных сшивок, причем это свойство усиливается при ацидозе. Подобное действие альдегидов и гидроксиалкеналей приводит к изменению структуры рецепторов, ионных каналов, цитоскелета клетки, ферментов, торможению синтеза внутриклеточных посредников и вызывает деструкцию ДНК и РНК.

Процессы повреждения белков и нуклеиновых кислот под действием АФК происходят параллельно с окислительным повреждением липидов. 
В окислительной модификации белков ведущая роль принадлежит NO, гипохлориту, супероксид-радикалу, гидроксил-радикалу, пероксинитриту. В окислительную модификацию белков вовлекаются различные аминокислотные фрагменты, такие как цистеин, метионин, гистидин, пролин, аргинин, триптофан, тирозин. Наиболее легко окисляются под действием АФК сульфгидрильные группы в цистеине и метионине с образованием сульфоновых и дисульфидных групп. Этот вид модификации является обратимым и его обращение зависит от энергетического потенциала клетки и наличия в ней восстановленных форм глутатиона, тиоредоксина.

Окисление SH-групп в белковых молекулах приводит к нарушению или модификации их функций. Так, под действием АФК на $\mathrm{K}^{+} / \mathrm{Na}^{+} \mathrm{AT \Phi -азу,} \mathrm{у} \mathrm{по-}$ следней утрачивается чувствительность к регулирующему действию АТФ, окисление $\mathrm{SH}$-группы ксантиндегидрогеназы превращает ее в ксантиноксидазу, которая сама продуцирует АФК, усиливая тем самым интенсивность оксидативного стресса. Окислительная модификация белковых молекул приводит к нарушению способности мембран генерировать, проводить нервный импульс, к нарушению рецепторных, медиаторных, энергетических, секреторных и метаболических систем клетки.

Избыток NO усиливает экспрессию каспаз, которые относятся к семейству IL-1 $\beta$-конвертирующих протеаз, причастных к разветвлению цепи апоптоза. Экспрессия каспазы 3 обнаружена в нейронах и астроглии пациентов с болезнью Альцгеймера, а каспазы 1 в нейронах пациентов с черепно-мозговой травмой и каротидным инсультом. Избыток АФК, особенно $\mathrm{OH}^{*}$ и $\mathrm{ONOO}^{-}$, способен подвергать окислительной модификации нуклеиновые кислоты, в результате чего происходит повреждение оснований, повреждение дезоксирибозы и появление новых ковалентных связей («сшивок»). Образовавшийся в результате взаимодействия $\mathrm{OH}^{\cdot}$ и $\mathrm{ONOO}^{-}$пероксинитрит способствует открытию гигантской поры митохондрий, а также нитрозилирует цитохром $\mathrm{C}$ в митохондриях, что приводит к изменению его функций, в частности он становится неспособным поддерживать перенос электронов в дыхательной цепи и не восстанавливается аскорбатом. Поскольку одновременно происходит выход цитохрома С (в том числе и нитрозилированного) в цитоплазму, то можно предполагать участие такого процесса нитрозилирования и в каких-то сигнальных процессах. Пероксинитрит нитрозилирует гуанин, что приводит к разрыву цепочек ДНК и к мутациям или запуску процессов апоптоза. Избыток NO ингибирует ферменты, ответственные за репарацию ДНК; показано действие на алкилтрансферазу, формамидопиримидин-ДНК-гликозилазу и лигазу. NO активирует PARP и АДФ-рибозилирование, особенно на фоне дефицита АTФ и накопления восстановленных пиридиннуклеотидов. NO положительно влияет на синтез белка р53, который индуцирует экспрессию Bax, Fas, p53AIP (apoptosis inducing protein) и других апоптогенных белков, а также перемещается в митохондрию при апоптозе, что может быть одной из причин выработки АФК и снижения трансмембранного потенциала на внутренней мембране. Ныне существует обобщенное понятие «митохондриальная дисфункция». Это типовой патологический процесс, не имеющий этиологической и нозологиче- 
ской специфичности. Развитие митохондриальной дисфункции приводит к нарушению обратного захвата медиаторов (катехоламинов, дофамина, серотонина), ионного транспорта, генерации и проведения импульса, синтеза белка de novo, процессов трансляции и транскрипции; активизируются паразитарные энергопродуцирующие реакции, что приводит к существенной убыли энергетических запасов клетки. Кроме того, под действием гидроксил-радикала происходит открытие митохондриальных пор с экспрессией и выходом в цитозоль проапоптотических белков. Открытие пор происходит за счет окисления тиольных групп цистеинзависимого участка белка внутренней мембраны митохондрий (АТФ/АДФ-антипортер), что превращает его в проницаемый неспецифический канал-пору. Открытие пор превращает митохондрии из «электростанций» в «топку» субстратов окисления без образования АТФ. В точных биохимических исследованиях было установлено, что нарушение кислородного режима тканей, гиперпродукция эксайтотоксичных аминокислот, снижение нормальной аккумуляции $\mathrm{Ca}^{2+}$ митохондриями, повреждение мембраны митохондрий АФК усиливает открытие пор и высвобождение апоптогенных белков из поврежденных митохондрий. В этом контексте существенна роль одного из нейротрофических факторов - фактора некроза опухоли- $\alpha$ (TNF- $\alpha$ ), с которым связаны открытие пор в митохондриях, последующее нарушение их мембран и развитие митоптоза. Митохондриальная пора представляет собой канал, проходящий через обе митохондриальные мембраны и состоящий из трех белков: транслокатора адениновых нуклеотидов, потенциалзависимого анионного канала (порина) и бензодиазепинового рецептора. Когда этот комплекс связывается с $\mathrm{Ca}^{2+}$, через мембранную пору могут проходить вещества с небольшой молекулярной массой. Это приводит к снижению мембранного потенциала и набуханию матрикса, целостность внешней мембраны неизбежно нарушается, и из межмембранного пространства в цитоплазму выходят белки апоптоза. Их несколько: фактор, индуцирующий апоптоз (APOptosis-inducing factor), вторичный митохондриальный активатор каспаз (second mitochondria-derived activator of caspases - Smac) и некоторые прокаспазы. Индуцирующий фактор направляется прямо в ядро, где вызывает деградацию ДНК. Наряду со специфическими апоптозными белками из митохондрии через открытую пору выходит цитохром C, который в норме служит конечным звеном электронтранспортной цепи. В цитоплазме этот белок связывается с белком Apaf-1 (APOptotic protease activating factor-1 - активирующий протеазу фактор 1) и формирует апоптосомный комплекс. Он с помощью Smac и еще одного фактора (Omi/HtrA2) активирует прокаспазу 9, которая, став каспазой 9, превращает два других профермента в каспазы 3 и 7; а они уже расщепляют структурные белки, приводя к появлению биохимических и морфологических признаков апоптоза. В числе первых можно назвать, в частности, переход фосфатидилсерина в наружный мембранный слой и фрагментацию ДНК под действием АФК и NO. Из вторых признаков наиболее характерны отшелушивание клетки от матрикса, сморщивание мембраны, сжатие ядра и формирование пузырьков с клеточным содержимым - апоптозных телец. Выходу цитохрома С в цитоплазму способствуют снижение $\mathrm{pH}$ при развитии лактат-ацидоза, усиление окислительной модифи- 
кации митохондриальных белков и липидов. Последнюю реакцию как раз и вызывают АФК, которые неизбежно образуются в результате паразитарных энергетических реакций. Цитохром С может высвобождаться в ответ на повышение концентрации ионов $\mathrm{Ca}^{2+}$, которое вызывает открывание поры, а также контролироваться белками семейства bcl-2. Именно они регулируют апоптоз на уровне митохондрий. С явлением митохондриальной дисфункции тесно связана гиперэкспрессия ранних генов - c-fos. Так, в условиях гиперпродукции АФК нейрохимическими и биоэнергетическими системами головного мозга в условиях ишемии, а также при ряде других нейродеструктивных патологических процессов, происходит активация экспрессии редоксчувствительных генов, многие из которых необходимы для защиты клеток от токсических эффектов окислительного стресса. Так, при нормальной концентрации кислорода в окружающей клетку среде (нормоксия) под действием АФК происходит в основном активация JunB, ATF-2 - факторов транскрипции, а в условиях окислительного стресса - преимущественно факторов c-Jun и c-fos. Активация именно этих факторов транскрипции в условиях гиперпродукции АФК объясняется тем, что JunB и c-fos содержат в своих ДНК-связывающих доменах высокочувствительные к АФК остатки цистеина - Cуs252, Суs54, Суs61. Окисление

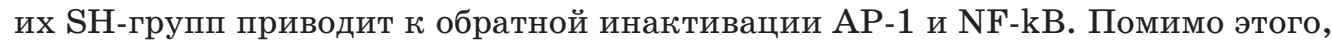
белок c-fos непосредственно участвует в процессе фрагментации митохондриальной ДНК и инициировании процессов апоптотической гибели нейрональной клетки. C-fos ответственен за гиперпродукцию NO при нейродеструктивных заболеваниях посредством активации индуцибельной NO-синтазы. C-fos представляет собой одну из основных ядерных мишеней для передачи сигналов регуляции клеточного роста и трансформации, вовлечен во множество клеточных функций, в том числе в процессы клеточной пролиферации и дифференцировки. NO является мощным нитрозилирующим агентом, мишенями которого могут быть нуклеофильные группы активных тиолов, амины, карбоксилы, гидроксилы и ароматические кольца. $\mathrm{NO}^{+}$образуется из избытка NO при участии двухвалентного железа и кислорода. $\mathrm{NO}^{-}$обладает восстановительными свойствами, оказывает позитивное инотропное, лузитропное действие на миокард, снижает порог судорожной готовности. В условиях ишемии, когда наблюдается гиперпродукция $\mathrm{NO}^{-}$на фоне лактат-ацидоза, проявляются прооксидантные свойства этого деривата оксида азота по отношению к тиолам и аминам.

Результаты исследований in vitro показывают, что внесение в суспензию нейронов донатора $\mathrm{NO}^{-}$соли Ангели снижает содержание глутатиона. Также с помощью соли Ангели было установлено, что $\mathrm{NO}^{-}$нарушает электрическую активность нейронов, угнетает активность натриевых каналов. По всей видимости, разнонаправленность $\mathrm{NO}^{-}$связана с его концентрацией, повышение которой приводит к образованию токсичного нитрит-аниона. $\mathrm{N}_{2} \mathrm{O}_{3}$, являясь источником $\mathrm{NO}^{+}$, проявляет свойства сильного нитрозилирующего агента, взаимодействует с алифатическими и ароматическими аминами и образует N-нитроамины. Нитроамины, а именно продукты их превращения, под действием Р450 (ион диазония и формальдегид) являются факторами, алкилирующими нуклеиновые кислоты, дезаминирующими пурины. Они угнетают О-6-метилгуанин-ДНК- 
метилтрансферазу, увеличивают образование 8-гидроксигуанина. $\mathrm{N}_{2} \mathrm{O}_{3}$ взаимодействует с цистеином с образованием S-нитрозоцистеина и с глутатионом с образованием S-нитроглутатиона. Данные реакции контролируются глутатионредуктазой и глутатионтрансферазой. При ингибировании этих ферментов в условиях ишемии происходит окислительная модификация низкомолекулярных тиолов, образование гомоцистеина, и как следствие - нарушение транспорта NO с образованием его цитотоксических дериватов, еще более усиливающих окисление тиолов. Наличие достаточно активной тиольной антиоксидантной системы, способной регулировать транспорт NO, обеспечивает и устойчивость клетки к нитрозирующему стрессу. Мишенями окислительной и нитрозирующей атаки пероксинитрита являются тиолы, $\mathrm{CO}_{2}$, металлопротеиды, нуклеиновые кислоты, метаболитотропные трансмиттеры и липиды. Пероксинитрит, являясь относительно стойким соединением, при смещении $\mathrm{pH}$ в кислую сторону быстро протонируется с образованием основного продукта - нитрат-аниона, а также гидроксил-радикала и диоксида азота, что обусловливает его окислительные свойства. Поэтому на начальных стадиях ишемии пероксинитрит взаимодействует с тиолами по типу нитрозилирования, в результате чего образуются нитрозотиолы. В дальнейшем при прогрессировании процесса и проявлениях лактат-ацидоза взаимодействие происходит по типу окисления с образованием более стойких дисульфидов. Пероксинитрит тормозит активность взаимодействующих метаболических циклов метионина и цистеина, подавляя ключевые ферменты, регулирующие уровень цистеина, и повышая образование гомоцистеина. Пероксинитрит реагирует и с метаболитотропным трансмиттером $\mathrm{CO}_{2}$ с образованием сильного нитрозилирующего агента - нитрозопероксикарбоната. Важным механизмом цитотоксического действия пероксинитрита является его реакция с тирозином и образование нитротирозина. Пероксинитрит значительно угнетает активность CuZnCOД и $\mathrm{MnCOД} \mathrm{посредством} \mathrm{нитрования} \mathrm{еe} 34$ тирозинового остатка, а также связывания с медью и изменения ее валентности. Пероксинитрит является специфическим агентом, необратимо угнетающим митохондриальное дыхание при ишемии, непосредственно взаимодействуя с железом активных центров ключевых энзимов, а также нитрозируя по S-, $\mathrm{N}$-, О-элементам тиольные, фенольные, гидроксильные и аминогруппы белковой части этих энзимов, а при более выраженном проявлении нитрозирующего стресса - необратимо окисляя их. Подавление митохондриального дыхания приводит к снижению заряда митохондрий, что может инициировать апоптотический процесс, а при отсутствии глюкозы - и к некрозу.

Наиболее подвержены окислению под действием АФК и активных дериватов $\mathrm{NO}$ пиримидиновые основания в положении $\mathrm{C}_{5}-\mathrm{C}_{6}$, образуя тимидингликоль, тимингликоль, цитозингликоль, которые могут подвергаться гидролитическому дезаминированию, превращаясь в производные метилурацила. Так, оксидативный стресс в условиях ишемии мозга вызывает образование ковалентных связей между ДНК и белками, например, между метильной группой тимина и кислородом тирозина и между соседними пиримидиновыми и пуриновыми остатками. Однако, наибольшее значение при многих патологических состояниях имеет окислительная модификация пиримидиновых оснований. 
В литературе накоплены многочисленные данные, касающиеся изучения механизмов перекисного окисления липидов (ПОЛ) и его роли в нормальном и патологическом функционировании клеток, однако АФК вызывают и окислительную модификацию белков (ОМБ) [32-36]. Считают, что в состоянии окислительного стресса атаке АФК подвергаются не липиды, а в первую очередь - белки плазматических мембран [32, 36, 37]. Подтверждением этого может служить так называемый феномен, названный Бергельсоном [цит. по 38] «молекулярной памятью липидов». Суть его заключается в том, что многие краткосрочные события, протекающие в белковой молекуле клеточной мембраны, влияют на долговременные параметры функционирования мембранного бислоя. При воздействии соответствующего агента на мембранный белок-рецептор, конформация последнего изменяется и в дальнейшем индуцирует изменение белок-липидных контактов, состояние липидов, окружающих белок. Эти изменения состояния липидов сохраняются и после отщепления лиганда от рецептора, т. е. служат способом закрепления рецептора в возбужденной конформации. Таким образом, «память» липидов обеспечивает усиление сигнала, передаваемого из внешней среды на клеточную мембрану [39].

В ОМБ особая роль принадлежит гидроксил-радикалу NO-радикалу, пероксинитриту, гипохлоридаанион-радикалу. В результате окислительной модификации белков образуются: орто-тирозин, 6-нитротриптофан, 3-нитротирозин, 2-оксогистидин, в белковой молекуле возникают карбонильные, сульфоновые группы, битирозиновые сшивки а также повышается степень фрагментации молекул [20, 24, 32, 40-45]. Многие авторы считают, что дитирозин является специфическим маркером окислительного стресса головного мозга [24, 32, 46]. Окислительная модификация белковых молекул приводит к нарушению метаболических систем нейрона. Так, гидроксил-радикал и пероксинитрит модифицирует тирозинкиназу (ключевое звено нейротрофики), Na-К-АТФ-азу, ксантиндегидрогеназу, супероксиддисмутазу и другие ферменты, участвующие в утилизации глутамата в астроглии. Появляются карбонильные и карбоксильные группы, возникают битирозиновые сшивки и повышается степень дефрагментации молекулы. Кроме того, АФК модифицируют антиапоптозные белки (bcl-2 и другие), снижая их функции, а избыток NO-радикала усиливает синтез проапоптотических белков (FAS и APO-1), приводя к апоптотической гибели нейрона [47, 48].

Многочисленные экспериментальные исследования показали, что в развитии патологических изменений, сопряженных с ишемическим повреждением головного мозга, большую роль играет СРО, в частности ОМБ [24, 32 , 49-53].

Отрицательный эффект окислительно-модифицированных белков в клетке, по мнению ряда авторов, связан с тем, что окисленные белки способны выступать в качестве источника свободных радикалов, истощать запасы клеточных антиоксидантов, таких как аскорбиновая кислота и глутатион. In vitro показано, что продукты свободнорадикального окисления белков опосредуют окислительные повреждения ДНК [54]. Также ПОБ приводит к сни- 
жению функции белков в цепи переносчиков электронов, активности АТФазы, избирательности действия транспортных пор. Изменение Red/Ox - потенциала митохондриальной мембраны может отражаться на дисфункции каскада дыхательной цепи, нарушая метаболизм в нейрональной клетке [24, $55,56]$. Следовательно, окисленные протеины являются не только «свидетелями», но и активными участниками свободнорадикального повреждения клетки. Окислительная модификация белков играет ключевую роль в молекулярных механизмах окислительного стресса и является пусковым механизмом к окислительной деструкции других молекул (липиды, ДНК) клетки. Избыток АФК в нейроне, особенно $\mathrm{OH}^{*}$ и $\mathrm{ONOO}^{-}$, способен подвергать окислительной модификации нуклеиновые кислоты, в результате чего происходит повреждение оснований, повреждение дезоксирибозы и появление новых ковалентных связей ( «сшивок»).

Таким образом, неконтролируемая продукция АФК биоэнергетическими и нейрохимическими системами нейрона и дальнейшее развитие оксидативного стресса являются важным звеном повреждающего действия нейронов при нейродеструктивных заболеваниях.

Учитывая, что ведущую роль свободнорадикальных процессов в развитии патологических процессов, связанных с реперфузионным повреждением ишемизированных тканей, при сахарном диабете, сердечной недостаточности, а также запуске процессов апоптотической гибели клеток, с постепенным накоплением необратимых повреждений клеточных структур и прогрессированием эндотелиальной дисфункции (ЭД), целесообразным является изучение особенностей протекания процессов свободнорадикального окисления в клинике, в частности - у больных ишемическим инсультом (ИИ), а именно, оценка динамики показателей, характеризующих наличие и выраженность оксидативного стресса у больных с мозговым ишемическим инсультом в зависимости от клинических особенностей заболевания, предварительно исследовав характер распределения изучаемых переменных.

На нижепредставленном рисунке 1.5 приведена диаграмма распределения с кривой Гаусса показателя Fе-индуцированной окислительной модификации белков крови (по уровню кетонфенилгидразонов) у больных с острым мозговым ишемическим инсультом. Судя по распределению, данные характеризуются свойствами нормального, гауссового, распределения.

Аналогичные, не отличающиеся от нормального распределения, изменения частот встречаемости были присущи и для других параметров, отражающих процесс окислительной конформационной изменчивости белков крови у больных в остром периоде ИИ как в целом у пациентов с церебральным инсультом, так и при разделении на подгруппы. Эти данные были подтверждены Шапиро-Уилка W-тестом и оценкой критерия Колмогорова-Смирнова, что позволяет нам в дальнейшем применять параметрические критерии для статистического анализа различий между выборками. 


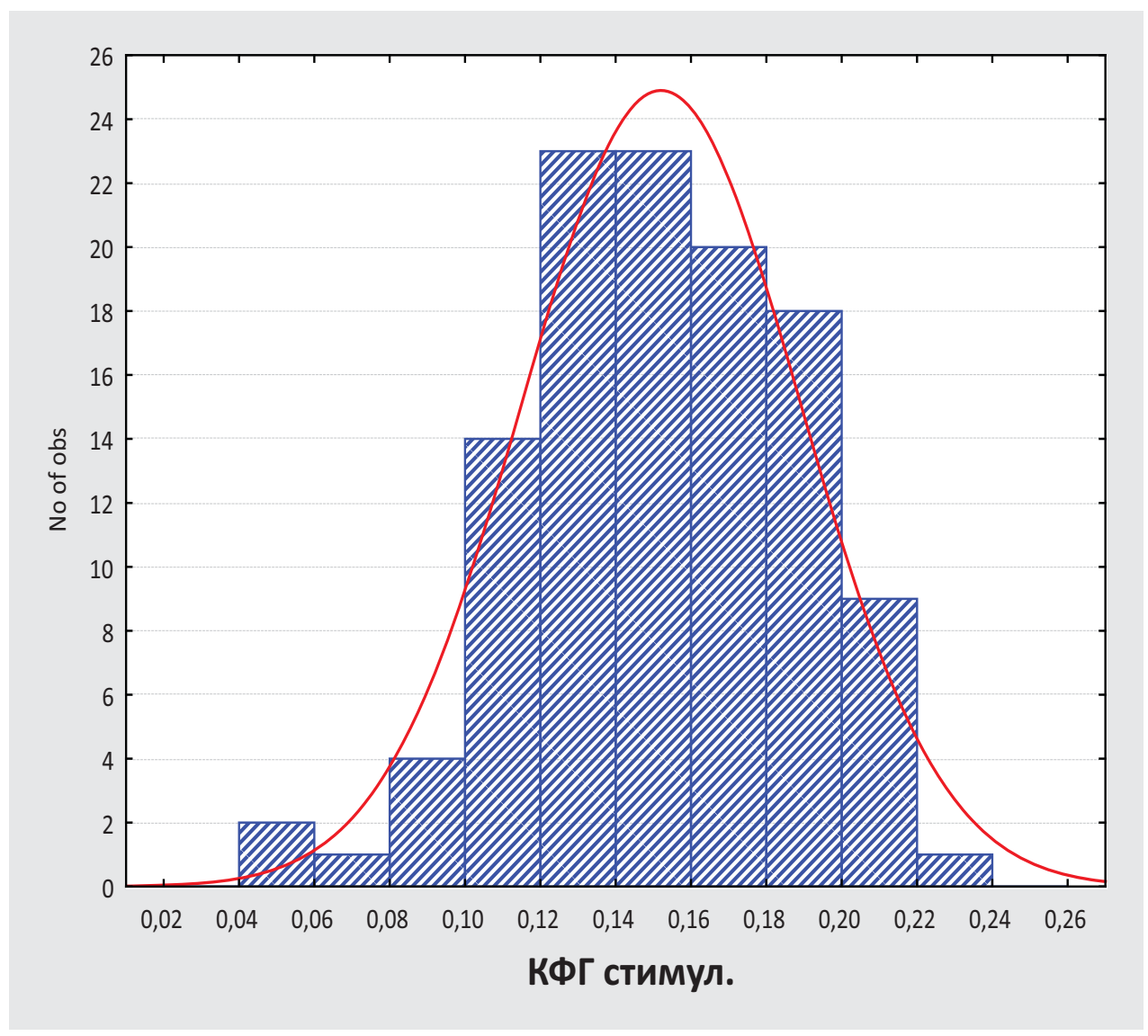

Рuc. 1.5. Диаграмма распределения с кривой Гаусса показателя $\mathrm{Fe}-$ индуцированной окислительной модификации белков крови (по уровню кетонфенилгидразонов) у больных с острым мозговым ишемическим инсультом

Полученные при исследовании уровня продукции свободных радикалов и активности процессов их элиминации результаты (см. табл. 1.2) продемонстрировали достоверное повышение в группе больных с ИИ по сравнению с группой дисциркуляторной энцефолопатии (ДЭП) величин как спонтанной, так и металл-индуцированной, окислительной модификации белков плазмы крови по уровню фенилгидразонов (увеличение АФГ на 104,35 \% и 158,95\%, и КФГ практически в 3 и 2,6 раза, соответственно, достигнутый уровень значимости меньше 0,05 во всех случаях).

Указанные изменения (повышение уровня как ранних (АФГ), так и поздних (КФГ) биомаркеров оксидативного стресса, при параллельном увеличении стимулированной концентрации этих параметров окислительной деструкции белковых молекул) сопровождались достоверным уменьшением антиокисли- 
тельного потенциала, о чем свидетельствует снижение АAC на 50,95 \% при сравнении с больными ДЭП.

Таблица 1.2

\section{Характеристика свободнорадикальных процессов и активность антиокислительных систем у больных дисциркуляторной энцефалопатией и мозговым ишемическим инсультом}

\begin{tabular}{|c|c|c|c|}
\hline \multirow{3}{*}{ Показатели } & \multicolumn{2}{|c|}{ Обследованные больные } & \multirow{3}{*}{$\begin{array}{c}\text { Величина } \\
\text { различий } \\
\text { между } \\
\text { группами, } \\
\%\end{array}$} \\
\hline & $\begin{array}{c}\text { В целом по группе } \\
\text { больных ишемическим } \\
\text { инсультом }\end{array}$ & $\begin{array}{l}\text { В целом по группе больных дис- } \\
\text { циркуляторной энцефалопатией }\end{array}$ & \\
\hline & $1(n=115)$ & $2(n=52)$ & \\
\hline $\begin{array}{l}\text { АФГ спонт., } \\
\text { усл. ед/г белка }\end{array}$ & $0,141 \pm 0,002^{*}$ & $0,069 \pm 0,002$ & 104,35 \\
\hline $\begin{array}{l}\text { АФГ стимул., } \\
\text { усл. ед/г белка }\end{array}$ & $0,246 \pm 0,004^{*}$ & $0,095 \pm 0,002$ & 158,95 \\
\hline $\begin{array}{l}\text { КФГ спонт., } \\
\text { усл. ед/г белка }\end{array}$ & $0,104 \pm 0,003^{*}$ & $0,035 \pm 0,004$ & 197,14 \\
\hline $\begin{array}{l}\text { КФГ стимул., } \\
\text { усл. ед/г белка }\end{array}$ & $0,151 \pm 0,003^{*}$ & $0,057 \pm 0,006$ & 164,91 \\
\hline $\begin{array}{l}\text { Антиокислительная } \\
\text { активность сыворотки, } \\
\text { усл. ед. }\end{array}$ & $18,77 \pm 0,47^{*}$ & $38,27 \pm 0,57$ & $-50,95$ \\
\hline
\end{tabular}

Примечание: * - достоверность различий $(\mathrm{p}<0,05)$ при сравнении с аналогичными показателями больных с дисциркуляторной энцефалопатией.

Далее проанализируем изменение параметров окислительной модификации протеинов крови в зависимости от тяжести неврологического дефицита по NIHSS (табл. 1.3). Важно подчеркнуть прослеживаемую четкую взаимосвязь уровня накопления этих маркеров окислительной модификации белка с изменением выраженности неврологического дефицита у больных ИИ согласно NIHSS. Так, у пациентов с суммарным балльным показателем более 7 (2-я подгруппа) наблюдается статистически значимое превышение как альдегид-, так и кетонфенилгидразонов (при оценке спонтанного окисления) на $36,04 \%$ и 33,84 \% при сопоставлении с аналогичным показателем подгруппы больных с ИИ с бальными значениями NIHSS не превышающими 7, соответственно. Индуцированная оксидация также оказалась достоверно выше во 2 -й подгруппе на 58,90 \% и 46,90 \%, соответственно, нежели в 1-й (табл. 1.3). 
Таблица 1.3

\section{Состояние процессов оксидации и активность антиокислительных систем у больных мозговым ишемическим инсультом различных групп тяжести по NIHSS}

\begin{tabular}{|c|c|c|c|c|c|c|c|c|}
\hline \multirow{3}{*}{ Показатели } & \multicolumn{3}{|c|}{ Больные ИИ } & \multirow[b]{2}{*}{$\begin{array}{c}\text { Больные } \\
\text { ДЭП }\end{array}$} & \multirow{2}{*}{\multicolumn{4}{|c|}{$\begin{array}{c}\text { Величина различий } \\
\text { между группами, } \\
\text { \% }\end{array}$}} \\
\hline & $\begin{array}{c}\text { До } 7 \\
\text { баллов }\end{array}$ & $\begin{array}{c}\text { Более } 7 \\
\text { баллов }\end{array}$ & $\begin{array}{c}\text { В целом } \\
\text { по группе }\end{array}$ & & & & & \\
\hline & $\begin{array}{c}1 \\
(n=32)\end{array}$ & $\begin{array}{c}2 \\
(n=83)\end{array}$ & $\begin{array}{c}3 \\
(n=115)\end{array}$ & $\begin{array}{c}4 \\
(n=52)\end{array}$ & 1 и 2 & 1 и 4 & 2 и 4 & 3 и 4 \\
\hline $\begin{array}{l}\text { АФГ спонт., } \\
\text { усл. ед/г белка }\end{array}$ & $\begin{array}{l}0,111 \pm \\
0,003^{*}\end{array}$ & $\begin{array}{l}0,151 \pm \\
0,002^{\star} \#\end{array}$ & $\begin{array}{l}0,14 \pm \\
0,002^{*}\end{array}$ & $\begin{array}{c}0,069 \pm \\
0,002\end{array}$ & 36,04 & 60,87 & 118,84 & 102,90 \\
\hline $\begin{array}{l}\text { АФГ стимул., } \\
\text { усл. ед/г белка }\end{array}$ & $\begin{array}{l}0,198 \pm \\
0,007^{\star}\end{array}$ & $\begin{array}{l}0,265 \pm \\
0,003^{\star} \#\end{array}$ & $\begin{array}{l}0,246 \pm \\
0,004^{\star}\end{array}$ & $\begin{array}{c}0,095 \pm \\
0,002\end{array}$ & 33,84 & 108,42 & 178,95 & 158,95 \\
\hline $\begin{array}{l}\text { КФГ спонт., } \\
\text { усл. ед/г белка }\end{array}$ & $\begin{array}{l}0,073 \pm \\
0,005^{\star}\end{array}$ & $\begin{array}{l}0,116 \pm \\
0,003^{\star} \#\end{array}$ & $\begin{array}{l}0,104 \pm \\
0,003^{*}\end{array}$ & $\begin{array}{c}0,035 \pm \\
0,004\end{array}$ & 58,90 & 108,57 & 231,43 & 197,14 \\
\hline $\begin{array}{l}\text { КФГ стимул., } \\
\text { усл. ед/г белка }\end{array}$ & $\begin{array}{l}0,113 \pm \\
0,004^{\star}\end{array}$ & $\begin{array}{l}0,166 \pm \\
0,005^{\star} \#\end{array}$ & $\begin{array}{l}0,151 \pm \\
0,003^{*}\end{array}$ & $\begin{array}{l}0,057 \pm \\
0,006\end{array}$ & 46,90 & 98,25 & 191,23 & 164,91 \\
\hline $\begin{array}{l}\text { Антиокислительная } \\
\text { активность сыво- } \\
\text { ротки, усл. ед. }\end{array}$ & $\begin{array}{l}21,49 \\
\pm 0,86^{\star}\end{array}$ & $\begin{array}{l}17,72 \pm \\
0,52^{\star} \#\end{array}$ & $\begin{array}{c}18,77 \pm \\
0,47^{\star}\end{array}$ & $\begin{array}{c}38,27 \pm \\
0,57\end{array}$ & $-17,54$ & $-43,85$ & $-53,70$ & $-50,95$ \\
\hline
\end{tabular}

Примечание: 1. * - достоверность различий $(\mathrm{p}<0,05)$ при сравнении с аналогичными показателями больных с дисциркуляторной энцефалопатией.

2. \# - достоверность различий $(\mathrm{p}<0,05)$ при сравнении с аналогичными показателями больных ИИ с показателем по шкале NIHSS до 7 баллов.

Изучение динамики АAC в зависимости от результатов комплексного количественного анализа по шкале NIHSS также показало, что по мере увеличения тяжести неврологической симптоматики, отмечается снижение ААС на $17,54 \%$. Важно отметить, что это снижение ассоциировалось, как мы уже указывали, со значительным повышением уровня параметров стимулированной окислительной модификации белка, что свидетельствует об истощении резервно-адаптационных возможностей организма и снижении устойчивости при патологической активации свободнорадикальных процессов в условиях оксидативно-антиоксидантного дисбаланса.

Анализ процессов оксидации и активность антиокислительных систем у больных мозговым ишемическим инсультом в зависимости от длительности основного заболевания (артериальной гипертензий представлен в табл. 1.3. 
Таблица 1.3

\section{Состояние процессов оксидации и активность антиокислительных систем у больных мозговым ишемическим инсультом с различной длительностью АГ}

\begin{tabular}{|c|c|c|c|c|c|c|c|c|}
\hline \multirow{3}{*}{ Показатели } & \multicolumn{3}{|c|}{ Больные ИИ } & \multirow[b]{2}{*}{$\begin{array}{c}\text { Больные } \\
\text { ДЭП }\end{array}$} & \multirow{2}{*}{\multicolumn{4}{|c|}{$\begin{array}{c}\text { Величина различий } \\
\text { между группами, } \\
\%\end{array}$}} \\
\hline & \multirow{2}{*}{$\begin{array}{c}\text { До } 10 \\
\text { лет } \\
\begin{array}{c}1 \\
(n=32)\end{array}\end{array}$} & \multirow{2}{*}{$\begin{array}{c}\text { Более } \\
10 \text { лет } \\
2 \\
(n=83)\end{array}$} & \multirow{2}{*}{$\begin{array}{c}\text { В целом } \\
\text { по груп- } \\
\text { пе боль- } \\
\text { ных ИИ }\end{array}$} & & & & & \\
\hline & & & & $\begin{array}{c}4 \\
(n=52)\end{array}$ & 1 и 2 & 1 и 4 & 2 и 4 & 3 и 4 \\
\hline $\begin{array}{l}\text { АФГ спонт., } \\
\text { усл. ед/г белка }\end{array}$ & $\begin{array}{l}0,126 \pm \\
0,005^{*}\end{array}$ & $\begin{array}{l}0,142 \pm \\
0,003^{* \#}\end{array}$ & $\begin{array}{l}0,14 \pm \\
0,002^{*}\end{array}$ & $\begin{array}{c}0,069 \pm \\
0,002\end{array}$ & 12,70 & 82,61 & 105,80 & 102,90 \\
\hline $\begin{array}{l}\text { АФГ стимул., } \\
\text { усл. ед/г белка }\end{array}$ & $\begin{array}{l}0,233 \pm \\
0,013^{*}\end{array}$ & $\begin{array}{l}0,248 \pm \\
0,004^{*}\end{array}$ & $\begin{array}{l}0,246 \pm \\
0,004^{\star}\end{array}$ & $\begin{array}{c}0,095 \pm \\
0,002\end{array}$ & 6,44 & 145,26 & 161,05 & 158,95 \\
\hline $\begin{array}{l}\text { КФГ спонт., } \\
\text { усл. ед/г белка }\end{array}$ & $\begin{array}{l}0,092 \pm \\
0,007^{*}\end{array}$ & $\begin{array}{l}0,106 \pm \\
0,003^{*}\end{array}$ & $\begin{array}{l}0,104 \pm \\
0,003^{*}\end{array}$ & $\begin{array}{c}0,035 \pm \\
0,004\end{array}$ & 15,22 & 162,86 & 202,86 & 197,14 \\
\hline $\begin{array}{l}\text { КФГ стимул., } \\
\text { усл. ед/г белка }\end{array}$ & $\begin{array}{l}0,129 \pm \\
0,009^{*}\end{array}$ & $\begin{array}{l}0,154 \pm \\
0,004^{* \#}\end{array}$ & $\begin{array}{l}0,151 \pm \\
0,003^{*}\end{array}$ & $\begin{array}{c}0,057 \pm \\
0,006\end{array}$ & 18,46 & 128,07 & 170,18 & 164,91 \\
\hline $\begin{array}{l}\text { Антиокислительная } \\
\text { активность сыво- } \\
\text { ротки, усл. ед. }\end{array}$ & $\begin{array}{c}20,78 \pm \\
1,48^{*}\end{array}$ & $\begin{array}{l}18,47 \pm \\
0,49^{* \#}\end{array}$ & $\begin{array}{c}18,77 \pm \\
0,47^{\star}\end{array}$ & $\begin{array}{c}38,27 \pm \\
0,57\end{array}$ & $-11,12$ & $-45,70$ & $-51,74$ & $-50,95$ \\
\hline
\end{tabular}

Примечание: 1. * - достоверность различий $(\mathrm{p}<0,05)$ при сравнении с аналогичными показателями больных с дисциркуляторной энцефалопатией.

2. \# - достоверность различий $(\mathrm{p}<0,05)$ при сравнении с аналогичными показателями больных ИИ с длительностью заболевания до 10 лет.

Как свидетельствуют представленные данные, по мере увеличения длительности первичного верифицирования гипертензии увеличиваются параметры как спонтанной, так и стимулированной окислительной модификации белков плазмы крови по уровню фенилгидразонов (отмечено повышение при анамнезе более 10 лет как альдегидных (только для базальной) на 12,7 \%, так и, в большей степени, для кетоных форм на 15,22 \% и 18,64 \%, соответственно). Более выраженная динамика именно кетоненилгидразонов логична, так как приведенные показатели являются поздними маркерами активации генерации свободнорадикальных процессов в организме.

Уровень антиоксидантной активности сыворотки оказался минимальным во 2-й подгруппе, составляя в среднем $18,47 \pm 0,49$ усл. ед., что на $11,12 \%$ меньше рассматриваемого показателя 1-й подгруппы и на 51,74 \% ниже уровня антиокислительной защиты у больных с ДЭП. Таким образом, в подгруппе с продолжительностью артериальной гипертензии более 10 лет регистрировались максимальные значения, отражающие интенсивность процессов оксида- 
ции при параллельном снижении антиокислительного потенциала сыворотки $(\mathrm{p}<0,05)$, что указывает на выраженный про- антиоксидантный дисбаланс у больных с более длительным анамнезом АГ при сопоставлении с противоположной подгруппой пациентов.

Кроме того, была проанализирована динамика параметров, характеризующих оксидативную модификацию белковых молекул в зависимости от степени тяжести артериальной гипертензии (АГ) (табл. 1.5).

Таблица 1.5

\section{Состояние процессов оксидации и активность антиокислительных систем у больных мозговым ишемическим инсультом с различной степенью артериальной гипертензии}

\begin{tabular}{|c|c|c|c|c|c|c|c|c|c|c|c|}
\hline \multirow{3}{*}{ Показатели } & \multicolumn{4}{|c|}{ Больные ИИ } & \multirow{2}{*}{$\begin{array}{l}\text { Боль- } \\
\text { ные } \\
\text { ДЭП }\end{array}$} & & & & & & \\
\hline & 1 сте- & 2 сте- & 3 сте- & $\begin{array}{c}\text { В целом } \\
\text { по группе }\end{array}$ & & \multicolumn{6}{|c|}{$\begin{array}{c}\text { Величина различий между группами, } \\
\%\end{array}$} \\
\hline & $\begin{array}{c}1 \\
(n=36)\end{array}$ & $\begin{array}{c}2 \\
(n=43)\end{array}$ & $\begin{array}{c}3 \\
(n=46)\end{array}$ & $\begin{array}{c}4 \\
(n=115)\end{array}$ & $\begin{array}{c}5 \\
(n=52)\end{array}$ & 1 и 2 & 1 и 3 & 1 и 5 & 2 и 3 & 2 и 5 & 3 и 5 \\
\hline $\begin{array}{l}\text { АФГспонт., } \\
\text { усл. ед/г } \\
\text { белка }\end{array}$ & $\begin{array}{l}0,14 \pm \\
0,005^{\star}\end{array}$ & $\begin{array}{l}0,132 \pm \\
0,004^{*}\end{array}$ & $\begin{array}{l}0,146 \pm \\
0,004^{*}\end{array}$ & $\begin{array}{l}0,14 \pm \\
0,002^{*}\end{array}$ & $\begin{array}{c}0,069 \pm \\
0,002\end{array}$ & $-5,71$ & 4,29 & $-50,71$ & 10,61 & $-47,73$ & $-52,74$ \\
\hline $\begin{array}{l}\text { АФГ стимул., } \\
\text { усл. ед/г } \\
\text { белка }\end{array}$ & $\begin{array}{c}0,248 \pm \\
0,01^{*}\end{array}$ & $\begin{array}{l}0,24 \pm \\
0,007^{*}\end{array}$ & $\begin{array}{l}0,251 \pm \\
0,005^{*}\end{array}$ & $\begin{array}{l}0,246 \pm \\
0,004^{*}\end{array}$ & $\begin{array}{l}0,095 \pm \\
0,002\end{array}$ & $-3,23$ & 1,21 & $-61,69$ & 4,58 & $-60,42$ & $-62,15$ \\
\hline $\begin{array}{l}\text { КФГ спонт., } \\
\text { усл. ед/г } \\
\text { белка }\end{array}$ & $\begin{array}{l}0,101 \pm \\
0,005^{*}\end{array}$ & $\begin{array}{l}0,103 \pm \\
0,006^{*}\end{array}$ & $\begin{array}{l}0,108 \pm \\
0,005^{*}\end{array}$ & $\begin{array}{l}0,104 \pm \\
0,003^{*}\end{array}$ & $\begin{array}{c}0,035 \pm \\
0,004\end{array}$ & 1,98 & 6,93 & $-65,35$ & 4,85 & $-66,02$ & $-67,59$ \\
\hline $\begin{array}{l}\text { КФГ стимул., } \\
\text { усл. ед/г } \\
\text { белка }\end{array}$ & $\begin{array}{l}0,151 \pm \\
0,006^{*}\end{array}$ & $\begin{array}{l}0,148 \pm \\
0,007^{*}\end{array}$ & $\begin{array}{l}0,156 \pm \\
0,005^{*}\end{array}$ & $\begin{array}{l}0,151 \pm \\
0,003^{*}\end{array}$ & $\begin{array}{l}0,057 \pm \\
0,006\end{array}$ & $-1,99$ & 3,31 & $-62,25$ & 5,41 & $-61,49$ & $-63,46$ \\
\hline $\begin{array}{l}\text { Антиокисли- } \\
\text { тельная } \\
\text { активность } \\
\text { сыворотки, } \\
\text { усл. ед. }\end{array}$ & $\begin{array}{l}20,15 \pm \\
0,88^{* *}\end{array}$ & $\begin{array}{c}18,46 \pm \\
0,73\end{array}$ & $\begin{array}{c}17,65 \pm \\
0,87^{*}\end{array}$ & $\begin{array}{c}18,77 \pm \\
0,47^{*}\end{array}$ & $\begin{array}{c}38,27 \pm \\
0,57\end{array}$ & $-8,39$ & $-12,41$ & $-47,38$ & $-4,6$ & $-107,31$ & $-116,83$ \\
\hline
\end{tabular}

Примечание: $1 . *$ - достоверность различий $(\mathrm{p}<0,05)$ при сравнении с аналогичными показателями больных с дисциркуляторной энцефалопатией.

2. \# - достоверность различий $(\mathrm{p}<0,05)$ при сравнении с аналогичными показателями больных ИИ с 1-й степенью АГ.

$3 . \Delta-$ достоверность различий $(\mathrm{p}<0,05)$ при сравнении с аналогичными показателями больных ИИ со 2-й степенью АГ.

При этом важно отметить, что у пациентов с различной степенью АГ параметры, характеризующие напряженность окислительно-восстановительных 
механизмов, существенно не отличались. Наблюдались тенденции к постепенному увеличению показателей, в частности - количественных характеристик окислительной деструкции белков плазмы по уровню фенилгидразонов, однако достоверных различий достичь не удалось. Зарегистрирована также ориентированность к регрессу антиокислительного потенциала сыворотки при ИИ по мере увеличения офисных значений систолического и диастолического АД, однако статической значимости различий по указанному показателю удалось достичь только при сопоставлении лиц с 1-й и 3 -й степенью гипертензии $(-12,41$ \%). Вследствие большого разброса статистическая разница между показателями КФГ в зависимости от степени АГ также не была зафиксирована, хотя можно отметить, что, если у больных гипертонической болезнью с 1-й степенью АГ величина указанного показателя была лишь на 107,31 \% меньше в сравнении с группой ДЭП, то у пациентов с АГ 3-й степени - различия составили уже 116,83 \%, причем как минимум, у четверти больных (нижний квартиль составил 15 усл. ед.) пациентов этой группы, как следует из таблицы 1.5 , значения антиокислительной активности были существенно ниже нормальных величин, что указывает на, практически, отсутствие защитных антиокислительных компенсаторных возможностей организма.

Интересные данные представлены в табл. 1.6, где показана динамика активности свободнорадикальных процессов в зависимости от локализации ишемического очага.

Таблица 1.6

\section{Состояние процессов оксидации и активность антиокислительных систем у больных мозговым ишемическим инсультом с различной локализацией ишемического очага}

\begin{tabular}{|c|c|c|c|c|c|c|c|c|c|c|c|}
\hline \multirow{3}{*}{ Показатели } & \multicolumn{4}{|c|}{ Больные ИИ } & \multirow[b]{2}{*}{$\begin{array}{l}\text { Боль- } \\
\text { ные } \\
\text { ДЭП }\end{array}$} & \multirow{2}{*}{\multicolumn{6}{|c|}{$\begin{array}{c}\text { Величина различий } \\
\text { между группами, } \\
\text { \% }\end{array}$}} \\
\hline & \multirow{2}{*}{$\begin{array}{c}\begin{array}{c}\text { Правая } \\
\text { геми- } \\
\text { сфера }\end{array} \\
\begin{array}{c}1 \\
(\mathrm{n}=39)\end{array}\end{array}$} & \multirow{2}{*}{$\begin{array}{c}\begin{array}{c}\text { Левая } \\
\text { геми- } \\
\text { сфера }\end{array} \\
\begin{array}{c}2 \\
(n=58)\end{array}\end{array}$} & \multirow{2}{*}{$\begin{array}{c}\begin{array}{c}\text { Верте- } \\
\text { бробази- } \\
\text { лярный } \\
\text { бассейн }\end{array} \\
\begin{array}{c}3 \\
(n=18)\end{array}\end{array}$} & \multirow{2}{*}{$\begin{array}{c}\text { В целом } \\
\text { по группе } \\
\text { больных } \\
\text { ИИ } \\
4 \\
(n=115)\end{array}$} & & & & & & & \\
\hline & & & & & $\begin{array}{c}5 \\
(n=52)\end{array}$ & 1 и 2 & 1 и 3 & 1 и 5 & 2 и 3 & 2 и 5 & 3 и 5 \\
\hline $\begin{array}{l}\text { АФГспонт., } \\
\text { усл. ед/ г } \\
\text { белка }\end{array}$ & $\begin{array}{l}0,141 \pm \\
0,004^{*}\end{array}$ & $\begin{array}{l}0,143 \pm \\
0,003^{*}\end{array}$ & $\begin{array}{l}0,126 \pm \\
0,005 * * \Delta\end{array}$ & $\begin{array}{l}0,14 \pm \\
0,002^{*}\end{array}$ & $\begin{array}{l}0,069 \pm \\
0,002\end{array}$ & 1,42 & $-10,64$ & $-51,06$ & $-11,89$ & $-51,75$ & $-45,24$ \\
\hline $\begin{array}{l}\text { АФГ стимул., } \\
\text { усл. ед/ г } \\
\text { белка }\end{array}$ & $\begin{array}{l}0,249 \pm \\
0,008^{*}\end{array}$ & $\begin{array}{l}0,252 \pm \\
0,006^{*}\end{array}$ & $\begin{array}{l}0,221 \pm \\
0,009 * \Delta \Delta\end{array}$ & $\begin{array}{l}0,246 \pm \\
0,004^{*}\end{array}$ & $\begin{array}{l}0,095 \pm \\
0,002\end{array}$ & 1,20 & $-11,24$ & $-61,85$ & $-12,30$ & $-62,30$ & $-57,01$ \\
\hline $\begin{array}{l}\text { КФГ спонт., } \\
\text { усл. ед/ г } \\
\text { белка }\end{array}$ & $\begin{array}{l}0,108 \pm \\
0,004^{*}\end{array}$ & $\begin{array}{l}0,107 \pm \\
0,004^{*}\end{array}$ & $\begin{array}{l}0,086 \pm \\
0,007^{* * \# \Delta}\end{array}$ & $\begin{array}{l}0,104 \pm \\
0,003^{*}\end{array}$ & $\begin{array}{l}0,035 \pm \\
0,004\end{array}$ & $-0,93$ & $-20,37$ & $-67,59$ & $-19,63$ & $-67,29$ & $-59,30$ \\
\hline
\end{tabular}


Продолжение табл. 1.6

\begin{tabular}{|c|c|c|c|c|c|c|c|c|c|c|c|}
\hline \multirow{3}{*}{ Показатели } & \multicolumn{4}{|c|}{ Больные ИИ } & \multirow[b]{2}{*}{$\begin{array}{l}\text { Боль- } \\
\text { ные } \\
\text { ДЭП }\end{array}$} & \multirow{2}{*}{\multicolumn{6}{|c|}{$\begin{array}{c}\text { Величина различий } \\
\text { между группами, } \\
\text { \% }\end{array}$}} \\
\hline & $\begin{array}{c}\text { Правая } \\
\text { геми- }\end{array}$ & $\begin{array}{l}\text { Левая } \\
\text { геми- }\end{array}$ & $\begin{array}{c}\text { Верте- } \\
\text { бробази- }\end{array}$ & $\begin{array}{c}\text { В целом } \\
\text { по группе }\end{array}$ & & & & & & & \\
\hline & $\begin{array}{c}1 \\
(n=39)\end{array}$ & $\begin{array}{c}2 \\
(n=58)\end{array}$ & $\begin{array}{c}3 \\
(n=18)\end{array}$ & $\begin{array}{c}4 \\
(n=115)\end{array}$ & $\begin{array}{c}5 \\
(n=52)\end{array}$ & 1 и 2 & 1 и 3 & 1 и 5 & 2 и 3 & 2 и 5 & 3 и 5 \\
\hline $\begin{array}{l}\text { КФГ стимул., } \\
\text { усл. ед/ г } \\
\text { белка }\end{array}$ & $\begin{array}{l}0,156 \pm \\
0,005^{*}\end{array}$ & $\begin{array}{l}0,152 \pm \\
0,005^{*}\end{array}$ & $\begin{array}{l}0,139 \pm \\
0,008^{*}\end{array}$ & $\begin{array}{l}0,151 \pm \\
0,003^{*}\end{array}$ & $\begin{array}{l}0,057 \pm \\
0,006\end{array}$ & $-2,56$ & $-10,90$ & $-63,46$ & $-8,55$ & $-62,50$ & $-58,99$ \\
\hline $\begin{array}{l}\text { Антиокисли- } \\
\text { тельная } \\
\text { активность } \\
\text { сыворотки, } \\
\text { усл. ед. }\end{array}$ & $\begin{array}{l}19,27 \pm \\
0,91^{*}\end{array}$ & $\begin{array}{l}18,26 \pm \\
0,62^{*}\end{array}$ & $\begin{array}{l}19,32 \pm \\
1,15^{*}\end{array}$ & $\begin{array}{l}18,77 \pm \\
0,47^{*}\end{array}$ & $\begin{array}{l}38,27 \pm \\
0,57\end{array}$ & $-5,24$ & 0,26 & 98,60 & 5,81 & 109,58 & 98,08 \\
\hline
\end{tabular}

Примечание: 1. * - достоверность различий $(\mathrm{p}<0,05)$ при сравнении с аналогичными показателями больных с дисциркуляторной энцефалопатией.

2. \# - достоверность различий $(\mathrm{p}<0,05)$ при сравнении с аналогичными показателями больных ИИ с локализацией патологического очага в правой гемисфере.

3. $\Delta$ - достоверность различий $(\mathrm{p}<0,05)$ при сравнении с аналогичными показателями больных ИИ с локализацией патологического очага в левой гемисфере.

Эволюция параметров оксидативной модификации микробиомолекул, в частности - протеинов, в зависимости от локализации, носила неоднозначный характер: не претерпевая существенных изменений в сравниваемых группах при полушарном инсульте, в то же время отмечалась достоверная отрицательная динамика в сравнении с пациентами с ишемическими изменениями в вертебро-базилярных сосудах, обеспечивающих мозговую перфузию $(-10,64 \%$ и $-11,89 \%$, а также $-11,24 \%$ и $12,3 \%$ по показателю спонтанной и индуцированной АФГ, соответственно - для левой и правой гемисферы). Различия для КФГ без индукции двухвалентным железом оказались более выраженными и составили $-20,37 \%$ и $-19,63 \%(p<0,05)$ также для левой и правой гемисферы при сравнении с аналогичными показателями лиц с ишемией в вертебро-базилярном бассейне. Динамика антиокислительного резерва сыворотки по рассматриваемому предиктору оказалась недостоверной.

Влияние возраста больных с ИИ на состояние про/антиоксидантного дисбаланса приведено в таблице 1.7 . 
Таблица 1.7

\section{Состояние процессов оксидации и активность антиокислительных систем у больных мозговым ишемическим инсультом} с различного возраста

\begin{tabular}{|c|c|c|c|c|c|c|c|c|}
\hline \multirow{3}{*}{ Показатели } & \multicolumn{3}{|c|}{ Больные ИИ } & \multirow{3}{*}{$\begin{array}{c}\text { Больные } \\
\text { ДЭП } \\
\\
4 \\
(n=52)\end{array}$} & \multirow{2}{*}{\multicolumn{4}{|c|}{$\begin{array}{c}\text { Величина различий между груп- } \\
\text { пами, } \\
\%\end{array}$}} \\
\hline & \multirow{2}{*}{$\begin{array}{c}\text { До } 60 \text { лет } \\
\begin{array}{c}1 \\
(n=51)\end{array}\end{array}$} & \multirow{2}{*}{$\begin{array}{c}\text { Более } 60 \\
\text { лет }\end{array}$} & \multirow{2}{*}{ 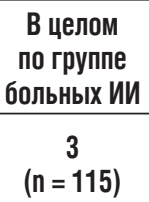 } & & & & & \\
\hline & & & & & 1 и 2 & 1 и 4 & 2 и 4 & 3 и 4 \\
\hline $\begin{array}{l}\text { АФГ спонт., } \\
\text { усл. ед/ г белка }\end{array}$ & $\begin{array}{l}0,139 \pm \\
0,004^{*}\end{array}$ & $\begin{array}{l}0,146 \pm \\
0,003^{*}\end{array}$ & $\begin{array}{l}0,14 \pm \\
0,002^{*}\end{array}$ & $\begin{array}{c}0,069 \pm \\
0,002\end{array}$ & 5,04 & 101,45 & 111,59 & 102,90 \\
\hline $\begin{array}{l}\text { АФГ стимул., } \\
\text { усл. ед/ г белка }\end{array}$ & $\begin{array}{l}0,248 \pm \\
0,006^{*}\end{array}$ & $\begin{array}{l}0,244 \pm \\
0,005^{\star}\end{array}$ & $\begin{array}{l}0,246 \pm \\
0,004^{*}\end{array}$ & $\begin{array}{c}0,095 \pm \\
0,002\end{array}$ & $-1,61$ & 161,05 & 156,84 & 158,95 \\
\hline $\begin{array}{l}\text { КФГ спонт., } \\
\text { усл. ед/ г белка }\end{array}$ & $\begin{array}{l}0,09 \pm \\
0,005^{\star}\end{array}$ & $\begin{array}{l}0,107 \pm \\
0,004^{*}\end{array}$ & $\begin{array}{l}0,104 \pm \\
0,003^{*}\end{array}$ & $\begin{array}{c}0,035 \pm \\
0,004\end{array}$ & 18,89 & 157,14 & 205,71 & 197,14 \\
\hline $\begin{array}{l}\text { КФГ стимул., } \\
\text { усл. ед/ г белка }\end{array}$ & $\begin{array}{l}0,148 \pm \\
0,005^{\star}\end{array}$ & $\begin{array}{l}0,154 \pm \\
0,005^{*}\end{array}$ & $\begin{array}{l}0,151 \pm \\
0,003^{*}\end{array}$ & $\begin{array}{c}0,057 \pm \\
0,006\end{array}$ & 4,05 & 159,65 & 170,18 & 164,91 \\
\hline $\begin{array}{l}\text { Антиокислительная } \\
\text { активность сыво- } \\
\text { ротки, усл. ед. }\end{array}$ & $\begin{array}{c}19,35 \pm \\
0,71^{*}\end{array}$ & $\begin{array}{l}16,1 \pm \\
0,64^{* \#}\end{array}$ & $\begin{array}{c}18,77 \pm \\
0,47^{\star}\end{array}$ & $\begin{array}{c}38,27 \pm \\
0,57\end{array}$ & $-16,8$ & $-97,78$ & $-137,7$ & $-50,95$ \\
\hline
\end{tabular}

Примечание: 1. * - достоверность различий $(\mathrm{p}<0,05)$ при сравнении с аналогичными показателями больных с дисциркуляторной энцефалопатией.

2 . \# - достоверность различий $(\mathrm{p}<0,05)$ при сравнении с аналогичными показателями больных ИИ возрастной группы до 60 лет.

Как наглядно видно из представленных данных, у пациентов с ИИ по мере старения прогрессивно увеличивается выраженность нарушений окислительно-восстановительного гомеостаза, о чем красноречиво свидетельствуют как данные изменения структуры протеинов исходно и после индукции металлом, особенно КФГ, так и регресс противостоящей интенсификации генерации свободных радикалов в условиях оксидативного стресса, показателя AAC, на $16,8 \%$.

Далее, с целью изучения влияния выраженности активации свободнорадикального окисления биомолекул на динамику нейронспецифичных белков, мы провели дисперсионный анализ по однофакторной схеме (табл. 1.8). Рассматриваемая в качестве независимой переменной АФГ спонт., согласно рассчитанному коэффициенту детерминации статистически значимо определяла около 33 \% совокупной вариации величины NSE ( $<0,001)$. При этом следует отметить весьма высокое значение показателя F-отношения 30,193 и наличие тесной достоверной функциональной взаимосвязи между АФГ и уровнем нейронспецифического энзима - енолазы, о чем свидетельствует достаточно 
высокий показатель рассчитанного эмпирического корреляционного отношения $(0,58)$. Также статистически значимым оказалось влияние оксидативной модификации на такой результативный признак, как общий, белок миелина. В соответствующем дисперсионном комплексе, согласно полученным данным, АФГ спонт. достоверно определяла около $53 \%$ вариации значений ОБМ при $\eta_{3}=0,28$ и $\mathrm{F}=15,32$, указывая на взаимосвязь между степенью деструкции мозговой ткани при ИИ и выраженностью процессов окислительной модификации белка. Также показательные, с этой точки зрения, результаты расчета дисперсионного отношения и доли общей дисперсии, которая определяется влиянием АФГ на белок S100: 10,07 и $20 \%$ при $\mathrm{p}=0,003$. Более того, рассмотрение функциональной зависимости путем расчета показателя эмпирического корреляционного отношения $(0,45)$ позволило установить наличие тесной взаимосвязи между изучаемыми признаками. Таким образом, оксидативный стресс выступает как один из ведущих факторов повреждения мозга при ишемии. Полученные данные объясняются тем, что при острой мозговой ишемии на фоне дисбаланса оксидантно-антиоксидантной системы происходит активация процессов пероксидации, что в совокупности вызывает развитие дистрофических и деструктивных изменений нейрональных мембран и формирование неврологического дефицита.

Таблица 1.8

Результаты однофакторного дисперсионного анализа влияния выраженности свободнорадикальных механизмов

(по данным АФГ спонт.) на уровень нейронспецифичных белков

\begin{tabular}{|c|c|c|c|c|c|c|c|c|}
\hline Фактор & Дисперсия & SS & $\begin{array}{l}\text { Степени } \\
\text { свободы }\end{array}$ & MS & $F$ & p & $\eta^{2}$ & $\eta$ \\
\hline \multirow[t]{3}{*}{ NSE } & Межгрупповая & 725,467 & 1 & 725,467 & 30,193 & $<0,001$ & \multirow{3}{*}{0,335} & \multirow{3}{*}{0,579} \\
\hline & Остаточная & 1441,638 & 60 & 24,027 & & & & \\
\hline & Общая & 2167,105 & 61 & & & & & \\
\hline \multirow[t]{3}{*}{ ОБМ } & Межгрупповая & 0,011 & 1 & 0,011 & 15,317 & $<0,001$ & \multirow{3}{*}{0,282} & \multirow{3}{*}{0,531} \\
\hline & Остаточная & 0,028 & 38 & 0,001 & & & & \\
\hline & Общая & 0,039 & 39 & & & & & \\
\hline \multirow[t]{3}{*}{ S100 } & Межгрупповая & 4524,745 & 1 & 4524,745 & 10,072 & 0,003 & \multirow{3}{*}{0,201} & \multirow{3}{*}{0,449} \\
\hline & Остаточная & 17969,146 & 40 & 449,229 & & & & \\
\hline & Общая & 22493,891 & 41 & & & & & \\
\hline
\end{tabular}

Примечание: «SS» - сумма квадратов; «MS» - средняя сумма квадратов; «df» — число степеней свободы; «F» - значение F-отношения Фишера; «p» — достигнутый уровень значимости различий, « $\eta^{2}$ - удельное значение влияния фактора, лежащего в основе группировки, среди совокупности факторов, воздействующих на результативный признак; «ך, - эмпирическое корреляционное соотношение. 
Одним из важных параметров при оценке параметров свободнорадикального окисления.

Одной из задач нашего исследования была оценка изменений метаболизма мощного вазодилататора, обладающего антиагрегантными и антипролиферативными свойствами, оксида азота. Перед выполнением статистических процедур мы изучили характер распределения частот встречаемости рассматриваемого параметра (см. рис. 1.6).

Указанная диаграмма с кривой Гаусса показателя NO сыворотки у больных с острым мозговым ишемическим инсультом (описываются характерной кривой, гауссианой), а также оценка критерия Колмогорова-Смирнова, позволяют нам проводить обработку результатов исследования параметрическими методами.

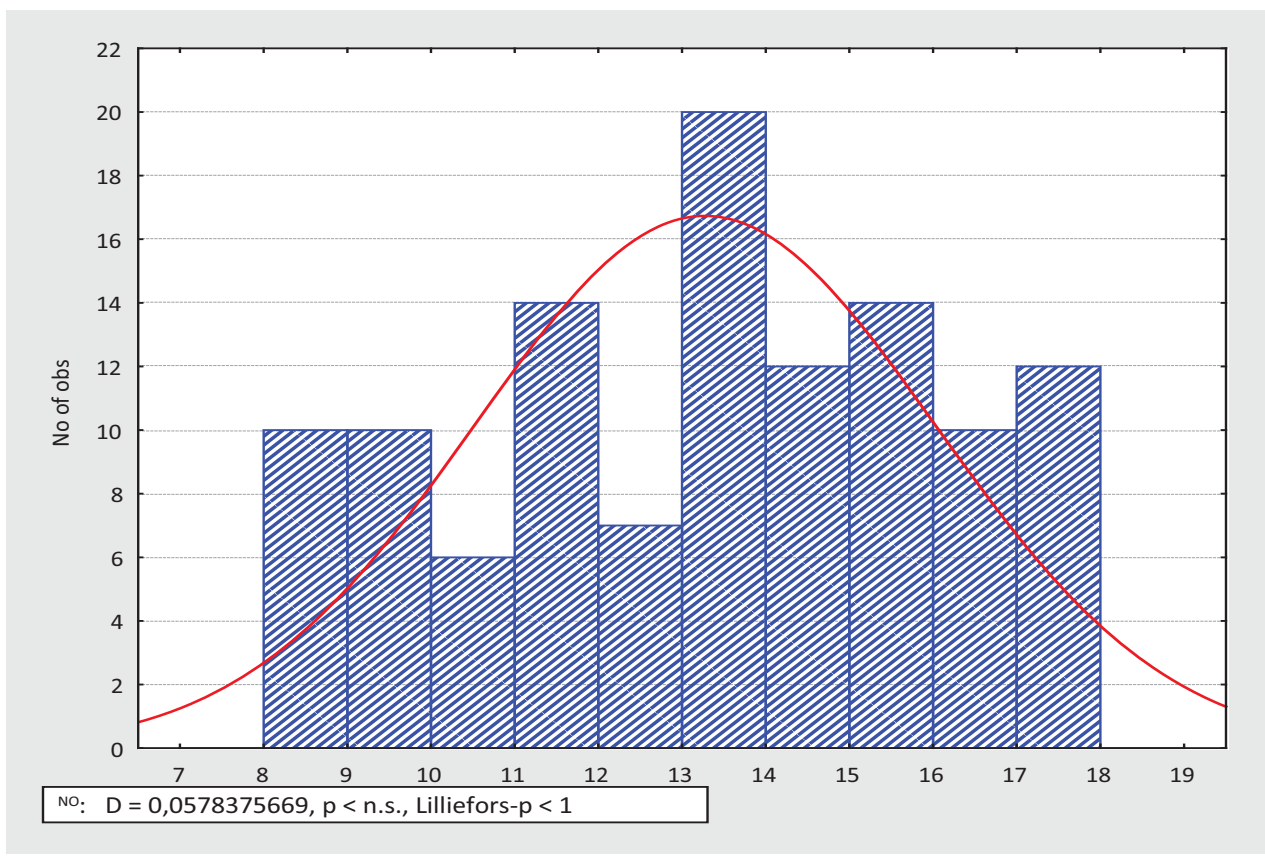

\section{Рис. 1.6. Диаграмма распределения с кривой Гаусса показателя уровня оксида азота у больных с острым мозговым ишемическим инсультом}

Далее мы оценили динамику показателей, характеризующих наличие эндотелиальной дисфункции у больных с мозговым ишемическим инсультом в зависимости от клинических особенностей заболевания. Выраженность различий между пациентами с ИИ и ДЭП по показателю конечных метаболитов оксида азота представлена в таблице (1.9).

Полученные результаты свидетельствуют, что существенные изменения у больных ИИ были зарегистрированы также со стороны показателя, характеризующего метаболизм NO. В частности, отмечалось выраженное снижение содержания NOx в сыворотке крови более чем на треть при сравнении с лица- 
ми с ДЭП (-30,61 \%), логично свидетельствуя о более выраженных патологических изменениях в функционировании васкулярного эндотелия в случае острых мозговых катастроф ишемического генеза.

Таблица 1.9

Показатели метаболизма оксида азота у больных дисциркуляторной энцефалопатией и мозговым ишемическим инсультом

\begin{tabular}{|c|c|c|c|}
\hline \multirow{3}{*}{ Показатели } & \multicolumn{2}{|c|}{ Обследованные больные } & \multirow{3}{*}{$\begin{array}{c}\text { Уровень различий } \\
\text { между группами, } \\
\%\end{array}$} \\
\hline & $\begin{array}{c}\text { В целом по группе больных } \\
\text { ишемическим инсультом }\end{array}$ & $\begin{array}{c}\text { В целом по группе больных } \\
\text { дисциркуляторной } \\
\text { энцефалопатией }\end{array}$ & \\
\hline & $1(n=115)$ & $2(n=52)$ & \\
\hline NOx, мкмоль/л & $13,24 \pm 0,26^{\star}$ & $19,08 \pm 0,27$ & $-30,61$ \\
\hline
\end{tabular}

Примечание: * - достоверность различий $(\mathrm{p}<0,05)$ при сравнении с аналогичными показателями больных с дисциркуляторной энцефалопатией.

Также весьма интересной и показательной представляется оценка метаболизма окиси азота, сигнальной молекулы в кардиоваскулярной системе, за открытие которой Robert Furchgott и двое его коллег получили Нобелевскую премию в 1998 году, в рамках нашего исследования в зависимости от тяжести по NIHSS (табл. 1.10).

Таблица 1.10

Показатели метаболизма оксида азота у больных мозговым ишемическим инсультом различных групп тяжести по NIHSS

\begin{tabular}{|c|c|c|c|c|c|c|c|c|}
\hline \multirow{3}{*}{ Показатели } & \multicolumn{3}{|c|}{ Больные ИИ } & \multirow{2}{*}{$\begin{array}{c}\text { Больные } \\
\text { ДЭП }\end{array}$} & \multirow{2}{*}{\multicolumn{4}{|c|}{ Величина различий между группами, \% }} \\
\hline & \multirow{2}{*}{$\begin{array}{c}\begin{array}{c}\text { До } 7 \\
\text { баллов } \\
\text { по NIHSS }\end{array} \\
\begin{array}{c}1 \\
(n=32)\end{array}\end{array}$} & \multirow{2}{*}{$\begin{array}{c}\begin{array}{c}\text { Более } 7 \\
\text { баллов } \\
\text { по NIHSS }\end{array} \\
\begin{array}{c}2 \\
(n=83)\end{array}\end{array}$} & \multirow{2}{*}{$\begin{array}{c}\text { В целом } \\
\text { по груп- } \\
\text { пе боль- } \\
\text { ных ИИ } \\
\begin{array}{c}3 \\
(n=115)\end{array}\end{array}$} & & & & & \\
\hline & & & & $\begin{array}{c}4 \\
(n=52)\end{array}$ & 1 и 2 & 1 и 4 & 2 и 4 & 3 и 4 \\
\hline NOx, мкмоль/л & $\begin{array}{c}15,37 \pm \\
0,35^{\star}\end{array}$ & $\begin{array}{c}12,42 \pm \\
0,28^{\star \#}\end{array}$ & $\begin{array}{c}13,24 \pm \\
0,26^{\star}\end{array}$ & $\begin{array}{c}19,08 \pm \\
0,27\end{array}$ & $-19,19$ & $-19,44$ & $-34,91$ & $-30,61$ \\
\hline
\end{tabular}

Примечание: 1. * - достоверность различий $(\mathrm{p}<0,05)$ при сравнении с аналогичными показателями больных с дисциркуляторной энцефалопатией.

2. \# - достоверность различий $(\mathrm{p}<0,05)$ при сравнении с аналогичными показателями больных ИИ с показателем по шкале NIHSS до 7 баллов.

Так, помимо выраженного снижения содержания NOx в сыворотке крови при сравнении с лицами с ДЭП, у больных 2-й подгруппы со значениями NIHSS

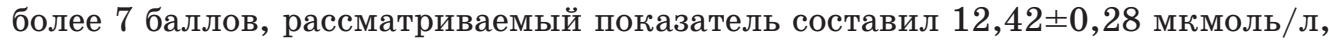
что на 34,91 \% меньше среднего значения в целом по группе больных с ДЭП и на $19,19 \%$ ниже, чем у больных с более легким течением заболевания (1-я подгруппа). 
Проанализируем параметры функционального статуса эндотелия в зависимости от длительности гипертензии (данные представлены в таблице 1.11).

Таблица 1.11

Показатели метаболизма оксида азота у больных мозговым ишемическим инсультом с различной длительностью заболевания АГ

\begin{tabular}{|c|c|c|c|c|c|c|c|c|}
\hline \multirow{3}{*}{ Показатели } & \multicolumn{3}{|c|}{ Больные ИИ } & \multirow[b]{2}{*}{$\begin{array}{c}\text { Больные } \\
\text { ДЭП }\end{array}$} & \multirow{2}{*}{\multicolumn{4}{|c|}{$\begin{array}{c}\text { Величина различий между } \\
\text { группами, \% }\end{array}$}} \\
\hline & Да 10 пет & Более 10 & $\begin{array}{l}\text { В целом } \\
\text { по группе }\end{array}$ & & & & & \\
\hline & $1(n=32)$ & $2(n=83)$ & $3(n=115)$ & $4(n=52)$ & 1 и 2 & 1 и 4 & 2 и 4 & 3 и 4 \\
\hline NOx, мкмоль/л & $\begin{array}{c}14,28 \pm \\
0,52^{\star}\end{array}$ & $\begin{array}{c}13,08 \pm \\
0,28^{\star}\end{array}$ & $\begin{array}{c}13,24 \pm \\
0,26^{\star}\end{array}$ & $\begin{array}{c}19,08 \pm \\
0,27\end{array}$ & $-8,40$ & $-25,16$ & $-31,45$ & $-30,61$ \\
\hline
\end{tabular}

Примечание: $1 . *$ - достоверность различий $(\mathrm{p}<0,05)$ при сравнении с аналогичными показателями больных с дисциркуляторной энцефалопатией.

2. \# - достоверность различий $(\mathrm{p}<0,05)$ при сравнении с аналогичными показателями больных ИИ с длительностью заболевания до 10 лет.

Как наглядно видно из представленных данных, у лиц с более длительным анамнезом гипертензии имеет место разница менее чем 10 \% (8,4 \% ) в сторону снижения концентрационного уровня конечных метаболитов окиси азота, которая приближается к статистической значимости.

Далее мы провели анализ влияния степени тяжести АГ по офисным величинам АД на величину метаболизма NO. Данные представлены в таблице 1.12 .

Таблииа 1.12

\section{Показатели метаболизма оксида азота у больных мозговым ишемическим инсультом с различной степенью артериальной гипертензии}

\begin{tabular}{|c|c|c|c|c|c|c|c|c|c|c|c|}
\hline \multirow{3}{*}{ Показатели } & \multicolumn{4}{|c|}{ Больные ИИ } & \multirow[b]{2}{*}{$\begin{array}{c}\text { Больные } \\
\text { ДЭП }\end{array}$} & \multirow{2}{*}{\multicolumn{6}{|c|}{ Величина различий между группами, \% }} \\
\hline & 1 сте- & 2 сте- & 3 сте- & $\begin{array}{c}\text { В целом } \\
\text { по группе }\end{array}$ & & & & & & & \\
\hline & $\begin{array}{c}1 \\
(n=36)\end{array}$ & $\begin{array}{c}2 \\
(n=43)\end{array}$ & $\begin{array}{c}3 \\
(n=46)\end{array}$ & $\begin{array}{c}4 \\
(n=115)\end{array}$ & $\begin{array}{c}5 \\
(n=52)\end{array}$ & 1 и 2 & 1 и 3 & 1 и 5 & 2 и 3 & 2 и 5 & 3 и 5 \\
\hline $\begin{array}{l}\text { NOx, } \\
\text { мкмоль/л }\end{array}$ & $\begin{array}{c}13,87 \pm \\
0,55^{\star}\end{array}$ & $\begin{array}{c}14,16 \pm \\
0,4^{\star}\end{array}$ & $\begin{array}{l}10,74 \pm \\
0,37^{* \# \Delta}\end{array}$ & $\begin{array}{c}13,24 \pm \\
0,26^{*}\end{array}$ & $\begin{array}{c}19,08 \pm \\
0,27\end{array}$ & 2,09 & $-22,57$ & 27,31 & $-24,15$ & 34,75 & 43,71 \\
\hline
\end{tabular}

Примечание: 1. * - достоверность различий $(\mathrm{p}<0,05)$ при сравнении с аналогичными показателями больных с дисциркуляторной энцефалопатией.

2. \# - достоверность различий $(\mathrm{p}<0,05)$ при сравнении с аналогичными показателями больных ИИ с 1-й степенью АГ.

3. $\Delta$ - достоверность различий $(\mathrm{p}<0,05)$ при сравнении с аналогичными показателями больных ИИ со 2-й степенью АГ. 
В отличие от параметров оксидативного стресса, степень АГ оказывала существенное и значимое влияние на функциональный статус сосудистого эндотелия, оцененного по уровню изменения метаболизма оксида азота. Согласно полученным данным, различия по подгруппам показателя величины NO при проведении биохимического исследования пропорционально нарастали, достигая наибольших различий при 3 -й степени $\mathrm{AГ}$, что на $43,71 \%, 22,57 \%$ и $24,15 \%$ ниже соответствующих значений для группы ДЭП и подгрупп с легкой и умеренной АГ. Причем, важно отметить, что даже при $\mathrm{AГ}$ 1-й степени уровень оксида азота статистически значимо (на $27,31 \%$ ) отличался от аналогичных значений пациентов с ДЭП.

В рамках настоящей работы мы также оценили динамику изменений эндотелиального релаксирующего фактора, синтезируемого неповрежденным эндотелием - оксида азота, в зависимости от локализации очага ишемии (данные представлены в таблице 1.13).

Таблица 1.13

\section{Показатели метаболизма оксида азота у больных мозговым ишемическим инсультом с различной локализацией ишемического очага}

\begin{tabular}{|c|c|c|c|c|c|c|c|c|c|c|c|}
\hline \multirow{3}{*}{ Показатели } & \multicolumn{4}{|c|}{ Больные ИИ } & \multirow{2}{*}{$\begin{array}{c}\text { Боль- } \\
\text { ные } \\
\text { ДЭП }\end{array}$} & \multirow{2}{*}{\multicolumn{6}{|c|}{ Величина различий между группами, \% }} \\
\hline & \multirow{2}{*}{\begin{tabular}{|c}
$\begin{array}{c}\text { Правая } \\
\text { геми- } \\
\text { сфера }\end{array}$ \\
$\begin{array}{c}1 \\
(n=39)\end{array}$
\end{tabular}} & \multirow{2}{*}{\begin{tabular}{|c|c}
$\begin{array}{c}\text { Левая } \\
\text { геми- } \\
\text { сфера }\end{array}$ \\
$\begin{array}{c}2 \\
(n=58)\end{array}$
\end{tabular}} & \multirow{2}{*}{$\begin{array}{c}\begin{array}{c}\text { Верте- } \\
\text { бробази- } \\
\text { лярный } \\
\text { бассейн }\end{array} \\
\begin{array}{c}3 \\
(n=18)\end{array}\end{array}$} & \multirow{2}{*}{\begin{tabular}{|c|}
$\begin{array}{c}\text { В целом } \\
\text { по груп- } \\
\text { пе боль- } \\
\text { ных ИИ }\end{array}$ \\
4 \\
$\left(\begin{array}{c}n=115) \\
\end{array}\right.$
\end{tabular}} & & & & & & & \\
\hline & & & & & $\begin{array}{c}5 \\
(n=52)\end{array}$ & 1 и 2 & 1 и 3 & 1 и 5 & 2 и 3 & 2 и 5 & 3 и 5 \\
\hline $\begin{array}{l}\text { NOx, } \\
\text { мкмоль/л }\end{array}$ & $\begin{array}{c}13,32 \pm \\
0,39^{*}\end{array}$ & $\begin{array}{c}12,76 \pm \\
0,37^{\star}\end{array}$ & $\begin{array}{c}14,62 \pm \\
0,64^{*}\end{array}$ & $\begin{array}{c}13,24 \pm \\
0,26^{*}\end{array}$ & $\begin{array}{c}19,08 \pm \\
0,27\end{array}$ & $-4,20$ & 9,76 & 43,24 & 14,58 & 49,53 & 30,51 \\
\hline
\end{tabular}

Примечание: $1 . *$ - достоверность различий $(\mathrm{p}<0,05)$ при сравнении с аналогичными показателями больных с дисциркуляторной энцефалопатией.

2. \# - достоверность различий $(\mathrm{p}<0,05)$ при сравнении с аналогичными показателями больных ИИ с локализацией патологического очага в правой гемисфере.

3. $\Delta$ - достоверность различий $(\mathrm{p}<0,05)$ при сравнении с аналогичными показателями больных ИИ с локализацией патологического очага в левой гемисфере.

Приведенные данные указывают, что, хотя наибольшие значения уровня $\mathrm{NO}$ зарегистрированы для подгруппы с патологическими изменениями в области вертебробазилярного бассейна, достоверных различий по рассматриваемому показателю достичь не удалось ( $\mathrm{p}>0,05)$.

При изучении степени вовлеченности эндотелия в патологический процесс при ИИ в зависимости от биологического возраста пациентов, получены данные, отраженные в таблице 1.14 . 
Таблица 1.14

Показатели метаболизма оксида азота у больных мозговым ишемическим инсультом различного возраста

\begin{tabular}{|c|c|c|c|c|c|c|c|c|}
\hline \multirow{3}{*}{ Показатели } & \multicolumn{3}{|c|}{ Больные ИИ } & \multirow[b]{2}{*}{$\begin{array}{c}\text { Больные } \\
\text { ДЭП }\end{array}$} & \multirow{2}{*}{\multicolumn{4}{|c|}{$\begin{array}{c}\text { Величина различий между группами, } \\
\%\end{array}$}} \\
\hline & \multirow{2}{*}{$\begin{array}{c}\text { До } 60 \text { лет } \\
\begin{array}{c}1 \\
(n=51)\end{array}\end{array}$} & \multirow{2}{*}{$\begin{array}{c}\text { Более } 60 \\
\text { лет } \\
2 \\
(n=64) \\
\end{array}$} & \multirow{2}{*}{$\begin{array}{c}\begin{array}{c}\text { В целом } \\
\text { по группе } \\
\text { больных } \\
\text { ии }\end{array} \\
3 \\
(\mathrm{n}=115)\end{array}$} & & & & & \\
\hline & & & & $\begin{array}{c}4 \\
(n=52)\end{array}$ & 1 и 2 & 1 и 4 & 2 и 4 & 3 и 4 \\
\hline $\begin{array}{l}\text { NOx, } \\
\text { мкмоль/л }\end{array}$ & $\begin{array}{c}13,26 \pm \\
0,39^{*}\end{array}$ & $\begin{array}{c}13,23 \pm \\
0,34^{*}\end{array}$ & $\begin{array}{c}13,24 \pm \\
0,26^{*}\end{array}$ & $\begin{array}{c}19,08 \pm \\
0,27\end{array}$ & $-0,23$ & $-30,50$ & $-30,66$ & $-30,61$ \\
\hline
\end{tabular}

Примечание: $1 . *$ - достоверность различий $(\mathrm{p}<0,05)$ при сравнении с аналогичными показателями больных с дисциркуляторной энцефалопатией.

2. \# - достоверность различий $(\mathrm{p}<0,05)$ при сравнении с аналогичными показателями больных ИИ возрастной группы до 60 лет.

Приведенные данные указывают на отсутствие статистически значимых различий в динамике уровня оксида азота у больных разных возрастных групп.

Соотносимость и сопоставимость напряженности антиоксидантных и эндотелиальных систем при остром мозговом ишемическом инсульте представлены на рисунке 1.7.

Из представленных данных видно, что при адекватном функционировании антиокислительной системы нарушения в метаболизме оксида азота наименьшие, и наоборот.

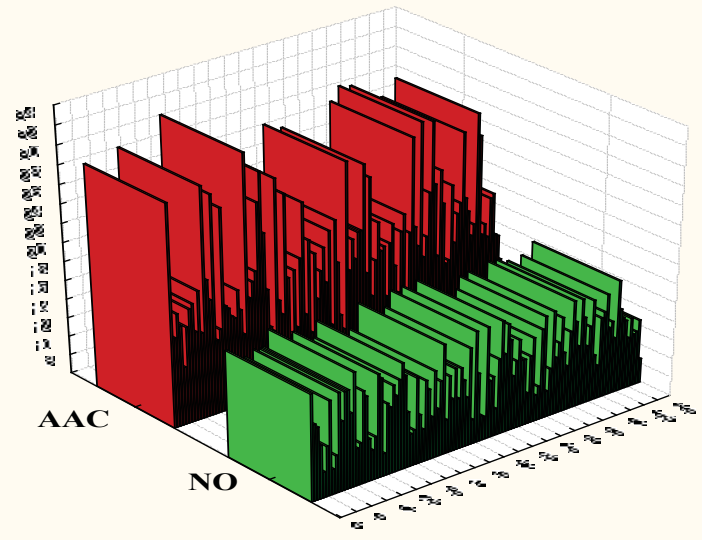

Рис. 1.7. Сопоставимость активности антиоксидантных и эндотелиальных систем при остром мозговом ишемическом инсульте 
Патогенетическая взаимосвязь нарушений окислительно-восстановительного гомеостаза, эндотелиальной дисфункции с нейронспецифичными белками при остром мозговом ишемическом инсульте. Учитывая наличие статистически значимой взаимосвязи различной степени выраженности между изучаемыми показателями, а также с целью установления не только наличия зависимости между исследуемыми признаками, но и направленности и степень выраженности воздействия различных факторов на отклик зависимой переменной, мы провели корреляционный анализ.

Результаты корреляционного анализа (таблица 1.15), показали, что, наряду с выявленными сильными положительными корреляционными взаимосвязями между показателями, характеризующими выраженность оксидативных процессов (АФГ и КФГ), существует сильная положительная взаимосвязь между уровнем нейронспецифичных белков и величиной параметров, отражающих тяжесть модификационных изменений белков.

Негативная корреляционная взаимосвязь средней силы была зарегистрирована между содержанием NOx в сыворотке крови и величиной показателей, характеризующих активность образования свободных радикалов, содержанием КФГ, АФГ. В свою очередь, ААС также была достоверно взаимосвязана с большинством из показателей, причем наиболее выражена была отрицательная корреляционная взаимосвязь с содержанием КФГ в крови, при позитивной взаимосвязи с сывороточным уровнем NOx.

Указанные данные подтверждаются и визуальной 3D-диаграммой (рис. 1.8) взаимосвязи нарушений обмена оксида азота и активации прооксидантных систем с иммунологическими сдвигами у пациентов с ИИ в остром периоде.

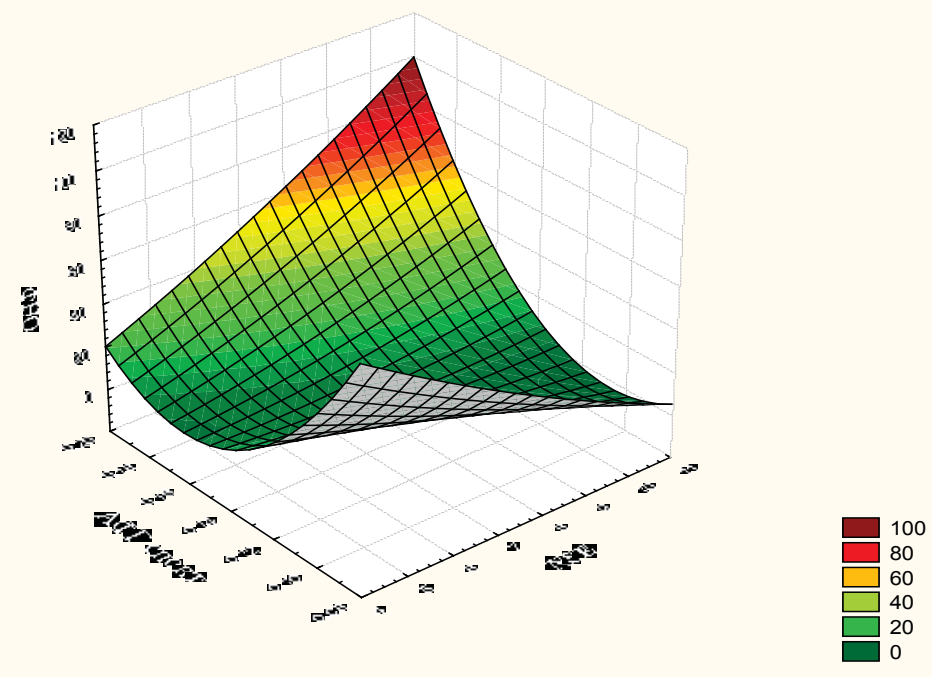

Puc. 1.8. Ассоциация изменений уровня НСЕ с ФНО- $\alpha$ и уровнем спонтанной оксидативной модификации белков сыворотки крови у больных с острым мозговым ишемическим инсультом 
Таким образом показано, что, по мере роста уровня интегрального маркера интенсификации свободнорадикального окисления, АФГ, индуцированной железом, наблюдается прогрессивное повышение уровня провоспалительного цитокина ФНО- $\alpha$ и сопровождается достоверным нарастанием нейронспецифичных белков в крови при ИИ в остром периоде.

Ниже представленная диаграмма (рис. 1.9) указывает на наличие тесной разнонаправленной взаимосвязи между выраженностью изменений уровня белка S100 с антиокислительной активностью сыворотки и величиной металлиндуцированной оксидативной модификации белков сыворотки крови у пациентов с мозговым ишемическим инсультом. Так, для пациентов с уровнем АAC менее 15 усл. ед. регистрировалось значимое существенное повышение уровня фенилгидразонов, кетоновой фракции (более 0,16 усл. ед/г белка), свидетельствующее о существенной активации свободнорадикальных механизмов и разнонаправленной зависимости между признаками. В то время как для белка S100 у больных с ИИ указанная зависимость также носила обратно направленную аппроксимацию и визуально характеризовалась существенным повышением уровня этого специфичного для нервной ткани белка у больных с низкими значениями антиокислительной активности сыворотки.

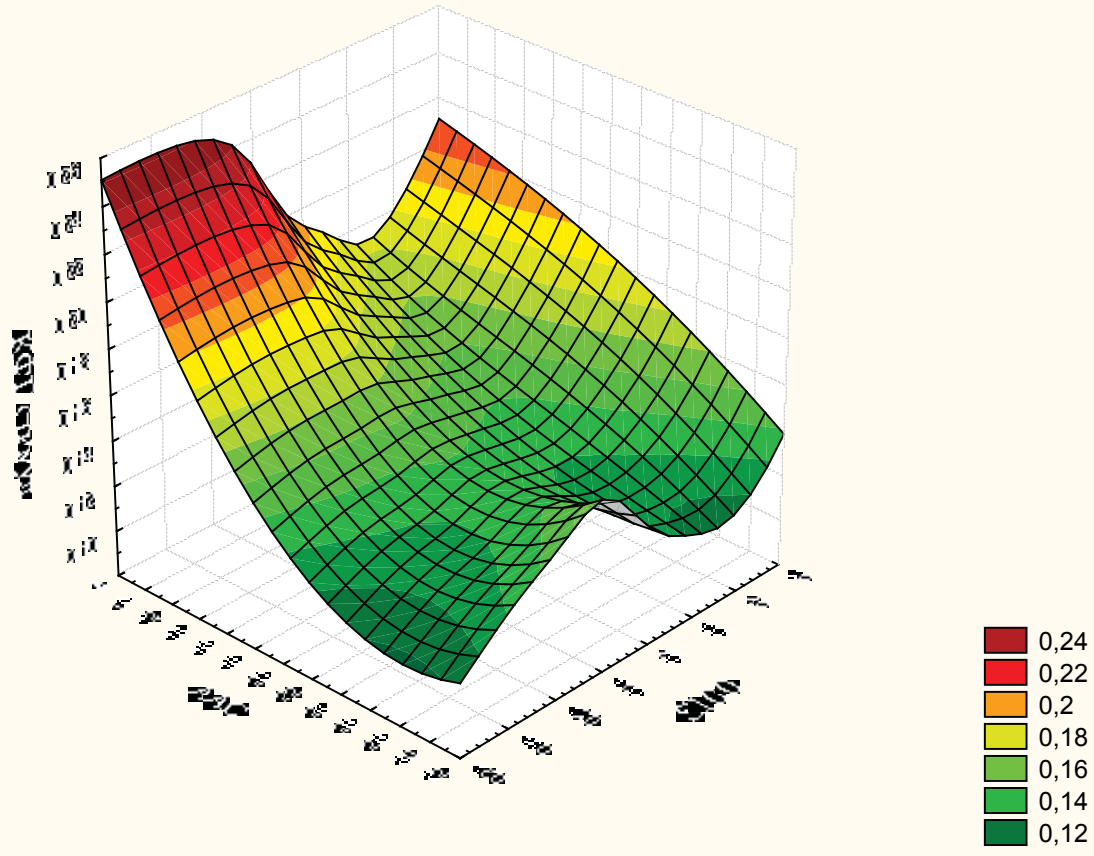

Рис. 1.9. Сопряженность изменений уровня белка $\mathrm{S} 100$ с антиокислительной активностью сыворотки и величиной металл-индуцированной оксидативной модификации белков сыворотки крови у больных с острым мозговым ишемическим инсультом 


\begin{tabular}{|c|c|c|c|c|c|c|c|c|c|c|c|c|c|}
\hline \multicolumn{14}{|r|}{$\stackrel{0}{\circ}$} \\
\hline \multicolumn{14}{|c|}{ 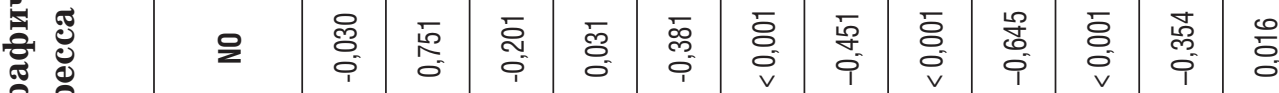 } \\
\hline \multirow{13}{*}{ 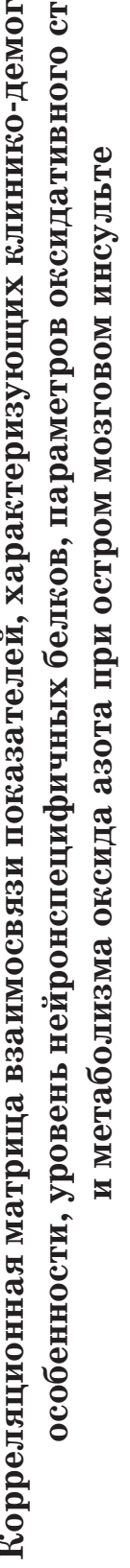 } & 此 & \begin{tabular}{l}
0 \\
\multirow{0}{0}{} \\
0
\end{tabular} & ্ָণ & $\frac{\bar{\sigma}}{5}$ & 祭 & 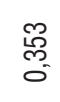 & $\begin{array}{l}\overline{8} \\
\overline{0} \\
\sigma^{-}\end{array}$ & 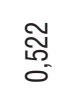 & $\begin{array}{l}\bar{\delta} \\
\overline{0} \\
\sigma^{-}\end{array}$ & $\begin{array}{l}\text { D } \\
\text { : } \\
0 \\
0\end{array}$ & $\begin{array}{l}\overline{8} \\
0 \\
0 \\
v\end{array}$ & o̊ & 능 \\
\hline & 昰 咭 & $\begin{array}{l}\frac{8}{0} \\
\frac{0}{0}\end{array}$ & 芯 & 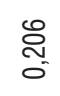 & స్ & స్ & $\begin{array}{l}5 \\
\varnothing \\
0 \\
0\end{array}$ & 焤 & $\begin{array}{l}\bar{\delta} \\
0 \\
0\end{array}$ & 苂 & $\begin{array}{l}\bar{\delta} \\
\bar{\delta} \\
v^{-}\end{array}$ & 年 & శ్ \\
\hline & 此 & 导 & 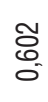 & ָ̊ & $\stackrel{0}{0}$ & 考 & 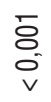 & 薃 & 용 & ơ & 용 & 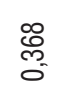 & $\tilde{O}$ \\
\hline & 每委 & : & 站 & 兽 & 응 & $\begin{array}{l}\text { స్రి } \\
\text { గ్ర }\end{array}$ & $\begin{array}{l}\bar{\delta} \\
\overline{0} \\
\sigma^{-}\end{array}$ & $\begin{array}{l}0 \\
\stackrel{0}{L} \\
0 \\
0\end{array}$ & $\begin{array}{l}\bar{\delta} \\
\overline{0} \\
\mathbf{v}^{-}\end{array}$ & 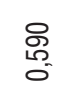 & $\begin{array}{l}\bar{\delta} \\
\delta \\
0 \\
v\end{array}$ & 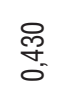 & O̊ \\
\hline & 옵 & $\begin{array}{l}\text { on } \\
\text { ○ } \\
\text { í }\end{array}$ & 음 & $\begin{array}{l}\text { ָ̊ } \\
\text { ○े }\end{array}$ & $\frac{\pi}{0}$ & 灾 & $\begin{array}{l}\bar{\delta} \\
0 \\
0 \\
v\end{array}$ & $\begin{array}{l}0 \\
\stackrel{0}{0} \\
\text { Oे }\end{array}$ & E. & 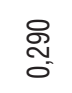 & $\begin{array}{l}0 \\
\tilde{8} \\
0\end{array}$ & : & 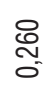 \\
\hline & 옹 & $\frac{\stackrel{2}{2}}{\frac{5}{0}}$ & 导 & 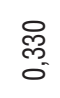 & 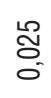 & 㞼 & $\begin{array}{l}\overline{8} \\
0 \\
0 \\
v\end{array}$ & $\underset{E}{E}$ & $\begin{array}{l}\overline{8} \\
\text { o } \\
v\end{array}$ & $\begin{array}{l}\tilde{N} \\
\hat{\sigma}\end{array}$ & $\begin{array}{l}\bar{\delta} \\
\text { - } \\
\text { v }\end{array}$ & - & \\
\hline & 층 & $\frac{\pi}{0}$ & $\frac{0}{0}$ & 옹 & $\frac{g}{\frac{g}{\sigma}}$ & 霉 & $\begin{array}{l}5 \\
\text { ㅇ. } \\
\text { v }\end{array}$ & $\begin{array}{l}\stackrel{0}{0} \\
\text { o. } \\
0\end{array}$ & $\begin{array}{l}\bar{\delta} \\
\text { O } \\
\text { v }\end{array}$ & - & & $\begin{array}{l}\frac{1}{N} \\
\sigma\end{array}$ & $\begin{array}{l}\bar{\delta} \\
\text { o. }\end{array}$ \\
\hline & 荝 & $\frac{5}{5}$ & ণ్ల్రి & $\begin{array}{l}\stackrel{0}{2} \\
\text { ल) } \\
0\end{array}$ & 응 & $\begin{array}{l}80 \\
10 \\
0 \\
0\end{array}$ & $\begin{array}{l}\bar{\delta} \\
\text { O } \\
\text { v }\end{array}$ & - & & $\begin{array}{l}0 \\
\text { O. } \\
\text { o. }\end{array}$ & 흐. & $\underset{T}{E}$ & 흠 \\
\hline & 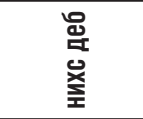 & 용 & 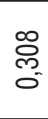 & $\stackrel{\infty}{\stackrel{\infty}{N}}$ & 응 & - & & $\begin{array}{l}\infty \\
0 \\
10 \\
0\end{array}$ & $\begin{array}{l}\bar{\delta} \\
\text { o } \\
\text { v }\end{array}$ & 守 & $\begin{array}{l}\bar{\delta} \\
0 \\
0 \\
v\end{array}$ & ঙ্ণ & $\begin{array}{l}\bar{\delta} \\
\overline{0} \\
\vee\end{array}$ \\
\hline & $\begin{array}{l}\text { 总 온 } \\
\text { 点 }\end{array}$ & $\stackrel{\bar{\Xi}}{\bar{\sigma}}$ & $\frac{5}{5}$ & - & & $\stackrel{\infty}{\check{N}}$ & 옹 & 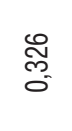 & 응 & 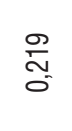 & $\frac{\text { g }}{\frac{\sigma}{0}}$ & 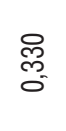 & 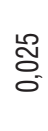 \\
\hline & 总忥 & - & & $\stackrel{\bar{N}}{\check{\sigma}}$ & $\frac{5}{5}$ & 용 & o̊ & $\frac{5}{5}$ & ণ్ల్రి & $\frac{\pi}{\tilde{\sigma}}$ & $\frac{0}{0}$ & $\frac{\stackrel{2}{R}}{\sigma}$ & 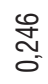 \\
\hline & 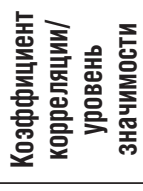 & 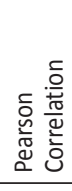 & 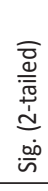 & 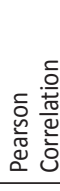 & 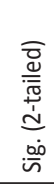 & 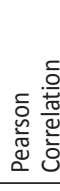 & 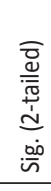 & 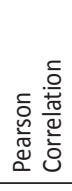 & 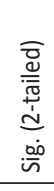 & 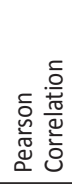 & 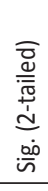 & 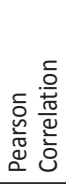 & 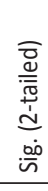 \\
\hline & 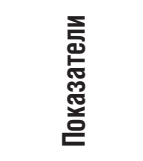 & & & & & & & & & & & & \\
\hline
\end{tabular}




\begin{tabular}{|c|c|c|c|c|c|c|c|c|c|c|c|c|c|c|}
\hline 安 & $\begin{array}{l}\text { న్ } \\
\text { i }\end{array}$ & $\begin{array}{l}\bar{\delta} \\
0 \\
0\end{array}$ & $\begin{array}{l}\text { గ్ర } \\
\text { in } \\
\text { in }\end{array}$ & $\begin{array}{l}\bar{\delta} \\
\overline{0} \\
v\end{array}$ & స్テ & $\begin{array}{l}\overline{8} \\
0 \\
0\end{array}$ & 里 & $\begin{array}{l}\bar{\delta} \\
\overline{0} \\
v\end{array}$ & 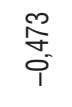 & $\begin{array}{l}\bar{\delta} \\
\overline{0} \\
v\end{array}$ & 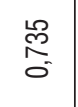 & $\begin{array}{l}\overline{8} \\
0 \\
\text { v }\end{array}$ & - & \\
\hline 을 & $\begin{array}{l}8 \\
\stackrel{8}{0} \\
i\end{array}$ & $\begin{array}{l}\bar{\delta} \\
\overline{0} \\
v\end{array}$ & $\frac{\infty}{0}$ & $\begin{array}{l}\overline{8} \\
\overline{0} \\
v\end{array}$ & 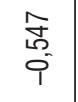 & $\begin{array}{l}\overline{8} \\
0 \\
\text { v }\end{array}$ & $\begin{array}{l}10 \\
5 \\
0 \\
0\end{array}$ & $\begin{array}{l}\bar{\delta} \\
\overline{0} \\
v\end{array}$ & $\begin{array}{l}\mathscr{0} \\
0 \\
0 \\
0 \\
0\end{array}$ & $\begin{array}{l}\overline{8} \\
\overline{0} \\
v\end{array}$ & - & & 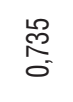 & $\begin{array}{l}\overline{8} \\
\overline{0} \\
v\end{array}$ \\
\hline 鱼 & 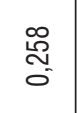 & $\frac{m}{5}$ & $\begin{array}{l}\text { ळे } \\
\text { ठ․ }\end{array}$ & $\begin{array}{l}\overline{8} \\
0 \\
0\end{array}$ & 营 & $\begin{array}{l}\overline{8} \\
0 \\
\end{array}$ & $\begin{array}{l}\text { 음 } \\
\text { ․ }\end{array}$ & $\begin{array}{l}5 \\
8 \\
0 \\
v\end{array}$ & - & & $\begin{array}{l}\mathscr{0} \\
0 \\
0 \\
i \\
i\end{array}$ & $\begin{array}{l}\bar{\delta} \\
\overline{0} \\
v\end{array}$ & 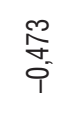 & $\begin{array}{l}\overline{8} \\
\\
\end{array}$ \\
\hline 느 봉 & 总 & 要 & 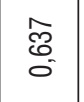 & हे & ח్ల & $\begin{array}{l}\overline{8} \\
\text { O } \\
\text { v }\end{array}$ & - & & 응 & $\begin{array}{l}\bar{\delta} \\
\text { o } \\
\text { v }\end{array}$ & $\begin{array}{l}10 \\
5 \\
0 \\
0 \\
0\end{array}$ & $\begin{array}{l}\bar{\delta} \\
\text { o. } \\
\text { v }\end{array}$ & $\begin{array}{l}0 \\
\frac{0}{+} \\
1\end{array}$ & $\begin{array}{l}\overline{8} \\
\text { O } \\
\text { v }\end{array}$ \\
\hline 每完 & 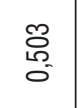 & 흥 & $\begin{array}{l}\widetilde{0} \\
\stackrel{0}{0} \\
0\end{array}$ & $\begin{array}{l}\bar{\delta} \\
0 \\
\dot{0}\end{array}$ & - & & ח్ & $\begin{array}{l}\bar{\delta} \\
\text { 음 } \\
\text { v }\end{array}$ & 营 & $\begin{array}{l}\bar{\delta} \\
\overline{0} \\
v\end{array}$ & $\begin{array}{l}\text { 旁 } \\
\text { i }\end{array}$ & $\begin{array}{l}\bar{\delta} \\
\text { o. } \\
\text { v }\end{array}$ & 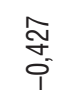 & $\begin{array}{l}\bar{\delta} \\
0 \\
\text { v }\end{array}$ \\
\hline 旨 㟀 & $\frac{10}{6}$ & $\begin{array}{l}\bar{\delta} \\
\text { o } \\
\text { v }\end{array}$ & - & & 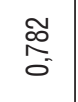 & $\begin{array}{l}\overline{8} \\
0 \\
0\end{array}$ & $\begin{array}{l}\hat{2} \\
\tilde{c} \\
0\end{array}$ & $\begin{array}{l}\bar{\delta} \\
\overline{0} \\
\dot{v}\end{array}$ & 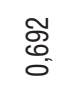 & $\begin{array}{l}\bar{\delta} \\
\overline{0} \\
v\end{array}$ & $\begin{array}{l}\stackrel{0}{2} \\
\text { i }\end{array}$ & $\begin{array}{l}\bar{\delta} \\
\text { o } \\
v\end{array}$ & 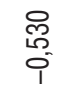 & $\begin{array}{l}\bar{\delta} \\
\text { o } \\
v\end{array}$ \\
\hline 웁 & - & & $\frac{10}{6}$ & $\begin{array}{l}\bar{\delta} \\
0 \\
\text { v }\end{array}$ & 艿 & $\overline{8}$ & 용 & 要 & $\begin{array}{l}\stackrel{\infty}{\sim} \\
\text { on }\end{array}$ & $\stackrel{m}{E}$ & $\begin{array}{l}0 \\
\stackrel{0}{0} \\
0\end{array}$ & $\begin{array}{l}\bar{\delta} \\
\overline{0} \\
v\end{array}$ & $\begin{array}{l}\text { م् } \\
\text { í }\end{array}$ & $\begin{array}{l}\bar{\delta} \\
\text { o } \\
v\end{array}$ \\
\hline 움 & $\begin{array}{l}\stackrel{L}{0} \\
0 \\
0\end{array}$ & 芯 & 总 & ס̊ & $\begin{array}{l}\infty \\
0 \\
0 \\
0 \\
0\end{array}$ & 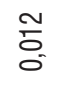 & $\begin{array}{l}\frac{8}{8} \\
0\end{array}$ & Оิ & o̊ & 눙 & $\begin{array}{l}\text { 芦 } \\
\text { i }\end{array}$ & O & 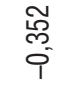 & $\begin{array}{l}0 \\
0 \\
0\end{array}$ \\
\hline 농 & 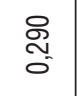 & $\begin{array}{l}\mathscr{8} \\
0 \\
0\end{array}$ & 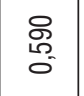 & $\begin{array}{l}\bar{\delta} \\
\text { o } \\
v\end{array}$ & ơ & 응 & 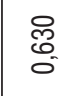 & $\begin{array}{l}\bar{\delta} \\
\text { o. } \\
v\end{array}$ & 总 & $\begin{array}{l}\bar{\delta} \\
\text { o } \\
\text { v }\end{array}$ & $\begin{array}{l}\text { 尔 } \\
0 \\
0\end{array}$ & $\begin{array}{l}\bar{\delta} \\
0 \\
0 \\
v\end{array}$ & 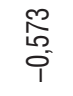 & $\begin{array}{l}\bar{\delta} \\
\text { o. } \\
\text { v }\end{array}$ \\
\hline 岕 & $\begin{array}{l}\mathscr{E} \\
\stackrel{N}{0} \\
0\end{array}$ & E. & $\begin{array}{l}0 \\
\stackrel{0}{R} \\
0 \\
0\end{array}$ & $\begin{array}{l}\bar{\delta} \\
\overline{0} \\
v\end{array}$ & ָָ̃ & 응 & 总 & $\begin{array}{l}\bar{\delta} \\
\text { o. } \\
\text { v }\end{array}$ & 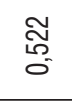 & $\begin{array}{l}\bar{\delta} \\
\text { o } \\
v\end{array}$ & 管 & $\begin{array}{l}\bar{\delta} \\
\overline{0} \\
v\end{array}$ & $\begin{array}{c}\hat{N} \\
\text { m } \\
i\end{array}$ & శ్ \\
\hline 矛递 & 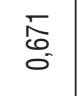 & $\begin{array}{l}\overline{0} \\
\text { o. } \\
\text { v }\end{array}$ & $\begin{array}{l}\stackrel{2}{\mathbb{N}} \\
0\end{array}$ & $\begin{array}{l}\bar{\delta} \\
0 \\
\text { v }\end{array}$ & 旡 & $\begin{array}{l}\overline{0} \\
\overline{0} \\
v\end{array}$ & స్ & $\begin{array}{l}\bar{\delta} \\
\overline{0} \\
v\end{array}$ & 敢 & $\begin{array}{l}\bar{\delta} \\
\text { o } \\
\text { v }\end{array}$ & $\begin{array}{l}\text { क } \\
\text { m } \\
\text { i }\end{array}$ & $\begin{array}{l}\overline{8} \\
8 \\
0 \\
v\end{array}$ & 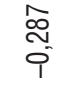 & శ్ \\
\hline $\begin{array}{l}\text { 占 } \\
\text { 点 } \\
\text { 点 }\end{array}$ & 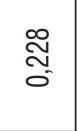 & $\frac{\pi}{0}$ & $\begin{array}{l}\bar{N} \\
\text { O } \\
0\end{array}$ & 응 & స్ & $\begin{array}{l}0 \\
0 \\
0\end{array}$ & $\begin{array}{l}\text { O̊. } \\
\text { o }\end{array}$ & స్ & $\frac{\bar{\sigma}}{0}$ & 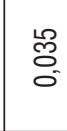 & 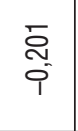 & оू & $\frac{\text { p }}{i_{1}^{-}}$ & $\frac{\stackrel{9}{0}}{5}$ \\
\hline 总 总 & 음 & 웅 & 艿 & 常 & 导 & ॄั & $\begin{array}{l}8 \\
0 \\
0\end{array}$ & 㣽 & $\begin{array}{l}0 \\
\vdots \\
0\end{array}$ & ্ָণ & $\begin{array}{l}\text { O্ } \\
\text { i. }\end{array}$ & 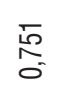 & $\begin{array}{l}\text { ¿ } \\
\text { O }\end{array}$ & 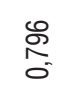 \\
\hline 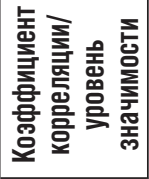 & 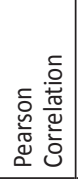 & 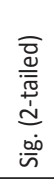 & 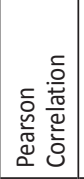 & 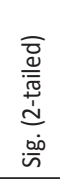 & 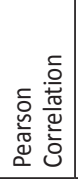 & 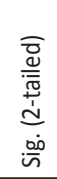 & 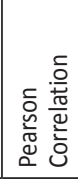 & 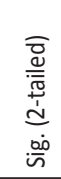 & 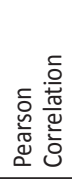 & 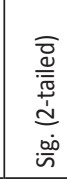 & 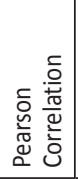 & 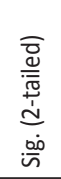 & 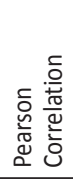 & 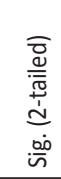 \\
\hline 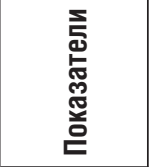 & i & & 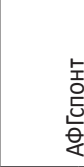 & & 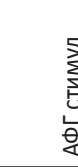 & & & & 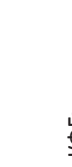 & 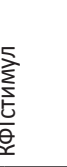 & & & & \\
\hline
\end{tabular}


На рисунке 1.10 представлена параллельность динамики уровня общего белка миелина с величиной металл-индуцированной оксидативной модификации белков сыворотки крови (по уровню кетонфенилгидразонов) и антиокислительной активностью сыворотки. Диаграмма указывает на наличие однонаправленной взаимозависимости динамики как концентрационного показателя общего белка миелина и выраженности нарушений окислительного гомеостаза по оценке спонтанной окислительной деструкции белков плазмы крови по уровню кетонфенилгидразонов, с величиной биодоступности оксида азота, отражающих наличие и выраженность эндотелиальной дисфункции. Так, у больных с ИИ повышение уровня базальной КФГ и выраженное нарушение метаболизма NO, статистически достоверно ассоциируется со значимым повышением уровня основного белка глиальной ткани в крови - ОБМ, и указывает на развитие существенной деструкции нервной ткани, что может являться важным аспектом формирования последующей клинико-неврологической симптоматики и усугубления дефицита.

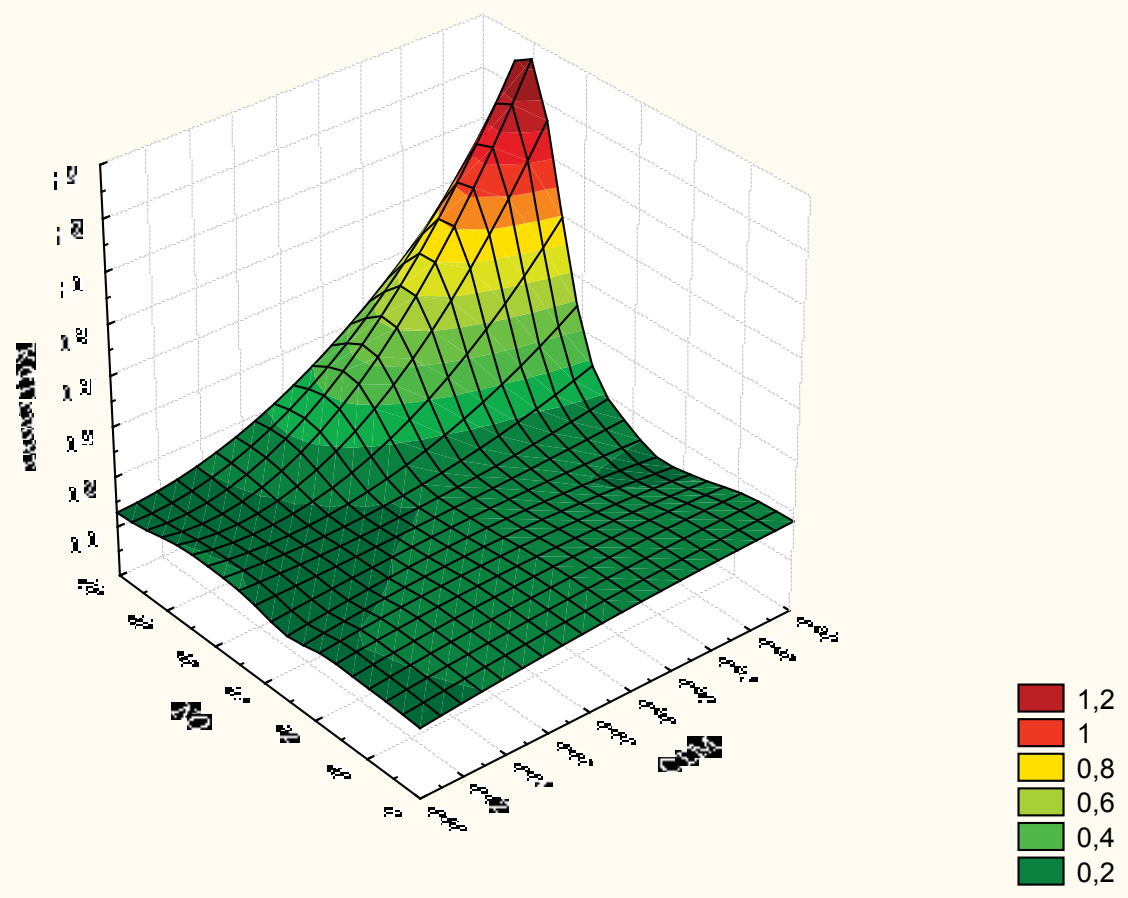

Рuc. 1.10. Сопряженность динамики уровня общего белка миелина с антиокислительной активностью сыворотки и величиной металл-индуцированной оксидативной модификации белков сыворотки крови (по уровню кетонфенилгидразонов) у больных с острым мозговым ишемическим инсультом 
Таким образом, оксидативный стресс выступает как один из ведущих факторов повреждения мозга при ишемии. Полученные данные объясняются тем, что при острой мозговой ишемии на фоне дисбаланса оксидантноантиоксидантной системы происходит активация процессов липопероксидации, что в совокупности вызывает развитие дистрофических и деструктивных изменений нейрональных мембран и формирование неврологического дефицита [12].

Выявленная нами в ходе исследования совокупность изменений параметров, характеризующих активность процессов генерации свободных радикалов и их элиминации под воздействием эндогенных антиоксидантных систем, у больных ИИ в остром периоде свидетельствует, с одной стороны, о выраженном увеличении продукции свободных радикалов, а с другой - о пониженной способности антиоксидантных систем организма осуществлять элиминацию образующихся свободных радикалов [7, 12-14]. Другими словами, полученные нами данные свидетельствуют о формировании оксидативного стресса в организме при ИИ. Наиболее наглядно эти процессы отражает значительное и высокодостоверное увеличение содержания в сыворотке крови АФГ и КФГ, являющихся специфическими маркерами повышенной продукции свободных радикалов (значительное увеличение их продукции было отмечено при целом ряде состояний, для которых доказана повышенная активность оксидативных процессов $[11,12,15,16])$.

Косвенным образом об увеличении активности процессов генерации свободных радикалов свидетельствует выявленное нами у больных ИИ статистически значимое уменьшение уровня NOx вследствие, согласно литературным данным, образования при свободнорадикальном окислении NO пероксинитрита с нарушением биодоступности NO, а также снижение уровня AAC $[4,8]$. У больных ИИ значительная часть выделяемого эндотелиальными клетками NO деградирует под воздействием свободных радикалов, а образующийся при этом пероксинитрит способствует дальнейшей активации процессов пероксидации биомолекул [3, 12]. Таким образом, результаты проведенного исследования свидетельствуют, что основным механизмом, который обуславливает нарушение метаболизма NO у больных ИИ, является активация процессов его деградации в условиях оксидативного стресса. Более того, собственные данные, а также результаты, полученные другими исследователями, позволяют сделать вывод о важной патогенетической роли свободных радикалов при ишемическом поражении головного мозга.

\section{6. РОЛЬ ВОСПАЛЕНИЯ И ЦИТОКИНОВЫЕ МЕХАНИЗМЫ НЕЙРОДЕСТРУКЦИИ}

Вещества, обусловливающие в очаге ишемии как повреждение, так и систему поддержки жизнеспособности клеток, представлены широким спектром регуляторных пептидов, включающих цитокины, нейротрофические и модуляторные факторы [3, 4]. 
Цитокины - это специфические иммунные медиаторы, представляющие собой небольшие растворимые полипептиды. Они продуцируются иммунокомпетентными (Т-клетки, макрофаги, микроглия) и неиммунокомпетентными (нейроны, астроциты) клетками. Идентифицированные на сегодняшний день цитокины сгруппированы в несколько больших семейств: интерлейкины (IL), факторы некроза опухоли (ТNF), интерфероны (ИФН), трофические факторы. Условно принято деление цитокинов на регуляторные, или противовоспалительные (IL-10, IL-4, трофические факторы) и провоспалительные (IL-1, IL-6, IL-8, фактор некроза опухоли (TNF) и др.) $[3,4]$.

В мозге цитокины организованы в невральный и глиальный компартменты, а также широко распространены в дискретных сетях. Они действуют аутокринно (стимулируют дальнейшую пролиферацию моноцитов) и паракринно (воздействуют на нейроны и эндотелиальные клетки). Связываясь со специфическими рецепторами, цитокины активируют системы вторичных внутриклеточных мессенджеров, включая протеинкиназы и фосфатазы [7, 41, 92].

Важно отметить, что IL-1, IL-6, TNF- $\alpha$ и некоторые другие цитокины регулируют функцию гипоталамо-гипофизарной системы, непосредственно воздействуя на передний гипофиз и осуществляя стыковку между нейроиммунной и нейроэндокринной системами [4]. Доказано, что один из наиболее мощных цитокинов - IL-1 - влияет на все уровни гипоталамо-гипофизарнонадпочечниковой системы, увеличивая секрецию кортикотропного рилизинггормона, АКТГ, глюкокортикоидов, рилизинг-фактора лютеинизирующего гормона, а также предпроложительно и других гормонов: соматотропного, фолликулостимулирующего, лютеинизирующего, пролактина. Таким образом, можно предположить общность сигнальных систем, используемых иммунными и нейроэндокринными клетками. Тесное взаимодействие между цитокинами и гормонами на центральном и периферическом уровнях обусловливает гормональные ответы на усиление экспрессии цитокинов. Это объясняет включение стресс-реализующих эндокринных систем в ответ на ишемию мозга в рамках общей реакции нейроиммуноэндокринной системы $[4,95]$.

Из-за свойственной цитокинам плейотропности трудно дать упрощенное представление об их функции. Цитокины контролируют рост, дифференцировку и функции большинства типов клеток; модулируют нейроэндокринную и терморегуляцию, репродукцию, сон, прием пищи и поддержание стабильной массы тела, когнитивные функции и поведение, выносливость. Иммунные медиаторы играют особую роль в запуске реакций воспаления, нарушений микроциркуляции и проницаемости гематоэнцефалического барьера, участвуют в механизмах смерти и выживания нейронов.

Семейство лигандов IL-1 состоит из трех изоформ: IL-1a, IL-1b и IL-1pa (антагонист рецептора IL-1), которые кодируются тремя различными генами, но распознаются одинаковыми рецепторами IL-1 типа I (IL-1RI) с сопоставимой аффинностью. IL-1a, и IL-1b биоактивны и приводят к разнообразным реакциям в клетках-мишенях. IL-1b синтезируется как большая молекула, которая биологически неактивна; она разделяется на части с массой 17 кД и становится активной под действием IL-1b-конвертирующего фермента (ICE). Микродозы 
IL-1 вырабатываются в норме у здоровых людей, способствуют экспрессии Сu-, Zn-СОД в нейронах, пролиферации астроглии. В условиях патологии, в том числе ишемии, выработка IL-1 микроглией является главным активирующим сигналом для индукции других провоспалительных цитокинов, а также стимуляции астроцитов к экспрессии индуцибельной NOS и гиперпродукции NO и его цитотоксических форм, а также иметаболитов арахидоновой кислоты. Установлено, что экспрессия гена IL-1 в мозге вызывает экспрессию проапоптических белков [3, 4].

Повышенная продукция IL-1b в условиях глобальной и фокальной ишемии продемонстрирована на животных моделях. Рекомбинированный человеческий IL-1b, введенный белым беспородным крысам после временной, 60минутной окклюзии средней мозговой артерии с последующей реперфузией, достоверно увеличивал отек мозга и размер церебрального инфаркта, а также количество адгезированных к эндотелию и инфильтрирующих область ишемии нейтрофилов, снижал экспрессию bcl-2, повышал уровень маркера нитрозирующего стресса - нитротирозина. Выраженность данных эффектов линейно коррелировала с введенной дозой цитокина. На мышах с генетическим дефектом интерлейкина (IL-1 knock-out) выявлены существенно меньшие размеры ишемического инфаркта мозга в сравнении с контрольными животными. Интрацеребральная инъекция антагониста рецептора IL-1 также уменьшала размеры повреждения, как у контрольных, так и у нокаутированных по IL-1 мышей $[4,6]$.

Важные результаты получены на клеточных моделях. На культуре срезов гиппокампа было установлено, что IL-lb потенцировал вызванную гипоксией нейродегенерацию. Результаты свидетельствуют о сложной парадигме про- или антиишемических эффектов цитокинов, зависящих, в частности, от изотипа вещества и от уровня его экспрессии (т. е. действующей концентрации). В ответ на экспрессию IL-1b в аденогипофизе секретируется изоформа IL-1pa, которая, в противоположность IL-1b, является эндогенным протективным агентом. По экспериментальным данным, протективный эффект экзогенного IL-1pa проявляется в $40 \%$ случаев острой фокальной церебральной ишемии. При нейтрализации биологической активности IL-1pa отмечается усиление гибели нейронов в ишемизированной области мозга. Доказано, что мPHК IL-1pa всегда сопровождает мPHК IL-1b. Токсические эффекты IL-1b и ингибиторов IL-1pa на нейроны реализуются как непосредственно, так и опосредованно через влияние на глиальные и эндотелиальные клетки. Понимание молекулярных механизмов экспрессии IL-1bpa и IL-1b в головном мозге в первые часы после ишемического инсульта позволит разработать новые терапевтические стратегии для предотвращения отсроченной гибели клеток $[4,6$, 95]. Экспериментальные исследования на моделях фокальной ишемии мозга у крыс выявили увеличение уровня IL-1b, совпадавшее с повышенной экспрессией растворимого Fas. Имеются убедительные данные, что нейроапоптоз при церебральной ишемии сопряжен с экспрессией факторов Fas и p53; IL-1b pacсматривается в качестве посредника этих процессов. Интерлейкин-10, оказывается вовлеченным в широкий круг клинических симптомов инсульта, рассе- 
янного склероза, менингита, БА, поведенческих расстройств при бактериальных инфекциях. Экспрессия IL-10 обеспечивает защиту нейронов и глиальных клеток мозга преимущественно за счет ингибирования проапоптотических цитокинов и за счет стимулирования защитных сигнальных реакций. Активация рецепторов IL-10 регулирует трансдукторные процессы с участием Jakl/Stat3, MAPК, фосфокиназы-3 и NF-kappaB, в свою очередь, сопряженных с контролем митохондриального апоптоза [7, 41, 42, 95].

Действие TNF- $\alpha$ - плейотропного полипептида, вырабатываемого нейтрофилами, активированными макрофагами, астроцитами и эндотелиальными клетками, во многом сходно с действием IL-1b. Благодаря широкой распространенности рецепторов к нему, TNF- $\alpha$ активирует различные пути сигнальной трансдукции: индуцирует или угнетает экспрессию генов факторов транскрипции и роста, цитокинов, их рецепторов, острофазных белков, что объясняет сложное иммуномодулирующее действие этого цитокина. Установлена митогенность TNF- $\alpha$ для определенных типов клеток [151-153]. У больных с ишемическим инсультом обнаружено более высокое содержание TNF- $\alpha$ в плазме крови, чем у здоровых людей. Нами установлено значительное повышение TNF- $\alpha$ в цитозоле сенсо-моторной коры у монгольских песчанок на 1-е и максимально - на 7-е сутки после необратимой окклюзии общей сонной артерии. Высокие значения TNF- $\alpha$ в цитозоле головного мозга монгольских песчанок с ОНМК сохранялись и на 21-е сутки эксперимента. Также имеются данные, что через 1 ч после реперфузии в ишемизированной коре мозга крысы при 60минутной окклюзии средней мозговой артерии отмечено значительное и достоверное увеличение содержания м-PHK, IL-1b и TNF- $\alpha$. Зарегистрирована дополнительная выработка TNF- $\alpha$ на кровеносных сосудах и астроцитах в области ишемического повреждения, сопровождающаяся активной воспалительной реакцией, при этом содержание TNF- $\alpha$ на микроглиальных клетках варьирует в зависимости от остроты воспаления. Показано, что TNF- $\alpha$ имеет отношение к повреждению миелина и олигодендроцитов. Эксперименты на моделях острой фокальной ишемии мозга продемонстрировали, что цитокины IL-1a и IL-1b, TNF- $\alpha$ являются ключевыми медиаторами микроглиальных нейроиммунных функций, вырабатываются локально в ответ на ишемизацию головного мозга и могут запускать молекулярные механизмы отсроченной гибели нейронов. При генетически опосредованном цитокиновом дисбалансе (повышение провоспалительных цитокинов IL1- $\beta$, TNF- $\alpha$, и снижение концентрации IL-10) увеличивается образование лимфоцитарно-тромбоцитарных агрегатов, повышается ристомицин-индуцированная агрегационная активность тромбоцитов, что при усиленной проницаемости сосудистой стенки и миграции иммунных клеток с высвобождением цитокинов в ткани мозга неблагоприятно влияет на дальнейшее течение цереброваскулярной патологии.

Вместе с тем остается неясным вопрос о взаимоотношении нейротоксичности и нейропротективных свойств TNF- $\alpha$. В экспериментах in vitro показано, что TNF- $\alpha$ в зависимости от концентрации может оказывать как токсическое действие на нейроны мозжечка, так и защищать культивированные нейроны. Продемонстрировано развитие большего по объему инфаркта мозга после окклюзии 
средней мозговой артерии у мышей с генетическим недостатком рецепторов к TNF- $\alpha$, а введение цитокина за 48 ч до окклюзии имело нейропротективный эффект. Увеличение выраженности и распространенности повреждения нейронов у TNF- $\alpha$-депримированных животных было обусловлено усилением процессов оксидантного стресса и подавлением экспрессии антиоксидантных ферментов. Это позволило предположить, что нейропротективные свойства TNF- $\alpha$ связаны с экспрессией антиоксидантных ферментов [4, 7, 43]. Таким образом, роль TNF- $\alpha$ при ишемическом инсульте представляется неоднозначной. Экспрессия TNF- $\alpha$ и увеличение его концентрации в макрофагах инфарктной ткани и в нейронах ишемизированной области мозга, с одной стороны, вызывает экспрессию проадгезивных молекул на эндотелии, что приводит к скоплению лейкоцитов, адгезии и миграции их из капилляров в мозг, а также экспрессии проапоптотических белков, активации индуцибельной NOS и миело-Cl-пероксидазы, усилению реакций нитрозирующего стресса. C другой стороны, TNF- $\alpha$ способствует ремоделированию ткани, регулирует глиоз и формирование рубца. По нашему мнению, TNF- $\alpha$ в зависимости от концентрации и этапа ишемического нейродеструктивного каскада может играть роль как нейропротектора, так и нейроинтоксиканта. Это приводит к выводу о необходимости фармакологической регуляции концентрации TNF- $\alpha$ в различные сроки церебральной ишемии для снижения его вклада в общий механизм нейродеструкции и повышения его участия процессе восстановления утраченных функций ЦНС $[4,42]$. Возможно, что потенциальные лекарственные препараты, модулирующие экспрессию TNF- $\alpha$, пополнят арсенал нейропротекторных средств $[4,6]$.

\section{7. НЕЙРОАПОПТОЗ}

Установлено, что в постгипоксическом периоде реализуются два механизма клеточной гибели, отличающиеся специфическими морфологическими характеристиками, - некроз и апоптоз. Однако, сегодня установлено, что список механизмов клеточной смерти не является полным [154, 229].

Последовательность патологических событий при некрозе всегда сходна: осмолиз, вызванный клеточным отеком, приводит к пассивной смерти поврежденной клетки. Одним из вторичных эффектов некроза является воспаление, вызываемое высвобождаемым клеточным содержимым и сопровождающееся выработкой цитокинов. Как правило, некроз развивается под действием экстремальной гипоксии, когда не успевают включаться адаптационные механизмы [152].

Апоптоз - запрограммированная клеточная гибель - является биологически наиболее сохранной формой смерти клетки, используется организмом для контроля числа, качества клеток и поддержания функционирования органов в процессе развития [107].

Соотношение этих типов гибели нейронов по объему поврежденных клеток зависит от степени и продолжительности гипоксии [143, 240]. В ряде случаев отмечено, что гибель нейронов иногда имеет черты и некроза, и апоптоза. Основ- 
ными элементами сходства между двумя вариантами смерти нервных клеток является оксидативный стресс, повышенное содержание свободных ионов кальция в цитоплазме, активация протеаз [86, 135]. Явления разрывов мембран нейронов, фрагментации их ДНК, характеризующие, соответственно, некроз и апоптоз, описывались иногда в одних и тех же пораженных клетках $[233,286]$.

В то же время, апоптоз и некроз имеют четкие различия. Прежде всего апоптоз - энергозависимый процесс, в отличие от некроза, нуждается в АТФ [29]. Также значимым отличием является временной аспект: апоптоз, в отличие от некроза, длится дольше. И главное - клеточная гибель путем апоптоза позволяет не повреждать соседние клетки и межклеточное пространство. Нейрон гибнет практически локально, с полной сохранностью околоклеточного пространства, и утилизирует свои органеллы до молекулярных составляющих - аминокислот, $\mathrm{CO}_{2}, \mathrm{H}_{2} \mathrm{O}$. В связи с этим попытка активно направить поврежденные клетки на путь апоптоза, а не некротической гибели, является предметом поиска многих исследователей, и механизмы индукции нейронального апоптоза в условиях острой церебральной ишемии интенсивно изучаются [233, 239, 244].

В развитии процесса апаптоза участвует множество сигнальных молекул, многие из которых регулируют и другие важные функции организма. К наиболее изученным факторам, способным запускать в нейроне программу апоптоза, относится оксид азота (NO) - одна из ключевых сигнальных молекул, регулирующих функции сердечно-сосудистой, нервной и иммунной систем организма [104, 264]. Концентрация NO начинает увеличиваться с первых минут ишемии, достигая максимума на 1-3 сут. В начальном периоде ишемии превалирует экспрессия конститутивной кальцийзависимой NO-синтазы (NOS), обусловленной трансмиттерным аутокоидозом. На этом этапе NO участвует в косвенных механизмах гибели нейрона - активации фосфолипаз, усилении образования гидроксил радикала, модуляции активности NMDA-рецепторов. Начиная с 7-14 суток при глобальной ишемии и с 1-3 суток при фокальной ишемии, т. е. в отсроченном постишемическом периоде, регистрируется гиперпродукция NO при участии индуцибельной NOS активированной глии, макрофагов и нейтрофилов [271].

Известно, что NO и его дериваты могут вызывать перекисное окисление фосфолипидов. Под действием цитотоксических дериватов NO и гидроксилрадикала происходит открытие митохондриальных пор, с экспрессией и выходом в цитозоль проапоптотических белков. Имеются данные о том, что NO прямо активирует открытие гигантской поры митохондрии, приводящей к выходу цитохрома C и запуску каспазного каскада. Открытие пор превращает митохондрии из «электростанций» в «топку» субстратов окисления без образования АТФ [65].

При этом важно подчеркнуть роль микроглии, которая в большом количестве синтезирует простаноиды, образующиеся из арахидоновой кислоты по циклооксигеназному пути, и NO, который синтезируется из аргинина при помощи индуцибельной NOS. Баланс между простаноидами и уровнем NO может определять направление микроглиальной реакции по нейропротекторному или по нейротоксическому пути [249, 266]. 
Соотношение NO и тиол-дисульфидной системы является фактором, определяющим дальнейшую судьбу нейрона в условиях ишемии, а именно тип его гибели. В условиях ишемических повреждений головного мозга в ранние сроки развивается нитрозирующий стресс, приводя к нитрозированию тиолов, изменяя тиол-дисульфидное равновесие белков митохондриальной поры. На этой стадии митохондриальная NOS играет защитную роль, регулируя клеточную гибель, переключая ее на более выгодный тип - апоптоз. Далее развиваются оксидативный и карбонильный стресс, которые существенно смещают тиол-дисульфидное равновесие в сторону окисленных тиолов, развивается стойкая митохондриальная дисфункция с дефицитом энергетических запасов клетки, развитием аутокоидоза, изменением ответа генома, и как следствие клетка погибает по типу некроза [7, 9, 35, 65, 157].

Нейроапоптоз развивается как каскадный процесс, который сопровождается активацией специфических про- или антиапоптотических белков, а также особенных протеолитических ферментов - каспаз. Существуют убедительные доказательства того, что центральная роль в продукции активных форм кислорода и последующем развитии апоптоза принадлежит митохондриям, изменению проницаемости их мембран в результате формирования специфического комплекса митохондриальных пор и инициации разрушения митохондрий - митоптоза [65, 279]. Таким образом, митоптоз при всех видах церебральной патологии является пусковым сигналом к запуску нейроапоптоза $[7,191,198]$.

Основная роль гибели нейронов зоны ишемической полутени принадлежит глутаматному каскаду и оксидативному стрессу. При этом одним из этапов является изменение характера экспрессии генов-индукторов апоптоза и геновингибиторов апоптоза, нарушение окислительно-восстановительных процессов за счет блокады митохондриального комплекса $[11,112,191]$. Важную роль в этом играют так называемые «ранние гены» семейства с-fos [88, 90, 194].

Так, в условиях гиперпродукции активных форм кислорода нейрохимическими и биоэнергетическими системами головного мозга, в условиях ишемии, а также при ряде других нейродеструктивных процессов происходит активация экспрессии чувствительных генов, многие из которых необходимы для защиты клеток от токсических әффектов окислительного стресса $[9,65,88,142]$. Экспериментальными работами последнего десятилетия показана значительная роль изменения характера экспрессии генов раннего реагирования c-fos в развитии апоптоза нейрональных клеток при нейродеструктивных заболеваниях. Белок c-fos непосредственно участвует в процессе фрагментации ДНК и инициировании процессов апоптотической гибели клетки [8, 65, 142, 252].

Одной из первичных реакций генома в ответ на различного генеза стресс является индукция белков теплового шока - Heat shock proteins (Hsp), которые называют согласно их молекулярным массам [241]. Существует класс белков (шаперо́ны), главная функция которых состоит в восстановлении правильной третичной структуры поврежденных белков, а также образовании и диссоциации белковых комплексов. Многие шапероны являются белками теплового 
шока, то есть белками, экспрессия которых начинается в ответ на рост температуры или другие клеточные стрессы [153].

В последнее время появились данные о роли Hsp в стабилизации индуцируемого гипоксией фактора (Hif-1a), который в условиях ишемии отвечает за обеспечение процессов пролиферации, апоптоза, ангиогенеза, стабилизации белковых молекул в условиях оксидативного стресса $[11,146,198]$. Также показано, что в условиях гипоксии Hsp70 вытесняется из комплекса с Hif-1a, что, в течение 20-30 мин гипоксии, предохраняет структуру фактора от прицельного протеолиза. Вероятно, Hsp70 способен увеличивать время жизни фактора HIF-1а в условиях до и после гипоксии и необходим клеткам для надлежащей реакции на лишение кислорода в условиях острого нарушения мозгового кровообращения [8, 97].

Активация микроглиальных продуктов в области пенумбры приводит к транзиторной активации генов, кодирующих факторы транскрипции (в том числе c-fos) в первые несколько минут от начала инсульта. Далее запускается вторая волна экспрессии генов белков теплового шока (Hsp70 и Hsp72), нарастающая в течение первых 1-2 часов заболевания и снижающаяся в 1-2-й день $[122,274]$.

В настоящее время известно, что митохондрии играют центральную роль в реализации всех трех типов программированной клеточной гибели (ПГК): апоптоза, аутофагии и некрозоподобной ПГК [7]. Митохондрии, испытывающие окислительный стресс, играют критическую роль в качестве триггера и медиатора ПГК. Установлено, что в межмембранном пространстве митохондрий локализованы белки, принимающие участие в реализации программированной гибели клетки, после высвобождения их в цитоплазму. Среди таких белков есть неактивные предшественники каспаз (прокаспаза-2, -3, -9) - ферментов, принимающи непосредственное участие в реализации танатогенной программы, ингибиторы белков, блокирующих апоптоз (Smac/DIABLO, Omni/HtrA2) и непосредственные индукторы программы клеточной гибели: цитохром C, активирующий каспазы, эндонуклеаза G и AIF, инициирующие клеточную гибель по независящему от каспаз механизму [11]. Механизмы выхода проапоптотических белков из митохондрий являются предметом активных дискуссий. Сегодня основным механизмом этого процесса признается формирование митохондриальных апоптотических пор и пор повышенной проницаемости (PTP-permeability transition pores) [7]. При нормальных обстоятельствах внутренняя мембрана митохондрии является почти непроницаемой, тогда как во внешней имеются каналы (в основном это VDAC), способные пропускать молекулы до 1000 Да. Открывание гигантской поры делает митохондриальные мембраны проницаемыми для растворенных веществ с молекулярной массой 1500 Да и более. Такое изменение проницаемости приводит к немедленной диссипации Dу. Затем нарушается метаболизм митохондрий, прекращается синтез митохондриальных белков и импорт белков, синтезированных в цитозоле. Идет разобщение окислительного фосфорилирования и прекращение синтеза АТФ, начинается гиперпродукция $\mathrm{O}^{2-}$ и исчерпание восстановительных эквивалентов. Всех этих изменений достаточно, чтобы вызвать ПГК. 
Существует несколько теорий участия гигантской поры в апоптотических сигнальных путях. Итог открытия поры - это всегда выход из митохондрии различных апоптогенных факторов, но предполагаемые механизмы этого процесса различны. Kroemer G. и др. считают, что сама пора, проходя через обе митохондриальные мембраны в месте их сближения, образует канал, позволяющий выходить из межмембранного пространства в цитоплазму белкам, находящимся в митохондрии в обычных условиях. Другие исследователи (Gottlieb R. A., 2000, Kowaltowski A. J. et al., 2001, Skulachev V.P., 2000) предполагают механизм, при котором пора открывается только во внутренней мембране, что вызывает нарушение распределения ионов между матриксом и цитоплазмой, происходит набухание митохондрии, приводящее к разрыву внешней мембраны и высвобождению апоптогенных факторов.

Важным участником апоптотических процессов является белок р53. В условиях нормального клеточного цикла и при невысоком уровне повреждений ДНК относительно низкие концентрации р53 постоянно стимулируют внутриклеточные системы защиты - рибонуклеотидредуктазу (ключевой фермент репарации ДНК), Mn-супероксиддисмутазу. Подобный оптимальный «тонус» функционирования защитных систем создает условия для длительного стационарного режима жизнедеятельности клетки. В условиях ишемии, при усилении процессов СРО, когда уровень повреждений ДНК начинает существенно повышаться, автоматически активируя поли(АДФ-рибозо)полимеразу-1 и ДНК-зависимые протеинкиназы, концентрация белка р53 будет неуклонно расти. При этом будут снижаться активность рибонуклеотидредуктазы, а также антиокислительных ферментов - Mn-COД и GPX, что увеличит поток свободных радикалов, активируя все митохондриальные пути апоптоза.

На сегодняшний день предполагается, что помимо участия митохондрий в процессах апоптоза, они играют ключевую роль в выборе клеткой пути реализации типа морфологической гибели. Данные различных исследователей свидетельствуют, что активизация механизмов той или иной формы ПГК может определяться количеством открытых пор в митохондриях. В том случае, если поры формируются в нескольких митохондриях, в клетке активируется процесс аутофагии. Когда поры открываются у большего числа митохондрий, в клетке инициируется апоптоз, что, вероятно, является следствием увеличения в цитоплазме количества цитохрома C и AIF. Наконец, когда в клетке практически во всех митохондриях открываются РТ-поры, происходит разобщение окисления, фосфорилирования и интенсивный гидролиз АТФ митохондриальной АТФ-азой, активизируются механизмы некрозоподобной клеточной гибели [7]. Существует мнение, что минимальное количество открытых пор принципиально не влияет на процесс клеточной гибели, при большем количестве открытых пор возможна инициация апоптоза, при генерализованном открытии митохондриальных пор реализуется процесс некроза [13]. Большое значение в «выборе» между реализацией апоптоза и некрозоподобной ПГК имеет уровень продукции АТФ в митохондриях. Известно, что при низком уровне АТФ в клетке протекает процесс программированной гибели по механизму некроза, достаточное энергообеспечение клетки способ- 
ствует прохождению ПГК по механизму апоптоза [12]. Предполагается, что выбор пути клеточной гибели по механизму апоптоза или некроза зависит от концентрации ионов кальция в цитозоле. При этом незначительное возрастание уровня ионов кальция в цитозоле приводит к развитию апоптоза, в то время как существенное возрастание их концентрации индуцирует некроз. Механизмом этого процесса является возможная зависимость количества формируемых митохондриальных пор от концентрации ионов $\mathrm{Ca} 2+$ в цитозоле, а также активация Са2+-зависимых протеаз, фосфолипаз и нуклеаз, приводящих к разрушению внутриклеточных структур и реализации ПГК по механизму некроза. Дополнительным механизмом может быть активация Са2+зависимой АТФ-азы митохондрий, способствующей истощению запасов АТФ в клетке [15]. В настоящее время показано, что одной из основных причин развития различных нарушений в тканях после ишемии и реперфузии является опосредованная митохондриальной дисфункцией активизация процессов гибели клеток. В научной литературе описываются процессы гибели клеток в условиях ишемии и реперфузии по механизму апоптоза и некроза, и вопрос о значении апоптоза при нейродеструктивных заболеваниях остается спорным. Однако в настоящее время все больше фактов, свидетельствует в пользу апоптотической гибели клетки. В отличие от апоптоза, некроз является более грубым клеточным повреждением, сопровождающимся вакуолизацией, резким «набуханием» клетки, лизисом мембран, выходом клеточного содержимого в межклеточное пространство, усилением синтеза провоспалительных интерлейкинов, цитокинов, развитием воспаления. В противоположность этому, апоптотическая гибель нейронов является оптимальным, упорядоченным процессом прекращения жизнедеятельности деструктивно измененных нейронов, при котором происходит стабилизация клеточных мембран, содержимое клетки утилизируется путем образования апоптотических телец и их фагоцитоза без развития воспалительной реакции.

Помимо вышеперечисленных факторов, влияющих на тип морфологической гибели клетки, немаловажная роль отводится так называемым генам раннего реагирования - «третичным месенджерам» (c-fos, c-jun, krox-20, zif/268). Известно, что белки c-fos, c-jun, krox-генных семейств играют решающую роль в контроле над клеточным циклом, развитием, ростом и клеточной дифференцировкой, а также определяют судьбу дифференцированных нейронов. Экспрессия генов приводит к синтезу ДНК-связанных протеинов, транскрипционных факторов, которые в свою очередь, вызывают экспрессию других генов, в частности - HIF-1, HSP70. Таким образом, гены раннего реагирования участвуют в передаче информации от клетки к клетке. Важно отметить, что все они, особенно c-fos, являются медиаторами типа нейрональной гибели (некроз/апоптоз). В условиях ишемии головного мозга, при срыве адаптационных возможностей организма, резкого увеличения маркерных продуктов окислительной деструкции макромолекул, смещения тиол-дисульфидного равновесия в сторону окисленных тиолов, происходит инактивация факторов транскрипции с последующим подавлением экспрессии генов c-fos и переключение путей гибели клеток с апоптоза на некроз [13, 39]. 
Поскольку нейроапоптоз является очень сложно регулируемым процесcoм, то и количество сигнальных путей, эффекторных механизмов и мессенджеров, участвующих в этом явлении, огромно. Одним из таких веществ является оксид азота.

Одно из проявлений нейротоксического действия NO - это инициация апоптоза. При индукции апоптоза окисью азота митохондрии выполняют функцию сенсора указанной сигнальной молекулы. Эти органеллы содержат большое количество гемсодержащих и железо-серных белков, с которыми, как упоминалось, $\mathrm{NO}$ (или $\mathrm{ONOO}^{-}$) активно соединяется даже при относительно низких наномолярных концентрациях. Активность митохондриальных белков суммируется в форме трансмембранного электроосмотического потенциала, и их ингибирование окисью азота вызывает деполяризацию внутренней митохондриальной мембраны [Беленичев И. Ф., Черний В. И., 2009].

Снижение трансмембранного потенциала до критического уровня вызывает открытие митохондриальных пор и полную деэнергизацию митохондрий, что способствует выходу в цитоплазму специфической протеазы AIF. Этот фермент расщепляет и активирует предшественник протеазы ICE, которая, в свою очередь, активирует ADP-рибозилтрансферазу и латентную ДНК-азу и инициирует дальнейшие превращения апоптоза.

Ингибирующий апоптоз белок Вc1-2 способен подавлять апоптоз, вызванный действием NO [Беленичев И.Ф., Черний В.И., 2009].

Окись азота, по-видимому, способна инициировать несколько независимых друг от друга программ гибели клеток. Показано, например, что NO вызывает накопление в клетках фактора р53, который исполняет ключевую роль в активации апоптоза, индуцируемого избытком глутамата или кальция в нейронах.

Результаты исследований позволили сделать предположение, что активация индуцибельной NO-синтазы может выполнять не только положительную роль, но и служить причиной гибели посредством апоптоза нейронов коры и гиппокампа, эндотелиоцитов сосудов мышечного типа и эндотелиоцитов капилляров. На культуре грушевидных нейронов мозжечка показано, что этот эффект NO сопровождается стимулированием экспрессии гена р53. Эксперименты с нейронами СА1-зоны гиппокампа выявили участие активации поли(АДР-рибоза)-синтетазы в индуцированном NO апоптозе [Беленичев И.Ф., Черний В.И., 2009].

По нашему мнению, одной из основных мишеней NO при развитии апоптоза являются митохондрии [Беленичев И.Ф., Павлов С.В., 2008]. В то же время имеются и противоположные данные, свидетельствующие о том, что введение инигибиторов NO-синтазы (L-NMMA) животным с ишемией головного мозга, напротив, усиливало нейроапоптоз. Показано, что дегенерация нейронов, протекающая по апоптозному механизму, предотвращается селективным блокатором IL-1b через повышение синтеза NO [Беленичев И.Ф., Супрун Э.В., 2012]. Многочисленными экспериментами установлено, что под действием $\mathrm{ONOO}^{-}(1-100$ мМ) около 37,8 \% клеток мозжечка гибнут посредством апоптоза in vitro. СОД, глутатионпероксидаза и $\mathrm{N}$-ацетилцистеин ингибировали фрагментацию ДНК и 
апоптоз нейронов, индуцированные пероксинитритом in vitro [Беленичев И. Ф., Павлов С. В., 2009]. Запрограммированная гибель нейронов, в которых репрессирована $\mathrm{Cu}, \mathrm{Zn}-\mathrm{COД}$ также связывается с образованием больших количеств эндогенного $\mathrm{ONOO}^{-}$[Беленичев И. Ф., Павлов С. В., 2009]. Микроконцентрации донаторов $\mathrm{NO}$ ингибируют вызванный депривацией ростовых факторов или добавлением TNF- $\alpha$ нейроапоптоз, возможно, через стимуляцию белка теплового шока HSP70 или ингибирование каспазы-3 [Belenichev I., Pavlov S., 2013]. Предполагается, что DNIC (5-10 мкM) подавляет нейроапоптоз, индуцированный IL-1b, усиливая образование NO, напротив, повышение концентрации DNIC $(0,5 \mathrm{MM})$ индуцирует нейроаппотоз за счет образования $\mathrm{ONOO}^{-}$[Беленичев И.Ф., Павлов С.В., 2009].

Условия, приводящие к повышению биодоступности NO и снижению образования $\mathrm{ONOO}^{-}$(активность СОД, восстановленные тиольные антиоксиданты), делают нейроны устойчивыми к Fas-индуцированному апоптозу, и наоборот - снижение биодоступности NO и повышение его цитотоксических форм увеличивает чувствительность клеток к сигналам, передаваемым через Fas-рецепторы. $\mathrm{H}_{2} \mathrm{O}_{2}$ совместно с ионами $\mathrm{Fe}^{2+}$ вызывала нейроапоптоз за счет превращения NO в пероксинитрит, одновременно наблюдалась депрессия bcl-2 и индукция c-fos. В эндотелиоцитах $\mathrm{H}_{2} \mathrm{O}_{2}(125-1000$ мкM) стимулирует активность NO-синтазы, которая включается в окислительное повреждение клеток [Беленичев И.Ф., Черний В.И., 2011].

Ферментативные антиоксиданты (каталаза, глутатионпероксидаза), а также $\alpha$-токоферол ингибируют апоптоз, однако аскорбиновая и галловая кислоты усиливают $\mathrm{H}_{2} \mathrm{O}_{2}$-индуцированный нейроапоптоз. Многие антиоксиданты, в том числе $\alpha$-токоферол, обладают также выраженным антипролиферативным действием.

В присутствии ионов металлов переменной валентности аскорбиновая кислотапроявляетпрооксидантныесвойстваиусиливает $\mathrm{H}_{2} \mathrm{O}_{2}$-индуцированный нейроапоптоз.

Следует упомянуть также о том, что производство NO вызывает значительные отрицательные эффекты и в продуцирующих его макрофагах. Показано, что фагоцитоз и выработка активных форм кислорода сильно подавляются у крысиных или перитонеальных макрофагов, культивируемых в условиях, позволяющих производить NO. Макрофаги, экспрессирующие iNOS или обработанные оксидом азота, имеют конденсированное ядро и цитоплазму. Таким образом, выделение NO активированными макрофагами ведет к их функциональной супрессии, и в конце концов - к апоптозу. Эти явления явно связаны c NO, поскольку предупреждаются добавлением ингибиторов NOS.

Другая проблема, возникающая при исследовании механизмов цитотоксичности азота, связана с используемыми для его генерации NO-донорами, описанными выше. Дело в том, что S-нитрозотиолы (в основном, GSNO и SNAP), используемые во многих исследованиях, способны участвовать в реакциях транснитрозилирования, то есть передавать $\mathrm{NO}^{+}$-группу тиолам (глутатиону и $\mathrm{SH}-г$ руппам белков) и таким образом нарушать их функционирование в клетке. При этом непонятно, относить ли такие реакции к эффектам собственно NO [133]. 
Показано, что в первую очередь NO (макрофагальный или экзогенный) ингибирует окислительное фосфорилирование в митохондриях нейроцитов. Это происходит, так как NO обратимо связывается с цитохромоксидазой ЭТЦ митохондрии. С другой стороны, подавление электронного транспорта в митохондрии приводит к генерации супероксида и образованию пероксинитрита. $\mathrm{ONOO}^{-}$, который подавляет ферменты дыхательной цепи уже необратимо, нитрозилируя их и отнимая железо. Подавление митохондриального дыхания приводит к падению Dу, что может привести к развитию митохондриальной дисфункции и инициировать апоптотический процесс [134].

Имеются данные и о прямой активации открытия гигантской поры оксидом азота, приводящей к выходу цитохрома $\mathrm{C}$ и запуску каспазного каскада, о чем было описано выше.

NO и его производные могут вызывать перекисное окисление фосфолипидов и окисление тиольных групп белков митохондриальной мембраны, что также приводит к высвобождению в цитозоль апоптогенных факторов.

Подводя итог, можно сделать вывод, что взаимозависимость нарушений рассмотренных выше процессов в митохондриях определяет возможность их взаимной индукции и стимуляции по принципу «порочного круга» . Следствием этого является развитие комплекса дегенеративных изменений в митохондриях: ослабление антиоксидантной защиты, изменения липидного и белкового состава митохондриальных мембран, подавление работы дыхательной цепи и продукция ее компонентами АФК, мобилизация цитохрома С в межмембранном пространстве, накопление повреждений в митохондриальном геноме и истощение пула митохондриальной ДНК. Повреждение митохондриальных генов вызывает нарушение процесса переноса электронов в дыхательной цепи, что активирует продукцию свободных радикалов в митохондрии [14]. Установлено, что подавление синтеза белка в митохондриях ассоциировано с увеличением восприимчивости нейрональных клеток к апоптотическим стимулам, опосредуемым NO [11]. Таким образом, при недостаточной активности антиоксидантных систем между продукцией свободных радикалов дыхательной цепью митохондрий и мутационным процессом в митохондриальной ДНК возможно формирование порочного круга, следствием которого является прогрессирование митохондриальной дисфункции. Нарушение любой из функций митохондрий - энергетической, танатогенной - или активизация продукции ими свободных радикалов может послужить причиной развития функциональных и морфологических нарушений в клетках головного мозга. 


\section{ГЛАВА 2}

\section{МОЛЕКУЛЯРНО-БИОХИМИЧЕСКИЕ МЕХАНИЗМЫ ЭНДОГЕННОЙ НЕЙРОПРОТЕКЦИИ И НЕЙРОПЛАСТИЧНОСТИ}

\section{1. РОЛЬ ГЕНОВ РАННЕГО РЕАГИРОВАНИЯ С-FОS В ПРОЦЕССАХ ВЫЖИВАНИЯ/ГИБЕЛИ НЕЙРОНОВ}

Экспериментальными работами последнего десятилетия показана значительная роль гиперэкспрессии генов раннего реагирования c-fos в развитии апоптоза нейрональных клеток при нейродеструктивных заболеваниях. Так, в условиях гиперпродукции АФК нейрохимическими и биоэнергетическими системами головного мозга, в условиях ишемии головного мозга, а также при ряде других нейродеструктивных патологий, происходит активация экспрессии редокс-чувствительных генов, многие из которых необходимы для защиты клеток от токсических эффектов окислительного стресса $[4,21,28]$. Так, при нормальной концентрации кислорода в окружающей клетку среде (нормоксия) под действием АФК происходит, в основном, активация JunB, ATF-2-факторов транскрипции, а в условиях окислительного стресса - преимущественно факторов c-Jun и c-fos. Активация именно этих факторов транскрипции в условиях гиперпродукции АФК объясняется тем, что JunB и c-fos содержат в своих ДНК-связывающих доменах высокочувствительные к АФК остатки цистеина - Cys252, Cys154, Cys61. Окисление их SH-групп приводит к обратной инактивации AP-1 и NF-kB. Помимо этого, белок c-fos непосредственно участвует в процессе фрагментации ДНК и инициировании процессов апоптотической гибели клетки $[3,12,13,25]$ (рис. 2.1).

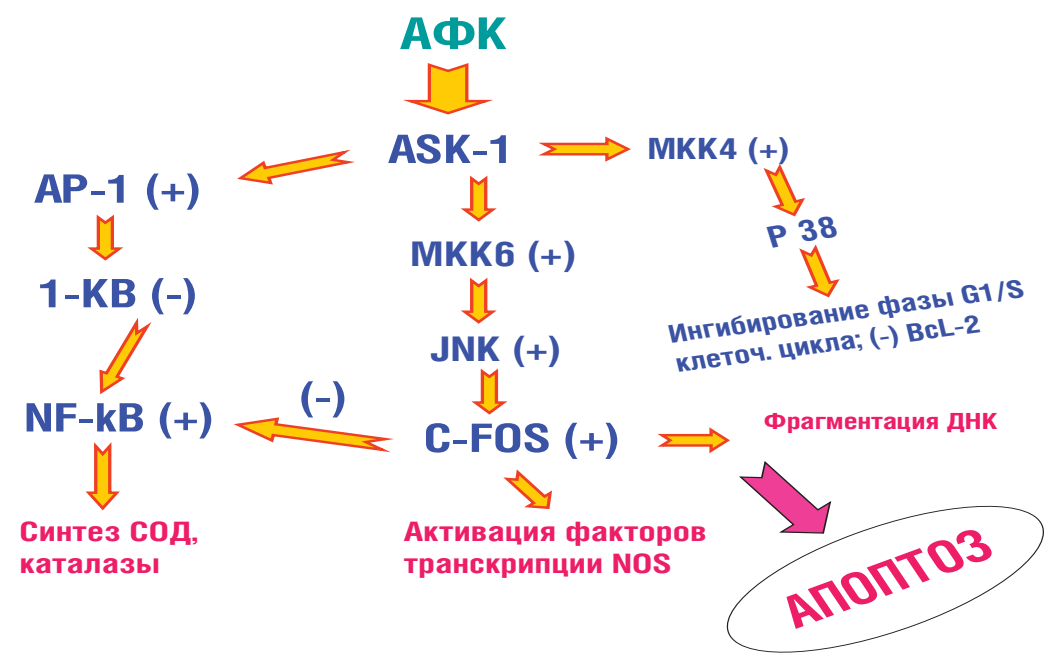

Рис. 2.1. Влияние АФК на экспрессию ранних генов 
Кроме того, рядом работ показано, что существенная роль в гиперпродукции NO при нейродеструктивных заболеваниях принадлежит индуцибельной NO-синтазе, которая экспрессируется под действием генов немедленного реагирования - c-fos, JunB и фактора транскрипции AP-1 [3, 14, 18, 19, 29].

C-fos был одним из первых генов, для продукта которого было показано участие в регуляции транскрипции. Этот ядерный ген представляет собой одну из основных ядерных мишеней для передачи сигналов регуляции клеточного роста и трансформации, вовлечен во множество клеточных функций, в том числе - в процессы клеточной пролиферации и дифференцировки [30-32].

Ген раннего реагирования c-fos быстро, и вместе с тем временно, активируется в ответ на воздействия самого широкого спектра. Он находится под контролем множественных сигналпередающих систем. Так, при действии разнообразных факторов, приводящих к активации клеточной пролиферации или дифференцировки, максимум экспрессии гена c-fos наблюдается обычно через 30-45 мин после воздействия. Промотор гена c-fos обладает сложной организацией, обусловливая необходимые функциональные свойства этого гена, связанные с клеточной дифференцировкой и пролиферацией, а также с целым рядом стрессовых реакций. При взаимодействии внешних факторов с клеточной поверхностью специфично активируются внутриклеточные процессы, приводящие к взаимодействию определенных транскрипционных факторов с промотоpoм гена c-fos. В зависимости от характера воздействия может активироваться большой набор путей передачи сигнала, центральную роль в которых играют как мембранные компоненты (рецепторы, G-белки и Ras-белки, адаптерные белки, тирозин-специфичные протеинкиназы), так и цитоплазматические протеинкиназы (РКС, РКА, компоненты МАР-киназного каскада). Несмотря на линейный характер многих путей передачи сигнала, многие их компоненты взаимодействуют с сопутствующими факторами, что усложняет сигналпередающую сеть и в то же время обогащает возможности тонкой регуляции гена c-fos [109-111].

Анализ промоторной области гена c-fos показал ее сложную организацию. В этом регионе находятся многочисленные взаимозависимые регуляторные элементы, ответственные за индукцию c-fos и базальный уровень его экспрессии (рис. 2.2) [112].

В состав промотора c-fos входят несколько сайтов, связывающих неидентифицированные факторы. Эти сайты названы FBS 1-6 (fos promotor binding site 1-6), и первый из них (FBS-1) расположен в позиции $-499 /-508$ п. н. от точки начала транскрипции. С элементом FBS-2 взаимодействует неизвестный белок с молекулярной массой 59 кДа, и это взаимодействие коррелирует с митотической активностью клеток [113-115].

Помимо элементов, определяющих (в большинстве случаев) индукцию гена c-fos, некоторые промоторные элементы служат для связывания факторов, подавляющих транскрипцию. Один из таких элементов - RCE (retinoblastoma control element), связывающий продукт гена восприимчивости к ретинобластоме, - белок Rb. Кроме того, элементы SRE и CRE в определенных физиологических условиях также определяют угнетение транскрипции гена c-fos. 


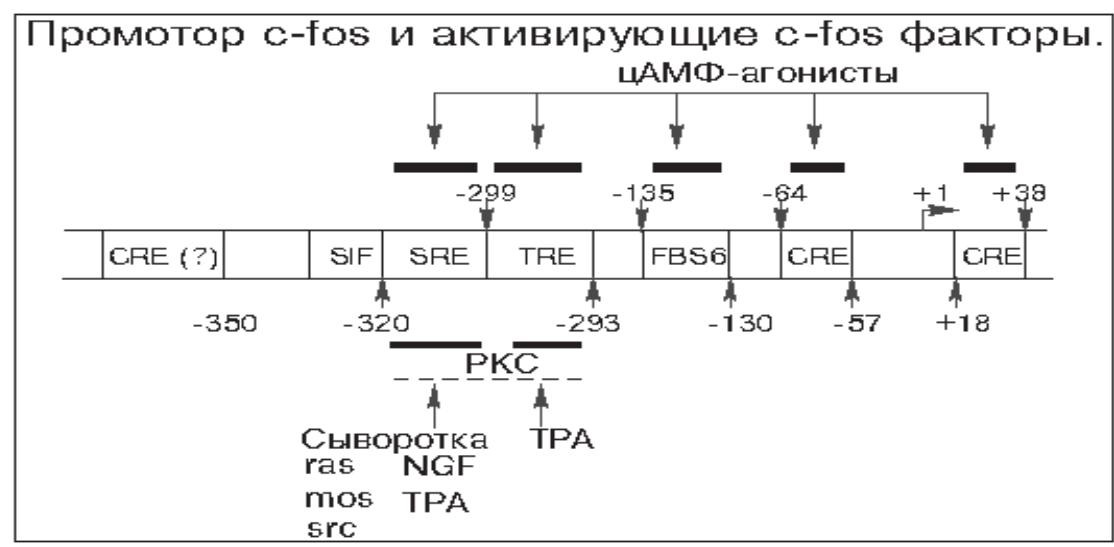

Рис. 2.2. Ген c-fos: промоторная область, схема

Таким образом, в связи с большим количеством путей, активирующих ген c-fos, его промоторная область обладает сложной организацией. При этом некоторые промоторные элементы гена с-fos находятся под контролем как РКСзависимых путей, так и сАМР-зависимых путей. Поэтому на уровне промотора гена c-fos и осуществляется взаимодействие этих сигнальных путей [116-117].

Помимо участия в процессах апоптотической гибели нейронов, гену c-fos принадлежит важная роль и в физиологических функциях организма. Так, Анохин К. В. и соавт. установили, что данный ген идеально подходит на роль универсального зонда для картирования мозга. Ген c-fos обладает рядом уникальных свойств. Во-первых, в спокойном состоянии клетки он «молчит», у него практически нет «фонового» уровня активности. Во-вторых, если в клетке начинаются какие-либо новые информационные процессы, он очень быстро откликается на них, нарабатывая РНК и белки. В-третьих, он универсален, то есть активируется в самых разных отделах центральной нервной системы - от спинного мозга до коры. В-четвертых, его активация связана с обучением, то есть с формированием индивидуального опыта. Многочисленные экспериментальные исследования показали, что ген c-fos не реагирует на очень сильную стимуляцию, например световую, звуковую или болевую в тех случаях, когда воздействие не несет в себе элементов новизны. Но как только ситуация обогащается новой информацией, ген «просыпается» $[107,118]$. На системном уровне активность генов в мозге при обучении переходит под когнитивный контроль. Так, в эксперименте мышей помещали в камеру, где им пришлось перенести серию слабых электрокожных раздражений. В ответ на это в нескольких областях мозга - в коре, гиппокампе и мозжечке бурно экспрессировался c-fos. Однако, если эту процедуру проводить ежедневно, то на шестой день ген уже не отвечает, мыши по-прежнему реагируют на удар током, но он для них становится уже не новым, а ожидаемым событием. Можно вновь вызвать активацию c-fos, если в очередной раз поместить мышей в камеру - и не подвергать их уже привычной процедуре. И в том и в другом случае ген отмечает событие, 
когда внешние стимулы не согласуются с матрицей индивидуальной памяти. Такое рассогласование происходит при любом усвоении новой информации, и поэтому ген c-fos - неизбежный спутник познавательных процессов в мозге [119]. Исследования Erdtmanna-Vourliotis M. и соавт. показали усиление экспрессии гена c-fos при наркотизации крыс. Так, при повторном введении морфина увеличивалась экспрессия c-fos в стриатуме, прилежащем ядре, зрительном бугорке, в цингулярной, пириформной, фронтальной коре и других структурах головного мозга крыс Вистар. Кроме того, исследователи отметили резкое усиление экспрессии гена c-fos на протяжении нескольких дней после прекращения наркотизации [120, 121].

Подобная динамика изменения экспрессии гена была отмечена нами в экспериментах при моделировании алкоголизма у крыс. Исследования экспрессии c-fos на третьи сутки введения 40 \% этанола животным показали статистически достоверное по отношению к интактным животным усиление экспрессии гена в CA1-зоне гиппокампа (зона, отвечающая за такие интегративные функции головного мозга, как обучение, мышление, память) (рис. 2.3).

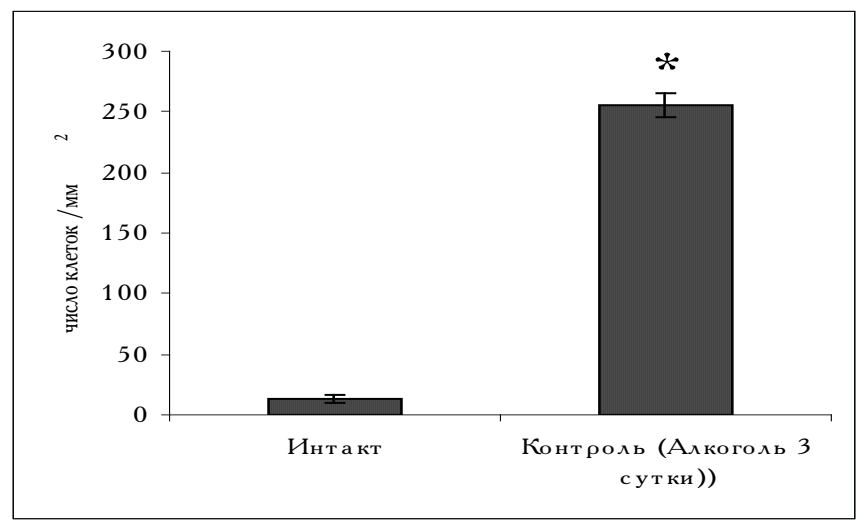

Примечание: * $p \leq 0,05$ по отношению к интакту.

Рис. 2.3. Экспрессия гена c-fos у животных на 3 день алкоголизации

Обучение интактных животных и животных, подвергшихся насильственной 30-суточной алкоголизации, в двухкамерной челночной системе для выработки у них условной реакции пассивного избегания (УРПИ), показало снижение экспрессии гена на фоне угнетения УРПИ и существенное повышение числа c-fos-позитивных нейронов в CA1-зоне гиппокампа в интактной группе животных, подвергшихся обучению (рис. 2.4). Важно отметить, что у животных с 1-месячной насильственной алкоголизацией в тесте УРПИ показано наличие стойкого когнитивного дефицита, что выражалось в снижении латентного времени захода животных в темный отсек. Можно предположить, что в механизме развития когнитивного дефицита у алкоголизированных крыс существенная роль принадлежит подавлению экспрессии гена раннего реагирования c-fos, 
что связано с его транскрипционной ролью в синтезе регуляторных белков, участвующих в механизме консолидации памяти $[109,122]$. Данное предположение подтверждается и опытами других исследователей, в которых показано, что подавление трансляции мPHК c-fos в структурах мозга нарушает кратковременную память на различных моделях обучения у разных видов животных $[119,123]$ (рис. 2.5).

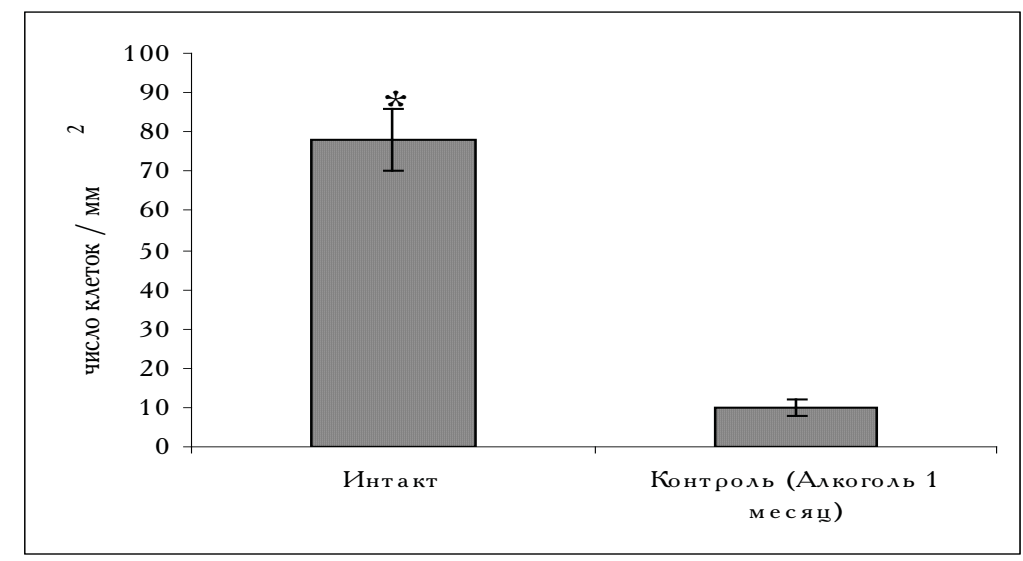

Примечание * $-\mathrm{p} \leq 0,05$ по отношению к контролю

Рис. 2.4. Экспрессия гена c-fos у крыс с 1-месячной алкоголизации после обучения в тесте УРПИ

Таким образом, вышепредставленные экспериментальные исследования позволяют сделать предположение, что ген c-fos является тем самым «мостиком», через который индивидуальный опыт животного вступает во взаимодействие со всем генетическим аппаратом [109].

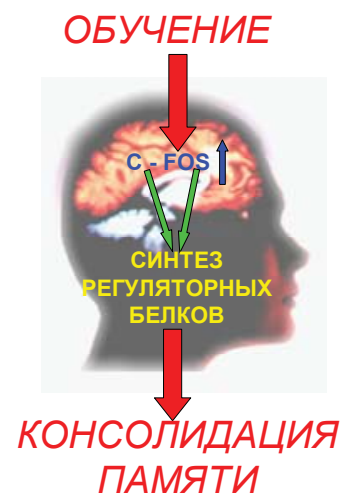

Puc. 2.5. Влияние экспрессии гена c-fos на механизмы памяти
Однако не всегда усиление экспрессии гена c-fos выполняет физиологическую функцию. В случае, когда экспрессия гена усиливается более чем в 20 раз, c-fos уже играет отрицательную роль. Гиперэкспрессия гена c-fos, как было отмечено выше, приводит к значительному повышению содержания в клетке белка c-fos, который непосредственно участвует в процессе фрагментации ДНК и инициировании процессов апоптической гибели клетки [124].

Наглядным примером отрицательной роли гиперэкспрессии c-fos может служить исследованная нами экспрессия гена c-fos 
при моделировании хронического иммобилизационного стресса. Проведенные исследования показали, что число c-fos-положительных нейронов в CA1-зоне гиппокампа у крыс с хроническим стрессом превышало более чем в 50 раз количество c-fos-положительных нейронов интактной группы. Параллельно с гиперэкспрессией гена c-fos в данной зоне гиппокампа нами было отмечено увеличение числа апоптотически и деструктивно измененных нейронов более чем на 60 \% по отношению к интакту. По нашему мнению, гиперэкспрессия c-fos в условиях хронического стресса обусловлена геперпродукцией АФК в тканях головного мозга. Известно, что в условиях окислительного стресса одной из первых реакций генома является индукция гиперэкспрессии генов немедленного реагирования - c-fos, за счет содержания в своих ДНК-связывающих доменах высокочувствительных к АФК остатков цистеина - Cys252, Cys154, Cys61 [109].

Нашими экспериментальными работами также была изучена экспрессия гена c-fos в условиях моделирования ишемии головного мозга. Как показали исследования, экспрессия гена при данной модельной патологии носила разнонаправленный характер.

Так, в условиях острой ишемии головного мозга (необратимая билатеральная окклюзия общих сонных артерий), показано увеличение содержания белка c-fos в первые 1-2 часа после начала ишемии и в течение 24 часов (увеличение c-fosположительных клеток в 4-5 слое сенсомоторной зоны коры в 10-15 раз) и максимальное снижение белка c-fos $\mathrm{\kappa}$ 4-м суткам (снижение c-fos-положительных клеток в 3,6 раза). Начиная с 7-х суток экспериментальной ишемии, наблюдается постепенное восстановление количества c-fos в нейронах 4-5 слоя сенсомоторной зоны коры с максимальным проявлением активности на 21-е сутки. Однако и на 21-е сутки ишемии содержание с-fos остается низким и не достигает уровня в первые часы после окклюзии. Изменение содержания c-fos в нейронах в разные сроки ишемии, с нашей точки зрения, тесно связано с преобладанием типа гибели клеток. Так, увеличение содержания c-fos происходило на фоне преобладания гибели клеток по типу апоптоза, а снижение - на фоне гибели по типу некроза. В восстановительный период происходит адаптация клетки и переключение гибели с пути некроза на апоптоз и снижение последнего [109, 125, 126$]$.

Исходя из вышеизложенного, можно сделать вывод, что активация гена c-fos происходит при любых воздействиях на клетку. Характер экспрессии гена будет определять дальнейшую судьбу клетки: либо в ней будут активироваться трансляционные, транскрипционные процессы, синтез пластических материалов, либо она апоптотически погибнет (гиперэкспрессия). Таким образом, учитывая чрезвычайно важную роль экспрессии гена c-fos в физиологических и патологических процессах, актуальной задачей экспериментальной медицины является поиск путей фармакологической коррекции различных патологических состояний, который будет направлен на коррекцию гипер- либо недостаточной экспрессии гена c-fos. 


\section{2. УЧАСТИЕ БЕЛКОВ ТЕПЛОВОГО ШОКА $\left(\mathrm{HSP}_{70}\right)$ В МЕХАНИЗМАХ ЭНДОГЕННОЙ НЕЙРОПРОТЕКЦИИ}

Известно, что церебральная ишемия вызывает гибель клеток головного мозга и сопровождается активацией наборов генов, которые обеспечивают адаптацию клеток и тканей к низкому содержанию кислорода [1].

В последнее время рядом экспериментальных работ установлена активация в условиях ишемии генов, кодирующих синтез белка HIF-1 (hypoxiainducible factor) особенно, его субъединицы HIF-1b (120 кДа), который в условиях ишемии отвечает за экспрессию гена эритропоэтина и еще приблизительно 60 генов, продукты которых участвуют в таких процессах как пролиферация, апоптоз, ангиогенез, стабилизация белковых молекул в условиях оксидативного стресса [2, 3]. Кроме того, в последнее время появились данные о роли белков теплового шока (HSP) в стабилизации HIF-1b при церебральной ишемии, сопровождающейся интенсификацией процессов свободнорадикального окисления, смещением тиол-дисульфидного равновесия, развитием нитрозирующего стресса, глутаматной эксайтотоксичности [3, 4$]$.

HSP индуцируются в клетках всех живых организмов в ответ на действие многочисленных стрессовых факторов, таких как тепловой шок, гипоксия, ишемия, метаболические нарушения, вирусная инфекция и воздействия фармакологических агентов. Гены этих белков активируются не только в условиях стресса, но и в ходе основных процессов клеточной жизнедеятельности, пролиферации, дифференцировки и апоптоза [5]. HSP принимают участие во всех процессах жизнедеятельности тканей и органов.

Среди многочисленных белков-шаперонов HSP выделяют полигенное семейство белков с молекулярной массой 70 кДа (HSP 70) [5]. Наиболее важным свойством белков семейства HSP 70 является их шаперонная активность или способность связывать поврежденные, денатурированные белки и вновь синтезированные полипептиды. Результатом такого связывания может стать исправление формы данного белка, транспорт его из цитоплазмы в другие клеточные органеллы или представление полипептида белок-модифицирующим или деградирующим системам, например, лизосомам. Шаперонная активность HSP 70 модулируется белками-помощниками или ко-шаперонами, связанными с молекулой HSP 70, нуклеотидами, содержанием одно- и дивалентных ионов, а также концентрацией белков-мишеней. В каждой клеточной органелле высших животных имеется свой шаперонный механизм, действие которого основано на определенном члене семейства HSP 70. Одним из наиболее примечательных свойств HSP 70 является защитная функция, которую белок демонстрирует в ходе реакции клетки или организма на действие различных неблагоприятных факторов среды. Получено много доказательств протективного эффекта HSP 70, по этой проблеме написаны сотни работ и несколько десятков монографий. Наиболее убедительные аргументы в пользу защитной функции HSP 70 получены в экспериментах по введению в клетки самого белка или его гена, после чего оценивалась устойчивость клеток к повреждающим факторам. Выяснилось, что протективный эффект HSP 70 зависит от дозы белка, полу- 
ченной данной клеткой, и проявляется по отношению к множеству факторов, в частности тех, которые вызывают программированную клеточную смерть, апоптоз. В настоящее время интерес к цитозащитным свойствам белковшаперонов выходит за рамки сугубо биологических исследований. Результаты экспериментов последних 10-15 лет, выполненных, в основном, на клеточных культурах и экспериментальных животных, дали возможность представить несколько направлений практического использования защитных свойств HSP 70 [1]. Во-первых, устойчивость клетки и организма в целом можно повысить путем увеличения внутриклеточного содержания HSP 70. Последнее может быть достигнуто в результате прекондиционирующих процедур (дозированное нагревание, гипоксия), под действием лекарственных препаратов, после трансфекции клеток геном HSP 70. Во-вторых, в последнее время привлекает внимание вопрос о защитных свойствах внеклеточного HSP 70. Уже в конце 1980-х гг. было обнаружено, что HSP 70 может покидать клетки глии моллюсков [29], эмбриональные клетки крысы [21] и выходить во внеклеточный матрикс. Сходные данные были получены при анализе белков, выходящих из клеток глиомы человека [19]. Оказавшись во внеклеточной среде, HSP 70 может взаимодействовать с соседними клетками, например, нейронами, и защищать их от гибели [22]. Защитный эффект экзогенного HSP 70 при действии индуцирующего апоптоз фактора некроза опухоли был показан также И. В. Гужовой и соавторами на линии клеток миелоидной лейкемии человека U-937 [18].

Таким образом, HSP 70, добавленный к клеткам извне, способен защищать их сходным с внутриклеточным белком образом. На тканевом уровне также было показано, что препарат HSP 70, состоящий из смеси двух изоформ: индуцибельной (HSP 70) и конститутивной (HSC70), при введении в глаз крысы поглощался сетчаткой и защищал фоторецепторы при их повреждении светом [30]. На срезах мозга мыши было показано, что рекомбинантный HSP 70, добавленный в инкубационную среду, имитировал защитный эффект теплового прекондиционирования, который заключался в нормализующем действии на миниатюрные синаптические токи, вызываемые гамма-аминомасляной кислотой, глутаминовой кислотой и глицином [24]. Взаимодействие HSP 70 с клеточной поверхностью и его поглощение было показано для нескольких типов клеток различного происхождения. В центральной нервной системе экзогенный HSP 70, вероятно, может взаимодействовать с глиальными клетками и нейронами. Иммуногистохимически показано, что обе изоформы HSP 70 в наибольшей степени представлены в синапсах. Однако, основная роль в функционировании эндо- и экзоцитоза синаптических пузырьков принадлежит HSC70 [31]. В коре мозга и гиппокампе крысы HSC70 является основным компонентом постсинаптической мембраны. Он также связан с аморфными субсинаптическими структурами и цистернами шипикового аппарата. HSP 70 обнаружен лишь в небольших количествах в постсинаптической мембране. Обе изоформы HSP 70 можно считать синаптическими маркерами [26]. Кроме того, они обнаружены в достаточном количестве в астроглие. Таким образом, можно предполагать, что HSP 70, может покидать клетки паренхимы мозга и поглощаться ими. Присутствие HSP 70 в синапсах предполагает его причастность 
к их функционированию и, возможно, к модуляции синаптической передачи. Наконец, необходимо дополнить картину взаимодействием внеклеточного HSP 70 со специализированными Toll-like рецепторами (TLR-2 и TLR-4), связанными с CD14 [15, 16] на поверхности микроглиальных клеток, имеющих мезенхимальное происхождение, которые традиционно считаются специализированными макрофагами ЦНС. В результате такого взаимодействия клетки микроглии активируются, что приводит к увеличению синтеза провоспалительных цитокинов. Последнее может иметь место и при центральном введении экзогенного HSP 70.

Положительной стороной активации микроглии HSP 70 может быть увеличение фагоцитоза и очищение межклеточного пространства от амилоидных отложений [23]. Таким образом, нельзя игнорировать еще одно очевидное свойство внеклеточного HSP 70: его процитокиновый әффект. Это свойство присуще не только HSP 70, но и другим шаперонам, таким как HSP90, HSP32. Для внеклеточного HSP 70 был предложен новый термин «шаперокин» [14]. В отличие от внеклеточного HSP 70 увеличение экспрессии и/или содержания внутриклеточного HSP 70 вызывает торможение передачи пролиферативных, апоптотических, воспалительных сигналов [20].

В настоящее время считается, что большинство защитных функций HSP связано с шаперонной активностью, т. е. с их способностью узнавать поврежденные или вновь синтезированные полипептиды и выправлять их структуру АТФ-опосредованным образом или удалять не поддающиеся исправлению белки через протеасомный аппарат. Было установлено, что один из шаперонов, белок HSP90, способен связываться с доменом PAS B-фактора и стабилизировать его. Другой клеточный шаперон, HSP 70, узнает иной структурный мотив молекулы HIF-1a, так называемый домен кислородзависимой деградации (ODD) [6]. Следует отметить, что роль этих межбелковых взаимодействий неясна; предполагается, что они необходимы для стабилизации HIF-1а в условиях нормоксии. В условиях гипоксии по крайней мере один из шаперонов (HSP 70) вытесняется из комплекса с HIF-1а белком ARNT, который в течение 20-30 мин гипоксии предохраняет структуру фактора от прицельного протеолиза. Таким образом, можно предположить, что HSP 70 способен увеличивать время жизни фактора HIF-1а в условиях до и после гипоксии и необходим клеткам для надлежащей реакции на лишение кислорода [7].

В последнее время появились данные о регулирующем действии белков HSP на явления митохондриальной дисфункции, развивающейся при ишемическом поражении головного мозга вследствие вышеперечисленных биохимических изменений в мозговой ткани. Однако, в доступных литературных источниках данной информации недостаточно, некоторые аспекты противоречивы, что и определяет перспективность дальнейших исследований [8-11].

С этой целью нами на первом этапе эксперимента были проведены исследования in vitro с внесением цитотоксических продуктов в суспензию нейрональных клеток.

Исследования in vitro показали, что введение в инкубационную среду цитотоксических соединений: глутамата (100 мкм), хлординитробензена 
(ХДБ) (80 мкм), а также DNIC (250 мкM) приводило к изменению характера экспрессии HSP70, HIF-1a, однако, данные изменения носили разнонаправленный характер. Так, в суспензиях с внесением глутамата и ХДБ наблюдалось постепенное увеличение концентрации белков HSP70 и HIF-1a с максимальным приростом на 30-ю минуту инкубации. Далее к 60-й минуте наблюдалось падение концентрации HSP70 в среднем на 33 \% по отношению к 15-й минуте, Hif1b оказался более устойчив, падение его активности составило в среднем $18 \%$ (рис. 2.6 а, б). Исследование суспензии с добавлением DNIC показало, что накопление HSP70 и HIF-1а на 15-ю минуту происходило менее интенсивно, чем в суспензиях с добавлением глутамата и ХДБ и на 60-ю минуту падение HSP70 по отношению к 15-й минуте составило 66 \%, а НIF1 а - на $50 \%$ (рис. 1 в).

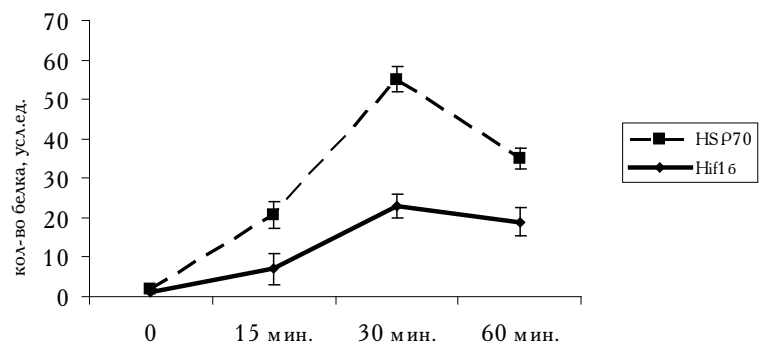

A

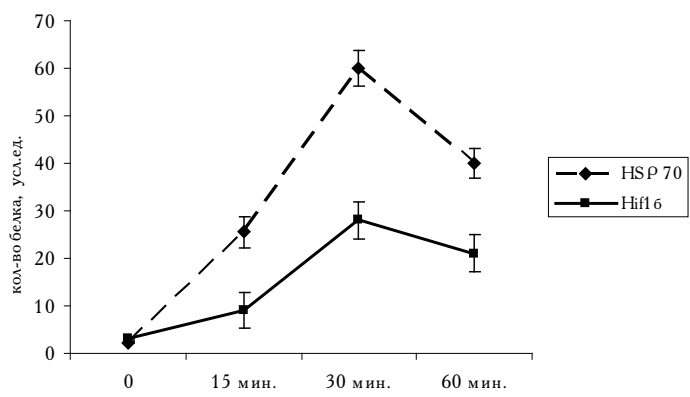

Б

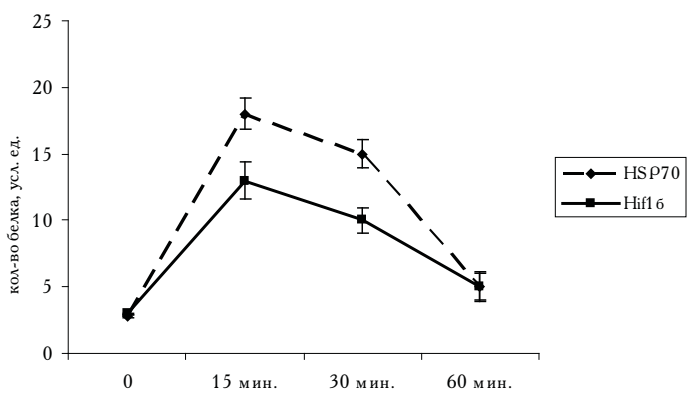

B

Puc. 2.6. Динамика изменения характера экспрессии HSP70, Hif 1b в суспензии нейронов с добавлением глутамата (А), ХДБ (Б), DNIC (B) 
Повышение в исследуемых суспензиях на 15-ю минуту экспрессии HSP70 и HIF-1а объясняется шаперонной функцией HSP 70 в условиях повреждающего действия различных токсических агентов на клетку. Считается, что белки теплового шока выполняют функции молекулярных шаперонов и предотвращают агрегацию поврежденных белков в клетке. В ряде работ было показано, что в условиях in vitro HSP70 способен предотвращать агрегацию окислительно поврежденных цитратсинтазы, глутатион-S-трансферазы, супероксиддисмутазы, лактатдегидрогеназы, малатдегидрогеназы $[18,19]$.

Кроме того, одной из основных функций HSP 70 является индукция, а также увеличение продолжительности жизни стабильной формы Hif1b, которая включает дальнейшие приспособительные реакции в клетке. HIF-1a, в свою очередь, образует активный димер с субъединицей HIF-1 и начинает играть роль транскрипционного фактора, запуская транскрипцию генов ответа на гипоксию. Кроме того, как было описано выше, HIF-1а является индукционным фактором в синтезе некоторых ферментов антиоксидантной защиты. Данным обстоятельством объясняется более длительное накопление в суспензии Hif $1 \mathrm{~b}$, кроме того, молекула Hif1b более стабильна к оксидативному стрессу [20].

Принимая во внимание полученные нами данные о способности HSP 70 в условиях токсического воздействия на клетку усиливать экспрессию фактора Hiflb, играющего первостепенную роль в клеточном ответе на гипоксию, можно предположить, что HSP 70 вмешивается в сигнальные пути ответа клетки на гипоксический стресс на уровне регуляции стабильности HIF-1a. Подобная двухступенчатая защита клетки является, по нашему мнению, эволюционно развитой и необходимой для усиления трансдукционного клеточного сигнала в ответ на повреждающие агенты.

Разнонаправленный характер экспрессии исследуемых белков в суспензиях с добавлением глутамата, ХДБ и DNIC объясняется тем, что DNIC является более токсической молекулой, так как NO, и особенно - продукты его превращения, такие как пероксинитрит $\left(\mathrm{ONOO}^{-}\right)$, ион нитрозония $\left(\mathrm{NO}^{+}\right)$, нитроксил $\left(\mathrm{NO}^{-}\right)$и диазоттриоксид $\left(\mathrm{N}_{2} \mathrm{O}_{3}\right)$, являются основными факторами реализации нитрозирующего стресса, в результате которого происходит прямое взаимодействие NO с металлами (гемовое железо гемоглобина, миоглобина, железосодержащих энзимов, негемовое железо железосерных белков и ДНК, медь и цинк активных центров ферментов), а также непрямое взаимодействие $\mathrm{NO}^{+}$(S-, N-, O-нитрозирование) с тиольными, фенольными, гидроксильными и аминогруппами белков и ДНК [21-23]. Слабой экспрессией факторов HSP70 и Hif $1 b$, и соответственно низкой их шаперонной активностью, объясняется значительный прирост в суспензии выделенных нейронов с DNIC по отношению к глутамату и ХДБ нитротирозина - основного маркера окислительного повреждения белковых молекул (рис. 2.7).

Вторым этапом наших исследований стало исследование характера экспрессии HSP70, Hif1b на модели ишемического поражения головного мозга на 4 -е и 12 -е сутки эксперимента.

Моделирование ишемического поражения на 4 -е сутки эксперимента показало существенное увеличение концентрации белков HSP70, Hif1b, что свя- 
зано, по нашему мнению, с их шаперонной активностью в условиях развивающегося оксидативного стресса, направленной на интенсификацию резервноадаптационных возможностей в острый период ишемии (рис. 2.8).

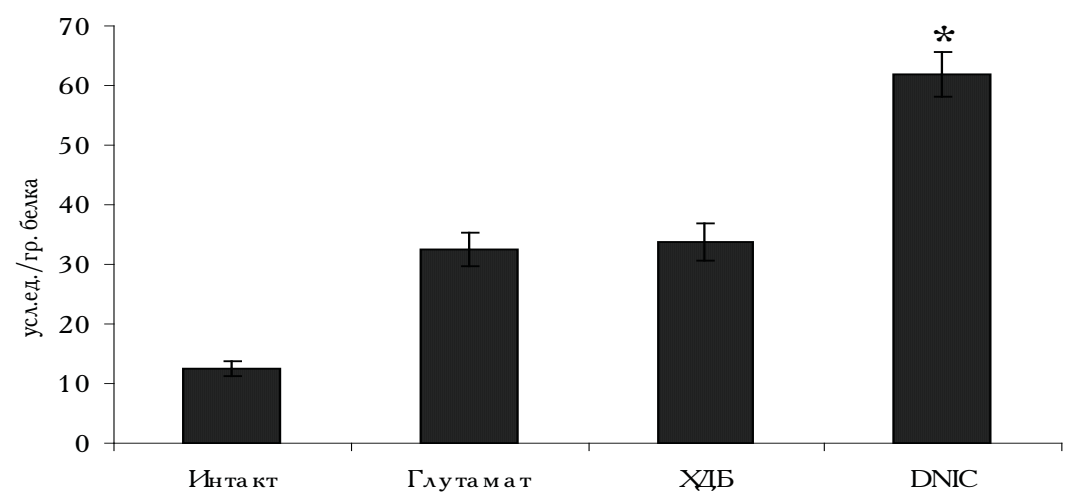

Примечание: * - p $\leq 0,05$ по отношению к глутамату и ХДБ.

Puc. 2.7. Концентрация нитротирозина в суспензиях выделенных нейронов с добавлением глутамата, ХДБ, DNIC

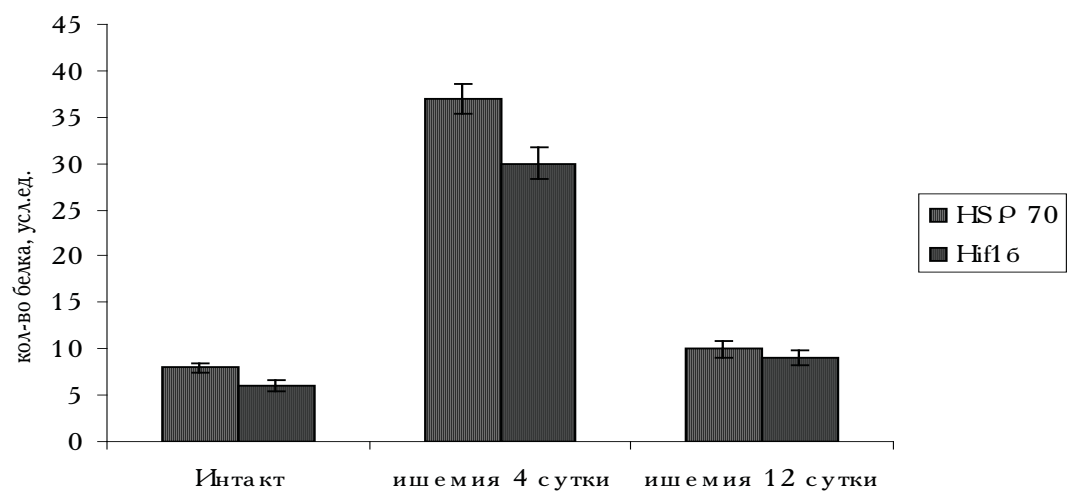

\section{Puc. 2.8. Характер экспрессии генов HSP 70 и Нif1b на 4 и 12 сутки моделирования ишемии головного мозга}

Известно, что, в зависимости от концентрации образовавшихся активных форм кислорода, окислительный стресс в конечном итоге ведет либо к некрозу, либо к апоптозу. Высокий уровень активных форм кислорода вызывает сильное повреждение белков, липидов, нуклеиновых кислот, следствием чего является некроз. Умеренный окислительный стресс вызывает программируемую гибель клетки, т. е. приводит к апоптозу. HSP 70 и Hif1b за счет позитив- 
ного влияния на синтез антиоксидантных ферментов, шаперонной активности, стабилизации актиновых филаментов препятствуют развитию некроза. Нейропротективная роль HSP 70 в условиях ишемии была показана и работами некоторых зарубежных исследователей [14, 18, 20]. Так, Papadopoulos M. С. была показана роль повышения экспрессии HSP70 в клетках мозга (астроцитах) в защите их от гибели, вызванной кислородным голоданием. Кроме того, была продемонстрирована способность очищенного препарата HSP70 повышать выживаемость нейронов, участвующих в глутаматергической синаптической передаче в обонятельной коре мозга крыс, от разрушающего воздействия тяжелой аноксии [24]. Тем не менее, до сих пор неясно, каков механизм защитного действия HSP70. Принимая во внимание данные о способности HSP 70 усиливать жизнеспособность нейрональной клетки в условиях гипоксии и факт взаимодействия HSP70 и HIF-1a, играющего первостепенную роль в клеточном ответе на гипоксию, можно предположить, что HSP70 участвует в регуляции сигнальных путей ответа клетки на гипоксический стресс на уровне регуляции стабильности HIF-1а. Зафиксированное нами повышение экспрессии HSP70 на 4-е сутки экспериментальной ишемии подтверждает значимость шаперона HSP70 для стабилизации системы реакции клеток на ишемию; по-видимому, этот механизм лежит в основе защитной активности белка.

Кроме того, нейропротективный эффект HSP 70 в условиях ишемии объясняется и его антиапоптотическим, а также митопротективным действием. В настоящее время в литературе постулируется три основных пути влияния белков теплового шока на процессы апоптоза. Во-первых, они могут влиять на функционирование и передачу сигнала от рецептора Fas/Apo1 внутрь клетки, во-вторых - они могут тем или иным способом влиять на выход цитохрома С из митохондрий, и наконец в-третьих - эти белки могут влиять на формирование апоптосом и активацию каскада каспаз. HSP27 блокирует апоптоз, вызванный активацией рецептора Fas/Apo1. После связывания с лигандом рецептор взаимодействует с адаптерными белками, одним из которых может быть белок FAD [25, 26]. Этот адаптерный белок связывает неактивную прокаспазу-8 и способствует ее активации при связывании рецептора с лигандом. Каспаза-8 активирует каспазы-3, -6 и -7 и тем самым инициирует протеолиз белков мишеней, что, в конечном итоге, приводит к апоптозу. Кроме того, каспаза-8 может активировать белок $\mathrm{Bid}$, вызывающий высвобождение цитохрома С из митохондрий. Место действия HSP27 в этой сложной цепочке реакций пока точно не установлено. Альтернативный путь запуска апоптоза через Fas/Apo1 включает белок Daxx. Механизм действия этого белка недостаточно изучен. В норме Daxx локализован в ядре, где он связан с определенными белками, но способен перемещаться в цитоплазму и играть роль адаптерного белка, ответственного за запуск каскада JNK-киназ путем активации Fas/Apo. Предполагают, что HSP 70 способен перемещаться в ядро, где он взаимодействует с Daxx, препятствуя его выходу в цитоплазму и активации рецептора. Ранее отмечалось, что HSP 70 могут участвовать в регуляции апоптоза не только на уровне рецептоpa Fas/Apo1, но и на уровне определенных внутриклеточных белков-мишеней [27]. Действительно, было показано, что HSP 70 предотвращает апоптоз, ини- 
циируемый митохондриями; при этом авторы предлагают разные механизмы действия белков теплового шока. Как известно, падение мембранного потенциала, вызываемое ишемией головного мозга, приводит к высвобождению цитохрома С из митохондрий. В цитоплазме цитохром C связывается с белком Apaf1, дезокси ATP и прокаспазой-9, формируя так называемую апоптосому. Формирование апоптосомы сопровождается автокаталитической активацией прокаспазы-9 и ее переходом в активную форму каспазы-9. Этот фермент активирует прокаспазу-3 и следующие за ней каспазы, участвующие в процессе апоптоза. HSP70 ингибирует апоптоз на этапе между высвобождением цитохрома С и расщеплением прокаспазы-9 в апоптосоме. В последнее время в литературе появились данные о том, что HSP70 способен взаимодействовать с цитохромом C [28]. Вопрос о том, какая часть освободившегося из митохондрий цитохрома С связывается с HSP 70, остается открытым. Рядом работ было показано, что HSP70 связывает лишь очень незначительную долю вышедшего из митохондрий цитохрома $\mathrm{C}$ и поэтому не может играть существенной роли в формировании апоптосомы [18, 29]. По данным этих авторов, HSP27 препятствует снижению мембранного потенциала, вызываемого белком Вах, но не взаимодействует с этим белком. Авторы предполагают, что при митохондриальном пути развития апоптоза HSP70 действует на более ранних этапах этого сложного процесса и предотвращает нарушение структуры актиновых филаментов. Данная гипотеза подтверждается и нашими исследованиями. Так, на 4-е сутки эксперимента на фоне значительного прироста HSP70 и Hif1a явления митохондриальной дисфункции (открытие митохондриальной поры, сохранность заряда митохондрий) не были выражены. Однако, регистрирование этих показателей на 12-е сутки эксперимента показало существенное проявление данных изменений, а именно: падение заряда митохондрий более чем на $60 \%$, а также открытие митохондриальной поры. Следует отметить, что данные изменения протекали на фоне падения активности HSP70 и Hif1b.

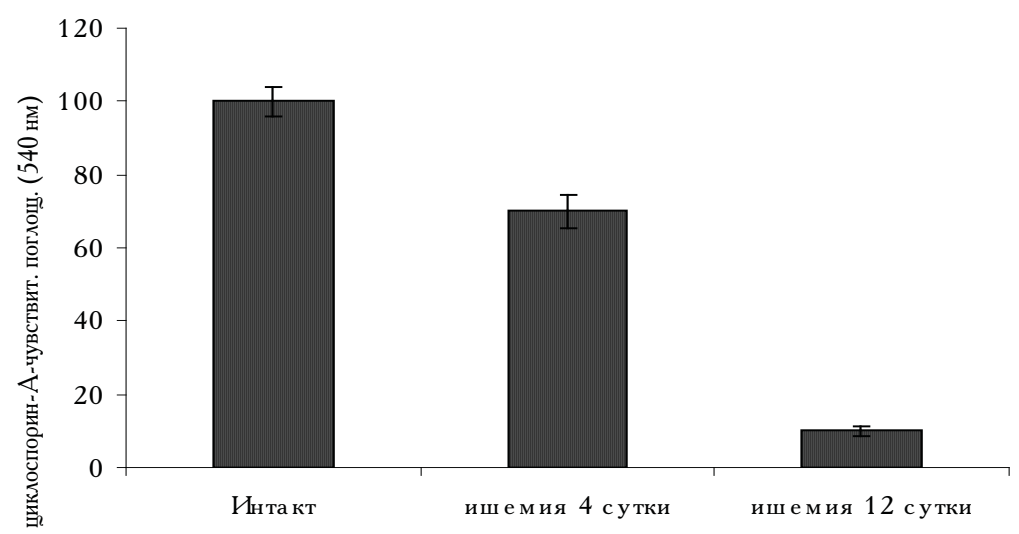

Puc. 2.9. Открытие митохондриальной поры на 4 и 12 сутки экспериментальной ишемии головного мозга 


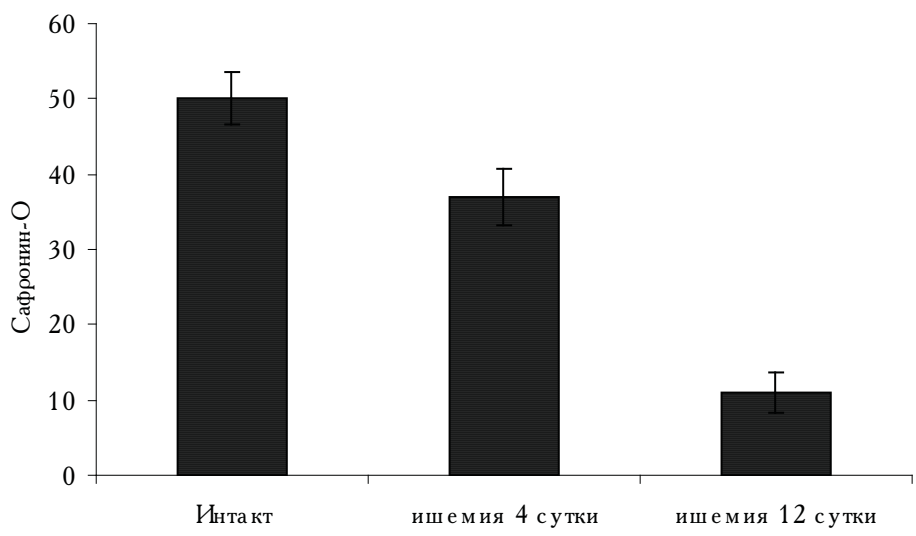

Рuc. 2.10. Изменение мембранного потенциала митохондрий мозга экспериментальных животных на 4-е и 12-е сутки эксперимента

Подобные динамические изменения объясняются, по нашему мнению, срывом адаптационных возможностей организма на 12-е сутки эксперимента, а также развитием нитрозирующего стресса, о чем свидетельствует увеличение количества нитротирозина в головном мозге более чем на 75 \% по отношению к животным на 4-е сутки (табл. 2.1).

Таблица 2.1

\section{Динамика изменений нитротирозина в тканях головного мозга животных в различные сроки эксперимента}

\begin{tabular}{|l|c|}
\hline \multicolumn{1}{|c|}{ Серии животных } & $\begin{array}{c}\text { Нитротирозин, } \\
\text { усл.ед./г белка }\end{array}$ \\
\hline Интакт & $8,7 \pm 1,43$ \\
\hline Ишемия, 4-е сутки & $20,8 \pm 1,75$ \\
\hline Ишемия, 12-е сутки & $84,2 \pm 2,7$ \\
\hline
\end{tabular}

Подобные изменения связаны с гиперпродукцией АФК и цитотоксических форм оксида азота, приводящих не только к модификации (обратимой и необратимой) макромолекул, в том числе и самих HSP70 и Hiflb, но и к снижению экспрессионной активности генов, кодирующих синтез последних. Рядом работ доказана роль дериватов оксида азота в подавлении генной активности и снижении уровня различных транскрипционных факторов. Нами в предыдущих работах было показано, что избыток таких форм оксида азота, как пероксинитрит и ион нитрозония, вначале нитролизуют тиольные редокс-зависимые - участки этих генов, затем, при повышении концентрации, окисляют их $[17,28]$. Пероксинитрит приводит к нитрозилированию гуа- 
нина и разрыву цепочек ДНК. В отношении повреждений генома известен еще один эффект NO: его дериваты с супероксид-радикалом ингибируют ферменты, ответственные за репарацию ДНК. В зависимости от источника (разные доноры NO) показано действие NO на алкилтрансферазу, формамидопиримидин-ДНКгликозилазу и лигазу. NO повышает активность PARP в клетках Беца и ADPрибозилирование при глобальной ишемии, возможно вследствие разрывов ДНК, но это скорее приводит к некрозу из-за истощения пула NAD и ATP [22].

Проведенными экспериментальными исследованиями на различные сроки ишемии (1 час, 6 часов, 24 часа, 48 часов, 72 часа, 120 часов и 21 сутки) установлено, что в период наибольших ишемических нарушений 24-72 часа наблюдается гиперпродукция лактата, на фоне угнетения ГК - фермента, катализирующего первую пусковую реакцию гликолиза (табл. 2.2). При оценке динамики изменений окислительного метаболизма обращает на себя внимание резкое угнетение СДГ (77-85\%) и изоцитрата $(56-70 \%)$. Восстановление этих показателей начинается лишь к 21-м суткам эксперимента. Обращает на себя внимание, первоначальное (с 1-го по 24-й час) повышение активности мМДГ и цМДГ с увеличением уровня малата (20-50\%), а в дальнейшем (48-й-72-й часы) умеренная депрессия ее активности (10\%) на фоне уменьшения содержания малата (16-38 \%) (табл. 2.2). Таким образом, наблюдается выраженное ингибирование цикла трикарбоновых кислот на участке цитрат-сукцинат. Столь резкое угнетение активности СДГ делает проблематичной реализацию сукцинатоксидазного пути поставки протонов в дыхательную цепь. Рост малата с повышением активности мМДГ и цМДГ в первые часы церебральной ишемии свидетельствует об активации малат-аспартатного челночного механизма транспорта восстановленных эквивалентов в митохондрии. Исследование показателей биоэнергетики в острый период ишемии (до 24 часов) выявило интересные закономерности: наиболее выраженно изменялись такие показатели, как активность митохондриальных и цитозольных НАД-МДГ и НАДФ-МДГ, а также содержание HSP70 и HIF-1а (рис.2.11).
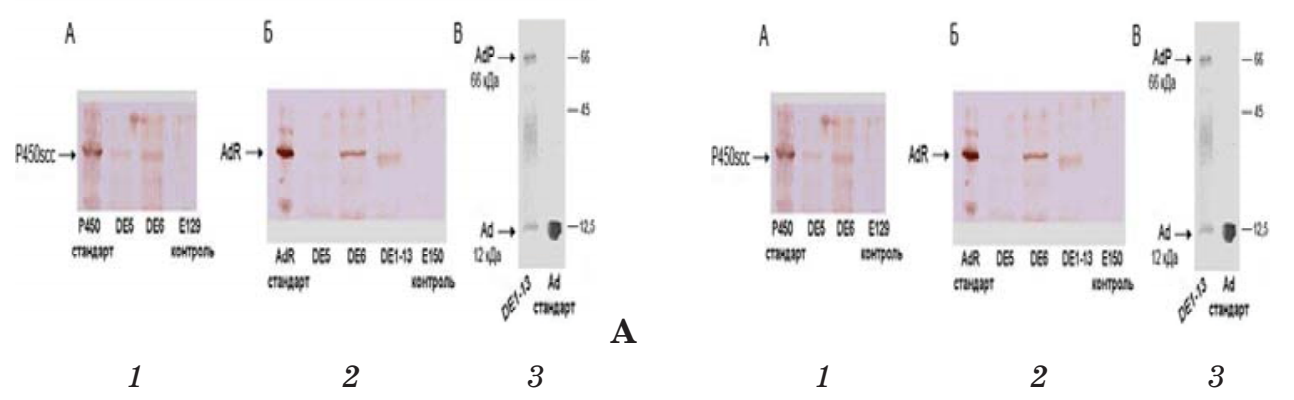

Прилечание:

1 - группа монгольских песчанок с легкой степенью неврологических нарушений;

2 - группа монгольских песчанок с тяжелой степенью неврологических нарушений;

3 - группа монгольских песчанок со средней степенью неврологических нарушений.

Puc. 2.11. Результаты иммунодетекции HIF-1a (A) и HSP70 (Б) белков 
Отмечался параллелизм в изменениях уровня малата и активности НАДМДГ митохондрий, цитоплазматической AcT и содержанием HSP70 HIF-1a. Установлена статистически достоверная корреляционная достоверность между изменениями уровня малата, НАД-МДГ и $\operatorname{HSP} 70$ (ч $=0,821 ; \mathrm{T}-2,94)$. Также было установлено, что общая тенденция к снижению малата была сопряжена с восстановлением НАДФ-МДГ и НIF-1a (ч $=0,839$; Т-3,09). Математическим анализом была установлена прямая зависимость между концентрацией HSP70белка и уровнем активности МДГ. Результаты данного бинарного регрессионного анализа показали тесную ассоциацию между уровнем экспрессии белков теплового шока, рассматриваемого в качестве независимого аргумента, и величиной активности МДГ митохондрий (рис. 2.12). Полученная зависимость носит прямой трансцендентный характер и статистически значимо аппроксимируется логарифмической моделью регрессии. Погрешность аппроксимации $(0,19)$ и величина остаточной дисперсии показывают высокую точность линейной модели, таким образом, задачу регрессионного анализа можно считать решенной $\left(R=0,93, R^{2}=0,86\right.$, нормированный $R^{2}=0,84$ при $F=53,25$, стандартная ошибка $0,604, \mathrm{p}=0,00082)$.

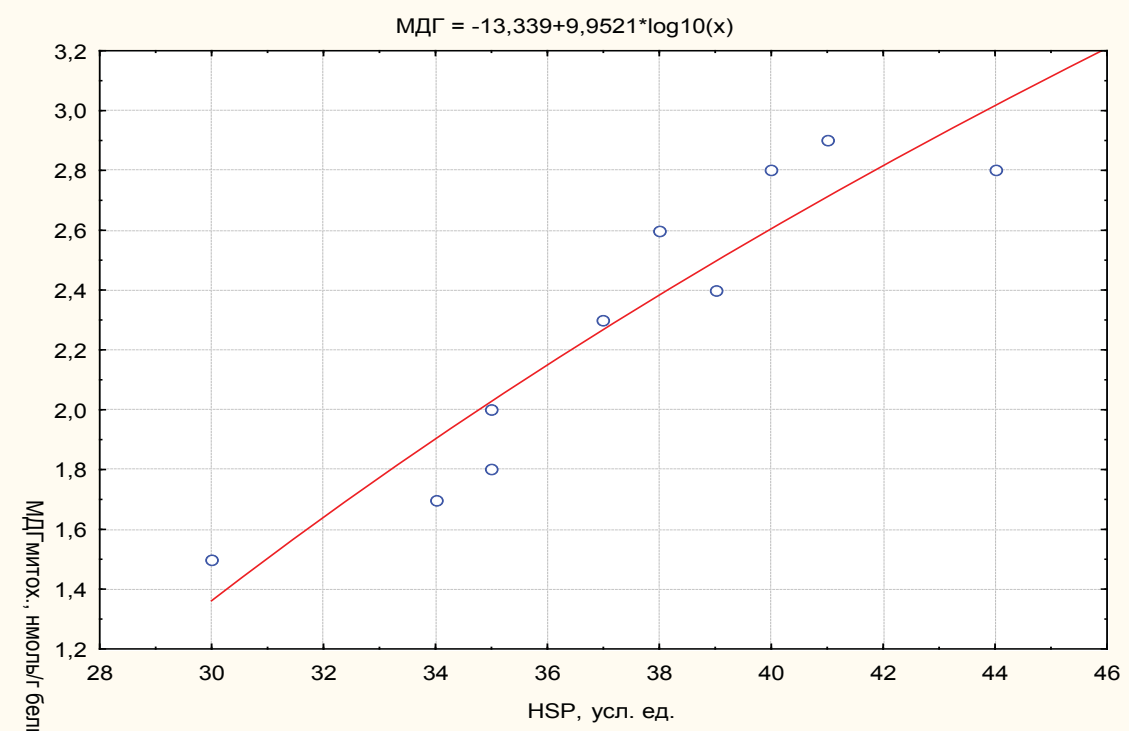

Рuc. 2.12. Результаты регрессионного анализа взаимосвязи HSP и МДГ

В целях выяснения роли малатного шунта в механизмах компенсаторной продукции энергии и молекулярных механизмах его регуляции, нами была проведена рандомизация животных с ОНМК по степени устойчивости к ишемии по баллам шкалы P. McGrow на 24-м часе ишемии. Анализ показал, что у животных с высокими баллами по P. McGrow (выраженная неврологическая симптоматика) содержание малата и HSP 70, HIF-1а наиболее низкое (рис. 2.11, табл. 2.3). При этом падение уровня малата в митохондриях корре- 
лировало с высокой степенью достоверности со снижением HSP70 (ч = 0,899; Т-11,4) и НАД-МДГ митохондрий (ч $=0,976$; Т-6,3), а также АсТ митохондрий $(ч=0,997 ;$ T-9,1) и АТФ (ч = 994; Т-9,3) (табл. 2.3, рис. 2.12). Эти факты убеждают в том, что продукция энергии в условиях острой церебральной ишемии зависит от функционирования малат-аспартатного шунта. В этом отношении, базируясь на многочисленных экспериментальных исследованиях, можно с определенной уверенностью сказать о преимуществе малат-аспартатного шунта, во-первых, как более устойчивого к гипоксии, а во-вторых - обеспечивающего протонами в условиях острой ишемии электрон-транспортную цепь, частично замещая сукцинатоксидазный механизм поставки протонов в электронную цепь. Кроме того, шунт Робертса лимитирован содержанием ГАМК в головном мозге. При этом рост малата является маркером производительности этой челночной системы, и уровень HIF-1а определяет возможность активации компенсаторного шунта энергии, а HSP70 - возможность его длительного функционирования. Данное утверждение подтверждается работами других исследователей. Так, исследованиями Dery M. A., Huang L. E., было установлено, что один из шаперонов, белок HSP90, способен связываться с доменом PAS B-фактора и стабилизировать его. Другой клеточный шаперон, HSP 70, узнает иной структурный мотив молекулы HIF-1a, так называемый домен кислородзависимой деградации (ODD) [25]. Следует отметить, что роль этих межбелковых взаимодействий неясна; предполагается, что они необходимы для стабилизации HIF-1а в условиях нормоксии. В условиях гипоксии, по крайней мере один из шаперонов (HSP 70) вытесняется из комплекса с HIF-1а белком ARNT, который в течение 20-30 мин гипоксии предохраняет структуру фактора от прицельного протеолиза. Таким образом, HSP 70 способен увеличивать время жизни фактора HIF-1а в условиях до и после гипоксии и необходим клеткам для надлежащей реакции на лишение кислорода.

Таблица 2.2

Состояние энергетического обмена головного мозга монгольских песчанок; концентрация HIF- и HSP-белков на разные сроки церебральной ишемии

\begin{tabular}{|c|c|c|c|c|c|c|c|c|}
\hline Показатели & интакт & 14 & 64 & 24 ч & 48 ч & 72 ч & 120 4 & 21 сутки \\
\hline $\begin{array}{l}\text { малат, } \\
\text { мкмоль/г ткани }\end{array}$ & $\begin{array}{l}0,44 \pm \\
0,022\end{array}$ & $\begin{array}{l}0,56 \pm \\
0,012^{*}\end{array}$ & $\begin{array}{l}0,87 \pm \\
0,032^{*}\end{array}$ & $\begin{array}{l}0,78 \pm \\
0,014^{*}\end{array}$ & $\begin{array}{l}0,37 \pm \\
0,034^{*}\end{array}$ & $\begin{array}{l}0,27 \pm \\
0,011^{*}\end{array}$ & $\begin{array}{l}0,25 \pm \\
0,023^{*}\end{array}$ & $\begin{array}{l}0,43 \pm \\
0,021\end{array}$ \\
\hline $\begin{array}{l}\text { изоцитрат, } \\
\text { мкмоль/г ткани }\end{array}$ & $\begin{array}{l}0,48 \pm \\
0,021\end{array}$ & $\begin{array}{l}0,67 \pm \\
0,027^{*}\end{array}$ & $\begin{array}{l}0,54 \pm \\
0,044^{*}\end{array}$ & $\begin{array}{l}0,21 \pm \\
0,027^{*}\end{array}$ & $\begin{array}{l}0,18 \pm \\
0,033^{*}\end{array}$ & $\begin{array}{c}0,14 \pm \\
0,018^{*}\end{array}$ & $\begin{array}{c}0,20 \pm \\
0,015^{*}\end{array}$ & $\begin{array}{c}0,27 \pm \\
0,031^{*}\end{array}$ \\
\hline $\begin{array}{l}\text { НАД-МДГ-мх, } \\
\text { мкмоль/г ткани/мин. }\end{array}$ & $\begin{array}{l}1,23 \pm \\
0,071\end{array}$ & $\begin{array}{l}1,87 \pm \\
0,016^{*}\end{array}$ & $\begin{array}{l}2,47 \pm \\
0,033^{*}\end{array}$ & $\begin{array}{l}2,11 \pm \\
0,041^{*}\end{array}$ & $\begin{array}{l}1,87 \pm \\
0,037^{*}\end{array}$ & $\begin{array}{l}1,12 \pm \\
0,016^{\star}\end{array}$ & $\begin{array}{l}1,11 \pm \\
0,019^{*}\end{array}$ & $\begin{array}{l}1,44 \pm \\
0,012^{*}\end{array}$ \\
\hline $\begin{array}{l}\text { СДГ, } \\
\text { мкмоль/г ткани/мин }\end{array}$ & $\begin{array}{l}5,4 \pm \\
0,21\end{array}$ & $\begin{array}{l}7,8 \pm \\
0,7^{*}\end{array}$ & $\begin{array}{c}5,2 \pm \\
0,3\end{array}$ & $\begin{array}{l}1,2 \pm \\
0,3^{*}\end{array}$ & $\begin{array}{l}1,2 \pm \\
0,5^{\star}\end{array}$ & $\begin{array}{l}1,0 \pm \\
0,2^{*}\end{array}$ & $1,2 \pm 0,5^{*}$ & $\begin{array}{c}3,77 \pm \\
0,5^{*}\end{array}$ \\
\hline $\begin{array}{l}\text { АТФ, } \\
\text { мкмоль/г ткани }\end{array}$ & $\begin{array}{l}2,94 \pm \\
0,085\end{array}$ & $\begin{array}{l}1,84 \pm \\
0,074^{*}\end{array}$ & $\begin{array}{c}1,5 \pm \\
0,068^{*}\end{array}$ & $\begin{array}{l}1,43 \pm \\
0,081^{*}\end{array}$ & $\begin{array}{l}1,32 \pm \\
0,047^{*}\end{array}$ & $\begin{array}{l}1,25 \pm \\
0,057^{*}\end{array}$ & $\begin{array}{l}1,23 \pm \\
0,074^{*}\end{array}$ & $\begin{array}{l}1,13 \pm \\
0,053^{*}\end{array}$ \\
\hline
\end{tabular}


Продолжение табл. 1

\begin{tabular}{|c|c|c|c|c|c|c|c|c|}
\hline Показатели & интакт & 14 & 64 & 244 & 48 ч & 72 ч & 1204 & 21 сутки \\
\hline ГК, мкмоль/г ткани/мин. & $\begin{array}{c}10,45 \pm \\
0,79\end{array}$ & $\begin{array}{l}18,65 \pm \\
1,23^{*}\end{array}$ & $\begin{array}{c}25,3 \pm \\
1,3^{*}\end{array}$ & $\begin{array}{l}16,2 \pm \\
0,65^{*}\end{array}$ & $\begin{array}{c}12,32 \pm \\
1,0^{*}\end{array}$ & $\begin{array}{l}7,43 \pm \\
0,68 *\end{array}$ & $\begin{array}{l}6,97 \pm \\
0,36^{*}\end{array}$ & $\begin{array}{c}7,06 \pm \\
0,6^{*}\end{array}$ \\
\hline $\begin{array}{l}\text { лактат, } \\
\text { мкмоль/г ткани }\end{array}$ & $2,65 \pm 0,36$ & $\begin{array}{l}3,96 \pm \\
0,31^{*}\end{array}$ & $\begin{array}{l}4,13 \pm \\
0,41^{*}\end{array}$ & $\begin{array}{c}5,4 \pm \\
0,28 *\end{array}$ & $\begin{array}{l}6,37 \pm \\
0,42^{*}\end{array}$ & $\begin{array}{c}6,4 \pm \\
0,36^{*}\end{array}$ & $\begin{array}{c}5,8 \pm \\
0,33^{*}\end{array}$ & $\begin{array}{c}5,1 \pm \\
0,27^{\star}\end{array}$ \\
\hline $\begin{array}{l}\text { HSP 70, } \\
\text { у.е./г белка }\end{array}$ & $15,4 \pm 0,31$ & $\begin{array}{l}22,5 \pm \\
0,48^{*}\end{array}$ & $\begin{array}{l}25,3 \pm \\
0,31^{*}\end{array}$ & $\begin{array}{l}23,6 \pm \\
0,51^{*}\end{array}$ & $\begin{array}{l}22,7 \pm \\
0,33^{*}\end{array}$ & $\begin{array}{c}20,6 \pm \\
0,5^{*}\end{array}$ & $\begin{array}{l}20,3 \pm \\
0,42^{*}\end{array}$ & $\begin{array}{l}18,7 \pm \\
0,4^{*}\end{array}$ \\
\hline $\begin{array}{l}\text { HIF-1a, } \\
\text { у.е./г белка }\end{array}$ & $18,5 \pm 0,65$ & $\begin{array}{l}31,5 \pm \\
0,48^{*}\end{array}$ & $\begin{array}{c}32,6 \pm \\
0,5^{*}\end{array}$ & $\begin{array}{l}27,9 \pm \\
0,43^{*}\end{array}$ & $\begin{array}{l}21,7 \pm \\
0,62^{*}\end{array}$ & $\begin{array}{l}20,4 \pm \\
0,41^{*}\end{array}$ & $\begin{array}{l}19,7 \pm \\
0,37^{*}\end{array}$ & $\begin{array}{l}19,2 \pm \\
0,52^{*}\end{array}$ \\
\hline $\begin{array}{l}\text { ЦХО, } \\
\text { мкмоль/г ткани/мин. }\end{array}$ & $\begin{array}{c}14,8 \pm \\
0,5\end{array}$ & $\begin{array}{c}13,5 \pm \\
0,3^{*}\end{array}$ & $\begin{array}{c}12,0 \pm \\
0,3^{*}\end{array}$ & $\begin{array}{l}9,2 \pm \\
0,5^{*}\end{array}$ & $\begin{array}{l}7,8 \pm \\
0,5^{\star}\end{array}$ & $\begin{array}{l}7,7 \pm \\
0,5^{*}\end{array}$ & $\begin{array}{l}8,4 \pm \\
0,3^{*}\end{array}$ & $\begin{array}{c}12,4 \pm \\
0,5^{*}\end{array}$ \\
\hline
\end{tabular}

Прилечание: $\quad$ * - $\leq 0,05$ по отношению к интакту

Таблица 2.3

\section{Показатели энергетического метаболизма и уровень HSP 70 и HIF-1а в головном мозге животных с различной степенью выраженности неврологических нарушений при ОНМК}

\begin{tabular}{|c|c|c|c|c|}
\hline Показатель & интакт & Легкая степень & Средняя степень & $\begin{array}{l}\text { Тяжелая } \\
\text { степень }\end{array}$ \\
\hline АТФ, мкмоль/г ткани & $2,98 \pm 0,092$ & $1,65 \pm 0,11^{*}$ & $1,312 \pm 0,12^{*}$ & $1,12 \pm 0,077^{*}$ \\
\hline Малат, мкмоль/г ткани & $0,44 \pm 0,022$ & $0,51 \pm 0,052^{*}$ & $0,37 \pm 0,052^{*}$ & $0,20 \pm 0,032^{*}$ \\
\hline Лактат, мкмоль/г ткани & $2,78 \pm 0,32$ & $3,77 \pm 0,47^{*}$ & $5,12 \pm 0,52^{*}$ & $6,58 \pm 0,21^{*}$ \\
\hline $\begin{array}{l}\text { НАДФ-МДГ-цт, } \\
\text { мкмоль/г ткани/мин }\end{array}$ & $5,23 \pm 0,21$ & $5,44 \pm 0,17^{*}$ & $4,91 \pm 0,81^{*}$ & $4,12 \pm 0,87^{\star}$ \\
\hline $\begin{array}{l}\text { НАДФ-МДГ-мх, } \\
\text { мкмоль/г ткани/мин }\end{array}$ & $6,27 \pm 0,12$ & $7,82 \pm 0,32^{\star}$ & $4,32 \pm 0,23^{*}$ & $3,00 \pm 0,21^{*}$ \\
\hline $\begin{array}{l}\text { НАД-МДГ-цт, } \\
\text { мкмоль/г ткани/мин }\end{array}$ & $1,57 \pm 0,052$ & $1,55 \pm 0,055$ & $1,12 \pm 0,032^{*}$ & $0,98 \pm 0,043^{*}$ \\
\hline $\begin{array}{l}\text { НАД-МДГ-мх, } \\
\text { мкмоль/г ткани/мин }\end{array}$ & $1,77 \pm 0,11$ & $2,65 \pm 0,12^{*}$ & $1,12 \pm 0,10^{*}$ & $0,82 \pm 0,032^{*}$ \\
\hline $\begin{array}{l}\text { АсТ-мх, } \\
\text { мкмоль/г ткани/мин }\end{array}$ & $3,67 \pm 0,22$ & $3,98 \pm 0,54$ & $2,34 \pm 0,43^{*}$ & $1,21 \pm 0,20^{*}$ \\
\hline $\begin{array}{l}\text { КФК-цт, } \\
\text { мкмоль/г ткани/мин }\end{array}$ & $0,97 \pm 0,021$ & $1,11 \pm 0,033$ & $0,82 \pm 0,021^{*}$ & $0,61 \pm 0,023^{*}$ \\
\hline $\begin{array}{l}\text { КФК-мх, } \\
\text { мкмоль/г ткани/мин }\end{array}$ & $0,82 \pm 0,012$ & $0,98 \pm 0,027^{*}$ & $0,78 \pm 0,017^{*}$ & $0,65 \pm 0,026^{*}$ \\
\hline $\begin{array}{l}\text { ЦХО, } \\
\text { мкмоль/г ткани/мин }\end{array}$ & $14,2 \pm 0,8$ & $11,3 \pm 0,7^{*}$ & $5,7 \pm 0,8^{*}$ & $4,0 \pm 0,7^{*}$ \\
\hline HSP 70, у.е./г белка & $15,4 \pm 0,31$ & $27,5 \pm 0,37^{*}$ & $23,2 \pm 0,4^{*}$ & $16,5 \pm 0,28^{*}$ \\
\hline HIF-1a, у.е./г белка & $18,5 \pm 0,65$ & $31,6 \pm 0,42^{*}$ & $26,4 \pm 0,3^{*}$ & $19,2 \pm 0,27$ \\
\hline
\end{tabular}

Прилечания: * - p $\leq$ 0,05 по отношению к интакту 
При общей оценке результатов исследования метаболизма нервной ткани можно выделить общие закономерности. Так, двухсторонняя перевязка общих сонных артерий сопровождается типичными для ишемии нарушениями биохимических процессов - активацией гликолиза с гиперпродукцией лактата, угнетением ферментов цикла Кребса и электрон-транспортной цепи, дефицитом АТФ на фоне угнетения экспрессии HSP70 и HIF-1а. Вместе с тем, исследование этих процессов в условиях динамического наблюдения и дифференциации по степени тяжести неврологических нарушений позволяет оценить их с позиции молекулярно-биохимических механизмов адаптации, сравнить степень нарушения отдельных звеньев метаболизма, компенсаторных путей синтеза энергии и регуляторных белков (HSP70 и HIF-1a). Так, степень угнетения СДГ, поставляющей протоны на ФАД-зависимый участок электрон-транспортной цепи намного выше, чем ЦХО, которая лимитирует поток электронов по всей цепи. Кроме того, имело место значительное снижение концентрации интермедиата ЦТК - изоцитрата. Эти факты позволяют предполагать что цикл Кребса, контролируемый цитратсинтетазой и $\alpha$-кетоглутаратдегидрогеназой существенно угнетен. При этом реализация компенсаторного сукцинатоксидазного механизма затруднена. Вместе с тем дыхательная цепь функционирует и продукция АТФ, хотя и на более низком уровне, осуществляется. Это предполагает наличие других компенсаторных механизмов поставки протонов к дыхательной цепи. В этой связи обращает на себя внимание факт роста малата и активности НАД-МДГ-мх, коррелирующий с уровнем HSP70, как в первые минуты ишемии, так и у животных, устойчивых к ишемии. Подобное наблюдение объясняется активацией малатаспартатного механизма транспорта восстановленных эквивалентов в митохондрии, участием в механизме активации и в контролировании его работы адаптационных белков - HSP70 и HIF-1a, причем, угнетение продукции малата и активности НАД-МДГ-мх коррелирует с падением АТФ, НSP70 и HIF-1a, а также со степенью неврологических нарушений. Можно предположить, что в ответ на формирование ишемии головного мозга экспрессируется HIF-1a, который инициирует запуск компенсаторных механизмов выработки энергии. В дальнейшем регуляция этих процессов переключается на HSP70, который пролонгирует действие HIF-1a, а также самостоятельно поддерживает экспрессию активности НАД-МДГ-мх, тем самым длительно поддерживая активность малат-аспартатного челночного механизма.

Таким образом, подводя итог вышесказанному, можно сделать вывод, что белки HSP70 и HIF-1а являются неизбежными спутниками патобиохимических реакций, развивающихся при ишемическом повреждении головного мозга. В данных условиях выполняют протективную функцию, реализующуюся посредством усиления синтеза антиоксидантных ферментов, стабилизации окислительно поврежденных макромолекул, прямого антиапоптотического и митопротективного действия. Подобная роль данных белков в клеточных реакциях при ишемии ставит вопрос о разработке новых нейропротективных средств, способных обеспечивать модуляцию/протекцию генов, кодирующих синтез белков HSP70 и HIF-1a. 


\section{3. БЕЛКИ ВCL-2 В РЕГУЛЯЦИИ НЕЙРОАПОПТОЗА}

На современном этапе исследование патогенеза заболеваний и повреждений нервной системы осуществляется с общебиологических позиций. В результате сложилось мнение об общих механизмах формирования патологического процесса при этих состояниях. Следует отметить, что многие изученные пути поражения нервной системы являются избыточным выражением существующих в рамках нормального гомеостаза реакций, что может быть обусловлено как экзогенными, так и эндогенными причинами. Обращает на себя внимание, что общие механизмы заболеваний нервной системы могут реализоваться на разных этапах патологического процесса. Следует также отметить, что большинство из этих данных получено в экспериментальных условиях, в связи с чем перенос их на патологию человека ограничен и требует чрезвычайной осторожности.

В настоящее время является общепризнанным, что ключевой фактор патогенеза заболеваний нервной системы - гибель нейрона - может быть двух видов: программированная клеточная смерть (апоптоз) и патологическая клеточная смерть (некроз). При этом прекращение жизнедеятельности клетки в процессе апоптоза и некроза имеет четкие морфологические различия.

Примером программированной смерти нейронов служит их гибель в процессе эмбриогенеза. Все более очевидной становится роль апоптоза как при острых заболеваниях и повреждениях нервной системы (ишемия, травма), так и при нейродегенеративных болезнях (болезнь Альцгеймера, боковой амиотрофический склероз, болезнь Паркинсона).

Регуляция апоптоза в нервной системе осуществляется многочисленными сигнальными системами. Причем пути реализации этого процесса могут быть различными: модуляция активности ферментов, модуляция факторов транскрипции (р53, AP-1, NF-кB), прямая активация генов раннего немедленного ответа (c-jun, c-fos).

В настоящее время все больший интерес исследователей привлекают так называемые белки семейства bcl-2. В настоящее время выделяют два класса этих белков: тормозящие апоптоз (bcl-2, bcl-xl bcl-w, Bfl-1, Brag-1, Mcl-1, A-l) и индуцирующие этот процесс (Bax, Bak, bcl-Xs, Bad, Bid, Bik, Hrk). Все белки этого семейства во многом гомологичны между собой, что позволяет им взаимодействовать между собой. Соотношение белков Вc1-2 агонистов и антагонистов апоптоза определяет способность клетки, в том числе и нейрона, отвечать на апоптотические сигналы [7]. Допускается, что антиапоптотическое действие Вс1-2 связано с нормализацией функции митохондрий, которые участвуют в реализации апоптоза $[15,16]$. Конкретными механизмами этого процесса являются:

1) блокирование высвобождения из митохондрий цитохрома $\mathrm{C}$;

2) участие белков Bc1-2 в формировании трансмембранных митохондриальных пор, что определяет трансмембранный потенциал, а также высвобождение различных активных соединений и ионов из митохондрий;

3) возможность проникновения этих белков в липидные структуры мембран и формирование ионных каналов, что имеет значение в субклеточном рас- 
пределении $\mathrm{Ca}^{2+}$ между ядром, митохондриями и эндоплазматическим ретикулумом.

Гены семейства Вс1-2 и каспаз экспрессируются нейронами как в онтогенезе, так и в зрелой нервной системе. Опыты Martinou J. C. et al. (1994) показали, что у трансгенных мышей с избыточной экспрессией Bc1-2 мотонейроны устойчивы к апоптозу. Однако при неонатальной аксонотомии они значительно атрофируются, но выживают [8]. Повышенная экспрессия Вах выявлена при боковом амиотрофическом склерозе и болезни Альцгеймера. Вс1-2 оказывает выраженное влияние на выживание любых нейронов и, в частности, мотонейронов.

Исследование Вс1-2 иммунохимическими методами в нейронах гиппокампа при болезни Альцгеймера в зависимости от степени тяжести, клинических симптомов и нейропатологических изменений (аутопсийные исследования) показало, что в целом экспрессия Вc1-2 в нейронах нарастала по мере прогрессирования и тяжести заболевания. Однако в нейронах, в которых идентифицированы нейрофибриллярные изменения, отмечено снижение Bc1-2, то есть синтез Вc1-2 резко снижается в этих дегенерирующих нейронах. Повышение Вс1-2 выявлено в астроцитах и эндотелии сосудов при болезни Альцгеймера. Повышение Вс1-2 рассматривается авторами как защитный механизм, тормозящий апоптоз в сохранных нейронах [12].

Выявлены отличия антиапоптотического действия Вc1-2 от эффектов фактора роста нервов (nerve growth factor, NGF): 1) NGF вызывает морфологическую дифференцировку клеток, а Вc1-2 - нет; 2) период выживания клеток под действием Bc1-2 короче, чем, соответственно, с NGF. Однако не продемонстрирована экспрессия Bc1-2 в ответ на NGF. Вместе с тем, Bc1-2 не подавляет апоптоз, вызванный дефицитом цилиарного нейротрофического фактора (ciliary neurotrophic factor, CNTF) в отличие от NGF. Это предполагает существование различных механизмов апоптоза.

Недавние исследования выявили частичную делецию гена, ответственного за экспрессию белка, ингибирующего нейрональный апоптоз, при спинальной мышечной атрофии (NIAP, neuronal inhibitory apoptosis protein) [13]. Этот белок гомологичен белку IAP вирусного происхождения (baculo virus). Установлено двойное действие полиовируса: индуцирование апоптоза за счет блока макромолекулярного синтеза, а при определенных условиях - наоборот - проявление антиапоптотической активности. В связи с этим следует отметить, что существует гипотеза в отношении фрагментации ДНК, сопровождающей апоптоз, которая, возможно, возникла как механизм противовирусной защиты чтобы не допустить репликации вируса в клетке. В настоящее время показано, что ряд вирусных белков тормозит апоптоз в нейроне.

В 1993 г. был идентифицирован новый ген, индуцирующий апоптоз исключительно в нервной системе - это ген низкоаффинного рецептора к фактору роста нервов (pTSNGFR) [11]. Следует отметить, что в нейронах зрелой нервной ткани нет экспрессии P15NGFR, который относится к семейству, включающему и гены рецепторов к факторам некроза опухоли, однако при 
болезни Альцгеймера и боковом амиотрофическом склерозе выявлена его повышенная экспрессия, соответственно, в базальных холинергических нейронах и в мотонейронах спинного мозга. Предполагается, что повышенная экспрессия p75NGFR способствует образованию арахидоновой кислоты, активации перекисного окисления липидов и развитию окислительного стресса. [2] Большое значение в развитии апоптоза отводится цитозольному фактору транскрипции (NF-кB), регулирующие экспрессию генов, кодирующих белки, которые участвуют в формировании иммунного ответа и реакций воспаления. NF-кB существует в двух формах: индуцибельной (в цитоплазме и синапсах) и конститутивной (в ядре). Этот фактор выявлен в синапсах коры больших полушарий, мозжечка и гиппокампа. Установлена возможность ретроградного транспорта NF-кB из синапса в ядро. Это новая сигнальная система для ядра. Экспрессия NF-кB имеет важное значение в нейрональной пластичности и синаптической активности [10]. Накапливаются данные в пользу участия NF-кB в развитии болезни Альцгеймера: (3-амилоид активирует NFкВ через образование активных метаболитов $\mathrm{O}_{2}$, tau-белки также активируют NF-кB. При этом NF-кB активируется вокруг бляшек на самых ранних стадиях болезни путем взаимодействия с RAGE-рецептором, общим для tau и A (3. В свою очередь активированный NF-кB совместно с метаболитами tau индуцирует экспрессию гена-предшественника амилоидного пептида. Вместе с тем следует отметить, что наряду с апоптотическим эффектом NF-кB при определенных условиях может оказывать и нейропротективное действие [3].

Некроз клетки - тип клеточной смерти, принципиально отличный от упорядоченного прекращения жизнедеятельности в процессе апоптоза развивающихся нейронов. Причиной этого процесса могут стать различные патогенные факторы: гипоксия, токсемия, гипертермия и др. При некрозе наблюдаются вакуолизация, резкое набухание клеток, завершающееся лизисом.

В последние годы установлено, что гены, имеющие значение в механизмах развития апоптоза, участвуют и при формировании нейронального некроза. Так, показано, что Вс1-2 ингибирует некроз [2]. Предполагается, что этот ген регулирует внутриклеточные процессы, в одних случаях приводящие к апоптозу, в других - к некрозу. Другой антиапоптотический ген bcl- $\mathrm{X}_{\mathrm{L}}$ подавляет не только апоптоз, но и некротическую гибель нейронов при гипоксии. Ингибиторы ICE протеаз также способны затормозить развитие не только апоптоза, но и некоторые формы некроза. Это предполагает наличие общих механизмов гибели клетки как при апоптозе, так и при некрозе [14].

В нейрональной культуре повышенная экспрессия p75NGFR вызывается введением (3-амилоидного пептида ((3-AР), морфологически при этом наблюдается картина, в большей степени похожая на некроз, чем на апоптоз. Допускается, что этот механизм может быть одним из звеньев патогенеза болезни Альцгеймера.

Выраженной нейрональной токсичностью обладают и некоторые амилоидогенные пептиды, в частности, (3-АР 1-40 и (3-AР 25-35, а также пептид прионного белка PrP 106-126. Сложилось мнение, что различные факторы, приводящие клетку к гибели, вызывают либо некроз (большие концентра- 
ции за короткое время), либо апоптоз (малые дозы за длительный период) [2, 14]. К этим факторам относятся активные метаболиты кислорода, концентрация внутриклеточного $\mathrm{Ca}^{2+}$, нарушение формирования $\mathrm{Ca}^{2+}$-каналов и $\mathrm{Ca}^{2+}$. гомеостаза, повышение чувствительности к глутамату его рецепторов, блок тахикининовых рецепторов и т. д.

Все эти исследования убеждают в существовании сложной системы регуляции апоптоза и некроза. Предполагается наличие и других, пока не идентифицированных, генов, регулирующих эти процессы в нервной системе.

Современный уровень знаний о молекулярных механизмах гибели нейрона при болезнях Альцгеймера, Паркинсона и Гентингтона, боковом амиотрофическом склерозе, эпилепсии, ишемии и гипогликемии явно недостаточен для понимания всех аспектов их патогенеза. Тем не менее, представляется весьма вероятным, что в повреждении нервных клеток при этих различных по этиологии заболеваниях принимают участие два стандартных механизма - окислительный стресс и эксайтотоксичность, которые могут индуцировать развитие некроза или апоптоза нейрона [1].

Таким образом, механизмы гибели нервной клетки при нейродегенеративных заболеваниях осуществляются преимущественно по механизму апоптоза, а при острых заболеваниях и повреждениях нервной системы - в основном по пути некроза. Реализация этих эффектов связана с изменением экспрессии ряда онкогенов в связи с развитием реакций окислительного стресса и эксайтотоксичности, являющихся одним из общих механизмов повреждения нервной системы при различных патологических состояниях.

\section{4. УЧАСТИЕ НЕЙРОТРОФИЧЕСКИХ ФАКТОРОВ В МЕХАНИЗМАХ НЕЙРОПЛАСТИЧНОСТИ}

В современной неврологии рассмотрение патогенеза многих заболеваний и вопросов восстановления нарушенных функций проводится с учетом процессов нейропластичности. Нейропластичность - способность нервной системы в ответ на эндогенные и экзогенные стимулы адаптироваться путем оптимальной структурно-функциональной перестройки. Согласно современным представлениям, репаративные процессы и компенсация нарушенных функций происходят за счет реорганизации центральной нервной системы. Нейропластичность характеризуется способностью нейронов изменять свои функции, количество и типы продуцируемых нейротрансмиттеров или структуру. Нейропластичность сопровождается изменениями цитоскелета, рецепторнобарьерно-транспортной системы (мембрана, синаптические контакты), системы синтеза биополимеров (цитоплазма), системы внутриклеточного гомеостаза $[23,27]$. Нейропластичность подразумевает также пластичность всех систем жизнеобеспечения нейрона, включая нейроглию и систему регуляции кровообращения головного мозга.

К основным механизмам пластичности головного мозга относятся изменения функциональной активности синапсов, количества, протяженности и конфигурации их активных зон, числа шипиков дендритов и синапсов на них, 
формирование новых синапсов, сопряженное с аксональным или дендритным спрутингом, длительное потенцирование или подавление, регулирующее эффективность синаптической передачи, изменение порога возбудимости потенциалзависимых мембранных каналов, компенсаторные возможности метаболизма на мембранном и молекулярном уровнях [31, 34].

Синаптическая пластичность является составляющей нейропластичности и рассматривается как свойство синапсов реагировать на физиологические и патологические воздействия изменением эффективности транссинаптической передачи информации [2, 31].

Выделяются следующие виды пластичности синапсов:

1) эволюционная, которая обеспечивает развитие простых нейронных сетей в сверхсложные мультимодульные сети, способные осуществлять высшие психические функции;

2) онтогенетическая, связанная с индивидуальным развитием и обеспечивающая приспособление организма к внешней и внутренней среде;

3) физиологическая, связанная с физиологической активацией функциональных систем;

4) реактивная, которая проявляется краткосрочной активацией синапсов после патологического воздействия на них различных факторов (ишемия, гипоксия, токсины);

5) адаптационная, связанная с длительной активацией существующих функциональных систем мозга и появлением новых в процессе адаптации организма к окружающей среде;

6) репаративная, которая обеспечивает восстановление функциональных систем мозга после их повреждения и реализуется всем спектром повышения эффективности синаптического пула, от активации сохранившихся синапсов до неосинаптогенеза и роста нервных отростков [10, 18].

Существует несколько основных направлений регуляции синаптической пластичности мозга [10]:

1) избирательное воздействие на определенные компоненты системы межнейронной трансдукции (рецепторы, ионные каналы) и различные уровни внутриклеточной регуляторной системы (кальциевая, фосфоинозитидная, аденозин- и гуанозинмонофосфатная);

2) повышение адаптивных возможностей нейронов головного мозга в целом;

3) целенаправленная нейропротекция с помощью различных медикаментозных и немедикаментозных средств.

В последние годы получено множество доказательств вовлечения в процессы нейропластичности нейротрофических ростовых факторов (НРФ) в патогенезе развития ишемических и нейродегенеративных заболеваний. НРФ относятся к физиологически активным полипептидам, которые регулируют рост и дифференцировку нейронов в развивающихся системах, а также их функциональную стабильность. В зрелом возрасте НРФ защищают нейрональные структуры от травматического, гипоксического, ишемического и других повреждений [7, 33]. Существующие данные свидетельствуют о важной роли 
НРФ и в генезе нейродегенеративных процессов. Установлено, что интравентрикулярное введение фактора роста нервной ткани (NGF) может полностью предотвращать вызванную повреждением дегенерацию нейронов. В нескольких независимых исследованиях установлено, что введение мышиного NGF кроликам делает обратимой возрастную атрофию холинергических нейронов в ядрах основания мозга, что предупреждает нарушения памяти у экспериментальных животных [4]. В эксперименте удалось показать, что интрацеребральное введение NGF существенно усиливает активность ацетилхолинтрансферазы и повышает уровень ацетилхолина в мозге.

Нейропластичность может реализовываться на молекулярном, синаптическом, нейронном и мультимодульном уровнях (отдел мозга или мозг в целом). В разной степени активация нейропластичности сопровождается стимуляцией экспрессии определенных генов, биосинтезом молекул рецепторов и ионных каналов, филаментозных белков синаптического цитоскелета, нейромедиатора, компонентов синаптической мембраны, молекул межклеточной адгезии, образованием незрелых контактов, их созреванием, активацией, гипертрофией и реорганизацией активных синапсов [10].

При каждом повреждении нервной системы после определенного латентного периода запускаются эндогенные нейропротективные реакции. Локальное повреждение ткани мозга также приводит к активации механизмов реактивной и репаративной нейропластичности. Первая является непосредственным ответом на патологическое воздействие сохранившихся нейронов, в то время как при репаративной включаются все компенсаторно-восстановительные механизмы [32]. Процессы нейропротекции и нейропластичности, регулирующиеся нейротрофическими факторами, во многом являются последовательными реакциями [33].

Изучение процесса нейропластичности неотделимо от исследования другого важнейшего для клинической неврологии вопроса - апоптоза. В последние годы он рассматривается как одно из звеньев многих патологических процессов, в том числе ишемического повреждения мозга, нейродегенерации, демиелинизирующих заболеваний. Формирование и поддержание структурнофункционального постоянства тканей и органов биологических систем определяются сбалансированностью процессов размножения и гибели клеток. Учитывая значимость динамического баланса массы клеток для обеспечения полноценности функционирования любого органа и организма в целом, можно предположить, что в процессе эволюции выработались универсальные, надежные и разнообразные в иерархическом построении механизмы регулирования клеточной гибели и регенерации.

Первое гистологическое описание смерти клеток было опубликовано в 1859 г. Р. Вирховом [9]. Тогда она называлась «дегенерацией», «некрозом», «умиранием». В дальнейшем понятия «некроз» и «некробиоз» использовали для характеристики «медленной смерти», или необратимого изменения тканей в живом организме. Такое понимание сохранилось до сегодняшнего дня. В настоящее время принято выделять следующие основные типы клеточной смерти: апоптоз и некроз. 
Апоптоз - определенный способ клеточной смерти в сформировавшейся ткани зрелого организма. Апоптоз является активным процессом реализации программы гибели клетки, он может инициироваться поступающими извне сигналами. Апоптоз представляет собой процесс, обязательный для существования многоклеточных организмов, и играет важную роль в процессе эмбрионального развития, в функционировании иммунной системы, а также любой другой системы, так как апоптоз - составная часть нормального клеточного оборота [14].

Наиболее изучен апоптоз при такой важнейшей клинической проблеме, как ишемическое поражение мозга.

Проблема ишемии мозга остается одной из самых острых проблем здравоохранения, что связано с ее высокой частотой и значимыми последствиями для пациентов и общества (высокий уровень инвалидизации и смертности). Значимость инсульта как медико-социальной проблемы растет с каждым годом. В 1998 г. в мире от мозгового инсульта умерли 5,1 млн человек и у 15 млн был зарегистрирован несмертельный инсульт. По прогнозам Всемирной организации здравоохранения, к 2020 г показатель смертности от мозгового инсульта составит 7,6 млн человек $[12,13,21]$. Помимо «эпидемии» инсульта перед здравоохранением стоит еще одна проблема - нейродегенеративные заболевания. Среди них особое внимание должно уделяться болезни Альцгеймера в связи с развитием тяжелого когнитивного дефицита. По самым приблизительным подсчетам, деменцией в мире страдают около 30 млн человек, а к 2050 г. число больных достигнет 120 млн человек [24, 25].

Еще в конце 70-х годов прошлого века были сделаны первые попытки раскрыть механизмы последовательного изменения функционального состояния и морфологии ткани мозга на фоне ишемии. Предполагают, что процесс программированной гибели нейронов играет ключевую роль в регуляции клеточного гомеостаза зрелой мозговой ткани. По данным Ч. Ворлоу и соавт. [6], в зоне критической или «нищей» перфузии нейрональная функция снижается, но клетки все еще остаются жизнеспособными с сохраненным ионным гемостазом. Вследствие того, что резерв локальной перфузии исчерпан, нейроны в зоне ишемической полутени становятся чувствительными к дальнейшему падению перфузионного давления. Ишемическая полутень представляет собой не только топографический локус, но в большей степени динамический процесс, развивающуюся зону биоэнергетического сдвига [6, 7].

Подтверждено отсутствие тождества между понятием острой фокальной церебральной ишемии, подразумевающей обратимость метаболических изменений в ткани мозга (транзиторные ишемические атаки), и формированием инфаркта мозга, т. е. стойкого морфологического дефекта. Эти состояния отличаются количественными, временными аспектами ишемии, различиями в комплексе гемодинамических и метаболических нарушений.

В условиях гипоперфузии механизмы компенсации истощаются, энергетическое обеспечение мозга становится недостаточным, в результате чего сначала развиваются функциональные расстройства, а затем и необратимые 
морфологические изменения мозга. При гипоперфузии мозга выявляются замедление кровотока, уменьшение содержания кислорода и глюкозы в крови, сдвиг метаболизма глюкозы в сторону анаэробного гликолиза, лактат-ацидоз, гиперосмолярность, капиллярный стаз, склонность к тромбообразованию, деполяризация клеток и клеточных мембран, активация микроглии, которая начинает вырабатывать нейротоксины, что наряду с другими патофизиологическими процессами приводит к гибели клеток $[8,11]$.

Ишемическое воздействие приводит к существенной реорганизации межнейрональных взаимоотношений, активации синаптогенеза и изменению эффективности функционирующих синапсов [3, 10]. При хронической церебральной ишемии легкой степени отмечается умеренная активация механизмов синаптической пластичности, при умеренной недостаточности кровообращения - максимальная. Пластическая реорганизация сохранившихся синапсов сочетается с активацией неосинаптогенеза, дифференцировкой незрелых контактов. При тяжелой хронической церебральной ишемии пластичность реализуется в основном посредством механизмов реорганизации сохранившихся функционально активных синапсов, что, вероятно, является недостаточным для оптимального обеспечения эффективной межнейронной интеграции [10].

В последние годы как в клинических, так и в экспериментальных исследованиях отмечалось особое значение нейропротективной терапии при цереброваскулярной патологии, а также в терапии нейродегенеративных заболеваний [19]. Наряду с этим обсуждалась роль нейропластичности в патогенезе аффективных расстройств. Следует отметить, что последнее вполне соответствует ряду современных представлений $[1,38]$ о морфологических изменениях при депрессивных расстройствах. По данным прижизненной нейровизуализации было отмечено уменьшение объема лобной коры (толщины орбитофронтальной коры, размера нейронов и уменьшение глиальных клеток), уменьшение объема гиппокампа и базальных ганглиев (особенно при депрессии с поздним началом). Кроме того, у больных с депрессией выявляются функциональные изменения мозга в виде снижения кровотока и метаболизма глюкозы преимущественно в префронтальной коре, миндалине и гиппокампе. Учитывая, что большинство исследователей связывает нарушения нейрональной пластичности с гиперактивностью гипоталамо-гипофизарно-надпочечниковой оси и, соответственно, гиперактивностью кортикотропин-рилизинг фактора, АКТГ и кортизола, привлекают к себе внимание данные о том, что и у больных с депрессиями было выявлено снижение мозгового нейротрофического фактора, нарушение метаболизма фосфолипидов, Р-субстанции и других нейрокининов, нарушение чувствительности глутаматных рецепторов [15]. Возможно, развитие структурных изменений в головном мозге является следствием указанных нарушений [34, 39]. Более того, предполагают [5, 35, 37], что изменения в миндалине и гиппокампе играют одну из решающих ролей в персистировании симптомов депрессии, тревоги, в развитии когнитивного снижения (если таковые отмечаются при депрессии), а также хронической боли.

В связи с этим можно привести и наблюдения, свидетельствующие о том, что деменция и аффективные нарушения частично пересекаются: при 
депрессии, как говорилось выше, иногда имеется когнитивный дефицит, а у больных с деменцией могут развиваться эмоциональные расстройства [23, 36]. Этому соответствуют данные о некоторых общих факторах, принимающих участие в развитии антидепрессивного эффекта и формировании процессов памяти и обучения (цАМР, нейротрофический фактор и др.) [1]. Остаются неясными механизмы указанной общности. Возможно, здесь играют роль генетические и стрессорные факторы. Наибольшее внимание сейчас уделяют кортикотропин-рилизинг фактору и новому семейству пептидов - teneurin C-terminal associated peptides (TCAP). Действие этих пептидов подобно действию других нейротрофических пептидов [30]. Едиными для деменции и депрессии являются нарушения нейротрансмиттерных систем, в частности холинергической иннервации, а также поражение белого вещества [28].

Выявленные нарушения делают целесообразным использование у больных с депрессией препаратов, обладающих действием, подобным влиянию нейротрофических факторов [29].

В настоящее время особое внимание уделяется механизмам нейропротекции и эффективности соответствующих лекарственных препаратов, в том числе обладающих действием, сходным с ростовыми факторами. Использование трофических факторов позволяет в определенной мере стимулировать процессы пластичности при ишемическом поражении [22]. Введение NGF в эксперименте было признано значимой нейропротективной стратегией терапии сосудистых поражений мозга и нейродегенерации, способной, с одной стороны, сохранять подвергающиеся дегенерации нейроны, а с другой - усиливать функции сохранившихся нейронов [7, 33]. Значимость упомянутых экспериментальных исследований чрезвычайно велика, поскольку они впервые позволили опровергнуть устоявшуюся догму, утверждающую, что человеческие нейроны не могут регенерировать. Однако доставка к нейрональным структурам больших белковых молекул нейротрофических факторов все еще остается труднопреодолимым с терапевтической точки зрения препятствием. В связи с этим открытие нейротрофических эффектов у отдельных нейропептидов, применяющихся в клинической практике, привлекло интерес исследователей и клиницистов к изучению их воздействия на патогенез как ишемических, так и дегенеративных повреждений головного мозга [33].

Целый ряд современных препаратов влияет на нейротрансмиссию. Так, значительный положительный эффект был получен при использовании FGF, GDGF, BDNF [20]. Таким образом, полученные на сегодняшний день результаты позволяют прийти к выводу, что концепция нейропластичности имеет огромное значение для понимания закономерностей протекания различных патологических процессов в центральной нервной системе, а также прогноза восстановления нарушенных функций. В этом направлении продолжаются активные исследования, касающиеся изучения эндогенных факторов, которые могут повышать нейрональную и глиальную активность, увеличивать продолжительность жизни клетки, стимулировать аксональный рост и развивать новые межнейрональные связи. Можно ожидать, что установление закономерностей развития нейропластичности и определяющих ее факторов 
позволит открыть дальнейшие перспективы разработки новых лекарственных препаратов.

Как уже отмечалось выше, процессы нейропластичности в ЦНС возникают на разных уровнях (молекулярном, клеточном, синаптическом, анатомическом - в последнем случае захватывая большие группы нейронов) не только в корковых отделах, но и в подкорковых структурах. При этом, помимо структурных изменений, отмечаются и динамические, последовательно сменяющие друг друга сдвиги функционального характера как в окружающей очаг повреждения зоне, так и на расстоянии от этого очага [10].

В основе преобразования интактной мозговой ткани при церебральных повреждениях лежат процессы деафферентации, нарушение равновесия между возбуждением и торможением, изменения возбудимости клеточных мембран, а также клиническое проявление существовавших до этого латентных связей и образования новых [29]. При этом в активации латентных связей ведущая роль отводится ГАМКергической системе [15]. Результаты экспериментальных исследований, основанных на ультраструктурных методиках, подтверждают наличие нейропластических изменений в виде увеличения плотности дендритов в корковых отделах при повторных двигательных заданиях в виде увеличения числа синапсов в моторной коре [49]. Имеет значение образование новых сосудов (ангиогенез) [53]. Разные отделы ЦНС обладают различным нейропластическим потенциалом. Так, кора головного мозга считается наиболее пластичной частью ЦНС, что обусловлено многообразием составляющих ее клеточных элементов и их связей. Имеет значение также и организация церебральных функций в коре, с одной стороны, строго локализованная в определенных зонах, с другой - «расширенная», богатая параллельными и реципрокными связями, зонами перекрытия [54]. Последнее характерно для таких функций, как внимание, сложные двигательные акты, гнозис, речь. И даже более просто организованные, на первый взгляд, структуры, как, например, пирамидный путь, оказываются весьма сложными по своей организации. В современных исследованиях показано, что помимо аксонов нейронов прецентральной извилины в пирамидный тракт входят аксоны нейронов премоторной, первичной сенсорной, теменной ассоциативной и дополнительной моторной коры, при этом от 10 до 30 \% волокон пирамидного пути проходят ипсилатерально [27, 35, 43, 52].

Концепция церебрального резерва. Области головного мозга с высоким потенциалом структурной нейропластичности развиваются у детей наиболее продолжительный период времени и эти же области наиболее подвержены изменениям при нейродегенеративных заболеваниях (болезни Альцгеймера) [48]. Однако барьером между прогрессирующим патологическим процессом или изменениями инволюционного характера - и их клинической реализацией является так называемый «церебральный резерв». Основными составляющими «церебрального резерва» являются количество клеточных элементов и церебральных путей, а также эффективность их функционирования, что, в частности, в условиях нормального старения сопровождается снижением риска развития деменции. 
Не менее важной является способность к компенсации нарушений на основе использования и формирования дополнительных путей и способов передачи сигнала. В частности, в восстановительном периоде инсульта происходит активация непораженного полушария головного мозга, подтверждением чему служат данные, полученные с помощью электрофизиологических, допплерографических и нейровизуализационных методов исследования. Было показано, что при попытке совершить движение паретичной конечностью у больных инсультом происходит активация сенсомоторной, премоторной и дополнительной моторной коры ипсилатерального полушария головного мозга [27].

Однако следует подчеркнуть неоднозначность прогностического значения этой активации. В частности, нередко отсутствует корреляция между выраженностью этой активации и благоприятным прогнозом. Активация коры ипсилатерального полушария головного мозга наиболее выражена в острейшую фазу инсульта, а затем она снижается; в ряде случаев наличие подобной активации связано с неблагоприятным прогнозом [27]. Подтверждением значимости церебрального резерва является снижение риска развития болезни Альцгеймера у лиц с высоким уровнем образования, значительной и постоянной познавательной активностью, а также большими размерами головного мозга $[18,36]$. Так, риск развития деменции в 4 раза выше у лиц с низким уровнем образования и небольшим размером головы [18].

В связи с этим следует заметить, что в основе возникновения болезни Альцгеймера у лиц пожилого и старческого возраста лежит не один, даже весьма значимый, фактор (например, отложение бета-амилоида), а комбинация факторов, в целом приводящих к комплексному нарушению функционирования ЦНС [18]. По данным патоморфологических исследований, у 18-65 \% лиц пожилого возраста без деменции выявляются изменения, соответствующие болезни Альцгеймера по широко используемым критериям CERAD [18].

Таким образом, клинически явными изменения головного мозга, обусловленные инволюционным или патологическим процессом, становятся по достижении морфологическими и функциональными сдвигами некоего порогового уровня. Вес головного мозга в среднем уменьшается на 2-3\% за десятилетие, начиная с 50 лет. У лиц пожилого возраста объем лобных долей уменьшен на $12 \%$, а височных - на $9 \%$ соответственно, при этом с возрастом объем теменных и затылочных долей уменьшается незначительно [18]. Имеются различия между полами в характере и степени атрофии лобных долей при старении [16]. Так, уменьшение объема лобных долей отмечается в основном у мужчин, у женщин при старении наиболее существенно уменьшается объем теменных долей. Результаты патоморфологических исследований свидетельствуют о том, что у взрослых уменьшение объема головного мозга за год составляет $0,32 \%$, при этом уменьшение объема височных долей за этот же срок достигает $0,68 \%$, а гиппокампа $0,82 \%$ [18]. Считается, что к 90 -летнему возрасту теряется примерно $10 \%$ 
из 20 миллиардов нейронов, так как у взрослого человека каждую секунду погибает 1 нейрон [18]. Помимо потери нейронов, при старении отмечаются изменения и «выживших" нейронов. В оставшихся нейронах происходит уменьшение объема перикариона и миелинизированных нервных волокон, а также значительная и относительно быстрая потеря синапсов. В настоящее время показано значение нарушений аксонального транспорта в генезе нейродегенеративных заболеваний. В основе этого лежат экспериментальные данные, полученные на модели трансгенных и мутантных животных, а также открытие мутаций двигательных протеинов при нейродегенеративных заболеваниях [44]. Нарушения модуляции и регуляции аксонального транспорта связывают с образованием патологических белков (белок-предшественник амилоида, тау, пресенилины и др.) [44]. Следует подчеркнуть наличие различий в подверженности тех или иных структур головного мозга обусловленным старением изменениям [40], что может быть связано с их селективной уязвимостью. Энторинальная кора и гиппокамп особенно подвержены подобным изменениям.

Восстановление двигательных функций после инсульта. Выделяют три уровня восстановления двигательных функций после инсульта [6]. Первым из них является истинное восстановление - возвращение нарушенных двигательных функций к исходному уровню. Оно возможно при отсутствии гибели нейронов, когда патологический очаг состоит преимущественно из инактивированных вследствие отека, гипоксии и диашиза клеток. Второй уровень восстановления - компенсация, основной механизм которой заключается в функциональной перестройке и вовлечении новых, ранее незадействованных структур. Третий уровень - реадаптация, или приспособление к имеющемуся дефекту [6]. Исследования, проведенные спустя 6-12 месяцев после перенесенного инсульта показывают, что в большинстве случаев спонтанного восстановления отмечается улучшение двигательных функций в виде увеличения независимости пациентов при передвижении и поддержании равновесия. При этом иных видимых улучшений в неврологическом статусе может и не быть, а сам больной адаптируется к имеющемуся дефекту [7]. $\kappa$ неблагоприятным факторам восстановления двигательных функций относят значительные размеры очага $[6,50]$, пожилой возраст (старше 65 , а особенно старше 80 лет) [6, 41], наличие когнитивных и эмоциональных нарушений $[5,6,41]$, тяжелый неврологический дефицит в острую фазу инсульта [50] и задержку с началом реабилитационных мероприятий [5]. В течение первых 2 месяцев после инсульта возможно развитие артропатий, значительно ухудшающих прогноз [6]. Показателями неблагоприятного восстановления ходьбы после перенесенного инсульта является наличие контрактур у пациента уже в остром периоде инсульта и гипермобильность в крупных суставах паретичной ноги [7], а также и в здоровой ноге [1]. Восстановление движений в паретичных конечностях может начаться уже в первые дни после инсульта, чаще через 1-2 недели. Восстановление движений (объем, сила) происходит в основном в первые 3-6 месяцев. Восстановление сложных двигательных навыков может продолжаться до нескольких лет [6]. «Pusher» - синдром, 
характеризующийся изменением восприятия тела в отношении гравитации и проявляющийся тем, что пациент при стоянии, ходьбе, и даже сидя, отталкивается непаретичными рукой и ногой, что не позволяет опираться на «здоровую» сторону и приводит к значительному ухудшению равновесия. При благоприятном исходе «pusher»-синдром регрессирует в течение 6 месяцев. По некоторым данным, «pusher»-синдром замедляет, но не ухудшает, восстановление статолокомоторных функций [17]. Было показано отсутствие тесной зависимости восстановления двигательных функций и регресса «pusher»-синдрома, однако при этом найдена связь данного синдрома с синдромом игнорирования [17]. У больных с поражением правого полушария головного мозга чаще отмечается более позднее функциональное восстановление по сравнению с больными с левосторонней локализацией очага - из-за более выраженного постурального дефекта $[12,45]$. Наличие синдрома игнорирования также замедляет восстановление статолокомоторных функций [41]. Сам по себе период восстановления может занимать от нескольких месяцев до нескольких лет [37, 39]. Наиболее активное восстановление двигательных функций происходит в первые 3 месяца, а функциональное улучшение продолжается до 6-12 месяцев [5]. Существует точка зрения, что также может использоваться раннее начало тренировки ходьбы - без ожидания восстановления поддержания равновесия при стоянии, учитывая различия в системах регуляции контроля ходьбы и инициации движения [31]. Считается, что реабилитационные мероприятия могут быть эффективны у 80 \% лиц, перенесших инсульт (10 \% имеют самопроизвольное двигательное восстановление, а у $10 \%$ реабилитационные мероприятия бесперспективны) [5].

Вместе с тем следует отметить и возможное неблагоприятное влияние на процесс восстановления чрезмерно активной реабилитации в раннем периоде инсульта или черепно-мозговой травмы [5, 22]. Так, форсированная нагрузка на паретичную конечность в течение первых 7-14 дней от начала развития инсульта может приводить к задержке восстановления двигательных функций и увеличению очага поражения [22]. В основе неблагоприятного влияния такой активной реабилитации на процесс восстановления может лежать дополнительный выброс глутамата и катехоламинов, гипервозбудимость нейронов в перифокальной зоне, а также нарушение баланса между процессами возбуждения и торможения [28]. После стабилизации повреждения увеличение нагрузки на пораженную конечность приводит к лучшему восстановлению утраченных функций, что в определенной мере может быть обусловлено активацией синаптогенеза. Замедляют процессы восстановления после инсульта агонисты ГАМКергических рецепторов (в частности - бензодиазепиновые производные) и некоторые антиконвульсанты (фенитоин, фенобарбитал) $[5,24]$. 


\section{5. РОЛЬ ЭСТРОГЕНОВ В РЕАЛИЗАЦИИ ЭНДОГЕННОЙ НЕЙРОПРОТЕКЦИИ. ТАМОКСИФЕН}

Несмотря на бурное развитие эндокринологии на протяжении последних 50 лет, пересмотр патофизиологических и биохимических основ развития многих патологических процессов в организме человека, до сих пор не получило широкого распространения и, соответственно, признания, предположение о влиянии гипоталамо-гипофизарных изменений на этиопатогенез многих нейродеструктивных заболеваний. В последнее время интерес клиницистов, фармакологов и физиологов вызывают механизмы нейропротективного действия эстрогенов [1-4]. Природными половыми стероидными гормонами являются эстрогены, гестагены и андрогены. Доказано, что первой ступенью их действия является взаимосвязь со специфическими рецепторами в цитоплазме клеток органов-мишеней. И хотя для всех классов стероидных гормонов найдены специфические рецепторы, каждый стероидный гормон может реагировать с рецепторами других классов стероидов. Между членами различных классов стероидов существуют очень незначительные химические различия и, в определенных условиях, организм может превращать один тип стероидов в другой. Такая взаимозаменяемость и разнонаправленность действия стероидов обусловлена их биологической значимостью и объясняет наличие всех трех видов половых стероидов (эстрогенов, гестагенов, андрогенов) во всех организмах, независимо от половой принадлежности.

Этапы биологического действия половых стероидов представляются следующим образом: воздействие гормона на рецептор и образование комплекса рецептор - гормон. В последующем комплекс транспортируется из цитоплазмы в ядро и вызывает синтез специфических белков, определяющих физиологический ответ клетки с последующим каскадом различных метаболических процессов в клетке.

Фармакодинамические эффекты половых стероидных гормонов разнообразны, что требует их отдельного рассмотрения. Самый большой класс половых стероидов - это эстрогены. Выделяют естественные эстрогены, синтетические эстрогены, фитоэстрогены и ксеноэстрогены. Естественные эстрогены представлены такими соединениями, как эстрон, эстрадиол, эстриол, которые имеются у человека и у животных и обеспечивают всю гамму физиологических воздействий. Синтетические эстрогены - это искусственно созданные соединения, в основном лекарственные препараты, с целью имитации физиологического действия гормонов при их недостатке в организме или необходимости избыточного, подавляющего действия. Фитоэстрогены - это химические вещества, выделенные из растений (изофлавоны, уместаны, лигнаны), обладающие эстрогеноподобной активностью вследствие их структурной схожести с эстрогенами человека и обладающие сродством с бета-эстрогеновыми рецепторами. Фитоэстрогены содержатся во многих пищевых продуктах и растениях, таких как бобы, зерно, орехи, фрукты, красный клевер, соя, цимицифуга. Wuttke W. (1998) отмечает, что корень цимицифуги содержит фракции, способные связываться с эстрогенными рецепторами и, по типу обратной отрицательной связи, 
тормозить циклическое выделение лютеинизирующего гормона. Экстракт корня цимицифуги вызывает экспрессию эстрогенных рецепторов в преоптическом ядре гипоталамуса, не действуя на матку. Фитоэстрогены считаются естественными селективными модуляторами эстрогеновых рецепторов, действующими как агонисты эстрогенов на сердечно-сосудистую систему, кости, мозг и как антиэстрогены - на молочную железу и матку. Ксеноэстрогены - это химические вещества с эстрогеноподобными свойствами, находящиеся в окружающей среде (лаки, краски, пестициды, некоторые виды косметической продукции и т. д.). Они конкурируют с натуральными эстрогенами за эстрогеновые рецепторы в различных тканях и органах, но оказывают, чаще всего, токсическое или онкогенное действие. Основное действие эстрогенов - это стимуляция роста клеток. Они обуславливают последовательные процессы: пролиферацию, гиперплазию и, при длительном и неконтролируемом поступлении, неоплазию [404]. Дефицит эстрогенов обуславливает снижение синтеза структурных протеинов - коллагена. Гипоэстрогения - одна из наиболее частых причин поражения кожи и ее придатков и проявляется в виде сухости, ломкости ногтей, появлении морщин, сухости и выпадения волос. Даже небольшой дефицит эстрогенов вызывает потерю коллагена из дермиса, соединительной ткани. Постепенно развивается старение кожи, образование морщин, развивается уретральный синдром.

В настоящее время проведены исследования, которые не только показали значение половых стероидов для метаболизма кожи, коллагена, но и доказали значимость заместительной гормонотерапии в предупреждении и лечении пролежней и трофических язв голеней. Даже изменение голоса, которое чаще развивается на пятом жизненном десятилетии, связывают с нарушением продукции половых стероидов. Изменение эластичности и трофики слизистых оболочек, мышц, хрящей, связанных с формированием голоса, объясняют снижением уровня эстрогенов и нарушением их соотношения с андрогенами. В литературе имеются данные о различных клинических проявлениях недостаточности половых стероидов. Так, выделяют: невротический вариант, с преобладанием психоневротических или вегетативно-невротических проявлений; вегетативнососудистый (с преимущественно вазомоторными реакциями и колебаниями артериального давления); кардиальный; метаболический, с наклонностью к ожирению, сахарному диабету, подагре, атеросклерозу. В последние годы выделяют артропатический синдром, при котором недостаток эстрогенов влечет за собой дегенеративные изменения суставных хрящей (артропатии), межпозвонковых дисков, нарушение структуры костной ткани - остеопороз. Появление психоэмоциональных нарушений объясняется тем, что эстрогены способствуют повышению синтеза ацетилхолина, следовательно - способствуют улучшению памяти, а при их дефиците память ухудшается. Они уменьшают активность МАО, следовательно - снижают депрессивное состояние. Дефицит эстрогенов ведет не только к развитию депрессии, но и к недостаточной выработке центрального нейротрансмиттера серотонина, что нарушает глубокий сон. $K$ тому же нарушается и сновидение (REM-сон), так как норадреналин, являющийся центральным нейротрансмиттером, очень быстро метаболизируется в условиях 
гипоэстрогении. Психические изменения вызываются не только нарушениями сна, но и снижением уровня $\beta$-эндорфина в отсутствие эстрогенов. Кроме того, эстрогены вызывают отщепление $\beta$-эндорфина от проопиомеланокортина и способствуют образованию серотонина и мелатонина. Серотонин является гормоном хорошего настроения, а мелатонин - онкопротектором. Таким образом, при развитии состояния гипоэстрогении нарушается как качество жизни, так и возникает угроза самой жизни. M. Stomati, C. Bersi и др. (1998) указывают, что снижение уровня половых стероидов в климактерии приводит к снижению концентрации $\beta$-эндорфина в плазме крови из-за нарушений в центральных нейроэндокринных системах. R. Roland, D. Sc. Tremlay (1998) полагают, что состояние гипоандрогении у мужчин характеризуется снижением ментальной и физической энергии, появлением чувства недомогания, нарушает качество жизни, что требует обязательной медикаментозной коррекции. Предложена специальная шкала для оценки степени выраженности климактерического гипоандрогенного состояния у мужчин. Другие исследователи также отмечают позитивное влияние андрогенов на деятельность мозга и состояние ментальных функций, причем как у мужчин, так и у женщин. Рецепторы к эстрогенам содержатся практически во всех структурах мозга, но больше всего их обнаружено в височной доле, гипоталамусе, базальном forebrain гиппокампа, caudate, putamen, mid-brain raphe, brainstem. Поскольку количественное содержание эстрогенов и андрогенов у женщин и у мужчин различно, то не удивительно, что существуют половые различия и в психопатологии. Так, широкомасштабное исследование, проведенное в Европе, показало, что в возрасте 90 лет болезнь Альцгеймера встречается с частотой 81,7 на 1000 человеко-лет у женщин и 24,0 - у мужчин. Общий риск заболеть болезнью Альцгеймера к 95 годам для 65-летней женщины составляет - 0,22, по сравнению с 0,09 у мужчин. Эти данные подтверждены и японскими исследователями, которые определили, что риск для женщин составляет 10,9, а для мужчин - 5,1. Многие авторы считают, что резкое снижение уровня эстрогенов в менопаузе, вследствие прекращения работы яичников, является интерактивным фактором риска развития психопатологии. Так, снижение, с возрастом, продукции эстрогенов ведет к нарушению процесса восприятия и чувствительности нервных клеток, особенно выраженное в поздней менопаузе и герипаузе. Ухудшается вербальная память, абстрактное восприятие, усвоение новой информации, нарушается визуальная память. Считают, что такие неврологические расстройства, как возрастное снижение памяти, болезнь Альцгеймера, эпилепсия, мигренеподобные головные боли, менингиома, рассеянный склероз, болезнь Паркинсона, расстройства сна и инсульт являются эстрогенозависимыми состояниями. Меньший риск развития заболеваний у мужчин объясняется тем, что даже у пожилых мужчин яички продолжают выделять тестостерон, который в процессе ароматизации превращается в эстрадиол, необходимый для деятельности мозга. Проведенные исследования свидетельствуют об эффективности гормональной терапии и при болезни Паркинсона, и при болезни Альцгеймера, и даже после перенесенного инсульта. Хотя, нужно отметить, что улучшение гормонального гомеостаза может быть обеспечено не только проведением заместительной гормонотерапии, 
но и использованием метаболиков, антигипоксантов и ноотропов.

Состояние центральной нервной системы и ментальных способностей у мужчин и женщин также различается. Так, как правило, у мужчин лучше развито пространственное восприятие и математическое мышление, у женщин - вербальный интеллект. Это объясняют половыми различиями кровоснабжения и метаболизма ЦНС: у мужчин они выше в темпоральной области, лимбической системе и гиппокампе, а у женщин - в таламусе и в поясной извилине. Доказано, что эстрогены усиливают церебральный и мозжечковый кровоток. Снижение с возрастом эстрогенной насыщенности, особо выраженное у женщин, ведет к тому, что на фоне снижения кровотока у женщин к 50 годам уменьшается количество клеток в преоптической области и развивается дисморфизм ядер. У мужчин редукция клеток выражена значительно меньше. К 80-100 годам, в случае отсутствия коррекции, развивается драматическое уменьшение количества клеток и манифестное течение психопатологических заболеваний, особо выраженное при наличии генетической предрасположенности. Проведение гормонотерапии ведет к ослаблению проявлений нарушений памяти, когнитивной дисфункции и даже к обратному развитию заболевания, что подтверждено электрофизиологическими методами исследования и магнитно-резонансной томографией.

Половые стероиды оказывают еще ряд опосредованных воздействий, среди которых наиболее значимым является влияние на состояние сердечнососудистой системы. Выделяют три основных группы механизмов, участвующих в реализации действия эстрогенов на сердечно-сосудистую систему:

а) влияющие на липидный обмен;

б) связанные с непосредственным влиянием на сосудистую стенку и активность эндогенных вазоактивных веществ;

в) опосредованные сосудистые эффекты.

Что касается действия на липидный обмен, то в настоящее время доказано, что эстрогены способствуют снижению уровня холестерина и липопротеинов низкой плотности, повышают уровень липопротеинов высокой плотности, тем самым снижая коэффициент атерогенности в организме. Эстрогены являются активными антиоксидантами в отношении липидов, окисленные формы которых ингибируют NO. M. Gelfand и соавт. (1997) отмечают, что дефицит эстрогенов в постменопаузе приводит к изменениям концентрации липидов в плазме крови: росту уровней атерогенных липопротеидов низкой плотности (ХС-ЛПНП) и снижению уровней липопротеидов высокой плотности (ХCЛПВП), что предопределяет частоту сердечно-сосудистых заболеваний в пожилом возрасте. Е. М. Aygen и соавт. (1999) считают, что атеросклеротические изменения в организме женщины становятся значимыми через 5 лет после удаления яичников, а ИБС может развиться через 10 лет после операции. Раннее назначение эстроген-заместительной терапии может предупредить и нивелировать нарушения липидного спектра крови, которые возникают уже через 3 месяца после хирургической менопаузы. Многие авторы не только подтверждают наличие взаимосвязи между атеросклеротическими изменениями в менопаузе и развитием заболеваний сердца и сосудов, но и обосновывают необходимость 
индивидуально подобранной, обоснованной заместительной гормонотерапии. Относительно влияния эстрогенов на сосудистую стенку существуют данные, что эстрогены обладают прямым вазодилатирующим действием и способны увеличивать эндотелийзависимое расширение коронарных артерий. Эти данные согласуются с исследованиями других авторов, подтверждающими эффект эстрадиола и андрогенов в предупреждении развития сердечно-сосудистых заболеваний. Кроме того, убедительно доказано влияние эстрогенов на толщину сосудистой стенки (особенно интимы), в том числе и на толщину общей сонной артерии.

E. Cicinelli и др. отмечают высокую эффективность эстрадиола в отношении повышения уровня NO. Они наблюдали максимальное значение NO в середине менструального цикла, на фоне пикового содержания эстрадиола. В пременопаузе и постменопаузе пероральное введение эстрадиола восстанавливает продукцию NO. Авторы объясняют кардиопротективное действие заместительной гормонотерапии именно изменением метаболизма NO, который непосредственно участвует в релаксации сосудов.

F. Facchinetti и соавт. отмечают, что NO синтезируется из L-аргинина и непосредственно участвует в процессах вазодилатации, регуляции адгезии и агрегации тромбоцитов, подавления пролиферации гладкомышечных клеток. В свою очередь, метаболизм L-аргинина-NO связан с влиянием эстрогенов. Авторы доказали, что после введения эстрадиола в крови достоверно увеличивается уровень нитритов/нитратов. При приеме эстрадиола среднее диастолическое давление достоверно ниже, чем при приеме плацебо $(\mathrm{p}<0,05)$. А наиболее выраженный эффект наблюдается в ночное время, когда максимально снижается и систолическое, и диастолическое давление $(p<0,01)$ по сравнению с приемом плацебо.

Таким образом, результаты исследований свидетельствуют, что эстрогены вызывают увеличение количества NO в клетках эндотелия, который, наряду с влиянием на тонус сосудистой мускулатуры, замедляет развитие атеромы за счет ингибирования пролиферации гладкомышечных клеток и одновременной стимуляции пролиферации эндотелиальных клеток. Терапия эстрогенами в течение 6 месяцев уменьшала площадь атерогенных бляшек в два раза.

Еще целый ряд авторов считает, что эстрогены снижают резистентность сосудистого кровотока, повышают индекс резистентности и индекс пульсации сосудов, увеличивают секрецию простациклина, снижают выработку тромбоксана, проявляют эффект антагониста кальция, повышают содержание релаксирующего фактора эндотелия. Протекторное действие эстрогенов на стенки сосудов объясняется тем, что дефицит эстрогенов вызывает повышение синтеза эндотелина. Это, в свою очередь, влечет повышение сопротивляемости сосудов и развитие, в конечном итоге, гипертензии. Развитию гипертензии способствует также нарушение соотношения адреналина и норадреналина, которое развивается на фоне гипоэстрогении. Доказано, что скорость кровотока и сопротивление в средней мозговой артерии коррелируют с уровнем эстрогенов в плазме крови. Указанные изменения связаны с дилатацией микрососудов дистальных артерий. Не подвергается сомнению в настоящее время факт наличия рецепто- 
ров эстрогенов в коронарных артериях. Считают, что состояние гипоэстрогении вызывает снижение артериального пульсового индекса в артерии матки, в каротидной артерии, a. brachialis и даже в центральной глазничной артерии. Терапия эстрогенами вызывает снижение сопротивления внутренней каротидной артерии и средних мозговых артерий, повышает пульсовой индекс, что свидетельствует об увеличении эластичности артерий.

T. Beljic и соавт. проводили исследования по изучению функции сердца у женщин в постменопаузе на фоне заместительной терапии эстрогенами. В целом заместительная гормонотерапия улучшает функцию сердца в постменопаузе. При гипоэстрогенном состоянии ослабляется формирование простациклина эндотелиальными клетками артерий и в сосудистой стенке преобладает действие тромбоксана, стимулирующее агрегацию тромбоцитов. Эстрогены влияют и на гемодинамику мозга. Так в репродуктивном периоде гемодинамика мозга имеет четкие половые различия: у женщин мозговой кровоток выше, чем у мужчин того же возраста. Во время беременности, сопровождающейся существенным повышением уровня эндогенных эстрогенов, мозговой кровоток также повышается. В пожилом и старческом возрасте, когда уровень половых стероидов резко снижается, принципиальных отличий в состоянии гемодинамики мозга у мужчин и женщин не наблюдается. В то же время, академик А. П. Нестеров (2003) отмечает, что «нарушения регуляции кровообращения в структурах головного мозга являются факторами риска возникновения и развития глаукомы». Многие авторы убедительно доказали наличие взаимосвязи между дефицитом половых стероидов, атеросклерозом и острым коронарным синдромом. Эстрогены являются антагонистами кортизола. Дефицит эстрогенов ведет к нарастанию катаболических процессов, глюконеогенеза, прогрессированию гиперинсулинемии. Поэтому у женщин диабет является более значительным фактором риска фатальной ишемии сердца, чем у мужчин. На фоне атрофических и фоновых процессов в поджелудочной железе дефицит эстрогенов провоцирует развитие недостаточности инсулина и сахарного диабета 2 типа.

Дефицит эстрогенов ведет также к увеличению массы тела, развитию ожирения. При отсутствии эстрогенов андрогены индуцируют резистентность тканей к действию инсулина, что ведет к развитию гиперинсулинемии.

Таким образом, еще одним вариантом гипоэстрогенного состояния является метаболический, проявляющийся нарастанием избыточной массы тела, вплоть до развития ожирения и (или) неполной (полной) формы метаболического синдрома - синдрома Х. Ведущим в этиологии метаболического синдрома является дефицит половых гормонов. Основные его проявления: увеличение массы тела с развитием абдоминального ожирения, инсулинорезистентность, гиперинсулинемия и дислипопротеинемия. Перераспределение жира по андроидному или гиноидному типу зависит от соотношения эстрогенов и андрогенов в организме. Зависимость морфоструктуры тела человека от половых стероидов настолько велика, что некоторые исследователи используют терапию андрогенами у мужчин или производными тестостерона, сочетанием андрогенов с эстрогенами у женщин для снижения общей массы тела и пере- 
распределения жира. Гипоэстрогения обуславливает снижение синтеза глобулина, связывающего половые стероиды (SHBG) и, тем самым, повышает уровень свободных, биологически активных андрогенов. Это очень четко прослеживается между пятым и шестым десятком жизни, когда на фоне инволютивной гипоэстрогении возрастает уровень тестостерона. Многие авторы считают, что, хотя на уровень андрогенов существенное влияние оказывают образ жизни, физические нагрузки, особенности диеты, - тем не менее в постменопаузе отмечается компенсаторное усиление внегонадного синтеза андрогенов у женщин, поскольку именно они обеспечивают эстрогенный статус после инволюции или удаления гонад. Дефицит половых стероидов (эстрогенов, андрогенов, прогестерона) является важнейшей причиной резорбции костной ткани, а их уровень достоверно коррелирует с концентрацией биохимических маркеров костного ремоделирования. И, наконец, эстрогены оказывают защитное действие против старения, обусловленное их антиапоптозным эффектом. Половые стероиды представляют собой антиапоптозный сигнал для клеток эпителия, глиальных и нервных клеток. J. Nilsen, R. Brinton (2003) и другие исследователи отмечают выраженное нейропротекторное действие эстрогенов, которые защищают нейроны от нарушений кальциевого гомеостаза. Именно эстрадиол индуцирует смягчающее действие кальция при воздействии глутамата и $\beta$-амилоида на гиппокампальные и кортикальные нейроны. Хирургическая менопауза ведет к повреждению нейрональной ткани и инициирует каскад повреждающих действий, результатом которых является ускоренное старение мозга, ухудшение памяти и более раннее проявление нейродегенеративных заболеваний. Однако нейроны представляют собой только одну десятую часть клеток мозга. В подавляющем большинстве остальные клетки представлены глией. Оказалось, что активность и функция макроглии, микроглии, астроцитов находится под непосредственным контролем эстрогенов. Механизм такого регуляторного и нейропротекторного действия эстрогенов до настоящего времени не совсем ясен. Считают, что их действие обусловлено многоплановыми эффектами, такими как антиоксидантное воздействие, регуляция цитокинов, хемокинов и факторов роста, влияние на иммунные клетки и процесс апоптоза. В экспериментальных исследованиях показано, что эстрогены стимулируют удлинение аксонов, рост дендритических отростков, синаптогенез - основные элементы, необходимые для обучения и функции памяти. Работами Н. Нonjo, T. Tamura, E. Matsumoto доказано, что эстрогены являются факторами роста для клеток центральной нервной системы, а терапия эстрогенами способствует развитию позитивных ацетилхолинэстеразных базальных нейронов. При учете этих данных уже не вызывает удивления тот факт, что проведение заместительной гормонотерапии значительно улучшает состояние когнитивной функции, восстанавливает память и улучшает течение всех нервных процессов. Несмотря на то, что эстрогены считаются «женскими» гормонами, их биологическая роль в мужском организме несомненна и обусловлена всеми вышеперечисленными метаболическими влияниями. Taк, van den Beld A.V. и coавт. (1998), обследовав 403 здоровых мужчин в возрасте от 73 до 94 лет, пришли к заключению, что эстрадиол является независимой детерминантой качества 
жизни и физического состояния. Уровень эстрадиола у мужчин с возрастом значительно снижается. При оценке качества жизни мужчин в баллах оказалось, что при низкой балльной оценке уровень эстрадиола на 18,4 \% ниже показателей этого гормона при высоких баллах шкалы оценки качества жизни. Концентрация же тестостерона коррелировала с мышечной силой и общей минеральной плотностью костной массы. Андропауза, или мужской климактерий, по данным M. Carruters (1998), является одним из наиболее часто встречающихся симптомов старения мужчин [295]. Считают, что основной причиной этой патологии, изучаемой уже более 50 лет, является гипоандрогения. Поэтому важной составной частью профилактической медицины у пожилых мужчин должна стать заместительная гормонотерапия тестостероном. Все эти данные убедительно свидетельствуют о разностороннем метаболическом действии половых стероидов, которое обеспечивает (прямо или косвенно) течение практически всех биохимических процессов в организме, отражается на состоянии всех видов тканей и обеспечивает физиологическое функционирование почти всех органов и систем. Попытки использовать половые гормоны в лечении инволюционных заболеваний глаз проводились еще в 60-80 гг. прошлого столетия. Однако существовавшие в то время лекарственные препараты обладали большим количеством побочных эффектов, поэтому данный вид терапии не получил широкого распространения. На современном этапе развития у пациентов и у врачей, особенно с низким уровнем знаний и аналитических возможностей, все еще остается предубеждение против использования заместительной гонадной терапии. Парадоксом является то, что терапия гормонами коры надпочечников и их аналогами, вызывающая значительные сдвиги как в общей гормональной системе, в том числе и половой, так и в иммунной системе, используется широко, бесконтрольно, а зачастую - даже без рекомендаций врача.

Учитывая важнейшую роль половых стероидов в состоянии соединительной ткани J. С. Huber (1998) выступил инициатором нового направления в медицине - «эстетической эндокринологии». Указывая на очевидную необходимость андрогенов для поддержания архитектоники соединительной ткани, он подчеркивает возможность их местного использования в целях замедления и прекращения прогрессирующего ослабления тургора соединительной ткани. J. C. Huber также отмечает, что в процессах старения соединительной ткани, кожи важная роль принадлежит не только эстрогенам (их значение уже не ставится под сомнение), но и прогестерону. Способность прогестерона ингибировать металлопротеинкиназу создает возможность предотвратить появление дряблости, складок и морщин на коже. При этом особое внимание уделяется возможности местного использования препаратов прогестерона. Многоцентровое исследование 188 здоровых женщин в постменопаузе с интактной маткой в возрасте от 40 до 65 лет показало, что на фоне приема заместительной гормонотерапии в течение года средние уровни холестерина и ХС-ЛПНП снизились у всех обследованных женщин (в среднем на 5 \% и 20 \% соответственно), a ХС-ЛПВП повысились на $20 \%(\mathrm{p}<0,01)$. W. M. Baal и соавт. (1998) отмечают положительное влияние циклической комбинированной заместительной 
гормонотерапии на показатели функции эндотелия даже у здоровых женщин в постменопаузе. Авторы обследовали 27 здоровых женщин в возрасте $52 \pm 3$ года в течение 15 месяцев. Оказалось, что концентрация фактора Виллебрандта снизилась на $22 \%$, уровень тромбомодулина - на $29 \%$, эндотелина-1 на $17 \%$, концентрация фибриногена - на 4 \% . В целом, влияние эстрогенов на поддержание стабильности артериального давления объясняется следующим образом: они обладают свойствами антагониста кальция, снижают уровень эндотелина, повышают уровень простациклина и уменьшают периферическое сопротивление сосудов. Определенное влияние оказывает и уровень прогестерона. Прогестины влияют на тонус артериол подобно антагонистам кальция, блокируя кальциевые каналы и препятствуя входу ионов Са в гладкомышечные клетки. Такое многокомпонентное действие и объясняет значение уровня половых стероидов в поддержании нормотензии индивидуума. Защитное действие эстрогенов от токсических воздействий, окислительного стресса и повреждений нервных клеток помогает снизить число нейродегенеративных заболеваний, в том числе и паркинсонизма, и болезни Альцгеймера. Считают, что риск развития болезни Альцгеймера снижается на 40-60\% при использовании в менопаузе эстрогенов и совершенно четко доказано, что эстрогены останавливают прогрессирование этого заболевания.

Широко известно, что прямое воздействие эстрогенов на органы и ткани обеспечивается рецепторно-опосредованным путем. В настоящее время отчетливо идентифицируются различные рецепторы эстрогенов (ER- $\alpha, \mathrm{ER}-\beta)$, которые локализуются в различных органах и тканях. Taк, ER- $\alpha$ - преимущественно в яичниках, матке, печени, почках, надпочечниках, макрофагах, CD8-T-лимфоцитах (супрессоры), вентромедиальных и аркуатных ядрах гипоталамуса. ER- $\beta$ - в супраоптических и паравентрикулярных ядрах гипоталамуса, гиппокампе в области полей CA1 и САЗ, зубчатой извилине, неокортексе, базальных ядрах, обонятельных луковицах, ядре-ложе терминальной полоски, шве среднего мозга, мозжечке, а также в легких, кишечнике, мочевом пузыре, лимфоидной ткани, жировой ткани [5-7].

Локализация большого количества $\beta$-эстрогеновых рецепторов в головном мозге свидетельствует об их значительной роли в функционировании нервных клеток и, как следствие, в осуществлении высших мозговых функций и регуляции жизнедеятельности всего организма, что обуславливает поиск перспективных нейропротекторов среди модуляторов $\beta$-эстрогеновых рецепторов. Ранними экспериментальными работами как отечественных, так и зарубежных авторов показано, что эстрогены проявляют нейропротективную активность при различных патологиях ЦНС. Однако известно, что эстроген имеет нежелательные стимулирующие эффекты на молочные железы и матку, которые ставят вопрос об увеличенном риске развития раковых образований молочной железы и матки, кроме того, эстроген проявляет и гормональную активность, что ограничивает его применение у мужчин. Эти потенциальные ограничения применения эстрогенов стимулировали интерес к исследованию и терапевтическому использованию нестероидных селективных модуляторов рецепторов эстрогена в качестве нейропротекторов [8-11]. 
В настоящее время появились препараты нового поколения, которые, не являясь непосредственно гормонами, тем не менее, оказывают избирательное гормоноподобное действие на специфические гормонорецепторы. Это класс селективных эстроген-рецепторных модуляторов (CЭPM или STEAR), обладающих тканеспецифическим механизмом действия. Эти препараты, оказывая уникальное эстрогеноподобное тканеспецифическое действие на костную, сердечно-сосудистую, нервную и другие системы, обладают преимущественно антиэстрогенным эффектом на молочные железы и матку, сводя к минимуму риск побочных эффектов. Доказано, что применение данных препаратов оказывает нейропротекторное действие, предупреждает развитие старческого слабоумия на 35-40 \% , снижает риск развития возрастных депрессий, предупреждает развитие остеопороза, замедляет развитие атеросклероза и предупреждает развитие ишемической болезни сердца, оказывая антиатерогенное действие.

Тамоксифен - это синтетический модулятор эстрогеновых рецепторов (группа СЭРМ), действие которого объясняется сочетанием трех различных механизмов. Прежде всего, действие препарата основано на тканеспецифическом эстрогеноподобном метаболизме стероидов. Вторым направлением является регуляция функции ферментов за счет ингибирования активности сульфатазы, замедления превращения неактивного эстрона в активный эстрадиол. Последний обладает онкогенным действием на клетки молочной железы и эндометрия в постменопаузальном периоде и снижение его уровня является важным достоинством Тамоксифена. И третье направление его действия - это активация рецепторов прогестерона с локальным образованием прогестагенного метаболита, обеспечивающего апоптоз опухолевых клеток молочной железы и эндометрия.

Тамоксифен с успехом был применен у женщин с артериальной гипертензией в возрасте 50-60 лет и старше, доказано его положительное влияние на центральную и периферическую гемодинамику, липидный спектр крови, тонус сосудов, функцию вегетативной нервной системы.

Фундаментальное исследование по влиянию Тамоксифена на сердечнососудистую систему было проведено в Великобритании в 2001 г., доложено и обсуждено на заседании Европейского общества кардиологов. Были представлены убедительные данные, свидетельствующие о многочисленных положительных воздействиях Тамоксифена на сердечно-сосудистую систему. Доказано, что Тамоксифен увеличивает фибринолиз без какого-либо существенного воздействия на показатели коагуляции, стимулирует сердечный выброс, скорость кровотока, релаксацию сосудов и при этом не влияет на метаболизм глюкозы и инсулина. Несомненным достоинством препарата является также его способность уменьшать уровень холестерина в организме и нормализовать липидный обмен, а также оказывать эстрогеноподобное влияние на слизистую и коллаген. Это препарат выбора у пациентов с онкогинекологическим анамнезом.

С помощью рентгеноструктурного анализа белков-адаптеров, связанных с комплексом «Тамоксифен + ЭР», удалось получить новую информацию о механизме действия этого препарата. Оказалось, что боковая цепь Тамоксифена находится вне пределов лиганд-связывающей области, в результате чего эта 
цепь переносится в положение, где связывающий участок коактиватора недоступен. Как следствие, комплекс «Тамоксифен + ЭР» еще может димеризоваться, но это событие не сопровождается серией белок-белковых взаимодействий, необходимых для инициации AF-2 - лиганд-зависимой С-концевой области. Таким образом, в основе смешанной агонист-антагонистической активности Тамоксифена лежат белок-белковые взаимодействия ЭР. Кроме того, связывание антагониста с ЭР предотвращает взаимодействие AF-2 с аппаратом транскрипции, но AF-1 аминотерминальной области рецептора остается свободным, что позволяет ЭР, будучи связанным с эстроген-чувствительным элементом ДНК, взаимодействовать с факторами транскрипции и осуществлять транскрипцию конкретных генов [5].

Известно также, что Тамоксифен проявляет агонист/антагонистическую активность в зависимости от дозы в отношении $\alpha$-ЭР и $\beta$-ЭР $[5,12,13]$.

В связи с вышеизложенными обстоятельствами, нами была проведена оценка нейропротективной активности Тамоксифена в опытах in vitro (суспензия выделенных нейронов), а также в условиях моделирования острого нарушения мозгового кровообращения по типу ишемического инсульта.

В ходе экспериментальных исследований установлено, что внесение в суспензию выделенных нейронов с добавлением избытка глутамата (100 мкM) Тамоксифена в концентрациях 0,1 мкМ и 10 мкМ приводило к достоверному снижению количества клеток с признаками некроза. Увеличение концентрации в суспезии Тамоксифена до 100 мкM приводило к исчезновению нейропротективного эффекта препарата, что связано, по нашему мнению и данным других исследований, с тем, что эффект агонист/антагонист в отношении $\beta$-ER зависит от концентрации препарата (табл. 2.4; рис. 2.13) [5, 7].

Механизм действия Тамоксифена в исследованиях in vitro объясняется, по нашему мнению, ограничением трансмиттерного аутокоидоза через усиление аффинности ГАМК-рецепторов. Это подтверждается и исследованиями зарубежных авторов, где высказывается предположение о доминировании в нейропротективном механизме действия эксайтотоксичной линии воздействия эстрогенов на секрецию глутамата и функционирование глутаматных рецепторов. В частности, происходит снижение гипервозбудимости за счет усиления аффинности ГАМК-рецепторов [23]. Кроме того, эстрогены уменьшают проявления нейропротивовоспаления за счет снижения уровня глутамата, который, в свою очередь, способен активировать транскрипционный фактор NF-kappaB, ответственный за усиление синтеза провоспалительных цитокинов [24]. Есть прямые экспериментальные данные - эстрогены предотвращают вызываемую агонистами глутаминовых рецепторов и нейротоксинами LPS (токсины граммположительных бактерий) гибель клеток в культурах глии и нейронов [25]. Модуляторы эстрогеновых рецепторов (только $17 \beta$-estradiol, $17 \alpha$-estradiol не работает) прерывают трансдукцию сигнала LPS от плазматической мембраны к внутриклеточным әффекторам и цитоскелету, а эстрогеновый рецептор ER- $\alpha$ опосредует ингибирование перемещения в ядро транскрипционного фактора провоспалительных цитокинов NF-кB. [26]. 
Таблица 2.4

Влияние Тамоксифена (0,1 мкM; 10 мкM; 100 мкМ) на количество дегенерирующих нейронов в суспензии с добавлением глутамата

\begin{tabular}{|l|c|c|}
\hline \multicolumn{1}{|c|}{ Серии } & $\begin{array}{c}\text { Количество исследо- } \\
\text { ваний в серии }\end{array}$ & $\begin{array}{c}\text { Количество дегенирирующих } \\
\text { нейронов в видимом поле } \mathbf{M} \pm \mathbf{m}\end{array}$ \\
\hline Интакт & $\mathrm{n}=10$ & $4 \pm 2$ \\
\hline Контроль & $\mathrm{n}=10$ & $83 \pm 7$ \\
\hline Тамоксифен 0,1 мкM & $\mathrm{n}=10$ & $31 \pm 4^{*}$ \\
\hline Тамоксифен 10 мкM & $\mathrm{n}=10$ & $53 \pm 5^{*}$ \\
\hline Тамоксифен 100 мкM & $\mathrm{n}=10$ & $79,5 \pm 6$ \\
\hline
\end{tabular}

Примечания: Контроль - суспензия нейронов + глутамат; * $-\mathrm{p} \leq 0,05$ по отношению к контролю.
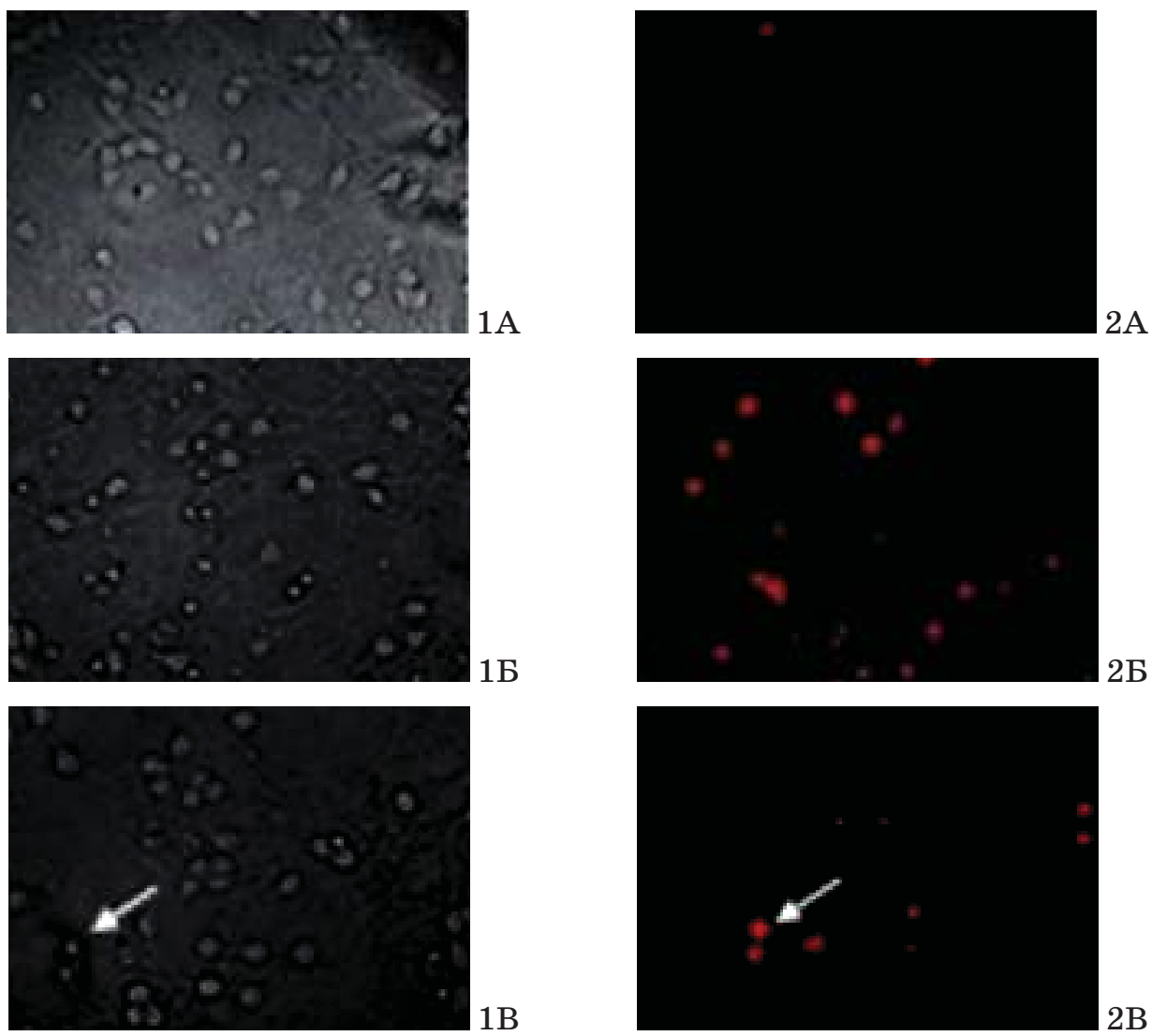

Рис. 2.13. Влияние Тамоксифена (0,1 мкМ) на количество дегенерирующих нейронов (увеличение $\times$ 100, флуоресцентный микроскоп Axioskop Ziess, Germany)

$\mathbf{1 A}$ - интакт; $\mathbf{1 6}$ - суспензия нейронов с добавлениел глуталата (100 лкM); $\mathbf{1 B}-$ суспензия нейронов, глуталат (100 лкM) + Талоксифен (0, 1лкM); 2A-2B - флуоресиентное свечение этидиум-положительных окрашенных нейронов соответствующих серий. 
Учитывая наличие выраженного нейропротективного действия Тамоксифена в опытах in vitro, вторым этапом нашего исследования была оценка нейропротективного действия Тамоксифена на модели перевязки сонной артерии монгольским песчанкам (ОНМК по типу ишемического инсульта), с дальнейшим изучением влияния Тамоксифена на показатели оксидативного стресса, митохондриальной дисфункции, энергетического метаболизма.

Так, введение экспериментальным животным Тамоксифена в дозе 1 мг/кг приводило к уменьшению содержания в митохондриальной фракции маркеров окислительного повреждения белков - АФГ и КФГ на 52 \% и 53 \% соответственно, а также маркера окислительной деструкции нуклеиновых кислот 8-OHG - на $46 \%$ (табл. 2.5).

Важным моментом в антиоксидантном действии Тамоксифена явилось его положительное воздействие на Mn-супероксиддисмутазу (MnSOD) - основной антиокислительный фермент в митохондриях, регулирующий открытие митоходриальной поры за счет торможения паразитарных реакций. Так, курсовое назначение Тамоксифена приводило к повышению активности MnSOD более чем на 57 \% по отношению к контролю (табл. 2.5).

Таблица 2.5

\section{Влияние Тамоксифена на некоторые показатели антиоксидантной системы в митохондриальной фракции головного мозга животных с ОНМК на 4-е сутки эксперимента}

\begin{tabular}{|c|c|c|c|}
\hline Показатели & $\begin{array}{c}\text { Ложнооперируемые } \\
\text { животные } \\
\text { (интакт) }\end{array}$ & $\begin{array}{c}\text { Животные с ОНМК } \\
\text { (контроль) }\end{array}$ & $\begin{array}{l}\text { Животные с ОНМК + } \\
\text { Тамоксифен }\end{array}$ \\
\hline АФГ,у.е. /г белка & $5,3 \pm 0,23$ & $21,3 \pm 2,12$ & $10,1 \pm 1,07^{\star}$ \\
\hline КФГ, у.е./ г белка & $2,1 \pm 0,15$ & $17,8 \pm 1,1$ & $8,4 \pm 0,45^{*}$ \\
\hline 8-OHG, нг/л & $34,4 \pm 2,6$ & $121,4 \pm 11,55$ & $65,4 \pm 4,2^{*}$ \\
\hline MnSOD, у.е./мг белка/мин. & $151,1 \pm 11,24$ & $44,2 \pm 3,17$ & $103,7 \pm 14,21^{*}$ \\
\hline
\end{tabular}

Антиоксидантный механизм нейропротективного действия Тамоксифена (повышение активности Mn-SOD, торможение окислительной модификации белка и нуклеиновых кислот в митохондриях мозга) раскрывают и его способность влиять на формирование митохондриальной дисфункции при ОНМК. Установлено, что назначение Тамоксифена животным с ОНМК приводило к увеличению содержания аминокислот с восстановленными тиольными группами - цистеина в среднем на $57 \%$, метионина на $63 \%$ — и снижало содержание гомоцистеина на $47 \%$, что свидетельствовало о регулирующем влиянии препарата на тиол-дисульфидное равновесие в головном мозге в условиях ишемии (рис. 2.14). 


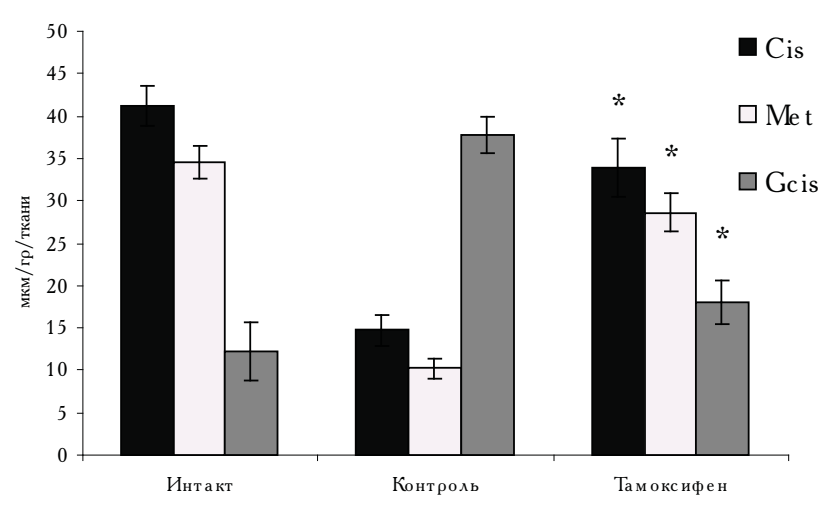

Примечание: * $-\mathrm{p} \leq 0,05$ по отношению к контролю. Cis - цистеин; Met - метионин; Gcis - гомоцистеин

\section{Рuc. 2.14. Влияние Тамоксифена на состояние тиол-дисульфидной системы в головном мозге животных с ОНМК на 4-е сутки эксперимента}

Вышеописанные антиоксидантные эффекты Тамоксифена обеспечивают его митотропное действие за счет регуляции реакции восстановления тиольных белков и, в конечном итоге, регуляции активности митохондриальной поры.

Так, назначение Тамоксифена (1 мг/кг) тормозило открытие митохондриальной циклоспорин-А-зависимой поры, в суспензии митохондрий нейронов ишемизированного полушария, а также восстанавливало мембранный потенциал митохондрий, что свидетельствовало о повышении функциональной активности митохондрий мозга животных с ОНМК, которые получали Тамоксифен (рис. 2, 3).

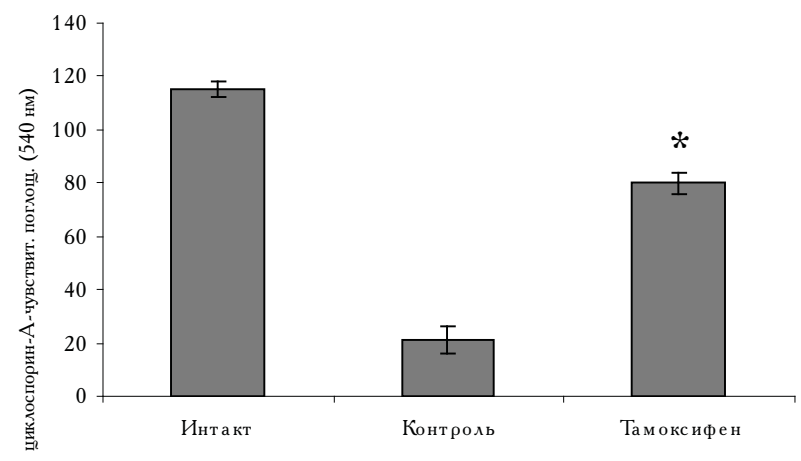

Примечание: * - $\mathrm{p} \leq 0,05$ по отношению к контролю.

Puc. 2.15. Влияние Тамоксифена на открытие поры митохондрий мозга животных с ОНМК на 4-е сутки эксперимента 


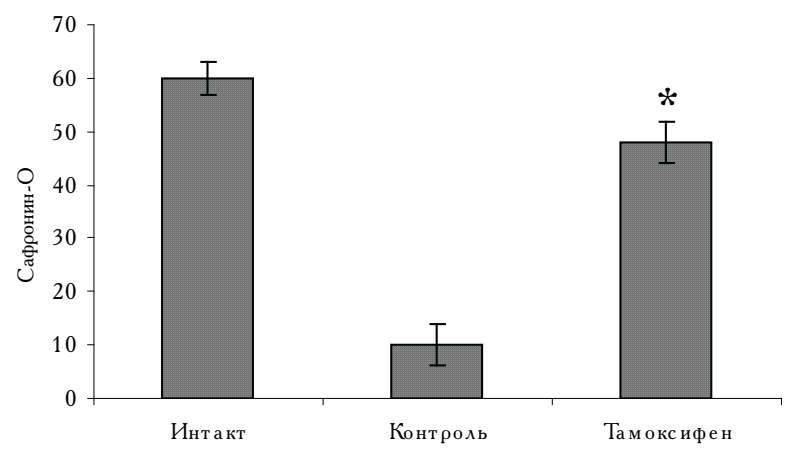

Примечание: * - p $\leq 0,05$ по отношению к контролю.

Puc. 2.16. Влияние Тамоксифена на изменение мембранного потенциала ( $\triangle \Psi)$ митохондрий мозга животных с ОНМК на 4-е сутки эксперимента

Подобное действие Тамоксифена на функциональную активность митохондрий и его высокая антиоксидантная активность объясняет нормализацию энергетического метаболизма в условиях ишемии. Так, курсовое назначение Тамоксифена экспериментальным животным способствовало значительной активации окислительной продукции энергии на дикарбоновом участке цикла Кребса (повышение уровня малата на 56 \% ) При этом наблюдалось увеличение активности сукцинатдегидрогеназы (СДГ) на 63 \% и цитохром-С-оксидазы (Ц-С-О) на 15 \% , что обеспечивало повышение продукции АТФ на 53 \% , (табл. 2.6).

Таблица 2.6

Влияние Тамоксифена на содержание интермедиатов энергетического метаболизма в цитозольной фракции головного мозга животных с ОНМК на 4-е сутки эксперимента

\begin{tabular}{|l|c|c|c|c|}
\hline \multicolumn{1}{c|}{$\begin{array}{c}\text { Группы } \\
\text { животных }\end{array}$} & $\begin{array}{c}\text { АТФ } \\
\text { мкм/г ткани }\end{array}$ & $\begin{array}{c}\text { Малат } \\
\text { мкм/г ткани }\end{array}$ & $\begin{array}{c}\text { Сдг } \\
\text { мкм/г ткани }\end{array}$ & $\begin{array}{c}\text { Ц-С-0 } \\
\text { мкм/г ткани }\end{array}$ \\
\hline Интакт & $2,86 \pm 0,06$ & $0,38 \pm 0,02$ & $5,8 \pm 0,11$ & $13,1 \pm 0,12^{\star}$ \\
\hline Контроль & $0,7 \pm 0,02$ & $0,14 \pm 0,01$ & $2,1 \pm 0,12$ & $6,2 \pm 0,07^{\star}$ \\
\hline Тамоксифен & $2,4 \pm 0,01$ & $0,32 \pm 0,03$ & $4,8 \pm 0,09$ & $9,8 \pm 0,07^{*}$ \\
\hline
\end{tabular}

Примечание: * - p $\leq 0,05$ по отношению к контролю.

Установленная нами нейропротективная активность Тамоксифена подтверждается и данными других исследователей. Так, Y. Zhао установил способность Тамоксифена и его метаболита ингибировать нейротоксическую систему глутамата и оказывать нейропротекторное действие при $\beta$-амилоидной амне- 
зии. В исследовании оценивали морфологические изменения в нейронах коры, гиппокампа, переднего мозга, участвующих в формировании когнитивного статуса. Показано, что Тамоксифен и 4 -гидрокситамоксифен не усиливали вызванное глутаматом повышение содержания внутриклеточного кальция и активацию NMDA-рецепторов. Кроме того, Тамоксифен и 4-гидрокситамоксифен блокировали вызванное $17 \beta$-эстрадиолом глутамат-зависимое повышение концентрации внутриклеточного кальция. При этом в культуральных средах гиппокампальных нейронов Тамоксифен увеличивал экспрессию антиапоптозного протеина Вc1-2, что свидетельствует о нейропротекторном действии препарата. Таким образом, Тамоксифен и 4-гидрокситамоксифен частично проявляют свойства агонистов ЭР в мозге, а в присутствии $17 \beta$-эстрадиола («чистого» агониста ЭР) они действуют как конкурентные антагонисты ЭР. Эти результаты подтверждаются рядом других исследований [27]. T. Ernst и соавт. установили способность Тамоксифена благоприятно модулировать процессы старения мозга. В исследовании участвовали женщины старше 65 лет, получавшие Тамоксифен при химиотерапии рака молочной железы. Оценивалось содержание миоинозитола (МИ), являющегося глиальным маркером. Показано, что у пациентов с различными неврологическими расстройствами существует тесная связь между повреждением структур мозга, повышением содержания МИ и быстрым ростом глии. У женщин, получавших Тамоксифен, содержание МИ было значительно ниже, чем в группе пациенток, получавших плацебо, но при этом показатели когнитивных тестов в обеих группах не различались. Результаты исследования свидетельствуют, что Тамоксифен и его метаболит не влияют на морфогенез нейронов и не участвуют в механизмах формирования памяти, но проявляют нейропротекторную активность [5].

Таким образом, в результате наших исследований можно предположить, что в нейропротекторном механизме действия Тамоксифена лежит, во-первых, его прямая антиоксидантная активность. Во-вторых, за счет позитивного влияния на состояние тиол-дисульфидной системы в нейрональной клетке, Тамоксифен реализует свое митопротективное действие, в связи с тем, что открытие митохондриальной поры происходит за счет окисления тиоловых групп цистеинзависимого участка белка внутренней мембраны митохондрий (АТФ/АДФ антипортер). В третьих, важным моментом механизма действия Тамоксифена, по нашему мнению, является его геномопротекторый эффект, выражающийся в защите ДНК от окислительного повреждения, поскольку окислительная модификация ДНК приводит к активации онкогенов, белков Вах, p53, стимулируя тем самым "рецепторы смерти» и апоптозные гены нейрональной клетки [28]. По-видимому, это общебиологическое, эволюционно значимое свойство для эстрогенов и необходимое для сохранности генетического материала у особей женского пола.

Кроме того, в настоящее время рядом зарубежных и отечественных ученых высказывается гипотеза о нейропротективном действии SERM, реализующемся за счет их позитивного влияния на факторы эндогенной цитопротекции - HSP и HIF-белки, общебиологическая и цитопротективная роль которых описана выше. 
В связи с этим, целесообразным, по нашему мнению, было проведение дополнительного, уточняющего исследования Тамоксифена в отношении его возможности влиять на синтез HSP70 белков и за счет этого реализовывть свое нейропротективное действие

С этой целью животные были распределены в следующие экспериментальные группы:

1. Интактная группа животных $(\mathrm{n}=10)$.

2. Контроль 1 и 4 сутки - животные с острой церебральной ишемией на 1 и 4 сутки эксперимента $(\mathrm{n}=10)$.

3. Ж Животные с острой церебральной ишемией на 1-е и 4-е сутки на фоне курсового назначения Тамоксифена цитрата в дозе 1 мг/кг (n=10).

Проведенными экспериментальными исследованиями установлено, что моделирование ОЦИ сопровождалось функционально-биохимическими изменениями в тканях головного мозга. Как видно из таблицы 1 , на 4-е сутки у животных с ОЦИ было зарегистрировано значительное повышение концентрации гомоцистеина (GCS) - на 77 \% по отношению к интактной группе животных. Известно, что GCS является предшественником глутатиона, уровень которого был снижен более чем на 52 \% у животных данной экспериментальной группы, что, по-видимому, связано с его потерей в антиоксидантных реакциях. Гипергомоцистеинемия за счет изменения активности NMDA-рецепторов приводит к накоплению внутриклеточного кальция, что, в свою очередь, влечет за собой подавление энергетической функции митохондрий. В митохондриях запускаются паразитарные энергопродуцирующие реакции, приводящие к гиперпродукции АФК, которые образуются на начальном участке дыхательной цепи митохондрий при участии NADH-CoQH ${ }_{2}$ редуктазы [16]. Избыток АФК в клетке приводит к окислительному стрессу, в результате чего окислению подвергаются ДНК и функционально активные белковые молекулы.

Кроме того, дефицит глутатиона приводит к развитию нитрозильного стресса в результате которого происходит взаимодействие цитотоксических дериватов NO с алифатическими и ароматическими аминами с образованием N- нитрозаминов, о чем может свидетельствовать повышение содержания в головном мозге НТ3 (на 80 \% по отношению к интактным крысам), зарегистрированное нами на 4-е сутки модельной патологии (табл. 2.7). Следует также отметить, что токсические дериваты оксида азота, гиперпродукция которых наблюдается в условиях нитрозильного стресса, взаимодействуют с цистеином с образованием S-нитрозоцистеина и с глутатионом с образованием S-нитроглутатиона. S-нитроглутатион является основной транспортной молекулой переноса NO. Некоторыми исследованиями установлено, что транспорт NO происходит с образованием $\mathrm{N}_{2} \mathrm{O}_{3}$, который затем нитрозилирует тиолы, еще более истощая запасы глутатиона и смещая тиол-дисульфидное равновесие [16, 17]. 
Таблица 2.7

Содержание в тканях головного мозга глутатиона, гомоцистеина, нитротирозина на 4-е сутки ОЦИ и на фоне введения Тамоксифена цитрата (1мг/кг)

\begin{tabular}{|c|c|c|c|}
\hline $\begin{array}{l}\text { Серии животных } \\
\quad(n=10)\end{array}$ & $\begin{array}{c}\text { Глут., } \\
\text { мкм/г ткани, } \\
(\mathrm{M} \pm \mathrm{m})\end{array}$ & $\begin{array}{c}\text { GCS, } \\
\text { мкм/г ткани, } \\
(\mathrm{M} \pm \mathrm{m})\end{array}$ & $\begin{array}{c}\text { HТ3, } \\
\text { усл.ед./г белка, } \\
\text { (М } \pm \text { m) }\end{array}$ \\
\hline Интакт & $4,4 \pm 0,56$ & $1,1 \pm 0,09$ & $1,25 \pm 0,16$ \\
\hline Контроль, ОЦИ, 4 сутки & $2,1 \pm 0,17^{*}$ & $4,8 \pm 0,15^{\star}$ & $6,5 \pm 0,18^{*}$ \\
\hline $\begin{array}{l}\text { ОЦИ } 4 \text { сутки + Тамоксифена } \\
\text { цитрат (1 мг/кг) }\end{array}$ & $3,8 \pm 0,14^{* *}$ & $2,3 \pm 0,12^{* *}$ & $2,0 \pm 0,17^{\star *}$ \\
\hline
\end{tabular}

Прилечания: * - p $\leq$ 0,05 по отношению к интактным крысам по критерию Mann-Whitney U; ** $-\mathrm{p} \leq$ 0,05 по отношению к контролю по критерию Mann-Whitney U.

Параллельно с развитием оксидативного и нитрозильного стрессов, смещением тиол-дисульфидного равновесия наблюдалось изменение характера экспрессии генов, кодирующих HSP70-белки. Известно, что в условиях ишемии головного мозга, защитная функция HSP70 является существенным фактором поддержания жизнеспособности клеток, находящихся в условиях острой гипоксии, а также под воздействием цито- и геномотоксических продуктов окислительного стресса. Реализация защитной и многих других функций белков HSP70 зависит от их шаперонной активности [18]. Под шаперонной активностью понимается способность узнавать и складывать вновь синтезированные полипептидные цепи в активные молекулы белков и восстанавливать нарушенную структуру белков. Показано, что за счет своей шаперонной активности HSP-белки участвуют в редукции окислительного стресса, репарации ионных каналов, апоптозе. Активация экспрессии белков теплового шока - одна из первых реакций клетки в ответ на ишемию и окислительный стресс. Методом вестерн-блот анализа установлено, что на 1-е сутки моделирования церебральной ишемии наблюдалось повышение концентрации HSP70 в головном мозге, направленное на восстановление окислительно поврежденных и денатурированных функционально активных белков, на регуляцию/модуляцию протеолиза белков, окислительно-восстановительных реакций, синтеза провоспалительных цитокинов, синаптической передачи (табл. 2.8). Общеизвестно, что в условиях ишемии общий биосинтез белка снижается, а синтез HSP70 резко увеличивается. При этом большинство HSP-белков находится в ядре среди поврежденных в результате оксидативного стресса прерибосом. Постепенно содержание HSP в ядре уменьшается, а в цитоплазме увеличивается. Известно, что характерным клеточным проявлением ишемии является агрегация и накопление денатурированных белков, активация свободнорадикальных процессов и кальциевая перегрузка. HSP 70 могут ограничивать эти сдвиги, дезагрегируя аномальные белковые агрегаты, участвуя в деградации необратимо поврежденных белков, повышая мощность антиоксидантных ферментов и ограничивая повреждающие эффекты кальциевой перегрузки за счет связывания рецептора кальция - кальмодулина $[18,19]$. Наконец, недавно стали появляться данные еще об одном ме- 
ханизме защитного действия HSP70 - блокаде гиперпродукции оксида азота (NO). Значимость этого эффекта HSP70 определяется тем, что гиперпродукция NO играет ключевую роль в развитии многих патологических состояний, таких как воспаление, гипотензия, ишемические повреждения органов и т. д. Кроме того, нашими более ранними работами, которые согласуются с исследованиями других авторов, было показана способность HSP70-белков пролонгировать время жизни основного адаптационного фактора - HIF-1 (индуцибельный фактор гипоксии, hypoxia-inducible factor), который в условиях гипоксии инициирует запуск компенсаторных механизмов выработки энергии [19, 20]. Данные адаптационные реакции в ответ на ишемию лимитированы во времени и уже на 4-е сутки ишемии нами была зарегистрировано значительное падение концентрации HSP70 белков в тканях головного мозга по отношению к 1-м суткам ишемии, что выражалось в уменьшении площади и оптической концентрации позитивно окрашенного комплекса на 69 \% и 76 \% соответственно. Данное обстоятельство, по-видимому, связано со срывом резервно-адаптационных возможностей организма, а также с усилением процессов свободнорадикального окисления. Обращает на себя внимание развитие у данной экспериментальной группы животных выраженной гипергомоцистеинемии, которая сопровождалась значительным приростом в головном мозге НТ3, в результате чего окислительной модификации подвергались сами HSP70-белки.

Установленная нами направленность молекулярно-биохимических изменений в головном мозге контрольной группы животных обусловливает развитие неврологического дефицита, начиная с 1-х суток ОЦИ, с максимальным проявлением на 4-е сутки эксперимента. Так, если на 1-е сутки ОЦИ неврологический дефицит по шкале McGrow составлял в среднем 4 балла, то на 4-е сутки - составлял более 7 баллов (рис. 2.17).

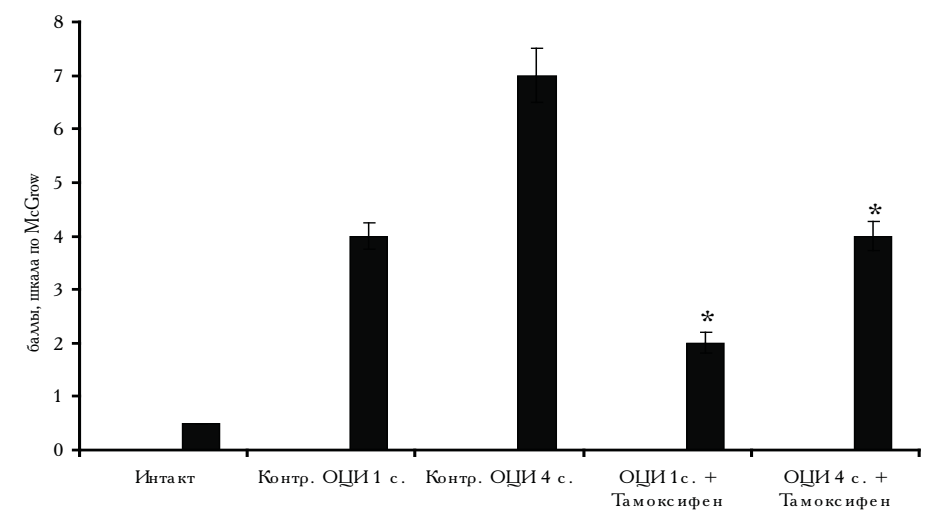

Прилечания: * - p $\leq$ 0,05 по отношению к контрольной группе животных по критерию МапnWhitney U.

Puc.2.17. Выраженность неврологического дефицита по шкале McGrow на 1-е и 4-е сутки экспериментальной ишемии и на фоне применения Тамоксифена цитрата (1 мг/кг) 
C целью установления нейропротективного профиля SERM - Тамоксифена цитрата нами было исследовано его влияние на представленные выше показатели тиол-дисульфидной и антиоксидантной систем.

Курсовое введение экспериментальным животным Тамоксифена цитрата в дозе 1 мг/кг, приводило к нормализации показателей тиол-дисульфидной системы, а также ограничивало развитие оксидативного стресса. Так, нами было зарегистрировано повышение содержания в головном мозге концентрации глутатиона (более чем на 37 \% по отношению к контролю). Способность Тамоксифена цитрата повышать содержание глутатиона, по нашему мнению, является одним из ключевых эффектов, реализующих его нейропротективное действие, поскольку в настоящее время установлено, что глутатион, помимо выраженного антиоксидантного действия (прямое взаимодействие с радикалами в неэнзиматических реакциях), является еще нейротрансмиттером и нейромодулятором (модулирует SH-группы NMDA-рецепторов). Восстановление тиолдисульфидного равновесия засчетповышения уровня глутатионав мозговой ткани приводило к ограничению оксидативного и нитрозильного стресса, что выражалось уменьшением в тканях головного мозга на 4-е сутки концентрации НТ3 (на 69 \% по отношению к контролю) и GCS - на $52 \%$.

Для установления механизма нейропротективного действия Тамоксифена цитрата нами также было изучено его влияние на описанную выше систему клеточной протекции - HSP70-белков, выраженный дефицит которых был нами зафиксирован у животных с ОЦИ. Кроме того, рядом исследователей была выдвинута гипотеза о HSP-опосредованном действии селективных модуляторов эстрогеновых рецепторов [14].

Проведенными исследованиями установлено, что назначение животным с ОЦИ Тамоксифена цитрата приводило к статистически достоверному повышению содержания HSP70-белков в мозговой ткани. Следует отметить, что на фоне назначения исследуемого препарата, содержание HSP70-белков остается повышенным и на 4 сутки эксперимента, в отличие от животных контрольной группы. Денситометрический анализ показал увеличение на 4-е сутки площади и оптической концентрации HSP-окрашенного комплекса в среднем на $51 \%$ по отношению к контрольной группе на те же сроки ОЦИ (табл. 2.8).

Таблица 2.8

Концентрация HSP 70-белков в тканях головного мозга крыс с ОЦИ на разные сроки ишемии и на фоне назначения Тамоксифена цитрата (1 мг/кг)

\begin{tabular}{|l|c|c|}
\hline \multicolumn{1}{|c|}{$\begin{array}{c}\text { Серии животных } \\
(\mathbf{n}=10)\end{array}$} & $\begin{array}{c}\text { Площадь +-окрашенного } \\
\text { комплекса, усл.ед., }(\mathrm{M} \pm \mathrm{m})\end{array}$ & $\begin{array}{c}\text { Оптическая концентрация } \\
\text { +-окрашенного комплекса, } \\
\text { усл.ед., (M } \pm \mathrm{m})\end{array}$ \\
\hline Интактные животные & $52,8 \pm 1,4$ & $0,22 \pm 0,028$ \\
\hline Контроль, Оци, 1-е сутки & $64,7 \pm 2,7^{*}$ & $0,34 \pm 0,04^{*}$ \\
\hline Контроль, Оци, 4-е сутки & $20,1 \pm 1,9^{*}$ & $0,081 \pm 0,027^{*}$ \\
\hline
\end{tabular}


Продолжение табл. 2.6

\begin{tabular}{|c|c|c|}
\hline $\begin{array}{l}\text { Серии животных } \\
\quad(n=10)\end{array}$ & $\begin{array}{c}\text { Площадь +-окрашенного ком- } \\
\text { плекса, усл.ед., (M } \pm \text { m) }\end{array}$ & $\begin{array}{c}\text { Оптическая концентрация } \\
+-0 \text { окашенного комплекса, усл. } \\
\text { ед., }(\mathrm{M} \pm \mathrm{m})\end{array}$ \\
\hline $\begin{array}{l}\text { ОцИ 1-е сутки + } \\
\text { Тамоксифена цитрат } \\
\text { (1 мг/кг) }\end{array}$ & $71,4 \pm 3,1^{\star *}$ & $0,39 \pm 0,025^{\star *}$ \\
\hline $\begin{array}{l}\text { ОцИ 4-е сутки + } \\
\text { Тамоксифена цитрат } \\
\text { (1 мг/кг) }\end{array}$ & $41,2 \pm 1,7^{\star *}$ & $0,17 \pm 0,021^{\star *}$ \\
\hline
\end{tabular}

Прилечания: * - p $\leq$,05 по отношению к интактныл крысал по критерию Mann-Whitnеy U; ** - p $\leq$ 0,05 по отношению к контролю по критерию Mann-Whitney U.

По нашему мнению, способность Тамоксифена цитрата повышать в условиях ишемии головного мозга содержание HSP70-белков обусловлена его геномными и внегеномными эффектами. Нашими предыдущими работами, которые согласуются с рядом экспериментальных работ зарубежных исследователей, показана способность эстрогенов и SERM модулировать экспрессию глобальных факторов транскрипции, ответственных за синтез HSP-белков. Кроме того, активация SERM $\beta$-эстрогеновых рецепторов головного мозга обусловливает отсоединение от последних HSP70-белков, что обеспечивает вхождение этих белков внутрь клетки и реализацию их биологической функции. Механизм данного взаимодействия связан с ролью HSP70 в поддержании в неактивном состоянии эстрогеновых рецепторов, не связанных с эстрогенами $[4,6,10]$. Предполагают, что обратная связь рецептора со стероидным лигандом, приводит к конформационным изменениям молекулы рецептора, освобождению его из комплекса с белками теплового шока и их вхождению внутрь клетки. Также некоторыми исследователями была выдвинута гипотеза о способности SERM усиливать экспрессию HSP70 за счет стимулирующего влияния на белковый фактор транскрипции - фактор теплового шока (FHS) [21].

Подобная направленность действия Тамоксифена приводила к уменьшению у данной группы животных неврологического дефицита по шкале McGrow. Как видно из рисунка 2.17, позитивная динамика наблюдалась у животных данной экспериментальной группы, начиная с 1-х суток ОЦИ.

Таким образом, проведенными экспериментальными исследованиями была установлена нейропротективная активность селективного модулятора эстрогеновых рецепторов - Тамоксифена цитрата, реализующаяся во-первых, за счет его способности повышать содержание HSP70-белков в тканях головного мозга в острый период ишемии. Во-вторых, Тамоксифен цитрат способен ограничивать развитие оксидативного и нитрозильного стрессов, что приводит к снижению концентрации в головном мозге гомоцистеина и нитротирозина и повышению глутатиона, восстанавливая тем самым тиол-дисульфидное равновесие в нервных клетках. Взаимопотенцирование данных эффектов Тамоксифена цитрата в условиях острой церебральной ишемии приводило к выраженному нейропротективному эффекту. 
Установленный нами нейропротективный профиль Тамоксифена цитрата обусловливает дальнейшую перспективность исследований в данном направлении с целью внедрения его в клиническую практику в качестве нейропротективного средства.

\section{6. ТИОЛ-ДИСУЛЬФИДНАЯ СИСТЕМА}

Понимание механизмов гибели нейрона при различных заболеваниях ЦНС и их фармакологическая регуляция является одной из центральных проблем современной нейрофармакологии и интенсивно изучается сейчас во всем мире [1]. Несмотря на интенсивность исследований в этой области и определенные успехи, актуальность данной проблемы не снижается, поскольку нейродеструктивные патологии ЦНС занимают ведущее место в структуре инвалидизации и смертности населения развитых стран. Согласно современным представлениям нейродеструкция ишемического генеза сопровождается развитием сложных патобиохимических каскадов в нейроне - нарушением энергетического метаболизма, развитием трансмиттерного аутокоидоза, формированием стойкой митохондриальной дисфункции, сопровождающейся гиперпродукцией АФК и $\mathrm{NO}$ в паразитарных реакциях, и экспрессией проапоптотических белков $[2,3]$. Известно, что запуск программы, ведущей к смерти нейрона, может осуществляться цитокинами, гормонами, АФК, дериватами NO, окисленными тиолами, продуктами окислительной модификации белков и нуклеиновых кислот. При действии подобных факторов на клетку, в ней запускается множество сигнальных путей, ведущих к нейтрализации последствий их отрицательного воздействия или, в случае непоправимого ущерба, к элиминации клетки. Такая элиминация поврежденных клеток происходит по пути апоптоза, или программированной клеточной гибели. В развитии апоптотического процесса участвует множество сигнальных молекул, многие из которых регулируют и другие важные функции организма. $\kappa$ наиболее изученным факторам, способным запускать в нейроне апоптотическую программу, относится оксид азота (NO) - одна из ключевых сигнальных молекул, регулирующих функции сердечно-сосудистой, нервной и иммунной систем организма. Уникальная химическая природа и большое число внутриклеточных мишеней для $\mathrm{NO}$ и его физиологически активных окислительно-восстановительных форм оставляют открытым вопрос, каким образом и сколь специфично опосредуется повреждающее действие оксида азота на нейрон в условиях ишемии. Многочисленными работами было показано непосредственное участие NO в процессе деструкции нейрона при ишемии при назначении животным с ОНМК селективных ингибиторов нейрональной и индуцибельной изоформ NOS, а также в опытах на животных с дефицитом гена, кодирующего iNOS. Получены данные о возрастании концентрации NO в мозге животных как с фокальной, так и с глобальной ишемией $[4,5]$. Концентрация NO начинает увеличиваться с первых минут ишемии, достигая максимума на 1-3-и сутки. Измерение активности NOS показало резкое увеличение активности этого фермента как в очаге ишемии, так и в пенумбре, однако без учета принадлежности к определенному типу NOS. Участие 
NO в повреждении и гибели нейрона имеет свою специфику и определяется изоформами NOS, а также видом и стадией развития инсульта. В начальном периоде ишемии превалирует экспрессия конституционной кальцийзависимой NOS, обусловленной трансмиттерным аутокоидозом. Продукция NO на этом этапе не является фактором, непосредственно определяющим гибель нейрона. На этом этапе NO участвует в косвенных механизмах гибели нейрона - активации фосфолипаз, усилении образования гидроксил-радикала, модуляции активности NMDA рецепторов. Начиная с 7-14-х суток при глобальной ишемии и с 1-3-х суток при фокальной ишемии, т. е. в отсроченном постишемическом периоде, регистрируется гиперпродукция NO при участии индуцибельной NOS активированной глии, макрофагов и нейтрофилов. Отсроченный характер экспрессии индуцибельной NOS связан с более поздними сроками появления активированной астро-, макроглии и клеток воспаления. При фокальной ишемии вышеобозначенные клетки - продуценты NO - находятся в пенумбре, а при глобальной ишемии - в наиболее чувствительных к дефициту кислорода структурах. Кроме NO-синтаз источником NO в организме теплокровных являются нитрат/нитрит-редуктазы, способные восстанавливать нитраты и нитриты. Нитроредуктазной активностью обладают глиоциты и тимоциты. Показано, что ксантиноксидаза обладает свойствами восстанавливать нитраты и нитриты до NO. Однако роль этой системы в развитии нейродеструкции не изучена. Сейчас идет активное изучение мишеней оксида азота и выяснение вопроса, является ли NO достаточно цитотоксичным, или же более активны его дериваты [5, 6-8]. Известно, что NO в клетках-мишенях образует активные дериваты, такие как нитрозоний $\left(\mathrm{NO}^{+}\right)$, нитроксил $\left(\mathrm{NO}^{-}\right)$и пероксинитрит $\left(\mathrm{ONOO}^{-}\right)$. Исследованиями последних лет установлено, что NO, и особенно - продукты его превращения, такие как пероксинитрит $\left(\mathrm{ONOO}^{-}\right)$, ион нитрозония $\left(\mathrm{NO}^{+}\right)$, нитроксил $\left(\mathrm{NO}^{-}\right)$и диазоттриоксид $\left(\mathrm{N}_{2} \mathrm{O}_{3}\right)$, являются основными факторами реализации нитрозирующего стресса, в результате которого происходит прямое взаимодействие NO с металлами (гемовое железо гемоглобина, миоглобина, железосодержащих энзимов, а также негемовое железо железосерных белков и ДНК, медь и цинк активних центров ферментов), а также непрямое взаимодействие $\mathrm{NO}^{+}$(S-, N-, О-нитрозирование) с тиольными, фенольными, гидроксильными и аминогруппами белков и ДНК. Подобное взаимодействие приводит к десенситации рецепторов, угнетению активности митохондриальных ферментов и фрагментации нуклеиновых кислот. Так, NO, обратимо связываясь с $\mathrm{Fe}^{3+}$ активного центра каталазы, значительно ингибирует ее как в начальном периоде ишемии, так и в постишемическом периоде фокальной ишемии мозга. Избыток NO угнетает гемовые ферменты электрон-транспортной цепи митохондрий. Значительные количества NO, наблюдаемые в постишемический период, могут взаимодействовать с гемовым железом и парными тиольными группами, образуя динитрозольный комплекс железа (DNIC). DNIC в отличие от NO, является более сильным нитрозилирующим агентом, взаимодействует с тиолами белков, гистидином, аспартатом, глутамином, метионином, цистеином, глутатионом и образуя N- и S-нитрозотиолы. DNIC в условиях ишемии подвергает необратимому нитрозилированию железосерные кластеры митохондриальных 
белков (НАДН-убихинон оксиредуктаза, сукцинат-убихинон оксиредуктаза, цис-аконитаза), тем самым участвуя в формировании митохондриальной дисфункции [4, 9-12]. Нашими исследованиями установлено, что DNIC значительно подавляет активность СОД, а также активность ферментов, регулирующих тиол-дисульфидное равновесие в клетке - глутатионредуктазы, глутатион-Sтрансферазы и глутатионпероксидазы в суспензии нейронов (рис. 2.18).

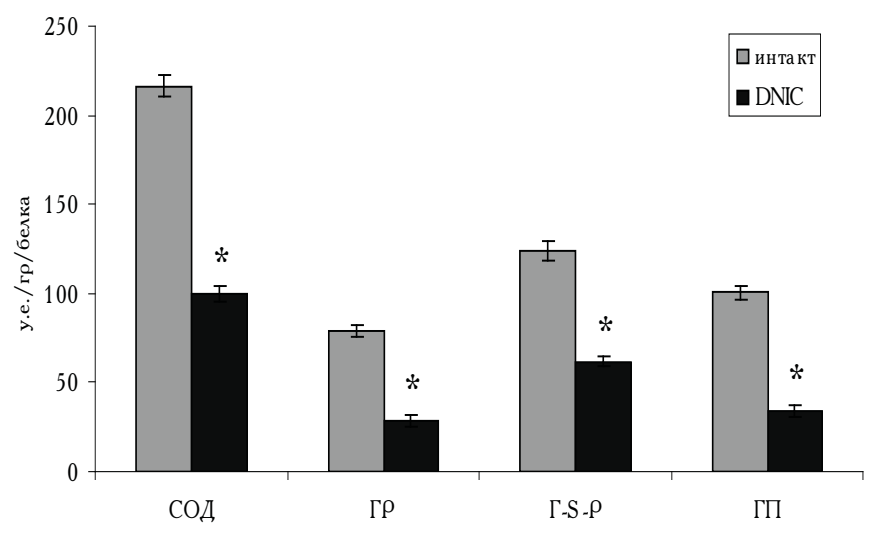

Примечания: * $-\mathrm{p} \leq 0,05$ по отношению к интакту; Интакт - суспензия нейронов без внесения DNIC; COД - супероксиддисмутаза; ГP - глутатионредуктаза; Г-S-P - глутатион-S-редуктаза; ГП - глутатионпероксидаза

\section{Puc. 1. Влияние DNIC на активность ферментов, регулирующих тиолдисульфидное равновесие в суспензии нейронов}

Смещение тиол-дисульфидной системы происходит за счет снижения ее восстановленных итермедиатов, значительно падает уровень митохондриального глутатиона. В физиологических условиях образование DNIC способствует депонированию и транспортировке NO, повышая его биодоступность и препятствуя образованию пероксинитрита. Однако, в условиях ишемического повреждения мозга, при гиперпродукции NO DNIC играет сугубо отрицательную роль в процессе нейродеструкции $[7,9]$.

$\mathrm{NO}^{+}$является мощным нитрозилирующим агентом, мишенями которого могут быть нуклеофильные группы активних тиолов, амины, карбоксилы, гидроксилы и ароматические кольца. $\mathrm{NO}^{+}$образуется из избытка $\mathrm{NO}$ при участии двухвалентного железа и кислорода. $\mathrm{NO}^{-}$обладает восстановительными свойствами, оказывает позитивное инотропное, лузитропное действие на миокард, снижает порог судорожной готовности. При ишемии $\mathrm{NO}^{-}$в условиях развивающегося лактат-ацидоза проявляются прооксидантные свойства этого деривата $\mathrm{NO}$ по отношению к тиолам и аминам. Получены данные in vitro, что внесение в суспезию нейронов донатора $\mathrm{NO}^{-}$соли Ангели снижает содержание глутатиона. Также с помощью соли Ангели было установлено, что $\mathrm{NO}^{-}$нарушает электрическую активность нейронов, угнетает активность натриевых каналов. По всей видимости, разнонаправленность $\mathrm{NO}^{-}$связано с его концентрацией, по- 
вышение которой приводит к образованию токсичного нитрит аниона. $\mathrm{N}_{2} \mathrm{O}_{3}$, являясь источником $\mathrm{NO}^{+}$, проявляет свойства сильного нитрозилирующего агента, взаимодействует с алифатическими и ароматическими аминами и образует $\mathrm{N}$-нитроамины. Нитроамины, а именно продукты их превращения под действием P450 (ион диазония и формальдегид) являются факторами алкилирующими нуклеиновыекислоты, дезаминирующиепурины, они угнетают $\mathrm{O}^{6}$-метилгуанинДНК-метилтрансферазу, увеличивают образование 8-гидроксигуанина. $\mathrm{N}_{2} \mathrm{O}_{3}$ взаимодействует с цистеином с образованием S-нитрозоцистеина и с глутатионом с образованием S-нитроглутатиона. S-нитроглутатион является основной транспортной молекулой переноса NO [13-16]. Некоторыми исследованиями установлено, что транспорт $\mathrm{NO}$ происходит с образованием $\mathrm{N}_{2} \mathrm{O}_{3}$, который затем нитрозилирует тиолы. Далее при участии дисульфидизомеразы высвобождается NO [17-18]. Существует еще механизм высвобождения NO из $\mathrm{S}-$ нитрозоглутатиона при участии глутамилтранспептидазы с образованием S-нитрозоцистеинилглицина, из которого высвобождается NO. B транспорте $\mathrm{S}$-нитрозоглутатиона принимает участие цистин, который восстанавливается до цистеина, а последний, реагируя с S-нитрозоглутатионом, образует S-цистеин.

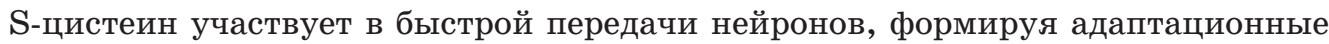
реакции нейрона на ишемию. Данные реакции контролируются глутатионредуктазой и глутатионтрансферазой. При ингибировании этих ферментов в условиях ишемии происходит окислительная модификация низкомолекулярных тиолов, образование гомоцистеина и, как следствие, нарушение транспорта NO с образованием его цитотоксических дериватов, еще более усиливающих окисление тиолов. Наличие в нейроне достаточно активной тиольной антиоксидантной системы, способной регулировать транспорт NO, обеспечивает и устойчивость клетки к нитрозирующему стрессу — наиболее раннему нейродеструктивному механизму в условиях ишемии. Известно, что в первые минуты ишемии мозга NO (макрофагальный или экзогенный) ингибирует окислительное фосфорилирование в митохондриях клеток-мишеней за счет обратимого связывания с цитохром-С-оксидазой митохондрии. Подавление электронного транспорта в митохондрии приводит к генерации супероксида, и как следствие - образованию $\mathrm{ONOO}^{-}$. Синтез пероксинитрита наблюдается в клетках с высокой активностью NO-синтазы и ферментов, продуцирующих АФК (касантиноксидаза, НАДН-оксиредуктаза, циклооксигеназа, липоксигеназа, ферменты электронтранспортной цепи). Последними исследованиями установлено, что на начальных стадиях ишемии уровень пероксинитрита может снижаться посредством митохондриальной нитроредуктазы, которая восстанавливает его с помощью НАДФН и НАДН в NO. Мишенями окислительной и нитрозирующей атаки пероксинитрита являются тиолы, $\mathrm{CO}_{2}$, металлопротеиды, нуклеиновые кислоты, метаболитотропные трансмиттеры и липиды $[2,4,19]$. Пероксинитрит, являясь относительно стойким соединением, при смещении рН в кислую сторону быстро протонируется с образованием основного продукта - нитрат-аниона, а также гидроксил-радикала и диоксида азота, что обуславливает его окислительные свойства. Поэтому на начальных стадиях ишемии пероксинитрит взаимодействует с тиолами по типу нитрозилирования, в результате чего образуются ни- 
трозотиолы. В дальнейшем при прогрессировании процесса и проявлениях лактат-ацидоза, взаимодействие происходит по типу окисления с образованием более стойких дисульфидов. Эти реакции вносят существенный вклад в механизмы нейродеструкции посредством смещения тиол-дисульфидной системы в сторону окисленных тиольных соединений, снижения восстановительного потенциала клетки, нарушения экспрессии генов за счет необратимого окисления цистеиновых остатков редокси зависимых доменов, разобщения МАР-киназного каскада. Пероксинитрит тормозит активность взаимодействующих метаболических циклов метионина и цистеина, подавляя ключевые ферменты, регулирующие уровень цистеина и повышая образование гомоцистеина. Пероксинитрит реагирует и с метаболитотропным трансмиттером $\mathrm{CO}_{2}$ с образованием сильного нитрозилирующего агента - нитрозопероксикарбоната. Важным механизмом нейротоксического действия пероксинитрита является его реакция с тирозином и образование нитротирозина. Пероксинитрит значительно угнетает активность $\mathrm{Cu}-\mathrm{Zn}-\mathrm{CO}$ и $\mathrm{Mn}-\mathrm{CO}$ посредством нитрования ее 34 тирозинового остатка, а также связывания с медью и изменения ее валентности. Пероксинитрит является специфическим агентом, необратимо угнетающим митохондриальное дыхание при ишемии, непосредственно взаимодействуя с железом активных центров ключевых энзимов, а также нитрозируя по S-, N-, O-элементам тиольные, фенольные, гидроксильные и аминогруппы белковой части этих энзимов, а при более выраженном проявлении нитрозирующего стресса - необратимо окисляя их. Подавление митохондриального дыхания приводит к падению заряда митохондрий, что может инициировать апоптотический процесс, а при отсутствии глюкозы - и к некрозу [4, 7, 12, 20]. Имеются данные о прямой активации открытия гигантской поры оксидом азота, приводящей к выходу цитохрома $\mathrm{C}$ и запуску каспазного каскада. Эти данные получены при воздействии на митохондрии таких цитотоксических дериватов NO, как пероксинитрит и ион нитрозония, в механизме которых лежит модификация тиольных белков митохондриальной поры. NO и его дериваты могут вызывать перекисное окисление фосфолипидов. Так, под действием цитотоксических дериватов NO и гидроксил-радикала происходит открытие митохондриальных пор, с экспрессисией и выходом в цитозоль проапоптотических белков. Открытие пор происходит за счет окисления или нитрозилирования тиольных групп цистеинзависимого участка белка внутренней мембраны митохондрий (АТФ/АДФантипортер), что превращает его в проницаемый неспецифический канал-пору. Открытие пор превращает митохондрии из «электростанций» в «топку» субстратов окисления без образования АТФ [21, 22]. Известно, что нарушение кислородного режима тканей, трансмиттерный аутокоидоз, нарушение аккумуляции $\mathrm{Ca}^{2+}$ митохондриями, повреждение мембраны митохондрий АФК и NO усиливают открытие пор и высвобождение апоптогенных белков из поврежденных митохондрий. Митохондриальная пора представляет собой канал, проходящий через обе митохондриальные мембраны и состоящий из трех белков: транслокатора адениновых нуклеотидов, потенциалзависимого анионного канала (порина) и бензодиазепинового рецептора. Когда этот комплекс связывается с $\mathrm{Ca}^{2+}$, через мембранную пору могут проходить вещества с небольшой молекулярной 
массой. Это приводит к падению мембранного потенциала и набуханию матрикса, целостность внешней мембраны неизбежно нарушается, и из межмембранного пространства в цитоплазму выходят белки апоптоза. Нитрозилирование белков по остаткам тирозина, осуществляемое $\mathrm{ONOO}^{-}$, может иметь серьезные функциональные последствия, так как оно подавляет фосфорилирование тирозина, то есть нарушает некоторые пути передачи сигнала в клетке [21]. Пероксинитрит может нитрозилировать и цитохром С в митохондриях, что приводит к изменению его функций, в частности он становится неспособным поддерживать перенос электронов в дыхательной цепи и не восстанавливается аскорбатом $[5,6,16]$. Поскольку одновременно происходит выход цитохрома С (в том числе и нитрованного) в цитоплазму, то можно предполагать участие такого нитрозилирования и в каких-то сигнальных процессах. Пероксинитрит приводит к нитрозилированию гуанина и разрыву цепочек ДНК. В отношении повреждений генома известен еще один эффект NO: его дериваты с супероксид-радикалом ингибируют ферменты, ответственные за репарацию ДНК. В зависимости от источника (разные доноры NO) показано действие NO на алкилтрансферазу, формамидопиримидин-ДНК-гликозилазу и лигазу. NO повышает активность PARP в клетках Беца и ADP-рибозилирование при глобальной ишемии, возможно вследствие разрывов ДНК, но это скорее приводит к некрозу из-за истощения пула NAD и ATP. B связи с действием NO и производных на ДНК интересны данные о его влиянии на экспрессию р53. Белок р53, подавляющий рост опухолей, поддерживает целостность генома и может вызывать остановку клеточного цикла или апоптоз. Известно, что р53 может индуцировать экспрессию Bax, Fas, p53AIP (apoptosis inducing protein) и других апоптогенных белков, а также сам перемещается в митохондрию при апоптозе, что может быть одной из причин выработки АФК и падения заряда митохондрий. В норме концентрация р53 в нейроне очень мала и он быстро деградирует. Повреждение ДНК ведет к накоплению p53. В экспериментах на культуре грушевидных нейронов мозжечка выявлено накопление р53 при гибели клеток, вызванной избытком донатора NO - нитропруссида натрия. Интересны данные о совместном участии в его регуляции гибели нейрона митохондрий и NO при ишемии мозга. Сделано заключение, что bcl-2 работает посредством снижения до нуля NOиндуцированного повышения экспрессии белка Вах. Взаимодействие NO с членами суперсемейства bcl-2 выражается также в том, что при действии оксида азота на клетку сильно понижается уровень внутриклеточного bcl-2-белка, возможно, через каспаз-индуцированное расщепление или р53-зависимое подавление его экспрессии [23-25]. Проапоптотический эффект оксида азота выражается также в индуцируемом им повышении экспрессии апоптогенных белков Bax.

В дополнение к описанным выше функциям митохондрий следует упомянуть последние исследования в этой области, показывающие, что митохондрия имеет отношение не только к восприятию апоптотического сигнала от NO, но и к производству самого NO. Действительно, в последних работах показано наличие конститутивной формы NOS в митохондриях. Было показано, что эта изоформа NOS локализована в митохондриальной мембране, судя по всему, во 
внутренней. Оказалось, что MNOS очень схожа с макрофагальной iNOS, но экспрессируется конститутивно. Пока не ясно, считать ли MNOS отдельной изоформой, или это iNOS, содержащая посттрансляционные модификации, которые ведут к иной субклеточной локализации. Очищенная MNOS при дефиците L-аргинина способна продуцировать супероксид-радикал [23]. Логично предположить участие этой $\mathrm{MNOS}$ в регуляции апоптоза, за счет влияния на тиолдисульфидное равновесие белков митохондриальной поры, как в реакции нитрозирования, так и окисления. Кроме того, получены данные о роли $\mathrm{MNOS}$ в регуляции уровня кальция в митохондрии. В норме MNOS препятствует поступлению избытка кальция в митохондрию, в условиях ишемии при повышении активности MNOS происходит повышение внутримитохондриального кальция и открытие митохондриальной поры.

По всей видимости, на начальных стадиях ишемии эта реакция играет защитную роль, т. к., регулируя кальцийзависимые механизмы открытия гиганской поры, MNOS способна активировать компенсаторные энергетические шунты $[7,11,13]$. В дальнейшем, особенно в постишемический период, нарастающая активность MNOS приводит к неконтролируемому открытию поры митохондрий и инициирует митоптоз. Кроме того, $\mathrm{NNOS}$ посредством выработки дозируемого уровня NO способна регулировать митохондриальное дыхание в норме и на начальных, компенсированных стадиях ишемии, модулируя активность цитохром-С-оксидазы, комплексы I и II электрон-транспортной цепи и уровень НАДФН, ФАД и коэнзима $\mathrm{Q}_{10}$, а также изменяя доступность $\mathrm{O}_{2}$ для акцептирования электронов. В дальнейшем роль $\mathrm{MNOS}$ меняется на кардинально противоположную - она участвует в активации паразитарных реакций образования АФК митохондриями.

Особого внимания в расширении представлений о механизмах цитотоксичности NO и гибели нейронов заслуживает тиол-дисульфидная система. Интермедиаты тиол-дисульфидной системы обладают транспортными свойствами в отношении NO, тем самым повышая его биодоступность. Кроме того, многие тиолы - глутатион, цистенин, метионин способны значительно ограничивать цитотоксичность NO и его дериватов, увеличивая шансы нейрона выжить при ишемии $[5,9,18]$.

Нашими исследованиями было установлено, что внесение в супернатант, содержащий митохондрии мозга крыс, восстановленного глутатиона или цистеина на фоне присутствия в среде (50 мкM) DNIC, приводило к увеличению активности малатдегидрогеназы, повышению заряда митохондрий и снижению маркеров окислительной модификации белка - альдегидфенилгидразо-

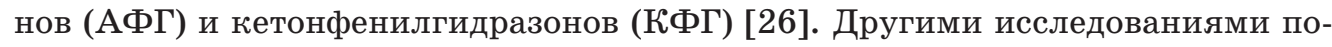
казано, что восстановленный глутатион в суспензии митохондрий мозга крыс ограничивал ингибирующее действие пероксинитрита in vitro на фосфорилирование белков с мол м. $60,45,29,22$ и 19 кД и увеличивал содержание белка теплового шока HSP 70 [23].

Учитывая вышеизложенное, перспективным является исследование состояния тиол-дисульфидной системы на модельной патологии в условиях острой ишемии головного мозга. 


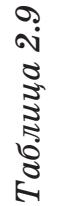

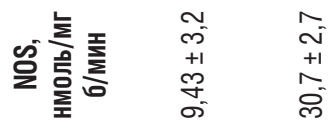

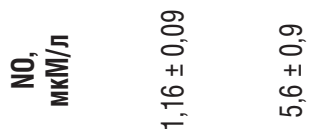

.

突

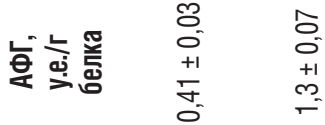

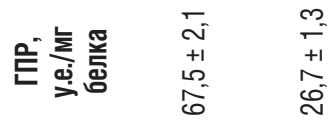

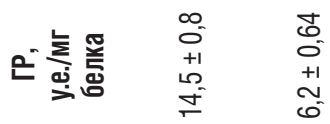

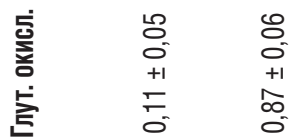

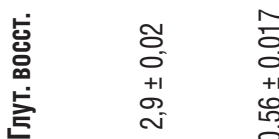

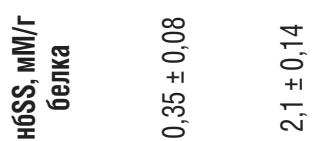

능ํㅇ

窝兽

$\begin{array}{ll}5 \\ 0 \\ +1 & + \\ 0 & +1 \\ 0 & +1 \\ 0 & 0\end{array}$

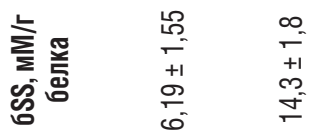

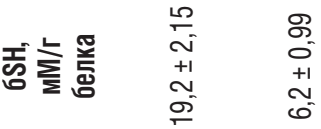

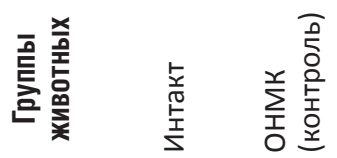

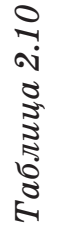

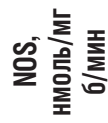

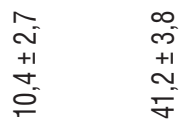

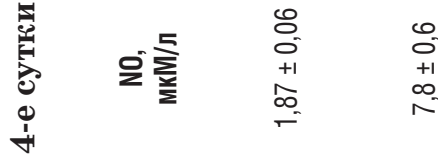

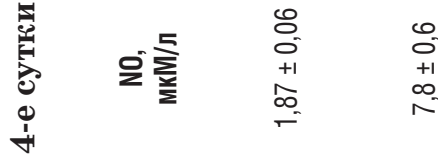

毞兽兽

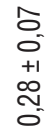

\begin{tabular}{l}
8 \\
0 \\
+1 \\
+1 \\
\hline
\end{tabular}

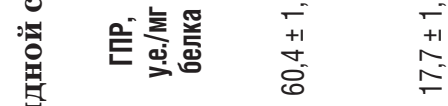

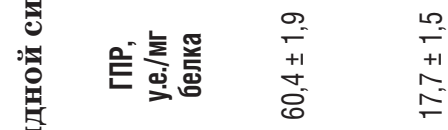

L

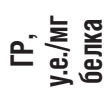

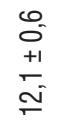

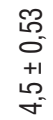

홍

$\hat{0}$
0
+1
0
0
0

0
0
0
+1
+

芦苔

논

$$
\text { 龒 }
$$

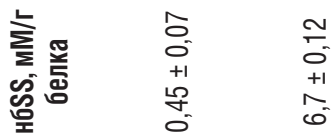

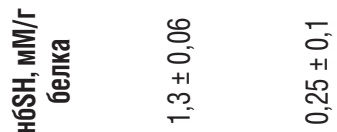

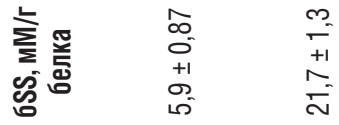

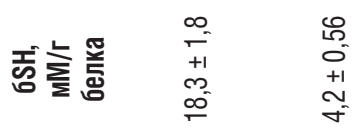
플 흘

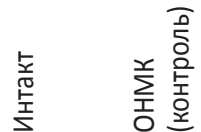


Так, у животных с церебральной ишемией в гомогенате головного мозга в первые сутки ишемии регистрировалось значительное количество окисленных тиолов, глутатиона, снижение уровня активности ГТ и ГПР, а также значительное увеличение АФГ (табл. 2.9). Параллельно с биохимическими изменениями в головном мозге отмечались и морфологические, проявляющиеся увеличением по отношению к интакту количества апоптирующих и некротирующих нейронов, с преобладанием гибели клеток по типу апоптоза (табл. 2.10, рис. 2.19).

Биохимические исследования тканей головного мозга животных с ОНМК на 4-е сутки эксперимента показали более значительный в сравнении с 1-ми сутками прирост окисленных $\mathrm{SH}$-групп и окисленного глутатиона, а также падение активности ГП и ГПР. Кроме того, отмечалось увеличение в головном мозге кетонфенилгидразонов (КФГ) - более позднего маркера окислительной деструкции белков, образующегося в условиях окислительного и карбонильного стресса, а также стабильных метаболитов NO и NO-синтазы (табл. 2.10). Подобные нейробиохимические изменения на 4-е сутки эксперимента приводят к существенным функциональным, необратимым изменениям в нейрональной клетке. За счет окисления тиольных групп цистеин-зависимого участка белка внутренней мембраны митохондрии способствуют открытию гигантской поры митохондрий и ее ферментных систем, приводя к развитию стойкой митохондриальной дисфункции, и как следствие - к ее гибели [21]. Важно отметить, что на 4-е сутки ишемии преобладал некротический тип гибели нейрона (повышение количества этидиум бромид (ЭБ)-положительно окрашенных нейронов - избирательная окраска некротически измененых клеток), что связано с развитием митохондриальной дисфункции, истощением энергетических запасов, значительным накоплением окисленных тиолов.

Таблица 2.11

\section{Тип морфологическиой гибели нейрональных клеток} на 1-е и 4-е сутки церебральной ишемии

\begin{tabular}{|c|c|c|c|c|}
\hline $\begin{array}{c}\text { Группы } \\
\text { животных }\end{array}$ & $\begin{array}{c}\text { Hoеcht+-нейроны } \\
\text { (апоптоз) } \\
\text { 1-е сутки, количество } \\
\text { клеток в видимом } \\
\text { поле }\end{array}$ & $\begin{array}{c}\text { ЭБ+-нейроны } \\
\text { (некроз) } \\
\text { 1-е сутки, количество } \\
\text { клеток в видимом } \\
\text { поле }\end{array}$ & $\begin{array}{c}\text { Hoecht+-нейроны } \\
\text { (апоптоз) } \\
\text { 4-е сутки, количество } \\
\text { клеток в видимом } \\
\text { поле }\end{array}$ & $\begin{array}{c}\text { ЭБ+-нейроны } \\
\text { (некроз) } \\
\text { 4-е сутки, количествс } \\
\text { клеток в видимом } \\
\text { поле }\end{array}$ \\
\hline Интакт & $5 \pm 1,5$ & $2 \pm 0,5$ & $4 \pm 2,1$ & $2 \pm 0,87$ \\
\hline $\begin{array}{l}\text { ОНМК } \\
\text { (контроль) }\end{array}$ & $43,6 \pm 3,3^{*}$ & $18 \pm 2,7^{*}$ & $12 \pm 3,4^{*}$ & $47,8 \pm 3,4^{*}$ \\
\hline
\end{tabular}



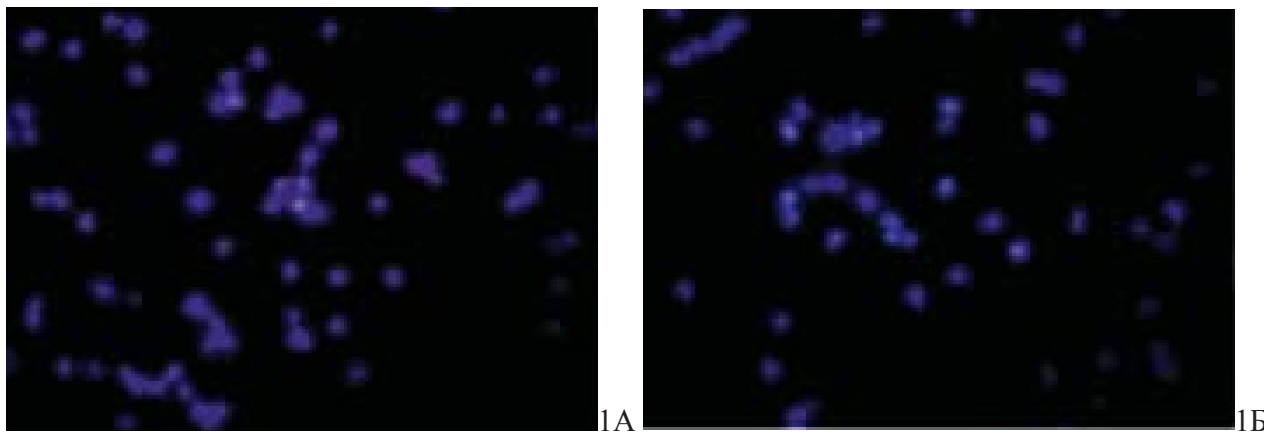

Рис. 2.19. Флюоресцентное свечение Ноесht-позитивных нейронов на 1-е сутки эксперимента (1А - контроль; 1 Б - интакт)

\section{Заключение}

Соотношение оксида азота и тиол-дисульфидной системы является фактором, определяющим дальнейшую судьбу нейрона в условиях ишемии, а именно - тип его гибели. В условиях ишемических повреждений головного мозга в ранние сроки развивается нитрозирующий стресс, приводя к нитрозированию тиолов, изменяя тиол-дисульфидное равновесие белков митохондриальной поры. На этой стадии митохондриальная NO-синтаза играет защитную роль, регулируя клеточную гибель, переключая ее на более выгодный тип апоптоз. Далее развивается оксидативный и карбонильный стресс, которые существенно смещают тиол-дисульфидное равновесие в сторону окисленных тиолов, развивается стойкая митохондриальная дисфункция с дефицитом энегретических запасов клетки, развитием аутокоидоза, изменением ответа генома, и как следствие - клетка погибает по типу некроза.

Вышеизложенное определяет целесообразность поиска эффективных средств фармакологической коррекции церебральной ишемии среди препаратов, способных оказывать модулирующее действие на основные интермедиаторы тиолдисульфидной системы головного мозга. 


\title{
ГЛАВА 3
}

\section{СОВРЕМЕННАЯ СТРАТЕГИЯ НЕЙРОПРОТЕКЦИИ. СРЕДСТВА ПЕРВИЧНОЙ НЕЙРОПРОТЕКЦИИ}

\author{
3.1. АНТАГОНИСТЫ NМDА- И АМРА-РЕЦЕПТОРОВ. ПРЕПАРАТЫ МАГНИЯ. \\ ГЛИЦИН
}

Современные представления о механизмах развития ишемического инсульта позволили выделить два основных направления патогенетической терапии: улучшение перфузии ткани мозга (ранняя реканализация сосуда и реперфузия) и нейропротективная терапия. Экспериментальные исследования показали, что возвращение крови в ишемизированную зону через реваскуляризированный участок артерии не всегда приводит к полной нормализации локального мозгового кровотока. Даже спустя всего 5 мин после дебюта ишемии в зоне ишемической полутени возникают поэтапные нарушения перфузии церебральной ткани: в первые минуты - гиперемия (или «роскошная перфузия»), затем - постишемическая гипоперфузия, что является результатом тяжелых нарушений микроциркуляции, вызванных высвобождением из ишемизированной ткани вазоактивных и провоспалительных метаболитов. Характер реперфузионной терапии определяется патогенетическим вариантом развития инсульта. В настоящее время разработано 5 поколений тромболитиков [1-10]:

I поколение - системные тромболитики: природные активаторы плазминогена (Стрептокиназа, Урокиназа);

II поколение - фибриноселективные тромболитики: рекомбинантный тканевый активатор плазминогена (rt-PA, Актилизе (альтеплаза)), Рекомбинантная проурокиназа;

III поколение - усовершенствованные rt-PA и другие активаторы плазминогена: фибринспецифичная форма rt-PA - Тенектеплаза, негликозилированная форма rt-PA - Ретеплаза, rt-PA с длительным периодом полувыведения - Ланотеплаза, ацилированный комплекс стрептокиназа + плазминоген, обеспечивающий направленную доставку к тромбу, фибринактивированный человеческий плазминоген;

IV поколение - усовершенствованные активаторы плазминогена III поколения (биосинтетические);

Vпоколение - композициитромболитиков(rt-PA + конъюгат «урокиназаплазминоген» и др.).

Тромболитики I поколения неприменимы в клинических условиях из-за системного действия на гемостаз и высокой частоты геморрагических осложнений. Тромболитики III-V поколений в настоящее время проходят испытания в экспериментальных доклинических работах и лишь планируются для испытаний в клинике.

Основную роль в клинической практике играют тромболитики II поколения: rt-PA и Рекомбинантная проурокиназа, обладающие малым системным тромболитическим эффектом, действующие преимущественно на свежий 
тромб и не активирующие факторы свертывания крови V и VII, что существенно снижает риск развития генерализованных геморрагических осложнений.

По сравнению с реперфузией, нейропротективная терапия более сложна и разнообразна, отражая разнообразие механизмов ишемического повреждения ткани мозга. Практически для каждого этапа ишемического каскада был разработан и прошел испытания хотя бы один препарат-нейропротектор. В настоящее время проводится более 30 мультицентровых международных исследований разной фазы, посвященных препаратам разных фармакологических групп с потенциальными нейропротективными свойствами [297-305].

По данным экспериментальных и клинических исследований, раннее применение нейропротекторов позволяет:

1) увеличивать долю транзиторных ишемических атак и «малых» инсультов среди острых нарушений мозгового кровообращения по ишемическому типу;

2) значительно уменьшать размеры инфаркта мозга;

3) удлинять период терапевтического окна, расширяя возможности для тромболитической терапии;

4) осуществлять защиту от реперфузионного повреждения.

Согласно работам Е. И. Гусева и В. И. Скворцовой (1999-2002), можно условно выделить два основных направления нейропротективной терапии. Первичная нейропротекиия направлена на прерывание быстрых механизмов некротической смерти клеток - реакций глутамат-кальциевого каскада. Этот вид нейропротекции должен быть начат с первых минут ишемии и продолжаться на протяжении первых 3-х дней инсульта, особенно активно в первые 12 часов. Вторичная нейропротекиия направлена на уменьшение выраженности отдаленных последствий ишемии - гиперпродукции оксида азота, оксидативного стресса, активации микроглии, экспрессии провоспалительных цитокинов, локального воспаления, митохондриальной дисфункции, усиления апоптоза. Она может быть начата спустя 3-6 часов после развития инсульта и должна продолжаться по меньшей мере 7 дней [4].

Нейропротекторы трудно классифицировать: сотни препаратов имеют различное строение и неодинаковый механизм действия. Т. А. Воронина и С. Б. Середенин (1993) выделили истинные ноотропы (ведущее свойство улучшение когнитивных функций: внимания, памяти, способности к анализу ситуации, принятию решений, ориентации в пространстве) и ноотропоподобные средства (препараты поливалентного комплексного нейропротекторного действия [4, 11, 299].

Для нейропротективных средств характерно:

- улучшение синаптической передачи, нейрональной пластичности, межполушарных взаимодействий, кортикальных и субкортикальных связей;

- стимуляция интегративных механизмов мозга (памяти, обучения);

- восстановление нарушенных функций ЦНС после ишемии, травм, интоксикаций;

- оптимизация пластического и энергетического обмена в нейронах; 
- сложность и многообразие механизмов действия;

- угнетение процессов пероксидации белков, нуклеиновых кислот, липидов; стабилизация мембран;

- сохранение дыхательной функции митохондрий и активности АТФ-аз;

- ингибирование лизосомальных ферментов;

- повышение скорости оборота АТФ, синтеза РНК, белков;

- способность улучшать мозговое кровообращение и его ауторегуляцию;

- незначительное влияние на психические функции при отсутствии утомления;

- низкая токсичность, хорошая переносимость;

- отсутствие лекарственной зависимости.

Среди антагонистов NMDA-рецепторов наиболее изучены антагонисты фенциклидинового сайта (Дизолципин, Декстрорфан, Церестат). Применение этих препаратов в экспериментальных условиях достоверно сокращало размеры инфарктных изменений при фокальной ишемии мозга, повышало выживаемость животных. Клинические испытания этих препаратов были прекращены из-за грубых побочных эффектов (нистагм, артериальная гипотония, катаплексия, локомоторные нарушения, галлюцинации и т. д.).

Следствием открытия феномена эксайтотоксичности явилось создание новых терапевтических стратегий - препаратов-антагонистов глутаматных NMDA- и AMPA-рецепторов, а также ингибиторов пресинаптического высвобождения глутамата. Несмотря на то, что у препаратов этих групп в эксперименте были продемонстрированы выраженные нейропротективные эффекты, клинические испытания большинства из них были прекращены из-за широкого спектра серьезных побочных явлений (психические, локомоторные, общие токсические).

В настоящее время продолжаются исследования эффективности Ремацемида - низкоаффинного неконкурентного антагониста NMDA-рецепторов, обладающего способностью ингибировать и потенциал-зависимые кальциевые каналы. В эксперименте при окклюзии средней мозговой артерии ремацимид снижал летальность животных, снижал накопление нитротирозина в $\mathrm{CA}_{1}$-зоне гиппокампа.

Церестат также проявлял нейропротективный эффект в условиях временной окклюзии средней мозговой артерии, уменьшая зону некроза, выраженность оксидативного стресса.

Одним из наиболее перспективных нейропротекторов является Кетамин. Кетамин и его метаболит норкетамин обладают способностью неконкурентно блокировать NMDA-рецепторы коры головного мозга, дозозависимо блокировать синтез и секрецию TNF- $\alpha$ и индуцированную TNF- $\alpha$ лейкоцитэндотелиальную адгезию, предотвращая таким образом вторичное поражение ЦНС при необратимой окклюзии сонных артерий и внутримозговом введении аутокрови монгольским песчанкам. Интенсивная терапия больных тяжелой ЧМТ, осложненной развитем комы, или больных с геморрагическим инсультом Кетамином внутривенно в дозе 500 мг/сутки приводила к снижению летальности в группе больных с ЧМТ на 60 \% , а в группе больных с геморрагиче- 
ским инсультом - в 2 раза. Осложнений, связанных с применением Кетамина отмечено не было.

Дизолципин в условиях эксперимента проявляет значительный нейропротективный эффект: достоверно уменьшает размер зоны инфаркта мозга при окклюзии средней мозговой артерии. Клинические испытания препарата были прекращены вследствие большого объема побочных эффектов (катаплексия, диплопия, локомоторные нарушения, артериальная гипотония [297-307].

Декстрорфан и его производное декстролеторфан - отличаются от Дизолципина тем, что наряду с блокадой NMDA-ассоциированных ионных каналов, блокируют и L-тип кальциевых каналов [307-309]. Декстрорфан и декстрометорфан, вводимые монгольским песчанкам с окклюзией средней мозговой артерии, вызывали уменьшение объема инфаркта мозга, снижали накопление маркера оксидативного стресса - нитротирозина - и экспрессию провоспалительных цитокинов. Однако клинические испытания этих препаратов обнаружили у них такие побочные эффекты, как нистагм, тошноту, рвоту, сонливость, галлюцинации, спутанность сознания, двигательные расстройства, артериальную гипотонию. Побочные эффекты возрастали с увеличением дозы препаратов, и дальнейшие клинические испытания были прекращены. Углубленные доклинические и клинические испытания не рбнаружили достоверного нейропротективного эффекта у конкурентных антагонистов NMDAрецепторов Церестата, Селфотела, Элипродила. Кроме того, назначение низких и средних доз этих препаратов вызывало тяжелые побочные әффекты (общетоксические, психические, двигательные).

Препараты магния. Еще одним средством, блокирующим NMDAзависимые каналы потенциалзависимым способом, являются ионы лагния. Рядом работ показано, что введение Магния хлорида или Магния сульфата животным с окклюзией обеих сонных артерий или с окклюзией средней мозговой артерии приводило к снижению гибели нейронов гиппокампа и сенсомоторной зоны коры мозга, уменьшало накопление маркерных продуктов окислительной модификации белка, увеличивало содержание антиапоптотического белка bcl-2 в нейронах гиппокампа. Введение Магния хлорида крысам с окклюзией обеих сонных артерий достоверно снижало гибель животных, уменьшало проявления неврологического и когнитивного дефицита, оказывало позитивное действие в отношении экспрессии генов раннего реагирования c-fos. Высокая нейропротективная активность ионов магния выявлена in vitro по способности снижать смертность нейронов при внесении в инкубационную среду избытка агонистов NMDA-рецепторов. Международные рандомизированные клинические испытания показали, что применение Магния сульфата позволяет достоверно увеличить долю больных с хорошим неврологическим восстановлением, снизить частоту неблагоприятных исходов ишемического инсульта и безопасно в плане развития нежелательных побочных явлений. По результатам экспериментальных работ, проведенных на моделях острой фокальной ишемии, наиболее перспективным направлением первичной нейропротекции является коррекция дисбаланса возбуждающих и тормозных нейротрансмиттерных систем с помощью активации естественных тормозных процессов [305-312]. 
Глицин. Внимание исследователей привлекает роль тормозного нейротрансмиттера глицина в механизмах острой церебральной ишемии.

Традиционно считалось, что аминокислота глицин проявляет нейротрансмиттерные свойства на уровне спинного мозга, продолговатого мозга и моста, высвобождаясь в основном из сегментарных интернейронов и проприоспинальных систем и ингибируя посредством аксо-дендритических и аксоаксональных контактов мотонейроны. Позднее была доказана роль глицина как тормозного нейротрансмиттера практически во всех отделах ЦНС. В головном мозге большая плотность глициновых рецепторов обнаружена не только в структурах ствола, но и в коре больших полушарий, стриатуме, ядрах гипоталамуса, проводниках от лобной коры к гипоталамусу, мозжечке. Рядом экспериментальных работ показано, что глицин в субмикромолекулярных концентрациях необходим для нормального функционирования глутаматных NMDAрецепторов. Активация NMDA-рецепторов возможна лишь при условии связывания глицина с их специфическими глициновыми сайтами, т. е. глицин является их коагонистом. Глицин значительно снижает гибель нейронов при добавлении в инкубационную среду агонистов NMDA-рецепторов - глутамата и NMDA, причем не только уменьшает гибель нейронов, но и влияет на морфологический тип гибели, переключая его с некроза на менее опасный апоптоз $[26,309-320]$.

Наряду с нейротрансмиттерным, глицин обладает также общеметаболическим действием, увеличивая окислительную продукцию энергии за счет компенсаторной активации шунта Робертса, повышая активность антиоксидантных ферментов, снижая проявления митохондриальной дисфункции [320].

Рандомизированное двойное слепое плацебо-контролируемое исследование установило, что применение глицина в дозе 1-2 г в сутки в течение 5 дней у пациентов с острым ишемическим инсультом (начиная с 6 часов после развития первых симптомов) позволяет обеспечить противоишемическую защиту мозга у больных с различной локализацией сосудистого поражения и разной тяжестью состояния, достоверно ускоряет регресс неврологической симптоматики ( $<0,01)$, улучшает функциональное восстановление больных и снижает 30 -дневную летальность, по сравнению с группой плацебо. Клиническими исследованиями показано достоверное уменьшение объема инфаркта мозга и торможение последующей кистозной трансформации очага на фоне применения глицина, а также ускоренная нормализация электроэнцефалографического паттерна.

Глицисед. Нашими экспериментальными исследованиями в опытах in vitro при моделировании эксайтотоксичности в суспензии нейронов установлена дозозависимость эффектов препарата аминокислоты глицина - Глициседа. Так, Глицисед в концентрации 0,1 мкМ оказывает потенцирующее действие на глутаминовые рецепторы и повышает нейрональную смертность в сравнении с контролем, как по типу некроза, так и по типу апоптоза. При внесении в инкубационные пробы Глициседа в концентрации 10 мкМ и моделировании глутаматной эксайтотоксичности наблюдалась тенденция к снижению смертности нейронов, что, возможно, связано с насыщением глициновых сайтов 
NMDA-рецепторов при данной концентрации глицина. Внесение высоких концентраций Глициседа (100 мкM) при моделировании эксайтотоксичности in vitro приводит к достоверному снижению гибели нейронов в этих пробах, по сравнению с группой контроля, причем отмечено, что гибель снижается, в основном, за счет уменьшения апоптотически измененных нейронов [26].

Нейропротективное действие Глициседа in vitro реализуется только посредством влияния на NMDA-рецепторы, но не на AMPA-/каинатные рецепторы, что подтверждается нашими исследованиями. Так, при добавлении Глициседа (100 мкM) в пробы с агонистом NMDA-рецепторов (N-метил-D-аспартат) наблюдался наиболее выраженный нейропротективный эффект. При инкубации проб с Глициседом (100 мкM) и неспецифическим агонистом глутаминовых рецепторов (глутамат) процент выживших нейронов несколько снижался. В пробах с агонистом каинатных/AMPA-рецепторов (каинат) глицин практически не оказывал защитного действия в отношении смертности нейронов. Как было отмечено выше, нейропротективное действие Глициседа проявляется в способности последнего регулировать развитие апоптоза нейронов, обусловленного глутаматной эксайтотоксичностью in vitro. Так, Глицисед в концентрации 100 мкM, повышал количество bcl-2-позитивных нейронов в инкубационных пробах с добавлением N-метил-D-аспартата и глутамата. В этой же концентрации Глицисед ограничивал повышенную экспрессию c-fos при моделировании эксайтотоксичности N-метил-D-аспартатом и глутаматом. Подобное действие связано с ограничением гиперактивности, в большей степени - NMDAрецепторов и индукцией реакций апоптоза (рис. 3.1).

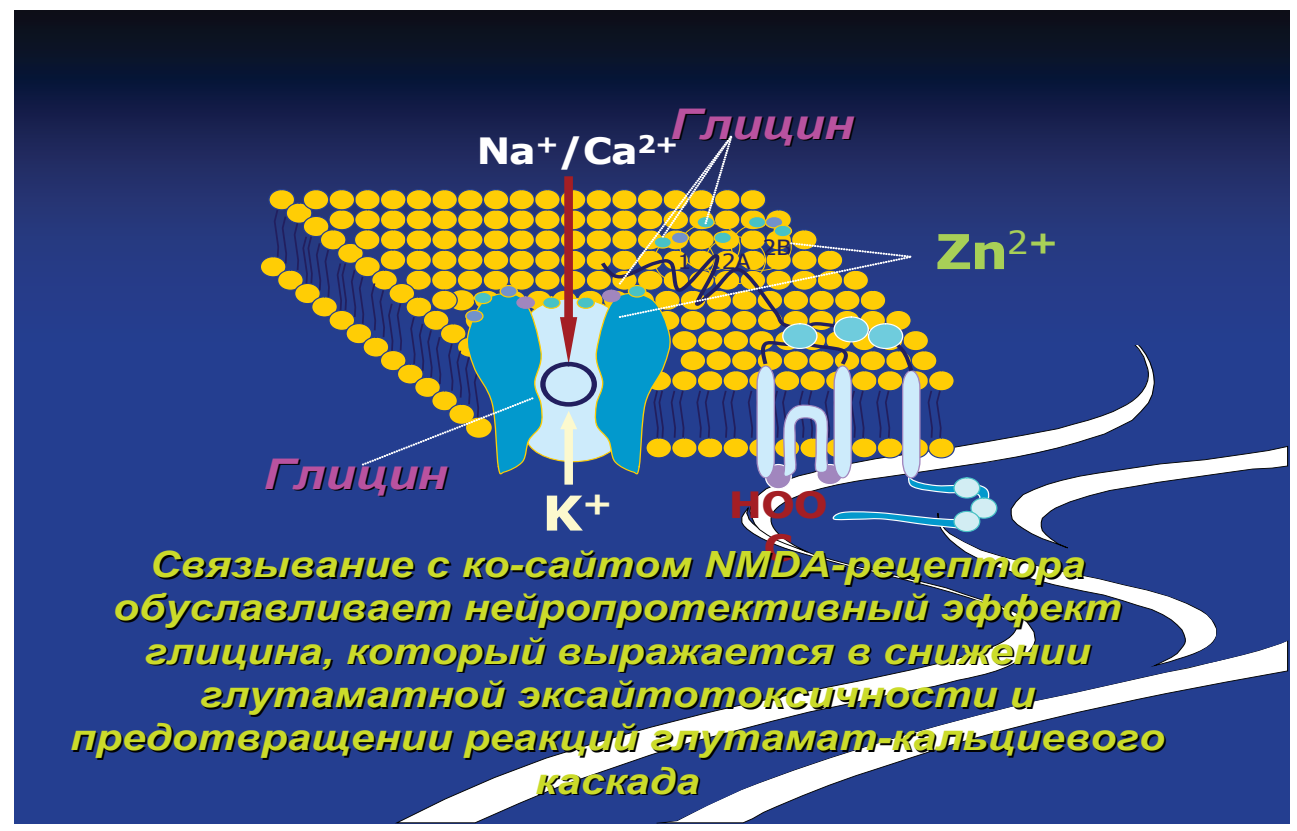

Рuc. 3.1. Гипотетический механизм действия глицина 
Нейропротективные эффекты Глициседа подтвердились и на модели двусторонней перевязки общих сонных артерий у крыс линии Wistar [158, 159].

Введение крысам с ОНМК Глициседа и Пирацетама оказывало нейропротективный эффект о чем свидетельствовало уменьшение летальности на 18-е сутки эксперимента. Назначение Глициседа приводило к более выраженному, по сравнению с Пирацетамом, снижению летальности. Глицисед и Пирацетам ослабляли развитие неврологического дефицита, ускоряли восстановление неврологического статуса животных с двусторонней перевязкой общих сонных артерий (ишемический инсульт), что свидетельствует об их нейропротективном эффекте. На этом фоне значительно выделялся Глицисед, который достоверно снижал проявления неврологической симптоматики, превосходя по показателям шкалы C. P. Mc Grow Пирацетам. Введение Глициседа и Пирацетама тормозило развитие когнитивного дефицита у животных с ОНМК, улучшало процессы обучения и памяти, о чем свидетельствовало увеличение латентного периода УРПИ на 18-е сутки эксперимента. Наиболее выраженным действием обладал Глицисед.

Кроме того, назначение экспериментальным группам животных Глициседа оказывало положительное влияние на энергетический метаболизм в тканях головного мозга ишемизированных животных. Назначение животным с ОНМК Глициседа приводило к значительной активации окислительной продукции энергии в цикле Кребса на участке изоцитрат-сукцинат, о чем свидетельствовало повышение уровня изоцитрата и активности СДГ. Подобное действие Глициседа обеспечивало утилизацию образовавшегося в шунте Робертса сукцината, и активацию сукцинатоксидазного пути поставки протонов в дыхательную цепь, о чем свидетельствовало повышение активности митохондриальной цитохром-С-оксидазы. Таким образом, Глицисед обеспечивал окислительную продукцию АТФ в условиях ишемии и обеспечивал эффективную ее утилизацию (повышение активности АТФ-азы). Глицисед также уменьшал активность анаэробного гликолиза (снижение уровня лактата). Введение Глициседа приводило к повышению уровня ГАМК и глицина в головном мозге крыс с ОНМК на фоне снижения активности ГДК и ГАМК-Т, что свидетельствовало о регуляторном воздействии на компенсаторную активацию шунта Робертса, не вызывая истощения нейротрансмиттерных аминокислот. Повышение тормозных аминокислот под действием Глициседа, по всей видимости, ограничивало возбуждение NMDA-рецепторов и снижало развитие глутаматной эксайтотоксичности и, тем самым, усиливало суммарное нейропротективное действие препарата (рис. 3.2).

В условиях модельной патологии Глицисед тормозил развитие оксидативного стресса. Так, в головном мозге животных, получавших Глицисед, наблюдалось снижение гиперферментемии синтазы оксида азота и уменьшение стабильных метаболитов NO - нитратов и нитритов. Введение Глициседа приводило и к уменьшению $(\mathrm{p}<0,05)$ продуктов ОМБ и ПОЛ - АФГ и КФГ, МДА, ДК, и ТК в ткани головного мозга животных с ОНМК. Кроме того, Глицисед оказывал благотворное действие в отношении ферментов антиоксидантной защиты (каталаза, супероксиддисмутаза), повышая их активность по сравнению 
с показателями контрольной группы. Подобный эффект Глициседа, на наш взгляд, объясняется его взаимодействием с глициновыми сайтами NMDAрецепторов, что обеспечивает нормальное функционирование этого рецепторноионоформного комплекса, ограничение его гиперактивации, а также снижение активации кальцийзависимой NO-синтазы, уменьшение продукции NO и торможение развития оксидативного стресса. Этим и объясняются полученные нами данные о снижении оксидативного стресса при введении Глициседа.

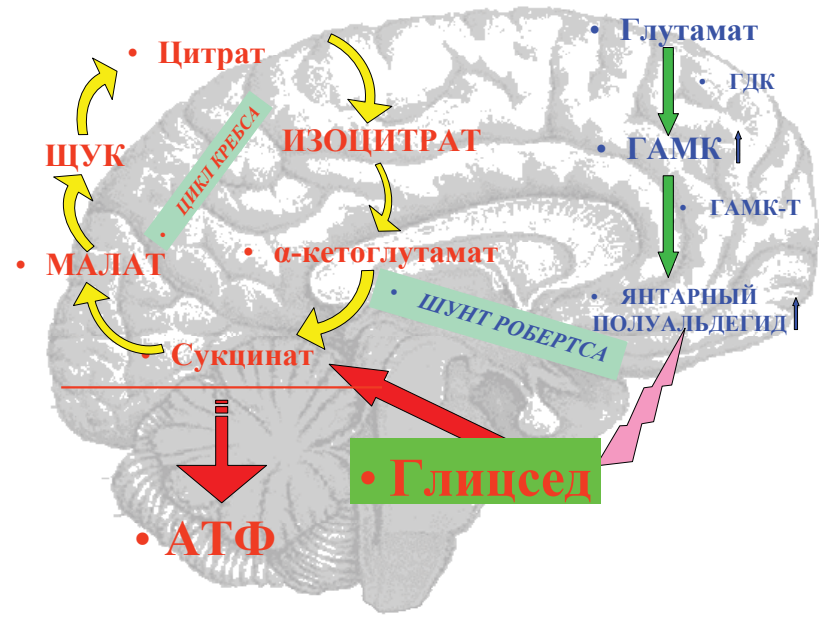

\section{Рис. 3.2. Энерготропный механизм действия Глициседа}

Нейропротективные эффекты Глициседа были доказаны нами и при проведении морфометрических исследований в головном мозге крыс с экспериментальной ишемией. Характер действия Глициседа на нейроглию при ОНМК проявлялся значительным снижением гибели нейронов и глиальных клеток в коре мозга, повышением их морфофункциональной активности (повышение содержания РНК), торможением апоптоза (см. табл. 3.1, 3.2, рис. 3.3). Важно отметить, что по многим исследуемым показателям Глицисед статистически достоверно превышал таковые показатели референс-препарата - Пирацетама.

Таблица 3.1

\section{Характеристика нейронов IV-V слоев коры головного} мозга крыс с экспериментальной ишемией

\begin{tabular}{|l|c|c|c|c|c|c|}
\hline \multirow{2}{*}{$\begin{array}{c}\text { Экспериментальные } \\
\text { группы }\end{array}$} & \multicolumn{2}{|c|}{$\begin{array}{c}\text { Плотность нейронов, } \\
\text { клеток/мм² }\end{array}$} & \multicolumn{2}{|c|}{$\begin{array}{r}\text { Площадь тел нейронов, } \\
\text { мкм2 }\end{array}$} & \multicolumn{2}{c|}{$\begin{array}{c}\text { Содержание РНК } \\
\text { в нейронах, ЕОП }\end{array}$} \\
\cline { 2 - 7 } & 4-е сутки & 18-е сутки & 4-е сутки & 18-е сутки & 4-е сутки & 18-е сутки \\
\hline $\begin{array}{l}\text { Ложнооперируемые } \\
\text { (интакт) }\end{array}$ & $1281 \pm 34$ & $1292 \pm 31$ & $75,21 \pm 1,12$ & $74,87 \pm 1,32$ & $9,69 \pm 0,15$ & $9,72 \pm 0,14$ \\
\hline $\begin{array}{l}\text { Животные с ОНМК } \\
\text { (контроль) }\end{array}$ & $1065 \pm 27$ & $1082 \pm 19$ & $64,19 \pm 0,9$ & $62,12 \pm 1,08$ & $5,4 \pm 0,2$ & $5,5 \pm 0,6$ \\
\hline
\end{tabular}




\begin{tabular}{|c|c|c|c|c|c|c|}
\hline \multirow{2}{*}{$\begin{array}{c}\text { Экспериментальные } \\
\text { группы }\end{array}$} & \multicolumn{2}{|c|}{$\begin{array}{l}\text { Плотность нейронов, } \\
\text { клеток/мм² }\end{array}$} & \multicolumn{2}{|c|}{$\begin{array}{l}\text { Площадь тел нейронов, } \\
\text { мкм2 }\end{array}$} & \multicolumn{2}{|c|}{$\begin{array}{l}\text { Содержание РНК } \\
\text { в нейронах, ЕОП }\end{array}$} \\
\hline & 4-е сутки & 18-е сутки & 4-е сутки & 18-е сутки & 4-е сутки & 18-е сутки \\
\hline $\begin{array}{l}\text { Животные с ОНМК } \\
+ \text { глицин }\end{array}$ & $1091 \pm 28$ & $1187 \pm 32^{*}$ & $69,97 \pm 1,14$ & $72,12 \pm 0,94^{*}$ & $6,83 \pm 0,18^{*}$ & $8,77 \pm 0,23^{\star}$ \\
\hline $\begin{array}{l}\text { Животные с ОНМК + } \\
\text { Пирацетам }\end{array}$ & $1060 \pm 38$ & $1163 \pm 26^{*}$ & $63,46 \pm 0,8$ & $68,71 \pm 0,93^{*}$ & $5,73 \pm 0,18$ & $8,03 \pm 0,23^{\star}$ \\
\hline
\end{tabular}

Таблица 3.2

\section{Плотность апоптотических и деструктивно измененных} клеток IV-V слоев коры головного мозга крыс с экспериментальной ишемией

\begin{tabular}{|l|c|c|c|c|}
\hline \multirow{2}{*}{$\begin{array}{c}\text { Экспериментальные } \\
\text { группы }\end{array}$} & \multicolumn{2}{|c|}{ Плотность клеток на 1 мм² } & \multicolumn{2}{|c|}{$\begin{array}{c}\text { Доля апоптотических } \\
\text { клеток, \% }\end{array}$} \\
\cline { 2 - 5 } & 4-е сутки & 18-е сутки & 4-е сутки & 18-е сутки \\
\hline $\begin{array}{l}\text { Ложнооперируемые } \\
\text { (интакт) }\end{array}$ & $107 \pm 9$ & $110 \pm 7$ & $4,5 \pm 0,53$ & $4,3 \pm 0,61$ \\
\hline $\begin{array}{l}\text { Животные с ОНМК } \\
\text { (контроль) }\end{array}$ & $294 \pm 18$ & $287 \pm 18$ & $17,45 \pm 0,8$ & $14,36 \pm 0,74$ \\
\hline $\begin{array}{l}\text { Животные с ОНМК } \\
\text { + глицин }\end{array}$ & $162 \pm 15^{\star}$ & $112 \pm 10^{*}$ & $8,7 \pm 0,47^{*}$ & $6,3 \pm 0,33^{*}$ \\
\hline \begin{tabular}{l} 
Животные с ОНМК + Пирацетам \\
\hline
\end{tabular} & $438 \pm 29^{*}$ & $153 \pm 18^{*}$ & $16,3 \pm 1,7$ & $6,4 \pm 0,52^{*}$ \\
\hline
\end{tabular}

В эксперименте на модели окклюзии средней мозговой артерии была показана нейропротективная активность антагониста глиционового сайта NMDAрецепторов Гавестенила [163].

Однако, международными рандомизированными клиническими исследованиями в группах 1804 пациентов было установлено, что гавестенил не снижает смертность и не влияет на функциональный исход по шкале Бартела. Определенный интерес представляют ингибиторы высвобождения глутамата (Лабелузол, Рилутек, Боризол), которые в условиях моделирования ОНМК показали достоверный нейропротективный эффект. Назначение этих препаратов в первые 4 суток после окклюзии общих сонных артерий приводило к уменьшению гибели нейронов гиппокампа и сенсомоторной коры, снижению образования маркерных продуктов оксидативного стресса, улучшению энергетических показателей нейрона. Проведенные рандомизированные клинические исследования Лабелузола в группе 3510 пациентов не выявили эффекта относительно смертности, но определили действие относительно функционального 
исхода по шкале Бартела (уменьшение неврологического дефицита). В настоящее время клинические исследования ингибиторов высвобождения глутамата продолжаются [318-321].
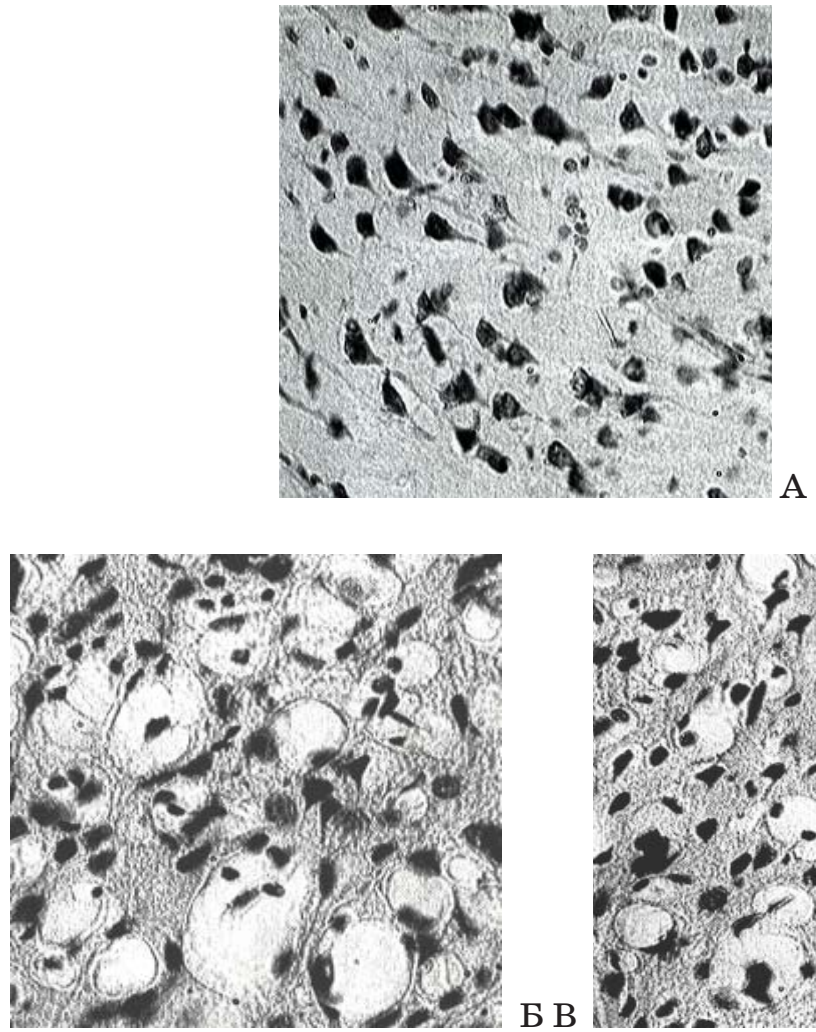

B B
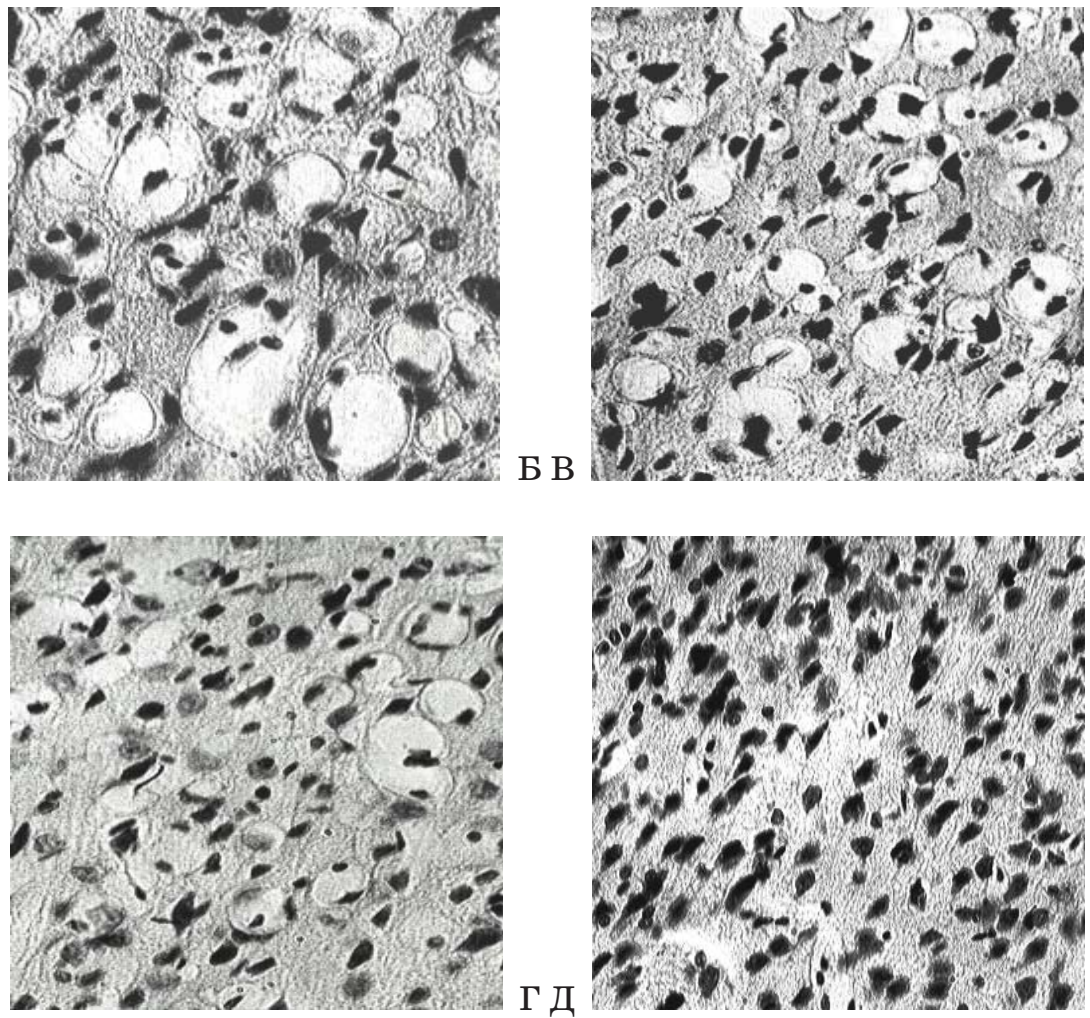

Рис. 3.3. Нейроны сенсомоторной зоны фронтальной коры крыс

А - интактная группа; $\mathbf{6}-$ ОНМК, 4-е сутки; В - ОНМК, 18-е сутки; Г-ОНМК свведениел глицина, 4-е сутки; Д-ОНМК с введениел глицина, 18-е сутки. 
Одним из перспективных направлений в создании средств первичной нейропротекции является использование агонистов ГАМК-рецепторов. Эти соединения не только снижают проявления эксайтотоксичности, но и обладают нейрометаболическим эффектом, регулируют процессы торможения в ЦНС. Экспериментальные исследования Клометиазола на модели окклюзии средней мозговой артерии у гербелов выявили у Клометиазола нейропротективную активность, направленную на уменьшение объема инфаркта мозга, снижение маркера оксидативного стресса - нитротирозина. Рандомизированные клинические исследования в группах 1360 пациентов выявили способность Клометиазола уменьшать проявления неврологического дефицита, не влияя при этом на летальность. Клинические исследования Клометиазола продолжаются [318, 320].

Предпринимаются попытки селективной блокады NMDA-рецепторов путем воздействия на их модуляторные (полиаминные и глициновые) сайты.

Наиболее перспективными оказались препараты антагонисты глицинового сайта, которые по силе нейропротективного действия не уступали фармакологическим стандартам и оказались более безопасными, чем другие антагонисты NMDA-рецепторов. В настоящее время 2 препарата этой группы ( $G V$-150526 u $A C E A-1021)$ проходят 2-ю стадию клинических испытаний. Определенный интерес представляют антагонисты и позитивные модуляторы AMPА-рецепторов. При экспериментальной ишемии мозга значительную нейропротективную активность показали NBOX и ZK200775. В то же время установлены грубые побочные эффекты этих препаратов (нефротоксичность и седация), что делает их неприменимыми в клинике. В Российской Федерации проходит клинические испытания препарат этой группы - Неоглютил, проявивший нейропротективные свойства в условиях моделирования ишемического и геморрагического инсульта [323, 324].

Таким образом, клинические испытания большинства наиболее сильных в эксперименте нейропротекторов - антагонистов глутаматных рецепторов были прекращены из-за грубых побочных эффектов, а использование менее токсичных антагонистов NMDA-рецепторов не всегда является эффективным.

Основным направлением первичной нейропротекции является прерывание быстрых механизмов глутамат-кальциевого каскада с целью коррекции дисбаланса возбуждающих и тормозных нейротрансмиттерных систем и активации естественных тормозных процессов. Этот вид нейропротекции должен быть начат с первых минут ишемии и продолжаться на протяжении первых 3-х дней инсульта, особенно активно - в первые 12 часов [26, 41, 42].

Во второй фазе клинических испытаний, проведенных у больных острым ишемическим инсультом, были показаны безопасность и хорошая переносимость Лубелузола. Лубелузол - соединение бензотиазола, являющееся блокатором натриевых каналов. Препарат предотвращает пресинаптическое высвобождение глутамата, снижает концентрацию нейротрансмиттера во внеклеточном пространстве периинфарктной зоны мозга, а также тормозит глутаматиндуцированную нейротоксичность оксида азота, снижая активность фермента NO-синтазы $[163,164,171,172]$. 
При его применении, начиная с первых 6-ти часов и в течение 5-ти дней (в дозе 10 мг/сут), летальность была на $10 \%$ меньше, чем в группе плацебо, и на 7 \% возрастало число больных с хорошим восстановлением нарушенных неврологических функций (полное восстановление или минимальные остаточные явления) через 3 месяца после инсульта.

\section{2. АНГИОЛИН - НОВЫЙ ПЕРВИЧНЫЙ НЕЙРОПРОТЕКТОР С ВЫРАЖЕННЫМ ВЛИЯНИЕМ НА ЭНДОТЕЛИЙ СОСУДОВ И МЕТАБОЛИЗМ}

Последние годы особое внимание как экспериментаторов так и клиницистов привлекает незаменимая аминокислота L-лизин как перспективный метаболитотропный нейропротектор. Известно, что в основе механизма действия L-лизина лежит свойство трансформироваться в организме в пипеколевую кислоту, которая усиливает аффинность ГАМК-бензодиазепин-рецепторного комплекса, а также обладает свойствами частичного антагониста рецепторов серотонина [318-321]. Это выражается противосудорожным, нейротрансмиттерным и нейромодулирующим эффектами (рис. 3.4). Еще одно биологически активное вещество, предшественником которого служит лизин-карнитин, который вовлечен в транспорт жирных кислот через мембрану митохондрий. Имеется ряд работ, посвященных исследованию нейротропных, иммунотропных, обезболивающих свойств L-лизина [318]. Изучение роли эндотелия в патогенезе и возможности фармакологического и немедикаментозного воздействия на его функциональное состояние являются предметом многих исследований и представляют значительный теоретический и практический интерес [136-137].

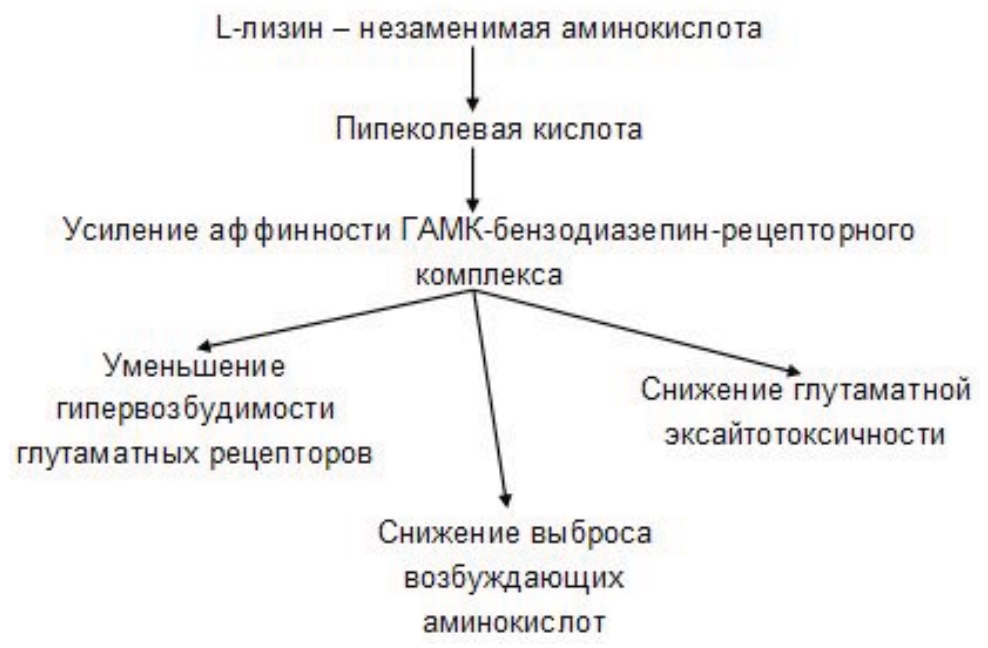

Puc. 3.4. Механизм действия незаменимой аминокислоты L-лизин 
Барьерные функции эндотелия сосудов как активного органа определяют его главную роль в организме человека: поддержание гомеостаза путем регуляции равновесного состояния противоположных процессов - тонуса сосудов (вазодилатация/вазоконстрикция), анатомического строения сосудов (синтез/ ингибирование факторов пролиферации), гемостаза (синтез и ингибирование факторов фибринолиза и агрегации тромбоцитов), местного воспаления (выработка про- и противовоспалительных факторов) [138-143].

При длительном воздействии повреждающих факторов, таких как ишемия, происходит изменение эндотелиального ответа с тенденцией к доминированию и хронической гиперактивации вазоконстрикции и гемокоагуляции, факторов роста и пролиферации, что, в конечном итоге, ведет к развитию эндотелиальной дисфункции [144-148]. Как известно, эндотелиальная дисфункция рассматривается как предиктор цереброваскулярных заболеваний. При этом изучение роли эндотелия в патогенезе цереброваскулярных заболеваний привело к пониманию, что эндотелий регулирует не только периферический кровоток, но и другие важные функции [149-152]. Именно поэтому объединяющей стала концепция об эндотелии как о мишени для профилактики и лечения патологических процессов, приводящих или реализующих цереброваскулярные заболевания. На сегодняшний день мало известно о положительном влиянии на функциональное состояние эндотелия препаратов различных фармакологических групп, относящихся к средствам первичной и вторичной нейропротекции. Поэтому большую ценность представляют данные о влиянии различных нейропротекторов на функциональные характеристики эндотелия [153-154]. Будущее за препаратами, обладающими не только нейропротективным эффектом, но и опосредованным позитивным влиянием на эндотелиальную функцию. Поэтому большой практический интерес представляют производные аминокислоты лизина - корректора нарушений функций эндотелия [155-158].

В последние годы широкое применение в неврологической и нейрохирургической практике получили Тиотриазолин и L-лизина эсцинат. Оба эти препарата, обладая уникальными свойствами, в различной степени способны прерывать каскад реакций, запускаемых в головном мозге в ответ на ишемическое поражение и уменьшать повреждение эндотелия [159-160].

L-лизина эсцинат обладает мощными противовоспалительными, антиэкссудативными и мембранотропными свойствами. В результате действия L-лизина эсцината повышается резистентность сосудов за счет уменьшения количества пор капилляров и увеличения проницаемости мембран эндотелиоцитов, что приводит к увеличению тока тканевой жидкости в просвет капилляра и уменьшению периваскулярного отека. Также наблюдается снижение активации эндотелиоцитов, предупреждая адгезию нейтрофилов на внутренней поверхности сосудистой стенки, что предотвращает ее повреждение [161-164].

Интерес нейропсихофармакологов и клиницистов привлекает антиоксидант с нейро- и кардиопротективными свойствами Тиотриазолин. Назначение Тиотриазолина улучшает энергетический метаболизм в тканях, активирует основные ферменты антиоксидантной системы, устраняет дисбаланс между тормозными и возбуждающими аминокислотами [165-170]. Снижает содер- 
жание оксида азота и активность NO-синтазы, на фоне увеличения содержания L-аргинина, тем самым восстанавливая NO-вазодилатацию [171-173]. Снижение содержания активных форм кислорода приводит к уменьшению повреждения эндотелиоцитов и нормальному их функционированию [174-175]. Тиотриазолин, обладая мощным антиоксидантным действием, опосредованно снижает повреждение эндотелиоцитов и предупреждает развитие эндотелиальной дисфункции. Это реализуется, в первую очередь, за счет уменьшения продуктов окислительной модификации белка и перекисного окисления липидов, а также уменьшения образования активных форм кислорода [176-177].

В 1983-1993 годах ведется изучение механизма действия Тиотриазолина, его фармакодинамики, токсичности, специфической активности, мутагенного, канцерогенного действий сотрудниками различных кафедр Запорожского государственного медицинского университета и Харьковского фармацевтического университета. На основании проведенных исследований было определено, что препарат обладает антиоксидантной, мембраностабилизирующей, противоишемической, антиаритмической, иммуномодулирующей, противовоспалительной, холатостимулирующей, противовирусной и стимулирующей регенерацию клеток активностью [178].

В основе противоишемического действия Тиотриазолина лежит его способность усиливать компенсаторную активацию анаэробного гликолиза, снижать степень угнетения окислительных процессов в цикле Кребса с сохранением внутриклеточного фонда аденозинтрифосфата, стабилизировать метаболизм кардиомиоцитов. Антиоксидантная активность препарата реализуется за счет его способности активировать антиоксидантную систему ферментов и тормозить процессы перекисного окисления липидов в ишемизированных участках, а также увеличивать активность антирадикальных ферментов - супероксиддисмутазу и каталазу, антиперекисный фермент - глутатионпероксидазу, способствуя более медленному расходу эндогенного антиоксиданта — токоферола [178-179]. Наряду с этим, Тиотриазолин тормозит образование начальных и конечных продуктов реакции перекисного окисления липидов в патологически измененных тканях, снижает чувствительность миокарда к адренергическим кардиостимулирующим воздействиям катехоламинов, препятствует прогрессивному угнетению сократительной активности сердца и развитию нарушений сердечного ритма [180-182]. Одним из наиболее важных свойств препарата является стабилизация зоны некроза и уменьшение области ишемизированной ткани. Также, на фоне введения препарата, увеличивается толерантность кардиомиоцитов и нейронов к гипоксической, циркуляторной и гемической гипоксии $[5,170,174]$. Противовоспалительный эффект Тиотриазолина реализуется за счет уменьшения явлений отека в измененных тканях и улучшения процессов микроциркуляции в результате снижения вязкости крови [5, 178-179].

Перечисленный выше сложный механизм действия Тиотриазолина и вызываемые им эффекты обусловили широкий спектр применения препарата в кардиологической, терапевтической, неврологической, хирургической, гинекологической, урологической, педиатрической, офтальмологической и многих других областях современной практической медицины [5, 179]. 
Важной для нас областью медицины для изучения свойств Тиотриазолина является практическая неврология, нейрохирургия и нейротравматология, в особенности те случаи, которые сопровождаются возникновением нарушения мозгового кровотока и приводят к появлению ишемизированных участков нервной ткани. Другим важным моментом изучения Тиотриазолина является увеличение числа сосудистых заболеваний головного мозга за последние два десятилетия [4-5, 170, 174, 176].

В настоящее время внимание исследователей привлекают препараты на основе янтарной кислоты [321-325]. Янтарная кислота, ее соли и эфиры сукцинаты - являются универсальным внутриклеточным метаболитом. Янтарная кислота является продуктом пятой и субстратом шестой реакции цикла Кребса (трикарбоновых кислот). Окисление янтарной кислоты осуществляет фермент сукцинатдегидрогеназа, который находится на внутренней мембране митохондрий и функция которого не зависит от системы НАД/НАДН+, что позволяет сохранять энергосинтезирующую функцию митохондрий в условиях гипоксии [321-325]. В условиях гипоксии сукцинаты снижают повышенную концентрацию других интермедиатов цикла - лактата, пирувата и цитрата. Янтарная кислота является перспективным геропротектором класса антиоксидантов, что подтверждается в опытах на животных увеличением максимальной продолжительности жизни и значительным снижением развития спонтанных опухолей [307, 318].

Антистрессорное и нейротропное действие янтарной кислоты заключается в участии в цикле Робертса ( $\gamma$-аминобутиратный шунт), при работе которого в нервной ткани из янтарной кислоты может образовываться $\gamma$-аминомасляная кислота (ГАМК), универсальный тормозной медиатор, количество которого при ишемических поражениях нервной ткани может резко снижаться вследствие усиления перекисного окисления липидов. При острой гипоксии мозга в эксперименте янтарная кислота уменьшала размеры ишемических повреждений и повышала выживаемость животных, ослабляя деструкцию нейронов, снижая содержание свободных радикалов и продуктов перекисного окисления липидов [307].

Кардиотропные эффекты янтарной кислоты обусловлены активацией сукцинатдегидрогеназы, и как следствие - увеличением ресинтеза АТФ в кардиомиоцитах и снижением уровня жирных кислот в участке ишемии, что проявляется антиаритмическим действием, стабилизацией коронарного кровотока и ограничением зоны некроза в миокарде. Также противоишемический эффект сукцинатов обусловлен восстановлением ключевого фермента дыхательной цепи цитохромоксидазы [307].

Янтарная кислота входит в целый ряд лекарственных форм, в которых используется антиоксидантная, алкопротекторная, актопротекторная и антигипоксическая направленность [307].

Базируясь на экспериментальных данных о фармакологических свойствах L-лизина, Тиотриазолина, янтарной кислоты, сотрудники НПО «Фарматрон» и кафедры фармацевтической химии Запорожского государственного медицинского университета синтезировали новые, раннее не известные, мо- 
лекулы: L-лизина сукцинат и L-лизина 3-метил-1,2,4-триазолил-5-тиоацетат [33-34] (рабочее название «Ангиолин»), которые представляют интерес в плане создания новых высокоэффективных и безопасных нейропротекторов, что и определяет целесообразность и перспективность проведения исследования в данном направлении [35-39].

Нашими экспериментальными исследованиями показана выраженная нейропротективная активность Ангиолина на модели церебральной ишемии.

Выживаемость животных в контрольной группе при моделировании церебральной ишемии составила 30 \% . Экспериментальная терапия соединением L-лизина увеличивала процент выживших животных. Так, выживаемость в группе животных, получавших L-лизина гидрохлорид, составила 60 \%, L-лизина сукцинат - 70 \% и L-лизина эсцинат - 80 \%. Введение референспрепаратов - Тиотриазолина и Пирацетама увеличивало выживаемость в экспериментальных группах на 80 \% и 50 \% соответственно. Наибольшее количество выживших животных наблюдалось в группе с введением Ангиолина, в состав которого входит незаменимая аминокислота L-лизин и 3-метил-1,2,4триазолил-5-тиоацетат, и составила 90 \% (табл. 3.3). Моделирование ОНМК по ишемическому типу в ранние сроки острого периода приводило к развитию тяжелой неврологической симптоматики во всех экспериментальных группах. Taк, назначение L-лизина гидрохлорида, L-лизина сукцината и L-лизина эсцината снижало проявления неврологического дефицита на 17,44 \%, 57,11 \% и в 1,24 раза соответственно относительно контрольной группы животных.

Таблица 3.3

\section{Влияние соединений L-лизина на выживаемость и развитие неврологического дефицита животных в острый период ишемического инсульта (M $\pm \mathbf{m})$}

\begin{tabular}{|c|c|c|c|}
\hline \multirow{2}{*}{ Группа животных } & \multicolumn{2}{|c|}{ Средний балл по шкале C.P. McGrow } & \multirow{2}{*}{$\begin{array}{c}\text { Кол-во выживших } \\
\text { животных на 4-е сутки, } \\
\%\end{array}$} \\
\hline & 4-е сутки & 18-е сутки & \\
\hline $\begin{array}{l}\text { Ложнооперированные } \\
\text { животные }(n=10)\end{array}$ & $0,2 \pm 0,13$ & $0,0 \pm 0,0$ & 100 \\
\hline Животные с ИИ $(n=6)$ & $16,83 \pm 1,89$ & $8,33 \pm 1,48$ & 30 \\
\hline $\begin{array}{l}\text { Животные с ИИ + L-лизина } \\
\text { гидрохлорид }(\mathrm{n}=6)\end{array}$ & $14,33 \pm 1,05$ & $7,5 \pm 1,34$ & 60 \\
\hline $\begin{array}{l}\text { Животные с ИИ + L-лизина } \\
\text { сукцинат }(\mathrm{n}=7)\end{array}$ & $10,71 \pm 1,19^{*}$ & $6,71 \pm 1,64$ & 70 \\
\hline $\begin{array}{l}\text { Животные с ИИ + L-лизина } \\
\text { эсцинат }(\mathrm{n}=8)\end{array}$ & $7,5 \pm 1,32^{\star} \S$ & $4,88 \pm 0,79$ & 80 \\
\hline $\begin{array}{l}\text { Животные с ИИ + } \\
\text { Ангиолин }(\mathrm{n}=9)\end{array}$ & $5,44 \pm 0,73^{\star} \S \Delta$ & $2,44 \pm 0,56^{\star} \S$ & 90 \\
\hline $\begin{array}{l}\text { Животные с ИИ + } \\
\text { Тиотриазолин }(\mathrm{n}=8)\end{array}$ & $9,63 \pm 1,03^{*}$ & $4,38 \pm 0,82^{*}$ & 80 \\
\hline
\end{tabular}


Продолжение табл. 3.3

\begin{tabular}{|l|c|c|c|}
\hline \multirow{2}{*}{ Группа животных } & \multicolumn{2}{|c|}{ Средний балл по шкале С.P. McGrow } & $\begin{array}{c}\text { Кол-во выживших } \\
\text { животных на 4-е сутки, } \\
\%\end{array}$ \\
\cline { 1 - 3 } & 4-е сутки & 18-е сутки & 50 \\
\hline $\begin{array}{l}\text { Животные с ИИ + } \\
\text { Пирацетам }(\mathrm{n}=5)\end{array}$ & $13,6 \pm 2,14$ & $6,6 \pm 1,36$ & 50 \\
\hline
\end{tabular}

* $-\mathrm{p}<0,05$ по отношению к контролю;

$\Delta-\mathrm{p}<0,05$ по отношению к группе с введением Тиотриазолина;

$\S-\mathrm{p}<0,05$ по отношению к группе с введением Пирацетама.

Введение Тиотриазолина и Пирацетама, в свою очередь, приводило к уменьшению неврологической симптоматики у животных на 74,89 \% и 23,77 \% соответственно относительно контроля. Проведение экспериментальной терапии Ангиолином уменьшало средний балл по шкале C.P. McGrow в 2,09 раза относительно контрольной группы (табл. 3.3).

В поздние сроки острого периода ишемического инсульта отмечается уменьшение неврологической симптоматики. Так, в контрольной группе животных в поздний срок острого периода отмечается снижение проявлений неврологического дефицита в 1,02 раза относительно острого периода. Назначение исследуемых соединений приводило к уменьшению неврологических нарушений в различной степени выраженности. Введение L-лизина гидрохлорида, L-лизина сукцината и L-лизина эсцината уменьшало неврологический дефицит на $11,11 \%, 24,11 \%$ и 70,94 \% соответственно относительно контроля. Назначение Тиотриазолина и Пирацетама, в свою очередь, приводило к уменьшению среднего балла по шкале C.P. McGrow на 90,48 \% и 26,26 \% соответственно относительно контрольной группы животных. Экспериментальная терапия Ангиолином приводила к снижению неврологической симптоматики в 2,4 раза относительно контрольной группы (табл. 3.3).

ОНМК по ишемическому типу к 4-м суткам эксперимента приводило к уменьшению содержания АТФ и АДФ в 1,88 раза и на $67,56 \%$ соответственно, на фоне увеличения содержания АМФ на 69,38 \% относительно контроля.

таблица 3.4

Влияние соединений L-лизина на содержание адениловых нуклеотидов в коре головного мозга крыс на 4-е сутки ИИ (M士m)

\begin{tabular}{|l|c|c|c|}
\hline \multicolumn{1}{|c|}{ Группа животных } & \multicolumn{1}{|c|}{$\begin{array}{c}\text { АТФ } \\
\text { мкмоль/г } \\
\text { ткани }\end{array}$} & $\begin{array}{c}\text { АДФ } \\
\text { мкмоль/г } \\
\text { ткани }\end{array}$ & $\begin{array}{c}\text { АМФ } \\
\text { мкмоль/г } \\
\text { ткани }\end{array}$ \\
\hline $\begin{array}{l}\text { Ложнооперированные животные } \\
(\mathrm{n}=10)\end{array}$ & $2,72 \pm 0,09$ & $0,46 \pm 0,01$ & $0,13 \pm 0,01$ \\
\hline Животные с ИИ $(\mathrm{n}=6)$ & $0,94 \pm 0,03$ & $0,27 \pm 0,02$ & $0,22 \pm 0,01$ \\
\hline $\begin{array}{l}\text { Животные с ИИ + L-лизина } \\
\text { гидрохлорида }(\mathrm{n}=6)\end{array}$ & $1,03 \pm 0,08$ & $0,31 \pm 0,03$ & $0,2 \pm 0,01$ \\
\hline
\end{tabular}


Продолжение табл. 3.4

\begin{tabular}{|l|c|c|c|}
\hline \multicolumn{1}{|c|}{ Группа животных } & $\begin{array}{c}\text { АТФ } \\
\text { мкмоль/г } \\
\text { ткани }\end{array}$ & $\begin{array}{c}\text { АДФ } \\
\text { мкмоль/г } \\
\text { ткани }\end{array}$ & $\begin{array}{c}\text { АМФ } \\
\text { мкмоль/г } \\
\text { ткани }\end{array}$ \\
\hline $\begin{array}{l}\text { Животные с ИИ + L-лизина } \\
\text { сукцинат ( } \mathrm{n}=7 \text { ) }\end{array}$ & $1,84 \pm 0,17^{*}$ & $0,38 \pm 0,03^{*}$ & $0,15 \pm 0,01^{*}$ \\
\hline $\begin{array}{l}\text { Животные с ИИ + L-лизина } \\
\text { эсцинат ( } \mathrm{n}=8)\end{array}$ & $1,1 \pm 0,06$ & $0,32 \pm 0,02$ & $0,19 \pm 0,01^{*}$ \\
\hline $\begin{array}{l}\text { Животные с ИИ + Ангиолин } \\
(\mathrm{n}=9)\end{array}$ & $2,15 \pm 0,1^{*} \S$ & $0,42 \pm 0,03^{*}$ & $0,13 \pm 0,01^{*} \S$ \\
\hline $\begin{array}{l}\text { Животные с ИИ + Тиотриазолин } \\
(\mathrm{n}=8)\end{array}$ & $1,88 \pm 0,14^{*}$ & $0,37 \pm 0,02^{*}$ & $0,15 \pm 0,01^{*}$ \\
\hline $\begin{array}{l}\text { Животные с ИИ + Пирацетам } \\
(\mathrm{n}=5)\end{array}$ & $1,53 \pm 0,14^{*}$ & $0,35 \pm 0,03$ & $0,17 \pm 0,02^{*}$ \\
\hline
\end{tabular}

* $-\mathrm{p}<0,05$ по отношению к контролю;

$\Delta-\mathrm{p}<0,05$ по отношению к группе с введением Тиотриазолина;

$\S-\mathrm{p}<0,05$ по отношению к группе с введением Пирацетама.

Таблица 3.5

Влияние соединений L-лизина на показатели углеводно-
энергетического обмена в коре головного мозга животных на 4-е сутки ишемического инсульта $(\mathrm{M} \pm \mathrm{m})$

\begin{tabular}{|l|c|c|c|}
\hline \multicolumn{1}{|c|}{ Группа животных } & $\begin{array}{c}\text { Пируват, } \\
\text { мкмоль/г ткани }\end{array}$ & $\begin{array}{c}\text { Лактат, мкмоль/г } \\
\text { ткани }\end{array}$ & $\begin{array}{c}\text { Малат, мкмоль/г } \\
\text { ткани }\end{array}$ \\
\hline $\begin{array}{l}\text { Ложнооперированные } \\
\text { животные (n=10) }\end{array}$ & $0,46 \pm 0,05$ & $2,32 \pm 0,09$ & $0,31 \pm 0,04$ \\
\hline Животные с ИИ (n=6) & $0,22 \pm 0,04$ & $8,52 \pm 0,14$ & $0,11 \pm 0,01$ \\
\hline $\begin{array}{l}\text { Животные с ИИ + L-лизина } \\
\text { гидрохлорида (n=6) }\end{array}$ & $0,27 \pm 0,05$ & $7,9 \pm 0,32 \S$ & $0,13 \pm 0,02$ \\
\hline $\begin{array}{l}\text { Животные с ИИ + L-лизина } \\
\text { сукцинат (n=7) }\end{array}$ & $0,36 \pm 0,02^{*}$ & $7,63 \pm 0,26^{\star} \S$ & $0,27 \pm 0,02^{*} \S$ \\
\hline $\begin{array}{l}\text { Животные с ИИ + L-лизина } \\
\text { эсцинат (n=8) }\end{array}$ & $0,3 \pm 0,04$ & $7,49 \pm 0,23^{*} \S$ & $0,14 \pm 0,02$ \\
\hline $\begin{array}{l}\text { Животные с ИИ + } \\
\text { «Ангиолин» (n=9) }\end{array}$ & $0,41 \pm 0,04^{*}$ & $4,69 \pm 0,15^{\star} \S \Delta$ & $0,29 \pm 0,04^{*} \S$ \\
\hline $\begin{array}{l}\text { Животные с ИИ + } \\
\text { Тиотриазолин (n = 8) }\end{array}$ & $0,38 \pm 0,02^{*}$ & $5,42 \pm 0,18^{\star} \S$ & $0,24 \pm 0,04^{*}$ \\
\hline $\begin{array}{l}\text { Животные с ИИ + } \\
\text { Пирацетам (n = 5) }\end{array}$ & $0,31 \pm 0,05$ & $10,34 \pm 0,45$ & $0,15 \pm 0,03$ \\
\hline
\end{tabular}

* $-\mathrm{p}<0,05$ по отношению к контролю;

$\Delta-\mathrm{p}<0,05$ по отношению к группе с введением Тиотриазолина;

$\S-\mathrm{p}<0,05$ по отношению к группе с введением Пирацетама. 
Назначение соединений L-лизина в различной степени выраженности приводило к нормализации углеводно-энергетического обмена и восстановлению содержания адениловых нуклеотидов. Моделирование ОНМК по ишемическому типу приводило к снижению пирувата в 1,09 раза, увеличению содержания лактата в 2,66 раза и уменьшению концентрации малата в 1,73 раза на 4-е сутки эксперимента относительно группы ложнооперированных животных. Введение L-лизина сукцината приводило к увеличению содержания пирувата и малата на $63,64 \%$ и в 1,41 раза соответственно относительно контроля. Назначение Ангиолина повышало концентрацию пирувата и малата на 86,87 \% и в 1,54 раза соответственно, на фоне снижения содержания лактата на 81,76\% . Необходимо также отметить, что введение Пирацетама на 4 -е сутки церебральной ишемии увеличивало концентрацию лактата в гомогенате головного мозга подопытных животных на 21,34 \% относительно контрольной группы, тем самым усиливая проявления лактат-ацидоза.

Назначение L-лизина сукцината приводило к увеличению содержания АТФ и АДФ на $95,74 \%$ и 40,07\% соответственно, а также уменьшало содержание АМФ на $44,48 \%$ в гомогенате головного мозга относительно контрольной группы. По-нашему мнению, такая высокая активность L-лизина сукцината, связана с включением в структуру данного соединения янтарной кислоты, которая является дополнительным источником сукцината в дикарбоновом участке цикла Кребса, о чем свидетельствует повышение уровня малата.

Введение Ангиолина повышало концентрацию АТФ и АДФ в 1,28 раза и на $53,66 \%$ соответственно, и снижало содержание АМФ на $68,98 \%$ относительно группы контроля. Высокая активность Ангиолина обусловлена наличием в его структуре 3 -метил-1,2,4-триазолил-5-тиоацетата, который за счет активации малат-аспартатного шунта обеспечивает дополнительную окислительную продукцию энергии.

Так, морфогистометрическими исследованиями установлено, что моделирование ОНМК по ишемическому типу приводило к стойкому неврологическому и когнитивному дефициту у экспериментальных животных на 4 -е сутки эксперимента

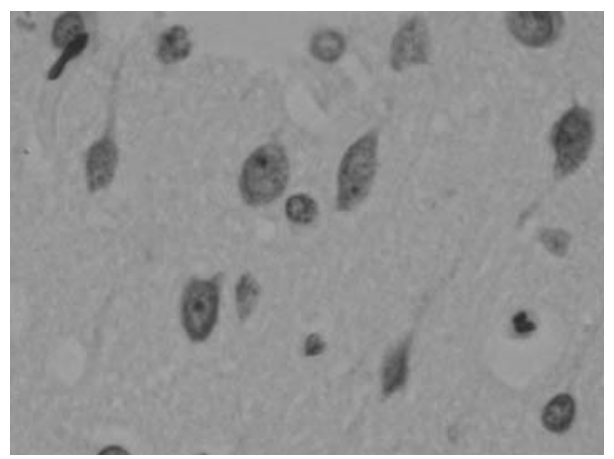

Рuc. 3.5. Микроскопическая фотография клеток IV-V слоев коры головного мозга крыс, подвергшихся экспериментальному моделированию ишемического инсульта 
При микроскопическом исследовании срезов головного мозга крыс, перенесших ишемический инсульт (рис. 3.5), определялись деструктивно измененные нейроны (повреждение клеточной стенки, сморщивание клетки), а также нейроны с морфофункциональными изменениями (нарушение размеров тел нейронов, накопление избыточного количества РНК в клетке).

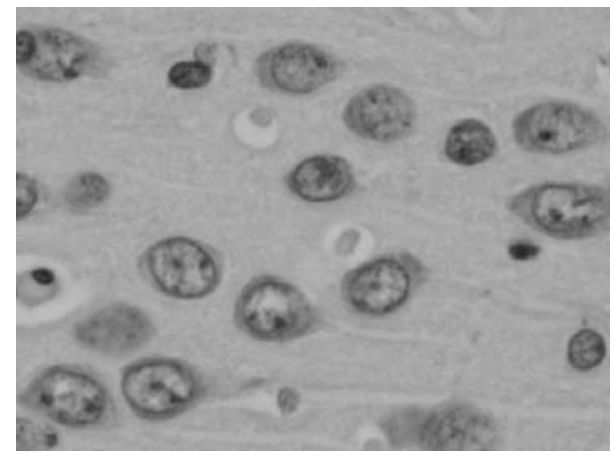

Рис. 3.6. Микроскопическая фотография клеток IV-V слоев коры головного мозга крыс, подвергшихся экспериментальному моделированию ишемического инсульта на фоне лечения Ангиолином

Моделирование ОНМК по ишемическому типу на 4-е сутки приводило к уменьшению плотности и площади тел нейронов на 36,87 \% и 8,54 \% соответственно, уменьшению содержания РНК в нейронах на 73,65 \% относительно ложнооперированной группы животных. Введение L-лизина эсцината в дозе 50 мг/кг приводило к увеличению плотности и площади нейронов на 10,99\% и $13,71 \%$, увеличивая содержание РНК на 42,79 \% по отношению к группе нелеченных животных. Назначение Ангиолина, приводило к увеличению плотности и площади тел нейронов на 34,26 \% и 3,01 \% соответственно, повышая содержание РНК в нейронах на 80,89 \% относительно контрольной группы (табл. 3.6; рис. 3.6).

Таблица 3.6

Морфофункциональное состояние нейронов головного мозга крыс при назначении соединений L-лизина на 4-е сутки моделирования ишемического инсульта (M \pm m)

\begin{tabular}{|l|c|c|c|}
\hline \multicolumn{1}{|c|}{ Группа животных } & $\begin{array}{c}\text { Плотность тел нейро- } \\
\text { нов, клеток/мм² }\end{array}$ & $\begin{array}{c}\text { Площадь тел нейронов, } \\
\text { мкм }^{2}\end{array}$ & $\begin{array}{c}\text { Содержание РНК } \\
\text { в нейронах, } \\
\text { Е0п }\end{array}$ \\
\hline $\begin{array}{l}\text { Ложнооперированные } \\
\text { животные }(\mathrm{n}=10)\end{array}$ & $1352 \pm 43$ & $74,33 \pm 1,33$ & $9,66 \pm 0,13$ \\
\hline Животные с ИИ $(\mathrm{n}=6)$ & $989 \pm 9$ & $68,49 \pm 0,41$ & $5,52 \pm 0,03$ \\
\hline $\begin{array}{l}\text { Животные с ИИ + } \\
\text { Ангиолин }(\mathrm{n}=9)\end{array}$ & $1327 \pm 10^{\star} \S \Delta$ & $70,55 \pm 0,58^{\star} \S \Delta$ & $10,0 \pm 0,11^{\star} \S$ \\
\hline $\begin{array}{l}\text { Животные с ИИ + } \\
\text { Тиотриазолин }(\mathrm{n}=8)\end{array}$ & $1193 \pm 21^{\star} \S$ & $67,42 \pm 0,44^{\star} \S$ & $9,87 \pm 0,12^{\star} \S$ \\
\hline $\begin{array}{l}\text { Животные с ИИ + } \\
\text { L-лизина эсцинат }(\mathrm{n}=8)\end{array}$ & $1097 \pm 34^{\star} \S$ & $77,89 \pm 0,98^{\star} \S$ & $7,88 \pm 0,1^{\star}$ \\
\hline
\end{tabular}




\begin{tabular}{|c|c|c|c|}
\hline \hline \multicolumn{5}{|c|}{ Пруппа животных } & $\begin{array}{c}\text { Плотность тел нейро- } \\
\text { нов, клеток/мм² }\end{array}$ & $\begin{array}{c}\text { Площадь тел нейронов, } \\
\text { мкм² }\end{array}$ & $\begin{array}{c}\text { Содержание РНК } \\
\text { в нейронах, } \\
\text { ЕОП }\end{array}$ \\
\hline $\begin{array}{l}\text { Животные с ИИ+ } \\
\text { Пирацетам }(n=5)\end{array}$ & $1000 \pm 34$ & $54,0 \pm 0,26^{*}$ & $7,88 \pm 0,13^{*}$ \\
\hline
\end{tabular}

* $-\mathrm{p}<0,05$ по отношению к контролю;

$\Delta-\mathrm{p}<0,05$ по отношению к группе с введением Тиотриазолина;

$\S-\mathrm{p}<0,05$ по отношению к группе с введением Пирацетама.

Моделирование ОНМК к 4-м суткам эксперимента приводит к выраженным дегенеративным процессам в отношении нейроглии, что проявляется в уменьшении плотности и площади тел глиальных клеток на 1,22\% и 10,31 \% соответственно, а также уменьшении содержания РНК на 13,33\%. Экспериментальная терапия L-лизина эсцинатом приводила к увеличению плотности глиальных клеток и содержанию в них РНК на 8,27\% и 26,67\% соответственно относительно группы животных с ОНМК. Введение Ангиолина достоверно повышало относительно контрольной группы и группы, получавшей Пирацетам, все параметры изучения нейроглии, что проявлялось в увеличении плотности и площади тел глиальных клеток на 21,06\% и 7,39\%, при увеличении содержания РНК на 40 \% относительно контроля.

Таблица 3.7

Характеристика глиальных клеток IV-V слоев коры головного мозга крыс на 4-е сутки экспериментальной ишемии, $\mathrm{M} \pm$ m

\begin{tabular}{|l|l|l|l|}
\hline \multicolumn{1}{|c|}{ Группа животных } & $\begin{array}{c}\text { Плотность глиальных } \\
\text { клеток, клеток/мм² }\end{array}$ & $\begin{array}{c}\text { Площадь тел } \\
\text { глиальных клеток, } \\
\text { мкм² }\end{array}$ & $\begin{array}{c}\text { Содержание РНК } \\
\text { в глиальных клетках, } \\
\text { ЕОП }\end{array}$ \\
\hline $\begin{array}{l}\text { Ложнооперированные } \\
\text { животные }(\mathrm{n}=10)\end{array}$ & $416 \pm 20$ & $20,8 \pm 0,37$ & $3,39 \pm 0,08$ \\
\hline Животные с ИИ $(\mathrm{n}=6)$ & $411 \pm 5$ & $22,97 \pm 0,09$ & $3,0 \pm 0,02$ \\
\hline $\begin{array}{l}\text { Животные с ИИ + } \\
\text { L-лизина эсцинат }(\mathrm{n}=8)\end{array}$ & $445 \pm 14^{*}$ & $23,08 \pm 0,18^{*} \S$ & $3,78 \pm 0,04 * \S$ \\
\hline $\begin{array}{l}\text { Животные с ИИ + } \\
\text { Ангиолин }(\mathrm{n}=9)\end{array}$ & $498 \pm 13^{*} \S$ & $24,7 \pm 0,11^{*} \S \Delta$ & $4,18 \pm 0,02 * \S$ \\
\hline $\begin{array}{l}\text { Животные с ИИ + } \\
\text { Тиотриазолин }(\mathrm{n}=8)\end{array}$ & $490 \pm 11^{*} \S$ & $22,31 \pm 0,12^{*} \S$ & $4,17 \pm 0,02 * \S$ \\
\hline $\begin{array}{l}\text { Животные с ИИ + } \\
\text { Пирацетам }(\mathrm{n}=5)\end{array}$ & $421 \pm 19$ & $21,11 \pm 0,17^{*}$ & $3,6 \pm 0,01^{*}$ \\
\hline
\end{tabular}

* $-\mathrm{p}<0,05$ по отношению к контролю;

$\Delta-\mathrm{p}<0,05$ по отношению к группе с введением Тиотриазолина;

$\S-\mathrm{p}<0,05$ по отношению к группе с введением Пирацетама. 
Моделирование ОНМК по типу ишемического инсульта увеличивало плотность и долю апоптотически измененных клеток IV-V слоев коры головного мозга в 1,08 раза и в 1,58 раза соответственно по отношению к интактной группе. Введение L-лизина эсцината и Ангиолина приводило к уменьшению плотности апоптотически измененных нейронов на 40,26 \% и в 1,1 раза соответственно, при этом уменьшая долю апоптотических клеток на 0,62 и в 1,84 раза соответственно по отношению к группе контроля (табл. 3.8).

Таблица 3.8

Плотность апоптических и деструктивно измененных клеток IV-V слоев коры головного мозга крыс на 4-е сутки экспериментальной ишемии, $\mathbf{M} \pm \mathbf{m}$

\begin{tabular}{|l|c|c|}
\hline \multicolumn{1}{|c|}{ Группа животных } & $\begin{array}{c}\text { Плотность клеток } \\
\text { на 1 мм² }\end{array}$ & $\begin{array}{c}\text { Доля апоптотических } \\
\text { клеток, \% }\end{array}$ \\
\hline Ложнооперированные животные $(\mathrm{n}=10)$ & $102 \pm 10$ & $5,51 \pm 0,54$ \\
\hline Животные с ИИ $(\mathrm{n}=6)$ & $211 \pm 13$ & $14,2 \pm 1,2$ \\
\hline Животные с ИИ + Ангиолин $(\mathrm{n}=9)$ & $101 \pm 3^{\star} \S \Delta$ & $5,01 \pm 0,21^{\star} \S \Delta$ \\
\hline Животные с ИИ + Тиотриазолин $(\mathrm{n}=8)$ & $170 \pm 8^{\star} \S$ & $8,0 \pm 0,84^{\star} \S$ \\
\hline Животные с ИИ + L-лизина эсцинат $(\mathrm{n}=8)$ & $151 \pm 17^{\star} \S$ & $14,3 \pm 1,6 \S \Delta$ \\
\hline
\end{tabular}

* $-\mathrm{p}<0,05$ по отношению к контролю;

$\Delta-\mathrm{p}<0,05$ по отношению к группе с введением Тиотриазолина;

$\S-\mathrm{p}<0,05$ по отношению к группе с введением Пирацетама.

Влияние Ангиолина на эндотелиоциты капилляров IV-V слоев коры головного мозга крыс в различные сроки церебральной ишемии. Одним из ведущих последствий острой ишемии является эндотелиальная дисфункция. Это проявляется в нарушении проницаемости сосудистой стенки, выходе жидкости в окружающие ткани, что усиливает явления ишемии.

Изучение капилляров IV-V слоев коры показало, что моделирование ОНМК приводило к уменьшению плотности ядер эндотелиоцитов на 47,83 \% , диаметра ядер на 10,83 \% и снижало концентрацию РНК на 38,21 \% относительно группы ложнооперированных животных. Уже на 4-е сутки экспериментальной терапии Ангиолином плотность и площадь ядер, а также концентрация РНК эндотелиоцитов, увеличивались на 21,2 \%, 17,8 \% и 48,6 \% соответственно, относительно группы контроля, достоверно превосходя как контрольную группу, так и группу, получавшую референс-препарат Пирацетам. 
Таблица 3.9

Характеристика эндотелиоцитов капилляров IV-V слоев коры головного мозга крыс с экспериментальной церебральной ишемией $(\mathrm{M} \pm \mathrm{m})$

\begin{tabular}{|c|c|c|c|c|}
\hline Группа животных & $\begin{array}{l}\text { Плотность ядер } \\
\text { на } 1 \text { мм² коры }\end{array}$ & $\begin{array}{l}\text { Площадь } \\
\text { ядер, мкм² }\end{array}$ & $\begin{array}{c}\text { Диаметр } \\
\text { ядер, мкм }\end{array}$ & $\begin{array}{c}\text { Концентрация } \\
\text { РНК в ядрах, } \\
\text { ЕОП }\end{array}$ \\
\hline $\begin{array}{l}\text { Ложнооперированные жи- } \\
\text { вотные }(\mathrm{n}=10)\end{array}$ & $887 \pm 14$ & $8,34 \pm 0,07$ & $2,77 \pm 0,01$ & $0,293 \pm 0,002$ \\
\hline $\begin{array}{l}\text { Животные с ИИ, } \\
\text { 4-е сутки }(n=6)\end{array}$ & $600 \pm 11$ & $8,38 \pm 0,06$ & $3,07 \pm 0,01$ & $0,212 \pm 0,001$ \\
\hline $\begin{array}{l}\text { Животные с ИИ + Ангиолин, } \\
\text { 4-е сутки }(\mathrm{n}=9)\end{array}$ & $727 \pm 10^{*} \S$ & $9,87 \pm 0,03^{*} \S$ & $3,11 \pm 0,01$ & $0,315 \pm 0,001 * \S$ \\
\hline $\begin{array}{l}\text { Животные с ИИ + Пирацетам, } \\
\text { 4-е сутки ( } \mathrm{n}=5)\end{array}$ & $608 \pm 15$ & $8,40 \pm 0,07$ & $3,06 \pm 0,01$ & $0,217 \pm 0,001$ \\
\hline $\begin{array}{l}\text { Животные с ИИ, } \\
\text { 18-е сутки }(n=6)\end{array}$ & $633 \pm 15$ & $9,11 \pm 0,03$ & $3,05 \pm 0,01$ & $0,268 \pm 0,001$ \\
\hline $\begin{array}{l}\text { Животные с ИИ + Ангиолин, } \\
\text { 18-е сутки }(n=9)\end{array}$ & $837 \pm 17^{\star} \S$ & $8,38 \pm 0,03^{*}$ & $2,93 \pm 0,01^{*}$ & $0,298 \pm 0,002^{\star} \S$ \\
\hline $\begin{array}{l}\text { Животные с ИИ + Пирацетам, } \\
18 \text {-е сутки ( } \mathrm{n}=5)\end{array}$ & $650 \pm 15$ & $9,05 \pm 0,05$ & $3,02 \pm 0,01$ & $0,273 \pm 0,001$ \\
\hline
\end{tabular}

* $-\mathrm{p}<0,05$ по отношению к контролю;

$\S-\mathrm{p}<0,05$ по отношению к группе с введением Пирацетама.

Исследование плотности ядер и концентрации РНК на 18-е сутки церебральной ишемии показало увеличение на $32 \%$ и $11,2 \%$ соответственно, по отношению к группе нелеченных животных (табл. 3.9).

К 18-м суткам эксперимента в контрольной группе животных наблюдалось значительное $(62,6$ \%) снижение пролиферации эндотелиоцитов, сравнительно с интактной группой, на фоне увеличения площади ядер на 9,45 \% и повышения концентрации эндотелий-пролиферирующего фактора роста (VEGF) на $3,85 \%$.

Таблица 3.10

Характеристика пролиферирующих эндотелиоцитов капилляров IV-V слоев коры головного мозга крыс на 18-е сутки экспериментальной церебральной ишемии (M $\pm \mathbf{m})$

\begin{tabular}{|l|c|c|c|c|}
\hline \multicolumn{1}{|c|}{ Группа животных } & $\begin{array}{c}\text { Плотность пролифе- } \\
\text { рирующих клеток } \\
\text { на 1 мм² коры }\end{array}$ & $\begin{array}{c}\text { Площадь ядер, } \\
\text { мкм² }^{2}\end{array}$ & $\begin{array}{c}\text { Диаметр ядер, } \\
\text { мкм }\end{array}$ & $\begin{array}{c}\text { Концентрация } \\
\text { VEGF, ЕИФ }\end{array}$ \\
\hline $\begin{array}{l}\text { Ложнооперированные } \\
\text { (п=10) }\end{array}$ & $771 \pm 26$ & $6,77 \pm 0,10$ & $2,88 \pm 0,02$ & $0,78 \pm 0,01$ \\
\hline $\begin{array}{l}\text { Животные с ИИ } \\
(\mathrm{n}=6)\end{array}$ & $474 \pm 22$ & $7,41 \pm 0,10$ & $2,92 \pm 0,02$ & $0,81 \pm 0,02$ \\
\hline
\end{tabular}




\begin{tabular}{|c|c|c|c|c|}
\hline \multicolumn{5}{|c|}{ Продолжение табл. 3.10} \\
\hline Группа животных & $\begin{array}{c}\text { Плотность пролисее- } \\
\text { рирующих клеток } \\
\text { на } 1 \text { мм² коры }\end{array}$ & $\begin{array}{c}\text { Площадь ядер, } \\
\text { мкм² }^{2}\end{array}$ & $\begin{array}{c}\text { Диаметр ядер, } \\
\text { мкм }\end{array}$ & $\begin{array}{c}\text { Концентрация } \\
\text { VEGF, ЕИФ }\end{array}$ \\
\hline $\begin{array}{l}\text { Животные с ИИ + } \\
\text { Ангиолин }(\mathrm{n}=9)\end{array}$ & $637 \pm 21^{*} \S$ & $8,12 \pm 0,09^{*} \S$ & $3,18 \pm 0,01^{\star} \S$ & $0,98 \pm 0,02^{*} \S$ \\
\hline $\begin{array}{l}\text { Животные с ИИ + } \\
\text { Пирацетам ( } n=5)\end{array}$ & $477 \pm 23$ & $7,43 \pm 0,11$ & $3,00 \pm 0,02$ & $0,86 \pm 0,02$ \\
\hline
\end{tabular}

* - $\mathrm{p}<0,05$ по отношению к контролю;

$\S-\mathrm{p}<0,05$ по отношению к группе с введением Пирацетама.

Соединение Ангиолин достоверно увеличивало плотность пролиферирующих клеток и площадь ядер на 34,4 \% и 9,6 \% соответственно, на фоне увеличения концентрации VEGF на 21 \% относительно контроля (табл. 3.10).

Влияние Ангиолина на эндотелиоциты стенки сосудов головного мозга животных в условиях моделирования ОНМК. Как отмечалось ранее, моделирование ОНМК приводит к выраженному снижению плотности и площади ядер, а также к снижению концентрации РНК в ядрах эндотелиоцитов.

Таблица 3.11

Характеристика эндотелиоцитов стенки сосудов головного мозга крыс с экспериментальной церебральной ишемией (M \pm m)

\begin{tabular}{|c|c|c|c|c|}
\hline Группа животных & $\begin{array}{c}\text { Плотность ядер } \\
\text { на } 1 \text { мм² стенки } \\
\text { сосудов }\end{array}$ & $\begin{array}{l}\text { Площадь } \\
\text { ядер, мкм² }\end{array}$ & $\begin{array}{l}\text { Диаметр } \\
\text { ядер, мкм }\end{array}$ & $\begin{array}{l}\text { Концентрация } \\
\text { РНК в ядрах, ЕОП }\end{array}$ \\
\hline $\begin{array}{l}\text { Ложнооперированные животные } \\
(\mathrm{n}=10)\end{array}$ & $14168 \pm 553$ & $7,04 \pm 0,26$ & $2,94 \pm 0,05$ & $0,294 \pm 0,003$ \\
\hline $\begin{array}{l}\text { Животные с ИИ, } \\
\text { 4-е сутки }(n=6)\end{array}$ & $9938 \pm 373$ & $8,00 \pm 0,25$ & $3,18 \pm 0,04$ & $0,231 \pm 0,002$ \\
\hline $\begin{array}{l}\text { Животные с ИИ + Ангиолин, } \\
\text { 4-е сутки (n = 9) }\end{array}$ & $12565 \pm 311^{*} \S$ & $8,14 \pm 0,23$ & $3,12 \pm 0,03$ & $0,310 \pm 0,001 * \S$ \\
\hline $\begin{array}{l}\text { Животные с ИИ + Пирацетам, } \\
\text { 4-е сутки ( } \mathrm{n}=5)\end{array}$ & $9939 \pm 340$ & $6,20 \pm 0,20$ & $3,17 \pm 0,03$ & $0,237 \pm 0,001$ \\
\hline $\begin{array}{l}\text { Животные с ИИ, } \\
18 \text {-е сутки }(\mathrm{n}=6)\end{array}$ & $11378 \pm 281$ & $5,43 \pm 0,11$ & $2,71 \pm 0,03$ & $0,247 \pm 0,001$ \\
\hline $\begin{array}{l}\text { Животные с ИИ + Ангиолин, } \\
18-е \text { сутки }(n=9)\end{array}$ & $13987 \pm 411 * \S$ & $\begin{array}{l}8,05 \pm \\
0,29 * \S\end{array}$ & $\begin{array}{l}3,14 \pm \\
0,05 * \S\end{array}$ & $0,317 \pm 0,003^{*} \S$ \\
\hline $\begin{array}{l}\text { Животные с ИИ + Пирацетам, } \\
18 \text {-е сутки }(n=5)\end{array}$ & $11487 \pm 267$ & $5,87 \pm 0,21$ & $2,80 \pm 0,02$ & $0,248 \pm 0,001$ \\
\hline
\end{tabular}

* - p $<0,05$ по отношению к контролю;

$\S-\mathrm{p}<0,05$ по отношению к группе с введением Пирацетама.

Так, на 4-е сутки моделирования церебральной ишемии отмечается снижение плотности ядер эндотелиоцитов на 42,56 \% и площади ядер на 13,64 \% на фоне уменьшения концентрации РНК в ядрах на 27,27 \% относительно группы ложнооперированных животных. Назначение Ангиолина увеличивало плотность 
и площадь ядер на $23 \%$ и 48,3 \% соответственно, при увеличении концентрации РНК в ядрах на $28,3 \%$ относительно контрольной группы (табл. 3.11 ).

Введение Ангиолина подопытным животным на 18-е сутки эксперимента приводило к нормализации состояния эндотелиоцитов сосудов головного мозга. Так, плотность ядер стенки сосуда увеличивалась на $23 \%$, площадь и диаметр - на $48,3 \%$ и 15,87 \% соответственно, а концентрация РНК повышалась на 28,3 \% относительно контроля, достоверно превосходя показатели группы референс-препаратов (табл. 3.11).

Таблица 3.12

Характеристика пролиферирующих эндотелиоцитов стенки сосудов головного мозга крыс с экспериментальной церебральной ишемией на 18-е сутки $(M \pm \mathbf{m})$

\begin{tabular}{|c|c|c|c|c|}
\hline Группа животных & $\begin{array}{c}\text { Плотность пролифери- } \\
\text { рующих клеток } \\
\text { на } 1 \text { мм² коры }\end{array}$ & $\begin{array}{c}\text { Площадь } \\
\text { ядер, мкм² }\end{array}$ & $\begin{array}{c}\text { Диаметр } \\
\text { ядер, мкм }\end{array}$ & $\begin{array}{c}\text { Концентрация } \\
\text { VEGF, ЕИФ }\end{array}$ \\
\hline Ложнооперированные (п=10) & $8430 \pm 893$ & $14,78 \pm 0,86$ & $3,82 \pm 0,12$ & $1,34 \pm 0,08$ \\
\hline Животные с ИИ $(n=6)$ & $2882 \pm 300$ & $6,68 \pm 0,46$ & $2,81 \pm 0,1$ & $3,00 \pm 0,18$ \\
\hline Животные с ИИ + Ангиолин (n = 9) & $4115 \pm 277^{*} \S$ & $14,12 \pm 0,77^{\star} \S$ & $3,67 \pm 0,07^{\star} \S$ & $4,18 \pm 0,31^{*} \S$ \\
\hline Животные с ИИ + Пирацетам ( $\mathrm{n}=5)$ & $2698 \pm 277$ & $6,70 \pm 0,44$ & $2,82 \pm 0,1$ & $3,00 \pm 0,11$ \\
\hline
\end{tabular}

* - p $<0,05$ по отношению к контролю;

$\S-\mathrm{p}<0,05$ по отношению к группе с введением Пирацетама.

Плотность пролиферирующих клеток сосудов головного мозга на 18-е сутки моделирования ишемического инсульта снижалась в 1,92 раза, площадь ядер эндотелиоцитов в 1,21 раза, а концентрация VEGF уменьшалась в 1,23 раза. Курсовое назначение Ангиолина увеличивало плотность пролиферирующих клеток на 42,8 \%, площадь ядер в 1,11 раза, диаметр ядер на $30,6 \%$, на фоне повышения концентрации VEGF на 40 \% относительно группы нелеченных животных и достоверно превосходя показатели группы с введением Пирацетама (табл. 3.12). Данные показатели свидетельствуют о выраженном эндотелиопротективном действии Ангиолин, эффект которого наблюдается уже на 4-е сутки развития мозговой катастрофы, а к 18-м суткам - максимально выражен.

Параллельными исследованиями также установлено позитивное влияние Ангиолина и на ультраструктуру нейроцитов и митохондрий на модели острой церебральной ишемии. Проведенной трансмиссионной электронной микроскопией $\mathrm{CA}_{1}$-зоны гиппокампа крыс на 4-е сутки модельной патологии установлено, что острая церебральная ишемия сопровождалась характерными гипоксическими изменениями морфологической ультраструктуры нейронов. Так, нарушения ультраструктуры нейронов имели мозаичный характер. Часть нейроцитов - с признаками некротических и некробиотических изменений. Большинство нейроцитов содержали ядра с признаками резко или умеренно ограниченной функциональной активности, с фрагментированной нуклеолем- 
мой. В перикарионе - вакуолярно-литическое повреждение органелл. Кроме того, в нейронах $\mathrm{CA}_{1}$-зоны были отмечены явления хроматолиза - набухание и вакуолизация цистерн пластинчатого аппарата, часто с деформацией цистерн и их фрагментацией. Вблизи - повышенное количество лизосом различной степени зрелости, мультивезикулярных телец и мелких осмиофильных включений. В эндоплазматическом ретикулуме - массивное образование вакуолеподобных цистерн (рис. 3.7).
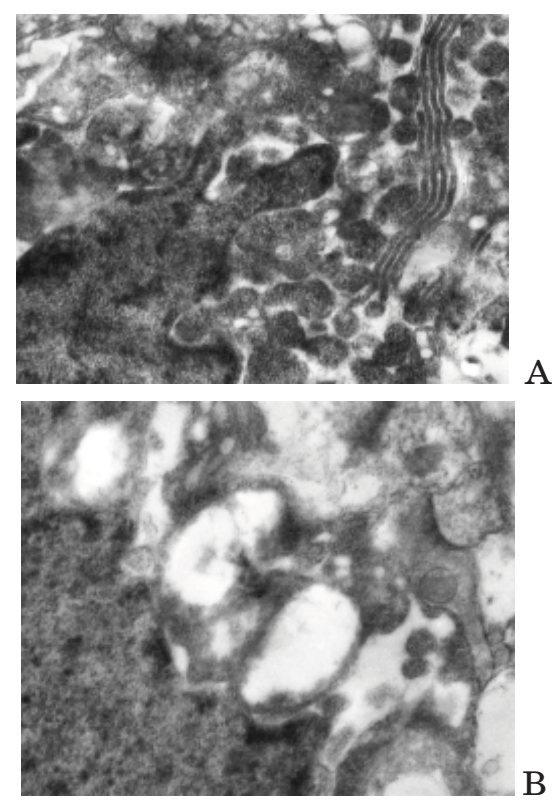

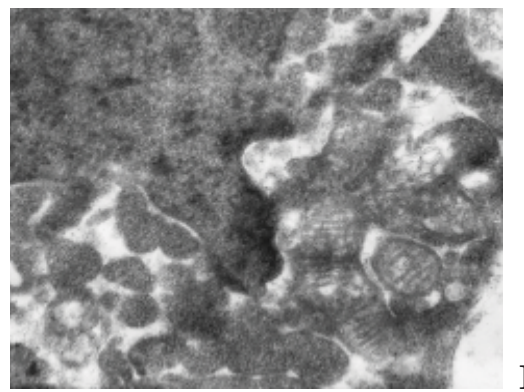

Б

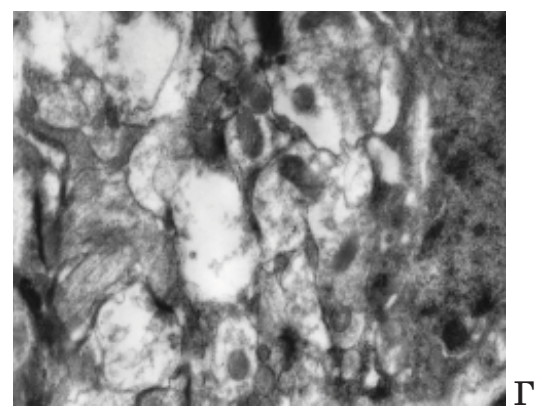

\section{Рuc. 3.7. Фрагмент нейроцита гиппокампа}

А - Интактнал группа. Митохондрии с варьирующими по плотности кристали и матриксом. Многочисленные элементы гранулярного эндоплазматического ретикулула. Развитый колплекс Гольджи. Электронограмла, ×25000.

Б - Парануклеарная зона, интактная группа. Ядро с улеренно активной нуклеоплазмой. Активные митохондрии больших размеров с признаками межмитохондриальных контактов. Многочисленные элементы гранулярного эндоплазматического ретикулула. Электронограмла, $\times 25000$.

В - Участок перикариона, контрольная группа. Вакуолярно-литическое повреждение митохондрий и эндоплазматического ретикулума. Единичные микромитохондрии. Электронограмла, $\times 30000$.

Г - Контрольная группа. Вакуолярно-литическое повреждение перикариона. Массивный кристолизис митохондрий. Электронно-плотные включения в составе многочисленных микромитохондрий. Деструкиия мембран гранулярного эндоплазматического ретикулула. Электронограмма, $\times 30000$.

Параллельно было зарегистрировано нарушение ультраструктуры митохондрий нейронов по вакуолярно-литическому типу. Большинство митохондрий были увеличены в размерах, имели фрагментированную наружную мембрану, разрушенные кристы и электронно-прозрачный матрикс, тогда 
как в интактной группе митохондрии в большинстве своем были сохранными (рис. 3.7). Иногда встречались митохондрии гигантских размеров за счет резкого отека матрикса. Незначительная часть митохондрий - с относительно сохраненными кристами, небольших размеров. Характерно наличие микромитохондрий с гетероморфной структурой: часть из них содержали стабильные мембраны в составе крист, другая часть - электронно-плотные включения на фоне плотного матрикса (рис. 3.7).

Нарушения ультраструктуры митохондрий нейронов проявлялись в значительном увеличении общей доли поврежденных нейронов в общей структуре митохондрий, что характеризовалось повышением абсолютного количества митохондрий более чем на $92 \%$ по отношению к интактной группе животных (табл. 3.13).

Таблица 3.13

\section{Влияние Ангиолина и Цереброкурина на долю митохондрий нейронов $\mathrm{CA}_{1}$-зоны гиппокампа, имеющих повреждения на 4-е сутки церебральной ишемии}

\begin{tabular}{|l|c|c|}
\hline \multicolumn{1}{|c|}{ Группы животных } & $\begin{array}{c}\text { Количество поврежденных } \\
\text { митохондрий (абсолютное } \\
\text { значение) }\end{array}$ & $\begin{array}{c}\text { Процентная доля поврежден- } \\
\text { ных митохондрий, \% }\end{array}$ \\
\hline Интактная & 6 & $7,5 \%$ \\
\hline Контрольная (ишемия, 4-е сутки) & $74 \pm 4,8$ & $92,5 \%$ \\
\hline Ангиолин (50 мг/кг) & $55 \pm 3,9 * *$ & $44 \%$ \\
\hline
\end{tabular}

Примечание: * $-\mathrm{p} \leq 0,05$ по отношению к контролю.

Назначение животным Ангиолина в дозе 50 мг/кг приводило к улучшению морфологической ультраструктуры нейронов и митохондрий. Так, нарушения ультраструктуры нейронов имели более разнообразный характер по сравнению с контрольной группой. Помимо единичных нейроцитов с признаками некробиотических изменений и большого количества нейроцитов с признаками относительной адаптации, встречались фигуры апоптоза нейронов. В основном это начальные стадии апоптотических процессов, развивающихся по митохондриальному типу. В таких клетках наблюдалось крупнодисперсное повреждение нуклеоплазмы с частично сохраненной активностью ядра. Лизосом немного. В перикарионе регистрировалась умеренная дезорганизация гранулярного ретикулума с набуханием цистерн и образованием вакуолеподобных цистерн. Митохондрии имели участки дефрагментации наружных мембран, частично разрушенные кристы, неравномерную электронную плотность матрикса. Изредка встречались митохондрии с сохраненной структурой крист. Большинство нейроцитов были с умеренными нарушениями перикариона по вакуолярному типу, содержали ядра с активной нуклеоплазмой или с признаками умеренно ограниченной функциональной активности. Нуклеолемма на всем протяжении стабильна, без фрагментации. Явления хроматолиза, набухание и вакуо- 
лизация цистерн пластинчатого аппарата и эндоплазматического ретикулума были не выражены (рис. 3.8).
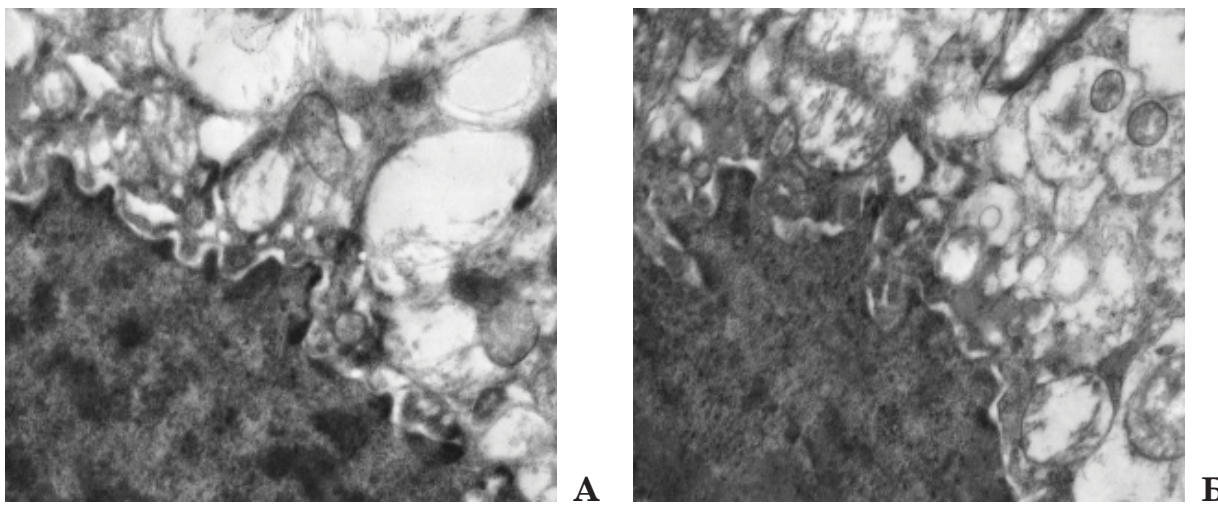

$\mathbf{6}$

Рuc. 3.8. Фрагмент нейроцита гиппокампа крысы с курсовым назначением Ангиолина (50 мг/кг)

A-Апоптозполитохондриальному типув фазеиндукиии.Дестабилизация.митохондриальных мембран. Частичный кристолизис и неравнолерная электронная плотность матрикса. Крупнодисперсное повреждение нуклеоплазмы. Электронограмма, ×30000.

Б - Вакуолярный тип повреждения перикариона. Активная нуклеоплазма. Умеренный кристолизис митохондрий.Стабильные мембраны микромитохондрий. Частичная деструкиия мембран гранулярного эндоплазматического ретикулула, Электронограмла. ×30000.

Митохондрии представлены различными по структуре органеллами. Встречались увеличенные в размерах митохондрии с вакуолярным типом повреждения, без признаков разрушения наружных мембран, с умеренным кристолизисом, электронно-светлым матриксом. Гигантские митохондрии не обнаружены. Часть митохондрий - с относительно стабильными кристами, небольших размеров, с умеренно плотным матриксом. Количество микромитохондрий существенно не отличается от контрольной группы, однако все они содержат стабильные наружные мембраны и кристы, гомогенный матрикс без электронно-плотных включений (рис. 3.8). Обращало на себя внимание значительное уменьшение общего числа поврежденных митохондрий. Так, на фоне введения Ангиолина, их количество снижалось более чем, на 26 \% по отношению к животным контрольной группы.

Влияние Ангиолина на плотность c-fos-позитивных нейронов CA1-зоны гиппокампа и тип их морфологической гибели у крыс на 4-е сутки церебральной ишемии. Как было описано выше, рядом экспериментальных работ последнего десятилетия показана значительная роль гипо- и гиперэкспрессии генов раннего реагирования c-fos в развитии морфологической гибели клеток головного мозга при нейродеструктивных заболеваниях, а также их непосредственное участие в процессах фрагментации митохондриальной ДНК, и как следствие - нарушении белоксинтетической функции митохондрий, что вносит определенный вклад в развитие митохондриальной дисфункции $[26,41,42]$. 
Известно, что в условиях гиперпродукции АФК митохондриальными биоэнергетическими системами головного мозга, в условиях ишемии головного мозга, происходит активация экспрессии редокс-чувствительных генов, многие из которых необходимы для инициирования белоксинтетических процессов в клетке. Так, при нормальной концентрации кислорода в окружающей клетку среде (нормоксия) под действием АФК происходит в основном активация JunB, ATF-2-факторов транскрипции, а в условиях окислительного стресca - преимущественно факторов c-Jun и c-fos. Активация именно этих факторов транскрипции в условиях гиперпродукции АФК объясняется тем, что ЈunB и c-fos содержат в своих ДНК-связывающих доменах высокочувствительные к АФК остатки цистеина - Cys 252, Cys154, Cys61. Окисление их SH-групп приводит к обратной инактивации AP-1 и NF-kB. Данные факторы глобальной транскрипции ответственны за экспрессию и синтез факторов эндогенной цитопротекции, а именно HIF и HSP, а также ключевых митохондриальных ферментов малат-аспартатного шунта, роль которых была нами подробно рассмотрена выше [10, 11, 26, 41, 42, 160].

Таким образом, учитывая чрезвычайно важную роль экспрессии гена c-fos в физиологических и патологических процессах, его следует рассматривать как перспективную мишень фармакологической коррекции митохондриальной дисфункции и ее отрицательных последствий в условиях церебральной ишемии.

Проведенными гистоиммунохимическими исследованиями установлено, что развитие церебральной ишемии на 4-е сутки сопровождалось значительным снижением количества c-fos-позитиных нейронов (в среднем на 78 \%) по отношению к интактной группе животных (рис. $3.9 ; 3.10)$. Рядом исследований показано, что характер экспрессии данного гена определяет тип гибели нейрона: апоптоз/некроз. В случае значительного снижения гена c-fos клетка погибает некротически [13]. Действительно, нами установлено, что уменьшение количества c-fos-позитивных нейронов в контрольной группе животных приводило к параллельному усилению морфологической гибели нейронов по типу некроза, о чем свидетельствовало превышение этидиум бромид положительных нейронов (некроз) по отношению к Hоecht-положительным нейронам (апоптоз), в среднем на 75 \% в данной экспериментальной группе (рис. 3.11).

Достоверность отличия $(\mathrm{p}<0,05)$ по отношению к группе интактных $(*)$, крыс с ишемией, 4-е сутки.

Реакция непрямой иммунофлуоресценции (первичные антитела c-fos (Sigma Chemical, USA), вторичные антитела — флюоресцент конъюгированный с козьими Ig (Sigma Chemical, USA). Изображение флуоресцентного микроскопа Axioskop (Ziess, Germany), видеокамера COHU — 4922 (USA).

Курсовое назначение Ангиолина (50 мг/кг) животным с острой ишемией приводило к достоверному повышению $(\mathrm{p} \leq 0,05)$ числа c-fos-позитивных нейронов $\mathrm{CA}_{1}$-зоны гиппокампа по сравнению с контрольной группой животных (в среднем на 71 \%). Эффекты исследуемых препаратов были выражены, однонаправлены и без достоверного превышения эффектов одного над другим. Следует отметить, что изучаемые препараты не оказывали на экспрессию с-fos 
стимулирующего влияния; назначение препаратов приводило к нормализации (без превышения уровня экспрессии c-fos в интактной группе) экспрессии гена т. е. они оказывали модулирующее влияние на исследуемый показатель.

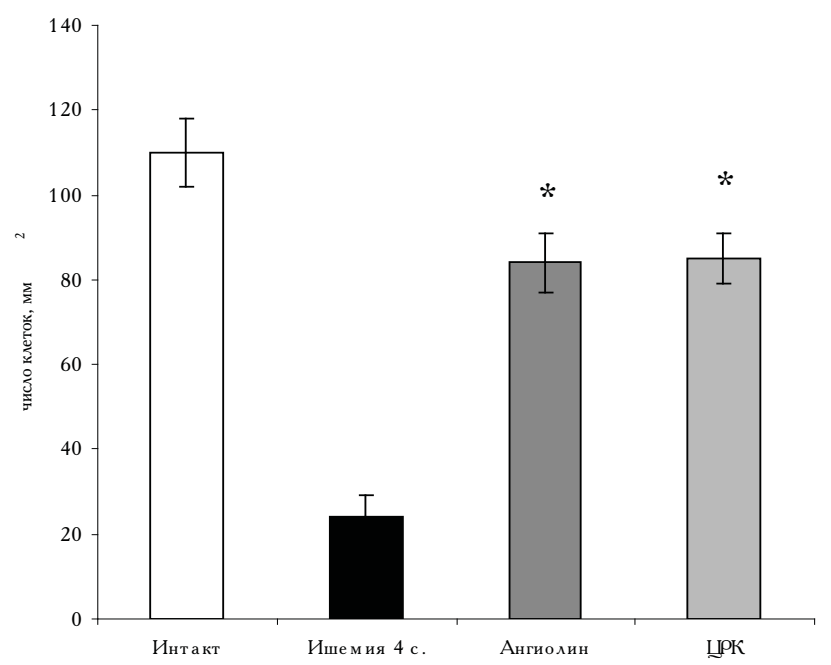

Рис. 3.9. Влияние Ангиолина на характер экспрессии гена с-fos в CA $\mathbf{A}_{\mathbf{1}}$-зоне гиппокампа головного мозга крыс на 4-е сутки ишемии
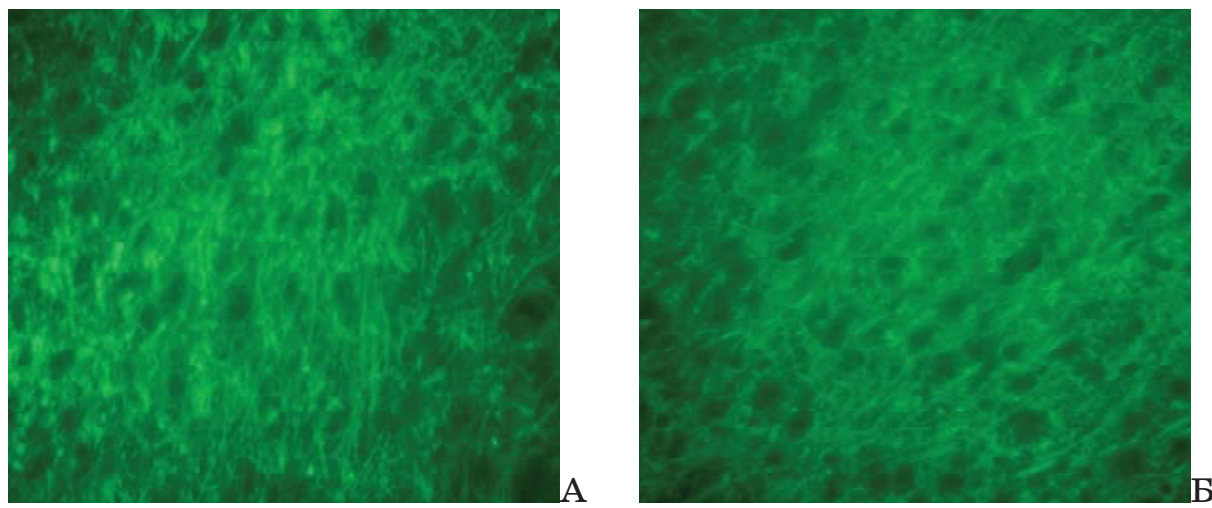

Рис. 3.10. Экспрессия белка c-fos в нейронах CA- -зоны гиппокампа интактной группы (А) и животных с острой ишемией головного мозга (Б)

За счет модулирующего влияния на ген c-fos Ангиолин в определенной степени влиял на морфологический тип гибели нейрона в условиях ишемии головного мозга, переключая его с некроза на апоптоз. Широко известно, что апоптотическая гибель нейронов является оптимальным упорядоченным процессом прекращения жизнедеятельности деструктивно измененных нейронов, 
при котором стабилизируются клеточные мембраны, содержание клеток утилизируется путем образования апоптотических телец и их фагоцитоза без развития воспалительной реакции. Из рисунка 3.11 видно, что при окраске Hoechst 33342 и этидиумом бромидом суспензии нейроцитов, выделенных из головного мозга крыс, получавших Ангиолин, преобладал апоптотический тип гибели нейронов, что проявлялось снижением количества некротирующих нейронов (положительная окраска этидиумом бромидом) с преобладанием апоптотирующих нейронов.

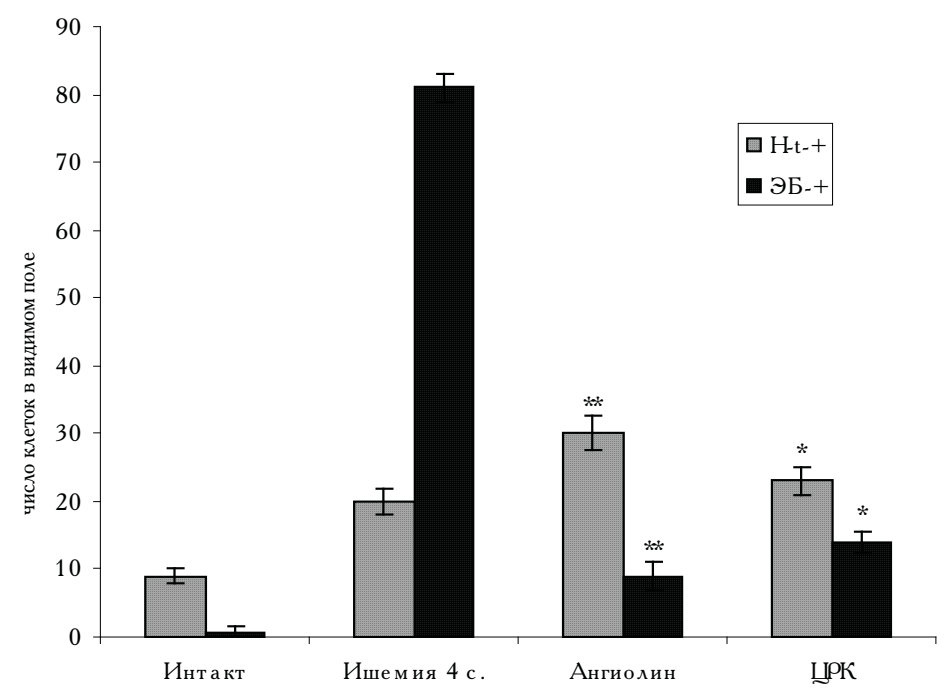

Рuc. 3.11. Влияние Ангиолина на тип морфологической гибели клеток у животных с острой ишемией головного мозга

Достоверность отличия ( $<<0,05)$ по отношению к группе интактных $(*)$, крыс с ишемией на 4-е сутки (\#) H-t+ - Hoechst-положительные нейроны;

ЭБ+ - Этидиум бромид положительные нейроны.

\section{3. БЛОКАТОРЫ НЕЙРОНАЛЬНЫХ КАЛЬЦИЕВЫХ КАНАЛОВ - НИМОТОП, ИСРАДИПИН, ДАРОДИПИН}

Кальций-индуцированная токсичность была открыта в конце 70-х годов. В связи с этим первой обоснованной стратегией нейропротекции стала разработка антагонистов потенциалзависимых кальциевых каналов. Среди средств первичной церебропротекции наиболее широкое применение в лечении ОНМК нашли антагонисты потенциалзависимых кальциевых каналов L-типа - производные дигидропиридина. Наиболее изучен препарат этой группы - Нимодипин, в основе фармакологического действия которого лежит 
предотвращение сосудистого спазма после субарахноидального кровоизлияния, усиление фибринолиза, торможение свободнорадикального окисления. Благодаря уникальному механизму действия и комплексному нейрофармакологическому эффекту Нимотоп занимает совершенно особое положение в современной клинической практике среди других вазотропных, ноотропных и нейропротекторных средств. Насколько неоднозначно мнение о применении Нимодипина при ишемическом инсульте, свидетельствует существование методических рекомендаций ведущих научных медицинских учреждений, содержащих взаимоисключающие подходы к лечению [148].

С нашей точки зрения, есть ряд обстоятельств, которые могут существенно влиять на эффективность Нимодипина.

Во-первых, как уже упоминалось выше, в период аноксии и в ранний постаноксический период содержание и синтез АТФ значительно снижаются. И поскольку без восполнения энергетического дефицита нервной ткани применение блокаторов кальциевых каналов малоэффективно, мы назначаем Нимодипин в сочетании с Актовегином, что позволяет ускорить восстановление энергетического дефицита нервной ткани. Актовегин активирует процессы аэробного окисления, повышает обмен высокоэнергетических фосфатов, улучшает транспорт глюкозы и поглощение кислорода в тканях [149].

Во-вторых - правильное дозирование. В начале курса терапии в течение 2 часов вводится по 1 мг Нимотопа (5 мл инфузионного раствора Нимодипина) в час (приблизительно 15 мкг/кг массы тела). При хорошей переносимости препарата (отсутствие снижения артериального давления и т. д.) через 2 часа дозу повышают до 2 мг (10 мл инфузионного раствора Нимодипина) в час (приблизительно 30 мкг/кг). Для пациентов с массой тела значительно меньше 70 кг или лабильным артериальным давлением начальная доза должна составлять 0,5 мг Нимотопа (2,5 мл инфузионного раствора Нимодипина) в час. Внутривенное введение следует начинать как можно раньше после начала заболевания и продолжать в течение 5-14 дней.

После окончания инфузий в течение 7 дней рекомендуется прием Нимодипина внутрь в дозе 60 мг 6 раз в сутки с промежутками в 4 часа (12 таблеток в сутки). В дальнейшем доза постепенно снижается до поддерживающей.

В Украине надлежащее внутривенное введение Нимотопа возможно только в отделениях интенсивной терапии, где имеется соответствующее оборудование и подготовленный персонал.

В-третьих - адекватный контроль артериального давления. Циркуляторный коллапс при ишемическом инсульте - очень редкое явление, а если он и наблюдается, то, как правило, за счет сопутствующих заболеваний, таких как острый инфаркт миокарда, нарушение ритма сердца, передозировка лекарственных средств, сепсис и т. д.

При артериальной гипотензии артериальное давление повышают, так как она сужает терапевтическое окно, способствует расширению зоны инфаркта, усугубляет прогноз. У больных с ишемическим и геморрагическим инсультом гораздо чаще наблюдается гипертензия. Однако она имеет транзиторный характер и, как правило, коррекция не требуется, пока пациент не поступит в стационар. 
Неэффективность применения Нимотопа при ишемическом инсульте связывают с его способностью вызывать развитие артериальной гипотензии, которая ухудшает кровоснабжение пенумбры. Но, по нашему опыту, при правильном введении препарата артериальная гипотензия развивается редко и легко корректируется с помощью либо волемической нагрузки, либо инотропной поддержки. Если артериальное давление все же плохо восстанавливается, то доза Нимодипина снижается до 0,5 мг/ч и менее, но препарат не отменяется. Курс лечения должен быть непрерывным. Рекомендуется продолжать введение инфузионного раствора Нимотопа при проведении анестезии, хирургических вмешательств и ангиографии. Однако адекватный контроль артериальной гипотензии и ее коррекция возможны только в условиях отделения интенсивной терапии.

B-четвертых - правильное применение препарата. Так как Нимодипин абсорбируется поливинилхлоридом, следует выбирать инфузионные трубки только из полиэтилена. Кроме того, Нимотоп чувствителен к свету, поэтому следует использовать флаконы и трубки темного цвета или защищать их светонепроницаемыми оболочками. В случае применения препарата при рассеянном дневном или искусственном освещении его можно использовать без специальной защиты до 10-12 часов.

B-пятых - правильное сочетание Нимодипина с другими лекарственными препаратами. Параллельно с непрерывным внутривенным введением Нимотопа возможны инфузии раствора глюкозы, хлористого натрия, других солевых растворов, Маннитола, альбумина, препаратов крови, декстранов и т. д. Для обеспечения достаточного разведения препарата рекомендуется, чтобы объем сопутствующей инфузии был не менее 1000 мл/сут. Нимодипин растворен в спирте, поэтому его нельзя назначать совместно с лекарственными средствами, несовместимыми со спиртом. Раствор Нимотопа нельзя добавлять непосредственно в инфузионную бутыль или смешивать с другими препаратами.

Применение Нимотопа может сочетаться с другими лекарственными средствами при комплексном лечении различных видов патологии. У больных с повышенным артериальным давлением, получающих гипотензивные средства, Нимодипин может усилить гипотензивный эффект. Не рекомендуется одновременно с Нимотопом применять бета-блокаторы, так как можно спровоцировать усиление отрицательного инотропного действия, вплоть до декомпенсации сердечной деятельности и неуправляемой гипотонии. По возможности следует избегать сочетанного введения Нимодипина с другими антагонистами кальция (например, Нифедипином, Верапамилом) или альфа-метилдопой. В случаях, когда такая комбинированная терапия необходима, требуется особо тщательный контроль состояния пациента.

Сочетанное применение Нимодипина с блокатором гистаминовых рецепторов Циметидином или Вальпроевой кислотой (противосудорожное средство) может привести к повышению концентрации Нимодипина в плазме крови.

При комбинированной терапии Нимодипином и потенциально нефротоксичными препаратами (аминогликозидами, цефалоспоринами, фуросемидом) возможны нарушения функции почек. Применение Нимотопа может 
усугублять эти расстройства у больных с уже имеющимся снижением функции почек.

Нимотоп следует применять с осторожностью при повышенном содержании жидкости в тканях головного мозга (генерализованном отеке мозга) или выраженном повышении внутричерепного давления.

Мы располагаем опытом применения Нимодипина при различных видах мозгового инсульта и тяжелой черепно-мозговой травме. В частности, с 1994 г. изучаем изменение реактивности мозга в ответ на применение препарата. Так, применение блокаторов кальциевых каналов (в том числе Нимодипина) в сочетании с нейротрофическими средствами (в частности, Актовегином) при остром нарушении мозгового кровообращения различного генеза патогенетически обосновано и высокоэффективно: способствует снижению летальности и инвалидизации.

Учитывая невозможность проведения рандомизированных исследований нейропротекторов, представленных на украинском рынке, мы избрали доступный нам путь изучения эффективности препаратов: использование метода интегрального количественного анализа электроэнцефалографии (прежде всего изучение реактивности мозга в ответ на фармакологическое воздействие) и оценку эффективности применяемых нами протоколов лечения с помощью метода нейросетевого моделирования.

Нами получены обнадеживающие результаты при применении не только Нимодипина, но и других нейропротекторов, не прошедших проверку методами доказательной медицины.

Помимо нашей воли, все пациенты с черепно-мозговой травмой и инсультом в нейрореанимационном отделении на протяжении последних пятнадцати лет «рандомизированы» в две группы: больным 1-й группы в основном осуществляется только поддержка экстрацеребрального гомеостаза, 2-й - экстра- и интрацеребральная поддержка с воздействием на все патогенетические звенья (в том числе введение Нимотопа). Летальность в группах отличается на десятки процентов! Причем результат легко воспроизводится в любом нейрореанимационном отделении Украины, где применяются нейропротекторы.

Согласно последним исследованиям, проведенным в ряде стран Европы и Азии [160], эффективно внутриартериальное введение Нимодипина для лечения и профилактики симптоматического спазма сосудов головного мозга, который развивается обычно на 3-и и 21-е сутки после кровоизлияния. Способность Нимотопа как блокатора кальциевых каналов улучшать неврологические исходы и снижать саму вероятность возникновения вазоспазма не подлежит сомнению [148, 149, 160].

Отдельного анализа заслуживают его геро- и стресспротекторные перспективы. Нимотоп, проникая через гематоэнцефалический барьер, избирательно связывается со специфическими дигидропиридиновыми рецепторами, являющимися составной частью кальциевых каналов L-типа. Результатом этого является существенное ограничение поступления ионов кальция внутрь нейронов и, соответственно, снижение внутриклеточной концентрации кальция. Важно отметить, что данные рецепторы локализуются в ЦНС как на ней- 
рональных и глиальных мембранах, так и в сосудистой стенке, что определяет наличие у Нимотопа двойного эффекта - нейротропного и вазотропного действия.

Наиболее очевидна целесообразность применения Нимотопа на этапе предболезни при сосудистой патологии головного мозга. В развитии хронических форм нарушения мозгового кровообращения, дисциркуляторной энцефалопатии, сосудистой деменции в подавляющем большинстве случаев выделяется достаточно длительный период предболезни, характеризующийся незначительно выраженной головной болью, легким головокружением, звоном в ушах и т. д. Этот период связан с начальным этапом гипоксии нейронов, изменением мембранных нейрональных структур вследствие нарушений микроциркуляции в мозге, незначительно выраженными спастическими сосудистыми реакциями, сдвигами в метаболизме клеток эндотелия, то есть с изменениями, характерными для физиологического старения ЦНС и состояния хронического стресса, в генезе которых, как упоминалось, важную роль играет накопление внутриклеточного кальция. Поэтому максимально раннее применение Нимотопа на донозологическом этапе до момента манифестации развернутой клинической картины той или иной формы цереброваскулярной патологии способно эффективно замедлить прогрессирование перечисленных проявлений и, соответственно, существенно отдалить клиническую стадию болезни. Это действие обусловлено наличием в спектре фармакологических эффектов Нимотопа вазотропного эффекта, связанного с влиянием на кальциевые каналы гладкомышечных клеток церебральных сосудов, особенно мелкого и среднего калибра, и проявляющегося предотвращением и/или ликвидацией сосудистого спазма, улучшением микроциркуляции и мозгового кровотока в целом без свойственного многим вазотропным средствам феномена «обкрадывания»; при этом специфическим феноменом является воздействие Нимотопа именно на зоны мозга с начальными нарушениями кровоснабжения, а также антиатерогенное действие, связанное со стабилизацией мембранных структур эндотелиальных клеток сосудов.

Механизмы нейропротекторного действия Нимотопа определяются снижением активации перекисного окисления липидов и образования свободных радикалов, уменьшением нейротоксического действия лактата, ослаблением проявлений феномена эксайтотоксичности, возникающего в результате активации глутаматных рецепторов при гипоксии и стрессе, а также в благотворном влиянии на нарушенные когнитивные и поведенческие расстройства, различные типы памяти и др. за счет активации роста дендритов и образования новых межнейронных связей, то есть улучшения пластических функций нейронов, их адаптационно-компенсаторных возможностей.

Особо стоит сказать об антиоксидантных свойствах производных дигидропиридинов. Экспериментальными исследованиями in vitro и in vivo было установлено, что производные дигидропиридина (Нимодипин, Дародипин, Нифедипин и др.) в концентрации $10^{-5} \mathrm{M}$ обладали антирадикальной активностью при взаимодействии со стабильным радикалом ДФПГ, тормозили металлкатализируемую пероксидацию липидов, защищали фосфолипидный бис- 
лой мембран от пероксидации, улучшали текучесть мембран. Однако по силе антиоксидантного действия в опытах in vitro производные дигидропиридина уступали $\alpha$-токоферолу [150, 153, 154]. В условиях моделирования ОНМК, Нимотоп достоверно снижал биохимические маркеры оксидативного стресса (АФГ и КФГ) в коре и $\mathrm{CA}_{1}$-зоне гиппокампа экспериментальных животных. Антиоксидантное и нейропротективное действие Нимотопа в условиях эксперимента проявлялась на фоне достаточного содержания АТФ в головном мозге животных с ОНМК. Нами было отмечено повышение, а в некоторых случаях и появление, нейропротективного и антиоксидантного действия Нимотопа при совместном его применении с Тиотриазолином или Мексидолом. Результаты исследования этого препарата в клинике дают противоречивые результаты его положительного действия на исход инсульта [169]. По всей видимости, положительный нейропротективный эффект Нимотопа зависит от энергетического потенциала нейрона и его стоит назначать совместно с препаратами, которые улучшают нейрометаболические процессы (Тиотриазолин, Тиоцетам, Актовегин, Мексидол, Ноофен и др.). Другими препаратами этой группы, испытанными при ишемическом инсульте являются Дародипин, Исрадипин, Цереброкраст. Причем по нейропротективному действию Цереброкраст в условиях моделирования ОНМК у монгольских песчанок по ряду показателей превосходит Нимодипин [148-150]. На моделях фокальной ишемии и внутримозгового кровоизлияния Цереброкраст снижал явления неврологического и когнитивного дефицита и повышал выживаемость животных. В группе больных с состоянием средней тяжести выявлена тенденция к нормализации спонтанной биоэлектрической активности мозга под влиянием Цереброкраста: достоверно нарастала мощность альфа-диапазона ЭЭГ в затылочно-центральных отделах полушарий, преимущественно на пораженной стороне, в связи с чем сглаживалась межполушарная асимметрия по альфа-ритму; уменьшалась выраженность диффузной медленной (сигма, тэта) активности. Сравнительный анализ усредненных картограмм ЭЭГ на 6-е сутки после развития инсульта подтвердил более полную нормализацию паттерна ЭЭГ на фоне применения Цереброкраста по сравнению с плацебо [148-150]. Однако, при тяжелых формах заболевания преимуществ лечения Цереброкрастом не установлено. В группе больных с каротидным ишемическим инсультом, леченных Цереброкрастом, тенденция к ускоренному и более полному регрессу неврологических нарушений, а также к улучшению функционального восстановления отмечена только у 22,5 \% больных с исходно «мягким» течением инсульта. Отмечаются и побочные эффекты Цереброкраста, характерные для дигидропиридинов [170].

\section{4. СЕЛЕКТИВНЫЕ МОДУЛЯТОРЫ ЭСТРОГЕНОВЫХ РЕЦЕПТОРОВ}

В последнее время определенный интерес представляют модуляторы эстрогеновых рецепторов, которые играют значительную роль в функционировании высших мозговых функций и регуляции жизнедеятельности всего организма - регулируют уровень нейроантиоксидантов (мелатонина и карно- 
зина), глобальных факторов транскрипции, участвующих в экспрессии ферментов антиоксидантной системы и ферментов тиол-дисульфидной системы [250-264], что обуславливает перспективность поиска нейропротекторов среди модуляторов $\beta$-эстрогеновых рецепторов.

В настоящее время появились препараты нового поколения, которые, не являясь непосредственно гормонами, тем не менее, оказывают избирательное гормоноподобное действие на специфические гормонорецепторы. Это класс селективных эстроген-рецепторных модуляторов (CЭPM или STEAR), обладающих тканеспецифическим механизмом действия. Эти препараты, оказывая уникальное, эстрогеноподобное тканеспецифическое действие на костную, сердечно-сосудистую, нервную и другие системы, обладают преимущественно антиэстрогенным эффектом на молочные железы и матку, сводя к минимуму риск побочных эффектов. Доказано, что применение данных препаратов оказывает нейропротекторное действие, предупреждает развитие старческого слабоумия на 35-40 \%, снижает риск развития возрастных депрессий, предупреждает развитие остеопороза, замедляет развитие атеросклероза и предупреждает развитие ишемической болезни сердца, оказывая антиатерогенное действие [241-252].

Ливиал - это синтетический модулятор эстрогеновых рецепторов (группа СЭРМ), действие которого объясняется сочетанием трех различных механизмов. Прежде всего, действие Ливиала основано на тканеспецифическом эстрогеноподобном метаболизме стероидов. Вторым направлением является регуляция функции ферментов за счет ингибирования активности сульфатазы, замедления превращения неактивного эстрона в активный эстрадиол. Последний обладает онкогенным действием на клетки молочной железы и эндометрия в постменопаузальном периоде и снижение его уровня является важным достоинством Ливиала. И третье направление его действия - это активация рецепторов прогестерона с локальным образованием прогестагенного метаболита, обеспечивающего апоптоз опухолевых клеток молочной железы и эндометрия [247-261].

Ливиал с успехом был применен у женщин с артериальной гипертензией в возрасте 50-60 лет и старше, доказано его положительное влияние на центральную и периферическую гемодинамику, липидный спектр крови, тонус сосудов, функцию вегетативной нервной системы [260].

Фундаментальное исследование по влиянию Ливиала (тиболона) на сердечно-сосудистую систему было проведено в Великобритании в 2001 г., доложено и обсуждено на заседании Европейского общества кардиологов. Были представлены убедительные данные, свидетельствующие о многочисленных положительных воздействиях Ливиала (тиболона) на сердечно-сосудистую систему. Доказано, что Ливиал увеличивает фибринолиз без какого-либо существенного воздействия на показатели коагуляции, стимулирует сердечный выброс, скорость кровотока, релаксацию сосудов и при этом не влияет на метаболизм глюкозы и инсулина. Несомненным достоинством препарата является также его способность уменьшать уровень холестерина в организме и нормализовать липидный обмен, а также оказывать эстрогеноподобное влияние на сли- 
зистую и коллаген. Это препарат выбора у пациентов с онкогинекологическим анамнезом [250-264].

Альтернативой синтетическим СЭРМ являются фито-СЭРМ. Доказано, что фито-СЭРМ способствуют не только уменьшению проявлений климактерического синдрома, но и являются профилактикой остеопороза, снижают частоту сердечно-сосудистых заболеваний, уменьшают количество депрессий, предотвращают развитие нейро-дегенеративных заболеваний, таких как болезнь Альцгеймера [265].

Фитогормоны - лекарственные растения, не обладающие эстрогенным эффектом и действующие благодаря своей изофлавиновой структуре. Фитогормоны выявляются в следующих растениях: цимицифуга, рапонтицин, мельброзия. Действующим началом в цимицифуге и рапонтицине являются терпенгликозиды, которые снижают скорость и проявления старения организма.

Фитогормоны (цимицифуга, рапонтицин и мельброзия) представляются интересными и мощными средствами для лечения симптомов старения, в форме заместительной терапии или даже как пищевые добавки для профилактики остеопороза, рака молочной железы и других нейродегенеративных и сердечнососудистых заболеваний [250].

Лечебные свойства корня цимицифуги были известны очень давно. Еще в 1933 г. F. Donner рекомендовал использовать его при лечении артралгических, миалгических и неврологических симптомов в период угасания функций организма. Другие авторы отмечали эффективность цимицифуги в лечении сердечно-сосудистой патологии, депрессии, мигрени. D. Seidlova-Wuttke считает, что цимицифуга представляет собой фито-СЭРМ с преимущественным влиянием на ЦНС, кости и артерии и отсутствием воздействия на матку.

Кроме того, для объективизации эффективности действия Климадинона при различных соматических, психологических или нейровегетативных расстройствах были проведены два международных рандомизированных контролированных и одно двойное слепое исследование с использованием клинически стандартизированных и международно признанных психометрических шкал. Исследования были проведены на почти 25000 пациентов. Доказано, что эффективность экстракта цимицифуги была эквивалентной эффективности эстрогенов, а в сравнении с плацебо - достоверно ее превосходила [265277].

Полученные данные свидетельствовали о том, что экстракт корня цимицифуги (Климадинон) способен связываться с эстрогенными рецепторами и вызывать их трансактивацию. Это действие не распространяется на матку и ограничивается лишь областью мозга, где под действием препарата происходит подавление секреции ЛГ, но не в такой степени и не так быстро, как на фоне введения эстрогенов.

Таким образом, данные литературы свидетельствуют о положительном действии современных препаратов гормонзаместительной терапии на деятельность сердечно-сосудистой системы, на нормализацию процессов пероксидации, синтеза NO, липидного обмена, на замедление апоптоза нервной ткани и предупреждение развития нейродегенеративных заболеваний. Поскольку 
в патогенезе развития глаукомы и глаукомной оптической нейропатии имеют место все вышеперечисленные факторы, а препараты, оказывающие селективное действие на эстрогеновые рецепторы, могут замедлить развитие инволюционных изменений, не имеют побочного действия, перспективным является изучение влияния препаратов группы СЭРМ на стабилизацию прогрессирования глаукомной оптической нейропатии [276].

В связи с вышеизложенным, актуальным на сегодня является изучение механизма нейропротективной активности селективных модуляторов эстрогеновых рецепторов.

Так, нами была проведена оценка способности модуляторов эстрогеновых рецепторов - Тамоксифена и Ливиала - влиять на патобиохимические процессы в клетках головного мозга в условиях депривации системы глутатиона in vitro (внесение в инкубационную среду CDMB).

С целью фармакокоррекции in vitro патологических изменений нейрона модуляторами эстрогеновых рецепторов, нами была предпринята попытка установить эффективные концентрации Тамоксифена и Ливиала. Интегральным показателям нейропротективной эффективности изучаемых лекарственных средств является их способность повышать количество выживших клеток в суспензии нейронов, преинкубированных с CDNB. С этой целью в суспензию нейронов вносили Тамоксифен и Ливиал в концентрациях 0,1 мкM; 10 мкM; 100 мкМ. Из рисунка 3.12 видно, что наиболее эффективной концентрацией для всех препаратов является 0,1 мкМ. В концентрации 0,1 мкМ Тамоксифен снижал количество апоптотически измененных нейронов на 50 \%, Ливиал более чем на 77 \% по отношению к контролю. Следует отметить, что препарат Ливиал по своему влиянию на исследуемый показатель статистически достоверно ( $\leq 0,05)$ превышал значения Тамоксифена.

Повышение концентрации препаратов приводило к постепенному ослаблению эффекта в дозе 10 мкМ и полному его отсутствию в концентрации 100 мкM, что, по нашему мнению, связано с тем, что в концентрации 0,1 мкM препараты более селективно проявляют агонистический эффект в отношении $\beta$-ER. C увеличением дозы, возможно, теряется тропность препаратов к рецепторам, а также изменяется характер влияния исследуемых средств на эстрогеновые рецепторы [275]. 


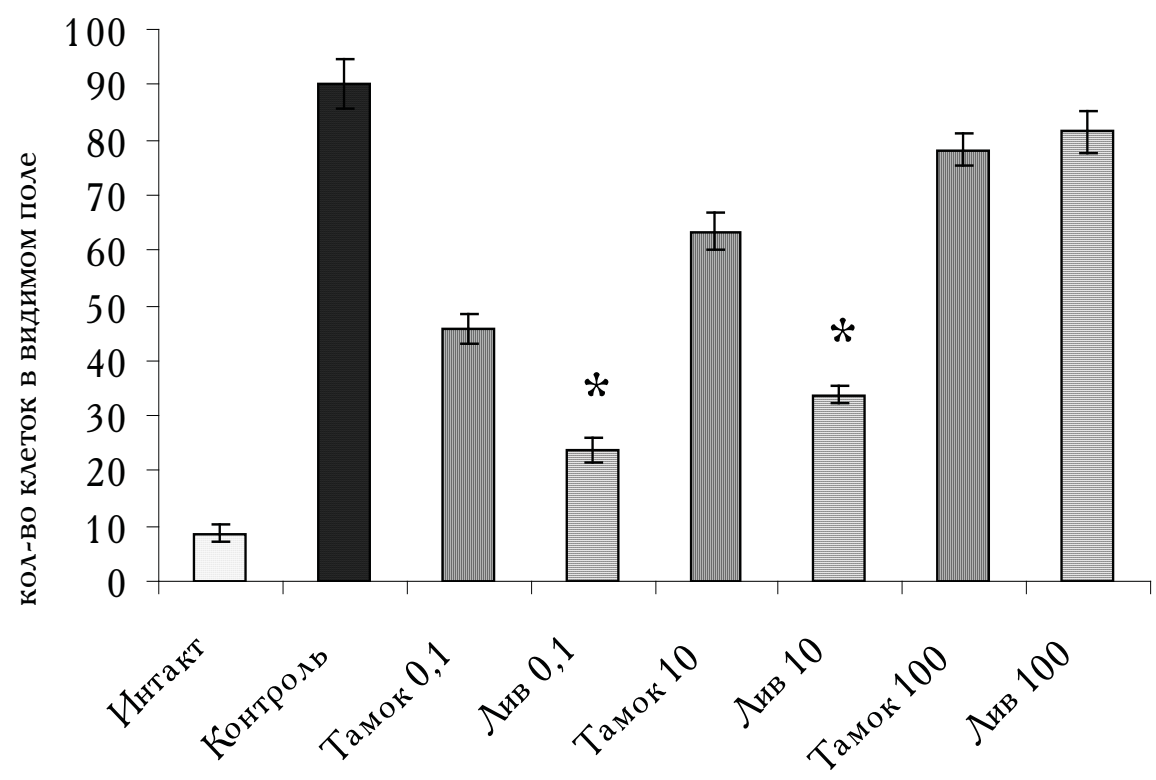

Примечание. Тамок - Тамоксифен; Лив - Ливиал; * $-\mathrm{p} \leq 0,05$ по отношению к Тамоксифену.

\section{Рис. 3.12. Влияние исследуемых препаратов на количество апоптотически измененных клеток в суспензии нейронов преинкубированных с DNCB (1мкM).}

Для исследования механизмов нейропротективного действия Тамоксифена и Ливиала нами была изучена их способность в концентрации 0,1 мкM влиять на показатели антиоксидантной, тиол-дисульфидной систем, митохондриальной дисфункции в суспензии нейронов и митохондрий, преинкубированных с CDNB.

Биохимическими исследованиями установлено, что введение в инкубационную среду Тамоксифена, Ливиала в концентрации 0,1 мк $\mathrm{M}$ приводило к уменьшению выраженности оксидативного стресса (снижение в среднем АФГ (на $32 \%$ ), КФГ (на $42 \%$ ), нитротирозина (на $47 \%$ ), повышение активности Mn-SOD на 33 \% по отношению к контролю); а также восстановлению тиол-дисульфидного равновесия (повышение концентрации восстановленного глутатиона (на $80 \%$ ) и снижение его окисленной формы в среднем на $65 \%$ ); повышение активности ферментов тиол-дисульфидной системы - Г-S-T и ГP на $65 \%$ и $48 \%$ соответственно. Позитивное действие исследуемые препараты оказывали и на антиоксидантную систему митохондрий, восстанавливая количество митохондриального глутатиона, а также повышая активность Mn-SOD (табл. 3.14). 
Таблица 3.14

\section{Влияние исследуемых препаратов на показатели антиоксидантной и тиол-дисульфидной систем в суспензии нейронов и митохондрий, преинкубированных с DNCB 1 мкM}

\begin{tabular}{lccc}
\multicolumn{1}{c}{ Показатели } & $\begin{array}{c}\text { Контроль } \\
\text { (суспензия нейронов } \\
\text { ( добавлением } \\
\text { 1мкM CDNB) }\end{array}$ & $\begin{array}{c}\text { Тамоксифен } \\
\mathbf{( 0 , 1} \text { мкM) }\end{array}$ & $\begin{array}{c}\text { Ливиал } \\
\text { (0,1 мкM) }\end{array}$ \\
АФГ, у.е./мг/белка & $11,8 \pm 1,16$ & $8,0 \pm 0,74$ & $7,24 \pm 0,36^{*}$ \\
КФГ, у.е./мг/белка & $5,2 \pm 0,24$ & $3,0 \pm 0,18$ & $3,2 \pm 0,11^{*}$ \\
Нитротирозин, у.е./мг/белка & $38,5 \pm 1,62$ & $25,54 \pm 1,73$ & $24,3 \pm 1,81^{*}$ \\
Мп-SОD, у.е/мг/белка/мин & $73,4 \pm 5,74$ & $98,3 \pm 4,38$ & $110,8 \pm 9,08^{*} \&$ \\
Глутатион восст, мкМ/гр/ткани & $0,54 \pm 0,08$ & $1,7 \pm 0,084$ & $2,8 \pm 0,12^{*} \&$ \\
Глутатион окисл. мкМ/гр/ткани & $0,47 \pm 0,042$ & $0,24 \pm 0,015^{*}$ & $0,17 \pm 0,012^{*} \&$ \\
Г-S-Т, у.е./мг/белка & $7,15 \pm 0,74$ & $20,5 \pm 1,15$ & $24,7 \pm 1,63^{*} \&$ \\
ГР, у.е./мг/белка & $5,2 \pm 0,47$ & $9,5 \pm 0,42$ & $11,7 \pm 0,2^{*} \&$ \\
Глутатион, восст.(митохондр.) & $2,11 \pm 0,10$ & $3,87 \pm 0,12^{*}$ & $4,77 \pm 0,10^{*}$ \\
мкМ/гр/ткани
\end{tabular}

Примечание: * $-\mathrm{p} \leq 0,05$ по отношению к контролю;

$\&-\mathrm{p} \leq 0,05$ по отношению к Тамоксифену.

Важно отметить, что по большинству исследуемых параметров Ливиал статистически достоверно ( $\leq \leq 0,05)$ превышал эффекты Тамоксифена.

Позитивное влияние исследуемых препаратов на антиоксидантную и тиол-дисульфидную системы обуславливает их способность снижать явления митохондриальной дисфункции. Из рисунка 3.13 видно, что модуляторы эстрогеновых рецепторов, в особенности Ливиал, ограничивали развитие митохондриальной дисфункции, тормозя открытие митохондриальной поры и сохраняя заряд митохондрий.

Таким образом, проведенными экспериментальными исследованиями была установлена достаточно высокая нейропротективная эффективность модуляторов эстрогеновых рецепторов в условиях депривации глутатионового звена тиол-дисульфидной системы в суспензии выделенных нейронов.

Подобное действие модуляторов эстрогеновых рецепторов, по нашему мнению, объясняется, во-первых, их прямыми антиоксидантными эффектами $[10,11,28,29]$. 


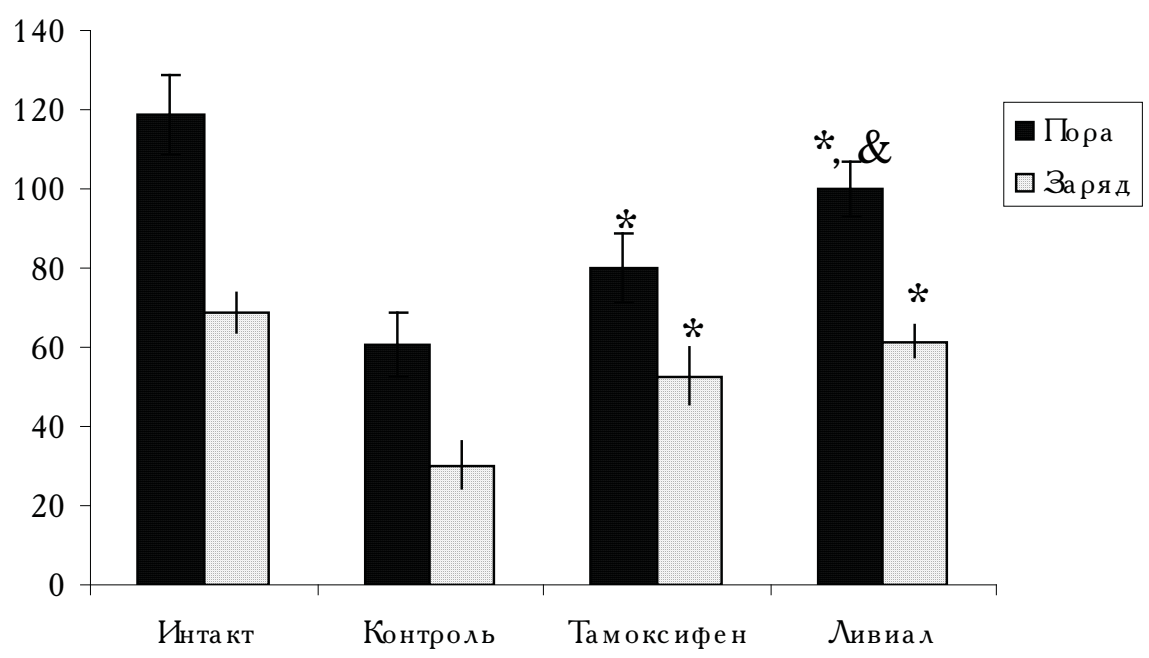

Примечание: * - p $\leq 0,05$ по отношению к контролю;

$\&-\mathrm{p} \leq 0,05$ по отношению к Тамоксифену.

Рuc. 3.13. Влияние исследуемых препаратов в концентрации 0,1 на показатели митохондриальной дисфункции в суспензии нейронов, преинкубированных с CDNB (1мкM)

Во-вторых, известно, что активация эстрогенами рецепторов включает в себя отсоединение последних от белков теплового шока (HSP), что обеспечивает проникновение HSP внутрь клетки [11, 27]. В последнее время появились данные о защитной роли белков теплового шока при церебральной ишемии, сопровождающейся интенсификацией процессов свободнорадикального окисления, смещением тиол-дисульфидного равновесия, развитием нитрозирующего стресса, глутаматной эксайтотоксичности [17, 30, 31]. HSP индуцируются в клетках всех живых организмов в ответ на действие многочисленных стрессовых факторов, таких как тепловой шок, гипоксия, ишемия, метаболические нарушения, вирусная инфекция и воздействия фармакологических агентов. Известно, что HSP принимают участие во всех процессах жизнедеятельности клетки. Большинство защитных функций HSP связано с шаперонной активностью, т. е. с их способностью узнавать поврежденные или вновь синтезированные полипептиды и выправлять их структуру АТФ-опосредованным образом или удалять не поддающиеся исправлению белки через протеасомный аппарат. За счет стабилизации окислительно поврежденных макромолекул, HSP способны препятствовать открытию митохондриальной поры, блокируя тем самым выход из митохондрий цитохрома С и проявляя прямое антиапоптотическое действие [19]. 
B третьих, исследованиями Dubal B.B., Brann D.W. установлено, что эстрогены модулируют экспрессию глобальных факторов транскрипции, в частности AP-1, ответственного за синтез основных ферментов антиоксидантной и тиол-дисульфидной систем, чем можно объяснить значительную способность Тамоксифена и Ливиала восстанавливать активность супероксиддисмутазы, глутатион-S-трансферазы, глутатионредуктазы [32, 33]. Кроме того, отмечено и антиапоптотическое действие эстрогенов, обусловленное стимуляцией экспрессии антиапоптотических белков семейства bcl-xL [13].

Параллельными исследованиями нами была произведена оценка терапевтической эффективности Тамоксифена (наиболее активный препарат в опытах in vitro) в условиях моделирования острой церебральной ишемии (ОЦИ).

Проведенными экспериментальными исследованиями установлено, что моделирование ОЦИ сопровождалось функционально-биохимическими изменениями в тканях головного мозга. Как видно из таблицы 1 , на 4 -е сутки у животных с ОЦИ было зарегистрировано значительное повышение концентрации гомоцистеина (GCS) - на 77 \% по отношению к интактной группе животных. Известно, что GCS является предшественником глутатиона, уровень которого был снижен более чем на 52 \% у животных данной экспериментальной группы, что по-видимому, связано с его потерей в антиоксидантных реакциях. Гипергомоцистеинемия за счет изменения активности NMDA-рецепторов приводит к накоплению внутриклеточного кальция, что в свою очередь влечет за собой подавление энергетической функции митохондрий. В митохондриях запускаются «паразитарные» энергопродуцирующие реакции, приводящие к гиперпродукции АФК, которые образуются на начальном участке дыхательной цепи митохондрий при участии NADH-CoQH2-редуктазы [16]. Избыток АФК в клетке приводит к окислительному стрессу, в результате чего окислению подвергаются ДНК и функционально активные белковые молекулы. Кроме того, дефицит глутатиона приводит к развитию нитрозильного стресса в результате которого происходит взаимодействие цитотоксических дериватов NO с алифатическими и ароматическими аминами с образованием $\mathrm{N}$-нитрозаминов, о чем может свидетельствовать повышение содержания в головном мозге НТ3 (на 80 \% по отношению к интактным крысам), зарегистрированное нами на 4-е сутки модельной патологии (табл. 1). Следует также отметить, что токсические дериваты оксида азота, гиперпродукция которых наблюдается в условиях нитрозильного стресса, взаимодействуют с цистеином с образованием S-нитрозоцистеина

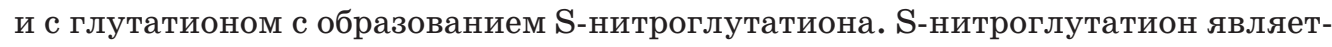
ся основной транспортной молекулой переноса NO. Некоторыми исследованиями установлено, что транспорт $\mathrm{NO}$ происходит с образованием $\mathrm{N}_{2} \mathrm{O}_{3}$, который затем нитрозилирует тиолы, еще более истощая запасы глутатиона и смещая тиол-дисульфидное равновесие [16, 17].

Параллельно с развитием оксидативного и нитрозильного стрессов, смещением тиол-дисульфидного равновесия, наблюдалось изменение характера экспрессии генов, кодирующих HSP 70 белки. Известно, что в условиях ишемии головного мозга защитная функция HSP 70 является существенным фактором поддержания жизнеспособности клеток, находящихся в условиях 
острой гипоксии, а также под воздействием цито- и геномотоксических продуктов окислительного стресса. Реализация защитной и многих других функций белков HSP 70 зависит от их шаперонной активности [18]. Под шаперонной активностью понимается способность узнавать и складывать вновь синтезированные полипептидные цепи в активные молекулы белков и восстанавливать нарушенную структуру белков. Показано, что за счет своей шаперонной активности HSP-белки участвуют в редукции окислительного стресса, репарации ионных каналов, апоптозе. Активация экспрессии белков теплового шока - одна из первых реакций клетки в ответ на ишемию и окислительный стресс. Методом вестерн-блот анализа установлено, что на 1-е сутки моделирования церебральной ишемии наблюдалось повышение концентрации HSP 70 в головном мозге, направленное на восстановление окислительно поврежденных и денатурированных функционально активных белков; на регуляцию/модуляцию протеолиза белков, окислительно-восстановительных реакций, синтеза провоспалительных цитокинов, синаптической передачи (табл. 2). Общеизвестно, что в условиях ишемии общий биосинтез белка снижается, а синтез HSP 70 резко увеличивается. При этом большинство HSP-белков находится в ядре среди поврежденных в результате оксидативного стресса прерибосом. Постепенно содержание HSP в ядре уменьшается, а в цитоплазме увеличивается. Известно, что характерным клеточным проявлением ишемии является агрегация и накопление денатурированных белков, активация свободнорадикальных процессов и кальциевая перегрузка. HSP 70 могут ограничивать эти сдвиги, дезагрегируя аномальные белковые агрегаты, участвуя в деградации необратимо поврежденных белков, повышая мощность антиоксидантных ферментов и ограничивая повреждающие эффекты кальциевой перегрузки за счет связывания рецептора кальция - кальмодулина $[18,19]$. Наконец недавно стали появляться данные еще об одном механизме защитного действия HSP 70 - блокаде гиперпродукции оксида азота (NO). Значимость этого эффекта HSP 70 определяется тем, что гиперпродукция NO играет ключевую роль в развитии многих патологических состояний, таких как воспаление, гипотензия, ишемические повреждения органов и т. д. Кроме того, нашими более ранними работами, которые согласуются с исследованиями других авторов, была показана способность HSP 70 белков пролонгировать время жизни основного адаптационного фактора - HIF-1 (индуцибельный фактор гипоксии, hypoxia-inducible factor), который в условиях гипоксии инициирует запуск компенсаторных механизмов выработки энергии [19, 20]. Данные адаптационные реакции в ответ на ишемию лимитированы во времени и уже на 4-е сутки ишемии нами было зарегистрировано значительное падение концентрации HSP 70 белков в тканях головного мозга по отношению к 1-м суткам ишемии, что выражалось в уменьшении площади и оптической концентрации позитивно окрашенного комплекса на 69 \% и 76 \% соответственно. Данное обстоятельство, по-видимому, связано со срывом резервно-адаптационных возможностей организма, а также с усилением процессов свободнорадикального окисления. Обращает на себя внимание развитие у данной экспериментальной группы животных выраженной гипергомоцистеинемии, которая сопровожда- 
лась значительным приростом в головном мозге НТЗ, в результате чего окислительной модификации подвергались сами HSP 70 белки.

Установленная нами направленность молекулярно-биохимических изменений в головном мозге контрольной группы животных обуславливает развитие неврологического дефицита, начиная с 1-х суток ОЦИ, с максимальным проявлением на 4-е сутки эксперимента. Так, если на 1-е сутки ОЦИ неврологический дефицит по шкале McGrow составлял в среднем 4 балла, то на 4-е сутки - более 7 баллов.

С целью установления нейропротективного профиля SERM - Тамоксифена цитрата, нами было исследовано его влияние на представленные выше показатели тиол-дисульфидной и антиоксидантной систем.

Курсовое введение экспериментальным животным Тамоксифена цитрата в дозе 1 мг/кг, приводило к нормализации показателей тиол-дисульфидной системы, а также ограничивало развитие оксидативного стресса. Так, нами было зарегистрировано повышение содержания в головном мозге концентрации глутатиона (более чем на 37 \% по отношению к контролю). Способность Тамоксифена цитрата повышать содержание глутатиона, по нашему мнению, является одним из ключевых эффектов, реализующих его нейропротективное действие, поскольку в настоящее время установлено, что глутатион, помимо выраженного антиоксидантного действия (прямое взаимодействие с радикалами в неэнзиматических реакциях), является еще нейротрансмиттером и нейромодулятором (модулирует SH-группы NMDA-рецепторов). Восстановление тиол-дисульфидного равновесия за счет повышения уровня глутатиона в мозговой ткани приводило к ограничению оксидативного и нитрозильного стресса, что выражалось уменьшением в тканях головного мозга на 4-е сутки концентрации НТ3 (на 69 \% по отношению к контролю) и GCS - на 52 \% .

Таблица 3.15

\begin{abstract}
Влияние тамоксифена цитрата (1 мг/кг) на показатели тиол-дисульфидной системы и содержание нитротирозина в тканях головного мозга монгольских песчанок на 4-е сутки экспериментальной ишемии
\end{abstract}

\begin{tabular}{|l|c|c|c|c|}
\hline $\begin{array}{l}\text { Экспериментальные } \\
\text { группы }\end{array}$ & $\begin{array}{c}\text { Глутатион вост., } \\
\text { мкM/г ткани }\end{array}$ & $\begin{array}{c}\text { Глутатион окисл., } \\
\text { мкM/г ткани }\end{array}$ & $\begin{array}{c}\text { Гомоцистеин } \\
\text { мкM/г ткани }\end{array}$ & $\begin{array}{c}\text { Нитротирозин } \\
\text { усл.ед./г белка }\end{array}$ \\
\hline Интакт & $4,1 \pm 0,5$ & $0,11 \pm 0,027$ & $1,2 \pm 0,15$ & $1,3 \pm 0,14$ \\
\hline $\begin{array}{l}\text { Контроль } \\
\text { (ишемия, 4-е сутки) }\end{array}$ & $2,9 \pm 0,13$ & $0,34 \pm 14$ & $4,5 \pm 0,18$ & $6,1 \pm 0,21$ \\
\hline $\begin{array}{l}\text { Тамоксифен цитрат } \\
\text { (1мг/кг) }\end{array}$ & $3,7 \pm 0,11^{*}$ & $0,22 \pm 0,1 *$ & $2,6 \pm 0,13^{*}$ & $2,0 \pm 0,17^{*}$ \\
\hline
\end{tabular}


Для установления механизма нейропротективного действия Тамоксифена цитрата нами также было изучено его влияние на описанную выше систему клеточной протекции - HSP 70 белков, выраженный дефицит которых был нами зафиксирован у животных с ОЦИ. Кроме того, рядом исследователей была выдвинута гипотеза о HSP-опосредованном действии селективных модуляторов эстрогеновых рецепторов [14].

Проведенными исследованиями установлено, что назначение животным с ОЦИ Тамоксифена цитрата приводило к статистически достоверному повышению содержания HSP 70 белков в мозговой ткани. Следует отметить, что на фоне назначения исследуемого препарата, содержание HSP 70 белков остается повышенным и на 4-е сутки эксперимента, в отличие от животных контрольной группы. Денситометрический анализ показал увеличение на 4-е сутки площади и оптической концентрации HSP-окрашенного комплекса в среднем на $51 \%$ по отношению к контрольной группе на те же сроки ОЦИ (рис. 3.13).

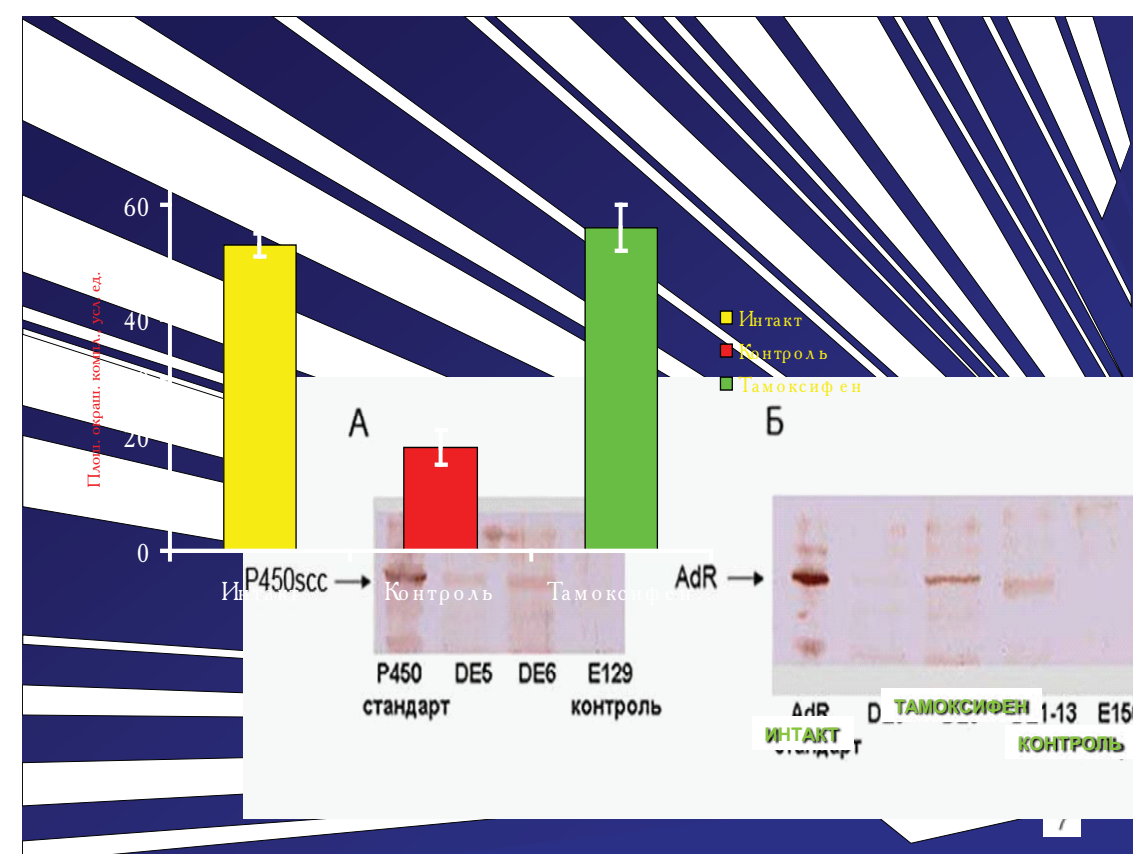

Puc. 3.13. Влияние Тамоксифена цитрата (1 мг/кг) на содержание HSPбелков в тканях головного мозга на 4-е сутки эксперимента по результатам денситометрического анализа

По нашему мнению, способность Тамоксифена цитрата повышать в условиях ишемии головного мозга содержание HSP 70 белков обусловлена его геномными и внегеномными эффектами. Нашими предыдущими работами, которые согласуются с рядом экспериментальных работ зарубежных исследователей, показана способность эстрогенов и SERM модулировать экспрессию гло- 
бальных факторов транскрипции, ответственных за синтез HSP-белков. Кроме того, активация SERM $\beta$-эстрогеновых рецепторов головного мозга обуславливает отсоединение от последних HSP 70 -белков, что обеспечивает вхождение этих белков внутрь клетки и реализацию их биологической функции. Механизм данного взаимодействия связан с ролью HSP 70 в поддержании в неактивном состоянии эстрогеновых рецепторов, не связанных с эстрогенами $[4,6,10]$. Предполагают, что обратная связь рецептора со стероидным лигандом, приводит к конформационным изменениям молекулы рецептора, освобождению его из комплекса с белками теплового шока и их вхождению внутрь клетки. Также, некоторыми исследователями была выдвинута гипотеза о способности SERM усиливать экспрессию HSP 70 за счет стимулирующего влиянии на белковый фактор транскрипции - фактор теплового шока (FHS) [21].

Подобная направленность действия Тамоксифена приводила к уменьшению у данной группы животных неврологического дефицита по шкале McGrow. Позитивная динамика наблюдалась у животных данной экспериментальной группы, начиная с 1-х суток ОЦИ.

Таким образом, проведенными экспериментальными исследованиями была установлена нейропротективная активность селективного модулятора эстрогеновых рецепторов - Тамоксифена цитрата, реализующаяся во-первых, за счет его способности повышать содержание HSP 70 белков в тканях головного мозга в острый период ишемии. Во-вторых, Тамоксифен цитрат способен ограничивать развитие оксидативного и нитрозильного стрессов, что приводит к снижению концентрации в головном мозге гомоцистеина и нитротирозина и повышению глутатиона, восстанавливая тем самым тиол-дисульфидное равновесие в нервных клетках. Взаимопотенцирование данных эффектов Тамоксифена цитрата в условиях острой церебральной ишемии приводило к выраженному нейропротективному эффекту.

Установленный нами нейропротективный профиль Тамоксифена цитрата обуславливает дальнейшую перспективность исследований в данном направлении с целью внедрения его в клиническую практику в качестве нейропротективного средства. 


\section{ГЛАВА 4}

\section{СРЕДСТВА ВТОРИЧНОЙ НЕЙРОПРОТЕКЦИИ - НЕЙРОМЕТАБОЛИЧЕСКИЕ ЦЕРЕБРОПРОТЕКТОРЫ, АНТИОКСИДАНТЫ, НЕЙРОТРОФИЧЕСКИЕ ЦЕРЕБРОПРОТЕКТОРЫ}

\section{1. ТИОЦЕТАМ — РОДОНАЧАЛЬНИК СЕМЕЙСТВА КОМБИНИРОВАННЫХ НЕЙРОМЕТАБОЛИЧЕСКИХ ЦЕРЕБРОПРОТЕКТОРОВ}

Наши дальнейшие интересы в области моделирования нового препарата церебропротективного действия были направлены в сторону комбинирования Пирацетама с Тиотриазолином. Тиотриазолин обладает соответствующими фармакологическими (высокая антиоксидантная, противоишемическая активность), фармако-технологическими (совместимость с другими препаратами) и фармакоэкономическими характеристиками [312-321].

Наибольшей активностью обладает комбинация, состоящая из 50 мг Тиотриазолина и 200 мг Пирацетама. Эта комбинация первоначально отобрана из экспериментальной серии на основании четкого противоишемического, антиоксидантного и антиамнестического эффекта. При последующем изучении эта комбинация продемонстрировала широкий спектр церебропротективных и ноотропных эффектов. На основании этой комбинации была разработана лекарственная форма - таблетки Тиоцетам [321-328].

Поскольку одним из основных свойств ноотропов является способность ослаблять амнестический эффект электрошока в тесте условного рефлекса пассивного избегания (УРПИ), характеризуя Тиоцетам как ноотроп, следует указать, что он ослабляет выраженность действия электрошока, при этом начальная активная доза препарата при внутрибрюшинном и пероральном введении составляет 25,0 мг/кг, а максимально антиамнестический эффект выражен в дозе 250,0 мг/кг. Антиамнестический эффект Тиоцетама выявлен не только на модели ретроградной амнезии, каковой является электрошок, наносимый после обучения, но также на ряде моделей антероградной амнезии. Тиоцетам устраняет амнезию, вызванную вводимыми перед обучением скополамином и Атропином.

Наряду с ослаблением амнестического эффекта перечисленных выше агентов препарат Тиоцетам также уменьшает степень мнестического дефицита, вызванного депривацией парадоксальной фазы сна (ПФС) и «конфликтной ситуацией» [330].

Тиоцетам в дозе 250,0 мг/кг устранял дефицит воспроизведения УРПИ, вызванного депривацией ПФС. Причем в этом тесте Тиоцетам достоверно превосходил Пирацетам в 5-6 раз, а в предыдущих - в 3-4 раза (Тиотриазолин в 2-4 раза).

Результаты исследований, полученных в условиях «конфликтной ситуации», создаваемой столкновением питьевого и оборонительного рефлексов, показали, что Тиоцетам обладает не только выраженным антиамнестическим 
действием (сохранность рефлекса УРПИ), но и антистрессорным действием, сохраняя ориентировочную активность животных, их двигательную активность, адекватность реагирования, снижение беспокойства и тревожности. Пирацетам в этом тесте оказывал достоверно менее (в 2,5 раза) выраженный антиамнестический эффект и не обладал антистрессорным действием, а Тиотриазолин не оказывал достоверного фармакологического действия. Курсовое назначение Тиоцетама в дозе 250,0 мг/кг перорально на протяжении 30 дней улучшало показатели кратковременной и долговременной памяти животных при их обучении в радиальном лабиринте. Жћивотные, которые получали Тиоцетам, опережали на 10-14 дней по большинству показателей группу получавших такую же дозу Пирацетама [330-337].

Следует отметить, что Тиоцетам устраняет мнестический дефицит не только перед обучением животных, но и после него, что свидетельствует о способности Тиоцетама положительно влиять на процессы первичной обработки информации, ее фиксации и консолидации. Пирацетам, как и большинство ноотропов группы рацетамного ряда, а также производные ГАМК, действует только на начальных этапах формирования памяти. Таким образом, для Тиоцетама характерен более широкий спектр ноотропного действия, чем для рацетамов и производных ГАМК. Исследование Тиоцетама в тесте «открытое поле» показало, что введение препарата в дозе 250,0 мг/кг внутрь и 125,0 мг/ кг внутрибрюшинно достоверно активировало горизонтальную исследовательскую деятельность животных, уменьшало время замирания и увеличивало количество выходов в центр. Общая двигательная активность достоверно не отличалась от таковой в группе, получавшей Пирацетам.

Другим немаловажным проявлением ноотропного действия Тиоцетама было его благоприятное воздействие на физическое и психическое развитие недоношенных крысят. По основным показателям физического развития (покрытие шерстью, прорезывание зубов, открытие глаз, прирост массы тела, двигательная активность) животные, получавшие Тиоцетам, не отставали от крысят, родившихся в срок, и достоверно по всем показателям опережали крысят, получавших Пирацетам. Тиоцетам повышал выживаемость недоношенных крысят в первые 7 суток жизни, на 71,4 \% достоверно превосходил Пирацетам, на $65 \%$ - Тиотриазолин.

Тиоцетам устранял нарушение когнитивно-мнестических функций у недоношенных животных, улучшая показатели кратковременной и долговременной памяти, активируя ориентировочно-исследовательскую активность. При этом Тиоцетам значительно улучшал обменные процессы в головном мозге недоношенных крысят (процессы биоэнергетики, углеводный обмен, синтез белка) [330-337].

Специальный интерес представляют данные об эффективности Тиоцетама при различных формах ишемии мозга. В условиях острого нарушения мозгового кровообращения (ОНМК), вызванного одно- и двухсторонней перевязкой наружных сонных артерий, а также внутримозгового кровоизлияния (ВК), вызванного введением аутокрови во внутреннюю капсулу головного мозга, продемонстрирована способность Тиоцетама, вводимого сразу после операции, 
снижать уровень смертности животных в острый период патологии. Тиоцетам достоверно повышал выживаемость животных с ОНМК и ВК на 55-70 \%, Пирацетам повышал этот показатель на 25-35 \%, а титриазолин на 40-55 \% .

Тиоцетам, вводимый в дозе 125,0 мг/кг внутрибрюшинно или в дозе 250,0 мг/кг per os в течение 4 дней после моделирования ОНМК и ВК, значительно снижал угнетение безусловных рефлексов на световые, звуковые и болевые раздражители. Тиоцетам достоверно уменьшал нарушения неврологического статуса (тремор конечностей, гипертонус мышц шеи и конечностей), улучшал двигательную и ориентировочно-исследовательскую активность. Введение Тиоцетама приводило к улучшению картины общей гистоструктуры мозга, что выражается в снижении явлений периваскулярного, перицеллюлярного и апикально-дендритного отеков, уменьшении числа ишемически измененных нейронов, также уменьшалось число спавшихся капилляров. Тиоцетам значительно активирует пролиферацию клеток глии и их функцию, вызывает усиление сателлитоза, что является ведущим фактором обеспечения жизнедеятельности нейронов при развитии ишемических повреждений головного мозга. Увеличивается, по сравнению с контролем, количество клеток астроглии на единицу площади: в 5-6 раз на фоне применения Тиоцетама, в 3-4 раза при использовании Тиотриазолина. Назначение Пирацетама в этих экспериментальных условиях оказывало умеренное действие. Тиоцетам увеличивал скорость элиминации погибших нейронов, по всей видимости, вследствие стимуляции активности микроглиальных клеток мозга; Тиотриазолин оказывал более умеренное действие, а Пирацетам не оказывал достоверного эффекта [352].

Тиоцетам вызывал ослабление процессов нейрональной гибели в сенсомоторной зоне фронтальной коры и CA1 зоны гиппокампа (в 2,5-2,3 раза) в острый период ОНМК. Тиотриазолин вызывал снижение нейрональной гибели в сенсомоторной зоне коры почти в два раза и в 1,4 раза в гиппокампе, а Пирацетам приводил к усилению нейрональной гибели, особенно в гиппокампе. Введение Тиоцетама приводило к снижению доли функционально неактивного гетерохроматина в 1,75-2,8 раза в ядрах нейронов лобной коры и гиппокампа. Это свидетельствовало о значительной стимуляции генной активности и об активации процессов трансляции. Тиотриазолин оказывал более умеренное действие в этом отношении, а Пирацетам его практически не оказывал. Тиоцетам, Тиотриазолин и Пирацетам приводили к достоверному снижению количества частоты случаев цитолиза нейронов в коре и гиппокампе. При этом степень снижения частоты цитолиза была выше у Тиоцетама. Причиной появления подобного действия у Тиоцетама могло служить то, что механизм церебропротективного действия данного комбинированного препарата в значительной степени обусловлен взаимопотенцированием антиоксидантных (влияние на активность АО-ферментов и образование АФК) и энерготропных (влияние на малатаспартатный челнок, окисление в цикле Кребса, гликолиз) свойств. Тиоцетам тормозит истощение запасов глюкозы и гликогена в нейроцитах в острый период ОНМК и ВК. Одновременно уменьшает гиперпродукцию лактата (в отличие от Пирацетама, который усиливает развитие лактат-ацидоза в острый период 
ишемии), нормализует активность глюкозо-6-фосфатдегидрогеназы. Показатели окислительной продукции энергии (НАД/НАДН, цитохром-С-оксидаза, уровень пирувата, малата и изоцитрата) превосходят уровень контроля, Тиотриазолина и Пирацетама. Поддержание Тиоцетамом окислительного углеводного метаболизма определяет повышение уровня макроэргических фосфатов (АТФ и креатинфосфата). Пирацетам в этих условиях оказывал преимущественное влияние на анаэробные пути образования энергии, увеличивая содержание лактата в тканях мозга, превышающее таковое в контрольных группах. Тиоцетам в большей степени, чем Пирацетам, корригирует нарушения биоэнергетики мозга при ОНМК, преимущественно за счет восстановления аэробных путей продукции энергии (рис. 4.1).

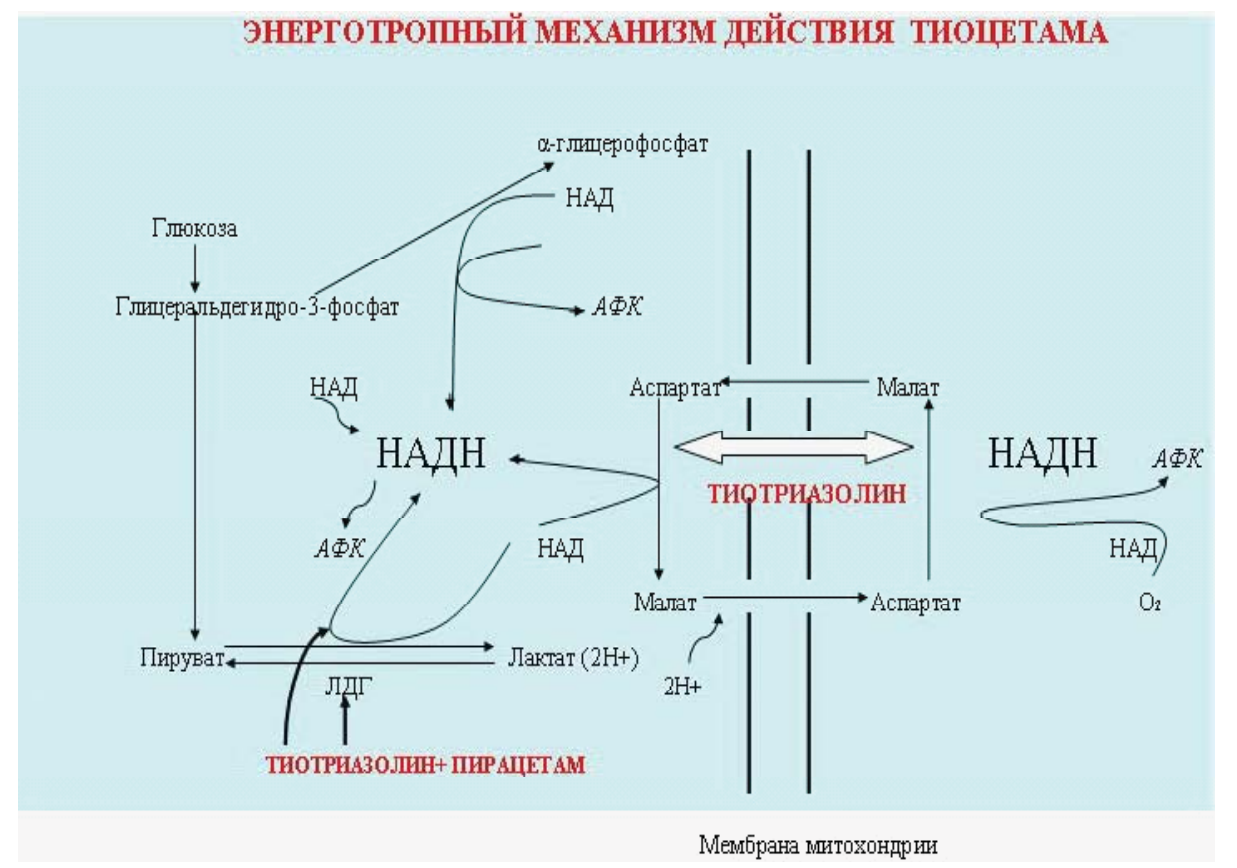

\section{Рuc. 4.1. Энерготропный механизм действия Тиоцетама}

Тиоцетам, не оказывая влияния на уровень белка в цитоплазме и митохондриях ишемизированных нейронов, существенно тормозил нарастание фонда свободных аминокислот и их нейродеструктивное действие. Тиоцетам значительно увеличивал уровень РНК в ядрах нейронов коры и гиппокампа животных с ОНМК и ВК, что указывает на активацию процессов протеинсинтеза и является адаптационной реакцией на гипоксию, обеспечивающей перестройку метаболизма мозга без повышения потребности в кислороде. Пирацетам не оказывал выраженного влияния на процессы синтеза РНК в тканях мозга [241].

Тиоцетам тормозил активность свободнорадикальных реакций в ишемизированном мозге, достоверно снижая накопление биотоксических продуктов 
(альдегидов, кетонов). Тиоцетам увеличивал активность антиоксидантных ферментов (супероксиддисмутаза, каталаза, глутатионпероксидаза), повышал фонд $\alpha$-токоферола. Антиоксидантный әффект Пирацетама был значительно хуже и реализовался за счет влияния на элементы «второго эшелона» антиоксидантной защиты (глутатионпероксидаза, $\alpha$-токоферол).

Тиоцетам оказывает церебропротективный эффект в реабилитационный период нарушения мозгового кровообращения (18 суток после моделирования), улучшая показатели углеводно-энергетического обмена, усиливая глиальный сателлитоз и ангиогенез, повышая активность антиоксидантной системы мозга, уменьшая проявления неврологического дефицита по шкале C. P. McGrow, а также снижая явления когнитивной недостаточности. В этот период ишемии мозга Тиоцетам значительно повышал ориентировочно-исследовательскую активность животных, снижал нарушение воспроизведения УРПИ. Учитывая данные о способности Тиоцетама уменьшать биохимические и гистологические нарушения при ВК, а также учитывая данные о фибринолитическом действии Тиотриазолина, были выполнены эксперименты, в которых исследовали влияние Тиоцетама на основные показатели тромбообразования. Показано, что Тиоцетам (125,0 мг/кг и 250,0 мг/кг per os) проявляет антикоагулянтную и фибринолитическую активность, усиливает дестабилизацию фибрина $[241,246]$.

Учитывая антиоксидантное действие Тиоцетама при моделировании ОНМК и ВК, было проведено исследование, подтверждающее участие прямого антиоксидантного эффекта в реализации церебропротективного действия. В опытах in vitro было показано, что смесь, содержащая $10^{-6} \mathrm{M}$ Тиотриазолина и $10^{-6}$ М Пирацетама, снижала накопление МДА во взвеси липопротеидов и гомогенате мозга в условиях усиления свободнорадикального окисления, вызванного добавлением $\mathrm{FeSO}_{4}$ и НАДФ Н. Пирацетам оказывал умеренный антиоксидантный эффект в концентрации $10^{-3} \mathrm{M}$. В этом тесте смесь Тиотриазолина и Пирацетама (Тиоцетам) превосходила действие Эмоксипина, Дибунола и $\alpha$-токоферола в аналогичных концентрациях. Смесь Тиотриазолина и Пирацетама (Тиоцетам) тормозила окислительную модификацию белка, снижая образование альдегидных и карбоксильных групп, снижая фрагментации белка в концентрации $10^{-6}$ M действующих компонентов. Пирацетам, даже в высоких концентрациях, не оказывал защитного действия. Смесь Тиотриазолина и Пирацетама (Тиоцетам) достоверно тормозит образование пероксинитрита и супероксид-радикала in vitro в вышеприведенных концентрациях действующих веществ. Пирацетам не оказывал в данных тестах антиоксидантного действия. Тиоцетам, вносимый в гомогенат мозга (Тиотриазолин $10^{-7} \mathrm{M}$, Пирацетам $\left.10^{-7} \mathrm{M}\right)$, достоверно снижал угнетение активности супероксиддисмутазы, сукцинатдегидрогеназы и накопление малонового диальдегида при воздействии токсических концентраций перекиси водорода и нитропруссида натрия.

Итак, можно заключить, что в отношении таких аспектов церебропротективного действия как антиоксидантное, противоишемическое, антиамнестическое, Тиоцетам выгодно отличается от Пирацетама и других препаратов рацетамного ряда, а также производных ГАМК (рис. 4.2). 


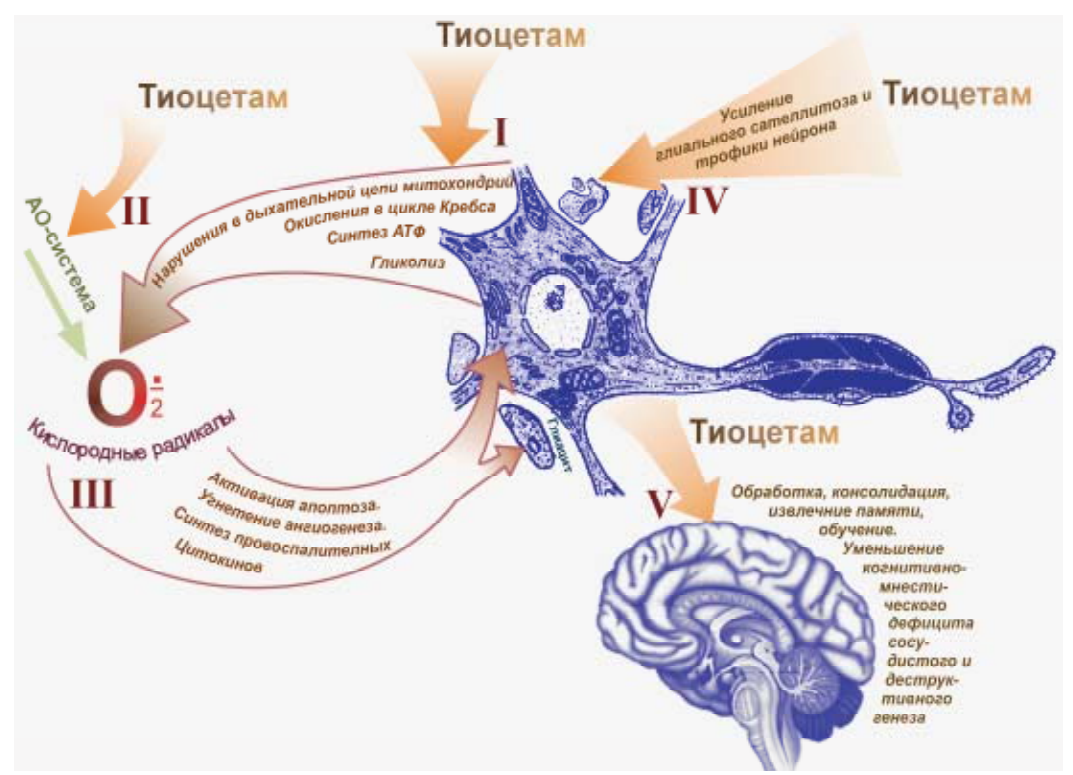

Рuc. 4.2. Гипотетический механизм действия Тиоцетама

Изучение ноотропной активности препарата Тиоцетам при экстремальных состояниях головного мозга. Ноотропную активность комбинированного препарата Тиоцетам проводили в опытах на 120 белых крысах линии Вистар обоего пола, массой 100-120 г, полученных из питомника Института фармакологии и токсикологии АМН Украины. Для оценки антиамнестического действия использовали методику условной реакции пассивного избегания (УРПИ) с последующим применением электрошока в качестве амнезирующего фактоpa. С этой целью животное помещали в светлый отсек двухкамерной установки и регистрировали латентное время захода в темный отсек камеры, где крыса получала однократный удар током через электродный пол (обучение). Непосредственно после обучения применяли электрошок (110 В, 50 Гц, 500 мс). Воспроизведение рефлекса осуществляли через 24 часа после обучения. В другой серии эксперимента амнезию УРПИ вызывали внутрибрюшинным введением скополамина в дозе 2,5 мг/кг.

Изучение ноотропной активности проводили также при модельных экстремальных состояниях. Опыты проводили на белых крысах линии Вистар, массой 180-220 г. Обучение животных проводили по методике условного рефлекса пассивного избегания (УРПИ) в двухкамерной установке, состоящей из двух отсеков - светлого и темного. Крысу помещали в светлый отсек, фиксировали латентное время захода в темный отсек, где животное получало удар током и выбегало в светлый отсек. Воспроизведение УРПИ проверяли через 24 часа. O сохранности навыка судили по изменению латентного времени захода в темный отсек.

Препараты вводились внутрибрюшинно в дозах: Тиоцетам -250 мг/кг, Пирацетам - 400 мг/кг, Феназепам - 1,0 мг/кг. 
В первой серии опытов экстремальные условия создавались по методу Жувэ, ограничением двигательной активности и сна. Для этого крыс размещали на 24 часа на площадке диаметром 6,0 см (1 крыса на площадке) в плексигласовом бассейне, заполненном водой $\left(\mathrm{t} \approx 5^{\circ} \mathrm{C}\right)$. Площадки возвышались над бассейном на 1,5-2 см. В бассейне было 5 площадок.

В данных условиях происходила избирательная депривация парадоксальной фазы сна (ПФС), т. к. во время ПФС мышцы животных расслаблялись и они падали в воду. Депривацию ПФС проводили непосредственно после обучения. Препараты вводили перед обучением.

Во второй серии опытов экстремальные ситуации создавались в условиях столкновения питьевого и оборонительного рефлексов по общепринятой методике «конфликтной ситуации».

Эксперимент начинали с тренировки крыс с целью выработки у них навыка взятия воды из поилки. Для повышения питьевой мотивации и чувства жажды, в течение 2 суток в условиях питьевой депривации, животных держали на сухом рационе. Затем в одно и то же время в течение 3-х суток животных помещали на 10 минут в клетку для получения воды. На четвертый день тренировки крысе через 5 сек после начала питья, наносили удар током через электрод, находящийся возле носика поилки.

Таким образом, столкновение двух рефлексов (питьевого и оборонительного) приводило к созданию экстремальной ситуации, при которой страх получения болевого раздражения удерживал животное от взятия воды.

В дальнейшем (через 30 мин) в течение 20 мин, регистрировалось количество взятий воды, число подходов к поилке и величина общей двигательной активности по числу пересеченных квадратов. Препараты вводили в течение всего периода тренировки 1 раз в сутки.

Исследования показали, что проведение электрошока сразу после обучения УРПИ, также как и введение Атропина, вызывает забывание навыка у контрольных животных при воспроизведении через 24 часа после обучения (табл. 4.1).

Таблица 4.1

\section{Влияние исследуемых препаратов на амнезию УРПИ, вызванную атропином}

\begin{tabular}{|l|c|c|}
\hline \multicolumn{1}{|c|}{ Препарат } & $\begin{array}{c}\text { Доза, мг/кг } \\
\text { в/6 }\end{array}$ & $\begin{array}{c}\text { Латентное время рефлекса } \\
\text { при воспроизведении УРПИ, сек }\end{array}$ \\
\hline Контроль без амнезии (п=6) & - & $136,5+21,6$ \\
\hline Контроль с амнезией (Атропин) (n=6) & 40,0 & $22,5 \pm 2,4$ \\
\hline Пирацетам (п=6) & 200,0 & $37,0 \pm 6,2^{*}$ \\
\hline Тиотриазолин (п=6) & 50,0 & $57,8 \pm 7,6^{*}$ \\
\hline Тиоцетам (п=6) & 250,0 & $74,8 \pm 6,2^{\star \circ}$ \\
\hline
\end{tabular}

Прилечание: $\quad *-p<0,05$ по отношению к контролю с алнезией;

- $-p<0,05$ по отношению $к$ Пирацеталу. 
Назначение Тиотриазолина, Пирацетама и Тиоцетама экспериментальным животным до обучения с последующим проведением электрошока, или введением Атропина вызывало значительное увеличение латентного времени рефлекса по сравнению с контрольными животными (табл. 4.2).

Таблица 4.2

\section{Влияние исследуемых препаратов на амнезию УРПИ, вызванную электрошоком}

\begin{tabular}{|c|c|c|}
\hline Препарат & $\begin{array}{c}\text { Доза, мг/кг } \\
\text { в/б }\end{array}$ & $\begin{array}{c}\text { Латентное время рефлекса } \\
\text { при воспроизведении УРПИ, сек }\end{array}$ \\
\hline Контроль без амнезии (п=6) & - & $120,6 \pm 14,5$ \\
\hline Контроль с амнезией (электрошок) (п=6) & - & $20,7 \pm 2,6$ \\
\hline Пирацетам (п=6) & 200,0 & $28,6 \pm 3,7^{*}$ \\
\hline Тиотриазолин (п=6) & 50,0 & $42,6 \pm 4,8^{*}$ \\
\hline Тиоцетам (n=6) & 250,0 & $61,6 \pm 5,2^{* \circ}$ \\
\hline
\end{tabular}

Прилечание: $\quad *-p \leq 0,05$ по отношению к контролю с алнезией;

- $-p \leq 0,05$ по отношению к Пирацеталу.

Наиболее активным было назначение препарата Тиоцетам как при проведении электрошока, так и при введении Атропина. Таким образом, антиамнестический эффект, т. е. способность предупреждать или ослаблять нарушения обучения и памяти, является основным проявлением действия ноотропных препаратов.

Анализ результатов в группах контрольных животных (с депривацией и без нее) показал, что депривация ПФС, проводимая непосредственно после сеанса обучения, приводит к нарушению навыка УРПИ. При сопоставлении показателей двух контрольных групп можно отметить, что у животных, не подвергающихся депривации ПФС, латентное время захода в темный отсек при воспроизведении УРПИ значительно возрастает, по сравнению с этими же показателями при обучении. Это свидетельствует о сохранности у крыс навыка пассивного избегания. У животных, подвергшихся депривации ПФС, латентное время захода в темный отсек при воспроизведении УРПИ незначительно отличалось от показателей, полученных при обучении, что указывает на отчетливый дефицит воспроизведения навыка УРПИ (табл. 4.3).

Таблица 4.3

\section{Влияние Тиоцетама на латентное время захода крыс в темный отсек при выработке УРПИ}

\begin{tabular}{|l|c|c|}
\hline \multicolumn{2}{|c|}{ Группа животных } & \multicolumn{2}{|c|}{ Латентное время, сек } \\
\cline { 2 - 3 } & Обучение & Воспроизведение \\
\hline Контрольные крысы без депривации ПФС & $1,52 \pm 0,42$ & $58,3+4,35$ \\
\hline Контрольные крысы с депривацией ПФС & $1,73 \pm 0,34$ & $3,50+0,54$ \\
\hline
\end{tabular}


Продолжение табл. 4.3

\begin{tabular}{|c|c|c|}
\hline \multirow{2}{*}{ Группа животных } & \multicolumn{2}{|c|}{ Латентное время, сек } \\
\cline { 2 - 3 } & Обучение & Воспроизведение \\
\hline Крысы с депривацией ПФС, получавшие Тиоцетам & $3,53 \pm 0,79$ & $72,2+5,84^{\star \circ} €$ \\
\hline Крысы с депривацией ПФС, получавшие Пирацетам & $4,44 \pm 0,83$ & $14,5+1,17^{\star}$ \\
\hline Крысы с депривацией ПФС, получавшие Феназепам & $2,05 \pm 0,68$ & $2,20+1,01$ \\
\hline
\end{tabular}

Примечание: $\quad *-p<0,05$ по отношению $к$ депривации;

$\circ-p \leq 0,05$ по отношению $к$ Пирацеталу;

$€-p \leq 0,05$ по отношению к Феназепаму.

Введение Тиоцетама за 30 минут до обучения устраняло дефицит воспроизведения УРПИ, вызванный депривацией ПФС. У депривированных животных, получавших Тиоцетам, при воспроизведении навыка, латентный период захода в темный отсек камеры достоверно возрастает по сравнению с этими же показателями контрольных депривированных животных и приближается к данным контрольных групп (животные без депривации ПФС).

Пирацетам оказывает менее заметное антиамнестическое действие у крыс, подвергшихся депривации ПФС.

Феназепам, в противоположность этому, не оказывает влияния на нарушенный навык УРПИ у крыс, подвергшихся депривации ПФС. Латентный период захода в темный отсек при воспроизведении навыка УРПИ у крыс, подвергшихся депривации ПФС и получавших Феназепам, практически не отличается от показателей контрольных депривированных крыс.

Таким образом, проведенные исследования показали, что при экстремальных воздействиях, вызванных депривацией ПФС, наряду с нарушением сна, наблюдается дефицит воспроизведения УРПИ. Тиоцетам и Пирацетам устраняют дефицит воспроизведения УРПИ, причем по силе антиамнестического действия Тиоцетам превосходит Пирацетам, а транквилизатор Феназепам не обладает этим действием.

Результаты исследований, полученных в условиях «конфликтной ситуации», создаваемой столкновением питьевого и оборонительного рефлексов, показали, что получение болевого удара в момент питья воды вызывает у животных чувство страха, сопровождающееся отчетливо выраженной тахикардией, колебаниями дыхания, неадекватностью реагирования. Контрольные животные в этой ситуации делают еще 1-2 попытки получить воду и затем отказываются от них.

Феназепам, обладающий отчетливым антистрессорным действием, устраняет в этой ситуации чувство страха у животных, что выражается в увеличении числа взятий воды в 7-8 раз. Общая двигательная активность при этом ниже, чем у контрольных животных.

Тиоцетам также оказывает антистрессорное действие, увеличивая число взятий воды в 4-5 раз по сравнению с контрольной группой. При этом значи- 
тельно возрастало число подходов к поилке и общая двигательная активность (табл. 4.4).

Таблица 4.4

\begin{abstract}
Анксиолитическое действие Тиоцетама на поведение крыс при столкновении питьевого и оборонительного рефлексов в условиях «конфликтной ситуации»
\end{abstract}

\begin{tabular}{|l|c|c|c|}
\hline Группа животных & Число взятий воды & Число подходов к поилке & $\begin{array}{c}\text { Двигательная } \\
\text { активность }\end{array}$ \\
\hline Контроль & $1,7+0,86$ & $5,7 \pm 0,86$ & $13,0 \pm 2,97$ \\
\hline Тиоцетам & $9,7 \pm 3,09^{\star}$ & $24,8 \pm 4,17^{\star}$ & $56,2 \pm 5,49^{\star \circ} €$ \\
\hline Пирацетам & $8,5 \pm 1,96^{\star}$ & $15,0 \pm 2,20$ & $38,8 \pm 2,77^{\star}$ \\
\hline Феназепам & $13,8 \pm 1,68$ & $5,7 \pm 1,27$ & $5,5+1,72$ \\
\hline
\end{tabular}

Прилечание: $\quad *-p<0,05$ по отношению к контролю;

- $-p<0,05$ по отношению $к$ Пирацеталу;

$€-p<0,05$ по отношению $к$ Феназепалу.

Пирацетам оказывал подобное по направленности, но менее выраженное, чем у Тиоцетама антистрессорное действие.

Таким образом, Тиоцетам оказывает выраженное антиамнестическое действие в условиях депривации ПФС, превосходя по действию Пирацетам и Феназепам. Кроме этого, оказывает стресспротективное действие в условиях «конфликтной ситуации», превосходя по некоторым показателям Пирацетам (количество взятий воды) и Феназепам (общая двигательная активность).

По всей видимости, защитное действие Тиоцетама в условиях экспериментально смоделированных экстремальных состояний обусловлено его антиамнестическим эффектом.

Исследование эффективности препарата Тиоцетам на модели нарушения мозгового кровообращения. Исследования проводили на 140 крысах линии Вистар массой 240-260 г. обоего пола, полученных из питомника ИФТ AMH Украины. Нарушение мозгового кровообращения моделировали путем двухсторонней перевязки общих сонных артерий под нембуталовым наркозом (40 мг/кг). Часть животных выводили из эксперимента на 4-е и на 18-е сутки после операции. Для биохимических и гистологических исследований забирался головной мозг. Препараты вводили внутрибрюшинно на протяжении всего исследования (4 и 18 суток): Пирацетам - 250 мг/кг, Тиотриазолин - 50 мг/кг, Тиоцетам - 250 мг/кг.

В течение первых суток после билатеральной перевязки внутренних сонных артерий состояние крыс - тяжелое. Жиивотные заторможены, малоподвижны, слабо реагируют на внешнее раздражение. Часть крыс находилась в коматозном состоянии. У 30 \% животных отмечено нарушение характера дыхания и сердечная аритмия. Снижены рефлексы на световые, звуковые и болевые раздражения. Животные имеют двигательные расстройства: повышенный 
тонус разгибателей спины и задних конечностей, тонические судороги и тремор мышц конечностей. Ж Животные отказывались от воды и пищи. У погибающих животных роговица становилась стекловидной, мутной; исчезал роговичный рефлекс. Нарастали явления нарушения дыхания и сердечного ритма. Тремор конечностей переходил в судороги, и животное погибало. В первые сутки после операции погибло 33 \% контрольных крыс. На фоне применения Тиоцетама не наблюдалась гибель животных, в отличие от применения Пирацетама и Тиотриазолина. Причиной гибели животных являлся отек мозга.

На 18-е сутки после операции животные, получавшие Тиотриазолин и Тиоцетам, по соматическому и неврологическому статусу не отличались от интактных крыс. Они приобретали нормальную позу, полностью восстанавливались адекватные реакции на внешние раздражители. Кроме того, полностью восстанавливался пищевой рефлекс, но сохранялось напряжение мышц шеи. У контрольных животных неврологическая симптоматика постепенно исчезала, однако сохранялись двигательные расстройства: гипертонус мышц шеи и конечностей, а у части крыс - тремор конечностей. У животных, погибших в течение первых трех суток после операции, при гистологическом исследовании наблюдались мозаичные постаноксические повреждения как в области коры, так и в области базальных ядер конечного мозга. Эти процессы проявлялись расширением переполненных кровью сосудов, тромбозом мелких сосудов, перисосудистым отеком, ишемическими изменениями в нейронах (гиперхроматоз, кариопикноз, кариолизис, вакуолизация ядер и цитоплазмы нейронов). Большинство нейронов коры имели эозинофильную цитоплазму, вокруг них - выраженный перинейрональный отек. Реакция астроглии не выражена. Клетки сморщены, их ядра - пикнотические. У животных, погибших на вторые и третьи сутки, около нейронов располагались 1-2 клетки астроглии (олигодендроциты и астроциты) - это явления перинейронального сателлитоза. Прогрессировали ишемические и некротические повреждения нейронов: пикноз ядер с гомогенизацией гиперхромного хроматина, усиливалась эозинофилия цитоплазмы. Вокруг таких погибших нейронов не выявлялось сателлитной глии. Около нейронов и клеток глии отмечается выраженный перицеллюлярный отек. У части астроцитов - резкое набухание перинейрональных отростков. В клетках астроглии также выявлен пикноз ядер с гомогенизацией хроматина, увеличение объема цитоплазмы.

Согласно современным представлениям, четвертые сутки жизни завершают острый период при развитии ишемических поражений головного мозга. К этому периоду в контроле погибло 66 \% крыс: получавших Пирацетам $55 \%$, Тиотриазолин - $33 \%$ и Тиоцетам - $22 \%$.

Курсовое назначение Пирацетама, Тиотриазолина и Тиоцетама животным в острый период экспериментального нарушения мозгового кровообращения приводило к нормализации многих показателей углеводно-энергетического обмена, торможению СРО и реактивации антиоксидантной системы, а также к снижению гиперферментемии МВ-КФК. При общей положительной направленности в действии препаратов и их комбинации на биоэнергетические процессы выявляются и определенные количественные различия в их влиянии 
на изучаемые показатели. Так, чрезвычайно важным моментом в действии Пирацетама, Тиотриазолина и Тиоцетама являлось увеличение у леченных животных уровня АТФ на фоне увеличения содержания его предшественника - АДФ и уменьшения количества АМФ, по сравнению с нелеченными животными. Однако, количественно эти изменения были более наглядны при применении комбинированного препарата Тиоцетама, в отличие от использования Пирацетама и Тиотриазолина. Применение Тиоцетама более выраженно снижало уровень молочной кислоты и увеличивало содержание пировиноградной и яблочной кислот.

Таким образом, назначение Тиоцетама оказывает более выраженное влияние на процессы аэробного и анаэробного окисления углеводов, и как следствие - сильнее увеличивает энергетический фонд клеток.

Результатом улучшения энергетического статуса клеток головного мозга и уменьшения выраженности ишемического их повреждения, по-видимому, является снижение содержания продуктов СРО и реактивация антиоксидантной системы. Так, назначаемые препараты повышали активность СОД, каталазы, ГПР, снижали расходование $\alpha$-токоферола и накопление ДК, ТК и МДА в мозговой ткани. Назначение Тиоцетама приводило к более выраженному антиоксидантному эффекту. Одновременно с уменьшением степени повреждения цитоплазматических мембран в реакциях СРО происходило и существенное снижение показателей гиперферментемии, которое было более выраженным при действии комбинированного препарата Тиоцетам.

Назначение Пирацетама и Тиотриазолина, а также Тиотриазолина, в реабилитационный период животным с экспериментальной ишемией головного мозга приводило к восстановлению окислительных процессов и энергетических ресурсов нейроцитов. Комбинированный препарат Тиоцетам оказывал более выраженный церебропротективный эффект.

В препаратах головного мозга исследованных на 4-е сутки эксперимента выявлены приспособительные изменения. Увеличивается количество клеток астроглии на единицу площади: в 5-7 раз - на фоне лечения Тиоцетамом, в 4,3-5,4 раза при лечении Тиотриазолином и в $1,5-2,4$ раза - в контроле. Многие из таких клеток расположены периневронально - это явление периневронального сателлитоза. Явления сателлитоза ярче проявляются после назначения Тиоцетама. В субэпендимальных зонах боковых желудочков выявлены крупные очаги пролиферации глиальных клеток - поля глиоза. Часть из таких клеток, расположенных в центре очага, - недифференцированные глиоциты, а по периферии располагаются короткоотростчатые клетки. Под пограничной глиальной мембраной мозга регистрируется увеличение содержания клеток микроглии и астроцитов вне связи с деструктивными изменениями. Пролиферативные изменения наиболее ярко выражены у животных, получивших препарат Тиоцетам. Описанные изменения положительны для дальнейшего прогноза на восстановление очагов поражения и для выживания. Морфологическая картина строения мозга после применения Пирацетама не отличается от контроля, а в некоторых случаях явления нейродегенерации более выражены. 
Нейропротективное действие препарата Тиоцетам в условиях модельных судорожных состояний. Модель ГАМК-дефицитных судорог воспроизводили путем введения животным тиосемикарбазида подкожно в дозе 30 мг/кг. Препарат Тиоцетам вводили внутрибрюшинно в дозе 500 мг/кг за 30 минут до введения тиосемикарбазида. Препараты сравнения вводили: Мидокалм подкожно, Фенобарбитал, Пирацетам внутрибрюшинно в дозах 25, 20 и 500 мг/кг соответственно, за 30 минут до введения тиосемикарбазида.

Картину судорог оценивали по времени появления и продолжительности отдельных компонентов судорожного припадка - клонической и тонической фазы. На пике судорожного припадка животных выводили из эксперимента, удаляли кору головного мозга и помещали в жидкий азот. Ткань коры головного мозга гомогенизировали в жидком азоте и обрабатывали по общепринятым биохимическим методикам.

Проведенными исследованиями было установлено, что препарат Тиоцетам проявляет противосудорожное действие. Так, назначение Тиоцетама экспериментальным животным непосредственно перед введением тиосемикарбазида достоверно отдаляет появление судорожного припадка на 62,0 \% . Назначение эталонных препаратов Фенобарбитала и Мидокалма увеличивало время появления судорог у животных на 44,6 и 46,8 \% соответственно (табл. 4.5).

Таблица 4.5

\section{Влияние препарата Тиоцетам на показатели экспериментальных судорог}

\begin{tabular}{|l|c|c|c|}
\hline \multicolumn{1}{|c|}{ Препараты } & $\begin{array}{c}\text { Латентный период, } \\
\text { мин }\end{array}$ & $\begin{array}{c}\text { Продолжительность } \\
\text { клонической фазы, сек }\end{array}$ & $\begin{array}{c}\text { Продолжительность } \\
\text { тонической фазы, сек }\end{array}$ \\
\hline Контроль & $52,71 \pm 4,33$ & $58,14 \pm 6,56$ & $23,71 \pm 4,74$ \\
\hline Тиоцетам & $85,4 \pm 2,42^{*}$ & $37,2 \pm 1,74$ & $10,4 \pm 1,50^{\star}$ \\
\hline Пирацетам & $79,4 \pm 2,21^{*}$ & $38,6 \pm 2,00$ & $12,8 \pm 1,74$ \\
\hline Мидокалм & $77,4 \pm 2,72^{*}$ & $43,8 \pm 3,56$ & $5,4 \pm 2,79^{*}$ \\
\hline Фенобарбитал & $76,2 \pm 3,97^{*}$ & $40,75 \pm 1,52$ & $18,0 \pm 1,52$ \\
\hline
\end{tabular}

Прилечание: * - $\leq \leq 0,05$ относительно к контролю.

Назначение препарата Пирацетам увеличивало латентный период возникновения судорог на 50,6 \% , что согласуется с результатами других исследователей. Тиоцетам влиял на продолжительность клонической фазы и был сопоставим в этом отношении с Мидокалмом и Фенобарбиталом.

Дальнейший анализ действия Тиоцетама на данной модели судорог показал, что препарат по продолжительности тонической фазы судорог был сопоставим с Пирацетамом, но был менее эффективным, чем Мидокалм. Так, его назначение животным уменьшало продолжительность тонической фазы судорог на 54,7 \% , а Мидокалма - на 77,2 \% . Фенобарбитал не вызвал достоверных изменений продолжительности тонической фазы судорог. 
Таким образом, назначение препарата Тиоцетам перед моделированием ГАМК-дефицитных судорог приводит к модификации судорожной картины, за счет увеличения латентного периода и сокращения продолжительности тонической фазы, причем эффективность Тиоцетама сопоставима с действием Мидокалма и Фенобарбитала.

Биохимические исследования коры головного мозга экспериментальных животных на пике судорожного припадка выявили в действии Тиоцетама значительный нейропротективний эффект, который значительно превосходит подобный у Пирацетама, и тем более у Мидокалма и Фенобарбитала. Так, в коре головного мозга животных, получавших Тиоцетам, наблюдалось значительное снижение активности СРО. Содержание ДК снижалось на 46,5 \%, ТК на $45,3 \%$, в сравнении с контрольной группой. У животных, которые получали Пирацетам, наблюдалось снижение ДК и ТК на 23,2 и 20,3 \% соответственно. Назначение Мидокалма и Фенобарбитала приводило к незначительному снижению продуктов СРО (табл. 4.6).

Таблица 4.6

\section{Влияние препарата Тиоцетам на содержание продуктов СРО} в тканях головного мозга крыс на пике судорожного припадка

\begin{tabular}{|l|c|c|c|c|}
\hline \multicolumn{1}{|c|}{ Препараты } & $\begin{array}{c}\text { МДА, } \\
\text { мкмоль/г ткани }\end{array}$ & $\begin{array}{c}\text { ДК, } \\
\text { мкмоль/г ткани }\end{array}$ & $\begin{array}{c}\text { ТK, } \\
\text { мкмоль/г ткани }\end{array}$ & $\begin{array}{c}\text { N03-, } \\
\text { нмоль/г ткани }\end{array}$ \\
\hline контроль & $0,93 \pm 0,05$ & $1,55 \pm 0,10$ & $0,64 \pm 0,02$ & $24,14 \pm 1,24$ \\
\hline Тиоцетам & $0,32 \pm 0,03^{*}$ & $0,83 \pm 0,075^{*}$ & $0,35 \pm 0,04^{*}$ & $13,4 \pm 1,17^{*}$ \\
\hline Пирацетам & $0,50 \pm 0,05^{*}$ & $1,19 \pm 0,12^{*}$ & $0,51 \pm 0,07^{*}$ & $17,6 \pm 1,12^{*}$ \\
\hline Мидокалм & $0,87 \pm 0,10$ & $1,32 \pm 0,14$ & $0,55 \pm 0,04$ & $18,6 \pm 1,11^{*}$ \\
\hline Фенобарбитал & $0,79 \pm 0,03$ & $1,27 \pm 0,06$ & $0,56 \pm 0,02$ & $21,0 \pm 1,24$
\end{tabular}

Примечание: $p \leq 0,05$ по отношению к контролю.

Вероятным звеном нейропротективного и антиоксидантного действий Тиоцетама является снижение гиперпродукции NO в коре головного мозга на пике судорожного припадка. Так, в тканях мозга животных, которым вводили Тиоцетам, было выявлено снижение стабильного метаболита $\mathrm{NO}-\mathrm{NO}_{3}{ }^{-}$ на $44,4 \%$ в сравнении с контрольной группой (табл. 4.6). Снижая содержание $\mathrm{NO}_{3}^{-}$, а скорее всего - и гиперпродукцию $\mathrm{NO}$ в тканях головного мозга на пике судорожного припадка, Тиоцетам уменьшает и нейротоксическое действие пероксинитрит (ONOO*) радикала.

Назначение Пирацетама снижало продукцию $\mathrm{NO}_{3}^{-}$на 26,9 \% , а назначение Мидокалма и Фенобарбитала не приводило к достоверным изменениям этого продукта в коре головного мозга.

Таким образом, препарат Тиоцетам обладает значительным нейропротективным эффектом, который превосходит по силе действия Пирацетам на модели судорог, вызванных тиосемикарбазидом. 
Изучение нейрпротективного действия препарата Тиоцетам на модели острой ишемии и реперфузии. Острую ишемию и реперфузию головного мозга моделировали временным выключением кровотока по сонным артериям.

Препараты вводили дважды, за 30 минут до наложения лигатуры и перед реперфузией. Тиотриазолин $2,5 \%$ вводили в дозе 50 мг/кг, Пирацетам $10 \%-$ 200 мг/кг, Тиоцетам - 250 мг/кг. Препараты вводили внутривенно.

Полученные результаты свидетельствуют, что назначение препарата Тиоцетам непосредственно перед окклюзией сонной артерии и реперфузией приводила к нормализации реакций СРО. Так, у животных получавших Тиоцетам в период временного пережатия сонной артерии, и что особенно важно - за 30 минут до реперфузии, регистрировалось достоверное снижение МДА в плазме артериальной крови (табл. 4.7).

Таблица 4.7

\section{Влияние Тиоцетама на содержание МДА (мкмоль мл) в плазме артериальной крови в период ишемии и реперфузии}

\begin{tabular}{|c|l|c|c|}
\hline № п/п & \multicolumn{1}{|c|}{ Группа животных } & $\mathbf{3 0 ~ м и н ~ п е р е в я з к и ~}$ & $\mathbf{3 0 ~ м и н ~ р е п е р ф у з и и ~}$ \\
\hline 1 & $\begin{array}{l}\text { Животные после временной окклюзии } \\
\text { сонной артерии (контроль) }\end{array}$ & $0,77 \pm 0,06$ & $1,0 \pm 0,06$ \\
\hline 2 & $\begin{array}{l}\text { Животные после временной окклюзии } \\
\text { сонной артерии+ Пирацетам }\end{array}$ & $0,67 \pm 0,06$ & $0,65 \pm 0,06^{*}$ \\
\hline 3 & $\begin{array}{l}\text { Животные после временной окклюзии } \\
\text { сонной артерии+ Тиотриазолин }\end{array}$ & $0,61 \pm 0,05^{*}$ & $0,60 \pm 0,07^{*}$ \\
\hline 4 & $\begin{array}{l}\text { Животные после временной окклюзии } \\
\text { сонной артерии+ Тиоцетам }\end{array}$ & $0,57 \pm 0,04^{*}$ & $0,56 \pm 0,05^{*}$ \\
\hline 5 & Интактные животные & \multicolumn{2}{|c|}{$0,46 \pm 0,03$} \\
\hline
\end{tabular}

Примечание: $p \leq 0,05$ по отношению к контролю.

У животных, получавших до операции и реперфузии Пирацетам, подтверждением защитного действия Тиоцетама в период острой ишемии и реперфузии являются нормализация показателей углеводно-энергетического обмена и состояния антиоксидантной системы в тканях мозга на 3 -и сутки (наиболее опасный период после операционных вмешательств).

В тканях мозга животных, получавших Тиоцетам, наблюдались нормализация основных показателей углеводно-энергетического обмена, повышение активности АО-системы, снижение продуктов пероксидации. Так, повышение фонда АТФ происходило на фоне снижения содержания лактата и повышения уровня малата и пирувата, что свидетельствует о выраженном влиянии Тиоцетама на аэробное окисление. В действии Пирацетама и Тиотриазолина был выявлен аналогичный эффект, но меньший по силе.

Назначение Тиоцетама в период острой ишемии и реперфузии вызывало повышение активности АО-ферментов в тканях мозга на 3-и сутки после операции. Так, регистрировали повышение активности СОД, каталазы, ГПР, увеличение содержание $\alpha$-токоферола. 
Результатом улучшения энергетического статуса клеток головного мозга и уменьшения выраженности их ишемического повреждения является снижение продуктов СРО (ДК, ТК и МДА). Назначение Пирацетама и Тиотриазолина оказывало меньший по выраженности антиоксидантный эффект.

Высокую нейропротективную активность Тиоцетам продемонстрировал не только в экспериментальных, но и в клинических исследованиях, проведенных на кафедре нервных болезней Днепропетровской государственной медицинской академии под руководством профессора Л. А. Дзяк. В исследование были включены 125 больных, находящихся на стационарном и амбулаторном лечении. Все пациенты, являвшиеся потенциальными участниками испытания, были проинформированы о характере клинического испытания, исследуемом и референтном препаратах, а также о возможном риске, связанном с приемом препаратов. Все пациенты, включенные в исследование, дали письменное информированное согласие на участие в испытании [247-250].

Критериями включения больных в клиническое испытание были: возраст 18-65 лет, диагностированная дисциркуляторная энцефалопатия II стадии на фоне атеросклеротического поражения сосудов головного мозга, верифицированного данными церебральной ангиографии. Критериями исключения больных были: повышенная чувствительность к компонентам исследуемого препарата; беременность; лактация; психические расстройства; психомоторное возбуждение; лечение препаратами, влияющими на мозговое кровообращение и мозговой метаболизм, в течение двух месяцев, предшествующих включению пациента в исследование; артериальная гипертензия с АД выше 165/100 мм рт. ст.; клинически значимые отклонения лабораторных показателей; сопутствующие декомпенсированные заболевания или острые состояния, способные повлиять на результаты исследования. Больные были рандомизированы в две клинические группы: I группа (основная) - 75 пациентов, из них 38 женщин и 37 мужчин в возрасте от 38 до 65 лет; назначался препарат Тиоцетам (АО «Галичфарм») по 2 таблетки 3 раза в сутки в течение 21 дня; II группа (контрольная) - 50 пациентов, из них 27 женщин и 23 мужчины в возрасте от 33 до 60 лет; назначался препарат Пирацетам (Украина) по 0,4 г, прием по 1 таблетке 3 раза в сутки в течение 21 дня. Лечение исследуемым препаратом проводилось в виде монотерапии. С учетом приведенных данных обе группы репрезентативны по половому и возрастному признакам. K атеросклеротическим поражениям сосудов в исследуемых группах относились: атеросклеротическое стенозирование магистральных артерий головы (внутренних сонных и позвоночных артерий до 75 \%), окклюзии внутренних сонных артерий. Соответственно в I группе - 48 \%, 32 \% и 20 \%, во II группе - 44 \% , 38 \% и 18 \%. Мультифокальное атеросклеротическое поражение магистральных артерий головы диагностировалось у 18 больных I группы и 9 больных II группы. Сочетанное поражение обоих каротидных бассейнов (соответственно 9 и 8 пациентов), каротидного и вертебрального бассейнов (соответственно 7 и 1 пациент); у 2 больных I группы выявлено сочетание окклюзии правой внутренней сонной артерии и стеноза левой внутренней сонной артерии (соответственно 80 \% и 75 \% ). У всех пациентов диагноз дисциркуляторной эн- 
цефалопатии II стадии был подтвержден клинически - данными неврологического статуса и параклинически - рентгеновской компьютерной томографией головного мозга. Сопутствующая компенсированная соматическая патология выявлена у 15 больных I группы и 7 - II группы. Она была представлена: патологией желудочно-кишечного тракта (холецистопанкреатиты, колиты), мочекаменной болезнью, фиброматозом тела матки, дискогенным радикулоневритом. В ходе исследования у каждого пациента оценивался неврологический статус по специально разработанной методике и проводилось двукратное (день 0 и день 21) обследование, включавшее проведение электроэнцефалографии и исследование когнитивных и мнестических функций. Для характеристики состояния биоэлектрической активности головного мозга производилось двукратное электроэнцефалографическое (ЭЭГ) исследование (компьютерные электроэнцефалографы с топографическим картированием биопотенциалов Neurolab 2000 и DX-ExpertTM, г. Харьков, Украина). Использована шкала балльной оценки основных компонентов кривой, основанная на классических семиологических показателях. Оценивались следующие показатели:

- доминирующий ритм (1 балл - a, 2 балла - b, 3 балла - d, 4 балла - q);

- форма волн (1 балл - синусоидальная, 2 балла дезорганизованная);

- вольтаж доминирующего ритма (1 балл - 10-40 mcv, 2 балла 41-100 mcv, 3 балла - 100-200 mcv, 4 балла — более $200 \mathrm{mcv})$;

- индекс быстрая волна - медленная волна (1 балл - менее $15 \%$, 2 балла - 16-30 \% , 3 балла - 31-60\%, 4 балла - более 60 \% );

- межполушарная асимметрия (1 балл - нет, 2 балла - а-диапазон, 3 балла - b-диапазон);

- наличие пароксизмальной активности (1 балл - нет, 2 балла есть);

- $\quad$ наличие ирритативной активности (1 балл - нет, 2 балла - есть);

- наличие стволовой дисфункции (1 балл - нет, 2 балла верхнестволовая, 3 балла - нижнестволовая).

Исследование когнитивных и мнестических функций включало градационную оценку оперативной (Леонтьев А. Н., 1972), зрительной (Кроткова О. А., 1986), слуховой, вербальной (Рубинштейн С. Я., 1970, Лурия А. Р., 1976), моторной (Лурия А. Р., 1969), эмоциональной (Леонтьев А. Н., 1972) памяти с помощью набора проб. Тестовая шкала модифицирована Шестопаловой Л. Ф. (2002) с возможностью цифровой обработки полученных данных (соответственно от 0 до 3 баллов, где 0 баллов - отсутствие нарушений, 3 балла - тяжелые нарушения функции). Также проводился мониторинг соматических и лабораторных показателей исследований с целью оценки общего влияния препарата на организм пациента (в начале и конце исследования). Оценка эффективности препарата проводилась по следующим критериям: динамика данных когнитивных функций и памяти, динамика данных ЭЭГ (соответственно: 3 балла - при статистически достоверной позитивной динамике двух показателей, 2 балла одного, 1 балл - отсутствие статистически значимых изменений). 
Производилась оценка переносимости исследуемого препарата с учетом частоты возникновения побочных явлений и их влияния на прием препарата [334, 335].

Оценка полученных данных показала, что исследование в запланированном режиме закончили все пациенты. Коэффициент «приверженности лечению» составил 1,0. Динамическая оценка соматических показателей данных в обеих группах не выявила отклонений от базисных показателей за весь период наблюдения. Использование исследуемого и референтного препаратов выявило влияние на биоэлектрическую активность мозга пациентов после применения в течение 21 суток. Так, у пациентов I группы отмечено статистически значимое влияние Тиоцетама на следующие характеристики: доминирующий ритм (уменьшение представленности медленноволновой патологической активности на 41 \% ), форма волн (уменьшение фактов регистрации дезорганизованной формы волн - 31 \%), индекс «медленная волна - быстрая волна» (уменьшение доли медленноволновой активности в спектре - $21 \%$ ), стволовая дисфункция (увеличение случаев отсутствия признака - 32 \%) (р < 0,05). Отмечены недостоверные изменения показателей: вольтаж доминирующего ритма (увеличение амплитуды доминирующего ритма), пароксизмальная активность (увеличение количества случаев регистрации вспышек в а и q диапазонах). Отмечено отсутствие влияния препарата на показатели межполушарной асимметрии, ирритативной активности. Оценка динамики биоэлектрической активности пациентов II группы показала статистически значимое влияние приема препарата контроля Пирацетама на: показатель стволовой дисфункции (увеличение количества случаев отсутствия регистрации признака $-24 \%$ ) (p < 0,05) [334]. Нормализующее влияние на доминирующий ритм, форму волн, индекс «быстрая волна - медленная волна» было статистически незначимым. Следует отметить, что в рассматриваемой группе влияние приема препарата на показатели вольтажа доминирующего ритма и пароксизмальной активности было минимальным и недостоверным. Таким образом, сравнительная оценка влияния препаратов в клинических группах продемонстрировала большее позитивное влияние на исследуемые показатели препарата Тиоцетам (I группа). У пациентов контрольной группы (препарат Пирацетам) отмечена недостоверная тенденция к увеличению показателей пароксизмальной активности (негативная тенденция). Данные динамического исследования когнитивных функций продемонстрировали следующие особенности:

- $\quad$ в I группе отмечено статистически значимое положительное влияние Тиоцетама на все исследованные функции: увеличение показателя «количество строк» на $27 \%(\mathrm{p}<0,05)$, уменьшение доли ошибок на $32 \%(\mathrm{p}<0,01)$, ускорение выполнения пробы Шульте на $32 \%$ $(\mathrm{p}<0,01)$;

- воІІгруппезарегистрированостатистическизначимоеположительное влияние приема контрольного препарата на показатель «количество строк» теста Бурдона на $22 \%(\mathrm{p}<0,05) ;$ количество ошибок этого теста и скорость выполнения тестаШульте также претерпевали позитивные изменения, но они были статистически недостоверными. 
Также проводилось динамическое тестирование показателей функции памяти. Анализ показателей в обеих клинических группах свидетельствует о позитивном влиянии исследуемого препарата на основные виды памяти, причем статистически значимым является влияние на моторную и оперативную память, в то время как изменения зрительной и вербальной памяти, будучи позитивными в количественном отношении, не имели статистической значимости. У пациентов I группы отмечены следующие количественные характеристики позитивных статистически значимых влияний Тиоцетама: улучшение показателей моторной памяти на $43 \%(\mathrm{p}<0,01)$, оперативной, эмоциональной, опосредованной памяти - на $41 \%(\mathrm{p}<0,05)$. У больных II группы изменение данных показателей составило соответственно $22 \%$ и $28 \%(\mathrm{p}<0,05)$. Регистрация субъективной симптоматики на фоне назначения исследуемого препарата не выявила существенных отрицательных изменений. Отмечено отсутствие изменений лабораторных показателей в обеих клинических группах на протяжении времени приема исследуемого препарата. По результатам исследования, за время применения препарата Тиоцетам у пациентов не было зарегистрировано ни одного случая развития побочных явлений (повышенная возбудимость, раздражительность, беспокойство, расстройства сна, повышенная утомляемость, сонливость, аллергические реакции, расстройства функции ЖКТ, головокружение, тремор) либо аллергических реакций. Оценка переносимости по использованной балльной шкале -3 балла (хорошая переносимость). На основании результатов клинических испытаний была проведена суммарная оценка эффективности использования препарата Тиоцетам. Отмечено позитивное влияние препарата Тиоцетам на следующие показатели биоэлектрической активности головного мозга у больных дисциркуляторной энцефалопатией II стадии на фоне атеросклеротического поражения магистральных артерий головы: доминирующий ритм, форма волн, индекс «медленная волна - быстрая волна», стволовая дисфункция, показатели когнитивных функций и памяти (моторной, вербальной, зрительной, оперативной, эмоциональной, опосредованной). Статистически значимым положительный эффект является для моторной и оперативной (эмоциональной, опосредованной) памяти. Зарегистрировано преобладание позитивного влияния препарата исследования в сравнении с референтным препаратом. С учетом вышеизложенных фактов получен суммарный балл эффективности препарата среди участвовавших в исследовании больных: для I группы (Тиоцетам) - 2,56; для II группы (Пирацетам) $-2,12$.

Доказана эффективность применения Тиоцетама, разработаны дозы при его назначении детям с различными органическими поражениями головного мозга для улучшения качества лечения. Исследования, проведенные в Донецком государственном медицинском университете под руководством профессоpa C. К. Евтушенко, ставили следующие задачи: оценить влияние препарата Тиоцетам на клиническую картину заболевания (динамика неврологической симптоматики и изменение психических функций) у детей с органическим поражением головного мозга; изучить особенности церебральной гемодинамики у детей с органическим поражением головного мозга методом УЗДГ до и во 
время лечения; изучить особенности биоэлектрической активности головного мозга методом электроэнцефалокартирования у детей с когнитивными нарушениями до и во время лечения; разработать дозы и методику включения в процесс лечения детей с органическим поражением головного мозга препарата Тиоцетам [334].

Предмет исследования: динамика неврологической симптоматики и психических функций, изменение церебральной гемодинамики и биоэлектрической активности мозга у детей с органическим поражением головного мозга на фоне терапии.

Объект исследования: дети в возрасте от 1 года до 16 лет (40 человек) с органическим поражением головного мозга с преобладанием в клинической картине когнитивных нарушений.

Критерии включения ребенка в программу исследования: наличие когнитивных и/или речевых расстройств разной степени выраженности (затруднение концентрации внимания, снижение оперативной и долговременной памяти, интеллектуальной продуктивности, общей активности, алалия, афазия) вследствие органического заболевания головного мозга, длительной антиэпилептической терапии. Наличие неврологических нарушений вследствие перенесенного инсульта, апаллического синдрома. Наличие синдрома недостаточности мозгового кровообращения (головные боли, головокружение, обмороки) вследствие патологической извитости сосудов, обусловленной врожденной слабостью соединительной ткани; отсутствие противопоказаний к приему Тиоцетама (выраженных нарушений функции почек, диабета, повышенной чувствительности к препарату); согласие родителей ребенка на участие в исследовании. Клинические исследования препаратов (оценка неврологического и соматического статуса, когнитивных функций, речевого развития), с использованием шкалы оценки психических функций у детей с органическими заболеваниями нервной системы (по С. К. Евтушенко, О. А. Дубовцевой, 1999).

Инструментальные: ультразвуковая допплерография экстра- и интрацеребральных сосудов (ультразвуковой сканер «Logidop-4», Kranzbuhler, Германия); электроэнцефалокартирование (ЭЭГ-комплекс «DXNT-32»).

Для проведения исследования были выделены две группы больных в возрасте от 1 года до 16 лет.

І группу (20 человек) составили пациенты с преобладанием в клинической картине сосудистых расстройств (головные боли, головокружение, синкопальные состояния) вследствие патологической извитости сосудов (обусловленной врожденной слабостью соединительной ткани) - 15 детей, и перенесенного острого нарушения мозгового кровообращения - 5 детей. В неврологическом статусе у пациентов этой группы отмечался задний межъядерный офтальмопарез, асимметрия носогубных складок, оживление сухожильных рефлексов (в $60 \%$ случаев с анизорефлексией).

Bo II группу (20 человек) были включены больные с преобладанием в клинической картине когнитивных нарушений (затруднение концентрации внимания, снижение оперативной и долговременной памяти, интеллектуальной продуктивности, общей активности, алалия, афазия) и органической не- 
врологической симптоматики. В эту группу вошли больные с церебральным параличом (4 ребенка), последствиями церебрального арахноидита (2 пациента), CADASIL (1 пациент), лейкодистрофией Канавана ван Богарта (1 пациент), фенилкетонурией (1 пациент), последствиями черепно-мозговых травм (2 пациента), эпилептической энцефалопатией (3 пациента), болезнью Штрюмпеля (2 пациента), рассеянным склерозом (2 пациента), синдромом Штурге-Вебера (1 пациент), апаллическим синдромом (1 пациент). В неврологическом статусе у детей II группы отмечался нистагм, задний межъядерный офтальмопарез, нарушение мышечного тонуса, парезы в конечностях различной степени выраженности, повышение сухожильных рефлексов, нарушение координации, когнитивные расстройства (19-28 баллов по шкале оценки психических функций у детей с органическими заболеваниями нервной системы при норме 30 баллов) и эпилептические приступы (у 5 детей).

Всем детям в исследуемых группах было проведено ультразвуковое допплерографическое исследование сосудов шеи и головного мозга (аппарат «Logidop-4», Kranzbuhler, Германия). В I группе у 18 детей были выявлены признаки нарушения тонуса сосудов (дистония вен, снижение тонуса экстрацеребральных артерий), асимметрия кровотока по позвоночным артериям отмечалась у 6 пациентов, венозный отток из полости черепа был затруднен у 9 детей (причем у 2 из них отмечались признаки повышения внутричерепного давления). Во II группе у 8 детей отмечалась асимметрия кровотока по артериям головного мозга (из них у 2 больных обнаружены признаки дефицита кровотока по средней мозговой артерии), у 16 пациентов - выраженная дистония вен с затруднением (преимущественно асимметричным) венозного оттока из полости черепа с признаками повышения внутричерепного давления.

Компьютерная электроэнцефалография (ЭЭГ-комплекс «DXNT-32») была проведена 10 больным в I группе и 16 больным во II группе. B I группе у 8 детей были выявлены умеренные диффузные изменения биоэлектрической активности мозга, у 2 - гиперсинхронный тип ЭЭГ. Во II группе пароксизмальная активность зарегистрирована у 5 пациентов, у 4 - полушарная асимметрия (у 1 больного отмечалось выраженное угнетение базовых ритмов над правым полушарием), у 10 детей отмечались выраженные диффузные изменения биоэлектрической активности мозга.

Тиоцетам применялся в комплексной терапии у детей, учитывая его способность повышать стабильность клеточных мембран путем физического воздействия на фосфолипиды, оказывать противоишемический и антиоксидантный эффект, накапливаться в сером веществе головного мозга, улучшать интегративную и когнитивную деятельность.

Тиоцетам назначался в два приема (утром и днем). Суточная доза препарата составляла:

— у детей в возрасте от 1 до 2 лет (5 человек) - 0,125 г;

— у детей в возрасте от 3 до 5 лет (4 человека) - 0,250 г;

— у детей в возрасте от 6 до 10 лет (13 человек) - 0,5 г;

— у детей в возрасте от 10 до 16 лет (18 человек) - 0,75 г. 
Курс лечения в условиях неврологического отделения ОДКБ составлял в среднем 15 дней (затем рекомендовалось продолжить прием препарата амбулаторно).

На фоне приема Тиоцетама у одного ребенка (мальчик, 13 лет, диагноз: последствия оптико-хиазмального арахноидита с атрофией зрительных нервов) отмечались побочные явления в виде тремора верхних конечностей, которые купировались после уменьшения дозы препарата. У одного ребенка (мальчик 1 года 3 месяцев, диагноз: церебральный паралич, двойная гемиплегическая форма) в течение первых двух дней приема препарата отмечалось беспокойство. Аллергических реакций у детей во время приема Тиоцетама не отмечалось.

Положительная динамика на фоне проводимой терапии отмечалась у всех больных I группы: уменьшилась частота и интенсивность головных болей, уменьшилось головокружение, синкопальные состояния не повторялись. Повторно ультразвуковое допплерографическое исследование сосудов шеи и головного мозга было проведено 10 пациентам этой группы. При этом у всех обследованных больных отмечалось уменьшение выраженности дистонии вен и затруднения венозного оттока из полости черепа, у 2 детей сохранялась незначительная асимметрия кровотока по позвоночным артериям.

Во II группе положительный эффект отмечался у 16 больных: улучшились речь и внимание (по шкале оценки психических функций - на 1-3 балла), повысилась общая активность, увеличился объем активных движений в паретичных конечностях, уменьшилась выраженность нарушений мышечного тонуса. У больных с эпилепсией учащения приступов на фоне приема Тиоцетама не отмечалось. При повторном ультразвуковом допплерографическом исследовании сосудов шеи и головного мозга, которое было проведено 14 пациентам II группы, выявлено уменьшение выраженности асимметрии кровотока по артериям мозга и внутричерепной гипертензии, улучшение венозного оттока из полости черепа.

Таким образом, терапевтическая эффективность и переносимость препарата Тиоцетам у детей с органическим поражением головного мозга достаточно высокая.

Разработаны дозы приема препарата у детей. Суточная доза: у детей в возрасте от 1 до 2 лет $-0,125$ г, у детей в возрасте от 3 до 5 лет $-0,25$ г, у детей в возрасте от 6 до 10 лет - 0,5 г, у детей в возрасте от 10 до 16 лет $-0,75$ г. Оптимальным следует считать прием препарата 2 раза в сутки - утром и днем. Курс лечения — не менее 4 недель.

Препарат способствует улучшению когнитивных функций детей с органическим поражением головного мозга. На фоне приема Тиоцетама отмечается улучшение кровотока по сосудам головного мозга. Препарат положительно влияет на биоэлектрическую активность мозга.

На основании исследований, проведенных в Донецком национальном медицинском университете под руководством члена-корреспондента АМНУ, профессора В. И. Черния, был доказан дозозависимый эффект препарата Тиоцетам, применяемого у пациентов с острой церебральной недостаточностью $(\mathrm{OЦН)} \mathrm{различного} \mathrm{генеза} \mathrm{-} \mathrm{в} \mathrm{острейшем} \mathrm{периоде} \mathrm{острого} \mathrm{нарушения} \mathrm{мозго-}$ 
вого кровообращениия (ОНМК) и тяжелой черепно-мозговой травмы (ЧМТ) [334].

Было обследовано 86 больных с ОЦН, относящихся к двум группам, сопоставимым по полу и возрасту. В первую группу входили 46 пациентов, перенесших ишемический инсульт (ИИ) -26 мужчин и 20 женщин, в возрасте от 43 до 62 лет. У 15-и человек выявлена локализация очага ишемии в бассейне левой среднемозговой артерии (ОНМК, ИИ БЛСМА), у 13-и исследуемых в бассейне правой среднемозговой артерии (ОНМК, ИИ БПСМА) и 18-и человек - в вертебробазилярном бассейне (ОНМК, ИИ ВББ). Вторая группа состояла из сорока больных (19 мужчин и 21 женщина, в возрасте от 30 до 50 лет) с черепно-мозговой травмой (ЧМТ), находящихся на лечении в нейрохирургическом центре ДОКТМО. Летальность в группе больных с ишемическим инсультом составила $13,04 \%$, а в группе с ЧМТ $-14,7 \%$.

Для оценки функции ЦНС проводили клиническое и неврологическое обследование. Степень неврологического дефицита у больных с ИИ определялась по Скандинавской шкале инсультов и составила при поступленни в отделение 2-12 баллов. Глубину коматозного состояния определяли с помощью шкалы ком Глазго (ШКГ). При поступлении в отделение первичная оценка степени нарушения сознания по ШКГ в первой группе составила 9-12 баллов, а во второй группе $-6-11$ баллов.

Для исследования использовали методы компьютерной и магнитнорезонансной томографии головного мозга, транскраниальной УЗДГ, ЭЭГ с применением метода интегрального количественного анализа ЭЭГ-паттернов (ИКА). Регистрация биопотенциалов мозга осуществлялась с помощью нейрофизиологического комплекса, состоящего из 8-канального электроэнцефалографа фирмы Medicor, персонального компьютера IBM PC AT с аналоговоцифровым преобразователем и специальным программным обеспечением «Brain mapping» для хранения и обработки электроэнцефалограмм.

Изучались количественные ЭЭГ показатели абсолютной мощности $(\mathrm{AM}, \mathrm{м \kappa} \mathrm{B} / \sqrt{ }$ Гц), относительной мощности $(\%)$ для $\delta$ - (1-4 Гц), $\theta-(5-7$ Гц), $\alpha-(8-12$ Гц), $\alpha 1-(9-11$ Гц), $\beta 1-(13-20$ Гц), $\beta 2-(20-30$ Гц) частотных диапазонов ЭЭГ. Для объективизации оценки ЭЭГ использован метод интегрального количественного анализа ЭЭГ-паттерна. Были разработаны интегральные коэффициенты (ИК), позволяющие провести оценку спектральной мощности всех частотных диапазонов ЭЭГ и определить значимость отдельных частотных спектров ЭЭГ в формировании целостного паттерна ЭЭГ.

ЭЭГ исследования проводили за 30 минут до первого введения Тиоцетама, на фоне максимальной концентрации препарата в плазме (через 0,5 часа после введения препарата) и после завершения курса лечения. Тиоцетам вводился внутривенно капельно с первых суток поступления в отделение нейрореанимации в суточной дозе 15, 20 и 30 мл на 150 мл физиологического раствора, в течение часа, на протяжении 7 дней. Реактивность мозга оценивалась по изменению абсолютной спектр-мощности и интегральных коэффициентов. Все полученные данные обрабатывались с использованием методов математической статистики, с применением корреляционного анализа. 
Таблица 4.8

Значения правополушарных показателей интегральных коэффициентов у больных с ОНМК и ЧМТ в 1-10-е сутки заболевания до и после введения 15 мл, 20 мл и 30 мл Тиоцетама

\begin{tabular}{|c|c|c|c|c|c|c|c|c|c|c|c|}
\hline $\begin{array}{l}\overline{\underline{\underline{E}}} \\
\text { 흔 }\end{array}$ & 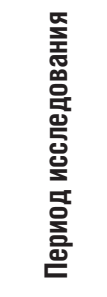 & 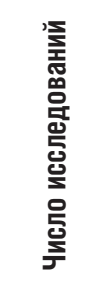 & 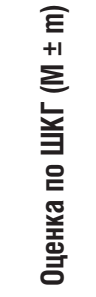 & 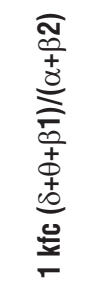 & 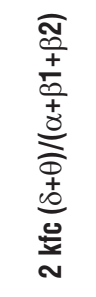 & 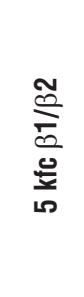 & $\begin{array}{l}\frac{10}{0} \\
\frac{\omega}{\frac{1}{2}} \\
0\end{array}$ & $\begin{array}{l}\bar{\partial} \\
\bar{\theta} \\
\frac{d}{i} \\
\infty\end{array}$ & $\begin{array}{l}\frac{\partial}{10} \\
\frac{0}{0} \\
0\end{array}$ & $\begin{array}{l}\bar{\gamma} \\
\frac{\gamma}{2} \\
\dot{t} \\
\dot{t}\end{array}$ & 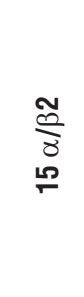 \\
\hline 노 & & $n=12$ & 15 & $\begin{array}{c}0,94 \pm \\
0,02\end{array}$ & $\begin{array}{c}0,62 \pm \\
0,01\end{array}$ & $\begin{array}{l}2,04 \pm \\
0,09 \#\end{array}$ & $\begin{array}{c}1,65 \pm \\
0,1 \#\end{array}$ & $\begin{array}{l}0,4 \pm \\
0,02\end{array}$ & $\begin{array}{l}0,31 \pm \\
0,02 \#\end{array}$ & $\begin{array}{c}0,78 \pm \\
0,04\end{array}$ & $\begin{array}{l}9,5 \pm \\
0,09\end{array}$ \\
\hline \multirow{4}{*}{ 产 } & $\begin{array}{l}\text { до вве- } \\
\text { дения }\end{array}$ & $\mathrm{n}=46$ & $11 \pm 4$ & $\begin{array}{c}3,57 \pm \\
0,24\end{array}$ & $\begin{array}{c}2,35 \pm \\
0,16\end{array}$ & $\begin{array}{l}1,5 \pm \\
0,13\end{array}$ & $\begin{array}{c}0,99 \pm \\
0,07\end{array}$ & $\begin{array}{c}1,99 \pm \\
0,16\end{array}$ & $\begin{array}{c}2,3 \pm \\
0,28\end{array}$ & $\begin{array}{c}1,03 \pm \\
0,06\end{array}$ & $\begin{array}{c}2,7 \pm \\
0,25\end{array}$ \\
\hline & $\begin{array}{l}\text { после } \\
15 \text { мл }\end{array}$ & $n=30$ & $\begin{array}{c}10,5 \pm \\
1.5\end{array}$ & $\begin{array}{l}3,89 \pm \\
0,26 \#\end{array}$ & $\begin{array}{l}2,54 \pm \\
0,16 \#\end{array}$ & $\begin{array}{c}1,46 \pm \\
0,12\end{array}$ & $\begin{array}{c}0,96 \pm \\
0,07\end{array}$ & $\begin{array}{l}2,13 \pm \\
0,15 \#\end{array}$ & $\begin{array}{c}2,56 \pm \\
0,24 \#\end{array}$ & $\begin{array}{c}1,69 \pm \\
0,48\end{array}$ & $\begin{array}{c}3,38 \pm \\
0,5\end{array}$ \\
\hline & $\begin{array}{l}\text { после } \\
20 \text { мл }\end{array}$ & $n=10$ & $\begin{array}{c}11,5 \pm \\
0,5\end{array}$ & $\begin{array}{c}2,32 \pm \\
0,341\end{array}$ & $\begin{array}{l}1,64 \pm \\
0,191\end{array}$ & $\begin{array}{l}0,98 \pm \\
0,27 \#\end{array}$ & $\begin{array}{c}1,12 \pm \\
0,14\end{array}$ & $\begin{array}{l}1,74 \pm \\
0,15 \#\end{array}$ & $\begin{array}{c}1,68 \pm \\
0,36\end{array}$ & $\begin{array}{l}1,1 \pm \\
0,14 \#\end{array}$ & $\begin{array}{l}1,59 \pm \\
0,2 \# 1\end{array}$ \\
\hline & $\begin{array}{l}\text { после } \\
30 \text { мл }\end{array}$ & $n=6$ & $\begin{array}{c}13,3 \pm \\
1,7\end{array}$ & $\begin{array}{c}2,38 \pm \\
0,2 \# 1\end{array}$ & $\begin{array}{l}1,84 \pm \\
0,1 \# 1\end{array}$ & $\begin{array}{l}0,42 \pm \\
0,0 \# 1\end{array}$ & $\begin{array}{l}0,75 \pm \\
0,1 \# 1\end{array}$ & $\begin{array}{c}2,59 \pm \\
0,3 \# 1\end{array}$ & $\begin{array}{l}2,28 \pm \\
0,27 \#\end{array}$ & $\begin{array}{l}1,57 \pm \\
0,2 \# 1\end{array}$ & $\begin{array}{l}1,45 \pm \\
0,2 \# 1\end{array}$ \\
\hline \multirow{4}{*}{ 歺 } & $\begin{array}{l}\text { до вве- } \\
\text { дения }\end{array}$ & $n=40$ & $\begin{array}{c}10,2 \pm \\
1,2\end{array}$ & $\begin{array}{c}3,46 \pm \\
0,25\end{array}$ & $\begin{array}{c}2,31 \pm \\
0,15\end{array}$ & $\begin{array}{c}1,38 \pm \\
0,1 \#\end{array}$ & $\begin{array}{c}0,93 \pm \\
0,04\end{array}$ & $\begin{array}{c}2,1 \pm \\
0,17\end{array}$ & $\begin{array}{c}2,29 \pm \\
0,2\end{array}$ & $\begin{array}{c}1,03 \pm \\
0,05\end{array}$ & $\begin{array}{c}2,72 \pm \\
0,2 \#\end{array}$ \\
\hline & $\begin{array}{l}\text { после } \\
15 \text { мл }\end{array}$ & $n=17$ & $\begin{array}{c}10,2 \pm \\
3,2\end{array}$ & $\begin{array}{l}3,73 \pm \\
0,23 \#\end{array}$ & $\begin{array}{c}2,38 \pm \\
0,14 \#\end{array}$ & $\begin{array}{l}1,45 \pm \\
0,11 \#\end{array}$ & $\begin{array}{c}0,97 \pm \\
0,06\end{array}$ & $\begin{array}{l}2,04 \pm \\
0,08 \#\end{array}$ & $\begin{array}{l}2,5 \pm \\
0,2 \#\end{array}$ & $\begin{array}{c}1,41 \pm \\
0,33\end{array}$ & $\begin{array}{c}2,76 \pm \\
0,13 \#\end{array}$ \\
\hline & $\begin{array}{l}\text { после } \\
20 \text { мл }\end{array}$ & $n=14$ & $\begin{array}{c}11,1 \pm \\
3,8\end{array}$ & $\begin{array}{c}3,32 \pm \\
0,24 \#\end{array}$ & $\begin{array}{c}2,12 \pm \\
0,16 \#\end{array}$ & $\begin{array}{c}1,39 \pm \\
0,13\end{array}$ & $\begin{array}{c}0,73 \pm \\
0,071\end{array}$ & $\begin{array}{l}1,55 \pm \\
0,161\end{array}$ & $\begin{array}{l}2,5 \pm \\
0,26 \#\end{array}$ & $\begin{array}{l}0,9 \pm \\
0,08 \#\end{array}$ & $\begin{array}{l}2,43 \pm \\
0,21 \#\end{array}$ \\
\hline & $\begin{array}{l}\text { после } \\
30 \text { мл }\end{array}$ & $\mathrm{n}=9$ & $\begin{array}{c}11,7 \pm \\
3,3\end{array}$ & $\begin{array}{c}3,04 \pm \\
0,41\end{array}$ & $\begin{array}{c}2,02 \pm \\
0,23\end{array}$ & $\begin{array}{l}1,02 \pm \\
0,22 \#\end{array}$ & $\begin{array}{c}0,82 \pm \\
0,11\end{array}$ & $\begin{array}{l}1,63 \pm \\
0,221\end{array}$ & $\begin{array}{c}2,33 \pm \\
0,36 \#\end{array}$ & $\begin{array}{c}0,91 \pm \\
0,06\end{array}$ & $\begin{array}{l}1,91 \pm \\
0,1 \# 1\end{array}$ \\
\hline
\end{tabular}

* - отсутствие достоверных различий с контрольной группой $(p<0,05)$;

\# - достоверность различий справа и слева $(p<0,05)$;

1 - достоверность различий до и после введения препарата $(p<0,05)$.

У пациентов с ОНМК наиболее выраженные изменения $(\mathrm{p}<0,05)$, относительно начальных данных, выявлены в правом полушарии после введения 30 мл (снижение 1-2-го, 5-го, 6-го, 14-го и 15 -го ИК при росте 8-го ИК), в левом полушарии при введении 15 мл (снижение 2-го, 9-го и 15 -го ИК при росте 8-го ИК), и в обеих гемисферах при введении 20 мл Тиоцетама (табл. 4.8 и 4.9). 
Таблица 4.9

\section{Значения левополушарных показателей интегральных коэффициентов у больных с ОНМК и ЧМТ в 1-10-е сутки заболевания до и после введения 15 мл, 20 мл и 30 мл Тиоцетама}

\begin{tabular}{|c|c|c|c|c|c|c|c|c|c|c|c|}
\hline 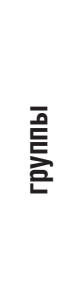 & 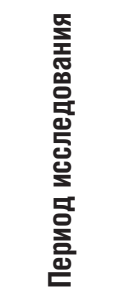 & 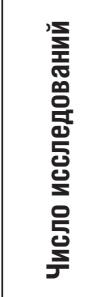 & 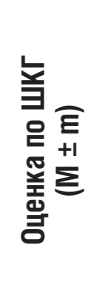 & 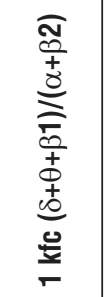 & 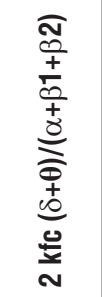 & 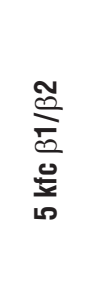 & $\begin{array}{l}\frac{0}{0} \\
0 \\
\frac{0}{1} \\
0\end{array}$ & $\begin{array}{l}\bar{\delta} \\
\frac{D}{0} \\
\stackrel{d}{\infty} \\
\infty\end{array}$ & $\begin{array}{l}\frac{\gamma}{00} \\
\frac{\vec{t}}{\sigma}\end{array}$ & 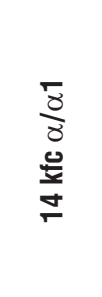 & 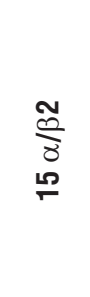 \\
\hline 느 & & $\mathrm{n}=12$ & 15 & $\begin{array}{c}0,93 \pm \\
0,03\end{array}$ & $\begin{array}{c}0,61 \pm \\
0,01\end{array}$ & $\begin{array}{l}1,53 \pm \\
0,03 \#\end{array}$ & $\begin{array}{l}1,41 \pm \\
0,08 \#\end{array}$ & $\begin{array}{c}0,38 \pm \\
0,02\end{array}$ & $\begin{array}{l}0,35 \pm \\
0,02 \#\end{array}$ & $\begin{array}{c}0,77 \pm \\
0,05\end{array}$ & $\begin{array}{l}6,7 \pm \\
0,07\end{array}$ \\
\hline \multirow{4}{*}{ 产 } & $\begin{array}{l}\text { до вве- } \\
\text { дения }\end{array}$ & $n=46$ & $\begin{array}{c}11 \pm \\
4\end{array}$ & $\begin{array}{c}3,34 \pm \\
0,27\end{array}$ & $\begin{array}{c}2,24 \pm \\
0,19\end{array}$ & $\begin{array}{l}1,62 \pm \\
0,06^{*}\end{array}$ & $\begin{array}{c}1,03 \pm \\
0,03\end{array}$ & $\begin{array}{c}1,92 \pm \\
0,02\end{array}$ & $\begin{array}{c}1,92 \pm \\
0,02\end{array}$ & $\begin{array}{c}1 \pm \\
0,07\end{array}$ & $\begin{array}{c}3,66 \pm \\
0,25\end{array}$ \\
\hline & $\begin{array}{l}\text { после } \\
15 \text { мл }\end{array}$ & $n=30$ & $\begin{array}{c}10,5 \pm \\
1.5\end{array}$ & $\begin{array}{l}3,61 \pm \\
0,22 \#\end{array}$ & $\begin{array}{l}3,73 \pm \\
0,2 \# 1\end{array}$ & $\begin{array}{c}1,72 \pm \\
0,1\end{array}$ & $\begin{array}{c}1,31 \pm \\
0,13^{\star} \# 1\end{array}$ & $\begin{array}{c}2 \pm \\
0,13 \#\end{array}$ & $\begin{array}{l}2,46 \pm \\
0,09 \# 1\end{array}$ & $\begin{array}{c}0,91 \pm \\
0,1 \#\end{array}$ & $\begin{array}{l}1,89 \pm \\
0,3 \# 1\end{array}$ \\
\hline & $\begin{array}{l}\text { после } \\
20 \text { мл }\end{array}$ & $\mathrm{n}=10$ & $\begin{array}{c}11,5 \pm \\
0,5\end{array}$ & $\begin{array}{c}2,42 \pm \\
0,151\end{array}$ & $\begin{array}{l}1,61 \pm \\
0,091\end{array}$ & $\begin{array}{l}1,58 \pm \\
0,2^{\star} \#\end{array}$ & $\begin{array}{c}0,97 \pm \\
0,11\end{array}$ & $\begin{array}{l}1,05 \pm \\
0,21 \# 1\end{array}$ & $\begin{array}{c}1,38 \pm \\
0,111\end{array}$ & $\begin{array}{l}0,8 \pm \\
0,11 \#\end{array}$ & $\begin{array}{l}3,55 \pm \\
0,32 \#\end{array}$ \\
\hline & $\begin{array}{l}\text { после } \\
30 \text { мл }\end{array}$ & $n=6$ & $\begin{array}{c}13,3 \pm \\
1,7\end{array}$ & $\begin{array}{l}3,06 \pm \\
0,29 \#\end{array}$ & $\begin{array}{l}2,01 \pm \\
0,15 \#\end{array}$ & $\begin{array}{l}1,14 \pm \\
0,07 \# 1\end{array}$ & $\begin{array}{c}1,01 \pm \\
0,08\end{array}$ & $\begin{array}{l}1,79 \pm \\
0,14 \#\end{array}$ & $\begin{array}{l}1,73 \pm \\
0,15 \#\end{array}$ & $\begin{array}{l}1,52 \pm \\
0,221\end{array}$ & $\begin{array}{c}3,46 \pm \\
0,4\end{array}$ \\
\hline \multirow{4}{*}{ 卢 } & $\begin{array}{l}\text { до вве- } \\
\text { дения }\end{array}$ & $n=40$ & $\begin{array}{c}10,2 \pm \\
1,2\end{array}$ & $\begin{array}{c}3,72 \pm \\
0,32\end{array}$ & $\begin{array}{c}2,47 \pm \\
0,21\end{array}$ & $\begin{array}{l}1,68 \pm \\
0,08 \#\end{array}$ & $\begin{array}{l}0,92 \pm \\
0,05\end{array}$ & $\begin{array}{c}1,95 \pm \\
0,16\end{array}$ & $\begin{array}{c}2,35 \pm \\
0,26\end{array}$ & $\begin{array}{c}0,99 \pm \\
0,05\end{array}$ & $\begin{array}{l}3,7 \pm \\
0,26 \#\end{array}$ \\
\hline & $\begin{array}{l}\text { после } \\
15 \text { мл }\end{array}$ & $\mathrm{n}=17$ & $\begin{array}{c}10,2 \pm \\
3,2\end{array}$ & $\begin{array}{l}2,73 \pm \\
0,16 \# 1\end{array}$ & $\begin{array}{l}1,79 \pm \\
0,11 \# 1\end{array}$ & $\begin{array}{l}1,68 \pm \\
0,11 \#\end{array}$ & $\begin{array}{c}1,04 \pm \\
0,07\end{array}$ & $\begin{array}{l}1,79 \pm \\
0,12 \#\end{array}$ & $\begin{array}{l}1,54 \pm \\
0,11 \# 1\end{array}$ & $\begin{array}{l}1,51 \pm \\
0,151\end{array}$ & $\begin{array}{l}3,69 \pm \\
0,23 \#\end{array}$ \\
\hline & $\begin{array}{l}\text { после } \\
20 \text { мл } \\
\end{array}$ & $n=14$ & $\begin{array}{c}11,1 \pm \\
3,8 \\
\end{array}$ & $\begin{array}{l}2,56 \pm \\
0,25 \# 1\end{array}$ & $\begin{array}{l}1,61 \pm \\
0,18 \# 1 \\
\end{array}$ & $\begin{array}{l}1,56 \pm \\
0,15^{\star}\end{array}$ & $\begin{array}{c}0,85 \pm \\
0,08\end{array}$ & $\begin{array}{l}1,48 \pm \\
0,161 \\
\end{array}$ & $\begin{array}{l}1,68 \pm \\
0,27 \# 1 \\
\end{array}$ & $\begin{array}{l}1,22 \pm \\
0,14 \# 1 \\
\end{array}$ & $\begin{array}{l}3,27 \pm \\
0,09 \#\end{array}$ \\
\hline & $\begin{array}{l}\text { после } \\
30 \text { мл }\end{array}$ & $n=9$ & $\begin{array}{c}11,7 \pm \\
3,3\end{array}$ & $\begin{array}{l}2,8 \pm \\
0,271\end{array}$ & $\begin{array}{l}1,79 \pm \\
0,211\end{array}$ & $\begin{array}{c}1,99 \pm \\
0,1 \#\end{array}$ & $\begin{array}{l}0,9 \pm \\
0,08\end{array}$ & $\begin{array}{l}1,41 \pm \\
0,211\end{array}$ & $\begin{array}{l}1,57 \pm \\
0,13 \# 1\end{array}$ & $\begin{array}{c}1 \pm \\
0,16^{*}\end{array}$ & $\begin{array}{l}4,25 \pm \\
0,081 \#\end{array}$ \\
\hline
\end{tabular}

У больных с ЧМТ в правом полушарии было выявлено отсутствие достоверных различий между уровнями ИК до и после введения 15 мл Тиоцетама и минимальные различия данных показателей до и после введения 20 и 30 мл препарата (табл. 4.8-4.9). Так, при введении Тиоцетама в дозе 20 мл выявлено снижение $(\mathrm{p}<0,05) 6$-го ИК - на $27,4 \%$, 8 -го ИК - на $35,5 \%$, а при введении 30 мл - снижение $(\mathrm{p}<0,05)$ только 8-го ИК - на $28,8 \%$. Более выраженные изменения $(\mathrm{p}<0,05)$, относительно начальных данных, выявлены в левом полушарии. После введения 30 мл отмечается $(\mathrm{p}<0,05)$ снижение 1-2-го, 8-10-го ИК при росте 5-го ИК. При введении 20 мл - снижение 1-2-го, 8-9-го ИК при росте 14-го ИК. После введения 15 мл Тиоцетама - снижение 1-2-го, 9-го при росте 14-го ИК (табл. 4.9). 


\section{Изменения количественных ЭЭГ-показателей - типы реакций ЦНС - у пациентов с ОНМК и ЧМТ в ответ на введение 15 мл, 20 мл и 30 мл Тиоцетама}

\begin{tabular}{|c|c|c|c|c|c|c|}
\hline $\begin{array}{c}\text { Варианты реакции } \\
\text { ЦНС }\end{array}$ & OHMK & OHMK & OHMK & ЧМТ & ЧМТ & ЧМТ \\
\hline Доза препарата & 15 мл & 20 мл & 30 мл & 15 мл & 20 мл & 30 мл \\
\hline Число исследований & $\begin{array}{c}30(60 \\
\text { реакций })\end{array}$ & $\begin{array}{c}10(20 \\
\text { реакций })\end{array}$ & $\begin{array}{c}6(12 \\
\text { реакций })\end{array}$ & $\begin{array}{c}17(34 \\
\text { реакций })\end{array}$ & $\begin{array}{c}14(28 \\
\text { реакций })\end{array}$ & $\begin{array}{c}9(18 \\
\text { реакций })\end{array}$ \\
\hline $\begin{array}{l}\text { Отсутствие изме- } \\
\text { нений }\end{array}$ & 0 & 0 & 0 & $\begin{array}{c}\text { I тип } 2 / 34 \\
(5,9 \%)\end{array}$ & $\begin{array}{c}\text { I тип } 2 / 28 \\
(7,1 \%)\end{array}$ & 0 \\
\hline $\begin{array}{l}\text { Рост дезорганиза- } \\
\text { ции ЭЭГ-паттерна }\end{array}$ & $\begin{array}{c}\text { II 1a } 2 / 60 \\
(3,3 \%) \\
\text { II 16 } 7 / 60 \\
(11,7 \%) \\
\text { III 1a 11/60 } \\
(18,3 \%) \\
\text { III } 164 / 60 \\
(6,7 \%)\end{array}$ & $\begin{array}{c}\text { II 1a 4/20 } \\
(20 \%) \\
\text { III 1a 4/20 } \\
(20 \%) \\
\text { III } 161 / 20 \\
\quad(5 \%)\end{array}$ & $\begin{array}{l}\text { II 1a } 4 / 12 \\
(33,3 \%)\end{array}$ & $\begin{array}{c}\text { II } 167 / 34 \\
(20,6 \%) \\
\text { III 1a } 6 / 34 \\
(16,8 \%)\end{array}$ & $\begin{array}{c}\text { II 1a } 12 / 28 \\
(42,9 \%) \\
\text { II } 164 / 28 \\
(14,3 \%) \\
\text { III } 162 / 28 \\
(7,1 \%)\end{array}$ & $\begin{array}{c}\text { III 1a } 4 / 18 \\
(22,2 \%) \\
\text { III 16 2/18 } \\
(11,1 \%)\end{array}$ \\
\hline $\begin{array}{l}\text { Снижение } \\
\text { дезорганизации } \\
\text { ЭЭГ-паттерна }\end{array}$ & $\begin{array}{c}\text { II 2a 2/60 } \\
(3,3 \%) \\
\text { I| } 266 / 60 \\
(10 \%) \\
\text { II 2a 6/60 } \\
(10 \%) \\
\text { II } 2610 / 60 \\
(16,7 \%)\end{array}$ & $\begin{array}{c}\text { II } 2 \text { 2a } 1 / 20 \\
(5 \%) \\
\text { III } 2 a 1 / 20 \\
(5 \%) \\
\text { III 3a 4/20 } \\
(20 \%)\end{array}$ & $\begin{array}{c}\text { III 2a } 5 / 12 \\
(41,7 \%) \\
\text { III 3a 1/12 } \\
(8,3 \%)\end{array}$ & $\begin{array}{c}\text { II 2a 2/34 } \\
(5,9 \%) \\
\text { I } 264 / 34 \\
(11,8 \%) \\
\text { III 2a } 1 / 34 \\
(2,9 \%) \\
\text { III } 266 / 34 \\
(17,6 \%)\end{array}$ & $\begin{array}{c}\text { III 2a 2/28 } \\
(7,1 \%) \\
\text { III 3a 4/28 } \\
(14,3 \%)\end{array}$ & $\begin{array}{c}\text { II 2a } 4 / 18 \\
(22,2 \%) \\
\text { III 3a 6/18 } \\
(33,3 \%)\end{array}$ \\
\hline $\begin{array}{l}\text { «Ипореактивные» } \\
\text { изменения }\end{array}$ & $\begin{array}{c}\text { III } 36 \text { 12/60 } \\
(20 \%)\end{array}$ & $\begin{array}{c}\text { III } 3 \text { б 5/20 } \\
(25 \%)\end{array}$ & $\begin{array}{c}\text { III } 36 \text { 2/12 } \\
(16,7 \%)\end{array}$ & $\begin{array}{c}\text { III } 3613 / 34 \\
(38,2 \%)\end{array}$ & $\begin{array}{c}\text { III } 3 \text { б 2/28 } \\
(7,1 \%)\end{array}$ & $\begin{array}{c}\text { III } 3 \text { б 2/18 } \\
(11,1 \%)\end{array}$ \\
\hline
\end{tabular}

По классификации типов реакций ЦНС у пациентов обеих групп в ответ на фармакологическое воздействие Тиоцетама были выявлены изменения ЭЭГпоказателей, относящиеся к трем типам (11 подгрупп) реакций ЦНС (табл. 4.10).

Сравнивая особенности формирования реакций ЦНС в ответ на введение Тиоцетама у пациентов с ОНМК и ЧМТ (табл. 4.10), следует отметить, что при введении 15 мл у пациентов с ОНМК выявлены реакции 9-и подгрупп, а у больных с ЧМТ - 8-и ПГ. Причем, изменения I типа свойственны только исследуемым с ЧМТ и не выявлены у больных с ОНМК. При ОНМК определяется практически равная частота так называемых «зеркальных», противоположно направленных реакций II типа: II 1а ПГ - 3 \% и II 2а подгруппы - 3 \% , II 16 $12 \%$ ПГ и II 2б подгруппы - 10 \%. У пациентов с ЧМТ в ответ на введение 15 мл препарата не выявлено реакций ЦНС II типа, отражающих снижение активирующих подкорковых влияний на кору (реакции II 1а и II 16 подгрупп).

У больных обеих подгрупп (после ОНМК и после ЧМТ) после введения 15 мл Тиоцетама преобладают реакции «перераспределения мощности» - III типа. Среди них доминируют изменения, относящиеся к III 3б ПГ (12/60 (20 \% ) 
в 1-й подгруппе и 13/34 (38,2 \%) - во второй), с увеличением $\beta 2$-мощности за счет редукции $\delta$-ритма с тенденциями к снижению 1-2-го, 5-го, 9-го, ИК, тенденцией к росту 6-го и 14 -го.

Прогностически благоприятные реакции ЦНС III 2б ПГ, с увеличением $\alpha$ мощности за счет синхронной редукции высокочастотного $\beta 2$ - и патологического дельта-ритмов, и умеренным снижением 8-9-го ИК, тенденцией к росту 5 -го и значительным увеличением уровня 15-го ИК, в обеих подгруппах встречаются с практически одинаковой частотой: 16,7 \% - у исследуемых с ОНМК, $17,6 \%$ - у пациентов с ЧМТ.

Не выявлено достоверных различий количества $(11 / 60$ (18,3 \% ) в 1-й подгруппе и 6/34 (16,8 \% ) - во второй) так называемых условно неблагоприятных реакций III 1 а ПГ, при которых отмечается активация медленноволновых $\delta$-и тета-ритмов за счет угнетения $\alpha 1$-активности (табл. 4.10).

После введения Тиоцетама в дозе 20 мл (табл. 4.10) выявлены значительные различия формирующихся фармакореакций ЦНС у пацентов обеих подгрупп. Так, у исследуемых с ОНМК доминировали изменения ЭЭГ показателей, относящиеся к III типу, а среди них — к гипореактивной III Зб ПГ реакций (25\% ). У пациентов с ЧМТ преобладали реакции ЦНС II типа, и наиболее часто встречаемыми среди них являлись изменения II 1а ПГ (42,9 \% ) с ростом суммарной мощности (CM) преимущественно за счет увеличения ACM медленноволновых патологических дельта- и тета-диапазонов с умеренной активацией $\alpha$-ритма, увеличением уровней 1 -го, 2-го, 9-го ИК и максимальным ростом показателей 5-го и 15-го ИК, что отражало угнетение активирующих воздействий ретикулярной формации на корковые структуры головного мозга.

Отсутствие достоверных изменений АCM и ИК - I тип реакций ЦНС выявлено в левой гемисфере у 2 пациентов $(7,1$ \% ) с ЧМТ и не зафиксировано у больных с ОНМК. У исследуемых с ОНМК преобладают асимметричные изменения ЭЭГ-показателей, а с ЧМТ - симметричные реакции ЦНС, отражающие синхронизацию ЭЭГ-процессов за счет выраженных межполушарных взаимодействий.

Следует отметить (табл. 4.8-4.9), что у исследуемых с ЧМТ, получавших Тиоцетам в дозе 20 мл, отмечается более высокий уровень нарушения сознания (среднегрупповые значения по ШКГ $=11,1 \pm 3,8$ ) по сравнению с пациентами с ОНМК (среднегрупповые значения по ШКГ $=11,5 \pm 0,5)$, что предопределило более грубую дезорганизацию ЭЭГ-паттерна у пациентов с ЧМТ. То есть, при более значимых исходных ЭЭГ-нарушениях отмечаются более выраженные нейротропные влияния Тиоцетама со значительным подкорковым компонентом фармакоответа. Это свидетельствует в пользу нашего тезиса о том, что выбор начальной дозы препарата Тиоцетам зависит, в первую очередь, от уровня нарушения сознания конкретного пациента.

В обеих подгруппах исследуемых (табл. 4.10) из реакций II типа преобладающими являлись изменения II 1а подгруппы, одинаково редко встречались изменения III 16 ПГ (5 \% - у пациентов с ОНМК, 7,1 \% — с ЧМТ), отсутствовали достоверные различия количества выявленных благоприятных реакций III 3а подгруппы (20 \% - у больных с ОНМК, 14,3\% — с ЧМТ) с активацией 
высокочастотного $\beta 2$-ритма за счет редукции альфа-активности с ростом 9 -го и снижением 15 -го ИК.

Следует отметить большее разнообразие вариантов фармакоответа -5 ПГ — на введение 30 мл Тиоцетама у исследуемых с ЧМТ (табл. 4.10). У больных с ОНМК доминировали реакции ЦНС II типа, а именно - II 2а подгруппы (5/12 (41,7 \% )), характеризующие процессы усиления активирующих подкорковых влияний. При ЧМТ (табл. 4.10) преобладали изменения АСМ и ИК, относящиеся к реакциям III типа, наиболее часто выявлялись перераспределения спектр-мощности в пользу высокочастотного $\beta 2$-ритма за счет угнетения патологической и альфа-частотной активности - реакции III За ПГ (6/18 (33,3%). Для пациентов с ОНМК типичными были симметричные реакции ЦНС в обоих полушариях, характеризующие выраженные изменения межполушарных взаимодействий после введения 30 мл Тиоцетама. У исследуемых с ЧМТ доминирующими были асимметричные реакции.

В обеих подгруппах исследуемых определяется практически равное количество гипореактивных III 3б реакций (табл. 4.10), из реакций II типа преобладающими являлись изменения II $2 \mathrm{a}$ ПГ, не выявлено отсутствия достоверных изменений ЭЭГ-параметров (реакций I типа).

Таким образом, применение Тиоцетама в максимальной дозе 30 мл у пациентов с ЧМТ и ОНМК должно быть дифференцированным и возможно только под нейрофизиологическим контролем.

На наш взгляд, снижение активирующих влияний кортико-лимбических структур, ретикулярной формации мозга, которое отражается в реакциях ЦНС II 1а и II $1 б$ ПГ, у пациентов с ОЦН различного генеза является прогностически неблагоприятным проявлением фармакореакции. Так, при ОНМк, вокруг зоны необратимого повреждения нейронов в мозговой ткани, в зоне обратимого повреждения (пенумбры), нервные клетки и нейроны испытывают глубокое торможение («охранительное торможение» по И. П. Павлову). Однако чрезмерное торможение является примером перехода саногенного процесса в патогенный, а снижение активирующих влияний ретикулярной формации на кору усугубляет тормозные процессы в измененных клетках пенумбры.

Из реакций II типа наиболее благоприятной следует считать II 2 а ПГ изменений, отражающих, во-первых, рост активирующих влияний на кору со стороны ретикулярной формации, и, во-вторых, характеризующихся угнетением патологической активности $\delta$ - и $\theta$-диапазонов. Такой тип реакции преобладал после введения 30 мл Тиоцетама пациентам 1 -й $(41,7$ \%) и 2 -й $(22,2$ \%) подгрупп.

Из реакций «перераспределения» мощности (III тип) прогностически благоприятными можно считать III 2 а подгруппу изменений, для которой типична активация $\alpha$ - и $\beta 2$-ритмов за счет угнетения дельта-активности. Возможно, такие реакции, особенно на стороне поражения, отражают корковые процессы восстановления обратимо поврежденных клеток мозговой ткани, их постсинаптической пропускной способности для высокочастотной стимуляции при ОНМК. Такие изменения АСМ и ИК составили при введении 15 мл препарата $10 \%$, при дозе 20 мл - 5 \% , а при 30 мл - 41,7 \% всех выявленных реакций 
у пациентов 1-й подгруппы (табл. 4.10). Для больных с ЧМТ (2-я подгруппа) такие реакции ЦНС не типичны (табл. 4.10): при введении 15 мл препарата они составляют 5,9 \%, при дозе 20 мл - 7,1 \%, а при 30 мл - не выявлены.

Интересны реакции III За ПГ, для которых характерно замещение альфаритма высокочастотной $\beta 2$-активностью, что считается ЭЭГ-коррелятом перехода от состояния покоя к напряжению при умственной деятельности у взрослых и характеризуют степень ирритации коры. В 1-й подгруппе больных при введении 20 мл препарата выявлены только симметричные реакции, относящиеся к III За подгруппе, которые составляли 20 \%, при введении 30 мл у 1-го пациента в левой гемисфере (8,3\%), а при введении 15 мл таких реакций не отмечалось. При ЧМТ подобные изменения АСМ и ИК определялись после применения Тиоцетама в дозе 20 мл в 14,3\%, преобладали при 30 мл введения в 33,3 \% всех выявленных ПГ реакций, и не определялись при применении дозы 15 мл.

К прогностически неблагоприятным следует отнести, прежде всего, II 1а и II 16 ПГ реакции, характеризующиеся нарастанием дезорганизации ЭЭГпаттерна за счет недостаточности стволовых активирующих влияний с увеличением спектр-мощности патологической, преимущественно $\delta$-волновой активности. Такие изменения в 1-й группе отмечались после введения 30 мл (33,3 \% реакций II 1а подгруппы), 15 мл (3,3 \% реакций II 1a ПГ и 18,3 \% - II 16 подгруппы) и 20 мл (20\% реакций II 1а ПГ) препарата (табл. 4.10). Следует отметить, что такого рода изменения АCM и ИК выявлены у 4-х больных, умерших в 1-5-е сутки после ОНМК. В группе пациентов с ЧМТ подобные реакции ЦНС были зафиксированы после введения Тиоцетама в дозе 20 мл - 4,9 \% реакций II 1а ПГ и 14,3 \% - II 1 П ПГ — и вдозе 15 мл - 20,6 \% реакций II 16 ПГ (табл. 4.10).

Реакции перераспределения III 1а и III 16 подгрупп, сопровождающиеся ростом медленноволновой активности за счет угнетения $\alpha$-ритма, можно назвать относительно неблагоприятными, так как они с одной стороны отражают умеренные дезорганизационные ЭЭГ-процессы, а с другой - свидетельствуют о формировании фармакологического ответа на корковом уровне, об относительном восстановлении функции нейронов в условиях обширных морфоструктурных постишемических и посттравматических повреждений клеток мозга. Такие изменения ACM и ИК характерны для пациентов с ОНМК при введении 15 мл (18,3 \% - III 1а ПГ и 6,7 \% - III 1 П ПГ реакций), и при введении 20 мл Тиоцетама (20\% и 5 \% , соответственно) (табл. 4.10). После введения 30 мл препарата подобные изменения у больных 1-й группы не выявлены. У исследуемых 2-й группы подобные реакции отмечались после введения 15 мл Тиоцетама (16,8 \% - III 1а ПГ реакций), 20 мл препарата (7,1 \% - III 1б ПГ реакций), 30 мл Тиоцетама (22,2 \% - III 1а ПГ и 11,1 \% - III 16 ПГ реакций).

Преобладание у пациентов с инсультом после введения 20 мл Тиоцетама, а у исследуемых с ЧМТ - после введения 15 мл препарата, прогностически благоприятных (II 2a, III 3а ПГ) и отсутствие неблагоприятных реакций, часто выявляемые изменения, предопределяющие дальнейшую коррекцию дозировки вводимого препарата (III 1a, III 16 и III 3б), позволяют считать 
данные дозы оптимальными исходными для пациентов с ОЦН различного генеза.

Таким образом, оценка ЭЭГ-изменений в ответ на фармакологическое воздействие Тиоцетама с помощью стандартных статистических методов, на наш взгляд, не корректна, так как среднестатистические значения всех исследуемых ЭЭГ-показателей в обеих группах исследуемых пациентов отличаются значительной вариабельностью, которая зависит от многообразия выявленных типов реакций ЦНС. Используя определение типа реактивности ЦНС в ответ на введение Тиоцетама, возможно оценить адекватность применяемой дозы препарата или необходимость ее коррекции у конкретного пациента с ОЦН различного генеза в острейшем периоде заболевания. Адекватной может считаться доза Тиоцетама, после которой выявлены изменения III 2a, III 3a, II 2a и III 2б подгрупп. Фармакологической реакцией, свидетельствующей о необходимости повышения дозы Тиоцетама, следует считать III Зб ПГ изменений. Необходимо уменьшить дозу вплоть, при необходимости, до полной отмены вводимого препарата при изменениях, относящихся к подгруппам II 1a, II 1б, II 2б. Лечебная тактика при выявлении изменений III 1а и III 16 подгрупп может быть следующей: увеличение дозы на 5 мл с обязательной интегральной оценкой ЭЭГ-паттерна после введения препарата. Выбор начальной дозы Тиоцетама у пациентов в острейшем периоде ЧМТ и ОНМК должен быть дифференцированным и проводиться под нейрофизиологическим контролем. 20 мл Тиоцетама является оптимальной начальной дозой для пациентов с ОНМК, 15 мл - для больных с ЧМТ. С помощью полученной классификации были определены критерии выбора оптимальной дозы препарата и тактика коррекции терапии у данной категории пациентов, представленные в таблице 4.11 .

Таблица 4.11

\section{Критерии выбора оптимальной дозы Тиоцетама}

\begin{tabular}{|c|c|c|c|c|c|}
\hline $\begin{array}{c}\text { Оптимальная } \\
\text { доза препа- } \\
\text { рата }\end{array}$ & $\begin{array}{c}\text { Степень дезор- } \\
\text { ганизации ЭЭг }\end{array}$ & $\begin{array}{c}\text { Уровень } \\
\text { сознания }\end{array}$ & $\begin{array}{c}\text { Исходная доза } \\
\text { препарата }\end{array}$ & $\begin{array}{c}\text { Степень дезор- } \\
\text { ганизации ЭЭГ }\end{array}$ & $\begin{array}{c}\text { Оптимальная } \\
\text { доза препарата }\end{array}$ \\
\hline 15 мл & возрастает & $\begin{array}{c}\text { Умеренное } \\
\text { оглушение }\end{array}$ & 25 мл & $\begin{array}{c}\text { Снижается или } \\
\text { стабильна }\end{array}$ & $\begin{array}{c}25 \text { мл } \geq \\
\text { до } 30 \text { мл }\end{array}$ \\
\hline 15 мл & возрастает & $\begin{array}{c}\text { Глубокое } \\
\text { оглшение }\end{array}$ & 20 мл & $\begin{array}{c}\text { Снижается или } \\
\text { стабильна }\end{array}$ & $\begin{array}{c}20 \text { мл } \geq \\
\text { до } 30 \text { мл }\end{array}$ \\
\hline 10 мл & возрастает & сопор & 15 мл & $\begin{array}{c}\text { Снижается или } \\
\text { стабильна }\end{array}$ & $\begin{array}{c}15 \text { мл } \geq \\
\text { до } 30 \text { мл }\end{array}$ \\
\hline 5 мл & возрастает & Кома I & 10 мл & $\begin{array}{c}\text { Снижается или } \\
\text { стабильна }\end{array}$ & $\begin{array}{c}10 \text { мл } \geq \\
\text { до } 20 \text { мл }\end{array}$ \\
\hline отмена & возрастает & Кома II & 5 мл & $\begin{array}{c}\text { Снижается или } \\
\text { стабильна }\end{array}$ & $\begin{array}{c}5 \text { мл } \geq \\
\text { до } 15 \text { мл }\end{array}$ \\
\hline- & Кома III & - & - & - \\
\hline
\end{tabular}


Таким образом, полученные клинико-экспериментальные данные свидетельствуют, что Тиоцетам проникает через гематоэнцефалический барьер и плаценту, в большей степени накапливается в сером веществе головного мозга. Препарат улучшает интегративную и когнитивную деятельность мозга, способствует процессу обучения, улучшает кратковременную и долговременную память, способствует восстановлению структуры и функции нейронов.

\section{2. ЦЦИТИКОлИН}

В последнее время внимание экспериментаторов и клиницистов привлек к себе препарат - Цитиколин (цитидин 5' -дифосфохолин, или ЦДФ-холин) который является соединением, присутствующим во всех клетках человеческого организма. ЦДФ-холин участвует в синтезе фосфатидилхолина - основного мозгового фосфолипида. Цитиколин уменьшает потерю фосфадитилхолина, распадающегося при ишемии головного мозга до жирных кислот и высокотоксичных свободных радикалов. Холин, входящий в состав Цитиколина, служит основой для образования ацетилхолина, дефицит которого в головном мозге во многом обуславливает развитие нарушений памяти и других когнитивных функций [4, 354, 355].

Цитиколин при приеме внутрь хорошо всасывается, его содержание в плазме крови после перорального приема имеет два пика: первый - через 1 ч после приема, второй - через 24 ч. После всасывания препарат распадается на холин и цитидин, которые проникают через гематоэнцефалический барьер и служат основой для образования Цитиколина в веществе головного мозга. Цитиколин выделяется из организма с мочой и при дыхании.

В клинических исследованиях у пациентов с различными заболеваниями нервной системы и добровольцев отмечена безопасность лечения Цитиколином. Анализ побочных эффектов на фоне терапии Цитиколином у 2817 пожилых больных (60-80 лет) показал, что побочные эффекты встречаются сравнительно редко, протекают легко и обычно не требуют отмены лечения. Среди указанных больных зарегистрирован 151 случай проявления побочных эффектов (около 5 \% ): наиболее частыми были периодические боли в желудке или диарея (102 случая), реже наблюдались артериальная гипотензия, брадикардия или тахикардия (16 случаев).

Экспериментальные исследования. При развитии ишемии головного мозга возникает снижение уровня аденозинтрифосфата, что приводит к утечке ионов через клеточные мембраны, деполяризации мембран, высвобождению глутамата и других возбуждающих аминокислот, приводящих к гибели нейронов по механизмам апоптоза и некроза. В экспериментальных исследованиях показано снижение активности участвующих в апоптозе нейронов каспаз и прокаспаз при введении Цитиколина. Цитиколин уменьшает потерю фосфолипидов, снижает образование полиненасыщенных жирных кислот, замедляет процессы перекисного окисления липидов. 
В экспериментальной модели инсульта у крыс изучалось влияние различных доз Цитиколина (100 и 500 мг/кг) в сравнении с плацебо в течение 6 суток. В группе крыс, получавших большие дозы Цитиколина, отмечено уменьшение объема инфаркта, а также уменьшение степени отека головного мозга.

В другом экспериментальном исследовании отмечено улучшение функционального восстановления при длительном ( 28 сут) использовании Цитиколина после развития инсульта.

Показано положительное влияние Цитиколина при его использовании в качестве дополнения к тромболизису в экспериментальной модели эмболического инсульта: размер инфаркта головного мозга был достоверно меньше, а функциональное восстановление было лучше в группах крыс, принимавших как тромболитик, так и Цитиколин в больших дозах (без тромболитика).

В экспериментальной модели эмболического инсульта сравнивалась эффективность Цитиколина, назначаемого до или после введения тромболитика (тканевого активатора плазминогена). Экспериментальные животныебыли разделены на пять групп: 1) контрольная; 2) с применением тромболитика в дозе 5 мг/кг через 30 мин после развития инсульта; 3) с применением Цитиколина по 250 мг/кг через 10 мин, 24 ч и 48 ч после развития инсульта; 4) с применением комбинации тромболитика с Цитиколином, вводимым до тромболитика; 5) комбинация тромболитика с Цитиколином, вводимым через 10 мин после тромболитика. В группе экспериментальных животных, которые получили комбинацию тромболитика (Стрептокиназа) с Цитиколином, вводимым после тромболизиса, установлено снижение частоты смертельных исходов и объема инфаркта головного мозга в сравнении с контрольной группой. При введении Цитиколина до тромболитика не отмечено преимуществ перед применением только тромболитика. Авторы связывают эффективность Цитиколина, введенного после тромболизиса, с обеспечением защиты вещества головного мозга от повреждения, возникающего при реперфузии вследствие тромболизиса.

Положительный результат получен и при использовании Цитиколина в качестве дополнения к другому тромболитику - Урокиназе.

В экспериментальных исследованиях показано, что Цитиколин уменьшает расстройства памяти и поведения животных.

Ишемический инсульт. Цитиколин последние 30 лет активно изучается в качестве нейропротектора. Несколько плацебо-контролируемых исследований в Западной Европе и Японии показали улучшение восстановления неврологических функций у больных, принимающих Цитиколин, в остром периоде ишемического инсульта. Отмечено положительное влияние Цитиколина на память и другие когнитивные функции у больных ишемическим инсультом. В исследованиях с использованием повторных магнитно-резонансных томограмм головного мозга показано уменьшение объема повреждения головного мозга на фоне приема Цитиколина [353-358].

В одном из многоцентровых плацебо-контролируемых исследований (Япония) изучалась эффективность Цитиколина в дозе 1000 мг/сут в течение 14 дней заболевания. 272 больных со средним или тяжелым ишемическим инсультом методом рандомизации были разделены на две группы: 133 пациента 
получали Цитиколин, 139 - плацебо. Результаты исследования показали положительное влияние Цитиколина на уровень сознания у больных с тяжелым инсультом. На 14-й день заболевания существенное улучшение состояния отмечено у 54 \% больных, которых лечили Цитиколином, и только у 29 \% в группе применения плацебо, что свидетельствует о положительном влиянии Цитиколина, назначаемого в первые сутки ишемического инсульта, на восстановление неврологических функций.

Наиболее крупные многоцентровые плацебо-контролируемые двойные слепые исследования эффективности Цитиколина при ишемическом инсульте были проведены в США. В одном из них сравнивалась эффективность различных доз Цитиколина (500, 1000 и 2000 мг/сут) и плацебо у 259 больных ишемическим инсультом. Все больные (65 человек в каждой из групп применения Цитиколина и 64 - в группе принимавших плацебо) получали Цитиколин или плацебо с первых суток заболевания. Лечение продолжалось в течение 6 недель с последующим наблюдением в течение еще 6 недель. Эффективность терапии оценивали по выраженности неврологического дефицита по Американской шкале тяжести инсульта, степень инвалидности - по индексу Бартела и шкале Рэнкина, когнитивные функции - по краткой шкале оценки психического статуса. По всем критериям на 12 -й неделе от начала развития инсульта отмечено улучшение в группе больных, принимавших Цитиколин, в сравнении с пациентами, принимавшими плацебо. Значительная степень восстановления неврологических функций (90 баллов и более по индексу Бартела) через 12 недель от начала развития инсульта (первичная цель исследования) достоверно чаще отмечалась в группе больных, принимавших Цитиколин в дозе 500 и 2000 мг/ сут, в сравнении с группой лиц, получавших плацебо. На основании полученных результатов авторы исследования рекомендовали дозу 500 мг Цитиколина в сутки в течение 6 недель, начиная с первых суток развития ишемического инсульта.

В следующем исследовании сравнивалась эффективность Цитиколина, принимаемого внутрь в дозе 500 мг/сут, и плацебо у 394 больных ишемическим инсультом. В исследование включались пациенты с ишемическим инсультом в бассейне средней мозговой артерии, у которых степень неврологического дефицита составляла 5 и более баллов по Американской шкале оценки тяжести инсульта. В целом не отмечено достоверного улучшения восстановления (по индексу Бартела и Американской шкале оценки тяжести инсульта) у больных, принимавших Цитиколин в течение 6 недель, в сравнении с группой пациентов, получавших плацебо, через 12 недель от начала развития инсульта. В определенной степени это могло быть обусловлено тем, что в группе применения плацебо оказались больные с исходно более легкой степенью инсульта (8 и менее баллов по Американской шкале оценки тяжести инсульта имели 22 \% больных в группе лечения и 34 \% больных в группе применения плацебо). Анализ эффективности лечения у больных, имеющих исходно значительную степень неврологического дефицита (8 и более баллов по Американской шкале оценки тяжести инсульта), показал, что очень хорошее восстановление (95 баллов и более по индексу Бартела) чаще встречалось в группе больных, получавших 
Цитиколин (33\%), чем в группе применения плацебо $(\mathrm{p}=0,05)$. Авторы делают вывод: Цитиколин эффективен у больных с умеренной и значительной степенью неврологического дефицита (8 баллов и более по Американской шкале оценки тяжести инсульта).

В еще одном исследовании оценивалась эффективность Цитиколина в дозе 2000 мг/сут (перорально в два приема) у 899 больных ишемическим инсультом в бассейне средней мозговой артерии. Лечение начиналось в первые сутки развития инсульта, продолжаясь в течение 6 недель с последующим наблюдением в течение еще 6 недель. В исследование включались больные, имеющие не менее 8 баллов по Американской шкале тяжести инсульта. Конечной точкой исследования было значительное восстановление неврологических функций (на 7 баллов и более по Американской шкале оценки тяжести инсульта) через 12 недель с момента развития инсульта. В конце лечения значительная степень восстановления установлена у $52 \%$ больных, которых лечили Цитиколином, и у 51 \% больных в группе применения плацебо (различия недостоверны). Однако очень хорошее восстановление (инвалидность по шкале Рэнкина 0-1 балл) достоверно чаще отмечалось в группе больных, принимавших Цитиколин (26\%), чем в группе больных, получавших плацебо (20\% случаев, $\mathrm{p}=0,025)$.

Был проведен анализ эффективности перорального применения Цитиколина на основе результатов нескольких плацебо-контролируемых исследований, в которых оценивались различные дозы Цитиколина $(500,1000$ и 2000 мг (сут) при ишемическом инсульте. В анализ было включено 789 больных, получавших Цитиколин, и 583 больных, получавших плацебо, исходно имевших инсульт средней или тяжелой степени выраженности (8 и более баллов по Американской шкале оценки тяжести инсульта). Значительное восстановление (степень инвалидности по шкале Рэнкина 1 балл или менее, степень инвалидности по шкале Бартела 95 баллов и более, регресс неврологических расстройств на 8 баллов и более по Американской шкале оценки тяжести инсульта) имело место у $25,2 \%$ больных, получавших Цитиколин, и достоверно реже ( $\mathrm{p}=$ $0,003)$ - у 20,2 \% больных - в группе применения плацебо. Наиболее часто $(27,9 \%)$ значительное восстановление наблюдалось у больных, принимавших Цитиколин в дозе 2000 мг/сут. Безопасность перорального применения Цитиколина не отличалась от плацебо. Авторы анализа делают вывод, что пероральное применение Цитиколина повышает вероятность значительного восстановления через 3 месяца с момента развития ишемического инсульта средней или тяжелой степени выраженности.

Положительное влияние Цитиколин оказывает при расстройствах памяти и поведения у пожилых пациентов с хроническими цереброваскулярными заболеваниями. Это заключение сделано на основе анализа результатов 14 исследований, в которых оценивалось влияние Цитиколина на когнитивные функции у пожилых больных, имеющих расстройство памяти вследствие хронических цереброваскулярных заболеваний, умеренное когнитивное расстройство или деменцию сосудистого генеза. В этих исследованиях лечение продолжалось от 20 дней до 12 месяцев (в семи исследованиях - от 20 до 30 дней, 
в одном - до 6 недель, в четырех - от 2 до 3 месяцев, в одном - более 3 месяцев и еще в одном - до 12 месяцев). Отмечена хорошая переносимость Цитиколина у пожилых больных, имеющих когнитивные расстройства.

Кровоизлияние в головной мозг. При кровоизлиянии в головной мозг возникает дополнительная ишемия в области прилежащих к гематоме тканей, что определяет возможность использования нейропротекторов в остром периоде инсульта. В экспериментальных моделях внутримозгового кровоизлияния показано уменьшение отека головного мозга и объема зоны ишемии вокруг гематомы при использовании Цитиколина [353-358].

В недавно проведенном в четырех университетских центрах Испании исследовании отмечен положительный эффект Цитиколина у больных с кровоизлиянием в головной мозг. В двойное слепое плацебо-контролируемое исследование было включено 38 больных в возрасте 40-85 лет, которые были госпитализированы в течение 6 ч после развития первичного кровоизлияния в полушарие головного мозга в области над мозжечковым наметом. Во всех случаях диагноз был подтвержден компьютерной или магнитно-резонансной томографией. У всех больных тяжесть инсульта превышала 8 баллов по шкале комы Глазго, а тяжесть неврологического дефицита была более 7 баллов по Американской шкале оценки тяжести инсульта. Больные в течение 2 недель получали плацебо или Цитиколин (1 г каждые 12 ч перорально, если больной мог самостоятельно глотать, или внутривенно). Эффективность определяли по степени инвалидности больных, оцениваемой через 3 месяца по модифицированной шкале Рэнкина. Среди больных, получавших Цитиколин, через 3 месяца 5 пациентов не нуждались в посторонней помощи (степень инвалидности по шкале Рэнкина менее 2 баллов), в то время как среди больных, получавших плацебо, - только один. Частота серьезных нежелательных явлений в двух группах больных была одинакова (у 4 больных в каждой группе). Полученные данные указывают на эффективность и безопасность применения Цитиколина при кровоизлиянии в головной мозг, но требуют подтверждения в более крупном многоцентровом исследовании.

У пожилых пациентов, перенесших кровоизлияние в мозг и имеющих расстройства памяти, отмечено, что применение Цитиколина в дозе 500 и 1000 мг/сут, а также в комбинации с Нимодипином (90 мг/сут), улучшает способность к запоминанию слов и предметов при их кратковременной (в течение 2 сек) демонстрации.

Таким образом, Цитиколин представляет собой лекарственное средство, которое зарегистрировано в нашей стране в качестве нейропротектора для лечения острой стадии инсульта (церебрального инфаркта, или кровоизлияния в мозг). Цитиколин прошел тщательное изучение в экспериментальных и крупных многоцентровых плацебо-контролируемых двойных слепых исследованиях, проведенных в Западной Европе, Японии и США. В экспериментальных исследованиях на животных показано, что Цитиколин уменьшает размеры церебрального инфаркта и увеличивает степень функционального восстановления. В нескольких клинических исследованиях показана эффективность Цитиколина, применяемого внутривенно или перорально, начиная 
с первых суток развития ишемического инсульта или кровоизлияния в мозг, в отношении восстановления неврологических функций. В экспериментальных исследованиях показано: применение Цитиколина после тромболизиса повышает эффективность лечения, что требует подтверждения в клинических многоцентровых плацебо-контролируемых исследованиях. Важно отметить, что имеются данные об эффективности Цитиколина при расстройствах памяти и поведения у пожилых больных, страдающих хроническими цереброваскулярными заболеваниями, расстройствами памяти и поведения. Большое значение для клинической практики имеет убедительно доказанная безопасность применения Цитиколина как при острых, так и при хронических формах цереброваскулярных заболеваний.

Высокую эффективность продемонстрировал Цитоколин в комбинации с Актовегином. Так, сотрудники кафедры анестезиологии, интенсивной терапии и медицины неотложных состояний ФИПО Донецкого национального медицинского университета под руководством члена-корреспондента АМНУ, профессора В. И. Черния показали, что комбинирование лекарственных средств обуславливает синергизм их действия, что позволяет применять сравнительно низкие дозы препаратов с уменьшением их побочных эффектов, а также существенно снизить стоимость лечения пациентов с ОЦН [319].

Обследован 91 больной с ОЦН различного генеза в нейрохирургическом центре Донецкого областного ДОКТМО. В 1-ю группу вошли 42 больных с острым нарушением мозгового кровообращения (ОНМК) (22 мужчины и 20 женщин, в возрасте от 43 до 62 лет), а во 2-ю - 49 пациентов с тяжелой черепномозговой травмой (ТЧМТ) (23 мужчины и 26 женщин, в возрасте от 16 до 52 лет). Летальность в 1-й группе составила $13,04 \%$, а во 2 -й группе - 14,7 \% ( $\mathrm{p}<0,05$ - достоверность различий между группами). Степень неврологического дефицита у больных с ОНМК по Скандинавской шкале инсультов (СШИ) составила 2-12 балов. Глубина коматозного состояния по шкале ком Глазго (ШКГ) в 1-й группе была 7-12 баллов, а во 2-й группе - 4-9 баллов. Исследования проводили до введения препаратов, на фоне максимальной концентрации препаратов в плазме (через 0,5 часа после введения препарата) и после завершения курса лечения. Актовегин вводился внутривенно капельно с первых суток поступления в отделение нейрореанимации в суточной дозе 20-30 мг/кг, Цераксон - в суточной дозе 20-30 мг/кг. Последовательное введение Актовегина и Цераксона применяли у $55(61,4$ \% ) исследуемых (27 пациентов с ОНМК и 28 больных с ЧМТ). У 36 (38,6 \%) пациентов (15 больных с ОНМК, 21 пациент с ЧМТ) Цераксон использовали изолированно (без Актовегина).

Проводили компьютерную томографию и магнитно-резонансную томографию головного мозга, транскраниальную УЗДГ. Регистрация биопотенциалов мозга осуществлялась с помощью нейрофизиологического комплекса, состоящего из 8-канального электроэнцефалографа фирмы Medicor, персонального компьютера IBM РC AT с аналогово-цифровым преобразователем и специальным программным обеспечением «Brain mapping» .

Изучались показатели абсолютной мощности (AМ, мкВ $/ \sqrt{\Gamma ц})$, относительной мощности (\%) для $\delta$ - (1-4 Гц), $\theta-(5-7$ Гц), $\alpha-(8-12$ Гц), $\alpha 1-(9-11$ Гц), 
$\beta 1-(13-20$ Гц), $\beta 2-(20-30$ Гц) частотных диапазонов ЭЭГ. Для объективизации оценки ЭЭГ использован метод интегрального количественного анализа ЭЭГпаттерна с применением интегральных коэффициентов (ИК, kfc), которые дают возможность провести оценку спектральной мощности всех частотных диапазонов ЭЭГ и определить значимость отдельных частотных спектров ЭЭГ в формировании целостного паттерна ЭЭГ.

$51(56,04 \%$ ) больной (22 исследуемых с ОНМК и 29 пациентов с ЧМТ) поступил в нейрореанимационное отделение ДОК ТМО в 1-е сутки после травмы или инсульта. При первичном обследовании (табл. 4.12) уровень нарушений сознания пациентов с ОНМК в бассейнах правой или левой среднемозговых артерий характеризовался как сопор, кома I, что соответствовало 9-12 баллам по шкале ком Глазго (ШКГ) и предопределяло выраженную дезорганизацию ЭЭГ-паттерна: по классификации Жирмунской-Лосева (кл. ЖЛ) преобладал IV дезорганизованный тип с преобладанием $\alpha$-активности. У пациентов с ишемическим инсультом в вертебробазилярном бассейне состояние сознания определялось как кома I-II, что соответствовало 7-11 баллам по ШКГ и сопровождалось значительными изменениями ЭЭГ-паттерна: IV тип и V дезорганизованный тип с преобладанием $\theta$ - и $\delta$-активности по кл. ЖЖЛ. Наиболее выраженный неврологический дефицит выявлен у больных с ЧМТ $-4-9$ баллов по ШКГ, что предопределяло наиболее значимые ЭЭГ-изменения.

Таблица 4.12.

\section{Результаты клинико-неврологического и ЭЭГ-исследований у пациентов с ОНМК и тяжелой ЧМТ при поступлении в отделение}

\begin{tabular}{|c|c|c|c|c|c|}
\hline $\begin{array}{c}\text { оцН } \\
\text { (генез) }\end{array}$ & $\begin{array}{c}\text { ШКГ \# } \\
\text { (баллы) }\end{array}$ & $\begin{array}{l}\text { Сши х } \\
\text { (баллы) }\end{array}$ & Тип ЭэГ * & $\begin{array}{c}\text { Среднее групп ээг1, } \\
\text { ди 95\% }\end{array}$ & $\begin{array}{l}\text { Состояние } \\
\text { сознания }\end{array}$ \\
\hline ИИ БПСМА & 9-12 & $6-12$ & IV & $\begin{array}{c}15,8 \\
15,4-16\end{array}$ & Сопор, кома I \\
\hline ИИ БЛСМА & $9-12$ & $6-12$ & IV-V & $\begin{array}{c}16,7 \\
15,9-17,4 \\
\end{array}$ & Сопор, кома I \\
\hline ИИ ВББ & $7-11$ & $2-8$ & V & $\begin{array}{c}17,8, \\
17-18,6\end{array}$ & Кома I-II \\
\hline ЧМТ & $4-9$ & - & V & $\begin{array}{c}18,6 \\
17,4-19,6\end{array}$ & Сопор, кома I-ІІ \\
\hline
\end{tabular}

\# - шкала ком Глазго;

- Скандинавская шкала инсультов;

* - тип ЭЭГ по классификации Жирмунской-Лосева;

1 - группа ЭЭГ по классификации Жирмунской-Лосева.

Наиболее выраженные отличия уровней интегральных коэффициентов (ИК) от значений контрольной группы «идеальная норма» определялись у пациентов с ЧМТ (рис. 4.3г). Выявлен максимальный $(\mathrm{p}<0,05)$ рост уровней - в $12-15$ раз - 9-го $\mathrm{kfc}(\delta / \alpha)$, в 7,8-8,6 раза -7 -го $\mathrm{kfc}(\theta / \alpha)$, в $5,8-5,9$ раза -1 -го kfc $((\delta+\theta+\beta 1) /(\alpha+\beta 2))$, при снижении $(\mathrm{p}<0,05)$ на $36,2-47,9 \%$ показателей 6 -го $\mathrm{kfc}(\theta / \delta)$ в обеих гемисферах. У больных с ишемическим ин- 
сультом в вертебробазилярном бассейне (рис. 4.3) также определялись значительный рост $(\mathrm{p}<0,05) 9$-го kfc - в 4-6 раз, 1 -го kfс и 2 -го $((\delta+\theta) /(\alpha+\beta 1+\beta 2))$ $\mathrm{kfc}$ - в 2,6-3,3 раза, больше в левом полушарии, и билатеральное уменьшение $(\mathrm{p}<0,05)$ 6-го kfc на 34-40\%. У пациентов с ИИ в бассейнах правой и левой CMA (рис. 4.3а-4.3б) максимальное увеличение $(\mathrm{p}<0,05)$, в 3,6-5,9 раза, уровней 9 -го $\mathrm{kfc}(\delta / \alpha)$ и 7-го kfc $(\theta / \alpha)$ зафиксировано в «интактных» полушариях, в пораженной гемисфере выявлен умеренный рост $(\mathrm{p}<0,05)$ в 2,5-2,9 раза 1-го $\mathrm{kfc}$ при снижении на 38-43\% 6-го kfc.

a)

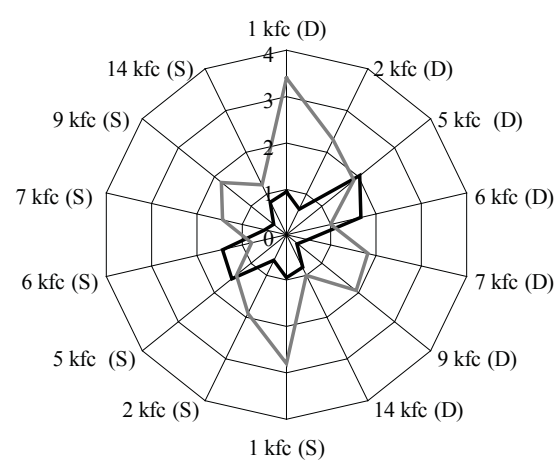

$-\mathrm{K} \Gamma$

в)

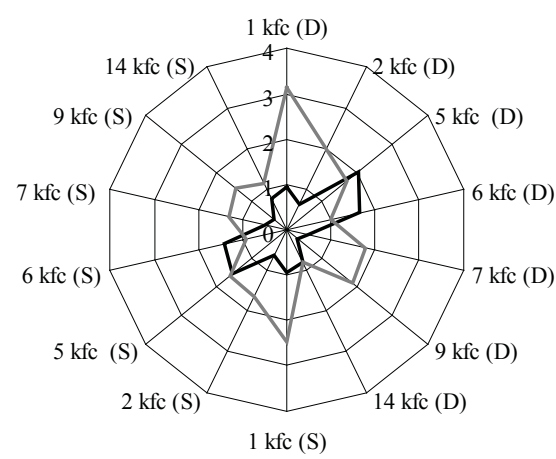

$-\mathrm{K \Gamma}$ б)

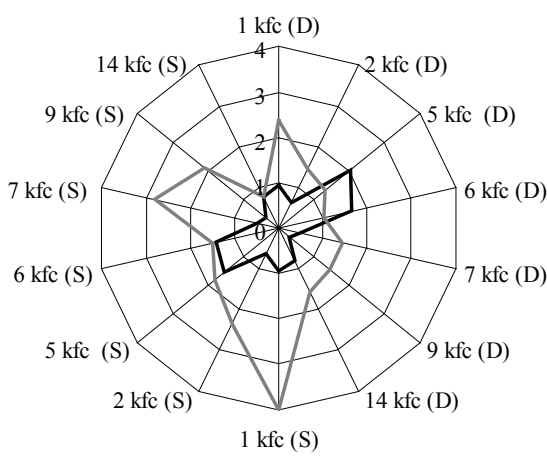

$-\mathrm{K} \Gamma$

— ИИ БПСМА

г)

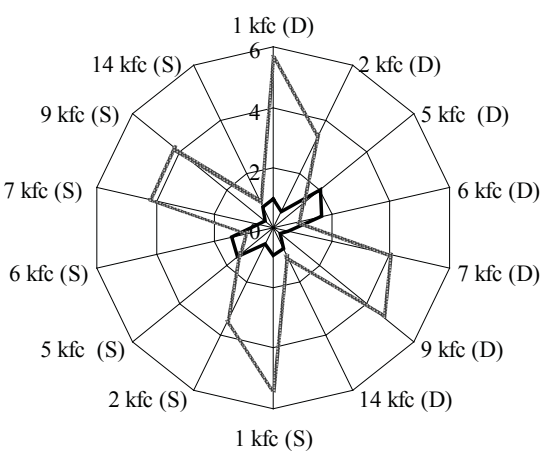

ImT

Puc. 4.3. Уровни интегральных коэффициентов (kfc) в правом (D) и левом (S) полушариях в группах с ишемическим (a) левополушарным инсультом (ИИ БЛСМА), (б) правополушарным инсультом (ИИ БПСМА), (в) вертебробазилярным инсультом (ИИ ВББ), (г) черепно-мозговой травмой (ЧМТ)

На основании классификации типов реакций ЦНС на фармакологическое воздействие у данной категории больных выявлено 11 подгрупп реакций (ПГР) ЦНС, относящихся к 3 основным типам. 
Таблииа 4.13

\section{Изменения ЭЭГ-показателей - типы реакций ЦНС - у пациентов ОЦН в ответ на введение препарата Актовегин}

\begin{tabular}{|c|c|c|c|}
\hline Варианты реакции ЦНС & Симметричные & Асимметричные & Всего исследований \\
\hline $\mathbf{n}$ & 31 (62 реакции) & 24 (48 реакций) & 55 (110 реакций) \\
\hline Отсутствие изменений & & І тип 6/48 (12,5%) & І тип 6/110 (5,5%) \\
\hline $\begin{array}{l}\text { Рост дезорганизации } \\
\text { ЭЭГ-паттерна }\end{array}$ & III 1a 12/62 (19,3 \%) & $\begin{array}{c}\text { II 1a 10/48 (20,8 \%) } \\
\text { II 16 8/48 (16,7\%) } \\
\text { III 1a } 3 / 48(6,3 \%) \\
\text { III 16 1/48 (2,1\%) }\end{array}$ & $\begin{array}{c}\text { II 1a 10/110 (9\%) } \\
\text { II 16 8/110 (7,2\%) } \\
\text { III 1a 15/110 (13,6\%) } \\
\text { III 16 1/110 (0,9\%) }\end{array}$ \\
\hline $\begin{array}{l}\text { Снижение дезорганиза- } \\
\text { ции ЭЭГ-паттерна }\end{array}$ & $\begin{array}{l}\text { III 2a 20/62 (32,3\%) } \\
\text { III 3a 10/62 (16,1\%) }\end{array}$ & III 2a 5/48 (10,4 \%) & $\begin{array}{c}\text { III 2a 25/110 (22,7 \%) } \\
\text { III 3a 10/110 (9\%) }\end{array}$ \\
\hline $\begin{array}{l}\text { «ипореактивные» изме- } \\
\text { нения }\end{array}$ & III 3 20/62 (32,3 \%) & III 3 15/48 (31,3 \%) & III Зб 35/110 (31,8 \%) \\
\hline
\end{tabular}

Введение Актовегина характеризовалось формированием двух вариантов «ответа» ЦНС (табл.4.13). У 31 пациента - 1-я подгруппа (14 пациентов с ОНМК и 17 больных с ЧМТ), получавших Актовегин, симметрично, в обеих гемисферах, определялись реакции III типа, с перераспределением ЭЭГ-мощности. Преобладали реакции подгрупп III 2а $(22,7$ \% всех ЭЭГизменений), с активацией мощности альфа- и $\beta 2$-диапазонов (нормальных ритмов ЭЭГ) за счет редукции дельта-активности, и III 3б $(31,8 \%$ всех ЭЭГ изменений), с увеличением $\beta 2$-мощности за счет редукции патологического дельта-ритма.

У 24 пациентов - 2-я подгруппа (13 пациентов с ОНМК и 11 больных с ЧМТ) в ответ на введение Актовегина выявлены асимметричные реакции ЦНС (табл. 4.13). Интересно, что у этих пациентов преобладали реакции II типа (37,5 \% всех реакций в данной подгруппе) - подгрупп II 1a (рост CM преимущественно за счет увеличения $\mathrm{ACM}$ медленноволновых патологических дельта- и тета-диапазонов с умеренной активацией альфа-ритма) и II $1 б$ (увеличение CM за счет повышения ACM дельта-, тета- и $\beta 2$-активности при стабильности показателей альфа-диапазона), отражающие снижение активирующих подкорковых влияний на кору головного мозга.

У двоих пациентов с ИИ ВББ и у четверых с ЧМТ асимметрично зафиксирована реакция ЦНС I типа, т. е. отсутствие достоверных изменений $\mathrm{ACM}$ и ИК в ответ на введение Актовегина. Доминирующим вариантом ответа ЦНС на введение Актовегина являлась так называемая гипоэргическая реакция III 3б, выявляемая в 31,8 \% случаев, как билатерально, так и асимметрично. 
a)

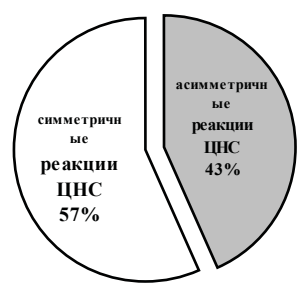

б)

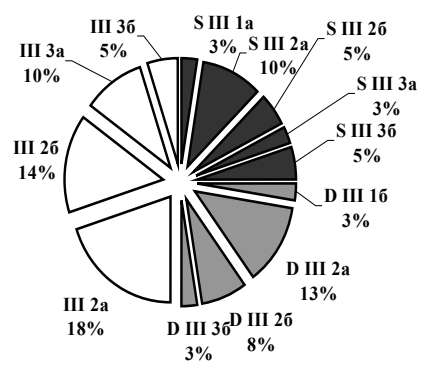

B)

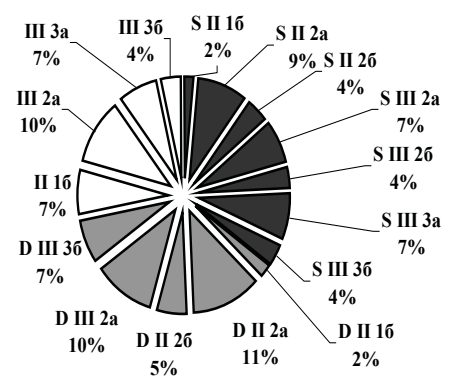

Puc. 4.4. Варианты асимметричных реакций в левой (S) и правой (D) гемисферах головного мозга и симметричных реакций ЦНС (а) при введении

Цераксона (на фоне Актовегина) в 1-й (б) и 2-й (в) подгруппах пациентов с острой церебральной недостаточностью различного генеза

Таблица 4.14

Изменения ЭЭГ-показателей - типы реакций ЦНС у пациентов ОЦН в ответ на введение препарата Цераксон

\begin{tabular}{|c|c|c|c|}
\hline Варианты реакции цНС & $\begin{array}{l}\text { 1-я подгруппа } \\
\text { (Актовегин } \\
\text { +Цераксон) }\end{array}$ & $\begin{array}{l}\text { 2-я подгруппа } \\
\text { (Актовегин } \\
\text { +Цераксон) }\end{array}$ & $\begin{array}{c}\text { Цераксон } \\
\text { без Актовегина }\end{array}$ \\
\hline $\mathrm{n}$ & 31 (62 реакции) & 24 (48 реакций) & 36 (72 реакции) \\
\hline Отсутствие изменений & - & - & - \\
\hline $\begin{array}{l}\text { Рост дезорганизации } \\
\text { ЭЭГ-паттерна }\end{array}$ & $\begin{array}{l}\text { III 1a 4/62 (6,5\%) } \\
\text { III 16 4/62 (6,5\%) }\end{array}$ & II $164 / 48(8,3 \%)$ & $\begin{array}{l}\text { II 1a 4/72 (5,5\%) } \\
\text { II 16 3/72 (4,2\%) } \\
\text { III 1a 7/72 (9,7\%) } \\
\text { III 1б 5/72 (6,9\%) }\end{array}$ \\
\hline $\begin{array}{l}\text { Снижение } \\
\text { дезорганизации ЭЭГ- } \\
\text { паттерна }\end{array}$ & $\begin{array}{c}\text { III 2a 22/62 (35,5\%) } \\
\text { III 26 15/62 (24,2\%) } \\
\text { III 3a 9/62 (14,5\%) }\end{array}$ & $\begin{array}{c}\text { II 2a 11/48 (22,9\%) } \\
\text { II 2б 2/48 (4,2\%) } \\
\text { III 2a 14/48 (29,2\%) } \\
\text { III 26 2/48 (4,2\%) } \\
\text { III 3a 8/48 (16,6\%) }\end{array}$ & $\begin{array}{c}\text { III 2a 14/72 (19,4\%) } \\
\text { III } 26 \text { 6/72 (8,3\%) } \\
\text { III 3a 12/72 (16,6\%) }\end{array}$ \\
\hline $\begin{array}{l}\text { «Гипореактивные» } \\
\text { изменения }\end{array}$ & III Зб 8/62 (12,9 \%) & III Зб 7/48 (14,6 \%) & III 36 21/72 (29,2 \%) \\
\hline
\end{tabular}


Применение Цераксона через 30 минут после Актовегина у 31 пациента 1-й подгруппы вызвало следующие варианты ответа: почти 47 \% реакций ЦНС, выявленных у 15 пациентов (рис. 4.4б), были симметричными и относились к реакциям перераспределения мощности. Среди асимметричных реакций (рис. 4.4б) также определялись только изменения ЭЭГ, относящиеся к III типу. Преобладающими вариантами фармакоответа являлись: реакция III 2 а подгруппы (35,5 \% ) со снижением уровня дезорганизации ЭЭГ-паттерна за счет активации $\alpha$ - и высокочастотного $\beta$-ритмов, снижение уровней $\mathrm{kfc} 1$-го, 2 -го, 5-го ( $\beta 1 / \beta 2), 7$-го, и наиболее выраженное - kfc 9-го ИК одновременно с ростом 14-го, и реакция III $26(24,2 \%)$ - перераспределение ЭЭГ-мощности с увеличением $\alpha$-активности за счет синхронной редукции высокочастотного $\beta 2$ - и «патологического» дельта-ритмов, умеренное снижение kfc 7-10-го ИК, тенденция к росту kfc 5-го и значительное увеличение уровня 15 -го $(\alpha / \beta 2)$. Такие варианты «фармакоответа» свидетельствуют о том, что доза вводимого нейропротектора была оптимальной, эффективной. Только у четверых пациентов данной подгруппы последовательное применение Актовегина и Цераксона вызвало так называемые условно благоприятные реакции ЦНС, характеризующиеся активацией медленноволновых, патологических ЭЭГ-ритмов: левополушарные III 1a (6,5 \% всех реакций) и правосторонние III 1a (6,5 \% ) ПГ. Такие варианты фармакоответа являются показанием для коррекции дозы применяемого нейропротектора.

У 24 пациентов - 2-я подгруппа - после последовательного применения Актовегина и Цераксона (рис. 4.4в, табл. 4.13), симметричные реакции ЦНС отмечались только в 28 \% случаев. Наиболее часто встречающимися среди них были «прогностически благоприятные» III 2a (10\%) и III 3а (7 \% ) подгруппы изменений ЭЭГ. У 13 пациентов данной подгруппы асимметричные реакции относились к II $2 \mathrm{a}$ (20\% всех изменений ЭЭГ) и II $26(9 \%)$ ПГ. Они характеризовались уменьшением CM за счет: а) угнетения медленноволновых $\delta$ - и $\theta$-ритмов с умеренной редукцией $\alpha$-активности с уменьшением уровней 1-4-го и увеличением 6-го ИК (II 2a подгруппа); б) снижения мощности всех частотных ЭЭГ-диапазонов с максимальным угнетением $\beta 2$-активности и ростом 5-го и 15 -го ИК (II 26 ПГ). Такие варианты фармакоответа свидетельствуют об активации подкорковых влияний на кору, о реализации фармакологической реакции на стволовом уровне и относятся к благоприятным реакциям ЦНС. Из реакций перераспределения мощности (III типа) доминировали реакции III 2 а подгруппы - 29,2 \% всех ЭЭГ-изменений.

У 36 пациентов введение Цераксона без Актовегина (табл. 4.14) характеризовалось вариабельностью фармакологических ответов - выявлены реакции ЦНС, относящиеся к 8 подгруппам, в то время как сочетанное введение Актовегина и Цераксона характеризовалось формированием 4-6-и подгрупп реакций ЦНС. Преобладали асимметричные реакции, преимущественно III типа, среди которых доминировали гипореактивные III 3б реакции 29,2 \% всех ЭЭГ-изменений. Такие ЭЭГ-изменения являются показанием для увеличения дозы применяемого нейротропного препарата. 
Суммируя вышеизложенное, следует подчеркнуть, что сочетанное применение Актовегина и Цераксона вызывало преимущественно изменения ЭЭГпаттерна, которые мы относим к благоприятным реакциям ЦНС. У 31 исследуемого 1-й подгруппы такие варианты фармакоответа определялись в 74,2 \%, у 24 пациентов 2-й подгруппы - в 77,1 \% случаев. Реакции III 2а подгруппы были доминирующими и выявлялись в 1-й и 2-й подгруппах (табл. 4.14) в 35,5 \% и 29,2 \% случаев, соответственно. Если Цераксон применялся отдельно (табл. 4.14), то реакции ЦНС со снижением дезорганизации ЭЭГ-паттерна составляли 44,3\% всех ЭЭГ-изменений.

Как при сочетанном с Актовегином, так и при изолированном применении Цераксона не выявлен I тип реакции ЦНС, то есть, отсутствие достоверных изменений показателей абсолютной спектральной мощности и интегральных коэффициентов. Биохимические реакции, протекающие на мембранах и внутриклеточно, которые лежат в основе главных эффектов Цераксона, являются энергопотребляющими, то есть, для их реализации необходимо достаточное количество прежде всего высокоэнергетических фосфатов, внутриклеточных энергоносителей. Актовегин, в силу своих возможностей стимулировать образование молекул АТФ, активизировать проникновение в клетку и утилизацию глюкозы - основного энергетического субстрата клеток ЦНС - обеспечивает необходимое количество внутриклеточной энергии для полноценной реализации эффектов Цитиколина (Цераксона). Таким образом, более эффективным является применение Цераксона вместе с Актовегином у пациентов с церебральной недостаточностью различной этиологии. Но включение нейропротекторов в комплекс интенсивной терапии в острой фазе ОНМК и ЧМТ предусматривает обязательное проведение мониторинга неврологического статуса, мозгового кровообращения и фармакомониторирование с помощью количественного анализа ЭЭГ. На основании результатов исследования рекомендуемыми оптимальными дозировками Актовегина и Цераксона при их совместном (последовательном) применении у пациентов с ОЦН в зависимости от степени нарушения сознания (табл. 4.15) являются:

Таблица 4.15

\section{Рекомендуемая коррекция доз Актовегина и Цераксона} у пациентов с ОЦН

\begin{tabular}{|c|c|c|c|c|c|}
\hline $\begin{array}{c}\text { Оптимальная } \\
\text { доза препа- } \\
\text { рата }\end{array}$ & $\begin{array}{c}\text { Степень } \\
\text { дезоргани- } \\
\text { зации ЭЭГ }\end{array}$ & $\begin{array}{l}\text { Уровень } \\
\text { сознания }\end{array}$ & $\begin{array}{c}\text { Исходная } \\
\text { доза пре- } \\
\text { парата }\end{array}$ & $\begin{array}{l}\text { Степень дезор- } \\
\text { ганизации ЭЭГ }\end{array}$ & $\begin{array}{c}\text { Оптимальная } \\
\text { доза препа- } \\
\text { рата }\end{array}$ \\
\hline $\begin{array}{l}1000 \mathrm{Mr}^{\mathrm{A}}+ \\
500 \mathrm{mr}^{4}\end{array}$ & возрастает & $\begin{array}{l}\text { Умеренное } \\
\text { оглушение }\end{array}$ & $\begin{array}{l}1000 \mathrm{Mr}^{\mathrm{A}}+ \\
500 \mathrm{Mr}^{\mathrm{L}}\end{array}$ & $\begin{array}{l}\text { Снижается или } \\
\text { стабильна }\end{array}$ & $\begin{array}{l}1000 \mathrm{Mr}^{\mathrm{A}}+ \\
1000 \mathrm{Mr}^{4}\end{array}$ \\
\hline $\begin{array}{l}1000 \mathrm{Mr}^{\mathrm{A}}+ \\
500 \mathrm{Mr}^{4}\end{array}$ & возрастает & $\begin{array}{l}\text { Глубокое } \\
\text { оглушение }\end{array}$ & $\begin{array}{l}1000 \mathrm{Mr}^{\mathrm{A}}+ \\
1000 \mathrm{Mr}^{Ц}\end{array}$ & $\begin{array}{l}\text { Снижается или } \\
\text { стабильна }\end{array}$ & $\begin{array}{l}1000 \mathrm{Mr}^{\mathrm{A}}+ \\
2000 \mathrm{Mr}^{Ц}\end{array}$ \\
\hline $\begin{array}{l}2000 \mathrm{Mr}^{\mathrm{A}}+ \\
500 \mathrm{Mr}^{Ц}\end{array}$ & возрастает & сопор & $\begin{array}{l}2000 \mathrm{Mr}^{\mathrm{A}}+ \\
1000 \mathrm{Mr}^{Ц}\end{array}$ & $\begin{array}{l}\text { Снижается или } \\
\text { стабильна }\end{array}$ & $\begin{array}{l}2000 \mathrm{Mr} \\
{ }^{\mathrm{A}}+2000 \mathrm{Mr}^{4}\end{array}$ \\
\hline
\end{tabular}


Продолжение табл.4.15

\begin{tabular}{|c|c|c|c|c|c|}
\hline $\begin{array}{c}\text { Оптимальная } \\
\text { доза препа- } \\
\text { рата }\end{array}$ & $\begin{array}{c}\text { Степень } \\
\text { дезоргани- } \\
\text { зации ЭЭГ }\end{array}$ & $\begin{array}{l}\text { Уровень } \\
\text { сознания }\end{array}$ & $\begin{array}{l}\text { Исходная } \\
\text { доза пре-- } \\
\text { парата }\end{array}$ & $\begin{array}{l}\text { Степень дезор- } \\
\text { ганизации ЭЭГ }\end{array}$ & $\begin{array}{c}\text { Оптимальная } \\
\text { доза препа- } \\
\text { рата }\end{array}$ \\
\hline $\begin{array}{l}2000 \mathrm{Mr}^{\mathrm{A}}+ \\
1000 \mathrm{Mr}^{4}\end{array}$ & возрастает & Кома I & $\begin{array}{l}2000 \mathrm{Mr}^{\mathrm{A}}+ \\
2000 \mathrm{Mr}^{4}\end{array}$ & $\begin{array}{l}\text { Снижается или } \\
\text { стабильна }\end{array}$ & $\begin{array}{l}2000 \mathrm{Mr}^{\mathrm{A}}+ \\
2000 \mathrm{Mr}^{4}\end{array}$ \\
\hline $\begin{array}{l}1000 \text { мг }^{\mathrm{A}}+ \\
500 \mathrm{Mr}^{4} \\
\text { или отмена }\end{array}$ & возрастает & Кома II & $\begin{array}{l}2000 \mathrm{Mr}^{\mathrm{A}}+ \\
2000 \mathrm{Mr}^{4}\end{array}$ & $\begin{array}{l}\text { Снижается или } \\
\text { стабильна }\end{array}$ & $\begin{array}{l}2000 \mathrm{Mr}^{\mathrm{A}}+ \\
2000 \mathrm{Mr}^{4}\end{array}$ \\
\hline $\begin{array}{l}1000 \text { мг }^{\mathrm{A}}+ \\
500 \text { мг }^{4} \\
\text { или отмена }\end{array}$ & возрастает & Кома III & $\begin{array}{l}2000 \mathrm{Mr}^{\mathrm{A}}+ \\
2000 \mathrm{mr}^{4}\end{array}$ & Стабильна & $\begin{array}{l}2000 \mathrm{Mr}^{\mathrm{A}}+ \\
2000 \mathrm{Mr}^{4}\end{array}$ \\
\hline
\end{tabular}

Несмотря на определенные успехи, достигнутые в лечении мозговых инсультов, эта проблема остается все еще достаточно актуальной. Арсенал современных средств церебропротекции не соответствует требованиям современной медицины. Если говорить конкретно о современных церебропротекторах, то они не всегда оказывают терапевтическую эффективность в условиях клиники, имеют ряд побочных эффектов при длительном применении.

\section{3. ФЕНОТРОПИЛ}

Среди циклических производных ГАМК по выраженности ноотропной активности несомненный интерес представляет фенильное производное рацетамового ряда Фенотропил (N-карбамоил-метил-4-фенил-2-пирролидон).

Фенотропил является новым оригинальным высокоэффективным ноотропным препаратом и обладает широким спектром сопутствующих компонентов фармакологической активности. По спектру действия и широте терапевтических доз он не имеет аналогов в отечественной и зарубежной фармакологии, при этом эффекты препарата зависят от дозы и исходного состояния обследуемого [359-370].

Так, в эксперименте нами проводилось изучение психо- и нейротропных эффектов и определение безопасности препарата. Было выявлено, что Фенотропил обладает выраженной антиамнестической активностью в дозах 6-750 мг/кг, оказывает прямое активирующее влияние на интегративные функции мозга, улучшает обменные процессы и регионарный кровоток в ишемизированных участках мозга, восстанавливает речь и двигательную активность при их нарушении, а в дозах 100-750 мг/кг обладает выраженной противогипоксической, противосудорожной и анксиолитической активностью. Психостимулирующее действие проявляется умеренно выраженным эффектом в отношении двига- 
тельной активности, повышением физической работоспособности, выраженным антагонизмом каталептическому действию нейролептиков, ослаблением выраженности снотворного действия этанола и гексенала. Фенотропил противодействует фенаминовой токсичности, повышает порог болевой чувствительности и порог агрессии. Препарат обладает мягким диуретическим действием. Отмечено значительное снижение массы тела на фоне курсового применения. Выявлена выраженная антидепрессивная активность без побочных реакций, присущих антидепрессантам, отмечено улучшение зрения и обоняния, обострение вкуса, улучшение периферического кровообращения, повышение сексуальной потенции. Препарат малотоксичен, легко проникает через гематоэнцефалический барьер, его эффекты развиваются с однократного приема. Фенотропил не обладает эмбриотоксичностью, мутагенными и канцерогенными свойствами. В экспериментах на животных снижает рост спонтанных злокачественных опухолей. Фенотропил не вызывает привыкания, зависимости и синдрома отмены [367-380].

Был проведен ряд исследований на мышах и крысах, в которых изучались различные виды фармакологической активности Фенотропила.

Проводилось двойное слепое сравнительное изучение адаптогенного и антистрессорного влияния нескольких ноотропных препаратов на крысах в различных экстремальных условиях [367-380]. Использовались три модели экспериментального стресса, получившие условные названия болевого, эмоциогенного и антиортостатического стресса. В качестве препаратов сравнения были взяты Пирацетам, Фенотропил, Пантогам (гопантеновая кислота), Фенибут и его изомеры, Пиридитол (пиритинол). Контролем являлись интактные животные, находившиеся в тех же экспериментальных условиях и получавшие физиологический раствор. Показателем эффективности препаратов служил защитный индекс, который вычислялся как разница между поражением слизистой оболочки желудка в контрольной группе и аналогичным показателем в группе животных, получавших вышеуказанные препараты. Максимальный защитный индекс мог быть равен единице, а нулевое значение индекса указывало на отсутствие эффекта. По результатам исследования наибольший защитный эффект при эмоциогенном стрессе оказывали Пирацетам, Фенотропил, Фенибут, Пантогам и Пиридитол (защитный индекс составил, соответственно, $1,0,0,99,0,89,0,87$ и 0,70$)$; при болевом стрессе - Фенибут, Фенотропил, Пирацетам, Пиридитол, Пантогам (защитный индекс составил, соответственно, $0,76,0,72,0,65,0,62,0,58)$; при антиортостатическом стрессе - Фенотропил, Фенибут, Пиридитол, Пирацетам, Пантогам (защитный индекс составил, соответственно, 1,0, 0,99, 0,56, $0,52,0,50)$. Видно, что Фенотропил и Фенибут высокоактивны при моделях любого стресса. Изучалось также влияние перечисленных ноотропных препаратов на уровень кортизола в крови. Было выявлено, что на фоне применения Фенотропила содержание кортизола в крови было достоверно ниже, чем в группе с физиологическим раствором, тогда как в группе Пирацетама в дозе 200 мг/кг уровень кортизола превышал показатели во всех исследуемых группах в $1,5-2$ раза. 
В другом исследовании изучалось влияние Пирацетама и Фенотропила на обменные процессы [187-189]. В процессе испытания сравнивались влияния препаратов на выработку условного рефлекса пассивного избегания у крыс при амнезии, вызванной максимальным электросудорожным шоком, скополамином и коразолом (антиамнестическая активность), оценивалась антигипоксическая активность (на различных моделях гипоксии), сравнивались влияния на двигательную активность (психостимулирующий эффект), противонаркотический эффект (для этанола), противосудорожная активность (судорожные агенты: бикукулин, коразол, кофеин, тиосемикарбазид, пикротоксин и электрошок). По результатам ноотропный эффект Фенотропила выявляется уже в дозе 3,0 мг/кг, при этом антиамнестическое действие Фенотропила в дозах 25-100 мг/кг превышает действие Пирацетама в дозах 300-1200 мг/кг в 12,5-40 раз. Фенотропил (50-300 мг/кг) высокоэффективен при всех видах гипоксии (Пирацетам проявляет некоторое антигипоксическое действие только в условиях гипобарической гипоксии, начиная с дозы 200 мг/кг). Фенотропил предупреждает развитие судорог и предотвращает гибель животных от них. В дозах 25-250 мг/кг Фенотропил повышает двигательную активность в первые 5-10 мин исследования на 8-18 \% , в следующие 15-20 мин двигательная активность снижается и становится даже несколько ниже таковой в контрольной группе. Фенотропил стимулирует окислительно-восстановительные процессы, увеличивая утилизацию глюкозы, повышает энергетический потенциал за счет ускорения оборота АТФ, повышает активность аденилатциклазы и глутаматдекарбоксилазы, усиливает синтез ядерной РНК. В дозах 100-300 мг/кг увеличивает содержание ДА, НА и серотонина (5-ОТ), практически не влияет на содержание ГАМК. Таким образом, Фенотропил является высокоэффективным ноотропным препаратом, значительно превосходящим по активности Пирацетам. При этом Фенотропил, в отличие от Пирацетама, обладает выраженной антигипоксической и противосудорожной активностью.

Возможности применения Фенотропила у здоровых лиц. Краснов В. Н. и соавт. изучали эффективность краткосрочного (до 10 дней) применения Фенотропила у 32 человек [377-380]. При этом использовались астенический, когнитивный, аффективный и психовегетативный разделы клиникопсихопатологической карты, шкала общего клинического впечатления. Наблюдения были разделены на 2 группы: 1) практически здоровые, испытывавшие астенические и субклинические аффективные (тревожно-депрессивные) и психовегетативные нарушения; 2) бывшие участники ликвидации последствий аварии на ЧАЭС с умеренно выраженным психоорганическим синдромом. У пациентов 2-й группы дополнительно проводилось нейропсихологическое исследование. При применении Фенотропила в дозах 200-400 мг/сут в течение 10 дней в обеих группах было выявлено активирующее действие с нормализацией вегетативной регуляции, повышением устойчивости к интенсивным физическим нагрузкам и эмоциональному напряжению, повышением успешности выполнения интеллектуальных задач с регистрируемым повышением уровня внимания, оперативной памяти, темповых и скоростных характеристик интеллектуальной деятельности. Отмечено умеренное снижение 
потребности в еде и сне, единичные эпизоды тревоги (компенсируемой в деятельности), также единичные нарушения засыпания, связанные с применением препарата позднее 15-16 часов. При десятидневном курсе применения более устойчивое положительное влияние, в частности на когнитивные функции, Фенотропил оказывал в 1-й группе наблюдения. Эффекты Фенотропила проявлялись с однократно применяемой дозы.

Применение Фенотропила в качестве корректора функционального состояния рекомендуется в дозе 100 мг однократно лицам, чья профессиональная деятельность связана с большими психическими и физическими нагрузками. Препарат прошел клиническую апробацию у лиц, работающих в напряженных, экстремальных условиях с разработкой схем применения препарата [379]. Использовались комплексные психологические и психофизиологические методы оценки динамики психического состояния у 57 мужчин в экстремальных условиях деятельности на фоне приема Фенотропила (50-500 мг/сут) в течение двухнедельного курса лечения. В наибольшей степени редукции были подвержены астеноневротический, астенический и астенодепрессивный синдромы. Первые отчетливые признаки наблюдались уже на 2-й день терапии, а в экстремальных условиях деятельности через 5-6 часов после однократного перорального приема. Если при наличии выраженной патологии дозы Фенотропила, вне зависимости от характера расстройств, были практически одинаковыми и варьировали лишь с учетом индивидуальных особенностей динамики состояния, то при менее выраженных нарушениях психической деятельности требовался более дифференцированный подбор доз. Так, в случае астеноневротического характера нарушений дозы Фенотропила при умеренно выраженных астенических расстройствах были менее высоки и составляли 50-200 мг/сут, а в случае астенодепрессивных проявлений для успешной коррекции состояния было необходимо более длительное лечение с применением 100-500 мг/сут. Фенотропил не увеличивал времени реакции и улучшал координацию движений. Кроме того, препарат имел благоприятный профиль переносимости. По результатам клинической апробации выраженное положительное влияние Фенотропила на психофизический статус пациентов наблюдалось при использовании его как сразу после экстремальных воздействий в остром периоде психических нарушений, так и в период проявления остаточных реакций.

Малюгин В. Н. и соавт. изучали влияние Фенотропила в различной дозировке на показатели физической и психической работоспособности людей, находящихся в привычных условиях учебно-тренировочной деятельности [380]. Группа практически здоровых мужчин получала однократно перед началом учебно-тренировочных занятий Фенотропил в дозе 100 мг, 200 мг или плацебо. Для исследования умственной работоспособности применялись 4 компьютеризованных теста: 1 - «перепутанные линии» (концентрация и устойчивость внимания); 2 - «отыскивание чисел» (способность к распределению внимания и устойчивости); 3 - «сортировка слов» (скорость переработки зрительной вербальной информации, а также темповая характеристика психических процессов); 4 - «запоминание» (исследование кратковременной памяти на вербальную информацию). Для исследования физической ра- 
ботоспособности испытуемых проводилась велоэргометрия (проба PWC-170), оценивались показатели абсолютной и относительной физической работоспособности. В исследовании показано повышение среднегрупповых значений показателей психической и физической работоспособности после интенсивной учебно-тренировочной нагрузки по сравнению с фоном, в частности повысились значения следующих показателей: концентрации и устойчивости внимания, способности к распределению внимания и его устойчивости, функциональной подвижности нервных процессов, кратковременной памяти, абсолютной и относительной физической работоспособности. Таким образом, Фенотропил способствует повышению интеллектуально-мнестической функции мозга. Выраженность воздействия на динамику психологических и физиологических показателей у практически здоровых лиц была выше при приеме 100 мг/сут Фенотропила, чем 200 мг/сут.

Влияние Фенотропила на устойчивость авиационных специалистов к гипоксии для сокращения продолжительности курса гипокситерапии изучали Разсолов Н. А. и соавт. в другом клиническом плацебо-контролируемом исследовании, в котором наблюдались пилоты и представители наземных профессий [193]. Критерием окончания формирования адаптации к гипоксии считали увеличение продолжительности дыхания гипоксической смесью до снижения парциального давления кислорода артериализированной крови в 2 раза на протяжении от первого цикла дыхания к третьему. Исследования проводили до и через 60 минут после приема Фенотропила в дозе 100 мг. У лиц летного состава и наземных профессий в начале курса лечения продолжительность дыхания гипоксической газовой смесью до снижения парциального давления кислорода на $50 \%$ составляла $2,8+0,3$ мин., а через 60 минут после приема препарата увеличивалась до $3,3+0,19$ минут $(\mathrm{p}<0,05)$. Применение плацебо не выявило такой динамики. Для формирования адаптации к гипоксии у пилотов потребовалось 10-11 сеансов, а у лиц наземных профессий - 14-15. При использовании плацебо средняя продолжительность курса лечения составляла у пилотов $18-20$, а у лиц наземных профессий - 25-28 сеансов. В исследовании было продемонстрировано, что Фенотропил оказывает защитный эффект при однократном приеме и ускоряет развитие адаптации к гипоксии при курсовом лечении. Это может быть использовано в клинической практике для сокращения сроков гипоксической терапии, а также для защиты лиц от повреждающего действия гипоксического фактора.

Португалов С. Н. и соавт. проводили сравнительное плацебоконтролируемое исследование Фенотропила, Сиднокарба и плацебо у спортсменов, имеющих большие физические и психоэмоциональные нагрузки [194]. Препараты применялись однократно в течение 3-х дней. Эффективность оценивали по гребному эргономическому тесту, по плавательному ступенчатому тесту, методом жидкостной газовой хроматографии и хромато-массспектрометрии, по биохимическим анализам (лактат, мочевина, глюкоза, 17 ОКС), по субъективной самооценке. Однократное применение Фенотропила повышало физическую работоспособность на 4-6 \% по сравнению с плацебо и на 2-4 \% по сравнению с Сиднокарбом. Применение Фенотропила в течение 
3-х дней сохраняло высокий уровень работоспособности и закрепляло достигнутые результаты. Фенотропил не оказывал влияния на гормональный профиль спортсменов. Применение Фенотропила существенно повышало резервы коры надпочечников, что свидетельствует о его стресс-протекторном действии. Побочных реакций на однократное и курсовое применение не обнаружено. Значительно улучшалось качество сна при сокращении его длительности, при пробуждении спортсмены отмечали чувство бодрости и хорошее настроение. Фенотропил не вызывал побочных отрицательных эффектов, присущих психостимуляторам (раздражительность, чувство внутренней напряженности, беспокойство, головная боль, опустошенность). Субъективно на фоне приема Фенотропила спортсмены отмечали прилив тепла, комфортность, уверенность в себе, отсутствие тревоги, отсутствие утомления, некоторое улучшение зрения.

Использование Фенотропила с лечебными целями. $K$ настоящему времени накоплен положительный опыт использования Фенотропила у лиц с различными заболеваниями ЦНС: ишемический инсульт в остром периоде, раннем восстановительном периоде, позднем восстановительном периоде, при дисциркуляторной энцефалопатии и при наличии начальных проявлений недостаточности мозгового кровообращения, в остром периоде черепно-мозговой травмы (ЧМТ) и при последствиях перенесенной ЧМТ, при астениях различного генеза [373-379].

Вельская Г. Н. и соавт. изучали эффективность Фенотропила у 42 больных в остром периоде инфаркта мозга легкой и средней степени тяжести [195]. Больные были разделены на две группы: основная (30 человек) помимо базисной терапии получала Фенотропил 100 мг/сут., контрольная (12 человек) помимо базисной терапии получала Пирацетам 1600 мг/сут. Уже на 10-й день лечения в обеих группах отмечались достоверные $(\mathrm{p}<0,05)$ улучшения по двум разделам шкалы Mini Mental State Examination (MMSE): «восприятие» и «память», а в группе Фенотропила - дополнительно по разделу «концентрация внимания и счет». К окончанию курса когнитивные функции по шкале MMSE достоверно $(\mathrm{p}<0,05)$ улучшились в двух подгруппах больных, однако динамика в процентном соотношении в группе Фенотропила была более выраженной, чем в группе Пирацетама ( $+20,2 \%$ и $+15,3 \%$, соответственно). Анализ изменений ЭЭГ показал, что после применения Фенотропила у больных усиливалась регулярность и выраженность альфа-ритма, у некоторых пациентов отмечалась нормализация реактивных показателей ЭЭГ, вследствие чего гипервентиляция не вызывала существенных изменений биоэлектрической активности головного мозга.

Герасимова М. М. и соавт. изучали эффективность Фенотропила у 20 больных в раннем восстановительном периоде мозгового инсульта. По выраженности неврологического дефицита больные были разделены на две подгруппы: с выраженными нарушениями (синдром внутренней капсулы, афазия, эмоционально-волевые расстройства -7 пациентов) и с умеренными нарушениями (пирамидный синдром, нарушения сна - 13 пациентов) [196]. Хороший результат лечения в виде полного восстановления функций и значи- 
тельного регресса неврологической симптоматики к концу месячного курса лечения был получен у 40 \% больных первой и у 85 \% больных второй подгрупп, удовлетворительный результат (уменьшение выраженности неврологической симптоматики) - у 50 \% и $15 \%$ больных, соответственно. Помимо этого, под влиянием лечения было выявлено достоверное $(\mathrm{p}<0,05)$ снижение уровня антител к общему белку миелину (на 33,9 \% ) и к фосфолипидам (на 6,7 \% ).

Савченко А. Ю. и соавт. при лечении 30 больных в позднем восстановительном периоде ишемического инсульта (через 1-3 года после инсульта) назначали Фенотропил в дозе 200 мг в сутки [368]. На фоне приема Фенотропила отмечена достоверная ( $<0,05)$ положительная динамика неврологических проявлений: уменьшение парезов и параличей, нарушения чувствительности, координации, высших мозговых функций. Когнитивные функции по шкале MMSE улучшились $(\mathrm{p}<0,05)$ с 12,12 $\pm 1,06$ до 16,36 $\pm 1,11$ баллов. Было выявлено улучшение $(\mathrm{p}<0,05)$ показателей качества жизни по шкале EuroQol-5D: мобильность (с 2,02 $\pm 0,18$ до $1,44 \pm 0,15$ баллов), самообслуживание (с 1,96 \pm 0,14 до $1,31+0,12$ баллов), бытовая активность (с 2,30 $\pm 0,18$ до 1,61 \pm 0,17 баллов), тревога (с $2,75 \pm 0,28$ до $1,74 \pm 0,15$ баллов).

Применение Фенотропила в терапии дисциркуляторных энцефалопатий открывает новые перспективы социально-трудовой реабилитации этого контингента больных. Спасенков Б. А. и соавт. [370] провели сравнительное изучение влияния Фенотропила на оптимизацию терапии дисциркуляторной энцефалопатии. Исследование проводилось в течение двух лет. Пациенты получали комплексную терапию с Пирацетамом или с Фенотропилом в течение 21 дня два раза в год. Применялись общеклинические и лабораторные методы, а также мониторный контроль. С первых дней эффективность лечения оценивалась более высоко пациентами, получавшими Фенотропил, чем пациентами, получавшими Пирацетам. Больные группы Фенотропила отмечали появление чувства «ясной головы", уменьшение жалоб на головные боли, (особенно лобновисочной локализации). Положительные эффекты увеличивались к концу 3-й недели. Показатель теста Лурия достоверно увеличивался у всех пациентов. Улучшалась координация движений, снижались проявления вестибулярных расстройств. Положительная динамика общего состояния больных группы Фенотропила на 85 \% превышала таковую у больных группы Пирацетама. На фоне Фенотропила у большинства больных улучшался сон, исчезли приступы депрессивного аффекта. У больных, наблюдавшихся в течение 2-х лет, на фоне приема Фенотропила (2 курса в год) состояние оставалось стабильным.

Густов А. В. и соавт. провели сравнительное исследование 50 пациентов с дисциркуляторной энцефалопатией I и II стадии с умеренными когнитивными нарушениями [198]. Больные были разделены на 2 однородные по составу группы - основную и группу сравнения. В основной группе прием Фенотропила внутрь в дозе 200 мг/сут начинался в стационаре, а затем продолжался амбулаторно. Пациенты группы сравнения в стационарных условиях получали традиционную терапию, затем амбулаторно продолжали прием Пирацетама по 1,2 г/сутки. Нейропсихологическое тестирование, неврологический и соматический осмотр проводились перед приемом препарата, через 15 и 30 дней 
терапии. Для оценки когнитивных функций были выбраны наиболее информативные тесты: вербальные ассоциации, повторение цифр, тест «10 слов», тест узнавания рисунков, проба на реципрокную координацию. В основной группе произошло достоверное улучшение показателей по всем тестам в конце лечения, а по некоторым - уже через 15 дней терапии Фенотропилом. Отмечалось также достоверное повышение речевой активности больных в основной группе: до лечения $-10,48 \pm 0,67$ баллов; через 15 дней $-12,37 \pm 0,70$ баллов; в конце лечения $-14,83 \pm 0,99$ баллов $(\mathrm{p}<0,05)$, чего не наблюдалось в группе сравнения. У пациентов, принимавших Фенотропил, увеличилось также количество запоминаемых слов в тесте «10 слов» по сравнению с исходными показателями; цифр в тесте на повторение цифр, повысилось количество узнанных рисунков. В группе сравнения достоверное отличие от показателей до лечения было лишь в тесте повторения цифр.

Как известно, самым ранним проявлением сосудистой церебральной патологии (еще до возникновения инсульта и клинически выраженной дисциркуляторной энцефалопатии) являются начальные проявления недостаточности мозгового кровообращения (НПНМК), критериями наличия которого являются повторяющиеся минимум один раз в неделю в течение минимум трех месяцев головная боль, головокружение, шум в голове, снижение памяти, снижение работоспособности (необходимо не менее двух из вышеперечисленных признаков). Известно, что нарастающие проявления НПНМК ведут к развитию следующей стадии - дисциркуляторной энцефалопатии, поэтому очень важно своевременно выявлять таких пациентов и корректировать проявления недостаточности мозгового кровообращения. Селянина Н. В. и соавт. провели исследование эффективности Фенотропила у 20 больных с НПНМК в возрасте от 40 до 50 лет [204]. Препарат назначался по 100 мг/сут в течение 30 дней. После проведенного курса лечения у пациентов уменьшились жалобы астенического плана: значительно снизились утомляемость, физическая усталость, в меньшей степени - тревога, раздражительность, исчезли головные боли. Показатели астении по шкале астении MFI-20 достоверно $(\mathrm{p}<0,01)$ снизились до уровня нормы, составив в среднем по группе $10,5 \pm 1,2$ баллов. Результаты тестирования по таблицам Шульте показали достоверное $(\mathrm{p}<0,01)$ уменьшение времени отыскивания чисел (с $32,1 \pm 3,3$ с до $24,3 \pm 2,8$ с). Показатели вегетативной дистонии по субъективной оценке пациентов (по вопроснику) и объективного статуса (по схеме) достоверно ( $<0,01)$ уменьшились. Качество жизни по визуально-аналоговой шкале улучшилось с $62 \%$ до 74,4 \% .

Калинский П. П. и соавт. проводили сравнительное изучение эффективности Фенотропила в дозе 100 мг (23 пациента) и стандартной ноотропной терапии (20 пациентов) в остром периоде ЧМТ [200]. Было выявлено, что к 7 -му дню в группе Фенотропила все пациенты отметили уменьшение астении, утомления, одновременно появилось чувство бодрости, активности, исчезла дневная сонливость и улучшился фон настроения. Незначительная головная боль сохранялась только у 8 человек (35\%). К этому же периоду у 11 человек (55\%) контрольной группы сохранялись жалобы астенического характера и умеренные вегетативные проявления. К 14-му дню терапии только у 4 человек (17 \% ), 
принимавших Фенотропил, сохранялись легкие жалобы астенического характера. К этому же периоду астенические проявления в контрольной группе сохранялись у 7 человек (35\%).

Одинак М. М. и соавт. изучали эффективность Фенотропила и Пирацетама при лечении последствий ЧМТ [373]. В исследование были включены две группы больных по 24 человека с различной давностью ЧМТ. Одна группа пациентов получала Пирацетам по 400 мг два раза в день, а другая — Фенотропил по 50 и 100 мг дважды в день. Курс лечения составлял 30 дней. Проводились субъективная оценка состояния, оценка динамики микроочаговых симптомов, нейрокартирование и транскраниальная ультразвуковая допплерография. Фенотропил по сравнению с Пирацетамом оказывал более выраженный положительный эффект, особенно в дозе 100 мг. Улучшение наступало уже на 3-4-й день и наиболее выраженно проявлялось у больных с астеническим синдромом. Большинство пациентов на фоне Фенотропила отмечали прилив сил, улучшение настроения, зрения. Хороший эффект отмечался у 58,3 \% больных в группе Фенотропила и 33,3 \% в группе Пирацетама, удовлетворительный эффект в $33,3 \%$ и 50 \% случаев, соответственно, а неудовлетворительный — в 8,4\% и $16,7 \%$ случаев, соответственно.

Федин А. И. и соавт. провели сравнительное плацебо-контролируемое исследование эффективности Фенотропила и Пирацетама у больных с астеническим синдромом и синдромом хронической усталости [379]. Все больные были разделены на три группы: получавшие Фенотропил в дозе 200-250 мг в сутки (68 человек), получавшие Пирацетам в дозе 1200 мг в сутки (65 человек), получавшие плацебо (47 человек). Длительность лечения составила 4 недели. Показатели оперативной памяти, оцениваемые с помощью ряда нейропсихологических методик (тест Лурия «запоминание 10 слов», таблицы Шульте), у больных в группе Фенотропила значительно превосходили аналогичные показатели при лечении Пирацетамом и плацебо (р < 0,05). Эффективность Фенотропила после курса лечения астенического синдрома и синдрома хронической усталости составила 83,3 \% (30 больных) и 87,5 \% (28 больных), соответственно. В то же время после курса лечения Пирацетамом хороший и удовлетворительный эффект был отмечен в 48,8 \% (22 пациента) при астеническом синдроме и в 55 \% (38 пациентов) при синдроме хронической усталости. На фоне применения плацебо у больных с обоими синдромами полного регресса жалоб и нормализации объективных показателей достигнуто не было.

В другом плацебо-контролируемом исследовании больные с астеническим синдромом психогенного генеза получали монотерапию Фенотропилом по 100 мг два раза в день или плацебо в течение 30 дней [206]. Проводились стандартное клинико-физиологическое исследование с учетом интенсивности основных жалоб по ступенчатой шкале и количественная оценка вегетативных расстройств (баллированный опросник; количественная оценка астенических расстройств). Средние показатели в группе, получавшей Фенотропил, значительно улучшились уже на 7-й день терапии. После курса лечения все показатели сохранялись на высоком уровне, значительно снизился уровень вегетативных расстройств, существенно отличаясь от соответствующих показателей 
в группе плацебо. В группе плацебо на 7-й день несколько увеличился показатель «самочувствие», но после курсового лечения наблюдалось его снижение. Средняя субъективная оценка эффективности лечения в группе Фенотропила практически в 2 раза превышала этот показатель в группе плацебо. Побочные эффекты у пациентов не наблюдались. В группе Фенотропила пациенты уже с первого дня лечения отмечали повышение работоспособности, улучшение настроения, прилив сил.

Подтвержден эффект малых доз Фенотропила в общесоматической практике[380]. Так, у 96 больных с такими заболеваниями, как вегетососудистая дистония, отдаленные последствия ЧМТ, снижение мнестико-интеллектуальных функций, цереброастеническая и астенодепрессивная симптоматика, гипертоническая болезнь с отчетливым астеническим симптомокомплексом, проводилась монотерапия Фенотропилом в течение 4 недель с титрованием суточной дозы от 12 до 100 мг. Эффекты Фенотропила в дозах 12,5-25 мг проявлялись с 3-го дня приема, а в дозах 50-100 мг - уже с 1-го дня. На фоне терапии улучшалось настроение, появлялась бодрость, уверенность, улучшалась память, адекватность реагирования, уменьшались или полностью исчезали головокружения, головная боль, усталость, разбитость, утомляемость, улучшался сон и сокращалась его продолжительность в среднем на 2 часа, корректировалось кровяное давление до нормы или снижалось на 10-20 мм. рт. ст., значительно повышались показатели психической и физической работоспособности. К 7-му дню терапии полностью исчезали проявления депрессивного симптомокомплекса.

Фенотропил в качестве ноотропного препарата оказывает положительный эффект также у лиц, страдающих хроническим алкоголизмом. Ивапец Н. Н. и соавт. изучали эффективность Фенотропила в постабстинентном синдроме и в период ремиссии [208]. Больные со II-III стадиями алкоголизма (соответственно, с выраженным «синдромом лишения», менее выраженным «синдромом лишения» или «в состоянии ремиссии») получали Фенотропил по 100 мг 1 или 2 раза в сутки в течение 3-14 дней. В большинстве случаев $(87,5 \%$ от общего числа) уже с 1-го дня приема проявлялись активирующий и ноотропный эффекты препарата, повышалось настроение, ускорялся темп мышления, уменьшались вялость, слабость, утомляемость. На фоне приема Фенотропила больные чувствовали себя более бодрыми и активными, снижалась раздражительность. Астенические и интеллектуально-мнестические расстройства уменьшались в зависимости от дня терапии. Более эффективной дозой у больных 3 -й группы являлась доза 50 и 100 мг при однократном применении в утренние часы. Эйфоризирующего эффекта на фоне применения Фенотропила не наблюдалось ни в одном случае. Стимулирующий эффект Фенотропила более выраженно проявлялся в дозе 50 мг в некотором увеличении двигательной активности. Во всех дозах препарат сокращал длительность ночного сна. Применение Фенотропила повышало потребность реализации деятельности, что необходимо учитывать при проведении терапии.

Фенотропил является эффективным и безопасным лекарственным средством ноотропной группы и может быть использован при широком круге асте- 
нических состояний от легких (физиогенная астения) до глубоких, витальных астенических состояний эндогенного генеза. Наилучшие результаты отмечались при лечении больных с органическими заболеваниями головного мозга различного генеза. Оценка эффективности Фенотропила у больных с органическими заболеваниями ЦНС различного генеза, при неврозах и неврозоподобных состояниях, шизофрении и циклотимии проводилась у 50 пациентов с длительностью заболевания 1-10 лет. Монотерапия Фенотропилом на фоне отмены предшествующего лечения проводилась в дозе 150-500 мг два раза в день в течение месяца. Состояние больных оценивалась клинико-описательным методом с применением квантифированной системы оценки: фон, на 3-й, 7-й, 14-й, 21-й и 30-й дни терапии. Фенотропил оказывал положительное воздействие на астеническую симптоматику, преимущественно у больных с органическим заболеванием головного мозга, оказывал влияние на интеллектуальномнестическую сферу, усиливал мощность среднечастотного $\alpha$-ритма в полоce 8,8-10,6 Гц. Выявлен отчетливый психоактивирующий эффект в первые 14 дней терапии. Сочетание ноотропного, психоактивирующего, вегетотропного и адаптогенного эффектов определяет своеобразие действия препарата. Стимулирующий эффект Фенотропила сопоставим с таковым у психостимуляторов, однако Фенотропил лишен нежелательных явлений, присущих психостимуляторам (развитие зависимости, толерантности, синдрома отмены и т. д.), и проявляет нормоэнергезирующий эффект [370-380].

В результате применения Фенотропила у людей как с признаками заболевания, так и здоровых наблюдались следующие эффекты:

- улучшение интегративной деятельности мозга, повышение работоспособности;

- улучшение кратковременной и долговременной памяти, способности к обучению, внимания и интеллектуальной активности;

- повышение устойчивости к воздействию различных агрессивных, экстремальных факторов: стресс, гипоксия, травмы, интоксикации (алкоголь и др.), шок и др.;

- повышение социальной адаптации и качества жизни.

- При наличии патологии ЦНС, помимо вышеперечисленных эффектов, Фенотропилу свойственны следующие:

- коррекция вегетативных нарушений;

- психоактивирующее и нормоэнергетизирующее влияние при астении без эйфоризации, без развития зависимости и синдрома отмены;

- быстрый и значительный регресс имеющейся очаговой неврологической симптоматики. 


\section{4. НЕЙРОТРОФИЧЕСКИЕ ЦЕРЕБРОПРОТЕКТОРЫ — КОРТЕКСИН, ЦЕРЕБРОКУРИН И ЦЕРЕБРОЛИЗИН. МИТОТРОПНЫЕ МЕХАНИЗМЫ НЕЙРОПРОТЕКЦИИ}

В последнее время активно ведется поиск высокоэффективных нейропротекторов среди нейропептидов [393-399]. Новым направлением в исследовании нейропептидов стало определение их роли в регуляции нейроапоптоза, а также их влияния на экспрессию генов раннего реагирования. Наряду с данными, свидетельствующими об участии вазоактивного пептида эндотелина-1 и его рецепторов (ETA) в ишемической патологии мозга, получена информация об антиапоптотической активности этого пептида. На ряде моделей нейроапоптоза было также продемонстрировано защитное действие кальцитонинового нейропептида (CGRP) и пептидного фрагмента ангиотензина IV. B то же время было установлено, что сам ангиотензин II, также как и пептид кальцийнейрин, напротив, способствует индукции проапоптотического каскада. Эти факты, демонстрирующие значимость нейропептидов и ростовых факторов в нормальной и патологической деятельности мозга, отражают организацию поливариантной системы химической регуляции, обеспечивающей как жизнеспособность и защиту нейронов от неблагоприятных влияний, так и программируемую гибель определенной части клеточной популяции в случае повреждения мозга [399]. Открытие нейротрофических пептидных факторов побудило к формированию новой стратегии фармакотерапии - пептидергической, или нейротрофной терапии нейродегенеративных патологий. Исходная идеология связывает нейродегенеративные патологии, включая болезнь Альцгеймера, с активностью различных нейротрофических факторов мозга и нейропептидов. На этой основе был разработан ряд препаратов, успешно применяемых в терапии большого спектра неврологических расстройств. Наибольший успех здесь выпал на долю Цереброкурина, Кортексина, Семакса, которые уже в течение последнего десятка лет успешно используются в клинике неврологических и психиатрических заболеваний. Нейропептиды свободно проникают через гематоэнцефалический барьер и оказывают многостороннее действие на ЦНС, что сопровождается высокой эффективностью и выраженной направленностью действия при условии их очень малой концентрации в организме. Кроме того, нейропептиды могут применяться как для первичной, так и для вторичной нейропротекции, что обуславливает их особое место среди других нейропротективных средств [394]. Тесная взаимосвязь всех отдаленных последствий ишемии, а также общность их триггерных механизмов позволяют наряду с локальным воздействием на них использовать модулирующие влияния через системы регуляторов, осуществляющих контроль за экспрессией вторичных клеточных мессенджеров, цитокинов и других сигнальных молекул, а также за запуском генетических программ апоптоза, антиапоптозной защиты, усиления нейротрофического обеспечения. Такие регуляторные (модуляторные) влияния устраняют общую дезинтеграцию во взаимодействии сложных и часто разнонаправленных молекулярнобиохимических механизмов, восстанавливая их нормальный баланс. Особо 
важную роль играют эндогенные регуляторы функций ЦНС - нейропептиды [399]. Их молекулы, представляющие собой короткие аминокислотные цепи, «нарезаются» из более крупных белковых молекул-предшественников ферментами протеолиза (процессинг) лишь «в нужном месте и в нужное время» в зависимости от потребностей организма. Нейропептиды существуют всего несколько секунд, но длительность их действия может измеряться часами. Эндогенное образование нейропептида в ответ на какое-либо изменение внутренней среды приводит к высвобождению ряда других пептидов, для которых первый является индуктором. Если их совместное действие однонаправлено, эффект будет суммированным и продолжительным. Выход пептида может регулироваться несколькими регуляторными пептидами предыдущего каскада. Таким образом, эффекторная последовательность совокупности пептидов образует так называемый пептидный регуляторный континуум, особенность которого заключается в том, что каждый из регуляторных пептидов способен индуцировать или ингибировать выход ряда других пептидов. В результате, первичные эффекты того или иного пептида могут развиваться во времени в виде цепных и каскадных процессов [393-396].

Особенностью структуры нейропептидов является наличие нескольких лигандных групп связывания, предназначенных для разных клеточных рецепторов. Это одно из «молекулярных объяснений» присущей им полифункциональности. Физиологическая активность нейропептидов во много раз превышает аналогичное действие непептидных соединений. В зависимости от места их высвобождения нейропептиды могут осуществлять медиаторную функцию (передачу сигнала от одной клетки к другой); модулировать реактивность определенных групп нейронов; стимулировать или тормозить выброс гормонов; регулировать тканевой метаболизм или выполнять функцию эффекторных физиологически активных агентов (вазомоторная, $\mathrm{Na}^{+}$-уретическая и другие виды регуляции). Известно, что нейропептиды способны регулировать активность про- и противовоспалительных цитокинов через модуляцию активности их рецепторов. При этом восстановление нормального баланса цитокинов происходит более эффективно, чем при воздействии на отдельные цитокиновые системы. Как правило, «цитокиновые» эффекты нейропептидов сопровождаются их влиянием на генерацию оксида азота и другие оксидантные процессы [400]. Многие нейропептиды проявляют выраженные нейротрофические ростовые свойства, а также проявляют способность регулировать экспрессию ранних генов. С учетом того, что нейропептиды легко проникают через гематоэнцефалический барьер (в отличие от полипептидных цепей факторов роста), трудно переоценить их потенциальную терапевтическую значимость.

Одним из первых препаратов нейропептидной природы является Кортексин, который содержит комплекс нейропептидов (адекватное, гармонично сбалансированное соотношение L-аминокислот, витаминов и микроэлементов для нормального функционирования нейронов). Молекулярная масса (в среднем 7 кДа) позволяет препарату проникать через гематоэнцефалический барьер и исключает любую возможность попадания в организм прионной инфекции [400]. Микроэлементы (цинк, марганец, селен, медь, магний и др., содержащи- 
еся в препарате, играют важную роль в жизни нейронов и формировании механизмов нейропротекции, участвуют в поддержании активности более 1000 внутриклеточных белков и ферментов, регулирующих процессы клеточной динамики и нейроапоптоза (табл. 4.16; табл. 4.17). Так, цинк - эссенциальный микроэлемент, влияющий на стабилизацию функции ряда рецепторов (NMDA, GABA, DOPA, ацетилхолиновых). Его дефицит или избыток вызывает преждевременный дефицит нейронов. Вместе с тем, цинк может выступать кофактором многочисленных нейропротекторов, облегчая их проникновение через гематоэнцефалический барьер (ГЭБ), и аффинитет связывания с рецепторамимишенями. Литий способствует торможению высвобождения эксайтотоксичных аминокислот глутамата и аспартата. Нейрохимические эффекты селена связаны с торможением апоптоза, активацией синтеза селензависимой глутаминопероксидазы и стимуляцией ангиогенеза. Терапевтическая концентрация марганца в ЦНС стимулирует синтез митохондриальной марганцезависимой супероксиддисмутазы, участвующей в инактивации супероксид-аниона. Активность многих транспортных и ферментативных систем нейрона связана с магнием, кроме того, он стабилизирует клеточные мембраны нейронов, оказывает седативный эффект на ЦНС.

Наряду с эффектами, обусловленными непосредственным влиянием нейропептидов и L-аминокислот, входящих в состав Кортексина, препарат участвует в регуляции металлолигандного гомеостаза в ЦНС.

Таблица 4.16

\section{Амсинокислотный (нмоль/мг) и витаминный (мкг/10 мг) состав Кортексина}

\begin{tabular}{|l|c|}
\hline L-аминокислоты & \\
\hline Аспарагиновая кислота & 446 \\
\hline Треонин & 212 \\
\hline Серин & 268 \\
\hline Глутаминовая кислота & 581 \\
\hline Пролин & 187 \\
\hline Глицин & 298 \\
\hline Аланин & 346 \\
\hline Валин & 240 \\
\hline Метионин & 0 \\
\hline Изолейцин & 356 \\
\hline Тирозин & 109 \\
\hline Фенилаланин & 162 \\
\hline Гистидин & 116 \\
\hline
\end{tabular}


Продолжение табл. 4.16

\begin{tabular}{|l|c|}
\hline L-аминокислоты (продолжение) \\
\hline Лизин & 253 \\
\hline Аргинин & 202 \\
\hline Витамины & \\
\hline Тиамин (В1) & 0,08 \\
\hline Рибофлавин (В2) & 0,03 \\
\hline Ниацин (РP) & 0,05 \\
\hline Ретинол (А) & 0,011 \\
\hline$\alpha$-токоферол (Е) & 0,007 \\
\hline
\end{tabular}

Таблииа 4.17

Кортексин - минеральные вещества (мкг/10мг)

\begin{tabular}{|l|c|}
\hline Медь & 0.2129 \\
\hline Железо & 2,26 \\
\hline Кальций & 22,93 \\
\hline Магний & 8,5 \\
\hline Калий & 19,83 \\
\hline Натрий & 643,2 \\
\hline Сера & 152,65 \\
\hline Фосфор & 91,95 \\
\hline Цинк & 4,73 \\
\hline Молибден & 0,0203 \\
\hline Кобальт & 0,0044 \\
\hline Марганец & 0,0061 \\
\hline Селен & 0,0745 \\
\hline Алюминий & 0,3104 \\
\hline Литий & 0,0340 \\
\hline
\end{tabular}

Аминокислотный спектр препарата представлен глутаминовой, аспарагиновой кислотами, глицином и др., которые являются L-формами, то есть левовращающимися молекулярными структурами, чем отличаются от аминокислот, синтезированных химическим путем (правовращающимися). Указанные особенности пространственного поведения аминокислот Кортексина позволяют им легче встраиваться в общий ритм метаболизма нейрона (что и обеспечивает биодоступность препарата). Баланс, существующий в Кортексине между 
возбуждающими аминокислотами-нейромедиаторами (глутаминовая кислота, глутамин, аспартат) и тормозными (глицин, таурин, фрагменты ГАМК, серин), определяет эффект снижения мышечного тонуса при патологии верхнего мотонейрона.

Препарат обладает высокой тропностью ко всем отделам головного мозга, эффективен в комплексе лечебных мероприятий, применяемых при нарушениях периферической нервной системы. Нейрометаболитотропные, нейропротекторные, ноотропные и противосудорожные свойства Кортексина позволили широко использовать его как в неврологии, нейрохирургии, психиатрии, так и в офтальмологии, особенно в тех случаях, когда имеющиеся патологические состояния сетчатки и других отделов глаза оказывают негативное воздействие на функцию зрительного нерва [400-406].

Мощное многофункциональное органотропное и регулирующее воздействие Кортексина на важнейшие структуры головного мозга и нервной системы при минимальной фармакологической нагрузке (пациент получает за 10 дневный курс всего 100 мг пептидов) проявляется как при лечении новорожденных, детских контингентов, взрослых, пожилых и старческих пациентов, так и практически здоровых лиц, связанных с высокоэмоциональной и напряженной деятельностью нервной системы в осложненных условиях и в стрессситуациях [329, 330].

Достаточно высокую ноотропную и церебропротективную активность продемонстрировал нейропептидный препарат - Селакс АКТГ(4-10), представляющий собой гептапептид (Met-Glu-His-Phe-Pro-Gly-Pro), и являющийся первым российским ноотропным препаратом неистощающего типа ?активности [407-412]. При интраназальном введении Семакс через 4 мин проникает через гематоэнцефалический барьер; период его полураспада в организме несколько минут, а терапевтическое действие при однократном введении продолжается 20-24 ч.

Пролонгирование действия Семакса связано с его последовательной деградацией, при которой большая часть эффектов нейропептида сохраняется у его фрагментов EHFPGP (Glu-His-Phe-Pro-Gly-Pro) и HFPGP (His-Phe-ProGly-Pro), также являющихся стабильными нейропептидами, самостоятельно модулирующими холинергическую нейротрансмиссию и генерацию оксида азота. В экспериментах на культуре ткани продемонстрировано мощное трофотропное действие препарата на нейроны холинергической группы, как в полной среде, так и в неблагоприятных условиях, обусловленных депривацией глюкозы и кислорода. При добавлении Семакса в дозе 100 нМ и 10 мкМ выживаемость нейронов достоверно повышалась примерно в 2 раза, что было сопоставимо с аналогичным эффектом NGF. Предварительные экспериментальные данные показывают, что рецепторы к Семаксу очень близки к меланокортиновым рецепторам MC3, MC4 и MC5 типов. Поскольку меланокортин является производным проопиомеланокортина, имеющего с АКТГ идентичную последовательность 13 аминокислот, такое предположение представляется реальным [412]. В экспериментах на животных установлено, что даже в очень малых дозах (3 мкг/кг) Семакс обладает ярко выраженным ноотропным әффектом, 
увеличивает адаптационные возможности мозга, повышая его устойчивость к стрессорным повреждениям, гипоксии и ишемии. Более высокие дозы Семакса (150-300 мкг/кг), не являясь токсичными и сохраняя ноотропные свойства малых доз, оказывают выраженное антиоксидантное, антигипоксическое, ангиопротекторное и нейротрофическое действие [410-424].

Клинико-иммунологический анализ показал иммуномодулирующую и нейротрофическую активность препарата: отмечалось повышение уровня противовоспалительных цитокинов, трофических факторов (IL-10, TNF- $\alpha$, TGF- $\beta 1$, BDNF, NGF), снижение экспрессии генов раннего реагирования c-fos, антиапоптотического белка bcl-2, а также повышение активности СОД в цереброспинальной жидкости. Противовоспалительные, антиоксидантные, нейротрофические и антиапоптозные эффекты Семакса могут быть связаны с его влиянием на молекулярные триггерные механизмы отдаленных последствий ишемии [423, 424].

Одним из наиболее перспективных препаратов нейротрофического ряда является Цереброкурин, который содержит свободные аминокислоты, нейропептиды и низкомолекулярные продукты контролируемого протеолиза низкомолекулярных белков и пептидов эмбрионов крупного рогатого скота. Механизм действия и точки приложения Цереброкурина принципиально отличаются от других препаратов нейропептидной природы, в частности от Церебролизина. Цереброкурин содержит пептиды, несущие в себе программу анализа состояния и строительства ЦНС. Таким образом, конечный эффект различается из-за качественно отличного механизма действия [426-432].

Защитные эффекты Цереброкурина на ткань мозга включают его оптимизирующее действие на энергетический метаболизм мозга и гомеостаз кальция, стимуляцию внутриклеточного синтеза белка, замедление процессов глутаматкальциевого каскада и перекисного окисления липидов. Вместе с тем, препарат обладает выраженными нейротрофическими эффектами. В исследованиях, проведенных в последние годы, установлена способность Цереброкурина повышать экспрессию гена транспортера глюкозы (GLUT-1) через гематоэнцефалический барьер и, таким образом, увеличивать ее транспорт к головному мозгу в условиях экспериментальной ишемии [426-432].

Показано также, что нейротрофические свойства Цереброкурина связаны с защитой цитоскелета нейронов вследствие ингибирования кальцийзависимых протеаз, в том числе кальпаина, и увеличения экспрессии микротубулярного кислого протеина 2 (MAP2). Наряду с этим, Цереброкурин увеличивает аффинность связывания BDNF с его рецепторами. Влияние препарата на trk-B рецепторы нейротрофинов может свидетельствовать о вовлечении его в регуляцию естественных факторов роста. В экспериментальных исследованиях выявлена способность Цереброкурина предотвращать гиперактивацию микроглии и снижать продукцию ИЛ-1 и других провоспалительных цитокинов, что отражает влияние препарата на выраженность местной воспалительной реакции и процессов оксидантного стресса в ишемизированной зоне мозга. Нашими работами показано, что применение Цереброкурина при острой церебральной ишемии способствует лучшему выживанию нейронов в зоне ишемической полутени и торможению отсроченной гибели нейронов [432-434]. 
В настоящее время в ряде клинических исследований была показана высокая эффективность Цереброкурина при различных патологиях ЦНС. Так, Евтушенко О. С. и соавт. была изучена эффективность применения Цереброкурина у детей с речевыми нарушениями и умственной отсталостью на фоне органического поражения ЦНС [429].

Больные были разделены на 4 группы: 1 - речевые расстройства без интеллектуальных расстройств (дизартрии, дислалии, моторные алалии); 2 - задержка психоречевого развития, вследствие перинатального гипоксическиишемического повреждения головного мозга (снижение когнитивных функций с нарушениями речи и двигательных функций); 3 - умственная отсталость (легкая, умеренная и выраженная умственная отсталость); 4 - расстройства психики при наследственных и хромосомных болезнях (болезнь Дауна, синдром Мартина-Белла, Франческетти и Клайнфелтера).

Курс лечения Цереброкурином прошли 84 ребенка. Первая группа детей с речевыми расстройствами составляла 20 человек: 10 детей с дизартрией, 10 человек с моторной алалией. Вторая группа - дети с задержкой психоречевого развития -20 человек. Третья группа - дети с умственной отсталостью -32 ребенка: 18 человек с легкой умственной отсталостью, 10 человек с умеренной и 4 человека с выраженной умственной отсталостью. Четвертая группа - наследственные и хромосомные болезни: болезнь Дауна -7 человек, синдром Мартина-Белла -3 человека, синдром Франческетти -1 человек и синдром Клайнфелтера -1 человек.

После проведенного лечения во всех четырех группах детей отмечалась положительная динамика. В речевой сфере увеличилась речевая активность у 60 \% детей, появились новые слова (70 \% ), фразовая речь (65 \% ), увеличился словарный запас, улучшилось звукопроизношение, понимание обращенной речи у $80 \%$ детей. В интеллектуальной сфере улучшилась концентрация и устойчивость внимания (70 \% ), зрительная и слуховая память (75 \%), увеличился темп мышления, появилось логическое и абстрактное мышление (65 \%), контакт стал более стабильным, появился интерес к обучению. Улучшилась социальная адаптация - появились навыки самообслуживания и опрятности, появился интерес к общению со сверстниками и обучению у 80 \% детей.

Применение препарата приводило к улучшению кровотока в каротидном бассейне и в бассейне позвоночных артерий у 76,9 \% детей, при этом дефицит кровоснабжения оставался у $10-15 \%$ детей, принимавших лечение Цереброкурином. Внутричерепная гипертензия и дистония вен были купированы у 70,0\% больных.

Со стороны биоэлектрической активности головного мозга отмечено нарастание амплитуды альфа- и бета-ритма, что отражает повышение уровня функционального состояния коры головного мозга. Клиническими проявлениями подобных изменений на ЭЭГ является улучшение речевой и психической деятельности, улучшение концентрации внимания и когнитивных функций.

Таким образом, проведенные клинические исследования показали, что Цереброкурин является эффективным препаратом в лечении органических заболеваний нервной системы у детей, сопровождающихся речевыми наруше- 
ниями, задержкой психоречевого развития, умственной отсталостью, а также при наследственных и хромосомных болезнях.

Клинические испытания препарата Цереброкурин проводил и Институт геронтологии АМН Украины [426].

В результате клинических наблюдений за больными, получавшими Цереброкурин, у всех пациентов было отмечено субъективное улучшение состояния. Оно выражалось в улучшении общего состояния больных, увеличении общей двигательной активности, уменьшении и исчезновении головных болей и головокружения, уменьшении эмоциональных нарушений (табл. 4.18).

Таблица 4.18

\section{Эффективность курсового лечения Цереброкурином в зависимости от выраженности церебральной сосудистой патологии}

\begin{tabular}{|l|c|c|c|c|c|c|c|c|c|}
\hline & \multirow{2}{*}{$\begin{array}{c}\text { кол-во } \\
\text { Обследуемые группы }\end{array}$} & \multicolumn{6}{|c|}{ Динамика симптомов } \\
\cline { 3 - 11 } & больных & \multicolumn{4}{|c|}{ субъективные } & \multicolumn{5}{|c|}{ органические } \\
\cline { 3 - 10 } & & $\mathbf{1}$ & $\mathbf{2}$ & $\mathbf{3}$ & $\mathbf{4}$ & $\mathbf{1}$ & $\mathbf{2}$ & $\mathbf{3}$ & $\mathbf{4}$ \\
\hline $\begin{array}{l}\text { Больные с остаточными } \\
\text { явлениями ОНМк }\end{array}$ & 49 & 6 & 18 & 25 & - & - & 9 & 34 & 6 \\
\hline $\begin{array}{l}\text { Дисциркуляторная } \\
\text { энцефалопатия }\end{array}$ & 17 & 8 & 9 & & & & 7 & 10 & \\
\hline
\end{tabular}

Прилечание: 1 - полное исчезновение силптола;

2 - значительное уленьшение;

3 - незначительное уленьшение;

4 - отсутствие эффекта.

В соответствии с таблицей 4.18, у всех больных как первой, так и второй группы наблюдалось отчетливое улучшение со стороны субъективной симптоматики - не было ни одного больного, у которого бы полностью отсутствовал эффект от лечения. Однако, если при дисциркуляторной энцефалопатии у больных наблюдалось полное исчезновение симптомов либо их значительное улучшение, то при грубой очаговой патологии, имеющейся у больных второй группы, наиболее частой реакцией было незначительное уменьшение жалоб. Подобные же тенденции отмечены и со стороны объективных симптомов. Однако, у 6 больных 1-й группы отсутствовало клинически распознаваемое улучшение патологической симптоматики, а превалирующее большинство пациентов реагировало незначительным улучшением. Во второй группе отсутствовали больные, которые бы не отреагировали положительной динамикой клинических симптомов на фоне проводимого лечения.

Данные реоэнцефалографических исследований свидетельствовали о благоприятных сдвигах как со стороны артериального притока, так и венозного оттока (табл. 4.19). 
Динамика частоты реоэнефалографических симптомов на фоне курсового приема Цереброкурина, \% .

\begin{tabular}{|c|c|c|c|}
\hline Показатели & до лечения & $\begin{array}{c}\text { после } \\
\text { лечения }\end{array}$ & $\mathbf{P}$ \\
\hline \multicolumn{4}{|c|}{ Повышение тонуса мозговых сосудов } \\
\hline І группа & 85,6 & 62,3 & $<0,1$ \\
\hline II группа & 48,3 & 17,2 & $<0,05$ \\
\hline \multicolumn{4}{|c|}{ Затруднение венозного оттока } \\
\hline I группа & 33,3 & 11,1 & $<0,05$ \\
\hline II группа & 28,3 & 7,8 & $<0,05$ \\
\hline
\end{tabular}

Таким образом, Цереброкурин оказывал вазоактивное действие. На основании реоэнцефалографического исследования видно, что у части пациентов уменьшался исходно повышенный тонус артериальных сосудов, нормализовался венозный отток.

Кроме того, было показано влияние Цереброкурина на биоэлектрическую активность мозга. Изменения отдельных ритмов ЭЭГ и перестройка ее структуры у лиц, перенесших ОНМК, имеют качественные и количественные различия при локализации патологии в правом и левом полушарии. Левое полушарие при инсульте перестраивается преимущественно в частотных характеристиках спектра, а правое - преимущественно в мощностных. Это положение подтверждается и данными, полученными в настоящих исследованиях. Асимметрия нарушений электрогенеза мозга при формировании устойчивого патологического очага после перенесенного ОНМК распространяется и на их реакцию на фармакологические воздействия (табл. 4.20).

Таблица 4.20

Амплитуда (мкв) основных ритмов головного мозга у больных с остаточными явлениями ОНМК до (1) и после (2) курсового лечения Цереброкурином (M \pm m)

\begin{tabular}{|l|c|c|c|c|c|c|c|c|}
\hline \multirow{2}{*}{ Ритмы } & \multicolumn{5}{|c|}{ Правая гемисфера } & \multicolumn{4}{c|}{ Левая гемисфера } \\
\cline { 2 - 9 } & $\mathbf{1}$ & $\mathbf{2}$ & Сдвиг & $\mathbf{P}$ & $\mathbf{1}$ & $\mathbf{2}$ & Сдвиг & $\mathbf{P}$ \\
\hline онмк в бассейне левой средней мозговой артерии \\
\hline альфа-ритм & $24,8+4,7$ & $25,5+3,1$ & $+0,5+0,3$ & $\mathrm{NS}$ & $25,9+4,1$ & $27,4+2,9$ & $+2,5+1,0$ & $<0,05$ \\
\hline бета-ритм & $21,8+3,9$ & $24,2+3,7$ & $+3,6+1,3$ & $<0,05$ & $21,9+4,5$ & $23,9+4,1$ & $+2,0+1,0$ & $<0,1$ \\
\hline дельта-ритм & $19,7+2,8$ & $17,4+3,0$ & $-2,6+1,2$ & $<0,05$ & $18,9+3,1$ & $18,8+3,1$ & $-0,1+0,9$ & NS \\
\hline
\end{tabular}


Продолжение табл. 4.20

\begin{tabular}{|l|c|c|c|c|c|c|c|c|}
\hline \multirow{2}{*}{ Ритмы } & \multicolumn{5}{|c|}{ Правая гемисфера } & \multicolumn{4}{c|}{ Левая гемисфера } \\
\cline { 2 - 9 } & $\mathbf{1}$ & $\mathbf{2}$ & Сдвиг & $\mathbf{P}$ & $\mathbf{1}$ & $\mathbf{2}$ & Сдвиг & $\mathbf{P}$ \\
\hline онмк в бассейне правой средней мозговой артерии \\
\hline альфа-ритм & $22,6+3,3$ & $25,2+2,9$ & $+2,6+1,2$ & $<0,05$ & $25,7+3,5$ & $27,8+3,3$ & $+2,1+1,0$ & $<0,05$ \\
\hline бета-ритм & $22,1+3,4$ & $22,0+1,9$ & $-0,1+1,5$ & NS & $24,2+2,3$ & $29,1+2,2$ & $+4,9+1,7$ & $<0,01$ \\
\hline дельта-ритм & $23,8+2,1$ & $23,3+2,2$ & $-0,6+0,6$ & NS & $22,6+3,0$ & $15,3+2,7$ & $-3,3+1,5$ & $<0,05$ \\
\hline тета-ритм & $12,9+3,6$ & $13,1+2,7$ & $+0,2+0,9$ & NS & $11,3+2,1$ & $11,4+2,2$ & $+0,1+0,6$ & NS \\
\hline
\end{tabular}

Прилечание: NS - отсутствие достоверных сдвигов.

Анализ наиболее общих тенденций в реакции биоэлектрической активности мозга можно свести к следующему:

1) Наиболее отчетливая положительная динамика в сложной перестройке ритмов мозга вне зависимости от очага поражения регистрируется в левом доминантном полушарии.

2) Мозаика изменений мощности ритмов, вызванных Цереброкурином, в здоровом правом полушарии при левосторонней локализации ишемического очага выражается в нарастании мощности бетаи дельта-ритмов. При ОНМК в правой гемисфере увеличивается мощность основного альфа-ритма. В целом меньший диапазон изменений ритмов мозга в правом полушарии можно связать с тем обстоятельством, что филогенетически оно более старо и более ригидно в отношении фармакологических влияний. Далее, правосторонние инсульты, как правило, реализуются на фоне генетической предрасположенности и относительно в молодом возрасте, что не может не отразиться на механизмах их развития и специфике протекания сонологических процессов. В пользу этого может говорить и тот факт, что наиболее низкие мощности альфаритма были зарегистрированы именно в правом полушарии при правостороннем поражении мозга.

Таким образом, проведенные клинические исследования отечественного препарата Цереброкурин показали у больных, перенесших ОНМК, на фоне приема Цереброкурина улучшение общего состояния, увеличение общей двигательной активности, уменьшение эмоциональных нарушений, головных болей и головокружений. В неврологической симптоматике отмечалось снижение мышечной гипертонии, повышение мышечной силы и объема движений в паретичной конечности, уменьшение анизокории, улучшение выполнения координационных проб. У пациентов с афатическими нарушениями наблюдалось улучшение спонтанной, диалоговой, автоматизированной повторной речи, появлялась способность к пересказу текста, увеличивался объем слухоречевой памяти. РЭГ-исследование показало вазоактивное действие препарата с умень- 
шением исходно повышенного тонуса артериальных сосудов и нормализацией венозного оттока. Анализ ЭЭГ отразил наиболее отчетливую положительную динамику в сложной перестройке ритмов мозга вне зависимости от очага поражения в левом доминантном полушарии; при ОНМК в правой гемисфере увеличивается мощность основного $\alpha$-ритма.

При клинико-лабораторной оценке Цереброкурина у пациентов с ОНМК определяется гиполипидемический эффект со снижением концентрации общего холестерина, ХС-ЛПНП крови, уменьшением коэффициента атерогенности. Препарат не оказывает сколько-нибудь заметного отрицательного влияния на процессы кроветворения, гемостаз, азотвыделительную функцию почек и пигментобразующую функцию печени.

У больных с психическими расстройствами резидуально-органического генеза на фоне Цереброкурина отмечалось значительное улучшение функции внимания, памяти, общей психомоторной активности. Изучено действие Цереброкурина при различной психиатрической патологии и по результатам полученного эффекта сделан вывод о показанности Цереброкурина при психоорганическом синдроме с интеллектуальной недостаточностью, специфических задержках интеллектуального и речевого развития, умственной отсталости, церебральной астении эндогенного, органического, сосудистого генеза, болезни Альцгеймера, старческом и атеросклеротическом слабоумии, постинсультном слабоумии, эпилептическом слабоумии, амнестическом корсаковском синдроме в рамках интоксикационных и инфекционных психозов, цереброастенических и астенодепрессивных состояниях, при резистентных депрессиях в комплексной терапии в сочетании с антидепрессантами.

В случае лечения дегенеративно-дистрофических заболеваний сетчатки Цереброкурин приводил к повышению остроты зрения у пациентов, страдающих влажными формами макулодистрофий, а также у лиц, оперированных по поводу отслойки сетчатки. Пациенты с выраженными органическими поражениями сетчатки при высокой осложненной близорукости и диабетической макулопатии в результате лечения отмечали улучшение социальной адаптации, повышение памяти и больший комфорт при чтении [426, 427].

В детской неврологии Цереброкурин широко применяется при детских церебральных параличах, синдроме Дауна, задержках психоречевого развития, алалии, афазии, когнитивных нарушениях [426, 427].

Данные исследования биологической активности головного мозга отражают повышение уровня функционального состояния коры, которые определяются улучшением церебральной гемодинамики. Клиническими проявлениями подобных изменений на ЭЭГ являются: увеличение моторной и психической активности, улучшение концентрации внимания и интеллектуальных функций, уменьшение интеллектуального недоразвития, улучшение когнитивных функций и более высокий уровень социальной адаптации.

У детей с моторной афазией после курса лечения Цереброкурином повышается концентрация внимания и речевой активности, оптимизируется самостоятельная речь, понимание речи, фонематический анализ, а также уменьшается количество парафразий. 
При моторной алалии препарат способствует увеличению словарного запаса, повышению речевой активности, улучшению концентрации внимания.

В случае дизартрии у детей в результате лечения отмечено улучшение артикуляции звуков, уменьшение кинетической диспраксии, увеличение скорости артикуляционных движений и темпа дифференцированных движений мышц кончика языка, уменьшение инертности и искажения слоговой структуры слова (пропуски, персеверации, перестановки слогов), уменьшение дистонических явлений мышц языка.

Первые результаты во время курса лечения Цереброкурином у детей с церебральным параличом выражаются в улучшении психофизического состояния, повышении эмоциональной и двигательной активности, в том числе и речевой. Причем стойкий эффект отмечается не по окончании лечения, а во время его с 4-6-й инъекции.

Клинические исследования препарата Цереброкурин у пациентов с острой церебральной недостаточностью (ОЦН) различного генеза также проводили в Донецком национальном медицинском университете сотрудниками кафедры анестезиологии, интенсивной терапии, медицины неотложных состояний, лабораторной диагностики и клинической физиологии ФИПО на базе нейрореанимационного отделения Донецкого областного клинического территориального медицинского объединения (ДОКТМО). Член-корр. АМНУ, д.м.н., профессор Черний В. И. с соавторами для оценки эффективности применения Цереброкурина у пациентов с различной степенью тяжести ОЦН использовали метод интегрального количественного анализа ЭЭГ-паттернов с определением реактивности ЦНС [429-432].

ЭЭГ-исследования проводились за 0,5 часа до и через 0,5 часа после внутримышечного введения Цереброкурина в дозе 2 мл в сутки. Изучались количественные показатели электроэнцефалограмм: абсолютная спектральная мощ-

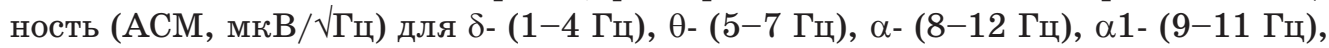
$\beta 1$ - (13-20 Гц), $\beta 2-(20-30$ Гц) частотных диапазонов ЭЭГ и показатели когерентности (межполушарная когерентность (МПКГ, \%), внутриполушарная когерентность (ВПКГ, \%)). Для объективизации оценки ЭЭГ использован метод интегрального количественного анализа ЭЭГ-паттерна с вычислением интегральных коэффициентов (ИК), позволяющих определить значимость отдельных частотных спектров ЭЭГ в формировании целостного паттерна ЭЭГ. Реактивность ЦНС оценивалась по изменению абсолютной спектр-мощности и интегральных коэффициентов с учетом особенностей МПКГ на основании классификации типов реакций ЦНС на фармакологическое воздействие.

32 пациента (15 женщин и 17 мужчин в возрасте от 17 до 60 лет), с первых суток поступления в нейрореанимационное отделение дОКТМО получавшие препарат Цереброкурин в дополнение к стандартному протоколу лечения, были разделены на 2 группы (табл. 4.21).

1-я группа состояла из 13 пациентов в острейшем восстановительном периоде после перенесенной тяжелой черепно-мозговой травмы (ТЧТМ), 2-я группа - из 19 больных с острым нарушением мозгового кровообращения 
(ОНМК). В качестве контрольной группы (КГ) использовали результаты ЭЭГисследования 12 соматически и неврологически здоровых добровольцев.

При поступлении в отделение выраженный неврологический дефицит у пациентов с ОНМК - 6-9 баллов по шкале ком Глазго (ШКГ), «сопор-кома I», у больных с ЧМТ - 3-7 баллов по ШКГ, «кома I-II» - предопределял резкую дезорганизацию ЭЭГ-паттерна. При визуальной оценке в обеих группах преобладали ЭЭГ-кривые V типа по классификации Жирмунской-Лосева с преобладанием $\delta$ - и $\theta$-активности.

Таблица 4.21

\section{Результаты клинико-неврологического и ЭЭГ-исследований у пациентов с ОНМК и тяжелой ЧМТ при поступлении в отделение}

\begin{tabular}{|l|c|c|}
\hline \multicolumn{1}{|c|}{ Группы } & 1-я (ОНМК) & 2-я (ТЧМТ) \\
\hline Число исследуемых & 19 & 13 \\
\hline ШКГ (баллы) \# & $6-9$ & $3-7$ \\
\hline Тип ЭЭГ * & $\mathrm{V}$ & $\mathrm{V}$ \\
\hline Группы ЭЭГ $^{\circ}$ & $16-19$ & $16-20$ \\
\hline Состояние сознания & сопор-кома I & кома I-II \\
\hline
\end{tabular}

Прилечание: \#-шкалакол Глазго;

* - тип ЭЭГ по классификации Жирлунской-Лосева;

○- группа ЭЭГ по классификации Жирлунской-Лосева.

При проведении интегрального количественного анализа исходных ЭЭГ-паттернов пациентов было выявлено, что уровни 1 -го $((\delta+\theta+\beta 1) /(\alpha+\beta 2))$ ИК (рис. 4.5) превышали ( $<0,05)$ показатели КГ: у пациентов 1 -й группы в 3,9-4,02 раза - и 2-й группы - в 4,6-5 раз. Отмечался симметричный рост ( $p$ $<0,05)$ значений 5-го $(\beta 1 / \beta 2)$ коэффициента на $26-34 \%$ у больных 2 -й группы за счет активации низкочастотного компонента бета-ритма.

Значения 9-го $(\delta / \alpha)$ и 11-го $(\delta / \theta)$ ИК (рис. 4.5) в исследуемых группах были выше $(\mathrm{p}<0,05)$ показателей КГ на 60-80 \%. Показатели 15-го $(\alpha / \beta 2)$ и 17-го $(\alpha 1 / \beta 2)$ ИК были в $1,5-3,8$ раза ниже $(\mathrm{p}<0,05)$ уровней контрольной группы, уровни 16-го $(\alpha / \beta 1)$ коэффициента также были снижены $(\mathrm{p}<0,05)$ на 22,8-68 \%. Однако, достоверных различий между значениями этих коэффициентов в обеих исследуемых группах не выявлено.

Изменения интегральных коэффициентов сочетались у пациентов обеих исследуемых групп с выраженными изменениями показателей межполушарной когерентности (МПКГ). Наиболее типичным было снижение (р < 0,05), относительно значений КГ, уровней МПКГ альфа-диапазона между симметричными центральными (C3C4) отделами головного мозга: в 1-й группе - на 35,7 \% , во 2-й - на 37,5 \% . Было зафиксировано менее выраженное уменьшение, по сравнению с КГ, показателей альфа-МПКГ в симметричных окципитальных (O1O2) - на 22,4-25,6 \% , и фронтальных (Fp1Fp2) - на 20,4$21,8 \%$ - областях полушарий.

$\mathrm{У}$ пациентов обеих групп средние значения МПКГ в центральных $\left(\mathrm{C}_{3} \mathrm{C}_{4}\right)$ и затылочных $\left(\mathrm{O}_{1} \mathrm{O}_{2}\right)$ отделах были снижены $(\mathrm{p}<0,05)$ на $18,2-19,9$ \% за счет 
уменьшения когерентности альфа-, дельта- и бета-частотных компонентов, что являлось отражением диэнцефальной недостаточности, так как динамика когерентности биопотенциалов симметричных центральных областей преимущественно свидетельствует о функциональном состоянии диэнцефальных образований.

Различия между 1-й и 2-й группами заключались в тенденциях к росту на 8,3-10,3 \% МПКГ височных областей $\left(\mathrm{T}_{3} \mathrm{~T}_{4}\right) \alpha$-диапазона и $\alpha 1$-поддиапазона у пациентов с ЧМТ.

Также отличались в обеих группах уровни МПКГ высокочастотного $\beta 2$-волнового диапазона. Рост $(\mathrm{p}<0,05)$ показателей $\beta 2$-когерентности на $20-$ $24,4 \%$ относительно значений в $К \Gamma$ в симметричных лобных $\left(\mathrm{Fp}_{1} \mathrm{Fp}_{2}\right)$, височных $\left(\mathrm{T}_{3} \mathrm{~T}_{4}\right)$ и центральных $\left(\mathrm{C}_{3} \mathrm{C}_{4}\right)$ областях был выявлен у пациентов 1-й группы, во 2-й группе данные показатели имели только тенденцию к увеличению $(\mathrm{p}>0,05)$ на $12,2-16,8 \%$.

Избыточный уровень межполушарной интеграции, проявляющийся ростом показателей когерентности, типичен для нарушения сознания на уровне сопора (Гриндель О. М., 1980), который отмечался более чем у 40 \% пациентов 1-й группы (ОНМК) (табл. 4.21). Кроме того, увеличение интеграции «быстрого» бета-ритма свидетельствовало о степени активации ретикулярной формацией ствола головного мозга (Могилевский А. Я., 1971), выраженной при ОНМК и умеренной (либо недостаточной) в условиях тяжелой ЧМТ.

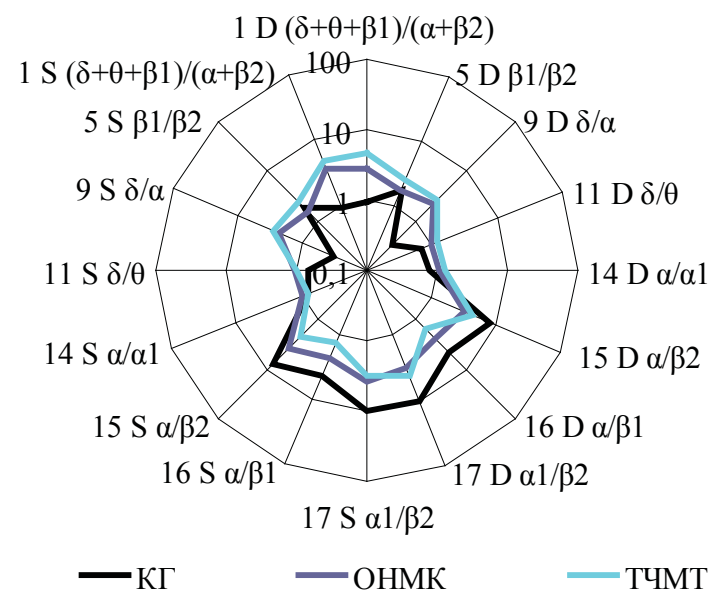

Puc. 4.5. Исходные уровни интегральных коэффициентов в правом (D) и левом (S) полушариях у больных 1-й (ОНМК) и 2-й (ТЧМТ) групп*

Примечание: *-логарифмическал шкала (ln)

Наряду с изменениями МПкГ, у исследуемых обеих групп были выявлены отличия уровней внутриполушарной когерентности (ВПКГ) от соответствующих показателей КГ. 
У пациентов обеих групп в левом полушарии было выявлено значительное снижение $(\mathrm{p}<0,05)$ на $22-24,7 \%$ уровней ВПКГ альфа-диапазона и $\alpha 1$ поддиапазона в коротких внутриполушарных парах $\left(\mathrm{Fp}_{1} \mathrm{C}_{3}\right),\left(\mathrm{Fp}_{1} \mathrm{~T}_{3}\right)$ и $\left(\mathrm{T}_{3} \mathrm{C}_{3}\right)$, то есть в передних и центральных отделах полушария, и тенденции к уменьшению $\alpha$ - и $\alpha 1$-ВПКГ в паре $\left(\mathrm{C}_{3} \mathrm{O}_{1}\right)$, то есть в задних отделах. Было отмечено падение $(\mathrm{p}<0,05)$ уровней ВПК $Г$ всех частотных диапазонов между центральной и височной областью левой гемисферы $\left(\mathrm{T}_{3} \mathrm{C}_{3}\right)$, т. е. моторно-речевой зоны коры. В передней области коры левого полушария (пары $\left(\mathrm{Fp}_{1} \mathrm{C}_{3}\right)$ и $\left(\mathrm{Fp}_{1} \mathrm{~T}_{3}\right)$ ) были зафиксированы: снижение $(\mathrm{p}<0,05)$ интеграции дельта-активности (уменьшение показателей $\delta$-ВПКГ на $19,2-21,4$ \% относительно данных КГ), рост $(\mathrm{p}<0,05)$ когерентности «быстрой» $\beta 2$-активности (до $20 \%$ ) и тенденции к снижению $(\mathrm{p}>0,05)$ когерентности медленного $\beta 1$-ритма $(14,7-19,2 \%)$.

Наиболее выраженные отличия показателей левосторонней ВПКГ между 1-й и 2-й группами пациентов были выявлены в центрально-окципитальной паре $\left(\mathrm{C}_{3} \mathrm{O}_{1}\right)$, то есть в заднем отделе полушария, проекции стволовых структур мозга. Так, у пациентов 1 -й группы $(\mathrm{OHMК)} \mathrm{был} \mathrm{отмечен} \mathrm{рост}(\mathrm{p}<0,05)$ на $18,2-23,4 \%$ среднего значения $\mathrm{B} \mathrm{C}_{3} \mathrm{O}_{1}$ когерентности за счет увеличения интеграции ритмов $\delta$-, $\theta$-, $\beta 1$ - и $\beta 2$-частотных диапазонов. У больных 2 -й группы (MT) была выявлена тенденция к снижению $(\mathrm{p}>0,05)$ показателя средней $\mathrm{C}_{3} \mathrm{O}_{1}$ внутриполушарной когерентности за счет дезинтеграции $\theta$-, $\alpha$ - и $\beta 2$-ритмов.

У пациентов обеих групп в правой гемисфере также, как и слева, отмечалось снижение $(\mathrm{p}<0,05)$ на $16,9-23,8 \%$ уровней ВПКГ альфа-диапазона и $\alpha 1$ поддиапазона в передних $\left(\mathrm{Fp}_{2} \mathrm{C}_{4}\right),\left(\mathrm{Fp}_{2} \mathrm{~T}_{4}\right)$, передне-центральных $\left(\mathrm{T}_{4} \mathrm{C}_{4}\right)$ и задних $\left(\mathrm{C}_{4} \mathrm{O}_{2}\right)$ отделах коры. Было отмечено снижение $(\mathrm{p}<0,05)$ на $21,4-22,6 \%$ уровней средней ВПКГ между височной и центральной $\left(\mathrm{T}_{4} \mathrm{C}_{4}\right)$ областями за счет уменьшения $\delta-, \theta-, \alpha-$ и $\beta 1$ ВПКГ.

В лобной и височной областях коры правого полушария (пара $\left(\mathrm{Fp}_{2} \mathrm{~T}_{4}\right)$ ) было зафиксировано падение $(\mathrm{p}<0,05)$ интеграции дельта-активности (показатели $\delta$-ВПКГ) - на 18,4-21,5 \% по сравнению с данными КГ. В центральноокципитальной паре $\left(\mathrm{C}_{4} \mathrm{O}_{2}\right)$ был отмечен рост $(\mathrm{p}<0,05)$ уровня ВПКГ тетадиапазона, на уровне тенденций проявлялись усиления интегации $\beta 2$-ритма и ослабление интеграции $\delta$-активности.

Отличия показателей правосторонней ВПКГ в 1-й и 2-й группах пациентов были выявлены преимущественно в передних отделах коры.

В лобно-центральной паре $\left(\mathrm{Fp}_{2} \mathrm{C}_{4}\right)$ у пациентов 1 -й группы был выявлен рост $(\mathrm{p}<0,05)$ на $19,7-22,4 \%$ показателей ВПКГ $\theta$-, $\beta 1$ - и $\beta 2$-частотных диапазонов и тенденции к увеличению $(\mathrm{p}>0,05)$ ВПКГ дельта-активности.

У больных 2 -й группы было зафиксировано снижение $(\mathrm{p}<0,05)$ уровней

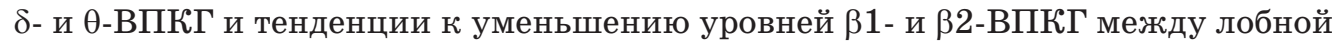
и центральной областями $\left(\mathrm{Fp}_{2} \mathrm{C}_{4}\right)$ правого полушария. Неспецифические, т. е. зависящие от состояния срединных и подкорковых образований (М. Н. Ливанов (1981), О. М. Гриндель (1983)), Fр-С когерентности обеих гемисфер, таким образом, отражали различную степень дисфункции подкорковых образований у пациентов с ОНМК и ЧМТ. Кроме того, значительное падение когерентности в лобных и центральных отделах коры билатерально в диапазонах тета- и бета- 
ритма интерпретируется авторами как проявление нейрональной и неокортикальной дезинтеграции (Besthom C.).

В лобно-височной паре $\left(\mathrm{Fp}_{2} \mathrm{~T}_{4}\right)$ падение $(\mathrm{p}<0,05)$ интеграции $\theta-, \beta 1$ - и $\beta 2$ частотных диапазонов было характерно для 2-й группы, тогда как для первой типичным было увеличение $(\mathrm{p}<0,05)$ уровней интеграции тета-ритма и всего бета частотного спектра ЭЭГ-активности.

Используя классификацию типов реакций ЦНС, у пациентов обеих групп были зафиксированы значимые изменения количественных и интегральных показателей ЭЭГ в ответ на фармакологическое воздействие Цереброкурина (табл. 4.22).

Таблииа 4.22

\section{Типы реакций ЦНС у пациентов с ОНМК и ЧМТ в ответ на введение Цереброкурина}

\begin{tabular}{|c|c|c|}
\hline Варианты реакции цНС & $\begin{array}{c}\text { OHMK } \\
\text { 1-я группа }\end{array}$ & $\begin{array}{c}\text { ЧМТ } \\
\text { 2-я группа }\end{array}$ \\
\hline$n$ & 19 (38 реакций) & 13 (26 реакций) \\
\hline Отсутствие изменений & І тип 2/38 (5 \%) & І тип 1/26 (4 \%) \\
\hline Рост дезорганизации ЭЭГ-паттерна & $\begin{array}{c}\text { II 1a 3/38 (8\%) } \\
\text { II 16 5/38 (13\%) } \\
\text { III 1a 4/38 (11\%) } \\
\text { III 1a } 2 / 38(5 \%)\end{array}$ & II 1a $3 / 26(12 \%)$ \\
\hline $\begin{array}{l}\text { Снижение } \\
\text { дезорганизации ЭЭГ-паттерна }\end{array}$ & $\begin{array}{l}\text { II 2a 9/38 (24 \%) } \\
\text { || } 2610 / 38(26 \%)\end{array}$ & $\begin{array}{c}\text { II 2a 3/26 (12\%) } \\
\text { II 26 5/26 (19\%) } \\
\text { III 26 8/26 (30\%) } \\
\text { III 3a 2/26 (8\%) }\end{array}$ \\
\hline «Гипореактивные» изменения & III Зб 3/38 (8 \%) & III 3 4/26 (15 \%) \\
\hline
\end{tabular}

Выявлено небольшое количество реакций I типа - отсутствие достоверных изменений показателей абсолютной спектральной мощности (ACM) и интегральных коэффициентов (ИК) - у пациентов обеих групп: от 4 \% (2-я группа) до 5 \% (1-я группа) (табл. 4.22). Подобные реакции были зафиксированы всегда асимметрично, чаще в правом полушарии.

У пациентов 1-й группы только 37 \% всех выявленных реакций характеризовались ростом ЭЭГ-дезорганизации. Преобладающей была реакция II 16 подгруппы (ПГ) (13\%), чаще билатеральная, с увеличением суммарной мощности (CM) за счет повышения ACM дельта- тета- и $\beta 2$-активности при стабильности показателя ACM $\alpha$-диапазона, с выраженным ростом уровней 1-го, снижением 5-го и вариабельностью изменений 15-го ИК, что связано в большей мере с активацией быстрого бета-ритма.

Во 2-й группе преобладающими реакциями с нарастанием дезорганизации ЭЭГ были изменения II 1а подгруппы $(12 \%)-$ рост CM за счет $(\mathrm{p}<0,05)$ увеличения ACM патологических дельта- и тета-диапазонов с умеренной активацией $\alpha$-ритма и перераспределением мощности в бета-частотном диапазоне в пользу медленного $\beta 1$-ритма, увеличением уровней 1-го, 9-го ИК и максимальным ростом показателей 5-го и 15 -го ИК. 
Снижение уровня дезорганизации ЭЭГ-паттерна (табл. 4.22) чаще наблюдалось во 2-й группе исследуемых с ЧМТ. Подобные реакции ЦНС составляли $69 \%$ всех изменений ЭЭГ. Среди них преобладали реакции перераспределения мощности III 26 ПГ (30\%), для которых типичны частотные перестройки на электроэнцефалограмме - увеличение $\alpha$-мощности за счет синхронной редукции высокочастотного $\beta 2$ - и патологического дельта-ритмов, умеренное снижение 9 -го ИК, тенденция к росту 5 -го и значительное увеличение уровня 15-го ИК.

В $31 \%$ случаев изменений ЭЭГ во 2-й группе были зафиксированы реакции II типа, характеризующиеся уменьшением $(\mathrm{p}<0,05) \mathrm{CM}$ за счет угнетения медленноволновых $\delta$ - и $\theta$-ритмов с умеренной редукцией $\alpha$-активности с уменьшением уровней 1-го и 11-го ИК (II 2 а подгруппа - $12 \%$ ), или за счет снижения ACM всех частотных ЭЭГ-диапазонов и максимальным угнетением $\beta 2$-активности при стабильности показателей ИК (II $2 б$ ПГ - $19 \%$ ). У пациентов 1-й группы (табл. 4.22) реакции II 2а и II $2 б$ ПГ, составляли $50 \%$ всех ЭЭГ-изменений. Следует отметить, что реакции II типа отражали изменения степени активирующих воздействий на кору со стороны подкорковых структур (ретикулярной формации), когда достоверное $(\mathrm{p}<0,05)$ увеличение суммарной мощности (CM) (1-я группа реакций) свидетельствовало о снижении активирующих подкорковых процессов, а снижение (2-я группа реакций) - об активации подкорковых влияний. То есть, реакция ЦНС II типа косвенно свидетельствует о реализации фармакологической реакции на стволовом уровне.

Так называемая гипореактивная реакция ЦНС ІІІ Зб ПГ с умеренным увеличением $\beta 2$-мощности за счет редукции $\delta$-ритма, свидетельствующая о необходимости увеличения дозы препарата, чаще была зафиксирована во 2 -й группе исследуемых (15\%), реже - в 1-й группе (8\%), преимущественно в правом полушарии.

В 1-й группе пациентов реакции, отражающие неэффективность Цереброкурина, встречались в 37 \% , благоприятные реакции ЦНС (II 2а, II 2б ПГ), свидетельствующие об адекватности проводимой терапии, составляли $50 \%$.

У больных 2-й группы $69 \%$ реакций ЦНС относились к прогностически благоприятным, неблагоприятные реакции составляли только $16 \%$.

Исследование динамики показателей межполушарной когерентности (МПКГ) в ответ на введение Цереброкурина в обеих группах пациентов выявило следующие особенности (табл. 4.23).

У пациентов 1 -й и 2 -й групп отмечался рост $(\mathrm{p}<0,05)$ показателей МПКГ альфа- и, особенно, $\alpha 1$-частотного диапазона в симметричных центральных отделах коры (до $42,1 \%$ в 1-й группе и до $61,5 \%$ - во второй), что являлось отражением роста функциональной активности диэнцефальных образований.

В проекционных стволовых зонах - симметричных окципитальных $\left(\mathrm{O}_{1} \mathrm{O}_{2}\right)$ отведениях - у пациентов с ОНМК был выявлен рост $(\mathrm{p}<0,05)$ уровней $\delta$-, $\beta 1$ - и, в меньшей степени, $\beta 2$-когерентности (соответственно, в 52,6\% и $31,6-47,4 \%$ случаев), что являлось ЭЭГ-коррелятом активации отделов ствола, преимущественно каудальных. 
Для больных с ЧМТ более характерным было снижение дельта- и $\beta 2$ частотной межполушарной $\left(\mathrm{O}_{1} \mathrm{O}_{2}\right)$ интеграции (соответственно, в 66,7 \% и 83,3 \% случаев), что свидетельствовало о частичном снятии чрезмерных восходящих влияний ретикулярной формации ствола и усилении влияний на кору со стороны диэнцефальных и базальных корковых регулирующих систем. ЭЭГкоррелятами подобных изменений регуляции корковой активности у пациентов 2 -й группы являлись также увеличения уровней $\delta$ - и $\beta 1$-МПКГ в симметричных лобных ( $\mathrm{Fp}_{1} \mathrm{Fp}_{2}$ ) отделах (соответственно, в $66,7 \%$ и $38,5 \%$ случаев), так как изменения показателей когерентности биоритмов симметричных лобных отделов отражают состояние базальных структур мозга.

Для пациентов 1-й группы в симметричных фронтальных $\left(\mathrm{Fp}_{1} \mathrm{Fp}_{2}\right)$ областях полушарий, напротив, было характерно снижение МПКГ в тета-диапазоне и $\alpha 1$-поддиапазоне (более чем в 50 \% случаев), что характеризовало уменьшение напряженности в регулирующей системе диэнцефального уровня за счет активации вышележащих медиобазальных отделов лобной коры и полюса лобной доли, которые также являются регуляторами активности неспецифической системы мозга.

Интересны разнонаправленные изменения межполушарной когерентности симметричных височных отделов $\left(\mathrm{T}_{3} \mathrm{~T}_{4}\right)$, выявленные у пациентов с ОНМК и ЧМТ в ответ на введение препарата Цереброкурин. В 1-й группе пациентов было зафиксировано снижение $(\mathrm{p}<0,05)$ показателей $\theta-, \beta 1$ - и $\beta 2$-МПКГ (соответственно, в $52,6 \%, 83,3 \%$ и $52,6 \%$ случаев), что свидетельствовало об уменьшении активности лимбических образований. У больных 2 -й группы, напротив, были отмечены тенденции к нарастанию сочетанности темпоральных областей - увеличение $(\mathrm{p}<0,05)$ показателей $\delta$-, $\beta 1$ - и $\beta 2$-МПКГ (соответственно, в $46,2 \%, 55 \%$ и 83,3\% случаев), что традиционно трактуется как результат активации гиппокампальных структур и большего их синхронизирующего влияния на формирование межполушарного взаимодействия (А. В.Семенович и соавт., 1995).

таблица 4.23

\section{Изменения МПКГ у пациентов с ОНМК и ЧМТ в ответ на введение Цереброкурина}

\begin{tabular}{|c|c|c|c|c|}
\hline \multirow[b]{2}{*}{ Изменение МПкГ > 15 \% } & \multicolumn{2}{|c|}{$\begin{array}{c}\text { OHMK } \\
\text { 1-я группа }\end{array}$} & \multicolumn{2}{|c|}{$\begin{array}{c}\text { ЧМТ } \\
\text { 2-я группа }\end{array}$} \\
\hline & $\begin{array}{c}\text { Увеличение } \\
\text { МПКГ } \\
(\mathbf{p}<0,05)\end{array}$ & $\begin{array}{c}\text { Снижение } \\
\text { МПКГ } \\
(p<0,05)\end{array}$ & $\begin{array}{c}\text { Увеличение } \\
\text { МПКГ } \\
\text { (р < 0,05) }\end{array}$ & $\begin{array}{c}\text { Снижение } \\
\text { МПКГ } \\
(p<0,05)\end{array}$ \\
\hline N (количество исследуемых) & 19 & 19 & 13 & 13 \\
\hline KG (Fp1Fp2) средняя & - & $3 / 19(15,9 \%)$ & - & - \\
\hline KG (Fp1Fp2) $\delta$ & $6 / 19(31,6 \%)$ & $6 / 19(31,6 \%)$ & $9 / 13(66,7 \%)$ & - \\
\hline KG (Fp1Fp2) $\theta$ & $3 / 19(15,9 \%)$ & $10 / 19(52,6 \%)$ & $7 / 13(5 \% 3)$ & $2 / 13(16,7 \%)$ \\
\hline KG (Fp1Fp2) $\alpha$ & $3 / 19(15,9 \%)$ & $3 / 19(15,9 \%)$ & - & $2 / 13(16,7 \%)$ \\
\hline KG (Fp1Fp2) $\alpha 1$ & $3 / 19(15,9 \%)$ & $10 / 19(52,6 \%)$ & - & $4 / 13(33,3 \%)$ \\
\hline KG (Fp1Fp2) $\beta 1$ & $5 / 19(26,3 \%)$ & $5 / 19(26,3 \%)$ & $5 / 13(38,5 \%)$ & $5 / 13(38,5 \%)$ \\
\hline
\end{tabular}


Продолжение табл. 4.23

\begin{tabular}{|c|c|c|c|c|}
\hline \multirow[b]{2}{*}{ Изменение МПКГ > 15 \% } & \multicolumn{2}{|c|}{$\begin{array}{c}\text { OHМK } \\
\text { 1-я группа }\end{array}$} & \multicolumn{2}{|c|}{$\begin{array}{c}\text { ЧМТ } \\
\text { 2-я группа }\end{array}$} \\
\hline & $\begin{array}{c}\text { Увеличение } \\
\text { МПКГ } \\
(p<0,05)\end{array}$ & $\begin{array}{c}\text { Снижение } \\
\text { МПКГ } \\
(p<0,05)\end{array}$ & $\begin{array}{c}\text { Увеличение } \\
\text { МПКГ } \\
\text { (р }<0,05)\end{array}$ & $\begin{array}{c}\text { Снижение } \\
\text { МПКГ } \\
(p<0,05)\end{array}$ \\
\hline KG (Fp1Fp2) $\beta 2$ & $6 / 19(31,6 \%)$ & $3 / 19(15,9 \%)$ & $2 / 13(16,7 \%)$ & $4 / 13(33,3 \%)$ \\
\hline KG (С3С4) средняя & $6 / 19(31,6 \%)$ & $3 / 19(15,9 \%)$ & - & $4 / 13(33,3 \%)$ \\
\hline $\mathrm{KG}(\mathrm{C} 3 \mathrm{C} 4) \delta$ & $3 / 19(15,9 \%)$ & $5 / 19(26,3 \%)$ & $3 / 13(23,1 \%)$ & $5 / 13(38,5 \%)$ \\
\hline KG (C3C4) $\theta$ & $6 / 19(31,6 \%)$ & $3 / 19(15,9 \%)$ & - & $2 / 13(16,7 \%)$ \\
\hline KG (C3C4) $\alpha$ & $6 / 19(31,6 \%)$ & $3 / 19(15,9 \%)$ & - & $9 / 13(66,7 \%)$ \\
\hline KG (C3C4) $\alpha 1$ & $8 / 19(42,1 \%)$ & - & $8 / 13(61,5 \%)$ & - \\
\hline KG (C3C4) $\beta 1$ & $6 / 19(31,6 \%)$ & $3 / 19(15,9 \%)$ & $4 / 13(33,3 \%)$ & $9 / 13(66,7 \%)$ \\
\hline KG (C3C4) $\beta 2$ & $3 / 19(15,9 \%)$ & $8 / 19(42,1 \%)$ & $3 / 13(23,1 \%)$ & $8 / 13(61,5 \%)$ \\
\hline KG (0102) средняя & $6 / 19(31,6 \%)$ & $6 / 19(31,6 \%)$ & - & $7 / 13(55 \%)$ \\
\hline KG (01O2) $\delta$ & $10 / 19(52,6 \%)$ & $3 / 19(15,9 \%)$ & - & $9 / 13(66,7 \%)$ \\
\hline KG $(0102) \theta$ & $6 / 19(31,6 \%)$ & $6 / 19(31,6 \%)$ & $4 / 13(33,3 \%)$ & $4 / 13(33,3 \%)$ \\
\hline KG (0102) $\alpha$ & $3 / 19(15,9 \%)$ & $6 / 19(31,6 \%)$ & - & $4 / 13(33,3 \%)$ \\
\hline KG (0102) $\alpha 1$ & $3 / 19(15,9 \%)$ & $3 / 19(15,9 \%)$ & $3 / 13(23,1 \%)$ & $4 / 13(33,3 \%)$ \\
\hline KG (0102) $\beta 1$ & $9 / 19(47,4 \%)$ & $3 / 19(15,9 \%)$ & - & $4 / 13(33,3 \%)$ \\
\hline KG (01O2) $\beta 2$ & $6 / 19(31,6 \%)$ & $6 / 19(31,6 \%)$ & - & $11 / 13(83,3 \%)$ \\
\hline KG (Т3Т4) средняя & - & $3 / 19(15,9 \%)$ & $4 / 13(33,3 \%)$ & - \\
\hline KG (T3T4) $\delta$ & $6 / 19(31,6 \%)$ & $4 / 19(21,1 \%)$ & $6 / 13(46,2 \%)$ & $4 / 13(30,8 \%)$ \\
\hline KG (T3T4) $\theta$ & $3 / 19(15,9 \%)$ & $10 / 19(52,6 \%)$ & $4 / 13(33,3 \%)$ & $2 / 13(16,7 \%)$ \\
\hline KG (T3T4) $\alpha$ & $3 / 19(15,9 \%)$ & $3 / 19(15,9 \%)$ & - & $7 / 13(55 \%)$ \\
\hline KG (T3T4) $\alpha 1$ & $3 / 19(15,9 \%)$ & $3 / 19(15,9 \%)$ & $2 / 13(16,7 \%)$ & - \\
\hline KG (T3T4) $\beta 1$ & $3 / 19(15,9 \%)$ & $16 / 19(83,3 \%)$ & $7 / 13(55 \%)$ & - \\
\hline KG (T3T4) $\beta 2$ & $6 / 19(31,6 \%)$ & $10 / 19(52,6 \%)$ & $11 / 13(83,3 \%)$ & - \\
\hline
\end{tabular}

У исследуемых 1-й группы в сравнении до и после введения препарата Цереброкурин были определены высокие прямые корреляционные связи $(\mathrm{r} \geq 0,85)$ между изменениями следующих показателей МПКГ: в симметричных затылочных $\left(\mathrm{O}_{1} \mathrm{O}_{2}\right)$ областях - $\theta$ - и $\alpha 1$-когерентности, $\beta 1$ - и $\beta 2$ КГ, $\theta$ - и $\beta 1$ когерентности, в соответствующих центральных $\left(\mathrm{C}_{3} \mathrm{C}_{4}\right)-\alpha$ - и $\beta 2 \kappa \Gamma, \beta 1$ - и $\beta 2$ КГ, $\theta$ - и $\beta 1$-когерентности, $\theta$ - и $\beta 2$-когерентности, в симметричных лобных $\left(\mathrm{Fp}_{1} \mathrm{Fp}_{2}\right)-\alpha 1$ - и $\beta 2$-когерентности, в соответствующих височных $\left(\mathrm{T}_{3} \mathrm{~T}_{4}\right)-\theta$ и $\alpha$-когерентности, $\delta$ - и $\beta 2$ КГ.

Такая сочетанность изменений показателей когерентности различных частотных диапазонов в симметричных точках обеих гемисфер свидетельствует о глобальном влиянии на формирование пространственно-временной структуры ЭЭГ неспецифических регулирующих структур мозга, что характерно для гипоталамических отделов.

У пациентов 2-й группы высокие прямые корреляционные связи ( $\mathrm{r} \geq$ 0,85) между изменениями показателей МПКГ были выявлены только в цен- 
тральных и окципитальных отделах: $\beta 1$ - и $\beta 2 \kappa \Gamma, \alpha 1$ - и $\beta 1$-когерентности в $\mathrm{C}_{3} \mathrm{C}_{4}$ отведениях и $\delta$ - и $\beta 2 \mathrm{~K} \Gamma, \delta$ - и $\beta 1$-когерентности в $\mathrm{O}_{1} \mathrm{O}_{2}$-отделах. В симметричных центральных областях были зафиксированы сильные обратные корреляционные связи $(\mathrm{r} \leq-0,85)$ между динамикой показателей МПКГ $\delta$ - и $\alpha 1$-частотных диапазонов, $\alpha$ - и $\alpha 1$-ритмов, $\alpha$ - и $\beta$-волновых активностей. Такое разобщение изменений показателей межполушарной когерентности ЭЭГ отражает, возможно, одновременную активацию различных уровней регулирующих систем мозга - от нижележащих стволовых до корковых медиобазальных - при введении Цереброкурина пациентам с ТЧМТ.

Так же для пациентов 1-й группы были характерны множественные сильные обратные корреляционные взаимосвязи $(\mathrm{r} \geq 0,85)$ между изменениями показателей МПКГ одного частотного диапазона в передних $\left(\mathrm{Fp}_{1} \mathrm{Fp}_{2}, \mathrm{~T}_{3} \mathrm{~T}_{4}, \mathrm{C}_{3} \mathrm{C}_{4}\right)$ и задних $\left(\mathrm{O}_{1} \mathrm{O}_{2}\right)$ областях коры. Такой характер связей был выявлен между динамикой МПКГ альфа-диапазона в лобных и центральных, лобных и височных отделах, МПКГ дельта-диапазона - в лобных и затылочных, центральных и затылочных областях, МПКГ тета-частотного диапазона - в центральных и окципитальных областях, МПКГ высокочастотного бета-ритма - в центральных и затылочных областях, в лобных и затылочных отделах. Возможно, это свидетельствует о тенденциях к восстановлению характерной для «нормы» реципрокности изменений в картине пространственно-временной организации биопотенциалов - признака сохранности и развития компенсаторных аппаратов ЦНС (И. С. Добронравова, 1989).

У больных 2-й группы обратные корреляционные зависимости изменений МПкГ в передне-задних отделах не были выявлены, а прямые высокие корреляционные зависимости $(\mathrm{r} \geq 0,85)$ были характерны для МПКГ показателей лобных и височных областей в $\alpha 1-, \beta 1$ - и тета-частотных диапазонах, что следует рассматривать как проявление активации передних отделов мозга лобных долей, усиления тормозных влияний лобных отделов на остальные области коры при введении Цереброкурина больным с ЧМТ.

Таблииа 4.24

\section{Изменения ВПКГ у пациентов с ОНМК и ЧМТ в ответ на введение Цереброкурина}

\begin{tabular}{|c|c|c|c|c|}
\hline \multirow{2}{*}{$\begin{array}{c}\text { Левое полушарие } \\
\text { Изменение ВПКГ > } 15 \text { \% }\end{array}$} & \multicolumn{2}{|c|}{$\begin{array}{c}\text { OHМK } \\
\text { 1-я группа }\end{array}$} & \multicolumn{2}{|c|}{$\begin{array}{c}\text { ЧМТ } \\
\text { 2-я группа }\end{array}$} \\
\hline & $\begin{array}{c}\text { Увеличение } \\
\text { ВПКГ } \\
(\mathrm{p}<0,05)\end{array}$ & $\begin{array}{c}\text { Снижение ВПКГ } \\
(p<0,05)\end{array}$ & $\begin{array}{c}\text { Увеличение } \\
\text { ВПКГ } \\
(\mathrm{p}<0,05)\end{array}$ & $\begin{array}{c}\text { Снижение ВПКГ } \\
(\mathrm{p}<0,05)\end{array}$ \\
\hline N (количество исследуемых) & 19 & 19 & 13 & 13 \\
\hline KG (Fp1C3) средняя & $4 / 19(21,05 \%)$ & $4 / 19(21,05 \%)$ & 0 & 0 \\
\hline KG (Fp1C3) $\delta$ & $6 / 19(31,57 \%)$ & $10 / 19(52,6 \%)$ & $2 / 13(15,38 \%)$ & $2 / 13(15,38 \%)$ \\
\hline KG (Fp1C3) $\theta$ & 0 & 0 & $7 / 13(53,84 \%)$ & 0 \\
\hline KG (Fp1C3) $\alpha$ & $3 / 19(15,78 \%)$ & $7 / 19(36,8 \%)$ & 0 & 0 \\
\hline KG (Fp1C3) $\alpha 1$ & $3 / 19(15,78 \%)$ & 0 & 0 & $4 / 13(30,76 \%)$ \\
\hline
\end{tabular}




\begin{tabular}{|c|c|c|c|c|}
\hline \multicolumn{5}{|c|}{ Продолжение табл.4.24 } \\
\hline Левое полушарие & \multicolumn{2}{|c|}{$\begin{array}{c}\text { OHMK } \\
\text { 1-я группа }\end{array}$} & \multicolumn{2}{|c|}{$\begin{array}{c}\text { чМТ } \\
\text { 2-я группа }\end{array}$} \\
\hline Изменение ВПКГ > 15 \% & $\begin{array}{c}\text { Увеличение } \\
\text { ВПКГ } \\
(p<0,05) \\
\end{array}$ & $\begin{array}{c}\text { Снижение ВПКГ } \\
(p<0,05)\end{array}$ & $\begin{array}{c}\text { Увеличение } \\
\text { ВПКГ } \\
(\mathbf{p}<0,05) \\
\end{array}$ & $\begin{array}{c}\text { Снижение ВПКГ } \\
(p<0,05)\end{array}$ \\
\hline KG (Fp1C3) $\beta 1$ & $10 / 19(52,6 \%)$ & $7 / 19(36,8 \%)$ & $5 / 13(38,46 \%)$ & 0 \\
\hline KG (Fp1C3) $\beta 2$ & $6 / 19(31,57 \%)$ & $10 / 19(52,6 \%)$ & $7 / 13(53,84 \%)$ & $2 / 13(15,38 \%)$ \\
\hline KG (Fp1T3) средняя & 0 & $3 / 19(15,78 \%)$ & 0 & 0 \\
\hline KG(Fp1T3) $\delta$ & $6 / 19(31,57 \%)$ & $7 / 19(36,8 \%)$ & 0 & $11 / 13(84,61 \%)$ \\
\hline KG (Fp1T3) $\theta$ & $10 / 19(52,6 \%)$ & $3 / 19(15,78 \%)$ & 0 & $8 / 13(61,53 \%)$ \\
\hline KG (Fp1T3) $\alpha$ & $7 / 19(36,8 \%)$ & $2 / 19(10,5 \%)$ & $3 / 13(23,07 \%)$ & $2 / 13(15,38 \%)$ \\
\hline KG (Fp1T3) $\alpha 1$ & 0 & 0 & $2 / 13(15,38 \%)$ & $5 / 13(38,46 \%)$ \\
\hline KG (Fp1T3) $\beta 1$ & 0 & $9 / 19(47,36 \%)$ & $10 / 13(76,92 \%)$ & 0 \\
\hline KG (Fp1T3) $\beta 2$ & $10 / 19(52,6 \%)$ & $9 / 19(47,36 \%)$ & $11 / 13(84,61 \%)$ & $2 / 13(15,38 \%)$ \\
\hline KG (ТЗСЗ) средняя & $3 / 19(15,78 \%)$ & $4 / 19(21,05 \%)$ & 0 & 0 \\
\hline KG (T3C3) $\delta$ & $11 / 19(57,89 \%)$ & 0 & $4 / 13(30,76 \%)$ & $4 / 13(30,76 \%)$ \\
\hline KG (T3C3) $\theta$ & $5 / 19(26,3 \%)$ & $2 / 19(10,5 \%)$ & $5 / 13(38,46 \%)$ & $7 / 13(53,84 \%)$ \\
\hline KG (T3C3) $\alpha$ & $7 / 19(36,8 \%)$ & $6 / 19(31,57 \%)$ & 0 & 0 \\
\hline KG (ТЗС3) $\alpha 1$ & $3 / 19(15,78 \%)$ & $7 / 19(36,8 \%)$ & 0 & $4 / 13(30,76 \%)$ \\
\hline KG (ТЗС3) $\beta 1$ & $16 / 19(84,2 \%)$ & $3 / 19(15,78 \%)$ & $9 / 13(69,23 \%)$ & 0 \\
\hline KG (T3C3) $\beta 2$ & $6 / 19(31,57 \%)$ & $9 / 19(47,36 \%)$ & 0 & $9 / 13(69,23 \%)$ \\
\hline KG (С301) средняя & $11 / 19(57,89 \%)$ & 0 & $4 / 13(30,76 \%)$ & 0 \\
\hline KG (C301) $\delta$ & $10 / 19(52,6 \%)$ & $6 / 19(31,57 \%)$ & $7 / 13(53,84 \%)$ & $3 / 13(23,07 \%)$ \\
\hline KG (C301) $\theta$ & $7 / 19(36,8 \%)$ & $2 / 19(10,5 \%)$ & $5 / 13(38,46 \%)$ & $4 / 13(30,76 \%)$ \\
\hline KG (C301) $\alpha$ & $10 / 19(52,6 \%)$ & $4 / 19(21,05 \%)$ & $5 / 13(38,46 \%)$ & $5 / 13(38,46 \%)$ \\
\hline KG (C301) a1 & $2 / 19(10,5 \%)$ & $9 / 19(47,36 \%)$ & 0 & $9 / 13(69,23 \%)$ \\
\hline KG (C301) $\beta 1$ & $5 / 19(26,3 \%)$ & $4 / 19(21,05 \%)$ & $8 / 13(61,53 \%)$ & $3 / 13(23,07 \%)$ \\
\hline KG (C3O1) $\beta 2$ & $6 / 19(31,57 \%)$ & $12 / 19(63,15 \%)$ & $11 / 13(84,61 \%)$ & 0 \\
\hline
\end{tabular}

Так как при первом ЭЭГ-исследовании у пациентов обеих групп в левом полушарии преобладало снижение уровней когерентности в коротких внутриполушарных парах $\left(\mathrm{Fp}_{1} \mathrm{C}_{3}\right),\left(\mathrm{Fp}_{1} \mathrm{~T}_{3}\right)$ и $\left(\mathrm{T}_{3} \mathrm{C}_{3}\right)$, рост $(\mathrm{p}<0,05)$ значений ВПКГ, выявленный после применения препарата Цереброкурин (табл. 4.24), отражает восстановление типичной для нормы пространственно-временной организации биопотенциалов.

Прежде всего, следует отметить обязательные, но противоположно направленные, изменения уровней ВПКГ $\beta 1$ - и $\beta 2$-ритма, выявленные по всем исследуемым парам. Так, у пациентов 1-й группы, в лобных и центральных областях интеграция низкочастотного $\beta$-ритма была отмечена в 52,6 \%, дезинтеграция - в 36,8 \% случаев, рост $(\mathrm{p}<0,05)$ ВПКГ быстрого бета-ритма - 
в $31,6 \%$, снижение - в 52,6 \% случаев. Аналогичные тенденции изменений бета-когерентности были выявлены в парах $\left(\mathrm{Fp}_{1} \mathrm{~T}_{3}\right),\left(\mathrm{T}_{3} \mathrm{C}_{3}\right)$ и $\left(\mathrm{C}_{3} \mathrm{O}_{1}\right)$. У больных 2-й группы преобладали процессы интеграции бета-частотной активности, наиболее выраженными они были в центрально-окципитальной $\left(\mathrm{C}_{3} \mathrm{O}_{1}\right)$ - рост $\beta 1$-ВПКГ у 61,5 \% исследуемых, увеличение $\beta 2-$ ВПКГ - у 84,6 \% пациентов, во фронтально-темпоральной $\left(\mathrm{Fp}_{1} \mathrm{~T}_{3}\right)$ - увеличение $\beta 1$-ВПКГ у 76,9 \% пациентов, рост $\beta 2$-ВПКГ - у 84,6 \% исследуемых и во фронтально-центральной $\left(\mathrm{Fp}_{1} \mathrm{C}_{3}\right)$ - рост $\beta 1$-ВПКГ у 38,5 \% исследуемых, увеличение $\beta 2$-ВПКГ у 53,8 \% пациентов. Снижение уровня $\beta 2$-когерентности $69,2 \%$ у пациентов с ЧМТ было выявлено только между центральной и височной областью левой гемисферы $\left(\mathrm{T}_{3} \mathrm{C}_{3}\right)$.

Такая разнонаправленность изменений ВПКГ бета-ритма, прежде всего была связана с активацией или угнетением спектральной мощности бетадиапазона и отражала ирритацию или снижение неокортикального тонуса. Учитывая, что характеристики бета-активности зависят от сохранности моноаминергической и глутаматергической нейротрансмиссии (Н. Boddeke и соавт., 1997), причем рост мощности бета-частотного диапазона коррелирует с усилением глутаматергических возбуждающих влияний в структурах мозга, подобные тенденции изменений ВПКГ после введения Цереброкурина следует рассматривать как признаки симпатико- или парасимпатикотонии (T. Marczynski, L. Burns, 1976, А. Ф. Изнак и соавт., 1999).

Было отмечено, характерное для группы пациентов с ЧМТ, нарастание дезинтеграции только медленных дельта- и тета-ритмов в лобно-височной $\left(\mathrm{Fp}_{1} \mathrm{~T}_{3}\right)$ и центрально-височной парах $\left(\mathrm{T}_{3} \mathrm{C}_{3}\right)$ (табл. 4.24). Поскольку кора средних отделов височной области обладает тесными связями как со слуховыми и зрительными отделами коры, так и с медиобазальными отделами, имеющими прямое отношение к неспецифическим, тонизирующим механизмам и аффективным процессам (А. Р. Лурия, 1969), подобные тенденции изменений ВПКГ, возможно, характеризовали специфические процессы высшей нервной деятельности. О. М. Гриндель (1985) отмечала триггерную роль восстановления сочетанности активности височных и центральных отделов доминирующего полушария, т. е. моторно-речевой зоны коры. В левом полушарии рост ВПКГ в данной паре $\left(\mathrm{T}_{3} \mathrm{C}_{3}\right)$ чаще отмечался у пациентов 1 -й группы (табл. 4.24).

В правом полушарии (табл. 4.25) более выраженные процессы интеграции ритмов были типичны для пациентов 2-й группы. Прежде всего, это относилось к показателям ВПКГ в лобно-центральной $\left(\mathrm{Fp}_{2} \mathrm{C}_{4}\right)$ паре, где рост $(\mathrm{p}<0,05)$ уровня средней когерентности (в 84,5 \% случаев) был связан с синхронной интеграцией дельта - (76,9 \% случаев), $\theta-(53,7 \%$ случаев), альфа - (38,5 \% случаев), $\beta 1-$ (у всех исследуемых) и $\beta 2-(76,9 \%$ случаев) ритмов. Аналогичные тенденции были выявлены и в лобно-височной и височноцентральной парах у пациентов данной группы.

В задних отделах правой гемисферы - в центрально-окципитальной паре $\left(\mathrm{C}_{4} \mathrm{O}_{2}\right)$ - у исследуемых 2 -й группы преобладали снижение $(\mathrm{p}<0,05)$ когерентности медленных частотных ритмов и рост $(\mathrm{p}<0,05)$ сочетанности быстрых альфа- и бета-волновых ритмов. У пациентов 1 -й группы в задних отделах пра- 
вого полушария $\left(\mathrm{C}_{4} \mathrm{O}_{2}\right)$, наоборот, чаще было выявлено увеличение $(\mathrm{p}<0,05)$ когерентности дельта - $(84,2 \%$ случаев) и $\theta-(89,5 \%$ случаев) ритмов.

Интересны изменения ВПКГ в ответ на введение препарата Цереброкурин, зафиксированные у пациентов с ОНМК в лобно-височной $\left(\mathrm{Fp}_{2} \mathrm{~T}_{4}\right)$ паре (табл. 4.25). Здесь отмечались обязательные и противоположные изменения уровней $\alpha$-ВПКГ - рост $(\mathrm{p}<0,05)$ в $52,6 \%$ и снижение $(\mathrm{p}<0,05)$ в 47,4 \% случаев.

Выраженная динамика показателей ВПКГ в правой гемисфере по сравнению с левым полушарием, выявленная у пациентов обеих исследуемых групп, во-первых, связана с более тесным функциональным взаимодействием правого полушария с диэнцефальными структурами (Н. Н. Брагина и Т. А. Доброхотова) и активацией именно данных подкорковых образований у больных с ОНМК и ЧМТ под влиянием препарата Цереброкурин.

Кроме того, одним из неспецифических стресс-механизмов мозга является смена при стрессе доминирования полушарий (Л $\rightarrow \Pi)$. Поэтому, значимая правополушарная реакция на введение Цереброкурина, одним из компонентов которой было выраженное повышение внутриполушарной интеграции ЭЭГ-ритмов, являлась проявлением адекватных саногенетических процессов в условиях стресса при ОЦН различного генеза.

Таблица 4.25

\section{Изменения ВПКГ у пациентов с ОНМК и ЧМТ в ответ на введение Цереброкурина}

\begin{tabular}{|c|c|c|c|c|}
\hline Правое полушарие & \multicolumn{2}{|c|}{$\begin{array}{c}\text { OHMK } \\
\text { 1-я группа }\end{array}$} & \multicolumn{2}{|c|}{$\begin{array}{c}\text { ЧМТ } \\
\text { 2-я группа }\end{array}$} \\
\hline Изменение ВПкГ > 15 \% & $\begin{array}{c}\text { Увеличение } \\
\text { ВПКГ } \\
(\mathrm{p}<0,05) \\
\end{array}$ & $\begin{array}{c}\text { Снижение ВПКГ } \\
(\mathrm{p}<0,05)\end{array}$ & $\begin{array}{c}\text { Увеличение } \\
\text { ВПКГ } \\
(\mathrm{p}<0,05)\end{array}$ & $\begin{array}{c}\text { Снижение ВПКГ } \\
(p<0,05)\end{array}$ \\
\hline N (количество исследуемых) & 19 & 19 & 13 & 13 \\
\hline KG (Fp2C4) средняя & - & $3(15,8 \%)$ & $11(84,5 \%)$ & - \\
\hline KG (Fp2C4) $\delta$ & $7(36,8 \%)$ & $3(15,8 \%)$ & $10(76,9 \%)$ & $2(15,4 \%)$ \\
\hline KG (Fp2C4) $\theta$ & - & $5(26,3 \%)$ & $7(53,7 \%)$ & $2(15,4 \%)$ \\
\hline KG (Fp2C4) $\alpha$ & $3(15,8 \%)$ & $10(52,6 \%)$ & $5(38,5 \%)$ & - \\
\hline KG (Fp2C4) $\alpha 1$ & $6(31,6 \%)$ & $3(15,8 \%)$ & - & $2(15,4 \%)$ \\
\hline KG (Fp2C4) $\beta 1$ & $2(10,5 \%)$ & $8(42,1 \%)$ & $13(100 \%)$ & - \\
\hline KG (Fp2C4) $\beta 2$ & $2(10,5 \%)$ & $2(10,5 \%)$ & $10(76,9 \%)$ & - \\
\hline KG (Fp2C4) средняя & $10(52,6 \%)$ & $9(47,4 \%)$ & - & - \\
\hline KG(Fp2T4) $\delta$ & $7(36,8 \%)$ & $7(36,8 \%)$ & $9(69,2 \%)$ & $4(30,8 \%)$ \\
\hline KG (Fp2T4) $\theta$ & $11(57,9 \%)$ & $4(21,1 \%)$ & $4(30,8 \%)$ & $2(15,4 \%)$ \\
\hline KG (Fp2T4) $\alpha$ & $10(52,6 \%)$ & $9(47,4 \%)$ & - & $2(15,4 \%)$ \\
\hline KG (Fp2T4) $\alpha 1$ & $10(52,6 \%)$ & $4(21,1 \%)$ & - & $5(38,5 \%)$ \\
\hline KG (Fp2T4) $\beta 1$ & $5(26,3 \%)$ & $11(57,9 \%)$ & $5(38,5 \%)$ & $2(15,4 \%)$ \\
\hline KG (Fp2T4) $\beta 2$ & $7(36,8 \%)$ & $7(36,8 \%)$ & $4(30,8 \%)$ & $7(53,7 \%)$ \\
\hline
\end{tabular}


Продолжение табл. 4.25

\begin{tabular}{|l|c|c|c|c|}
\hline \multicolumn{1}{|c|}{ Правое полушарие } & \multicolumn{2}{|c|}{ ОНMK } & \multicolumn{2}{c|}{ ЧМт } \\
2-я группа
\end{tabular}

Таким образом, грубые изменения ЭЭГ-паттернов, выявленные у пациентов с ОНМК и ЧМТ при поступлении в нейрореанимационное отделение, в первую очередь, были обусловлены значительными морфоструктурными изменениями коры больших полушарий, о чем свидетельствовало резкое увеличение, относительно «нормальных» значений, показателей интегральных коэффициентов - 1-го $((\delta+\theta+\beta 1) /(\alpha+\beta 2)), 9$-го $(\delta / \alpha)$ и 11-го $(\delta / \theta)$. Однако, при тяжелой ЧМТ уровень морфоструктурных корковых нарушений был выше, чем при мозговом инсульте, об этом свидетельствовали не только достоверные различия уровней интегральных коэффициентов в обеих группах пациентов, но и различия показателей внутриполушарной когерентности, в частности, неспецифической. Например, выявленное у больных с ЧМТ билатеральное падение Fp-C интеграции (в лобных и центральных отделах) в диапазонах бета- и тета-ритма являлось ЭЭГ-коррелятом нейрональной и неокортикальной дезинтеграции, в то время, как противоположно направленные изменения лобно-центральной ВПКГ - рост справа и снижение слева, зафиксированные у пациентов с ОНМК, - отражали дисфункцию подкорковых образований, преимущественно диэнцефального уровня.

Помимо корковых деструктивных процессов особенности ЭЭГ были обусловлены вовлечением в патологический процесс при ОЦН различного генеза подкорковых структур лимбико-гипокампального, диэнцефального, стволового уровней, но степень дисфункции данных образований у пациентов обеих групп была различной. Очень показательными в этом отношении были раз- 
личия межполушарной интеграции тета-волновой ЭЭГ-активности, выявленные в 1-й и 2-й группах. У больных с ОНМК рост МПКГ тета-диапазона в симметричных лобных, окципитальных, темпоральных и, на уровне тенденций, в центральных областях свидетельствовал, согласно идеологии системных взаимоотношений (Завьялов А. В., 1990), о возрастании напряженности с ограничением функциональных резервов в системах, генерирующих $\theta$-ритм в условиях патологии, то есть, лимбических системах, главным образом, гиппокампе (Жирмунская Е. А., 1991). У пациентов с ЧМТ падение межполушарной интеграции тета-ритма отражало функциональную недостаточность лимбических структур. Не менее информативными являлись различия характеристик МПКГ быстрого бета-ритма в лобных и центральных отделах коры, выявленные в обеих группах. Значительный рост интеграции $\beta 2$-активности, характерный для пациентов 1 -й группы, и тенденции к росту уровня $\beta 2$-МПКГ у больных 2-й группы отражали разную степень активации ретикулярной формации стволовых структур мозга - выраженную при ОНМК и недостаточную - при ЧMT [425-430].

Различия морфоструктурных и функциональных нарушений корковых и подкорковых образований головного мозга при мозговом инсульте и тяжелой ЧМТ предопределяли различия фармакореакций, формирующихся у пациентов обеих исследуемых групп в ответ на введение препарата Цереброкурин. Для больных с ЧМТ было характерным: а) снижение дельта- и $\beta 2$-частотной межполушарной $\left(\mathrm{O}_{1} \mathrm{O}_{2}\right)$ интеграции, что свидетельствовало о частичном снятии чрезмерных восходящих влияний ретикулярной формации ствола; б) рост показателей МПКГ альфа- и, особенно, $\alpha 1$-частотного диапазона в симметричных центральных $\left(\mathrm{C}_{3} \mathrm{C}_{4}\right)$ отделах коры, что являлось отражением роста функциональной активности диэнцефальных образований; в) увеличение уровней $\delta$ -

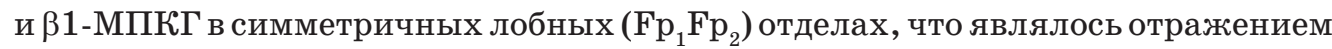
усиления влияний на кору со стороны базальных корковых регулирующих систем; г) тенденции к нарастанию сочетанности темпоральных областей - рост показателей $\delta$-, $\beta 1$ - и $\beta 2$-МПКГ, что традиционно трактуется как результат активации гиппокампальных структур и большего их синхронизирующего влияния на формирование межполушарного взаимодействия; д) в симметричных центральных областях были зафиксированы сильные обратные корреляционные связи $(\mathrm{r} \leq-0,85)$ между динамикой показателей МПКГ $\delta$ - и $\alpha 1$-частотных диапазонов, $\alpha$ - и $\alpha 1$-ритмов, $\alpha$ - и $\beta$-волновых активностей. Такое разобщение изменений показателей межполушарной когерентности ЭЭГ отражает, возможно, одновременную активацию различных «этажей» регулирующих систем мозга - от нижележащих стволовых до корковых медиобазальных.

В 1-й группе преобладали симметричные реакции II типа, при которых достоверное $(\mathrm{p}<0,05)$ увеличение суммарной мощности $(\mathrm{CM})(1$-я группа реакций $-21 \%$ всех ЭЭГ-изменений у пациентов с ОНМК) свидетельствовало о снижении активирующих подкорковых влияний на кору, а уменьшение СМ (2-я группа реакций - 50 \% всех ЭЭГ-реакций у больных с ОНМК) - об активации восходящих влияний ретикулярной формации. У пациентов с ЧМТ реакции II типа 1-й группы, отражающие снижение уровня активности ретикулярной 
формации, отмечались только у троих исследуемых, всегда асимметрично, в то время как ЭЭГ-изменения II типа 2-й группы, характеризующие усиление подкорковых влияний на кору, составляли более 30 \% всех реакций. Но доминировали у пациентов с ЧМТ ЭЭГ-изменения III типа (более 50 \% ЭЭГ-изменений) с преимущественной активацией $\alpha$-ритма (III тип 2 -я группа) и с ростом уровня мощности $\beta$-диапазона (III тип 3-я группа), которые отражали корковые процессы пространственно-временной реорганизации ЭЭГ в ответ на воздействие Цереброкурина. Можно сказать, что максимальный ЭЭГ-эффект применения данного препарата был зафиксирован на том уровне регуляторных мозговых систем, которые изначально отличались наиболее выраженной степенью дисфункции.

Для пациентов с ОНМК типичными были а) снижение межлобной $\left(\mathrm{Fp}_{1} \mathrm{Fp}_{2}\right)$ когерентности $\theta$ - и $\alpha 1$-диапазонов, что отражало уменьшение напряженности в регуляторной системе диэнцефального уровня; б) рост уровня межцентральной $\left(\mathrm{C}_{3} \mathrm{C}_{4}\right)$ когерентности альфа-диапазона, отражающий достаточный уровень функциональной активности диэнцефальных образований; в) увеличение «межокципитальной» $\left(\mathrm{O}_{1} \mathrm{O}_{2}\right)$ когерентности $\delta$-, $\beta 1$ - и $\beta 2$-диапазонов, что является ЭЭГ-коррелятом активации стволовых отделов, преимущественно каудальных; г) снижение $(\mathrm{p}<0,05)$ показателей $\theta-, \beta 1$ - и $\beta 2$-МПКГ симметричных височных отделов $\left(\mathrm{T}_{3} \mathrm{~T}_{4}\right)$, что свидетельствовало об уменьшении активности лимбических образований; д) сочетанность - высокие прямые корреляционные связи - изменений показателей когерентности различных частотных диапазонов в симметричных точках обеих гемисфер, свидетельствующая о глобальном влиянии на формирование пространственно-временной структуры ЭЭГ неспецифических регулирующих структур мозга, что характерно для гипоталамических отделов.

Таким образом, проведенные клинические исследования препарата Цереброкурин позволяют сделать следующие выводы:

1. Грубые изменения ЭЭГ-паттернов, выявленные у пациентов с ОНМК и ЧМТ были обусловлены значительными морфоструктурными изменениями коры больших полушарий, о чем свидетельствовало резкое увеличение коэффициентов - 1-го $((\delta+\theta+\beta 1) /(\alpha+\beta 2))$, 9-го $(\delta / \alpha)$ и 11-го $(\delta / \theta)$.

2. При тяжелой ЧМТ уровень морфоструктурных корковых нарушений был выше, чем при мозговом инсульте о чем свидетельствуют различия уровней интегральных коэффициентов в обеих группах пациентов и различия показателей внутриполушарной когерентности, в частности, неспецифической.

3. У пациентов обеих групп в левом полушарии преобладало снижение уровней когерентности в коротких внутриполушарных парах $\left(\mathrm{Fp}_{1} \mathrm{C}_{3}\right)$, $\left(\mathrm{Fp}_{1} \mathrm{~T}_{3}\right)$ и $\left(\mathrm{T}_{3} \mathrm{C}_{3}\right)$.

4. Рост значений ВПКГ, выявленный после применения препарата Цереброкурин, отражает восстановление типичной для нормы пространственно-временной организации биопотенциалов. 
5. Разнонаправленность изменений ВПКГ бета-ритма связана с активацией или угнетением спектральной мощности бета-диапазона и отражает ирритацию или снижение неокортикального тонуса. Причем рост мощности бета-частотного диапазона коррелирует с усилением глутаматергических возбуждающих влияний в структурах мозга. Подобные тенденции изменений ВПКГ после введения Цереброкурина следует рассматривать как признаки симпатико- или парасимпатикотонии.

6. Для пациентов с ЧМТ установлено нарастание дезинтеграции только медленных дельта- и тета-ритмов в лобно-височной $\left(\mathrm{Fp}_{1} \mathrm{~T}_{3}\right)$ и центрально-височной парах $\left(\mathrm{T}_{3} \mathrm{C}_{3}\right)$. Подобные тенденции изменений ВПКГ характеризуют триггерную роль восстановления сочетанности активности височных и центральных отделов доминирующего полушария, т. е. моторно-речевой зоны коры.

7. В задних отделах правой гемисферы - в центрально-окципитальной паре $\left(\mathrm{C}_{4} \mathrm{O}_{2}\right)$ - у исследуемых 2-й группы преобладали снижение когерентности медленных частотных ритмов и рост сочетанности быстрых - альфа- и бета-волновых ритмов. У пациентов 1-й группы в задних отделах правого полушария $\left(\mathrm{C}_{4} \mathrm{O}_{2}\right)$, наоборот, чаще было выявлено увеличение когерентности дельта- и $\theta$-ритмов.

8. Изменения ВПКГ в ответ на введение препарата Цереброкурин, зафиксированы у пациентов с ОНМК в лобно-височной $\left(\mathrm{Fp}_{2} \mathrm{~T}_{4}\right)$ паре, где отмечались обязательные и противоположные изменения уровней $\alpha$-ВПКГ - рост и снижение.

9. Выраженная динамика показателей ВПКГ в правой гемисфере по сравнению с левым полушарием, выявленная у пациентов обеих исследуемых групп, во-первых, связана с более тесным функциональным взаимодействием правого полушария с диэнцефальными структурами и активацией именно этих подкорковых образований у больных с ОНМК и ЧМТ под влиянием препарата Цереброкурин.

10. Одним из неспецифических стресс-механизмов мозга является смена при стрессе доминирования полушарий (Л П) Поэтому, значимая правополушарная реакция на введение Цереброкурина, одним из компонентов которой было выраженное повышение внутриполушарной интеграции ЭЭГ-ритмов, являлась проявлением адекватных саногенетических процессов в условиях стресса при ОЦН различного генеза.

11. Различия фармакореакций, формирующихся у пациентов в ответ на введение препарата Цереброкурин обусловлены различиями морфоструктурных и функциональных нарушений корковых и подкорковых образований головного мозга при мозговом инсульте и тяжелой ЧМТ. Максимальный ЭЭГ-эффект применения Цереброкурина был зафиксирован на том уровне регуляторных мозговых систем, которые изначально отличались наиболее выраженной степенью дисфункции. 
Таким образом, отечественный препарат Цереброкурин занимает достойное место в лечении органической патологии центральной нервной системы детей и взрослых, имеет ряд преимуществ перед медикаментозной ноотропной терапией, в том числе - выработка стойкого клинического эффекта.

В отношении Цереброкурина в настоящее время исследователи выделяют следующие аспекты его механизма действия [426-433]:

1. Нейротрофическая стимуляция - этот механизм обеспечивает жизнеспособность, дифференцировку нервной клетки, повышает ее устойчивость к повреждению. В связи с этим снижается смертность в острый период инсульта; препарат препятствует развитию цитотоксического отека мозга, защищает высокоспециализированные пирамидные клетки гиппокампа, ограничивает образование свободных радикалов после церебральной ишемии, улучшает микроциркуляцию головного мозга.

2. Нейромодуляторный эффект - проявляется в улучшении поведенческих реакций, памяти, обучаемости.

3. Метаболическая регуляция - оказывает протективное действие, защищая нервную клетку от молочнокислого ацидоза и улучшая утилизацию ею кислорода.

Учитывая, что в патогенезе нейродегенеративных заболеваний значительная роль принадлежит митохондриальной дисфункции, гиперэкспрессии генов раннего реагирования, инициации нейроапоптоза, нами была предпринята попытка в условиях эксперимента изучить влияние Цереброкурина на данные изменения и сопоставить эффект данного препарата с другими нейропептидными лекарственными средствами (Кортексин, Семакс).

Экспериментальные исследования были выполнены на 100 половозрелых самцах монгольской песчанки. Острое нарушение мозгового кровообращения моделировали путем односторонней перевязки сонной артерии. Характер экспресии гена c-fos исследовали не только на модели OHMК, но и на моделях хронического иммобилизационного стресса, алкоголизма.

Проведенные нами экспериментальные исследования также показали достаточно высокую эффективность Цереброкурина в условиях моделирования ишемии головного мозга на монгольских песчанках. Курсовое назначение Цереброкурина крысам линии Вистар с двухсторонней перевязкой общих сонных артерий (моделирование ОНМК) приводило к значительному снижению (в среднем на 67 \% ) процессов окислительной деструкции белков в суспензии митохондрий нейронов сенсомоторной зоны коры мозга. Подобное антиоксидантное действие Цереброкурина объясняет и его позитивное влияние на процессы митохондриальной дисфункции в условиях моделирования ОНМК. Так, была выявлена способность Цереброкурина тормозить открытие митохондриальной циклоспорин А-зависимой поры на 4-е сутки модельной патологии (рис. 4.6). Важно отметить, что данный эффект Цереброкурин продемонстрировал и в опытах in vitro при введении в инкубационную смесь, содержащую митохондрии нейронов гиппокампа, ионов $\mathrm{Ca}^{2+}(0,6$ мM) и нейротоксина - метил- 
фенилпиридиния (МФП) (0,4 мМ) (рис. 4.7). Как видно из рис. 4.6, Цереброкурин по своему влиянию на исследуемые показатели статистически достоверно превышал таковые показатели Кортексина и Семакса.

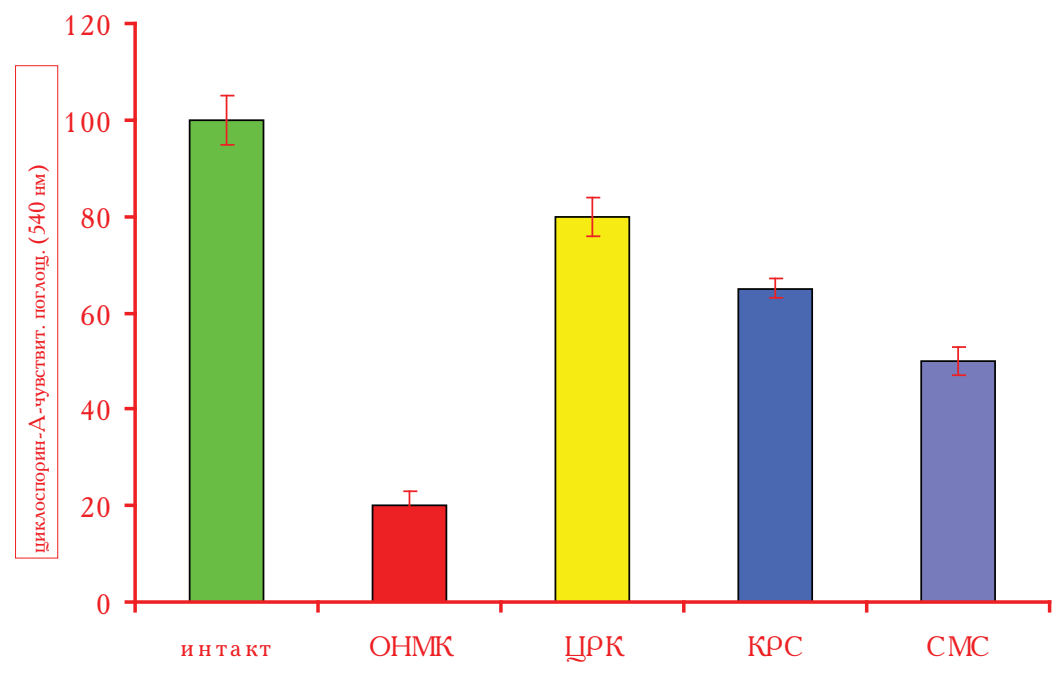

Рuc. 4.6. Вияние Цереброкурина (0,005 мл/кг) на открытие митохондриальной поры нейроцитов крыс с ОНМК (4-е сутки)

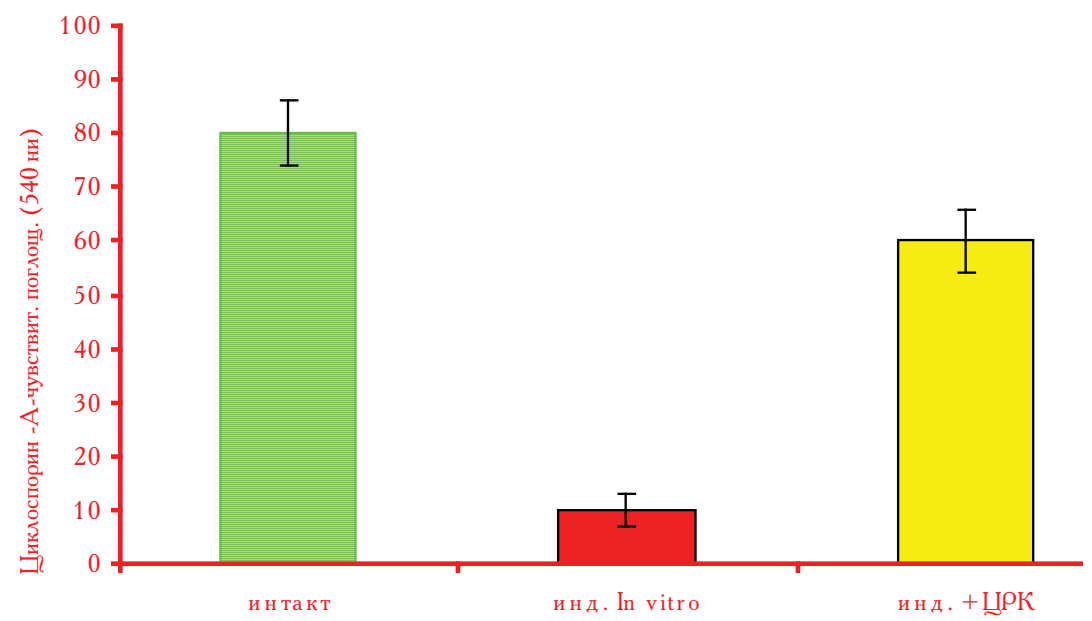

Рис. 4.7. Влияние Цереброкурина (0,400 мл) на индуцированное Са2+ (0,6 мМ) и МФП (0,4 мМ) открытие митохондриальной поры нейроцитов in vitro 
Таблииа 4.26

Показатели окислительной продукции энергии в головном мозге на 4-е сутки ОНМК

\begin{tabular}{|c|c|c|c|}
\hline Исследуемые показатели & $\begin{array}{c}\text { ОНМК } \\
\text { (контроль) }\end{array}$ & $\begin{array}{c}\text { ОНМК+ } \\
\text { Цереброкурин }\end{array}$ & интакт \\
\hline АТФ, мкM/г & $1,00 \pm 0,05$ & $\begin{array}{l}1,89 \pm 0,07 \\
\text { PST }<0,05\end{array}$ & $2,77 \pm 0.11$ \\
\hline Лактат, мкМ/г & $7,45 \pm 0,11$ & $\begin{array}{l}4,87 \pm 0,11 \\
\text { PST }<0,05\end{array}$ & $2,61 \pm 0,12$ \\
\hline Малат, мкМ/г & $0,18 \pm 0,01$ & $\begin{array}{l}0,45 \pm 0,01 \\
\text { PST }<0,05\end{array}$ & $0,38 \pm 0,02$ \\
\hline МДГ, мкМ/г/мин & $5,34 \pm 0,12$ & $\begin{array}{l}7,64 \pm 0,10 \\
\text { PST }<0,05\end{array}$ & $8,17 \pm 0,08$ \\
\hline КФК-цт, мкМ/мг/мин & $, 801 \pm 0,01$ & $1,117 \pm 0,03$ & $1,347 \pm 0,02$ \\
\hline КФК-мх, мкМ/мг/мин & $0,412 \pm 0,02$ & $\begin{array}{l}0,775 \pm 0,01 \\
\text { PST }<0,05\end{array}$ & $0,845 \pm 0,05$ \\
\hline Цитохром-С-оксидаза, мкМ/мг/мин & $3,11 \pm 0,2$ & $4,932 \pm 0,1$ & $5,89 \pm 0,1$ \\
\hline
\end{tabular}

Позитивное действие Цереброкурина в отношении функциональной активности митохондрий мозга выражалось и в нормализации энергетического обмена. Так, при введении Цереброкурина, в головном мозге животных с ОНМК наблюдалось увеличение продукции АТФ в окислительных реакциях, о чем свидетельствовало увеличение содержания малата, повышение активности митохондриальной малатдегидрогеназы (МДГ) и цитохром-С-оксидазы. Цереброкурин влиял не только на продукцию энергии, но и на ее транспорт и утилизацию, о чем свидетельствовало повышение активности митохондриальной (м-КФК) и цитоплазматической (ц-КФК) креатинфосфокиназы. Важным моментом в действии Цереброкурина на энергетический обмен в условиях ишемии мозга было значительное снижение продукции лактата и, возможно, лактат-ацидоза (табл. 4.26).

Одним из ключевых моментов в нейропротективном эффекте Цереброкурина, Кортексина, Семакса оказалась их способность нормализовать экспрессию гена c-fos в условиях ОНМК, хронического иммобилизационного стресса (ХИС), моделирования алкоголизма.

Проведенные нами экспериментальные исследования показали достаточно высокую способность нейропептидов влиять на экспрессию генов раннего реагирования c-fos и связанные с ней процессы апоптотической гибели нейроцитов на различных модельных патологиях.

Так, лечебно-профилактическое введение Цереброкурина, Кортексина и Семакса животным при моделировании хронического иммобилизационного стресса приводило к достоверному снижению $(\mathrm{p} \leq 0,01)$ числа fos-позитивных 
нейронов в $\mathrm{CA}_{1}$-зоне гиппокампа по сравнению с контрольной группой животных. Как видно из рисунков 4.8 и 4.9 наиболее активным нейропептидом оказался Цереброкурин, который снижает количество fos-позитивных нейронов более чем на $70 \%$ по отношению к контролю.

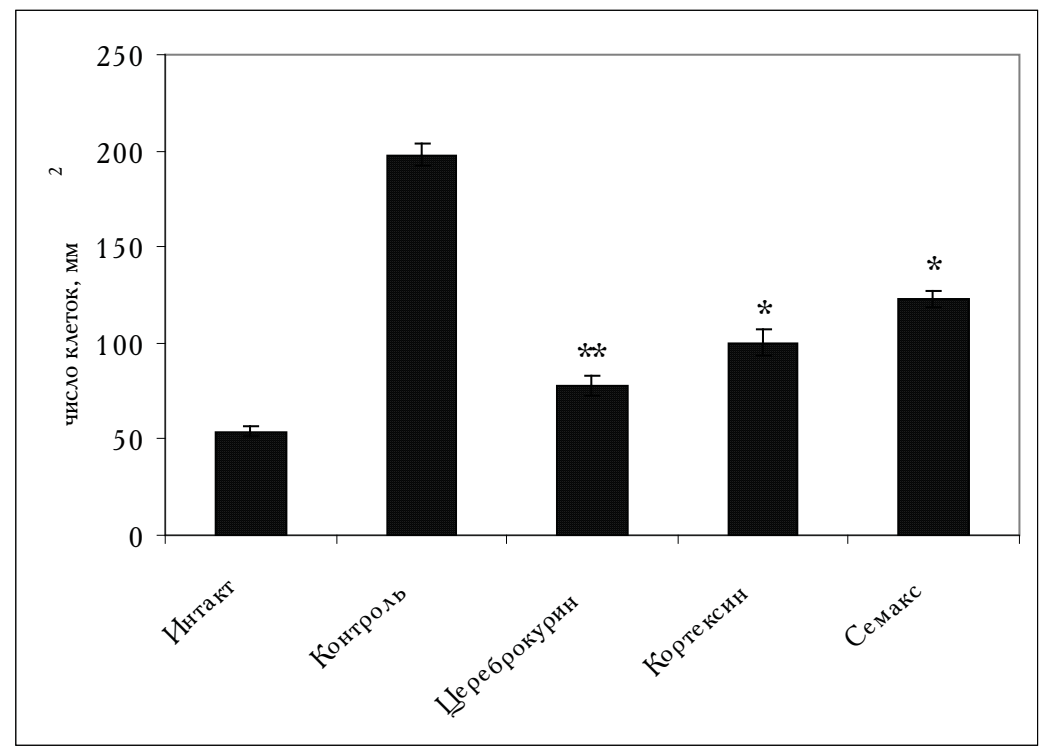

Примечание: * $-\mathrm{p} \leq \mathbf{0 , 0 5}$ по отношению к контролю;

$* *-\mathrm{p} \leq 0,05$ по отношению к Кортексину, Семаксу.

Рuc. 4.8. Влияние нейропептидов на гиперэкспрессию генов раннего реагирования c-fos в условиях хронического иммобилизационного стресса

За счет подавления экспрессии генов раннего реагирования c-fos Цереброкурин, Кортексин и Семакс способны в определенной степени влиять на процессы апоптотической гибели нейрона в условиях стресса. Это подтверждается нашим исследованием содержания антиапоптотического bcl-2 в $\mathrm{CA}_{1}$-зоне гиппокампа. Введение нейропептидов увеличивало количество bcl-2 в зоне $\mathrm{CA}_{1}$ зоны гиппокампа по сравнению с контрольной группой животных $(\mathrm{p} \leq 0,01)$, при этом Цереброкурин статистически достоверно $(\mathrm{p} \leq 0,01)$ превышал показатели Кортексина и Семакса [109].

Защитное действие Цереброкурина, Кортексина, Семакса проявлялось в восстановлении когнитивных функций животных, что выражалось увеличением латентного времени захода животных в темный отсек (рис. 4.10).

Как нами было описано выше, 30-дневное введение крысам алкоголя вызывало снижение экспрессии генов раннего реагирования c-fos, приводя при этом к нарушению процессов обучения и памяти. Курсовое назначение нейропептидов приводило к увеличению количества c-fos-позитивных нейронов в $\mathrm{CA}_{1}$-зоне гиппокампа по отношению к контрольной группе (рис. 4.11). Важно 
отметить, что увеличение экспрессии гена c-fos под влиянием Цереброкурина протекало на фоне восстановления когнитивных функций алкоголизированных животных (рис. 4.12).
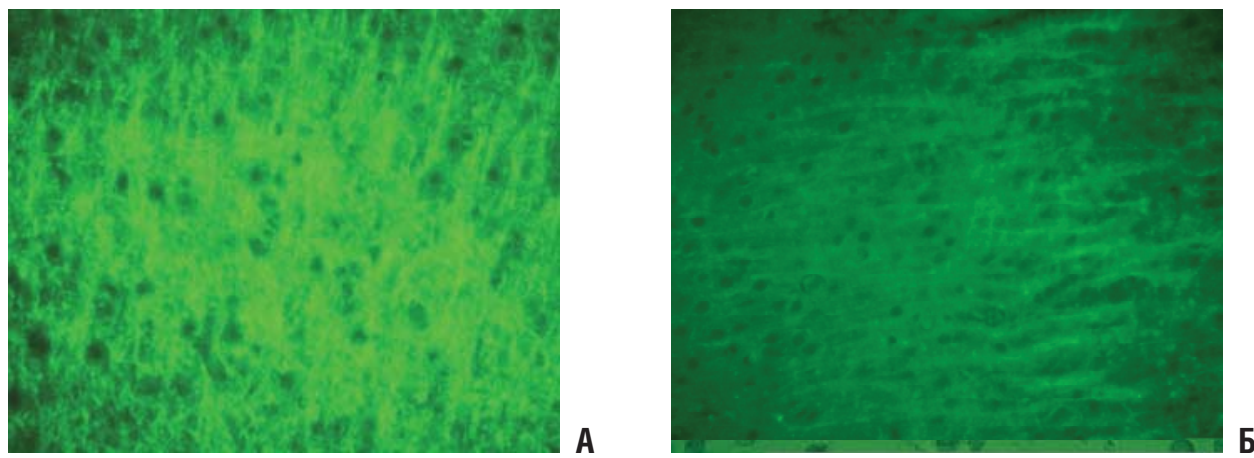

$\mathrm{A}-$ Экспрессия белка c-fos в нейронах $\mathrm{CA}_{1}$-зоны гиппокампа контрольной группы животных; Б - Экспрессия белка c-fos в нейронах $\mathrm{CA}_{1}$-зоны гиппокампа крыс с введением Цереброкурина.

Рuc. 4.9. Экспрессия белка с-fos в нейронах $\mathbf{C A}_{1}$-зоны гиппокампа у животных с ХИС. Реакция непрямой иммунофлуоресценции (первичные антитела c-fos (Sigma Chemical, USA), вторичные антитела - флуоресцент конъюгированный с козьими Ig (Sigma Chemical, USA). Изображение флуоресцентного микроскопа Axioskop (Ziess, Germany), видеокамера COHU — 4922 (USA)

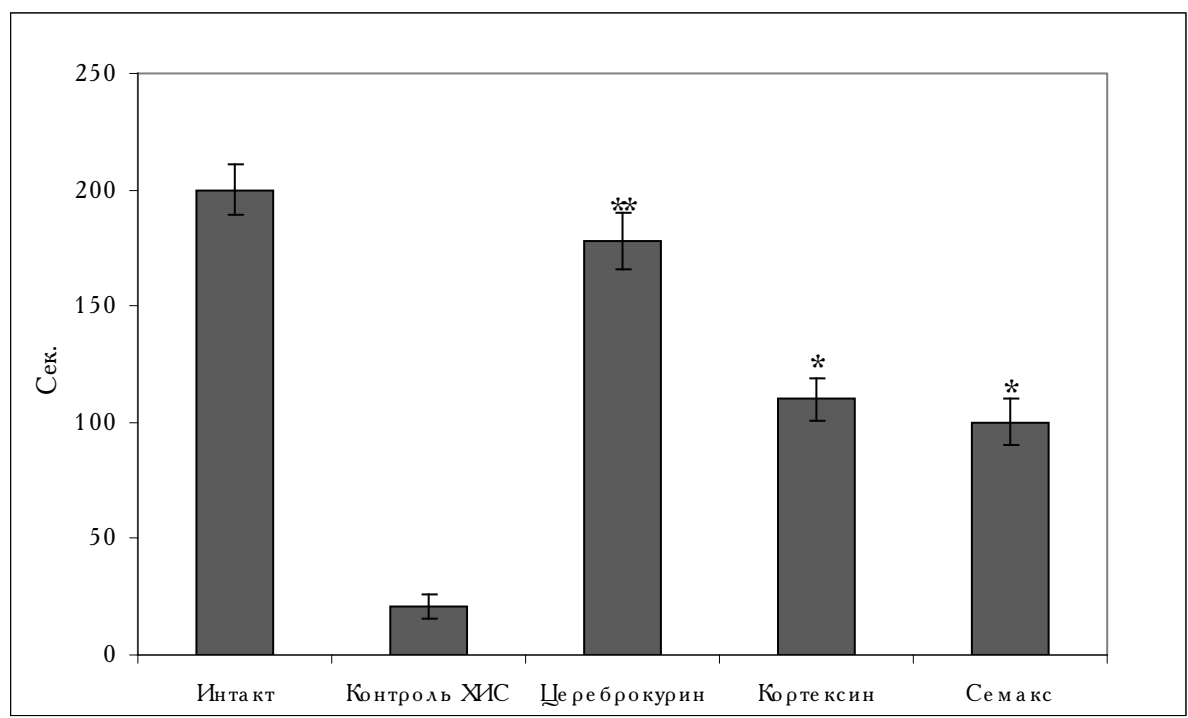

Примечания: * $-\mathrm{p} \leq 0,05$ по отношению к контролю; $* *-\mathrm{p} \leq 0,05$ по отношению к Кортексину, Семаксу.

Рuc. 4.10. Влияние нейропептидов на воспроизведение УРПИ у крыс, перенесших ХИС 


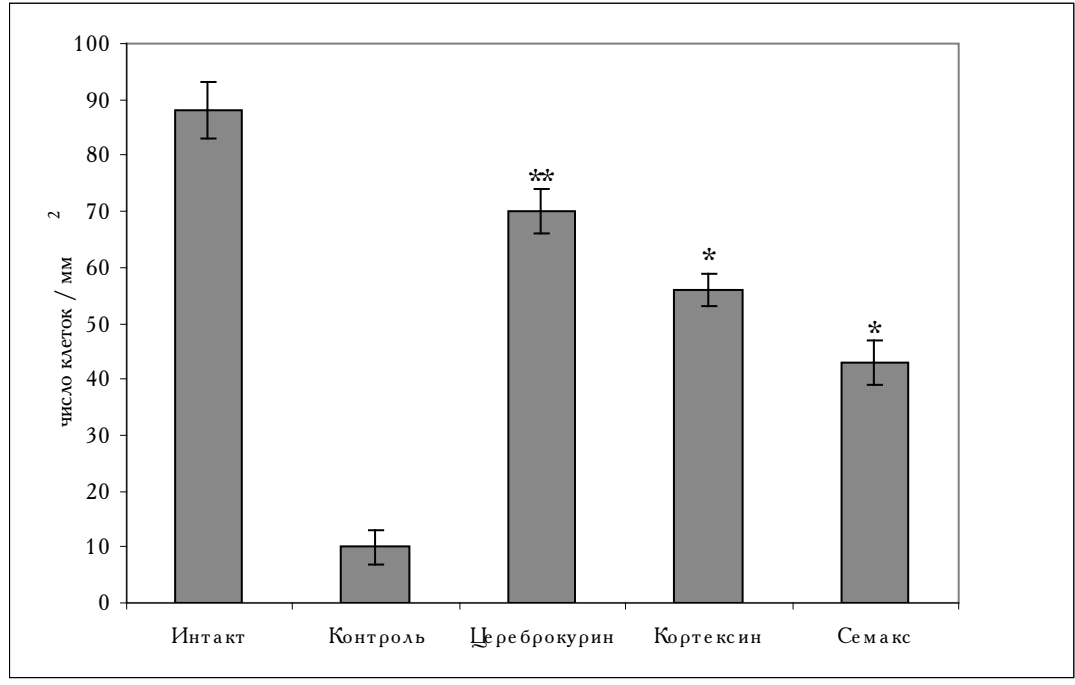

Рис. 4.11. Влияние нейропептидов на экспрессию генов раннего реагирования c-fos у крыс в условиях 30 -дневного введения этанола

Примечание: * $-\mathrm{p}<0,05$ по отношению к контролю;

$* *-\mathrm{p}<0,05$ по отношению к Кортексину, Семаксу.

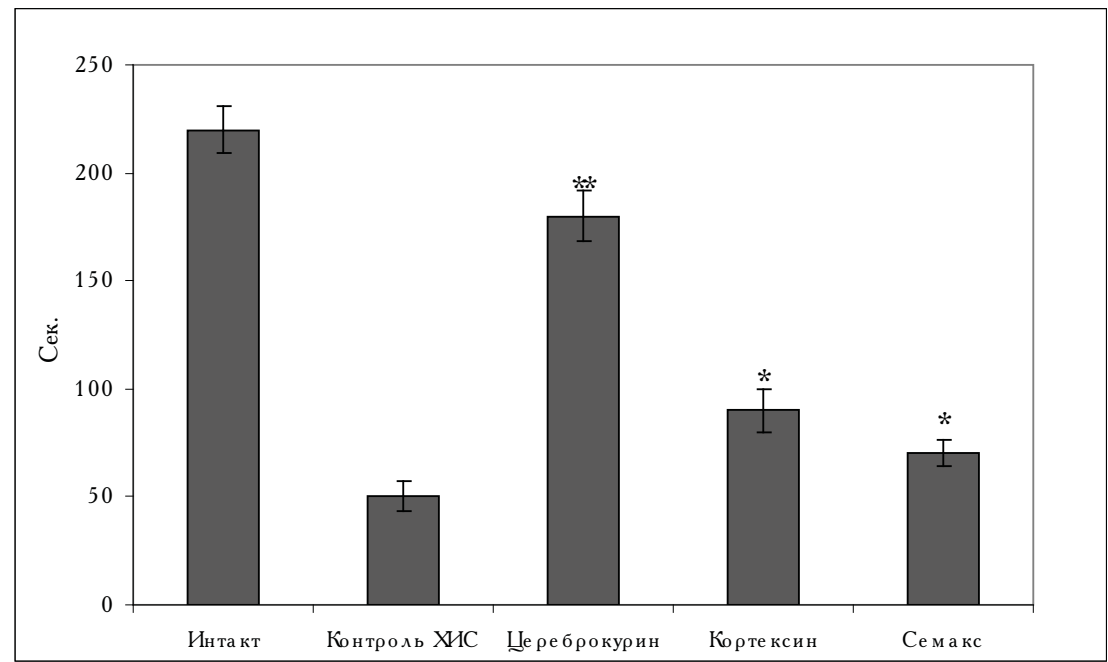

Примечания: * $-\mathrm{p}<0,05$ по отношению к контролю;

$* *-\mathrm{p}<0,05$ по отношению к Кортексину, Семаксу.

Рис. 4.12. Влияние нейропептидов на воспроизведение УРПИ у крыс с 1-месячным введением этанола 
В условиях моделирования ишемического повреждения головного мозга (ОНМК) нейропептиды также продемонстрировали способность на 21-е сутки (восстановительный период) нормализовать экспрессию гена c-fos. Данный эффект нейропептидов является одним из главных звеном их церебропротективного действия - за счет усиления экспрессии гена c-fos изменялся морфологический тип гибели нейронов, переключаясь на более мягкий апоптотический путь. Апоптотическая гибель нейронов является оптимальным, упорядоченным процессом прекращения жизнедеятельности деструктивно измененных нейронов, при котором стабилизируются клеточные мембраны, содержание клеток утилизируется путем образования апоптотических телец и их фагоцитоза, без развития воспалительной реакции. Из рисунка 4.13 видно, что наиболее активным оказался Цереброкурин, увеличивая количество c-fos в нейроцитах на 150 \% по отношению к контролю. Следует отметить, что при ишемическом повреждении головного мозга введение нейропептидов приводило не к гиперэкспрессии генов, а к их нормализации [119].

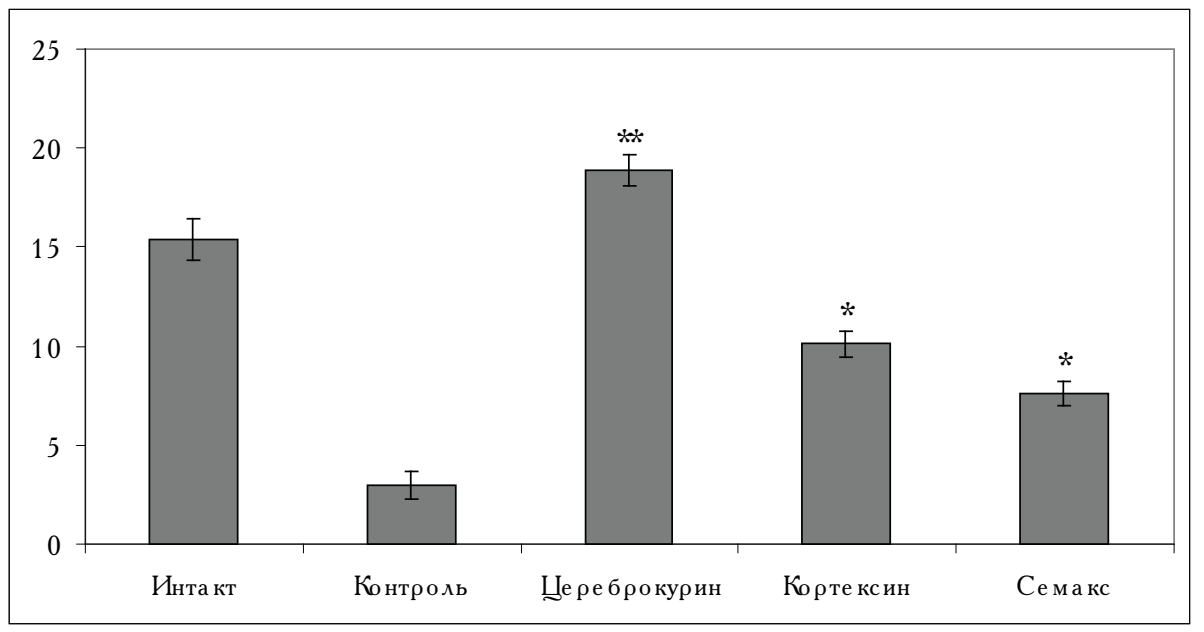

Примечание: * $-\mathrm{p} \leq 0,05$ по отношению к контролю;

$* *-\mathrm{p} \leq 0,05$ по отношению к Кортексину, Семаксу.

Puc. 4.13. Содержание c-fos в нейроцитах крыс, с моделированием ишемии головного мозга на 21-е сутки эксперимента

Вопрос о значении апоптоза в условиях ишемии головного мозга остается спорным, однако все больше фактов свидетельствует в его пользу [109]. В отличие от апоптоза, некроз клетки более грубое разрушение, которое сопровождается вакуолизацией, резким набуханием клетки, лизисом мембран, выходом клеточного содержимого в межклеточное пространство. При этом усиливается синтез воспалительных интерлейкинов и цитокинов, развивается воспаление. В зависимости от степени экспрессии, ген c-fos регулирует прцессы апоптоза/ некроза. Нормализация экспрессии данного гена под влиянием нейропептидов 
при ишемическом повреждении нейронов на 21-е сутки приводила к увеличению количества глиальных клеток и нейронов в коре головного мозга, а также к повышению их морфофункциональной активности (увеличение содержания РНК) (табл. 4.27; рис. 4.14).

Таблица 4.27

Влияние нейропептидов на нейроны коры головного мозга крыс с экспериментальной ишемией на 21-е сутки

\begin{tabular}{|l|c|c|c|}
\hline \multicolumn{1}{|c|}{$\begin{array}{c}\text { Экспериментальные } \\
\text { группы животных }\end{array}$} & $\begin{array}{c}\text { Плотность нейронов, } \\
\text { клетки/мм² }\end{array}$ & $\begin{array}{c}\text { Площадь тел } \\
\text { нейронов, мкм }{ }^{2}\end{array}$ & $\begin{array}{c}\text { Содержание РНК } \\
\text { в нейронах, Еоп }\end{array}$ \\
\hline Интакт & $1292 \pm 34$ & $74,87 \pm 1,32$ & $9,72 \pm 0,14$ \\
\hline Контроль (ишемия) & $980 \pm 19$ & $51,7 \pm 1,08$ & $5,1 \pm 0,3$ \\
\hline Ишемия+Цереброкурин & $1307 \pm 22^{*}$ & $70,82 \pm 0,72^{\star}$ & $9,17 \pm 0,17^{\star}$ \\
\hline Ишемия+Кортексин & $1100+11^{*}$ & $65,12 \pm 0,94^{*}$ & $7,49 \pm 0,28^{\star}$ \\
\hline Ишемия+Семакс & $1112+10^{\star}$ & $66,87 \pm 1,08^{\star}$ & $7,10 \pm 0,15^{\star}$ \\
\hline
\end{tabular}

Примечания: * $-\mathrm{p} \leq 0,05$ по отношению к контролю.
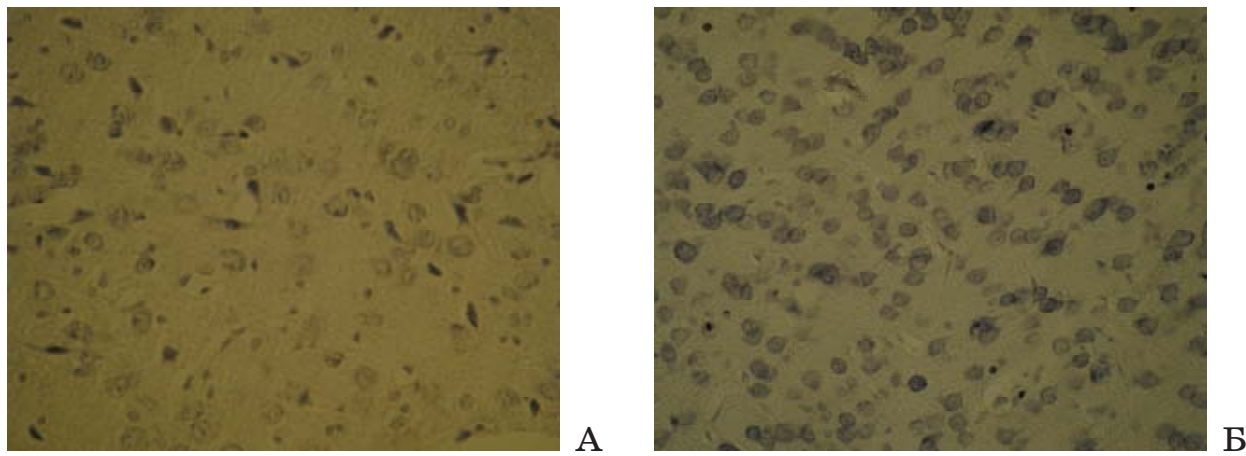

А - Контрольная группа животных (ишемия 21-е сутки);

Б - Цереброкурин + ишемия (21-е сутки).

Рuc. 4.14. Морфофункциональное состояние нейронов коры головного мозга крыс с экспериментальной ишемией на 21-е сутки. Окраска галлоцианин-хромовыми квасцами по Эйнарсону, × 100

Нейропротективное действие Цереброкурина в условиях эксперимента проявлялось восстановлением когнитивных функций экспериментальных животных, что выражалось в увеличении латентного времени захода животных в темный отсек, а также в снижении неврологической симптоматики по шкале McGrow (рис. 4.15). 


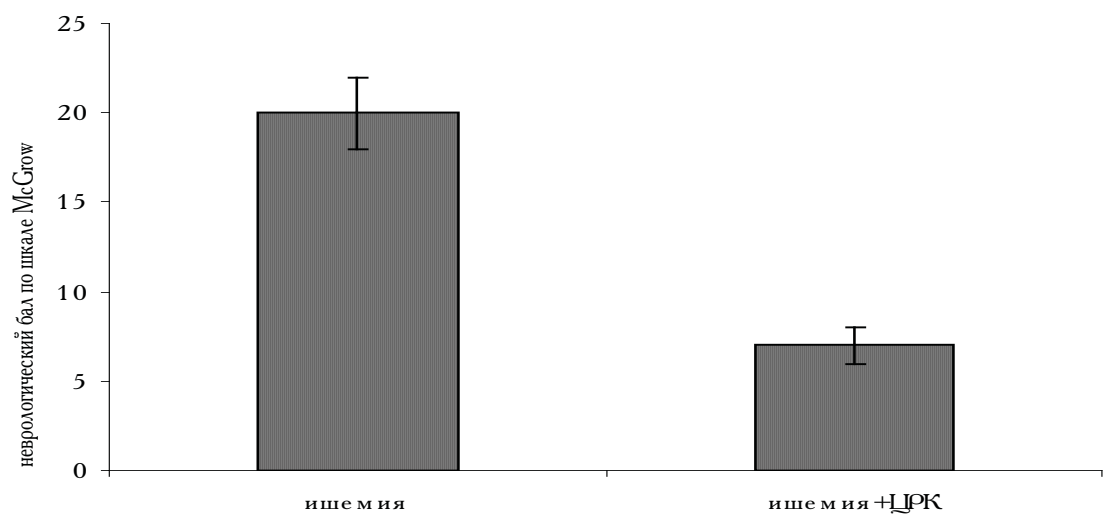

Рис. 4.15. Влияние Цереброкурина на неврологическую симптоматику животных с ОНМК

Таким образом, отечественный препарат Цереброкурин, как показал ряд клинических исследований, занимает достойное место в лечении органической патологии центральной нервной системы у детей и взрослых, имеет ряд преимуществ перед медикаментозной ноотропной терапией, в том числе - выработка стойкого клинического эффекта.

Кроме того, проведенные экспериментальные исследования показали явное преимущество данного препарата перед другими нейропептидами во влиянии на процессы нейроапоптоза, митохондриальной дисфункции, регуляции экспрессии гена c-fos. По нашему мнению, именно данные эффекты Цереброкурина определяют его сильный и стойкий нейротрофический и нейропротективный эффекты.

Резюмируя имеющиеся данные, можно рассматривать новый оригинальный препарат - Цереброкурин - как высокоактивный ноотроп, первичный и вторичный нейропротектор, ярко подтверждающий пептидергическую концепцию нейропротективного эффекта.

Сравнительная оценка энерготропного и митопротективного механизмов нейропротективного действия Церебролизина, Кортексина и Цереброкурина. Нами проведены многочисленные экспериментальные исследования нейропротективного действия нейротрофических церебропротекторов на модели острого нарушения мозгового кровообращения (ОНМК), вызванного одно- и двухсторонней перевязкой общих сонных артерий (наркоз: этаминал натрия 40 мг/кг) у белых беспородных крыс обоего пола, массой 160-180 г. С целью определения эффективной дозы Цереброкурина в условиях односторонней перевязки общей сонной артерии операция была произведена 75 белым беспородным крысам. О степени тяжести ОНМК судили по наличию признаков неврологического дефицита у прооперированных животных, который оценивали по шкале Stroke-index Mc Grow. Тяжесть состояния определялась по сумме соответствующих баллов. Отмечалось количество крыс с легкой симптоматикой 
до 2,5 баллов по шкале Stroke-index (вялость движений, слабость конечностей, односторонний полуптоз, тремор, манежные движения) и тяжелыми проявлениями неврологических нарушений (свыше 2,5 баллов) - парезы конечностей, паралич нижних конечностей, боковое положение и т. д.

Исследование неврологического статуса животных (табл. 4.28), выживших после моделирования патологии, с использованием шкалы Stroke-index Mc Grow показало, что в первый день наблюдения у большинства крыс преобладала тяжелая или средне-тяжелая симптоматика. У 50 \% ложнооперированных крыс отмечалась легкая симптоматика, а у 50 \% вообще отсутствовали признаки неврологического дефицита.

Регистрацию гибели крыс и исследование динамики развития неврологических нарушений, вызванных ОНМК, проводили в течение 4-х дней. Цереброкурин вводили внутрибрюшинно в дозах: 50 мкл/кг; 100 мкл/кг; 150 мкл/ кг веса; 300 мкл/кг ежедневно.

Таблица 4.28

\section{Признаки неврологического дефицита (по шкале Mc Grow)} у крыс на 1-е сутки ОНМК

\begin{tabular}{|c|c|c|c|c|c|}
\hline \multirow[t]{3}{*}{ Неврологический симптом } & \multirow{3}{*}{$\begin{array}{l}\text { Stroke } \\
\text { index }\end{array}$} & \multicolumn{4}{|c|}{ Количество особей } \\
\hline & & \multicolumn{2}{|c|}{ Ложнооперированные } & \multicolumn{2}{|c|}{ OHMK } \\
\hline & & кол-во & $\begin{array}{c}\% \text { от } \\
\text { общего } \\
\text { числа }\end{array}$ & кол-во & $\begin{array}{c}\% \text { от } \\
\text { общего } \\
\text { числа }\end{array}$ \\
\hline Вялость, замедленность движений & 0,5 & 4 & 40 & 53 & 70,7 \\
\hline Гиперактивность & 1,0 & 0 & 0 & 42 & 56 \\
\hline Отсутствие движений & 1,0 & 0 & 0 & 3 & 4 \\
\hline Тремор & 1,0 & 0 & 0 & 65 & 86,7 \\
\hline Односторонний полуптоз & 1,0 & 0 & 0 & 31 & 41,3 \\
\hline Двусторонний полуптоз & 1,5 & 0 & 0 & 6 & 8 \\
\hline Слабость конечностей & 1,5 & 1 & 10 & 54 & 72 \\
\hline Односторонний птоз & 1,5 & 0 & 0 & 9 & 12 \\
\hline Двусторонний птоз & 1,5 & 0 & 0 & 5 & 6,7 \\
\hline Манежные движения & 2,0 & 0 & 0 & 62 & 82,7 \\
\hline Судороги тонические, клонические & 2,0 & 0 & 0 & 47 & 62,7 \\
\hline Наклон головы & 3,0 & 0 & 0 & 42 & 56 \\
\hline Отсутствие роговичного рефлекса & 3,0 & 0 & 0 & 18 & 24 \\
\hline Паралич задних конечностей & 3,0 & 0 & 0 & 55 & 73,3 \\
\hline Коматозное состояние & 7,0 & 0 & 0 & 0 & 0 \\
\hline Смерть & 10,0 & 0 & 0 & 40 & 53,3 \\
\hline Общая численность группы & - & 10 & & 75 & \\
\hline
\end{tabular}

Примечание: у большинства крыс с ОНМК одновременно присутствовало несколько признаков неврологического дефицита. 


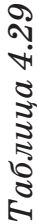

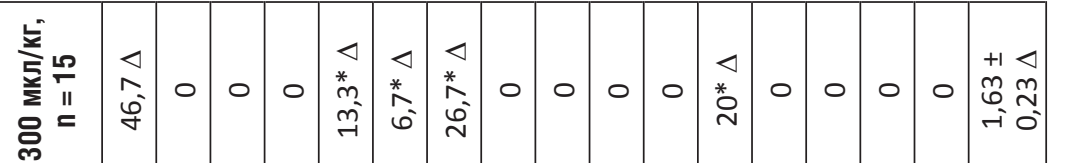

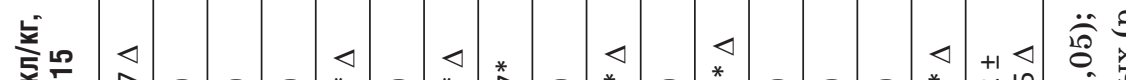

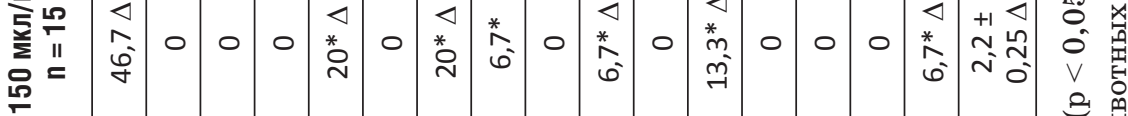

(․․․

赵

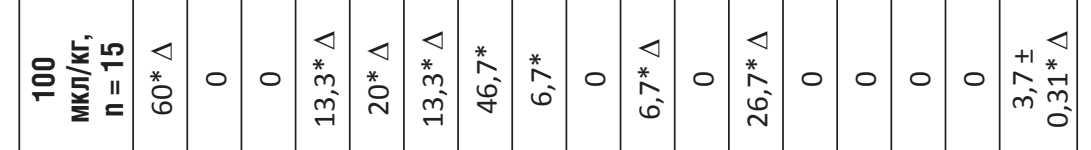
罗

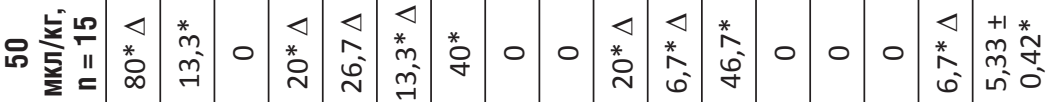

\section{مأ돋}

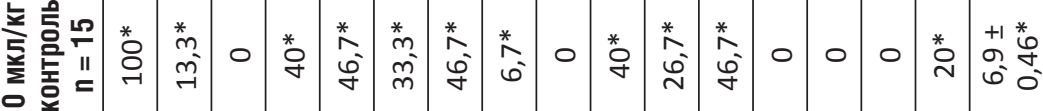

\section{흐으}

옿

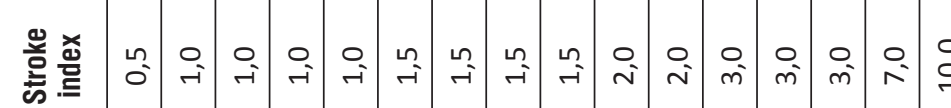


Животным из контрольной группы вводили физиологический раствор. Каждая группа в начале эксперимента состояла из 15 животных.

Результаты исследований показали положительный эффект увеличения дозы Цереброкурина - регрессию неврологического дефицита у крыс с ОНМК (табл. 4.29).

\section{Лог функция выживания}

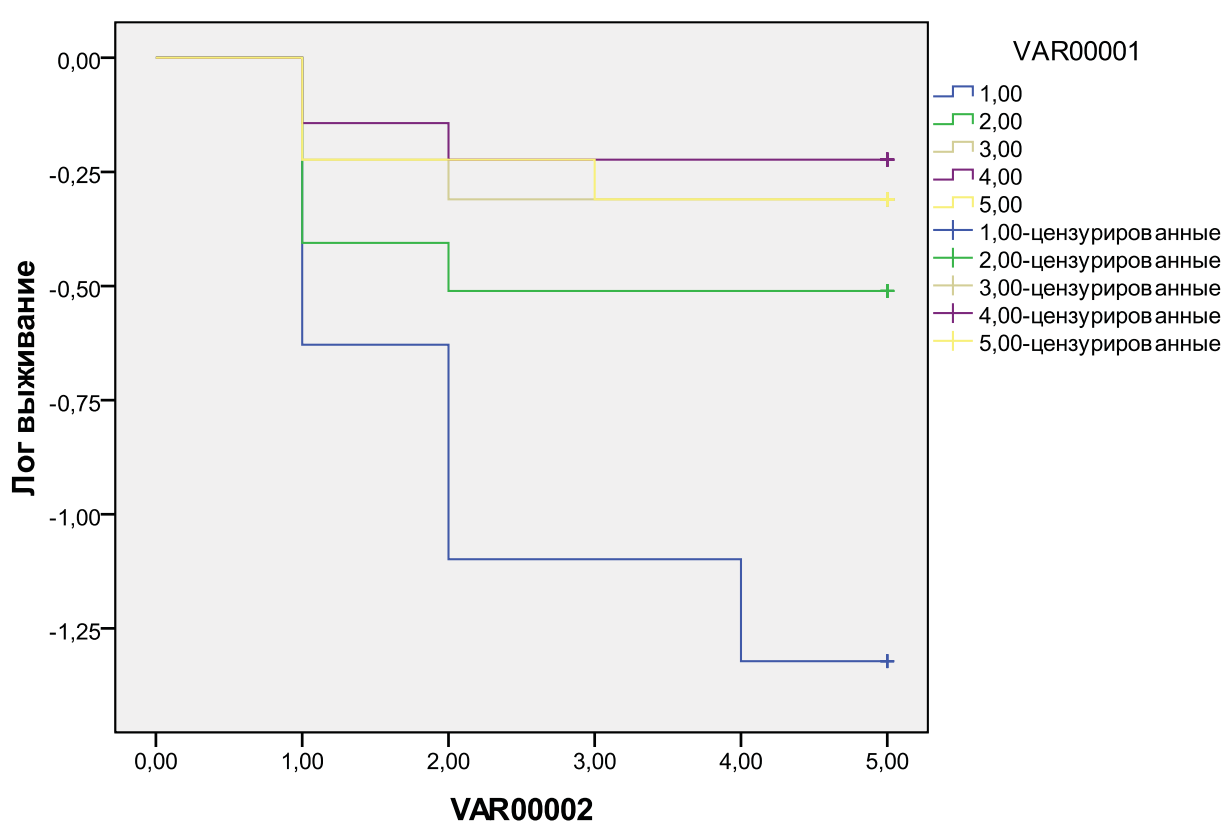

Рuc. 4.16. Преобразованные показатели выживаемости в экспериментальных группах

Регистрация гибели животных (табл. 4.30) показала, что в группе ложнооперированных животных (ЛЖћ) была $100 \%$ выживаемость, а в группе с ОНМК этот показатель составил всего 26,67 \% , причем за первые сутки погибло 46,67 \% животных.

Динамика ухудшения состояния и гибели крыс с ОНМК может свидетельствовать о скрытой недостаточности компенсаторных реакций организма, нарастающих в послеоперационном периоде, и развитии сопутствующих осложнений (отек, набухание тканей, нарушение интрацеребральной гемодинамики, ишемия мозга).

Для обработки данных процент выживаемости был преобразован в пробиты, а дозы препарата были логарифмированы (рис. 4.16). В токсикологиче- 
ских исследованиях необходимо также рассчитывать и коэффициент кумуляции, чтобы определить, кумулирует препарат или к нему возникает привыкание (рис.4.17).

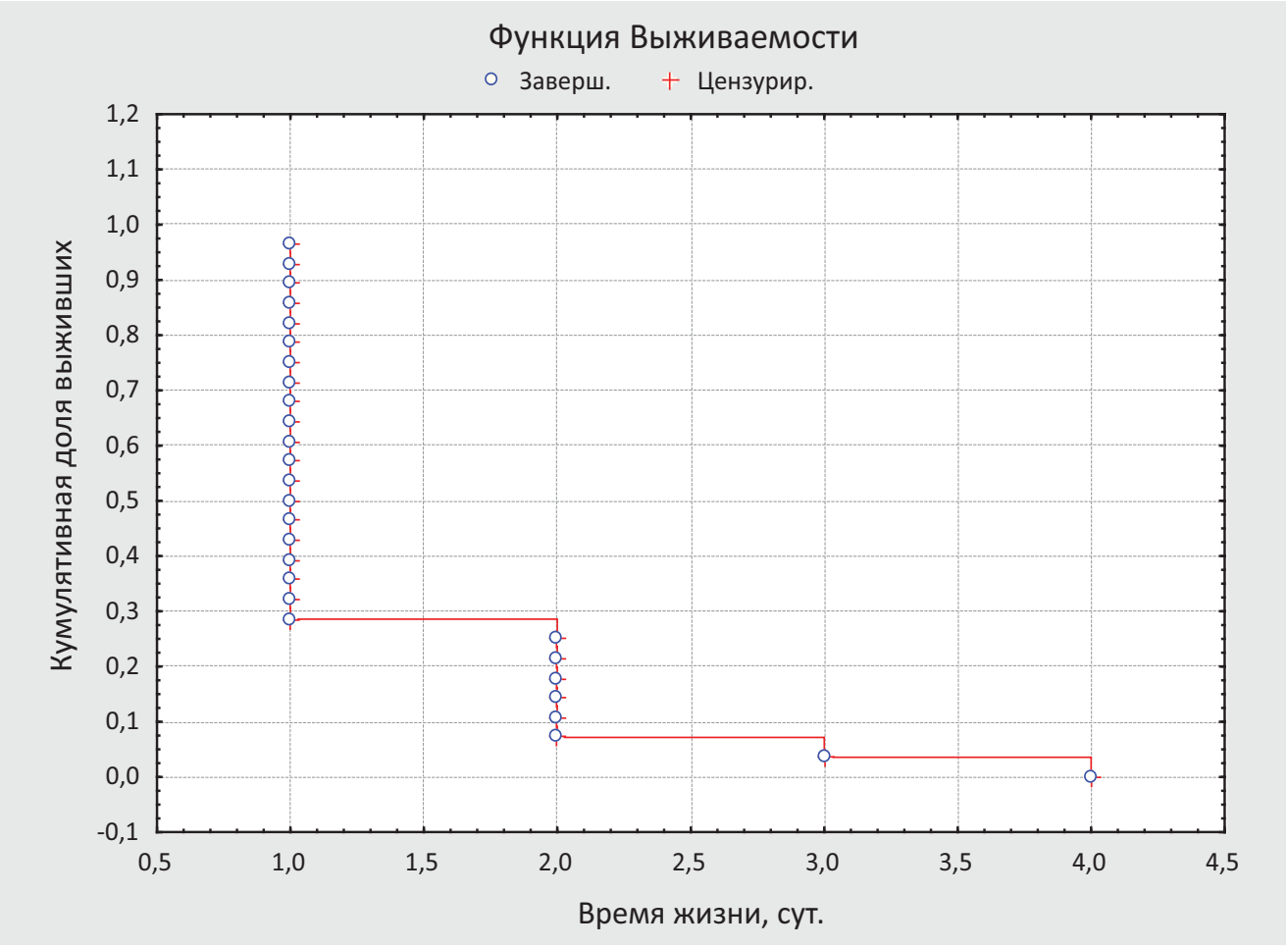

\section{Рuc. 4.17. Определение кумулятивной доли выживших животных}

Несмотря на тяжесть состояния прооперированных животных, Цереброкурин показал сильное протективное действие. Так, из 4-х исследуемых доз препарата, максимальный процент выживаемости отмечался в группах, где крысы получали препарат в дозах 150 мкл /кг веса и 300 мкл/кг, причем достоверных отличий этого показателя в вышеуказанных группах получено не было.

Исследование степени ОМБ (спонтанной и металл-катализируемой) показало, что с увеличением дозы Цереброкурина (табл. 4.31) достоверно по отношению к контрольной группе снижается содержание альдегидфенилгидразонов (АФГ) и кетонфенилгидразонов (КФГ) в ткани мозга животных с внутримозговой гематомой. Причем достоверных отличий в группах, получавших 150 мкл/кг веса и 300 мкл/кг веса, не наблюдалось.

Определение молочной кислоты показало (табл. 4.31, рис. 4.18), что минимальное ее содержание из всех групп животных с экспериментальным ОНМК обнаружено в той, где крысы получали на протяжении 4-х дней Цереброкурин 150 мкл/кг. 


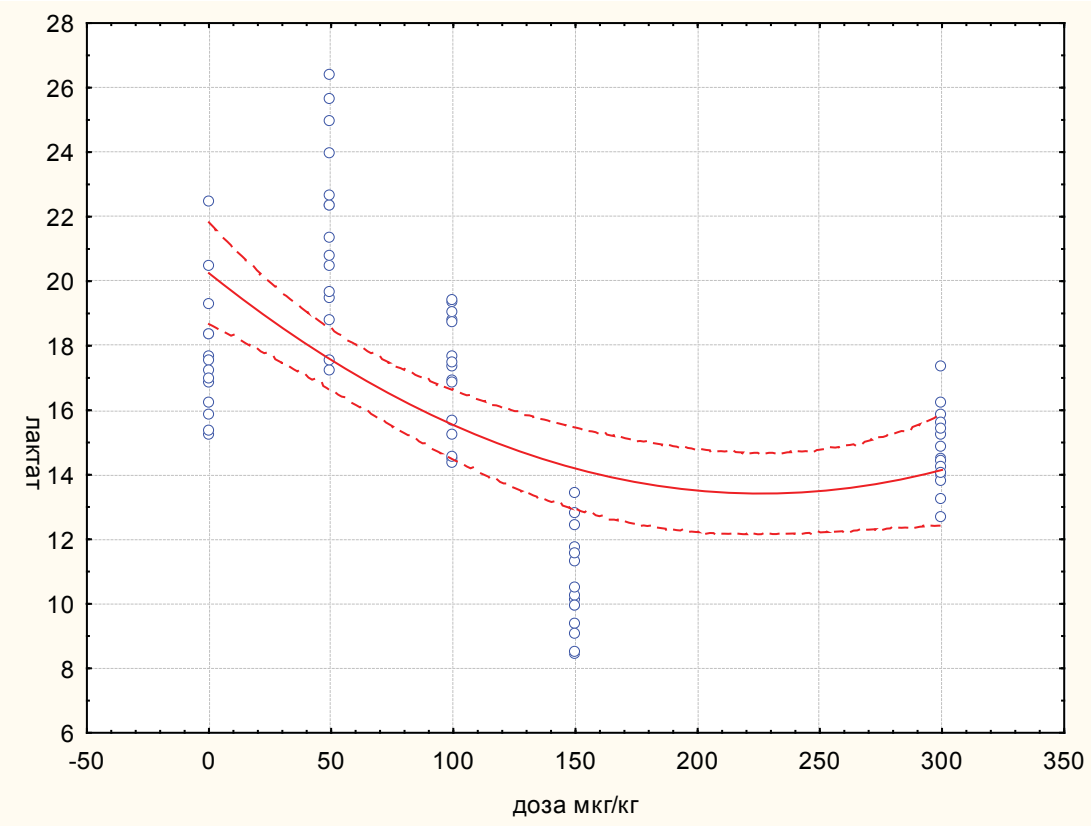

Рис. 4.18. Влияние дозы Цереброкурина на содержание лактата в ткани головного мозга крыс с ОНМК

Содержание пирувата (рис. 4.19) оказалось достаточно высоким в этой экспериментальной группе, что свидетельствует об активном восстановлении пиридиновых нуклеотидов, а следовательно - нормальном функционировании цикла трикарбоновых кислот в митохондриях нейронов.

Максимальная активизация аэробного гликолиза и торможение анаэробного наблюдалась в экспериментальной группе, где крысы с внутримозговой геморрагией получали Цереброкурин в дозе 150 мкл/кг. При этом проявления окислительного повреждения митохондриальных белков достоверно $(\mathrm{p}<0,05)$ снижались в данной экспериментальной группе, что способствует сохранению функциональной активности митохондрий.

Подбор наиболее эффективной дозы Цереброкурина в условиях ОНМК показал, что единственной дозой, которая по всем исследуемым параметрам (\% выживаемости, содержание молочной и пировиноградной кислоты, а также маркеров ОМБ) показала наличие достоверных отличий $(p<0,05)$ с контрольной группой животных, была доза препарата 150 мкл/кг веса животного. Дозы 100 мкл/кг и 300 мкл/кг показали достоверное снижение маркеров ОМБ, причем наименьшее их содержание отмечено в группе, получавшей 300 мкл/кг.

Математическая обработка полученных экспериментальных данных методом взвешенных наименьших квадратов позволила выделить наиболее эффективную дозу (150 мкл/кг) в диапазоне эффективных доз 120-200 мкл/кг. 


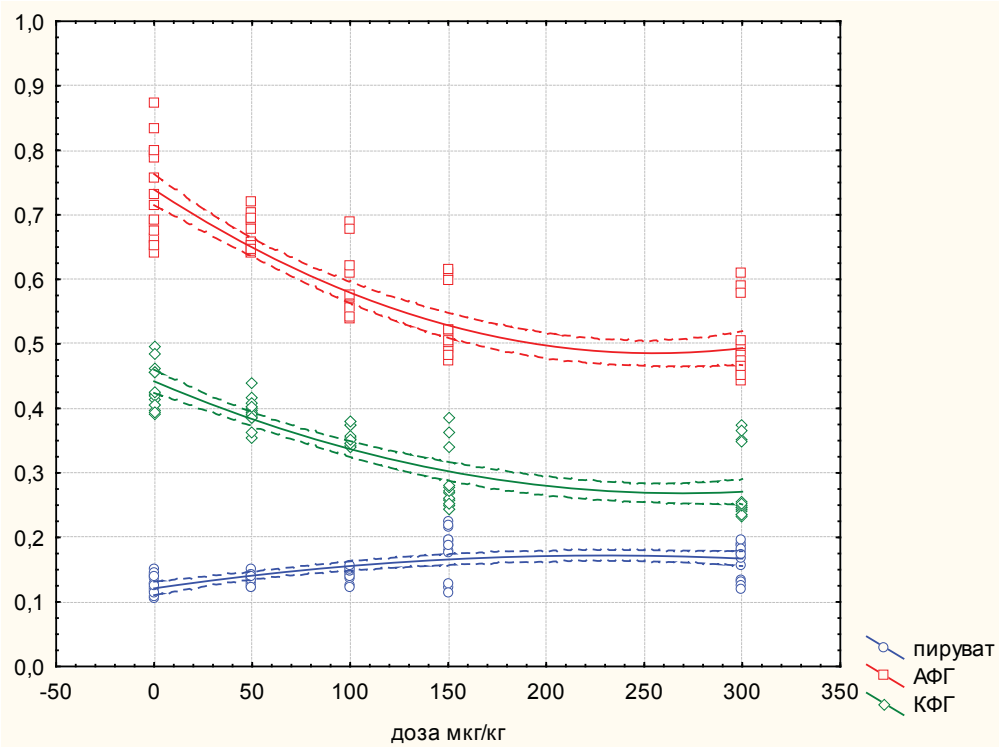

Puc. 4.19. Влияние дозы Цереброкурина на показатели окислительного стресса и содержание пировиноградной кислоты в ткани головного мозга крыс с ОНМК

ЗМГрафик поверхности (Копия эффективная дозаl 13v*75c)
доза мкг/кг = Расстояние взвешенных наименьших квадратов

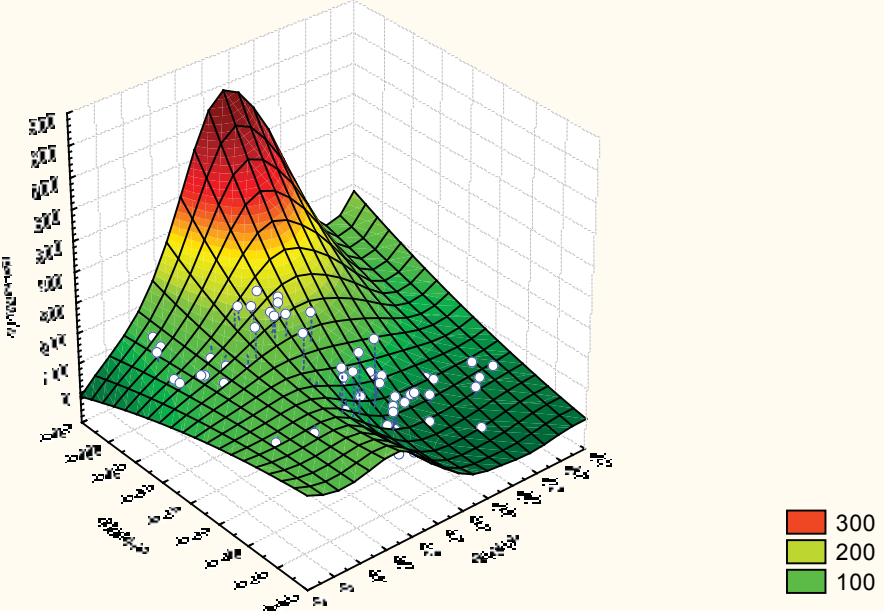

Рис 4.20. Определение эффективной дозы Цереброкурина методом взвешенных наименыших квадратов 


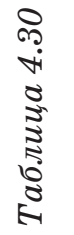

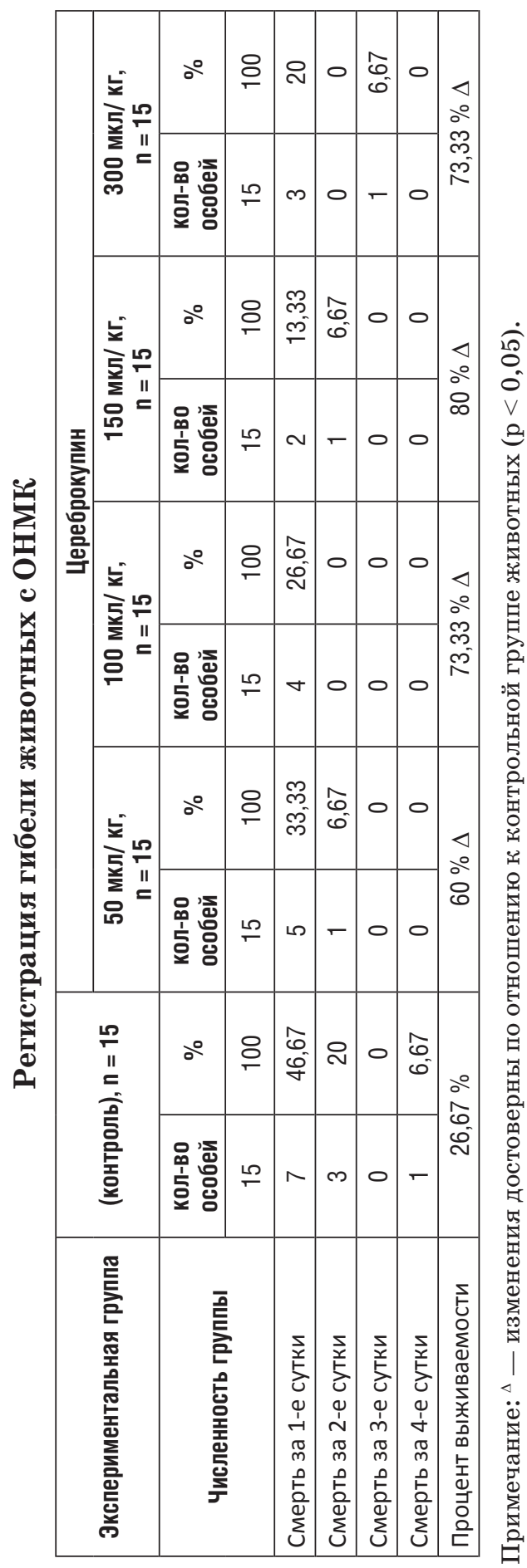

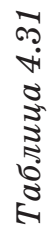

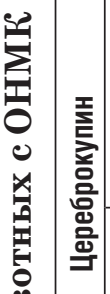

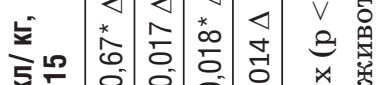

$\sum$ II \begin{tabular}{cc|c|c|}
0 & 0 & 0 & 0 \\
+1 & +1 & +1 & 0
\end{tabular}

\begin{tabular}{ccc|c}
+1 & +1 & +1 & 0 \\
$N$ & $\widetilde{N}$ & 5 & 0
\end{tabular}

\begin{tabular}{c|c|c|c|c} 
& \\
0 & N & 0 & 0 \\
0 & 0 & 0 \\
0 & 0 & 0 \\
0
\end{tabular}

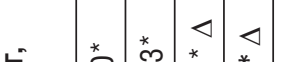

妾

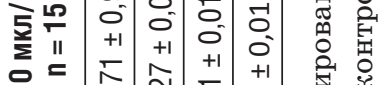

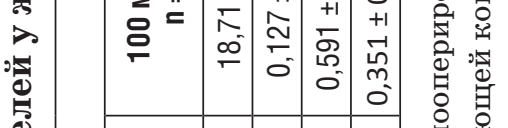

:

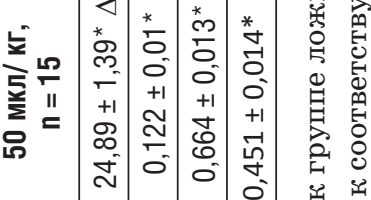



0
0
0
0
0
0
0
0
0
0
0
0
0
0

E* * * * $*$ *

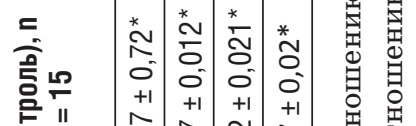

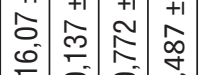

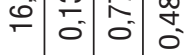

幽 薃

$\circ \circ$

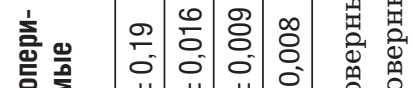

o $+1+1+1$

齐

西

垈 量皆

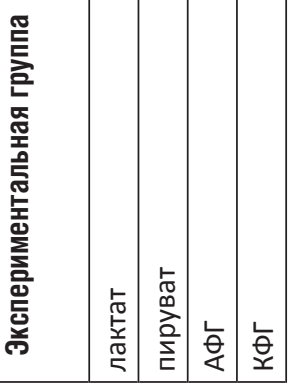

$\dot{10}$

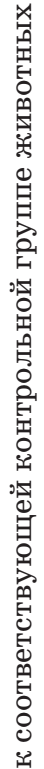

웅

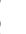

.
. 等 
Оценка митопротективного действия нейротрофических церебропротекторов в опытах in vitro и в условиях ОНМК (двухсторонняя перевязка сонных артерий). В исследованиях in vitro на изолированных митохондриях головного мозга нами установлено, что Церебролизин, Цереброкурин, Семакс и Кортексин повышают порог чувствительности митохондрий к индукторам МП. Известно, что образование МП характеризуется снижением светопоглощения суспензией, вызванным набуханием митохондрий и выходом $\mathrm{Ca}^{2+}$ во внемитохондриальное пространство после $\mathrm{Ca}^{2+}$-нагрузки органелл. Этот факт мы использовали при выборе препарата, который наиболее эффективно сдерживал разрушение органелл при воздействии цитотоксических концентраций $\mathrm{NO}^{-}$и $\mathrm{Ca}^{2+}$ в присутствии глутамата.

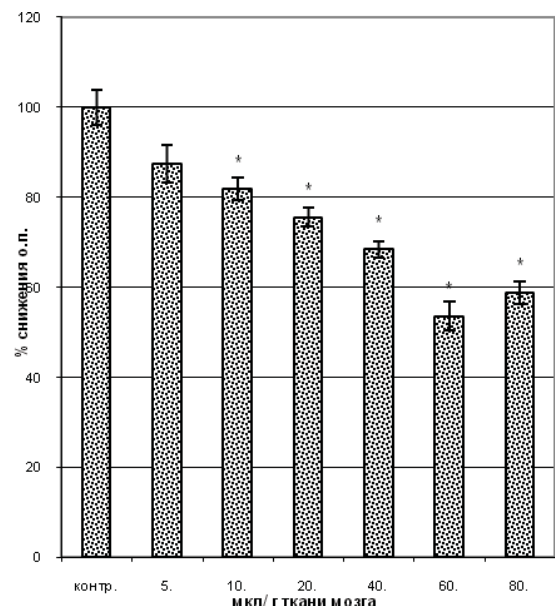

Примечание: *- изменения достоверны по отношению к контролю $(\mathrm{p}<0,05), \mathrm{n}=20$

Рис. 4.20. Влияние дозы Цереброкурина на открытие МП

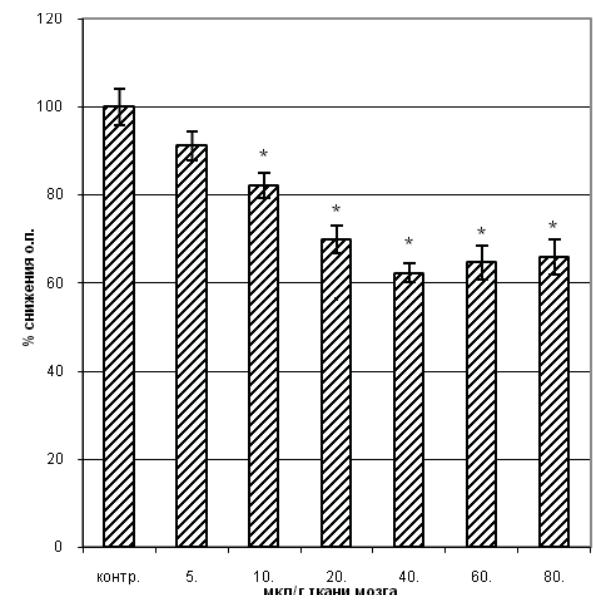

Примечание: *- изменения достоверны по отношению к контролю $(\mathrm{p}<0,05), \mathrm{n}=20$

Рис. 4.21. Влияние дозы Церебролизина на открытие МП

Анализируя полученные данные, необходимо отметить, что наилучший результат был получен с применением Цереброкурина (рис. 4.20) и Кортексина (рис. 4.23). Доза Цереброкурина, при которой изучаемый процесс подавлялся на 66,9 \% , по сравнению с контрольной пробой, составила 40 мкл/г ткани мозга. В присутствии Кортексина (60 мкл/г ткани мозга) изучаемый процесс подавлялся на 63,6 \% Дальнейшее увеличение дозы менее существенно влияло на интенсивность открытия МП.

Для Церебролизина доза 40 мкл/г ткани мозга также оказалась наиболее эффективной (рис. 4.21), хотя открытие МП снизилось всего на 37,7 \%. Для препарата Семакс наилучший эффект показала доза 60 мкл/г ткани мозга. Снижение открытия МП, соответственно, составило 46,4% (рис. 4.22). Немаловажным представляется тот факт, что препараты Цереброкурин и Кортексин показали результат, достоверно отличающийся от контрольной пробы даже при 
минимальной изучаемой концентрации (5 мкл/г ткани), что свидетельствует о высокой чувствительности порового комплекса митохондриальных мембран к влиянию препаратов.

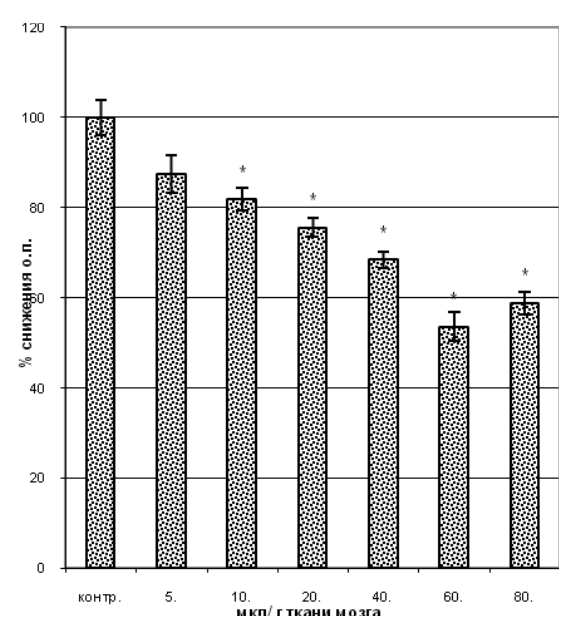

Примечание: * - изменения достоверны по отношению к контролю $(\mathrm{p}<0,05), \mathrm{n}=20$

Рис. 4.20. Влияние дозы Семакса на открытие МП

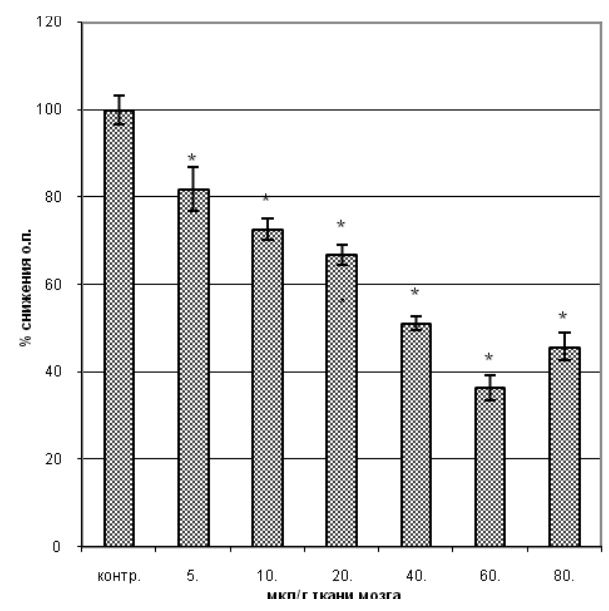

Примечание: * — изменения достоверны по отношению к контролю $(\mathrm{p}<0,05), \mathrm{n}=20$

Рис. 4.21. Влияние дозы Кортексина на открытие МП

Полученные результаты дают основание полагать, что модулируя митохондриальную проницаемость, а следовательно - и ионный баланс, нейротрофические церебропротекторы могут корректировать сигнальные процессы в нервных клетках. Этот факт позволяет также предположить модулирующий эффект препаратов на активность внутриклеточных ферментных систем и на метаболизм нейронов в целом. Следовательно, возникает необходимость дальнейшего изучения влияния Церебролизина, Цереброкурина, Семакса и Кортексина на жизнеспособность и сохранение функциональной активности изолированных митохондрий в условиях экспериментального ОНМК.

Изучение митопротективного действия нейротрофических церебропротекторов в условиях ОНМК (двухсторонняя перевязка сонных артерий). На сегодняшний день существует множество экспериментальных данных, свидетельствующих о том, что следствием развития любой нейродегенеративной патологии является массовое окислительное повреждение нейрональных белков, выполняющих самые различные функции. $\kappa$ числу этих белков относятся и мультиферментные комплексы, участвующие в окислительном фосфорилировании и транспорте электронов по дыхательной цепи митохондрий. Эффективность энергообразования зависит не только от своевременной доставки кислорода и энергетических субстратов к месту их потребления, но и от правильной структурно-функциональной организации многочисленных ферментных комплексов. 
ОНМК неизбежно влечет за собой развитие оксидативного и нитрозирующего стресса. В результате этого за довольно короткое время окислительному повреждению подвергается огромное количество белков, теряющих свои функциональные способности и в дальнейшем провоцирующих окислительные процессы. В таких условиях перед антиоксидантной системой стоит нелегкая задача: быстро и эффективно обезвредить кислородные радикалы. Очень многое зависит также и от геномного ответа, ведь продукты экспрессии генов раннего реагирования могут кардинально поменять сценарий разворачивающихся метаболических событий. Активация протеолиза поврежденных белков - необходимое условие для перехода клетки к состоянию адаптации и восстановления утраченных функций. Следует отметить, что это тоже энергозависимый процесс.

Таким образом, для комплексной оценки энерготропного влияния изучаемых препаратов в условиях моделируемой патологии необходимо сравнить их способность препятствовать развитию окислительного и нитрозирующего стресса.

Некоторые ткани, в числе которых находится головной мозг, обладают повышенной чувствительностью к окислительному стрессу, что связано с особенностью их химического строения и метаболизма. Повышенная чувствительность мозговой ткани обусловлена высокой степенью насыщения кислородом (1/5 от общего количества кислорода в организме), преобладанием полиненасыщенных жирных кислот, присутствием активной формы железа и низкой активностью отдельных звеньев ферментативной антиоксидантной защиты, в частности - каталазы.

При патологических состояниях в мозговой ткани создаются условия для интенсивной генерации радикальных продуктов, повышения окислительной деструкции белков, липидов, что приводит к нарушению структуры и функции клеточных мембран. Нами были проанализированы интенсивность окислительной деструкции (спонтанной и металл-катализируемой) белков изолированных митохондрий, выделенных методом дифференциального центрифугирования из ткани мозга крыс с экспериментальной внутримозговой гематомой.

Известно, что в результате окислительной модификации белков (ОМБ) наблюдается образование карбонильных производных, которые в присутствии 2,4-динитрофенилгидразина образуют 2,4-динитрофенилгидразоны. Альдегидфенилгидразоны (АФГ) регистрируются при длине волны 270 нм, а кетонфенилгидразоны (КФГ) - при 363 нм [139].

При анализе спонтанной окислительной деструкции митохондриальных белков было обнаружено статистически достоверное $(\mathrm{p}<0,05)$ по отношению к группе ЛЖ повышение уровня АФГ и КФГ во всех группах, где имело место экспериментальное ОНМК. Так, на 4-е сутки после ОНМК максимальное содержание продуктов ОМБ отмечалось в контрольной группе. Содержание АФГ и КФГ при спонтанной ОМБ увеличилось на 312,8 \% и 184,8 \%, а при стимулированной, соответственно - на $63 \%$ и 76,8 \% . На фоне применения изучаемых препаратов, отмечались достоверные как по отношению к контролю, так и ЛЖ изменения в содержании продуктов спонтанной ОМБ. Наилучший результат в 
этом сроке показал Кортексин, где содержание АФГ и КФГ снизилось, соответственно, на $72,2 \%$ и $79,1 \%$.

При металл-катализируемой ОМБ на 4-й день эксперимента наилучший результат отмечен у крыс, получавших Цереброкурин, где содержание АФГ и КФГ снизилось на $11,3 \%$ и $7,16 \%$.

Таблица 4.32

Степень окислительной модификации белков (у.е./мг белка) в митохондриях головного мозга крыс с ОНМК

\begin{tabular}{|c|c|c|c|c|}
\hline \multirow[t]{2}{*}{ Группа животных } & \multicolumn{2}{|c|}{ Спонтанная ОМБ } & \multicolumn{2}{|c|}{ Металл-катализируемая ОМБ } \\
\hline & $\begin{array}{c}\text { АФГ } \\
(270 \text { нм })\end{array}$ & $\begin{array}{c}\text { КФГ } \\
(363 \text { нм) }\end{array}$ & $\begin{array}{c}\text { АФГ } \\
(270 \text { нм })\end{array}$ & $\begin{array}{c}\text { КФГ } \\
(363 \text { нм })\end{array}$ \\
\hline $\begin{array}{l}\text { Ложноопериро-ванные жи- } \\
\text { вотные, } \mathrm{n}=10\end{array}$ & $\begin{array}{c}0,187 \\
\pm 0,009 \\
\end{array}$ & $\begin{array}{c}0,171 \\
\pm 0,008 \\
\end{array}$ & $\begin{array}{c}0,384 \\
\pm 0,028 \\
\end{array}$ & $\begin{array}{c}0,237 \\
\pm 0,013 \\
\end{array}$ \\
\hline $\begin{array}{l}\text { Животные с ОНМК } \\
\text { (контроль), 4-е сутки, n = } 10\end{array}$ & $\begin{array}{c}0,772 \\
\pm 0,021^{*}\end{array}$ & $\begin{array}{c}0,487 \\
\pm 0,019^{\star}\end{array}$ & $\begin{array}{c}0,626 \\
\pm 0,015^{*}\end{array}$ & $\begin{array}{c}0,419 \\
\pm 0,025^{\star}\end{array}$ \\
\hline $\begin{array}{l}\text { ОНМК +Цереброкурин, } \\
\text { 4-е сутки, } \mathrm{n}=10\end{array}$ & $\begin{array}{c}0,501 \\
\pm 0,017^{\star}\end{array}$ & $\begin{array}{c}0,269 \\
\pm 0,013^{\Delta *}\end{array}$ & $\begin{array}{r}0,555 \\
\pm 0,034^{*} \\
\end{array}$ & $\begin{array}{c}0,389 \\
\pm 0,010^{*} \\
\end{array}$ \\
\hline $\begin{array}{l}\text { ОНМК +Церебролизин, } \\
\text { 4-е сутки, } \mathrm{n}=10\end{array}$ & $\begin{array}{c}0,566 \\
\pm 0,031 \Delta^{*} \\
\end{array}$ & $\begin{array}{c}0,319 \\
\pm 0,026^{\Delta *} \\
\end{array}$ & $\begin{array}{c}0,582 \\
\pm 0,035^{\star} \\
\end{array}$ & $\begin{array}{c}0,417 \\
\pm 0,027^{\star} \\
\end{array}$ \\
\hline $\begin{array}{l}\text { ОНМК + Семакс, } \\
\text { 4-е сутки, } n=10\end{array}$ & $\begin{array}{c}0,400 \\
\pm 0,015^{\Delta *}\end{array}$ & $\begin{array}{c}0,198 \\
\pm 0,008 \Delta *\end{array}$ & $\begin{array}{c}0,565 \\
\pm 0,018^{\Delta *}\end{array}$ & $\begin{array}{c}0,406 \\
\pm 0,006^{*}\end{array}$ \\
\hline $\begin{array}{l}\text { ОНМК + Кортексин, } \\
\text { 4-е сутки, } \mathrm{n}=10\end{array}$ & $\begin{array}{c}0,215 \\
\pm 0,010^{\Delta *} \\
\end{array}$ & $\begin{aligned} & 0,102 \\
& \pm 0,006^{\Delta *} \\
&\end{aligned}$ & $\begin{array}{c}0,538 \\
\pm 0,045 \\
\end{array}$ & $\begin{array}{r}0,365 \\
\pm 0,017^{\star} \\
\end{array}$ \\
\hline $\begin{array}{l}\text { Животные с ОНМК } \\
\text { (контроль), 7-е сутки, n= } 10\end{array}$ & $\begin{array}{c}0,492 \\
\pm 0,043^{*} \\
\end{array}$ & $\begin{array}{c}0,324 \\
\pm 0,014^{\star} \\
\end{array}$ & $\begin{array}{c}1,797 \\
\pm 0,149^{\star} \\
\end{array}$ & $\begin{array}{c}0,564 \\
\pm 0,064^{*} \\
\end{array}$ \\
\hline $\begin{array}{l}\text { ОНМК +Цереброкурин, } \\
\text { 7-е сутки, } \mathrm{n}=10\end{array}$ & $\begin{array}{c}0,372 \\
\pm 0,020^{\star} \Delta \\
\end{array}$ & $\begin{array}{c}0,210 \\
\pm 0,036^{\star \Delta} \Delta \\
\end{array}$ & $\begin{array}{c}0,606 \\
\pm 0,049^{\star \Delta} \\
\end{array}$ & $\begin{aligned} & 0,331 \\
\pm & 0,026^{* \Delta}\end{aligned}$ \\
\hline $\begin{array}{l}\text { ОНМК +Церебролизин, } \\
\text { 7-е сутки, } \mathrm{n}=10\end{array}$ & $\begin{array}{c}0,384 \\
\pm 0,017^{* \Delta} \\
\end{array}$ & $\begin{array}{c}0,278 \\
\pm 0,009^{* \Delta} \\
\end{array}$ & $\begin{array}{c}0,938 \\
\pm 0,021^{* \Delta} \\
\end{array}$ & $\begin{array}{r}0,442 \\
\pm 0,021^{*} \\
\end{array}$ \\
\hline $\begin{array}{l}\text { ОНМК + Семакс, } \\
\text { 7-е сутки, } \mathrm{n}=10\end{array}$ & $\begin{aligned} & 0,316 \\
& \pm 0,009 * \Delta \\
&\end{aligned}$ & $\begin{array}{c}0,201 \\
\pm 0,005^{\star \Delta} \\
\end{array}$ & $\begin{array}{c}0,611 \\
\pm 0,008^{\star \Delta} \Delta \\
\end{array}$ & $\begin{array}{c}0,371 \\
\pm 0,007^{\star \Delta} \\
\end{array}$ \\
\hline $\begin{array}{l}\text { ОНМК + Кортексин, } \\
\text { 7-е сутки, } \mathrm{n}=10\end{array}$ & $\begin{array}{c}0,355 \\
\pm 0,012^{\star \Delta} \\
\end{array}$ & $\begin{array}{c}0,260 \\
\pm 0,010^{\star \Delta} \\
\end{array}$ & $\begin{array}{c}0,971 \\
\pm 0,090^{*} \\
\end{array}$ & $\begin{array}{c}0,417 \\
\pm 0,028^{*} \\
\end{array}$ \\
\hline $\begin{array}{l}\text { Животные с ОНМК } \\
\text { (контроль), 21-е сутки, n = } 10\end{array}$ & $\begin{array}{c}0,879 \\
\pm 0,028^{*} \\
\end{array}$ & $\begin{array}{r}0,425 \\
\pm 0,015^{\star} \\
\end{array}$ & $\begin{aligned} & 2,17 \\
& \pm 0,129^{\star} \\
&\end{aligned}$ & $\begin{array}{r}0,645 \\
\pm 0,023^{*} \\
\end{array}$ \\
\hline $\begin{array}{l}\text { ОНМК +Цереброкурин, } \\
\text { 21-е сутки, } \mathrm{n}=10\end{array}$ & $0,579 \pm 0,011^{\Delta^{*}}$ & $0,296 \pm 0,005^{\Delta^{\star}}$ & $0,597 \pm 0,010^{\Delta^{*}}$ & $0,365 \pm 0,023^{\Delta^{*}}$ \\
\hline $\begin{array}{l}\text { ОНМК + Церебролизин, } \\
\text { 21-е сутки, } \mathrm{n}=10\end{array}$ & $0,611 \pm 0,023^{\Delta *}$ & $0,324 \pm 0,014^{\Delta *}$ & $0,812 \pm 0,030^{\Delta *}$ & $0,421 \pm 0,019^{\Delta \star}$ \\
\hline $\begin{array}{l}\text { OНМК + Семакс, } \\
21-е \text { сутки, } \mathrm{n}=10\end{array}$ & $0,559 \pm 0,007^{\star \star}$ & $0,299 \pm 0,008^{\Delta *}$ & $0,570 \pm 0,016^{\Delta^{*}}$ & $0,359 \pm 0,017^{\Delta *}$ \\
\hline $\begin{array}{l}\text { ОНМК + Кортексин, } \\
21 \text {-е сутки, } \mathrm{n}=10\end{array}$ & $0,578 \pm 0,012^{\Delta \star}$ & $0,280 \pm 0,008^{\Delta *}$ & $0,570 \pm 0,016^{\Delta \star}$ & $0,35 \pm 0,016^{\Delta \star}$ \\
\hline
\end{tabular}

Примечание: * - изменения достоверны по отношению к группе ложнооперированных животных $(\mathrm{p}<0,05)$;

${ }^{\Delta}$ - изменения достоверны по отношению к контролю $(\mathrm{p}<0,05)$. 
На 7-й день эксперимента наименьшее содержание АФГ и КФГ в митохондриях зафиксировано у крыс, получавших Семакс, где уровень вышеуказанных маркеров спонтанной ОМБ снизился, соответственно, на 35,77 \% и 37,96 \%. В отношении стимулированной ОМБ наилучший эффект показал Цереброкурин. На фоне его применения уровень АФГ и КФГ снизился на 66,28 \% и 41,31 \% .

В ходе исследований отмечалась тенденция к постепенному нарастанию содержания маркеров ОМБ. Максимальные значения были зафиксированы у животных контрольной группы на 21-й день после экспериментального ОНМК. В случае спонтанной ОМБ содержание АФГ и КФГ увеличилось по сравнению с ЛЖ, соответственно, на 370 \% и 148,5 \%. При стимулированной ОМБ - на 465,1 \% и $172 \%$. На фоне применения исследуемых препаратов (табл. 4.32), содержание маркеров ОМБ достоверно $(\mathrm{p}<0,05)$ снижалось. Максимальное снижение содержания маркеров спонтанной ОМБ (АФГ и КФГ), соответственно, отмечалось в группе, где животные с экспериментальным ОНМК получали Семакс - на 36,4 \% и 29,7 \% . При металл-катализированной ОМБ лучшие результаты получены в группе, получавшей Кортексин (снижение уровня АФГ и КФГ, соответственно, на 73,7 \% и 45,7\%.

Выявленное нами повышение интенсивности окислительной модификации митохондриальных белков, позволяет увидеть общую направленность свободнорадикальных процессов, пусковым механизмом для которых явилось интрацеребральное кровоизлияние. В отличие от пероксидации липидов, ОМБ носит более избирательный и специфический характер, что связано с большим разнообразием функциональной нагрузки нейрональных и глиальных белков. Результатом окислительной модификации мембранных белков является отсутствие возобновления протонного градиента, что ведет к прекращению выработки АТФ. Если в цепи биологического окисления образуются разрывы из-за нехватки каких-либо коферментов или ингибирования ферментных комплексов, - это также остановит работу митохондриального генератора. В таких условиях утилизация кислорода невозможна, даже при его наличии в ткани. Дефицит энергии при клеточной гипоксии расстраивает работу цитоскелета, что может явиться причиной отсоединения рибосом от мембран шероховатого эндоплазматического ретикулума и насыщения цитоплазмы утратившими свой адресный маршрут белковыми молекулами. Такие белки денатурируют, окисляются, провоцируя дальнейшие повреждения митохондрий. Происходит, в частности, разборка липопротеидных частиц и уменьшается их растворимость. Все эти патобиохимические процессы, в конечном итоге - провоцируют дальнейшие метаболические нарушения нервной ткани, подавляют биосинтез нейротрофических и ростовых факторов глиальными клетками. На фоне трофического дефицита, геном нейронов, получая «сигналы бедствия» реализует суицидную программу. Так происходит значительное расширение очага поражения.

Препараты из группы нейротрофических церебропротекторов в ходе исследований показали свою способность снижать окислительную модификацию митохондриальных белков, сводя к минимуму вышеперечисленные нарушения клеточного метаболизма. 
Для полноты представления о механизмах нейропротективного эффекта нейротрофических церебропротекторов в ходе эксперимента проводились исследования активности NO-синтазы (NOS), каталазы и содержания стабильных метаболитов оксида азота в ткани головного мозга крыс всех экспериментальных групп.

Полученные экспериментальные данные свидетельствуют о том, что пик активности NOS, а также максимальное содержание нитритов в ткани головного мозга, приходится на 7-й день после моделируемого ОНМК в контрольной группе. На этом сроке вышеуказанные показатели превосходят аналогичные в группе ЛЖ на $352,2 \%$ и $293 \%$.

В отдаленном периоде наблюдается регресс активности NOS и содержания метаболитов NO. На фоне применения исследуемых препаратов максимальное снижение уровня нитритов отмечалось в группах, где животные с ОНМК получали Семакс (4-е и 21 -е сутки) и Церебролизин (7-е сутки). Здесь содержание нитритов было на $35 \%, 47,7 \%$ и $59,2 \%$ ниже, чем в соответствующих контрольных группах.

Активность NOS на 4-е сутки эксперимента была максимально снижена по отношению к контрольной группе у животных, получавших Кортексин (на $66,4 \%$ ), на 7-е сутки - в группе, получавшей Семакс (на $38,6 \%$ ), на 21 -е - в группе, получавшей Семакс $-50,9 \%$.

Исследования активности каталазы показали, что во всех группах, за исключением двух (Кортексин, 4-е сутки и Семакс, 21-е сутки) наблюдались достоверные отличия в сравнении с контролем (табл. 4.33).

Так, на 4-е сутки после экспериментального ОНМК, наибольшая активность каталазы отмечалась в группе с Цереброкурином (на 40,8 \% выше, чем в контроле), на 7-е сутки - в группе с Кортексином (на $43,9 \%$ ), и на 21 -е - в группе с Кортексином (на 69 \% выше, чем в контроле).

Таблица 4.32

\section{Содержание нитритов, активность NO-синтазы и каталазы в ткани головного мозга крыс с ОНМК}

\begin{tabular}{|c|c|c|c|}
\hline Группа животных & Нитриты, мкмоль/г & $\begin{array}{c}\text { Активность NO- } \\
\text { синтазы, } \\
\text { нмоль/г ткани/мин }\end{array}$ & $\begin{array}{l}\text { Активность катала- } \\
\text { зы, мккат/мг белка }\end{array}$ \\
\hline $\begin{array}{l}\text { Ложнооперированные } \\
\text { животные, } \mathrm{n}=10\end{array}$ & $10,64 \pm 0,55$ & $4,58 \pm 0,25$ & $3,45 \pm 0,096$ \\
\hline $\begin{array}{l}\text { Животные с ОНМК (кон- } \\
\text { троль), 4-е сутки, n = } 10\end{array}$ & $16,82 \pm 0,84^{*}$ & $14,29 \pm 1,14^{*}$ & $4,14 \pm 0,22^{*}$ \\
\hline $\begin{array}{l}\text { ОНМК + Цереброкурин, } \\
\text { 4-е сутки, } \mathrm{n}=10\end{array}$ & $14,01 \pm 0,59^{\star \Delta}$ & $13,82 \pm 0,14^{\star \Delta}$ & $5,83 \pm 0,23^{\star} \Delta$ \\
\hline $\begin{array}{l}\text { ОНМК + Церебролизин, } \\
\text { 4-е сутки, } \mathrm{n}=10\end{array}$ & $14,49 \pm 0,37^{* \Delta}$ & $5,91 \pm 0,13^{\star \Delta}$ & $5,17 \pm 0,39 * \Delta$ \\
\hline $\begin{array}{l}\text { ОНМК + Семакс, } \\
\text { 4-е сутки, } \mathrm{n}=10\end{array}$ & $10,94 \pm 0,55^{\Delta}$ & $8,3 \pm 0,66^{\star \Delta}$ & $5,4 \pm 0,33^{\star \Delta}$ \\
\hline 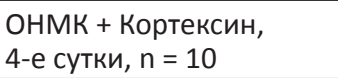 & $14,46 \pm 0,86^{\star \Delta}$ & $4,8 \pm 0,42^{\Delta}$ & $4,6 \pm 0,39^{*}$ \\
\hline
\end{tabular}




\begin{tabular}{|c|c|c|c|}
\hline \multicolumn{4}{|c|}{ Продолжение табл.4.33 } \\
\hline Группа животных & Нитриты, мкмоль/г & $\begin{array}{c}\text { Активность NO- } \\
\text { синтазы, } \\
\text { нмоль/г ткани/мин. }\end{array}$ & $\begin{array}{l}\text { Активность катала- } \\
\text { зы, мккат/мг белка }\end{array}$ \\
\hline $\begin{array}{l}\text { Животные с ОНМК (кон- } \\
\text { троль), 7-е сутки, n = } 10\end{array}$ & $41,82 \pm 2,78^{*}$ & $20,71 \pm 0,85^{\star}$ & $4,58 \pm 0,11^{*}$ \\
\hline $\begin{array}{l}\text { ОНМК + Цереброкурин, } \\
\text { 7-е сутки, } \mathrm{n}=10\end{array}$ & $21,75 \pm 1,34^{\star \Delta}$ & $18,55 \pm 0,41 * \Delta$ & $5,82 \pm 0,21^{* \Delta}$ \\
\hline $\begin{array}{l}\text { ОНМК + Церебролизин, } \\
\text { 7-е сутки, } \mathrm{n}=10\end{array}$ & $17,05 \pm 1,18^{\star \Delta}$ & $13,59 \pm 0,52^{\star \Delta}$ & $5,49 \pm 0,26^{\star \Delta}$ \\
\hline $\begin{array}{l}\text { ОНМк + Семакс, } \\
\text { 7-е сутки, } n=10\end{array}$ & $18,93 \pm 0,75^{\star \Delta}$ & $12,71 \pm 0,79^{\star \Delta}$ & $5,91 \pm 0,35^{\star \Delta}$ \\
\hline $\begin{array}{l}\text { ОНМК + Кортексин, } \\
\text { 7-е сутки, } \mathrm{n}=10\end{array}$ & $19,63 \pm 1,54^{* \Delta}$ & $14,84 \pm 0,137^{\star \Delta}$ & $6,59 \pm 0,30^{* \Delta}$ \\
\hline $\begin{array}{l}\text { Животные с ОНМК (кон- } \\
\text { троль), } 21 \text {-е сутки, } \\
n=10\end{array}$ & $25,23 \pm 1,46^{\star}$ & $17,16 \pm 0,26^{*}$ & $2,45 \pm 0,25^{\star}$ \\
\hline $\begin{array}{l}\text { ОНМК + Цереброкурин, } \\
\text { 21-е сутки, } \mathrm{n}=10\end{array}$ & $19,24 \pm 0,51^{* \Delta}$ & $14,16 \pm 0,70^{* \Delta}$ & $3,79 \pm 0,12^{\star \Delta}$ \\
\hline 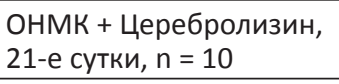 & $18,34 \pm 0,31^{* \Delta}$ & $14,50 \pm 0,38^{* \Delta}$ & $3,68 \pm 0,22^{\Delta}$ \\
\hline $\begin{array}{l}\text { ОНМК+ Семакс, } \\
21-е \text { сутки, n = } 10\end{array}$ & $13,19 \pm 0,57^{\star \Delta}$ & $8,43 \pm 0,62^{\star \Delta}$ & $2,98 \pm 0,30$ \\
\hline $\begin{array}{l}\text { ОНМК + Кортексин, } \\
21-е \text { сутки, } \mathrm{n}=10\end{array}$ & $17,69 \pm 0,8^{\star \Delta}$ & $13,11 \pm 0,45^{\star \Delta}$ & $4,14 \pm 0,34^{\Delta}$ \\
\hline
\end{tabular}

Примечание: * - изменения достоверны по отношению к группе ложнооперированных животных $(\mathrm{p}<0,05)$;

${ }^{\Delta}$ - изменения достоверны по отношению к контролю $(\mathrm{p}<0,05)$.

Таким образом, в ходе проведенных исследований установлено, что применение нейротрофических церебропротекторов в условиях моделированного ОНМК снижает проявление нитрозирующего стресса и мобилизирует антиоксидантную систему организма.

В условиях ОНМК, когда все клеточные мембраны, включая и мембраны митохондрий, подвергаются мощной атаке свободных радикалов, большое значение приобретает фармакологическая коррекция митохондриальной проницаемости. «Шоковое» открытие МП - результат серьезных метаболических нарушений - как правило, заканчивается гибелью клетки. Интермедиаты NO• способны регулировать активный трансмембранный ионный транспорт за счет модуляции мембранных ферментов и белков, входящих в структуру ионных каналов. Так, обратимое окисление $\mathrm{SH}-г$ руппы $\mathrm{Na}^{+} / \mathrm{K}^{+}$-зависимой АТФ-азы под воздействием NO ведет к снижению ее сродства к субстрату, и, соответственно, каталитической активности фермента. Подавляют активность $\mathrm{Na}^{+} /$ $\mathrm{K}^{+}$-зависимой АТФ-азы также и внутриклеточные комплексы NO с низкомолекулярными тиолами, которые содержат $\mathrm{Fe}^{2+}$, вследствие чего происходит их окисление. АТФ/АДФ-антипортер теряет способность поддерживать ионный градиент, превращаясь в неспецифический канал. Окисление энергетических 
субстратов в данном случае не заканчивается синтезом АТФ, и энергодефицит усугубляется. До тех пор, пока этот процесс обратим, существует вероятность восстановления митохондриальных функций. При шоковом открытии МП гибель органеллы, а затем и всей клетки, неизбежна. Поэтому большой научный интерес вызывает способность препаратов влиять на изучаемый процесс. Определение интенсивности открытия МП в суспензии митохондрий, выделенных из ткани мозга животных всех экспериментальных групп на 4-е сутки эксперимента, показало, что только между группами ОНМК + Цереброкурин и Лжћ не обнаружено достоверных отличий, что говорит о способности препарата эффективно препятствовать развитию нарушений барьерной функции митохондриальных мембран.

Наиболее активно процесс открытия МП протекает в суспензии митохондрий, выделенных из головного мозка крыс контрольной группы, что характеризуется выраженным снижением ее светопоглощающей способности вследствие набухания органелл.

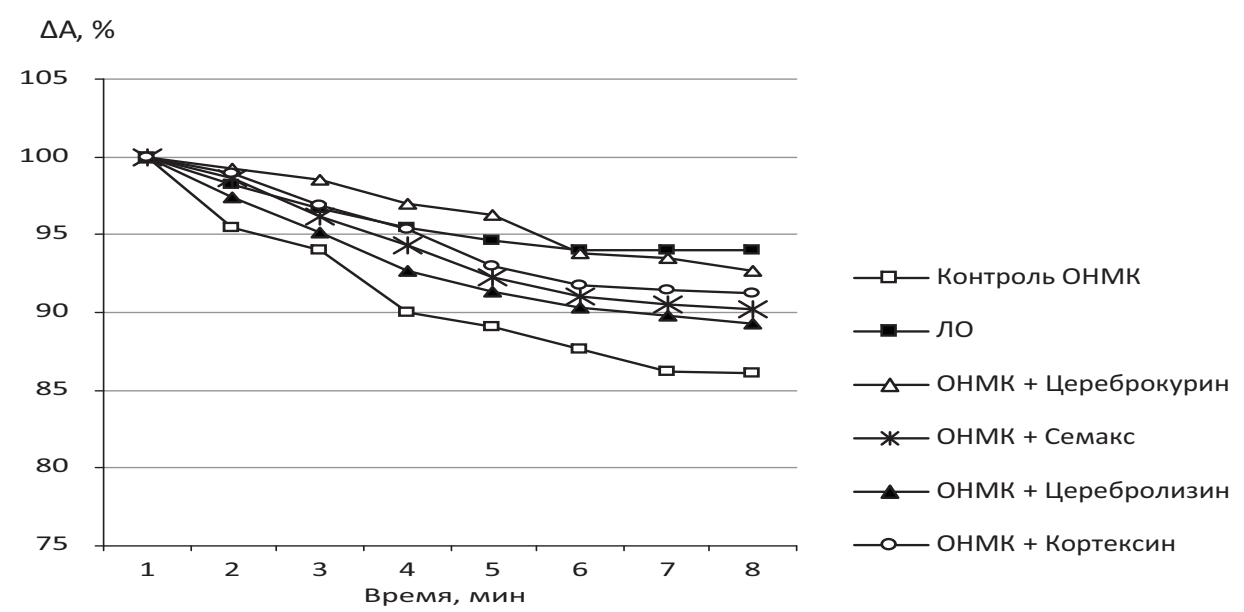

Рис. 4.24. Интенсивность открытия МП на 4-е сутки эксперимента ОНМК

Если проследить изменения митохондриальной проницаемости в динамике эксперимента (рис. 4.24), то во всех группах животных с моделированным ОНМК максимального значения она достигает на 7-й день после операции. В подостром периоде, так же как и в остром, интенсивнее всего повышается проницаемость мембран митохондрий, выделенных из мозга крыс контрольной группы. Наилучший митопротективный эффект показали Цереброкурин (в 1,8 раза снижая интенсивность процесса порообразования) и Кортексин (в 1,76 раза). Церебролизин и Семакс снижали интенсивность открытия МП, соответственно, в 1,4 раза и 1,2 раза.

Существенное снижение степени «шокового» открытия МП позволяет сохранить процесс окислительного фосфорилирования и синтеза АТФ, что чрезвычайно важно для выживаемости нейронов в стрессовых условиях, в противном случае митохондрии захватывают значительные количества кальция, это 
приводит к инактивации их ферментов, денатурации белков, стойкой утрате способности к продукции АТФ.

На фоне применения нейротрофических церебропротекторов снижается степень развития тканевой гипоксии и сохраняется способность митохондрий быть акцепторами кислорода и энергетических субстратов.

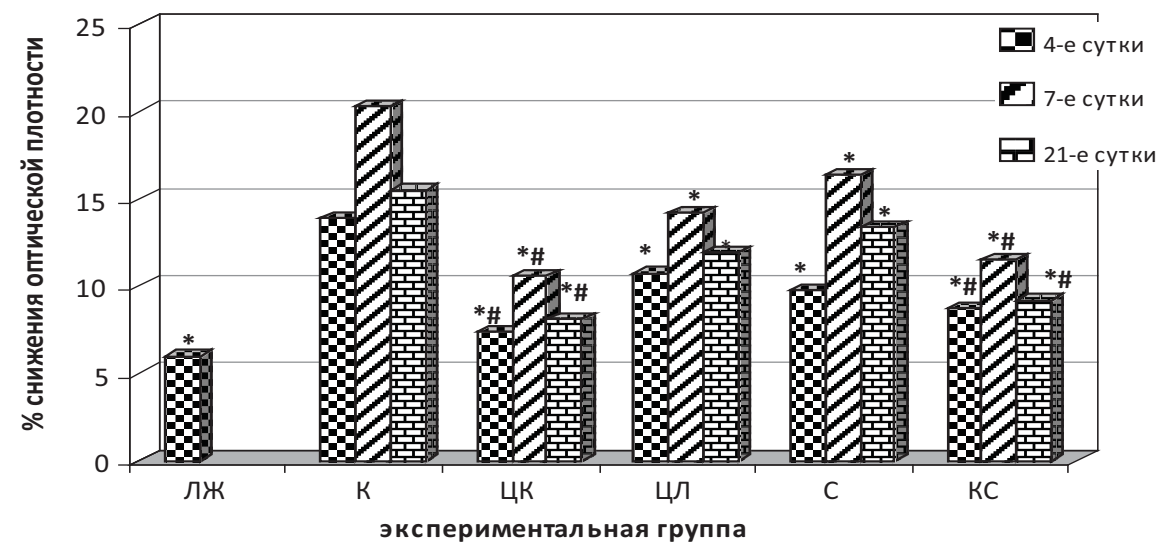

Puc. 4.25. Динамика изменения митохондриальной проницаемости

Примечание: \# - изменения достоверны по отношению к группе, получавшей Церебролизин $(\mathrm{p}<0,05)$;

* 一 изменения достоверны по отношению к контролю $(\mathrm{p}<0,05)$.

Сохранение функциональной активности митохондрий в условиях ОНМК позволяет им также утилизировать жирные кислоты, препятствуя образованию эндогенных мыл и повышению детергентной активности цитозоля, что сохраняет целостность липидных мембран. В противном случае детергентный эффект замыкал бы цепь фатальных событий, ведущих к «точке необратимости» гибельных процессов, поскольку мыла разрушают мембраны органоидов и на клетку обрушивается удар гидролаз, активных радикалов и других метаболитов, изолированных до этого момента в различных отсеках клетки.

В ходе исследований выявлен важный механизм нейропротективной активности нейропептид-содержащих препаратов - способность оказывать защитное действие в отношении митохондрий нейронов, что объясняет энерготропные эффекты этих препаратов, позволяющие поддерживать функциональную активность мозга в экстремальных ситуациях.

Энерготропное действие нейротрофических церебропротекторов в условиях ОНМК (двухсторонняя перевязка общих сонных артерий). Механизмы энергостабилизирующего действия исследуемых препаратов могут быть различными, мы остановились на изучении ключевых звеньев энергетического метаболизма. Для сравнения эффективности применения Цереброкурина, Церебролизина, Семакса и Кортексина с целью коррекции энергообмена нервной ткани после моделированного ОНМК у белых крыс все животные были поде- 
лены на 12 групп. Препараты вводились внутрибрюшинно. Забор биологического материала для исследований производился на 4-е, 7-е и 21-е сутки после оперативного вмешательства, т.к. закономерности процессов распространения структурно-функциональных изменений внутри зоны пенумбры определяют окончательный размер инфаркта мозга на 3-5-е сутки заболевания. В течение 3-7 дней происходит также снижение белкового синтеза и селективная экспрессия генов раннего реагирования. Следовательно, взяв для исследований ткань головного мозга на четвертые и седьмые сутки после моделирования патологии, мы имеем возможность увидеть нарушения церебрального метаболизма в самом разгаре патологического процесса. Более поздние сроки взятия материала (21-е сутки) позволяют проследить степень регрессии метаболических нарушений как естественным путем, так и под влиянием исследуемых препаратов. В гомогенате ткани головного мозга определяли содержание адениловых нуклеотидов (АТФ, АДФ, АМФ), глюкозы, лактата, пирувата, интермедиатов цикла трикарбоновых кислот (изоцитрата, сукцината, малата), а также активность дегидрогеназ пентозофосфатного пути окисления глюкозы (малатдегидрогеназы и глюкозо-6-фосфат дегидрогеназы). Остановимся более подробно на энерготропном действии каждого из вышеуказанных препаратов.

В ходе эксперимента было выявлено, что моделирование ОНМК сопровождалось стойкими нарушениями энергетического метаболизма нервной ткани, прежде всего - снижением пула АТФ (табл. 4.34).

Рекордно низкое содержание в ткани мозга АТФ было зафиксировано на 4-7-е сутки эксперимента в контрольной группе (в 2,25 раза ниже, чем у ложнооперированных крыс). Для животных, получавших внутрибрюшинно Цереброкурин, уровнь этого макроэрга снизился к 7 -му дню всего в 1,26 раза и к 21-м суткам после ОНМК практически нормализовался.

Содержание АДФ, напротив, увеличилось в головном мозге животных контрольной группы. На 4-й и 7-й день эксперимента его уровень превосходил таковой у ложнооперированных животных (ЛЖ) в 1,5 раза. У животных, получавших Цереброкурин, на всех этапах эксперимента были отмечены достоверные отличия в содержании АДФ как с соответствующими контрольными группами, так и с группой сравнения (ложнооперированные крысы).

таблица 4.34

\section{Содержание адениловых нуклеотидов в ткани мозга крыс} с ОНМК, (мкмоль/г ткани)

\begin{tabular}{|l|c|c|c|}
\hline \multicolumn{1}{|c|}{ Группа животных } & АТФ & АДФ & АМФ \\
\hline $\begin{array}{l}\text { Ложнооперированные животные, } \\
\mathrm{n}=10\end{array}$ & $3,17 \pm 0,25$ & $0,56 \pm 0,03$ & $0,19 \pm 0,014$ \\
\hline $\begin{array}{l}\text { Животные с ОНМК (контроль), } \\
\text { 4-е сутки, } \mathrm{n}=10\end{array}$ & $1,51 \pm 0,03^{*}$ & $0,82 \pm 0,012^{*}$ & $0,31 \pm 0,011^{*}$ \\
\hline $\begin{array}{l}\text { ОНМК + Цереброкурин, } \\
\text { 4-е сутки, } \mathrm{n}=10\end{array}$ & $2,33 \pm 0,016^{\star} \Delta$ & $0,68 \pm 0,015^{\star \Delta}$ & $0,24 \pm 0,011^{* \Delta}$ \\
\hline $\begin{array}{l}\text { Животные с ОНМК (контроль), } \\
\text { 7-е сутки, } \mathrm{n}=10\end{array}$ & $1,41 \pm 0,017^{*}$ & $0,82 \pm 0,015^{*}$ & $0,43 \pm 0,022^{*}$ \\
\hline
\end{tabular}


Продолжение табл. 4.33

\begin{tabular}{|l|c|c|c|}
\hline \multicolumn{1}{|c|}{ Группа животных } & АТФ & АДФ & АМФ \\
\hline $\begin{array}{l}\text { ОНМК + Цереброкурин, } \\
\text { 7-е сутки, } \mathrm{n}=10\end{array}$ & $2,52 \pm 0,013^{* \Delta}$ & $0,71 \pm 0,011^{\star \Delta}$ & $0,23 \pm 0,012 \underline{\Delta}$ \\
\hline $\begin{array}{l}\text { Животные с ОНМК (контроль), } \\
\text { 21-е сутки, } \mathrm{n}=10\end{array}$ & $1,72 \pm 0,043^{*}$ & $0,76 \pm 0,025^{*}$ & $0,35 \pm 0,018^{*}$ \\
\hline $\begin{array}{l}\text { ОНМК + Цереброкурин, } \\
\text { 21-е сутки, } \mathrm{n}=10\end{array}$ & $2,76 \pm 0,103^{\Delta}$ & $0,65 \pm 0,019^{* \Delta}$ & $0,26 \pm 0,021^{* \Delta}$ \\
\hline
\end{tabular}

Примечание: * - изменения достоверны по отношению к группе ложнооперированных животных $(\mathrm{p}<0,05)$;

${ }^{\Delta}$ - изменения достоверны по отношению к соответствующей контрольной группе животных $(\mathrm{p}<0,05)$

Содержание АМФ максимально увеличилось в ткани мозга крыс контрольной группы на 7-е сутки после ОНМК (в 2,26 раза по сравнению с ЛЖЖ). Применение Цереброкурина снижало содержание АМФ в тканях мозга крыс с ОНМК и достоверно отличалось от аналогичных показателей в контрольных группах на 4-й, 7-й и 21-й день эксперимента.

Содержание глюкозы в тканях мозга крыс с ОНМК также претерпевало существенные изменения (табл. 4.35). Так, минимальный показатель был отмечен в контрольной группе на 7 -е сутки эксперимента (в 1,82 раза ниже, чем в группе сравнения). Аналогичный показатель у животных, получавших Цереброкурин, был всего в 1,13 раза ниже, чем у ЛЖћ, что, вероятно, свидетельствует о стимулирующем влиянии препарата на доставку данного энергетического субстрата, а это немаловажно в условиях ишемии.

Таблица 4.35

\section{Содержание глюкозы, лактата и пирувата в ткани головного мозга} крыс с ОНМК, (мкмоль/ г ткани)

\begin{tabular}{|c|c|c|c|}
\hline Группа животных & Лактат & Пируват & Глюкоза \\
\hline $\begin{array}{l}\text { Ложнооперированные } \\
\text { животные, } \mathrm{n}=10\end{array}$ & $2,99 \pm 0,19$ & $0,19 \pm 0,016$ & $2,2 \pm 0,097$ \\
\hline $\begin{array}{l}\text { Животные с ОНМК (контроль), } \\
\text { 4-е сутки, n = } 10\end{array}$ & $16,07 \pm 0,72^{*}$ & $0,14 \pm 0,012^{*}$ & $1,53 \pm 0,052^{*}$ \\
\hline $\begin{array}{l}\text { ОНМК + Цереброкурин, } \\
\text { 4-е сутки, } \mathrm{n}=10\end{array}$ & $10,72 \pm 0,67^{\star \Delta}$ & $0,18 \pm 0,019$ & $1,72 \pm 0,082^{\star} \Delta$ \\
\hline $\begin{array}{l}\text { Животные с ОНМК (контроль), } \\
\text { 7-е сутки, } \mathrm{n}=10\end{array}$ & $20,22 \pm 0,24^{*}$ & $0,11 \pm 0,010^{*}$ & $1,21 \pm 0,025^{\star}$ \\
\hline $\begin{array}{l}\text { ОНМК + Цереброкурин, } \\
\text { 7-е сутки, } n=10\end{array}$ & $18,59 \pm 0,40 * \Delta$ & $0,21 \pm 0,017^{\Delta}$ & $1,95 \pm 0,079^{\Delta}$ \\
\hline $\begin{array}{l}\text { Животные с ОНМК (контроль), } \\
21 \text {-е сутки, n = } 10\end{array}$ & $21,2 \pm 0,46^{*}$ & $0,14 \pm 0,010^{*}$ & $1,61 \pm 0,022^{*}$ \\
\hline $\begin{array}{l}\text { ОНМК + Цереброкурин, } \\
\text { 21-е сутки, } \mathrm{n}=10\end{array}$ & $16,12 \pm 0,42^{\star \Delta}$ & $0,22 \pm 0,023^{\Delta}$ & $2,51 \pm 0,084^{\Delta}$ \\
\hline
\end{tabular}

Примечание: * - изменения достоверны по отношению к группе ложнооперированных животных $(\mathrm{p}<0,05)$;

${ }^{\Delta}$ - изменения достоверны по отношению к контролю $(\mathrm{p}<0,05)$ 
Противоположная ситуация наблюдалась в содержании молочной кислоты в ткани головного мозга. Для животных контрольной группы отмечено постепенное нарастание уровня этого метаболита, и максимальное значение было зафиксировано на 21-й день эксперимента (в 7,09 раза выше, чем у ЛҮК).

Проанализировав полученные экспериментальные данные по динамике содержания лактата в ткани мозга всех групп с ОНМК, получавших Цереброкурин на протяжении 4-х, 7-ми и 21-го дня, хотелось бы отметить его достоверное $(\mathrm{p}<0,05)$ снижение в сравнении с соответствующими контрольными группами животных.

Следующий энергетический субстрат, вызвавший интерес для исследований - пируват. Находясь на перекрестке метаболических реакций, он может косвенно показать направленность протекания гликолиза и интенсивность потребления восстановительных эквивалентов. Как известно, фермент лактатдегидрогеназа (ЛДГ) может работать в двух направлениях: лактат $\rightarrow$ пируват и пируват $\rightarrow$ лактат. Выбор направления работы фермента зависит от характера энергетических субстратов, а также интенсивности накопления восстановленных пиридиновых нуклеотидов. Проанализировав содержание пирувата в головном мозге крыс с ОНМК на 4-й, 7-й и 21-й день эксперимента, было отмечено низкое его содержание (в 1,3-1,7 раза ниже, чем у ложнооперированных крыс), хотя уровень лактата стремительно повышался. Что же мешало ЛДГ начать работу в направлении лактат $\rightarrow$ пируват? Возможно, причиной этого было снижение потребления НАДН дыхательной цепью митохондрий из-за нарастающей гипоксии. У крыс, получавших Цереброкурин, содержание пирувата достоверно не отличалось от такового у ЛЖ и уровень молочной кислоты был достоверно ниже, чем в соответствующих контрольных группах.

Для полноты представления о характере протекания гликолиза мы проанализировали содержание субстратов цикла трикарбоновых кислот в ткани мозга всех экспериментальных группах.

Согласно нашим исследованиям, НАД-зависимый митохондриальный комплекс является наиболее слабым звеном дыхательной цепи, и при возникновении биоэнергетического компонента гипоксии страдает в первую очередь. В ходе эксперимента было обнаружено, что гипоксия головного мозга способствовала снижению содержания НАД-зависимого субстрата цикла трикарбоновых кислот - изоцитрата. Так, в контрольной группе на 4-й день после моделирования ОНМК уровень изолимонной кислоты снизился на $59,26 \%$ по сравнению с ЛЖ и оставался низким на всех этапах эксперимента. На фоне применения Цереброкурина достоверных отличий в содержании изоцитрата по сравнению с ЛЖ отмечено не было, а вот со всеми соответствующими контрольными группами были получены достоверные отличия.

Следующий исследованный нами энергетический метаболит — малат. Будучи НАД-зависимым субстратом, яблочная кислота вызывает научный интерес в связи с возможным ее участием в функционировании малат-аспартатного челночного механизма. Минимальное содержание малата отмечалось в контрольной группе на 7-й день после ОНМК (в 1,87 раза меньше, чем у ЛЖ). 
К 21-м суткам после экспериментального ОНМК его уровень оставался достаточно низким (в 1,56 раза ниже, чем у ЛЖ $)$.

Таблииа 4.36

Содержание малата, пирувата и изоцитрата в ткани головного мозга крыс с ОНМК, (мкмоль/г ткани)

\begin{tabular}{|l|c|c|c|}
\hline \multicolumn{1}{|c|}{ Группа животных } & Изоцитрат & Малат & Сукцинат \\
\hline $\begin{array}{l}\text { Ложнооперированные } \\
\text { животные, } \mathrm{n}=10\end{array}$ & $0,027 \pm 0,0014$ & $0,28 \pm 0,019$ & $0,82 \pm 0,026$ \\
\hline $\begin{array}{l}\text { Животные с ОНМК (контроль), } \\
\text { 4-е сутки, } \mathrm{n}=10\end{array}$ & $0,011 \pm 0,0012^{*}$ & $0,18 \pm 0,018^{\star}$ & $0,86 \pm 0,018$ \\
\hline $\begin{array}{l}\text { ОНМК + Цереброкурин, } \\
\text { 4-е сутки, } \mathrm{n}=10\end{array}$ & $0,022 \pm 0,0021^{\Delta}$ & $0,35 \pm 0,049^{\star} \Delta$ & $0,75 \pm 0,025^{\Delta}$ \\
\hline $\begin{array}{l}\text { Животные с ОНМК (контроль), } \\
\text { 7-е сутки, } \mathrm{n}=10\end{array}$ & $0,013 \pm 0,0013^{*}$ & $0,15 \pm 0,014^{*}$ & $0,43 \pm 0,032^{\star}$ \\
\hline $\begin{array}{l}\text { ОНМК + Цереброкурин, } \\
\text { 7-е сутки, } \mathrm{n}=10\end{array}$ & $0,025 \pm 0,0016^{\star}$ & $0,34 \pm 0,015^{\star}$ & $0,97 \pm 0,053^{\star \Delta}$ \\
\hline $\begin{array}{l}\text { Животные с ОНМК (контроль), } \\
\text { 21-е сутки, } \mathrm{n}=10\end{array}$ & $0,015 \pm 0,0014^{*}$ & $0,18 \pm 0,018^{\star}$ & $0,49 \pm 0,018^{\star}$ \\
\hline $\begin{array}{l}\text { ОНМК + Цереброкурин, } \\
\text { 21-е сутки, } \mathrm{n}=10\end{array}$ & $0,032 \pm 0,0028^{\star}$ & $0,31 \pm 0,015^{\star}$ & $0,82 \pm 0,025^{\star} \Delta$ \\
\hline
\end{tabular}

Примечание: * - изменения достоверны по отношению к группе ложнооперированных животных $(\mathrm{p}<0,05)$

$\Delta$ - изменения достоверны по отношению к соответствующей контрольной группе $(\mathrm{p}<0,05)$.

Таким образом, наблюдаемое нами снижение содержания НАД-зависимых субстратов (изоцитрата и малата) свидетельствует о значительном торможении реакций цикла трикарбоновых кислот. В этой связи интересным представляется тот факт, что в ткани мозга животных с ОНМК, получавших Цереброкурин, на 4-е сутки после операции обнаружено достоверное повышение содержания малата (на 57,14 \%), по сравнению с контрольной группой, что, вероятнее всего, свидетельствует об активации под влиянием препарата шунтирующих метаболических потоков. Это, в свою очередь, является необходимым условием для запуска репаративных и приспособительных клеточных механизмов.

В экстремальных ситуациях для нервной ткани характерно функционирование так называемого ГАМК-шунта, поставляющего дополнительное количество янтарной кислоты в ЦТК. Сукцинат может стимулировать энергообразование независимо от накопления НАДН, поскольку сукцинат-дегидрогеназа ФАД-зависимая. Это позволяет нейронам безкислородным путем получать дополнительное количество ФАДН, используемого в основ-ном для пластических целей. $\kappa$ тому же янтарная кислота обладает каталити-ческими способностями по отношению к циклу трикарбоновых кислот. Определение содержания янтарной кислоты в ткани мозга животных всех экспериментальных групп показало, что небольшое повышение его уровня в контрольной группе на 4-е сутки эксперимента сменяется стремительным (в 1,91 раза сравнительно с ЛЖ) снижением на 7-е. В отдаленные сроки эксперимента ситуация не изменилась. Содержание 
сукцината оставалось низким, в 1,67 раза ниже, чем в группе ЛЖ. В группе животных, получавших Цереброкурин, на 7-й день после моделированного ОНМК зафиксировано рекордно высокое содержание янтарной кислоты (в 1,2 раза выше, чем у ЛЖЖ), что, вероятнее всего, связано с активацией ГАМК-шунта.

К числу реакций, в ходе которых восстанавливается НАДФ, столь необходимый для пластических целей и работы антиоксидантной системы, относятся дегидрогеназные реакции пентозофосфатного пути (ПФП). Остановимся на более подробном изучении активности глюкозо-6-фосфат дегидрогеназы (Г-6-Ф ДГ) и НАДФ-зависимой малатдегидрогеназы (НАДФ-МДГ). Основная доля активности этих ферментов сосредоточена в растворимой фракции клетки, но с помощью современных методов выявлена локализация дегидрогеназ ПФП и в других компартментах клетки: митохондриях, ядрах, микросомах. Активацию ПФП можно рассматривать как альтернативный путь энергообразования в ткани мозга, подвергшегося гипоксическому воздействию.

В ходе изучения активности Г-6-ФДГ установлено, что у животных контрольной группы она снижалась, начиная уже с 4-го дня эксперимента. Максимально низкая активность отмечалась на 7-й день эксперимента (в 1,9 раза ниже, чем у ЛЖ) и существенной активации не наблюдалось вплоть до окончания эксперимента. У животных с ОНМК, получавших Цереброкурин ситуация улучшилась не намного.

На 4-е и 7-е сутки сохранялись достоверные отличия с группой сравнения (ЛЖ). Лишь к 21-м суткам после операции у животных, получавших препарат, активность фермента достоверно повысилась (в 1,24 раза) в сравнении с ЛЖ, что, вероятнее всего, связано с активацией пролиферативных процессов. НАДФ-МДГ в группах с ОНМК, получавших Цереброкурин, возрастала на $66 \%$ на 4 -е сутки наблюдения и на $33 \%$ - на 7 -е сутки.

Таблица 4.35

Активность дегидрогеназ пентозофосфатного пути, (нмоль НАДФН 2 /мин на 1 мг белка)

\begin{tabular}{|l|c|c|}
\hline \multicolumn{1}{|c|}{ Группа животных } & Г6ФДГ & МДГ \\
\hline Ложнооперированные животные & $11,59 \pm 0,54$ & $28,94 \pm 1,76$ \\
\hline Животные с ОНМК (контроль), 4-е сутки, $\mathrm{n}=10$ & $7,59 \pm 0,41^{*}$ & $15,06 \pm 1,05^{*}$ \\
\hline ОНМК + Цереброкурин, 4-е сутки, $\mathrm{n}=10$ & $8,36 \pm 0,44^{*}$ & $25,46 \pm 1,53^{\star}$ \\
\hline Животные с ОНМК (контроль), 7-е сутки, $\mathrm{n}=10$ & $6,06 \pm 0,39^{*}$ & $12,61 \pm 0,85^{*}$ \\
\hline ОНМК + Цереброкурин, 7-е сутки, $\mathrm{n}=10$ & $8,29 \pm 0,38^{*} \Delta$ & $23,83 \pm 1,37^{*} \Delta$ \\
\hline Животные с ОНМК (контроль), 21-е сутки, $\mathrm{n}=10$ & $7,42 \pm 0,35^{*}$ & $21,74 \pm 1,19^{*}$ \\
\hline ОНМК + Цереброкурин, 21-е сутки, $\mathrm{n}=10$ & $14,31 \pm 0,60^{*} \Delta$ & $28,01 \pm 0,99 \Delta$ \\
\hline
\end{tabular}

Примечание: * - изменения достоверны по отношению к группе ложнооперированных животных $(\mathrm{p}<0,05)$;

${ }^{\Delta}$ - изменения достоверны по отношению к соответствующей контрольной группе $(\mathrm{p}<0,05)$. 
В группе животных с ОНМК на 7-й день исследования активность фермента снизилась максимально (в 2,29 раза) по сравнению с группой сравнения (ЛЖ ). Возможно, причиной снижения активности дегидрогеназ ПФП послужило развитие окислительного и нитрозирующего стресса, влекущее за собой изменения нативного состояния вышеуказанных ферментов. Проанализировав динамику соотношения адениловых нуклеотидов в ткани головного мозга крыс с ОНМК, получавших Кортексин, можно сказать следующее: самое низкое содержание АТФ отмечено на 4 -й день эксперимента (в 1,38 раза ниже, чем у ЛЖ); в соответствующей контрольной группе уровень АТФ, соответственно, ниже в 2,1 раза. Причем показатели этой группы достоверно отличаются как от ЛЖ, так и от животных контрольной группы.

Таблица 4.38

Содержание адениловых нуклеотидов в ткани мозга крыс с ОНМК, (мкмоль/г ткани)

\begin{tabular}{|c|c|c|c|}
\hline Группа животных & АТФ & АДФ & АMФ \\
\hline $\begin{array}{l}\text { Ложнооперированные живот- } \\
\text { ные, } n=10\end{array}$ & $3,17 \pm 0,25$ & $0,56 \pm 0,03$ & $0,19 \pm 0,014$ \\
\hline $\begin{array}{l}\text { Животные с ОНМК (контроль), } \\
\text { 4-е сутки, } \mathrm{n}=10\end{array}$ & $1,51 \pm 0,03^{*}$ & $0,82 \pm 0,012^{*}$ & $0,31 \pm 0,011^{*}$ \\
\hline $\begin{array}{l}\text { ОНМК + Кортексин, } \\
4 \text {-е сутки, } \mathrm{n}=10\end{array}$ & $2,29 \pm 0,04^{* \Delta}$ & $0,73 \pm 0,021^{* \Delta}$ & $0,28 \pm 0,014^{*}$ \\
\hline $\begin{array}{l}\text { Животные с ОНМК (контроль), } \\
\text { 7-е сутки, } n=10\end{array}$ & $1,41 \pm 0,017^{*}$ & $0,82 \pm 0,015^{\star}$ & $0,43 \pm 0,022^{*}$ \\
\hline $\begin{array}{l}\text { ОНМК + Кортексин, } \\
\text { 7-е сутки, } \mathrm{n}=10\end{array}$ & $2,68 \pm 0,042^{\Delta}$ & $0,66 \pm 0,021^{* \Delta}$ & $0,25 \pm 0,021^{*}$ \\
\hline $\begin{array}{l}\text { Животные с ОНМК (контроль), } \\
\text { 21-е сутки, } \mathrm{n}=10\end{array}$ & $1,72 \pm 0,043^{*}$ & $0,76 \pm 0,025^{\star}$ & $0,35 \pm 0,018^{*}$ \\
\hline $\begin{array}{l}\text { ОНМК + Кортексин, } \\
21 \text {-е сутки, } \mathrm{n}=10\end{array}$ & $2,72 \pm 0,26^{\Delta}$ & $0,63 \pm 0,018^{\Delta}$ & $0,20 \pm 0,019^{\Delta}$ \\
\hline
\end{tabular}

Примечание: * - изменения достоверны по отношению к группе ложнооперированных животных $(\mathrm{p}<0,05)$;

${ }^{\Delta}$ - изменения достоверны по отношению к контролю $(\mathrm{p}<0,05)$.

В дальнейшем наблюдалось постепенное повышение уровня АТФ на фоне применения Кортексина, и уже к 21-му дню эксперимента его содержание достоверно не отличалось от такового у ЛЖћ, что свидетельствует о вероятном восстановлении энергопродуцирующей функции митохондрий.

На фоне применения Кортексина, содержание АДФ и АМФ на 4-й день эксперимента, соответственно, возросло в 1,3 и 1,47 раза по сравнению с аналогичным показателем у ЛЖ. В дальнейшем отмечалась постепенная регрессия содержания этих соединений в ткани головного мозга, и к 21-му дню вышеуказанные показатели в группе с Кортексином и ЛЖ достоверно не отличались.

Содержание молочной кислоты в ткани мозга крыс с ОНМК, получавших Кортексин, на 4-й, 7-й и 21-й день эксперимента повысилось, соответственно, в 4,2, 6,1 и 5,02 раза по сравнению с ЛЖ゚. 
Уровень лактата на фоне применения Кортексина достоверно отличался как от ЛЖК, так и от соответствующей контрольной группы. В этих группах уровень сукцината был в 1,14 раза ниже, чем у ЛЖ, а уровень глюкозы, соответственно - в 1,28 и 1,18 раза. К 21-му дню после ОНМК содержание вышеуказанных метаболитов достоверно отличалось от значений контрольной группы, от показателей ЛЖ достоверных отличий не было.

Определение содержания НАД-зависимых субстратов (изоцитрата и малата) показало, что в ткани головного мозга крыс, получавших на протяжении 4-х, 7-ми и 21-го дня Кортексин, достоверного изменения уровня изолимонной и яблочной кислоты не наблюдалось. Эти данные свидетельствуют о том, что применение Кортексина позволяет сохранить функционирование ЦТК в условиях церебральной ишемии.

Таблица 4.39

Содержание глюкозы, лактата и сукцината в ткани головного мозга крыс с ОНМК, (мкмоль/г ткани)

\begin{tabular}{|c|c|c|c|}
\hline Группа животных & Лактат & Сукцинат & Глюкоза \\
\hline $\begin{array}{l}\text { Ложнооперированные } \\
\text { животные, } \mathrm{n}=10\end{array}$ & $2,99 \pm 0,19$ & $0,81 \pm 0,025$ & $2,19 \pm 0,096$ \\
\hline $\begin{array}{l}\text { Животные с ОНМК (контроль), } \\
\text { 4-е сутки, } \mathrm{n}=10\end{array}$ & $16,07 \pm 0,72^{*}$ & $0,86 \pm 0,018^{*}$ & $1,53 \pm 0,052^{*}$ \\
\hline $\begin{array}{l}\text { ОНМК + Кортексин, } \\
4 \text {-е сутки, } \mathrm{n}=10\end{array}$ & $12,62 \pm 0,47^{\star \Delta}$ & $0,71 \pm 0,015^{\star \Delta}$ & $1,71 \pm 0,033^{\star \Delta}$ \\
\hline $\begin{array}{l}\text { Животные с ОНМК (контроль), } \\
\text { 7-е сутки, n = } 10\end{array}$ & $20,22 \pm 0,24^{*}$ & $0,43 \pm 0,032^{\star}$ & $1,21 \pm 0,025^{\star}$ \\
\hline $\begin{array}{l}\text { ОНМК + Кортексин, } \\
\text { 7-е сутки, } \mathrm{n}=10\end{array}$ & $18,38 \pm 0,23^{\star \Delta}$ & $0,71 \pm 0,029 * \Delta$ & $1,86 \pm 0,037^{\star} \Delta$ \\
\hline $\begin{array}{l}\text { Животные с ОНМК (контроль), } \\
21-е \text { сутки, } \mathrm{n}=10\end{array}$ & $21,2 \pm 0,46^{*}$ & $0,49 \pm 0,018^{*}$ & $1,61 \pm 0,022^{*}$ \\
\hline $\begin{array}{l}\text { ОНМК + Кортексин, } \\
21 \text {-е сутки, } \mathrm{n}=10\end{array}$ & $15,02 \pm 0,32^{\star \Delta}$ & $0,77 \pm 0,029^{\Delta}$ & $2,04 \pm 0,065^{\Delta}$ \\
\hline
\end{tabular}

Примечание: * - изменения достоверны по отношению к группе ложнооперированных животных, $(\mathrm{p}<0,05)$;

$\Delta$ - изменения достоверны по отношению к контролю, $(\mathrm{p}<0,05)$.

Для животных, получавших Кортексин, отмечалось достоверное по отношению к ЛЖ повышение содержание пировиноградной кислоты в 1,42 и 1,53 раза, соответственно, что, вероятнее всего, отражает интенсивность потребления восстановленных пиридиновых нуклеотидов дыхательной цепью митохондрий. 
таблииа 4.40

Содержание малата, пирувата и изоцитрата в ткани головного мозга крыс с ОНМК, (мкмоль/г ткани)

\begin{tabular}{|c|c|c|c|}
\hline Группа животных & Изоцитрат & Малат & Пируват \\
\hline $\begin{array}{l}\text { Ложнооперированные } \\
\text { животные, } \mathrm{n}=10\end{array}$ & $0,027 \pm 0,0014$ & $0,28 \pm 0,019$ & $0,19 \pm 0,016$ \\
\hline $\begin{array}{l}\text { Животные с ОНМК (контроль), } \\
\text { 4-е сутки, } \mathrm{n}=10\end{array}$ & $0,011 \pm 0,0012^{*}$ & $0,18 \pm 0,018^{*}$ & $0,14 \pm 0,012^{*}$ \\
\hline $\begin{array}{l}\text { ОНМК + Кортексин, } \\
\text { 4-е сутки, } \mathrm{n}=10\end{array}$ & $0,022 \pm 0,0024^{\Delta}$ & $0,29 \pm 0,010^{\Delta}$ & $0,18 \pm 0,019$ \\
\hline $\begin{array}{l}\text { Животные с ОНМК (контроль), } \\
\text { 7-е сутки, } \mathrm{n}=10\end{array}$ & $0,013 \pm 0,0013^{*}$ & $0,15 \pm 0,014^{*}$ & $0,11 \pm 0,010^{*}$ \\
\hline $\begin{array}{l}\text { ОНМК + Кортексин, } \\
\text { 7-е сутки, } \mathrm{n}=10\end{array}$ & $0,027 \pm 0,0028^{\Delta}$ & $0,31 \pm 0,014^{\Delta}$ & $0,27 \pm 0,028^{* \Delta}$ \\
\hline $\begin{array}{l}\text { Животные с ОНМК (контроль), } \\
21-е \text { сутки, n = } 10\end{array}$ & $0,015 \pm 0,0014^{*}$ & $0,18 \pm 0,018^{*}$ & $0,14 \pm 0,010^{*}$ \\
\hline $\begin{array}{l}\text { ОНМК + Кортексин, } \\
21 \text {-е сутки, } \mathrm{n}=10\end{array}$ & $0,031 \pm 0,0030^{\Delta}$ & $0,35 \pm 0,013^{* \Delta}$ & $0,29 \pm 0,024^{\star \Delta}$ \\
\hline
\end{tabular}

Примечание: * - изменения достоверны по отношению к группе ложнооперированных животных $(\mathrm{p}<0,05)$;

${ }^{\Delta}$ - изменения достоверны по отношению к контролю $(\mathrm{p}<0,05)$.

Несмотря на вышеперечисленные эффекты Кортексина, обнаружить достоверно значимые показатели его влияния на активность ГбФДГ не удалось (табл. 4.41) на 4-е и 7-е сутки эксперимента. Лишь к 21-му дню активность Г6ФДГ приблизилась к таковой у ЛЖ. Существенных изменений в активности НАДФ-МДГ на фоне применения препарата не произошло.

Таблица 4.41

\section{Активность дегидрогеназ пентозофосфатного пути, (нмоль НАДФН 2 /мин на 1 мг белка)}

\begin{tabular}{|l|c|c|}
\hline \multicolumn{1}{|c|}{ Группа животных } & ГбФДГ & МДГ \\
\hline Ложнооперированные животные, $\mathrm{n}=10$ & $11,59 \pm 0,54$ & $28,94 \pm 1,76$ \\
\hline Животные с ОНМК (контроль), 4-е сутки, $\mathrm{n}=10$ & $7,59 \pm 0,41^{*}$ & $15,06 \pm 1,05^{*}$ \\
\hline ОНМК + Кортексин, 4-е сутки, $\mathrm{n}=10$ & $7,78 \pm 0,41^{*}$ & $20,0 \pm 0,79^{*} \Delta$ \\
\hline Животные с ОНМК (контроль), 7-е сутки, $\mathrm{n}=10$ & $6,06 \pm 0,39^{*}$ & $12,61 \pm 0,85^{*}$ \\
\hline ОНМК + Кортексин, 7-е сутки, $\mathrm{n}=10$ & $7,13 \pm 0,33^{*}$ & $23,14 \pm 1,30^{*} \Delta$ \\
\hline Животные с ОНМК (контроль), 21-е сутки, $\mathrm{n}=10$ & $7,42 \pm 0,35^{*}$ & $21,74 \pm 1,19^{*}$ \\
\hline ОНМК + Кортексин, 21-е сутки, $\mathrm{n}=10$ & $12,03 \pm 0,44^{\star}$ & $26,13 \pm 1,07{ }^{\star}$ \\
\hline
\end{tabular}

Примечание: * - изменения достоверны по отношению к группе ложнооперированных животных $(\mathrm{p}<0,05)$;

${ }^{\Delta}$ - изменения достоверны по отношению к контролю $(\mathrm{p}<0,05)$. 
Таким образом, экспериментальные данные, полученные в группах крыс с моделированным ОНМК, свидетельствуют о благоприятном влиянии Кортексина на восстановление энергетического метаболизма ишемизированного головного мозга.

Исследование динамики содержания макроэргических соединений в ткани головного мозга крыс с ОНМК на фоне применения Семакса показало наличие достоверных отличий уровня АТФ на всех этапах эксперимента как в сравнении с ЛЖ, так и с соответствующими контрольными группами (табл. 4.42).

Таблица 4.42

\section{Содержание адениловых нуклеотидов в ткани мозга крыс с ОНМК, (мкмоль/г ткани)}

\begin{tabular}{|c|c|c|c|}
\hline Группа животных & АТФ & АДФ & АМФ \\
\hline $\begin{array}{l}\text { Ложнооперированные живот- } \\
\text { ные, } n=10\end{array}$ & $3,17 \pm 0,25$ & $0,56 \pm 0,03$ & $0,19 \pm 0,014$ \\
\hline $\begin{array}{l}\text { Животные с ОНМК (контроль), } \\
\text { 4-е сутки, } n=10\end{array}$ & $1,51 \pm 0,03^{*}$ & $0,82 \pm 0,012^{*}$ & $0,31 \pm 0,011^{*}$ \\
\hline $\begin{array}{l}\text { ОНМК + Семакс, } \\
\text { 4-е сутки, } \mathrm{n}=10\end{array}$ & $1,66 \pm 0,024^{\star \Delta}$ & $0,82 \pm 0,023^{*}$ & $0,53 \pm 0,022 * \Delta$ \\
\hline $\begin{array}{l}\text { Животные с ОНМК (контроль), } \\
\text { 7-е сутки, } \mathrm{n}=10\end{array}$ & $1,41 \pm 0,017^{\star}$ & $0,82 \pm 0,015^{\star}$ & $0,43 \pm 0,022^{*}$ \\
\hline $\begin{array}{l}\text { ОНМК + Семакс, } \\
\text { 7-е сутки, } \mathrm{n}=10\end{array}$ & $1,98 \pm 0,053^{*} \Delta$ & $0,77 \pm 0,015^{*}$ & $0,29 \pm 0,016^{*}$ \\
\hline $\begin{array}{l}\text { Животные с ОНМК (контроль), } \\
21 \text {-е сутки, n = } 10\end{array}$ & $1,72 \pm 0,043^{*}$ & $0,76 \pm 0,025^{\star}$ & $0,35 \pm 0,018^{*}$ \\
\hline $\begin{array}{l}\text { ОНМК + Семакс, } \\
21-е \text { сутки, } \mathrm{n}=10\end{array}$ & $2,58 \pm 0,042^{*} \Delta$ & $0,72 \pm 0,025^{\star}$ & $0,29 \pm 0,022^{*}$ \\
\hline
\end{tabular}

Примечание: * - изменения достоверны по отношению к группе ложнооперированных животных $(\mathrm{p}<0,05)$;

${ }^{\Delta}$ - изменения достоверны по отношению к соответствующей контрольной группе животных $(\mathrm{p}<0,05)$.

По сравнению с экспериментальными животными, получавшими Цереброкурин, животные, получавшие Семакс, имели более низкий показатель соотношения АТФ/АДФ+АМФ, что свидетельствует о менее выраженном энерготропном влиянии Семакса.

С целью определения эффективности Семакса в плане восстановления обменных процессов в ЦТК митохондрий нейронов головного мозга на 4-е, 7-е и 21-е сутки после экспериментального ОНМК, определялось содержание изолимонной и яблочной кислоты (табл. 4.43). 
Таблииа 4.43

Содержание малата, пирувата и изоцитрата в ткани головного мозга крыс с ОНМК, (мкмоль/г ткани)

\begin{tabular}{|l|c|c|c|}
\hline \multicolumn{1}{|c|}{ Группа животных } & Изоцитрат & Малат & Пируват \\
\hline $\begin{array}{l}\text { Ложнооперированные } \\
\text { животные, } \mathrm{n}=10\end{array}$ & $0,027 \pm 0,0014$ & $0,28 \pm 0,019$ & $0,19 \pm 0,016$ \\
\hline $\begin{array}{l}\text { Животные с ОНМК (контроль), } \\
\text { 4-е сутки, } \mathrm{n}=10\end{array}$ & $0,011 \pm 0,0012^{*}$ & $0,18 \pm 0,018^{*}$ & $0,14 \pm 0,012^{*}$ \\
\hline $\begin{array}{l}\text { ОНМК + Семакс, } \\
\text { 4-е сутки, } \mathrm{n}=10\end{array}$ & $0,020 \pm 0,0014^{\star \Delta}$ & $0,30 \pm 0,024^{\star}$ & $0,16 \pm 0,014$ \\
\hline $\begin{array}{l}\text { Животные с ОНМК (контроль), } \\
\text { 7-е сутки, } \mathrm{n}=10\end{array}$ & $0,013 \pm 0,0013^{*}$ & $0,15 \pm 0,014^{*}$ & $0,11 \pm 0,010^{\star}$ \\
\hline $\begin{array}{l}\text { ОНМК + Семакс, } \\
\text { 7-е сутки, } \mathrm{n}=10\end{array}$ & $0,014 \pm 0,0016^{\star \Delta}$ & $0,25 \pm 0,018^{\Delta}$ & $0,15 \pm 0,012^{\Delta}$ \\
\hline $\begin{array}{l}\text { Животные с ОНМК (контроль), } \\
\text { 21-е сутки, } \mathrm{n}=10\end{array}$ & $0,015 \pm 0,0014^{\star}$ & $0,18 \pm 0,018^{\star}$ & $0,14 \pm 0,010^{*}$ \\
\hline $\begin{array}{l}\text { ОНМК + Семакс, } \\
\text { 21-е сутки, } \mathrm{n}=10\end{array}$ & $0,020 \pm 0,0015^{\star \Delta}$ & $0,28 \pm 0,029^{\star}$ & $0,16 \pm 0,013$ \\
\hline
\end{tabular}

Примечание: * - изменения достоверны по отношению к группе ложнооперированных животных $(\mathrm{p}<0,05)$;

${ }^{\Delta}$ - изменения достоверны по отношению к соответствующей контрольной группе животных $(\mathrm{p}<0,05)$.

Так, на фоне применения препарата, происходило снижение содержания изоцитрата (максимальное - в 1,93 раза - на 7-е сутки эксперимента). Уровень яблочной кислоты у животных, получавших Семакс, оставался относительно стабильным, что, очевидно, связано с дополнительной доставкой малата малат-аспартатным челночным механизмом. В отношении пирувата (табл. 4.43), выраженного влияния Семакс не показал - содержание этого метаболита оставалось низким во всех группах, получавших препарат. Наглядно соотношение вышеуказанных метаболитов в остром и отдаленном периоде эксперимента видно на рисунках 4.26-4.27.

Из всех исследуемых препаратов наиболее выраженный энерготропный эффект показал Цереброкурин на 4-е сутки после ОНМК и Кортексин - на 21-е сутки. Энерготропное влияние Семакса оказалось наименее выраженным.

Определение содержания молочной кислоты в ткани мозга экспериментальных животных с ОНМК показало, что на фоне применения препарата отмечались достоверные по отношению к соответствующей контрольной группе изменения. Наиболее выраженные изменения в содержании лактата омечались на 21-й день эксперимента. Содержание глюкозы у крыс, получавших Семакс, на 4-е сутки снизилось в 1,35 раза, а к 21-му дню практически достигло уровня интакта. Содержание янтарной кислоты достоверно увеличивалось на фоне применения препарата в ткани головного мозга животных во все сроки наблюдения. 


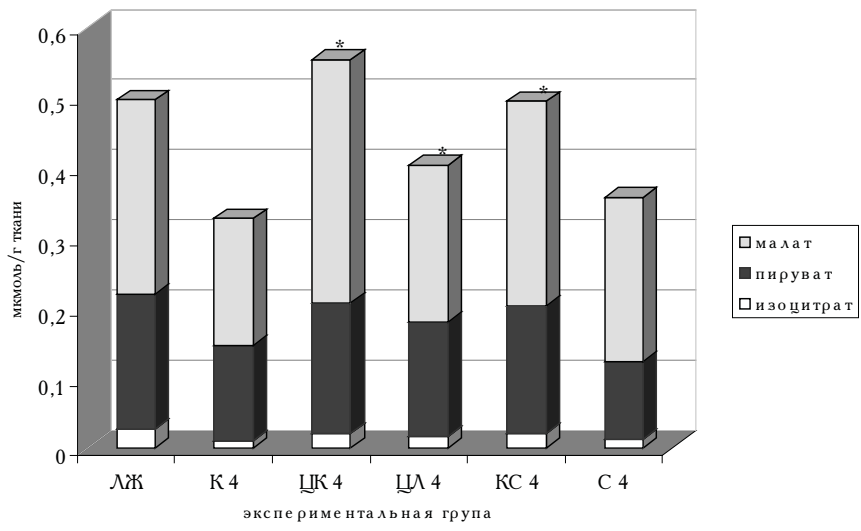

ЛЖ - группа ложнооперированных животных, К - контрольная группа, ЦК - лечение Цереброкурином, ЦЛ - лечение Церебролизином, КС - лечение Кортексином, С - лечение Семаксом.

Примечание: * - изменения достоверны по отношению к соответствующей контрольной группе животных $(\mathrm{p}<0,05)$.

Рuc. 4.26. Содержание изоцитрата, малата и пирувата в ткани головного мозга крыс на 4-й день после экспериментального ОНМК

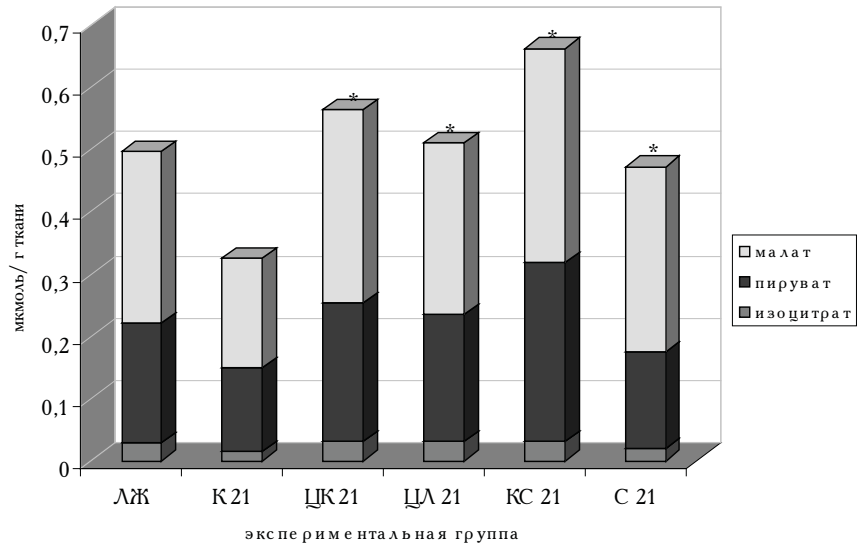

Лж - группа ложнооперированных животных, К - контрольная группа, ЦК - лечение Цереброкурином, ЦЛ - лечение Церебролизином, КС - лечение Кортексином, С - лечение Семаксом.

Примечание: * - изменения достоверны по отношению к соответствующей контрольной группе животных $(\mathrm{p}<0,05)$.

Рuc. 4.27. Содержание изоцитрата, малата и пирувата в ткани головного мозга крыс на 21-й день после экспериментального ОНМК 
Таблица 4.44

Содержание глюкозы, лактата и сукцината в ткани головного мозга крыс с ОНМК, (мкмоль/г ткани)

\begin{tabular}{|c|c|c|c|}
\hline Группа животных & Лактат & Сукцинат & Глюкоза \\
\hline $\begin{array}{l}\text { Ложнооперированные } \\
\text { животные, } \mathrm{n}=10\end{array}$ & $2,99 \pm 0,19$ & $0,81 \pm 0,025$ & $2,19 \pm 0,096$ \\
\hline $\begin{array}{l}\text { Животные с ОНМК (контроль), } \\
\text { 4-е сутки, } \mathrm{n}=10\end{array}$ & $16,07 \pm 0,72^{\star}$ & $0,86 \pm 0,018^{\star}$ & $1,53 \pm 0,052^{*}$ \\
\hline $\begin{array}{l}\text { ОНМК + Семакс, } \\
\text { 4-е сутки, } \mathrm{n}=10\end{array}$ & $13,01 \pm 0,48^{\star \Delta}$ & $0,50 \pm 0,028^{*} \Delta$ & $1,62 \pm 0,044^{*}$ \\
\hline $\begin{array}{l}\text { Животные с ОНМК (контроль), } \\
7 \text {-е сутки, } \mathrm{n}=10\end{array}$ & $20,22 \pm 0,24^{*}$ & $0,43 \pm 0,032^{*}$ & $1,21 \pm 0,025^{*}$ \\
\hline $\begin{array}{l}\text { ОНМК + Семакс, } \\
\text { 7-е сутки, } \mathrm{n}=10\end{array}$ & $16,89 \pm 0,47^{\star \Delta}$ & $0,63 \pm 0,027^{\star} \Delta$ & $1,70 \pm 0,054^{\star \Delta}$ \\
\hline $\begin{array}{l}\text { Животные с ОНМК (контроль), } \\
21 \text {-е сутки, } \mathrm{n}=10\end{array}$ & $21,2 \pm 0,46^{*}$ & $0,49 \pm 0,018^{*}$ & $1,61 \pm 0,022^{*}$ \\
\hline $\begin{array}{l}\text { ОНМК + Семакс, } \\
21-е \text { сутки, } \mathrm{n}=10\end{array}$ & $14,63 \pm 0,59^{* \Delta}$ & $0,70 \pm 0,025^{\star \Delta}$ & $1,91 \pm 0,043^{\Delta}$ \\
\hline
\end{tabular}

Примечание: * - изменения достоверны по отношению к группе ложнооперированных животных $(\mathrm{p}<0,05)$;

${ }^{\Delta}$ - изменения достоверны по отношению к контролю $(\mathrm{p}<0,05)$.

На активность дегидрогеназ пентозофосфатного пути Семакс выраженного влияния не оказал (табл. 4.45). Так, на 4-й, 7-й и 21-й день ОНМК, активность Г6ФДГ была, соответственно, в $1,46,1,34$ и 1,27 раза ниже, чем у ЛЖ.

Для МДГ прослеживается подобная тенденция. Активность фермента на вышеуказанных сроках, соответственно, в $1,65,1,32$ и 1,22 раза ниже, чем у ЛЖ๙. Заметной активации дегидрогеназ ПФП, связанной с усилением пролиферативных и синтетических процессов в клетках, выявлено не было.

Таблица 4.45

\section{Активность дегидрогеназ пентозофосфатного пути, (нмоль НАДФН 2 ммин на 1 мг белка)}

\begin{tabular}{|c|c|c|}
\hline \multicolumn{1}{|c|}{ Группа животных } & ГбФДг & Мдг \\
\hline Ложнооперированные животные, $\mathrm{n}=10$ & $11,59 \pm 0,54$ & $28,94 \pm 1,76$ \\
\hline $\begin{array}{l}\text { Животные с ОНМК (контроль), } \\
\text { 4-е сутки, } \mathrm{n}=10\end{array}$ & $7,59 \pm 0,41^{*}$ & $15,06 \pm 1,05^{\star}$ \\
\hline
\end{tabular}


Продолжение табл. 4.45

\begin{tabular}{|l|c|c|}
\hline \multicolumn{1}{|c|}{ Группа животных } & ГбФдг & мдг \\
\hline $\begin{array}{l}\text { ОНМк + Семакс, } \\
\text { 4-е сутки, } \mathrm{n}=10\end{array}$ & $7,93 \pm 0,42^{*}$ & $17,59 \pm 0,58^{*}$ \\
\hline $\begin{array}{l}\text { Животные с ОНМк (контроль), } \\
\text { 7-е сутки, } \mathrm{n}=10\end{array}$ & $6,06 \pm 0,39$ * & $12,61 \pm 0,85^{*}$ \\
\hline $\begin{array}{l}\text { ОНМк + Семакс, } \\
\text { 7-е сутки, } \mathrm{n}=10\end{array}$ & $8,66 \pm 0,31^{*} \Delta$ & $21,96 \pm 0,87^{*} \Delta$ \\
\hline $\begin{array}{l}\text { Животные с ОНМК (контроль), } \\
\text { 21-е сутки, } \mathrm{n}=10\end{array}$ & $7,42 \pm 0,35^{*}$ & $21,74 \pm 1,19$ * \\
\hline $\begin{array}{l}\text { ОНМк + Семакс, } \\
\text { 21-е сутки, } \mathrm{n}=10\end{array}$ & $9,13 \pm 0,42^{*} \Delta$ & $23,72 \pm 0,91^{*}$ \\
\hline
\end{tabular}

Примечание: * - изменения достоверны по отношению к группе ложнооперированных животных $(\mathrm{p}<0,05)$;

$\Delta$ - изменения достоверны по отношению к контролю $(\mathrm{p}<0,05)$.

Анализ полученных результатов показал, что использование Семакса с целью коррекции постинсультного энергодефицита имеет положительную динамику, хотя не все звенья энергетического метаболизма восстанавливаются в равной степени эффективно. Для полноты представления о метаболических эффектах препарата и объяснения его энерготропного действия необходимы сведения, касающиеся влияния Семакса на сохранение клеточных белков в нативном состоянии, а также на предотвращение развития окислительного и нитрозирующего стресса.

Церебролизин - один из наиболее популярных и широко используемых препаратов в неврологической практике. С момента его активного внедрения прошло уже более 40 лет. За это время в лабораториях различных стран проведено множество испытаний эффективности его применения при самых различных нейродегенеративных патологиях. В наших исследованиях этот препарат был выбран в качестве эталона для сравнения.

Исследование содержания АТФ в тканях головного мозга животных с ОНМК, получавших Церебролизин, показало, что достоверное увеличение содержания этого макроэрга по сравнению с контрольной группой наблюдалось на 7-е и 21-е сутки. В содержании АДФ достоверные отличия выявлены только с группой ложнооперированных крыс, выраженных отличий с контрольными группами не наблюдалось. В отношении АМФ прослеживается аналогичная тенденция, за исключением 21-го дня, где уровень АМФ был достоверно ниже, чем в соответствующей контрольной группе. Определение таких важных метаболитов энергообмена как лактат и сукцинат показало достоверные отличия по отношению к аналогичным показателям контроля. 
Таблииа 4.46

\section{Содержание адениловых нуклеотидов в ткани мозга крыс с ОНМК, (мкмоль/г ткани)}

\begin{tabular}{|l|c|c|c|}
\hline \multicolumn{1}{|c|}{ Группа животных } & АТФ & АДФ & АМФ \\
\hline $\begin{array}{l}\text { Ложнооперированные живот- } \\
\text { ные, } \mathrm{n}=10\end{array}$ & $3,17 \pm 0,25$ & $0,56 \pm 0,03$ & $0,19 \pm 0,014$ \\
\hline $\begin{array}{l}\text { Животные с ОНМК (контроль), } \\
\text { 4-е сутки, } \mathrm{n}=10\end{array}$ & $1,51 \pm 0,03^{*}$ & $0,82 \pm 0,012^{*}$ & $0,31 \pm 0,011^{*}$ \\
\hline $\begin{array}{l}\text { ОНМк + Церебролизин, } \\
\text { 4-е сутки, } \mathrm{n}=10\end{array}$ & $1,62 \pm 0,033^{*}$ & $0,82 \pm 0,023^{*}$ & $0,56 \pm 0,031^{*} \Delta$ \\
\hline $\begin{array}{l}\text { Животные с ОНМк (контроль), } \\
\text { 7-е сутки, } \mathrm{n}=10\end{array}$ & $1,41 \pm 0,017^{*}$ & $0,82 \pm 0,015^{*}$ & $0,43 \pm 0,022^{*}$ \\
\hline $\begin{array}{l}\text { ОНМк + Церебролизин, } \\
\text { 7-е сутки, } \mathrm{n}=10\end{array}$ & $2,02 \pm 0,064^{\star}$ & $0,79 \pm 0,022^{*}$ & $0,44 \pm 0,025^{\star}$ \\
\hline $\begin{array}{l}\text { Животные с ОНМк (контроль), } \\
\text { 21-е сутки, } \mathrm{n}=10\end{array}$ & $1,72 \pm 0,043^{*}$ & $0,76 \pm 0,025^{*}$ & $0,35 \pm 0,018^{*}$ \\
\hline $\begin{array}{l}\text { ОНМк + Церебролизин, 21-е } \\
\text { сутки, } \mathrm{n}=10\end{array}$ & $2,70 \pm 0,040^{\star}$ & $0,69 \pm 0,035^{*}$ & $0,22 \pm 0,021^{\star}$ \\
\hline
\end{tabular}

Примечание: * - изменения достоверны по отношению к группе ложнооперированных животных $(\mathrm{p}<0,05)$;

$\Delta$ - изменения достоверны по отношению к контролю $(\mathrm{p}<0,05)$.

Положительные результаты в динамике содержания вышеуказанных интермедиатов очевидны. Так уровень лактата на 4-й день повысился в 4,4 раза; на 7-й — в 5,49 раза, а на 21-й — в 5,78 раза по отношению к ЛЖ.

Таблица 4.47

\section{Содержание глюкозы, лактата и сукцината в ткани головного мозга крыс с ОНМК, (мкмоль/г ткани)}

\begin{tabular}{|l|c|c|c|}
\hline \multicolumn{1}{|c|}{ Группа животных } & Лактат & Сукцинат & Глюкоза \\
\hline $\begin{array}{l}\text { Ложнооперированные } \\
\text { животные, } \mathrm{n}=10\end{array}$ & $2,99 \pm 0,19$ & $0,81 \pm 0,025$ & $2,19 \pm 0,096$ \\
\hline $\begin{array}{l}\text { Животные с ОНМК (контроль), } \\
\text { 4-е сутки, } \mathrm{n}=10\end{array}$ & $16,07 \pm 0,72^{*}$ & $0,86 \pm 0,018^{*}$ & $1,53 \pm 0,052^{*}$ \\
\hline $\begin{array}{l}\text { ОНМК + Церебролизин, } \\
\text { 4-е сутки, } \mathrm{n}=10\end{array}$ & $13,12 \pm 0,35^{\star} \Delta$ & $0,51 \pm 0,027^{\star} \Delta$ & $1,53 \pm 0,065^{\star}$ \\
\hline $\begin{array}{l}\text { Животные с ОНМк (контроль), } \\
\text { 7-е сутки, } \mathrm{n}=10\end{array}$ & $20,22 \pm 0,24^{*}$ & $0,43 \pm 0,032^{*}$ & $1,21 \pm 0,025^{\star}$ \\
\hline
\end{tabular}




\begin{tabular}{|l|c|c|c|}
\hline \multicolumn{1}{|c|}{ Группа животных } & Лактат & Пукцинат & Глюкоза \\
\hline $\begin{array}{l}\text { ОНМК + Церебролизин, } \\
\text { 7-е сутки, } \mathrm{n}=10\end{array}$ & $16,44 \pm 0,58^{*} \Delta$ & $0,62 \pm 0,028^{*} \Delta$ & $1,68 \pm 0,047^{*} \Delta$ \\
\hline $\begin{array}{l}\text { Животные с ОнМК (контроль), } \\
\text { 21-е сутки, } \mathrm{n}=10\end{array}$ & $21,2 \pm 0,46^{*}$ & $0,49 \pm 0,018^{*}$ & $1,61 \pm 0,022^{*}$ \\
\hline $\begin{array}{l}\text { ОНМк + Церебролизин, } \\
\text { 21-е сутки, } \mathrm{n}=10\end{array}$ & $17,29 \pm 0,22^{*} \Delta$ & $0,67 \pm 0,029^{*} \Delta$ & $2,02 \pm 0,079 \Delta$ \\
\hline
\end{tabular}

Примечание: * - изменения достоверны по отношению к группе ложнооперированных животных $(\mathrm{p}<0,05)$;

${ }^{\Delta}$ - изменения достоверны по отношению к контролю $(\mathrm{p}<0,05)$.

Содержание янтарной кислоты на 7-е и 21-е сутки было, соответственно в 1,44 и 1,37 раза выше, чем в контрольных группах. Уровень глюкозы к 21-м суткам ОНМК практически приблизился к таковому у ЛЖћ, что говорит о частичной стабилизации энергетических процессов в головном мозге под влиянием препарата.

Определение уровня НАД-зависимых субстратов ЦТК - яблочной и изолимонной кислоты - показало, что на фоне применения препарата, на 7-е и 21-е сутки эксперимента были выявлены достоверные отличия в содержании малата по сравнению с соответствующими контрольными группами (табл. 4.48). Содержание изолимонной кислоты в группах с препаратом достоверно отличалось от контрольных групп на всех этапах эксперимента. Причем в отдаленном периоде после ОНМК эти показатели приблизились к таковым у ЛЖ, что свидетельствует о нормализации работы ЦТК под влиянием Церебролизина. Содержание изолимонной и яблочной кислоты на 21-й день эксперимента в группе, получавшей препарат, превосходило аналогичные показатели в контрольной группе, соответственно, в 2 и 1,5 раза.

Таблица 4.48

Содержание малата, пирувата и изоцитрата в ткани головного мозга крыс с ОНМК, (мкмоль/г ткани)

\begin{tabular}{|l|l|l|l|}
\hline \multicolumn{1}{|c|}{ Группа животных } & \multicolumn{1}{|c|}{ Изоцитрат } & \multicolumn{1}{|c|}{ Малат } & \multicolumn{1}{|c|}{ Пируват } \\
\hline $\begin{array}{l}\text { Ложнооперированные } \\
\text { животные, } \mathrm{n}=10\end{array}$ & $0,027 \pm 0,0014$ & $0,28 \pm 0,019$ & $0,19 \pm 0,016$ \\
\hline $\begin{array}{l}\text { Животные с ОНМК (контроль), } \\
\text { 4-е сутки, } \mathrm{n}=10\end{array}$ & $0,011 \pm 0,0012^{*}$ & $0,18 \pm 0,018^{*}$ & $0,14 \pm 0,012^{*}$ \\
\hline $\begin{array}{l}\text { ОНМК + Церебролизин, } \\
\text { 4-е сутки, } \mathrm{n}=10\end{array}$ & $0,018 \pm 0,0014^{* \Delta}$ & $0,22 \pm 0,023^{*}$ & $0,16 \pm 0,013$ \\
\hline $\begin{array}{l}\text { Животные с ОНМК (контроль), } \\
\text { 7-е сутки, } \mathrm{n}=10\end{array}$ & $0,013 \pm 0,0013^{*}$ & $0,15 \pm 0,014^{*}$ & $0,11 \pm 0,010^{*}$ \\
\hline $\begin{array}{l}\text { ОНМК } \text { Церебролизин, } \\
\text { 7-е сутки, } \mathrm{n}=10\end{array}$ & $0,018 \pm 0,0010^{\Delta}$ & $0,23 \pm 0,020^{\Delta}$ & $0,17 \pm 0,015^{\Delta}$ \\
\hline
\end{tabular}


Продолжение табл. 4.48

\begin{tabular}{|l|c|c|c|}
\hline \multicolumn{1}{|c|}{ Группа животных } & \multicolumn{1}{|c|}{ Изоцитрат } & Малат & \multicolumn{1}{c|}{ Пируват } \\
\hline $\begin{array}{l}\text { Животные с ОНМК (контроль), } \\
21 \text {-е сутки, } \mathrm{n}=10\end{array}$ & $0,015 \pm 0,0014^{*}$ & $0,18 \pm 0,018^{*}$ & $0,14 \pm 0,010^{*}$ \\
\hline $\begin{array}{l}\text { ОНМК + Церебролизин, } \\
\text { 21-е сутки, } \mathrm{n}=10\end{array}$ & $0,030 \pm 0,0016^{\star}$ & $0,27 \pm 0,017^{\star}$ & $0,21 \pm 0,017^{\Delta}$ \\
\hline
\end{tabular}

Примечание: * - изменения достоверны по отношению к группе ложнооперированных животных $(\mathrm{p}<0,05)$;

${ }^{\Delta}$ - изменения достоверны по отношению к контролю $(\mathrm{p}<0,05)$.

Содержание пировиноградной кислоты у животных с ОНМК, получавших Церебролизин, достоверно превышало таковое у крыс из соответствующих контрольных групп на 7-й и 21-й день после моделирования ОНМК (табл. 4.48), соответственно, в 1,55 и 1,5 раза.

Активность Г6ФДГ в ткани головного мозга крыс с ОНМК, получавших Церебролизин, достоверно отличалась от таковой в контрольной группе на 7-е и 21-е сутки. В отдаленном периоде эксперимента этот показатель достиг дооперационного уровня, но не превысил его.

Таблииа 4.49

\section{Активность дегидрогеназ пентозофосфатного пути, (нмоль НАДФН ${ }_{2} /$ мин на 1 мг белка)}

\begin{tabular}{|c|c|c|}
\hline Группа животных & гбФдГ & мдг \\
\hline $\begin{array}{l}\text { Ложнооперированные } \\
\text { животные, } \mathrm{n}=10\end{array}$ & $11,59 \pm 0,54$ & $28,94 \pm 1,76$ \\
\hline $\begin{array}{l}\text { Животные с ОНМК (контроль), } \\
4 \text {-е сутки, } \mathrm{n}=10\end{array}$ & $7,59 \pm 0,41^{*}$ & $15,06 \pm 1,05^{\star}$ \\
\hline $\begin{array}{l}\text { ОНМК + Церебролизин, } \\
\text { 4-е сутки, } \mathrm{n}=10\end{array}$ & $7,75 \pm 0,35^{\star}$ & $18,97 \pm 0,91^{*} \Delta$ \\
\hline $\begin{array}{l}\text { Животные с ОНМК (контроль), } \\
\text { 7-е сутки, n = } 10\end{array}$ & $6,06 \pm 0,39^{*}$ & $12,61 \pm 0,85^{\star}$ \\
\hline $\begin{array}{l}\text { ОНМК + Церебролизин, } \\
\text { 7-е сутки, } \mathrm{n}=10\end{array}$ & $8,45 \pm 0,29^{*} \Delta$ & $24,06 \pm 1,10^{*} \Delta$ \\
\hline $\begin{array}{l}\text { Животные с ОНМК (контроль), } \\
21 \text {-е сутки, } \mathrm{n}=10\end{array}$ & $7,42 \pm 0,35^{\star}$ & $21,74 \pm 1,19^{*}$ \\
\hline 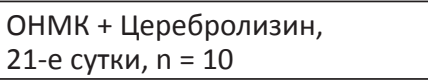 & $11,24 \pm 0,45 \Delta$ & $27,32 \pm 1,17 \Delta$ \\
\hline
\end{tabular}

Примечание: * - изменения достоверны по отношению к группе ложнооперированных животных $(\mathrm{p}<0,05)$;

${ }^{\Delta}$ - изменения достоверны по отношению к контролю $(\mathrm{p}<0,05)$

Активность МДГ (табл. 4.49) в группах, получавших препарат, достоверно отличалась от таковой в контрольных группах на всех сроках эксперимента и нормализовалась к 21-м суткам. В сравнении с контрольной группой активность фермента была в 1,5 раза выше. 
Таким образом, в ходе исследований было показано энерготропное влияние Церебролизина. Для того, чтобы выявить наиболее эффективный препарат из рассмотренных выше нейротрофических церебропротекторов, необходимо изучить их в сравнительном аспекте.

Анализируя полученные результаты, хотелось бы отметить, что каждый из исследуемых препаратов показал наличие энерготропного влияния в условиях ОНМК. В ходе исследований, безусловно, обнаружены достоверные отличия в механизме и эффективности их действия. Было показано, что у животных, получавших нейротрофические церебропротекторы, развитие энергетического дефицита было менее выраженным, чем у животных из контрольной группы.

Для углубленного анализа состояния энергообеспечения были оценены дополнительные параметры энергообмена. Показатель энергетического заряда (Э3) в контрольной группе был достоверно снижен: в остром периоде на $27,4 \%$, в подостром - на $26,6 \%$, а в отдаленном - на $23,9 \%$, что отражает значительное снижение степени заполнения высокоэнергетическими связями системы АТФ-АДФ-АМФ.

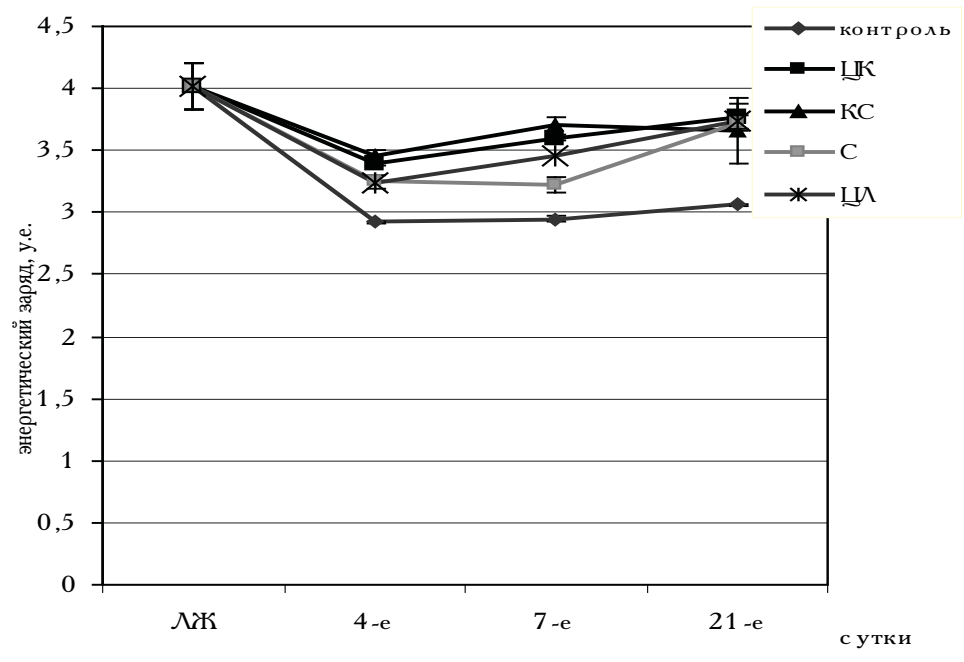

Puc. 4.28. Показатель энергетического заряда в экспериментальных группах

На фоне применения исследуемых препаратов, снижение показателя ЭЗ было менее существенным. Так, на четвертые и седьмые сутки, наилучший эффект получен у крыс, которые получали Кортексин (рис. 4.28). Снижение ЭЗ, соответственно, составило $14 \%$ и 7,5 \%. На 21-й день наилучший результат показал Цереброкурин (ЭЗ снизился всего на 5,5 \%).

Изучение энергетического потенциала (ЭП) (рис. 4.29) показало резкое уменьшение его в контрольной группе на 4 -й, 7 -й и 21 -й день ОНМК, соответственно, на $68,6 \%, 70,8 \%$ и $61,1 \%(\mathrm{p}<0,05)$, что свидетельствует о значительном снижении активности дыхательной цепи митохондрий, поскольку митохондриальные нарушения коррелируют с фазными изменениями в содержании компонентов адениннуклеотидного пула - АТФ, АДФ, АМФ. 


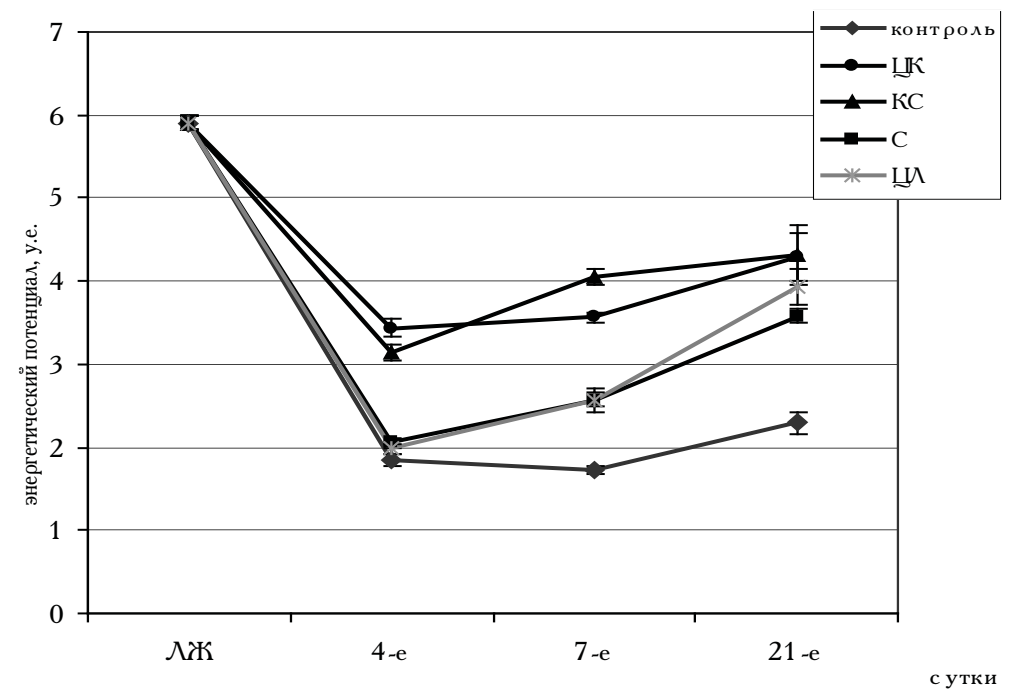

\section{Рис. 4.29. Показатель энергетического потенциала в экспериментальных группах}

Применение нейротрофических церебропротекторов способствовало коррекции митохондриальных нарушений и увеличению ЭП. Так, на фоне лечения Цереброкурином в остром периоде показатель снизился всего на 41,6 \% (р $<0,05)$. В подостром и отдаленном периоде наилучший эффект показал Кортексин (ЭП снизился всего на $31,3 \%$ и $26,7 \%$, соответственно).

Аналогичная тенденция отмечена относительно индекса фосфорилирования (ИФ). В контрольной группе (рис. 4.30) он снижен в вышеуказанные сроки наблюдения на $64,6 \%, 64,7 \%$ и $56,7 \%$, что свидетельствует о нарушении соотношения между АТФ и пулом АДФ-АМФ. В ткани мозга животных, получавших исследуемые препараты, индекс фосфорилирования снизился менее существенно.

Так, на фоне лечения Цереброкурином в остром и отдаленном периоде показатель снизился, соответственно, всего на 39,8 \% и $25,5 \%(\mathrm{p}<0,05)$. В подостром периоде наилучший эффект показал Кортексин (ЭП снизился всего на $29,2 \%$ ).

Показатель термодинамического контроля дыхания (ТДК), отражающий зависимость активности дыхательной цепи митохондрий от интенсивности фосфорилирования в целом, в контрольной группе на 4-е сутки снизился на $11,5 \%$ (рис. 4.31). На 7-е и 21 -е сутки нарушения ТДК усугубились, что проявилось в снижении показателя, соответственно, на 35,3 \% и $26,6 \%$. Терапия Цереброкурином показала наилучший эффект в остром и подостром периоде. При этом на 4-й день показатель снизился всего на 2,7 \%, а на 7-й день - повысился на $6,4 \%$. В отдаленном периоде лучший эффект показал Кортексин, применение которого способствовало повышению ТДК на $12,1 \%$. 


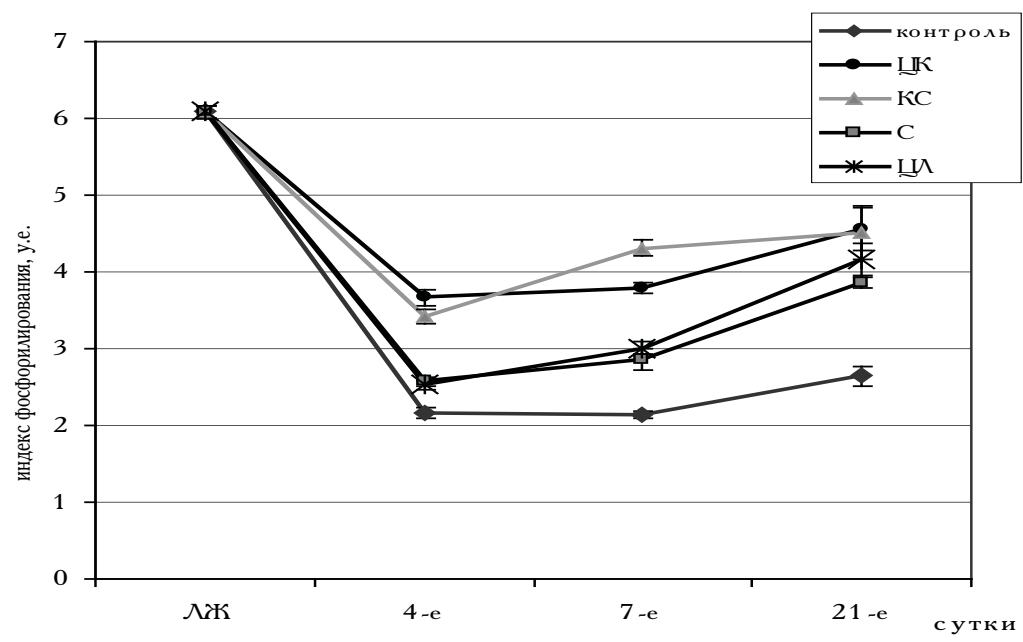

Рис. 4.30. Показатель индекса фосфорилирования в экспериментальных группах

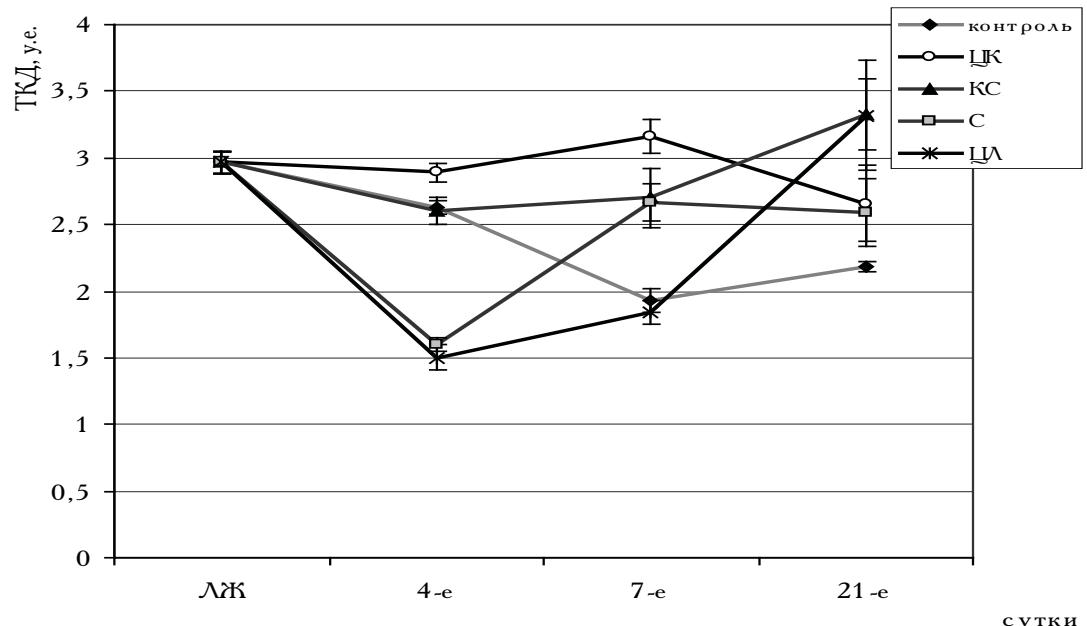

Рuc. 4.31. Показатель термодинамического контроля дыхания в экспериментальных группах

Истощение энергетических резервов головного мозга, при недостаточной его оксигенации, приводит к замедлению дальнейшего окисления лактата в пируват. Развивающийся метаболический ацидоз представляет собой дополнительный повреждающий фактор при гипоксии. Индекс лактат/пируват отражает процессы аэробного/анаэробного окисления глюкозы и свидетельствует о компенсаторно-приспособительных возможностях организма. 
В ходе исследований установлены достоверные отличия $(\mathrm{p}<0,05)$ в содержании молочной кислоты на фоне применения нейротрофических церебропротекторов. Наиболее стремительное ее повышение в ткани мозга наблюдалось у крыс из контрольных групп на 4-е, 7-е, и 21-е сутки (соответственно в 5,37, 6,76 и 7,09 раза в сравнении с ЛЖ). Пик роста содержания лактата в контрольной группе и у крыс, получавших Церебролизин, приходится на 21-е сутки, а у животных, получавших Цереброкурин и Кортексин - на 7-е. Затем отмечается постепенный регресс в содержании молочной кислоты, что может быть связано как с активацией под действием препаратов цикла трикарбоновых кислот, так и с усилением глиальной трансформации лактата в пируват. Влияние исследуемых препаратов на активацию аэробного гликолиза наглядно отражает индекс лактат/пируват (рис.4.32). Так, в остром периоде эксперимента наилучший результат показал Цереброкурин (снижение индекса на $48 \%$ ); в подостром и отдаленном - Кортексин (снижение индекса, соответственно, на $63 \%$ и $66 \%$ ).

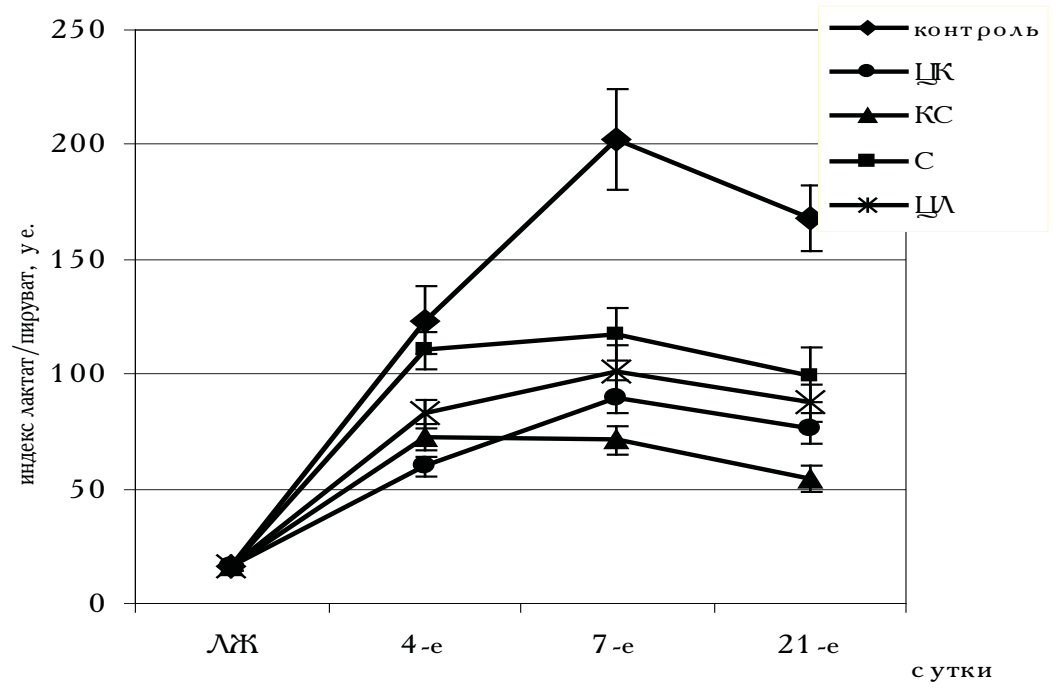

Рис. 4.32. Индекс лактат/пируват в экспериментальных группах

Анализ содержания глюкозы в тканях мозга прооперированных крыс (рис. 4.33-4.35), показал, что минимальное ее содержание отмечалось в ткани мозга животных из контрольной группы на 7 -е сутки эксперимента (в 1,82 раза ниже, чем у ЛЖ). Наилучшие результаты по увеличению содержания глюкозы в ткани мозга были получены в группах, где прооперированные животные получали Цереброкурин и Кортексин. Так, на 4-е, 7-е и 21-е сутки после моделированной патологии уровень глюкозы на фоне применения Цереброкурина был в $1,12,1,61$ и 1,56 раза выше, чем в соответствующих контрольных группах, а на фоне применения Кортексина, соответственно - в 1,12, 1,54 и 1,27 раза. 


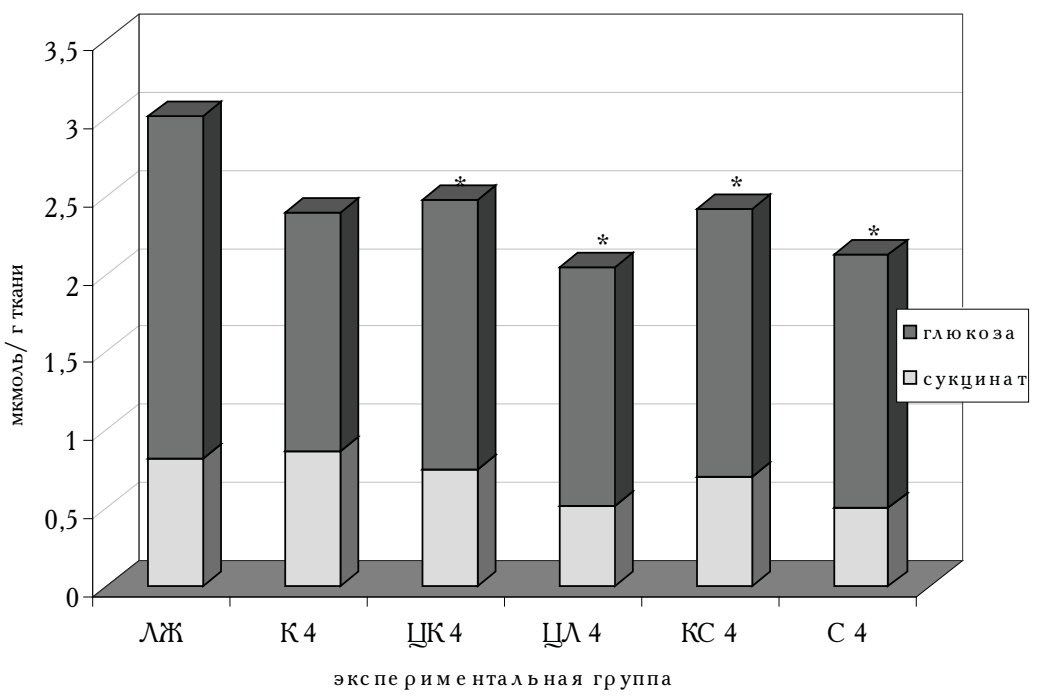

Лж - группа ложнооперированных животных, К - контрольная группа, ЦК - лечение Цереброкурином, ЦЛ - лечение Церебролизином, КС - лечение Кортексином, С - лечение Семаксом.

Примечание: * - изменения достоверны по отношению к контрольной группе $(\mathrm{p}<0,05)$.

\section{Рuc. 4.33. Содержание глюкозы и янтарной кислоты в ткани головного мозга на четвертый день эксперимента}

Окисление янтарной кислоты в шестой реакции цикла Кребса осуществляется с помощью сукцинатдегидрогеназы, характерной особенностью которой является локализация на внутренней поверхности мембран митохондрий и независимость ее активности от концентрации окисленной и восстановленной формы НАД/НАДН, что позволяет сохранить энергосинтезирующую функцию митохондрий в условиях гипоксии и ишемии при нарушении НАД-зависимого дыхания клеток.

Противоишемический эффект янтарной кислоты связан не только с активацией сукцинатдегидрогеназного окисления, но и с восстановлением активности ключевого окислительно-восстановительного фермента дыхательной митохондриальной цепи - цитохромоксидазы. Кроме того, сукцинат положительно влияет на оксигенацию внутренней среды, стабилизирует структуру и повышает функциональную активность митохондрий, является индуктором синтеза некоторых белков, влияет на ионный обмен в клетке. 


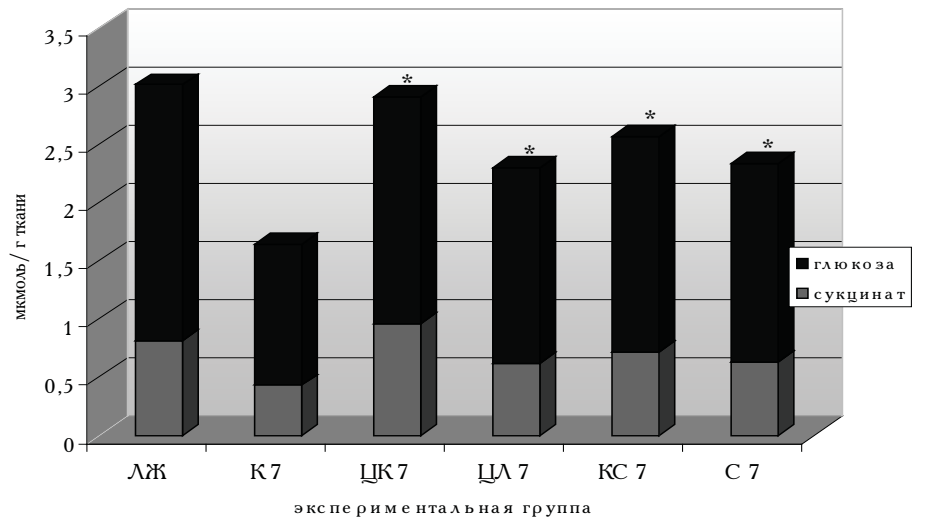

$$
\begin{aligned}
& \text { Лж }- \text { группа ложно- } \\
& \text { оперированных } \\
& \text { животных, } \\
& \text { К } \text { контрольная } \\
& \text { группа, } \\
& \text { ЦК }- \text { лечение } \\
& \text { Цереброкурином, } \\
& \text { цл }- \text { лечение } \\
& \text { Церебролизином, } \\
& \text { КС } \quad \text { лечение } \text { Кортексином, } \\
& \text { С } \quad \text { лечение Семаксом. }
\end{aligned}
$$

Примечание: * - изменения достоверны по отношению к контрольной группе $(\mathrm{p}<0,05)$.

Puc. 4.34. Содержание глюкозы и янтарной кислоты в ткани головного мозга на седьмой день эксперимента

Определение содержания янтарной кислоты в ткани мозга животных всех экспериментальных групп (рисунки 4.33-4.35), показало, что небольшое повышение ее уровня в контрольной группе на 4-е сутки эксперимента сменяется стремительным (в 1,91 раза сравнительно с ЛЖ⿱ $)$ снижением на 7-е. В отдаленном сроке эксперимента (на 21-й день) ситуация улучшилась не намного. Содержание сукцината оставалось низким, в 1,67 раза ниже, чем в группе Лжћ. В группе животных, получавших Цереброкурин, на 7-й день после ОНМК, зафиксировано рекордно высокое содержание янтарной кислоты (в 1,2 раза выше, чем у ЛЖ⿱乛⿻).

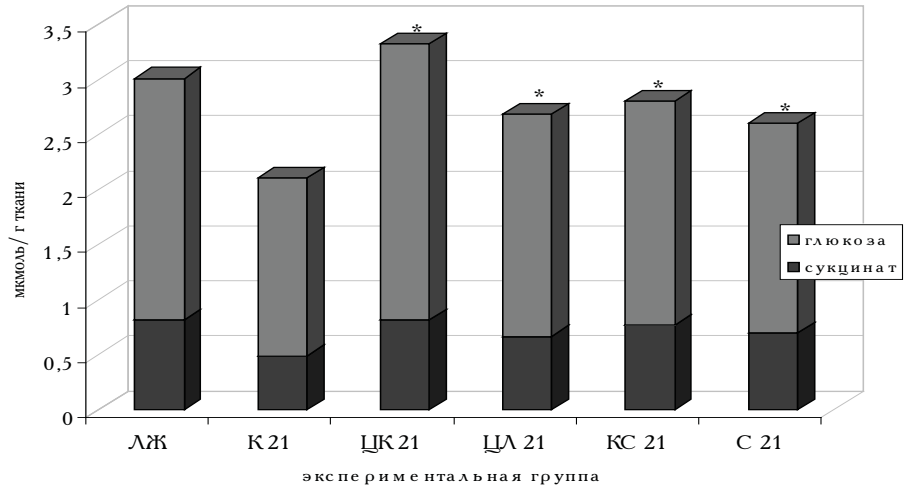

$$
\begin{aligned}
\text { лж }- & \text { группа ложно- } \\
& \text { оперированных } \\
& \text { животных, } \\
\text { К }- & \text { контрольная } \\
& \text { группа, } \\
\text { цК }- & \text { лечение } \\
& \text { Цереброкурином, } \\
\text { цл }- & \text { лечение } \\
& \text { Церебролизином, } \\
\text { кс }- & \text { лечение } \\
& \text { Кортексином, } \\
\text { с - }- \text { лечение Семаксом. } &
\end{aligned}
$$

Примечание: * - изменения достоверны по отношению к контрольной группе $(\mathrm{p}<0,05)$.

Puc. 4.35. Содержание глюкозы и янтарной кислоты в ткани головного мозга в отдаленном периоде эксперимента 
Проанализировав содержание пирувата в головном мозге крыс с ОНМК на 4-й, 7-й и 21-й день эксперимента было отмечено низкое его содержание (в 1,3-1,7 раза ниже, чем у ложнооперированных крыс. У крыс с ОНМК, получавших Цереброкурин, содержание пирувата достоверно не отличалось от такового у ЛЖ, и уровень молочной кислоты был достоверно ниже, чем в соответствующих контрольных группах. Для животных с церебральной патологией, получавших Кортексин в течение 7-ми и 21-го дня, отмечалось достоверное по отношению к ЛЖ повышение содержание пировиноградной кислоты в 1,42 и 1,53 раза, соответственно. Этот препарат показал лучший результат.

Следующий, исследованный нами энергетический метаболит - малат. Яблочная кислота, как компонент основного энергетического цикла клетки, участвует также в функционировании сопряженной системы малатдегидрогеназных реакций. Они протекают в митохондриях и цитоплазме, обеспечивая перенос восстановительных эквивалентов через митохондриальные мембраны, непроницаемые для пиридиннуклеотидов.

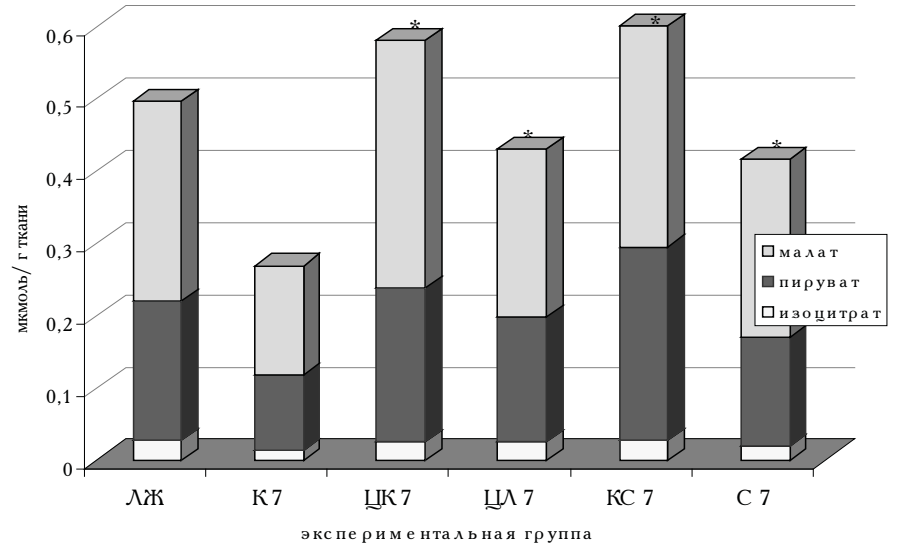

$$
\begin{aligned}
& \text { Лж }- \text { группа ложно- } \\
& \text { оперированных } \\
& \text { животных, } \\
& \text { К } \text { контрольная } \\
& \text { группа, } \\
& \text { ЦК }- \text { лечение } \\
& \text { Цереброкурином, } \\
& \text { Цл }- \text { лечение } \\
& \text { Церебролизином, } \\
& \text { КС }- \text { лечение } \\
& \text { Кортексином, } \\
& \text { С } \quad \text { лечение Семаксом. }
\end{aligned}
$$

Примечание: * — изменения достоверны по отношению к контрольной группе $(\mathrm{p}<0,05)$.

\section{Рuc. 4.36. Содержание глюкозы и янтарной кислоты в ткани головного мозга в подостром периоде эксперимента}

Для импорта восстановительных эквивалентов в форме НАДН $+\mathrm{H}^{+}$ (кофермент-связанного водорода), образующихся в цитоплазме путем гликолиза, в митохондриях используется челночный механизм посредством пары малат-оксалоацетат. Основной функцией этого механизма является перенос восстановительных эквивалентов в составе малата. Для животных контрольной группы в подостром периоде эксперимента отмечалось минимальное содержание малата (в 1,87 раза меньше, чем у ЛЖ).

В этой связи интересным представляется факт, что в ткани мозга животных с ОНМК, получавших Цереброкурин, на 4-е сутки после ОНМК обнаружено достоверное повышение (в 1,25 раза) содержания малата, по сравнению 
с группой ЛЖћ. На 7-й и 21-й день уровень этого метаболита достоверных отличий с группой сравнения не показал.

Применение Кортексина показало лучший результат на 21-й день эксперимента. Эти данные, вероятнее всего, свидетельствуют об активации под влиянием препаратов шунтирующих метаболических потоков, а также об усилении потребления восстановительных эквивалентов дыхательной цепью митохондрий.

В ходе эксперимента было обнаружено, что гипоксия головного мозга способствовала снижению содержания НАД-зависимого субстрата цикла трикарбоновых кислот - изоцитрата. Отмечено снижение уровня изоцитрата в контрольной группе на 4 -й день после ОНМК в 2,45 раза; к 21-м суткам уровень изоцитрата оставался низким (в 1,8 ниже, чем в группе сравнения), что свидетельствует о глубоком торможении скорости цикла трикарбоновых кислот. Препараты Кортексин и Цереброкурин наиболее выражено стимулировали реакции аэробного окисления глюкозы. Так, на 4-й день эксперимента отмечалось небольшое снижение содержания изоцитрата (в 1,22 раза), а к 21-м суткам оно превышало аналогичный показатель в группе сравнения в 1,15 раза. Применение препарата Семакс оказалось с этой точки зрения наименее эффективным. На 4-й день эксперимента уровень изоцитрата был в 2,08 раза ниже, чем в группе сравнения, и к 21-му дню существенной нормализации его содержания не отмечалось (в 1,42 раза ниже группы сравнения).

Изолимонная кислота, кроме участия в энергетическом обмене, может быть источником восстановительных эквивалентов (прежде всего НАДФ) для различных биосинтетических процессов. Подобная роль изоцитрата в клетке вызывает большой интерес при изучении метаболизма данного субстрата при OHMK.

Активность изоцитратдегидрогеназы регулируется в зависимости от концентраций $\mathrm{Mg}^{2+}$, изоцитрата, НАД+, НАДН и АМФ. Кроме субстратсвязывающих центров для НАД', изоцитрата и $\mathrm{Mg}^{2+}$ фермент имеет также положительные и отрицательные эффекторные участки. Изоцитрат - положительный эффектор; его связывание кооперативно, т. е. связывание на каком-либо одном участке облегчает связывание на других. Оба участка связывания для АМФ стимулируют активность фермента. Таким образом, ферментная активность определяется отношениями НАД ${ }^{+}$НАДН и АМФ/АТФ.

Еще одним из путей адаптации метаболизма ткани мозга к гипоксическим условиям является активация пентозофосфатного пути окисления. Нами была исследована активность глюкозо-6-фосфат дегидрогеназы (Г6ФДГ) и малатдегидрогеназы (МДГ) в ткани мозга всех экспериментальных групп. Так, в острый период наблюдалось снижение активности Г6ФДГ во всех группах с ОНМК в среднем в 1,5 раза (с небольшим отличием) по сравнению с ложнооперированными крысами. Только в группе с Цереброкурином снижение активности Г6ФДГ было менее существенно (в 1,38 раза). К 7 -му дню в контрольной группе активность фермента еще снизилась (в 1,92 раза), а в группах, где животные с внутримозговой гематомой получали Церебролизин и Семакс, отмечалось небольшое повышение активности Г6ФДГ. К 21 -му дню эксперимен- 
та в контрольной группе активность фермента оставалась низкой; в группе с Цереброкурином она достоверно превышала таковую у ложнооперированных животных в 1,2 раза; в группах с Кортексином и Церебролизином активность Г6ФДГ приблизилась к показателям группы сравнения. Исходя из полученных результатов можно предположить, что активация Г6ФДГ в отдаленном периоде после экспериментального ОНМК происходила в группах, получавших Церебролизин, Кортексин, и особенно Цереброкурин. Этот факт дает основания полагать, что именно в данном временном промежутке активируются синтетические и восстановительные процессы в поврежденной ткани головного мозга. Особенно интенсивно, судя по всему, активируются обменные процессы под влиянием Цереброкурина.

Что же касается активности НАДФ-зависимой МДГ, то можно сказать следующее: на 4-е сутки эксперимента в контрольной группе отмечалось снижение активности фермента в 1,94 раза по сравнению с группой ложнооперированных крыс. Из всех групп животных с экспериментальной терапией выделялась группа, получавшая Цереброкурин. В этой группе активность фермента снизилась всего в 1,33 раза. На 7-й день эксперимента в контрольной группе активность фермента немного повысилась, но все равно оставалась достоверно ниже, чем в группе сравнения (в 1,63 раза). Наилучше показали себя в данном сроке препараты Церебролизин и Цереброкурин, где изучаемый показатель был ниже, соответственно, в 1,35 раза и 1,4 раза.

В норме доля пентозофосфатного пути в количественном превращении глюкозы обычно невелика, но его значение в обмене веществ весомо. Он поставляет восстановленный НАДФН. Другая функция пентозофосфатного цикла заключается в том, что он поставляет пентозофосфаты для синтеза нуклеиновых кислот и многих коферментов, что имеет большое значение при активации репаративных процессов поврежденной ткани. Ферменты пентозофосфатного пути локализованы во внемитохондриальном пространстве клетки в цитозоле.

Взаимодействие гликолитического и пентозофосфатного путей обеспечивает возможность постоянного приспособления концентраций НАДФН, АТФ и строительных блоков, например рибозо-5-фосфата и пирувата, для удовлетворения потребностей клеток.

Большая часть кислорода, потребляемого клеткой (около 80 \%), используется, как указано, в митохондриях с участием цитохромоксидазы. Это так называемый оксидазный путь. Данный путь дает клетке энергию в виде АТФ. Помимо цитохромоксидазы существуют другие оксидазы, которые катализируют реакции окисления веществ с образованием перекиси водорода. Наряду с этим существует альтернативный путь окисления - оксигеназный. Он не дает клетке энергии, кислород включается в субстрат с образованием новой гидроксильной или карбоксильной группы. Этот путь реализуется, в основном, в мембранах эндоплазматического ретикулума (микросомах).

Так, в условиях ОНМК происходит ингибирование конечного IV комплекса цепи переноса электронов с одновременным стимулированием активности сукцинатдегидрогеназы, переносящей электроны на $\mathrm{Q}$, который, в свою очередь, реагирует с $\mathrm{O}_{2}$ с образованием $\mathrm{O}_{2}{ }^{-}$. Такой энергетический дисбаланс в 
митохондриях, приводящий к снижению синтеза АТФ, усилению генерации активных форм кислорода (АФК) и развитию окислительного стресса, вызывает радикал-индуцированное цитотоксическое нарушение мембран, повреждение ДНК и как следствие - гибель клеток. Усиление продукции свободных радикалов на фоне ацидоза связано с повышенным высвобождением в кислой среде триггера окислительных механизмов - железа - из его связей с трансферриноподобными белками, что интенсифицирует реакции Haber-Weiss. Следствием является быстропереходящее митохондриальное повреждение со снижением активности цитохромоксидазы и цитохрома $\mathrm{A}-\mathrm{A}_{3}$.

Для полноты представлений о метаболических нарушениях, происходящих в ткани головного мозга животных с экспериментальной внутримозговой гематомой, мы исследовали содержание в ткани головного мозга животных некоторых маркеров развития окислительного и нитрозирующего стресса. Интенсивность продукции монооксида азота, а также степень окислительной модификации митохондриальных белков напрямую связаны с эффективностью работы ферментов, участвующих в энергопродукции. Препараты, претендующие называться энерготропными, должны корректировать как можно больше метаболических процессов, а также влиять на степень развития стрессовых нарушений. Следовательно, изучение эффективности их влияния в сравнительном аспекте при данной церебральной патологии представляет большой интерес.

Таким образом, свободнорадикальное окисление, являясь в норме частью общего адаптационного процесса, направленного на поддержание клеточного гомеостаза, регуляцию проницаемости мембран, рецепции нейромедиаторов, ферментативного катализа при глубоких нарушениях трофики мозга, в совокупности с системой фосфолипаз, образует основу патологического повреждающего комплекса.

В настоящее время накоплены многочисленные данные, свидетельствующие о том, что в состоянии окислительного стресса атаке АФК подвергаются не липиды, а в первую очередь белки плазматических мембран. При воздействии соответствующих агентов на мембранный белок-рецептор конформация последнего изменяется и в дальнейшем индуцирует изменения белоклипидных контактов, состояния липидов, окружающих белок. Эти изменения сохраняются и после отщепления лигандов от рецептора, т. е. служат способом закрепления рецептора в возбужденной конформации. Окислительная модификация белка рассматривается как одна из возможных причин инактивации ферментов, изменения структурной организации белков при ОНМК. Окислительно модифицированные белки служат субстратом для протеолитических ферментов. Активированный таким образом протеолиз способствует дальнейшему усилению деструктивных процессов в очаге воспаления. ОМБ также приводит к снижению функции белков в цепи переноса электронов, активности АТФ-азы, избирательности действия транспортных пор. Нами была проанализирована интенсивность окислительной модификации (спонтанной и металлкатализированной) митохондриальных белков. Исследования содержания альдегидфенилгидразонов (АФГ) при спонтанной ОМБ показали, что наибольшее 
их количество было в митохондриях контрольной группы животных на 4-е и 21-е сутки ОНМК. Уровень АФГ превышал таковой у животных группы сравнения в 4,13 и 4,7 раза соответственно. Наилучшие результаты на 4 -е сутки после экспериментального ОНМК были отмечены у крыс, получавших Кортексин и Семакс, где содержание АФГ всего в 1,1 и 2,14 раза, соответственно, превышало аналогичный показатель в группе сравнения. На 7-й день ОНМК можно отметить группы с Семаксом и Цереброкурином, где изучаемый показатель в 1,69 и 1,8 раза превышал таковой в группе ложнооперированных животных. $\mathrm{K}$ 21-му дню эксперимента во всех группах наблюдалось повышение интенсивности ОМБ, что, предположительно, связано с усиленным протеолизом поврежденных белков для подготовки к замене их вновь синтезированными. Наименьшее содержание АФГ зафиксировано в группе животных, получавших Семакс, где их содержание в 2,98 раза было выше, чем в группе сравнения. Что же касается содержания кетонфенилгидразонов (КФГ) в ткани мозга, то можно сказать следующее: наибольшее количество КФГ зафиксировано в контрольной группе животных на 4 -е сутки эксперимента (в 2,85 раза больше, чем в группе сравнения). На 4-й день эксперимента наилучший показатель зарегистрирован в группе с Кортексином (всего в 1,63 раза превышал таковой у ложнооперированных животных). На 7-й день после экспериментального ОНМК лучший показатель отмечен в группе крыс, получавших Семакс (в 1,17 раз выше, чем в группе сравнения). На 21-й день эксперимента из всех групп прооперированных животных следует отметить группу с Кортексином, где содержание КФГ всего в 1,64 раза выше, чем у крыс из группы сравнения. Таким образом мы видим, что использование нейропептидсодержащих препаратов при ОНМК существенно влияет на степень окислительного повреждения митохондриальных протеинов, заметно подавляя этот процесс, что очень важно для сохранения жизнеспособности и энергообеспечения нейронов и глии.

Изучение металл-катализируемой ОМБ наглядно продемонстрировало степень истощения резервно-адаптационных возможностей митохондрий нервной ткани животных всех экспериментальных групп. Так было выявлено, что максимально интенсивное повышение уровня АФГ наблюдалось на 21-й день ОНМК в контрольной группе (в 5,65 раза). Эффективнее всего в этом сроке оказалось применение Кортексина (повышение уровня АФГ по сравнению с ложнооперированными животными в 1,48 раза).

ОМБ провоцирует также интенсификацию окислительной модифика-ции нуклеиновых кислот, что приводит к нарушению экспрессирующего геномного синтеза функциональных, структурных, регуляторных и других продуктов, увеличению проапоптотических генов CCD95 и р53, p35, снижению экспрессии антиапоптотического белка bcl-2.

В наших экспериментах выявлено, что применение препаратов, содержащих в своем составе низкомолекулярные нейропептиды, существенно влияет на продукцию NO в ткани мозга, а также на активность NO-синтазы. Так, в контрольной группе животных уровень NO на 4-е сутки эксперимента повысился в 1,58 раза в сравнении с ложнооперированными крысами; на 7-е сутки уже зафиксировано превышение в 4,4 раза. Далее отмечался медленный 
регресс продукции NO, и к 21-м суткам ОНМК его содержание в ткани мозга было в 2,38 раза выше, чем в группе ложнооперированных крыс. В сравнительном аспекте, среди изучаемых препаратов, наиболее эффективно сдерживали повышение уровня NO Семакс и Церебролизин. Так, на 4-е сутки эксперимента только в группе животных, получавших Семакс, не было отмечено достоверного повышения содержания NO. На 7-й день после ОНМК наименьшее содержание NO было зафиксировано в группе, получавшей Церебролизин (всего в 1,6 раза выше, чем у крыс группы сравнения). К 21-му дню эксперимента лучший результат отмечался в группе с Семаксом (в 1,24 раза выше, чем у ложнооперированных животных).

Активность NO-синтазы у животных с OHMК (контрольной) нарастала постепенно и на 4-е сутки повысилась в 3,12 раза. К 7 -му дню эксперимента активность фермента возросла в 4,7 раза в сравнении с группой ложнооперированных крыс и на 21 -й день оставалась высокой (в 3,74 раза выше, чем в группе сравнения).

Экспериментально показано, что применение нейротрофических церебропротекторов в острый период церебральной ишемии в той или иной степени модулировало активность NO-синтазы. Так, на 4-й день ОНМК активность NO-синтазы во всех группах животных, за исключением тех, что получали Церебролизин, достоверно не повысилась по сравнению с ложнооперированными крысами. Но уже к 7-му дню проявились отличия в различных группах животных по степени активности фермента. Так, наибольшая активность (в 3,26 раза больше, чем в группе сравнения) NO-синтазы отмечена в группе с Кортексином, а наименьшая - с Церебролизином (в 2,31 раза). К 21-му дню эксперимента мы наблюдали существенную регрессию активности фермента в группе животных, получавших Семакс (в 1,95 раза выше, чем в группе сравнения).

Интересные данные получены нами в исследованиях на изолированных митохондриях, выделенных из ткани головного мозга. Нарушение нормальной аккумуляции $\mathrm{Ca}^{2+}$ митохондриями, гиперпродукция NO в условиях окислительного стресса способствуют открытию неспецифических митохондриальных пор (МП) и освобождению апоптогенных белков из поврежденных митохондрий.

Если проследить динамику изменения митохондриальной проницаемости на 4-е, 7-е и 21-е сутки ОНМК во всех группах животных, то наибольший ее подъем наблюдается в контрольной группе на 7-й день эксперимента. Наиболее подавляется процесс открытия МП в митохондриях, выделенных из мозга животных с ОНМК, которые получали Цереброкурин и Кортексин.

Комплекс МП содержит множество мишеней для внешнего воздействия и регулируется многими эндогенными физиологическими эффекторами. Вот далеко не полный их список: активные формы кислорода и азота, концентрация ионов $\mathrm{Ca}^{2+}$ и $\mathrm{Mg}^{2+}$, изменения мембранного потенциала, соотношение адениловых нуклеотидов (АТФ, АДФ, АМФ), пиримидиновый и тиоловый редоксстатусы, некоторые пептиды, изменения в составе bcl-2 комплекса и др. Влияние нейротрофических церебропротекторов на интенсивность открытия МП можно объяснить многообразием физиологических эффекторов природного 
происхождения, входящих в состав препаратов (микроэлементы, низкомолекулярные пептиды, аминокислоты и т. д.). Соотношение и количество компонентов изучаемых препаратов, по всей видимости, определяют степень эффективности их воздействия.

Еще одним из важнейших факторов, имеющим особое значение при церебральной ишемии, является активность ферментов, обезвреживающих продукты свободнорадикальных реакций. В процессе ишемии вследствие энергодефицита снижается активность ферментов антиоксидантной защиты: супероксиддисмутазы, связанной с восстановлением кислорода до перекиси водорода, каталазы (восстановление перекиси водорода до воды) и глутатионпероксидазы (нерадикальное разложение перекиси водорода и органических перекисей). Существуют ли пути, обеспечивающие защиту мембран нейронов и глиальных элементов от повреждающего действия избытка свободных радикалов и цитотоксинов путем предотвращения действия прооксидантных факторов, гидролаз, органических и неорганических перекисей для сохранения целосности как отдельных мембран, так и поддержания объема и структур клеток в целом? На этот вопрос можно ответить утвердительно при изучении состояния антиоксидантной системы защиты ткани мозга. В ходе эксперимента мы исследовали активность каталазы в ткани мозга животных всех групп и получили такие результаты: на 4-е сутки после ОНМК у животных контрольной группы этот показатель достоверно не отличался от показателей экспериментальных групп. Во всех группах с ОНМК, которые получали исследуемые препараты, активность каталазы повысилась в 1,5-1,7 раза, с небольшим отличием. На 7-й день эксперимента во всех группах, за исключением контрольной, активность каталазы немного повысилась, особенно у животных, получавших Кортексин (в 1,91 раза больше чем в группе сравнения). В контрольной группе каталаза снизила свою активность в 1,41 раза, что может быть связано либо с развивающимся энергодефицитом, или же с инактивацией фермента вследствие мощной окислительной атаки. К 21-му дню эксперимента активность каталазы в группах с Церебролизином и Цереброкурином приблизилась до уровня ложнооперированных животных. В контрольной группе и группе с Семаксом активновность фермента была, соответственно, в 1,41 и 1,23 раза ниже, чем в группе сравнения, а в группе с Кортексином - в 1,2 раза выше. Все эти данные дают основание полагать, что препараты, имеющие в своем составе низкомолекулярные нейропептиды, активируют в головном мозге контроль за интенсивностью свободнорадикального окисления. Основные механизмы их действия основаны на стимуляции естественных ферментных систем, к числу которых относятся и антиоксидантные системы. Восстановительные процессы под влиянием нейротрофических церебропротекторов, вероятнее всего, происходят и в нервных, и в глиальных клетках, обеспечивая координацию взаимодействий между всеми типами клеток в нервной ткани.

Как же объяснить наблюдаемые нами энерготропные эффекты от применения нейротрофических церебропротекторов? Ответ на этот вопрос, вероятно, кроется в многообразии составляющих компонентов Церебролизина, Цереброкурина и Кортексина. Поскольку все эти препараты являются гидролизатами 
головного мозга животных и имеют натуральное происхождение, в их составе, кроме широкого спектра аминокислот, микроэлементов и низкомолекулярных нейропептидов, имеются и некоторые наиболее ценные фракции фосфолипидов, восстановленный глутатион и другие, до конца еще не изученные компоненты. Каждый из них обладает своей сферой нейропротективного действия, а вместе они образуют гармоничный ансамбль, позволяющий наладить нарушенные вследствие интрацеребрального кровоизлияния нейронально-глиальные отношения, восстановить трофическую функцию нейроглии.

Известно, что по составу нейротрофики природного происхождения многокомпонентны и до конца не изучены. Использование высоких технологий при изготовлении позволяет сохранить в нейротрофических препаратах не только эссенциальные элементы, активность антиоксидантных ферментов, но и активность факторов роста, транскрипционных белков. Наиболее изученным среди вышеперечисленных препаратов является Церебролизин, поскольку он применяется в неврологической практике уже более сорока лет. В составе Церебролизина было обнаружено наличие тиролиберина, глутатиона, а также повторяющихся характерных сочетаний аминокислот коллагена и энкефалинов. Аминокислотные последовательности, характерные для энкефалинов, способны регулировать болевую чувствительность, а также адаптационные процессы. Микро- и макроэлементы, входящие в состав препаратов-гидролизатов мозгового вещества животных (K, Na, Mg, Ca, P, Si, Cu, Co, Fe, Mn, Cr, Li, Zn, Sn и др., всего 68 элементов), играют важнейшую роль в функционировании ряда энзимов. Наличие витаминной активности нейротрофических церебропротекторов свидетельствует о применении бережных и щадящих методик экстракции и сохранения исходной субстанции.

Как известно, для работы энергопреобразующего механизма, лежащего в основе окислительного фосфорилирования, нужно, чтобы каждый ферментный комплекс дыхательной цепи был ориентирован во внутренней митохондриальной мембране определенным образом - так, чтобы все протоны перемещались в одном направлении, т. е. из матрикса наружу. Специфическая ориентация в бислое свойственна всем мембранным белкам и очень важна для их функции. Последствия ОНМК неизбежно влекут за собой нарушения организации белковых комплексов в митохондриальных мембранах, что существенно затрудняет транспорт электоронов. Вышеперечисленные компоненты нейротрофических препаратов в той или иной степени препятствуют повреждению клеточных мембран или же способствуют быстрому их восстановлению. На фоне применения препаратов эффективно восстанавливалась функциональная активность митохондрий нейронов, снижалась степень окислительного повреждения митохондриальных белков, активировались ферменты антиоксидантной защиты. Немаловажным является экспериментально выявленное повышение активности дегидрогеназ пентозофосфатного пути окисления глюкозы в ткани мозга крыс, получавших Цереброкурин, что свидетельствует об активации синтетических и репаративных процессов на фоне применения препарата. Все эти эффекты способствуют активации энергетических процессов в нейронах, восстановлению нейрональных митохондриальных цитохромоксидаз, что нор- 
мализует процессы тканевого дыхания, приводя к ингибированию глутаматиндуцированного апоптоза.

Подводя итог проведенных исследований, хотелось бы отметить, что применение Цереброкурина и Кортексина с первого для после ОНМК более выраженно, чем применение Церебролизина и Семакса препятствовало развитию отека-набухания головного мозга в остром периоде инсульта, что четко визуализировалось во время забора биологического материала. Под действием препарата наиболее эффективно восстанавливался уровень трофического обеспечения головного мозга и энергосинтезирующая функция митохондрий. Все это сопровождалось быстрым регрессом неврологического дефицита и повышением процента выживаемости животных с моделированной внутримозговой геморрагией. Нашими исследованиями впервые выявлено энерготропное звено нейропротективного механизма действия нейротрофических церебропротекторов, теоретически обоснована и экспериментально доказана целесообразность их применения для фармакокоррекции нарушений энергопродуцирующей функции митохондрий головного мозга при ОНМК.

\section{5. РОЛЬ И МЕСТО АНТИОКСИДАНТОВ ВО ВТОРИЧНОЙ НЕЙРОПРОТЕКЦИИ}

Современный арсенал антиоксидантных средств довольно большой и постоянно пополняется новыми препаратами, отличающимися друг от друга по механизму действия.

Антиоксидантные средства - вещества природного или синтетического происхождения, взаимодействующие не только с липидными радикалами («прямые» антиоксиданты), но и тормозящие оксидативный стресс путем влияния на одну или несколько стадий образования активных форм кислорода, реактивирующие АО-ферменты.

Исходя из вышеперечисленных представлений о механизмах инициирования и протекания оксидативного стресса, все известные антиоксидантные средства можно разделить по механизму действия на следующие группы:

I - Ингибиторы основных путей образования активных форм кислорода:

- ингибиторы ксантиноксидазы (аллопуринол);

- ингибиторы NO-синтазы (7-нитроиндазол и 1-(2-флюорометилфенил)имидазол, $\mathrm{N}$ - $\omega$-нитро-L-аргинин).

II - Скавенджеры активных форм кислорода:

- скавенджеры супероксид-радикала (мочевина, Тиотриазолин, тиомочевина, церулоплазмин, никотиновая кислота и ее производные, препараты наномеди);

- скавенджеры гидроксил-радикала (маннитол, этанол, диметилсульфоксид, альбумин, триптофан, суспензия меди, L-метионин); 
- скавенджеры синглетного кислорода (гистидин, производные фенилалкиламинов);

- скавенджеры NO и его дериватов (глутатион, метионин, унитиол, Тиотриазолин, п-нитрофенил-трет-бутан)

III - Скавенджеры свободных радикалов жирных кислот и гидроперекисей липидов (прямые антиоксиданты):

- производные 6-оксихроманов ( $\alpha$-токоферола ацетат, $\alpha$-токоферола сукцинат, $\alpha$-токоферола фосфат, тролокс);

- производные 3-; 6-оксопиридинов, 1, 4-дигидропиримидинов и 1,2дигидрохинолинов (Эмоксипин, Мексидол, Нимотоп, Сантохин (этоксиквин));

- производные фенолов и полифенольные соединения (ионол, фенозан и его литиевые, натриевые и калиевые соли, разные полифенольные растительные комплексы чабреца, гвоздики, душицы и других растений;

- фолавоноиды и их препараты (фламин, фламикор, кверцетин, рутин, элтон и другие);

- алифатические и ароматические серосодержащие соединения (метионин, унитиол, глутатион, Тиотриазолин, гептрал, ацетилцистеин, серосодержащие производные пиперидина);

- производные оксикислот (галловая, хлорогеновая, кофеиновая, п-оксибензойная, аскорбиновая и прочие кислоты, галлоаскорбат);

- убихиноны (убихинон, коэнзим $\mathrm{Q}_{10}$ );

- селениты (селенит натрия, Se-метионин, Se-глутатион);

- ретинолы и $\beta$-каротины.

IV - Хелаторы микроэлементов, в особенности металлов d-подуровня (трилон Б, купренил, дисферал, унитиол, пектины).

V - Рекомбинантные препараты антиоксидантных ферментов (каталаза, супероксиддисмутаза, глутатионпероксидаза).

VI - Рекомбинантные препараты факторов, регулирующих экспрессию эндогенных антиоксидантов (препараты HSP70, HIF, глутаредоксин).

Из всех вышеперечисленных групп наибольшее распространение нашли прямые антиоксиданты. К этой группе относятся токоферолы, Дибунол, убинон. Из существующих восьми видов токоферолов, наибольшей антиоксидантной активностью обладает $\alpha$-токоферол.

Наиболее полно изучена антиоксидантная активность $\alpha$-токоферола на экспериментальных моделях ишемии миокарда и в клинике при инфаркте миокарда. $\alpha$-Токоферола ацетат снижает степень нарушения функции ультраструктуры миокарда, увеличивает процесс выживаемости животных, снижает интенсивность оксидативного стресса, о чем свидетельствовало снижение конечного продукта - малонового диальдегида (МДА) в сыворотке крови. Известно, что $\alpha$-токоферолы успешно применяются в качестве антимутагенов, они обладают протекторным эффектом в отношении химически индуцирован- 
ного мутагенеза на микроорганизмах и клетках млекопитающих in vitro и in vivo. Кроме того, в экспериментах in vivo показано, что $\alpha$-токоферол защищал ДНК клеток мозга крыс от повреждающего действия метилэтилкетонпероксида, сильного индуктора свободных радикалов. Недостатком $\alpha$-токоферола является неполная инактивация свободных радикалов.

Дибунол является липофильным, пространственно экранированным фенолом. Взаимодействуя со свободными радикалами, Дибунол образует соединения, стабилизированные двумя треm-бутильными группами, и, в отличие от токоферолов, образует стабильные радикалы, то есть предотвращает дальнейшее инициирование цепной реакции, что обуславливает его высокую антиоксидантную активность.

Доказана эффективность применения Дибунола при ишемии миокарда и головного мозга. Так, введение Дибунола крысам с ишемией головного мозга увеличивало выживаемость животных, тормозило накопление маркеров оксидативного стресса в тканях мозга при неизменной активности АО ферментов. На модели инфаркта миокарда показано, что Дибунол в дозе 120 мг/кг снижает накопление конечных продуктов СРО в миокарде и уменьшает зону некроза. Однако отмечено, что Дибунол в дозе 500 мг при хроническом введении вызывал токсические эффекты. Высокие дозы Дибунола повреждали транспорт $\mathrm{Ca}^{2+}$ в мембранах скелетных мышц, вызывали агрегацию тромбоцитов, гемолиз эритроцитов.

Другой группой прямых антиоксидантов являются производные оксипиридинов. Установлено, что антиоксидантная активность оксипиридинов зависит от полярности гидроксигруппы и введения в молекулу электронодонорных заместителей.

В настоящее время в клинической практике нашли применение два препарата антиоксидантного действия, производных 3-оксипиридина - Эмоксипин и Мексидол (гидрохлорид и сукцинат 3-окси-6-метил-2-этилпиридина). Впервые Эмоксипин был применен в глазной практике для лечения внутриглазных кровоизлияний, диабетической ретинопатии, тромбоза центральной вены сетчатки и ее ветвей, осложненной миопии.

В дальнейшем Эмоксипин стали успешно применять при лечении других заболеваний, сопровождающихся усилением процессов СРО (инфаркт миокарда, кожные заболевания, глаукома и т. д.). Назначение Эмоксипина при остром инфаркте миокарда приводит к стабилизации мембран кардиомиоцитов, нормализует метаболизм сердечной мышцы. Мексидол, подобно Эмоксипину, является ингибитором свободных радикалов, но обладает более выраженным противоишемическим действием, а по антиоксидантному действию превосходит Дибунол. В последнее время широко используется высокая нейропротективная активность Мексидола. На моделях окклюзионного нарушения мозгового кровообращения Мексидол снижал летальность животных, проявления неврологического и когнитивного дефицита, достоверно снижал количество дегенерирующих и апоптотически измененных нейронов в коре и гиппокампе. При применении Мексидола отмечается повышение активности СОД, уменьшение образования маркерных продуктов окислительной модификации белков и фос- 
фолипидов, сохранение физико-химических констант фосфолипидного бислоя мембраны. Мексидол вызывал значительное повышение окислительной продукции энергии за счет активации компенсаторных шунтов и интенсификации аэробных путей утилизации глюкозы. Клиническая эффективность (120 пациентов с ОНМК) Мексидола проявлялась регрессом общемозговых нарушений (в том числе расстройств сознания) и значимо более быстрым, по сравнению с плацебо-группой, восстановлением двигательных функций, редукцией признаков вазомоторной нестабильности. В настоящее время проводятся рандомизированные клинические исследования Мексидола.

Производные 1,4-дигидропиридина, проявляют нейропротекторную активность при ишемии головного мозга, улучшая показатели гемодинамики и снижая уровень маркеров оксидативного стресса в тканях мозга.

Механизм действия 1,4-дигидропиридинов обусловлен взаимодействием их с гидроперекисями липидов после проникновения молекул-антиоксидантов в толщину липидного слоя мембраны, либо напротив, после выхода гидроперекисей, а именно - их активных групп ООН, которые содержатся где-то в середине углеродной цепочки жирных кислот, из мембраны в водную фазу. 1,4-Дигидропиридины влияют на микроводность липидного слоя мембран и поэтому снижают скорость свободно-радикальных реакций, так как скорость реакций пероксидации зависит от вязкости липидной матрицы.

Антиоксидантными свойствами прямого типа действия обладают также убихиноны, которые по химической структуре близки к токоферолам, и их антиоксидантный эффект зависит от восстановительных свойств кольца. Отмечено, что убихиноны снижают образование маркерных продуктов оксидативного стресса в тканях и стабилизируют мембраны.

Высокая антиоксидантная активность выявлена у производных фенилтрет-бутилнитронов: $\alpha$-фенил-N-трет-бутилнитрон (PBN), 2-сульфофенил-Nтрет-бутилнитрон (S-PBN) и 2,4-дисульфофенил-N-трет-бутилнитрон (NXY059), которые являются специфическими скавенджерами АФК и NO, а также свободных радикалов. Наиболее хорошо известно из этих соединений вещество PBN - специфический ингибитор супероксид-радикала, гидроксил-радикала, аллоксильного радикала, пероксинитрит-радикала in vitro. Исследованы нейропротективные свойства $\mathrm{PBN}$ при ишемии и ишемии-реперфузии головного мозга у грызунов и приматов. Доказаны нейропротективные свойства PBN при экспериментальных нейродеструктивных патологиях, в культуре нейронов при глутаматной эксайтотоксичности. Выявлено, что PBN ингибирует индуцибельную NO-синтазу, снижая тем самым выработку NO` и пероксинитритрадикала, снижая окислительную модификацию тирозина при окклюзии средней мозговой артерии у гербилов.

Проведенные рандомизированные клинические исследования NXY-059 (в анализ включено 1699 пациентов с ОНМК) показали улучшение основного исхода по шкале Ранкина и отсутствие эффекта по индексу Бартела. В эксперименте на модели окклюзии средней мозговой артерии у гербилов получены данные о нейропротективной активности антиоксиданта тирилазида (уменьшение объема инфаркта мозга). Рандомизированные клинические исследования 
(1757 пациентов с ОНМК и ЧМТ ) показали, что при назначении тирилазида смертность и проявление неврологической симптоматики были на $20 \%$ выше, чем в группе контроля.

Прямым антиоксидантным эффектом обладают также различные тиолы. Их антиоксидантный эффект обусловлен восстановительными способностями двухвалентной серы в тиольных группах. Тиольные группы связывают свободные радикалы и, тем самым, предотвращают белки от разрушения. Имеются данные об антиоксидантном эффекте метионина, глутатиона восстановленного, $\mathrm{N}$-ацетилцистеина.

Другую большую группу антиоксидантных средств составляют ингибиторы активных форм кислорода. По мнению ряда авторов, эта группа препаратов эффективнее прямых антиоксидантов за счет своего действия на начальных этапах оксидативного стресса. Ее можно разделить на две подгруппы: АО ферменты и другие биологически активные соединения.

Назначение препаратов СОД (эрготеин) в дозе $5000 \mathrm{Ed} /$ кг животным с экспериментальной ишемией миокарда улучшало показатели электрокардиограммы, уменьшало зону некроза миокарда, стабилизировало показатели гемодинамики, снижало содержание продуктов СРПО в миокарде, способствовало сохранению АТФ. Однако, применение эрготеина после формирования ишемии защитного эффекта не оказывало.

Имеются данные о возможности применения меди в качестве антиоксидантного средства. Так, введение высокодисперсной меди в дозе 0,2 мг/кг животным с инфарктом миокарда, реактивировало АО ферменты, снижало накопление продуктов оксидативного стресса, увеличивало выживаемость животных [168].

Существенное антиоксидантное действие оказывают и селенсодержащие соединения. Это связано с тем, как отмечалось ранее, что селен входит в активный центр ГПР. Антиоксидантный әффект селена ряд авторов объясняет его накоплением в очаге ишемии и прямым мембраностабилизирующим действием, а также включением селена в Sе-зависимую ГПР.

Не останавливаясь на этом подробно, следует указать, что кроме положительных вышеперечисленных влияний на живой организм, селен в тестах in vitro и in vivo с использованием клеток млекопитающих, продемонстрировал мутагенные, мутагенпотенциирующие и антимутагенные свойства. Поэтому справедлива будет точка зрения, что механизмы антиоксидантного и других эффектов препаратов селена тесно связаны с процессами подавления образования свободных радикалов и гидроперекисей липидов. Огромный интерес представляет селен-содержащий препарат Эбселен, обладающий ГПР-подобной активностью. Эбселен способен взаимодействовать с пероксинитрит-анионом и ингибировать липооксигеназу, NO-синтазу, экспрессию проапоптотического фактора TNF- $\alpha$. В экспериментах in vitro на культуре нейронов мозжечка, установлено, что Эбселен снижает образование нитротирозина и IL-1 $\beta$, вызванные избытком перекиси водорода и кислород-субстратной депривацией. Эбселен ингибирует перекисное окисление мембранных фосфолипидов и тормозит фермент липоксигеназу в каскаде арахидоновой кислоты, блокирует продукцию супероксид-аниона активированными лейкоцитами. В эксперименте было 
показано, что Эбселен в условиях перевязки сонных артерий нормализует окислительную продукцию энергии, подавляет открытие митохондриальной поры, уменьшает фрагментацию м-ДНК и выход проапоптотических факторов. На модели фокальной ишемии Эбселен уменьшал объем инфаркта мозга и проявления неврологического дефицита.

В отличие от многих других селенорганических соединений Эбселен обладает низкой токсичностью. Рандомизированное клиническое исследование в группе 540 пациентов с ишемическим инсультом показало, что Эбселен хорошо переносится и его назначение в течение первых двух суток от начала заболевания достоверно улучшает исход инсульта. Было отмечено значительное снижение объема инфаркта и улучшение функционального восстановления у больных, начавших получать препарат в первые 6 часов от начала заболевания. В настоящее время клинические испытания этого препарата продолжаются.

Противоишемический эффект присущ и другим ингибиторам свободных форм кислорода - Маннитолу и мочевине, изученным при экспериментальном инфаркте миокарда. В качестве эффективного антиоксиданта интерес представляет препарат нейроантиоксидантного гормона эпифиза мелатонин, который является ингибитором пероксинитрита, гидроксил-радикала и способствует экспрессии генов, ответственных за синтез Cu-Zn-COД. Установлена нейропротективная активность мелатонина на различных экспериментальных моделях острого нарушения кровообращения в головном мозге (глобальная или фокальная ишемия за счет окклюзии артерий, фототромбоз, черепномозговая травма и т. д.), направленная на снижение гибели нервных клеток и уменьшение развития оксидативного стресса. Мелатонин снижал образование нейротоксических свободнорадикальных соединений и аккумуляцию внутриклеточного кальция, накопление глутамата и оксида азота, усиление апоптоза, предотвращал падение уровня нейротрофических факторов роста. При введении мелатонина (4-5 мг/кг) предварительно или в первые 1-2 часа после пережатия средней мозговой артерии либо кортикального фототромбоза у крыс существенно (на 40-50 \% ) ограничивалась зона инфаркта мозга без гемодинамических сдвигов. Нейропротективный эффект мелатонина был установлен и по данным морфометрических характеристик нейронов различных церебральных образований (неокортекса, гиппокампа, стриатума). Было установлено, что мелатонин значительно снижал гибель нейронов $\mathrm{CA}_{1}$-зоны гиппокампа. При этом ограничивалось нейротоксическое воздействие на них монооксида азота и возбуждающих аминокислот (глутамата, каината) с одновременным уменьшением выраженности мозгового отека.

К антиоксидантам относятся препараты, блокирующие основные пути образования активных форм кислорода. Данная группа еще мало изучена. Основным представителем данной группы является блокатор ксантиноксидазного пути образования активных форм кислорода - аллопуринол. Защитный эффект аллопуринола объясняют не только тем, что он блокирует ксантиноксидазу, предотвращая образование супероксид-радикала, но и стимулирующим влиянием на синтез АТФ. Антиоксидантный эффект аллопуринола был установлен при экспериментальной ишемии миокарда. 
К группе ингибиторов путей образования АФК и $\mathrm{NO}$ можно отнести ингибиторы NO-синтазы. В связи с раскрытием роли NO-синтазы в патогенезе нейродеструктивных заболеваний проводятся работы по изучению нейропротективной, противовоспалительной, противоопухолевой активности ингибиторов NO-синтазы. Показана эффективность применения Nи $\mathrm{N}-\omega$-нитро-L-аргинина в условиях ишемии и ишемии-реперфузии головного мозга. Установлено, что однократное применение $\mathrm{N}$ - $\omega$-нитро-L-аргинина на модели фокальной ишемии мозга у крыс оказывало нейропротективное действие - уменьшение зоны инфаркта, торможение реакций оксидативного стресса. $\mathrm{N}$ - $\omega$-нитро-L-аргинин в небольших дозах (10 мг/кг), блокирующих исключительно индуцибельную-NO-синтазу, в условиях экспериментальной ишемии головного мозга, вызванной окклюзией средней мозговой артерии, ограничивал зону инсульта, уменьшал уровень биомаркеров повреждения нейроцитов, снижал активность СРО у крыс, кошек и мышей, а в больших дозах (250-300 мг/кг), блокирующих как индуцибельную NO-синтазу, так и нейрональную NO-синтазу, оказывал проишемический эффект. Продолжаются экспериментальные и клинические испытания селективных блокаторов нейрональной NO-синтазы (7-нитроиндазол и 1-(2-флюорометилфенил)-имидазол), которые достоверно уменьшали размер инфарктной зоны после фокальной и глобальной церебральной ишемии у животных. Относительно селективная блокада iNO-синтазы аминогуанидинами также оказала мощное нейропротективное действие в условиях экспериментального инсульта. Аминогуанидины обладают защитными свойствами даже при задержке лечения на 24 ч, что представляет безусловный интерес в плане их возможного клинического применения в терапии ишемического инсульта.

Особого внимания в этой группе антиоксидантов заслуживает препарат Тиотриазолин, созданный учеными Запорожского медицинского университета.

Тиотриазолин в настоящее время широко применяется в клинической практике в качестве антиоксидантного и мембраностабилизирующего средства, проявляющего противоишемические, кардиопротективные, гепатопротективные, ранозаживляющие свойства. Тиотриазолин уменьшает образование АФК в митохондриях, сохранение окислительной продукции энергии, а также в ксантиноксидазной реакции. Тиотриазолин, снижая гиперпродукцию супероксид-радикала и пероксинитрита, предупреждает окислительную модификацию белковых структур рецепторов, ионных каналов, ферментов, факторов транскрипции. Тиотриазолин конкурирует с сульфгидрильными группами цистиновых, цистеиновых и метиониновых фрагментов белковых молекул за супероксид-радикал, в результате чего предотвращает как обратимую, так и необратимую их модификацию. В результате ингибирования обратимой модификации предотвращается образование -S-S- связи в цистеиновых участках $\mathrm{Na}^{+} / \mathrm{K}^{+}$-АТФазы, уменьшается потеря чувствительности фермента к регулирующему действию АТФ. Более значимое по эффективности действие Тиотриазолина реализуется в отношении необратимой модификации сульфгидрильных групп ряда белковых молекул под действием АФК. Оказывая тормозящее воздействие на необратимую окислительную модификацию 
сульфгидрильных групп цистеиновых фрагментов белковых молекул, Тиотриазолин нормализует сдвиги red/ox-регуляции в условиях оксидативного стресса. Кроме того, Тиотриазолин может участвовать в восстановлении этих групп при обратимой инактивации, принимая на себя роль Redox Faktor-1. Тормозя окислительную инактивацию фактора транскрипции NF-kappaß при избытке АФК, Тиотриазолин, возможно, усиливает активацию экспрессии редокс-чувствительных генов, которые необходимы для защиты клеток от токсических эффектов оксидативного стресса. Среди этих генов есть гены ответственные за синтез супероксиддисмутазы. В последнее время было установлено, что Тиотриазолин обладает антиапоптозным действием. Являясь скавенджером NO, Тиотриазолин способен регулировать гибель нейронов в уловиях нитрозирующего стресса. Проведенными экспериментальными исследованиями in vitro установлено, что инициирование в суспензии нейронов нитрозирующего стресса нитропруссидом натрия (160 мкM) приводит к повышению количества апоптирующих и некротирующих нейронов, с преобладанием гибели клетки по типу некроза. Введение в инкубационную среду $\mathrm{N}$-нитро-L-аргинина в концентрации $10^{-1} \mathrm{M}$ приводило к снижению общего числа погибших клеток, при этом статистически достоверно не влияя на тип их морфологической гибели. Внесение в инкубационную среду Тиотриазолина в условиях инициации нитрозирующего стресса в концентрации $10^{-5}-10^{-3}$ вызывало значительное снижение общего числа погибших клеток с преобладанием гибели по типу апоптоза. Нейропротективное действие Тиотриазолина объясняется наличием в химической структуре Тиотриазолина свободных

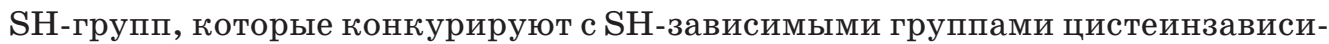
мого участка белка внутренней мембраны митохондрии с пероксонитритом, что в свою очередь препятствует развитию митохондриальной дисфункции с последущим запуском гибели всей нейрональной клетки. Кроме кардиопротективного, гепатопротективного и противоишемического действия Тиотриазолина получены данные о его нейропротективном действии при необратимой окклюзии общих сонных артерий.

Изучены антиоксидантные свойства хелаторов металлов переменной валентности - дисферала, купренила и цитрата натрия.

В последнее десятилетие в качестве перспективного антиоксидантанейропротектора рассматривается белок теплового шока массой 70 кДа(HSP70). Протективная функция HSP белков в условиях острой ишемии направлена на координацию свертывания новосинтезированных белков, исправление частично деструктурированных и, особенно, окислительно модифицированных белковых молекул, на перенос белков через клеточные мембраны, ингибирование агрегации белков и осуществление деградации по протеосомному пути. Кроме того, необходимо учитывать и тот факт, что HSP-белки являются основными индукторами фактора НIF, который включает дальнейшие приспособительные реакции в клетке. Показано, что HSP-белок является шапероном фактора НIF и увеличивает продолжительность его жизни в условиях дефицита кислорода и гиперпродукции АФК. Белок НIF, в свою очередь, образует активный димер с субъединицей HIF-1 и начинает играть роль транскрипционного фактора, 
запуская транскрипцию генов ответа на гипоксию. Кроме того, как было показано нашими более ранними экспериментальными работами HIF является индукционным фактором в синтезе некоторых ферментов антиоксидантной защиты - СОД и ГПР. Нами проведены некоторые исследования роли HSP70 в поддержании оптимальной антиоксидантной защиты в нейронах коры головного мозга крыс в условиях церебральной ишемии. В опытах in vitro при введении деприватора глутатионовой системы (1 мM CDNB, хлординитробензола) в нейронах коры головного мозга крыс наблюдалось истощение цитозольного и митохондриального пулов GSH, значительное повышение АФК и снижение HSP70, а также снижение жизнедеятельности клеток. Введение Hsp70 в нейроны, преинкубированные с CDNB, приводило к увеличению уровня GSH, снижению АФК. В опытах in vivo в условиях острой церебральной ишемии в нейронах коры головного мозга крыс, хотя и наблюдалось стремительное снижение уровня глутатиона, экспрессия HSP 70 увеличивалась. Увеличение уровня HSP 70 приводило к нормализации глутатионового звена тиол-дисульфидной системы, и повышению устойчивости клеток к ишемии. Введение экзогенного HSP 70 приводило к увеличению функциональной активности глутатионовой системы в нейронах коры ишемизированого головного мозга крыс.

То есть, было показано, что HSP 70, белки с ярко выраженными нейропротекторными свойствами, в условиях ишемии мобилизируют антиоксидантные ресурсы в нейронах, в частности - увеличивают уровень как цитозольного так и митохондриального глутатиона, который препятствует развитию оксидативного стресса.

Немаловажное значение приобрел поиск новых природных водорастворимых антиоксидантов для основных отраслей удовлетворения жизненных потребностей человека. Проводившиеся в течение ряда лет исследования в значительной мере расширили область представлений о натуральных веществах и лекарственных средствах, обладающих АОА. Экспериментальные исследования показали, что среди широко распространенных природных соединений высокой АОА обладают различные группы дубильных веществ.

АОА обладают изомеры катехина, выделенные из листа зеленого чая и виноградных косточек, которые применяются в косметологии. Для этих же целей используются гидролизуемый галлотаннин из стручков рожкового дерева (Ceratonia) сем. бобовых, экстракты коры и веток березы (Betula), эвкалипта (Eucalyptus) и др., процианидины, выделенные из луба хвойных пород деревьев и т. д.

Проводилось изучение AOA многих других классов растительных веществ. Указанная активность определена для стеролов и алифатических кислот - лимонной, яблочной, фумаровой, молочной, фитиновой, абсцизовой. Для повышения водорастворимости ряда липофильных АО было предложено получать соединения включения на основе циклодекстринов.

Среди объектов, представляющих интерес в качестве источников получения антиоксидантов, можно выделить группу сельскохозяйственных и пищевых растений, в том числе и отходы их переработки. Так, из видов лука (Allium) получали весьма активные ингибиторы окислительных процессов. Высказано 
предположение, что этими свойствами обладают алкилсульфоксиды, характерные для данного рода, или танины луковой шелухи. Установлено, что высушенные плоды рябины (Sozbus), калины (Viburnum), брусники (Vaccinium), черной смородины (Ribes) содержат от 0,26 до 0,9 г/кг веществ с AOA.

Была изучена активность и состав антиоксидантов пряноароматических растений. Экстракцией слабыми растворами щелочей из черного перца и аниса выделена сумма полифенолов, обладающих АOА. Некоторые растения сем. яснотковых - розмарин (Rosmarinum), мята (Menthae), шалфей (Salvia), чабрец (Thimus), базилик (Ocinum) содержат 0,07-0,84\% веществ терпеноидной природы, ответственных за проявление антиоксидантной активности. Кроме того, розмарин и виды шалфея являются традиционными источниками получения полифенольных дитерпеноидов - карнозола, розмариновой кислоты и таншинонов, проявляющих высокую АОА. Из высушенных бутонов гвоздики (Eugenia) сем. миртовых выделены достаточно эффективные АО также фенольной природы.

Из некоторых лекарственных растений (солодки, облепихи, подорожника) выделены водорастворимые АО. Например, экстракт корня солодки (Glycyrrhisa) или шрота после получения глицирризиновой кислоты, смешанный в определенном соотношении с галловой кислотой, обладает хорошей стабильностью и проявляет высокую АОА. Гидрофильный экстракт плодов облепихи (Нуррорhае) за счет высокого содержания алифатических кислот препятствует течению окислительных процессов.

Последовательной экстракцией различными растворителями из травы душицы (Origanum) были получены отдельные группы природных веществ (терпены, стеролы, полифенолы и их гликозиды), для которых установлена различная степень АОА. На примере водных и водно-спиртовых экстрактов зверобоя (Hypericum) была показана корреляция между АОА и содержанием в них фенольных соединений.

Источником получения меланоидных АО может служить растительное сырье, имеющее стабильную естественную пигментацию. Например, разработана технология получения меланина из выжимок черных сортов винограда. Средство используется для лечения биохимических обменных нарушений, связанных с патологиями, спровоцированными СРР в клетках.

Околоплодники семян подсолнечника (техническое название - лузга, шелуха) являются одним из самых доступных источников получения АО. Очищенный продукт или неочищенный концентрированный экстракт нетоксичны, проявляют высокую АОА.

В настоящее время выявлена взаимосвязь антиоксидантной активности с другими видами биологической активности (противовоспалительной, ранозаживляющей, противоишемической, ноотропной). Учитывая это, поиск веществ с антиоксидантной активностью также ведется среди различных классов биологически активных соединений. Так, в последнее время появились публикации о наличии данной активности среди бензофуранов, антрахинонов, хромонов, триазолов, пиридинов, пиримидинов, хиназолинов, акридинов, ксантинов, теофиллинов и других гетероциклов. 


\title{
ГЛАВА 5
}

\section{ОСНОВНЫЕ СТРАТЕГИИ НЕЙРОПРОТЕКЦИИ ПРИ ОСТРОЙ ЦЕРЕБРАЛЬНОЙ НЕДОСТАТОЧНОСТИ, ОБУСЛОВЛЕННОЙ ТЯЖЕЛОЙ ЧЕРЕПНО- МОЗГОВОЙ ТРАВМОЙ И МОЗГОВЫМ ИНСУЛЬТОМ}

\author{
5.1. ХАРАКТЕРИСТИКА ОСНОВНЫХ НЕЙРОПРОТЕКТОРОВ, \\ ПРИМЕНЯЕМЫХ ДЛЯ ЛЕЧЕНИЯ ТЯЖЕЛОЙ ЧЕРЕПНО-МОЗГОВОЙ \\ ТРАВМЫ И МОЗГОВОГО ИНСУЛЬТА В УКРАИНЕ
}

Нейроцитопротекторы - собирательное понятие, которое отражает свойства группы препаратов, способных повышать выживаемость нейронов в условиях острой гипоксии и ишемии [1], хотя единого патогенетического механизма действия у данной группы лекарственных средств не существует.

К цитопротекторам относятся препараты, повышающие устойчивость клеток мозга к гипоксии и ишемии, в том числе корригирующие уровень клеточной энергии в условиях гипоксии, улучшающие кровоснабжение головного мозга, усиливающие функциональную активность нейронов и глиальных клеток, нормализующие медиаторный дисбаланс, нарушенный в условиях ишемии и гипоксии.

Повышения эффективности каждого лекарственного препарата можно добиться при рациональном использовании, т. е. применении с учетом их фармакокинетики и фармакодинамики и в оптимальных дозировках [2].

На основании данных литературы для лечения постгипоксической энцефалопатии рекомендуется большой выбор нейротропных препаратов, обладающих антигипоксантным действием [3].

1 групnа. Антигипоксанты, снижающие энергетические потребности мозга (оксибутират натрия, бензодиазепины и т. п.).

2 әруппа. «Прямые антигипоксанты» (стимуляторы аэробного метаболизма), влияющие на тканевой обмен путем увеличения утилизации кислорода и глюкозы, улучшения тканевого дыхания (Цито-Мак, Актовегин).

3 группа. Ноотропные и ГАМК-ергические средства, стимулирующие энергетический метаболизм. Пирацета́м - основной представитель данной группы препаратов, которые обычно применяют при общем состоянии пациента с оценкой по шкале ком Глазго выше 9-10 баллов.

4 әрупnа. Препараты нейро-медиаторного, нейрорецепторного, нейротрофического действия, которые в недалеком прошлом использовались только в восстановительном, реабилитационном периоде (Цереброкурин, Церебролизин, Цитиколин, Глиатилин, Семакс).

Ноотропы - вещества, которые активируют высшую интегративную деятельность мозга, восстанавливают нарушенные мнестические и мыслительные функции, снижают неврологические дефициты и повышают резистентность организма к экстремальным воздействиям. Но необходима определенная структурная целостность ткани мозга и соответствующий уровень функ- 
циональной активности для реализации әффекта ноотропов, стимулирующих энергетический метаболизм.

В связи с прогрессом в области нейрохимии, молекулярной биологии, экспериментальной и клинической фармакологии появилось большое число исследований, в том числе клинико-фармакологических, позволяющих с современной точки зрения представить механизм действия и области применения ноотропных препаратов. Особенно много работ посвящено изучению Пирацетама, который до настоящего времени остается эталонным ноотропным препаратом.

Хорошо изучены фармакологические эффекты Пирацетама. Его мембраностабилизирующий эффект проявляется уменьшением микровязкости мембран нейронов, нормализацией проницаемости фосфолипидного слоя мембран нейронов и соотношения холестерин/фосфолипиды. Пирацетам активирует естественную антиоксидантную систему организма - каталазу и супероксиддисмутазу. Антигипоксический эффект достигается за счет стимуляции альтернативных путей метаболизма в условиях гипоксии - пентозофосфатного и гексозофосфатного, нормализации процессов окислительного фосфорилирования, накопления макроэргических соединений (АТФ), что обеспечивает поддержание полноценного уровня тканевого дыхания. Белоксинтетический эффект осуществляется стимуляцией транскрипции генов, ответственных за белковый синтез в нейронах. Это приводит в том числе и к активации межполушарного обмена информацией за счет развития межнейронных связей, к улучшению памяти и способности к обучению. Нейромедиаторный эффект достигается за счет влияния Пирацетама на систему ионных каналов $\mathrm{Na}^{+}, \mathrm{K}^{+}$, $\mathrm{Ca}^{2+}$, активации синтеза ацетилхолина и М-холинорецепторов, синтеза серотониновых, дофаминовых и адренорецепторов, высвобождения глутамата, и как следствие - нормализации нейромедиаторного дисбаланса. Вазотропный эффект проявляется ослаблением спастических реакций гладкомышечных клеток сосудов мозга, уменьшением вязкости плазмы и цельной крови за счет снижения агрегации тромбоцитов и степени их адгезии к эндотелию сосудов мозга, оптимизации процессов мозгового кровообращения [434-444].

Биодоступность Пирацетама составляет около 100 \%, он не связывается с белками плазмы крови, проникает через гематоэнцефалический барьер, накапливается в мозговой ткани, во внутренних органах. Избирательно накапливается в тканях коры головного мозга, преимущественно - в лобных, теменных и затылочных долях, в мозжечке и базальных ганглиях. В организме Пирацетам практически не подвергается биотрансформации и выделяется преимущественно почками в неизмененном виде. В течение 24-30 часов после однократного приема выделяется 90-100 \% от введенной дозы препарата.

В настоящее время Пирацетам рекомендуют для лечения коматозных состояний после перенесенных инсультов, травм и интоксикаций головного мозга как в остром периоде, так и в периоде восстановительной терапии после этих состояний, причем при лечении коматозных состояний у больных с травмами головы, инсультом рекомендуемая начальная доза составляет 9-12 г/ сутки, поддерживающая - 4,8-2,4 г/сутки [4]. Однако это - спорное поло- 
жение. Кома служит противопоказанием к применению средств, обладающих стимулирующим действием (психостимуляторов, дыхательных аналептиков, ноотропов). Ноотропные препараты (Пирацетам) вызывают психомоторное возбуждение и противопоказаны при нарушениях сознания глубже оглушениясопора. При любом коматозном состоянии, независимо от глубины церебральной недостаточности применение средств, возбуждающих ЦНС (препараты из группы ноотропов), не рекомендуется к введению, так как приводит к растормаживанию подкорковых структур, вызывает психомоторное возбуждение или судороги, в конечном итоге еще больше угнетая кору [445-452]. Поэтому Пирацетам в средней дозе 30-200 мг/кг в сутки целесообразно применять при глубине нарушения сознания выше 9-10 баллов по шкале ком Глазго.

Таким образом, вопрос об использовании нейропротекторных свойств ноотропов у больных с тяжелой ЧМТ и мозговым инсультом, осложненными коматозным состоянием, является актуальным. Решение данной проблемы оптимизация фармакотерапии за счет применения комбинированных нейротропных средств. Перспективно также применение нового церебропротективного препарата - Тиоцетама, представляющего собой комбинацию Пирацетама с Тиотриазолином.

Тиоцетам - это препарат, который сочетает в своем действии ноотропные, мнемотропные, антигипоксические свойства Пирацетама с противоишемическими, антиоксидантными и мембраностабилизирующими свойствами Тиотриазолина, чем выгодно отличается от Пирацетама и других аналогичных ноотропов. Он может и должен применятся во всех периодах течения ОЦН, но эффект должет быть дозозависимый [451].

Наибольшей активностью обладает комбинация, состоящая из 0,05 г Тиотриазолина и 0,2 г Пирацетама. На основании этой комбинации была разработана лекарственная форма - таблетки и ампулы Тиоцетам. Комбинация продемонстрировала широкий спектр церебропротективных и ноотропных эффектов. Об этом свидетельствует целый ряд экспериментальных исследований, проведенных в Запорожском медицинском университете под руководством профессора И.Ф. Беленичева, представленных в 4-й главе, подтверждающих что антиоксидантное, противоишемическое, антиамнестическое действия Тиоцетама выгодно отличаются от Пирацетама, а также других препаратов рацетамного ряда и производных ГАМК [452-457].

Экспериментальными исследованиями доказано, что фармакологический эффект Тиоцетама обуславливается взаимопотенцирующим действием Тиотриазолина и Пирацетама. Комплексный препарат Тиоцетам, разработанный украинскими учеными, увеличивает интенсивность функционирования метаболического ГАМК-шунта и концентрацию ГАМК в ишемизированных тканях, нормализует нейромедиаторный (дофамин- и норадренергический), обмен, снижает выраженность вестибулярных расстройств, улучшает ассоциативные процессы, интегративную деятельность мозга, стимулирует процессы мышления и памяти, улучшает способность к концентрации и обучению. Он ускоряет утилизацию глюкозы при аэробном и анаэробном пути окисления, увеличивает фонд АТФ, стабилизирует церебральный метаболизм, тормозит 
свободнорадикальные процессы в тканях мозга, реактивирует ферментативную антиоксидантную систему (СОД), улучшает реологические свойства крови, стабилизирует и уменьшает зоны некроза и ишемии, стимулирует пластические и биоэнергетические процессы в нервной ткани.

В интенсивной терапии острой церебральной недостаточности (ОЦН), обусловленной тяжелой черепно-мозговой травмой (ЧМТ) или мозговым инсультом (МИ), актуальной остается проблема определения сроков начала лечения Тиоцетамом и критериев выбора оптимальной дозы Тиоцетама с помощью метода интегрального количественного анализа ЭЭГ-паттернов и изучения реактивности мозга [452-457].

Изучение типов реакции ЦНС в ответ на фармакологическое воздействие дало возможность количественно оценить увеличение или уменьшение дезорганизации ЭЭГ-паттерна и определить уровень нейрофизиологического воздействия препарата на мозг (кора-подкорка, кора-кора).

В результате проведенных исследований были определены типы реакций ЦНС в ответ на фармакологичекое воздействие - введение Тиоцетама [458].

Из реакций перераспределения мощности (III тип) прогностически благоприятными можно считать III 2а подгруппу изменений, для которой типична активация $\alpha$ - и $\beta 2$-ритмов за счет угнетения дельта-активности (см. главу 5.6.). Возможно, такие реакции, особенно на стороне поражения, отражают корковые процессы восстановления обратимо поврежденных клеток мозговой ткани, их постсинаптической пропускной способности для высокочастотной стимуляции.

Факторами, влияющими на эффективность интенсивной терапии Тиоцетамом, являются, с одной стороны, функциональная сохранность церебральных структур, нейромедиаторных и метаболических механизмов, участвующих в функциональном ответе, а с другой - доза Тиоцетама.

Используя определение типа реакции ЦНС в ответ на введение Тиоцетама, возможно оценить адекватность применяемой дозы препарата и необходимость ее коррекции (табл. 5.1).

Таблица 5.1

Варианты ответа ЦНС на фармакологическое воздействие - введение Тиоцетама у пациентов с ЧМТ и мозговым инсультом

\begin{tabular}{|l|l|l|}
\hline № n/п & \multicolumn{1}{|c|}{$\begin{array}{c}\text { Тип фармакологической реакции } \\
\text { на введение Тиоцетама }\end{array}$} & \multicolumn{1}{|c|}{ Тактика применения Тиоцетама } \\
\hline 1. & III 2a, III 3a, II 2а, II 26 и III 26 подгруппы & Адекватная доза Тиоцетама \\
\hline 2. & III 36 подгруппа & $\begin{array}{l}\text { Необходимость повышения дозы } \\
\text { Тиоцетама }\end{array}$ \\
\hline 3. & I, III 1а и III 16 подгруппы & Необходимость подбора дозы Тиоцетама \\
\hline 4. & II 1а, II 16, подгруппы & $\begin{array}{l}\text { Необходимость уменьшения дозы } \\
\text { Тиоцетама или отмена препарата }\end{array}$ \\
\hline
\end{tabular}


Так, адекватной может считаться доза Тиоцетама, после которой выявлены изменения III 2a, III 3a, II 2a и III $2 б$ подгрупп.

Фармакологической реакцией, свидетельствующей о необходимости повышения дозы Тиоцетама, следует считать III $3 б$ ПГ изменений.

Тактика при выявлении изменений III 1а и III 1 подгрупп должна быть следующей: подбор дозы препарата с обязательной интегральной оценкой ЭЭГпаттерна после введения препарата.

Необходимо уменьшить дозу вводимого препарата при изменениях, относящихся к подгруппам II 1a, II 1б, II $2 б$.

Таким образом, с помощью метода ИКА ЭЭГ может быть выявлена степень функционального поражения или функциональной сохранности церебральных структур при ОЦН, определяющая в конечном итоге уровень сознания больного.

Нами разработана методика определения адекватной дозы Тиоцетама на основе сопоставления метода оценки нарушения сознания по шкале ком Глазго и метода интегрального количественного анализа: уровня дезорганизации ЭЭГ-паттерна с исследованием реактивности мозга в ответ на введение Тиоцетама (рис. 5.1). Начиная с первых-вторых суток после травмы, исследуют реактивность мозга на введение Тиоцетама. Вводят 5 мл препарата (начальная доза - НД) и по изменению электроэнцефалограммы, записанной до начала введения препарата и через 20-30 минут после окончания введения Тиоцетама, определяют тип реакции ЦНС.

Если типы реакций на введение свидетельствуют об увеличении дезорганизации паттерна, то введение препарата прекращают, но на следующий день исследование повторяют и т. д.

Если типы реакций на введение начальной дозы Тиоцетама свидетельствуют об уменьшении дезорганизации паттерна или паттерн не изменяется, дозу повышают еще на 5 мл и т. д. до момента появления дезорганизации ЭЭГ-паттерна. После этого возвращаются на предыдущую дозу, ее оставляют. Тестируют на следующий день на адекватной дозе (не вызывающей усиления дезорганизации) и т. д. Параллельно проводят оценку нарушения сознания по шкале ком Глазго и проводят корреляционный анализ между примененной дозой Тиоцетама и уровнем сознания по шкале ком Глазго (баллы), количественными показателями ЭЭГ (интегральные показатели). В результате будет рекомендована доза препарата в зависимости только от результатов исследования и уровня сознания по шкале ком Глазго. Такой подход позволит с большой степенью чувствительности судить о действии Тиоцетама при той или иной степени нарушения сознания (оглушение-сопор-кома).

На основании полученных данных об особенностях реактивности ЦНС при введении различных доз Тиоцетама у пациентов с ТЧМТ были разработаны рекомендации по подбору дозировки данного препарата, представленные в виде табл. 5.2.

Исходной дозой для введения Тиоцетама у пациентов с ТЧМТ при уровне неврологического дефицита до 10 баллов по ШКГ является 5 мл $(0,5$ г). Под контролем нейрофизиологического (ЭЭГ, УЗ ТКДГ) и клинического мониторин- 
га суточная доза Тиоцетама может быть постепенно (шаг - 5 мл) увеличена до 20 мл максимально.

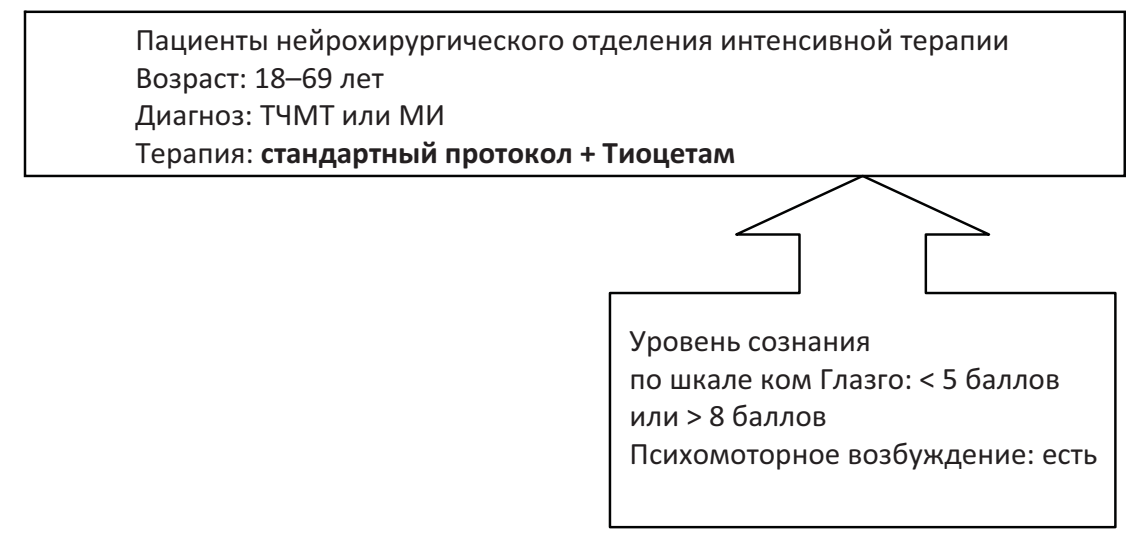

Применение препарата Тиоцетам в дозе:

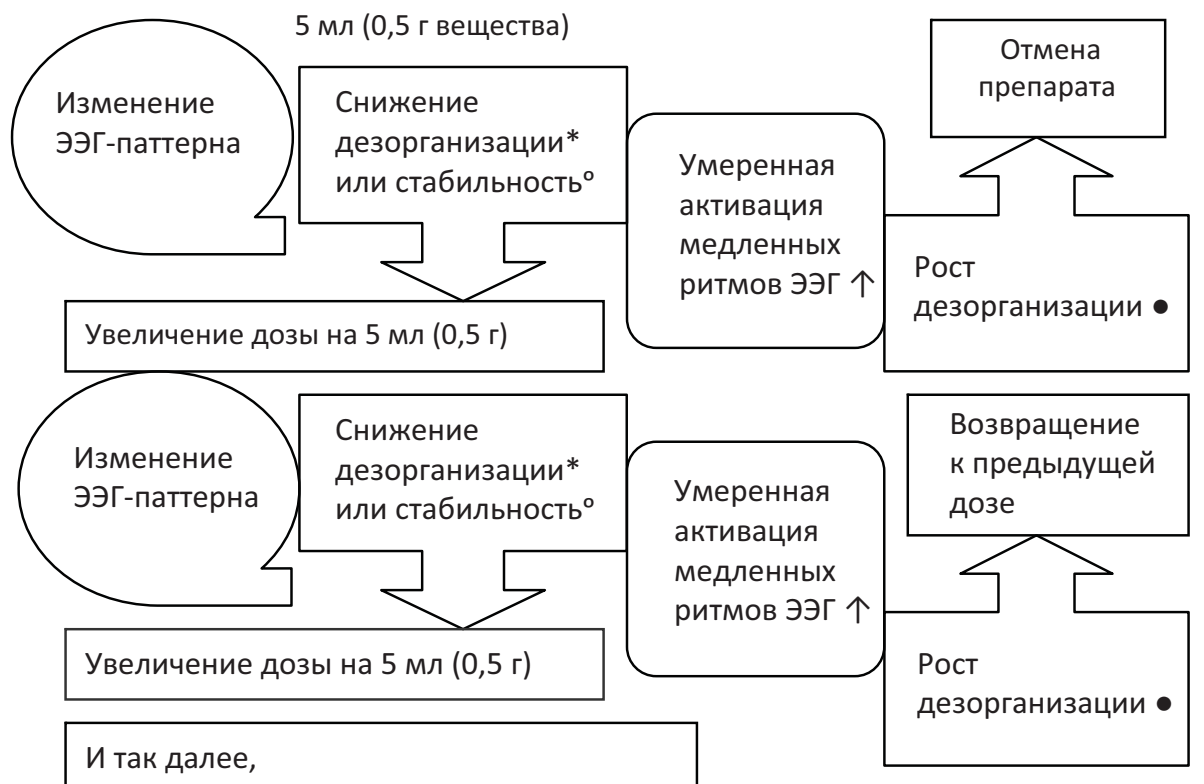

максимально до 30 мл (3 г вещества)

Примечание: * - типы реакций ЦНС II 2а, II 26, III 2a, III 26, III 3а, III 36 подгрупп

○ - типы реакций ЦНС I

个 - типы реакций ЦНС III 1a, III 16 подгрупп

- - типы реакций ЦНС II 1a, II 16 подгрупп

Рuc. 5.1. Схема подбора дозы введения препарата Тиоцетам у пациентов с ТЧМТ и МИ 
Таблица 5.2

Исходная и эффективные дозы препарата Тиоцетам при подборе дозировки введения на основании оценки реактивности ЦНС у пациентов с ТЧМТ

с различной степенью нарушения сознания по шкале ком Глазго

\begin{tabular}{|c|c|c|c|c|c|c|}
\hline $\begin{array}{c}\text { Оптималь- } \\
\text { ная доза } \\
\text { препарата }\end{array}$ & $\begin{array}{c}\text { Степень } \\
\text { дезоргани- } \\
\text { зации ЭЭГ }\end{array}$ & $\begin{array}{c}\text { Уровень } \\
\text { сознания }\end{array}$ & По ШКГ & $\begin{array}{c}\text { Исходная } \\
\text { доза пре- } \\
\text { парата }\end{array}$ & $\begin{array}{c}\text { Степень } \\
\text { дезоргани- } \\
\text { зации ЭЭГ }\end{array}$ & $\begin{array}{c}\text { Оптималь- } \\
\text { ная доза } \\
\text { препарата }\end{array}$ \\
\hline 5 мл & возрастает & $\begin{array}{l}\text { ясное } \\
\text { сознание }\end{array}$ & $\begin{array}{l}15 \\
\text { баллов }\end{array}$ & 10 мл & $\begin{array}{l}\text { снижается } \\
\text { или } \\
\text { стабильна }\end{array}$ & $\begin{array}{l}\text { не более } \\
15 \text { мл }\end{array}$ \\
\hline 5 мл & возрастает & $\begin{array}{l}\text { умеренное } \\
\text { оглушение }\end{array}$ & $\begin{array}{l}13-14 \\
\text { баллов }\end{array}$ & 10 мл & $\begin{array}{l}\text { снижается } \\
\text { или } \\
\text { стабильна }\end{array}$ & $\begin{array}{l}15 \text { мл -> } \\
\text { до } 20 \text { мл }\end{array}$ \\
\hline 5 мл & возрастает & $\begin{array}{l}\text { глубокое } \\
\text { оглушение }\end{array}$ & $\begin{array}{l}11-12 \\
\text { баллов }\end{array}$ & 10 мл & $\begin{array}{l}\text { снижается } \\
\text { или } \\
\text { стабильна }\end{array}$ & $\begin{array}{l}15 \text { мл -> } \\
\text { до } 25 \text { мл }\end{array}$ \\
\hline отмена & возрастает & сопор & $\begin{array}{l}\text { 8-10 } \\
\text { баллов }\end{array}$ & 5 мл & $\begin{array}{l}\text { снижается } \\
\text { или } \\
\text { стабильна }\end{array}$ & $\begin{array}{l}10 \text { мл -> } \\
\text { до } 20 \text { мл }\end{array}$ \\
\hline отмена & возрастает & кома I & $\begin{array}{l}\text { 6-7 } \\
\text { баллов }\end{array}$ & 5 мл & $\begin{array}{l}\text { снижается } \\
\text { или } \\
\text { стабильна }\end{array}$ & $\begin{array}{l}10 \text { мл -> } \\
\text { до } 20 \text { мл }\end{array}$ \\
\hline
\end{tabular}

Исходной дозой для введения Тиоцетама у пациентов с МИ при уровне неврологического дефицита до 10 баллов по ШКГ является 5 мл $(0,5$ г). Под контролем нейрофизиологического (ЭЭГ и УЗ ТКДГ) и клинического мониторинга суточная доза Тиоцетама может быть постепенно («шаг» - 5 мл) увеличена до 30 мл. Исходной дозой для введения Тиоцетама у пациентов с МИ при уровне неврологического дефицита от 11 до 15 баллов по ШКГ является 5 мл $(0,5$ г). При уровне нарушения сознания 11-12 баллов (глубокое оглушение) суточная доза Тиоцетама может быть постепенно увеличена до 30 мл максимально. При уровне нарушения сознания 13-14 баллов (умеренное оглушение) суточная доза Тиоцетама может быть постепенно увеличена до 15 мл. При уровне сознания 15 баллов (ясное сознание) суточная доза Тиоцетама может быть постепенно увеличена не более чем до 15 мл (табл. 5.3).

Таблица 5.3

Исходная и эффективные дозы препарата Тиоцетам при подборе дозировки введения на основании оценки реактивности ЦНС у пациентов с МИ с различной степенью нарушения сознания по шкале ком Глазго

\begin{tabular}{|l|l|l|l|l|l|l|}
\hline $\begin{array}{c}\text { Оптималь- } \\
\text { ная доза } \\
\text { препарата }\end{array}$ & $\begin{array}{c}\text { Степень } \\
\text { дезоргани- } \\
\text { зации ЭЭГ }\end{array}$ & $\begin{array}{c}\text { Уровень } \\
\text { сознания }\end{array}$ & По ШКГ & $\begin{array}{c}\text { Исходная } \\
\text { доза пре- } \\
\text { парата }\end{array}$ & $\begin{array}{c}\text { Степень } \\
\text { дезоргани- } \\
\text { зации ЭЭГ }\end{array}$ & $\begin{array}{c}\text { Оптималь- } \\
\text { ная доза } \\
\text { препарата }\end{array}$ \\
\hline 5 мл & возрастает & $\begin{array}{l}\text { ясное } \\
\text { сознание }\end{array}$ & 15 баллов & 10 мл & $\begin{array}{l}\text { снижается } \\
\text { или } \\
\text { стабильна }\end{array}$ & $\begin{array}{l}\text { не более } \\
15 \text { мл }\end{array}$ \\
\hline
\end{tabular}


Продолжение табл. 5.3

\begin{tabular}{|l|l|l|l|l|l|l|}
\hline $\begin{array}{c}\text { Оптималь- } \\
\text { ная доза } \\
\text { препарата }\end{array}$ & $\begin{array}{c}\text { Степень } \\
\text { дезоргани- } \\
\text { зации ЭЭГ }\end{array}$ & $\begin{array}{l}\text { Уровень со- } \\
\text { знания }\end{array}$ & По ШКг & $\begin{array}{c}\text { Исходная } \\
\text { доза пре- } \\
\text { парата }\end{array}$ & $\begin{array}{c}\text { Степень } \\
\text { дезоргани- } \\
\text { зации ЭЭг }\end{array}$ & $\begin{array}{c}\text { Оптималь- } \\
\text { ная доза } \\
\text { препарата }\end{array}$ \\
\hline отмена & возрастает & $\begin{array}{l}\text { умеренное } \\
\text { оглушение }\end{array}$ & $\begin{array}{l}13-14 \\
\text { баллов }\end{array}$ & 5 мл & $\begin{array}{l}\text { снижается } \\
\text { или } \\
\text { стабильна }\end{array}$ & $\begin{array}{l}10 \text { мл } \geq \\
\text { до } 15 \text { мл }\end{array}$ \\
\hline отмена & возрастает & $\begin{array}{l}\text { глубокое } \\
\text { оглушение }\end{array}$ & $\begin{array}{l}11-12 \\
\text { баллов }\end{array}$ & 5 мл & $\begin{array}{l}\text { снижается } \\
\text { или } \\
\text { стабильна }\end{array}$ & $\begin{array}{l}10 \text { мл } \geq \\
\text { до } 30 \text { мл }\end{array}$ \\
\hline отмена & возрастает & сопор & $\begin{array}{l}8-10 \\
\text { баллов }\end{array}$ & 5 мл & $\begin{array}{l}\text { снижается } \\
\text { или } \\
\text { стабильна }\end{array}$ & $\begin{array}{l}10 \text { мл } \geq \\
\text { до } 30 \text { мл }\end{array}$ \\
\hline отмена & возрастает & кома I & $\begin{array}{l}6-7 \\
\text { баллов }\end{array}$ & 5 мл & $\begin{array}{l}\text { снижается } \\
\text { или } \\
\text { стабильна }\end{array}$ & $\begin{array}{l}10 \text { мл } \geq \\
\text { до } 30 \text { мл }\end{array}$ \\
\hline отмена & возрастает & кома II & 5 баллов & 5 мл & $\begin{array}{l}\text { снижается } \\
\text { или } \\
\text { стабильна }\end{array}$ & $\begin{array}{l}10 \text { мл } \geq \\
\text { до } 30 \text { мл }\end{array}$ \\
\hline
\end{tabular}

В результате проведенных исследований установлено следующее:

1. Церебропротективное действие (антиоксидантное, противоишемическое, антиамнестическое) Тиоцетама выгодно отличается от Пирацетама и других препаратов рацетамного ряда и производных ГАМК.

2. В интенсивной терапии острой церебральной недостаточности, обусловленной тяжелой черепно-мозговой травмой или мозговым инсультом актуальной остается проблема определения сроков начала лечения Тиоцетамом и критериев выбора оптимальной дозы препарата.

3. Выбор начальной дозы Тиоцетама у пациентов с ЧМТ и ОНМК должен быть дифференцированным и проводиться под нейрофизиологическим контролем.

4. Включение препарата в комплекс интенсивной терапии в острой фазе заболевания предусматривает проведение мониторинга неврологического статуса, исследование спектральной мощности ЭЭГ, изучение реактивности ЦНС в ответ на фармацевтическое воздействие.

Известно, что при аноксии мозга и в постаноксическом периоде важнейшим звеном комплекса повреждающих механизмов является свободнорадикальное окисление и фосфолипазный гидролиз фосфолипидов клеточных мембран. В совокупности с распадом АТФ, входом кальция в клетку, эксайтотоксическим действием возбуждающих аминокислот, протеолитическими механизмами повреждения цитоскелета клеток мозга эти повреждающие факторы в момент аноксии мозга и на ранних этапах постаноксического периода 
существенно изменяют структурную базу организации всех функций одних клеток и необратимо повреждают другие, более чувствительные клетки мозга [13]. В отдаленном постаноксическом периоде степень активации данных повреждающих факторов зависит от активности мозга и адекватности снабжения нейронов кислородом. При аноксии и в постаноксическом периоде выявляются патологические изменения всех основных механизмов регуляции структурнофункционального состояния клеточных мембран, глубокие конформационные и патологические перестройки их фосфолипазной основы и белковых субмембранных комплексов ионных каналов, различных ионных насосов [14].

Значение перекисного окисления и гидролиза фосфолипидов клеточных мембран для постаноксической патологии мозга определяются тем, что нервная ткань характеризуется высоким содержанием липидов (до 50 \% от сухой массы ткани), являющихся основным субстратом свободных радикалов и фосфолипаз. Фосфолипиды нервной ткани составляют до 70 \% от суммарного содержания липидов в сером веществе и до 45-50\% - в белом веществе мозга [13].

Целесообразность использования в раннем периоде острой локальной ишемии мозга ловушек свободных радикалов и препаратов, разрушающих перекиси (с сульфидными и тиоловыми группами: унитиола, тиосульфата натрия и т. д.), была доказана еще в 80-е годы прошлого столетия. Тогда же патогенетически обосновано одновременное с ними применение токоферолов и каротиноидов, связывающих катализаторы и инактивирующих синглетный кислород. Наряду с Тиотриазолином к современным антиоксидантам относится Мексидол, Нейротропин.

Мексидол - соль 2-этил-6-метил-3-оксипиридина, структурного аналога витамина $\mathrm{B}_{6}$, и янтарной кислоты - является антиоксидантом нового поколения. Он ингибирует процессы перекисного окисления липидов, активирует эндогенную антиоксидантную систему супероксиддисмутазы и церулоплазмин, предупреждает снижение активности глутатионзависимых ферментов (глутатионпероксидазы, глутатионредуктазы), в результате чего достоверно уменьшается активность процессов оксидантного стресса. Модулируя активность мембраносвязанных ферментов (кальций-независимой фосфодиэстеразы, аденилатциклазы, ацетилхолинэстеразы), рецепторных комплексов (бензодиазепинового, GABA, ацетилхолинового), и усиливая их способность связывания с лигандами, Мексидол способствует сохранению структурно-функциональной организации биомембран, транспорта нейромедиаторов и улучшению синаптической передачи $[15,16,17]$.

Он обладает способностью усиливать компенсаторную активацию аэробного гликолиза, снижать степень угнетения окислительных процессов в цикле Кребса в условиях гипоксии с увеличением содержания АТФ и креатинфосфата, активировать энергосинтезирующие функции митохондрий [18]. Установлено также, что нейропротекторный эффект сукцинат-2-этил-6-метил3-оксипиридина объясняется не только нейрометаболическим действием, но и циркуляторным цереброваскулярным эффектом (уменьшение вазоконстрикции интракраниальных сосудов, ликвидация асимметрии кровотока, рост ско- 
рости венозного оттока, симметричное снижение линейной и систолической скорости кровотока).

Одним из наиболее перспективных направлений метаболической защиты мозга от ишемии считается непосредственное воздействие на системы нейротрансмиттеров и нейромодуляторов мозга, на нейрональные рецепторы, создание условий для нормализации соотношения процессов возбуждающей и тормозной нейротрасмиссии [19].

Установлено, что в основе когнитивных нарушений при церебральной недостаточности лежит холинергическая недостаточность, обусловленная снижением выработки ацетилхолина, нарушением баланса холинергических энзимов, потерей холинергических нейронов. Ацетилхолин широко представлен в различных отделах нервной системы: в базальных ганглиях и таламусе, сером веществе полушарий, хвостатом ядре, ярах моста, передних рогах боковых желудочков, вегетативных образованиях ЦНС [20].

В норме уровень сознания обеспечивается полноценной реализацией когнитивных функций полушарий головного мозга при взаимодействии коры с пробуждающими механизмами ретикулярной активирующей системы [21].

Любое афферентное возбуждение (сенсорное, двигательное, тактильное) трансформируется в два потока возбуждений. Один поток по специфическим путям достигает специфической для данного раздражения проекционной области коры; другой - от специфического пути по коллатералям попадает в ретикулярную формацию и от нее в виде мощного восходящего возбуждения направляется к коре больших полушарий, активируя ее. Лишенная связей с ретикулярной формацией, кора головного мозга приходит в недеятельное состояние. Так формируется стволово-таламо-кортикальная субсистема активации головного мозга, которая обеспечивает ясное сознание.

Кора получает проекции от четырех основных медиаторных систем дофаминергической, норадреналинергической, серотонинергической и холинергической. Однако только холинергическая система причастна к активации коры [22].

Кортикальная активация при стимуляции ретикулярной формации ствола, обязательно сопровождается высвобождением ацетилхолина в коре, т. е. ретикулярная активирующая система действует на кору через холинергические афференты. Конечное звено корковой активации холинергично и представлено мускариновыми (М-) рецепторами нейронов коры, чувствительными к ацетилхолину [23].

Базальная холинергическая система переднего мозга через таламус реализует корковую активацию на значимые стимулы. Каудо-таламо-кортикальная система также использует таламус для создания в коре картины распределения локусов активации, необходимой для выполнения той или иной деятельности. Кортикофугальные влияния, главным образом из префронтальной коры, достигают холинергической активационной системы через стриопаллидарную (хвостатое и прилегающее ядра). Генерализованная реакция активации, вызываемая сенсорными стимулами вследствие возбуждения ретикулярной формации среднего мозга, опосредована холинергической системой переднего мозга. 
Последняя имеет прямое отношение к регуляции цикла бодрствование-сон, что сближает механизм генерализованного ориентировочного рефлекса с функциональным состоянием бодрствования [22, 24, 25].

Различные уровни функционирования медиаторной холинергической системы мозга - от выраженной недостаточности до функциональной сохранности - обеспечивают формирование различных уровней сознания — от комы, сопора и оглушения до бодрствования и ясного сознания.

Предшественники холина - экзогенные вещества, которые в организме превращаются в холин и обеспечивают поддержку, восстановление и синтез фосфолипидов клеточных мембран, а также нейромедиаторов ацетилхолина и дофамина. $K$ предшественникам холина относят лецитин, холина альфосцерат и цитидин-5-дифосфохолин натрия [26]. На сегодняшний день известны два класса медикаментозных препаратов, направленных на преодоление холинергической недостаточности:

1) препараты, непосредственно восполняющие дефицит ацетилхолина. К ним относятся:

- холиномиметик центрального действия - холина альфосцерат (Глиатилин), являющийся прекурсором ацетилхолина, проникающим через гематоэнцефалический барьер;

- цитидин-5-дифосфохолин натрия (Цитиколин), который является донором холина в процессах синтеза ацетилхолина [27];

2) ингибиторы ацетилхолинэстеразы: прозерин, Галантамин, Нейромидин и др.

Важная роль фосфолипидов в головном мозге хорошо известна. Нейрональная мембрана представляет собой фосфолипидный бислой. Изменение этого слоя часто обусловлено усилением процессов ПОЛ нейрональных мембран и является инициирующим механизмом патологии нейрона [483].

Установлена способность фосфолипидов и деацитилированных фосфолипидов поддерживать целостность мембран нервных клеток путем восстановления синтеза фосфолипидов и нейротрансмиттера ацетилхолина в поврежденном мозге. Поэтому центральные холиномиметики (холина альфосцерат, цитидин-5-дифосфохолин), являясь источниками холина и фосфатидилхолина, поддерживая физиологический уровень ацетилхолина, обладают мембраностабилизирующими свойствами, служат средствами, восстанавливающими межнейрональную трансмиссию.

Цитиколин. Определенный интерес в изучении нейропротекции представляет Цитиколин $[29,30]$, эффективность которого доказана многочисленными клиническими исследованиями и публикациями [29].

В 1987 г. в Японии фирмой Тоуо Jozo Со был зарегистрирован препарат Рекогнан (Recognan E), международное наименование которого Цитиколин (Citicoline). Цитиколин зарегистрирован более чем в 40 странах мира. На рынках Японии Цитиколин (его свободное основание) представлен как лекарство, а в США - как пищевая добавка. Натриевая соль Цитиколина (Цераксон) применяется как лекарственное средство на фармацевтическом рынке ряда стран 
Европы и Латинской Америки. В настоящее время препарат в том или ином виде выпускается такими странами как Италия и Испания. В 2006 г. Цитиколин (Цераксон) появился и в Украине.

Цитиколин (основание): химическое название: цитидин-5-дифосфохолин, молекулярная формула: $\mathrm{C}_{14} \mathrm{H}_{27} \mathrm{~N}_{4} \mathrm{O}_{11} \mathrm{P}_{2}$. Молекулярная масса: 489,31.

Структурная формула состоит из рибозы, пирофосфата, цитозина (азотистое основание) и холина (рис. 5.2).

Цитиколин (цитидин-5-дифосфохолин) - это органическое вещество, которое относится к группе нуклеотидов - биомолекул, играющих важную роль в клеточном метаболизме. Существует такое понятие как эндогенный и экзогенный цитиколин. Эндогенное образование цитиколина является этапом синтеза из холина фосфатидилхолина. Цитиколин (цитидин-5-дифосфохолин) является незаменимым предшественником фосфатидилхолина (лецитина), основного фосфолипида всех клеточных мембран, включая нейрональные мембраны. Холин принимает также участие в синтезе ацетилхолина, а цитиколин является донором холина в процессах синтеза ацетилхолина [31].

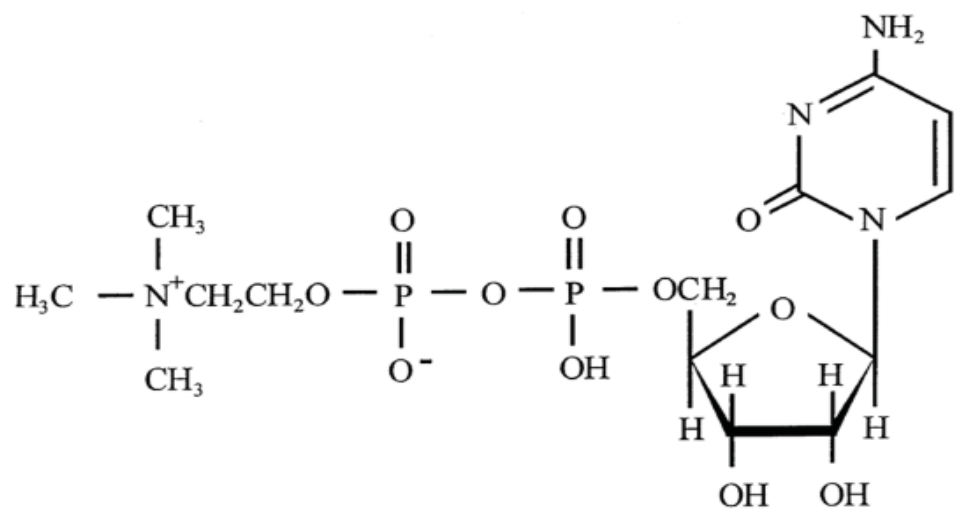

\section{Puc.5.2. Структурная формула Цитиколина (цитидин-5-дифосфохолин)}

Цитиколин (натриевая соль) - в препарате Цитиколин (Цераксон) находится в виде натриевой соли (это не влияет на фармакологическое действие, только химическое свойство).

Химическое название: цитидин-5-дифосфохолин натрия. Молекулярная формула: $\mathrm{C}_{14} \mathrm{H}_{25} \mathrm{~N}_{4} \mathrm{NaO}_{11} \mathrm{P}_{2}$. Молекулярная масса: 510,31.

Цитидин-5-дифосфохолин натрия - аналог эндогенного цитиколина. Фармакотерапевтическая группа: психостимулирующие и ноотропные средства. Код АТC N06BX06. Цитиколин вырабатывается из хлорида холина и оротовой кислоты посредством ферментации.

Анализируя фармакокинетику Цитиколина необходимо отметить такие качества как водорастворимость, биологическую доступность до 99 \%, причем биодоступность при пероральном и парентеральном путях введения практически одинакова. Элиминация из организма осуществляется в основном с вы- 
дыхаемым воздухом и с мочой. Пиковые уровни в плазме носят двухфазный характер - первый через 1 час после перорального приема и второй - через 24 часа.

Экзогенный цитиколин при попадании в желудочно-кишечный тракт гидролизуется в тонком кишечнике. В результате гидролиза в стенке кишечника и в печени образуются холин и цитидин. После всасывания холин и цитидин попадают в системный кровоток, участвуют в различных процессах биосинтеза и проникают в мозг через гематоэнцефалический барьер, где происходит ресинтез цитиколина из холина и цитидина.

Ресинтезированный в мозге цитиколин активирует биосинтез фосфатидилхолина и предотвращает его катаболизм из нейрональных мембран. Он поддерживает нормальный уровнь кардиолипина (основной компонент митохондриальных мембран) и сфингомиелина, участвует в синтезе ацетилхолина, стимулирует синтез глутатиона и ослабление процессов пероксидации липидов (антиоксидантный эффект), нормализует активность $\mathrm{Na}^{+}-\mathrm{K}^{+}$-АТФ-азы, вызывает ослабление активности фосфолипазы А2. Все эти эффекты способствуют активации энергетических процессов в нейронах, восстановлению нейрональных митохондриальных цитохромоксидаз, что нормализует процессы тканевого дыхания, приводят к ингибированию глутамат-индуцированного апоптоза [31].

Таким образом, свободнорадикальное окисление, являясь в норме частью общего адаптационного процесса, направленного на поддержание клеточного гомеостаза, регуляцию проницаемости мембран, рецепции нейромедиаторов, ферментативного катализа при аноксии мозга, в совокупности с системой фосфолипаз, образует основу патологического повреждающего комплекса. Ведущей точкой приложения последнего являются клеточные мембраны, а конечным эффектом - нарушение функционирования ферментных систем клеток, увеличение диффузной проницаемости мембран и стойкие нарушения ионного гомеостаза, приводящие к гибели клеток мозга [32].

Как видно из патогенеза аноксии, основные нейропротекторные механизмы действия Цитиколина (Цераксона) направлены на прерывание ряда важных патофизиологических процессов в пораженном мозге: 1) как предшественник мембранных фосфолипидов препарат увеличивает их продукцию и восстанавливает мембранные нарушения за счет усиления синтеза; 2) ингибирует фосфолипазу, предупреждая активацию свободных радикалов; 3) снижает концентрацию свободных жирных кислот в зоне пенумбры; 4) блокирует апоптоз-триггерный механизм, предотвращая гибель клеток; 5) восстанавливает функцию поврежденных холинергических нейронов, улучшая двигательные функции [33].

В эксперименте на различных моделях острой церебральной недостаточности (травматическое повреждение головного мозга, локальная и глобальная ишемия мозга, внутримозговое кровоизлияние) доказана эффективность Цитиколина, которая выражается в уменьшении выраженности ишемического повреждения головного мозга. Исследования, проведенные in vivo и in vitro показали следующее. Использовались традиционные экспериментальные модели: 
транзиторная и длительная ишемия переднего мозга у песчанок, транзиторная глобальная и фокальная церебральная ишемия у крыс, эмболический ишемический инсульт у крыс, субарахноидальное кровоизлияние и травма головного мозга у крыс, гипоксия у морских свинок. Введение цитидин-5-дифосфохолина уменьшало уровень ПОЛ и повышало выживаемость животных, восстанавливало метаболизм глюкозы и увеличивало синтез ацетилхолина, уменьшало дисфункцию гематоэнцефалического барьера, объем области ушиба головного мозга и его отека, а также улучшало память и обучаемость у собак [31, 34]. Получены данные об эффективном сочетании Цитиколина с другими нейропротекторами. Исследовано применение в комбинации с Нимодипином, блокаторами NMDA-рецепторов, основным фактором роста фибробластов, тканевым активатором плазминогена и Урокиназой. При этом основным эффектом таких комбинаций является уменьшение зоны инфарктов мозга и улучшение функционального состояния мозга [35].

Многоцентровые рандомизированные плацебо-контролируемые клинические исследования Цитиколина достаточно убедительно свидетельствуют об эффективности препарата при ишемическом инсульте [34, 36].

Максимальный терапевтический эффект получен при применении Цитиколина в дозе 2000 мг/сутки, что повышало вероятность благоприятного исхода по сравнению с плацебо на 38 \% [37].

Установлена эффективность применения Цитиколина не только в пределах терапевтического окна, но и на протяжении первых суток. Продолжаются исследования по расширению показаний для применения Цитиколина. Обнадеживающие данные получены при клиническом применении Цитиколина при острой церебральной недостаточности различного генеза. Установлена эффективность Цитиколина у больных, перенесших черепно-мозговую травму, у больных с геморрагическим инсультом, у пациентов с болезнью Альцгеймера, при постаноксической и постгипоксической энцефалопатиях различной этиологии. Особо эффективен Цитиколин при лечении такого варианта черепномозговой травмы как диффузное аксональное повреждение [38].

Доказанные клинические эффекты Цитиколина (Цераксона) заключаются в следующем: при остром ишемическом инсульте Цераксон уменьшает рост объема церебрального инфаркта, увеличивает вероятность полного восстановления пациентов через 3 месяца после перенесенного инсульта. При черепномозговой травме Цераксон уменьшает отек мозга у пациентов с ЧМТ, увеличивает вероятность полного восстановления пациентов через 2 месяца после ЧМТ, увеличивает долю пациентов, способных к самообслуживанию. Цераксон улучшает когнитивные функции: память, внимание, мышление.

Существующие на сегодняшний день показания для применения Цераксона: острые и хронические нарушения мозгового кровообращения, черепномозговая травма и ее последствия, когнитивные, сенситивные, моторные и другие неврологические нарушения вследствие церебральной патологии дегенеративного и сосудистого происхождения [31].

Установлено, что не следует назначать препарат пациентам с высоким тонусом парасимпатической нервной системы. Взаимодействуя с другими ле- 
карствами, Цитиколин усиливает эффект леводопы. Необходимо помнить, что Цераксон может стимулировать парасимпатическую систему. Длительное применение Цитиколина не сопровождается токсическими эффектами, независимо от способа введения [35].

Многочисленными исследованиями было показано, что эффективное дозирование Цитиколина (Цераксона) составляет при парентеральном введении 500-1000 мг 2 раза в день в зависимости от тяжести состояния [29]. Причем при острых и неотложных состояниях максимальный эффект достигается при назначении препарата в первые 24 часа. Максимальная суточная доза при парентеральном назначении составляет 2000 мг, при пероральном приеме 600 мг. Минимальный рекомендованный курс лечения -45 дней. Время лечения, при котором наблюдается максимальный терапевтический эффект составлет 12 недель.

Мы располагаем опытом лечения Цитиколином с 1989 г., когда впервые применили этот препарат (ацехолин Рекогнан производства Японии) для лечения больной с тяжелой черепно-мозговой травмой. Изучив биомеханику травмы, данные компьютерной томографии, мы установили превалирование у больной биомеханики ускорение-замедление над ударно-противоударной биомеханикой: диффузное аксональное повреждение тяжелой степени, что и послужило поводом для применения Цитиколина. На протяжении 25 лет мы используем Цитиколин (японского, итальянского и испанского производства) как препарат нейромедиаторного, нейрорецепторного, нейротрофического действия у больных с острой церебральной недостаточностью различного генеза (постасистолический синдром, отравление угарным газом и метаном, черепномозговая травма, мозговой инсульт и др.).

Метаанализ результатов исследований выявил эффективность Цитиколина при ишемическом инсульте и ЧМТ, клинические исследования его эффективности продолжаются [37].

При ЧМТ Цитиколин следует комбинировать с препаратами, снижающими степень нейронального и диффузного аксонального повреждения, обладающими противовоспалительным эффектом. $\mathrm{K}$ таким препаратам причисляют гипертонический раствор, статины, прогестерон, эритропоэтин, циклоспорин А [38].

Получены данные об эффективном сочетании Цитиколина с другими нейропротекторами. Исследовано применение в комбинации с Нимодипином, блокаторами NMDA-рецепторов, основным фактором роста фибробластов, тканевым активатором плазминогена и Урокиназой. При этом основным эффектом таких комбинаций является уменьшение зоны инфарктов мозга и улучшение функционального состояния мозга $[39,34,40]$.

Глиатилин (L-альфа глицерилфосфорилхолин ( $\alpha$-GPC) или холина альфосцерат) - холиномиметик с преимущественным влиянием на ЦНС. В состав препарата входит 40,5 \% метаболически защищенного холина [41, 44]. При попадании в организм холина альфосцерат расщепляется под действием ферментов на холин и глицерофосфат: холин участвует в биосинтезе ацетилхолина $(\mathrm{AX})$ - одного из основных медиаторов нервного возбуждения; глицерофосфат 
является предшественником фосфолипидов (фосфатидилхолина) нейронной мембраны [41].

Часть его структурной формулы - это холин, причем в связанном с глицерофосфатом виде он легко проникает через гематоэнцефалический барьер. Холин идет в дальнейшем на синтез медиатора ацетилхолина, остаток молекулы (глицерофосфат) является субстратом для синтеза фосфатидилхолина, то есть фосфолипида, являющегося главной составляющей билипидного слоя всех клеточных мембран [30, 41, 27].

Глиатилин обладает не только мембрано-стабилизирующими и противоотечными свойствами, но и пробуждающим эффектом у пациентов в коматозных состояниях. Дозозависимый эффект повышения сознания связывают со способностью Глиатилина стимулировать выделение ацетилхолина из пресинаптических терминалей и восстанавливать синаптическую нейротрансмиссию в первые минуты после введения препарата [44]. Таким образом, Глиатилин улучшает передачу нервных импульсов в холинергических нейронах, положительно воздействует на пластичность нейрональных мембран и на функцию рецепторов. Основа лечения когнитивных нарушений при острой церебральной недостаточности различного генеза - коррекция холинергической недостаточности.

Глиатилин улучшает церебральный кровоток, усиливает метаболические процессы в головном мозге, активирует структуры ретикулярной формации головного мозга и восстанавливает сознание при травматическом поражении головного мозга. Глиатилин, с одной стороны, являясь донором холина, увеличивает синтез ацетилхолина, что в свою очередь имеет положительное воздействие на нейротрансмиссию, с другой - глицерофосфат участвует в синтезе фосфатидилхолина (мембранного фосфолипида). В результате то и другое оказывает положительное воздействие на мембранную эластичность и на функции рецепторов, что улучшает синаптическую трансмиссию.

Принципиальным отличием холина альфосцерата, по данным Di Perri R., et al., является способность нормализовать уровень ацетилхолина в остром периоде заболевания - от холина Глиатилин отделяет одна неэнергозатратная реакция, в то время как Цитиколин - пять энергозатратных реакций [44]. Именно поэтому центральный холинергический препарат, Глиатилин, обладает не только мембраностабилизирующими и противоотечными свойствами, но и пробуждающим эффектом у пациентов в коматозных состояниях.

По сравнению с другими предшественниками холина, например с Цитиколином, Глиатилин не только принимает участие в восстановлении билипидного слоя нейрональных мембран, но и повышает уровень выделения ацетилхолина, необходимого для активации базальной холинергической системы переднего мозга - модулирующей субсистемы активации коры, обеспечивающей пробуждение [30, 41, 43].

Сопоставляя действие Цитиколина и Глиатилина нельзя ставить знак равенства между препаратами: у Цитиколина превалирующий эффект связан с действием на мембраны, воздействие на нейротрансмиссию намного скромнее, и наоборот: у Глиатилина превалирующий эффект связан с действием 
на нейротрансмиссию, а воздействие на мембраны менее выражено. Поэтому, для усиления соответствующих эффектов препаратов возможно имеет смысл применять их в комплексе. По данным В. В. Афанасьева [45], результатом взаимодействия Глиатилина и Цитиколина является коэргическое действие, предотвращающее «аутоканнибализм» фосфотидилхолина.

Таким образом, установлены три основных механизма, с помощью которых реализуется нейропротективный эффект холина альфосцерата при острой церебральной недостаточности:

1) Глиатилин - донор ацетилхолина, способствующий восстановлению межнейронных связей и нейротрансмиссии;

2) Глиатилин осуществляет прямую репарацию нейрональных мембран;

3) метаболотропное действие Глиатилина, связанное с уменьшением дегенерации свободных жирных кислот.

Холина альфосцерат первоначально был предложен для лечения болезни Альцгеймера, при которой выявлен дефицит нейромедиатора ацетилхолина, связанный с дегенерацией холинергических нейронов в базальном ядре Мейнерта. Это открыло новый этап в разработке медикаментозной терапии, направленной на коррекцию когнитивных нарушений при этом заболевании.

В настоящее время появились исследования, указывающие на положительный эффект Глиатилина (в связи с его нейротрофическим и нейропротективным действием) как при острых повреждениях центральной нервной системы (травматического и сосудистого генеза), так и при хронических сосудистых заболеваниях головного мозга. Показана эффективность применения Глиатилина в лечении острых нарушений мозгового кровообращения: острого ишемического инсульта, транзиторной ишемической атаки, геморрагического инсульта $[41,42,45,46]$.

Положительный эффект Глиатилина у группы больных с когнитивными нарушениями, по-видимому, связан с тем, что при этих заболеваниях также страдают холинергические структуры мозга, имеющие отношение к памяти.

В течение последних двух десятков лет клиническая әффективность и переносимость холина альфосцерата (Глиатилина) была изучена в целом ряде клинических исследований, наиболее крупным из которых явился открытый многоцентровой эксперимент с 2058 пациентами проведенный Barbagallo S. G. et al. [47]. Лечение начиналось не позднее 10 дней после инсульта или транзиторной ишемической атаки (ТИА). Все результаты подтверждают эффективность холин альфосцерата при восстановлении неврологических и психических расстройств, являющихся следствием цереброваскулярных нарушений, что было наиболее очевидно (достоверно) к третьему месяцу наблюдений $[45$, $47,48,49]$.

Метаанализ тринадцати клинических испытаний (Parnetti L. и соавт., 2001), проведенных на 2484 пациентах также показал эффективность применения Глиатилина при острой церебральной патологии, проявившуюся в значительной компенсации неврологического дефицита [50]. 
В период с 1997 по 2010 год проводились сравнительные клиникоморфологические исследования эффективности применения Глиатилина при острой церебральной ишемии, подтвердившие высокую клиническую эффективность препарата в достижении регресса как общемозговой, так и грубой очаговой неврологической патологии. Экспериментальные работы, сопровождавшиеся ультраструктурным и гистологическим контролем, позволили обнаружить подтверждения цитопротекторных свойств Глиатилина в момент гипоксического повреждения и стимуляции регенеративных и репаративных процессов в случае стабилизации энергетического гомеостаза мозгового вещества в регионе повреждения [43, $51,52,53]$.

Открытые клинические исследования по применению Глиатилина проведены у 4256 пациентов в различных медицинских центрах России (СанктПетербург, Москва, Екатеринбург, Новосибирск, Омск, Томск, Саратов, Челябинск). Были применены следующие курсы лечения Глиатилином:

1) острейший период ишемического инсульта - 1000 мг 2 раза в день внутривенно или внутримышечно (длительность: 3-5 суток при ишемическом инсульте и 5-14 суток при геморрагическом);

2) инсультсглубокимрасстройствомсознания, требующимподдержания витальных функций - 1000 мг 4 раза в день с интервалом в 6 часов, внутривенно в течение 5-7 суток;

3) ранний восстановительный период после инсульта и период реабилитации - 400 мг 2 раза в день, внутрь в течение 2 месяцев, начиная со 2-й недели заболевания;

4) формированиеглубокогодвигательного, афатического, мнестического дефекта после перенесенного инсульта - 400 мг 2 раза в день, внутрь, со 2-й недели заболевания в течение 6 месяцев.

Для оценки эффективности лечения применялись следующие методы контроля: шкала комы Глазго, шкала MAST, оригинальная шкала (Гусев Е. И., Скворцова В. И., 1991), шкала Barthell. Эффективность лечения выражалась в уменьшении степени тяжести, длительности течения инсульта, сокращении периода и снижении степени выраженности тяжелого расстройства сознания за счет активизации корковых и стволовых структур головного мозга. Установлен выраженный пробуждающий эффект, увеличение выживаемости пациентов, снижение уровня инвалидизации после перенесенного ишемического или геморрагического инсульта.

Открытые клинические исследования по применению Глиатилина также были проведены у 369 пациентов с острой черепно-мозговой и спинно-мозговой травмой в различных медицинских центрах России (Санкт-Петербург, Москва, Новосибирск, Челябинск, Казань). Доза Глиатилина при ушибе головного мозга с глубоким расстройством сознания, требующим поддержания витальных функций, составила 1000 мг 1-4 раза в сутки внутривенно капельно, с первых суток в течение 6-15 дней. При ушибе головного мозга средней и легкой степени тяжести доза Глиатилина составила 1000 мг 1 раз в день внутривенно или внутримышечно с 1-х по 7-е сутки, затем внутрь по 400 мг 2 раза в день в те- 
чение 2 месяцев. При сотрясении головного мозга доза Глиатилина составила 400 мг внутрь, 2 раза в день в течение месяца с 1-х суток заболевания. Для оценки эффективности лечения применялись следующие методы контроля: шкала комы Глазго, компьютерная и магнитно-резонансная томография, ЭЭГ, транскраниальная ультразвуковая допплерография. Эффективность лечения выражалась в пробуждающем действии, быстром регрессе амнестических расстройств, более раннем регрессе неврологической симптоматики, сокращении сроков реабилитации больных. Применение препарата в остром периоде заболевания снизило летальность и переход в вегетативное состояние, снизило процент больных, имеющих в подостром и резидуальном периодах признаки инвалидности тяжелой степени.

Сравнительный анализ позволяет считать, что применение Глиатилина по предложенной схеме оказалось эффективным. Глиатилин, примененный в остром периоде ишемического инсульта, достоверно предотвращал потенциально возможное значительное расширение конечных размеров морфологического дефекта мозговой ткани к концу острого периода инсульта. В среднем, конечный объем инфаркта мозга по данным диффузионно-взвешенной МРТ превысил объем необратимого повреждения нервной ткани у пациентов, получавших Глиатилин, только на $13 \%$, при этом у пациентов плацебо-группы конечный объем повреждения к 30 дню наблюдения возрастал на 180 \% [41].

Проведенное исследование позволило установить, что применение Глиатилина для лечения пациентов с ишемическим инсультом способствует уменьшению неврологического дефицита и увеличению способности пациентов к самообслуживанию.

Количественная оценка конечного объема инфарктной зоны в группе обследованных больных дает возможность говорить об эффективном сохранении массы мозгового вещества в области обратимых изменений у больных с ишемическим инсультом средней степени тяжести. Полученные результаты также позволяют предположить, что большая степень восстановления нарушенных функций при использовании Глиатилина в лечении пациентов с ишемическим инсультом может быть объяснена меньшим конечным объемом поражения мозга [41].

Описанные свойства Глиатилина определили основные показания к его применению:

1) острый и восстановительный периоды тяжелой черепно-мозговой травмы с преимущественно стволовым уровнем поражения (нарушение сознания, коматозное состояние, очаговая полушарная симптоматика, симптомы поражения ствола мозга);

2) ишемический инсульт;

3) дегенеративные или инволюционные мозговые психоорганические синдромы и последствия цереброваскулярной недостаточности;

4) деменция различного генеза (в том числе болезнь Альцгеймера);

5) изменения в эмоциональной и поведенческой сфере: эмоциональная нестабильность, раздражительность, снижение интереса;

6) старческая псевдомеланхолия. 
Безопасность применения препарата Глиатилин изучалась в 43 исследованиях (12 949 пациентов). Побочные эффекты регистрировались в 0,0-2,14 \% случаев в виде: изжоги, тошноты, бессонницы, головных болей, усиления перистальтики кишечника, что привело к отмене препарата в 0,0-0,7 \% случаев.

Исследована фармакодинамика и фармакокинетика препарата. После приема внутрь абсорбция Глиатилина составляет 88 \% . Препарат легко проникает через ГЭБ, накапливается преимущественно в головном мозге (концентрация достигает 45 \% от уровня в плазме крови), легких и печени. Метаболизм и выведение: 85 \% выводится легкими в виде диоксида углерода, остальное количество (15\% ) - почками и через кишечник [41].

На основе проведенных исследований выработаны дозы Глиатилина для лечения острой и хронической церебральной недостаточности. При острых состояниях Глиатилин вводят внутримышечно или внутривенно (медленно) по 1000 мг в сутки (утром) в течение 15-20 суток. Затем - по 1200 мг (800 мг утром, 400 мг днем) в течение 6 месяцев. При хронической цереброваскулярной недостаточности и синдромах деменции Глиатилин назначают внутрь по 400 мг (1 капсула) 2-3 раза в сутки, предпочтительно до еды. Продолжительность лечения составляет 3-6 месяцев.

Таким образом, базируясь на собственных экспериментальноклинических исследованиях нейропротективного профиля модуляторов холинергической системы головного мозга, а также анализируя результаты работ других авторов, можно сделать следующие выводы , определяющие роль и место препаратов этой группы в стратегии поэтапной нейропротекции.

Важнейшим результатом экспериментальных и клинических исследований является демонстрация нейропротективной эффективности холиномиметиков центрального действия в период уже состоявшейся острой церебральной ишемии, т. е. в период, когда ишемический каскад «глютаматной эксайтотоксичности» и «кальциевой гибели» уже запущен.

Принципиально важным свойством холина альфосцерата является его способность проникать через гематоэнцефалический барьер, подвергаясь метаболизму именно в ткани головного мозга. После введения в организм, вследствие воздействия ряда ферментов, холина альфосцерат расщепляется на холин и глицерофосфат, при этом их высвобождение происходит непосредственно в ткани головного мозга.

Глиатилин (холина альфосцерат) является первым и пока единственным на украинском рынке препаратом, содержащим 40,5 \% метаболически защищенного и активного холина, который восполняет дефицит эндогенного ацетилхолина в центральной нервной системе, стабилизирует нейрональные мембраны, что обеспечивает восстановление двигательных, когнитивных, эмоциональных и поведенческих функций, оказывает пробуждающее действие при нарушении сознания.

Ипидакрин. Для современной нейротравматологии с общей тенденцией к утяжелению черепно-мозговых травм, сопровождающихся все более длительной комой и грубыми посткоматозными психическими нарушениями, решающее значение приобретает применение препаратов, способствующих уско- 
рению выхода из комы и последующему восстановлению психической деятельности больных.

Одним из средств, способствующих ускорению выхода из комы, является Амиридин (Ипидакрин), разработанный в Государственном институте азотной промышленности и разрешенный к применению Фармкомитетом МЗ СССР 27.01.1983 г. Препарат Амиридин выпускается на Олайнском химико-фармацевтическом заводе «Олайнфарм» (Латвия) под торговым названием Нейромидин [54]. Нейромидин является холиномиметическим препаратом, эффект которого обусловлен с одной стороны блокадой калиевых каналов мембран, а с другой - обратимым ингибированием холинэстеразы $[54,55]$. Это приводит к стимулирующему влиянию на проведение импульса в нервномышечном синапсе и в ЦНС.

Нейромидин действует на все звенья в цепи процессов, обеспечивающих проведение возбуждения в нервных волокнах: он стимулирует пресинаптическое нервное волокно, увеличивает выброс нейромедиатора в синаптическую щель, уменьшает разрушение ацетилхолина ферментом, повышает активность постсинаптической клетки прямым и опосредованным медиаторным воздействием [54].

Препарат способствует более быстрому выходу из комы и показан при поражениях ЦНС травматического и сосудистого генеза. Обладает ноотропным, мнемотропным, психостимулирующим, антиастеническим и антидепрессивным действием [56, 57, 58]. Поэтому он показан в остром периоде ЧМТ как компонент комбинированного лечения: на разных стадиях восстановления сознания после комы, при корсаковском синдроме, при дисмнестических синдромах, при нарушениях познавательной деятельности, праксиса и речи, при астеническом синдроме, при эмоционально-личностных нарушениях [56].

На основании проведенных исследований мы рекомендуем оптимальную дозировку Нейромидина при тяжелой чепепно-мозговой травме в зависимости от степени нарушения сознания (табл. 5.4).

Таблица 5.4

Рекомендуемая коррекция дозы Нейромидина в группе пациентов с ЧМТ

\begin{tabular}{|c|c|c|c|c|c|}
\hline $\begin{array}{c}\text { Оптимальная } \\
\text { доза препа- } \\
\text { рата }\end{array}$ & $\begin{array}{c}\text { Степень дезорга- } \\
\text { низации ЭЭГ }\end{array}$ & $\begin{array}{l}\text { Уровень } \\
\text { сознания }\end{array}$ & $\begin{array}{l}\text { Исходная доза } \\
\text { препарата }\end{array}$ & $\begin{array}{c}\text { Степень дезорга- } \\
\text { низации ЭЭГ }\end{array}$ & $\begin{array}{c}\text { Оптималь- } \\
\text { ная доза } \\
\text { препарата }\end{array}$ \\
\hline $5 \mathrm{Mr}$ & возрастает & $\begin{array}{l}\text { умеренное } \\
\text { оглушение }\end{array}$ & $10 \mathrm{Mr}$ & $\begin{array}{l}\text { снижается или } \\
\text { стабильна }\end{array}$ & $15 \mathrm{Mr}$ \\
\hline 5-10 Mr & возрастает & $\begin{array}{l}\text { глубокое } \\
\text { оглушение }\end{array}$ & $15 \mathrm{Mr}$ & $\begin{array}{l}\text { снижается или } \\
\text { стабильна }\end{array}$ & $20 \mathrm{Mr}$ \\
\hline 5-15 мг & возрастает & сопор & $20 \mathrm{Mr}$ & $\begin{array}{l}\text { снижается или } \\
\text { стабильна }\end{array}$ & $30 \mathrm{Mr}$ \\
\hline 5-15 мг & возрастает & кома I & $30 \mathrm{Mr}$ & $\begin{array}{l}\text { снижается или } \\
\text { стабильна }\end{array}$ & $45 \mathrm{Mr}$ \\
\hline отмена & возрастает & кома II & $30 \mathrm{Mr}$ & $\begin{array}{l}\text { снижается или } \\
\text { стабильна }\end{array}$ & $45 \mathrm{Mr}$ \\
\hline- & - & кома III & - & - & - \\
\hline
\end{tabular}


Использование определения типа реактивности ЦНС в ответ на введение Нейромидина с помощью количественной ЭЭГ с применением метода интегральной количественной оценки ЭЭГ-паттерна позволяет оценивать адекватность применяемой дозы препарата и необходимость ее коррекции.

Доза Нейромидина у пациентов с ЧМТ зависит от уровня нарушения сознания и должна подбираться по рекомендуемой схеме и корригироваться под нейрофизиологическим контролем.

Фармакологической реакцией, свидетельствующей о необходимости повышения дозы препарата, следует считать III 3б ПГ изменений, о необходимости уменьшить дозу вводимого препарата - II 1a, II 16.

Нейропептиды. В ангионеврологии и нейротравматологии применяется ряд препаратов (Церебролизин, Цереброкурин, Кортексин, Семакс), влияющих на нейропластические, нейромедиаторные, нейропротективные, нейротрофические и интегративные процессы в мозге [3, 8].

Реорганизация нейрональных процессов представляет собой совокупность ряда механизмов, включающих функционирование ранее неактивных путей, нейротрофическое восстановление волокон сохранившихся клеток с формированием новых синапсов, активацию нейрональных цепей. Поэтому продолжается поиск высокоэффективных нейропротекторов среди средств, восстанавливающих межнейрональную трансмиссию, обладающих трофическими и модуляторными свойствами, оказывающих регенераторно-репаративное действие, способствуя восстановлению нарушенных функций [59]. Начиная с первых дней заболевания, после формирования морфологических инфарктных изменений в веществе мозга, все большее значение приобретает репаративная терапия, направленная на улучшение пластичности здоровой ткани, окружающей инфаркт мозга, активацию образования полисинаптических связей, увеличение плотности рецепторов [60].

Иванова Н. Е., Панунцев В. С. указывают, что уровень трофического обеспечения вещества мозга влияет на механизмы некротических и репаративных процессов. Даже при сформировавшемся очаге ишемии высокий уровень трофического обеспечения способствует регрессу неврологического дефицита [60]. Поэтому продолжается поиск высокоэффективных нейропротекторов среди нейропептидов [8].

Нейропротекторы, обладающие трофическими и модуляторными свойствами (нейропептиды), оказывают и регенераторно-репаративное действие, способствуя восстановлению нарушенных функций.

Перспективным направлением в исследовании нейропептидов стало определение их роли в регуляции нейроапоптоза и влияния на экспрессию генов раннего реагирования. Нейропептиды проникают через гематоэнцефалический барьер и оказывают многофакторное действие на ЦНС, что сопровождается высокой эффективностью и выраженной направленностью действия. Клинико-иммунологический анализ показал иммуномодулирующую и нейротрофическую активность нейропептидов. Установлено повышение уровня противовоспалительных цитокинов, трофических факторов (IL-10, TNF- $\alpha$, TGF- $\beta 1$, BDNF, NGF), снижение экспрессии генов раннего реагирования c-fos, 
антиапоптотического белка bcl-2, а также повышение активности СОД в цереброспинальной жидкости [8]. Противовоспалительные, антиоксидантные, нейротрофические и антиапоптозные эффекты нейропептидов могут быть связаны с влиянием на молекулярные триггерные механизмы отдаленных последствий ишемии [8].

Открытие нейротрофических пептидных факторов побудило к формированию новой стратегии фармакотерапии - пептидергической, или нейротрофной терапии нейродегенеративных патологий. В настоящее время в интенсивной терапии неврологических заболеваний применяется шесть препаратов нейропептидной природы: Кортексин, Цереброкурин, Актовегин, Семакс, Церебролизин и Дельталицин [3, 8, 61].

Нейропептиды - эндогенные регуляторы функций ЦНС длительность действия, которых может измеряться часами. Молекулы нейропептидов представляют собой короткие аминокислотные цепи, образующиеся в результате протеолиза из более крупных белковых молекул-предшественников и существующие всего несколько секунд. Эндогенное образование нейропептида происходит в ответ на какое-либо изменение внутренней среды, что приводит к высвобождению ряда других пептидов, для которых первый является индуктором. Первичные эффекты того или иного пептида могут развиваться во времени в виде цепных и каскадных процессов [8].

Многие нейропептиды проявляют выраженные нейротрофические ростовые свойства, а также проявляют способность регулировать экспрессию ранних генов.

Особенностью структуры нейропептидов является наличие нескольких лигандных групп связывания, предназначенных для разных клеточных рецепторов. Нейропептиды способны регулировать активность про- и противовоспалительных цитокинов через модуляцию активности их рецепторов. Нейропептиды могут осуществлять медиаторную функцию, модулировать реактивность определенных групп нейронов, стимулировать или тормозить выброс гормонов, регулировать тканевой метаболизм.

Кортексин. Препарат нейропептидной природы, который представляет собой лиофилизат, полученный из мозга телят и содержащий активные нейропептиды с молекулярной массой до 10000 Да [400].

Кортексин содержит комплекс нейропептидов (адекватное, гармонично сбалансированное соотношение L-аминокислот, витаминов и микроэлементов для нормального функционирования нейронов). Препарат обладает высокой тропностью для всех отделов головного мозга, эффективен в комплексе лечебных мероприятий, применяемых при нарушениях периферической нервной системы. Кортексин является универсальным стресс-протектором [8].

Семакс. Выраженную ноотропную и церебропротективную активность продемонстрировал нейропептидный препарат - Семакс АКТГ (4-10), представляющий собой гептапептид (Met-Glu-His-Phe-Pro-Gly-Pro), и являющийся первым российским ноотропным препаратом неистощающего типа активности [8]. При интраназальном введении Семакс через 4 мин проникает через гематоэнцефалический барьер; период его полураспада в орга- 
низме несколько минут, а терапевтическое действие при однократном введении продолжается 20-24 ч. Пролонгирование действия Семакса связано с его последовательной деградацией, при которой большая часть эффектов нейропептида сохраняется у его фрагментов EHFPGP (Glu-His-Phe-ProGly-Pro) и HFPGP (His-Phe-Pro-Gly-Pro), также являющихся стабильными нейропептидами, самостоятельно модулирующими холинергическую нейротрансмиссию и генерацию оксида азота. Противовоспалительные, антиоксидантные, нейротрофические и антиапоптозные эффекты Семакса могут быть связаны с его влиянием на молекулярные триггерные механизмы отдаленных последствий ишемии [8].

Актовегин. Одним из высокоэффективных препаратов, способствующих активации церебральных и мультиорганных реституционных механизмов, является Актовегин [487].

Актовегин представляет собой депротеинизированный гемодериват, получаемый из крови телят путем ультрафильтрации; помимо неорганических электролитов и других микроэлементов, содержит 30 \% органических веществ. Биологически активные вещества, входящие в состав Актовегина: большинство основных макроэлементов, среди которых магний, натрий, кальций, фосфор и эссенциальные, нейроактивные микроэлементы - $\mathrm{Si}, \mathrm{Cu}$. Макрои микроэлементы, входящие в состав Актовегина, являются частью нейропептидов, ферментов и аминокислот, поэтому значительно лучше усваиваются, распознаваясь нейронами, чем макро- и микроэлементы, находящиеся в составе солей. Магний, по данным последних исследований, - основной компонент нейропептидных ферментов [3, 25].

Актовегин оказывает положительное действие на нарушенный церебральный метаболизм при ишемии, наблюдаются заметные изменения в накоплении глюкозы, АТФ и лактата под действием основных субстратов препарата. Кроме общей церебральной ишемии, гемодиализат с успехом применялся для улучшения энергетического статуса клеток при поражениях гиппокампа. Структурный анализа раствора Актовегина выявил в нем присутствие 6 основных микроэлементов (натрия, калия, кальция, фосфора, магния). Магний входит в Актовегин на правах компонента нейропептидных фрагментов и ферментов в качестве каталитического центра. При этом необходимо отметить, что по данным современной нейробиохимии именно магний является каталитическим центром всех известных на сегодняшний день нейропептидов головного мозга и имеет статус нейроседативного иона. Актовегин обладает как центральным действием, стимулируя процессы церебрального метаболизма, так и достаточно выраженным действием при периферических артериальных нарушениях.

Применение Актовегина позволяет решить ряд кардинальных проблем для восстановления функции мозга: увеличить поступление глюкозы в клетку, усилить ее окисление за счет активации ферментов окислительного фосфорилирования, улучшить энергетическое обеспечение клеток в условиях гипоксии. Рядом отечественных и зарубежных исследователей было доказано значительное увеличение синтеза АТФ под влиянием Актовегина [63]. 
Церебролизин - препарат, состоящий из низкомолекулярных нейропептидов $(75 \%)$ и свободных аминокислот ( $25 \%)$, получаемый по стандартизированным биотехнологическим методикам с использованием ферментативного расщепления очищенных белков головного мозга свиней, хорошо известен и широко используется в мире более 40 лет. Церебролизин представляет собой концентрат, содержащий низкомолекулярные биологически активные нейропептиды (лейэнкефалин, метэнкефалин, нейротензин, вещество Р, Р-эндорфин и др.) с молекулярным весом, не превышающим 10000 дальтон (15\%), и свободные аминокислоты (85 \% ). Церебролизин обладает комплексным нейротрофическим и нейропротективным действием [60,61].

Нейротрофическая активность Церебролизина, сходная с активностью естественных нейротрофических факторов, например фактора роста нервов, была подтверждена целым рядом экспериментальных исследований. Один из механизмов антиапоптозной активности данного препарата связан с уменьшением повреждающего действия глутамата на нейроны [411].

Мультимодальное нейроспецифическое действие Церебролизина установлено различными экспериментальными исследованиями, клиническая эффективность препарата подтверждена в ходе проспективных рандомизированных двойных слепых плацебо-контролируемых клинических испытаний, проводившихся с учетом международных требований GCP в ряде международных центров [60].

Установлено, что Церебролизин улучшает транспорт глюкозы через ГЭБ (продукция GLUT1), тем самым увеличивая число жизнеспособных нейронов и продлевая время выживаемости последних после ишемии и гипоксии, способен ингибировать образование ОН-радикалов при экспериментальной ишемии у мышей. Кроме того, была доказана способность Церебролизина защищать митохондрии нейронов от повреждающего воздействия лактат-ацидоза. Церебролизин имеет высокую общую активность СОД. Церебролизин тормозит апоптоз нейронов и улучшает рост дендритов и аксонов. Церебролизин содержит макроэлементы (МаЭ) и эссенциальные микроэлементы (МЭ), проявляет витаминную активность тиамина (витамина $\mathrm{B}_{1}$ ), фолиевой кислоты, цианкобаламина, витамина Е, содержит до 100 короткоцепочечных пептидов, в том числе глутатион и тиролибериновые фрагменты [60].

Цереброкурин является одним из наиболее перспективных препаратов нейротрофического ряда, который содержит свободные аминокислоты, нейропептиды и низкомолекулярные продукты контролируемого протеолиза низкомолекулярных белков и пептидов эмбрионов крупного рогатого скота. Механизм действия и точки приложения Цереброкурина принципиально отличаются от других препаратов нейропептидной природы, в частности от Церебролизина. Цереброкурин содержит пептиды, несущие в себе программу анализа состояния и строительства ЦНС. Таким образом, конечный эффект различается из-за качественно отличного механизма действия [64].

Защитные эффекты Цереброкурина на ткань мозга включают его оптимизирующее действие на энергетический метаболизм мозга и гомеостаз кальция, стимуляцию внутриклеточного синтеза белка, замедление процессов 
глутамат-кальциевого каскада и перекисного окисления липидов. Вместе с тем, препарат обладает выраженными нейротрофическими эффектами. В исследованиях, проведенных в последние годы, установлена способность Цереброкурина повышать экспрессию гена транспортера глюкозы (GLUT-1) через гематоэнцефалический барьер и, таким образом, увеличивать ее транспорт к головному мозгу в условиях экспериментальной ишемии [426, 427]. Показано также, что нейротрофические свойства Цереброкурина связаны с защитой цитоскелета нейронов вследствие ингибирования кальцийзависимых протеаз, в том числе кальпаина, и увеличения экспрессии микротубулярного кислого протеина 2 (MAP2). Наряду с этим, Цереброкурин увеличивает аффинность связывания нейротрофического фактора головного мозга (BDNF) с его рецепторами. Влияние препарата на trk-B рецепторы нейротрофинов может свидетельствовать о вовлечении его в регуляцию естественных факторов роста. В экспериментальных исследованиях выявлена способность Цереброкурина предотвращать гиперактивацию микроглии и снижать продукцию ИЛ$1 \alpha$ и других провоспалительных цитокинов, что отражает влияние препарата на выраженность местной воспалительной реакции и процессов оксидантного стресса в ишемизированной зоне мозга [65]. В настоящее время показано, что применение Цереброкурина при острой церебральной ишемии способствует лучшему выживанию нейронов в зоне ишемической полутени и торможению отсроченной гибели нейронов $[64,65]$.

Дельталицин является синтетическим нанопептидом, структурно соответствующим своему эндогенному аналогу. Это смесь синтетического эндогенного нанопептида, называемого пептидом, индуцирующим дельта-сон (1 весовая часть), и аминокислоты глицина (10 весовых частей). Индуцирующий дельтасон пептид имеет определенную аминокислотную последовательность. Пептид дельта-сна как основной действующий компонент Дельталицина является природным, вырабатываемым в организме нейромодуляторным пептидом, обладающим широкой фармакологической активностью. Этот пептид проявляет стрессопротективное и адаптогенное действие, увеличивает устойчивость организма к воздействию различных неблагоприятных стрессовых факторов и при патологических состояниях вследствие заболеваний разной этиологии. Пептид дельта-сна обладает антидепрессивным и противосудорожным действием, нормализует сон, проявляет антитоксические свойства, повышает умственную и физическую работоспособность, ограничивает вегетативные расстройства и кардиоваскулярные нарушения $[4,5,6,8]$. Дельталицин выпускается в виде лиофилизированного порошка для приготовления назальных капель, одна ампула содержит пептид дельта-сна 0,3 мг (0,0003 г), производитель ЧАО «Биофарма», Украина, г. Киев.

Дельталицин - представитель нейропротекторов нового поколения с сочетанным антиоксидантным, стрессопротекторным и антидепрессивным действием, обеспечивающим защиту нейронов от разрушения токсическими, инфекционными и другими повреждающими агентами [66,67]. Принципиальное отличие Дельталицина от традиционных антиоксидантов состоит в том, что его антиоксидантное действие заключается не в поглощении уже 
образовавшихся свободных радикалов кислорода, а в интенсивном подавлении самой функции образования свободных радикалов в клетках головного мозга [68].

Нимодипин. Некоторые нейропротекторы вызывают особый интерес у исследователей, в связи с чем существует очень большое количество рандомизированных исследований, которые часто являются взаимоисключающими и продолжаются по сегодняшний день. Это относится к антагонистам потенциалзависимых кальциевых каналов и прежде всего - к Нимодипину. В настоящее время, он является практически единственным доказанным эффективным церебральным $\mathrm{Ca}^{2+}$-блокатором.

Кальциевая гипотеза повреждения нейронов [487] является ведущим механизмом развития метаболических нарушений в зоне ишемической полутени [487]. Одними из главных повреждающих звеньев ишемического каскада, приводящим к смерти нейрона, являются: поступление в нейрон ионов кальция $\left(\mathrm{Ca}^{2+}\right)$, активация синтеза оксида азота (NO), липолиз фосфолипидов, перекисное и гидроперекисное окисление липидов. В неповрежденные нейроны и глиальные клетки мозга $\mathrm{Ca}^{2+}$ попадает в основном через потенциалчувствительные ионселективные каналы четырех типов - L, T, N, P, осуществляющие транспорт одно и двухвалентных ионов. В условиях патологии присоединяется диффузное проникновение $\mathrm{Ca}^{2+}$ в результате аноксической деструкции фосфолипидного бислоя мембраны клеток [62].

Связываясь с дигидропиридиновыми рецепторами, расположенными на мембранах нейронов, нейроглиальных клетках и сосудах мозга, Нимодипин (Dilceren, Nimotop), избирательно блокирует потенциалзависимые $\mathrm{Ca}^{2+}$ каналы L-типа, составляющие в коре большого мозга 23 \% от общего количества потенциалзависимых $\mathrm{Ca}^{2+}$-каналов. Препарат расширяет спазмированные сосуды головного мозга, вызывая противоишемический эффект, обладает церебропротекцией, повышая толерантность к ишемии и нейротоксинам, обладает выраженными антиоксидантными свойствами, предотвращает или устраняет отек головного мозга [70].

Модулируя поступление ионов кальция, главным образом в нейроны коры головного мозга и гиппокампа, он влияет на нейромедиаторный баланс, защищает нейроны, стабилизирует их функции, устраняет вазоспазм и повышает толерантность к ишемии, нейротоксинам, снижает смертность, связанную с субарахноидальными кровоизлияниями [71].

Согласно литературным данным, Нимодипин является одним из лучших препаратов, способных снижать смертность, связанную с субарахноидальными кровоизлияниями на почве аневризмы [72].

После блокады рецепторов глутамата (NMDA, AMPA), ионселективных кальциевых потенциалзависимых каналов увеличивается латентный период аноксической деполяризации, но развитие аноксической деполяризации не блокируется полностью, а внеклеточная концентрация кальция уменьшается только на 50 \% . При аноксии мозга увеличивается диффузное проникновение $\mathrm{Ca}^{2+}$ в нейроны в результате аноксической деструкции фосфолипидного бислоя мембраны. 
Что касается ишемического инсульта, то превалирует суждение о негативном әффекте от применения препарата, в то же время существуют и противоположные результаты. H. J. Gelmers et al. [483] провели двойное слепое рандомизированное исследование Нимодипина в сравнении с плацебо у больных с острым ишемическим инсультом. Лечение Нимодипином, по сравнению с плацебо, значительно понизило уровень летальности (в группе, принимавшей Нимодипин - 8,9 \% , в группе, принимавшей плацебо - 20,4 \% ). Наблюдение за больными продолжали 6 месяцев. В группе, леченной Нимодипином, неврологический результат был значительно лучше.

Насколько неоднозначно мнение о применении Нимодипина при ишемическом инсульте свидетельствует существование методических рекомендаций ведущих научных медицинских учреждений с взаимоисключающими подходами к лечению [62].

С нашей точки зрения, есть ряд обстоятельств, которые могут существенно влиять на эффективность Нимодипина.

Первое обстоятельство - функцию ионных насосов, осуществляющих активный транспорт ионов против градиента концентрации, выполняют различные АТФ-азы, основным субстратом которых является АТФ. В период аноксии и раннем постаноксическом периоде содержание и синтез АТФ значительно снижается. Поэтому, без восстановления энергетического дефицита нервной ткани применение блокаторов кальциевых каналов мало эффективно.

Второе обстоятельство - правильное дозирование. В начале курса терапии в течение 2-х часов вводится по одному мг Нимотопа (5 мл инфузионного раствора Нимодипина) в час (приблизительно 15 мкг/кг массы тела в час). При хорошей переносимости препарата (отсутствие снижения артериального давления и т. д.) через 2 часа дозу увеличивают до двух мг Нимотопа (10 мл инфузионного раствора Нимодипина) в час (приблизительно 30 мкг/кг массы тела в час). Для пациентов с весом значительно ниже 70 кг или лабильным артериальным давлением начальная доза должна составлять 0,5 мг Нимотопа (2,5 мл инфузионного раствора Нимодипина) в час. Внутривенную терапию следует начинать как можно раньше после начала заболевания и продолжать в течение 5-14-и дней.

После окончания инфузионной терапии в течение семи дней рекомендуется прием Нимодипина внутрь в дозе 60 мг 6 раз в сутки с промежутками в 4 часа (12 таблеток в сутки). В последующем доза постепенно снижается с назначением поддерживающей терапии.

В условиях Украины правильное внутривенное применение Нимотопа возможно только в отделениях интенсивной терапии, где есть соответствующее оборудование и подготовленный персонал.

Третье обстоятельство - адекватный контроль артериального давления. Циркуляторный коллапс при ишемическом инсульте очень редкое явление, если он и наблюдается, то, как правило, за счет сопутствующих заболеваний, таких как острый инфаркт миокарда, нарушение ритма сердца, передозировка лекарственных средств, сепсис и т. д. 
При артериальной гипотензии артериальное давление повышают, т. к. артериальная гипотензия суживает терапевтическое окно, способствует расширению зоны инфаркта, усугубляет прогноз. У больных с ишемическим и геморрагическим инсультом гораздо чаще наблюдается гипертензия. Однако она имеет транзиторный характер и, как правило, коррекция не требуется, пока больной не поступит в стационар.

Неэффективность применения Нимотопа при ишемическом инсульте связывают с его свойством вызывать развитие артериальной гипотензии, которая ухудшает кровоснабжение пенумбры. Но артериальная гипотензия при правильном применении препарата развивается, по нашему опыту, редко и легко корригируется либо волемической нагрузкой, либо инотропной поддержкой. Если артериальное давление все же плохо восстанавливается, то снижается доза вводимого препарата до 0,5 мг/час и менее, но препарат не отменяется. Курс лечения должен быть непрерывным. Рекомендуется продолжать введение инфузионного раствора Нимотопа в ходе анестезии, хирургических вмешательств и ангиографии.

Однако, адекватный контроль за развитием артериальной гипотензии и ее коррекция возможны только в условиях отделения интенсивной терапии.

Четвертое обстоятельство - правильное применение препарата. Так как действующее вещество раствора Нимотопа для вливаний (Нимодипин) абсорбируется поливинилхлоридом, следует применять инфузионные трубки только из полиэтилена. Кроме того, Нимодипин чувствителен к свету, поэтому следует использовать флаконы и трубки темного цвета или защищать их светонепроницаемыми оболочками. При применении препарата при рассеянном дневном или искусственном освещении его можно использовать без специальной защиты до 10-12 часов.

Пятое обстоятельство - правильное сочетание Нимодипина с другими лекарственными препаратами. Параллельно с непрерывным внутривенным введением Нимотопа может проводиться инфузионная терапия, включающая растворы глюкозы, хлористого натрия, другие солевые растворы, Маннитол, альбумин, кровь, декстраны и т. д. Чтобы обеспечить достаточное разведение Нимотопа, рекомендуется объем сопутствующей инфузии не ниже 1000 мл в сутки. Нимодипин растворен в спирте, поэтому нельзя назначать Нимотоп совместно с лекарственными средствами, несовместимыми со спиртом. Раствор Нимотопа нельзя добавлять непосредственно в инфузионную бутыль или смешивать с другими препаратами.

Применение Нимотопа может сочетаться с другими лекарственными препаратами при комплексном лечении различных патологий. У больных с повышенным артериальным давлением, получающих гипотензивные средства, Нимотоп может усилить гипотензивный эффект. Не рекомендуется одновременно с Нимодипином применять бета-блокаторы, так как можно спровоцировать усиление отрицательного инотропного действия вплоть до декомпенсации сердечной деятельности и неуправляемой гипотонии. Следует по возможности избегать сочетанного применения Нимодипина с другими антагонистами кальция (например, нифедипином, верапамилом) или с альфа-метилдопой. В слу- 
чаях, когда такое сочетание необходимо, терапия должна проводиться в условиях особенно тщательного контроля.

Сочетанное применение Нимодипина с Н2-антагонистом циметидином или с вальпроевой кислотой (противосудорожное средство) может привести к повышению концентрации Нимодипина в плазме.

При комбинированной терапии Нимодипином и потенциально нефротоксичными препаратами (например, аминогликозиды, цефалоспорины, фуросемид) возможны нарушения функции почек. Применение Нимотопа может приводить к усугублению нарушений у больных с уже имеющимся снижением функции почек.

Нимотоп следует применять с осторожностью при повышенном содержании жидкости в тканях головного мозга (генерализованном отеке мозга) или явном повышении внутричерепного давления.

Мы располагаем опытом применения Нимодипина при различных видах мозгового инсульта и тяжелой ЧМТ с 1994 г. по сегодняшний день, изучая изменение реактивности мозга в ответ на применение препарата. Было установлено, что применение блокаторов кальциевых каналов (в частности Нимодипина) в сочетании с нейротрофическими средствами (в частности Актовегина) при остром нарушении мозгового кровообращения различного генеза патогенетически обосновано и высокоэффективно: приводит к снижению летальности, уменьшает инвалидизацию.

Учитывая невозможность проведения рандомизированных исследований нейропротекторов, которые существуют на украинском рынке, мы избрали доступный нам путь изучения эффективности препаратов:

1) использование метода интегрального количественного анализа ЭЭГпаттерна (прежде всего изучение реактивности мозга в ответ на фармакологическое воздействие) [8].

2). Оценка эффективности применяемых нами протоколов лечения с помощью метода нейросетевого моделирования [7].

Нами получены обнадеживающие результаты при применении не только Нимодипина, но и других нейропротекторов, не прошедших проверку методами доказательной медицины.

Фенотропил (N-карбамоил-метил-4-фенил-2-пирролидон). Это ноотропный препарат нового поколения, выпускаемый АО «Олайнфарм» (Латвия) под торговым названием Энтроп ${ }^{\circledR}$. С химической точки зрения Энтроп является аналогом Пирацетама с включением в молекулу Пирацетама ГАМК-производного препарата Ноофен (гидрохлорид $\beta$-фенил- $\gamma$-аминомасляной кислоты). Именно это включение обуславливает существенные расхождения в спектрах фармакологических действий этих препаратов [73].

Важной терапевтической особенностью и существенными преимуществами Энтропа перед Пирацетамом и другими ноотропами являются сочетание ноотропного и психотропных эффектов [74, 75]. Энтроп, активируя когнитивные функции и интегративную работу мозга, повышает устойчивость организма к экстремальным воздействиям, повышает физическую работоспособность. Механизмы реализации эффектов Энтропа определяются, прежде всего, 
стимуляцией метаболических, биоэнергетических и пластических процессов в головном мозге, в т. ч. усилением синтеза белка и фосфолипидов, повышением скорости оборота информационных молекул, полимодальным влиянием на широкий диапазон синаптических систем - холинергическую, адренергическую, дофаминергическую, глутаматергическую и, главным образом, ГАМКергическую [75].

Наиболее изученные клеточные эффекты Энтропа - это повышение уровня АТФ, активация аденилатциклазы, уменьшение активности $\mathrm{Na}^{+} / \mathrm{K}^{+}$АТФ-азы, угнетение кортикального выброса пролина, усиление синтеза ядерной РНК в мозге, усиление утилизации глюкозы и др. [75, 76].

Эффекты Энтропа зависят от исходного функционального состояния ЦНС - уровня биоэлектрической активности нейронных ансамблей ЭЭГ [77].

Высокий уровень ЭЭГ-дезорганизации (значения 1-го интегрального коэффициента выше 3,5) у пациентов с ОЦН после введения Энтропа предопределяет значительную активацию преимущественно серотонинергической системы мозга с гиперпродукцией серотонина, с ускорением процессов метаболизма в нейроглиальной популяции и с умеренными асимметричными ангиоспастическими эффектами при непосредственном воздействии серотонина на морфологически измененные сосуды мозга. Применение Энтропа в этих случаях необходимо начинать с суточной дозы в 100 мг с последующей пошаговой коррекцией дозировки (шаг - 100 мг) под обязательным нейрофизиологическим контролем с определением типов реакций ЦНС.

Менее выраженная ЭЭГ-дезорганизация (уровень 1-го интегрального коэффициента ниже 3,5) у пациентов с ОЦН после применения Энтропа предопределяет значительную активацию преимущественно норадренергической системы мозга с активацией гипоталамо-гипофизарной системы, диэнцефального уровня неспецифической регуляторной системы головного мозга и структур правого полушария с симметричной оптимизацией скорости артериального кровотока в каротидных и вертебробазилярном бассейнах. Применение Энтропа в этих случаях следует начинать с суточной дозы в 300 мг и продолжать в течение двух недель [77].

Основные фармакологические эффекты Энтропа, реализуемые через нейромедиаторные системы головного мозга при ОЦН, обеспечивают восстановление умственной активности за счет холинергических активаторов, которые поддерживают общую активацию корковых функций, и адренергических ингибиторов, контролирующих и модулирующих эту активацию с тем, чтобы сделать функции мозга гибкими и адекватными функциональной задаче.

Применение Энтропа при тяжелой ЧМТ в дозе 300 мг в сутки приводит к активации мозгового кровотока: нивелирует асимметрию кровотока, увеличивает линейную скорость кровотока и скорость венозного оттока. 


\section{2. ВЗАИМОДЕЙСТВИЕ НЕЙРОЦИТОПРОТЕКТОРОВ}

Перспективным направлением в лечении острой церебральной недостаточности является поиск эффективной комбинации лекарственных средств, влияющих на разные этапы патобиохимических процессов и стимулирующих восстановительные процессы в нервной ткани $[1,2,3,4,5]$.

Комбинирование лекарственных средств обусловливает синергизм их действия, что позволяет применять сравнительно низкие дозы препаратов с уменьшением их побочных эффектов. Не следует забывать и об экономическом аспекте сочетанного применения нейропротекторов, позволяющим существенно снизить стоимость лечения пациентов с ОЦН.

Сложность решения вопроса о сочетании тех или иных нейротропных препаратов при лечении острой церебральной недостаточности различной этиологии связана с отсутствием данных об их эффективности с позиций доказательной медицины (evidence-basedmedicine) [3, 4, 5, 6].

Под взаимодействием лекарственных веществ В. В. Афанасьев, И. Ю. Лукьянова [7] понимают оцениваемое клинически и измеряемое методами функциональной и лабораторной диагностики увеличение (или ослабление) силы и длительности действия одного препарата, вызванное назначением другого препарата, включая алкоголь, биологические добавки или продукты питания.

Предпринимались попытки подобрать адекватный инструмент для лечения ишемического инсульта путем сочетания фармакокинетики ингредиентов, по-разному влияющих на звенья ишемического каскада и последствия ишемии [8]. Авторы считают, что предложенная комбинация может сопоставить и сбалансировать нейропротекторные эффекты Цераксона, Мексидола, L-лизина эсцината, и, в конечном итоге, повысить эффективность лечения и уменьшить полипрагмазию при лечении пациентов с острым ишемическим инсультом.

Получены данные об эффективном сочетании Цитиколина с другими нейропротекторами. Исследовано применение в комбинации с Нимодипином, блокаторами NMDA-рецепторов, основным фактором роста фибробластов, тканевым активатором плазминогена и Урокиназой. При этом основным эффектом таких комбинаций является уменьшение зоны инфарктов мозга и улучшение функционального состояния мозга [9, 10].

С целью ответа на главный вопрос - эффективно ли применение того или иного нейропротективного средства либо комбинации препаратов - мы применили один из ведущих методов оценки функции центральной нервной системы - количественную электроэнцефалографию. С помощью метода интегрального количественного анализа ЭЭГ-паттерна $[11,12,13]$ мы изучаем реактивность ЦНС в ответ на применение нейропротектора конкретному пациенту в динамике лечения [12].

Нами иследовано сочетанное применение Нимодипина и Актовегина. Одновременное использование Актовегина необходимо для восстановления энергетического дефицита нервной ткани за счет повышения обмена высоко- 
энергетических фосфатов (АТФ), что способствует более эффективному восстановлению гомеостаза аноксически деполяризованной клетки [14].

Необходимо отметить, что функцию ионных насосов, осуществляющих активный транспорт ионов против градиента концентрации, выполняют различные АТФ-азы, основным субстратом которых является АТФ. В период аноксии и в раннем постаноксическом периоде содержание и синтез АТФ значительно снижается. Результатом этого является дисфункция различных АТФ-аз, которая в совокупности с дисфункцией энергонезависимых ионселективных каналов и увеличением проницаемости мембраны приводит к различным нарушениями ионного обмена. Последние проявляются в виде формирования так называемой терминальной или аноксической стойкой длительной деполяризации нейрональной мембраны [15].

Восстановление ионного гомеостаза в постаноксическом периоде начинается тогда, когда концентрация тканевой АТФ в мозге достигает 30,040,0 \% контрольного уровня и зависит от интенсивности процессов рефосфорилирования АМФ, АДФ, синтеза новых аденозиновых нуклеотидов. Поэтому после перенесенной аноксии восстановление концентрации ионов в клетках мозга начинается только через две-три минуты рециркуляционного периода и заканчивается, когда концентрация АТФ составляет 60,0 \% от контрольного уровня. Следовательно, при значительном дефиците макроэргических соединений восстановление ионного гомеостаза в постаноксическом периоде не завершается [14]. Поэтому, без восстановления энергетического дефицита нервной ткани применение блокаторов кальциевых каналов должно быть менее эффективным. Примение Нимодипина в сочетании с Актовегином позволяет ускорить восстановление энергетического дефицита нервной ткани. Актовегин активирует процессы аэробного окисления, повышает обмен высокоэнергетических фосфатов, улучшает транспорт глюкозы и поглощение кислорода в тканях [16].

Нами было проведено определение объективных критериев оценки эффективности применения нейропротекторов Актовегина и Цераксона, целесообразности их сочетанного использования с помощью метода интегрального количественного анализа ЭЭГ-паттернов и изучения реактивности мозга в ответ на применение препарата. Сочетанное применение Актовегина и Цераксона вызывало преимущественно изменения ЭЭГ-паттерна, которые мы относим к благоприятным реакциям ЦНС и существенно отличалось от реакций ЦНС при изолированном введении Цераксона или Актовегина.

На основании результатов исследования мы рекомендуем оптимальные дозировки Актовегина и Цераксона при их совместном (последовательном) применении у пациентов с ОЦН в зависимости от степени нарушения сознания (табл. 5.5).

Взаимодействие лекарственных средств происходит по законам фармакодинамики, фармакокинетики и фармакогенетики, что важно для прогнозирования результата взаимодействия. Назначение лекарственных препаратов и их дозы необходимо планировать, с тем, чтобы исключить ожидаемые побоч- 
ные явления. В оптимальном варианте лучше использовать трех- или четырехкомпонентные комбинации лекарственных веществ [7].

Таблииа 5.5

\section{Рекомендуемая коррекция доз Актовегина и Цераксона у пациентов с ОЦН}

\begin{tabular}{|c|c|c|c|c|c|}
\hline $\begin{array}{c}\text { Оптимальная } \\
\text { доза препа- } \\
\text { рата }\end{array}$ & $\begin{array}{c}\text { Степень } \\
\text { дезоргани- } \\
\text { зации ЭЭГ }\end{array}$ & $\begin{array}{c}\text { Уровень со- } \\
\text { знания }\end{array}$ & $\begin{array}{c}\text { Исходная } \\
\text { доза препа- } \\
\text { рата }\end{array}$ & $\begin{array}{l}\text { Степень дезор- } \\
\text { ганизации ЭЭГ }\end{array}$ & $\begin{array}{c}\text { Оптимальная } \\
\text { доза препа- } \\
\text { рата }\end{array}$ \\
\hline $\begin{array}{l}1000 \mathrm{mr}^{*}+ \\
500 \mathrm{mг \#}\end{array}$ & возрастает & $\begin{array}{l}\text { умеренное } \\
\text { оглушение }\end{array}$ & $\begin{array}{l}1000 \mathrm{Mr}^{*}+ \\
500 \mathrm{mr}^{*}\end{array}$ & $\begin{array}{l}\text { снижается или } \\
\text { стабильна }\end{array}$ & $\begin{array}{l}1000 \mathrm{~m}^{*}+ \\
1000 \mathrm{мг \#}\end{array}$ \\
\hline $\begin{array}{l}1000 \mathrm{Mr}^{*}+ \\
500 \mathrm{мг \#}\end{array}$ & возрастает & $\begin{array}{l}\text { глубокое } \\
\text { оглушение }\end{array}$ & $\begin{array}{l}1000 \mathrm{mr}^{*}+ \\
1000 \mathrm{mr}\end{array}$ & $\begin{array}{l}\text { снижается или } \\
\text { стабильна }\end{array}$ & $\begin{array}{l}1000 \mathrm{mг}^{*}+ \\
2000 \mathrm{мг \#}\end{array}$ \\
\hline $\begin{array}{l}2000 \mathrm{mr}^{*}+ \\
500 \mathrm{mr}\end{array}$ & возрастает & сопор & $\begin{array}{l}2000 \mathrm{mr}^{*}+ \\
1000 \mathrm{mr}^{+}\end{array}$ & $\begin{array}{l}\text { снижается или } \\
\text { стабильна }\end{array}$ & $\begin{array}{l}2000 \mathrm{мг}^{*} \\
+2000 \mathrm{мг \#}\end{array}$ \\
\hline $\begin{array}{l}2000 \mathrm{mr}^{*}+ \\
1000 \mathrm{mr}^{*}\end{array}$ & возрастает & кома I & $\begin{array}{l}2000 \mathrm{mr}^{*}+ \\
2000 \mathrm{mr} \#\end{array}$ & $\begin{array}{l}\text { снижается или } \\
\text { стабильна }\end{array}$ & $\begin{array}{l}2000 \mathrm{mr}^{*}+ \\
2000 \mathrm{mr} \#\end{array}$ \\
\hline $\begin{array}{l}1000 \text { мг *+ } \\
500 \text { мг\# } \\
\text { или отмена }\end{array}$ & возрастает & кома II & $\begin{array}{l}2000 \mathrm{mr}^{*}+ \\
2000 \mathrm{mr \#}\end{array}$ & $\begin{array}{l}\text { снижается или } \\
\text { стабильна }\end{array}$ & $\begin{array}{l}2000 \mathrm{mr}^{*}+ \\
2000 \mathrm{мг \#}\end{array}$ \\
\hline $\begin{array}{l}1000 \text { мг *+ } \\
500 \text { мг\# } \\
\text { или отмена }\end{array}$ & возрастает & кома III & $\begin{array}{l}2000 \mathrm{mr}^{*}+ \\
2000 \mathrm{mr}\end{array}$ & стабильна & $\begin{array}{l}2000 \mathrm{mr}^{*}+ \\
2000 \mathrm{mr}^{*}\end{array}$ \\
\hline
\end{tabular}

* — доза препарата Актовегин

\# - доза препарата Цераксон

Основываясь на многокомпонентности постишемического каскада, разработаны саногенетически оправданные комбинации лекарственных препаратов, потенцирующих действие друг друга при лечении ишемии любой этиологии. Эти комбинации позволяют значительно уменьшить уровень постишемического нейронального повреждения, так как комплекс препаратов воздействует практически на все этапы ишемического каскада. В данном случае речь не идет о полипрагмазии, так как мишенью для каждого из препаратов является отдельное звено порочного круга постишемического каскада. Каждое из этих звеньев не является слабым и прервать этот часто необратимый патофизиологический каскад можно именно с применением комплексного воздействия [17]. Комбинирование нейроцитопротекторов являются одним из условий их эффективного действия [2, 17, 18].

Однако, на практике, выполнить фармакологически правильное сочетание препаратов не всегда возможно не только по экономическим, но и по ряду других причин, таких как: отсутствие рационального подхода к комбинированию нейроцитопротекторов и их общепризнанной классификации, отсутствие рационального подхода к разработке комбинаций их по фармакодинамике, по фармакокинетике т. к. при разнонаправленном действии векторов главного 
действия применяемых веществ создаются условия для развития нежелательных эффектов [19].

При появлении нежелательного действия важно понять, за счет чего оно произошло: из-за изменения состояния больного, вследствие его заболевания или из-за развития собственно побочного действия лекарственных веществ, т. к. в ряде случаев побочное действие лекарств может иметь проявления, сходные с клинической картиной, обусловленной заболеванием. Вероятность побочного действия лекарственных веществ при назначении двух препаратов составляет $5,6 \%$. Если количество одновременно назначаемых препаратов превышает восемь наименований, эта вероятность увеличивается на $100 \%$ (Sloan, 2004).

Адекватность дозовых сочетаний с учетом индивидуальной чувствительности к ним, прогноз возможных побочных эффектов и оценка степени их значимости в процессе лечения (соотношение «риск-польза») требуют дальнейшего изучения на большей выборке больных $[19,20]$.

\section{3. СТРАТЕГИИ НЕЙРОПРОТЕКЦИИ ПРИ ТЯЖЕЛОЙ ЧЕРЕПНО- МОЗГОВОЙ ТРАВМЕ}

Повреждение головного мозга и смерть после ЧМТ являются следствием первичного и вторичного повреждения головного мозга $[1,2]$. Первичная травма головного мозга обусловлена непосредственно биомеханическими механизмами, происходящими в момент удара, воздействием на паренхиму мозга. Вторичное повреждение мозга происходит в минуты, часы и дни после первичной травмы. Это комплекс процессов (внутри- и внемозговых, системных), осложняющих первичную травму. К ним относят: отек мозга, гематомы, гидроцефалию, внутричерепную гипертензию, вазоспазм, метаболические нарушения, иммунологические расстройства, эпилептические приступы и инфекционные осложнения. Благоприятные результаты лечения достигаются, если эти вторичные, поздние нарушения, приводящие к снижению церебральной перфузии, предотвращаются или хорошо реагируют на терапию. Это отразилось в неуклонном и значительном снижении смертности после тяжелой ЧМТ: с 50 \% до $35-25 \%$ и ниже за последние 30 лет [1]. Тенденция к снижению смертности и более благоприятным исходам ЧМТ вызвана применением основанных на доказательствах протоколов, подчеркивающих значение мониторинга и поддержания адекватной церебральной перфузии $[2,3]$.

В настоящее время общепринято, что лечение тяжелой ЧМТ должно базироваться на научной обоснованности комплекса интенсивной терапии, который предусматривает использование в основном тех методов, эффективность которых объективно доказана с помощью рандомизированных контролируемых исследований, ограничивает или исключает применение сомнительных и неэффективных методов [4, $5,6,7]$.

Такие организации, как NICE (National institute for clinical excellence) и BTF (Brain trauma foundation) регулярно выпускают протоколы и рекоменда- 
ции ведения пациентов с тяжелой черепно-мозговой травмой. Нами были изучены существующие рекомендации BTF (актуальное на данный момент 3-е издание подготовлено в 2007 году) и рекомендации ERABI team (Evidence-Based Reviewof Moderate to Severe Acquired Brain Injury), которые датируются 2013 годом. Данные этих протоколов основаны на мультицентровых проспективных рандомизированных исследованиях и соответствуют принципам доказательной медицины.

Анализируя большое количество современных протоколов по лечению ЧМТ, необходимо отметить, что практические рекомендации основаны на трех уровнях доказательств: 1-й: стандарт, который необходимо применять обязательно; 2-й: рекомендации, применять желательно; 3-й: опционная информация, которая применяется по усмотрению [8].

Анализируя проблемы интенсивной терапии при тяжелой черепномозговой травме с позиций доказательной медицины в современной нейротравматологии, необходимо отметить следующее: в силу недостаточного количества исследований 1 -го и даже 2-го класса, рекомендации на уровне стандартов сформулированы только для разделов гипервентиляции, применения глюкокортикоидов и роли противосудорожной терапии $[9,10,11,12]$. Для остальных пунктов - сформулированы на уровне опций (вариантов, мнений) [13]. Что касается применения нейропротекторов, то рекомендации по их применению в современных руководствах по интенсивной терапии тяжелой ЧМТ отсутствуют $[13,14]$. С другой стороны в литературе широко обсуждаются возможности фармакологической нейропротекции при ЧМТ [15].

Из доказательств 1-го уровня установлено, что применение гормонов при ЧМТ увеличивает летальность на 4 \%. Поэтому они не рекомендуются к применению.

Из доказательств 2-го уровня приняты рекомендации, касающиеся следующих положений: необходимо избегать гипотензии и поддерживать систолическое АД более 90 мм рт. ст., избегать профилактической гипервентиляции ( $\mathrm{pCO}_{2}$ менее 35 мм рт. ст), проводить мониторинг ВЧД всех пациентов с оценкой по ШКГ менее 8 баллов и имеющимися нарушениями на КТ, поддерживать ВЧД на уровне не более 20 мм рт. ст.

Рекомендуется установка желудочкового катетера, как наиболее безопасный, реальный и относительно недорогой способ мониторинга ВЧД (ошибка метода \pm 2 мм в пределах 0-20 мм рт. ст.). Рекомендовано для профилактики раннего судорожного синдрома (до 7 дней) профилактическое применение антиконвульсантов. Но профилактическое применение противосудорожных препаратов для предупреждения отсроченных судорог не рекомендуется. Кормление больных с ЧМТ необходимо начинать в первые трое суток (полный калораж). Аналгоседация также применяется на основании доказательств 2-го уровня. Поддержание церебральной перфузии (2-ой уровень доказательств).

Из доказательств 3-го уровня рекомендуется избегать гипоксии: $\mathrm{pO}_{2}$ должно быть более 60 мм рт. ст., а сатурация более $90 \%$. В случае применения гипервентиляции, необходимо мониторировать уровень кислорода в луковице яремной вены $[8,10]$. 
Показатель ВЧД приобрел в последние годы весомое значение и стал, по сути, краеугольным камнем в терапии тяжелой черепно-мозговой травмы [16]. Все современные протоколы и рекомендации по лечению тяжелой ЧМТ основаны на постоянном мониторинге ВЧД, поддержании его в пределах нормы и быстрой коррекции. Благодаря внедрению протоколов, основанных на принципах доказательной медицины, сейчас в США у 85 \% больных с тяжелой черепно-мозговой травмой ведется мониторирование ВЧд, что привело за 10 лет к значительному снижению смертности и улучшению исходов.

В протоколах появился целый ряд новых положений $[17,18,19]:$ мониторинг содержания кислорода в ткани мозга: сатурация кислорода в луковице яремной вены $\left(\mathrm{SjO}_{2}\right)$, метод прямого определения напряжения кислорода в ткани мозга $\left(\mathrm{ptiO}_{2}\right)$ и метод церебральной оксиметрии $\left(\mathrm{rSO}_{2}\right)$.

В последние годы к гипотермии, как методу нейропротекции, активно приковано внимание. Гипотермия оказывает следующие положительные эффекты: уменьшает уровень мозгового метаболизма, уменьшает степень неврологических осложнений ЧМТ, разрушение ткани, уменьшает аксональное повреждение, отёк, микрососудистую дисфункцию [19]. При снижении температуры у больных ЧМТ до уровня $32-35^{\circ} \mathrm{C}$ более 48 часов снижается смертность (3-й уровень доказательств).

3-й уровень доказательств касается профилактики инфекционных осложнений при тяжелой ЧМТ, профилактики венозных тромбозов, которые при тяжелой ЧМТ встречаются в 20 \% наблюдений, гиперосмолярной терапии.

Рекомендуется введение Маннитола в дозе $0,25-1,0$ мг/кг для снижения ВЧД, избегая гипотензии (2-ой уровень доказательств). Рассматривается тщательное мониторирование ВЧД при применении Маннитола (3-ий уровень доказательств). Маннитол, создающий осмолярный градиент, мобилизует воду вокруг интактного ГЭБ и нормализует местный мозговой кровоток. Гипертонический раствор оказывает аналогичный, иногда более сильный, осмолярный градиент, также снижающий ВЧД. Для интенсивной терапии повышенного ВЧД, гиперосмолярные растворы следует вводить каждые 4-6 часов или просто непрерывно, потому что феномен «рикошета» может привести к обратному изменению онкотического давления, перемещению жидкости во внутриклеточное пространство мозга [20]. Тщательный контроль инфузионной терапии, электролитного статуса и осмолярности (менее 320 ммоль/л) - обязательные условия для использования гипертонических растворов. При осмолярности более 320 ммоль/л Маннитол противопоказан.

К сожалению, ни один прокол лечения ЧМТ, основанный на доказательной медицине не акцентирует внимание на инфузионной терапии. Тем не менее, поддержание нормального коллоидно-осмотического давления - крайне важный момент интенсивной терапии тяжелой черепно-мозговой травмы. Введение альбумина пациентам, находящимся в критическом состоянии, считалось в последнее время нежелательным элементом терапии, увеличивающим смертность. Однако, последние метаанализы показали отсутствие неблагоприятных реакций на введение альбумина, более того, установлено, что гиперон- 
котический 20 \% раствор альбумина улучшает органную функцию, оцениваемую по шкале SOFA [21,22,23].

Необходимо отметить, что постоянно ведутся разработки новых направлений интенсивной терапии ЧМТ. Например, декомпрессионная краниотомия - это метод, по поводу которого в настоящее время нет однозначного мнения. По последним данным, размер краниотомии должен быть не менее 15 на 15 см [24].

Мониторинг при тяжелой ЧМТ крайне важен, строго показан пациентам с аналгоседацией, находящимся на ИВЛ. Кроме стандартного системного мониторинга, важно постоянное мониторирование ВЧД и ЦПД (церебрального перфузионного давления). Основная цель интенсивной терапии - достижение ЦПД до 70 мм рт. ст., при этом ICP (интракраниальное давление) должно быть ниже 25 мм рт.ст. в первые сутки а МАР (среднее артериальное давление) должно быть около 95 мм рт. ст. [7].

Стабильная или улучшающаяся неврологическая симптоматика предусматривает следующие физиологические параметры: $\mathrm{SjO}_{2}$ и rSO2 55-75 \% ; $\mathrm{PbtiO}_{2}>20 \mathrm{mmHg}$; ВЧД не более 20-25 мм рт. ст., СРР не менее 60 мм рт. ст.; $\mathrm{PaCO}_{2}$ 33-40 мм рт. ст.; $\mathrm{PaO}_{2}$ не менее 140 мм рт.ст.; ЦВД 5-10 мм рт. ст. При этом осмолярность в плазме крови в норме или выше, а концентрация глюкозы, калия и натрия в плазме крови в пределах нормы [22, 25].

В крупном исследовании, проведенном Американским национальным институтом инсульта, была сделана попытка комбинирования 6 наиболее успешных новых нейротропных препаратов с комплексом классической интенсивной терапии ЧМТ с целью создания эффективной нейропротекции [26]. Особо подчеркивается важность проведения полного комплекса лечения в первые 72 часа после травмы.

Из множества крупных мировых исследований, проводящихся в данный момент, внимание привлекает успешное использование эритропоэтина при тяжелой ЧМТ австралийскими и американскими исследователями [19, 27]. Эритропоэтин - это гликопротеиновый гормон с цитокиноподобным эффектом. Доказано, что он проникает через гематоэнцефалический барьер и оказывает нейропротективное действие на ЦНС, снижает смертность у пациентов с травмой [28]. Системное введение единственной дозы эритропоэтина временно увеличивает нейрогенез в сформированной мозговой ткани [34]. Введение эритропоэтина оказывало нейропротективный әффект во всех исследованиях, моделировавших травму ЦНС. Терапевтическое окно эритропоэтина составляет 6 часов [29].

В настоящее время появились доказательства нейропротекторных свойств статинов, не связанных с действием на холестерин. $К$ примеру, в острой стадии ЧМТ, статины оказывают противовоспалительный эффект, благодаря чему уменьшается вероятность развития церебрального отека и внутричерепной гипертензии, они обладают эндотелиопротекторными свойствами, благодаря чему восстановление церебральной перфузии после травмы происходит значительно быстрее [30, 35]. Назначение Аторвастатина после ЧМТ значимо 
снижает неврологический дефицит, повышает выживаемость нервных клеток и синапсогенез в пограничной зоне повреждения и в $\mathrm{CA}_{3}$ области гиппокампа, индуцирует ангиогенез в этих областях в эксперименте на крысах [32].

Новый препарат в списке нейропротекторов - это прогестерон. Он хорошо известен и широко используется в акушерстве и гинекологии, однако достоверно изучено наличие рецепторов к нему в ЦНС у мужчин и женщин. Прогестерон влияет на нейрональную дифференцировку в период беременности. С точки зрения терапии ЧМТ, прогестерон защищает и восстанавливает гематоэнцефалический барьер, уменьшает церебральный отёк путем уменьшения вазогенного и цитотоксического отёка, нормализует ауторегуляцию воды в мозговой ткани (аквапориновые каналы), блокирует воспалительный каскад и синтез провоспалительных цитокинов в ответ на нейротравму, уменьшает свободнорадикальное и липидное окисление и наконец, уменьшает выраженность апоптоза [30, 31, 35].

В настоящее время рассматривается нейропротекторная терапия, направленная на прерывание каскада эксайтотоксичности в мозговой ткани до того момента, когда процесс нейронального повреждения станет необратимым [36]. Допаминергический агонист Амантадин оказывает влияние и на допаминовые, и на NMDA-рецепторы. Амантадин усиливает высвобождение пресинаптического допамина и ингибирует обратный захват допамина, что приводит к увеличению количества допамина в синаптической щели. Препарат может также увеличить плотность постсинаптических допаминовых рецепторов и изменить конформацию этих рецепторов. Амантадин действует как антагонист рецепторов NMDA, блокируя глутамат - активатор NMDA-рецепторов, что объясняет пожительный эффект от применения Амантадина у пациентов с ЧМТ [36].

Ограниченное количество исследований показывают, что Амантадин ускоряет выход пациента из комы. Недавнее рандомизированное исследование установило, что применение Амантадина у пациентов после ЧМТ сокращает сроки реабилитации. В последнем метаанализе ECABI, проведенном в 2013 году, говорится, что Амантадин может улучшать сознание и познавательную функцию у коматозных пациентов с ЧМТ.

Таким образом, для современной нейротравматологии с общей тенденцией к утяжелению черепно-мозговых травм, сопровождающихся все более длительной комой и грубыми посткоматозными психическими нарушениями, решающее значение приобретает применение препаратов, способствующих ускорению выхода из комы и последующему восстановлению психической деятельности больных.

Общими задачами лечения являются адекватная оксигенация, перфузия, питание, гликемический контроль и нормотермия. Должна проводиться защита мозга от судорог.

Не рекомендуется гипервентиляция для контроля ВЧД, усиливающая степень ишемии. Гипервентиляция при показателях $\mathrm{PaCO}_{2}$ ниже 34 мм. рт. ст. может привести к увеличению гипоперфузии мозговой ткани. Применение трометамина противодействует пагубным последствиям длительной гипервентиляции и приводит к лучшим результатам лечения у пациентов с ЧМТ. Ги- 
пероксия может противодействовать возникновению неблагоприятных последствий длительной гипервентиляции для контроля ВЧД у пациентов с ЧМТ.

Осмотерапия, по-прежнему, является общепринятым и доказавшим свою эффективность способом регуляции ВЧД, не заменяющим однако декомпрессионную краниотомию, которая должна проводиться как можно раньше. У взрослых проведение стандартной краниотомии приводит к улучшению контроля ВЧД и лучшим клиническим исходам к 6-му месяцу, по сравнению с пациентами, которым выполнена ограниченная краниотомия.

Доказано, что поднятие головного конца кровати на $30^{\circ}$ приводит к понижению ВЧД и улучшает показатели ЦПД у пациентов с ЧМТ. Установлено, что дренаж цереброспинальной жидкости приводит к уменьшению ВЧД и повышению ЦПД у пациентов с ЧМТ. Пронационное положение может увеличить оксигенацию и ЦПД у пациентов с острой респираторной недостаточностью.

Исход пациентов с черепно-мозговой травмой зависит от возраста, неврологического статуса, тяжести травмы и качества ухода. Качество ухода зависит, в свою очередь, от уровня развития здравоохранения. В лечении пациентов с тяжелой черепно-мозговой травмой важно не только лечение в специализированном отделении. Важными элементами являются: догоспитальная помощь, быстрая доставка в специализированный центр, госпитальный лечебно-реабилитационный комплекс.

Таким образом, уровень качества лечения больных с ЧМТ зависит не только от соответствующей интенсивной терапии, но и от качества организации медицинской помощи. Полное применение протоколов лечения, основанных на принципах доказательной медицины и достоверно снижающих смертность, зависит напрямую от организации системы здравоохранения [9, 10, 11 , $32,33]$.

\section{4. СОВРЕМЕННЫЕ ПОДХОДЫ К ДИАГНОСТИКЕ И ЛЕЧЕНИЮ ИШЕМИЧЕСКОГО ИНСУЛЬТА}

Ключевым вопросом в диагностике и лечении инсульта является изучение степени поражения мозговой ткани и гематоэнцефалического барьера. Необходимо отметить, что данные по патофизиологии ишемического инсульта существенно расширились за последние годы. Доказана общность патогенетических изменений, как при ишемическом инсульте, так и при нарушениях мозгового кровообращения по геморрагическому типу и травмах мозга [1]. Известные изменения в зоне пенумбры, сформированные преимущественно под патологическим воздействием глутаматного каскада, и есть главная цель в терапии ишемического инсульта [2].

Для изучения динамических аспектов взаимосвязи процессов, проходящих в мозге, используются методы функциональной визуализации, основанные на новейших технологиях. Такие методы как функциональное магнитнорезонансное сканирование, позитронно-эмиссионная томография (ПЭТ) и ком- 
пьютерная однофотонная томография позволяют наблюдать многообразные формы активности в разных областях человеческого мозга во время решения всевозможных когнитивных задач [3]. Самое большое преимущество ПЭТ в том, что разные радиоиндикаторы могут показывать кровообращение, оксигенацию и метаболизм глюкозы в тканях работающего мозга. Среди существующих в настоящее время методов нейровизуализации ИИ ведущее место принадлежит магнитно-резонансной томографии (MPT), в том числе таким ее методикам, как диффузионно-взвешенная МРТ (ДВ-МРТ) и МРТ-перфузия, позволяющим визуализировать очаг повреждения уже в первые минуты после его развития, а также оценивать при этом состояние кровотока в различных участках мозга [4].

Информативным при ишемических нарушениях мозгового кровообращения является совместное использование диффузионно-взвешенной и перфузионной МРТ головного мозга, которое позволяет выявлять зону ишемической полутени и индивидуализировать лечение больного. Метод является золотым стандартом в диагностике объемов пенумбры, соотношение PWI-DWI (диффузионно-взвешенная MPT показывает объем потенциально восстановимой ткани, а перфузионно-взвешенная МРТ — ткани, необратимо пострадавшей [4].

В настоящее время основным методом оценки метаболизма головного мозга является тканевой микродиализ. Методика тканевого микродиализа основана на пассивной диффузии веществ, находящихся в интерстициальной жидкости головного мозга, через полупроницаемую мембрану. При помощи микродиализа возможно определение концентрации глюкозы, глицерола, глутамата и отношения лактат/пируват [5].

Сочетание новых методов с традиционными (позитронно-эмиссионная томография, функциональная магнитно-резонансная томография, сканирование и магнитная энцефалография) дает возможность исследовать процессы, происходящие в человеческом мозге, на макроскопическом уровне.

Несмотря на бурное развитие методов функциональной нейровизуализации с детальным исследованием кровообращения мозга и его метаболизма, адекватную интегральную оценку состояния ЦНС можно получить только с помощью ЭЭГ-исследования [6]. Современная электроэнцефалография относится к числу наиболее распространенных методов исследования деятельности головного мозга человека в норме и патологии. Неинвазивность и безопасность, отсутствие ограничений по времени исследования и состоянию человека, меньшая стоимость, по сравнению с рентгенологическими методами нейровизуализации, являются бесспорными достоинствами данного метода. Внедрения методов математического анализа существенно повысили информативность ЭЭГ $[7,8,9,10,11]$.

В последнее время все больше внимания привлекает диагностика, включающая определение нейроспецифических белков (НСБ) - биологически активных молекул, специфичных для нервных тканей в плазме крови, отражающих повреждение мозговой ткани. За последние 30 лет найдено и охарактеризовано более 60 различных НСБ [12]. 
При повреждениях мозговой ткани эти исследования помогают дифференцировать повреждения различных видов мозговой ткани. Наиболее привлекательно использование теста НСБ для определения постишемических повреждений мозга [13].

На сегодняшний день наиболее перспективными маркерами повреждения центральной нервной системы и головного мозга являются следующие:

- NSE (нейрон-специфическая энолаза) - гликолитический нейронспецифический изофермент энолазы. Фермент присутствует в клетках нейроэктодермального происхождения, нейронах головного мозга и периферической нервной ткани. Наиболее привлекательно использование теста NSE для определения постишемических повреждений мозга [14].

- GFAP (глиофибриллярный кислый протеин) является специфическим белком филаментов астроцитов; рост антител к нему сопровождает процессы патологического разрастания астроглиальных клеток (глиоз). Является одним из главных иммуноцитохимических маркеров астроцитов - представителя макроглии в ЦНС. В качестве маркера астроцитов он широко применяется в диагностических целях и в экспериментальных работах при исследовании функций нервной системы в норме и при патологии [15]. Постоянно возрастающее число работ, посвященных астроцитам, связано с многообразием функций, которые, как установлено за последние два десятилетия, выполняют в центральной нервной системе эти клетки [15]. Ряд исследований посвящен изучению активности нейронспецифичных белков при нейродегенеративных заболеваниях, черепно-мозговой травме и нарушениях мозгового кровообращения [15]. В зависимости от типа поражения нервной ткани (преимущественное поражение нейронов или глии), имеется возможность более точно корректировать интенсивную терапию в индивидуальном порядке и таким образом достичь дифференцированного подхода к терапии.

Как известно, мозговая ткань, отделенная ГЭБ, принадлежит к классу скрытых аутоантигенов [16]. На фоне разрушения ГЭБ в результате ответа на ишемию мозговой ткани толерантность к этим молекулам не возникает и их попадание в кровоток может приводить к иммунному ответу, что влечет за собой развитие прямой цитотоксичности [17]. Авторы статьи считают, что перспективным методом в диагностике поражения мозговой ткани является изучение титров антител, как к серому, так и к белому веществу головного мозга. Возможность определения титра антител к мозговой ткани может коррелировать с изучением таких нейронспецифических белков, как нейронспецифическая энолаза (антитела к серому веществу) и глиофибриллярный кислый протеин (белое вещество). Создание антигенного комлекса с последующим определением титра антител к серому и белому веществу головного мозга в острейшем периоде ишемического инсульта может быть реальной альтернативой использо- 
ванию дорогостоящих и малодоступных маркеров повреждения ЦНС. Наиболее распространенным алгоритмом лечения острейшего периода ишемического инсульта считаются рекомендации организации "American Heart Association » (последние были изданы в 2013 году) [6].

Основной тренд рекомендаций: по всем пунктам требуются дальнейшие исследования. Более того, нет ни одного пункта рекомендаций, трактуемого, как однозначно эффективный и безопасный метод лечения [22].

$\mathrm{C}$ позиций доказательной медицины, интенсивная терапия острых цереброваскулярных расстройств включает три основные группы мероприятий [6]:

1) неспецифические, или общие, мероприятия(поддержание витальных функций);

2) специфические мероприятия улучшение перфузии (внутривенный или внутриартериальный тромболизис);

3) нейропротекция;

4) превентивные мероприятия (антикоагулянты, антиагреганты, статины, хирургия сонных артерий).

В рекомендациях «Stroke» достаточно четко описан алгоритм терапии на каждом этапе лечения [5]. На догоспитальном этапе рекомендуется:

1. Не снижать артериальное давление.

2. Провести первичный кардиомониторинг.

3. Поддерживать $\mathrm{SpO}_{2}>94 \%$.

4. Обеспечить венозный доступ; рестриктивная инфузионная терапия.

5. Определить концентрацию глюкозы и провести ее коррекцию. Не вводить дестрозосодержащие растворы.

6. Записать время начала симптомов заболевания.

7. Не давать лекарства перорально.

8. Как можно быстрее доставить пациента в инсультный центр или ближайшую больницу, готовую для лечения инсульта.

9. Предупредить по телефону сотрудников больницы.

10. После прибытия пациента в клинику и до введения препарата rtPa должно пройти не более 60 минут [19].

Для оценки степени тяжести используется шкала NIHSS. Далее проводятся общие диагностические мероприятия, включающие: КТ или MPT мозга без контраста, определение уровня глюкозы, оксигенации крови, электролитов крови, показателей ренальной функции, показателей общего анализа крови, тромбоцитов, маркеров кардиальной ишемии, протромбина, МНО, АЧТВ, запись ЭКГ $[6,19]$. По необходимости и решению врача диагностическую программу можно расширить: определение тромбинового времени (если пациент принимает ингибиторы тромбина или Ха-фактора), показателей функции печени, токсикологической панели, уровня алгоколя крови, газы крови (если есть подозрение на гипоксию), рентгенография легких, ЭЭГ (если есть судороги), люмбальная пункция (если подозревается геморрагический инсульт, но на КТ нет признаков геморрагии) [6]. 
Как уже говорилось выше, с целью нейровизуализации необходимо выполнение КТ или МРТ перед началом терапии. Рекомендуется неинвазивное исследование интракраниальных сосудов перед тромболизисом или тромбэктомией. «Золотой стандарт» - перфузионно-взвешенная MPT [15].

После выполнения комплекса диагностических мероприятий, следует организовать первичные лечебные мероприятия, включающие:

1. Борьба с гипоксией (сатурация $<96 \%>5$ минут). Кислород. ИВЛ.

2. Подъем головного конца кровати на $15-30^{\circ}$ Профилактика аспирации.

3. Гипертермия. Антипиретики по показаниям.

4. Кардиомониторинг (ЭКГ, холтер).

5. Артериальная гипертензия. Коррекция, если >185/110 ммрт. ст. Урапидил (10-50 мг). Лабеталол (10-20 мг). Никардипин (5 мг/час в/в).

6. Инфузионная терапия при гиповолемии в объеме 30 мл/кг/сут.

7. Поддержание нормогликемии.

Весомые достижения в изучении патофизиологии ишемического повреждения головного мозга определили успех реперфузионных методик в терапии инсультов. Препаратом выбора при этом является тканевой активатор плазминогена (tPA) [6]. Другие тромболитические агенты на сегодняшний день не обнаружили своих преимуществ перед tPA. $K$ сожалению, к применению тромболитической терапии существует ряд ограничений, прежде всего связанных с короткой продолжительностью терапевтического окна. Уже через 3 ч от начала инсульта преимущества от применения tPA существенно уменьшаются, перекрываясь стремительно возрастающим риском геморрагических осложнений.

Многочисленные попытки найти препарат, который был бы столь же эффективным, как tPA, но более безопасным, пока не увенчались успехом, хотя исследования в этом направлении продолжаются. Перспективным является такой новый тромболитик, как десмотеплаза, обладающий более высоким аффинитетом к фибрину, чем tPA. Вероятно, десмотеплаза может стать первым тромболитиком, показанным в пределах первых 9 ч после начала инсульта. В настоящее время проходят исследования III фазы с этим препаратом.

На сегодняшний день, единственным одобренным FDA методом фармакологической терапии ИИ является введение Актилизе в дозировке 0,9 мг/кг, максимум 90 мг [6]. Однако, для данного препарата известно 3 показания и 22 противопоказания. Необходимо быть готовыми к таким осложнениям, как кровотечения и сосудистый отек (у 6,5 \% пациентов). Именно по этой причине в специализированных центрах США и Западной Европы данный метод применяется лишь у 5-15 \% больных с ИИ.

Существуют альтернативные эффективные способы реваскуляризации путем эндоваскулярных вмешательств для пациентов, которым противопоказан внутривенный тромболизис. $К$ ним относятся: внутриартериальное введение rtPa, механическое удаление тромба для достижения реканализации (концентричный нитиноловый ретривер (MERCI); эндоваскулярный фотоакустиче- 
ский реканализатор (EPAR); система PENUMBRA), «восстанавливающие» это стенты восстанавливающие просвет в артерии (Solitaire FR и Trevo) - новый способ стентирования, не требующий двойной антикоагулянтной терапии. Эффективность реканализации - в 81 \% случаев, улучшение - в 67 \%, смертность - 31 \% [6]. В Украине также применяют методы эндоваскулярной хирургии: выполнение каротидной эндартерэктомии, эндоваскулярной ангиопластики со стентированием, устранение деформаций анатомического хода артерий, создание обходного шунтирования, стентирование внутренней сонной артерии при ее стенозе. $\kappa$ сожалению, и эти методы обладают недостатками в виде гиперплазии неоинтимы после установки стента.

К мероприятиям дальнейшей комплексной терапии относится введение антикоагулянтов и антиагрегантов [6]. Эффективность антикоагулянтов и ингибиторов тромбина в острейшем периоде не доказана (класс 2б, уровень доказательности Б). Не рекомендуется введение антикоагулянтов в течение 24 часов от момента введения rtPa (класс 2б, уровень доказательности Б). Рекомендуется введение аспирина в дозировке 325 мг в первые двое суток перорально (класс 1, уровень доказательности А). Эффективность клопидогреля не доказана (класс 2б, уровень доказательности С) [19].

Данная стратегия согласуется с выводами многих исследователей $[5,6]$. B исследовании D. Leys et al., комбинированная терапия улучшала результаты лечения и исходы острого ишемического инсульта. Мероприятия включали: поддержание жизненных функций и биологических параметров в пределах нормы, профилактику осложнений, госпитализацию в инсультное отделение, введение rtPA в пределах 3-4,5 часов (если тромболизис не проводится - введение аспирина в дозе 160-300 мг), декомпрессивная краниотомия для пациентов с повышенным внутричерепным давлением или риском развития злокачественного инфаркта мозга.

Также, внимание уделяется методикам гиперволемии и гемодилюции при помощи введения гидроксиэтилкрахмалов и альбумина [6]. Альбумин рекомендуется, как в сочетании с rtPa, так и отдельно. Исследования оптимальных дозировок продолжаются (от 0,34-2 г/кг 25 \% альбумина). С целью оптимизации уровня мозгового кровотока рекомендуется управляемая гипертензия: сначала короткий период (60 минут) применения вазопрессоров для оценки переносимости [6]. Целевое значение среднего систолического давления (СД) - 180 мм рт. ст. Продолжаются исследования оптимального уровня СД. Для вазодилатации рекомендован Пентоксифиллин. Однако, его эффективность доказана в малых исследованиях. Также, применяется баллонная дилатация сосудов методом NeuroFlow, но без доказательств эффективности в масштабных исследованиях [6].

Некоторые компоненты рекомендаций появились впервые, а именно раздел, касающийся борьбы с отеком головного мозга. При данной патологии преобладает цитотоксический отек с пиком развития на 4-е сутки. Рекомендуется избегать введения гипосмолярных растворов, антигипертензивных препаратов, глюкозы, поддерживать нормооксигенацию, нормотермию. Обеспечить подъем головного конца кровати на 20-30. Терапия Маннитолом: 
0,25-0,5 г/кг (в/в 20 минут), каждые 6 часов. Максимальная доза -2 г/кг. Гипервентиляция с целевым значением $\mathrm{PaCO}_{2}-30-35 \mathrm{~mm} \mathrm{Hg}$. Для гипертонических растворов, кортикостероидов, внутрижелудочкового дренирования не доказана эффективность в качестве препаратов для борьбы с отеком головного мозга [6].

За последние годы произошла значительная трансформация представлений о нейропротекции. Подход к реализации нейропротективного воздействия является, пожалуй, наиболее спорным и обсуждаемым моментом. Классическая идеология лечения ишемии мозга, представление о пенумбре, глутаматной эксайтотоксичности и т. д. предусматривает применение первичной и вторичной нейропротекции [20]. Причем первичная нейропротекция направлена на прерывание быстрых реакций глутамат-кальциевого каскада, свободнорадикальных механизмов, которая начинается с первых минут ишемии и продолжается в течение трех дней. А вторичная нейропротекция направлена на блокаду провоспалительных цитокинов, молекул клеточной адгезии, торможение прооксидантных ферментов, восстановление нейротрофики и прерывание апоптоза. Вторичная нейропротекция может быть начата через 6-12 часов после сосудистого инцидента и продолжаеться не менее 7 суток [20].

Клинические испытания, проверяющие множество потенциальных нейропротекторных веществ, дали отрицательные или разочаровывающие результаты [504-508]. Метаанализ международных исследований нейропротекции, проведенный в США выявил два нейропротектора - Церебролизин и Цитиколин, которые соответствуют критериям доказательной медицины [6]. Ученые считают, что наибольший интерес для изучения в этом направлении представляют такие группы препаратов, как антагонисты глутамата, антиоксиданты, блокаторы кальциевых каналов, хелаторы кальция и некоторые другие [14].

Учитывая, что уже существуют препараты для воздействия на пенумбру, стал вопрос о средствах доставки этого препарата к месту действия. Таким веществом могут быть липосомы. Липосомы могут транспортировать лекарства, надолго удерживая их в кровотоке, облегчая процесс их проникновения через ГЭБ в паренхиму мозга [14]. На липосомах можно закреплять любой нейропротектор, например Цитиколин, хорошо известный, доказавший свою эффективность во многих исследованиях [14]. На липосомах можно закреплять вещества, снижающие метаболизм мозга (Лидокаин, Бензокаин, Диазепам). При их прямой доставке в ишемизированную ткань возможно быстрое снижение метаболизма пенумбры. Кроме того, возможна прямая доставка молекул АТФ, закрепленных на липосомах (с целью восполнения энергетических потерь) [4]. Таким образом, по мнению исследователей, новые перспективные пути доставки нейропротекторов могут помочь в быстром восстановлении ишемизированной ткани головного мозга [22].

В рекомендациях крайне сжато освещается вопрос использования нейропротекторов. В настоящее время, нет нейропротектора, доказавшего эффективность и улучшающего исход ИИ [6]. Однако, нейропротекцию используют и включают в нее: фармакологическую, метод гипотермии, лазерную терапию и гипербарическую оксигенацию (класс 3 , уровень док. А). Рекомендуются ста- 
тины (класс IІа, доказательность В) [6]. На сегодняшний день изучаются более 1000 препаратов, проводится более 100 клинических исследований (в самых неожиданных комбинациях: кофеин, алкоголь, каннабиол). Тем не менее, данных по эффективности пока не получено. Причина, скорее всего, кроется в невозможности адаптации методов доказательной медицины к мультифакторным заболеваниям. В малых исследованиях доказана эффективность магнезии, Цитиколина, Церебролизина, но препарата для мононейропротекции не найдено.

Исследователи склоняются к использованию полинейропротекции применению нескольких препаратов, каждый из которых воздействует на конкретное патологическое звено.

В Украине применение нейропротекторов регламентировано приказами МЗУ № 487 и № 602. В данных приказах отсутствуют четкие протоколы применения нейропротекторов, однако их использование и назначение разрешено по усмотрению лечащего врача.

Нефармакологическая нейропротекция, о которой говорилось выше, применяется в виде гипотермии $\left(34-35^{\circ} \mathrm{C}\right.$ с очень медленным последующим согреванием (риск эффекта рикошета, отека, повышения ВЧД), ГБО (эффективность при АТА от $1,5-3,0$ ) и путем фотобиостимуляции методом инфракрасного лазера.

Необходимо остановиться также на вопросе нутритивной поддержки пациентов с ИИ. Нейрореанимационному контингенту больных необходим особый тип нутриционной поддержки, в связи с интенсификацией катаболизма и длительным голоданием. Рекомендуется энтеральное желудочное введение смесей или смешанное энтерально-парентеральное (если энтерально невозможно обеспечить более 60 \% потребностей). Общий калораж составляет 20-30 ккал/кг/день с повышенным белковым содержанием. Наиболее частые осложнения - увеличение объема внутрижелудочного содержимого и гипергликемия. Начинать питание необходимо максимально рано (уровень доказательности $\mathrm{Ib})$, энтеральным путем (Ib), положение полусидя (снижение ВЧд, снижение риска аспирации) (ІІа). Нет исследований, доказывающих преимущество парентерального питания. Парентеральное питание показано только в случае медикаментозной седации. Калораж должен составлять 20-25 ккал/кг/сут, у седированных пациентов: 25-30 ккал/кг/сут, глюкоза: не более 5 г/кг/сут, жиры: 0,7-1,5 г/кг/сут, белки в первую неделю: 1,3-1,5 г/кг/сут, начиная со второй недели: 1,3 /кг/сут.

Нейропротекцию подразделяют также на прямую (применение лекарственных средств или физиологических воздействий, ингибирующих биохимические, метаболические и клеточные последствия ишемического повреждения) и непрямую (обеспечение восстановления кровотока и доставки энергетических субстратов к ишемизированной, но не погибшей ткани мозга) [5]. Более широкое определение нейропротекции включает применение лечебных подходов, снижающих частоту возникновения новых или повторных инсультов или уменьшающих объем и выраженность повреждения мозга в случае развития инсульта. 
Рациональная нейроцитопротекция при острой и хронической ишемии мозга - это воздействие на разные этапы ишемического каскада для создания условий, адаптирующих нейроны к новым функциональным условиям [26]. Основные механизмы воздействия нейроцитопротекторов на системы патологических дисбалансов, возникающих при остром инсульте, включают: блокаду медленных $\mathrm{Ca}^{2+}$-каналов, предотвращающую расстройства функций $\mathrm{Na}$, Са-АТФ-азы (к препаратам, обладающим таким действием, относится Нимодипин); конкурентный антагонизм к НМДА-рецепторам, который свойственен Мемантину; аллостерическое ингибирование канала НМДА-рецептора, которое обусловливает нейропротективное действие сульфата магния; сохранение композиции нейрональных мембран за счет стабилизации их фосфолипидных структур, свойственное Цитиколину; использование энергетических ресурсов промежуточного обмена веществ, которое лежит в основе антигипоксического действия Актовегина и антиоксидантов на основе янтарной кислоты [6].

Однако неудачи, последовавшие при клинических исследованиях новых препаратов, привели к тому, что в руководствах по лечению инсульта, подготовленных наиболее известными в мире специалистами, либо не упоминается о нейропротекции вовсе, либо очень коротко констатируется, что поскольку клинические исследования не подтвердили эффективность нейропротекции, для её применения в клинической практике нет оснований. За исключением внутривенного тромболизиса, который показан в 5-15\% ишемического инсульта, и некоторых нейропротекторов (Цитиколин), большинство лекарственных средств, успешно применявшихся в экспериментальных исследованиях, оказались неэффективными в клинических исследованиях [6].

Вместе с тем, исследования показали, что клиническая эффективность нейропротекторов снижается вследствие дефицита доставки их в ишемизированную ткань или недостаточно благоприятного действия на белое вещество, где нет многих рецепторов - точек приложения нейропротекторных препаратов, что может обусловливать их неэффективность при подкорковых инсультах. Возможными причинами провала нейропротекторных стратегий могли быть назначения «не тех» средств, «не в тех» дозах, «не в то» время, «не тем» больным [27]. К нефармакологической нейропротекции относят гипотермию, предупреждение гипергликемии, нестабильности гемодинамики, гипоксемии и гиперкапнии, гемодилюцию, нормализацию повышенного внутричерепного давления, коррекцию кислотно-щелочного и электролитного дисбаланса $[27,28]$. Для фармакологической нейропротекции используют препараты как уменьшающие активность обмена веществ в клетке, так и воздействующие на звенья ишемического каскада [27, 29].

Исходя из вышесказанного, к методам патогенетической терапии острого периода ишемического инсульта относится целый ряд терапевтических мероприятий: гипотермия, нейропротекция, гемодилюция, гемикраниоектомия, ангиопластика со стентированием, механическая деструкция тромба, введение антикоагулянтов, тромболизис, введение антиагрегантов. 
Патогенетическая терапия ишемического инсульта должна основываться на базисной терапии, выполненной в соответствии с современными международными рекомендациями. Кроме того, именно комплексная терапия, включающая методы фармакологической и нефармакологической нейропротекции может обеспечить успех к лечении данного контингента больных.

\section{5. ЭВОЛЮЦИЯ СТРАТЕГИИ НЕЙРОПРОТЕКЦИИ}

В XX столетии произошла эволюция концепций механизмов повреждения ишемизированной ткани мозга и взглядов на лечение острого ишемического инсульта и постгипоксической (постаноксической) энцефалопатии [1].

Исходя из идеологии пенумбры был разработан подход к патофизиологическому лечению церебральной ишемии. Он предложен Гусевым Е. И. и Скворцовой В. И. и предусматривает применение первичной и вторичной нейропротекции [2]. Причем первичная нейропротекция, направленная на прерывание быстрых реакций глутамат-кальциевого каскада, свободнорадикальных механизмов, начинается с первых минут ишемии и продолжается в течение трех дней. А вторичная нейропротекция, направленная на блокаду провоспалительных цитокинов, молекул клеточной адгезии, торможение прооксидантных ферментов, восстановление нейротрофики и прерывание апоптоза, может быть начата через 6-12 часов после инцидента и продолжается не менее 7 суток [2].

Практически для каждого этапа патобиохимического каскада, развивающегося при церебральной ишемии (так называемая «кальциевая гипотеза» повреждения нейронов [2]), разработано нейропротективное средство, эффективность которого была показана в экспериментальных исследованиях. Направления патогенетической нейропротекторной терапии ишемии головного мозга существуют, но клинические испытания, проверяющие множество потенциальных нейропротекторных веществ, дали отрицательные или разочаровывающие результаты [3].

В последнее время многие авторы склоняются к мысли о том, что немаловажную роль играет несоответствие между относительно здоровыми экспериментальными животными, у которых инсульт вызывается одномоментной окклюзией артерии, и реальными пациентами, страдающими атеросклерозом, сахарным диабетом, артериальной гипертензией, ишемической болезнью сердца и другими хроническими заболеваниями, а также, как правило, имеющими ряд факторов риска (пожилой возраст, пол, курение и др.) [4].

Kроме того, A. R. Young et al. [4] считают, что, вероятно, проблема coстоит в том, что исследователи концентрируют внимание на защите нейронов. Однако инсульт - это не только повреждение и гибель нейронов, это болезнь головного мозга в целом. Поэтому нейропротекция должна состоять в защите не только нейронов, но и астроцитов, олигодендроцитов, микроглии и всех механизмов, нарушающихся при ишемии. Очень важно обратить внимание на изменения, которые происходят во время ишемии не только в сером, но и в белом 
веществе головного мозга. Недостаточно внимания уделяется также проблеме повреждения микроциркуляторного русла и, в частности, поражению эндотелиоцитов. Авторы статьи [4] указывают на необходимость защиты не столько нейронов, сколько условной нейроваскулярной единицы, составляющей единый структурно-функциональный элемент ткани головного мозга, подобно тому, как в почках принято рассматривать в качестве единого целого нефрон с его канальцами и связанными с ним микрососудами. По всей видимости, реализация такого подхода на практике будет обозначать необходимость подбора не одного или двух нейропротективных препаратов, а целой схемы нейропротективного лечения. Отсюда понятна вся сложность предстоящей задачи - не только отыскать эффективные и безопасные препараты, но и изучить их различные комбинации, и прежде всего - в сочетании с методом выбора, то есть с реперфузией при помощи tPA. По всей видимости, именно комбинации препаратов с разнонаправленным протективным действием позволят совершить прорыв в изучении проблемы нейропротекции при инсультах, считают и другие специалисты $[4,5,6,7,8,9]$.

В структуре терапевтических воздействий при церебральной ишемии ведущую роль играют два основных направления [4]:

1) улучшение гемодинамики с целью компенсации нарушенного мозгового кровообращения и адекватного обеспечения структур мозга энергетическими субстратами и кислородом;

2) защита нейронов от ишемии, сохранение их структуры, целостности и функциональной активности.

Существует термин «гибкость метаболизма», который подразумевает клеточную адаптацию к быстро изменяющимся потребностям в энергии [9]. Воспалительные процессы, запущенные цитокинами и хемокинами, снижают скорость утилизации глюкозы и переводят клетки в катаболическое состояние [9]. Целью терапии в данном случае является прекращение данных реакций и оптимизация утилизации энергии. В конечном итоге сложнейших биохимических реакций, факторы роста увеличивают потребление глюкозы и ее утилизацию $[10,11]$.

Теоретически идеальный нейропротектор должен являться антагонистом сразу нескольких повреждающих факторов. В большинстве работ, публикуемых в последние 5-7 лет, содержатся рекомендации, уточняющие отдельные точки приложения нейропротекторной терапии, основными направлениями которой являются следующие:

1. Коррекция энергетического обмена путем снижения повреждающего действия гипоксии и уменьшения энергетической потребности нейронов.

2. Стимуляция окислительно-восстановительных процессов и усиление утилизации глюкозы.

3. Уменьшение интенсивности свободнорадикального и перекисного окисления липидов.

4. Стимуляция системы нейротрансмиттеров и нейромодуляторов. 
5. Торможение высвобождения возбуждающих медиаторов (глутамат, аспартат), обладающих эксайтотоксическим действием.

6. Стимуляция репаративных процессов, которые связывают с такими понятиями как нейротрофичность, нейропротекция, нейропластичность [12].

Нейротрофичность - естественный процесс, который выражается в пролиферации, миграции, дифференциации и выживании нервных клеток.

Нейропротекцию определяют, как непрерывную адаптацию нейрона к новым функциональным условиям. Нейропротекция представляет собой сумму всех механизмов, направленных против повреждающих факторов.

Нейропластичность включает в себя восстановление функций после естественных повреждений и других нарушений, вызванных любыми агентами.

Эти три фундаментальных биологических процесса не имеют четко выраженных границ. Они накладываются и смешиваются друг с другом. Каждый из них имеет две стороны: абсолютную и относительную. Абсолютная сторона определяет механизмы, вызывающие активацию ДНК и проявляющиеся усилением репаративного белкового синтеза, а относительная - механизмы, вызывающие в итоге преимущественную активацию процессов в мембранах, цитозоле и цитоплазматических органеллах, блокирующих клеточную смерть и параллельно имеющих возможность индуцировать появление репаративных молекул. Абсолютные механизмы преимущественно контролируются нейротрофическими факторами и нейротрофноподобными молекулами, а относительные связаны с блокаторами ионных каналов, агонистами и антагонистами определенных рецепторов, ловушками свободных радикалов, хелаторами металлов и др. Все эти защитные механизмы могут быть естественными или фармакологически активированными. Они переплетены между собой и вместе вызывают комплекс процессов, таких как сохранение и регенерация нервной ткани [12]. Фармакологическая коррекция, направленная на ограничение нитрозирующего, оксидативного и карбонильного стрессов, позволяет снизить количество деструктивно измененных клеток, а также переключить тип гибели клетки с некроза на апоптоз [13].

В отличие от повреждающего эффекта избыточной и длительной активации экстрасинаптических NMDA-рецепторов, их физиологическая стимуляция в синапсах способствует выживанию нейронов, активируя нейротрофические и нейропластические процессы (глутамат играет важную роль в процессах дифференцировки, миграции и жизнеспособности нейронов, в основном, через усиление входящего тока $\mathrm{Ca}^{2+}$ ), в то время как значительное снижение активности NMDA-рецепторов in vivo приводит к распространенному апоптозу среди развивающихся клеток, усугубляет текущие нейродегенеративные процессы, блокирует ишемическое прекондиционирование, то есть снижает возможность выживания клеток в условиях ишемии [51].

Установлено, что мозг содержит самовосстанавливающиеся стволовые клетки, из которых могут формироваться предшественники нейронов, астро- 
цитов и олигодендроцитов, способные мигрировать, дифференцироваться и интегрироваться в мозге [14, 15].

Установлено, что нейроны, помимо трансмиттеров, могут синтезировать нейротрофические факторы и цитокины, которые антеградно и ретроградно транспортируются аксонами и влияют на синтез, высвобождение и эффективность действия трансмиттеров. Нейротрофические вещества изменяют функциональную активность нейронов, имеющих рецепторы для этих классов веществ [16].

Получены новые сведения о функционировании нейроглии. Установлено, что астроциты через соответствующие рецепторы постоянно информируются о состоянии нейронов, участвуют в синтезе и инактивации нейротрансмиттеров, синтезируют нейротрофины и цитокины, защищают нервные клетки от гибели [17].

В связи с накопленными данными о роли воспаления в процессе вторичного повреждения мозговой ткани при ишемии мозга, травме и кровоизлиянии, актуальным является вопрос о возможных путях фармакологической коррекции этой реакции. Начиная с первых дней заболевания, после формирования морфологических инфарктных изменений в веществе мозга, все большее значение приобретает репаративная терапия, направленная на улучшение пластичности здоровой ткани, окружающей инфаркт мозга, активацию образования полисинаптических связей, увеличение плотности рецепторов [18].

Одной из универсальных составляющих патогенеза повреждения нервной ткани является трофическая дисрегуляция, приводящая к биохимической и функциональной диафференциации нейронов с инициированием каскада патобиохимических процессов [19].

Современные данные о патофизиологии ишемического и травматического повреждения мозга свидетельствуют о патогенетическом единстве механизмов клеточного повреждения при любой острой церебральной недостаточности (ОЦН), что обусловлено обязательно возникающей тканевой ишемией $[20,21]$.

Однотипно развивается реакция глиальных клеток на повреждающий фактор (травму, ишемию, кровоизлияние) с развитием дисбаланса цитокинов, локальной (на уровне ЦНС) воспалительной реакции, ведущей к повреждению нейронов, гематоэнцефалического барьера (ГЭБ) и нарушениям микроциркуляции [42]. Гиперактивность системы NMDA-рецепторов, оксидативный стресс, также, как и продукция провоспалительных цитокинов глиальными клетками, являются основными патогенетическими направлениями формирования отека мозга и индуцирования процессов апоптоза нейронов [21, 22].

Нейровоспаление - это процесс, развивающийся как при травмах, так и при инсультах. При ЧМТ воспаление является закономерным механизмом, особенно при открытой ЧМТ. Различают острую и хроническую стадии воспаления, с изначальной инфильтрацией полиморфными лейкоцитами и макрофагами, а позже - и с вовлечением других типов клеток [23]. Воспаление при ЧМТ сопровождается демиелинизацией $[24,25]$. 
Выделяются провоспалительные цитокины (фактор некроза опухоли TNF- $\alpha$, IL-1, IL-6) активированными иммунными клетками или глиальными клетками. Они играют роль пускового триггера в воспалительном процессе [23]. Также увеличивается содержание хемокинов, CCL2, RANTES - уровни их содержания коррелируют с тяжестью состояния [26].

Роль цитокинов при ЧМТ сложна, ведь они оказывают как отрицательный, так и положительный эффект [24]. Так, к примеру, TNF- $\alpha$, затрудняющий быстрый ответ организма на воспаление, позже участвует в регенеративной фазе восстановления [24]. IL-6 на ранних стадиях повреждения участвует в защите от воспаления, а позже его гиперсинтез астроцитами приводит к гибели нейронов и развитию неврологической симптоматики [25]. Таким образом, любая стратегия борьбы с нейровоспалением должна учитывать возможную двойственность механизмов ответа на повреждение.

Церебральная ишемия также быстро приводит к развитию воспалительного процесса в головном мозге, а именно - к инфильтрации лимфоцитов и продукции цитокинов [26, 27]. Гибель нейронов происходит в основном в зоне поражения. Как и при ЧМТ, наблюдается повышенный уровень содержания провоспалительных цитокинов после ишемического повреждения $[23,25,26,27]$. IL-1 играет важнейшую роль в острой нейрональной дегенерации после инсульта $[27,28]$, в то время как высокие уровни IL-6 коррелируют с объемом инфаркта и тяжестью инсульта [24].

В идеале, эффективное лечение должно предотвращать смерть поврежденных клеток в зоне пенумбры, восстанавливать функционирование и метаболическую активность как в нейронах, так и в олигодендроцитах и обеспечивать компенсаторные изменения по коллатералям. Однако, на сегодняшний день, испытания нейропротективных препаратов не увенчались успехом $[26,27,28]$.

Установлено, что в результате повреждения головного мозга вследствие черепно-мозговой травмы (ЧМТ), геморрагического инсульта (ГИ), ишемического инсульта (ИИ) у всех больных, независимо от вида и исхода мозгового повреждения в острейшем периоде (1-10 сутки), формируются неспецифические постагрессивные, стереотипно текущие синдромы. Наиболее устойчивыми, клинически и прогностически значимыми, в этом периоде являются: синдром приспособительной артериальной гипертензии, приспособительной гипернатриемии, воспалительный синдром, синдром гемостазиологических нарушений, гиперферментемия и гиперлактатемия, катаболический синдром. Количественные и качественные характеристики синдромов однотипны у больных с ЧМТ, ГИ и ИИ и различаются только в зависимости от исхода и степени повреждения мозга.

Постагрессивные реакции сохраняют адаптационный потенциал до 5 суток (точка невозвращения). После этого срока избыточное напряжение компенсаторных механизмов приводит к их истощению. Оптимальная продолжительность максимального напряжения компенсаторных реакций у больных с ЧМТ, ГИ и ИИ составляет 3 суток. В эти сроки интенсивная терапия имеет наибольшую эффективность. 
Неспецифические постагрессивные синдромы у больных с неблагоприятными исходами ЧМТ, ГИ и ИИ имеют идентичные морфологические эквиваленты, выявляемые при патологоанатомических исследованиях, которые сопоставимы по степени выраженности, распространенности, локализации и частоте встречаемости.

Общность патогенеза, патокинеза и танатогенеза, обусловленная стереотипностью течения неспецифических синдромов, позволяет рассматривать больных ЧМТ, ГИ и ИИ как единую популяцию нейрореанимационных больных, что делает возможным и необходимым унификацию и стандартизацию лечебно-диагностических и прогностических подходов к ведению больных с мозговыми повреждениями в острейшем периоде [29].

Рациональная нейроцитопротекция при острой и хронической ишемии мозга - это воздействие на разные этапы ишемического каскада для создания условий, адаптирующих нейроны к новым функциональным условиям $[30,31]$. Современный взгляд на патохимические реакции гипоксии и ишемии позволяет считать дефицит энергии основным, но не единственным компонентом, возникающим при ишемическом повреждении церебральных структур.

Основные механизмы воздействия нейроцитопротекторов на системы патологических дисбалансов, возникающих при остром инсульте, включают: блокаду медленных $\mathrm{Ca}^{2+}$-каналов, предотвращающую расстройства функций $\mathrm{Na}$, Са-АТФ-азы (к препаратам, обладающим таким действием, относится Нимодипин); конкурентный антагонизм к НМДА-рецепторам, который свойственен Мемантину; аллостерическое ингибирование канала НМДА-рецептора, которое обусловливает нейропротективное действие сульфата магния; сохранение композиции нейрональных мембран за счет стабилизации их фосфолипидных структур, свойственное Цитиколину; использование энергетических ресурсов промежуточного обмена веществ, которое лежит в основе антигипоксического действия Актовегина и антиоксидантов на основе янтарной кислоты [30, 31, $32,33]$.

Авторы считают, что цитопротекторы разных классов необходимо комбинировать определенным образом для своевременной коррекции гипоксического дисбаланса [30, 31, 32, 33]. Метаболический, оксидативный и медиаторный дисбалансы, возникающие при острой и нарастающие при хронической ишемии головного мозга, изучены в наибольшей степени. Более того, достаточно хорошо, как в эксперименте, так и в клинической практике, изучены рациональные комбинации нейроцитопротекторов, позволяющие управлять если не возникновением, то прогрессированием постишемического повреждения клеток. Применение нейрозащитного лечения должно обеспечить эффективность как при ЧМТ, так и при ишемическом и геморрагическом инсультах: возможность максимально раннего использования (до выполнения компьютерной томографии и магнитно-резонансной томографии), снижение тяжести течения острых ЦВР, уменьшение объёма инфаркта головного мозга, увеличение терапевтического окна для выполнения тромболизиса, защиту головного мозга от вторичного реперфузионного повреждения [34, 35]. 
Однако неудачи, последовавшие при клинических исследованиях новых препаратов, привели к тому, что в руководствах по лечению инсульта, подготовленных наиболее известными в мире специалистами, либо не упоминается о нейропротекции вовсе, либо очень коротко констатируется, что поскольку клинические исследования не подтвердили эффективность нейропротекции, для её применения в клинической практике нет оснований [36, 37]. За исключением внутривенного тромболизиса, который показан в 5-15 \% ишемического инсульта, и некоторых нейропротекторов (Цитиколин), большинство лекарственных средств, успешно применявшихся в экспериментальных исследованиях, оказались неэффективными в клинических исследованиях [39, 40$]$.

Вместе с тем, исследования показали, что клиническая эффективность нейрозащитных средств снижается вследствие дефицита доставки их в ишемизированную ткань или недостаточно благоприятного действия на белое вещество, где нет многих рецепторов - точек приложения нейропротекторных препаратов, что может обусловливать их неэффективность при подкорковых инсультах. Возможными причинами «провала» нейропротекторных стратегий могли быть назначения «не тех» средств, «не в тех» дозах, «не в то» время, «не тем» больным [38].

Одновременно анализ показал, что отсутствие положительной доказательной базы при проведении клинических исследований могло быть связано с выявленными ошибками или недостатками в дизайне как доклинических, так и клинических исследований. Более того, профессор Jean-LouisVincent, который является непререкаемым авторитетом в проблеме интенсивной терапии и неотложной медицины, считает, что проводить рандомизиованные плацебо-контролируемые двойные (тройные) слепые исследования в области интенсивной терапии чрезвычайно сложно из-за невозможности их унификации.

Для преодоления этих трудностей и ошибок в разработке методов нейропротекторного лечения было проведено несколько «круглых столов» с участием представителей академической медицины и фармакологической индустрии, были выработаны рекомендации в отношении стандартизации дизайнов проведения доклинических и клинических испытаний препаратов и методов при лечении острого инсульта и нейровосстановительного лечения [34, 42, 43$]$.

Анализ позволил выделить два методологически разных вида нейропротекции: нефармакологическую и фармакологическую [35, 44, 45].

К нефармакологической нейропротекции относят гипотермию, предупреждение гипергликемии, нестабильности гемодинамики, гипоксемии и гиперкапнии, гемодилюцию, нормализацию повышенного внутричерепного давления, коррекцию кислотно-щелочного и электролитного дисбаланса [46]. Для фармакологической нейропротекции используют препараты как уменьшающие активность обмена веществ в клетке, так и воздействующие на звенья ишемического каскада $[42,43,44,45,47,46]$.

Успехи фундаментальных исследований повреждений мозга зародили надежду на то, что лечебные воздействия, направленные на устранение или угнетение тех или иных звеньев патогенеза, могут предотвратить повреждения ткани мозга и, следовательно, снизить летальность вследствие инсульта или травмы, а также уменьшить обусловленную ими инвалидность [35]. 
Группы фармакологических препаратов, которые применяют с целью сохранения функции головного мозга, к настоящему времени все более узко специализированы для решения конкретных патогенетических задач, однако их эффективность, как в эксперименте, так и в клинической практике неоднозначна. В дальнейшем в соответствии с гипотезами токсичности возбуждающих аминокислот и кальциевой гибели нейронов при фокальной ишемии мозга, было разработано большое число препаратов, влияющих на эти механизмы клеточного повреждения [48, 49].

Учитывая огромное количество препаратов, существующих на фармацевтическом рынке Украины, которые обладают нейропротекторными свойствами, и отсутствие возможности проведения в нашей стране мультицентровых рандомизированных плацебо-контролируемых исследований этих нейропротекторов, необходим активный поиск доступных и информативных методов оценки әффективности сочетанного применения нейротропных препаратов пациентам с ОЦН.

С целью ответа на главный вопрос - эффективно ли применение того или иного нейропротективного средства либо комбинации препаратов - мы считаем целесообразным применить один из ведущих методов оценки функции центральной нервной системы - количественную электроэнцефалографию. С помощью метода интегрального количественного анализа ЭЭГ-паттерна [50], метода нейросетевого моделирования изучить реактивность ЦНС в ответ на применение нейропротектора у конкретного пациента в динамике лечения [50].

Ранее приведенная патогенетическая концепция ишемическогипоксического повреждения мозга и недостаточно эффективное лечение тяжелой ЧМТ, мозгового инсульта и глобальной ишемии мозга требует пересмотра стратегии нейропротекторной терапии: первичное воздействие должно быть направлено в первую очередь на восстановление реологических свойств крови, микроциркуляции, устранение эндотелиальной дисфункции, функционального состояния нейроглии и ГЭБ, то есть на участки белого вещества, а не серого. И только после этого должна осуществляться вторичная нейропротекция, влияющая в основном на нейроцит. Для реализации данной идеологии необходим поиск базовых препаратов, ключевыми свойствами которых должно являться воздействие, с одной стороны, на эндотелиальную дисфункцию, а с другой на нейротрофические и нейропластические свойства нейроцитов.

\section{6. КОНЦЕПЦИЯ ПАТОГЕНЕТИЧЕСКОЙ НЕЙРОПРОТЕКЦИИ ПОРАЖЕННОГО МОЗГА}

Перспективным направлением в лечении острой церебральной недостаточности является поиск эффективной комбинации лекарственных средств, влияющих на разные этапы патобиохимических процессов и стимулирующих восстановительные процессы в нервной ткани $[1,2,3,4,5]$. Отсюда понятна вся сложность предстоящей задачи — не только отыскать эффективные и безопас- 
ные препараты, но и изучить их различные комбинации. Именно комбинации препаратов с разнонаправленным протективным действием позволят совершить прорыв в изучении проблемы нейропротекции при инсультах, - считают и другие специалисты $[6,7,8,9,10]$.

В настоящее время особо подчеркивается, что невозможно терапевтически контролировать патогенетический каскад с помощью применения только одного нейропротектора, имеющего только один механизм воздействия на патологический процесс. Считается, что нейропротекция будущего - это комбинированная терапия. Сейчас развиваются различные подходы для разных видов патологии с применением комбинаций $[12,13,14,15$, $16,17]$.

Сложность решения вопроса о сочетании тех или иных нейротропных препаратов при лечении острой церебральной недостаточности различной этиологии связана с отсутствием данных об их эффективности с позиций доказательной медицины (evidence-based medicine) [18].

Все выше изложенное натолкнуло нас на мысль провести ретроспективное исследование исходов течения тяжелой черепно-мозговой травмы в зависимости от вида нейропротективной терапии у пациентов, которые находились в нейрореанимационном отделении ДОКТМО на протяжении последних 14 лет с 1992 г. по 2006 г.

Изучено 1030 историй болезни (646 мужчин и 384 женщины) в возрасте от 21 до 68 лет, которые перенесли тяжелую ЧМТ.

Тяжесть травмы по шкале Глазго на момент госпитализации: 455 человек 3-6 баллов; 575 человек 7-10 баллов. Из 1030 больных умерло 436 человек (летальность 36,9 \% ). Все больные с ЧМТ в нейрореанимационном отделении на протяжении последних 14 лет ретроспективно распределены на группы: 1 группа - с поддержкой экстрацеребрального гомеостаза; 2-8 группы - с поддержкой экстра- и интрацеребрального гомеостаза.

Математическое моделирование исходов лечения тяжелой черепномозговой травмы проведено с применением нейронных сетей [20]. В качестве входных параметров были выбраны: 1) возраст больного; 2) время, прошедшее от момента получения травмы до начала специализированной интенсивной терапии; 3) оценка тяжести травмы по шкале ком Глазго на момент госпитализации и в процессе лечения; 4) наличие/отсутствие оперативного вмешательства; 5) варианты лечебно-реанимационного комплекса. Была проведена разбивка входных данных для пациентов на классы (кластеры) с помощью программы Statistca Neural Networks (x1-x8).

Протоколы лечения больных: X1 (134 чел.) - умеренная гипервентиляция, петлевые диуретики + бензодиазепиновые транквилизаторы + глюкокортикоиды; X2 (248 чел.) - умеренная гипервентиляция, петлевые диуретики + бензодиазепиновые транквилизаторы; X3 (63 чел.) - X2 + препараты, восстанавливающие мозговой кровоток и метаболизм; X4 (94 чел.) - Х3 + Актовегин; X5 (78 чел.) - X2 + Актовегин; X6 (112 чел.) - X2 + Нимодипин + Актовегин; X7 (205 чел.) - X2 + Актовегин + L-лизина эсцинат; X8 (96 чел.) - X2 + Нимодипин + Актовегин $+\mathrm{L}$-лизина эсцинат. 
Распределение исследуемых групп больных в зависимости от исхода заболевания, степени тяжести травмы и протокола лечения представлено на данных графиках (рис. 5.3).

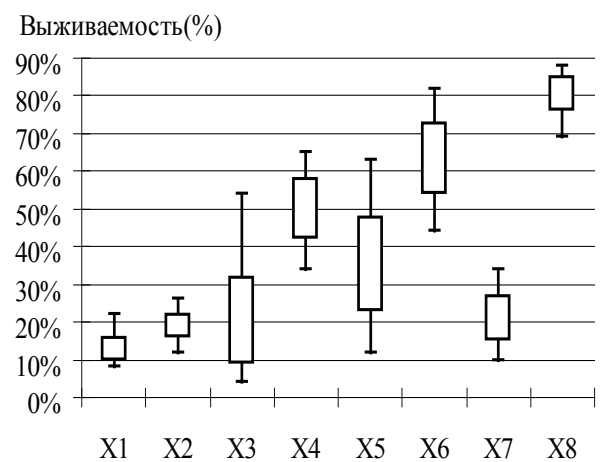

шкала кол Глазго < 6 баллов

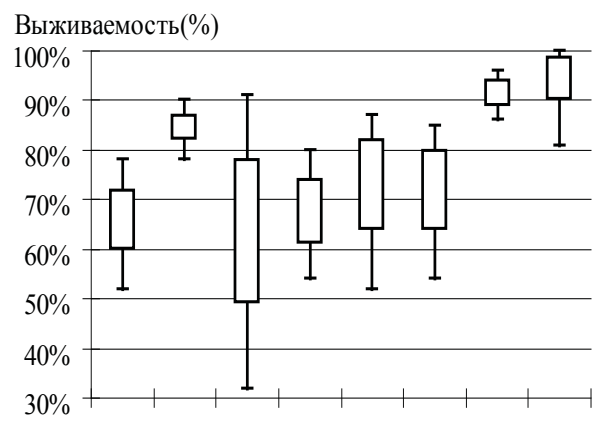

$\begin{array}{llllllll}\mathrm{X} 1 & \mathrm{X} 2 & \mathrm{X} 3 & \mathrm{X} 4 & \mathrm{X} 5 & \mathrm{X} 6 & \mathrm{X} 7 & \mathrm{X} 8\end{array}$

шкала кол Глазго > 6 баллов

\section{Рис. 5.3. Распределение исследуемых групп в зависимости от исхода заболевания, степени тяжести травмы и протокола лечения}

В результате исследования было установлено, что выживаемость больных с тяжелой ЧМТ с одной стороны зависит от степени тяжести травмы (оценка по шкале ком Глазго $>$ или $<6$ баллов), а с другой - от включения церебропротекторов в лечебно-реанимационный комплекс. Установлено, что если больным с тяжелой ЧМТ (оценка по шкале ком Глазго $>6$ баллов) наряду с экстрацеребральным воздействием расширить комплекс за счет включения препаратов, восстанавливающих энергетический дефицит нервной ткани, улучшающих венозный отток из полости черепа, лечение отека и набухания головного мозга, то это приводит к увеличению выживаемости от $85 \pm 3 \%$ до $92 \pm 3 \%$ $(\mathrm{p}<0,05)-$ рис. 5.4 .

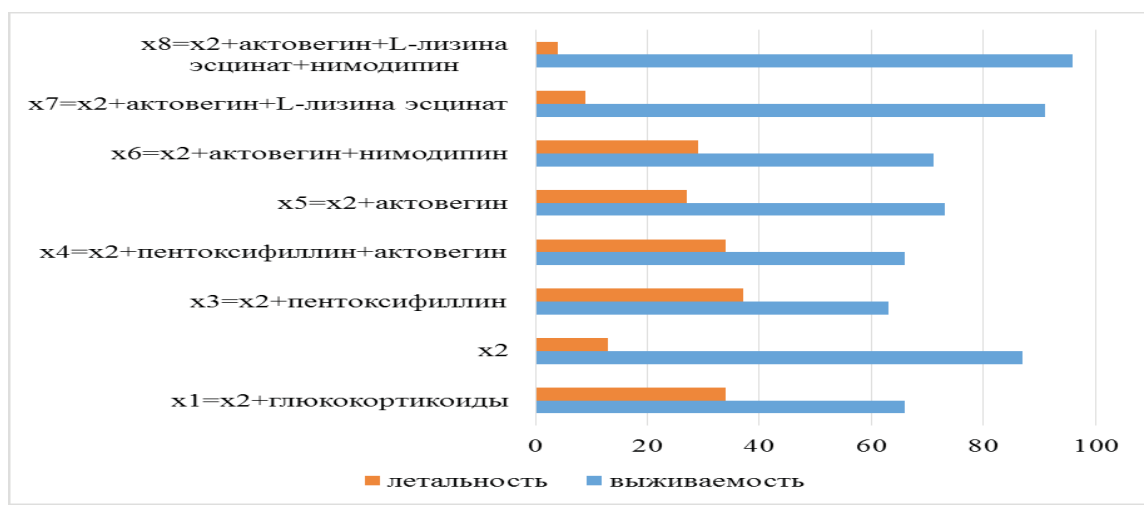

Рис. 5.4. Влияние на выживаемость комплексов интенсивной терапии (ретроспективный анализ) у пациентов второй группы (уровень неврологического дефицита по ШІКГ - более 6 баллов) 
Больным с крайне тяжелой ЧМТ (оценка по шкале ком Глазго $<6$ баллов) целесообразно, наряду с экстрацеребральным воздействием, применять вариант лечебно-реанимационного комплекса, включающий снижение внутричерепного давления (умеренную гипервентиляцию, петлевые диуретики) и создание охранительного торможения - бензодиазепиновые транквилизаторы), восстановление мозгового кровотока, метаболизма мозга, восстановление энергетического дефицита нервной ткани и нейромедиаторного баланса, улучшение венозного оттока из полости черепа, профилактику и лечение отека и набухания головного мозга, устранение церебрального вазоспазма. Расширение комплекса за счет включения нейропротекторов привело к увеличению выживаемости с $19 \pm 3 \%$ до $50 \pm 2 \%(\mathrm{p}<0,05)$ в 4 -й группе, до $35 \pm 3 \%(\mathrm{p}<0,05)$ в 5 -й группе, до $65 \pm 2 \%(\mathrm{p}<0,05)$ в 6 -й и до $82 \pm 3 \%(\mathrm{p}<0,05)$ в 8 -й группе (рис. 5.5).

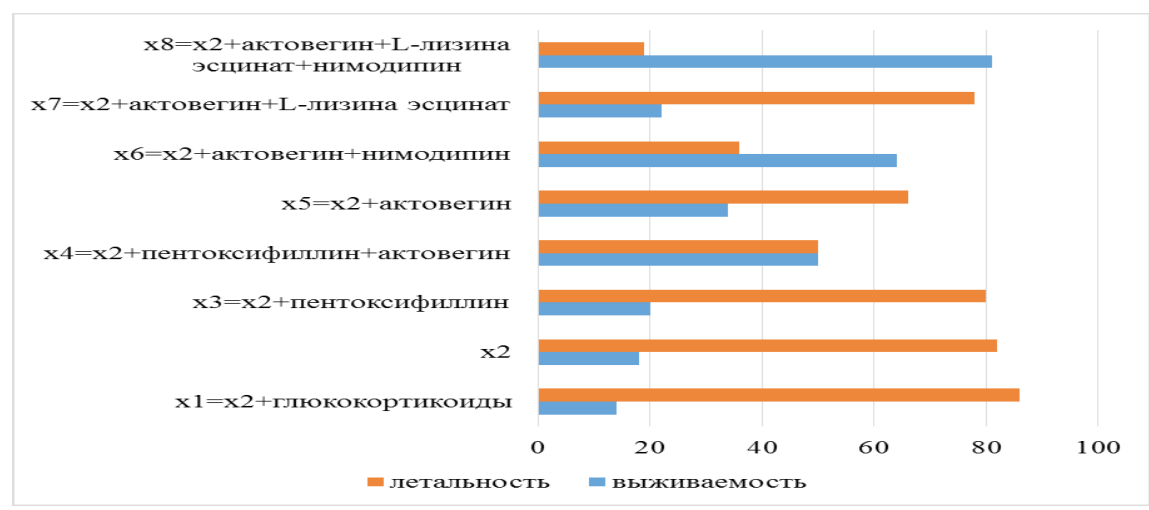

Рис. 5.5. Влияние на выживаемость комплексов интенсивной терапии (ретроспективный анализ) у пациентов первой группы (уровень неврологического дефицита по ШКГ — менее 6 баллов)

Полученные результаты показали следующее: применение нейропротекторов целесообразно; чем тяжелее ЧМТ, тем более существенно нейропротекторы влияют на выживаемость; чем более обоснован с точки зрения патофизиологии комплекс лечения тяжелой ЧМТ, тем он эффективнее.

Учитывая, что полученные данные во многом противоречат рандомизированным исследованиям по нейропротекции, мы решили реализовать патогенетический подход к лечению тяжелой ЧМТ и мозгового инсульта как в эксперименте, так и в клинике.

Была поставлена цель исследования: разработать, патогенетически обосновать и внедрить в клиническую практику новую стратегию применения нейропротекторов при черепно-мозговой травме и мозговом инсульте различной этиологии.

В эксперименте на двух группах животных с моделированной острой травмой и ишемией мозга была проведена экспериментальная проверка стратегии нейропротекторной терапии, включающей первичную нейропротекцию, направленную на восстановление реологических свойств крови, микроцирку- 
ляции, эндотелиальной дисфункции, функционального состояния нейроглии и ГЭБ, ликвидацию отека-набухания головного мозга. И вторичную нейропротекцию, направленную, в основном, на регенераторно-репаративные процессы, нейротрофику и нейропластичность в нейроцитах и клетках глии [21, 22].

Эксперимент проведен на белых беспородных крысах самцах, которым была нанесена стандартная (одинаковая по силе и месту приложения) ЧМТ. Для объективизации оценки тяжести ЧМТ проведены следующие исследования: изучение неврологического дефицита, исследование динамики летальности, исследование биохимических маркеров повреждения головного мозга (креатинфосфокиназа, продукты ПОЛ, дериваты NO), морфологическое и морфометрическое исследование головного мозга. Периоды исследования - от 24 ч до 21 суток после травмы.

Экспериментально на модели ЧМТ доказана эффективность патогенетического подхода к двухэтапному нейропротективному воздействию: комплекс препаратов для первичной нейропротекции, включающий восстановление реологических свойств крови, микроциркуляции, функции ГЭБ, уменьшение эндотелиальной дисфункции, улучшение текучести крови, снижение ее вязкости, уменьшение отека-набухания головного мозга, увеличение его перфузии, повышение доставки кислорода и глюкозы к мозгу, блокаду ЦОГ2, улучшение утилизации глюкозы ишемизированными клетками, прежде всего глиальными; комплекс препаратов для «вторичной» нейропротекции, влияющий преимущественно на регенераторно-репаративные процессы, нейротрофику и нейропластичность в нейроцитах и клетках глии.

З九ивотным экспериментальной серии № 1 медицинские препараты не вводились. Жиивотным экспериментальной серии № 2 через 3 часа после нанесения травмы интрабрюшинно капельно-струйно, последовательно вводились препараты первичной нейропротекции в следующих дозировках: L-лизина эсцинат 0,15 мг/кг, Реосорбилакт - 10 мл/кг, Гекодез - 10 мл/кг, Тиотриазолин 0,5 мг/кг, Латрен - 1,5 мг/кг, Диностат - 0,1 мг/кг, с последующим повторным введением препаратов через сутки в зависимости от сроков выведения животного из эксперимента.

Животным экспериментальной серии № 3 через 3 часа после нанесения травмы интрабрюшинно капельно-струйно, последовательно вводились препараты вторичной нейропротекции в следующих дозировках: Тиоцетам 0,25 мг/кг, Актовегин - 16 мг/кг, Цераксон - 20 мг/кг, Цитофлавин 0,25 мл/кг, Цереброкурин - 0,05 мг/кг, с последующим повторным введением препаратов через сутки в зависимости от сроков выведения животного из эксперимента.

В экспериментальной серии № 4, также как и в других сериях, через 3 часа после нанесения травмы каждому животному интрабрюшинно вводили препараты первичной, а затем через 30 минут - вторичной нейропротекции в соответствующих дозировках, с последующим повторным введением препаратов через сутки в зависимости от сроков выведения животного из эксперимента.

Жиивотных выводили из эксперимента в течение 3-х часов после истечения определенного срока эксперимента путем декапитации. Придерживаясь 
всех требований и положений Европейской конвенции по защите позвоночных животных, использованных для исследовательских и других научных целей (Страсбург, 1986), каждое животное перед декапитацией выводили из эксперимента под тиопентал-натриевым наркозом (40 мг/кг) внутрибрюшинно.

Установлено, что выраженность компенсаторно-приспособительных процессов (динамика показателей оксидантной и антиоксидантной систем, дериватов оксида азота), морфометрических показателей (удельный объем сосудов и нейронов, процентное соотношение структурно сохранных нейронов, обратимых и необратимых дистрофических изменений в нейронах), морфологических изменений (пролиферация нейроглии, нейрональный саттелитоз, низкая степень микроглиоза) была значительно выше у животных, которым после экспериментальной стандартизованной травмы проводили комплексное лечение, включающее первичную и вторичную нейропротекцию.

При экспериментальной черепно-мозговой травме, применение двухэтапной нейропротекции приводит к значительному улучшению репаративных процессов мозговой ткани. В 4-й группе животных, получавших указанный комплекс препаратов, на 21-е сутки выявлено снижение удельного объема микроциркуляторного русла коры с $0,214 \pm 0,02$ до $0,146 \pm 0,03$; увеличение удельного объема нейронов в 1,6 раза, из них доля структурно сохранных нейронов увеличилась с $56,6 \% \pm 5 \%$ до $94,0 \% \pm 1 \%$, а доля необратимых изменений в нейронах снизилась с $23,9 \% \pm 5,1 \%$ до $0,9 \% \pm 0,5 \%$ по сравнению с животными, не получавшими такую терапию (1-я группа) - рис. 5.6-5.8.

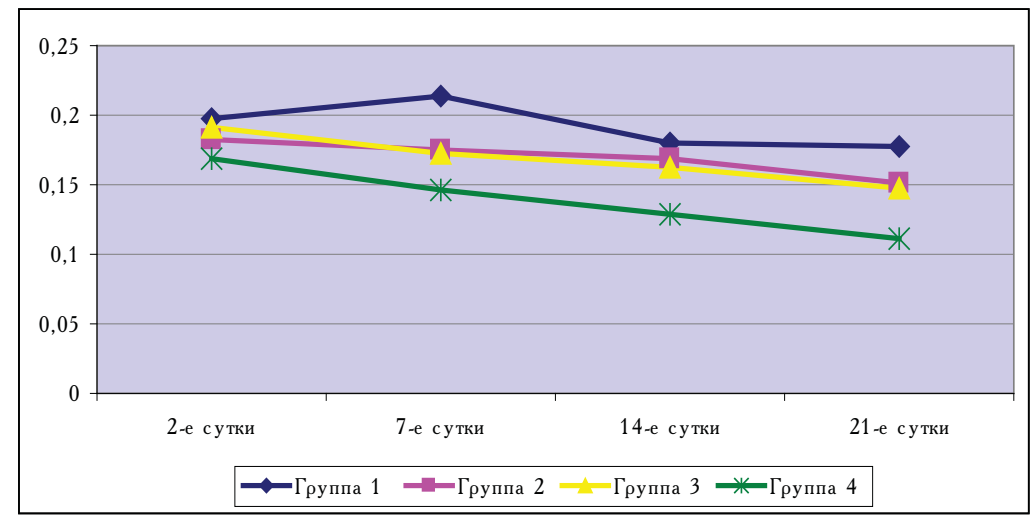

Рис. 5.6. Динамика удельного объема сосудов (Vv) МГЦР коры головного мозга крыс при черепно-мозговой травме в группах 1-4 в разные сроки от начала эксперимента

Динамика летальности крыс в сериях составила: группа 1 (без нейропротекции) $-48 \%$, группа 2 (первичная нейропротекция) - $18 \%$, группа 3 (вторичная нейропротекция) $-24 \%$, группа 4 (первичная + вторичная нейропротекция) - $16 \%$. Полученные данные свидетельствуют об эффективности предложенной концепции и особой важности первичной нейропротекции: у крыс, получавших только вторичную нейропротекцию, летальность на $6 \%$ выше, чем в группе 2 , и на $8 \%$ выше, чем в группе 4 (крКУ, $\left.\chi^{2} \mathrm{p}<0,05\right)$. 


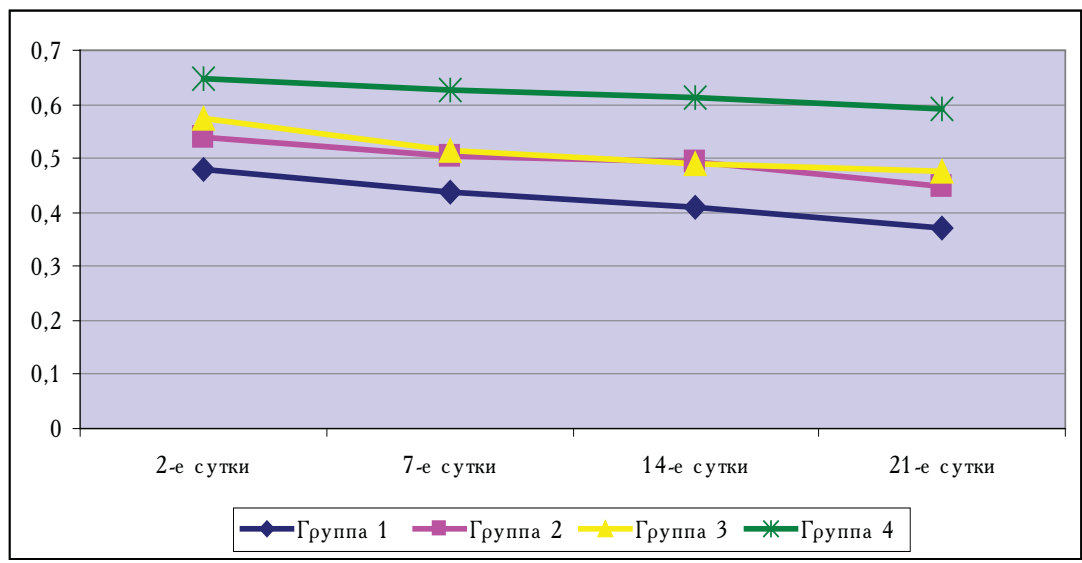

Puc. 5.7. Динамика удельного объема нейронов (Vn) коры головного мозга крыс при черепно-мозговой травме в группах 1-4 в разные сроки от начала эксперимента

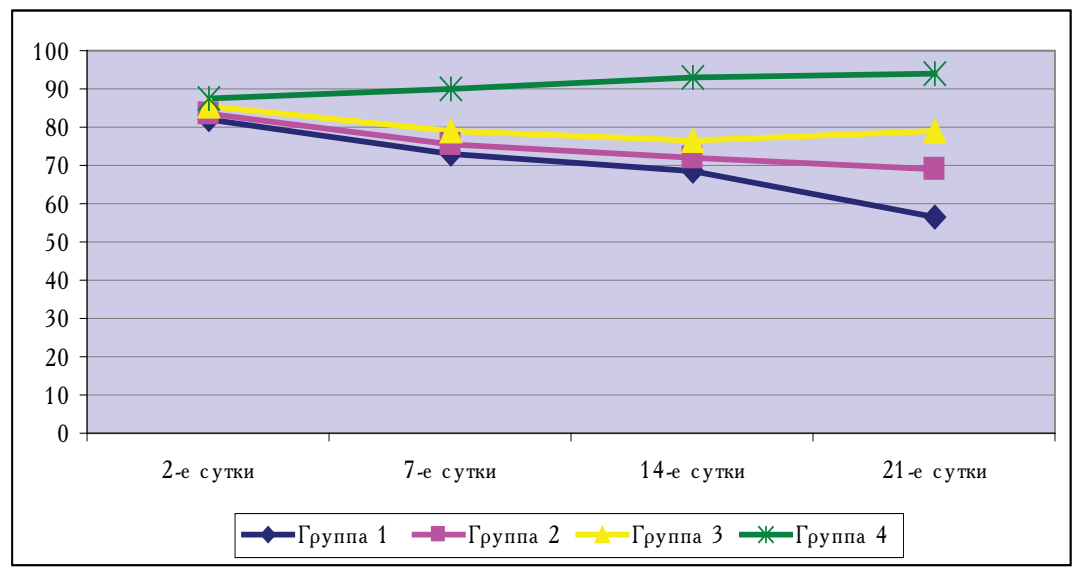

Рис. 5.8. Динамика процента структурно сохранных нейронов в коре головного мозга крыс (\% от Vn) при черепно-мозговой травме в группах 1-4 в разные сроки от начала эксперимента

Выраженность компенсаторно-приспособительных процессов, в частности, пролиферация нейроглии, нейрональный саттелитоз, низкая степень микроглиоза в сочетании с приведенными выше объективными количественными показателями, позволяют прийти к выводу о том, что оптимальные и адекватные проявления лечебного патоморфоза имели место в экспериментальной группе 4, то есть у животных, которым после нанесения экспериментальной стандартизованной травмы проводилось комплексное лечение, включающее: Лизин, Реосорбилакт, Гекодез, Тиотриазолин, Латрен, Династат, Тиоцетам, Актовегин, Цераксон, Цереброкурин. 
Острое нарушение мозгового кровообращения по типу ишемического инсульта моделировали путем необратимой односторонней перевязки сонной артерии у монгольских песчанок. Целью настоящего исследования была оценка эффективности комбинированной поэтапной нейропротекции, ее способности влиять на характер экспрессии генов раннего ответа и морфофункциональные показатели нейронов.

В наших экспериментальных исследованиях установлено, что моделирование ишемического повреждения головного мозга приводило к значительному изменению ответа генома, проявляющемуся нарушением характера экспрессии гена раннего реагирования c-fos [23, 24, 25].

Об эффективности проводимой фармакокоррекции судили по выраженности неврологического дефицита, который определяли по шкале McGrow [26]. Определяли следующие показатели [27]: плотность нейронов, глиальных клеток, апоптотических и деструктивно измененных нейронов как количество клеток на $1 \mathrm{~mm}^{2}$ площади среза, клеточный состав в области IV-V слоев коры и CA1-зоны коры гиппокампа в процентах, площадь тел нейронов, глиальных клеток, апоптотических и деструктивно измененных нейронов $\left(\right.$ мкм $\left.^{2}\right)$, концентрацию РНК в нейронах, глиальных клетках, апоптических и деструктивно измененных нейронах (единицы оптической плотности, $\mathrm{E}_{\text {оп }}$ ), которые рассчитывают как логарифм отношения оптической плотности тела клетки к оптической плотности межклеточного вещества, содержание РНК в нейронах, глиальных клетках, апоптотических и деструктивно измененных нейронах (единицы оптической плотности, $\mathrm{E}_{\text {оп) }}$ ), которые рассчитывают как произведение концентрации РНК и площади клеток, количество деструктивно измененных клеток.

Проведен анализ морфофункционального состояния нейронов коры мозга в условиях острой ишемии и под влиянием различных схем лечения.

На 4-е сутки эксперимента (табл. 5.6), было зарегистрировано значительное уменьшение числа c-fos-позитивных клеток: более чем на $71 \%$ по отношению к интактной группе животных. Подобные изменения экспрессии c-fos связаны, по-видимому, с преобладанием типа гибели клеток, в связи с известной ролью гена c-fos в процессах апоптоза/некроза. Ранними исследованиями установлено, что снижение экспрессии с-fos в острый период ишемии приводит к усилению гибели клеток по типу некроза [491].

Изменения характера экспрессии в ядре генов раннего реагирования, третичных мессенджеров (гена c-fos, гена c-jun, гена krox-20, гена zif/268 и др.) можно расценивать как неспецифическую реакцию генома на любое повреждающее воздействие, в том числе на ишемию. Известно, что белки fos-, jun- и krox-генных семейств играют решающую роль в контроле за клеточным циклом, развитием, ростом и клеточной дифференцировкой, а также определяют судьбу дифференцированных нейронов. Экспрессия генов приводит к синтезу ДНК-связанных протеинов, транскрипционных факторов, которые в свою очередь вызывают экспрессию других генов раннего реагирования. Таким образом, гены раннего реагирования участвуют в передаче информации от клетки к клетке. 
Интересно, что транскрипционные факторы могут являться медиаторами как нейрональной смерти, так и выживания клеток.

На 21-е сутки эксперимента (восстановительный период) было отмечено незначительное, по сравнению с 4-е сутками ишемии, увеличение экспрессии c-fos, что связано с переключением в восстановительный период типа клеточной гибели с некроза на апоптоз (табл. 5.6). Изменение содержания c-fos в нейронах в разные сроки ишемии, с нашей точки зрения, тесно связано с преобладанием апоптоза. Так, увеличение содержания c-fos происходило на фоне преобладания гибели клеток по типу апоптоза, а снижение - к усилению гибели по типу некроза. В восстановительный период происходит адаптация клетки и переключение гибели с пути некроза на апоптоз и снижение последнего $[32,33]$.

Таблица 5.6

Влияние первичной и вторичной нейропротективной терапии на характер экспрессии гена c-fos и на концентрацию белка bcl-2 в нейронах $\mathrm{CA}_{1}$-зоны гиппокампа

\begin{tabular}{|l|c|c|}
\hline \multicolumn{1}{|c|}{ Группы животных } & Кол-во c-fos-+ клеток, мм² & Кол-во bcl-2-+- клеток, мм $^{2}$ \\
\hline Интакт & $14,8 \pm 2,0$ & $98,0 \pm 6,2$ \\
\hline Контроль, 4-е сут. & $4,2 \pm 1,5$ & $46,0 \pm 3,6$ \\
\hline ПН, 4-е сут. & $7,0 \pm 1,7^{*}$ & $52,9 \pm 3,2^{*}$ \\
\hline Контроль, 21-е сут. & $8,2 \pm 2,3$ & $24,9 \pm 3,4$ \\
\hline ВН, 21-е сут. & $13,5 \pm 3,0 \&$ & $54,6 \pm 3,1 \&$ \\
\hline ПН+ВН & $15,9 \pm 2,5^{\star \star}$ & $94,7 \pm 2,4^{* *}$ \\
\hline
\end{tabular}

Примечание (здесь и далее). * - p $<0,05$ по отношению к контролю 4 сутки;

$\&-\mathrm{p}<0,05$ по отношению к контролю 21 сутки;

$* *-\mathrm{p}<0,05$ по отношению к вторичной нейропротекции, 21 сутки;

ПН - первичная нейропротекция;

ВН - вторичная нейропротекция;

ПН+ВН - комбинированная нейропротекция: первичная + вторичная.

Современные авторы рассматривают с-fos как ранний маркер активации сигнальных систем при апоптозе [34]. Протеин c-fos образует димеры с другими белками - D- Jim, c-jun, ATF (активизирующий фактор транскрипции), в результате чего образуется фактор транскрипции AР-1-комплекс. При этом механизм активации апоптоза геном раннего ответа c-fos, а также его продуктом - фактором транскрипции АР-1, по-видимому, обусловлен либо синтезом патологических белков, либо индукцией образования гипотетического апоптотического фактора. Активизация генов немедленного ответа в нейроне может осуществляться через протеинкиназный каскад p21ras-MAPK или сфингомиелиназо-церамидный сигнальный путь. В результате повышается транскрипция этих генов, что способствует развитию апоптоза [35, 36]. 
Установленные нами изменения характера экспрессии c-fos под влиянием первичной и вторичной нейропротективной терапии в восстановительный период, носят, по нашему мнению, адаптационный характер и необходимы для переключения гибели клетки с пути некроза на апоптоз и снижение последнего. Действительно, гистохимические исследования bcl-2-позитивных нейронов показали тесную корреляцию между характером экспрессии гена c-fos и количеством bcl-2-позитивных нейронов. Так, на 4-е сутки после ишемии было отмечено падение, более чем в 2 раза числа bcl-2 позитивных клеток, с последующим, на 21-е сутки увеличением их количества (табл. 5.6).

Изменения характера ответа генома в условиях моделирования ишемического повреждения головного мозга сопровождались нарушениями морфофункционального состояния как нейронов $\mathrm{CA}_{1}$-зоны гиппокампа, так и глиальных клеток. Так, начиная с 4 -х суток ишемии, наблюдалось падение плотности и площади нейронов и глиоцитов (в среднем на 30 \%) по отношению к интактной экспериментальной группе, максимум которого приходился на 21-е сутки. Кроме того, было отмечено снижение транскрипционной активности нейроцитов и глии, что выражалось постепенным уменьшением концентрации РНК в ядре. Подобные морфофункциональные сдвиги в нейронах головного мозга приводили к увеличению числа деструктивно измененных клеток (табл. 5.7, 5.8).

Таблица 5.7

Влияние первичной и вторичной нейропротекторной терапии на морфофункциональное состояние нейронов $\mathrm{CA}_{1}$-зоны гиппокампа

\begin{tabular}{|c|c|c|c|c|}
\hline Группы животных & $\begin{array}{c}\text { Плотность } \\
\text { нейронов, мм² }\end{array}$ & $\begin{array}{c}\text { Площадь клеток, } \\
\text { мм² }^{2}\end{array}$ & $\begin{array}{l}\text { Конц. РНК, } \\
\text { Еоп }\end{array}$ & $\begin{array}{l}\text { Число деструктивно } \\
\text { измен. клеток, мм² }\end{array}$ \\
\hline Интакт & $1184,6 \pm 125,3$ & $75,2 \pm 5,4$ & $10,1 \pm 1,3$ & $86,5 \pm 7,1$ \\
\hline Контроль, 4-е сут. & $8+, 9 \pm 75,2$ & $59,6 \pm 4,6$ & $5,4 \pm 0,9$ & $+, 9 \pm 11,9$ \\
\hline ПН, 4-е сут. & $969,8 \pm 59,4^{*}$ & $64,4 \pm 4,5^{\star}$ & $5,9 \pm 0,5$ & $206,9 \pm 8,6^{*}$ \\
\hline Контроль, 21-е сут. & $767,2 \pm 30,6$ & $49,8 \pm 4,6$ & $4,6 \pm 0,7$ & $+, 3 \pm 7,7$ \\
\hline ВН, 21-е сут. & $970,0 \pm 29,2 \&$ & $66,1 \pm 5,1 \&$ & $6,9 \pm 0,5 \&$ & $+, 2 \pm 8,6 \&$ \\
\hline $\mathrm{nH}+\mathrm{BH}$ & $23 \pm 37,8^{\star *}$ & $70,9 \pm 3,1^{\text {** }}$ & $9,9 \pm 0,7^{\star *}$ & $115,0 \pm 9,4^{* *}$ \\
\hline
\end{tabular}

Примечание: * p $-<0,05$ по отношению к контролю 4 сутки; $\&-p<0,05$ по отношению к контролю 21 сутки; ** - $<<0,05$ по отношению к вторичной нейропротекции, 21 сутки; ПН - первичная нейропротекция; ВН - вторичная нейропротекция; ПН+ВН - комбинированная нейропротекция: первичная + вторичная. 
Таблииа 5.8

Влияние первичной и вторичной нейропротекторной терапии на морфофункциональное состояние клеток глии

\begin{tabular}{|l|c|c|c|}
\hline \multicolumn{1}{|c|}{ Группы животных } & $\begin{array}{c}\text { Плотность глиальных } \\
\text { клеток, мм }\end{array}$ & $\begin{array}{c}\text { Площадь глиальных } \\
\text { клеток, } \text { мм }^{2}\end{array}$ & Концентрация РНК, Еоп \\
\hline Интактные & $448,7 \pm 9,9$ & $24,5 \pm 2,7$ & $3,3 \pm 0.3$ \\
\hline Контроль, 4-е сут. & $353.6 \pm 14,7$ & $18,6 \pm 2,0$ & $1,4 \pm 0,12$ \\
\hline ПН, 4-е сут. & $33,3 \pm 8,1^{*}$ & $20,5 \pm 1,3^{*}$ & $1,5 \pm 0,14$ \\
\hline Контроль, 21-е сут. & $309,1 \pm 7,4$ & $13,2 \pm 1,7$ & $1,0 \pm 0,11$ \\
\hline ВН, 21-е сут. & $379,2 \pm 9,1 \&$ & $20,8 \pm 1,3 \&$ & $2,4 \pm 0,2 \&$ \\
\hline ПН+ВН & $430,0 \pm 10,1^{* *}$ & $23,0 \pm 1,6^{\star *}$ & $3,2 \pm 0,15^{\star *}$ \\
\hline
\end{tabular}

Примечание: * - $<<0,05$ по отношению к контролю 4 сутки;

$\&-\mathrm{p}<0,05$ по отношению к контролю 21 сутки;

** - $<<0,05$ по отношению к вторичной нейропротекции, 21 сутки;

ПН - первичная нейропротекция;

ВН - вторичная нейропротекция;

ПН+ВН - комбинированная нейропротекция: первичная + вторичная.

Действие лекарственных средств первичной и вторичной нейропротекции проявлялось увеличением плотности глиальных клеток и нейронов в коре головного мозга как на 4-е, так и на 21-е сутки эксперимента, а также повышением их морфофункциональной и транскрипционной активности (увеличение содержания РНК) и снижением количества деструктивно измененных клеток (табл.5.7). Как видно из табл.5.8, комбинация первичной и вторичной нейропротекции более выраженно влияла на клетки глии.

Для оценки патогенетической взаимосвязи, а также для выявления аспектов нейропротективного действия комбинации средств первичной и вторичной нейропротекции мы, при помощи диаграмм рассеивания и бинарного регрессионного анализа, провели оценку характера сопряженности уровня генной активности и величины визуально измененных нейронов у экспериментальных животных группы контроля и у крыс после терапии комбинацией препаратов первичной и вторичной нейропротекции (рис. 5.9 и 5.10).

Как свидетельствует комплексная оценка данных проведенного регрессионного анализа и диаграмм рассеивания, у крыс без терапии (контроль) характер ассоциации между уровнем экспрессии c-fos и количеством нормальных нейронов носил вид полиномиальной (степенной) квадратичной функции, указывая, что малое количество недеградированных нейроцитов сопряжено как с низким уровнем c-fos, так и с резким повышением ее активности (гиперэкспрессия c-fos может быть маркером программируемой гибели нейронов головного мозга в условиях ишемии).

Эта U-образная зависимость также свидетельствовала, что нормальные нейроны чаще регистрируются в диапазоне 2,5-4,5 c-fos-позитивных клеток. 
В тоже время у крыс на фоне моделирования острого нарушения мозгового кровообращения, после терапии комбинацией препаратов первичной и вторичной нейропротекции, отмечали позитивное действие на плотность нормально функционирующих нейронов, вероятно, за счет модуляции генной активности HSP.

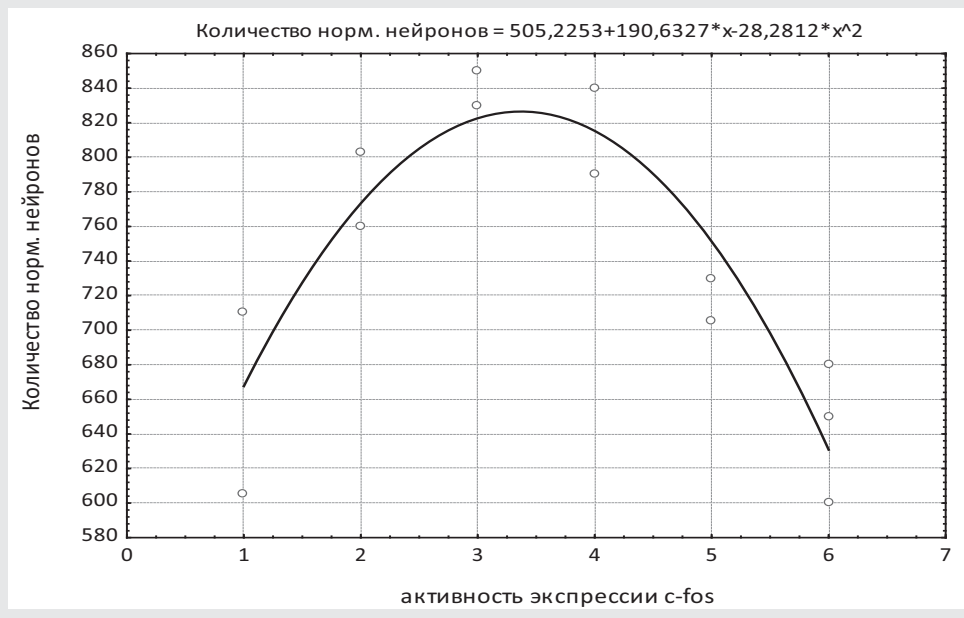

Рuc. 5.9. Регрессионная модель взаимосвязи активности экспрессии c-fos и количества структурно-нормальных нейронов головного мозга крыс группы контроля после моделирования острого нарушения мозгового кровообращения

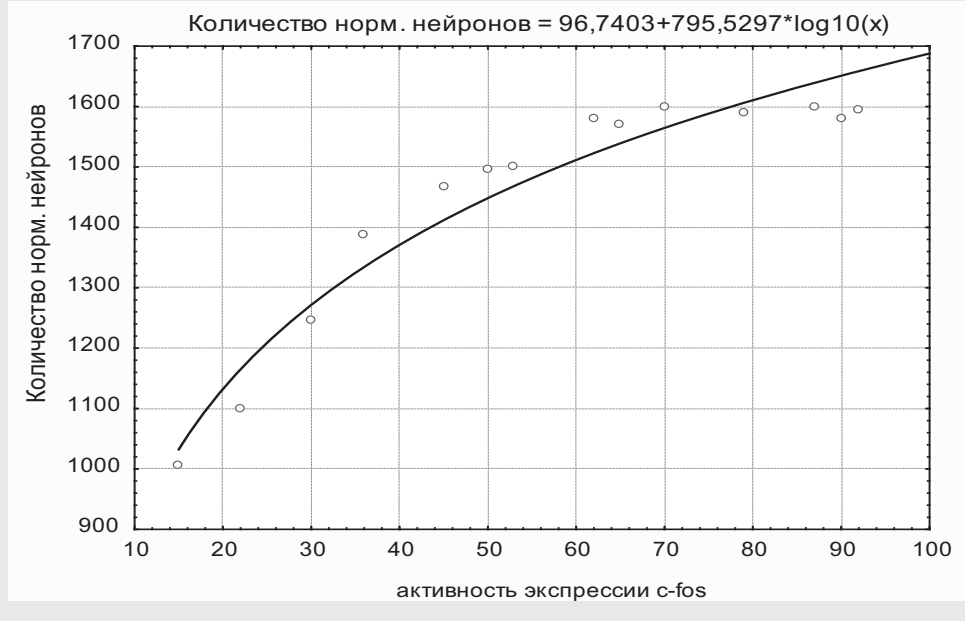

Рис. 5.10. Регрессионная модель взаимосвязи активности экспрессии c-fos и количества нормальных нейроцитов головного мозга крыс после терапии в рамках моделирования острого нарушения мозгового кровообращения 
Установленная нами в эксперименте эффективность комбинации средств первичной и вторичной нейропротекции объясняется возможностью назначаемых препаратов воздействовать на многокомпонентный постишемический каскад, при этом значительно уменьшая уровень нейронального повреждения, так как комплекс препаратов способен влиять на все этапы ишемического каскада. В данном случае мишенью для каждого из препаратов является отдельное патогенетическое звено порочного круга постишемического каскада, и прервать данный необратимый каскад можно именно с применением комплексного воздействия [502, 503].

Таким образом, установлено, что за счет способности препаратов усиливать экспрессию гена c-fos изменялся и морфологический тип гибели нейронов, переключаясь на более мягкий апоптотический путь. Апоптотическая гибель нейронов является оптимальным, упорядоченным процессом прекращения жизнедеятельности деструктивно измененных нейронов, при котором стабилизируются клеточные мембраны, содержание клеток утилизируется путем образования апоптотических телец и их фагоцитоза без развития воспалительной реакции.

Нами впервые были получены экспериментальные данные о роли белков теплового шока (HSP70) и фактора, индуцированного гипоксией (HIF-1), в патогенезе церебральной ишемии, формировании эндогенных механизмах нейропротекции и нейропластиченсти, а также экспериментально установлено участие HSP и HIF-1 в реализации молекулярно-биохимических механизмов защитного действия средств первичной и вторичной нейропротекции.

Моделирование ишемического повреждения головного мозга вызывало активацию наборов генов, которые обеспечивают адаптацию клеток и тканей к низкому содержанию кислорода, а именно фактора, индуцированного гипоксией - HIF-1 (hypoxia-inducible factor), и белков теплового шока HSP70.

Как видно из табл. 5.9, моделирование ишемического поражения на 4-е сутки эксперимента показало существенное увеличение концентрации белков HSP70, HIF-1а в тканях головного мозга, что связано, по нашему мнению, с их шаперонной активностью в условиях развивающегося оксидативного нарушения гомеостаза, направленной на интенсификацию резервно-адаптационных возможностей в острый период ишемии. На 21-е сутки нами было зарегистрировано существенное снижение концентрации исследуемых белков. Подобные динамические изменения объясняются срывом адаптационных возможностей организма на 21-е сутки эксперимента, что обусловлено гиперпродукцией активных форм кислорода и цитотоксических форм оксида азота, приводящих не только к модификации (обратимой и необратимой) макромолекул, в том числе и самих HSP70 и HIF-1a, но и снижением экспрессионной активности генов, кодирующих синтез последних [38].

Позитивная динамика при назначении препаратов наблюдалась и при изучении концентрации в тканях головного мозга HIF- и HSP-белков. Назначение как первичной, на 4-е сутки, так и вторичной, на 21-е сутки нейропротекции приводило к достоверному повышению содержания HIF- и HSP-белков в головном мозге. Их комбинация приводила к усилению эффекта. Из табл.5.9 
видно, что назначение первичной и вторичной нейропротекции повышало содержание HSP-белков и HIF-белков более, чем в 1,5 раза по отношению к контролю на 21-е сутки.

Таблица 5.9

Влияние первичной и вторичной нейропротекторной терапии на концентрацию HSP- и HIF-белков в головном мозге животных с моделированием ишемического инсульта

\begin{tabular}{|l|c|c|}
\hline \multicolumn{1}{|c|}{ Группы животных } & HSP, усл. ед. & HIF, усл. ед. \\
\hline Интактные & $59,8 \pm 2,5$ & $27,0 \pm 9,1$ \\
\hline Контроль, 4-е сут. & $98,2 \pm 3,6$ & $48,6 \pm 7,6$ \\
\hline ПН, 4-е сут. & $5,3 \pm 7,9^{*}$ & $68,1 \pm 4,4^{\star}$ \\
\hline Контроль, 21-е сут. & $38,9 \pm 2,4$ & $24,3 \pm 4,7$ \\
\hline ВН, 21-е сут. & $69,5 \pm 2,1 \&$ & $50,6 \pm 7,9 \&$ \\
\hline ПН+ВН & $93,6 \pm 2,0^{* *}$ & $69,1 \pm 4,6^{\star *}$ \\
\hline
\end{tabular}

Примечания: * $-\mathrm{p}<0,05$ по отношению к контролю 4-е сутки;

$\&-\mathrm{p}<0,05$ по отношению к контролю 21-е сутки;

$* *-\mathrm{p}<0,05$ по отношению к вторичной нейропротекции, 21-е сутки; ПН - первичная нейропротекция; ВН - вторичная нейропротекция; ПН+ВН - первичная нейропротекция + вторичная нейропротекция.

Действие препаратов первичной и вторичной нейропротекции реализуется, по-видимому, за счет их способности повышать концентрацию в тканях головного мозга HSP-белков. В условиях ишемического повреждения головного мозга HSP70 и HIF-1а за счет позитивного влияния на синтез антиоксидантных ферментов, шаперонной активности, стабилизации актиновых филаментов препятствуют развитию некроза. Кроме того, рядом работ была показана роль повышения экспрессии HSP70 в клетках мозга (в астроцитах) в защите их от гибели, вызванной кислородным голоданием. Была продемонстрирована способность очищенного препарата HSP70 повышать выживаемость нейронов, участвующих в глутаматергической синаптической передаче в обонятельной коре мозга крыс, от разрушающего воздействия тяжелой аноксии [39, 40$]$.

Принимая во внимание данные о способности HSP70 усиливать жизнеспособность нейрональной клетки в условиях гипоксии и факт взаимодействия HSP70 и HIF-1a, играющего первостепенную роль в клеточном ответе на гипоксию, можно предположить, что HSP70 участвует в регуляции сигнальных путей ответа клетки на гипоксический стресс на уровне регуляции стабильности HIF-1а. Зафиксированное нами повышение экспрессии HSP70 на 4-е сутки экспериментальной ишемии подтверждает значимость шаперона HSP70 для стабилизации системы реакции клеток на ишемию; по-видимому, этот механизм лежит в основе защитной активности белка.

Способность препаратов первичной и вторичной нейропротекции в условиях ишемии головного мозга нормализовать экспрессию гена c-fos, регулировать концентрацию HIF- и HSP-белков на 21-е сутки приводила к увеличению плотности глиальных клеток и нейронов в коре головного мозга как на 4-е, 
так и на 21-е сутки эксперимента, а также к повышению их морфофункциональной активности (увеличению содержания РНК) и снижению количества деструктивно измененных клеток. Как видно из табл. 5.9, комбинация первичной и вторичной нейропротекции более выражено влияла на исследуемые показатели.

Нейропротективное действие ПН, ВН, ПН+ВН проявлялось увеличением плотности глиальных клеток и нейронов в коре головного мозга как на 4-е, так и на 21-е сутки эксперимента, а также повышением их морфофункциональной и транскрипционной активности (увеличение содержания РНК) и снижением количества деструктивно измененных клеток.

Нейропротективное действие препратов как ПН так и ВН проявлялось в уменьшении неврологического дефицита, о чем свидетельствовало достоверное снижение среднего балла по шкале C. P. McGrow, а комбинация ПН+BH имела достоверно более выраженное действие на исследуемый показатель (табл. 5.10).

Таблица 5.10

Средний балл неврологического дефицита по шкале C. P. McGrow у монгольских песчанок с моделированием острого нарушения мозгового кровообращения и с назначением препаратов первичной и вторичной нейропротекции

\begin{tabular}{|c|c|}
\hline Группы животных $(\mathbf{n}=\mathbf{1 0})$ & Средний балл по шкале McGrow $(\mathbf{M} \pm \mathbf{m})$ \\
\hline Интактные & $18, + \pm 2,41$ \\
\hline Контроль, 4-е сут & $9,31 \pm 0,82^{*}$ \\
\hline ПН, 4-е сут. & $12,62 \pm 1,28$ \\
\hline Контроль, 21-е сут. & $8,52 \pm 0,63 \&$ \\
\hline ВН, 21-е сут. & $5,11 \pm 0,52^{* \star}$ \\
\hline ПН+ВН &
\end{tabular}

Примечания: * - p <0,05 по отношению к контролю 4-е сутки;

$\&-\mathrm{p}<0,05$ по отношению к контролю 21-е сутки;

$* *-\mathrm{p}<0,05$ по отношению к вторичной нейропротекции, 21-е сутки;

ПН - первичная нейропротекция; ВН - вторичная нейропротекция;

ПН+BН - первичная нейропротекция + вторичная нейропротекция.

Таким образом, реализация нейропротективного действия препаратов первичной и вторичной нейропротекции осуществляется, по-видимому, за счет их способности повышать концентрацию в тканях головного мозга HSPбелков.

В условиях ишемического повреждения головного мозга белки теплового шока (HSP) и фактор, индуцированный гипоксией (HIF-1) за счет позитивного влияния на синтез антиоксидантных ферментов, за счет шаперонной 
активности, стабилизации актиновых филаментов препятствуют развитию некроза. Принимая во внимание данные о способности HSP усиливать жизнеспособность нейрональной клетки в условиях гипоксии и факт взаимодействия HSP и HIF, играющего первостепенную роль в клеточном ответе на гипоксию, можно предположить, что HSP участвует в регуляции сигнальных путей ответа клетки на гипоксический стресс на уровне регуляции стабильности HIF. Известно, что компоненты разработанной нами поэтапной нейропротективной терапии (Цереброкурин, Тиотриазолин, Тиоцетам), непосредственно или опосредованно способны модулировать экспрессию генов раннего реагирования c-fos и таким образом запускать программу синтеза адаптационных белков (в том числе HSP и HIF) в нейронах в условиях острой церебральной ишемии [24].

Данными исследованиями показано, что поэтапное комбинирование средств первичной и вторичной нейропротекции по предложенной нами схеме оказывает позитивное воздействие на экспрессию HSP и HIF и значительно повышает их концетрацию в головном мозге в условиях ишемии. Таким образом, полученные нами результаты исследования раскрывают не только молекулярный механизм нейропротекторного действия поэтапной терапии острых нарушений мозгового кровообращения, но и являются экспериментальным обоснованием для внедрения ее в клиническую практику [24, 25].

В результате эксперимента на двух группах животных с моделированной острой травмой и ишемией мозга была проведена экспериментальная проверка стратегии нейропротекторной терапии и сделаны следующие выводы: изучая морфогенез и лечебный патоморфоз посттравматической энцефалопатии у крыс с черепно-мозговой травмой выявлено, что применение двухэтапной нейропротекции приводит к значительному улучшению репаративных процессов мозговой ткани, предложенная двухэтапная нейропротекция снижает летальность крыс с 48 \% до 16 \%, значительно уменьшает неврологический дефицит и приводит к существенной коррекции антиоксидантной системы головного мозга.

Установлен молекулярный механизм воздействия двухэтапного комплекса нейропротекторов в условиях острой церебральной ишемии на экспрессию гена раннего реагирования и программу синтеза адаптационных белков в нейронах.

Экспериментальными исследованиями на моделях ишемии мозга установлено, что поэтапное комбинирование средств первичной и вторичной нейропротекции по разработанной схеме непосредственно или опосредованно способно модулировать экспрессию генов раннего реагирования c-fos и таким образом запускать программу синтеза адаптационных белков (в том числе HSP и HIF) в нейронах в условиях острой церебральной ишемии и значительно повышать их концетрацию в головном мозге. Установлен рост концентрации в тканях головного мозга HSP-белков и фактора, индуцированного гипоксией (HIF-1), которые за счет шаперонной активности, стабилизации актиновых филаментов, препятствуют развитию некроза. Максимальное модулирование экспрессии генов раннего реагирования c-fos имело место у животных, которым после 
экспериментальной ишемии проводилось комплексное лечение, включающее первичную и вторичную нейропротекцию.

Экспериментально на модели ишемии мозга доказано, что патогенетический подход к двухэтапному нейропротективному воздействию способен усиливать экспрессию гена c-fos, изменять морфологический тип гибели нейронов, переключаясь на более мягкий апоптотический путь, который является оптимальным, упорядоченным процессом прекращения жизнедеятельности деструктивно измененных нейронов.

Таким образом, реализация действия препаратов первичной и вторичной нейропротекции происходит, по-видимому, за счет их способности повышать концентрацию в тканях головного мозга HSP-белков [41]. В условиях ишемического повреждения головного мозга белки HSP и HIF препятствуют развитию некроза за счет позитивного влияния на синтез антиоксидантных ферментов, шаперонной активности, стабилизации актиновых филаментов. Кроме того, рядом работ была показана роль повышения экспрессии HSP70 в клетках мозга (в астроцитах) в защите их от гибели, вызванной кислородным голоданием. Также была продемонстрирована способность очищенного препарата HSP70 повышать выживаемость нейронов, участвующих в глутаматергической синаптической передаче в обонятельной коре мозга крыс, от разрушающего воздействия тяжелой гипоксии $[42,43]$. Принимая во внимание данные о способности HSP усиливать жизнеспособность нейрональной клетки в условиях гипоксии и факт взаимодействия HSP и HIF, играющего первостепенную роль в клеточном ответе на гипоксию, можно предположить, что HSP участвует в регуляции сигнальных путей ответа клетки на кислородное голодание на уровне регуляции стабильности HIF.

Нейропротективное действие ПН, ВН, ПН+ВН проявлялось увеличением плотности глиальных клеток и нейронов в коре головного мозга как на 4-е, так и на 21-е сутки эксперимента, а также повышением их морфофункциональной и транскрипционной активности (увеличение содержания РНК) и снижением количества деструктивно измененных клеток.

Максимальный уровень плотности и площади клеток нейронов, концентрация РНК зафиксированы на 21-е сутки эксперимента в 4-й серии монгольских песчанок, получавших первичную и вторичную нейропротективную терапию.

В нейронах гиппокампа максимальное количество гена c-fos, (гена первичного или раннего ответа), и белка bcl-2 (B-cell lymphoma 2 - белок-супрессор апоптоза (программируемой клеточной гибели)) также выявлено на 21-е сутки эксперимента в 4-й серии монгольских песчанок, получавших первичную и вторичную нейропротективную терапию.

Интегральный показатель нейропротективного действия препаратов как ПН, так и ВН - это уменьшение неврологического дефицита, о чем свидетельствовало достоверное снижение среднего балла по шкале C. P. McGrow, a их комбинация имела более выраженное действие на исследуемый показатель. Именно в этой 4-й серии экспериментальных животных на 21-е сутки выявлено максимальное уменьшение неврологического дефицита - достоверное снижение среднего балла по шкале C. P. McGrow. 
Экспериментальная проверка эффективности нейропротекторной терапии в клинике была начата с изучения реактивности ЦНС в ответ на введение нейропротекторов у пациентов с черепно-мозговой травмой и мозговым инсультом различной локализации и этиологии для определения функциональных взаимоотношений поврежденных мозговых структур.

Первой задачей нашего клинического исследования явилась количественная оценка изменений ЭЭГ при раздражениях (FTS, фармакологическое воздействие), которые недоступны при визуальном анализе, с тем, чтобы приблизиться к пониманию механизмов развития ответных реакций мозга. Использован интегральный количественный анализ оценки электроэнцефалограммы для изучения характера реактивных перестроек ЭЭГ в ответ на нейротропное фармакологическое воздействие. В качестве нейропротектора был выбран препарат Тиоцетам, исследован его дозозависимый эффект.

Реактивность (Reactivity) [70] — подверженность отдельных ЭЭГ-ритмов или ЭЭГ в целом изменяться под влиянием сенсорной стимуляции или других физиологических воздействий ЦНС, оценивали по изменению (в \%) показателей абсолютной спектр-мощности - absolute spectral power (ASP) и интегральных коэффициентов (ИК) ЭЭГ-паттерна у конкретного пациента в ответ на введение нейротропного препарата (формула 1):

$$
\mathrm{R}=\text { Реактивность }=\frac{\text { Фоновый показатель после введение препарата }}{\text { Фоновый показатель до введение препарата }} \times 100-100
$$

На основании анализа записей ЭЭГ у 82 больных с диагнозом «острое нарушение мозгового кровообращения» (121 ЭЭГ - до и 121 ЭЭГ — после введения нейротропного препарата) и записей ЭЭГ у 133 пациентов с тяжелой ЧМТ (177 электроэнцефалограмм - до и 177 ЭЭГ - после введения нейротропного препарата - Тиоцетама [45] - были выявлены типы реакции ЦНС на фармакологическое воздействие - всего 596 электроэнцефалограмм.

Из 596 ЭЭГ (1192 типов реакций, по 596 справа и слева) исследований суммарная спектральная мощность практически не изменялась (диапазон изменений $\pm 10 \%$ ) в 118 случаях (6 \% всех изменений). Такие изменения были отнесены к І типу реакций ЦНС (рис. 5.11).

В 913 случаях (45 \% всех ЭЭГ-изменений) суммарная спектральная мощность умеренно увеличивалась в диапазоне от 10 до 30 \% . В 513 случаях (25 \% всех ЭЭГ-изменений) суммарная спектральная мощность умеренно снижалась от -10 до $-30 \%$. Подобные изменения были отнесены к III типу реакций ЦНС, к так называемым реакциям перераспределения мощности.

В 274 случаях (14\% всех ЭЭГ-изменений) суммарная спектральная мощность значительно увеличивалась - более чем на 30 \% . В 204 случаях (10\% всех ЭЭГ изменений) суммарная спектральная мощность значительно снижалась - более чем на -30 \% . Такие изменения были отнесены к II типу реакций ЦНС, причем снижение CM - II 2 подтип, а увеличение - II 1 подтип реакций ЦНС. 


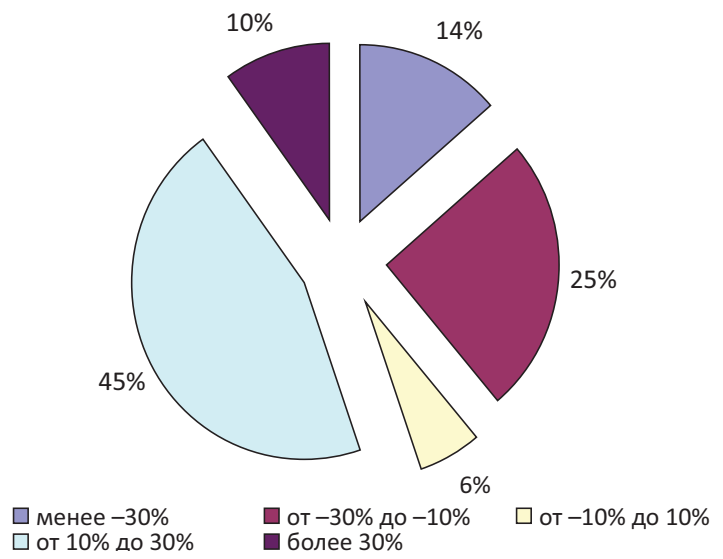

Рuc. 5.11. Число изменений показателей суммарной абсолютной спектральной мощности у пациентов с мозговым инсультом и тяжелой ЧМТ

Затем с помощью корреляционного анализа изменений (R) показателей абсолютной спектр-мощности и интегральных коэффициентов (ИК) ЭЭГпаттерна до и после фармакологического воздействия были установлены взаимно некоррелируемые варианты этих изменений - это и были типы реакции ЦНС на фармакологическое воздействие.

I тип (рис. 5.12) характеризовался отсутствием изменений (не более \pm $10 \%$ ) показателей суммарной ASP и интегральных коэффициентов (ИК).
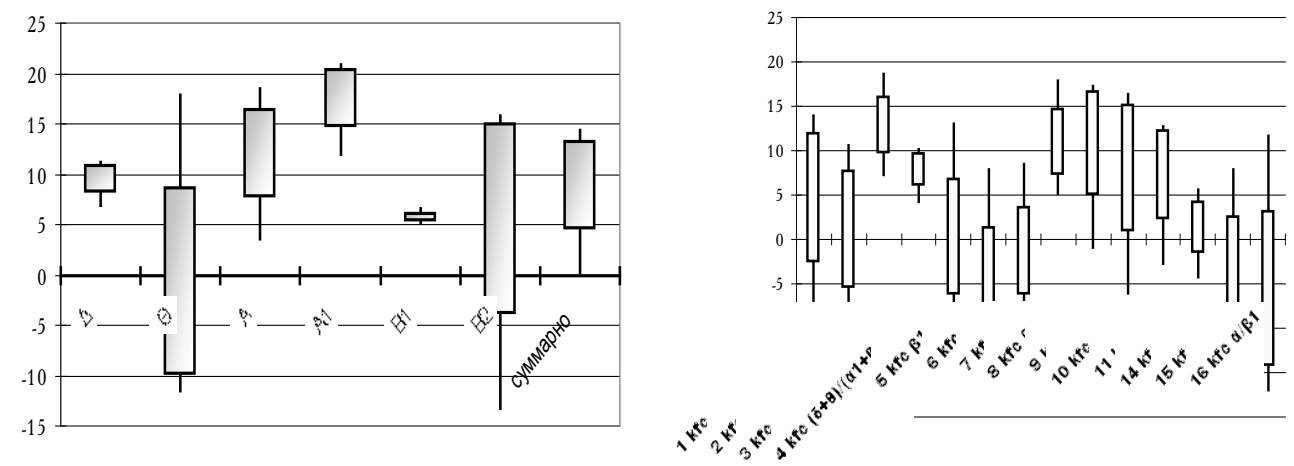

\section{Рис. 5.12. Изменения абсолютной спектральной мощности и интегральных коэффициентов при реакции ЦНС I типа}

Для II типа реакций свойственно выраженное (статистически значимое - более $\pm 30 \%$ ) изменение - рост или снижение - уровня суммарной ЭЭГ-мощности (CM). Соответственно с увеличением или снижением данного показателя выделены две группы реакций ЦНС у данной категории пациентов после введения Тиоцетама. 
При увеличении суммарной спектр-мощности ЭЭГ (II тип, 1-я группа реакций), безусловно, прямо пропорционально связанным с аугментацией увеличением амплитуды электрической активности [46]. Чаще всего отмечались следующие закономерности изменений абсолютной спектральной мощности во всех исследуемых диапазонах: рост СМ преимущественно за счет увеличения ASP медленноволновых патологических дельта- и тета-диапазонов (рис. 5.13) с умеренной активацией $\alpha$-ритма (1а подгруппа (ПГ)) и увеличение CM за счет повышения ASP дельта-, тета- и $\beta 2$-ктивности (рис. 5.14) при стабильности показателей альфа диапазона (1б ПГ) (рис. 5.15). Для ПГ $1 б$ характерно увеличение суммарной ЭЭГ-мощности с ростом $\alpha$-мощности при синхронной редукции высокочастотного бета 2- и патологического дельта-ритма. Для II 1г ПГ (рис. 5.16) было характерно увеличение суммарной ЭЭГ-мощности с ростом $\beta 2$-мощности при синхронной редукции или отсутствии значимых изменений, как патологических дельта- и тета-ритмов.

Следует отметить, что реакции ЦНС II 1а подгруппы (ПГ) (рис. 5.13) сопровождаются преимущественной активацией $\alpha 1$-поддиапазона и перераспределением мощности в бета-частотном диапазоне с преобладанием низкочастотного $\beta 1$-ритма. Для этой подгруппы реакций характерно увеличение уровней 1-го, 2-го, 9-го ИК. Максимального роста достигают показатели 5-го и 15 -го ИК.
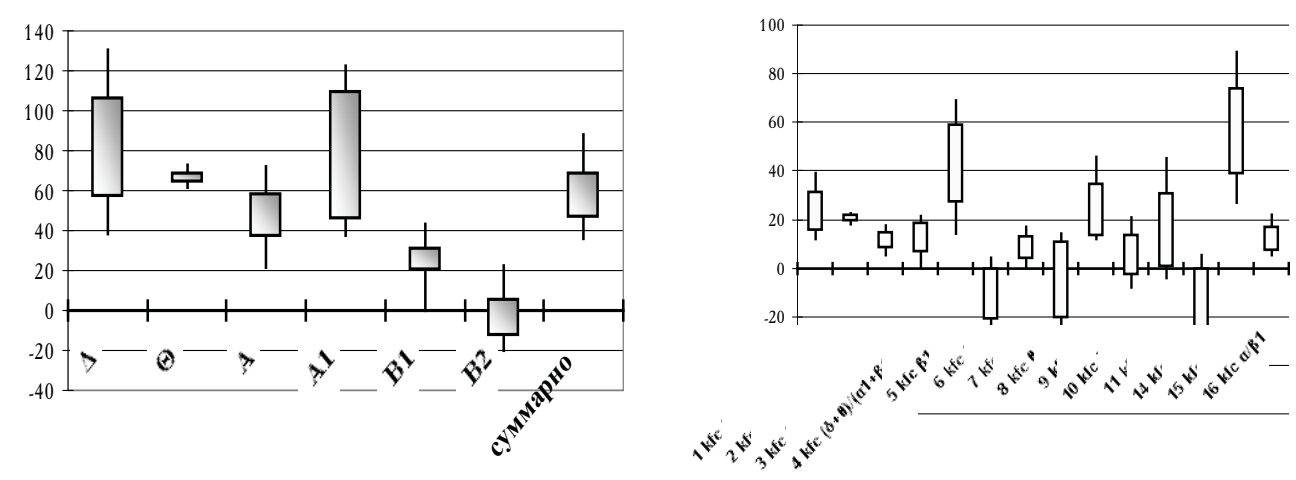

Рис. 5.13. Изменения абсолютной спектральной мощности и интегральных коэффициентов при реакции ЦНС II типа 1а подгруппы

B подгруппе реакций II 16 с увеличением CM за счет повышения ASP дельта-, тета- и $\beta 2$-активности (рис. 5.14) показатель ASP $\alpha$-диапазона стабилен, но отмечаются тенденции к угнетению $\alpha 1$-ритма. Особенностями реакций II 1 П ПГ следует считать выраженный рост уровней 3-го, 4-го, 8-го, 10-го, снижение 5 -го и вариабельность изменений 15 -го ИК, связанные в большей мере с активацией быстрого бета-ритма. 

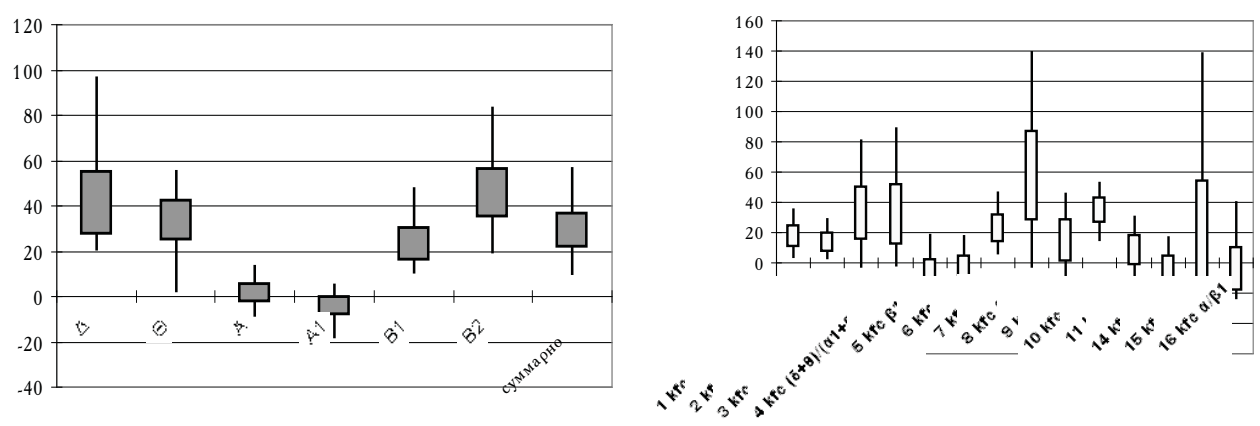

\section{Рuc. 5.14. Изменения абсолютной спектральной мощности и интегральных коэффициентов при реакции ЦНС II типа 16 подгруппы}

Было выявлено, что первое введение Энтропа в дозе 100 мг характеризовалось формированием двух вариантов ответа ЦНС, чего не встречалось при применении Тиоцетама.

Интересна реакция II 1в ПГ, для которой характерны уменьшение дезорганизации ЭЭГ-паттерна за счет активации альфа-ритма и снижения активирующих подкорковых влияний на кору (рис. 5.15). Такие реакции были выявлены у 3 исследуемых в ответ на введение Энтропа в дозе более 100 мг в сутки, всегда асимметрично.
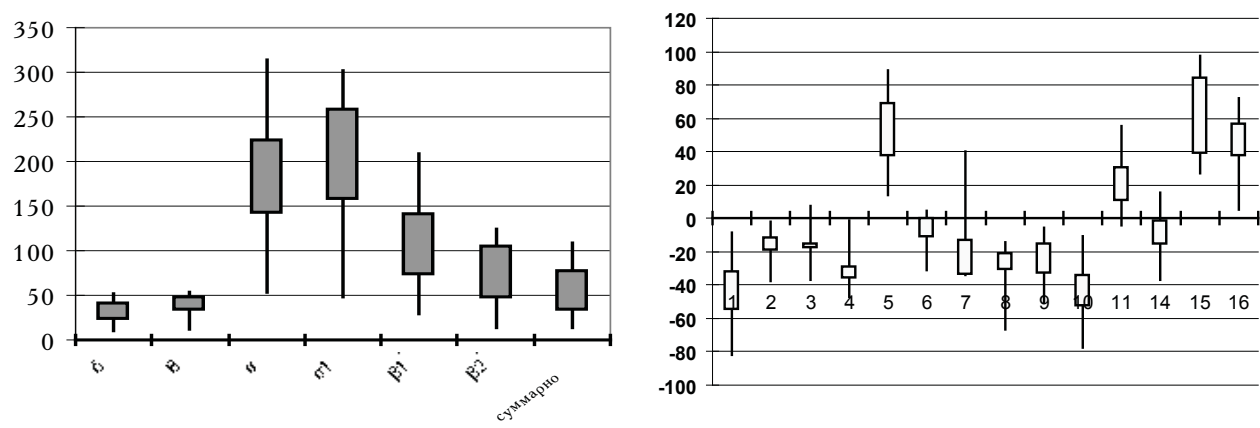

\section{Рuc. 5.15. Изменения абсолютной спектральной мощности и интегральных коэффициентов при реакции ЦНС II типа 1в подгруппы}

Для симметричных реакций II 1г подгруппы было типично увеличение уровня суммарной ЭЭГ-мощности за счет значительного роста абсолютной спектр-мощности (ASP) высокочастотного $\beta 2$-диапазона (20-30 Гц) во всех исследуемых областях коры, что являлось ЭЭГ-коррелятом корковой ирритации (рис. 5.16).

При снижении CM (II тип, 2-я группа реакций), прямо пропорционально связанном с аугментацией (Attenuation - снижение амплитуды электрической активности в ответ на физиологические стимулы или электрическое раздраже- 
ние мозга), которая в этом случае называется блокированием [47], выявлены следующие закономерности изменений ASP. Уменьшение CM преимущественно за счет угнетения медленноволновых $\delta$ - и $\theta$-ритмов с умеренной редукцией -активности (II 2a подгруппа), причем такая десинхронизация ЭЭГ связана с ростом активности ретикулярной формации среднего и продолговатого мозга. И снижение CM за счет ASP всех частотных ЭЭГ-диапазонов (II 26 подгруппа), причем такое блокирование отражает активацию ретикулярной формации, прежде всего, ствола мозга и приводит к снижению коркового компонента ЭЭГ у пациентов с острой церебральной недостаточностью (ОЦН) различного генеза при повышении общего уровня функциональной активности мозга.
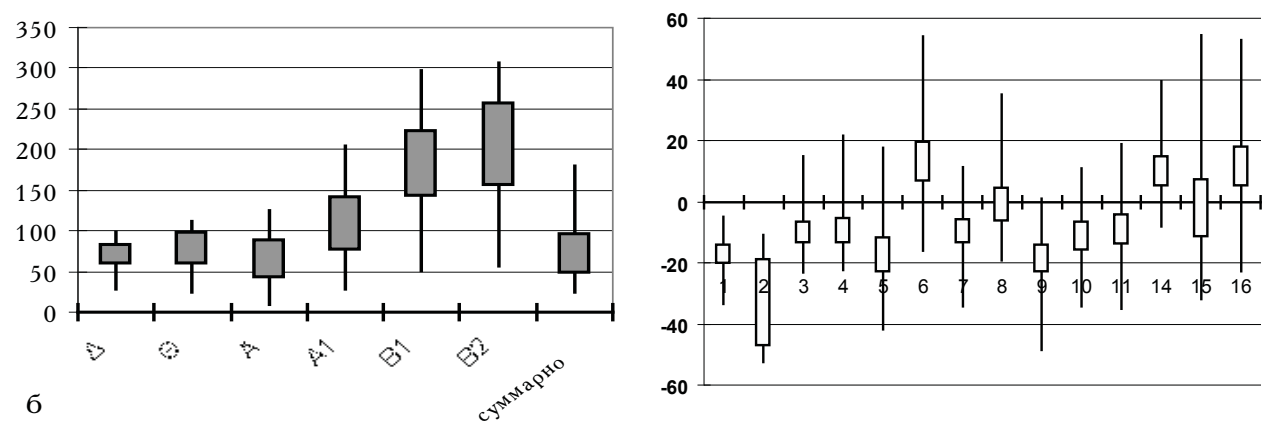

\section{Рис. 5.16. Изменения абсолютной спектральной мощности и интегральных коэффициентов при реакции II типа 1г подгруппы}

Для реакций II 2a подгруппы (рис. 5.17) характерно снижение уровней большинства ИК, наиболее показательно уменьшение уровней 1-4-го, 11-го ИК и увеличение обратного ему 6-го ИК, что связано с выраженным угнетением $\delta$-ритма. Следует отметить значительную вариабельность изменений ASP $\alpha 1$-поддиапазона, что предопределяет достаточно широкий разброс значений 14-го и 16-го ИК.
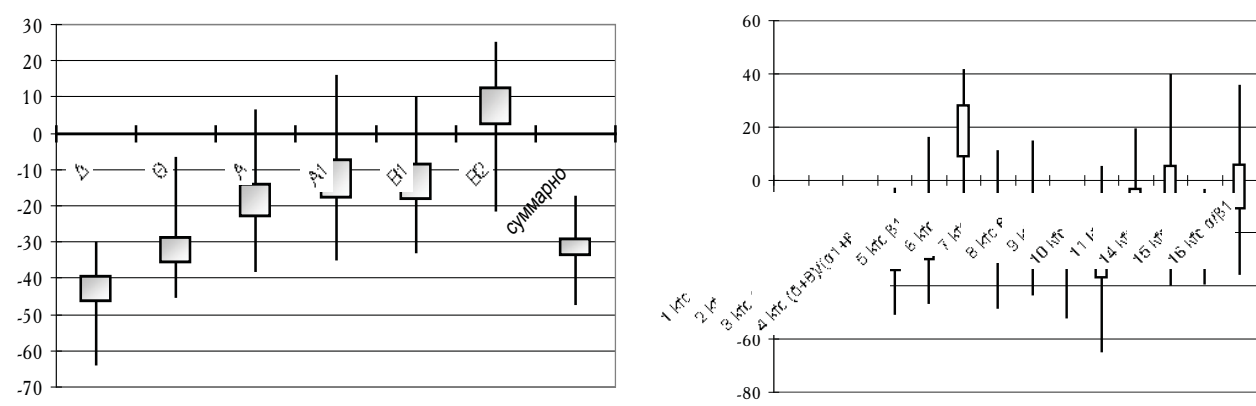

Рuc. 5.17. Изменения абсолютной спектральной мощности и интегральных коэффициентов при реакции ЦНС II типа 2а подгруппы 
Синхронность снижения ASP всех ЭЭГ-диапазонов, типичная для реакций II $2 б$ ПГ (рис. 5.18) предопределяет стабильность показателей ИК. Исключения составляют только 5-й и 15 -й ИК, рост которых обусловлен угнетением высокочастотного бета-ритма.
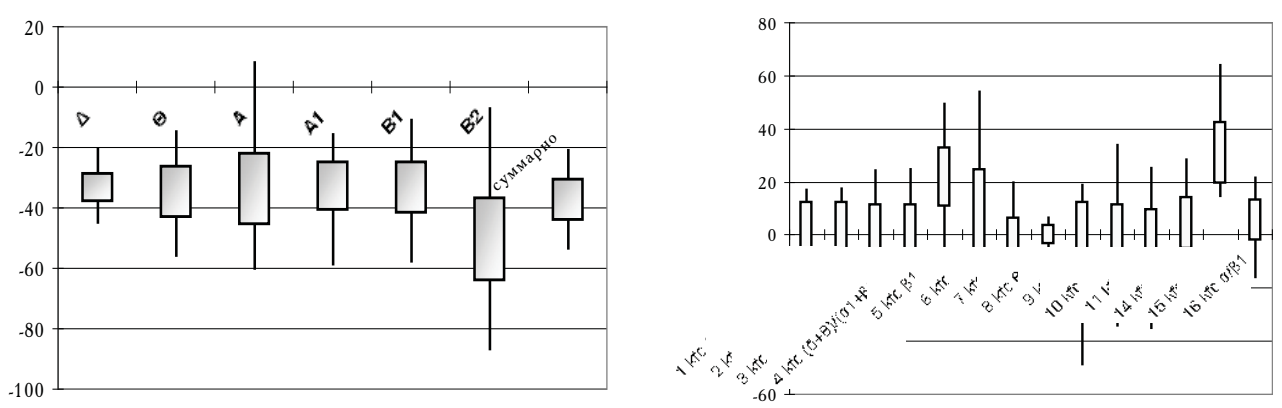

\section{Рис. 5.18. Изменения абсолютной спектральной мощности и интегральных коэффициентов при реакции ЦНС II типа 2б подгруппы}

Реакции II типа, с обязательным ростом (1 группа реакций) или снижением (2 группа реакций) CM, на наш взгляд, отражают изменения степени активирующих воздействий на кору со стороны подкорковых структур (ретикулярной формации), когда увеличение суммарной СМ свидетельствует о снижении активирующих процессов стволового и активации вышележащих уровней неспецифической регуляции, а снижение - об активации ретикулярных стволовых (или среднего мозга) подкорковых влияний с умеренным снятием влияний вышерасположенных структур неспецифической регуляции - таламуса и диэнцефальных образований при формировании ЭЭГ-паттернов.

Следует отметить, что реакция II 1а подгруппы проявляется в ситуациях, когда таламический ЭЭГ-ритм дельта-диапазона генерируется отдельной клеткой таламуса на самом глубоком уровне ее гиперполяризации, тетадиапазона - на менее глубоком гиперполяризационном уровне $[48,49,50]$ или дельта-ритм корковой генерации усиливается при разобщении корковых и таламических структур, но при обязательном подавлении сигналов (гипофункции) от восходящей активационной системы ствола мозга [49].

Реакция II $1 б$ подгруппы также формируется при снижении функции активирующей системы стволового уровня и таламической гиперактивации при нарушении внутриталамических взаимодействий - между неспецифическими ядрами таламуса, но это сопровождается ростом метаболической активности корковых структур и, возможно, проявлением выраженной ГАМК-ергической корковой реакции.

Реакция II 1в ПГ отражает выраженную генерацию регулярно действующим таламусом альфа-ритма при адекватном взаимодействии между неспецифическими ядрами таламуса — синхронизированное торможение ретикулярными нейронами (вентральный таламус - ретикулярное ядро) таламокортикальных нейронов при их относительной деполяризации. 
Реакция II 1г ПГ - значительная $\beta 2$-синхронизация, таким образом, отражает процессы выраженной корковой ирритации (сверхактивации), что происходит как реакция на сильную активацию корковых нейронных сетей, когда тормозные (ГАМКергические) нейроны получают достаточное возбуждение от внешних входов (таламо-кортикальные и стволо-кортикальные воздействия) и рядом расположенных возбуждающих корковых нейронов. Такое торможение происходит циклично, и каждый цикл - цикл бета-активности [49].

Таким образом, реакции II типа описывают значимую реализацию фармакологической реакции на конкретный нейротропный препарат на стволовом (II $2 б$ подгруппа) уровне, на уровне ретикулярной формации среднего мозга и продолговатого мозга (II 2а подгруппа), на уровне неадекватно функционирующих неспецифических ядер таламуса при выраженной функциональной недостаточности ствола (II 1a ПГ), на уровне разобщенно действующих неспецифических ядер таламуса при выраженной стволовой недостаточности и при значительной активации таламо-кортикальных взаимодействий с ростом метаболической активности корковых структур (II 16 ПГ), на уровне таламо-кортикальных нейронов при их относительной деполяризации при адекватном взаимодействии между неспецифическими ядрами таламуса (II 1в ПГ), на уровне корковых тормозных нейронов, которые получают достаточное возбуждение от внешних входов (таламо-кортикальные и стволо-кортикальные воздействия) (II 1г ПГ).

III тип реакций ЦНС характеризуется умеренными или незначительными изменениями (менее \pm 30 \% ) CM, а изменения ЭЭГ-паттерна связаны с перераспределением спектральной мощности, с активацией ЭЭГ-ритма одного частотного диапазона за счет угнетения другого. Отмечаются следующие варианты перераспределения активности: с увеличением мощности медленноволновых, так называемых, «патологических» ритмов (III тип, 1-я группа), с преимущественной активацией альфа-ритма (III тип, 2-я группа) и с ростом уровня мощности бета-диапазона (III тип, 3-я группа).

Интегративная деятельность мозга основана на кооперативной деятельности множества функциональных единиц - «колонок», «нейронных ансамблей», «нейронных модулей», в пределах которых осуществляется циркуляция возбуждения, отраженного в поверхностно регистрируемых колебаниях ЭЭГ, работающих по вероятностно-статистическому принципу с попеременным пространственно-временным распределением [51, 52]. Причем циркуляция импульсов внутри этих объединений и создает циклические контуры связи [49, 52], поэтому ЭЭГ чувствительна как к радиальным, так и к тангенциальным (поверхностным) источникам возбуждения [52]. Изменения ЭЭГ, относящиеся к III типу, при ОЦН различного генеза связаны с морфофункциональными перестройками на корковом уровне. Смещение пика ЭЭГ-активности в медленноволновой дельта-частотный диапазон может быть связано с активацией нейроглиальной популяции, процессов метаболизма и церебрального энергетического обмена, так как медленные биоэлектрические процессы мозга частотой ниже 1 Гц рассматриваются в литературе как корреляты подобных процессов [49, 54]. Активацию медленной активности более высокой частоты дельта-диапазона 
традиционно связывают со снижением уровня оксигенации коры, чаще сосудистого генеза, связанного как с падением, так и с выраженным ростом АД [53]. Смещение пика спектр-мощности в диапазон тета-ритма реализуется через системы нейромедиаторов: тета-активность 6-7,5 Гц связана с холинергической, 5-6 Гц - серотонинергической, а 4-5 Гц - адренергической активацией [52]. Умеренная активация альфа-ритма коркового генеза, который является ритмом состояния «холостого хода» корковых областей, отражает процессы снижения метаболической активности коры. Однако, данная активность, по мнению Р. И. Мачинской [52], играет важную роль в объединении структур мозга для различных видов сенсорной или когнитивной деятельности, формируя динамическую основу их функционального взаимодействия, как бы подготавливая корковые структуры к осуществлению процессов мышления. Также смещение пика ЭЭГ-активности в область высокочастотного альфа-ритма (11-12 Гц) может быть связано с деятельностью дофаминергической системы [55]. Превалирование в ЭЭГ альфа- и бета-частот и снижение пространственной синхронизации биопотенциалов, напротив, связаны с формированием более адекватных условий протекания этих процессов в состоянии бодрствования. Поэтому перераспределение мощности в диапазон бета-ритма является отражением когнитивных процессов в коре и, также, связанные с ними выраженные процессы активации ГАМКергических и серотонинергических нейромедиаторных - преимущественно тормозных корковых процессов $[52,55]$.
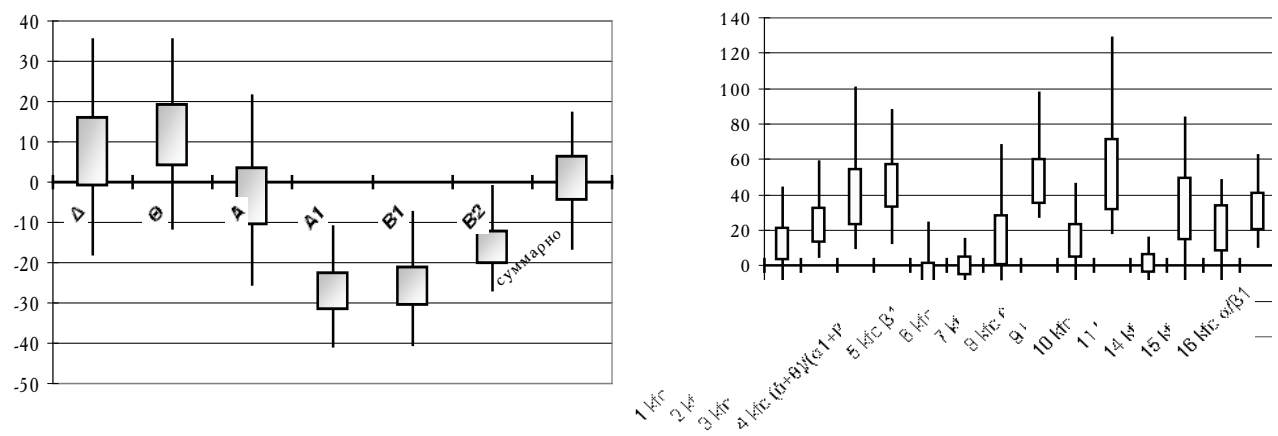

\section{Рuc. 5.19. Изменения абсолютной спектральной мощности и интегральных коэффициентов при реакции ЦНС III типа 1а подгруппы}

Одним из наиболее часто встречающихся типов реакций является III 1a, при которой отмечается активация медленноволновых $\delta$ - и тета-ритмов за счет угнетения $\alpha 1$-активности (рис. 5.19). Часто такое замещение альфа1-ритма сопровождается снижением уровня преимущественно низкочастотного компонента бета-активности. Для III 1 а ПГ реакций характерно увеличение уровней 3-го, 4-го, 8-го, 10-го 14-го и 16-го ИК.

Интересна реакция перераспределения мощности с синхронной активацией дельта- и бета-ритмов за счет угнетения всех частотных диапазонов $\alpha$-активности (III 16 ПГ) (рис. 5.20). Для этой подгруппы реакций характерно увеличение уровней 9 -го, 10-го и 11 -го ИК и снижение уровня 6 -го, 15 -го и 16 -го ИК. 

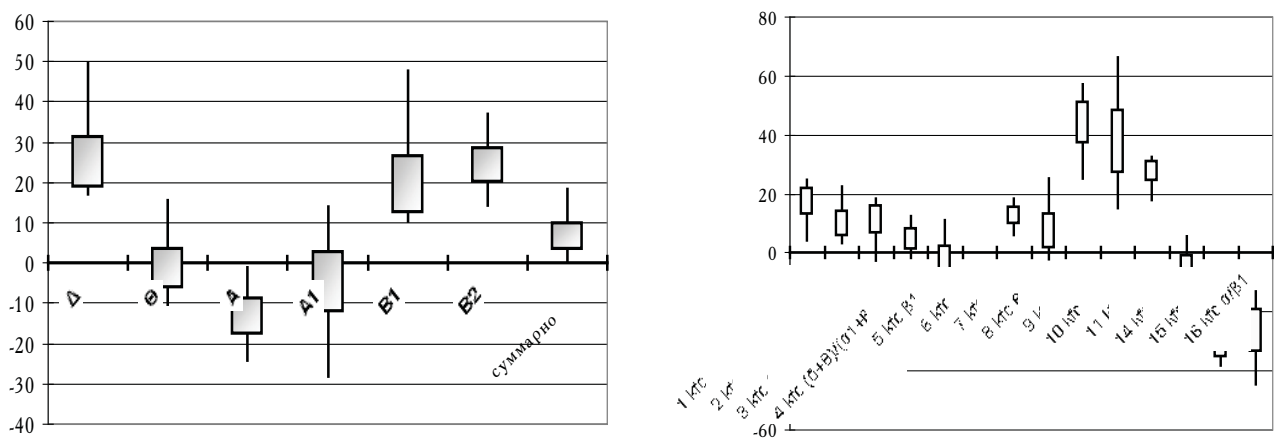

\section{Рис. 5.20. Изменения абсолютной спектральной мощности и интегральных коэффициентов при реакции ЦНС III типа 16 подгруппы}

Реакция перераспределения ЭЭГ-мощности с активацией мощности $\alpha$ - и $\beta 2$-диапазонов (нормальных ритмов ЭЭГ) за счет редукции дельтаактивности (III 2a) представлена на рисунке 5.21. Для этой подгруппы реакций характерно снижение уровней 1-го, 2-го, 5-го, 7-го и наиболее выраженное - 9-го ИК одновременно с ростом 14-го и 16-го ИК. Следует отметить, что рост спектр-мощности $\alpha$-диапазона связан с активацией частотных полос медленного (8-9 Гц) и быстрого (11-12 Гц) альфа-ритма при стабильности $\alpha 1$ поддиапазона.

Перераспределение ЭЭГ-активности с увеличением $\alpha$-мощности за счет синхронной редукции высокочастотного бета 2- и патологического дельтаритмов (III тип 2б подгруппа) характеризуется умеренным снижением 7-10го ИК, тенденцией к росту 5 -го и значительным увеличением уровня 15 -го ИК (рис. 5.22). Следует отметить тенденцию к росту 14 -го ИК, свидетельствующую о том, что активация альфа-ритма связана с преимущественным увеличением ASP $\alpha 1$-поддиапазона.
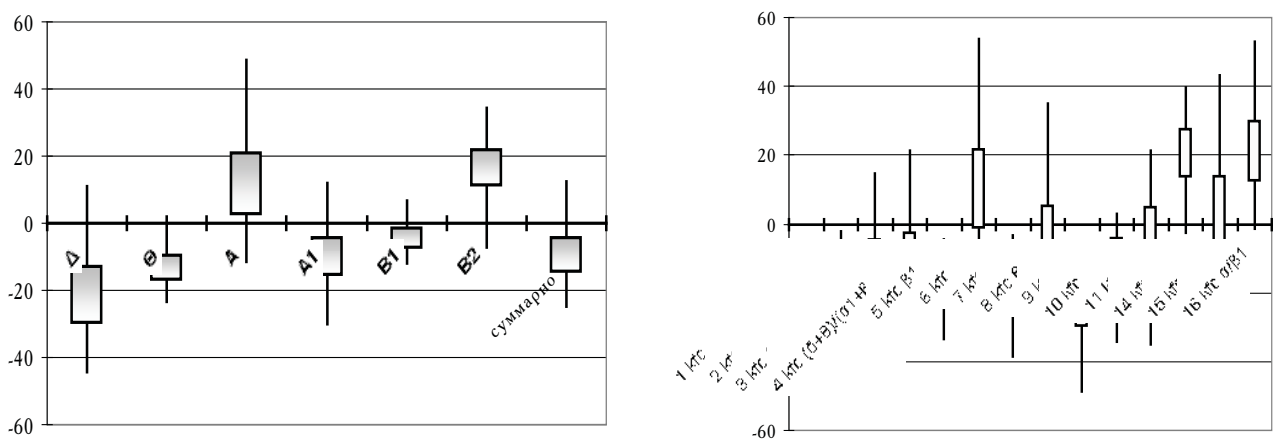

Рuc. 5.21. Изменения абсолютной спектральной мощности и интегральных коэффициентов при реакции ЦНС III типа 2 а подгруппы 

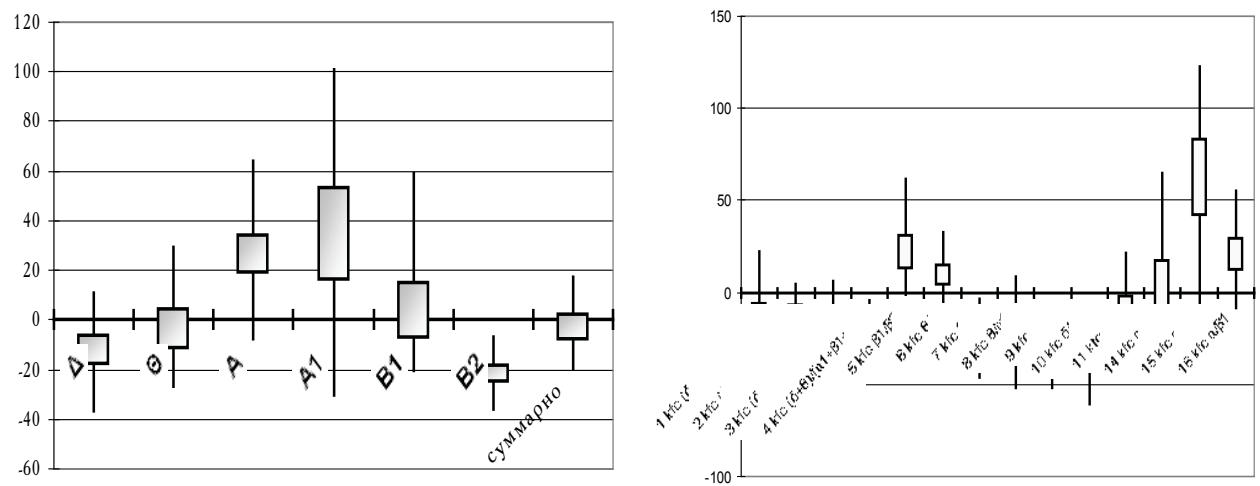

Рис. 5.22. Изменения абсолютной спектральной мощности и интегральных коэффициентов при реакции ЦНС III типа $2 б$ подгруппы

К 3-й группе реакций перераспределения мощности следует отнести активацию высокочастотного $\beta 2$-ритма за счет редукции альфа-активности (III 3а ПГ) (рис. 5.23). Наиболее выраженными изменениями ИК в данной подгруппе реакций является рост 7-го, 9-го ИК и снижение 15-го ИК.

Перераспределение ЭЭГ-активности с увеличением $\beta 2$-мощности за счет редукции $\delta$-ритма (III тип 3б подгруппа) характеризуется тенденцией к снижению 1-2-го, 5-го, 9-го, 10-го, 11-го ИК, тенденцией к росту 6-го, 14-го и 16 го ИК (рис. 5.24). Следует отметить, что выявлены преимущественно тенденции к изменениям ИК, возможно такие реакции следует считать гипореактивными.
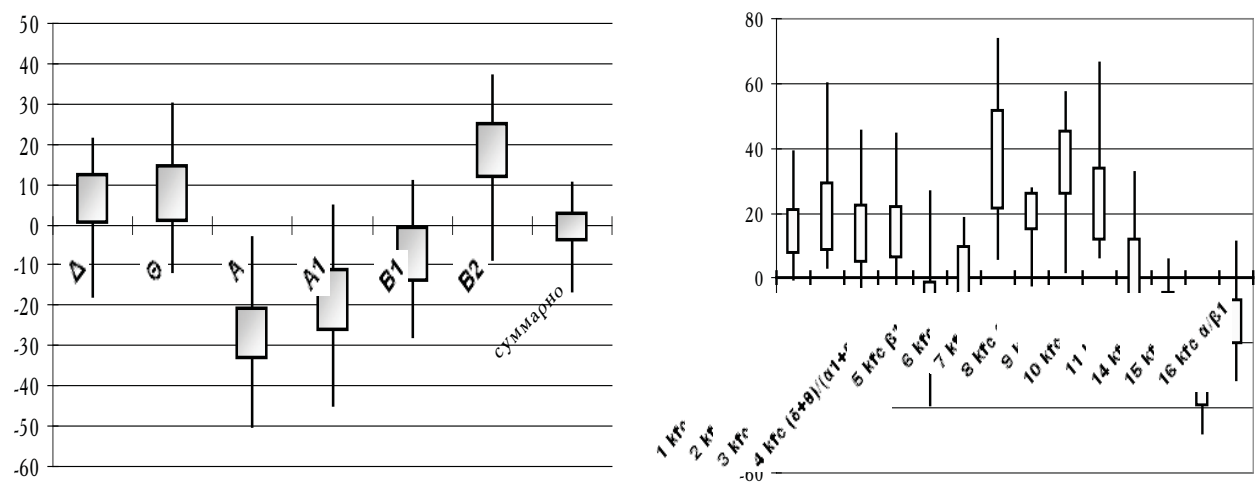

Рис. 5.23. Изменения абсолютной спектральной мощности и интегральных коэффициентов при реакции ЦНС III типа За подгруппы 

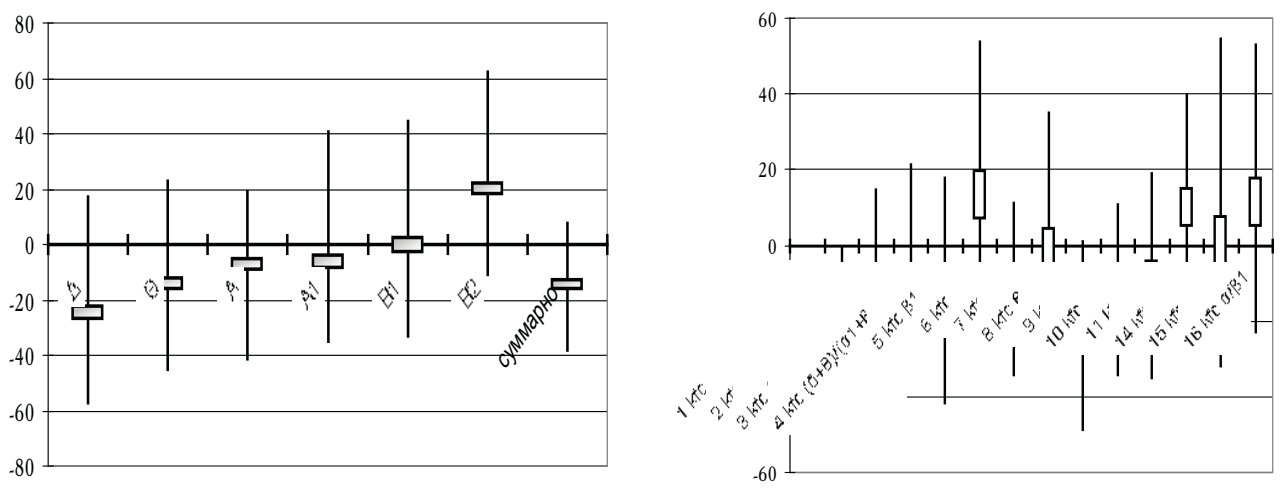

Рuc. 5.24. Изменения абсолютной спектральной мощности и интегральных коэффициентов при реакции ЦНС III типа 3б подгруппы

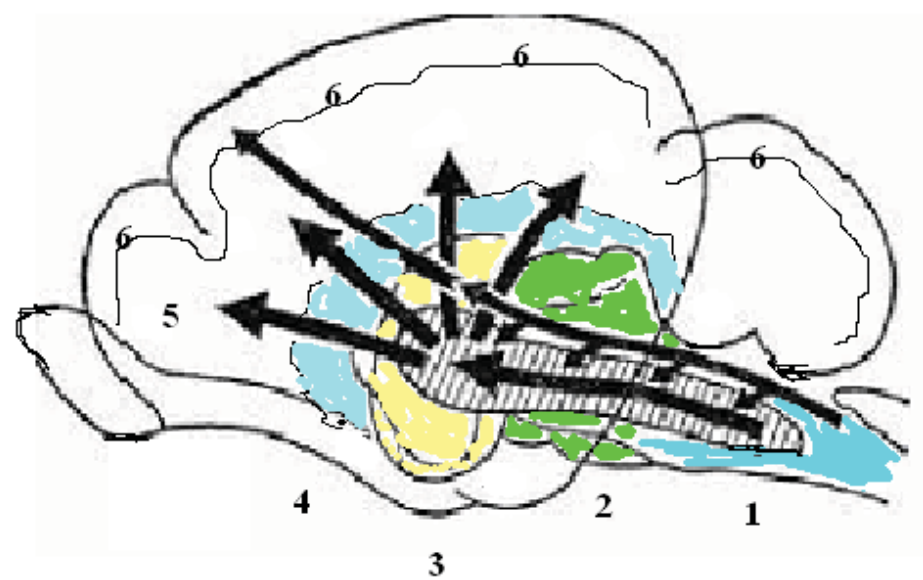

1 - стволовой уровень ретикулярной формации мозга; 2 - уровень ретикулярной формации среднего мозга и продолговатого мозга; 3 - таламический уровень неспецифической регуляции мозга; 4 - лимбико-гиппокампальные структуры неспецифической регуляции; 5 - восходящие таламокортикальные связи; 6 - кора больших полушарий мозга.

Рис. 5.25. Уровни приложения фармакологических реакций ЦНС II типа в ответ на введение нейротропных препаратов при острой церебральной недостаточности различного генеза

Изучение типов реакции ЦНС в ответ на фармакологическое воздействие дало возможность количественно оценить увеличение или уменьшение дезорганизации ЭЭГ-паттерна и определить уровень нейрофизиологического воздействия препарата на мозг (кора-подкорка, кора-кора) (табл. 5.11). 
Вышеизложенное позволило прийти к заключению о том, что I тип - отсутствие достоверных изменений показателей абсолютной спектральной мощности и интегральных коэффициентов - прогностически неблагоприятный [528533]. II тип 1а подгруппа, 1б подгруппа - увеличение СМ ЭЭГ-паттерна, преимущественно за счет повышения ASP патологических дельта- и тета-диапазонов прогностически неблагоприятный; 1в подгруппа - увеличениеСМЭЭГ-паттерна, преимущественно за счет повышения ASP альфа-активности - прогностически благоприятный. Реакции II типа отражают изменения корково-подкорковых взаимодействий в ответ на фармакологическое воздействие.

Реакции ЦНС типа II 1а и II 1б ПГ отнесены к прогностически неблагоприятным, так как они характеризуются нарастанием дезорганизации ЭЭГ-паттерна за счет недостаточности стволовых активирующих влияний с увеличением спектр-мощности патологической, преимущественно $\delta$-волновой активности.

II тип 2а подгруппа, 26 подгруппа - уменьшение CM ЭЭГ-паттерна, преимущественно за счет угнетения $\delta$ - и $\theta$-ритмов - прогностически благоприятные. Из реакций II типа наиболее благоприятной следует считать 2 а ПГ изменений, отражающих, во-первых, рост активирующих влияний на кору со стороны ретикулярной формации, и, во-вторых, характеризующихся угнетением патологической активности $\delta$ - и $\theta$-диапазонов.

III тип 1а подгруппа, 16 подгруппа - перераспределение мощности за счет активации $\delta$ - и $\theta$-ритмов и угнетения $\alpha 1$-активности - относительно неблагоприятные. Реакции перераспределения III 1а и III 16 подгрупп можно назвать относительно неблагоприятными, так как они свидетельствуют об относительном восстановлении функции нейронов в условиях обширных морфоструктурных постишемических повреждений клеток мозга, но отражают умеренные дезорганизационные ЭЭГ-процессы. III тип 2а подгруппа, 2б подгруппа - перераспределение ЭЭГ-мощности с активацией мощности $\alpha$ - и $\beta 2$ диапазонов за счет редукции дельта-активности - прогностически благоприятные. Реакции III типа - изменения взаимодействий на уровне коры мозга в ответ на фармакологическое воздействие.

Из реакций перераспределения мощности (III тип) прогностически благоприятными можно считать III 2 а подгруппу изменений, для которой типична активация $\alpha$ - и $\beta 2$-ритмов за счет угнетения дельта-активности. Возможно, такие реакции, особенно на стороне поражения, отражают корковые процессы восстановления обратимо поврежденных клеток мозговой ткани, их постсинаптической пропускной способности для высокочастотной стимуляции.

III тип За подгруппа, Зб подгруппа - перераспределение ЭЭГ-активности с увеличением $\beta 2$-мощности за счет редукции $\delta$-ритма - прогностически благоприятные. Реакции III типа - изменения взаимодействий на уровне коры мозга в ответ на фармакологическое воздействие. Интересны реакции III 3а ПГ, для которых характерно замещение альфа-ритма высокочастотной $\beta 2$ активностью, что считается ЭЭГ-коррелятом перехода от состояния покоя к напряжению при умственной деятельности у взрослых.

Факторами, влияющими на эффективность интенсивной терапии Тиоцетамом, являются, с одной стороны, функциональная сохранность церебраль- 


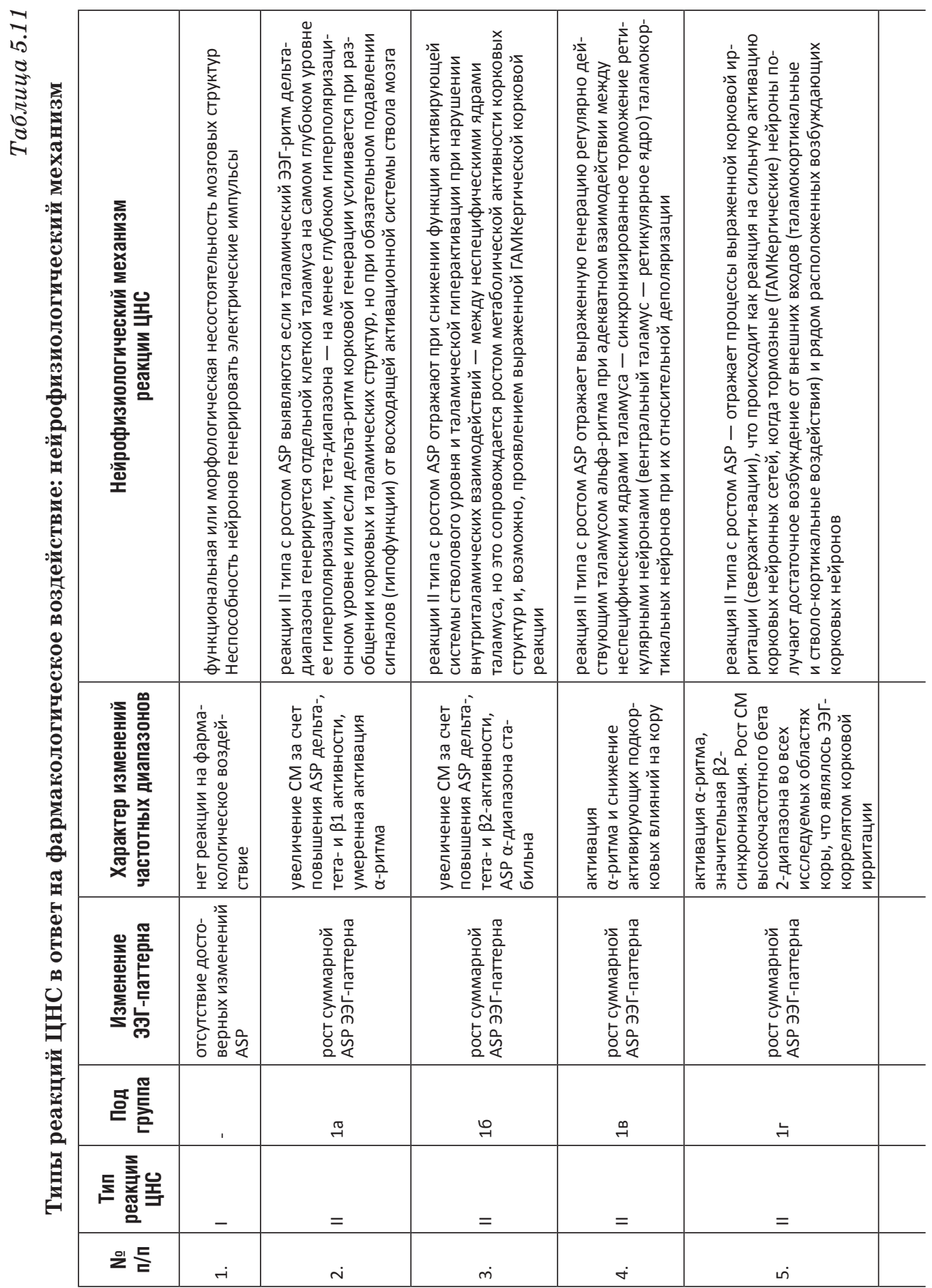




\begin{tabular}{|c|c|c|c|c|c|c|c|}
\hline 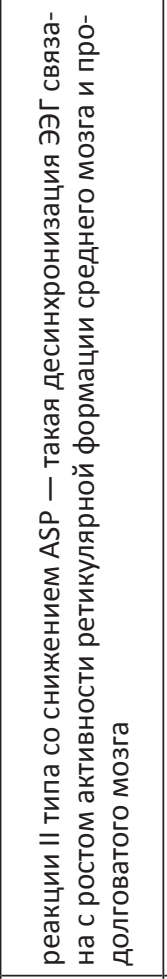 & 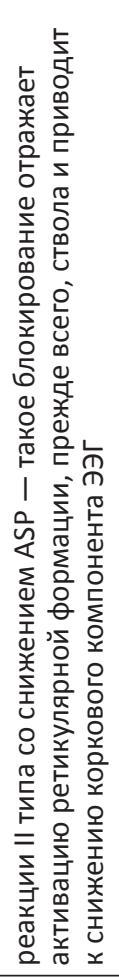 & 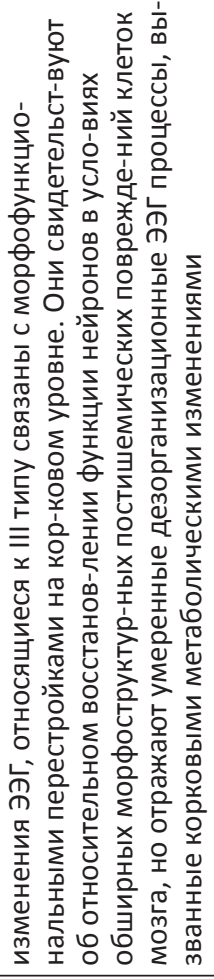 & 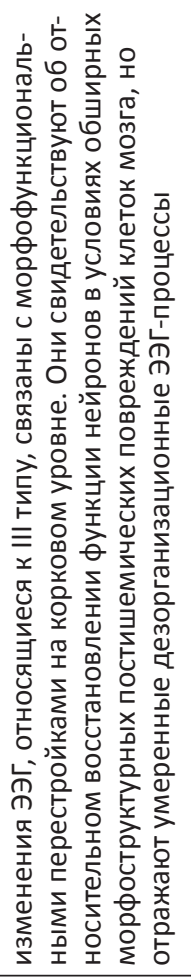 & 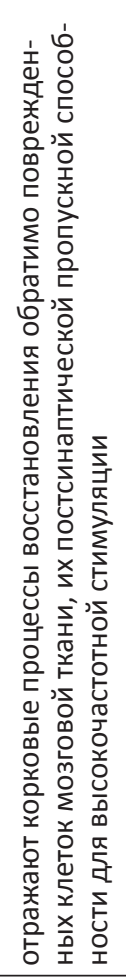 & 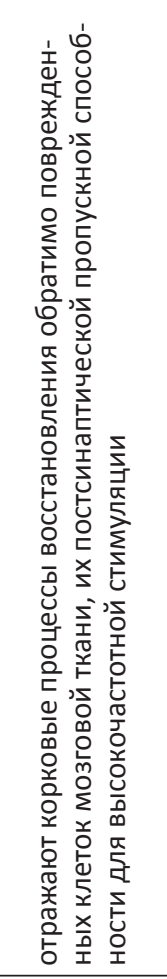 & 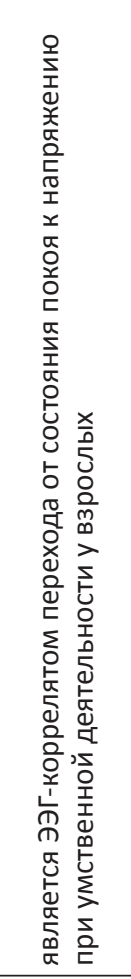 & 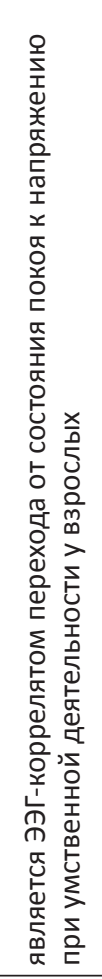 \\
\hline 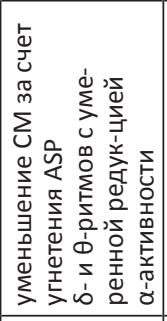 & 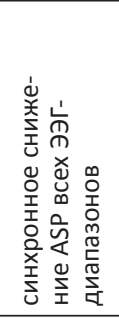 & 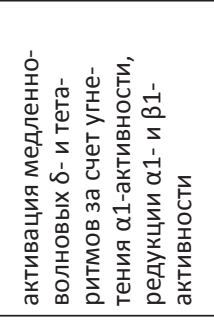 & 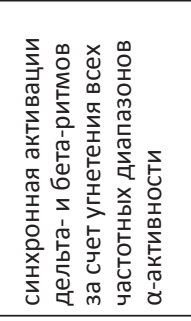 & 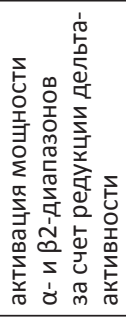 & 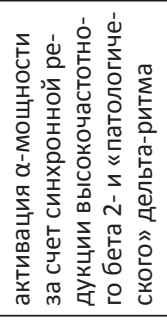 & 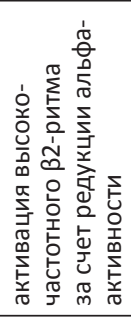 & 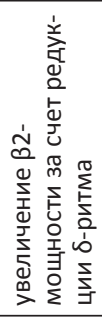 \\
\hline 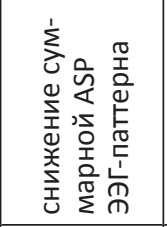 & 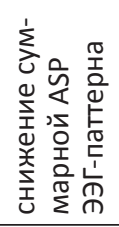 & 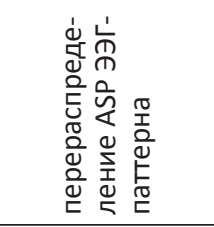 & 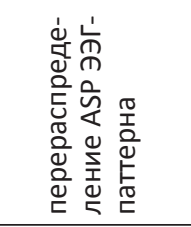 & 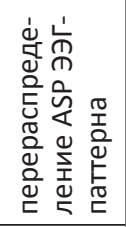 & 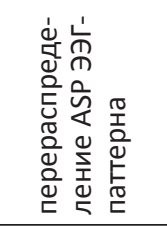 & 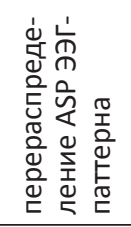 & 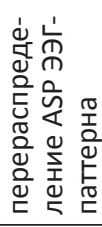 \\
\hline 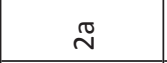 & $\stackrel{\bullet}{\sim}$ & $\stackrel{\pi}{\sim}$ & $\stackrel{0}{\sim}$ & $\stackrel{\widetilde{N}}{\text { }}$ & $\stackrel{\bullet}{N}$ & $\stackrel{\mathbb{m}}{\mathrm{m}}$ & $\stackrel{m}{m}$ \\
\hline$=$ & $=$ & $\equiv$ & $\equiv$ & $\equiv$ & $\equiv$ & $\equiv$ & $\equiv$ \\
\hline $6^{\circ}$ & $N$ & $\infty^{\circ}$ & $\sigma^{\circ}$ & 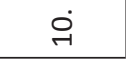 & $\vec{r}$ & 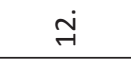 & $\vec{\sim}$ \\
\hline
\end{tabular}


ных структур, нейромедиаторных и метаболических механизмов, участвующих в функциональном ответе, а с другой - доза Тиоцетама.

Используя определение типа реакции ЦНС в ответ на введение Тиоцетама, возможно оценить адекватность применяемой дозы препарата и необходимость ее коррекции.

Сопоставив типы реакций и подгруппы, полученные на введение Тиоцетама, с типами реакций и подгруппами, полученными на введение других нейропротекторов, мы убедились в их неспецифичности и идентичности для любого нейропротектора. Но при исследовании реактивности мозга в ответ на применение различных нейропротекторов мы установили, что на введение Фенотропила и Энтропа, кроме описанных типов реакций и подгрупп, существует еще две подгруппы во II типе: II 1в, II 1г. Таким образом, выявлены три типа (13 подгрупп) реакций ЦНС на фармакологическое воздействие - введение различных ноотропных препаратов.

Определен этиопатогенез исследуемых реакций. Установлено, что реакции II типа отражают изменения корково-подкорковых взаимодействий в ответ на фармакологическое воздействие. Из реакций II типа наиболее благоприятной является II 2 а подгруппа, отражающая, во-первых, рост активирующих влияний на кору со стороны ретикулярной формации, и, во-вторых, характеризующая угнетение патологической активности $\delta$ - и $\theta$-диапазонов. Реакции ЦНС типа II 1а и II 1б ПГ отнесены к прогностически неблагоприятным, так как они характеризуются нарастанием дезорганизации ЭЭГ-паттерна за счет недостаточности стволовых активирующих влияний с увеличением спектрмощности патологической, преимущественно $\delta$-волновой активности.

Реакции III типа - это изменения взаимодействий на уровне коры мозга в ответ на фармакологическое воздействие. Прогностически благоприятными можно считать III 2 а подгруппу изменений, для которой типична активация $\alpha$ - и $\beta 2$ ритмов за счет угнетения дельта-активности, которые отражают корковые процессы восстановления обратимо поврежденных клеток мозговой ткани, их постсинаптической пропускной способности для высокочастотной стимуляции. Реакции III За ПГ, для которых характерно замещение альфа-ритма высокочастотной $\beta 2$-активностью, что считается ЭЭГ-коррелятом перехода от состояния «покоя» к напряжению при умственной деятельности у взрослых. Реакции перераспределения III 1а и III 1б подгрупп можно назвать «относительно неблагоприятными», так как они свидетельствуют об относительном восстановлении функции нейронов в условиях обширных морфоструктурных постишемических повреждений клеток мозга и отражают умеренные дезорганизационные ЭЭГ-процессы. Сопоставив типы реакций и подгруппы, полученные на введение Тиоцетама, с типами реакций и подгруппами, полученными на введение других нейропротекторов, мы убедились в их неспецифичности и идентичности для любого нейропротектора.

На основе разработанной классификации типов реакций ЦНС на фармакологическое воздействие мы приступили к разработке патогенетически обоснованного применения различных нейротропных препаратов в комплексном лечении тяжелой ЧМТ и мозгового инсульта. Это было второй задачей нашего экспериментального и клинического исследования. 
Изучение типов реакции ЦНС в ответ на фармакологическое воздействие дало возможность количественно оценить увеличение или уменьшение дезорганизации ЭЭГ-паттерна и определить уровень нейрофизиологического воздействия препарата на мозг (кора-подкорка, кора-кора). Поэтому определение типов реакции ЦНС в ответ на фармакологическое воздействие позволяет получить объективные критерии оценки эффективности применения нейропротектора [56].

В интенсивной терапии острой церебральной недостаточности (ОЦН), обусловленной тяжелой черепно-мозговой травмой (ЧМТ) или мозговым инсультом (МИ), актуальной остается проблема сочетанного применения нейропротекторов, определения сроков начала лечения нейропротектором и критериев выбора оптимальной дозы нейропротектора с помощью метода интегрального количественного анализа ЭЭГ-паттернов, изучения реактивности мозга и определения типов реакции на фармакологическое воздействие.

При первичном обследовании (табл. 5.12) выявлено, что у пациентов с ОНМК и ЧМТ был зафиксирован выраженный неврологический дефицит. Это предопределяло резкую дезорганизацию ЭЭГ-паттерна: по классификации Жирмунской-Лосева преобладал V тип с преобладанием $\delta$-активности.

При проведении интегрального количественного анализа исходных ЭЭГпаттернов было выявлено, что уровни 1 -го $((\delta+\theta+\beta 1) /(\alpha+\beta 2))$ интегрального коэффициента (ИК) превышали $(\mathrm{p}<0,05)$ показатели КГ ( идеальная норма») у пациентов с ОНМК - в 3,9-4,0 раза - и у больных с ЧМТ - в 4,6-5,0 раз.

За счет активации низкочастотного компонента бета-ритма отмечался симметричный рост $(\mathrm{p}<0,05)$ значений 5 -го $(\beta 1 / \beta 2)$ коэффициента у больных с ЧМТ. Значения 9-го $(\delta / \alpha)$ и 11-го $(\delta / \theta)$ ИК в обеих исследуемых группах были выше $(\mathrm{p}<0,05)$ показателей КГ. Показатели 15 -го $(\alpha / \beta 2)$ и 17 -го $(\alpha 1 / \beta 2)$ ИК были в $1,5-$ 3,8 раза ниже $(\mathrm{p}<0,05)$ уровней контрольной группы, уровни 16 -го $(\alpha / \beta 1)$ коэффициента также были снижены $(\mathrm{p}<0,05)$. Однако, достоверных различий между значениями этих коэффициентов в обеих исследуемых группах не выявлено.

Изменения интегральных коэффициентов сочетались у пациентов обеих групп с выраженными изменениями показателей межполушарной (МП) когерентности (Coh). У пациентов с ОНМК и ЧМТ отмечалось уменьшение $(\mathrm{p}<0,05)$ показателей межполушарной $\alpha$-когерентности всех исследуемых отделов коры. Но более высокие $(\mathrm{p}<0,05)$ показатели Coh височных областей $\left(\mathrm{T}_{3} \mathrm{~T}_{4}\right)$ $\alpha$-диапазона и $\alpha 1$-поддиапазона были выявлены у пациентов с ЧМТ.

Средние значения Coh в центральных $\left(\mathrm{C}_{3} \mathrm{C}_{4}\right)$ и затылочных $\left(\mathrm{O}_{1} \mathrm{O}_{2}\right)$ отделах были снижены $(\mathrm{p}<0,05)$ за счет уменьшения когерентности альфа-, дельтаи бета-частотных компонентов, что являлось отражением как диэнцефальной, так и стволовой недостаточности, т. к. динамика когерентности биопотенциалов симметричных центральных областей преимущественно свидетельствует о функциональном состоянии диэнцефальных образований, а изменения когерентности в симметричных окципитальных отделах отражают уровень стволовых влияний на кору. Наиболее выраженные отличия между группами пациентов с ОНМК и ЧМТ были выявлены для показателей внутриполушарной (BП) когерентности (Coh). В левой гемисфере в центрально-окципитальной 
паре $\left(\mathrm{C}_{3} \mathrm{O}_{1}\right)$, то есть в заднем отделе полушария - проекции стволовых структур мозга, у пациентов с ОНМК был зафиксирован рост $(\mathrm{p}<0,05) \mathrm{BП}_{3} \mathrm{O}_{1}$ когерентности за счет увеличения интеграции ритмов $\delta$-, $\theta$-, $\beta 1$ - и $\beta 2$-частотных диапазонов. В правой гемисфере отличия между пациентами с ОНМК и ЧМТ были типичными для передних отделов коры. В лобно-центральной паре $\left(\mathrm{Fp}_{2} \mathrm{C}_{4}\right)$ у пациентов с ОНМК был выявлен рост $(\mathrm{p}<0,05)$ показателей внутриполушарной Coh $\theta$-, $\beta 1$ - и $\beta 2$-частотных диапазонов. У больных с ЧМТ было зафиксировано снижение $(\mathrm{p}<0,05)$ уровней $\delta$ - и $\theta$ - ВП Coh между лобной и центральной областями $\left(\mathrm{Fp}_{2} \mathrm{C}_{4}\right)$ правого полушария. Неспецифические, т. е. зависящие от состояния срединных и подкорковых образований, Fp-C когерентности обеих гемисфер, таким образом, отражали различную степень дисфункции подкорковых образований у пациентов с ОНМК и ЧМТ.

В результате проведенного статистического анализа (T-W, крКУ, KD, критерий $\left.\chi^{2} \mathrm{p}<0,05\right)$, включающего в себя также определение параметров когерентности (коэффициент корреляции Кендалла $\tau>0,75$ или $\tau<-0,75$ ), условно были выделены несколько групп нейропротективных препаратов, при введении которых у пациентов с ОЦН различного генеза - ОНМК или тяжелой ЧМТ - были выявлены сходные изменения параметов количественной ЭЭГ.

Изучена реактивность мозга в ответ на введение нейротропных препаратов (L-лизина эсцинат, Актовегин, Цитиколин, Мексидол, Церебролизин, Цереброкурин, Глиатилин, Нейромидин, цитофлавин, Нимодипин, фенотропил, Тиоцетам) с учетом типов реакции ЦНС и оценкой особенностей механизмов действия препаратов, критериев адекватности применяемой дозы препарата, необходимости и возможности ее коррекции. Разработано патогенетическое обоснование применения различных нейротропных препаратов в комплексном лечении тяжелой ЧМТ и мозгового инсульта. Например, максимальный ЭЭГ-эффект применения Церебролизина у пациентов с ОНМК был зафиксирован на корковом уровне с усилением влияний лобных отделов на остальные области коры. У больных с ЧМТ наиболее выраженный эффект был связан как с увеличением влияний медиобазальных отделов лобной коры и полюса лобной доли на тонус коры, так и с активацией на оральном стволовом и, особенно, лимбическом уровнях регуляторных мозговых систем, что связано с действием Церебролизина на холинергические нейроны области гиппокампа. Максимальный ЭЭГ-эффект применения Цереброкурина у пациентов с ОНМК был зафиксирован на диэнцефальном и корковом уровне, у пациентов с ЧМТ - на лимбическом, корковом уровнях с выраженной активацией регуляторных структур диэнцефального уровня и функционально более связанных с ними образований правого полушария.

Так, в ответ на введение препаратов L-лизина эсцината, Мексидола, цитофлавина, Актовегина и Нимодипина [57] реакции ЦНС (табл. 5.12), характеризующиеся снижением уровня дезорганизации ЭЭГ, составляли около половины всех ЭЭГ-изменений. Преобладали реакции перераспределения мощности III типа, которые связаны с морфофункциональными перестройками на корковом уровне. Практически с одинаковой частотой (30-35 \% всех изменений ЭЭГ) отмечались реакции, сопровождающиеся в той или иной степени активацией низко- или, чаще, высокочастотного бета-ритма (табл. 5.12). 
Это реакции со снижением (подгруппы 2б, За и 3б) или ростом дезорганизации электроэнцефалограммы (III 1б ПГ). Причем, максимальный уровень активации бета-ритма был выявлен в ответ на введение Нимодипина - более $52 \%$ таких реакций ЦНС, связанных с активацией ГАМК-ергических и серотонинергических нейромедиаторных, преимущественно тормозных, короковых процессов [55]. Достаточно часто встречающиеся (26-32 \% всех ЭЭГ-изменений) реакции ЦНС, относящиеся к подгруппам III 1а и б, со смещением пика мощности в диапазоны дельта- и тета-активности, связаны со способностями данных препаратов влиять на активацию нейроглиальной популяции, процессов метаболизма и церебрального энергетического обмена [531], на изменение уровня оксигенации коры, связанного как с падением, так и с выраженным ростом АД [531], или даже на реализацию фармакологического эффекта данных нейропротекторов через системы нейромедиаторов: с холинергической, серотонинергической, адренергической активацией [531]. Функциональная нагрузка, вызываемая возбуждающей синаптической стимуляцией, реализуемой через действие этих систем, обеспечивает активацию и регуляцию трофических и пластических внутриклеточных процессов, предотвращает частичную деафферентацию и, следовательно, глубокие расстройства функции нейрона [532, 533] коры, что способствует многократному усилению входного сигнала и реализуют его эффект в виде адекватной реакции нейрона [533].

Нарастание сочетанности альфа-ритма в обеих гемисферах (увеличение Coh med $\alpha$-диапазона между всеми симметричными отделами коры) через 30 мин после введения L-лизина свидетельствует об активации подкорковых генераторов этой активности, прежде всего, зрительного бугра, базальных корковых структур мозга. Снижение сочетанности дельта ритма (Coh $\mathrm{Fp}_{1} \mathrm{Fp}_{2}$ и Coh $\mathrm{O}_{1} \mathrm{O}_{2}$ ) через 60 мин после введения L-лизина - связано с его положительным влиянием на корковые регуляторные процессы.

Большое количество средних и высоких прямых ранговых корреляционных связей (ПРКС) между показателями изменений уровней 1-го ИК (рис. 5.26) в симметричных темпоральных и центральной областях обеих гемисфер характеризует триггерную роль восстановления сочетанности активности височных и центральных отделов, т. е. моторно-речевой зоны коры [75] в ответ на фармакологическое воздействие препарата Цитофлавин.

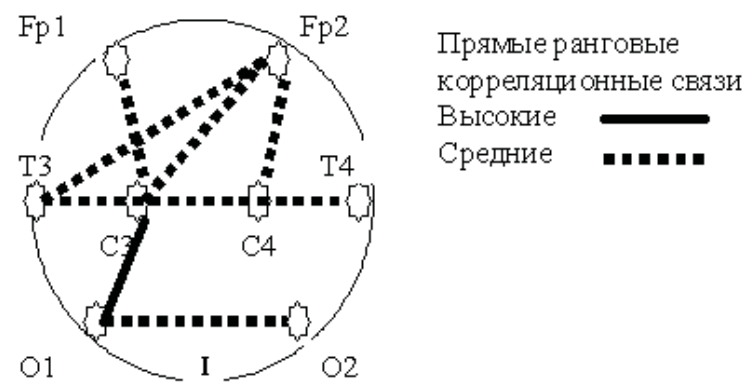

Рис. 5.26. Прямые и обратные высокие и средние ранговые корреляционные связи между изменениями показателей 1-го коэффициента в ответ на введение препарата цитофлавин 
таблица 5.12

\section{Изменения ЭЭГ-показателей - типы реакций ЦНС - у пациентов с ОЦН в ответ на введение нейротропных препаратов}

\begin{tabular}{|c|c|c|c|c|c|c|}
\hline Группы & & ЧМТ Глиатилин & $\begin{array}{c}\text { ЧМТ } \\
\text { Цереброкурин } \\
2 \text { мл/ сут }\end{array}$ & $\begin{array}{c}\text { ЧМТ } \\
\text { Церебролизин } \\
50 \text { мл/ сут }\end{array}$ & L-лизина эсцинат ЧМТ & Актовегин ОЦН \\
\hline $\begin{array}{r}\text { Варианты ре } \\
\text { ЦНС (n }\end{array}$ & кции & 72 & 26 & 28 & 552 & 110 \\
\hline $\begin{array}{l}\text { Отсутствие } \\
\text { изменений }\end{array}$ & 1 & $10 / 72(0 \%) \mathrm{K}$ & $11 / 26(4 \%)$ & $12 / 28(7 \%)$ & I 64/552 (11,6\%) & | 4/110 (3,6\%) \\
\hline $\begin{array}{l}\text { Рост дезор- } \\
\text { ганизации } \\
\text { ЭЭГ-паттерна }\end{array}$ & $\begin{array}{l}\text { II } 1 \mathrm{a} \\
\text { II } 16 \\
\text { III } 1 \mathrm{a} \\
\text { III } 16\end{array}$ & $\begin{array}{c}\text { II 1a 24/72 (33,3\%) } \\
\text { II 16 10/72(13,9\%) } \\
\text { III 1a 2/72 (2,8\%) } \\
\text { III } 164 / 72(5,6 \%)\end{array}$ & II 1a 3/26 (12\%) & II 1a 4/28 (14 \%) & $\begin{array}{c}\text { II 1a 58/552 (10,5\%) } \\
\text { II 16 7/552 (1,2\%) } \\
\text { III 1a 121/552(21,9\%) } \\
\text { III } 16 \text { 29/552 (5,2\%) }\end{array}$ & $\begin{array}{l}\text { II 1a } 12 / 110(10,9 \%) \\
\text { II } 1610 / 110(9,1 \%) \\
\text { III 1a } 8 / 110(7,3 \%) \\
\text { III } 162 / 110(1,8 \%)\end{array}$ \\
\hline $\begin{array}{l}\text { Снижение } \\
\text { дезоргани- } \\
\text { зации ЭЭГ- } \\
\text { паттерна }\end{array}$ & $\begin{array}{l}\text { II } 1 \mathrm{~B} \\
\text { II } 1 \mathrm{r} \\
\text { II } 2 \mathrm{a} \\
\text { II } 26 \\
\text { III } 2 \mathrm{a} \\
\text { III } 26 \\
\text { III } 3 a\end{array}$ & $\begin{array}{c}\text { I| 1в 0/72 (0\%) } \\
\text { II 1г } 1 / 72(1,4 \%) \\
\text { I| 2а 20/72 (27,8\%) } \\
\text { II 260/72 (0\%) } \\
\text { III 2a 2/72 (2,8\%) } \\
\text { III 26 4/72 (5,6\%) } \\
\text { III 3a 0/72 (0\%) }\end{array}$ & $\begin{array}{c}\text { II } 2 \text { a 3/26 (12 \%) } \\
\text { II } 26 \text { 5/26 (19 \%) } \\
\text { III } 268 / 26 \\
(30 \%) \\
\text { III 3a 2/26 (8\%) }\end{array}$ & \begin{tabular}{|c} 
II 2 2a $4 / 28(14 \%)$ \\
II $264 / 28(14 \%)$ \\
III $267 / 28$ \\
$(26 \%)$ \\
III $3 a 2 / 28(7 \%)$
\end{tabular} & $\begin{array}{c}\text { II 1в 37/552 (6,7\%) } \\
\text { II 2a 61/552 (11,1\%) } \\
\text { II 26 18/552 (3,2\%) } \\
\text { III 2a 97/552 (17,6\%) } \\
\text { III 26 8/552 (1,4\%) } \\
\text { III 3а 34/552 (6,1\%) }\end{array}$ & $\begin{array}{l}\text { III 2a 28/110 (25,5\%) } \\
\text { III 3a 12/110 (10,9 \%) }\end{array}$ \\
\hline $\begin{array}{l}\text { «Гипореак- } \\
\text { тивные» } \\
\text { изменения }\end{array}$ & III 36 & III 36 0/72 (0 \%) & $\begin{array}{c}\text { III } 364 / 26 \\
(15 \%)\end{array}$ & $\begin{array}{c}\text { III } 365 / 28 \\
(18 \%)\end{array}$ & III 36 18/552 (3,3 \%) & III 36 34/110 (30,9 \%) \\
\hline
\end{tabular}

Продолжение табл. 5.12

Изменения ЭЭГ-показателей - типы реакций ЦНС - у пациентов ОЦН в ответ на введение нейротропных препаратов

\begin{tabular}{|c|c|c|c|c|c|}
\hline \multicolumn{2}{|c|}{$\begin{array}{c}\text { Группы } \\
\text { ОНМК Глиатилин }\end{array}$} & $\begin{array}{c}\text { ОНМК } \\
\text { Цереброкурин }\end{array}$ & $\begin{array}{c}\text { ОНМК } \\
\text { Церебролизин }\end{array}$ & $\begin{array}{c}\text { ОНМK } \\
\text { L-лизина эсцинат }\end{array}$ & ОНМК Нимодипин \\
\hline $\begin{array}{l}\text { Варианты реакции } \\
\text { ЦНС (n) }\end{array}$ & 48 & 38 & 12 & 204 & 260 \\
\hline Отсутствие изменений & | 6/48 (12,5\%) & I 2/38 (5 \%) & | 1/12 (8 \%) & | 29/204 (14,2\%) & | 28/260 (10,8 \%) \\
\hline $\begin{array}{l}\text { Рост дезорганизации } \\
\text { ЭЭГ-паттерна }\end{array}$ & $\begin{array}{c}\text { I| 1a 0/48 (0\%) } \\
\text { I| } 160 / 48(0 \%) \\
\text { III 1a 10/48 (20,8\%) } \\
\text { III 16 2/48 }(4,2 \%)\end{array}$ & $\begin{array}{c}\text { II 1a } 3 / 38(8 \%) \\
\text { II 16 5/38(13\%) } \\
\text { III 1a 4/38 (11\%) } \\
\text { III 1a } 2 / 38(5 \%)\end{array}$ & $\begin{array}{l}\text { II 1a } 1 / 12(8 \%) \\
\text { III 1a } 1 / 12(8 \%)\end{array}$ & $\begin{array}{l}\text { II 1a 29/204 (14,2\%) } \\
\text { III 1a 48/204 (23,5\%) } \\
\text { III 16 7/204 (3,4\%) }\end{array}$ & $\begin{array}{c}\text { II 1a 26/260 (10\%) } \\
\text { II 16 7/260 (2,7\%) } \\
\text { III 1a 30/260 (11,5\%) } \\
\text { III 16 4/260 (1,5\%) }\end{array}$ \\
\hline $\begin{array}{l}\text { Снижение } \\
\text { дезорганизации ЭЭГ- } \\
\text { паттерна }\end{array}$ & 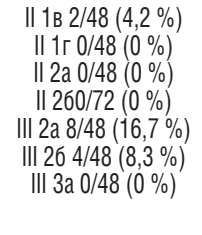 & $\begin{array}{l}\text { II 2a } 9 / 38(24 \%) \\
\text { || } 2610 / 38(26 \%)\end{array}$ & $\begin{array}{l}\text { II 2a 4/12 (32 \%) } \\
\text { I 26 3/12 (24 \%) }\end{array}$ & 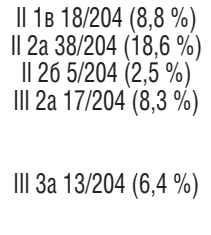 & 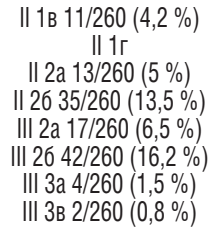 \\
\hline $\begin{array}{l}\text { «Гипореактив-ные» из- } \\
\text { менения }\end{array}$ & |II 36 16/48 (33,3 \%) & III 36 3/38 (8 \%) & ||| 36 2/12 (16 \%) & & III 36 41/260 (15,8 \%) \\
\hline
\end{tabular}




\begin{tabular}{|c|c|c|c|c|c|}
\hline Цераксон ОЦН & $\begin{array}{c}\text { Последовательное } \\
\text { применение } \\
\text { Актовегин+Цераксон } \\
\text { при ОЦН }\end{array}$ & Энтроп при ТЧМТ & Нейромидин при ОЦН & ОНМК Цитофлавин & ЧМТ Цитофлавин \\
\hline 74 & 110 & 166 & 122 & 92 & 28 \\
\hline- & & & | 3/122 (2,5\%) & I 16/92 (17,75 \%) & I 5/28 (18\%) \\
\hline $\begin{array}{l}\text { II 1a 3/74 (4,05\%) } \\
\text { II } 162 / 74(2,7 \%) \\
\text { III 1a } 7 / 74(9,5 \%) \\
\text { III } 164 / 74(5,4 \%)\end{array}$ & $\begin{array}{l}\text { II } 164 / 110(3,6 \%) \\
\text { III } 1 \text { a 3/110 (2,7\%) }\end{array}$ & $\begin{array}{c}\text { II 1a 5/166 (3\%) } \\
\text { III 1a 5/166 (3\%) } \\
\text { III16 11/166 (6,6\%) }\end{array}$ & $\begin{array}{c}\text { II 1a } 7 / 122(5,7 \%) \\
\text { II 16 6/122 (4,9\%) } \\
\text { III 1a } 23 / 122(18,9 \%) \\
\text { III 16 7/122 (5,7\%) }\end{array}$ & $\begin{array}{c}\text { II 1a 3/92 (3,2\%) } \\
\text { II } 165 / 92(5,4 \%) \\
\text { III 1a } 30 / 92(32,6 \%) \\
\text { III } 163 / 92(3,2 \%)\end{array}$ & $\begin{array}{c}\text { II 1a } 2 / 28(7 \%) \\
\text { II 16 2/28 (7\%) } \\
\text { III 1a 5/28 (18\%) } \\
\text { III 16 1/28 (3,6\%) }\end{array}$ \\
\hline $\begin{array}{c}\text { III 2a 16/74 (21,6\%) } \\
\text { III 26 5/74 (6,8\%) } \\
\text { III 3a } 12 / 74(16,3 \%)\end{array}$ & $\begin{array}{c}\text { II 2a 10/110(9\%) } \\
\text { II 26 4/110 (3,6\%) } \\
\text { III 2a } 40 / 110(36,4 \%) \\
\text { III 26 18/110 (16,4\%) } \\
\text { III 3a } 15 / 110(13,6 \%)\end{array}$ & $\begin{array}{c}\text { II 1в 12/166 (7,2 \%) } \\
\text { II 1г 22/166 (13,3\%) } \\
\text { II 2a 14/166 (8,4 \%) } \\
\text { III 2a 26/166 (15,7\%) } \\
\text { III 26 35/166 (21,1\%) } \\
\text { III 3a 9/166 (5,4\%) }\end{array}$ & $\begin{array}{c}\text { II 1в 5/122 (4 \%) } \\
\text { II 1г } \\
\text { II 2a 15/122 (12,3\%) } \\
\text { II 26 7/122 (5,7\%) } \\
\text { III 2a 21/122 (17,2\%) } \\
\text { III 26 6/122 (4,9\%) } \\
\text { III 3a }\end{array}$ & $\begin{array}{l}\text { II 2a 5/92 (5,4 \%) } \\
\text { II 26 2/92 (2,2\%) } \\
\text { III 2a 9/92(9,8\%) }\end{array}$ & $\begin{array}{l}\text { II 2a } 1 / 28(3,6 \%) \\
\text { II 26 1/28 (3,6\%) } \\
\text { III 2a } 1 / 28(3,6 \%)\end{array}$ \\
\hline III 36 25/74 (33,8 \%) & III 36 16/110 (14,5 \%) & III 36 27/166 (16,3 \%) & III 36 22/122 (18 \%) & III 36 19/92 (20,8 \%) & III 36 10/28 (35,7\%) \\
\hline
\end{tabular}

\begin{tabular}{|c|c|c|c|c|}
\hline ОЦН Мексидол & ОЦН Цитофллавин & ОЦН Тиоцетам & $\begin{array}{c}\text { ОНМК } \\
\text { Тиоцетам }\end{array}$ & ТЧМТ Тиоцетам \\
\hline 128 & 120 & 172 & 92 & 80 \\
\hline | 10/128 (7,8 \%) & | 21/120 (17,5\%) & | 4/172 (2,3\%) & I 0/92 (0 \%) & | 4/80 (5 \%) \\
\hline $\begin{array}{c}\text { II 1a 18/128 (14,1\%) } \\
\text { II 16 } \\
\text { III 1a 22/128 (17,2\%) } \\
\text { III 16 6/128 (4,7\%) }\end{array}$ & $\begin{array}{c}\text { II 1a } 5 / 120(4,2 \%) \\
\text { II 16 7/120 (5,8\%) } \\
\text { III 1a } 35 / 120(29,2 \%) \\
\text { III } 164 / 120(3,3 \%)\end{array}$ & $\begin{array}{c}\text { II 1a 20/172 (11,6\%) } \\
\text { II 16 11/172 (6,4\%) } \\
\text { III 1a 25/172 (14,5\%) } \\
\text { III 16 11/172 (6,4\%) }\end{array}$ & $\begin{array}{c}\text { I| 1a 8/92 }(8,7 \%) \\
\text { II 16 7/92 (7,6\%) } \\
\text { III 1a 15/92 }(16,3 \%) \\
\text { III } 167 / 92(7,6 \%)\end{array}$ & $\begin{array}{c}\text { I| 1a 12/80(15\%) } \\
\text { I| } 164 / 80(5 \%) \\
\text { III 1a } 10 / 80(12,5 \%) \\
\text { III } 164 / 80(5 \%)\end{array}$ \\
\hline 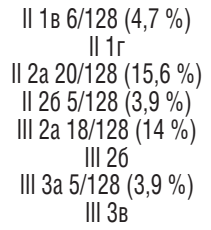 & $\begin{array}{c}\| 1 \mathrm{~B} \\
\| 1 \mathrm{r} \\
\text { || 2a } 6 / 120(5 \%) \\
\text { || } 263 / 120(2,5 \%) \\
\text { || } 2 \mathrm{a} 10 / 120(8,3 \%)\end{array}$ & 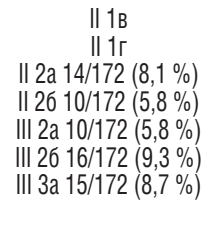 & 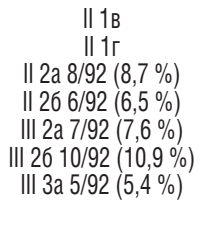 & 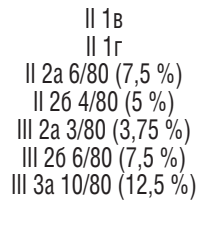 \\
\hline III 36 18/128 (14 \%) & III 36 29/120 (24,2 \%) & III 36 36/172 (20,9 \%) & |l| 36 19/92 (20,7 \%) & III 36 17/80 (21,3 \%) \\
\hline
\end{tabular}


Высокие ПРКС между показателями изменения 1-го ИК (рис. 5.26) в левой гемисфере отражали особую синхронность функционирования корковых структур левого (преимущественно доминирующего) полушария под влиянием цитофлавина. Высокие прямые ранговые корреляционные связи между показателями изменения 1-го ИК (рис. 5.26) в правой и левой окципитальных областях свидетельствуют об умеренной активации ретикуло-стволовых структур мозга.

Интересны высокие и средние прямые корреляционные связи между показателями роста абсолютной спектральной мощности высокочастотного $\beta 2$-диапазона в правой фронтальной области и во всех остальных исследуемых областях коры (рис. 5.27).

Активацией цикла трикарбоновых кислот (цикла Кребса) с помощью цитофлавина компенсируется нарушене энергетического обеспечения клеток, и на ЭЭГ пациентов мы отмечали преимущественно признаки неспецифического общеактивационного характера с чертами эраузал-реакции - корковых реакций III типа, которая стала возможной благодаря энергетическому обеспечению работы синапсов с помощью цитофлавина.

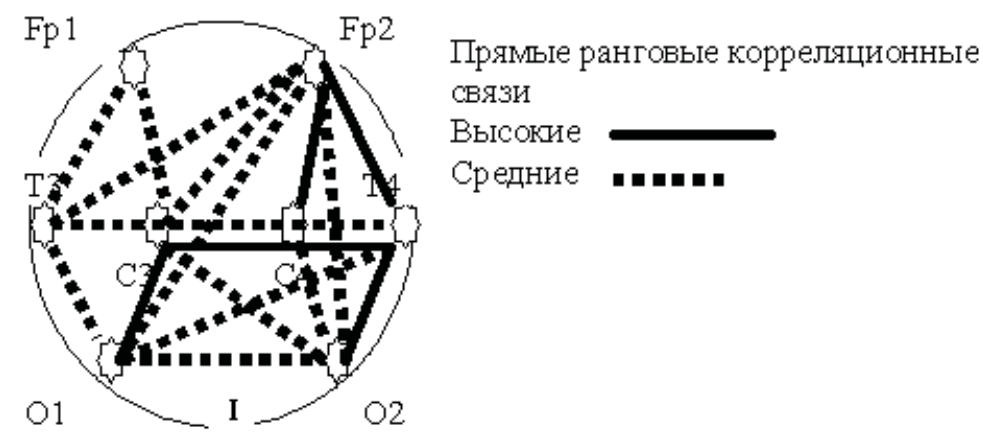

Рuc. 5.27. Прямые и обратные высокие и средние ранговые корреляционные связи между изменениями показателей абсолютной спектральной мощности $\beta 2$-диапазона в ответ на введение препарата Цитофлавин

Прогностически благоприятными изменениями кровотока в интракраниальных сосудах у пациентов после проведенной терапии с включением Мексидола являются: достоверное уменьшение или отсутствие асимметрии кровотока (АК) при право- или левополушарном мозговом инсульте; достоверный рост скорости венозного оттока, более выраженный на стороне поражения; симметричное снижение линейной скорости кровотока (ЛСК), систолической скорости кровотока (ССК) практически до нормальных значений; уменьшение вазоконстрикции интракраниальных сосудов, в том числе в бассейне пораженной артерии.

Преимущественно у пациентов с тяжелой ЧМТ, очень редко - при ОНМК, в ответ на введение препаратов Церебролизин [58], Цереброкурин [59], 
Тиоцетам [56], Энтроп [56] и после последовательного применения сочетания препаратов Актовегин+Цитиколин было зарегистрировано самое самое большое число реакций ЦНС, характеризующихся снижением уровня дезорганизации ЭЭГ - 56-93 \% всех изменений ЭЭГ. Также преобладали корковые реакции перераспределения мощности III типа (58-90 \% всех изменений ЭЭГ), однако среди них доминировали реакции, сопровождающиеся активацией бета-ритма $-57-74 \%$ всех реакций ЦНС. Чаще $\left(\mathrm{p}<0,05\right.$, критерий $\left.\chi^{2}\right)$, чем в первой группе, в ответ на применение препаратов данной группы были зафиксированы реакции ЦНС III типа со смещением пика спектр-мощности в диапазон альфа-ритма $-27-53 \%$ всех изменений ЭЭГ. Незначительное количество реакций III 1а и б подгрупп (0-21 \%) подтверждало общие тенденции к ускорению фоновой ЭЭГ за счет активации диапазонов альфа- и, особенно, бета-частот при снижении доли медленноволновых ритмов. Также небольшим (до 14-26 \% ) было число реакций, отражающих, как гиперактивацию таламической системы генерации ритма ЭЭГ в условиях значительной недостаточности структур ретикулярной формации ствола (II 1а и II 1б), так и, напротив, активацию ретикулярной формации ствола (II 2б) и среднего мозга (II 2a) [31]. Чаще подобные реакции ЦНС напрямую зависели от увеличения дозировки вводимого препарата (Церебролизин в суточной дозе более 40 мл, Тиоцетам более 20 мл, Энтроп - более 200 мг).

У пациентов после включения в стандартный протокол препарата Энтроп было зафиксировано увеличение $(\mathrm{p}<0,05)$ показателей артериального кровотока справа: по СМА - на 92,8 \%, по ПМА - на 75,4 \%, по ПА — на 69,4 \% . Слева максимально увеличивались по сравнению с исходными данными уровни Vps в ПМА - на 104,5 \% и в позвоночной артерии — на 86,3 \% . Возрастала $(\mathrm{p}<0,05)$ скорость венозного оттока в прямом синусе - на $34,3 \%$. На 14 -е сутки терапии с применением Энтропа было зафиксировано отсутствие у пациентов гемодинамически значимой асимметрии кровотока по ПМА, снижение уровня циркуляторного сопротивления в ПМА, больше справа, рост линейной скорости кровотока по СМА. Подобные изменения показателей артериального и венозного мозгового кровотока были обусловлены способностью $\mathrm{N}$-карбамоилметил-4-фенил-2-пирролидона оптимизировать регионарный кровоток в ишемизированных участках мозга при тяжелой ЧМТ.

В течение 7 суток после терапии с включением в стандартный протокол препарата Тиоцетам, были выявлены наиболее значимые изменения систолической скорости кровотока (Vps) во всех исследуемых артериях $(\mathrm{p}<0,05)$ : справа максимально увеличивалась $(\mathrm{p}<0,05)$ систолическая скорость кровотока $(\mathrm{Vps})$ в среднемозговой артерии (CMA) - на 79,9\%, слева - Vps в переднемозговой артерии (ПМА) - на 90,7 \% . Значительно возрастали $(\mathrm{p}<0,05)$ показатели оттока в прямом венозном синусе (ПС) - на $94,6 \%$. По окончанию терапии у данных пациентов были зафиксированы самые низкие (по сравнению с группой контроля, получавшей терапию по стандартному протоколу) уровни систолодиастолического соотношения (S/D) и индекса пульсации (IP) в позвоночных артериях (ПА), что свидетельствовало о значительном снижении циркуляторного сопротивления в вертебробазилярном бассейне. 
В ответ на введение Церебролизина при мозговом инсульте отмечалось уменьшение уровня Coh $\mathrm{O}_{1} \mathrm{O}_{2}$ дельта-частотного диапазона, что характеризовало снижение уровня функциональной напряженности стволовых структур; рост значений $\delta$ - $\beta 1$ - Coh $\mathrm{Fp}_{1} \mathrm{Fp}_{2}$, что было связано с увеличением влияний медиобазальных отделов лобной коры и полюса лобной доли на тонус коры; синхронное падение Coh $\mathrm{O}_{1} \mathrm{O}_{2}$ и $\mathrm{Coh} \mathrm{Fp}_{1} \mathrm{Fp}_{2}$ альфа- и тета-ритмов на фоне нарастания сочетанности $\mathrm{Coh}_{3} \mathrm{~T}_{4}$, что является коррелятом вовлечения в процесс активации лимбических структур.

В ответ на введение Цереброкурина при мозговом инсульте, напротив, было характерно снижение $\mathrm{Coh} \mathrm{Fp}_{1} \mathrm{Fp}_{2}$ в тета- и, дельта-диапазонах при одновременном росте Coh $\mathrm{T}_{3} \mathrm{~T}_{4}$ в $\theta$-, $\alpha$ - и $\beta 1$-диапазонах, что характеризовало активацию регулирующей системы диэнцефального уровня с уменьшением функциональной напряженности медиобазальных отделов лобной коры и полюса лобной доли.

В ответ на введение Церебролизина при ТЧМТ отмечается уменьшение уровня Coh $\mathrm{O}_{1} \mathrm{O}_{2}$ дельта-частотного диапазона, что характеризовало снижение уровня функциональной напряженности стволовых структур; рост значений $\delta$ - и $\beta 1$ - Coh $\mathrm{Fp}_{1} \mathrm{Fp}_{2}$, что было связано с увеличением влияний медиобазальных отделов лобной коры и полюса лобной доли на тонус коры; синхронное падение Coh $\mathrm{O}_{1} \mathrm{O}_{2}$ и Coh $\mathrm{Fp}_{1} \mathrm{Fp}_{2}$ альфа- и тета-ритма на фоне нарастания сочетанности Coh $\mathrm{T}_{3} \mathrm{~T}_{4}$, что является коррелятом вовлечения в процесс активации лимбических структур. В ответ на введение Цереброкурина при ТЧМТ, напротив, было выявлено снижение $\mathrm{Coh} \mathrm{Fp}_{1} \mathrm{Fp}_{2}$ тета- и, дельта-диапазонах при одновременном росте $\mathrm{Coh}_{3} \mathrm{C}_{4}$ в $\theta$-, $\alpha$ - и $\beta 1$-диапазонах, что характеризовало активацию регулирующей системы диэнцефального уровня с уменьшением функциональной напряженности медиобазальных отделов лобной коры и полюса лобной доли.

Более высокая морфологическая и функциональная дифференцировка клеток головного мозга свиней, субстрата препарата Церебролизин, возможно, предопределяет сродство пептидов данного препарата к более молодым и более дифференцированным структурам коркового и гиппокампально-лимбического уровня головного мозга человека. Поэтому максимальный ЭЭГ-эффект применения препарата Церебролизин был зафиксирован на корковом уровне с усилением влияний лобных отделов на остальные области коры. Низкая дифференцировка клеток эмбрионов крупного рогатого скота, субстрата Цереброкурина, вероятно, предопределяет сродство пептидов данного препарата к филогенетически более старым и менее дифференцированным структурам диэнцефального уровня головного мозга человека. Поэтому максимальный ЭЭГ-эффект был зафиксирован на диэнцефальном и корковом уровне, у пациентов с ЧМТ на лимбическом, корковом уровнях с выраженной активацией регуляторных структур диэнцефального уровня и функционально более связанных с ними образований правого полушария.

Доказан нейропротекторный эффект L-лизина эсцината, который является опосредованным из-за отсутствия его непосредственного влияния на нейроциты и связан с непосредственным восстановительным влиянием на нейроглию, сосудистый эндотелий, ГЭБ, процессы отека-набухания головного мозга. 
Установлено, что применение Цитиколина через 30 мин после введения Актовегина увеличивает количество реакций, характеризующихся снижением уровня дезорганизации ЭЭГ, до 93,5 \% , а количество «гипоэргических реакций III $3 б$ ПГ снижалось до 14,5 \% . Доказано, что нейропротекторный эффект Мексидола объясняется не только его нейрометаболическим действием, но и циркуляторным, цереброваскулярным эффектом: уменьшением вазоконстрикции интракраниальных сосудов, ликвидацией асимметрии кровотока, ростом скорости венозного оттока, симметричным снижением линейной и систолической скорости кровотока (ЛСК, ССК).

При сравнении эффективности действия двух нейропептидов - Цереброкурина и Церебролизина - было установлено, что не существует особых различий между реакциями ЦНС в ответ на введение препарата Цереброкурин в суточной дозе 2 мл и препарата Церебролизин в суточной дозе 50 мл у больных с ЧМТ или ОНМК. Преобладали реакции, характеризующиеся снижением уровня дезорганизации ЭЭГ $(49,4 \%$ всех реакций ЦНС в ответ на введение 50 мл Церебролизина и 57,8 \% всех реакций в ответ на введение 2 мл Цереброкурина), причем доминировали реакции II типа - преимущественно II 2a и II 26 подтипов, отражающие функциональное восстановление регулирующих систем мозга от стволового до коркового уровня. Было доказано, что у пациентов с мозговым инсультом и черепно-мозговой травмой отсутствие усвоения навязываемых ЭЭГ-ритмов при фотостимуляции является предиктором морфофункциональных нарушений на любом уровне активирующих модулирующих систем головного мозга и эффективно корригируется применением Глиатилина. Активация цикла трикарбоновых кислот (цикла Кребса) с помощью цитофлавина компенсирует нарушение энергетического обеспечения клеток и на ЭЭГ характеризуется признаками неспецифического общеактивационного характера с чертами эраузал-реакции - корковых реакций III типа с активацией высокочастотного бета-диапазона - III $3 б(24,2$ \% ) и III 16 (3,3 \% ) — или с активацией дельта- и тета-диапазонов III 1a (29,2 \% ). В ответ на введение препарата Нимодипин у пациентов с ишемическим и геморрагическим инсультом преобладали реакции, характеризующиеся снижением уровня дезорганизации ЭЭГ (63,5 \% всех реакций ЦНС), из них доминировали реакции перераспределения мощности III типа (40,8 \% всех реакций ЦНС). Среди реакций II типа (35,4 \% всех реакций ЦНС) также преобладали реакции, снижающие уровень дезорганизации ЭЭГ (22,8 \% всех реакций ЦНС). Установлен дозозависимый эффект фенотропила (Энтроп). Доказано, что постепенное увеличение дозы Энтропа в течение трех суток до 300 мг у больных с тяжелой ЧМТ приводит к снижению ЭЭГ-дезорганизации с поэтапной, лево- и правополушарной, активацией альфа-волнового частотного диапазона и высокочастотной бета 2-ритма. Установлено влияние Энтропа на при тяжелой ЧМТ в дозе 300 мг в сутки на активацию мозгового кровотока: нивелирует асимметрию кровотока, увеличивает линейную скорость кровотока и скорость венозного оттока.

Преимущественно у пациентов с ОНМК в ответ на введение препаратов Нейромидин, Глиатилин, Тиоцетам, Цитиколин при его самостоятельном применении и после последовательного введения сочетания препаратов 
Актовегин+Цитиколин, было зарегистрировано самое среднее число реакций ЦНС, характеризующиеся снижением уровня дезорганизации ЭЭГ 43-56 \% всех изменений ЭЭГ. Именно в этой группе зафиксирована самая высокая частота роста дезорганизации ЭЭГ-паттерна (25-40 \% всех реакций ЦНС), в большей мере за счет «корковых» реакций III 1а и б подгрупп (табл. 5.12). Выявлены достаточно низкая частота реакций II 1а и II 16 подгрупп (рост активности таламической системы генерации ритма ЭЭГ) и средняя частота реакций II 2 а и II 26 подгрупп (активация ретикулярной формации ствола и среднего мозга), что подтверждает реализацию основных эффектов данных препаратов при мозговом инсульте преимущественно на корковом уровне. Практически с одинаковой частотой (28-58 \% ) были зафиксированы реакции, сопровождающиеся активацией бета-ритма или смещением пика спектр-мощности в диапазон альфа-ритма. Следует отметить более частую активацию именно высокочастотного $\beta 2$-ритма (19-40%). Достаточно высокая частота активации $\delta$ - и, особенно, $\theta$ - и $\beta 2$-ритма в ответ на применение данных препаратов отражает неспецифическую общую корковую активацию с чертами эраузал-реакции, зависящую от сочетания и взаимодействия холинергической и преимущественно тормозных корковых ГАМКергических и серотонинергических нейромедиаторных систем. Учитывая, что Цитиколин и Глиатилин по своей структуре являются предшественниками ацетилхолина, Нейромидин обладает выраженным антихолинэстеразным действием, Тиоцетам, за счет Пирацетамовой составляющей, оказывает выраженное влияние на холин- и серотонинергические синапсы, данные нейрофизиологические реакции отражают восстановление функции восходящей активирующей холинергической системы ЦНС в условиях умеренного неврологического дефицита при ОНМК различного генеза.

После анализа особенностей фармакологического ответа на введение Глиатилина, Нейромидина и Цитиколина (Цераксона) с учетом реактивных перестроек исходной электроэнцефалограммы при фотостимуляции с частотой 2, 5 и 10 Гц (предикторов морфофункциональных нарушений на любом уровне активирующих модулирующих систем головного мозга) (рис. 5.28), было установлено следующее.

Для всех групп были выявлены статистически значимые (критерий хиквадрат (Chi-square) различия долей реакций ЦНС при введении трех препаратов на уровне значимости $\mathrm{p}<0,05$ (рис. 5.29-5.32).

Если до введения препарата «исходная» ЭЭГ относилась к 1-й группе (рис. 5.29, табл. 5.13), то после введения препарата Глиатилин преобладали реакции ЦНС II типа, отражающие функциональные изменения подкорковых неспецифических регуляторных систем и характеризующиеся значимым снижением (II $2 \mathrm{a}-24,2 \%$ ) или ростом (II $1 \mathrm{a}-21,2 \%$, II $16-6,06 \%$, II 1в $1,5 \%$, II 1г - 1,5 \% ) суммарной мощности ЭЭГ-паттерна.

После введения Цераксона (Цитиколина) преобладали реакции, которые отражали значимое уменьшение дезорганизации ЭЭГ-паттерна за счет усиления влияний на кору со стороны подкорковых неспецифических регуляторных систем. Эффекты Цитиколина реализовались как на подкорковом (реакции 
ЦНС II 2а группы - 27,6 \% от всего числа реакций), так и на корковом уровнях (реакций III типа - до 40 \% ), как через холинергические, так и через моноаминергические структуры ЦНС.
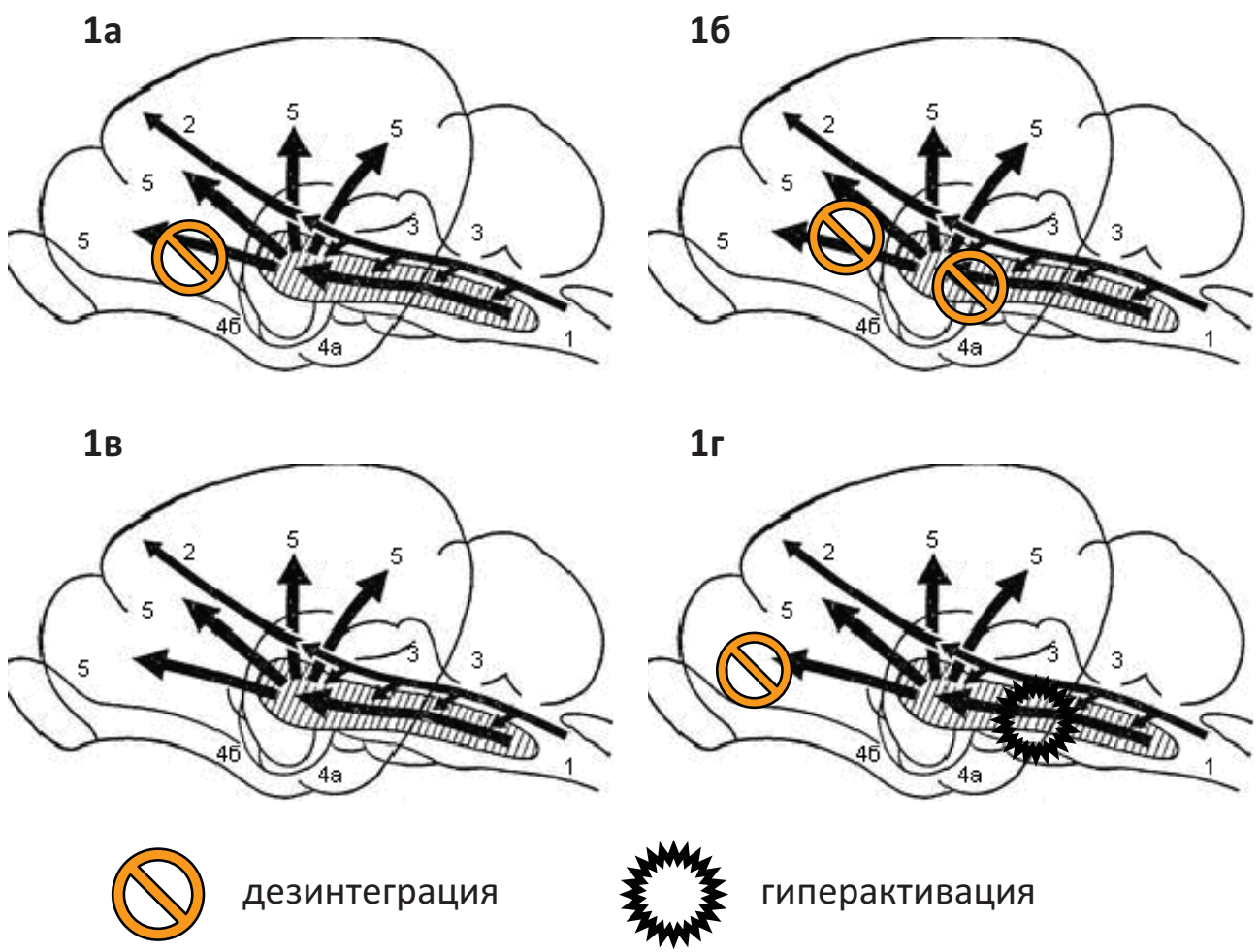

гиперактивация

1 и 2 - специфический (лемнисковый) проводящий путь; 3 - коллатерали, отходящие от специфического пути к ретикулярной формации ствола мозга; $\mathbf{4 a}$ - восходящая активирующая система ретикулярной формации; 46 - таламус; 5 - генерализованное влияние ретикулярной формации через таламокортикальные связи на кору больших полушарий.

\section{Рис. 5.28. Изменения функционирования модулирующих субсистем} активации головного мозга в 1-й (1a), 2-й (1б), 3-й (1в) и 4-й (1г) группах ЭЭГ

В ответ на введение препарата Нейромидин наиболее часто отмечались ареактивные реакции ЦНС І типа - 21,9 \%, и реакции ЦНС II 2а группы 22,6 \% от всего числа реакций. Поэтому последовательное применение Цераксона и Глиатилина было наиболее эффективным у пациентов, ЭЭГ которых относятся к 1-й группе. Если до введения препарата «исходная» ЭЭГ относилась ко 2-й группе (рис. 5.30, табл. 5.13), то после введения Глиатилина преобладали реакции ЦНС III типа $(60 \%)$, из них чаще регистрировались реакции III 2a подгруппы (48 \%), его фармакологические эффекты обеспечивали прямую холинергическую кортикальную активацию. 


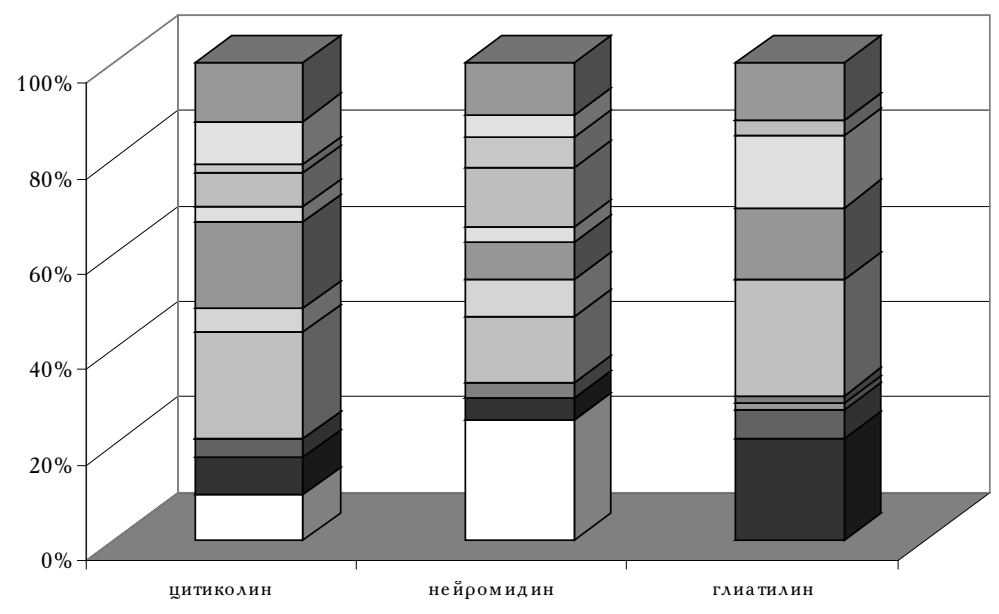

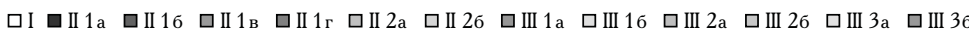

Рuc. 5.29. Типы реакций ЦНС в ответ на введение препаратов Цераксона (Цитиколина), Нейромидина и Глиатилина у пациентов с ОЦН с исходными ЭЭГ, относящимися к 1-й группе

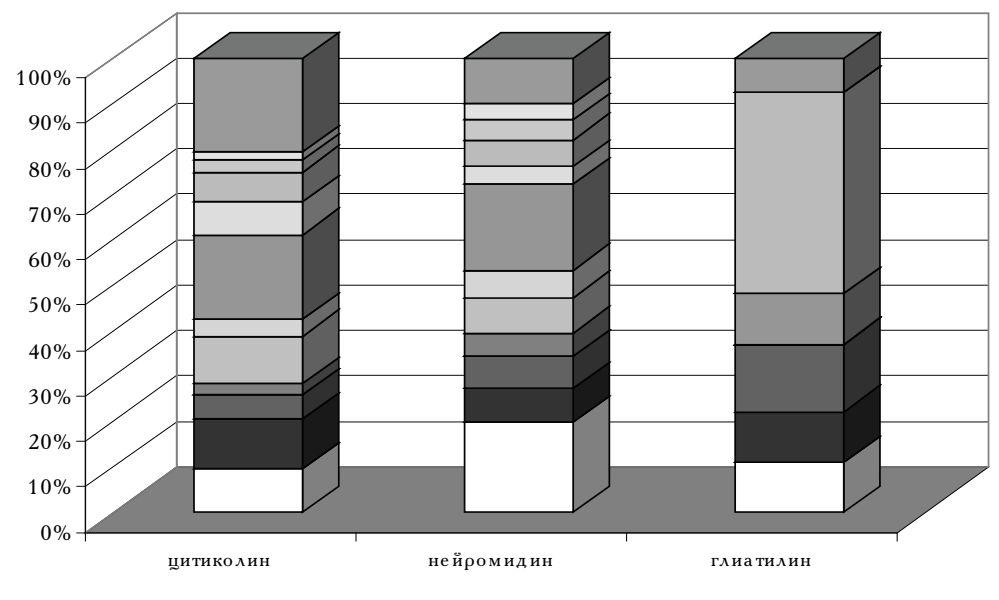

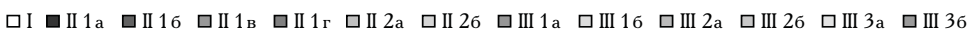

\section{Рис. 5.30. Типы реакций ЦНС в ответ на введение препаратов Цераксона} (Цитиколина), Нейромидина и Глиатилина у пациентов с ОЦН с исходными ЭЭГ, относящимися ко 2-й группе

После введения препарата Цераксона (Цитиколина) преобладали реакции ЦНС III типа (36,9 \%), из которых доминировали гипореактивные реакции III 3б подгруппы (около 21 \%) с перераспределением пика спектральной мощности в бета-диапазон, что отражало оптимизацию процессов нейротранс- 
миссии в коре за счет как прямой репарации нейрональных мембран, так и уменьшения дегенерации свободных жирных кислот Цитиколином [63, 69, 65]. Учитывая, что базальная холинергическая модулирующая субсистема активации мозга в данном случае не функционирует, такие подкорковые активирующие эффекты Цитиколина, вероятнее всего, реализовывались путем влияний на синтез дофамина, а именно - за счет усиления активности тирозингидроксилазы, тормозящей обратный захват дофамина в нервные окончания. В ответ на введение препарата Нейромидин также преобладали реакции ЦНС III типа $(37,1$ \% ), из которых гипореактивные реакции III 3б подгруппы составляли около 27 \% всех реакций ЦНС, ареактивные - 20 \% . Последовательное применение Цитиколина и Глиатилина было также более эффективным у пациентов, ЭЭГ которых относились ко 2-й группе исследования.

Если до введения препарата исходна» ЭЭГ относились к 3-й группе (рис. 5.31) то в ответ на введение препарата Глиатилин преобладали реакции ЦНС II типа $(66,7$ \%), характеризующиеся таламической дельта-активацией коры, когда чрезмерные таламические влияния на кору при снижении регуляторных воздействий ствола обусловливают рост коркового медленноволнового компонента в формировании суммарной ЭЭГ-кривой. Рост дезорганизации ЭЭГ-паттерна после подобных фармакореакций предопределяет нецелесообразность раннего (при поступлении в отделение) применения Глиатилина у пациентов, ЭЭГ которых относятся к 3-й группе. Преобладание реакций ЦНС III типа, чаще с активацией быстрых, альфа- и бета-ритмов, в ответ на введение Цераксона и в меньшей степени Нейромидина позволяет отметить эффективность последовательного применения этих препаратов пациентам, ЭЭГ которых относятся к 3-й группе.

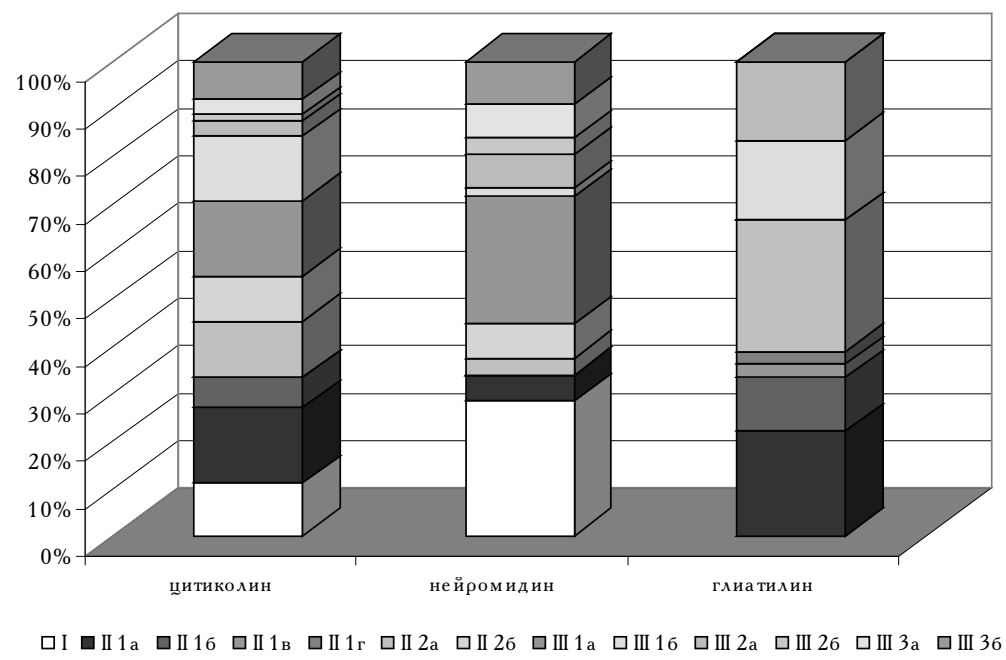

Рuc. 5.31. Типы реакций ЦНС в ответ на введение препаратов Цераксона (Цитиколина), Нейромидина и Глиатилина у пациентов с ОЦН с исходными ЭЭГ, относящимися к 3-й группе 


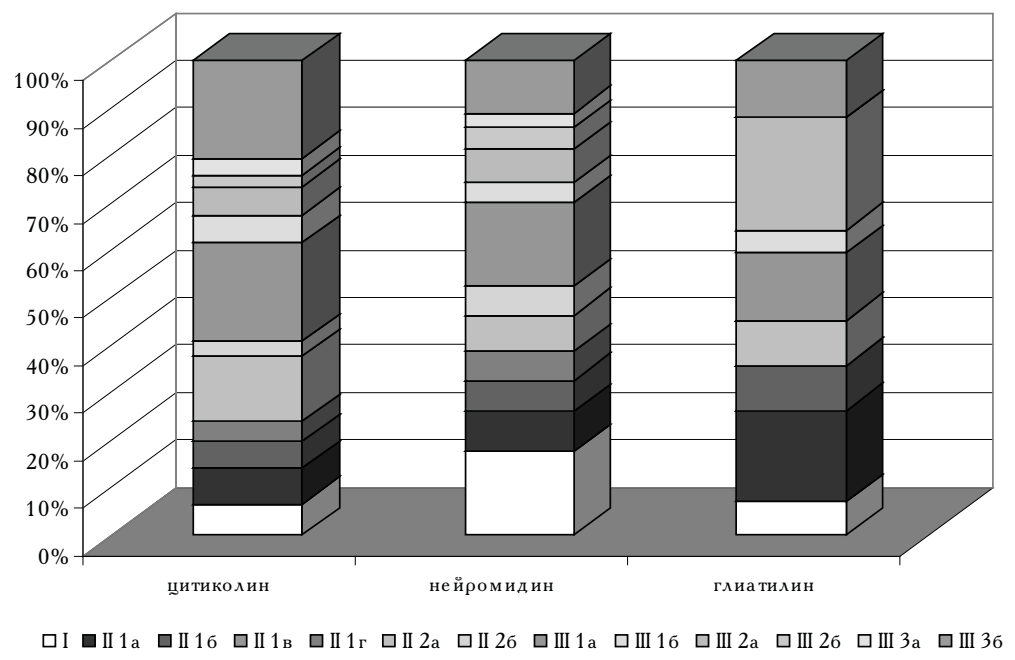

Рuc. 5.32. Типы реакций ЦНС в ответ на введение препаратов Цераксона (Цитиколина), Нейромидина и Глиатилина у пациентов с ОЦН с исходными ЭЭГ, относящимися к 4-й группе

Если исходная ЭЭГ была отнесена к 4-й группе (рис. 5.32), то после введения препарата Глиатилин преобладали реакции ЦНС III типа (54,8 \%), из которых доминировали реакции III 2а подгруппы (20,8 \% ), которые характеризуют корковые процессы перераспределения мощности в диапазон альфа-ритма. Достаточно часто регистрировались реакции II типа $(38,1$ \%), причем преобладали реакции II 1a, которые отражают снижение функциональной активности подкорковых неспецифических регуляторных систем с активацией коры больших полушарий за счет роста спектр-мощности коркового дельта-ритма. В ответ на введение препарата Цераксон также доминировали реакции ЦНС III типа (38,6 \% ), чаще всего регистрировались изменения ЭЭГ III 1а подгруппы также 26,6 \% всех реакций. После введения препарата Нейромидин несколько чаще отмечались реакции ЦНС III типа $(37,7$ \% ), причем преобладали реакции III 1а и III 16 подгрупп (около 22 \% всех реакций ЦНС), гипореактивные изменения ЭЭГ III Зб подгруппы составляли около 20 \% от всего числа реакций. Реакции ЦНС II типа (34 \% ) II 1 и II 2 групп были зарегистрированы практически с равной частотой - соответственно 14,7 и и 13,6 \% всех реакций ЦНС. Такие реакции ЦНС на введение Нейромидина отражают его фармакологический эффект блокирования калиевых каналов с торможением фазы реполяризации вместе со следовой фазой гиперполяризации, которые в норме обеспечиваются выходящим током ионов калия [90]. Причем, подобное блокирование происходит в мембранах нейронов, которые имеют не только холинергические, но и серотонин-, адрен- и дофаминергические синапсы, что в данном случае приводит к оптимизации внутриталамических взаимодействий (ретикулярное ядро - вентральные ядра) [57]. Поэтому, последовательное применение Глиа- 
тилина и Нейромидина было наиболее эффективным у пациентов, ЭЭГ которых относятся к 4-й группе.

Вероятно, следует выделить еще одну группу препаратов, которая состоит из Глиатилина, Цереброкурина, Церебролизина и комплекса Актовегин+Цитиколин, применяемых в терапии исключительно тяжелой ЧМТ. В этих условиях в ответ на применение столь различных групп препаратов (Цереброкурин, Церебролизин, Актовегин относятся к нейропептидам, Глиатилин - предшественник холина и, соответственно, ацетилхолина, Цитиколин - предшественник ключевых ультраструктурных компонентов клеточной мембраны, преимущественно фосфолипидов) с максимальной частотой были выявлены реакции ЦНС II типа 1а и б подгрупп - 13,8-47,2 \% , которые отражают процессы генерации таламического дельта-ритма отдельной клеткой таламуса на самом глубоком уровне ее гиперполяризации и тета-ритма на менее глубоком гиперполяризационном уровне [70], но при обязательном подавлении сигналов от восходящей активационной системы ствола мозга ретикулярной формации (РФ). Одновременно отмечалось и достаточно большое число реакций II типа 2а и б подгрупп - 15-34,7 \%, которые были связаны, соответственно, с ростом активности ретикулярной формации среднего мозга и продолговатого мозга и с активацией РФ ствола. Другими словами, этот вариант нейрофизиологических ответов на фармаковоздействие можно назвать преимущественно подкорковым, когда эффект реализуется на различных уровнях неспецифических регулирующих структур ГМ - от стволового до диэнцефального и таламического при более умеренных корковых проявлениях. Следует особо подчеркнуть очень высокий уровень неврологического дефицита у данной категории пациентов в острейшем периоде тяжелой ЧМТ, который отражает соответственно высокий уровень морфоструктурных и грубых функциональных нарушений практически всех структур ЦНС.

Таким образом, использование определения типа реактивности ЦНС в ответ на введение нейротропного препарата с помощью количественной ЭЭГ с применением метода интегральной количественной оценки ЭЭГ-паттерна с определением типов реакций ЦНС позволило оценивать адекватность применяемой дозы препарата, необходимость и возможность ее коррекции. Фармакологической реакцией, свидетельствующей о необходимости повышения дозы препарата, следует считать III 3б ПГ изменений и I типа реакций. О необходимости уменьшить дозу вводимого препарата свидетельствуют реакции ЦHC II 1a, II 16 подгрупп. В ответ на введение препарата L-лизина эсцинат возникает большое количество реакций ЦНС, сопровождающихся активацией низко- или, чаще, высокочастотного бета-ритма, что может свидетельствовать о восстановлении моноаминергической и глутаматергической нейротрансмиссии. Учитывая механизм действия препарата L-лизина эсцинат, отсутствие его непосредственного влияния на нейроциты, нейропротекторный эффект является опосредованным и связан с непосредственным восстановительным влиянием препарата на глию, сосудистый эндотелий, ГЭБ. Таким образом, можно сделать вывод о том, что препарат L-лизина эсцинат вполне можно использовать в качестве базового препарата для первичной нейропротекции. Приме- 
нение Актовегина необходимо для восстановления энергетического дефицита нервной ткани, он способствует более эффективному восстановлению гомеостаза аноксически деполяризованной клетки и реализации нейрофармакологических эффектов Цитиколина.

Сочетание метода интегрального количественного анализа ЭЭГ-паттерна с УЗДГ повышает достоверность оценки эффективности антиоксидантной терапии. Изменения ЭЭГ-реактивности и основных цереброваскулярных характеристик через 30 минут после однократного введения Мексидола пациентам в острейшем периоде инсульта предопределяют необходимость включения данного препарата в состав (протокол) наиболее ранней интенсивной и патогенетически направленной терапии ишемического инсульта - первичной нейропротекции. Реакции ЦНС, относящиеся к II $2 б$ подгруппе, являются коррелятом процессов активации холинергических структур ЦНС. ЭЭГ-изменения, относящиеся к II 1в подгруппе, отражают процессы активации лобных долей и усиление тормозных влияний лобных отделов на остальные области коры. Максимальный ЭЭГ-эффект применения препарата Церебролизин у пациентов с ОНМК был зафиксирован на корковом уровне с усилением влияний лобных отделов на остальные области коры. У больных с ЧМТ наиболее выраженный эффект был связан как с увеличением влияний медиобазальных отделов лобной коры и полюса лобной доли на тонус коры, так и с активацией на оральном стволовом и, особенно, лимбическом уровнях регуляторных мозговых систем, что связано с действием Церебролизина на холинергические нейроны гиппокампальной области.

Максимальный ЭЭГ-эффект применения препарата Цереброкурин у пациентов с ОНМК был зафиксирован на диэнцефальном и корковом уровне, у пациентов с ЧМТ - на лимбическом, корковом уровнях с выраженной активацией регуляторных структур диэнцефального уровня и функционально более связанных с ними образований правого полушария.

Более высокая морфологическая и функциональная дифференцировка клеток головного мозга свиней, субстрата препарата Церебролизин, возможно, предопределяет сродство пептидов данного препарата к более молодым и более дифференцированным структурам коркового и гиппокампально-лимбического уровня головного мозга человека. Менее выраженная дифференцировка клеток эмбрионов крупного рогатого скота, субстрата препарата Цереброкурин, вероятно, предопределяет сродство пептидов данного препарата к филогенетически более старым и менее дифференцированным структурам диэнцефального уровня головного мозга человека. Максимальный ЭЭГ-эффект после применения Цереброкурина и Церебролизина был зафиксирован на том уровне регуляторных мозговых систем, который изначально отличался наиболее выраженной степенью дисфункции.

Применение препаратов с доказанным холинергическим эффектом обязательно для нормализации соотношения процессов возбуждающей и тормозной нейротрансмиссии у пациентов с острой церебральной недостаточностью различного генеза (ОНМК и ТЧМТ). Выбор холинергических препаратов для пациентов с ОЦН должен быть патогенетически обоснован с учетом нарушений функционирования модулирующих субсистем активации головного мозга, предикторами 
которых являются усвоение или отсутствие усвоения навязываемого ритма световых мельканий при монохроматической фотостимуляции на ЭЭГ. Нейрофизиологические методы оценки степени сохранности модулирующих субсистем активации головного мозга позволяют врачу проводить начальный дифференцированный подбор холинергических препаратов при лечении ОЦН различного генеза. У пациентов с ОЦН различного генеза отсутствие усвоения навязываемых ЭЭГ-ритмов при фотостимуляции является предиктором морфофункциональных нарушений на одном из уровней активирующих модулирующих холинергических субсистем головного мозга. У пациентов всех исследуемых подгрупп более выраженные реактивные ЭЭГ-изменения на введение блокатора кальциевых каналов Нимодипина, относящиеся к прогностически благоприятным типам реакциии ЦНС, выявлены в области поражения: при ГЛПИ - в левой гемисфере, при ГППИ - в правой гемисфере, при ГВБИ - на уровне подкорковых образований. Постепенное увеличение дозы Энтропа в течение трех суток до 300 мг у больных с тяжелой ЧМТ приводит к снижению ЭЭГ-дезорганизации с поэтапной, лево- и правополушарной, активацией альфа-волнового частотного диапазона и высокочастотной активацией бета 2-ритма. Преобладали асимметричные реакции III 2a, III 2б, III 3a, II 2a и II 1г подгрупп. Применение Энтропа при тяжелой ЧМТ в дозе 300 мг в сутки также приводит к активации мозгового кровотока: нивелирует асимметрию кровотока, увеличивает линейную скорость кровотока и скорость венозного оттока.

Третьей задачей нашего экспериментального клинического исследования была разработка критериальной оценки эффективности медикаментозной коррекции на основе нейросетевых моделей нормально функционирующего и пораженного мозга.

Для достижения поставленной цели применен комплексный подход к исследованию электрической активности мозга: классификация ЭЭГ, укладывающихся в понятие «норма» по методу Е. А. Жћирмунской, В. С. Лосева [53] (полуколичественный анализ); метод спектрально-когерентного анализа ЭЭГ как адекватный метод оценки функционального состояния мозга, позволяющий определить его целостную деятельность; метод интегрального количественного анализа ЭЭГ-паттернов [71], который позволяет создать математические модели пространственно-временной организации электрической активности мозга, соответствующие уровню и характеру функционирования ЦНС; метод нейросетевого кластерного анализа с исследованием реактивности мозга в ответ на фотостимуляцию, который позволяет создавать нейросетевые модели изменений электрической активности мозга.

Нейросетевой анализ электрической активности мозга включал подготовительный этап - выделение группы основных (некоррелируемых) признаков. При проведении кластеризации испытуемых в многомерном пространстве признаков коэффициентов, показателей спектральной мощности и когерентности важным является условие их независимости (отсутствия высоких прямых или обратных корреляционных связей). В связи с этим на первом этапе был проведен корреляционный анализ значений полученных коэффициентов (ранговая корреляция Кендалла). 


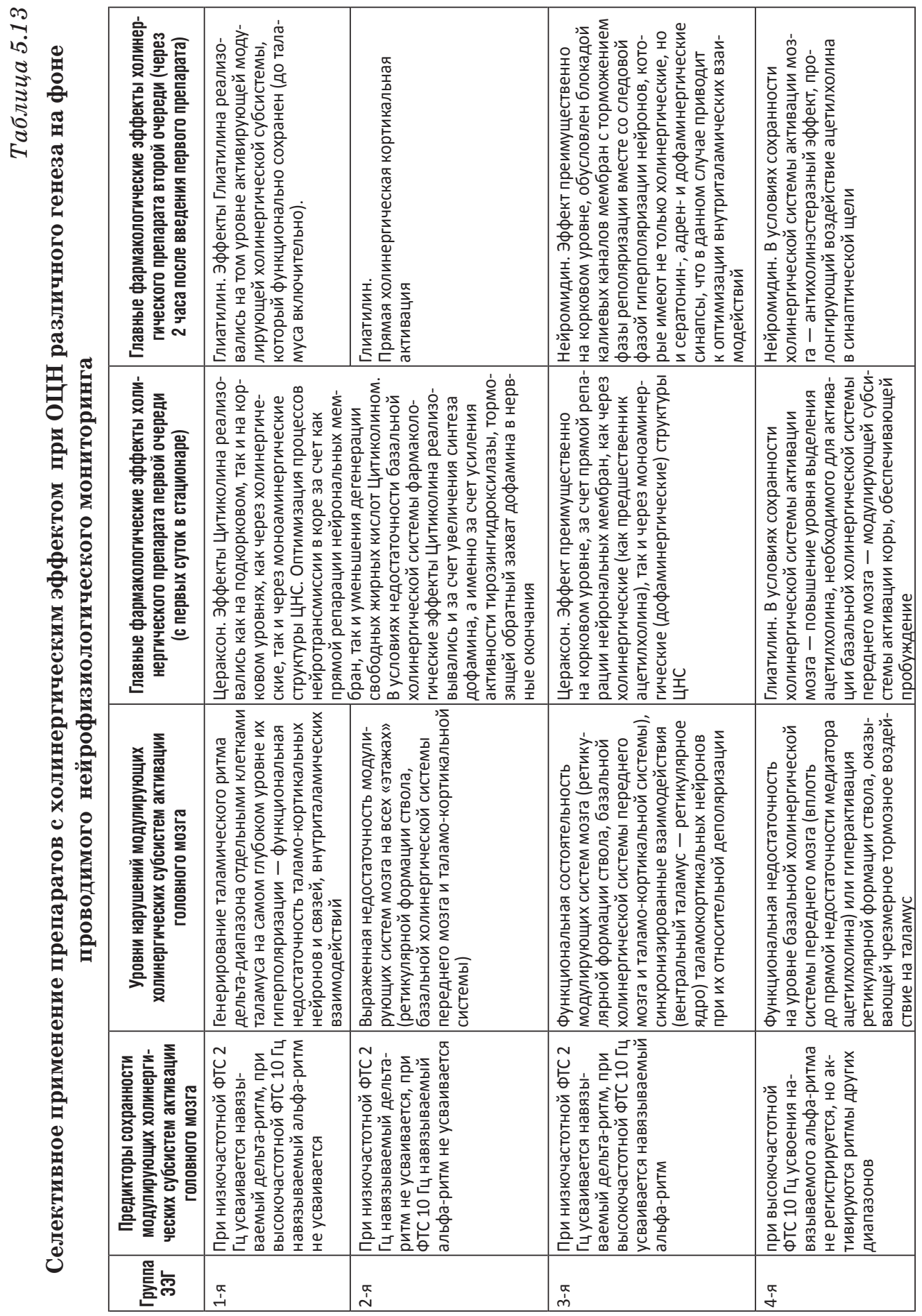


В результате для значений интегральных коэффициентов (всего 20 ИК для правого и левого полушария) и показателей спектральной мощности (всего 8 показателей для правой и левой гемисферы) был выделен набор 9 взаимно-некоррелированных признаков. Каждый из этих признаков представлял группу параметров, высоко (коэффициент корреляции Кендалла $\tau>0,75$ или $\tau<-0,75)$ коррелированных между собой.

Так, были выделены следующие группы взаимно-некоррелированных признаков.

1. Группа коэффициента ИК $1 \mathrm{med}-(\delta+\theta+\beta 1) /(\alpha+\beta 2)$ усреднено для всех отведений - показатель соотношения степени активации неспецифических регуляторных систем головного мозга стволового и лимбического уровней с формированием адекватных таламокортикальных взаимодействий в обеспечении достаточного тонуса коры.

2. Группа коэффициента ИК $5 \mathrm{med}-(\beta 1 / \beta 2)$ усреднено для всех отведений показатель перераспределения внутри бета-частотного ЭЭГ-диапазона пика абсолютной спектральной мощности, отражающий степень участия в формировании тонуса коры подкорковых структур, входящих в состав холинергической системы (например, хвостатого ядра).

3. Группа коэффициента ИК $11 \mathrm{med}-(\delta / \theta)$ усреднено для всех отведений показатель степени активности лимбических структур при формировании ЭЭГ и согласованности взаимодействий данного уровня неспецифических регуляторных систем головного мозга со стволовыми структурами.

4. Группа коэффициента ИК $12 \mathrm{med}$ - показатель асимметрии усреднено для всех отведений в частотном диапазоне от 0,5 до 30 Гц.

5. Группа коэффициента ИК $14 \mathrm{D}-(\alpha / \alpha 1)$ для всех отведений правого (D) полушария - показатель, который позволяет проанализировать степени таламических и кортикальных вкладов в результирующий альфа-ритм в исследуемых областях коры.

6. Группа коэффициента ИК $14 \mathrm{~S}-(\alpha / \alpha 1)$ для всех отведений левого (S) полушария.

7. Группа коэффициента ИК $15 \mathrm{med}-(\alpha / \beta 2)$ усреднено для всех отведений - показатель, который характеризует достаточно сложные корковые-корковые, корково-таламические, корково-лимбические взаимодействия.

8. Группа показателя ASP $\delta \mathrm{S}$ - абсолютной спектральной мощности дельта-волнового (0,5-4 Гц) диапазона во всех отведениях левого (S) полушария, которую у здорового человека традиционно связывают с функциональным состоянием срединных и, прежде всего, стволовых отделов головного мозга.

9. Группа показателя ASP $\beta 2 \mathrm{~S}$ - абсолютной спектральной мощности $\beta 2$-волнового (более 20 Гц) диапазона во всех отведениях левого (S) полушария, которую традиционно связывают у здорового человека с функциональным состоянием (ирритацией) коры. 
Для пространства показателей межполушарной и внутриполушарной когерентности был выделен набор 10 взаимно-некоррелированных признаков. Каждый из этих признаков также представлял группу параметров, высоко (коэффициент корреляции Кендалла $\tau>0,75$ или $\tau<-0,75$ ) коррелированных между собой. Были выделены следующие группы взаимно-некоррелированных признаков:

1. Группа показателя Coh meda - межполушарной когерентности альфа-волнового диапазона (частотой 8-13 Гц) усреднено для всех симметричных отведений $\left(\mathrm{Fp}_{1} \mathrm{Fp}_{2} ; \mathrm{T}_{3} \mathrm{~T}_{4} ; \mathrm{C}_{3} \mathrm{C}_{4} ; \mathrm{O}_{1} \mathrm{O}_{2}\right)$.

2. Группа показателя Coh med - межполушарной когерентности $\alpha 1$-волнового диапазона (частотой 9-11 Гц), усреднено для всех симметричных отведений $\left(\mathrm{Fp}_{1} \mathrm{Fp}_{2} ; \mathrm{T}_{3} \mathrm{~T}_{4} ; \mathrm{C}_{3} \mathrm{C}_{4} ; \mathrm{O}_{1} \mathrm{O}_{2}\right)$.

3. Группа показателя $\mathrm{Coh} \mathrm{Fp}_{1} \mathrm{Fp}_{2} \mathrm{AF}$ - межполушарной когерентности в частотном диапазоне от 0,5 до 30 Гц в симметричных лобных (фронтальных) отведениях $\left(\mathrm{Fp}_{1} \mathrm{Fp}_{2}\right)$.

4. Группа показателя Coh $\mathrm{T}_{3} \mathrm{~T}_{4} \mathrm{AF}$ - межполушарной когерентности в частотном диапазоне от 0,5 до 30 Гц в симметричных височных (темпоральных) отведениях $\left(\mathrm{T}_{3} \mathrm{~T}_{4}\right)$.

5. Группа показателя $\mathrm{Coh} \mathrm{C}_{3} \mathrm{C}_{4} \mathrm{AF}-$ межполушарной когерентности в частотном диапазоне от 0,5 до 30 Гц в симметричных центральных отведениях $\left(\mathrm{C}_{3} \mathrm{C}_{4}\right)$.

6. Группа показателя $\mathrm{Coh} \mathrm{O}_{1} \mathrm{O}_{2} \mathrm{AF}-$ межполушарной когерентности в частотном диапазоне от 0,5 до 30 Гц в симметричных затылочных (окципитальных) отведениях $\left(\mathrm{O}_{1} \mathrm{O}_{2}\right)$.

7. Группа показателя $\mathrm{Coh} \mathrm{Fp}_{1} \mathrm{~T}_{3} \mathrm{AF}$ - внутриполушарной когерентности в частотном диапазоне от 0,5 до 30 Гц в лобном $\left(\mathrm{Fp}_{1}\right)$ и височном $\left(\mathrm{T}_{3}\right)$ отведениях левого (S) полушария.

8. Группа показателя $\mathrm{Coh}_{4} \mathrm{O}_{2} \mathrm{AF}$ - внутриполушарной когерентности в частотном диапазоне от 0,5 до 30 Гц в центральном $\left(\mathrm{C}_{4}\right)$ и затылочном $\left(\mathrm{O}_{2}\right)$ отведениях правого (D) полушария.

9. Группа показателя $\mathrm{Coh}_{3} \mathrm{O}_{1} \mathrm{AF}$ - внутриполушарной когерентности в частотном диапазоне от 0,5 до 30 Гц в центральном $\left(\mathrm{C}_{3}\right)$ и затылочном $\left(\mathrm{O}_{1}\right)$ отведениях левого (S) полушария.

10. Группа показателя Coh $\mathrm{T}_{4} \mathrm{C}_{4} \mathrm{AF}$ - внутриполушарной когерентности в частотном диапазоне от 0,5 до 30 Гц в височном $\left(\mathrm{T}_{4}\right)$ и центральном $\left(\mathrm{C}_{4}\right)$ отведениях правого (D) полушария.

Затем была разработана нейросетевая модель, включающая электроэнцефалограммы организованного типа, которая использовалась для создания нейросетевых моделей мозгового инсульта и ЧМТ.

Для проведения кластеризации данных в многомерном пространстве признаков использовался особый тип нейронных сетей, которые представляют собой сети, обучающиеся без выходных сигналов («обучение без учителя», которые были предложены Kohonen) - сети Кохонена [72, 73]. 
В качестве объекта классификации были использованы записи ЭЭГ, полученные при обследовании 72 добровольцев, у которых изменения электрической активности мозга укладывались в понятие «норма». Для построения автоматической классификации электроэнцефалограмм по результатам исследования электрической активности мозга в состоянии спокойного бодрствования была создана нейронная сеть Кохонена со 160 нейронами - 160 коэффициентов мощности и когерентности для протокола записи ЭЭГ «спокойное бодрствование» - во входном слое и четырьмя нейронами в выходном.

Установлено, что для ЭЭГ, записанных в состоянии «спокойное бодрствование», организованного типа, характерного для здорового человека (I тип единой классификации электрической активности головного мозга по классификации Е. А. ЖЖирмунской, В. С. Лосева), в многомерном пространстве признаков коэффициентов спектральной мощности и когерентности может быть выделено 4 различные группы, у которых изменения электрической активности мозга укладывались в понятие «норма» .

ЭЭГ организованного типа, характерная для здорового человека, в ответ на ахроматическую ритмическую фотостимуляцию, при проведении кластеризации испытуемых в многомерном пространстве признаков коэффициентов спектральной мощности и когерентности, может дифференцироваться только на два нейрона в выходном слое и таким образом может быть разделена на две группы.

При анализе параметров 338 электроэнцефалограмм пациентов с мозговым инсультом с помощью нейронной сети Кохонена с 680 нейронами во входном слое (170 параметров мощности, интегральных коэффициентов и показателей когерентности для протокола записи ЭЭГ «спокойное бодрствование, фотостимуляция $2,5,10$ Гц») и четырьмя нейронами в выходном, было доказано, что все анализируемые объекты эффективно разделялись в 680 -мерном пространстве признаков на 4 различные группы-кластеры $(\mathrm{Cl})$.

При анализе распределения в кластерах электроэнцефалограмм пациентов с инсультами, различными по этиологии и локализации, были выявлены статистически значимые различия 1-го, 2-го и 3-го кластеров (рис. 5.33). Во все кластеры входили ЭЭГ пациентов и с ишемическим, и с геморрагическим мозговым инсультом.

Правополушарные инсульты преобладали во 2-м кластере (48,8 \% всех пациентов), левополушарные - в третьем (78 \% всех пациентов), вертебробазилярные - в 4 -м (48,8 \% всех пациентов).

Минимальный уровень ( $<0,05$, анализ Крускала-Уоллиса (аКУ), критерий Данна (кД), критерий хи-квадрат $\left.\left(\chi^{2}\right)\right)$ 1-го и ИК (рис. 5.33) был выявлен в ЭЭГ 2-го кластера, что свидетельствовало о самом низком уровне дезорганизации ЭЭГ-паттерна в данном кластере. Максимальные значения $(\mathrm{p}<0,05$, аКУ, кД, $\chi^{2}$ ) 1-го ИК были зафиксированы в 1-м кластере, уровень дезорганизации ЭЭГ-паттернов был в этом кластере самым высоким.

Уровень дезорганизации ЭЭГ в 3-м и 4-м кластерах был практически одинаковым, о чем свидетельствовали значения 1-го ИК, не имеющие значимых различий в этих кластерах (p>0,05, аКУ, кД, $\left.\chi^{2}\right)$. По показателю 5-го ИК вы- 
явлены значимые отличия ( $<<0,05$, аКУ, кД, $\left.\chi^{2}\right)$ преимущественно параметров 1-го и 3 -го кластеров от значений 2-го и 4-го кластеров. Причем, в 1-м и 3-м кластерах отмечались более низкие показатели этого ИК, свидетельствующие о менее выраженной активации низкочастотного $\beta 1$-ритма.

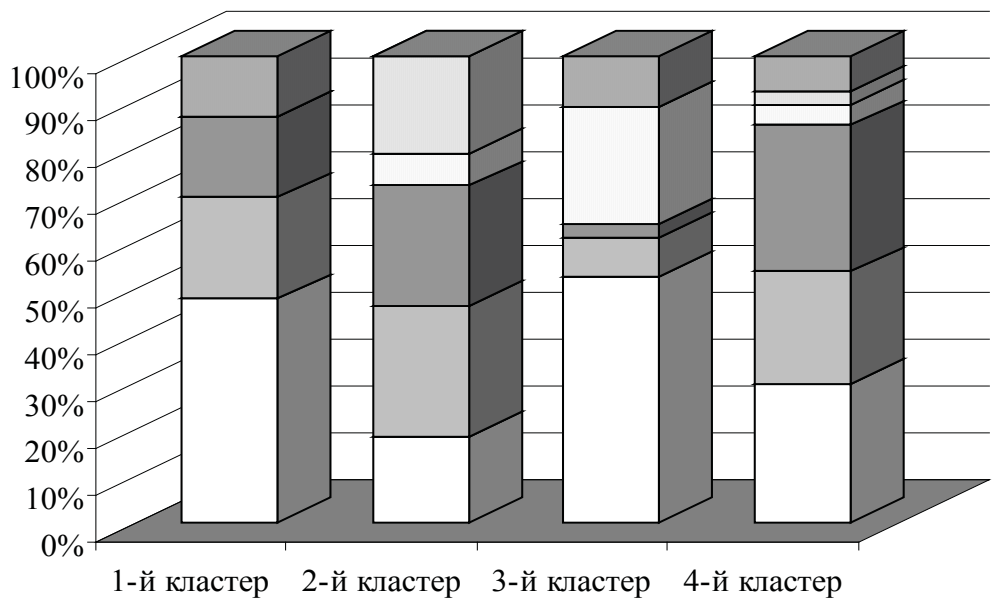

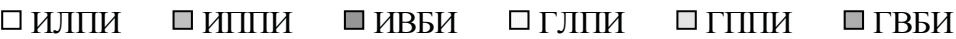

Различие является статистически значимым на уровне значимости $\mathrm{p}<0,001$ (критерий $\chi^{2}$ ); ИЛПИ - ишемический левополушарный инсульт, ИППИ - ишемический правополушарный инсульт; ИВБИ - ишемический вертебробазилярный инсульт; ГЛПИ - геморрагический левополушарный инсульт, ГППИ - геморрагический правополушарный инсульт; ГВБИ геморрагический вертебробазилярный инсульт.

\section{Рис. 5.33. Распределения в кластерах ЭЭГ пациентов с мозговым инсультом различной этиологии (ишемический и геморрагический) и локализации (лево-, правополушарный и в вертебробазилярном бассейне)}

По значениям 11-го ИК были отмечены значимые его отличия $(\mathrm{p}<0,05$, аКУ, кД, $\chi^{2}$ ) в 3 -м кластере по сравнению с уровнями 1-го и 4-го кластеров. Причем, в 3-м кластере были зафиксированы самые низкие показатели этого коэффициента, что свидетельствовало о менее выраженной активности лимбических структур неспецифических регуляторных систем головного мозга по сравнению со стволовыми при формировании ЭЭГ.

Показатели 12-го ИК (асимметрии) косвенно характеризовали доминирование активности, преимущественно патологической, медленноволновой, в левой гемисфере (кластер 3), выраженное правополушарное доминирование (кластер 2). Иными словами, ЭЭГ в данных кластерах были выражено асимметричными. Были также зафиксированы тенденции к правосторонней (4-й кластер) и к левосторонней (1-й кластер) ЭЭГ асимметрии. Поэтому, были выявлены значимые различия ( $<0,05$, аКУ, кД, $\left.\chi^{2}\right)$ уровней 12 -го ИК 3-го кластера по сравнению с показателями 2-го и 4 -го кластеров. 
Интересны различия показателей 14-го ИК, позволяющего выявить степени таламических и кортикальных «вкладов» в результирующий альфа-ритм в исследуемых областях коры, в правой (D) и левой (S) гемисферах. B правой гемисфере минимальный уровень (p<0,05, aКУ, кД, $\left.\chi^{2}\right)$ данного ИК был характерен для 2-го кластера. В левом полушарии минимальный уровень $(\mathrm{p}<0,05$, aКУ, кД, $\chi^{2}$ ) 14-го ИК был типичным для 3-го кластера.

Также были выявлены отличия в кластерах и по показателю 15-го ИК, который характеризует сложные корково-корковые, корково-таламические и таламо-кортикальные взаимодействия для обеспечения адекватных когнитивных процессов в коре. Максимальный уровень 15-го ИК был характерен для 2-го кластера, что свидетельствовало об относительной функциональной сохранности таламо-кортикальных связей.

Наиболее благоприятным при мозговом инсульте следует считать 2-й кластер ЭЭГ с минимальным уровнем дезорганизации ЭЭГ-паттерна, сохранностью таламо-кортикальных связей для обеспечения адекватных когнитивных процессов в коре, с предикторами функциональной несостоятельности структур лимбической системы (медиальной области среднего мозга) и умеренной гиперактивации диэнцефального и стволового (преимущественно, каудального) уровней неспецифической регуляции ЦНС.

Наиболее инертным, прогностически неблагоприятным и многочисленным при мозговом инсульте следует считать 4-й кластер ЭЭГ: с умеренным уровнем ЭЭГ-дезорганизации, с минимальным уровнем активности лимбической системы в формировании тонуса коры, с признаками функциональной недостаточности таламо-кортикальных и стволовых отделов головного мозга, как орального, так и каудального уровней.

Следует подчеркнуть, что параметры ЭЭГ 1-го кластера отличаются от других кластеров, прежде всего, самым высоким уровнем дезорганизации (1 ИК), с минимальным уровнем участия в формировании тонуса коры подкорковых структур активирующей холинергической системы (5-й ИК), с максимальной степенью активности стволовой системы в формировании тонуса коры (11 ИК), с отсутствием значимой ЭЭГ-асимметрии (12-й ИК), с преобладанием таламической альфа-активности в правом полушарии (14 (D и S) ИК), с выраженной недостаточностью таламо-кортикальных взаимодействий (минимальный уровень 15-го ИК) - рис. 5.34.

Параметры ЭЭГ 3-го кластера отличаются от других кластеров умеренным уровнем дезорганизации (1 ИК), с минимальным уровнем участия в формировании тонуса коры подкорковых структур активирующей холинергической системы (5-й ИК), с максимальной степенью активности лимбической системы в формировании тонуса коры (11 ИК), с левополушарной ЭЭГ-асимметрией (12-й ИК), с преобладанием таламической альфа-активности в правом полушарии (14 (D и S) ИК), с умеренной недостаточностью таламо-кортикальных взаимодействий (минимальный уровень 15-го ИК) - рис. 5.34.

Нами были выявлены (рис. 5.35) значимые различия в кластерах (p $<0,05$, aКУ, кД, $\chi^{2}$ ) для межполушарной когерентности дельта-волнового диапазона с частотой 0,5-4 Гц усреднено для всех симметричных отведений $\left(\mathrm{Fp}_{1} \mathrm{Fp}_{2} ; \mathrm{T}_{3} \mathrm{~T}_{4}\right.$; 
$\mathrm{C}_{3} \mathrm{C}_{4} ; \mathrm{O}_{1} \mathrm{O}_{2}$; Coh med $\delta$ ). Причем, в электроэнцефалограммах 1-го кластера уровень данного показателя был зафиксирован максимальным, во 2-м кластере минимальным, что характеризовало самый низкий уровень активации стволового уровня неспецифического регулирования.

Также были отмечены значимые различия в кластерах (p<0,05, aКУ, кД, $\left.\chi^{2}\right)$ для межполушарной когерентности в частотном диапазоне от 0,5 до З0Гц в симметричных височных отведениях (Coh $\left.\mathrm{T}_{3} \mathrm{~T}_{4} \mathrm{AF}\right)$. Причем, более высокий уровень когерентности ( $<<0,05$, аКУ, кД, $\left.\chi^{2}\right)$, свидетельствующий о достаточно высоком уровне функциональной активности лимбической системы головного мозга, был зафиксирован в кластерах 1-м и 3-м. Минимальный уровень Coh $\mathrm{T}_{3} \mathrm{~T}_{4} \mathrm{AF}\left(\mathrm{p}<0,05\right.$, aКУ, кД, $\left.\chi^{2}\right)$, отражающий гипофункцию структур гиппокампально-лимбической системы, был выявлен в кластерах 2-м и 4-м.
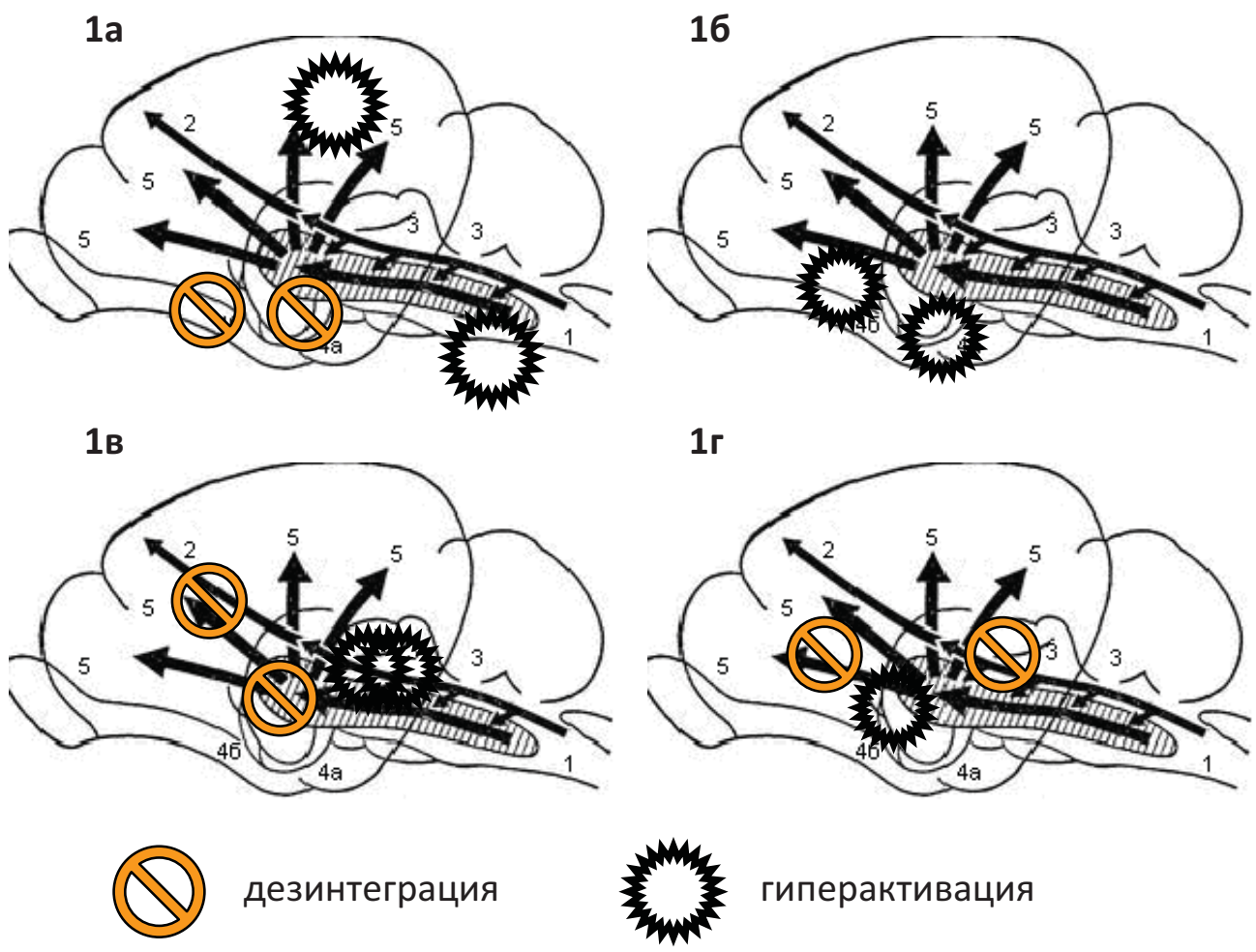

гиперактивация

1 и 2 - специфический (лемнисковый) проводящий путь; 3 - коллатерали, отходящие от специфического пути к ретикулярной формации ствола мозга; $\mathbf{4 a}$ - восходящая активирующая система ретикулярной формации; 4 б - таламус; 5 - генерализованное влияние ретикулярной формации через таламокортикальные связи на кору больших полушарий.

Рис. 5.34. Изменения модулирующих субсистем активации головного мозга в 1-м (1а), 2-м (1б), 3-м (1в) и 4-м (1г) кластерах ЭЭГ при мозговом инсульте 
Были выявлены значимые различия в кластерах (p<0,05, аКУ, кД, $\left.\chi^{2}\right)$ для межполушарной когерентности в частотном диапазоне от 0,5 до 30 Гц в симметричных затылочных (окципитальных) отведениях $\left(\mathrm{O}_{1} \mathrm{O}_{2}\right)\left(\mathrm{Coh} \mathrm{O}_{1} \mathrm{O}_{2} \mathrm{AF}\right)$. Причем в электроэнцефалограммах 1-го и 2-го кластеров значения данного показателя были зафиксированы на максимальном уровне, что свидетельствовало о достаточно высоком уровне функциональной активности стволовых структур головного мозга, преимущественно, каудального уровня, а в 3-м и 4-м кластеpax были зафиксированы минимальные $\left(\mathrm{p}<0,05\right.$, аКУ, кД, $\left.\chi^{2}\right)$ значения Coh $\mathrm{O}_{1} \mathrm{O}_{2} \mathrm{AF}$, что указывало на функциональную недостаточность структур ствола.

Из показателей внутриполушарной когерентности значимые различия в кластерах $\left(\mathrm{p}<0,05, \mathrm{aКУ,} \mathrm{кД,} \chi^{2}\right)$ были выявлены для Coh $\mathrm{T}_{4} \mathrm{C}_{4} \mathrm{AF}$-когерентности в частотном диапазоне от 0,5 до 30 Гц между височным $\left(\mathrm{T}_{4}\right)$ и центральным $\left(\mathrm{C}_{4}\right)$ отведениями правого (D) полушария, которая характеризует состояние как моторно-речевой зоны коры, так и срединных и подкорковых образований (RF среднего мозга, медиальные ядра перегородки), что связано и с тесным функциональным взаимодействием правого полушария с диэнцефальными структурами.

Причем, для 4-го кластера были типичными самые высокие значения данного параметра, превышающие уровень нормы, что свидетельствовало, согласно идеологии системных взаимоотношений, о выраженном росте напряженности с ограничением функциональных резервов в системах среднего мозга и медиобазальных структур коры.

Для так называемой «когнитивной оси» (Свидерская Н. Е., 1993) (более высокие значения когерентности в левой лобно-височной и в правой теменнозатылочной области) при множественных сравнениях (анализ КрускалаУоллиса) для 4 выборок (кластеров) показателей внутриполушарной когерентности в частотном диапазоне от 0,5 до 30 Гц между центральным $\left(\mathrm{C}_{4}\right)$ и заты-

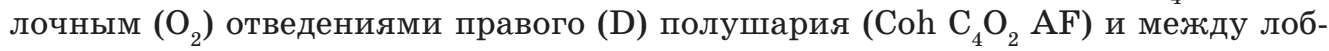
ным $\left(\mathrm{Fp}_{1}\right)$ и височным $\left(\mathrm{T}_{3}\right)$ отведениями левого $(\mathrm{S})$ полушария $\left(\mathrm{Coh} \mathrm{Fp}_{1} \mathrm{~T}_{3} \mathrm{AF}\right)$ статистически значимых различий обнаружено не было.

Значимые статистические различия ( $<0,05$, аКУ, кД, $\left.\chi^{2}\right)$ в 4 -х кластеpax были выявлены для показателей внутриполушарной когерентности в частотном диапазоне от 0,5 до 30 Гц между центральным $\left(\mathrm{C}_{3}\right)$ и затылочным $\left(\mathrm{O}_{1}\right)$ отведениями левого (S) полушария (Coh $\left.\mathrm{C}_{3} \mathrm{O}_{1} \mathrm{AF}\right)$, отражающие локальные (мамилло-таламическая система, медиальная область среднего мозга) влияния на синхронизацию биоэлектрической активности коры больших полушарий. Наиболее высокие уровни внутриполушарной когерентности между центральным $\left(\mathrm{C}_{3}\right)$ и затылочным $\left(\mathrm{O}_{1}\right)$ отведениями левого $(\mathrm{S})$ полушария были выявлены в кластерах 1-м и 3-м, самый низкий уровень - в 4-м кластере, что являлось предиктором выраженной функциональной недостаточности структур лимбической системы (медиальной области среднего мозга).

Таким образом, в наиболее благоприятном при мозговом инсульте 2-м кластере ЭЭГ были зафиксированы: низкий уровень межполушарной когерентности дельта-волнового диапазона; низкий уровень суммарной когерентности в симметричных височных отделах и высокий уровень суммарной меж- 
затылочной когерентности; низкие показатели суммарной внутриполушарной когерентности между центральным $\left(\mathrm{C}_{3}\right)$ и затылочным $\left(\mathrm{O}_{1}\right)$ отведениями левого (S) полушария.

В наиболее неблагоприятном 4-м кластере ЭЭГ были выявлены: самый низкий уровень межполушарной когерентности дельта-волнового диапазона; самый низкий уровень суммарной когерентности в симметричных височных и окципитальных отделах; самые низкие показатели суммарной внутриполушарной когерентности между центральным $\left(\mathrm{C}_{3}\right)$ и затылочным $\left(\mathrm{O}_{1}\right)$ отведениями левого (S) полушария и самые высокие показатели - между височным $\left(\mathrm{T}_{4}\right)$ и центральным $\left(\mathrm{C}_{4}\right)$ отведениями правого (D) полушария.

Для 1-го кластера типичными были: самый высокий уровень межполушарной когерентности дельта-волнового диапазона; высокие уровни суммарных межвисочной и межзатылочной когерентностей; самые низкие показатели - внутриполушарной когерентности между височным $\left(\mathrm{T}_{4}\right)$ и центральным $\left(\mathrm{C}_{4}\right)$ отведениями правого (D) полушария.

Параметры ЭЭГ 3-го кластера отличаются от других кластеров: достаточно высоким уровнем межполушарной когерентности дельта-волнового диапазона; высоким уровнем суммарной межвисочной когерентности; достаточно высокими показателями суммарной внутриполушарной когерентности между центральным $\left(\mathrm{C}_{3}\right)$ и затылочным $\left(\mathrm{O}_{1}\right)$ отведениями левого $(\mathrm{S})$ полушария и самыми низкими показателями когерентности между височным $\left(\mathrm{T}_{4}\right)$ и центральным $\left(\mathrm{C}_{4}\right)$ отведениями правого (D) полушария.

При анализе параметров 270 электроэнцефалограмм пациентов с тяжелой ЧМТ с помощью нейронной сети Кохонена со 680 нейронами во входном слое и четырьмя нейронами в выходном, все анализируемые объекты эффективно разделялись в 680 -мерном пространстве признаков на 4 различных группы - кластеры $(\mathrm{Cl})$.

Таким образом, наиболее благоприятным при черепно-мозговой травме также следует считать 2-й кластер ЭЭГ с самым низким уровнем ЭЭГдезорганизации $(1,11$ ИК), с выраженным участием в формировании тонуса коры подкорковых структур, входящих в состав активирующей холинергической системы (например, таламус и хвостатое ядро) (5-й ИК), с доминированием ЭЭГ-активности в правой гемисфере (12-й ИК), с преобладанием корковой составляющей альфа-ритма как в левой, так и в правой гемисферах (14 (D и S) ИК), с признаками функциональной сохранности таламо-кортикальных связей для обеспечения адекватных когнитивных процессов в коре (15 ИК), с минимальным уровнем дельта- и высокочастотной бета-активности в левой гемисpepe.

При черепно-мозговой травме самым тяжелым (неблагоприятным) следует считать 3 -й кластер ЭЭГ с умеренным уровнем ЭЭГ-дезорганизации (1 ИК), с минимальным уровнем активации подкорковых холинергических структур, (5-й ИК), со средним уровнем активности лимбической системы в формировании тонуса коры (11 ИК), с левосторонней ЭЭГ-асимметрией (12-й ИК) за счет доминирования в левой гемисфере медленноволновой дельта-частотной активности (ASP $\delta$ S), с преобладанием таламической альфа-активности справа (14 
(D) ИК), с признаками максимально выраженной функциональной недостаточности таламо-кортикальных взаимодействий для обеспечения адекватных когнитивных процессов в коре (15 ИК) (рис. 5.35).

Параметры ЭЭГ 4-го кластера отличаются от других кластеров прежде всего самым высоким уровнем дезорганизации (1 ИК), со средним уровнем участия в формировании тонуса коры подкорковых структур активирующей холинергической системы (5-й ИК), с максимальной степенью активности лимбической системы в формировании тонуса коры (11 ИК), с тенденцией к правосторонней ЭЭГ-асимметрии (12-й ИК), с преобладанием таламической альфа-активности в левом полушарии (14 (D и S) ИК), с выраженной недостаточностью таламо-кортикальных взаимодействий (средний уровень 15 -го ИК).
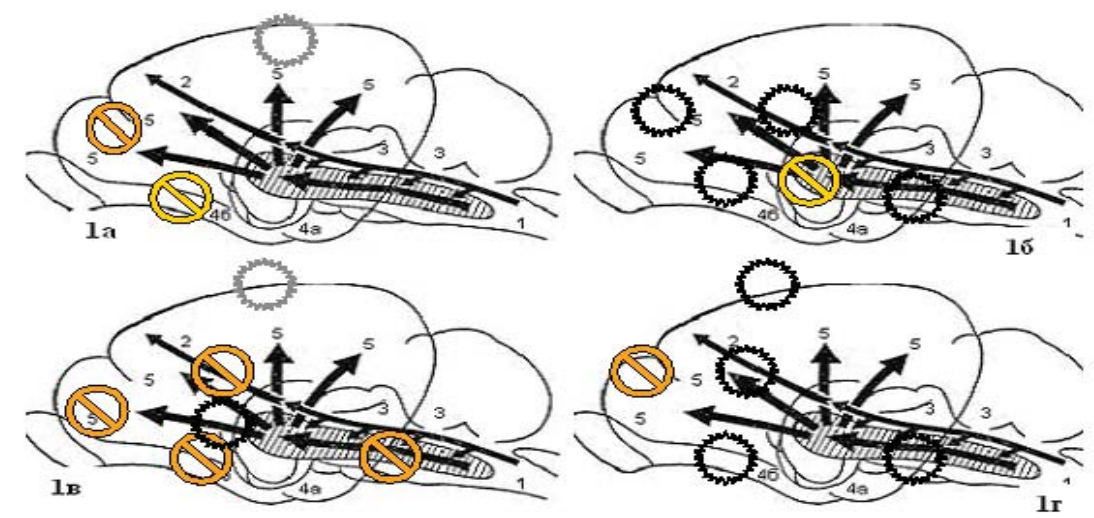

дезинтеграция

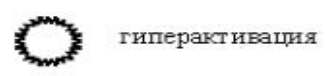

1 и 2 - специфический (лемнисковый) проводящий путь; 3 - коллатерали, отходящие от специфического пути к ретикулярной формации ствола мозга; $\mathbf{4 a}$ - восходящая активирующая система ретикулярной формации; 4 б - таламус; 5 - генерализованное влияние ретикулярной формации через таламокортикальные связи на кору больших полушарий.

\section{Рис. 5.35. Изменения модулирующих субсистем активации головного мозга в 1-м (1а), 2-м (1б), 3-м (1в) и 4-м (1г) кластерах ЭЭГ при черепно-мозговой травме}

Параметры ЭЭГ 1-го кластера отличаются от других кластеров умеренным уровнем дезорганизации (1 ИК), с минимальным уровнем участия в формировании тонуса коры подкорковых структур активирующей холинергической системы (5-й ИК), со средним уровнем активности лимбической системы в формировании тонуса коры (11 ИК), с умеренной правосторонней ЭЭГ-асимметрией (12-й ИК), с преобладанием коркового компонента альфаактивности, как в правом, так и в левом полушариях (14 (D и S) ИК), с выраженной недостаточностью таламо-кортикальных взаимодействий (минимальный уровень 15-го ИК) (рис. 5.35). 
Нами были выявлены значимые различия в кластерах (p<0,05, аКУ, кД, $\chi^{2}$ ) для межполушарной когерентности альфа-волнового диапазона усреднено для всех симметричных отведений $\left(\mathrm{Fp}_{1} \mathrm{Fp}_{2} ; \mathrm{T}_{3} \mathrm{~T}_{4} ; \mathrm{C}_{3} \mathrm{C}_{4} ; \mathrm{O}_{1} \mathrm{O}_{2} ; \mathrm{Coh}\right.$ med $\left.\delta\right)$. В ЭЭГ 1-го и 3-го кластеров уровень данного показателя был зафиксирован минимальным, а во 2-м и 4-м кластерах - максимальным, что характеризовало самый высокий уровень активации таламического уровня неспецифического регулирования.

Значимые различия в кластерах (p<0,05, аКУ, кД, $\left.\chi^{2}\right)$ также были характерными для межполушарной когерентности дельта-волнового диапазона с частотой 0,5-4 Гц, причем в электроэнцефалограммах 1-го кластера уровень данного показателя был зафиксирован минимальным, 2-го кластера - максимальным, что характеризовало выраженную активацию стволового уровня неспецифического регулирования.

Значимые различия в кластерах (p<0,05, аКУ, кД, $\left.\chi^{2}\right)$ были выявлены также для межполушарной когерентности в частотном диапазоне от 0,5 до 30 Гц в симметричных лобных отведениях (Coh Fp $\left.\mathrm{Fp}_{2} \mathrm{AF}\right)$. Причем, наиболее высокий $\mathrm{p}<0,05$, аКУ, кД, $\chi^{2}$ ) уровень когерентности, свидетельствующий о достаточно высоком уровне функциональной активности на уровне оральных отделов ствола головного мозга, был зафиксирован в 4-м и во 2-м кластерах. А минимальный уровень ( $<<0,05$, аКУ, кД, $\left.\chi^{2}\right)$, отражающий гипофункцию структур стволовой системы, был выявлен в кластерах 3-м и 1-м.

В отличие от ЭЭГ кластеров, типичных для мозгового инсульта, при тяжелой ЧМТ значимые различия ( $<0,05$, аКУ, кД, $\left.\chi^{2}\right)$ для суммарной межполушарной когерентности в симметричных височных отведениях $\left(\mathrm{Coh} \mathrm{T}_{3} \mathrm{~T}_{4}\right.$ AF), были выявлены только для 1-го и 2-го кластеров. Причем, более высокий ( $<<0,05$, аКУ, кД, $\chi^{2}$ ) уровень когерентности, свидетельствующий о достаточно высоком уровне функциональной активности лимбической системы головного мозга, был зафиксирован во 2-м кластере.

Были выявлены значимые различия в кластерах (p < 0,05, аКУ, кД, $\left.\chi^{2}\right)$ для суммарной межполушарной когерентности в симметричных затылочных (окципитальных) отведениях (Coh $\left.\mathrm{O}_{1} \mathrm{O}_{2} \mathrm{AF}\right)$, причем в электроэнцефалограммax 2-го кластера значения данного показателя были зафиксированы на максимальном уровне, что свидетельствовало о достаточно высоком уровне функциональной активности стволовых (каудальных отделов) структур головного мозга, а в 1-м и 3-м кластерах были зафиксированы минимальные $(\mathrm{p}<0,05$, aКУ, кД, $\chi^{2}$ ) значения Coh $\mathrm{O}_{1} \mathrm{O}_{2} \mathrm{AF}$, что указывало на выраженную функциональную недостаточность данных структур ствола.

Из показателей внутриполушарной когерентности значимые различия в кластерах (p<0,05, aКУ, кД, $\left.\chi^{2}\right)$ были выявлены для Coh $\mathrm{T}_{4} \mathrm{C}_{4} \mathrm{AF}$-когерентности в частотном диапазоне от 0,5 до 30 Гц между височным $\left(\mathrm{T}_{4}\right)$ и центральным $\left(\mathrm{C}_{4}\right)$ отведениями правого (D) полушария. Причем, для 2-го кластера были типичными самые высокие значения данного параметра, не превышающие однако уровень нормы, что свидетельствовало, согласно идеологии системных взаимоотношений [74], о выраженном росте напряженности в системах среднего мозга и медиобазальных структур коры. 
При множественных сравнениях (анализ Крускала-Уоллиса) для 4 выборок (кластеров) для так называемой «когнитивной оси» $[75,76]$ были выявлены только статистически значимые различия показателей внутриполушарной когерентности в частотном диапазоне от 0,5 до 30 Гц между лобным $\left(\mathrm{Fp}_{1}\right)$ и височным ( $\mathrm{T}_{3}$ ) отведениями левого (S) полушария (Coh Fp $\left.\mathrm{T}_{3} \mathrm{AF}\right)$. Причем, в ЭЭГ 1-го кластера значения Coh $\mathrm{Fp}_{1} \mathrm{~T}_{3} \mathrm{AF}$ были самыми низкими.

Значимые статистические различия $\left(\mathrm{p}<0,05\right.$, аКУ, кД, $\left.\chi^{2}\right)$ в 4-х кластерах были выявлены для показателей внутриполушарной когерентности в частотном диапазоне от 0,5 до 30 Гц между центральным $\left(\mathrm{C}_{3}\right)$ и затылочным $\left(\mathrm{O}_{1}\right)$ отведениями левого (S) полушария (Coh $\left.\mathrm{C}_{3} \mathrm{O}_{1} \mathrm{AF}\right)$, отражающие локальные (мамилло-таламическая система, медиальная область среднего мозга) влияния на синхронизацию биоэлектрической активности коры больших полушарий. Самый высокий уровень внутриполушарной когерентности между центральным $\left(\mathrm{C}_{3}\right)$ и затылочным $\left(\mathrm{O}_{1}\right)$ отведениями левого $(\mathrm{S})$ полушария был выявлен в ЭЭГ 3-го кластера, самый низкий уровень - в ЭЭГ 2-го кластера, что также являлось предиктором функциональной недостаточности структур медиальной области среднего мозга.

Таким образом, в наиболее благоприятном, при тяжелой ЧМТ, 2-м кластере ЭЭГ были зафиксированы: самый высокий уровень межполушарной когерентности дельта- и альфа-волнового диапазонов; максимальный уровень суммарной межполушарной когерентности в симметричных фронтальных, центральных, темпоральных и окципитальных отделах, что характеризовало высокий уровень функциональной активности практически всех уровней неспецифической регуляции головного мозга - стволового, диэнцефального и лимбико-гиппокампного; и максимальные показатели когерентности между височным $\left(\mathrm{T}_{4}\right)$ и центральным $\left(\mathrm{C}_{4}\right)$ отведениями правого (D) полушария, что характеризовало рост напряженности в системах среднего мозга и медиобазальных структур коры.

В наиболее неблагоприятном 3-м кластере ЭЭГ были выявлены: самый низкий уровень межполушарной когерентности альфа-волнового диапазона; самые низкие уровни суммарной когерентности в симметричных фронтальных, центральных, темпоральных и окципитальных отделах, что свидетельствовало о выраженной недостаточности функционирования всех уровней неспецифической регуляции головного мозга; самые высокие показатели суммарной внутриполушарной когерентности между центральным $\left(\mathrm{C}_{3}\right)$ и затылочным $\left(\mathrm{O}_{1}\right)$ отведениями левого (S) полушария и самые низкие показатели - между височным $\left(\mathrm{T}_{4}\right)$ и центральным $\left(\mathrm{C}_{4}\right)$ отведениями правого (D) полушария, что отражало гиперактивацию структур лимбической системы (медиальной области среднего мозга) и функциональную недостаточность систем среднего мозга (RF среднего мозга, медиальные ядра перегородки) и медиобазальных структур коры.

Для 1-го кластера типичными были: достаточно низкий уровень межполушарной когерентности дельта- и альфа-волнового диапазонов; самый низкий уровень суммарной межфронтальной когерентности, что характеризовало функциональную недостаточность неспецифических регулирующих структур 
на уровне оральных отделов ствола головного мозга и самый низкий уровень суммарной внутриполушарной когерентности между лобным и височным отведениями левого полушария, отражающий значительную недостаточность коркового уровня формирования биоэлектрической активности головного мозга и выраженной когнитивной недостаточности.

Параметры ЭЭГ 4-го кластера отличаются от других кластеров достаточно высоким уровнем межполушарной когерентности дельта-волнового диапазона; высоким уровнем суммарной межфронтальной когерентности, что характеризовало гиперфункцию оральных отделов ствола головного мозга и самой высокой суммарной внутриполушарной когерентностью между лобным и височным отведениями левого полушария, которая свидетельствовала о достаточно выраженной когнитивной сохранности данной категории пациентов с тяжелой ЧMT.

Затем было проведено исследование нейропротекторного фармакологического воздействия на ЦНС с помощью нейросетевых моделей. При статистическом анализе 4-х групп типов реакций ЦНС у пациентов с ЧМТ и МИ, чьи исходные ЭЭГ-параметры относились к 4-м кластерам, было выявлено, что в ответ на введение препаратов L-лизина эсцината, Мексидола и Актовегина их различия не являлись статистически достоверными. То есть, характер фармакологического ответа на данные препараты не был связан с исходными электроэнцефалографическими параметрами и, соответственно, с уровнем функционирования нейронов. Особенности фармакоответа на данные препараты зависели от иных условий - уровня функционирования гематоэнцефалического барьера, нейроглии, состояния мозгового кровотока, выраженности отека мозга [56]. Таким образом, установлено, что особенности фармакологического ответа на препараты Актовегин, Мексидол и L-лизина эсцинат не зависят от исходного, до введения препаратов, уровня биоэлектрической активности головного мозга в условиях мозгового инсульта или тяжелой ЧМТ. Данные препараты действуют преимущественно на белое вещество и обеспечивают необходимый уровень функционирования гематоэнцефалического барьера, нейроглии.

Особенности фармакологического ответа на препараты Цитиколин, Тиоцетам, Цереброкурин (Церебролизин), Нейромидин, цитофлавин, фенотропил зависели от исходного (до введения препаратов) уровня биоэлектрической активности головного мозга в условиях мозгового инсульта или тяжелой ЧМТ, так как они действовали преимущественно на серое вещество мозга - нейроцит.

Нами установлена тропность отдельных нейропротекторов к определенным кластерам. Реакции на фармакологическое воздействие Цитиколина при исходном состоянии биоэлектрической активности головного мозга, характерном для 4-го и 3-го кластеров, у пациентов с МИ и для 1-го и 3-го кластеров у больных с ТЧМТ, резко отличались от всех остальных групп, так как среди реакций ЦНС преобладали «благоприятные», со снижением уровня дезорганизации ЭЭГ-паттернов. Преобладающие благоприятные реакции ЦНС на фармакологическое воздействие Тиоцетама были зафиксированы при исходном состоянии биоэлектрической активности головного мозга, характерном для 1-го 
кластера, у пациентов с мозговым инсультом и для 1-го и 4-го кластеров у больных с ТЧМТ. Реакции на фармакологическое воздействие нейропептидов Цереброкурина или Церебролизина - при исходном состоянии биоэлектрической активности головного мозга, характерном для 3-го кластера, у пациентов с мозговым инсультом и для 3-го и 4-го кластеров у больных с ТЧМТ, отличались от всех остальных групп - среди реакций ЦНС преобладали благоприятные изменения ЭЭГ-паттернов со снижением уровня их дезорганизации. Для препарата Нейромидин, напротив, максимальная эффективность применения была выявлена у пациентов, чьи исходные ЭЭГ-параметры укладываются в характеристики 1-го и, в меньшей степени, 2-го кластеров (модель ТЧМТ) и 2-го и 1-го кластеров (модель мозгового инсульта).

Исследование нейропротекторного фармакологического воздействия на ЦНС с помощью нейросетевых моделей позволило нам рекомендовать комплексы терапии для первичной и вторичной нейропротекции у пациентов с мозговым инсультом (табл. 5.14 и табл. 5.15) ЧМТ, чьи исходные ЭЭГ-параметры относились к 4-м кластерам обеих моделей.

Таблица 5.14

\section{Рекомендованные комплексы терапии для первичной и вторичной нейропротекции у пациентов с мозговым инсультом, чьи исходные ЭЭГ-параметры относились к 4-м кластерам}

\begin{tabular}{|c|c|c|c|c|}
\hline Кластеры & Cl 1 & CI 2 & Cl 3 & Cl 4 \\
\hline $\begin{array}{l}\text { Нейрофизио- } \\
\text { логические осо- } \\
\text { бенности }\end{array}$ & $\begin{array}{l}\text { «Дезоргани- } \\
\text { зованный» }\end{array}$ & $\begin{array}{l}\text { "Благоприят-ный» } \\
\text { с минимальным } \\
\text { уровнем дезоргани- } \\
\text { зации паттерна }\end{array}$ & $\begin{array}{l}\text { Среднетя- } \\
\text { желый }\end{array}$ & $\begin{array}{l}\text { «Инертный», самый } \\
\text { неблагоприят-ный }\end{array}$ \\
\hline $\begin{array}{l}\text { Первичная ней- } \\
\text { ропротекция }\end{array}$ & \multicolumn{4}{|c|}{ Актовегин, L-лизина эсцинат, Мексидол } \\
\hline $\begin{array}{l}\text { Вторичная ней- } \\
\text { ропротекция }\end{array}$ & Тиоцетам & $\begin{array}{l}\text { Цереброкурин } \\
\text { (Церебролизин) в СД } \\
\text { более } 2 \text { мг (10 мл) }\end{array}$ & $\begin{array}{l}\text { Цераксон } \\
\text { (Цитиколин) }\end{array}$ & $\begin{array}{l}\text { Цераксон } \\
\text { (Цитиколин) }\end{array}$ \\
\hline $\begin{array}{l}\text { Вторичная ней- } \\
\text { ропротекция }\end{array}$ & Нейромидин & Нейромидин & $\begin{array}{l}\text { Цереброку- } \\
\text { рин } \\
\text { (цереброли- } \\
\text { зин) }\end{array}$ & $\begin{array}{l}\text { Цереброкурин } \\
\text { (Церебролизин) в СД } \\
\text { более } 2 \text { мг (10 мл) }\end{array}$ \\
\hline $\begin{array}{l}\text { Вторичная ней- } \\
\text { ропротекция }\end{array}$ & & & & $\begin{array}{l}\text { Тиоцетам в мини- } \\
\text { мальной дозировке } \\
5 \text { мл с индиви- } \\
\text { дуальным пошаго- } \\
\text { вым подбором Сд } \\
\text { («шаг» - } 5 \text { мл) }\end{array}$ \\
\hline
\end{tabular}

Примечание: СД - суточная доза. 
Таблица 5.15

Рекомендованные комплексы терапии для первичной и вторичной нейропротекции у пациентов с тяжелой ЧМТ, чьи исходные ЭЭГ-параметры относились к 4-м кластерам

\begin{tabular}{|c|c|c|c|c|}
\hline Кластеры & Cl1 & CI 2 & CI 3 & CI 4 \\
\hline $\begin{array}{l}\text { Нейрофизиологи- } \\
\text { ческие особен- } \\
\text { ности }\end{array}$ & $\begin{array}{l}\text { Средне- } \\
\text { тяжелый }\end{array}$ & $\begin{array}{l}\text { Благоприятный» } \\
\text { с минимальным } \\
\text { уровнем дезоргани- } \\
\text { зации паттерна }\end{array}$ & $\begin{array}{l}\text { Инертный», } \\
\text { самый неблаго- } \\
\text { приятный }\end{array}$ & $\begin{array}{l}\text { Дезоргани- } \\
\text { зованный }\end{array}$ \\
\hline $\begin{array}{l}\text { Первичная нейро- } \\
\text { протекция }\end{array}$ & \multicolumn{4}{|c|}{ Актовегин, L-лизина эсцинат, Мексидол } \\
\hline $\begin{array}{l}\text { Вторичная нейро- } \\
\text { протекция }\end{array}$ & $\begin{array}{l}\text { Цераксон } \\
\text { (Цитиколин) }\end{array}$ & $\begin{array}{l}\text { Цереброкурин } \\
\text { (цереброли-зин) в СД } \\
\text { более } 2 \text { мг (10 мл) }\end{array}$ & $\begin{array}{l}\text { Цераксон } \\
\text { (Цитиколин) }\end{array}$ & $\begin{array}{l}\text { Цереброкурин } \\
\text { (церебролизин) }\end{array}$ \\
\hline $\begin{array}{l}\text { Вторичная нейро- } \\
\text { протекция }\end{array}$ & Тиоцетам & $\begin{array}{l}\text { Тиоцетам в мини- } \\
\text { мальной дозировке } \\
5 \text { сл с индиви- } \\
\text { дуальным пошаго- } \\
\text { вым подбором СД } \\
\text { («шаг» - } 5 \text { мл) }\end{array}$ & $\begin{array}{l}\text { Цереброкурин } \\
\text { (цереброли- } \\
\text { зин) }\end{array}$ & Тиоцетам \\
\hline $\begin{array}{l}\text { Вторичная нейро- } \\
\text { протекция }\end{array}$ & Нейромидин & Нейромидин & & \\
\hline
\end{tabular}

Примечание: СД - суточная доза.

На основе данных нейросетевого моделирования были разработаны комплексы терапии для первичной и вторичной нейропротекции у пациентов с мозговым инсультом и тяжелой ЧМТ, чьи исходные ЭЭГ-параметры относились к 4-м кластерам обеих моделей (рис. 36).

Таким образом, нами разработана, проверена экспериментально и внедрена в клиническую практику методика двухэтапной нейропротекци у пациентов с мозговым инсультом и тяжелой ЧМТ. Первичная нейропротекция должна быть направлена, в первую очередь, на восстановление реологических свойств крови, микроциркуляции, эндотелиальной дисфункции, улучшение текучести крови, снижение ее вязкости, блокаду ЦОГ 2. После начала проведения указанного комплекса мероприятий осуществляется вторичная нейропротекция, влияющая преимущественно на нейроциты и клетки глиальной ткани.

Вследствие такого подхода происходит уменьшение отека-набухания головного мозга, увеличение его перфузии, повышение доставки кислорода и глюкозы. На этом фоне принципиально важно улучшить утилизацию глюкозы ишемизированными клетками, прежде всего глиальными. На данном этапе лечения также чрезвычайно важна роль перекисного окисления липидов в па- 
тогенезе повреждений мозга. С одной стороны, нейроны поражает гипоксия, активирующая ПОЛ. А с другой - опасным может быть избыток кислорода, который вызывает активацию перекисей, разрушающих белки и липиды клеточных мембран. Баланс между этими процессами должен иметь принципиальное влияние на исход повреждений мозга. На фоне ишемического поражения мозга преимущественное воздействие указанного комплекса происходит на участки белого вещества, а не серого, оказывая влияние на функциональное состояние нейроглии и ГЭБ.

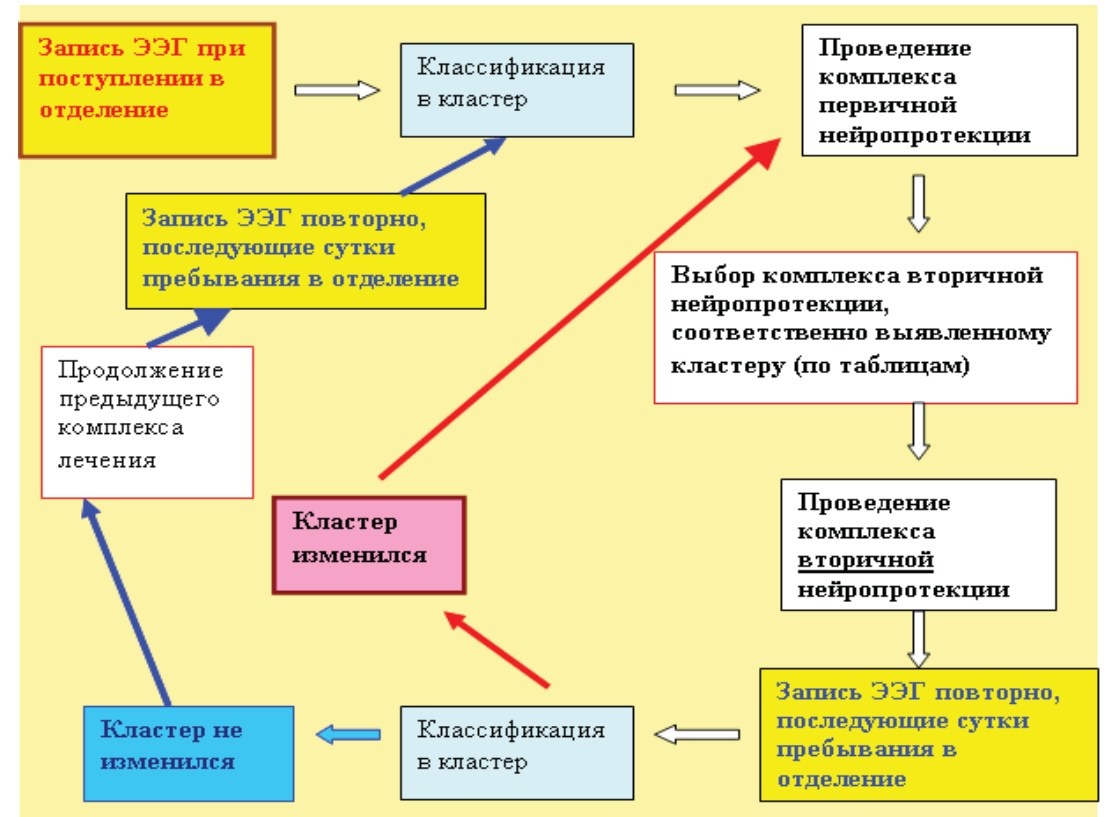

\section{Рис. 5.36. Алгоритм применения комплекса терапии для двухэтапной нейропротекции у пациентов с мозговым инсультом и тяжелой ЧМТ}

При решении данной задачи важно определить клиническое значение лекарственных средств для восстановления трансмембранного ионного баланса, регуляции холин- и дофаминергической активности мозга, влияния на цикл янтарной кислоты, блокирования избыточного синтеза оксида азота, для обеспечения нейротрофического действия.

Таким образом, мы выявили в эксперименте на модели ЧМТ и МИ лабораторных животных и доказали эффективность воздействия на репаративные процессы мозговой ткани двухэтапной патогенетической нейропротекции. Далее мы изучили реактивность мозга в ответ на фотостимуляцию и введение нейротропных препаратов в норме и патологии, и разработали оптимальный лечебно-реанимационный комплекс, который позволяет автоматически классифицировать электроэнцефалограммы при ЧМТ и МИ, тестировать применяемые нейропротекторы и объективно оценивать их эффективность. 
Разработанная нами стратегия нейропротекции внедрена в клиническую практику лечебных учреждений Донецка и Макеевки. В табл. 5.16 представлена динамика летальности за последние 9 лет по основным нозологическим группам в нейрореанимационном центре ДОКТМО (по данным статистических отчетов).

Показано, что внедрение в клиническую практику разработанной стратегии нейропротекции привело к снижению летальности пациентов с тяжелой изолированной черепно-мозговой травмой на $14,3 \%$, с ишемическим инсультом на 21,9 \% , геморрагическим инсультом - на 18,6 \% (табл. 5.16).

При проведении анализа динамики изменения летальности использовался критерий выявление тренда для упорядоченных градаций.

Таблица 5.16

Динамика летальности с 2003 по 2011 годы по основным нозологическим группам в нейрореанимационном центре ДОКТМО

\begin{tabular}{|l|l|c|c|c|c|c|c|c|c|c|}
\hline № & $\begin{array}{c}\text { Нозологическая } \\
\text { единица }\end{array}$ & $\mathbf{2 0 0 3}$ & $\mathbf{2 0 0 4}$ & $\mathbf{2 0 0 5}$ & $\mathbf{2 0 0 6}$ & $\mathbf{2 0 0 7}$ & $\mathbf{2 0 0 8}$ & $\mathbf{2 0 0 9}$ & $\mathbf{2 0 1 0}$ & $\mathbf{2 0 1 1}$ \\
\hline 1. & ЧМт изолирован. & $31,2 \%$ & $31,4 \%$ & $31,3 \%$ & $30,3 \%$ & $28,1 \%$ & $27,9 \%$ & $18,7 \%$ & $17,4 \%$ & $16,9 \%$ \\
\hline 2. & ЧМт сочетанная & $22,8 \%$ & $12,5 \%$ & $20,6 \%$ & $21,7 \%$ & $13,5 \%$ & $16,2 \%$ & $15,0 \%$ & $19,2 \%$ & $8,8 \%$ \\
\hline 3. & ОнМк общая & $37,9 \%$ & $31,1 \%$ & $37,1 \%$ & $33,1 \%$ & $24,9 \%$ & $30,2 \%$ & $25,4 \%$ & $25,7 \%$ & $19,2 \%$ \\
\hline 4. & $\begin{array}{l}\text { ОНМК геморра- } \\
\text { гич. }\end{array}$ & $39,6 \%$ & $38,6 \%$ & $40,3 \%$ & $36,8 \%$ & $29 \%$ & $30,4 \%$ & $28,1 \%$ & $27,1 \%$ & $21 \%$ \\
\hline 5. & $\begin{array}{l}\text { ОнМк ишемиче- } \\
\text { ские }\end{array}$ & $36 \%$ & $23,1 \%$ & $32,5 \%$ & $27,7 \%$ & $17,1 \%$ & $29,6 \%$ & $18 \%$ & $20,9 \%$ & $14,1 \%$ \\
\hline
\end{tabular}

Для нозологической единицы «ЧМТ изолированная» получено значение критерия $\chi^{2}=39,1$, выявлено наличие тренда на уровне значимости $\mathrm{p}<0,001$. Это указывает на снижение $(\mathrm{p}<0,001)$ уровня летальности для больных с диагнозом «ЧМТ изолированная» в нейрореанимационном центре ДОКТМО с внедрением в клиническую практику разработанной стратегии нейропротекции (рис. 5.37).

При анализе динамики уровня летальности для больных с диагнозом «ЧМТ сочетанная» значение критерия $\chi^{2}=1,6$, наличие тренда не выявлено, $\mathrm{p}=0,207$.

При анализе динамики уровня летальности для больных с ОНМК выявлено наличие тренда для больных с диагнозом «ОНМК общая» $\left(\chi^{2}=9,9, \mathrm{p}=0,002\right)$, для больных с ОНМК по геморрагическому типу $\left(\chi^{2}=7,4, \mathrm{p}=0,006\right)$, проходивших лечение в нейрореанимационном центре ДОКТМО. При анализе динамики уровня летальности для больных с ОНМК по ишемическому типу значение критерия $\chi^{2}=3,7, \mathrm{p}=0,05$. Это указывает на снижение $(\mathrm{p}<0,05)$ уровня летальности для этих категорий исследуемых больных (рис. 5.38). 


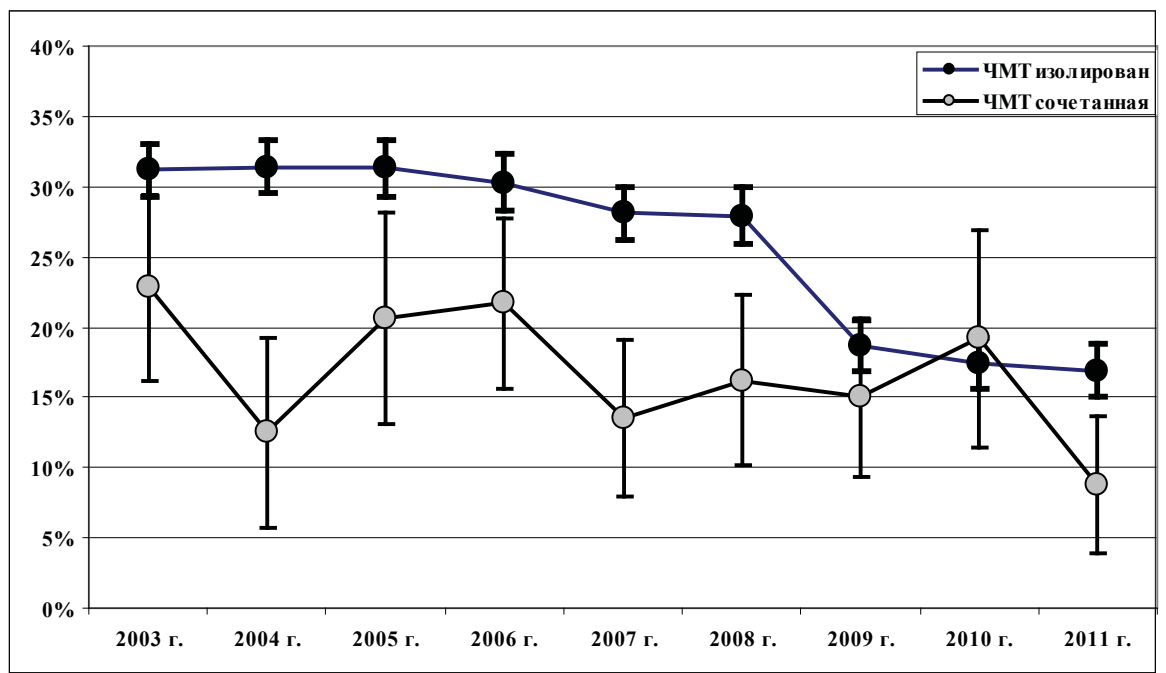

Рuc. 5.37. Динамика летальности с 2003 по 2011 годы по основным нозологическим группам с ЧМТ в нейрореанимационном центре ДОКТМО (указан \% летальных исходов \pm стандартная ошибка)

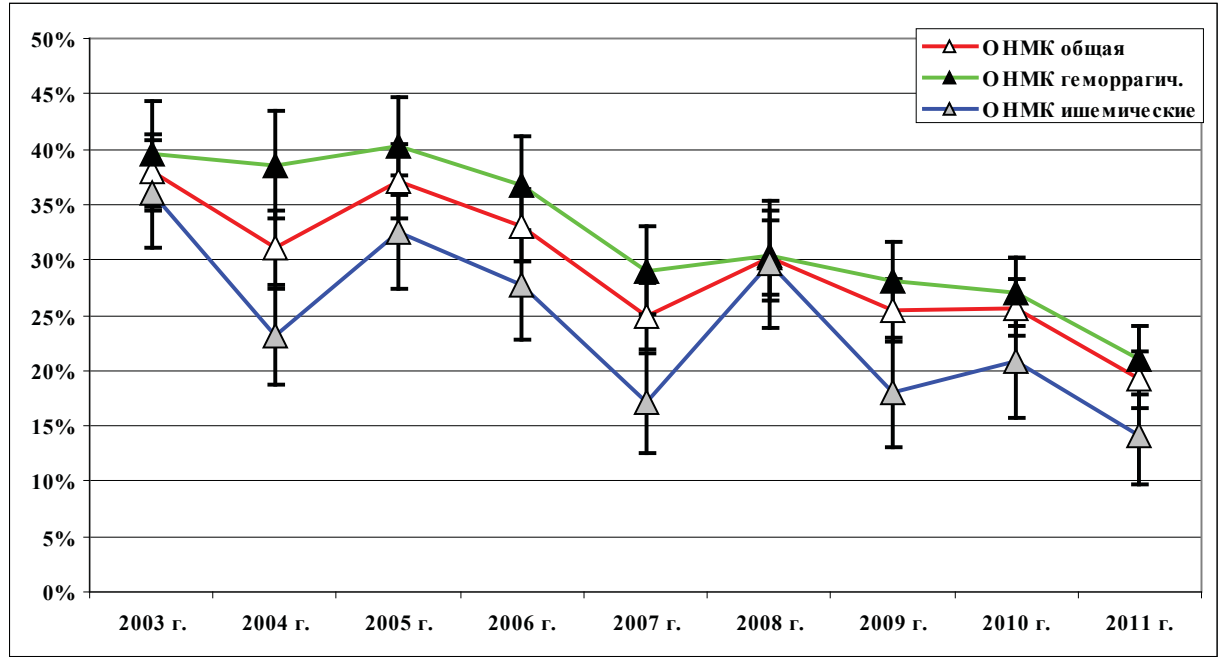

Рис. 5.38. Динамика летальности с 2003 по 2011 годы по основным нозологическим группам с ОНМК в нейрореанимационном центре ДОКТМО (указан \% летальных исходов \pm стандартная ошибка) 
Таким образом показано, что внедрение в клиническую практику разработанной стратегии нейропротекции привело к снижению летальности пациентов с черепно-мозговой травмой, геморрагическим и ишемическим инсультом $(\mathrm{p}<0,05)$ в нейрореанимационном центре ДОКТМО с внедрением в клиническую практику разработанной стратегии нейропротекции.

Разработан и обоснован принцип патогенетической двухэтапной нейропротекции пораженного мозга, при которой первичная неспецифическая группа препаратов обеспечивает функционирование гемато-энцефалического барьера и нейроглии, а вторичное воздействие на нейроны проводится специфическим нейропротектором, определенным для конкретного пациента исходным состоянием биоэлектрической активности мозга. 


\section{СПИСОК ЛИТЕРАТУРЫ}

1. Дубенко О. Є. Причини і наслідки лакунарних інсультів головного мозку / О. Є. Дубенко, Г. Є. Костровська, С. Л. Костровський // Укр. неврологіч. журн. - 2007. - № 1. - С. 7-10.

2. Клініко-нейрофізіологічна оцінка когнітивних функцій у хворих за хронічної ішемії головного мозку в період відновлення після хірургічного втручання / Л. Л. Чеботарьова, І. В. Степаненко, М. В. Глоба [та ін.] // Укр. нейрохірургіч. журн. - 2014. - № 1. - С. 10-15.

3. Мурашко Н. К. Хронічне порушення мозкового кровообігу: акцент на діагностику та лікування / Н. К. Мурашко, Р. В. Сулік // Ліки України. 2011. — № 9 (155). - С. 58-63

4. Гусев Е. И. Ишемия головного мозга / Е. И. Гусев, В. И. Скворцова. - М. : Медицина, 2011. - 321 с.

5. Стаднік В. М. Нейровізуалізація в діагностиці церебрального інсульту / В. М. Стаднік, В. В. Куценко // Здоров’я України. - 2010. — № 1. - С. 78.

6. Румянцева С. А. Патофизиологическая основа комплексной нейропротекции при ишемии мозга / С. А. Румянцева, В. В. Афанасьев, Е. В. Силина // Журн. неврологии и психиатрии. - 2009. - № 3. - С. 64-68.

7. Лукьянова Л. Д. Дизрегуляция аэробного энергетического обмена - типовой патологический процесс / Л. Д. Лукьянова // Дизрегуляционная патология. - М. : Медицина, 2002. - С. 188-215.

8. Huss J. D. Mitochondrial energy metabolism in heart failure: a question of balance / J. D. Huss, D. P. Kelly // J. Clin. Invest. — 2005. - Vol. 115. - P. 547-555.

9. Swerdlow R. H. Mitochondrial Medicine and the Neurodegenerative Mitochondriopathies / R. H. Swerdlow // Pharmaceuticals. - 2009. N 2. - P. 150.

10. Лукьянова Л. Д. Регуляторная роль митохондриальной дисфункции при гипоксии и ее взаимодействие с транскрипционной активностью / Лукьянова Л. Д., Дудченко А. М. // Вестн. РАМН. - 2007. — № 2. - С. 3-13.

11. Roles of Oxidative Stress, Apoptosis, PGC-la and Mitochondrial Biogenesis in Cerebral Ischemia / S. D. Chen, D. I. Yang, T. K. Lin, F. Z. Shaw // Int. J. Mol. Sci. - 2011. - Vol. 12, N 10. - P. 7199-7215.

12. Guo M. F. Mechanisms related to neuron injury and death in cerebral hypoxic ischaemia / M. F. Guo, J. Z. Yu, C. G. Ma // Folia Neuropathol. — 2011. Vol. 49, N 2. - P. 78-87.

13. Early predictive biomarkers for lesion after transient cerebral ischemia / C. Berthet, H. Lei, R. Gruetter, L. Hirt // Stroke. - 2011. - Vol. 42, N 3. P. 799-805.

14. Mitochondrial preconditioning: a potential neuroprotective strategy / S. C. Correia, C. Carvalho, S. Cardoso [et al.] // Front Aging Neurosci. — 2010. Vol. 26, N 2. - P. 138. 
15. Губский Ю. И. Токсическая гибель клетки: свободно-радикальное повреждение ДНК и апоптоз / Губский Ю. И. // Лікування та діагностика. 2001. - № 4. - C. 8-11.

16. Cao W. Oxygen free radical involvement in ischemia and reperfusion injury to brain / Cao W., Carney J. M. // Neurosci. Lett. — 2000. - Vol. 88, N 4. P. 233-238.

17. Дубініна О. Ю. Окиснювальний стрес і окиснювальна модифікація білків / Дубініна О. Ю. // Мед. хімія. - 2001. - Т. 3, № 2. C. $5-11$.

18. Acidosis has opposite effects on neuronal survival during hypoxia and reoxygenation / R. Almaas, M. Pytte, J. K. Lindstad [et al.]// J. Neurochem. 2003. - Vol. 84. - P. 1018-1027.

19. Dhar-Mascareno M. Hypoxia — reoxygenation — induced mitochondrial damage and apoptosis in humsn endothelial cells / Dhar-Mascareno M., Cacramo J. M. // Free Radic. Biol. Med. - 2005. - Vol. 38, N 10. - P. 1548-1554.

20. Buttini M. Induction of interleukin-1 beta $\mathrm{m}$ RNA after cerebral ischemia in the rat / Buttini M., Sauter A. // Mol. Brain Res. - 2003. - Vol. 23, N 7. P. 126-134.

21. Cutting Edge: different toll-like receptor agonists instruct dendritic cells to induce distinct Th responses via differential modulation of extracellular signal-regulated kinase-mitogen-activated protein kinase and c-Fos / Agrawal S., Agrawal A., Doughty B. [et al.] // J. Immunol. — 2003. — Vol. 171. — P. 4984-4989.

22. David J. C. Perinatal expression of heat shock proteins HSC 70 and HSP 70 in neural and neural tissues of the piglet / J. C. David, R. M. Tanguay, J. F. Crongnet // Brain Res. Dev. Brain Res. - 2001. Vol. 128. - P. 91-99.

23. Beere H. M. The stress of dying: the role of heat shock proteins in the regulation of apoptosis / H. M. Beere // J. Cell Science. — 2004. — Vol. 117. — P. 26412651.

24. Антигипоксическая активность бис(N-ацетил-L-цистеинато)цинк(II) сульфат октагидрата в динамике острой нормобарической гипоксии / А. В. Евсеев, М. А. Евсеева, Э. А. Парфенов, В. А. Правдивцев // Психофармакология, биология наркология. - 2006 . T. 6, № 3. - С. 1270-1274.

25. Giordano F. J. Oxygen, oxidative stress, hypoxia, and heart failure / F. G. Giordano // J. Clin. Invest. - 2005. - Vol. 115. — P. 500-508.

26. Фармакологическая коррекция повреждений нейронов сенсомоторной зоны фронтальной коры в условиях экспериментального нарушения мозгового кровообращения / Беленичев И. Ф., Горбачева С. В., Дунаев В. В., Бухтиярова Н. В. // Эксперим. и клинич. фармакология. - 2007. - Т. 70, № 6. - С. 13-16.

27. Сравнительная оценка нейропротективного действия глицина, солей магния, тиотриазолина в некоторых их комбинациях в условиях моделирова- 
ния ишемического инсульта / Горбачева С. В., Беленичев И. Ф., Кучеренко Л. И. [и др.] / / Вісник Вінницького нац. мед. ун-ту. — 2007. — № 11. — С. 757-758.

28. Влияние тиотриазолина, глицина, магния и их комбинаций на ответ генома и показатели антиоксидантной активности в коре головного мозга крыс с церебральной ишемией / Губский Ю. И., Беленичев И. Ф., Левицкий Е. Л. [и др.] // Совр. пробл. токсикологии. - 2007. - № 3. - С. 61-65.

29. Рыбников В. Ю. Пептидная регуляция функций мозга / В. Ю. Рыбников, Н. Г. Закуцкий. - СПб. : Стела, 2000. - 24 с.

30. Скромец А. А. Новые возможности нейропротекции в лечении ишемического инсульта / А. А. Скромец, Л. В. Стаховская, А. А. Белкин // Журн. неврологии и психиатрии. - 2008. - Т. 22. - С. 32-38.

31. Conant R. Therapeutic applications of citicoline for stroke and cognitive dysfunction in the elderly: a review of the literature / Conant R., Schauss A. G. // Altern. Med. Rev. - 2004. - Vol. 9 (1). P. 17-31.

32. Neurotrophic and neuroprotective effects of estrogen: Basic mechanisms and clinical implications / D. W. Brann, K. Dhandapani, C. Wakade [et al.] // Steroids. - 2007. - Vol. 72. - P. 381-405.

33. Acute treatment with tamoxifen reduces ischemic damage following middle cerebral artery occlusion / H. Kimelberg, P. Feurstel, Y. Jin [et al.] // Neuroreport. - 2000. - Vol. 11. - P. 2675-2679.

34. Karaseva T. L. Study of the influence of 1,4-benzodiazepine anxiolytics on memory processes in rats / T. L. Karaseva, L. V. Popova, V. I. Pavlovsky // Abstr. Int. Conf. chemistry of nitrogen containing heterocycles. - Kharkiv, 2003. - P. 252.

35. Елисеев А. А. Регуляция биосинтеза тетрапироллов и изопреноидов интегральными мембранными рецепторами семейства МБР/ TspO / А. А. Елисеев // Успехи биологич. химии. - 2003. — Т. 43. C. 329-364.

36. Фармакологічні властивості 1,3,4-бензтриазепинів з різними замісниками / Л. В. Попова, С. В. Власюк, В. І. Павловський [та ін.] / Ф Фармац. журн. 2002. - № 2. - С. 82-92.

37. Егоров А. А. Эндотелиотропные свойства L-лизина эсцината при моделировании ОНМК / Егоров А. А. // Тез. Докл. II Междунар. молодежного мед. конгресса, С.-Петербург, 5-7 дек. 2007 г. - СПб., 2007. - С. 180.

38. Чекман I. С. Метаболічні препарати в сучасній експериментальній та клінічній фармакології / Чекман I. С. // Актуальні питання фармац. та мед. науки та практики : зб. наук. ст. - Запоріжжя, 2002. - Вип. 8. - С. 11-17.

39. Основные механизмы формирования защиты головного мозга при адаптации к гипоксии / А. А. Солкин, Н. Н. Белявский, В. И. Кузнецов, А. А. Николаев // Вестн. ВГМУ. - 2012. - Т. 1, № 1. C. $6-14$. 
40. Yoshida S. Influence of transient ischemia on lipid-soluble antioxidants, free fatty acids and energy metabolites in rat brain / Yoshida S., Abe K. // Brain Res. - 2002. - Vol. 245, N 5. - P. 307-316.

41. Колесник Ю. М. Сигнальная роль активных форм кислорода в регуляции физиологических функций / Колесник Ю. М., Беленичев И. Ф., Ганчева О. В. // Патология. - 2005. - Т. 2, № 1. C. $4-10$.

42. Основні шляхи утворення активних форм кисню в нормі та при ішемічних патологіях / Губський Ю. І., Бєленічев І. Ф., Коваленко С. І. [та ін.] // Совр. пробл. токсикологии. - 2004. - № 2. C. 8-16.

43. Witko-Sarsat V. Advamed oxidation protein products as a novel markers of oxidative stress in ischemia / Witko-Sarsat V., Friedlander M. // J. Neurochem. - 2000. - Vol. 22, N 6. - P. 342-350.

44. Синицкая Н. С. Роль пептидов в свободнорадикальном окислении и старении организма / Синицкая Н. С., Хавинсон В. Х. // Успехи совр. биологии. - 2002. - Т. 122, № 6. - С. 557-568.

45. Nilsen J. Mechanism of estrogen-mediated neuroprotection: regulation of mitochondrial calcium and Bcl-2 expression / Nilsen J., Brinton R. D. // Proc. of the Nat. Acad. of Sciences of the United States of America. - 2003. - N 100. - P. 2842-2847.

46. Cisnetti F. A new pantadentate ligand forms both a di- and mononuclear Mncomplex: electrochemical, spectroscopic and superoxiddismutase activity stadies / F. Cisnetti, A. Lefevre, R. Gillot // Eur. J. of Inorganic Chem. 2007. - N 28. - P. 4472-4480.

47. Активность и получение частично очищенного препарата митохондриальной супероксиддисмутазы печени при экспериментальной термической травме / Н. В. Диденко, А. Г. Соловьева // Фундаментальные исследования. -2013 . — № 7. - С. 305-309.

48. Functional Status of Mitochondrial Pore in the Brain of Laboratory Rats Subjected to Prolonged Emotional Stress / G. Burjanadze, K. Menabde, M. Gavashelidze [et al.] // J. of Stress Physiol. \& Biochem. - 2011. — Vol. 7, N 4. - P. 88-96.

49. Dimatteo M. A. Superoxide, nitric oxide, peroxynitrite and cytokine combinations all cause functional impairment and morpfological changes in rat islets of Langerhans and insulin secreting cell lines, but dictate cell death by different mechanisms / Dimatteo M. A., Loweth A. C., Thomas S. // Apoptosis. - 1997. - N 2. - P. 164-169.

50. Cadenas E. Mitochondrial Free Radical Generation Oxidative Stress and Aging / Cadenas E., Davies K. J. A. // Free Radic. Biol. Med. - 2000. - Vol. 29, N 3-4. - P. 222-230.

51. Флеров М. А. Перекисное окисление липидов в стриатуме крыс при стрессе после введения кортизола / Флеров М. А., Герасимова И. А., Раицкая В. В. // Рос. физиол. журн. им. И. М. Сеченова. - 2002. - Т. 88, № 7. - С. 881-885. 
52. Калинина Е. В. Участие тио-, перокси- и глутаредоксинов в клеточных редокс-зависимых процессах / Калинина Е. В., Чернов Н. Н., Саприн А. Н. // Успехи биологич. химии. - 2008. - Т. 48. C. $319-358$.

53. Лук'янчук В. Д. Окисний гомеостаз мозку при ішемії мозку і досвід експериментальної фармакотерапії / Лук'янчук В. Д., Савченкова Л. В., Бібік О. Ю. // Журн. АМН України. — 2001. — Т. 7, № 4. - С. 647-659.

54. Picroside II could reduce the concentration of $\mathrm{H} 2 \mathrm{O} 2$ and enhance the activity of CAT in cerebral ischemic injury in rats / $\mathrm{Li} \mathrm{Yan}, \mathrm{Li} \mathrm{Sun}$, Ling Wang [et al.] // J. of Med. Res. and Pract. - 2013. - Vol. 2, N 8. - P. 223-228.

55. Rivier C. H. In the rat, endogenous nitric oxide modulates the response of the hypothalamic-pituitart-adrenal axis to interleucin-1 beta, vasopressin, and oxytocin / Rivier C., Shen G. H. // J. Neurosci. - 1994. - N 14. - P. 1985-1993.

56. Immobilization-induced stress activates neuronal nitric oxide synthase (nNOS) mRNA and protein in hypothalamic-pituitary-adrenal axis in rats / Kishimoto J., Tsuchiya T., Emson P. C., Nakayama Y. // Brain Res. 1996. - N 720. - P. 159-171.

57. Leza J. C. The effect of stress on homeostasis in JCR-LA-cprats: the role of nitric oxide / Leza J. C., Salas E., Sawicki G. // Pharmacol. Exp. Ther. 1998. - N 286. - P. 1397-1403.

58. Rivier C. Role of nitric oxide and carbon monooxide in modulating the ACTH response to immune and nonimmune signals / Rivier C. // Neuroimmunomodulation. - 1998. - N 5. - P. 203-213.

59. Izumi Harukuni. Mechanisms of Brain Injury after Global Cerebral Ischemia / Harukuni Izumi, Bhardwaj Anish // Neurol. Clin. - 2006. - Vol. 24. - P. $1-21$.

60. Foster Nitric oxide-mediated modulation of the murine locomotor network / D. Foster Joshua, Dunford Catherine, T. Keith Sillar, B. Miles Gareth // J. Neurophysiol. - 2014. - Vol. 111. - P. 659-674.

61. Kehrer J. P. Cause-effect of oxidative stress and apoptosis / Kehrer J. P. // Teratology. - 2000. - Vol. 62. - P. 235-246.

62. Richter C. Ca release from mitochondria induced by prooxidants / Richter C., Free B. // Free Radic. Biol. Med. - 1988. - Vol. 4. P. 365-375.

63. Nitric oxide is involved in the modulation of serotonin release in rat locus coeruleus in vivo / Sinner C., Kaehler S. T., Philippu A., Singewald N. // N. Pharmacol. - 2000. - Vol. 61, N 4. - P. 276.

64. Досенко В. Є. Патофізіологічні аспекти генетичного поліморфізму ендотеліальної NO-синтази / Досенко В. Є., Загорій В. Ю., Мойбенко О. О. // Фізіол. журн. - 2002. — Т. 48, № 6. - С. 86-101.

65. Modulation of endogenous antioxidant enzymes by nitric oxide in rat C- 6 glial cells / Dobashi K., Pahan K., Chahal A., Singh I. // J. Neurochem. - 1997. N 68. - P. 1806-1903. 
66. Asmis R. Oxidised LDL promotes peroxide-mediated mitochondrial dysfunction and cell death in human macrofages: a caspase-3independent pathway / R. Asmis, J. G. Begley // Circ. Res. - 2003. Vol. 92. - P. 20-29.

67. Акатов В. С. Участие митохондрий в инициации кальциноза в трансплантантах клапанов сердца и сосудов / В. С. Акатов, Н. И. Рындина, Р. М. Муратов // Докл. АН. - 2006. - Т. 406, № 6. - С. 832-834.

68. Crow M. T. Hypoxia, BNip3 Proteins, and the Mitochondrial Death Pathway in Cardiomyocytes / M. T. Crow // Circ. Res. - 2002. Vol. 91. - P. 183-185.

69. Mayer B. Mitochondrial regulation of apoptosis / B. Mayer, R. Oberbauer // News Physiol. Sci. - 2003. - Vol. 18. - P. 89-94.

70. Guimaraes C. A. Programmed cell death:apoptosis and alternative deathstyles / C. A. Guimaraes, R. Linden // Eur. J. Biochem. - 2004. — Vol. 217. P. 1638-1650.

71. Тодоров И. Н. Митохондрии: окислительный стресс и мутации митохондриальной ДНК в развитии патологий, процессе старения и апоптозе / И. Н. Тодоров // Рос. хим. журн. - 2007. - T. LI, № 1. - C. 93-106.

72. Role of the mitochondrial permeability transition in myocardial disease / J. N. Weiss, P. Korge, H. M. Honda, P. Ping // Circ. Res. - 2003. - Vol. 93. P. 292-301.

73. $\mathrm{Xu}$ C. Endoplasmic reticulum stress: cell life and death decisions / C. Xu, B. Bailly Maitre, J. C. Reed // J. Clin. Invest. - 2005. Vol. 115. - P. 2656-2664.

74. Mitochondrio-nuclear translocation of AIF in apoptosis and necrosis / E. Daugas, S. A. Susin, N. Zamzami [et al.] // FASEB J. — 2000. — Vol. 14. P. 729-739.

75. Ishemia, rather than reperfusion, inhibits respiration through cytochrome oxidase in the isolated, perfused rabbit heart: role of cardiolipin / E. J. Lesnefsky, Q. Chen, T. J. Slabe [et al.]// Am. J. Physiol. Heart Circ. Physiol. 2004. - Vol. 287. - P. H258-H267.

76. Протеомный анализ митохондрий сердца Bos taurus. Идентификация «растворимых белков» митохондрий / Е. В. Дайниченко, А. Н. Болдырев, К. В. Барылюк, Н. Б. Поляков // Биоорганич. химия. - 2009. - Т. 35, № 34. - С. 457-470.

77. Пескин А. В. Взаимодействие активного кислорода с ДНК : (обзор) / Пескин А. В. // Биохимия. - 1997. - Т. 62, вып. 12. - С. 1571-1578.

78. Губський Ю.І. Перекисно-антиоксидантний механізм регуляції активності хроматину / Губський Ю. І., Левицький Е. Л. // Журн. АМН України. 1997. - Т. 3, № 2. - С. 275-281.

79. Дубинина Е. Е. Окислительная модификация белков: окисление триптофана и образование битирозина в очищенных белках с использованием системы Фентона / Дубинина Е. Е., Гавровская С. В., Кузьмич Е. В. // Биохимия. -2002 . - Т. 67 , № 3. - С. 413-421. 
80. Vemuganti R. Inhibition of intercellular adhesion molecule-1 protein expression by antisense oligonucleotides is neuroprotective after transient middle cerebral artery occlusion in rat / Vemuganti R., Dempsey R. I, Bowen K. K. // Stroke. - 2004. - Vol. 35, N 1. - P. 179-184.

81. Мишуніна Т. М. Вплив антиоксидантів на міжнуклеосомну фрагментацію ДНК у тканині щитоподібної залози хворих із різною тиреоїдною патологією / Т. М. Мишуніна, О. В. Калініченко, Л. І. Пількевич // Укр. біохім. журн. - 2007. - Т. 79, № 5. C. $186-195$.

82. Ляхович В. В. Активная защита при окислительном стрессе. Антиоксидант-респонсивный элемент / В. В. Ляхович, В. А. Вавилин, Н. К. Зенков // Биохимия. - 2006. - Т. 71, вып. 9. C. $1183-1197$.

83. Дисфункция митохондрий при нейродегенеративных заболеваниях / Н. П. Судаков В. А., Бывальцев, С. Б. Никифоров, В. А. Сороковников // Журн. неврологии и психиатрии. - 2010. - № 9. C. 87-91.

84. Devi L. Mitochondrial import and accumulation of -synuclein impair complex I in human dopaminergic neuronal cultures and Parkinson disease brain / L Devi., V. Raghavendran, B. M. Prabhu // J. Biol. Chem. - 2008. - Vol. 283. - P. 9089-9100.

85. Sullivan P. G. Proteasome inhibition alters neural mitochondrial homeostasis and mitochondria turnover / P. G. Sullivan, N. B. Dragicevic, J. H. Deng // J. Biol. Chem. - 2004. — Vol. 279. — P. 20699-20707.

86. Yoon S. Okadaic acid induces JNK activation, bim overexpression and mitochondrial dysfunction in cultured rat cortical neurons / S. Yoon, J. Choi, J. Yoon // Neurosci Lett. - 2006. - Vol. 394. — P. 190-195.

87. Votyakova T.V. -dependent and independent production of reactive oxygen species by rat brain mitochondria / T. V. Votyakova, I. J. Reynolds // J. Neurochem. - 2001. - Vol. 79. P. 266-277.

88. Guilivi C. Mitochondria as generators and targets of nitric oxide / Guilivi C. // Novaris Found. Symp. - 2007. - Vol. 287. - P. 92-100.

89. Bolanos J. P. Persistent mitochondrial damage by nitric oxide and its derivatives: neuropathological implications / J. P. Bolanos, S. J. R. Heales // Front Neuroenergetics. - 2010. - Vol. 2. P. 1-9.

90. Окисленный глутатион вызывает активацию рецептора эпидермального фактора роста и МАР-киназ ERK 1, 2 / Василенко К. П., Бурова Е. Б., Антонов В. Г., Никольский Н. Н. // Цитология. - 2006. - Т. 48, № 6. C. $800-807$.

91. Filomeni G. Cell signaling and the glutathione redox system / Filomeni G., Rotilio G., Ciriolo M. R. // Biochem. Pharmacol. - 2002. N 64. - P. 1057-1064. 
92. Glutathione deficiency is associated with impaired survival in HIV disease / Leonore A. Herzenberg, Stephen C. De Rosa, J. G. Regson Dubs [et al.] // Proc. Natl. Acad. Sci. USA. - 1997. - Vol. 94. P. 1967-1972.

93. Панов А. В. Роль нарушений энергетического обмена в патогенезе болезни Хантингтона / А. В. Панов // Успехи функциональной нейрохимии. Сб. статей. - С.-Петербург. - 2003. - 271 с.

94. Роль редокс-зависимых сигнальных систем в регуляции апоптоза при окислительном стрессе / Н. В. Рязанцева, В. В. Новицкий, Н. Ю. Часовских, Е. В. Кайгородова // Цитология. - 2009. - Т. 51, № 4. - C. 329-334.

95. Pellegrino Mark W. Signaling the mitochondrial unfolded protein response / W. Pellegrino Mark, M. Nargund Amrita, M. Haynes Cole // ELSEVIER. 2013. - Vol. 1833, N 2. - P. 410-416.

96. Бессонова Л. О. Роль системы глутатиона в антиоксидантной защите при сочетанной патологии гипоксического генеза / Л. О. Бессонова, Н. В. Верлан, Л. С. Колесниченко // Сиб. мед. журн. - 2008. — № 6. - С. 19-21.

97. Mitochondrial Import Efficiency of ATFS-1 Regulates Mitochondrial UPR Activation / M. Nargund Amrita, W. Pellegrino Mark, J. Fiorese Christopher, M. Baker Brooke // Science. - 2012. — Vol. 337, N 6094. - P. 587-590.

98. Importing mitochondrial proteins: machineries and mechanisms / A. Chacinska, C. M. Koehler, D. Milenkovic [et al.] // Cell. — 2009. - Vol. 138, N 4. - P. 628-633.

99. Endoplasmic reticulum: ER stress regulates mitochondrial / R. Bravo, T. Gutierrez, F. Paredes, D. Gatica // Int. J. of Biochem. \&Cell Biol. 2012. - Vol. 44. - P. 16-20.

100. Coupling mitochondrial dysfunction to endoplasmic reticulum stress response: a molecular mechanism leading to hepatic insulin resistance / J. H. Lim, H. J. Lee, Ho Jung M., J. Song // Cell Signal. - 2009. — Vol. 21. — P. 169177.

101. Buttke T. M. Oxidative stress as a mediator of apoptosis / Buttke T. M., Sadstrom P. A. // Immunol. Today. - 1994. - Vol. 15. - P. 7-14.

102. Stoian I. Apoptosis and free radicals / Stoian I., Oros A., Moldoveanu E. // Biochem. and Mol. Med. - 1996. - Vol. 59. — P. 93-97.

103. Lin K. T. Reactive oxygen species participate in peroxynitriteinduced apoptosis in HL-60 cells / Lin K. T., Xue J. Y., Sun F. F. // Biochem. and Biophys. Res. Communs. - 1997. - Vol. 230. P. 115-121.

104. Skulachev V. P. Programmed death phenomena: from organelle to organism / V. P. Skulachev // Ann. N. Y. Acad. Sci. - 2002. - Vol. 959. - P. 214237.

105. Carmody R. J. Signalling apoptosis a radical approach / Carmody R. J., Cotter T. G. // Redox Rep. - 2001. - Vol. 6. - P. 77-90. 
106. Лю Б. Н. Кислородно-перекисная концепция апоптоза и возможные варианты его механизма / Лю Б. Н. // Успехи совр. биологии. - 2001. T. 121, № 5. - C. 488-501.

107. Kohno T. Relation of oxidative stress and glutatione to CD 95 (FAS/ APO-1)-mediated apoptosis of adult T cell leukemia cells / Kohno T., Yamada Y., Hata T. // J. Immunol. - 1996. - Vol. 156, N 12. P. 4722-4728.

108. Bjorkerud B. Contrary effects of lighting and storgly oxidized LDL with potent promotion of growth versus apoptosis on arterial smooth muscle cells / Bjorkerud B// Arterioscl. Thrombosis and Vasc. Biol. — 1996. — Vol. 16. P. 416-424.

109. Скулачев В. П. Феноптоз: запрограммированная смерть организма / Скулачев В. П. // Биохимия. - 1999. — Т. 64, № 12. — С. 1679-1688.

110. Regulation of apoptotic and inflammatory cell signaling in cerebral ischemia: the complex roles of heat shock protein $70 /$ R. G. Giffard, R. Q. Han, J. F. Emery [et al.] // Anesthesiology. - 2008. Vol. 109. - P. 339-348.

111. Heat shock protein 70 promotes cell survival by inhibiting lysosomal membrane permeabilization / J. Nylandsted, M. Gyrd-Hansen, Danielewicz A. [et al.] // J. Exp. Med. — 2004. - Vol. 200. - P. 425-435.

112. Valproic acid-mediated Hsp70 induction and anti-apoptotic neuroprotection in SH-SY5Y cells / T. Pan, X. Li, W. Xie [et al.] // FEBS Lett. - 2005. - Vol. 579. - P. 6716-6720.

113. Celastrols as inducers of the heat shock response and cytoprotection / S. D. Westerheide, J. D. Bosman, B. N. Mbadugha [et al.] // J. Biol. Chem. 2004. - Vol. 279. - P. 56053-56060.

114. Лукьянова Л. Д. Роль биоэнергетических нарушений в патогенезе гипоксии / Л. Д. Лукьянова // Патологич. физиология и эксперим. терапия. 2004. 一 № 2. - С. 2-11.

115. Лукьянова Л. Д. Митохондриальная дисфункция - типовой патологический процесс, молекулярные механизмы гипоксии / Лукьянова Л. Д. // Проблемы гипоксии: молекулярные, физиологические и клинические аспекты / под ред. Л. Д Лукьяновой, И. Б. Ушакова. - М.: Истоки, 2004. $-8-50 \mathrm{c}$.

116. Лукьянова Л. Д. Биоэнергетическая гипоксия: понятие, механизмы и способы коррекции / Лукьянова Л. Д. // Бюл. эксперим. биологии и медицины. - 1997. - Т. 124, № 9. - С. 244-254.

117. Mechanostasis in apoptosis and medicine / D. D. Chan, W. S. van Dyke, M. Bahls [et al.] // Mol. Biol. - 2011. - Vol. 106. - P. 517-524.

118. Shear Stress Inhibits Apoptosis of Ischemic Brain Microvascular Endothelial Cells / T. Shan, B. Yulong, L. Yang [et al.] // Int. J. Mol. Sci. - 2013. - Vol. 14. - P. 1412-1427.

119. Kroemer G. Mitochondrial membrane permeabilization in cell death / G. Kroemer, L. Galluzzi, C. Brenner // Physiol Rev. — 2007. - Vol. 87. — P. 99-163. 
120. Cyclophilin D controls mitochondrial pore-dependent $\mathrm{Ca}(2+)$ exchange, metabolic flexibility, and propensity for heart failure in mice / J. W. Elrod, R. Wong, S. Mishra [et al.] // J. Clin. Invest - 2010. — Vol. 120. — P. 36803687.

121. Mitochondrial Unselective Channels throughout the eukaryotic domain / S. Uribe-Carvajal, L. A. Luevano-Martinez, S. Guerrero-Castillo [et al.] // Mitochondrion. - 2011. - Vol. 11. - P. 382-390.

122. Inhibition of the mitochondrial permeability transition for cytoprotection: direct versus indirect mechanisms / C. Martel, L. Huynh, A. Garnier [et al.] // Biochem. Res. Int. - 2012. - Vol. 2012. - P. 1-13.

123. p53 opens the mitochondrial permeability transition pore to trigger necrosis / Vaseva A. V., Marchenko N. D., Ji K., Tsirka S. E. // Cell. - 2012. - Vol. 149. - P. 1536-1548.

124. Signal transduction to the permeability transition pore / A. Rasola, M. Sciacovelli, B. Pantic, P. Bernardi // FEBS Lett. - 2010. - Vol. 584. P. 1989-1996.

125. Mitoparan and target-selective chimeric analogues: membrane translocation and intracellular redistribution induces mitochondrial apoptosis / S. Jones, C. Martel, A. S. Belzacq-Casagrande [et al.] // Biochim. Biophys. Acta 2008. - Vol. 1783. - P. 849-863.

126. Endoplasmic reticulum stress induces calcium-dependent permeability transition, mitochondrial outer membrane permeabilization and apoptosis / A. Deniaud, O. Sharaf el dein, E. Maillier [et al.] // Oncogene. — 2008. Vol. 27. - P. 285-299.

127. Inhibition of mitochondrial membrane permeability as a putative pharmacological target for cardioprotection / D. Morin, R. Assaly, S. Paradis, A. Berdeaux // Curr. Med. Chem. - 2009. - Vol. 16. - P. 4382-4398.

128. Um H. D. Fas mediated apoptosis in human monocytes by a reactive oxygen intermediate dependent pathway / Um H. D., Orenstein J. M., Wahl S. M. // J. Immunol. - 1996. - Vol. 156, N 9. — P. 3469-3477.

129. Gopalakrishna R. Protein kinase C signaling and oxidative stress / Gopalakrishna R., Jaken S. // Free Radic. Biol. Med. - 2000. — Vol. 28. P. 1349-1361.

130. Fulda S. Molecular aspects of apoptosis induced by anticancer drugs in neuroblastoma cells / Fulda S., Susin S. A., Kroemer G. // Cancer Res. 1998. - Vol. 58. - P. 4453-4460.

131. Zoratti M. The mitochondrial permeability transition / Zoratti M., Szabo I. // Biochim. Biophys. Acta. - 1995. - Vol. 1241, N 2. - P. 139-176.

132. Зайчик А. Ш. Основы общей патологии / А. Ш. Зайчик, Л. П. Чурилов. СПб., 2000. - Ч. 2 : Основы патохимии. - 384 с.

133. VEGF, Bcl-2 and Bad regulated by angiopoietin-1 in oleic acid induced acute lung injury / Q. Guo, J. Jin, J. X. Yuan [et al.] // Biochem. Biophys. Res. Commun. - 2011. - Vol. 413. - P. 630-636.

134. Kroemer G. The proto-oncogene Bcl-2 and its role in regulating apoptosis / Kroemer G. // Nature Med. - 1997. - Vol. 3. - P. 614-620. 
135. Martinou J. K. Overexepression of bcl-2 in transgenic mice protects neurons from naturally occurring cell death and experimental ishemia / Martinou J. K., Dubois-Dauphin V., Staple J. K. // Neuron. - 1994. - Vol. 13. - P. 1017-1030.

136. McCarthy N. J. Inhibition of ced-3/ICE related proteases does not prevent cell death induced by oncogenes, DNA damage or the Bcl-2 Homologue Bak / McCarthy N. J., Whyte M. K., Gilbert C. S. // J. Cell. — 1997. — Vol. 36. P. 215-227.

137. Goldsmith Kelly C. Mitochondrial Bcl-2 Family Dynamics De fine Therapy Response and Resistance in Neuroblastoma / Kelly C. Goldsmith, M. Gross, S. Peirce, D. Luyindula [et al.] // Cancer Res. — 2012. — Vol. 72, № 10. P. 2565-2577.

138. Gottlieb R. A. Mitochondria: execution central / R. A. Gottlieb // FEBS Lett. - 2000. - Vol. 482, N 1-2. - P. 6-12.

139. Activation of pro-death Bcl-2 family proteins and mitochondria apoptosis pathway in tumor necrosis factor-alpha-induced liver injury / Y. Zhao, S. Li, E. E. Childs, D. K. Kuharsky // J. Biol. Chem. - 2001. - Vol. 276. - P. 27432-27440.

140. James J. L. Shear stress and spiral artery remodelling: The effects of low shear stress on trophoblast-induced endothelial cell apoptosis / J. L. James, G. S. Whitley, J. E. Cartwright // Cardiovasc. Res. - 2011. - Vol. 90. - P. 130-139.

141. Tsujimoto Y. Bcl-2 family: Life-or-death switch / Y. Tsujimoto, S. Shimizu // FEBS Lett. - 2000. - Vol. 466. - P. 6-10.

142. Outer mitochondrial membrane permeability can regulate coupled respiration and cell survival / M. G. Vander Heiden, N. S. Chandel, X. X. Li [et al.] // Natl. Acad. Sci. USA. - 2000. - Vol. 97. - P. 4666-4671.

143. Акопова О. В. Влияние потенциалзависимого транспорта калия на мембранный потенциал митохондрий мозга крыс / О. В. Акопова, В. И. Носарь, Л. И. Колчинская // Укр. биохим. журн. - 2013. - Т. 85, № 1. - С. 33-41.

144. Reed J. C. Bcl-2 and the regulation of programmed cell death / J. C. Reed // J. Cell Biol. - 1994. - Vol. 124, N 1-2. - P. 1-6.

145. Cand C. Apoptosis-inducing factor (AIF): key to the conserved caspaseindependent pathways of cell death? / C. Cand , F. Cecconi, Ph. Dessen // J. of Cell Science. - 2002. - Vol. 115. - P. 4727-4734.

146. The flavonoid quercetin induces cell cycle arrest and mitochondria-mediated apoptosis in human cervical cancer (HeLa) cells through p53 induction and NFB inhibition / R. V. Priyadarsini, R. S. Murugan, S. Maitreyi, K. Ramalingam // Eur. J. Pharmacol. — 2010. — Vol. 649. — P. 84-91.

147. Miyashita T. Tumor suppressor p53 is a direct transcriptional activator of the human Bax gene / T. Miyashita, J. C. Reed // Cell. — 1995. — Vol. 80. — P. 293-299. 
148. Post-treatment of Bax-inhibiting peptide reduces neuronal death and behavioural deficits following global cerebral ischemia / B. Han, Q. Wang, G. Cui [et al.] // Neurochem. Intl. - 2011. -Vol. 58. - P. 224-233.

149. Satou T. Immunoreactivity for Bcl-2 protein within neurons in the Alzheimers disease brain increases with disease severity / T. Satou, B. J. Cummungs, C. W. Cotman // Brain. Res. - 1995. - Vol. 697. - P. 35-43.

150. Khatun S. Generation of hydrogen peroxide mediates hanging death-induced neuronal cell apoptosis in the dentate gyrus of the rat brain / S. Khatun, S. K. Chaube, C. N. Bhattacharya // Brain Res. Bull. - 2013. - Vol. 95. - P. $54-60$.

151. Irrinki M. Requirement of FADD, NEMO, and BAX/BAK for Aberrant Mitochondrial Function in Tumor Necrosis Factor Alpha-Induced Necrosis / M. Irrinki, K. Mallilankaraman, J. Thapa, C. Chandramoorthy [et al.] // Mol. and cellular biol. - 2011. - Vol. 31, № 18. - P. 3745-3758.

152. Cao G. Translocation of apoptosis-inducing factor in vulnerable neurons after transient cerebral ischemia and in neuronal cultures after oxygen glucose deprivation / G. Cao, R. Clark, W. Pei // J. Cereb. Blood Flow Metab. 2003. - Vol. 23. - P. 1137-1150.

153. Graham S. Bcl-2 family gene products in cerebral ischemia and traumatic brain injury / S. Graham, J. Chen, R. Clark // J. Neurotrauma. - 2000. Vol. 17. - P. 831-841.

154. Chai J. Structural and biochemical basis of apoptotic activation by Smac/ DIABLO / J. Chai, C. Du, J. Wu // Nature - 2000. — Vol. 406. - P. 855862 .

155. Larner S. Increased expression and processing of caspase-12 after traumatic brain injury in rats / S. Larner, R. Hayes, D. McKinsey // J. Neurochem. 2004. - Vol. 88. - P. 78-90.

156. Leker $R$. The role of p53 induced apoptosis in cerebral ischemia: effects of the p53 inhibitor pifithrin alpha / R. Leker, M. Ahronowiz // Exp. Neurol. 2004. - Vol. 187. - P. 486-487.

157. Дозозависимый характер антиапоптотического и токсического действия уабаина в первичной культуре нейронов коры крысы / А. Е. Большаков, Д. А. Сибаров, П. А. Абушик [и др.] // Биологич. мембраны. - 2012. Т. 29, № 6 . - С. 422-428.

158. Болдырев А. А. Дискриминация между апоптозом и некрозом нейронов под влиянием окислительного стресса / Болдырев А. А. // Биохимия. 2000. - T. 65, № 7. - С. 981-990.

159. Bester H. Changes in tactile stimuli-induced behavior and c-Fos expression in the superficial dorsal horn and in parabrachial nuclei after sciatic nerve crush / H. Bester, S. Beggs, C. J. Woolf // J. Comp. Neurol. — 2000. -Vol. 428. P. 45-61.

160. Expression and involvement of c-fos and c-jun protooncogenes in programmed cell death by growth factor deprivation in lymphoid cell lines / Colotta F., Polentarutti N., Sironi M., Mantovani A. // J. Biol. Chem. - 1992. - Vol. 267. - P. 18278-18283. 
161. Herdegen F. The c-Jun transcription factor-bipotential mediator of neuronal death, survival and regeneration / Herdegen F., Skene P., Bauhr M. // TINS. - 1997. - Vol. 20. - P. 373-376.

162. Eno C. Distinct roles of mitochondria- and ER-localized Bcl-xL in apoptosis resistance and $\mathrm{Ca} 2+$ homeostasis / C. Eno, E. F. Eckenrode, K. E. Olberding, G. Zhaov // Mol. Biology of the Cell. - 2012. - Vol. 23. - P. 2605-2618.

163. Janknecht R. Regulation of the c-fos promoter / Janknecht R. // Immunobiology. - 1995. - Vol. 193. - P. 137.

164. Complex mechanisms for c-fos and c-jun degradation / Jariel-Encontre I., Salvat C., Steff A. [et al.] // Mol. Biol. Rep. - 1997. — Vol. 24. - P. 51.

165. Okazaki K. The Mos/MAP kinase pathway stabilize c-Fos by phosphorylation and augments its transforming activity in NIH 3T3 cells / Okazaki K., Sagata N. // EMBO J. - 1995. - Vol. 14. - P. 5048.

166. Jinnah H.A. Expression of $\mathrm{c}$-fos in the Brain after Activation of L-Type Calcium Channel / H. A. Jinnah, K. Egami, L. Rao // Dev. Neurosci 2003. - Vol. 25. - P. 403-411.

167. Programmed cell death in the absence of c-Fos and c-Jun / Roffler-Tarlov S., Gibson J., Tarlov E. [et al.] // Development. — 1996. — Vol. 122. — P. 1-9.

168. Фильченков А. А. Апоптоз кортикальных нейронов при развитии ишемических инсультов / Фильченков А. А., Залесский В. Н. // Нейрофизиология. - 2002. - Т. 34, № 6. - С. 468-484.

169. Залесский В. Н. Методы ранней диагностики апоптоза in vitro, in vivo для оценки хронических токсикантов / Залесский В. Н., Великая Н. В. // Совр. пробл. токсикологии. - 2006. - № 1. - С. 78-82.

170. Апоптотический и аутофагический пути гибели клетки при гипертрофии и ремоделировании миокарда / Залесский В. Н., Стаднюк Л. А., Великая Н. В. // Журн. АМН України. — 2003. - Т. 9, № 4. - С. 699-712.

171. Турпаев К. Т. Активные формы кислорода и регуляция активности генов : (обзор) / Турпаев К. Т. // Биохимия. — 2002. - Т. 67, № 3. - С. 339-352.

172. Влияние окислительного стресса на активность синтазы оксида азота мозга in vitro и in vivo / Онуфриев В. В., Степаничев М. Ю., Митрохина О. С. [и др.] // Рос. физиол. журн. - 1999. - Т. 85, № 4. - С. 531-537.

173. Chaperone-mediated coupling of endoplasmic reticulum and mitochondrial Ca2+ channels / G. Szabadkai, K. Bianchi, P. Varnai [et al.] // J. Cell. Biol. 2006. - Vol. 175. - P. 901-911.

174. Regulation of hypoxia-inducible factor 1alpha is mediated by an O2-dependent degradation domain via the ubiquitin-proteasome pathway / Huang L. E., Gu J., Schau M., Bunn H. F. // Proc. Nat. Acad. Sci. USA. - 1998. — Vol. 95. P. 7987-7996.

175. Visualization of the three-dimensional organization of hypoxia-inducible factor-1 alpha and interacting cofactors in subnuclear structures / BerchnerPfannschmidt U., Wotzlaw C., Merten E. [et al.] // Biol. Chem. — 2004. Vol. 385. - P. 231-237.

176. Zamkova M. Heat shock transcriptional factor 1 effect on the level of reactive oxygen species via regulation of sestrins' expression depends on cell type / M. 
Zamkova M., P. Kopnin, B. Kopnin // The EMBO Meeting 2010 (Abstracts) P. 196.

177. Dery M. A. Hypoxia-inducible factor 1: regulation by hypoxic and non-hypoxic activators / Dery M. A., Michaud M. D., Richard D. E. // Int. J. Biochem. Cell Biol. - 2005. - Vol. 37. - P. 535-540.

178. Молекулярный шаперон HSP70 защищает клетки нейробластомы SK-NSH от гипоксического стресса / Н. С. Тихонова, О. С. Москалева, Б. А. Маргулис, И. В. Гужова // Цитология. - 2008. — Т. 50, № 5. - С. 467-472.

179. Антипова Т.А. Влияние афобазола на содержание стресс-белка HSP 70 в ткани мозга крыс при глобальной переходящей ишемии / Т. А. Антипова, И. О. Логвинов, И. Н. Курдюмов [ и др.] // Эксперим. и клин. фармакол. 2009. - Т. 72, № 1. - С. 29-32.

180. Carcinogenic metals induce hypoxia-inducible factor-stimulated transcription by reactive oxygen species-independent mechanism / K. Salnikow, W. Su, M. V. Blagosklonny, M. Costa // Cancer Res. - 2000. - Vol. 60. - P. 33753378 .

181. Semenza G. L. Targeting HIF-1 for cancer therapy / G. L. Semenza // Nature Rev. Cancer - 2003. - Vol. 3. - P. 721-732.

182. PI3K/AKT is required from heat shock proteins to protect hypoxia-inducible factor-1 from pVHL-independent degradation / J. Zhou, T. Schmid, R. Franc, R. Bruno // Biol. Chem. - 2004. - Vol. 279. - P. 13506-13513.

183. More efficient induction of HLA-A*0201-restricted and carcinoembryonic antigen (CEA)-specific CTL response by immunization with exosomes prepared from heat-stressed CEA-positive tumor cells / S. Dai, T. Wan, B. Wang [et al.] // Clin. Cancer Res. - 2005. - Vol. 11. - P. 7554-7563.

184. Interaction of the PAS B domain with HSP90 accelerates hypoxia-inducible factor-1 alpha stabilization / D. M. Katschinski, L. Le, S. G. Schindler [et al.] // Cell Physiol. Biochem. - 2004. - Vol. 14. - P. 351-360.

185. HInteraction of the PAS B domain with HSP90 accelerates hypoxia-inducible factor-1alpha stabilization / Katschinski D. M., Le L., Schindler S. G. [et al.] // Cell Physiol. Biochem. - 2004. - Vol. 14. - P. 351-360.

186. Overexpressed heat shock protein 70 attenuates hypoxic injury in coronary endothelial cells / Suzuki K., Sawa Y., Kaneda Y. [et al.] // J. Mol. Cell Cardiol. - 1998. - Vol. 30. - P. 1129-1136.

187. Brown I. R. Induction of heat shock (stress) genes in the mammalian brain by hyperthermia and other traumatic events: a current perspective / Brown I. R. // J. Neurosci. Res. - 1990. - Vol. 27. - P. 247-255.

188. The heat-shock response: regulation and function of heat-shock proteins and molecular chaperones / Morimoto R. I., Kline M. P., Bimston D. N., Cotto J. J. // Essays Biochem. - 1997. - Vol. 32. - P. 17-29.

189. Nowak T. S. Jr. Stress protein and proto-oncogene expression as indicators of neuronal pathophysiology after ischemia / Nowak T. S. Jr., Osborne O. C., Suga S. // Prog. Brain Res. - 1993. - Vol. 96. - P. 195-208. 
190. Transgenic mice expressing the human inducible Hsp70 have hippocampal neurons resistant to ischemic injury / Plumier J. C., Krueger A. M., Currie R. W. [et al.] // Cell Stress Chaperones. - 1997. - N 2. - P. 162-167.

191. Белок теплового шока (Hsp70) протектирует активность глутаматергической синаптической передачи в обонятельной коре мозга крыс in vitro от тяжелой аноксии / Мокрушин А. А., Павлинова Л. И., Гужова И. В., Маргулис Б. А. // Докл. РАН. - 2004. - Т. 394, № 3. - С. 419-422.

192. The neuroprotective potential of heat shock protein 70 (HSP70) / Yenari M. A., Giffard R. G., Sapolsky R. M., Steinberg G. K. // Mol. Med. Today. 1999. - Vol. 5. - P. 525-531.

193. Role of chaperones $70 \mathrm{kDa}$ in pathogenesis of seizures with different etiology / Khudik K. A., Nitsinskaya L. E., Guzhova I. V. [et al.] // Abstr. of the 11th Multidisciplinary Int. Neuroscience and Biological Psychiatry Conf. «Stress and behavior». - St.-Petersburg, 2008. - P. 59-60.

194. Khudik K. The role of inferior colliculus in audiogenic seizures in KrushinskiiMolodkina rats / Khudik K. // Abstr. of the 12th Multidisciplinary Int. Neuroscience and Biological Psychiatry Conf. «Stress and behavior». - St.Petersburg, 2009. - P. 39.

195. Kim N. Anti-inflammatory properties and pharmacological induction of Hsp70 after brain injury / N. Kim, J. Y. Kim, M. A. Yenari // Inflammopharmacology. - 2012. - Vol. 2012. - P. 177-185.

196. Heat shock protein 70 upregulation by geldanamycin reduces brain injury in a mouse model of intracerebral hemorrhage / A. Manaenko, N. Fathali, H. Chen [et al.] // Neurochem. Int. - 2010. - Vol. 57. - P. 844-850.

197. Mehta S. L. Molecular targets in cerebral ischemia for developing novel therapeutics / S. L. Mehta, N. Manhas, R. Raghubir // Brain. Res. Rev. 2007. - Vol. 54. - P. 34-66.

198. Wong C. H. Modulation of neuro-inflammation and vascular response by oxidative stress following cerebral ischemiareperfusion injury / C. H. Wong, P. J. Crack // Curr. Med. Chem. - 2008. - Vol. 15. - P. 1-14.

199. Heat shock proteins protect against ischemia and inflammation through multiple mechanisms / Q. Jones, T. S. Voegeli, G. Li, Y. Chen // Inflamm. Allergy Drug Targets. - 2011. - Vol. 10. - P. 247-59.

200. Overexpression of Hsp-70 protects astrocytes from combined oxygen-glucose deprivation / Papadopoulos M. C., Sun X. Y., Cao J. [et al.] / / Neuroreport. 1996. - Vol. 7. - P. 429-432.

201. Lee J. Hypoxia-inducible Factor-1 (HIF-1)-independent Hypoxia Response of the Small Heat Shock Proteinhsp-16.1Gene Regulated by Chromatinremodeling Factors in the Nematode Caenorhabditis elegans / J. Lee // J. of Biol. Chem. - 2013. - Vol. 288, N 3. - P. 1582-1589.

202. Weidemann A. Biology of HIF-1 / A. Weidemann, R. S. Johnson / Cell Death Differ. - 2008. - Vol. 15. - P. 621-627.

203. Bernardi R. PML inhibits HIF-1 alpha translation and neoangiogenesis through repression of mTOR / R. Bernardi / Nature. — 2006. — Vol. 442. P. 779-785. 
204. Mehlen P. Small stress proteins as novel regulators of apoptosis. Heat shock protein 27 blocks Fas/APO-1- and staurosporine-induced cell death / P. Mehlen, K. Schulze-Osthoff, A. P. Arrigo // J. Biol. Chem. - 1996. - Vol. 271. - P. 16510-16514.

205. Gupta S. HSP60, Apoptosis and the Heart / S. Gupta, A. A. Knowlton // J. Cell. Mol. Med. - 2005. - Vol. 9, N 1. - P. 51-58.

206. Панасенко О. О. Структура и свойства малых белков теплового шока / О. О. Панасенко, М. В. Ким, Н. Б. Гусев // Успехи биологич. химии. 2003. - T. 43. - C. 59-98.

207. Марченков В. Молекулярные шаперонины прокариотических и эукариотических клеток / В. Марченков // Успехи биологич. химии. — 2006. - Т. 46. - C. 279-290.

208. Holtzman D. M. Caspases: a treatement target for neurodegenerative disease / D. M. Holtzman, M. Deshmukh // Nature Medicine. — 1997. — Vol. 3. P. 954-955.

209. Shimizu S. Retardation of chemical hypoxia-induced necrotic cell common mediators in apoptotic and necrotic signal transductions / S. Shimizu, Y. Eguchi, W. Kamiike // Oncogene. - 1996. - Vol. 12. - P. 2045-2050.

210. Distinct hsp70 domains mediate apoptosis-inducing factor release and nuclear accumulation / K. Ruchalski, H. Mao, Z. Li [et al.] // J. Biol. Chem. - 2006. Vol. 281. - P. 7873-7880.

211. The carboxyl-terminal domain of inducible Hsp70 protects from ischemic injury in vivo and in vitro / Y. Sun, Y. B. Ouyang, L. Xu [et al.] // J. Cereb. Blood Flow Metab. - 2006. - Vol. 26. - P. 937-950.

212. Selective depletion of heat shock protein 70 (Hsp70) activates a tumorspecific death program that is independent of caspases and bypasses Bcl-2/ J. Nylandsted, M. Rohde, K. Brand [et al.] // Proc. Nat. Acad. Sci. USA. 2000. - Vol. 97. - P. 7871-7876.

213. Drug-induced Myc-mediated apoptosis of cancer cells is inhibited by stress protein Hsp70 / E. A. Afanasyeva, E. Yu. Komarova, L.-G. Larsson [et al.] // Int. J. Cancer. - 2007. - Vol. 121, N 12. - P. 2615-2621.

214. Inhibition of Daxx-mediated apoptosis by heat shock protein 27 / S. J. Charette, J. N. Lavoie, H. Lambert, J. Landry // Mol. Cell Biol. — 2000. Vol. 20. - P. 7602-7612.

215. Concannon C. G. On the role of Hsp27 in regulating apoptosis / C. G. Concannon, A. M. Gorman, A. Samali // Apoptosis. - 2003. - Vol. 8. - P. 61-70.

216. Dewson G. Mechanisms by which Bak and Bax permeabilise mitochondria during apoptosis / G. Dewson, R. M. Kluck // J. Cell Sci. - 2009. Vol. 122. - P. 2801-2808.

217. Havasi A. Hsp27 Inhibits Bax Activation and Apoptosis via a Phosphatidylinositol 3-Kinase-dependent Mechanism / A. Havasi, Z. Li, Z. Wang // J. Biol. Chem. - 2008. - Vol. 283. - P. 12305-12313.

218. Lelj-Garolla B. Self-association of a small heat shock protein / B. Lelj-Garolla, A. G. Mauk // J. Mol. Biol. — 2005. - Vol. 345. — P. 631-642. 
219. Кайгородова Е. В. Действие ингибиторов белков теплового шока 90 и 27 на дексаметазониндуцированный апоптоз опухолевых клеток / Е. В. Кайгородова, Н. В. Рязанцева, В. В. Новицкий // Бюл. сиб. медицины. 2010. - T. 9, № 3. - С. 68-71.

220. Liang Z. Expression of carboxyl terminus of HSP70-interacting protein (CHIP) indicates poor prognosis in human gallbader carcinoma / Z. Liang // Oncology letters. - 2013. - Vol. 5. - P. 813-818.

221. Belenichev I. F., Bukhtiyarova N. V. Disturbance of HSP70 Chaperone Activity is a pssible mechanism of Mitochodrial Dysfunction // Neurochem. Journal. - 2011. - Vol. 5,№ 4. - P. 251-256.

222. Роль оксиду азоту в регулюванні фізіологічних функцій у нормі та при ішемічній патології / Бєленічев І. Ф., Дмитряков В. О., Бєляєва О. О. [та ін.] // Військова медицина України. — 2002. — Т. 2, № 3. - С. 48-59.

223. Kleinert H. Regulation of the expression of inducible nitric oxide synthase / H. Kleinert, P. Schwarz, U. Forstermann // Biol. Chem. -2003. - Vol. 384, N 10-11. - P. 1343-1364.

224. Dysfunctional regulations of endothelial nitric oxide synthase (eNOS) expression in response to exercise in mice lacking one eNOS gene / A. Kojda, Y. N. Cheng, J. Burchfield, D. G. Iarrisin // Circulation. - 2001. - Vol. 103. - P. 2839-2844.

225. Strick A. T. Nitric oxide donor compounds inhibit the toxicity of oxidized lowdensity lipoprotein to endothelian cells / Strick A. T., Hogg N., Thomas J. P. // FEBS Lett. - 1995. - Vol. 361. - P. 291-294.

226. Estevez A. G. Nitric oxide and superoxide contribute to motor neuron apoptosis induced by trophic factor deprivation / Estevez A. G., Spear N., Mannuel S. M. // J. Neurosci. - 1998. - Vol. 18. - P. 923-931.

227. Гарматина О. Ю. Индуцибельная синтаза оксида азота при патологии сердца : (обзор лит. и собственные исследования) / О. Ю. Гарматина, Н. М. Ткаченко, А. А. Майбенко // ЗЖурн. АМН України. - 2005. — Т. 11, № 4. - С. 645-649.

228. Горрен А. К. Универсальная и комплексная энзимология синтазы оксида азота : обзор / А. К. Горрен, Б. Майер // Биохимия. - 1998. - Т. 63, № 7. - С. 878-880.

229. Пшенникова М. Г. Оксид азота как фактор генетически детерменированной устойчивости к стрессовым повреждениям и адаптационной защиты / Пшенникова М. Г., Бондаренко Н. А., Шимкович М. В. // Бюл. эксперим. биологии и медицины. - 2001. - Т. 132, № 11. - С. 510-513.

230. Armstead W. M. Nitric oxide contributes to opioid release from glia during hypoxia / Armstead W. M. // Brain Res. - 1998. — N 813. - P. 398-401.

231. Nitric oxide donor induces HSP70 accumulation in the heart and in cultured cells / Malyshev I. Yu., Malugin A. V., Golubeva L. Yu. [et al.] // FEBS Leters. - 1996. - N 391. - P. 167-170.

232. Влияние NO-синтазы на поведенческие и структурные изменения головного мозга при хроническом стрессе / Ховряков А. В., Кругляков П. П., Ай- 
рапетянц М. Г., Сосунов С. А. // Морфология. - 2002. - Т. 121, № 2-3. C. 167.

233. Gaseous Transmitters and neuroendocrine regulation / Brann D. W., Bhat G. K., Lamar C. A., Mahesh V. B. // Neuroendocrinology. — 1997. - N 65. P. 385-395.

234. Вовлечен ли оксид азота в адаптационную защиту органов от стрессорных повреждений? / Маленюк Е. Б., Аймашев Н. П., Манухина Е. Б. [и др.] // Бюл. эксперим. биологии и медицины. - 1998. - Т. 126, № 9. - С. 274-277.

235. Paul V. A role of nitric oxide as a inhibitor of gamma-amonobutiric acid transaminase in rat brain / Paul V., Jayakumar A. R. // Brain Res. Bull. 2000. - N 51. - P. 43-46.

236. Максимович H. Е. Использование L-аргинина и ингибиторов образования оксида азота для коррекции воспалительного процесса в мозге крыс при его ишемиии/реперфузии / Н. Е. Максимович // Иммунопатология, аллергология, инфектология. - 2004. - № 3. - С. 14-17.

237. Ladecola C. Inducible nitric oxide synthase gene expression in vascular cells after transient focal cerebral ischemia / C. Ladecola, F. Zhang, R. // Stroke. 1996. - Vol. 27, N 8. - P. 1373-1380.

238. Максимович Н. Е. Понятие о нитроксидергической системе мозга. Роль нейрональных источников / Н. Е. Максимович // Журн. ГрГМУ. 2003. - № 4. - C. 7-11.

239. Garthwaite J. Concepts of neural nitric oxideemediated transsmission / Garthwaite J. // Eur. J. Neurosci. - 2008. - Vol. 27. - P. 2783-2802.

240. Kapil V. Inorganic nitrate and the carrdiovascular system / Kapil V., Webb A. J., Ahluwalia A. // Heart. — 2010. — Vol. 96. — P. 1703-1709.

241. The involvement of nitric oxide synthase neurons in enteric neuropathies / Rivera L. R., Poole D. P., Thacker M. [et al.] // Neurogastroenterol. Motil. 2011. - Vol. 23. - P. 980-988.

242. Takahashi T. Pathophysiological significance of neuronal nitric oxide synthase in the gastrointestinal tract / Takahashi T. // J. Gastrooenterol. — 2003. Vol. 38. - P. 421-430.

243. Induction of inducible nitric oxide synthase: a protective mechanism in colitissinduced adeenocarcinoma / Zhang R., Ma A., Urbanski S. J. [et al.] // Carcinogenesis. - 2007. - Vol. 28. - P. 1122-1130.

244. Stomach NO synnthesis / Benjamin N., O’Driscoll F., Dougall H. [et al.] // Nature. - 1994. - Vol. 368. - P. 502.

245. Intragastric nitric oxide is abolished in intubated patients and restored by nitrite / Bjorne H., Govoni M., Tornberg D. C. [et al.] // Crit. Care Med. 2005. - Vol. 33. - P. 1722-1727.

246. Ткач С. М. Биологические эффекты оксидов азота в желудочноокишечном тракте / С. М. Ткач, К. С. Пучков, Ю. Г. Кузенко / Сучасна геронтологія. 2013. - № 4. - C. 118-128. 
247. Лукьянова Л. Д. Биоэнергетическая гипоксия - молекулярный механизм тканевой гипоксии и адаптация организма / Л. Д. Лукьянова // Укр. физиол. журн. - 2008. - Т. 49, № 3. - С. 17-35.

248. Хазанов В. А. Прошлое, настоящее и будущее биоэнергетической фармакологии / В. А. Хазанов // Регуляторы энергетического метаболизма. Клинико-фармакологические аспекты : материалы симп. - Томск, 2004. - C. 3-7.

249. Run-down of the GABA-A response under experimental ischaemia in acutely dissociated CA1 pyramidal neurones of the rat / N. Harata, J. Wu, H. Ishibashi [et al.] // J. Physiol. — 1997. — Vol. 500. — P. 673-688.

250. Ваизова О. Е. Фармакологическая и экстракорпоральная коррекция дисфункции эндотелия при церебральном атеросклерозе : автореф. дис. на соискание ученой степени д-ра мед. наук / О. Е. Ваизова. - Томск, 2006. $51 \mathrm{c.}$

251. Бабичев В. Н. Половые гормоны и центральная нервная система / В. Н. Бабичев // Рос. хим. журн. - 2005. - Т. XXLIX, № 1. - С. 138-143.

252. De Kloet E. R. Hormones, Brain and Stress / De Kloet E. R. // Endocrine Regulations. - 2003. - Vol. 37. - P. 51-68.

253. Compagnone N. A. Neurosteroids: biosynthesis and function of the senovel neuromodulators / Compagnone N. A., Mellon S. H. // Front. Neuroendocrinol. - 2000. - Vol. 21, N 1. - P. 1-56.

254. Dubrovsky B. O. Steroids, neuroactive steroids and neurosteroids in psychopathology / Dubrovsky B. O. // Prog. Neuropsychopharmacol. Biol. Psychiatry. - 2005. - Vol. 29, N 2. - P. 169-192.

255. Garcia-Segura L. M. Neuroprotection by estradiol / Garcia-Segura L. M., Azcoitia I., DonCarlos L. L. // Prog. Neurobiol. — 2001. - Vol. 63, N 1. P. 29-60.

256. Schantz S. L. Cognitive Effects of Endocrine-Disrupting Chemicals in Animals / Schantz S. L., Widholm J. J. // Environmental Health Perspectives. 2001. - Vol. 109, N 12. - P. 1197-1206.

257. Meharvan S. Novel Mechanisms for Estrogen-Induced Neuroprotection / Meharvan S., Dykens J. A., Simpkins J. W. // Experim. Biology and Medicine. - 2006. - Vol. 231. - P. 514-521.

258. Hippocampal synthesis of estrogens and androgens which are paracrine modulators of synaptic plasticity: synaptocrinology / Mukai H., Takata N., Ishii H. T. [et al.] // Neuroscience. - 2006. — Vol. 138, N 3. - P. 757-764.

259. Kinase-mediated regulation of common transcription factors accounts for the bone-protective effects of sex steroids / S. Kousteni, L. Han, J. R. Chen [et al.] // J. Clin. Invest. - 2003. - Vol. 111, N 11. - P. 1651-1654.

260. Estrogen, cognition and female ageing / Genazzani A. R., Pluchino N., Luisi S., Luisi M. // Human Reproduction Update. - 2007. - Vol. 13, N 2. P. 175-187.

261. Testosterone and aggressiveness / Giammanco M., Tabacchi G., Giammanco S. [et al.] // Med. Sci. Monit. — 2005. - Vol. 11, N 4. - P. 136-145. 
262. Green P. S. Neuroprotective effects of estrogens: potential mechanisms of action / Green P. S., Simpkins J. W. // Int. J. Dev. Neurosci. - 2000. - Vol. 18, N 4-5. - P. 347-358.

263. Rupprecht R. Neuroactive steroids: mechanisms of action and neuropsychopharmacological properties / Rupprecht R. // Psychoneuroendocrinology. - 2003. - Vol. 28, N 2. - P. 139-168.

264. Estrogen synthesis in the central nucleus of the amygdala following middle cerebral artery occlusion: Role in modulating neurotransmission / Saleh T. M., Connell B. J., Legge C., Cribb A. E. // Neuroscience. - 2005. — Vol. 135, N 4. - P. 1141-1153.

265. Wojtal K. Endogenous neuroprotective factors: neurosteroids / Wojtal K., Trojnar M. K., Czuczwar S. // J. Pharmacol. Reports. - 2006. — Vol. 58. P. 335-340.

266. Estrogen and aging affect the subcellular distribution of estrogen receptoralpha in the hippocampus of female rats / Adams M., Fink S. E., Shah R. A. [et al.] // J. of Neuroscience. - 2002. - Vol. 22. - P. 3608-3614.

267. Brinton R. D. Cellular and molecular mechanisms of estrogen regulation of memory function and neuroprotection against Alzheimer's disease: recent insights and remaining challenges / Brinton R. D. // Learning and Memory. 2001. - N 8. - P. $121-133$.

268. Harris H. A. Characterization of th e biological roles of the estrogen receptors, ERalpha and ERbeta, in estrogen target tissues in vivo through the use of an Eralpha-selectiv eligand / Harris H. A., Katzenellenbogen J. A., Katzenellenbogen B. S. // Endocrinology. — 2002. — N 143. — P. 41724177.

269. Thornton M. J. The biological actions of estrogens on skin / Thornton M. J. // Exp. Dermatol. - 2002. - Vol. 11. - P. 487-502.

270. Tsai M. J. Molecular mechanisms of action of steroid/thyroid receptor superfamily members / M. J. Tsai, B. W. O'Malley // Ann. Rev. Biochem. 1994. - Vol. 63. - P. 451-486.

271. Cloning and characterization of human estrogen receptor beta isoforms / J. T. Moore, D. D. McKee, K. Slentz-Kesler [et al.] // Biochem. Biophys. Res. Commun. - 1998. - Vol. 247, N 1. - P. 75-78.

272. Estrogen receptors alpha and beta are differentially expressed in developing human bone / S. Bord, A. Horner, S. Beavan, J. J. Compston // Clin. Endocrinol. Metab. - 2001. - Vol. 86, N 5. - P. 2309-2314.

273. Revelli A. Nongenomic actions of steroid hormones in reproductive tissues / A. Revelli, M. Massobrio, J. Tesarik // Endocr. Rev. - 1998. — Vol. 19, N 1. - P. 3-17.

274. Luoma J. I. Caveolin proteins and estrogen signaling in the brain / Luoma J. I., Boulware M. I., Mermelstein P. G. // Mol. Cell. Endocrinol. - 2008. Vol. 290, N 1-2. - P. 8-13.

275. Control of estrogen receptor ligand binding by Hsp90 / A. E. Fliss, S. Benzeno, J. Rao, A. J. Caplan // J. Steroid. Biochem. Mol. Biol. - 2000. — Vol. 72, N 5. - P. 223-230. 
276. Tamoxifen, a selective estrogen receptor modulator, reduces ischemic damage caused by middle cerebral artery occlusion in the ovariectomized female rat / Mehta S. H., Dhandapani K. M., De Sevilla L. M. [et al.] // Neuroendocrinology. - 2003. - Vol. 77. - P. 44-50.

277. Cahill M. A. Progesterone receptor membrane component 1: an integrative review / M. A. Cahill // J. Steroid. Biochem. Mol. Biol. - 2007. - Vol. 105. - P. 16-36.

278. Казакова С. Б. Сравнительный анализ әстрогенов и тамоксифена на высшие функции мозга / Казакова С. Б., Сапронов Н. С. // Эксперим. и клинич. фармакология. - 2008. - Т. 7, № 6. - С. 49-53.

279. Tenenbaum M. Effects of estrogen against LPS-induced inflammation and toxicity in primary rat glial and neuronal cultures / Tenenbaum M., Azab A. N., Kaplanski J. // J. of Endotoxin Res. - 2007. - Vol. 13, N 3. - P. 158166.

280. Estrogen Action in Neuroprotection and Brain Inflammation / Pozzi S., Benedusi V., Maggi A., Vegeto E. // Ann. of the New York Acad. of Sci. 2006. - Vol. 1089. - P. 302-323.

281. Tamoxifen protects against acute tumor necrosis factor ainduced cardiac injury via improving mitochondrial functions. / Zhao Y., Wang L. M., Chaiswing L. [et al.] // Free Radic. Biol. Med. - 2006. — Vol. 40. - P. 1234-1241.

282. Liqin Z. Estrogen receptor a and a differentially regulate intracellular Ca2+ dynamics leading to ERK phosphorylation and estrogen neuroprotection in hippocampal neurons / Liqin Z., Roberta D. Brinton // Brain Res. - 2007. Vol. 1172, N 3. - P. 48-59.

283. Differential protective properties of estrogen and tamoxifen against methamphetamine-induced nigrostriatal dopaminergic toxicity in mice / D’Astous M., Mickley K. R., Dluzen D. E., Di PaoloT. // Neuroendocrinology. 2005. - Vol. 82. - P. 111-120.

284. Cardoso C. M. Protection of tamoxifen against oxidation of mitochondrial thiols and $\mathrm{NAD}(\mathrm{P}) \mathrm{H}$ underlying the permeability transition induced by prooxidants / Cardoso C. M., Almeida L. M., Custodio J. B. // Chem. Biol. Interact. - 2004. - Vol. 148. - P. 149-161.

285. Dluzen E. Gender differences in modulatory effects of tamoxifen upon the nigrostriatal dopaminergic system / Dluzen E., Mickley K. R. // Pharmacol. Biochem. Behav. - 2005. - Vol. 80. - P. 27-33.

286. Эстрогены и головной мозг / Е. Н. Карева, О. М. Олейникова, В. О. Панов [и др.] // Вестн. РАМН. - 2012. — № 2. - С. 48-59.

287. Estrogen receptor b protects against acoustic trauma in mice / Meltser I., Tahera Y., Simpson E. [et al.] // J. Clin. Invest. - 2008. - Vol. 118, N 4. P. 1563-1570.

288. Selective estrogen receptor-beta agonists repress transcription of proinflammatory genes / Cvoro A., Tatomer D., Tee M. K. [et al.] // Immunol. - 2008. - Vol. 180. - P. 630-636.

289. Estradiol regulates angiopoietin-1 mRNA expression through estrogen receptor-alpha in a rodent experimental stroke model / Ardelt A. A., 
McCullough L. D., Korach K. S. [et al.] // Stroke. - 2005. — Vol. 36. - P. $337-341$.

290. 17-beta-estradiol induces heat shock proteins in brain arteries and potentiates ischemic heat shock protein induction in glia and neurons / $\mathrm{Lu} \mathrm{A.,} \mathrm{Ran} \mathrm{R.}$ Q., Clark J. [et al.] // J. Cereb. Blood Flow. Metab. — 2002. — Vol. 22. - P. 183-195.

291. Mermelstein P. G. Membrane-localised oestrogen receptor alpha and beta influence neuronal activity through activation of metabotropic glutamate receptors / Mermelstein P. G. // Neuroendocrinol. - 2009. - Vol. 21, N 4. P. 257-262.

292. Contribution of estrogen receptors alpha and beta to the effects of estradiol in the brain / Morissette M., Le Saux M., D’Astous M. [et al.] // J. Steroid. Biochem. Mol. Biol. - 2008. - Vol. 108, N 3-5. - P. 327-338.

293. Estrogen-like activity of tamoxifen and raloxifene on NMDA receptor binding and expression of its subunits in rat brain / Cyr M., Thibault C., Morissette M. [et al.] // Neuropsychopharmacology. - 2001. — Vol. 25, N 2. - P. 242257.

294. The gad2 promoter is a transcriptional target of estrogen receptor a (ERa) and ERb: A unifying hypothesis to explain diverse effects of estradiol / Hudgens E. D., Ji L., Clifford D. [et al.] // Neurosci. — 2009. — Vol. 29, N 27. — P. 8790-8797.

295. Шимановский И. Л. Комплексное влияние женских половых гормонов на сердечно-сосудистую систему: польза и риск / И. Л. Шимановский // Междунар. мед. журн. - 2007. — № 3. - С. 51-55.

296. Воронкова К. В. Применение нобена (идебенона) в терапии деменции и нарушений памяти, не достигших степени деменции / К. В. Воронкова, М. Н. Мелешков // Журн. неврологии и психиатрии им. С. С. Корсакова. -2008 . - № 4. - С. 30-47.

297. Bergamasco B. Effects of idebenone in elderly subjects with cognitive decline. Results of a multicentre clinical trial / B. Bergamasco // Arch. Gerontl. Geriatr. - 1992. - Vol. 15, N 3. - P. 279-286.

298. Erkinjuntti T. Treatment of vascular dementia evidence from clinical trials with cholinesterase inhibitors / T. Erkinjuntti, G. Roman, S. Gauthier // J. Neurol. Sci. - 2004. - Vol. 226, N 1-2. - P. 63-66.

299. Иммунометаболические эффекты регуляторов энергетического обмена при нарушении гомеостаза / [Г. А. Лазарева, И. Л. Бровкина, А. И. Лазарев и др.]. - Курск, 2006. - 329 с.

300. Оковитый С. В. Клиническая фармакология антигипоксантов (ч. II) / Оковитый С. В. // ФАРМиндекс-Практик. - 2005. - Вып. 7. - С. 48-63.

301. Шаталин Ю. В. Сравнительная характеристика антиоксидантных свойств гипоксена и дурохинона методом хемолюминесценции / Шаталин Ю. В., Наумов А. А., Поцелуева М. М. // Биофизика. - 2008. - Т. 53, вып. 1. C. 100-106.

302. Перепеч Н. Б. Олифен в терапии ишемической болезни сердца - первые результаты и перспективы клинического применения / Перепеч Н. Б., 
Михайлова И. Е., Недошивин А. О. // Междунар. мед. обзоры. - 1993. № 4. - С. 328-333.

303. Андрианов В. П. Применение антигипоксантов олифена и амтизола для лечения больных с хронической недостаточностью кровообращения ІІБ стадии / Андрианов В. П., Бойцов С. А., Смирнов А. В. // Терапевт. арх. 1996. 一 № 5. - С. 74-78.

304. Заржецкий Ю. В. Влияние сукцината натрия на функциональные, биохимические и морфологические показатели восстановления ЦНС у крыс после 10-минутной остановки кровообращения / Ю. В. Заржецкий // Янтарная кислота в медицине, пищевой промышленности и сельском хозяйстве : сб. науч. ст. - Пущино, 1997. - С. 96-103.

305. Petit P.X. Mitochondrial implication in cell desth / P. X. Petit// Mitochondria in pathogenesis. - 2001. - P. 157-167.

306. Влияние димефосфона и ксидифона на минеральный обмен и перекисное окисление липидов крыс на модели «пульс-терапии» преднизолоном / И. Х. Валеева, Л. Е. Зиганшина, З. А. Бурнашова, А. У. Зиганшин // Эксперим. и клинич. фармакология. - 2003. - Т. 66, № 1. - С. 46-49.

307. Лукьянчук В. Д. Антигипоксанты: состояние и перспективы / В. Д. Лукьянчук, Л. В. Савченкова // Эксперим. и клинич. фармакология. 1998. - Т. 64, № 4. - С. 72-79.

308. Островская В. Ф. Применение димефосфона в комплексном лечении больных генерализованным пародонтитом средней степени тяжести / Островская В. Ф. // Забайкальский мед. вестн. - 2007. - № 3. - С. 13-15.

309. Камчатнов П. Р. Хронические расстройства мозгового кровообращения. Возможности метаболической терапии / П. Р. Камчатнов. - М., 2008. 39 с.

310. Зозуля И. С. Нейропротекторы, ноотропы, нейрометаболиты в интенсивной терапии поражений нервной системы / И. С. Зозуля, В. Ю. Мартынюк, О. А. Майструк. - К., 2005. - 130 с.

311. Острая церебральная недостаточность / В. И. Черний, В. Н. Ельский, Г. А. Городник, А. Н. Колесников. - Донецк, 2007. - 511 с.

312. Гусев Е. И. Ишемия головного мозга / Е. И. Гусев, В. И. Скворцова. - М. : Медицина, 2001. - 328 с.

313. Беленичев И. Ф., Бухтиярова Н. В. Современные подходы к терапии острого нарушения мозгового кровообращения, основные стратегии нейропротекции // Новости медицины и фармации. - 2008. - № 5(237). - C.2147.

314. Воронина Т. А. Гипоксия и память. Особенности эффектов и применения ноотропных препаратов / Воронина Т. А. // Вестн. РАМН. - 2000. № 9. - С. 531-537.

315. Пирадов М. А. Нейрореаниматология инсульта: состояние проблемы / Пирадов М. А. // Вестн. РАМН. - 2003. — № 12. - С. 68-70.

316. Chapman C. A. Neuroprotective approaches to the treatment of neurodegenerative disorders / C. A. Chapman, C. W. Olanov. - London : Academic Press Limited, 2002. - 360 p. 
317. Беленичев И. Ф., Бухтиярова Н. В. Антиоксидантная модуляция показателей сопряженных систем NO и восстановленных тиолов в головном мозге крыс // Нейронауки: теоретические и клинические аспекты. - 2013. 一 Т. 9, № 1. - С.123-129.

318. Антиоксиданты: клинико-фармакологический аспект / И. С. Чекман, И. Ф. Беленичев, Н. А. Горчакова, Л. И. Кучеренко // Укр. мед. часопис. 2014. — № 1 (99) - С. 23-33.

319. Лукьянова Л. Д. Фармакологическая коррекция митохондриальной дисфункции при гипоксии / Лукьянова Л. Д. // Проблемы гипоксии: молекулярные, физиологические и клинические аспекты / под ред. Л. Д. Лукьяновой, И. Б. Ушакова. - М. : Истоки, 2004. - С. 456-487.

320. Бєленічев І. Ф. Антиоксиданти: сучасне уявлення, перспективи створення / Бєленічев І. Ф., Коваленко С. І., Дунаев В. В. // Ліки. — 2002. — № 1. — C. 25-29.

321. Церебропротекторные эффекты антиоксидантов при нейроиммуноэндокринных нарушениях, связанных с токсическим действием кислородных радикалов / Дунаев В. В., Губский Ю. И., Беленичев И. Ф. [и др.] // Совр. пробл. токсикологии. - 2004. - № 1. - С. 33-39.

322. Полевик И. В. Церебропротективные эффекты эмоксипина при моделировании мозговых сосудистых расстройств / Полевик И. В. // Фармакол. вісник. - 1999. - № 5. - С. 29-33.

323. Поварова О. В. Влияние фенил-t-бутилнитрона, мексидола и нооглютила на зону поражения мозга и память крыс после окклюзии средней мозговой артерии / Поварова О. В., Гаритова Т. Л., Каленикова Е. И. // Эксперим. и клинич. фармакология. - 2004. - Т. 67, № 1. - С. 3-6.

324. Веселинский И. Ш. Применение корректоров ПОЛ и гемостаза в комплексном лечении больных с цереброваскулярными расстройствами / Веселинский И. Ш., Сонник А. В. // Журн. неврологии и психиатрии. - 1997. T. 97, № 2. - С. 51-54.

325. Belenichev I. F., Bukhtiyarova N. V. Molecularly-biochemical and neuropsychophysiological aspects of neuroprotective activity of mexidol during chronic immobilizational stress // Molecular Pharmacology. - 2013. - № 2. - P.1-6.

326. Чеснокова Н. П. Возможности эффектиного использования антиоксидантов и антигипоксантов в экспериментальной и клинической медицине / Н. П. Чеснокова, Е. В. Понукалина, М. Н. Бизенкова, Г. А. Афанасьева // Успехи совр. естествознания. — 2006. — №8. - С. 18-25.

327. Бєленічев I. Ф. Дослідження церебропротективних властивостей деяких похідних 3-метил-1,2,4-триазоліл-5-тіокарбонових кислот за умов моделювання ішемічного пошкодження головного мозку / Бєленічев І. Ф. // Одеський мед. журн. - 1998. — № 4 (48). — С. 5-9.

328. Беленичев И. Ф. Фармакокоррекция патобиохимических нарушений мозговой ткани в период моделирования острой ишемии и реперфузии мозговой ткани некоторыми производными 1,2,4-триазола / Беленичев И. Ф. // Актуальні питання фармац. та мед. науки і практики. - Запоріжжя, 1998. - Вип. 2, т. II. - С. 10-16. 
329. Болгов Д. М. Вплив тіотріазоліну на перебіг вільнорадикальних реакцій у структурах мозку щурів з компресійною травмою / Болгов Д. М., Савченкова Л. В. // Ліки. - 2001. - № 5-6. - С. 18-24.

330. Классификация, механизмы действия и перспективы создания антиоксидантных средств : (обзор) / Беленичев И. Ф., Коваленко С. И., Мазур И. А. [и др.] // Актуальні питання фармац. та мед. науки і практики. Запоріжжя, 1999. - Вип. 4. - С. 61-75.

331. Беленичев И. Ф. Некоторые аспекты противоишемического действия тиотризолина в условиях экспериментального нарушения мозгового кровообращения / Беленичев И. Ф., Мазур И. А., Коваленко С. И. // Акт. питання фармац. та мед. науки і практики. - Запоріжжя. - 2002. - Вип. VIII. - C. 43-48.

332. Лущак В.И. Окислительный стресс и механизмы защиты от него / В. И. Лущак // Биохимия. - 2001. - Т. 66, № 5. - С. 592-609.

333. Беленичев И. Ф. Влияние тиотриазолина на развитие нейроиммуноэндокринных нарушений, вызванных гиперпродукцией активных форм кислорода при ишемии головного мозга / Беленичев И. Ф., Мазур И. А., Чекман И. С. // Аллергология и иммунология. - 2006. - Т. 7, № 33. - С. $272-274$.

334. Метаболитотропные препараты / [Мазур И. А., Беленичев И. Ф., Чекман И. С., Волошин Н. А. и др.]. - Запорожье, 2007. - 304 с.

335. Belenichev I. F., Bukhtiyarova N. V., Kucherenko L. I. Effect of spin trapping compound $\mathrm{PBN}$ and Thiotriazoline on the outcome from experimental middle cerebral artery occlusion// Molecular Pharmacology. — 2010. — № 3. P. 90-95.

336. Резніченко Г. І. Ефективність застосування тіотриазоліну та пірацетаму в терапії хронічної плацентарної недостатності / Резніченко Г. І. // Педіатрія, акушерство та гінекологія. — 2004. — № 1. - С. 110-116.

337. Трофименко А. И. Моделирование церебральной ишемии посредством коагуляции средней мозговой артерии у крыс / А. И. Трофименко, А. Х. Каде, В. П. Лебедев // Фундаментальные исследования. — 2012. — № 2. - С. 215-218.

338. Омельянчик Л. О. Вивчення антиоксидантної та протиішемічної дії 4-тіо похідних хінальдину на моделі гострого порушення мозкового кровообігу / Омельянчик Л. О., Бєленічев І. Ф., Бражко О. А. // Ліки. - 2000. № 1-2. - С. 36-40.

339. Функціональні і патобіохімічні зміни мозкової тканини за умов експериментальної ішемії та їх корекції сумішшю тіотриазоліну та пірацетаму / Бєленічев І. Ф., Мазур І. А., Стець В. Р. [та ін.] // Фізіол. журн. - 1998. - Т. 44, № 3. - С. 16-19.

340. Состояние гематоэнцефалического барьера при инсультах у больных с артериальной гипертензией в условиях фармакокоррекции / Беленичев И. Ф., Дунаев В. В., Мазур И. А. [и др.] // Врачеб. дело. — 1995. — № 5-6. - С. 124-126. 
341. Долгинцев M. Е. Нейротропные и иммунотропные эффекты L-лизина : aвтореф. дис. на соискание ученой степени канд. мед. наук / М. Е. Долгинцев. - Курск, 2007. - 24 с.

342. Долгинцев M. Е. Влияние аминокислоты L-лизина на различные виды боли / М. Е. Долгинцев // Материалы XI межвуз. конф. молодых ученых «Актуальные проблемы патофизиологии». - СПб., 2005. - С. 18-20.

343. Belenichev I. F., Bukhtiyarova N. V., Kucherenko L. I The endotheliumprotective effect of 3-methyl-1,2,4-triazolyl-5-thioacrtate(S)-2,6diaminohoexanic acid (lysinium) :Effects on the expression of vascular endothelial growth factor(VEGF) and the characteristics of the endotheliocytes of the cerebral vessels of animals with cerebral ischemia // Neurochemical Journal. - 2013. - Vol.7, № 4. - P. 296-303.

344. Chang Y. F. Lysine metabolism in the human and the monkey: demonstration of pipecolic acid formation in the brain and other organs / Y. F. Chang // Neurochem. Res. - 1982. — Vol. 7, N 5. - P. 577-588.

345. Chang Y. F. L-lysine is a barbiturate-like anticonvulsant and modulator of the benzodiazepine receptor / Y. F. Chang, X. M. Gao // Neurochem. Res. 1995. - Vol. 20, N 8. - P. 931-937.

346. Chang Y. F. Modulation of benzodiazepine by lysine and pipecolic acid on pentylenetetrazol-induced seizures / Y. F. Chang, V. Hargest, J. S. Chen // Life Sci. - 1988. - Vol. 43, N 15. - P. 1177-1188.

347. Chronic L-lysine develops anti-pentylenetetrazol tolerance and reduces synaptic GABAergic sensitivity / Y. F. Chang, Y. Wang, R. K. Cauley, X. M. Gao // Eur. J. Pharmacol. - 1993. - Vol. 233, N 2-3. - P. 209-217.

348. Flodin N. W. The metabolic roles, pharmacology, and toxicology of lysine / N. W. Flodin // J. Am. Coll. Nutr. - 1997. - Vol. 16, N 1. - P. 7-21.

349. Gao X. M. Enhancement of benzodiazepine receptor binding by L-lysine is chloride-dependent and due to increase in binding affinity / X. M. Gao, Y. F. Chang // Eur. J. Pharmacol. - 1989. - Vol. 173, N 2-3. - P. 197-200.

350. Совченкова Л. В. Деякі аспекти енергетичного обміну в тканині мозку при гіпоксичному синдромі та фармакокорекції // Ліки. - 1999. — №3-4. C. 59-62.

351. Belenichev I. F., Bukhtiyarova N. V. The thiol-disulfide balance and the nitric oxide system in the brain tissue of rats subjectedto experimental acute impairment of cerebral blood flow: the therapeutic effects of nootropic drugs // Neurochemical Journal. — 2014. - Vol. 8, No. 1. — P. 24-27.

352. Ярош О. К., Дудко О. Т. Комбінована дія аміналону та пірацетаму на процесі пам’яті й інші функції ЦНС // Ліки. - 2003. - №1-2. - С. 59-65.

353. Середенин С. Б., Мелкумян Д. С., Вальдман Е. А. влияние афобазола на содержание BDNF в структурах мозга инбредных мышей с различным фенотипом эмоционально-стрессовой реакции // Экспер. и клин. фармакол. 2006. - T. 69 , №3. - С. 3-6.

354. Ахапкина В. И. Экспериментальная и клиническая фармакология препарата Фенотропил. ХІ Российский национальный конгресс «Человек и лекарство». Тезисы докладов. 19-23 апреля 2004. - М., 2004. - С.70. 
355. Ахапкина В. И., Воронина Т. А. Спектр фармакологических эффектов фенотропила // Фарматека - 2-5. - № 13. - С. 19-25.

356. Момолов С. Н. Современные тенденции развития психофармакологии // Журн. неврол. и психиатр. им. С. С. Корсакова. - 1998. - № 5. - С. 1219.

357. Антонова М. И., Прокопов А. А., Берлянд А. С. Количественный анализ фенотропила в биологических объектах методом газожидкостной хроматографии. // Химико-фармацевтический журн. - 2003. - № 37, Т. 11. — C. 7-8.

358. Ахапкина В. И. Адаптогенное действие ноотропных лекарственных средств в экспериментальном стрессе у животных. // Фарматека. - 2005. № 13. - C. 19-25.

359. Ахапкина В. И. Адаптогенное действие ноотропных препаратов. // Рос. мед. журн. - 2005. — № 3. - С. 40-43.

360. Ахапкина В. И., Воронина Т. А. Сравнительная характеристика ноотропной активности препарата Фенотропил. XI Российский национальный конгресс «Человек и лекарство». Тезисы докладов. 19-23 апреля 2004. — M., 2004. - C. 70.

361. Краснов В. Н., Коханов В. П., Ахапкина В. И. Фенотропил как адаптогенное и ноотропное средство. ХІ Российский национальный конгресс «Человек и лекарство». Тезисы докладов. 19-23 апреля 2004. - М., 2004. - С. 615 .

362. Вахов В. П., Ахапкина В. И. Использование Фенотропила у лиц, работающих в напряженных экстремальных условиях. XI Российский национальный конгресс «Человек и лекарство». Тезисы докладов. 19-23 апреля 2004. - M., 2004. - C. 603.

363. Малюгин В. Н., Черпанов Е. Г., Ахапкина В. И. Изучение влияния препарата Фенотропил на функциональное сотояние и работоспособность в процессе учебно-тренировочной деятельности. XI Российский национальный конгресс «Человек и лекарство». Тезисы докладов. 19-23 апреля 2004. M., 2004. - C. 617.

364. Разсолов Н. А., Чижов А. Я., Потиевский Б. Г., Потиевская В. И. Нормобарическая гипокситерапия. Методические рекомендации для авиационных врачей. - М., 2002.

365. Португалов С. Н., Ахапкина В. И. Результаты применения Фенотропила в практике спортивной медицины. XI Российский национальный конгресс «Человек и лекарство». Тезисы докладов. 19-23 апреля 2004. москва. С. 621.

366. Бельская Г. Н., Деревянных Е. А., Макарова Л. Д., Крылова Л. Г., Попов В. Д. опыт применения фенотропила у больных в остром периоде инфаркта головного мозга / / Атмосфера. Нервные болезни. — 2005. — №1 . C. 25-28.

367. Герасимова О. А., Чичановская Л. В., Слезкина Л. А. Клиникоиммунологические аспекты влияния фенотропила на последствия цере- 
брального инсульта // Журн. неврол. и психиатр. им. С. С. Корсакова. 2005. - № 5. - C. 63-64.

368. Савченко А. Ю., Захарова Н. С., Степанов И. Н. Лечение последствий органического поражения головного мозга фенотропилом. // Журню неврол. и психиатр. им. С. С. Корсакова. - 2005. - № 12. - С. 22-26.

369. Густов А. В., Смирнов А. А., Коршунова Ю. А., Андриянова Е. В. Фенотропил в лечении дисциркуляторной энцефалопатии. // Журн. неврол. и психиатр. им. С. С. Корсакова. - 2006. - №5. - С. 34-38.

370. Спасенков Б. А., Ахапкина В. И., Спасенков М. Г. Применение ноотропного препарта Фенотропил в комплексной дисциркуляторной энцефалопатии. XI Российский национальный конгресс «Человек и лекарство». Тезисы докладов. 19-23 апреля 2004. - М., 2004. - С. 349.

371. Калинский П. П., Соловьев А. П. Опыт применения фенотропила при лечении астенического синдрома и вегетативных нарушений острого периода закрытой черепно-мозговой травмы. Отчет об апробации препарата в Главном клиническом госпитале Тихоокеанского флота. - Владивосток, 2005.

372. Чикина Е. С., Левин В. В. Черепно-мозговые травмы: применение современных ноотропных препаратов в острый период и при лечении посттравматической энцефалопатии // Врач. — 2005. - №11. - С. 53-58.

373. Одинак М. М., Емельянов А. Ю., Ахапкина В. И. Применение Фенотропила при лечении последствий черепно-мозговых травм. XI Российский национальный конгресс «Человек и лекарство». Тезисы докладов. 19-23 апреля 2004. - М., 2004. - С. 278.

374. Алешина Н. В., Степанов В. П., Филипова С. Ю. Применение препарата фенотропил для лечения астенодепрессивных синдромов при отдаленных последствиях черепно-мозговых травм // Трудный пациент. - 2005. №5. - С. 15-18.

375. Селянина Н. В., Шутов А. А. опыт применения фенотропила у больных с начальными проявлениями недостаточности мозгового кровоснабжения мозга. // Атмосфера. Нервные болезни. - 2005. - № 4. - С. 30-32.

376. Ахапкина В. Н., Федин А. И., Аведисова А. С., Ахапкин Р. В. Эффективность Фенотропила при лечении астенического синдрома хронической усталости // Атмосфера. Нервные болезни. - 2004. - № 3. - С. 28-31.

377. Колосова С. А., Воробьева О. В., Ахапкина В. И. Результаты клинических иследований применения Фенотропила при лечении астенических расстройств психогенного генеза. ХI Российский национальный конгресс «Человек и лекарство». Тезисы докладов. 19-23 апреля 2004. - М., 2004. - C. 194.

378. Волошин В. М., Ахапкина В. И. Эффективность малых доз Фенотропила в общесоматической практике. ХI Национальный конгресс «Человек и лекарство». Тезисы докладов. 19-23 апреля 2004. - М., 2004. - С. 112.

379. Иванец Н. Н., Ахапкина В. И. Применение Фенотропила у больных хроническим алкоголизмом. XI Российский национальный конгресс «Человек и лекарство». Тезисы докладов. 19-23 апреля 2004. - М., 2004. - С. 169. 
380. Александровский Ю. А., Аведисова А. С., Ахапкина В. И. Клиникофизиологическая оценка эфективности ноотропного препарата Фенотропил в психиатрической практике. XI Российский национальный конгресс «Человек и лекарство». Тезисы докладов. 19-23 апреля 2004. - М., 2004. - C.59.

381. Бєленічев І. Ф., Коваленко С. І., Дунаев В. В. Антиоксиданти: сучасне уявлення, перспективи створення // Ліки. - 2002. - №1. - С. 25-29.

382. Владимиров Ю. А., Арчаков А. И. Перекисное окисление липидов в биологических мембранах. - М.: Наука, 1972. - 252 с.

383. Floyd R. A. Interaction of -phenyl-N-tret-butyl nitrone and alternative electron acceptors with complex I indicate a substrate reduction site upstream from rotenone binding site // J. Neurochem. - 2000. - Vol. 71, № 11. P. 2549-2557.

384. Allan S. M., Parker L. C., Collins B. Cortical cell death induced by IL-1 is mediated via actions in the hypothalamus of the rat // Proc. Natl. Acad. Sci. USA. - 2000. - Vol. 97. - P. 5580-5585.

385. Янишевский С. Н., Одинак М. М., Вознюк И. А., Онищенко Л. С. Клиническая и морфологическая оценка эффективности препаратов с метаболической активностью при острой церебральной ишемии. - В кн.: Современные подходы к диагностике и лечению нервных и психических заболеваний. - СПб, 2000. - $458 \mathrm{c}$.

386. Xue D., Slivka A., Buchan A. M. // Stroke. — 1998. — № 29. - P. 12-17.

387. Полевик И. В. Церебропротективные эффекты эмоксипина при моделировании мозговых сосудистых расстройств // Фармакол. вісн. - 1999. № 5. - C. 29-33.

388. Поварова О. В., Гаритова Т. Л., Каленикова Е. И. Влияние фенил-tбутилнитрона, мексидола и ноогютила на зону поражения мозга и память крыс после окклюзии средней мозговой артерии // Эксперим. и клин. фармакол. - 2004. - Т. 67, № 1. - С. 3-6.

389. Веселинский И. Ш., Сонник А. В. Применение корректоров ПОЛ и гемостаза в комплексном лечении больных с цереброваскулярными расстройствами // Журн. неврологии и психиатрии. - 1997. - Т. 97, № 2. - С. 5154 .

390. Vemuganti R., Dempsey R. J., Bowen K. K. Inhibition of intercellular adhesion molecule-1 protein expression by antisense oligonucleotides is neuroprotective after transient middle cerebral artery occlusion in rat // Stroke. - 2004. Vol. 35, № 1. - P. 179-184.

391. Лавлинский А. Д. Реамберин (пострегистрационные клинические исследования 1999-2005 г.). - 2005. - С. Петербург. - 143 с.

392. Левицкий Е. Л. Пути и механизмы реализации антиоксидантного эффекта в клетке // Фармакол. вісн. - 1998. - № 2. - С. 68-71.

393. Floyd R. A. Free radicals damage to protein and DNA: Mechanisms involved and relevant observations on brain undergoing oxidative stress // Ann. Neurol. - 2002. - Vol. 32, № 2. - P. 22-37. 
394. Островская Р. У., Гудашева А. В., Воронина Т. А. Стратегия создания дипептидных нейропсихотропных лекарственных препаратов // Экспер. и клин. фармакол. - 2003. - Т. 66, № 2. - С. 15-19.

395. Belenichev I. F., Sokolik E. P. Nitrozine stress and neurological disorders in experimental alcohol intoxication and their pharmacological correction by neuropeptides// Mol. Pharmacology. — 2011. — Vol.11, №4. - P.12-17.

396. Гудашева Т. А. Стратегия создания дипептидных нейропсихотропных лекарственных препаратов / Гудашева Т. А., Сколдинов А. П. // Эксперим. и клинич. фармакология. - 2003. - Т. 66, № 2. - С. 15-19.

397. Маньковский Н. Б. Современный подход к терапии когнитивных нарушений. Нейрометаболическая терапия / Н. Б. Маньковский, Н. Ю. Бочинская. - К., 2005. - 47 с.

398. Динзбург А. Л. Стресс-протективный эффект нейропептидов у обезьян / Динзбург А. Л., Чирков А. М., Чиркова С. К. // Патологич. физиология и эксперим. терапия. - 1995. - Вып. 1. - С. 19-21.

399. К Клодт П. М. Изучение эффектов гептапептида селанка; на содержание моноаминов и: их метаболитов в структурах мозга крыс Wistar / Клодт П. М., Кудрин В. С., Наркевич В. Б. // Психофармаколия и биологич. наркология. - 2005. - Т. 5, № 3. - С. 984-988.

400. Кортексин: Новые возможности в лечении ишемического инсульта / Скоромец А. А., Стаховская JI. В., Белкин А. А. [и др.] // Нейропротекция при острой и хронической недостаточности мозгового кровообращения. СПб., 2007. - С. 7-16.

401. Каскадное последействие при введении пептида, вызывающего дельта-сон / Судаков К. В., Кохлан Дж. П., Котов А. В. [и др.] // Бюл. эксперим. биологии и медицины. - 1995. - Т. 119, № 1. - С. 6-9.

402. Шабанов П. Д. Пептидные нейропротекторы / Шабанов П. Д. // Фармакология - практическому здравоохранению. - СПб., 2007. - С. 233.

403. Сравнительное изучение поведенческих эффектов кортексина и церебролизина при их введении в желудочки мозга и внутрибрюшинно / Шабанов П. Д., Лебедев А. А., Павленко В. П. [и др.] // Эксперим. и клинич. фармакология. - 2007. - Т. 70, № 3. - С. 13-19.

404. Шабанов П. Д. Фармакология пептидных препаратов / Шабанов П. Д. // Мед. акад. журн. - 2008. - Т. 8, № 4. - С. 3-24.

405. Шабанов П. Д. Психофармакологический профиль ноотропоподобных пептидов / Шабанов П. Д. // Психофармакология и биологич. наркология. 2009. - Т. 9, вып. 1-2. - С. 2517-2523.

406. Идентификация в мозге крыс цикло-пролилглицина, нового эндогенного пептида с ноотропной активностью / Гудашева Т. А., Бойко С. С., Акпаров В. Х. [и др.] //Докл. АН. - 1996. — Т. 350, № 6. - С. 834-836.

407. Метаболизм пептида PGP при разных способах введения / Золотарев Ю. А., ЖЖуйкова С. Е., Ашмарип И. П. [и др.] // Бюл. эксперим. биологии и медицины. - 2003. - Т. 135, № 4. - С. 423-426.

408. Новикова Д. А. Влияние комплексной терапии на содержание нейротрофических факторов у новорожденных с церебральной ишемией / Новикова Д. А. // Рос. педиатрич. журн. - 2012. — № 5. - С. 8-12. 
409. Мамчур В. И. Церебропротекция: возможности медикаментозной защиты ишемизированного мозга / Мамчур В. И., Дронов С. Н., ЗЖилюк В. И. // Раціональна фармакотерапія. - 2008. - № 3. - С. 1-7.

410. Долговременное действие пептидных регуляторов: отложенные и инверсные эффекты холецистокинина-4 и -3 / Ашмарин И. П., Данилова Р. А., Рудько О. И. [и др.] // Мед. акад. журн. - 2004. — Т. 4, № 1. - С. 4-13.

411. Дмитриенко Д. В. Церебропротекция нейропептидами острейшего периода ишемического инсульта / Дмитриенко Д. В., Шетекаури С. А. // Нейропротекция при острой и хронической недостаточности мозгового кровообращения / под ред. А. А. Скоромца, М. М. Дьяконова. - СПб. : Наука, 2007. - С. 42-47.

412. Островская Р. У. Эволюция проблемы нейропротекции / Островская Р. У. // Эксперим. клинич. фармакология. - 2003. - Т. 66, № 2. - С. 32-37.

413. Cerebrolysin reduces microglial activation in vivo and in vitro: a potential mechanism of neuroprotection / Alvarez X. A., Lombardi V. R., FernandezNovoa L. [et al.] // J. Neural Transm. Suppl. — 2000. — Vol. 59. - P. 281292.

414. Cerebrolysin improves brain bioelectrical activity pattern and cognitive functioning in traumatic brain injury and in senile dementia / Alvarez X. A., Sampedro C., Perez P. [et al.] // Int. J. Neuropharmacol. — 2002. — Vol. 5. — P. 92.

415. Олесюк-Нехамес А. Г. Значення нейротрофічної терапії з застосуванням церебролізину для покращення лікування і прогнозу хворих із травмами периферичних нервів / А. Г. Олесюк-Нехамес // Міжнар. неврологіч. журн. - 2009. — № 3 (25). - С. 45-48.

416. Селанк и короткие пептиды семейства тафтсина в регуляции адаптивного поведения при стрессе / Козловская М. М., Козловский И. И., Вальдман Е. А., Середенин С. Б. // Рос. физиол. журн. им. И. М. Сеченова. - 2002. T. 88, № 6. - С. 751-761.

417. Влияние дипептида вилона на устойчивость крыс к эмоциональному стрессу / Коплик Е. В., Мещеряков А. Ф., Перцов С. С. [и др.] // Рос. физиол. журн. им. И. М. Сеченова. - 2002. - Т. 88, № 11. - С. 1440-1452.

418. Ишемия головного мозга в медицине критических состояний. Нейропротекция. (Патофизиология, терминология, характеристика препаратов) : метод. рекомендации / [Черний В. И., Колесников А. Н., Городник Г. А. и др.]. - К., 2007. - 72 с.

419. Левин О. С. Влияние кортексина на нейрофизиологические и двигательные нарушения при дискуляторной энцефалопатии / Левин О. С., Сагова M. M. // Terra Medica - Кортексин. - 2004. - № 1. - С. 15-19.

420. Цыган В. Н. Влияние кортексина на память и внимание / Цыган В. Н., Богословский М. М. // Воен.- мед. журн. - 2004. — № 9. - С. 46-48.

421. Применение кортексина в лечении синдрома нарушения внимания с гиперреактивностью у детей и подростков : метод. рекомендации / [Чутко Л. С., Кропотов Ю. Д., Рыжак Г. А. и др.]. - СПб., 2003. - 40 с. 
422. Влияние пептида семакса на выживаемость культивируемых клеток феохромоцитомы крысы при окислительном стрессе / Сафарова Э. Р., Шрам С. И., Золотарев Ю. А., Мясоедов Н. Ф. // Бюл. эксперим. биологии и медицины. - 2003. - Т. 135, № 3. - С. 309-313.

423. Гектапептид семакс стимулирует экспрессию BDNF в различных отделах мозга крысы in vivo / Долотов О. В., Середенина Т. С., Левицкая Н. Г. [и др.] // Докл. АН. - 2003. - Т. 391, № 1. - С. 131-134.

424. Беленичев И. Ф. Роль белков теплового шока в реализации молекулярнобиохимических механизмов нейропротенкции// Фармакологія та лікарська токсикологія. - 2013. - № 6 (36). - С.18-23.

425. Левин О.С. Диагностика и лечение дисциркуляторной энцефалопатии / О.С. Левин // Мет пособие. - М., 2010. -8 с.

426. Материалы экспериментальных и клинических испытаний препарата «Цереброкурин®» / [Ена Л. М., Кузнецова С. М., Кузнецов В. Н. и др.]. К., 1997. - 115 c.

427. Сергиенко А. Н. Применение препарата «Цереброкурин®» при лечении дегенеративно-дистрофических заболеваний сетчатки / Сергиенко А. Н. // Новости медицины и фармации. - 2001. - № 12 (97). — С. 8.

428. Пептиды в регуляции межполушарной асимметрии мозга у млекопитающих и их возможные нейрохимические механизмы (эволюционные аспекты исследования) / Т. Н. Соллертинская, М. В. Шорохов, Н. Ф. Мясоедов, Л. А. Андреева // Ассиметрия. - 2013. - Т. 7, № 2. - С. 4-15.

429. Евтушенко О. С. Ноотропы и нейропротекторы в современной клинической нейрофармакологии / О. С. Евтушенко // Междунар. неврологич. журн. - 2013. - № 3 (57). - С. 20-27.

430. Цитопротективная и нейротрофическая терапия при церебральном инсульте / М. Ю. Мартынов, А. Н. Ясаманова, И. А. Щукин [и др.] // Клиницист. - 2013. - № 1. - С. 14-20.

431. Евтушенко О. С. Результаты проведения клинической апробации препарата цереброкурин в донецком областном клиническом центре нейрореабилитации детей с органическими заболеваниями ЦНС / Евтушенко О. С. // Цереброкурин. - К., 2006. - С. 23-34.

432. Сиротюк М. В. Цереброкурин и гипербарическая оксигенация в лечении детского церебрального паралича / Сиротюк М. В. // Новости медицины и фармации. - 2004. - № 18 (158). - С. 13.

433. Волкова Н. М. Возрастные особенности адаптации автономных механизмов регуляция сердечного ритма при умеренном воздействии атмосферной гипоксии / Н. М. Волкова // Астана Мед. журн. - 2013. — № 1 (75). — С. $53-59$.

434. Вивчення впливу цереброкурину та ліпіну на зміни мітохондрій тканини мозку щурів в умовах експериментальної моделі гіпоксії / Знаменська Т. К., Похилько В. І., Розова К. В. [та ін.] // Лікарська справа. - 2006. - № 8. - С. 84-88.

435. Жћилюк В. И. Роль эндотелия в механизмах нейропротективного действия ноотропных средств в условиях гипергликемии / В. И. Жилюк, 
В. И. Мамчур // Журн. НАМН України. - 2013. - Т. 19, № 2. C. 184-193.

436. Wilson D. M. Ultrastructure and cytochemistry of nerve cells / D. M. Wilson // J. Physiol. - 2006. - Vol. 239. - P. 571-594.

437. Hartl F. U. Molecular chaperons in cellular protein folding / Hartl F. U. // Nature. - 1999. - Vol. 381. - P. 571-580.

438. Скулачев В. П. Эволюция биологических механизмов запасания энергии / Скулачев В. П. // Соросовский образоват. журн. - 1997. - № 5. - С. 11-19.

439. Fonseca S. G. WFS1 is a novel component of the unfolded protein response and maintains homeostasis of the endoplasmic reticulum in pancreatic beta-cells / S. G. Fonseca, M. Fukuma, K. L. Lipson // J. Biol. Chem. - 2005. - Vol. 280. - P. 39609-39615.

440. Митохондриальный белковый профиль и его роль в патологических процессах / Е.А. Костерина, И. И. Козенков, В. А. Касымов, П. А. Каменский // Бюл. сиб. медицины. - 2013. - Т. 12, № 3. - С. 5-17.

441. Беленичев И. Ф. Фармакокоррекция нейропептидами нитрозирующего стресса и неврологических нарушений при экспериментальной алкогольной интоксикации / И. Ф. Беленичев, Е. П. Соколик // Фармакологія та лікарська токсикологія. - 2011. - № 5. - С. 26-27.

442. Беленичев И. Ф. Фармакологическая модуляция системы окиси азота при моделировании хронической алкогольной интоксикации у крыс / И. Ф. Беленичев, Е. П. Соколик // Эксперим. и клинич. фармакология. 2011. - № 10. - С. 43-45.

443. Егоров А. Н. Роль нитрозирующего стресса в механизмах нейродеструкции в условиях пренатальной алкогольной интоксикации и пути фармакокоррекции возникающих нарушений / А. Н. Егоров, И. Ф. Беленичев, Е. П. Соколик // Запорож. мед. журн. - 2012. — № 5. - С. 25-28.

444. Боголепов Н. Н. Ультраструктура мозга при гипоксии / Н. Н. Боголепов. М. : Медицина, 1979. - 163 с.

445. Бабичев В. Н. Физиологический смысл множественности рецепторов половых гормонов / В. Н. Бабичев // Биомед. химия. - 2005. - Т. 51, вып. 6. - C. 603-616.

446. Presence of constitutive and inducible forms of heat shock protein 70 in the cerebral cortex and hippocampal synapses / Moon I. S., Park I. S., Schenker L. T. [et al.] // Cereb. Cortex. 2001. - Vol. 11, N 3. - P. 238-248.

447. Андреева Л. И. Теоретическое и прикладное значение белков теплового шока 70 кДа; возможность практического применения и фармакологической коррекции / Андреева Л. И. // Обзоры по клинич. фармакологии и лек. терапии. - 2002. - Т. 1, № 2. - С. 2-18.

448. HSP70 peptidembearing and peptide-negative preparations act as chaperokines / Asea A., Kabingu E., Stevenson M.A. [et al.] // Cell Stress Chaperones. 2000. - Vol. 5, N 5. - P. 425-431. 
449. Центральные эффекты белка теплового шока с молекулярной массой 70 кДа / Андреева Л. И., Шабанов П. Д., Маргулис Б. А. [и др.] // Психофармакол. и биологич. наркология. - 2005. - Т. 5, № 1. - С. 794-803.

450. Виноградов В. М. Фармакологические средства для профилактики и лечения гипоксии (состояние проблемы) / Виноградов В. М. // Кислородный гомеостазис и кислородная недостаточность. - К. : Наук. думка, 1978. — С. 183-192.

451. Беленичев И. Ф. Структурно-функциональные и биохимические изменения мозговой ткани в условиях экспериментальной гипоксии головного мозга / Беленичев И. Ф., Башкин И. Н., Визир В. А. / Компенсаторноприспособительные механизмы внутренних органов и головного мозга в норме, патологи и эксперименте. - Тюмень, 1991. - С. 104-110.

452. Сопряженность изменений метаболизма в мозговой ткани и миокарде при экспериментальной гипоксии головного мозга / Беленичев И. Ф., Башкин И. Н., Визир В. А., Дунаев В. В. // Сб. работ «Коррекция сердечнососудистых нарушений в клинике и эксперименте». - Винница, 1991. C. $7-10$.

453. Механизмы участия митохондрий в развитии патологических процессов, сопровождающихся ишемией и реперфузией / Судаков Н. П., Никифоров С. Б., Константинов Ю. М. [и др.] / Бюл. ВСНЦ РАМН. - 2006. - № 5. C. 332-336.

454. Belenichev I. F., Bukhtiyarova N. V., Pavlov S. V. Malate-aspartate shunt in neuronal adaptation to ishemic conditions: molecular-biochrmical mechanisms of activation and regulation // Neurochemical Journal 2012. — № 1, Vol. 29. - C. 28-34.

455. Ершиков С. М. Интенсивность глюконеогенеза и содержание углеводов в ткани печени крыс при гипокинезии / Ершиков С. М. // Вопр. мед. хими. - 1987. - Т. 33, № 2. - С. 87-90.

456. Биохимические аспекты когнитивного дефицита при различных заболеваниях / Т. Т. Киспаева, М. А. Грудень, Н. П. Черных, В. И. Скворцова // Журн. неврологии и психиатрии. - 2008. - Т. 108, № 11. - С. 102-105.

457. The prognostic value of domain-specific cognitive abilities in acute first-ever stroke / Nys G. M., van Zandvoort M. J., de Kort P. L. [et al.] // Neurology. - 2005. - Vol. 64, N 5. - P. 821-827.

458. O’Brien J. T. Vascular Cognitive Impairment / O’Brien J. T. // Neurology. 2004. - Vol. 63. - P. 1618-1623.

459. Swank M W (2000). Conditioned c-Fos in mouse NTS during expression of a learned taste aversion depends on contextual cues / M W. Swank // Brain Research. - 2000. - Vol. 862, (1-2). - P. 138-144.

460. Wiedenmayer C. P. Developmental changes in c-fos expression to an agespecific social stressor in infant rats / Wiedenmayer C. P., Barr G. A. // Beh. Brain Res. - 2001. - Vol. 126. - P. 147-157.

461. Protein N-acylation H2O2-mediated covalent modification of protein by lipid peroxidation-derived saturated aldehydes / K. Ishino, T. Shibata, T. Ishii, Y. T. Liy // Chem Res. Toxicol. — 2008. - Vol. 21. — P. 1261-1270. 
462. Identification and characterization of a novel human methyltransferase modulating Hsp70 protein function through lysine methylation / Jakobsson M. E., Moen A., Bousset L. [et al.] // J. Biol. Chem. — 2013. — Vol 27 (288). P. 27752-27763.

463. Opposing Roles for ATF2 and c-Fos in c-Jun-Mediated Neuronal Apoptosis / Y. Zhongmin, G. Shoufang, L. Jingyan [et al.] // Mol. and Cell. Biol. — 2009. Vol. 29, N 9. - P. 2431-2442.

464. Activating transcription factor 3 up-regulated by c-Jun NH(2)-terminal kinase/c-Jun contributes to apoptosis induced by potassium deprivation in cerebellar granule neurons / Y. Mei, Z. Yuan, B. Song, D. Li [et al.] // Neuroscience. - 2008. - Vol. 151. - P. 771-779.

465. Berretta S. Infralimbic cortex activation increases c-Fos expression in intercalated neurons of the amygdala / S. Berretta, H. Pantazopoulos, M. Caldera, P. Pantazopoulos // Neuroscience - 2005. - Vol. 132. - P. 943953.

466. C-FOS suppresses ovarian cancer progression by changing adhesion / L. Oliveira-Ferrer, K. Rober, V. Haustein [et al.] // Brit. J. of Cancer. — 2014. Vol. 110. - P. 753-763.

467. Александров Ю. И. Закономерности формирования и реализации индивидуального опыта / Александров Ю. И., Греченко Т. Н., Гаврилов В. В. // Журн. высш. нервной деятельности им. И.П. Павлова. - 1997. - Т. 1, № 2. - С. 243-260.

468. Губский Ю. И. Нейропротективный эффект глицина при моделировании глутаматной «эксайтотоксичности» in vitro / Ю. И. Губский, С. В. Горбачева, И. Ф. Беленичев // Совр. пробл. токсикологии. - 2008. - № 1. - С. 28-34.

469. Влияние тиотриазолина на интегративную функцию центральной нервной системы крыс при хронической алкогольной интоксикации / Ю. М. Колесник, И. С. Чекман, И. А. Мазур, И. Ф. Беленичев // Доп. НАН України. 2012. 一 № 6. - С. 163-168.

470. Sheng M. The regulation and function of c-fos and other immediate early genes in the nervous system / Sheng M., Greenberg M. E. // Neuron. - 1990. Vol. 4, issue 4. - P. 477-485.

471. Quirk G. J. Neural mechanisms of extinction learning and retrieval / G. J. Quirk, D. Mueller // Neuropsychopharmacology - 2008. — Vol. 33. P. 56-72.

472. Афанасьев В. В. Патофизиология и нейропротективная терапия / В. В. Афанасьев, С. А. Румянцева, Е. В. Силина // Мед. совет. - 2008. № 9-10. - C. 16-24.

473. Афанасьев В. В. Медицина критических состояний: роль нейропротекторов в современной клинической практике / В. В. Афанасьев // Мед. вестн. - 2011. — № 39 (1030)

474. Effect of combined therapy with thrombolysis and citicoline in a rat model of embolic stroke / M. Alonso de Leci ana, M. Guti rrez, J. M. Roda [etal.] // J. neurol. sci. - 2006. - Vol. 247, № 2. - P. 121-129. 
475. Hertz L. Energy metabolism in the brain / L. Hertz, G. A. Dienel // Int. rev. neurobiol. - 2002. - Vol. 51. - P. 1-102.

476. Neuroprotection and stroke: time for a compromise / A. R. Young, C. Ali, A. Duret te, D. Vivien // J. neurochem. - 2007. - Vol. 103, № 4. - P. 13021309.

477. Saver J, Choline precursors in acute and subacute stroke: a meta-analysis / J. Saver, J. Wilterdink // Stroke. - 2002. - Vol. 33. - P. 353.

478. Wahlgren N. Systemic thrombolysis in clinical practice: what have we learned after the Safe Implementation of Thrombolysis in Stroke Monitoring Study / N. Wahlgren // Cerebrovasc. dis. - 2009. — Vol. 27, suppl. 1. - P. 168176.

479. Бурчинский С. Г. Новые возможности нейропротекции / С. Г. Бурчинский // Междунар. неврол. журн. - 2006. — № 4 (8). — С. 188-193.

480. Верещагин Е. И. Современные возможности нейропротекции при острых нарушениях мозгового кровообращения и черепно-мозговой травме (обзор литературы) / Верещагин Е. И. // Журн. интенсив. терапии. - 2006. № 3. - C. 4-28.

481. Инсульт: диагностика, лечение, профилактика / под ред. З. А. Суслиной, М. А. Пирадова. - М. : МЕДпресс-информ, 2008. - 283 с.

482. Ишемия головного мозга в медицине критических состояний. Нейропротекция. (патофизиология, терминология, характеристика препаратов) : метод. рек. / В. И. Черний, А. Н. Колесников, Г. А. Городник [и др.]. - К., 2007. - $72 \mathrm{c}$.

483. Новиков В. Е. Возможности фармакологической нейропротекции при черепно-мозговой травме / В. Е. Новиков // Психофармакология и биологическая наркология. - 2007 - Т. 7, вып. 2. - С. 1500-1508.

484. Синяченко О. В. Оксид азота в терапевтической практике / О. В. Синяченко, Т. В. Звягина. - Донецк : ООО «Юго-Восток Лтд», 2001. - 258 с.

485. Non-pharmacologicalneuroprotection: roleofemergencystrokemanagement / R. Leira, M. Blanco, M. Rodr guez-Y ez [etal.] // Cerebrovasc. Dis. - 2006. Vol. 21, suppl. 2. - P. 89-98.

486. Ежов А. Нейронные сети в медицине / А. Ежов, В. Чечеткин // Открытые системы. - 1997. - № 4. - С. 34-37.

487. Острая церебральная недостаточность / В. И. Черний, В. Н. Ельский, Г. А. Городник, А. Н. Колесников. - Донецк, 2007. - С. 58-143.

488. Complex mechanisms for c-fos and c-jun degradation/ I. Jariel-Encontre, C. Salvat, A. M. Steff [etal.] // Mol. biol. rep. — 1997. - Vol. 24, № 1-2. — P. $51-56$.

489. Беленичев И. Ф. Механизмы формирования ишемической нейродеструкции: соотношение оксида азота и тиол-дисульфидной системы как фактор, определяющий судьбу нейрона / И. Ф. Беленичев, С. В. Павлов, Н. В. Бухтиярова // Нейронауки: теоретичні та клінічні аспекти. - 2010. — Т. 6, № 2. - С. 20-27. 
490. Беленичев И. Ф. Модуляторы эстрогеновых рецепторов - перспективные нейропротекторы / И. Ф. Беленичев, С. В. Павлов // Патологія. — 2009. T. 6, № 2. - С. 11-13.

491. Черний Т. В. Ранний ответ генома и анализ морфофункционального состояния нейронов сенсомоторной зоны коры головного мозга в условиях острой церебральной ишемии и на фоне комбинированной поэтапной нейропротекции / Т. В. Черний, И. Ф. Беленичев, С. В. Павлов // Нейронауки: теоретичні та клінічні аспекти. - 2010. — Т. 6, № 2. - С. 11-15.

492. Kajdacsy-BallaAmaralA. C. ChallengesinImplementingevidencebasedmedicine / A. C. Kajdacsy-BallaAmaral, G. D. Rubenfeld // Annualupd ateinintensivecareandemergencymedicine 2012 / ed. J.-L. Vincent. - Berlin : Springer-Verlag Berlin, 2012. - P. 828-834.

493. Kolesnik Y. M. Image analysis system for quantitative immunofluorescence measurement / Y. M. Kolesnik, A. V. Abramov // Microscop. analysis. 2002. - № 5. - P. 12-16.

494. Митохондриальная дисфункция при церебральной патологии. Нейропротекция Цереброкурином / И. Ф. Беленичев, Ю. М. Колесник, С. В. Павлов [и др.] // Междунар. неврол. журн. — 2008. - № 4 (20). — С. 23-29.

495. Cutting edge: different Toll-like receptor agonists instruct dendritic cells to induce distinct Th responses via differential modulation of extracellular signal-regulated kinase-mitogen-activated protein kinase and c-Fos / S. Agrawal, A. Agrawal, B. Doughty [et al.] // J. immunol. - 2003. - Vol. 171, № 10. - P. 4984-4989.

496. Monocyte chemoattractant protein-1 deficiency is protective in a murine stroke model / P. M. Hughes, P. R. Allergini, M. Rudin, [etal.] // J. cereb. bloodflowmetab. - 2002. - Vol. 22, № 3. - P. 308-317.

497. Programmed cell death in the absence of c-Fos and c-Jun / S. Roffler-Tarlov, J. J. Brown, E. Tarlov [et al.] // Development. — 1996. — Vol. 122, № 1. — P. $1-9$.

498. Holtzman D. M. Caspases: a treatment target for neurogenerative disease / D. M. Holtzman, M. Deshmukh // Nat. med. - 1997. — Vol. 3, № 9. - P. 954-955.

499. Retardation of chemical hypoxia-induced necrotic cell death by Bcl-2 and ICE inhibitors: possible involvement of common mediators in apoptotic and necrotic signal transductions / S. Shimizu, Y. Eguchi, W. Kamiike [etal.] // Oncogene. - 1996. - Vol. 12, № 10. - P. 2045-2050.

500. Expression and involvement of c-fos and c-jun protooncogenes in programmed cell death induced by growth factor deprivation in lymphoid cell lines / F. Colotta, N. Polentarutti, M. Sironi, A. Mantovani // J. biol. chem. - 1992. Vol. 267, № 26. - P. 18278-18283.

501. Черний Т. В. Ранний ответ генома и анализ морфофункционального состояния нейронов сенсомоторной зоны коры головного мозга в условиях острой церебральной ишемии и на фоне комбинированной поэтапной нейропротекции / Т. В. Черний, И. Ф. Беленичев, С. В. Павлов // Нейронауки: теоретичні та клінічні аспекти. - 2010. — Т. 6, № 2. - С. 11-15. 
502. The heat-shock response: regulation and function of heat-shock proteins and molecular chaperones / R. I. Morimoto, M. P. Kline, D. N. Bimston, J. J. Cotto // Essays biochem. - 1997. - Vol. 32. - P. 17-29.

503. PI3K/Akt is required for heat shock proteins to protect hypoxia-inducible factor 1alpha from pVHL-independent degradation / J. Zhou, T. Schmid, R. Frank, B. Br ne // J. biol. chem. - 2004. - Vol. 279, № 14. - P. 1350613513.

504. Reduction in myocardial apoptosis associated with overexpression of heat shock protein 70 / K. Suzuki, Y. Sawa, K. Kagisaki [et al.] // Basicres. cardiol. - 2000. - Vol. 95, № 5. - P. 397-403.

505. Семченко В. В. Постаноксическая энцефалопатия / В. В. Семченко, С. С. Стефанов, Г. В. Алексеева. - Омск : Омская областная типография, 1999.$448 \mathrm{c}$.

506. Мониторинг спонтанной биоэлектрической активности мозга в нейроанестезиологии и нейрохирургии / О. Б. Белоусова, Ю. М. Филатов, О. Б. Сазонова, Л. В. Шишкина / Сосудистая нейрохирургия: Материалы III съезда нейрохирургов России, 4- 8 июня 2002 г., Санкт-Петербург. - СПб., 2002. - С. 303-304.

507. Островая Т. В. Исследование реактивности ЦНС в ответ на фармакологическое воздействие (Тиоцетам) / Т. В. Островая, В. И. Черний, И. А. Андронова // Междунар. неврол. журн.- 2007. - № 2 (12). - С. 53-62.

508. Зенков Л. Р. Функциональная диагностика нервных болезней : рук.для врачей / Л. Р. Зенков, М. А. Ронкин. - М. : МЕДпресс-информ, 2004. — С. $384-433$.

509. Belsh J. M. Posterior rhythmic slow activity in EEG after eye closure. / J. M. Belsh, S. Chokroverty, G. Barabas // Electroencephalogr. clin. neurophysiol. - 1983. - Vol. 56, № 6. - P. 562-568.

510. Данилова Н. Н. Психофизиология : учебник для вузов / Н. Н. Данилова. М. : Аспект Пресс, 2001. - 373 с.

511. Кропотов Ю. Д. Количественная ЭЭГ, когнитивные вызванные потенциалы мозга человека и нейротерапия / Ю. Д. Кропотов. - Донецк : изд-во Заславский А. Ю., 2010. - 512 с.

512. Мониторинг спонтанной биоэлектрической активности мозга в нейроанестезиологии и нейрохирургии / О. Б. Белоусова, Ю. М. Филатов, О. Б. Сазонова, Л. В. Шишкина / Сосудистая нейрохирургия: Материалы III съезда нейрохирургов России, 4-8 июня 2002 г., Санкт-Петербург. - СПб., 2002. С. 303-304.

513. Гриндель О. М. Методы математического анализа ЭЭГ / О. М. Гриндель, Е. Л. Машеров, В. Г. Воронов // Нейрофизиологические исследования в клинике. - М. : Антидор, 2001. - С. 24-38.

514. Шарова Е. В. Современные возможности ЭЭГ в анализе функциональных нарушений при тяжелых повреждениях головного мозга / Е. В. Шарова // Нейронауки: теоретичні та клінічні аспекти. - 2009. - Т. 5, № 1-2. — C. $49-58$. 
515. ЭЭГ и ВП в прогнозировании развития посттравматических бессознательных состояний после тяжелой травмы мозга / Е. В. Шарова, О. С. Зайцев, Г. А. Щекутьев [и др.] / Нейронауки: теоретические и клинические аспекты . - 2008. - Т. 4, № 2. - С. 82-89.

516. ЭЭГ и ВП в прогнозировании развития посттравматических бессознательных состояний после тяжелой травмы мозга / Е. В. Шарова, О. С. Зайцев, Г. А. Щекутьев [и др.] / / Нейронауки: теоретические и клинические аспекты . - 2008. - Т. 4, № 2. - С. 82-89.

517. Панюшкина С. В. Электроэнцефалографические закономерности динамики нейромедиаторных процессов у больных с невротическими расстройствами : (патогенетические и фармакотерапевтические аспекты) : автореф. дис. на соиск. ученой степ.д-ра мед. наук : спец. 14.00.18 «Психиатрия» / С. В. Панюшкина. - М., 2000. - 36 с.

518. Островая Т. В. Исследование реактивности ЦНС в ответ на фармакологическое воздействие (Тиоцетам) / Т. В. Островая, В. И. Черний, И. А. Андронова // Междунар. неврол. журн. - 2007. — № 2 (12). - С. 53-62.

519. Крыжановский Г. Н. Общая патофизиология нервной системы : рук. / Г. Н. Крыжановский. - М. : Медицина, 1997. - 352 с.

520. Применение церебролизина при церебральном ишемическом инсульте : метод. рек. / под ред. В. И.Скворцовой. - М., 2006. - 25 с.

521. Сергиенко А. Н. Применение препарата «Цереброкурин» при лечении дегенеративно-дистрофических заболеваний сетчатки / А. Н. Сергиенко // Новости медицины и фармации. — 2001. - № 12 (97). - С. 8.

522. Данилова Н. Н. Психофизиология : учебник для вузов / Н. Н. Данилова. М. : Аспект Пресс, 2001. - 373 с.

523. Многоцентровое (пилотное) исследование эффективности глиатилина при остром ишемическом инсульте / М. М. Одинак, И. А. Вознюк, М. А. Пирадов [и др.] // Клинич. неврология. - 2010. — Т. 4, № 1. - С. 20-27.

524. Saver J, Choline precursors in acute and subacute stroke: a meta-analysis / J. Saver, J. Wilterdink // Stroke. - 2002. — Vol. 33. - P. 353.

525. Танович А. Цитиколин в лечении травматического поражения мозга / А. Танович, В. Алфаро, Х. Х. Секадес // Укр. неврол. журн. — 2007. — № 2. — C. 99-111.

526. Adibhatla R. M. Cytidine 5'-diphosphocholine (CDP-choline) in stroke and other CNS disorders / R. M. Adibhatla, J. F. Hatcher // Neurochem. res. 2005. - Vol. 30, № 1. - P. 15-23.

527. Flentge F. Choline administration and acetylcholine in brain / F. Flentge, C. J. Van Den Berg // J. neurochem. - 1979. - Vol. 32, № 4. - P. 1331-1333.

528. Saver J, Choline precursors in acute and subacute stroke: a meta-analysis / J. Saver, J. Wilterdink // Stroke. - 2002. - Vol. 33. - P. 353.

529. Saver J. L. Citicoline: update on a promising and widely available agent for neuroprotection and neurorepair / J. L. Saver // Rev. neurol. dis. - 2008. Vol. 5, № 4. - P. 167-177. 
530. AdibhatlaR. M. Citicoline: neuroprotectivemechanismsincerebralischemia / R. M. Adibhatla, J. F. Hatcher, R. J. Dempsey // J. neurochem. - 2002. Vol. 80, № 1. - P. 12-23.

531. AdibhatlaR. M. Citicoline: neuroprotectivemechanismsincerebralischemia / R. M. Adibhatla, J. F. Hatcher, R. J. Dempsey // J. neurochem. - 2002. Vol. 80, № 1. - P. 12-23.

532. Болдырева Г. Н. Электрическая активность мозга человека при поражении диэнцефальных и лимбических структур / Г. Н. Болдырева. - М. : Наука, 2000. - $181 \mathrm{c.}$

533. Острова Т. В. Алгоритм діагностики реактивності ЦНС методами штучного інтелекту / Т. В. Острова, В. І. Черній, А. І. Шевченко. - Донецьк : ІПШІ МОНУ і НАНУ «Наука і освіта», 2004. - 180 с.

534. Лях Ю. Е. Анализ результатов медико-биологических исследований и клинических испытаний в специализированном статистическом пакете MEDSTAT / Ю. Е. Лях, В. Г. Гурьянов // Вестн. гигиены и эпидемиологии. - 2004. - Т. 8, № 1. - С. 155-167.

535. Лях Ю. Е. Обоснование выбора оптимального числа кластеров для метода самоорганизующихся карт Кохонена / Ю. Е. Лях, В. Г. Гурьянов // Клинич. информатика и телемедицина. - 2005. - Т. 2, № 1. - С. 124.

536. Зорин Р. А. Изучение межполушарной когерентности альфа-ритма у пациентов с болезнью Паркинсона / Р. А. Зорин // Количественная ЭЭГ и нейротерапия : материалы Всерос. науч.-практ. конф. - СПб. : Человек и здоровье, 2007. - С. 36.

537. Данилова Н. Н. Психофизиология : учебник для вузов / Н. Н. Данилова. М. : Аспект Пресс, 2001. - 373 с.

538. Шарова Е. В. Современные возможности ЭЭГ в анализе функциональных нарушений при тяжелых повреждениях головного мозга / Е. В. Шарова // Нейронауки: теоретичні та клінічні аспекти. - 2009. — Т. 5, № 1-2. C. 49-58. 
БЕЛЕНИЧЕВ И. Ф., ЧЕРНИЙ В. И., НАГОРНАЯ Е. А., ПАВЛОВ С. В., ЧЕРНИЙ Т. В., ГОРЧАКОВА Н.А., БУХТИЯРОВА Н. В., АНДРОНОВА И. А., КУЧЕРЕНКО Л. И.

\section{НЕЙРОПРОТЕКЦИЯ И НЕЙРОПЛАСТИЧНОСТЬ}

Підписано до друку 05.09.2014. Формат 60×84 1/16 Друк офсетний. Папір офсетний. Гарнітура SchoolBookC. Друк. арк. 32,75. Обл. вид. арк. 41,39.

Тираж 0000 экз. Заказ № 00000

\footnotetext{
Издательство ТОВ «Полиграф плюс» 01004, вул. Горького, 5Б, Київ, тел: (044) 502-39-78, факс (044) 427-03-75 e-mail: office@poligraph-plus.kiev.ua www.poligraph-plus.kiev.ua
} 